\title{
Nationality requirements in olympic sports
}

Citation for published version (APA):

Wollmann, A. S. (2016). Nationality requirements in olympic sports. [Doctoral Thesis, Maastricht University]. Wolf Legal Publishers. https://doi.org/10.26481/dis.20160628aw

Document status and date:

Published: 01/01/2016

DOI:

10.26481/dis.20160628aw

Document Version:

Publisher's PDF, also known as Version of record

\section{Please check the document version of this publication:}

- A submitted manuscript is the version of the article upon submission and before peer-review. There can be important differences between the submitted version and the official published version of record.

People interested in the research are advised to contact the author for the final version of the publication, or visit the DOI to the publisher's website.

- The final author version and the galley proof are versions of the publication after peer review.

- The final published version features the final layout of the paper including the volume, issue and page numbers.

Link to publication

\footnotetext{
General rights rights.

- You may freely distribute the URL identifying the publication in the public portal. please follow below link for the End User Agreement:

www.umlib.nl/taverne-license

Take down policy

If you believe that this document breaches copyright please contact us at:

repository@maastrichtuniversity.nl

providing details and we will investigate your claim.
}

Copyright and moral rights for the publications made accessible in the public portal are retained by the authors and/or other copyright owners and it is a condition of accessing publications that users recognise and abide by the legal requirements associated with these

- Users may download and print one copy of any publication from the public portal for the purpose of private study or research.

- You may not further distribute the material or use it for any profit-making activity or commercial gain

If the publication is distributed under the terms of Article $25 \mathrm{fa}$ of the Dutch Copyright Act, indicated by the "Taverne" license above, 
Anna Sabrina Wollmann

\section{Nationality Requirements in Olympic Sports}

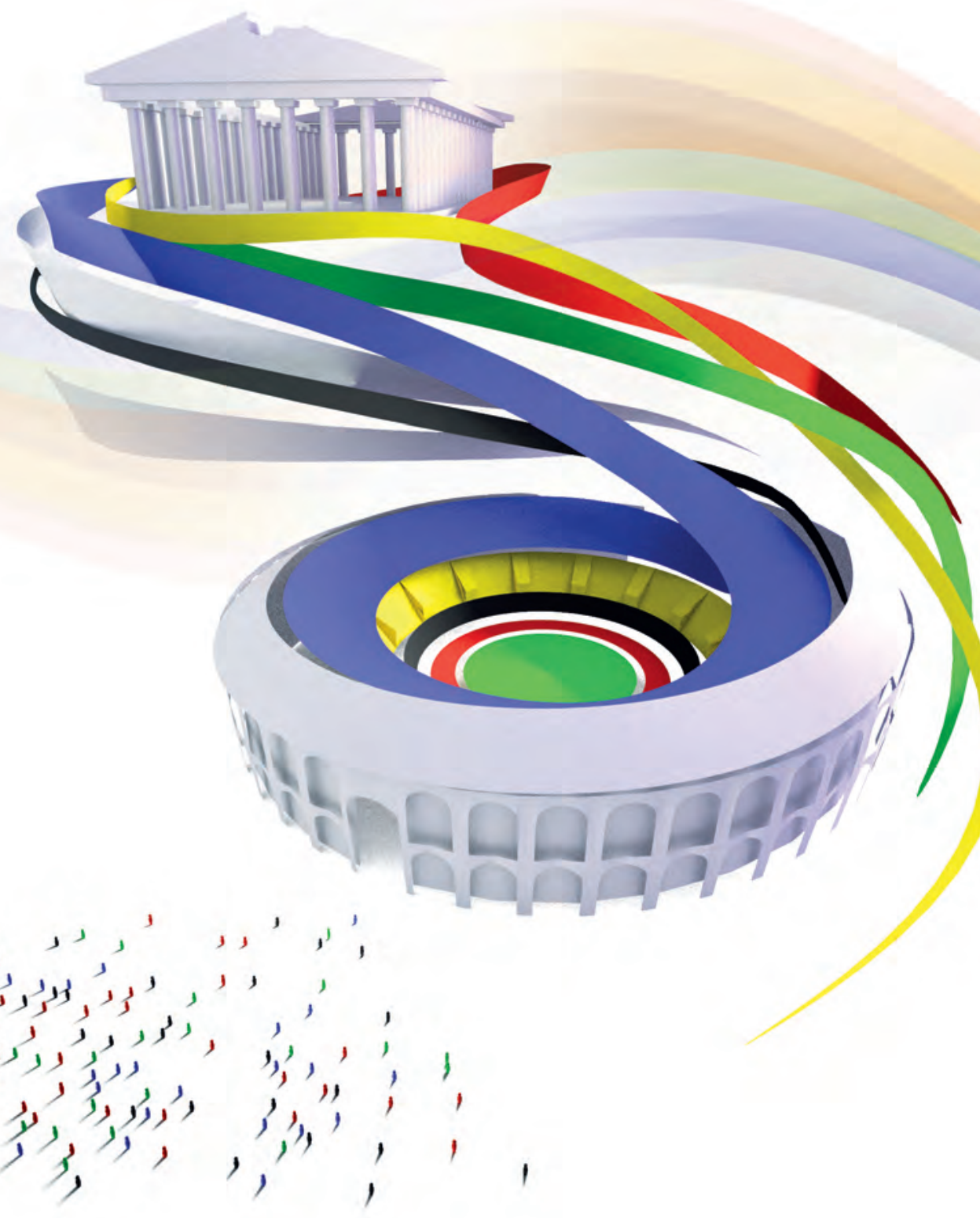


Nationality Requirements in

Olympic Sports

Anna Sabrina Wollmann 
Nationality Requirements in Olympic Sports

Anna Sabrina Wollmann

ISBN: 978-9462-4032-15

Published by:

Wolf Legal Publishers (WLP)

PO Box 313

5060 AH Oisterwijk

The Netherlands

E-Mail: info@wolfpublishers.nl

www.wolfpublishers.com

Cover () Thomas Pähler

(c) Anna Sabrina Wollmann

All rights reserved. No part of this publication may be reproduced, stored in a retrieval system or transmitted in any form, or by any means, electronic, mechanical, photocopying, recording or otherwise, without the prior permission in writing from the author. 


\title{
Nationality Requirements in Olympic Sports
}

\author{
DISSERTATION
}

To obtain the degree of Doctor

at Maastricht University, on the authority of the Rector Magnificus,

Prof. dr. L.L.G Soete

in accordance with the decision of the Board of Deans,

to be defended in public

on Tuesday $28^{\text {th }}$ June 2016 , at 14.00 hours

by

Anna Sabrina Wollmann 


\section{Supervisor:}

prof. dr. G. R. de Groot

\section{Co-supervisor:}

dr. O. W. Vonk

\section{Assessment committee:}

Prof. dr. M.G. Faure (Chairman)

Prof. dr. S. Van den Bogaert (Universiteit Leiden)

Dr. S.F.G. Rammeloo

Prof. dr. M.P. Vink

Prof. dr. P.Wautelet (Université de Liège) 


\section{Acknowledgements}

"It's a dangerous business [...] going out your door. You step onto the road, and if you don't keep your feet, there's no knowing where you might be swept off to."

J.R.R. Tolkien -the Lord of the Rings

When I first stepped onto the 'road' of nationality requirements in Olympic sports I had been planning on writing a paper on Hannah Arendt and statelessness for a master level course on European Migration Law and citizenship. That paper was never written and instead I began to delve into the eligibility criteria of three sporting federations: equestrian, fencing and football. So much was left to explore in that context and thus, after the initial paper, my feet swept me off to write a Master Thesis about the same topic. This time twelve sports were included: archery, canoe kayak, equestrian, fencing, football, handball, hockey, modern pentathlon, rowing, sailing, shooting and triathlon. And my feet just kept sweeping me off to now tackle the eligibility criteria of all 35 Olympic sports.

All of this would not have been possible without my supervisors René de Groot and Olivier Vonk who helped me with great patience, as I tend to think faster than I type, leaving sentences dangling precariously in the air. My warmest thanks to them and also to Hildegard Schneider who not only supervised both my Bachelor theses both at the FdR and at FASoS, but also with whom I had the pleasure to work. Special thanks also to my law faculty colleagues, Antonia Waltermann, Sascha Hardt and Vanessa Tünsmeyer and all those to whom I have talked during $\mathrm{PhD}$ lunches for their support and feedback.

My warmest thanks also to those people at all the sporting federations that helped me and not only provided me with all the documents, but who also encouraged me.

This book would look significantly less enticing without the amazing cover designed by Thomas. Thanks a lot for understanding my vague and weird ideas and turning them into such a marvellous concept.

Writing a $\mathrm{PhD}$ is a strenuous task, especially as an external $\mathrm{PhD}$ candidate whose sole focus is the dissertation. When arriving in Maastricht in summer $2008 \mathrm{I}$ had the enormous luck - or maybe the foresight - to take up fencing and join MAS Incontro. Fencing and the circle of friends I gained through it has been essential for me to maintain a healthy work-life balance throughout my time in Maastricht. Thanks a lot thus to MAS Incontro Maîtres Inge, Bas and Pierre and all fencers, especially Erik (who notably was not only also a colleague of mine at TIER, but also agreed to support me as paranimf), Renée, Piter, Myra and Niels. Thanks also to Iris (who checked my Dutch summary and is also my paranimf) and Lucien, though not fencers, but nevertheless part of group.

Thanks a lot to my movie-pals Reinier, who ensured I was kept up to date with pop-culture and Marieke (notably also a colleague at TIER), who followed me to many arthouse films. I fondly remember my time at TIER and my former colleagues Iryna and Carla whose $\mathrm{PhD}$ writing and defencing process I witnessed first hand and who supported me.

When spending (too much) time writing a $\mathrm{PhD}$ and engulfed in academia and university sports one starts to live in a certain bubble. I am just extremely grateful to 


\section{NATIONALITY REQUIREMENTS IN OLYMPIC SPORTS}

those who helped me burst the bubble: Iva for coffee breaks and the occasional drinks in Maastricht; Shiraz for amazing dinners in Maastricht; Katharina for coffee in Bonn, Helmut for his support and Celine \& Matt for overall great fun in the UK and showing me that universities and academic bubbles are completely the same, but yet very different around the world.

When writing a PhD one goes from hunched over and brooding over a journal article or book to sitting hunched over and brooding at a computer writing a journal article or a book. I am thus extremely grateful to those teachers who helped me to "un-hunch" and not only stay mentally, but also physically fit: thanks a lot Aisha, Digna, Jessica and Marta.

When working on any extremely long-term project, such as a $\mathrm{PhD}$, it is necessary to step aside for a moment and look at everything with fresh eyes. The greatest way to completely change one's outlook is to be on stage and to act. Thus my most special thanks to my theatre friends from the Bonn University Shakespeare Company and the Dauertheatersendung. Whether it was Titus Andronicus, 15minute Hamlet, Macbeth or Faust I, you were a source of inspiration, motivation and great fun. Thank you for helping me to achieve a healthy work-life balance and stay on the right side of sanity. Dixit!

And last, but no means least, thanks a lot to my family for all their support. 


\section{Table of contents}

1. Introduction p. 1

1.1. Nationality and citizenship laws p. 1

1.2. Modern Olympic Games and eligibility p. 3

1.3. Research questions p. 5

$\begin{array}{lll}\text { 1.4. Terminology p. } 9 & \text { p. }\end{array}$

$\begin{array}{lll}\text { 1.5. Glossary } & \text { p. } 9\end{array}$

2. M ethodology p. 15

2.1. Tertiumcomparationis p. 16

2.2. Tertiumvalutationis p. 17

2.3. Data gathering p. 19

3. Principles of nationality law $\quad$ p. 21

3.1. Nationality and Citizenship p. 22

3.1.1. Nationality and Citizenship - terminology and development

p. 22

$\begin{array}{lll}\text { 3.1.2. } & \text { Connotations of 'nationality' and 'citizenship' } & \text { p. } 24 \\ \text { 3.2. } & \text { Nationality as the manifestation of a genuinelink } & \text { p. } 28\end{array}$

3.3. Acquisition of nationality p. 29

3.3.1. Acquisition at birth p. 29

3.3.2. Naturalisation p. 32

3.3.3. Option rights p. 35

3.4. Dual nationality p. 36

3.5. Nationality and territorial transfers p. 37

3.6. Loss of nationality p. 39

3.6.1. Loss of nationality ex lege or at the initiative
of the state

3.6.2. Loss of nationality at the individual's initiative p. 42

$\begin{array}{ll}\text { 3.7. Nationality and its problems } & \text { p. } 42\end{array}$

3.7.1. Statelessness p. 43

3.7.2. Asylum seekers and refugees p. 44

3.7.3. Current debate on 'passports' on sale p. 45

$\begin{array}{lll}\text { 3.8. Touchstone principles of nationality law } & \text { p. } 47\end{array}$

$\begin{array}{lll}\text { 4. Lex sportiva and nationality } & \text { p. } 49\end{array}$

$\begin{array}{lll}\text { 4.1. The status of lex sportiva } & \text { p. } 49\end{array}$

4.2. Usage of 'nationality' and 'citizenship' in the sporting
context

4.3. The genuinelink in sports p. 50

4.3.1. Genuinelink in national leagues and national teams p. 50

4.3.2. Genuinelink in sporting competitions - a debated topic p. 51

4.3.3. Sporting competitions and statelessness p. 52

4.4. A proposed sporting nationality p. 54

4.5. The CAS and eligibility cases p. 55

4.6. Nationality Requirements in the Olympic Charter p. 58 
5. Classic Sports p. 63

5.1. Athletics p. 66

5.1.1. Athletics critical reflection p. 67

5.1.2. Rules applicable since $2011 \quad$ p. 67

5.2. Biathlon p. 73

5.2.1. Biathlon critical reflection p. 74

5.2.2. Rules applicable since $2012 \quad$ p. 74

$\begin{array}{lll}\text { 5.3. Triathlon } & \text { p. } 75\end{array}$

5.3.1. Triathlon critical reflection $\quad$ p. 75

5.3.2. Rules applicable since $1989 \quad$ p. 76

5.4. Modern Pentathlon p. 81

5.4.1. Modern Pentathlon critical reflection p. 82

5.4.2. Rules applicable since November $2015 \quad$ p. 82

5.4.3. Rules applicable 2013-2015 p. 83

5.4.4. Rules applicable $2005-2012 \quad$ p. 84

5.5. Weightlifting p. 85

5.5.1. Weightlifting critical reflection p. 86

5.5.2. Rules applicable since $2013 \quad$ p. 86

6. Sports focussing on body control p. 91

6.1. Aquatics p. 92

6.1.1. Aquatics critical reflection p. 94

6.1.2. Rules applicable since $2005 \quad$ p. 94

$\begin{array}{lll}\text { 6.2. Gymnastics } & \text { p. } 97\end{array}$

6.2.1. Gymnastics critical reflection p. 98

6.2.2. Rules applicable since $2005 \quad$ p. 99

7. M artial Arts without bodily contact between contestants p. 103

7.1. Archery p. 105

7.1.1. Archery critical reflection p. 106

7.1.2. Rules applicable since April 2012 p. 106

7.2. Fencing p. 109

7.2.1. Fencing critical reflection p. 110

7.2.2. Rules applicable since $2005 \quad$ p. 110

7.3. Shooting p. 113

7.3.1. Shooting critical reflection $\quad$ p. 113

$\begin{array}{lll}\text { 7.3.2. } & \text { Rules applicable since } 2 & \text { p. } 114\end{array}$

8. M artial Arts with direct bodily contact between

$\begin{array}{ll}\text { contestants } & \text { p. } 117\end{array}$

8.1. Boxing p. 119

8.1.1. Boxing critical reflection p. 120

8.1.2. Rules applicable since 2015 p. 120

8.1.3. Rules applicable $2013-2015 \quad$ p. 121

8.2. Judo p. 122

8.2.1. Judo critical reflection p. 122

8.2.2. Rules applicable since 2005 p. 123

8.3. Taekwondo p. 125

8.3.1. Taekwondo critical reflection $\quad$ p. 125 
8.3.2. Rules applicable since 2010

p. 126

8.4. Wrestling

p. 128

8.4.1. Wrestling critical reflection

p. 129

8.4.2. Rules applicable since 2015

p. 129

8.4.3. Rules applicable 2012 - 2015

p. 132

8.4.4. Rules applicable 2009 - 2012

p. 134

9. Team sports involving a ball

p. 137

9.1. Basketball

p. 141

9.1.1. Basketball critical reflection

p. 141

9.1.2. Rules applicable since 2004

p. 142

9.2. Football

p. 147

9.2.1. Football critical reflection

p. 148

9.2.2. Rules applicable since 2008

p. 148

9.2.3. Rules applicable 2007

p. 152

9.2.4. Rules applicable $2005-2007$

p. 152

9.3. Handball

p. 154

9.3.1. Handball critical reflection

p. 154

9.3.2. Rules applicable since 2011

p. 155

9.4. Hockey

p. 157

9.4.1. Hockey critical reflection

p. 157

9.4.2. Rules applicable since 2010

p. 158

9.5. Ice Hockey

p. 162

9.5.1. Ice Hockey critical reflection

p. 163

9.5.2. Rules applicable since 2003

p. 163

9.6. Rugby

p. 167

9.6.1. Rugby critical reflection

p. 168

9.6.2. Rules applicable since 2013

p. 168

9.7. Volleyball

p. 179

9.7.1. Volleyball critical reflection

p. 180

9.7.2. Rules applicable since 2013

p. 180

\section{B all spots with rackets}

10.1. Badminton

p. 183

p. 185

10.1.1. Badminton critical reflection

p. 185

10.1.2. Rules applicable since 2005

p. 186

10.2. Tennis

10.2.1. Tennis critical reflection

p. 188

p. 189

10.2.2. Rules applicable since 2005

p. 190

10.2.3. Fed and Davis Cup

p. 193

10.3. Table Tennis

p. 195

10.3.1. Table Tennis critical reflection

p. 196

10.3.2. Rules applicable since 2005

p. 196

11. A iming with an object for a goal

p. 201

11.1. Curling

p. 202

11.1.1. Curling critical reflection

p. 203

11.1.2. Rules applicable since 2010

p. 203 
11.1.3. Rules applicable $2015-2010 \quad$ p. 204

11.2. Golf p. 205

11.2.1. Golf critical reflection 206

11.2.2. Rules applicable since June 2014 p. 206

11.2.3. Rules applicable $2005-2014 \quad$ p. 207

12. M ovement over ground p. 209

12.1. Cycling p. 211

12.1.1. Cycling critical reflection p. 212

12.1.2. Rules applicable since 2005 p. 213

$\begin{array}{lll}\text { 12.2. Equestrian } & \text { p. } 217\end{array}$

12.2.1. Equestrian critical reflection p. 217

12.2.2. Rules applicable since 2005 p. 219

13. M ovement over water p. 227

13.1. Canoe Kayak p. 229

13.1.1. Canoe Kayak critical reflection p. 230

13.1.2. Rules applicable since $2011 \quad$ p. 230

13.2. Rowing p. 233

13.2.1. Rowing critical reflection p. 233

13.2.2. Rules applicable since October 2013 p. 234

13.2.3. Rules applicable $2005-2012$ p. 234

13.3. Sailing p. 236

13.3.1. Sailing critical reflection $\quad$ p. 237

13.3.2. Rules applicable since 2012 p. 237

14. M ovement over ice and snow p. 241

14.1. Bobsleigh p. 243

14.1.1. Bobsleigh critical reflection p. 244

14.1.2. Bobsleigh p. 244

14.1.3. Rules applicable since $2005 \quad$ p. 244

14.1.4. Bobsleigh skeleton p. 245

14.1.5. Rules applicable since 2005 p. 246

14.2. Luge p. 248

14.2.1. Luge critical reflection $\quad$ p. 248

14.2.2. Artificial Track p. 248

14.2.3. Rules applicable since $1998 \quad$ p. 249

14.2.4. Natural Track p. 251

14.2.5. Rules applicable since $1998 \quad$ p. 251

14.3. Skating p. 253

14.3.1. Skating critical reflection p. 254

14.3.2. Rules applicable since 2012 p. 255

14.4. Skiing p. 259

14.4.1. Skiing critical reflection 261

14.4.2. Rules applicable since $2013 \quad$ p. 261

15. Comparison p. 273

15.1. Terminology p. 275

15.1.1. Nationality/Citizenship p. 275 
15.1.2. Domicile/Residence

15.2. Is changing the country of representation possible?

p. 281

15.3. Which forms of acquisition of nationality are accepted and which additional requirements need to be fulfilled?

15.4. What is the position of athletes with dual or multiple nationality after having competed for one of the countries?

15.5. Which residence requirements exist and when are they applicable?

p. 283

15.5.1. Residence requirements after the acquisition of a new nationality

15.5.2. Residence requirements for minors

15.6. Which waiting or non-competition periods are applicable and under which circumstances?

15.7. For which country may stateless athletes compete and under which circumstances?

15.8. How do territorial transfers affect the athletes' choice regarding country of representation?

15.9. Is competing for the country of residence possible and if so under certain circumstances?

15.10. What is the situation for minors regarding changes of country of representation?

15.11. Is the number of changes of the country of representation limited in any way?

16. Compatibility of eligibility criteria and nationality law

16.1. Sporting federations should recognise the athlete's nationality and should have provisions for stateless athletes and refugees that allow them to continue to compete internationally

16.2. Changes of country of representation have to be allowed and should not be limited by a maximum number of changes

16.2.1. Maximum number of changes p. 298

16.2.2. Changes in case of multiple nationality p. 299

16.2.2.1.Multiple nationality from birth p. 299

16.2.2.2. Multiple nationality acquired later in life p. 299

16.2.3. Changes in case of territorial transfers p. 300

16.3. The genuinelink between athlete and country should be recognised by the sporting federations if established via i) ius soli, ius sanguinis or a combination thereof ii) option rights iii) facilitated naturalisation after marriage or iv) naturalisation

16.3.1. Eligibility codes and ius sanguinis and/or ius soli or a combination thereof

16.3.2. Eligibility codes and option rights

16.3.3. Eligibility codes and facilitated naturalisation after marriage

16.3.4. Eligibility codes and naturalisation

p. 304 
16.3.4.1.Residence as a factor for the genuinelink p. 304

16.3.4.2. Time as a factor for the genuinelink 305

16.4. Gender equality should be respected p. 307

16.5. Sporting federations should provide rules for those who lost their nationality and allow them to continue $\begin{array}{ll}\text { their career } & \text { p. } 307\end{array}$

16.6. There should be no discriminatory rules p. 307

16.7. Rules concerning minor athletes should offer additional $\begin{array}{ll}\text { protection } & \text { p. } 308\end{array}$

16.7.1. Minors competing internationally p. 308

16.7.2. Transition from minor athlete to adult athlete p. 309

17. Solutions p. 311

17.1. Problems p. 311

17.2. Solution 1: The free market approach $\quad$ p. 312

17.2.1. Implementing the free market approach p. 312

17.2.2. Desirability of the free market approach p. 312

17.3. Solution 2: A separate sporting nationality p. 313

17.3.1. Granting a 'sporting nationality' p. 314

17.3.2. Eligibility criteria for a sporting nationality

17.3.3. Sporting nationality and dual nationals p. 316

17.3.4. Sporting nationality and the rights it might entail p. 317

17.3.5. Changing a sporting nationality p. 317

17.4. Solution 3: A sporting licence in accordance with international standards of nationality law p. 318

17.4.1. Calling it 'licence' instead of nationality p. 319

17.4.2. Draft article p. 319

17.4.3. How is this draft article in accordance with standards of international nationality law ?

17.4.4. How does this draft article solve the current

problems inherent in current eligibility codes? p. 322

18. Conclusions and recommendations p. 325

18.1. Nationality law and the touchstone principles thereof p. 325

18.2. What are the eligibility criteria currently employed by
the Olympic Sports?

18.3. To what extend are these currently applicable eligibility criteria in accordance with the international standards of nationality law? p. 329

18.3.1. Terminology p. 329

18.3.2. Sporting federations should recognise the athlete's nationality and should have provisions for stateless athletes and refugees that allow them to continue to compete internationally

18.3.3. Changes of country of representation have to be allowed and should not be limited by a maximum number of changes 
18.3.4. The genuinelink between athlete and country should be recognised by the sporting federations if established via i) ius soli, ius sanguinis or a combination thereof ii) option rights iii) facilitated naturalisation after marriage or iv) naturalisation

18.3.5. Gender equality should be respected

18.3.6. Sporting federations should provide rules for those who lost their nationality and allow them to continue their career

18.3.7. There should be no discriminatory rules

18.3.8. Rules concerning minor athletes should offer additional protection

18.3.9. Waiving eligibility requirements

18.4. How can tensions that may exist between the criteria applied by the sporting federations and the international standards of nationality law be solved?

18.4.1 Option 1: a free market approach

18.4.2. Option 2: a separate sporting nationality

18.4.3. Option 3: A sporting licence in accordance with international standards of nationality law

19. Bibliography

p. 339

19.1. Literature

p. 339

19.2. Case law

p. 351

19.3. Conventions

p. 353

19.4. National Laws

p. 354

19.5. Sport Information

p. 355

19.6. Sport Statutes

p. 371

19.7. Other

p. 401

20. List of abbreviations and new terminology

p. 403

21. Appendices

p. 409

21.1. IOC Charter

p. 409

21.2. Sport federation rules and statutes

p. 410

22. Summary

p. 659

23. Samenvatting

p. 667

24. Z usammenfassung

25. Valorisation addendum

p. 685

25.1. Olympic sports and nationality requirements in the societal and economic context

25.2. The importance of Olympic sports and their nationality requirements for different audiences 
NATIONALITy REQUiREMENTS IN OLYMPIC SPORTS

25.3. The innovative character of this dissertation's approach

p. 687

25.4. The practical applicability of the research results

p. 687

25.5. Implementing the research results

p. 688

26. Biography

p. 689 


\section{List of Tables}

Tablel: Levels of rules relevant to this dissertation p. 15

Tablell. Overview of the IOC's eligibility requirements $\quad$ p. 60

Table IV: Topics dealt with in classic sports

TableIV: Overview of the eligibility requirements for athletics p. 66

TableV: Overview of the eligibility requirements for biathlon p. 74

TableVI: Overview of the eligibility requirements for triathlon p. 77

TableVII: Overview of the eligibility requirements for modern pentathlon

p. 81

Table VIII: Overview of the eligi bility requirements for weightlifting p. 85

TableIX: Topics dealt with in sports that focus on body control p. 91

TableX: Overview of the eligibility requirements for aquatics p. 94

TableXI: Overview of the eligibility requirements for gymnastics p. 98

TableXII: Topics dealt with in Martial Arts without bodily contact p. 103

TableXIII: Overview of the eligibility requirements for archery p. 105

TableXIV: Overview of the eligibility requirements for fending p. 109

TableXV: Overview of the eligibility requirements for shooting p. 113

TableXVI: Topics dealt with in Martial Arts with direct bodily contact

p. 117

TableXVII: Overview of the eligibility requirements for boxing p. 119

TableXVIII: Overview of the eligibility requirements for judo

p. 122

TableXIX: Overview of the eligibility requirements for tadkwondo

p. 125

TableXX: Overview of the eligibility requirements for wrestling

p. 128

TableXXI: Topics dealt with in Team sports involving a ball

p. 137

TableXXII: Overview of the eligi bility requirements for basketball

TableXXIII: Overview of the eligi bility requirements for football

TableXXIV Overview of the eligibility requirements for handball

TableXXV: Overview of the eligi bility requirements for hockey

p. 141

p. 147

p. 154

p. 157

TableXXVI: Overview of the eligibility requirements for icehockey p. 162

TableXXVII: Overview of the eligibility requirements for nugby p. 167

TableXXVIII: Overview of the eligibility requirements for volleyball p. 179

TableXXIX: Topics dealt with in sports involving rackets

p. 183

TableXXX: Overview of the eligi bility requirements for badminton p. 185

TableXXXI: Overview of the eligibility requirements for tennis p. 188

TableXXII: Overview of the eligibility requirements for table tennis p. 195

Table: XXXIII: Topics dealt with in sports aiming with an object for a goal

p. 201

TableXXXIV: Overview of the eligibility requirements for curling p. 202

TableXXXV: Overview of the eligi bility requirements for golf

p. 205

TableXXXVI: Topics dealt with in sports that focus on movement over ground

p. 209

TableXXXVII: Ovenview of the eligibility requirements for cycling p. 212

TableXXXVIII: Overview of the eligibility requirements for equestrian

Table XXXIX: Topics dealt with in Sports that focus on movement over water

TableXL: Overview of the eligi bility requirements for canoekayak p. 229

TableXLI: Overview of the eligibility requirements for rowing p. 233 
TableXLII: Overview of the eligibility requirements for sailing

TableXLIII. Topics dealt with in sports that focus on movement over ice and Snow

p. 236

p. 241

TableXLIV: Overview of the eligibility requirements for bobsleigh

p. 244

TableXLV: Overview of the eligibility requirements for bobsleigh skeleton

TableXLVI: Overview of the eligibility requirements for luge - artificial track

p. 245

p. 248

TableXLVII: Overview of the eligibility requirements for luge - natural track

p. 251

TableXLVIII: Overview of the eligibility requirements for skating

TableXLIX: Overview of the eligibility requirements for skiing

Table L: Themean/ standard eligibility criteria of October 2013

Table LI: Usage of 'citizenship' and 'national ity' in Olympic Sports

Table LII: Usage of 'residence' and 'domicile' in Olympic Sports

Table LIII Sport Associations and their abbreviations

p. 254

p. 261

p. 274

p. 276

p. 280

p. 403

List of Figures

Figurel: Sport governing bodies

p. 10 


\section{Introduction}

Three Greek inventions transcend time and space democracy, citizenship and the Olympic Games. While not all people live in a democracy, hold a citizenship or have thetal ent to competein a sport at Olympic leve, everyone is aware of the existence of these concepts. The link between democracies and their citizens is also well established and widely known. ${ }^{1}$ Contrarily, the connection between citizenship and the Olympic Games is rather uncharted territory. Although al ready in ancient Greece the athletes were citizens of the respective city-states and their participation and victory was not only attributed to them but al so to the city-states, ${ }^{2}$ current eligibility criteria are more complex by far. Eligibility codes do not exist in a vacuum and thus, in addition to the complexity of eligibility criteria, more difficulties arise at the interplay between this criteria and international law or national codes delineating nationality and citizenship for a specific country - and which areno less complex in themselves.

In order to explore this terra incognita and to unraved these complexities, one needs to ask several questions. Firstly, what are the eligibility criteria currently employed by the Olympic Sports? There are 35 sports that are at present considered Olympic and will therefore be analysed in this dissertation. ${ }^{3}$ Furthermore, one has to look at rules concerning ditizenship and nationality that exist at the level of national and international law. Another question is to what extent these currently applicable eligibility criteria are in line with international standards of nationality law. While answers to these two questions would start charting the fiedd of citizenship/nationality law and Olympic sports, merely enumerating the problems is not enough and would be the equival ent of writing 'hic sunt dracones' on themap to mark difficult territory. The central question thus needs to be: how can the tensions that may exist between the criteria applied by the sporting federations and intemational standards of nationality law besolved. This dissertation aims to providea possible solution.

\subsection{Nationality and citizenship laws}

As mentioned above, nationality and citizenship laws are important and complex enough to fill whole libraries devoted solely to them Nationality or citizenship, their transferral and the rights inherently linked to them are amongst the most vital topics for human beings. And with current mass-migrations the question to which state a person is linked and which state should thus offer its protection to the person is frequently at the heart of modern day conflicts. ${ }^{4}$ Which passport a person holds

R. Bauböck (2014b), p. 20f; R. Falk (2012), 15; A. Shachar (2014), p. 5.

D. Panagiotopoul os (2012), pp. 63 .

Please see the Annex for Table LII for an overview of the various sports, their governing organi sation - and most importantly the commonly used abbreviation that will al so be used in this paper - as well as the different sport's Olympic history, eg. when it first became Olympic, since when women are competing in this sport and whether the sport has been featured continuously at the Games since its debut.

$4 \quad$ T. A. Aleinikoff and D. B. Klusmeyer (2002), p. 2; K. Hailbronner (2006), pp. 36f; A. Shachar (2009), pp. 7ff. 
predetermines a human's possi bilities, ranging from the more mundane things, such as trave possibilities, ${ }^{5}$ to the more important aspects of job opportunities, education and overall life expectancy. Consequently, affiliation with the affluent countries is highly coveted, ${ }^{6}$ whil estateless peopl e often face diresituations. ${ }^{7}$

Due to its importance, the universal declaration of human rights (UDHR) indudes one provision dealing solely with nationality and the inherent right of a human being thereto. ${ }^{8}$ Furthermore, arbitrary deprivation of nationality is forbidden and - especially important in the context of this dissertation - states may in principlenot deny a human being the possibility to change his or her national ity. ${ }^{9}$ However, the UDHR does at best impose a moral obligation on states and not a legal one ${ }^{10}$ Any state or non-state actor denying a person a nationality or preventing someone from changing his or her nationality acts contrary to themoral duty sterming from the UDHR.

Looking at how states attribute their nationality to a person in practice, one finds that this is primarily done at the time of birth, with factors like the place of birth (ius soli) ${ }^{11}$ or blood retations (ius sanguinis) ${ }^{12}$ determining which nationality a child receives. In recent years, a convergence has taken place, with ius soli countries adopting some ius sanguinis aspects and vice versa. ${ }^{13}$ That way, traditional ius soli countries under certain circumstances often grant their nationality to children of their nationals born abroad, i.e in service of the country. ${ }^{14}$ Ius sanguinis countries in turn use the possibility under certain circumstances to indude children born to migrants living on their territory who would otherwise remain foreigners forever. ${ }^{15}$ Changing or acquiring a nationality at a point after birth is usually significantly more difficult compared to acquisition at birth. Naturalisation is mostly residence based, ${ }^{16}$ although the required duration and the definition of residence varies among countries. ${ }^{17}$ However, there are often compensation possibilities for people who rendered or are likely to render important senvices to the state Some possibilities even exist to acquire citizenship in retum for a sum of for money, ${ }^{18}$ which does not require the usual

\footnotetext{
R. Bauböck (2014a), p. 1.

R. Bauböck (2014b), p. 19; P. Ochoa (2014), p. 23; A. Shachar (2014), p. 3; P. Spiro (2014), p. 9.

E. Horváth (2008), p. 19; O. W. Vonk, M. P. Vink, G. R. deGroot (2013), p. 12.

Art. 15(1) UDHR. Although it does not specify to which nationality a person has the right.

Art. 15(2) UDHR.

O. W. Vonk, M. P. Vink, G. R. deGroot (2013), p. 16.

K. Hailbronner (2006), p. 56; T. A. Aleinikoff and D. B. Klusmeyer (2002), p. 2; G. R. de Groot, (2006b), pp. 5f; P. J. Spiro (2013), p. 31; M. P. Vink (2005), p. 11; O. W. Vonk (2012), p. 45; H. Waldrauch (2006a), p. 128.

12 P. J. Spiro. (2013), p. 31; M. P. Vink (2005), p. 11; O. W. Vonk (2012), p. 45; H. Waldrauch (2006a), p. 125; G. R. de Groot and J J. Kuipers (2006), p. 144.

K. Hail bronner (2006), p. 54; P. Weis (1979), p. 95.

K. Hail bronner (2006), p. 54; T. A. Aleinikoff and D. B. Klusmeyer (2002), p. 2.

K. Hail bronner (2006), p. 39; T. A. Aleinikoff and D. B. Klusmeyer (2002), p.2.

H. Waldrauch (2006a), pp. 134f; M. P. Vink (2005), p. 11; P. Weis (1979), p. 100.

H. Wal drauch (2006a), p. 148; see S. W. Goodman and M. M. Howard (2013), pp. 111 - 139 for recent developments.

18 See A. Shachar and R. Bauböck (Eds.) (2014), Should Citizenship be for Sale? EUI Working Papers, for moreinformation and discussion.
} 
residence periods ${ }^{19}$ or integration and language tests ${ }^{20}$ that others seeking naturalisation haveto demonstrate

Even countries with usually rather restrictive naturalisation procedures may offer passports to athletes with promising careers. ${ }^{21}$ Contrarily, athletes from (divil) war stricken countries, who do not change their nationality, face the same perils as other civilians in these conflicts and are thus as likely to become refugees or asylum seekers. ${ }^{22}$ The influence thus of officials issuing passports is evaluated by scholars differently. While several scholars consider the fast-track naturalisations for athletes to be an 'abuse of naturalisation'23 others actively campaign for even quicker naturalisations to improve the pool of athletes of the respective country. ${ }^{24}$ In addition, a third school of thought exists. These scholars favour the creation of a separate 'sporting nationality' that is entirely disconnected from the national ity granted by the state $^{25}$ According to them, decoupling nationality and team representation would reduce the need for fast-track naturalisations and could lead to a freemarket approach. Such a solution is however opposed by scholars from the other schools of thought, as the basis for eligi bility for a ' national' team should be having the relevant nationality. ${ }^{26}$ There is thus currently an on-going debate about nationality and citizenship in the context of sports and representativeteams.

\subsection{M odern Olympic $G$ ames and eligibility}

In August 2016 all eyes will be on Rio. For 19 days, athletes fromall over the world will compete in 306 medal events. 918 medals - gold, silver and bronze for each discipline - will be awarded to the three athletes or teams who have reached the pinnade of their sport Over the past months, athl etes have competed fiercely during the qualification rounds in 28 sports and 41 disciplines to gain their ticket to the Olympic Games. Competing at this level is every athlete's dreamand, for some, it may be a once in a lifetime chance ${ }^{27}$ In light of current events and the high number of people forced to fle from their home country, ${ }^{28}$ for the first time, the IOC will allow refugee athletes to compete during the 2016 Games. As they will not be able to compete for the country from which they have fled, they will compete under the IOC

Portugal only requires one week per year, see A. Shachar (2014), pp. $3 f$.

R. Barbulescu (2014), p. 16.

K. Hailbronner (2006), p. 60.

BBC News (21st August 2012) Somalia Olympic Runner 'drowns trying to reach Europe'; Ben Quinn (The Guardian, 15th August 2012) Eritrea's flag-carrying runner seeks asylum in UK to flee repressive regime - Olympic athlete and middle-distance runner is one of four from country seeking escape from repressive regime.

H. Andres (2009), p. 4; R. Siekmann (2006), p. 123.

C. D. Hall (2012), p. 206ff.

Y. Hafner (2008), p. 1; Y. Hafner (2012), p. 216; D. Oswald (2009a), p. 58.

H. Andres (2009), p. 4 ff.

H. Andres (2009), p. 4; G. Engel brecht (2004), p. 8.

UNHCR estimates that there are currently at least 10 million stateless people and Amnesty International estimates that thereare currently 50 million refugees.
} 
flag and the Olympic Anthem will be played during the ceremonies ${ }^{29}$ So far, it remains und ear how the qualification for the individual disciplines will be handled; yet through this measure the IOC addresses current problems and reacts to circumstances athletes might find themsel ves in.

Since the first official IOC Games in 1896, the Olympics have been the most important international competition for most sports. $Y$ \& these Games are more than 'games' for all the stakeholders involved. ${ }^{30}$ Countries, the International Olympic Committee (IOC), thenational Olympic committees (NOCs), sporting federations, and sponsors are as much involved in the Olympic Games as the individual athletes themselves ${ }^{31}$

The countries hosting the games want to present themselves in a way that combines their roots with their future In 2012, an impressive will to sway and to give a modern picture of one of the oldest European monarchies could be seen. In the sequence "Happy and Glorious", Her Majesty Queen Elizabeth II took on her first ever acting role in which she and James Bond, played by Danie Craig, hurried to the opening ceremony. Her Majesty addressed Bond with "Good evening, Mr Bond" when he picked her up at Buckingham Palace. Taking a helicopter to fly across London to the stadium, they flew over cheering crowds. Arriving in the nick of time, they jumped with Union J ack parachutes from the helicopter - although for the jump they both had stunt doubles. When Elizabeth II addressed thecrowds, she was wearing the same dress as she had in the film sequence ${ }^{32}$ Likewise, Russia's opening of the Winter Olympics in 2014 aimed to impress, with their athletes compeing in seven sports with 15 disciplines. Also, states sending their athl letes to the Olympics want to have as many medal lists in their ranks as possible, and hence the talent hunt, both within the country and beyond, has increased and governments prescribe increasingly higher goals for their teams. ${ }^{33}$ Olympic sports have becomea highly political issue

For the athletes wishing to compete in the 28 sports and 41 disciplines at Rio, the technical and sporting requirements they need to fulfil are rather clear cut: qualification requirements are set and anti-doping rules are in place ${ }^{34}$ The tricky aspect, on which athletes sometimes do not have any influence, is for which country they may compete. This is considerably more difficult as it is not the athlete's quantifiable sporting performance that matters, but it is the athlete's nationality ${ }^{35}$ or

29

T. Bach (2015), Speech on the occasion of the adoption of the resolution "Building a peaceful and better world through sport and the Olympic ideal" by IOC President Thomas Bach, UN General Assembly, New Y ork, 26 October 2015.

D. Oswal d (2009b), pp. 2 f.

Please find an overview of the relevant stakeholders as well as an explanation of the sports' infrastructure in Chapter 1.5.

London Olympics 2012 Opening Ceremony: Happy and Glorious.

The German National Olympic Committee wishes to take between 40 and 70 medals back to Germany from Rio, see: DSOB will in Rio mindestens 44 Medaillen, Frankfurter Allgemeine Zeitung (3rd August, 2015); Zielvorgaben für Olympia: Politiker kritisieren überzogene MedaillenErwartung Süddeutsche Zeitung (11 ${ }^{\text {th }}$ August, 2012).

Art. 43 IOC Charter 2013.

Term used i. a. by Fencing: Art 9.2.2 FIE statutes of December 2016 (wording unchanged since 2005). 
citizenship ${ }^{36}$ that determines which country the athlete is eligible to represent In principle, nationality or citizenship is granted to new-boms ${ }^{37}$ and thus every athlete should in principle have a claim to at least onenationality or citizenship. ${ }^{38}$

$Y \in$, an athlete's nationality or citizenship can be subject to some changes, as the example of Italian midfielder Camoranesi illustrates. Born in Argentina, the fact that he had Italian grandparents enabled him to be called up for the Italian national team. Nevertheless, as Camoranesi's statement shows, 'I have an Italian passport but that is not enough for me to fed Italian', 39 in some cases the real link between a player and the country he or she represents can be somewhat questionable. Another example of representing a country with which there seems to be no apparent connection is the case of US basketball player Hammon. After not being selected for her national team for the 2008 Bejing Summer Games, a fast-track naturalisation procedure ensured her Russian citizenship and the eligibility for their Olympic team She had in fact spent some seasons competing in the Russian league, yet she neither fulfilled the residence requirement nor had Russian ancestors. ${ }^{40}$

To contravene mercenary tendencies and to prevent athletes from changing their nationality too frequently, the IOC and individual sporting federations have adopted certain rules regulating changing the country of representation. ${ }^{41}$ While indeed deterring some quick changes, these measures may lead to rather absurd situations in which athletes continue to compete for countries, even if they no longer have that nationality. ${ }^{42}$

\subsection{Research questions}

Problems arise from an interplay of different rules that exist on three levels. On the first leve, there is the Olympic Charter, which includes eligibility criteria for athletes wishing to compete in the Olympics. According to the artides and byelaws of the Olympic Charter, the sporting federations are free to determine the digibility of athletes, ${ }^{43}$ yet the federation's regulations sometimes go into greater detail regarding therequirements for therepresentation of countries in the Olympic Games. There is an interplay between rules set by the IOC and those set by the sporting federations which need to beapproved by theIOC.

36

Term used i.a. by Athletics: Definitions International Association of Athletics Federations competition rules 2016 - 2017 in forceas from $1^{\text {st }}$ November 2015.

K. Hail lbronner (2006), p. 54; P. J. Spiro (2013), pp. 31f; M. P. Vink (2005), p. 11; H. Waldrauch (2006a), pp. 121 ff.; P. Weis (1979), p. 95.

Unless, through a combination of circumstances, the child remains stateless, see P. Weis (1979), pp. 161f. and O. W. Vonk, M. P. Vink, and G. R. de Groot (2013).

'Argentina's my anthem Camoranesi' taken from

http://soccernet.espn.go.com/news/story?id $=371118 \& c c=5739$.

A. Shachar (2011), pp. 209f.

For example, a residence requirement as enacted in Equestrian: Art. 119(2.2.2) FEI general

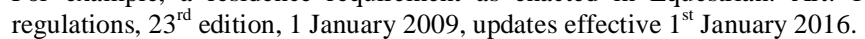

As for example in Rugby: Regulation. 8.2 International Rugby Board handbook, as framed by the International Rugby Board, last updated: $1^{\text {st }}$ January, 2016.

Byelaw to rule 40 IOC Charter 2013. 
The second level is that of the international sport federations and their respective constitutions and codes of eligibility. These apply to athletes competing in the respective sports for national teams in any international competition, not just the Olympics. In addition, there is an interplay between the countries' laws on nationality and the codes of eligibility of the federations, since, in most cases, in order to become eligible for a national team, the athlete in question has to be recognised by the state involved as a national. ${ }^{44}$ The sport federations do, however, impose additional requirements in certain cases to decide on an athlete's eligibility, such as residence requirements, ${ }^{45}$ ancestral ties to the country, ${ }^{46}$ or competition in the relevant national leagues, ${ }^{47}$ in addition to a non-competition period.

Finally, on the highest level there are the international rules regarding nationality as well as the nationality laws of the individual states. These are applicable to everyone, athletes and non-athletes when the nationality of an individual has to be determined.

The focus of this dissertation will be on the rules of the Olympic and sport federation level as well as the interplay between all three levels. The most important questions arethus:

1) What arethe eligi bility ariteria currently employed by theOlympic Sports?

2) To what extent is it problematic to align these currently applicable eligibility criteria with intemational standards of nationality law?

3) How can tensions that may exist between the criteria applied by the sporting federations and theinternational standards of national ity law be solved?

In order to answer these questions, the methodology described in Chapter 2 will be used. In the following, emphasis will first be placed on the legal concept of nationality (Chapter 3). This theoretical backbone of the thesis underscores the nature of nationality as the manifestation of a genuine link between a person and the state (Chapter 3.2). In addition to including a differentiation between the terms 'nationality' and 'citizenship' (Chapter 3.1), Chapter 3 will elaborate briefly on the most important aspects of nationality: acquisition (Chapter 3. 3) and loss of national ity (Chapter 3.6). The more complex aspects, such as dual nationality (Chapter 3.4) and nationality changes as consequences of teritorial transfers (Chapter 3.5), will al so be induded.

One notable exception is luge which only requires the athlete do have the necessary training and have a good standing with the relevant federation, see Art. 3 International Luge regulations Artificial Track - approved at the $62^{\text {nd }}$ FIL congress on June $20^{\text {th }}, 2014$ in Innsbruck/ Austria; Art. 6 International Luge regulations - Natural Track - 2012 edition approved at the $60^{\text {th }}$ FIL congress on J une $15^{\text {th }} 2012$ in Riga / Latvia.

$45 \quad$ Art. 21(b) book 3 chapter I FIBA rule book 2014 - 2019; Art. 7(d) FIFA statutes: regulations governing the application of the statutes 2015; Art. 44.2.2 Sports regulations Volleyball version: $15^{\text {th }}$ May 2014.

46 Art. 7(b) FIFA statutes: regulations governing the application of the statutes 2015; Art. 119.2.2.3 FEl general regulations $23^{\text {rd }}$ edition, $1^{\text {st }}$ anuary 2009 , updates effective $1^{\text {st }}$ J anuary 2016.

$47 \quad$ Art. 21(b) book 3 chapter I FIBA rule book 2014 - 2015; Art. 406(1.6) IIHF statutes and bylaws 2014 - 2018 of May 2014; Art. 406(1.8) IIHF statutes and bylaws 2014 - 2018 of May 2014. 
Furthermore, this dissetation will briefly delve into current problems regarding nationality, ranging from 'passports for sale' to statelessness, asylum seekers and refugees (Chapter 3.7). Finally, the touchstone principles of nationality law, i.e the principles according to which the sports' eligibility criteria will be examined, will be named (Chapter 3.8.).

Thereafter, this dissertation will focus on national ity especially in the context of lex sportiva, i.e sports law. Following a brief summary on the status of lex sportiva (Chapter 4.1), the usage of the terms 'citizenship' and 'nationality' (Chapter 4.2), as well as the position of the genuine link in the sports context (Chapter 4.3), will be addressed ${ }^{48}$ Furthermore, a brief discussion of the separate sporting nationality as advocated by some authors will be given (Chapter 4.4), although a more in-depth analysis will follow in 'Solutions' (Chapter 17.3). In addition, a short overview of the position of the Court of Arbitration in Sport (CAS) and its cases dealing with nationality and eligibility matters will be given (Chapter 4.5), before turning to the national ity requirements set by the Olympic Charter (Chapter 4.6).

In the foll owing chapters (Chapter 5 - 14), the nationality requirements of all the currently recognised Olympic sports, as provided by the international associations of the respective sport on their websites, will be analysed to answer the first research question for each sport individually. For sports that deal with the nationality requirements for their different disciplines separately, namely luge and bobsleigh, the individual disciplines will be analysed. In order to achieve a better understanding of the technicalities of the respective sport, a brief outline of what the sport entails shall be given prior to turning to the actual nationality requirements. For the analysis of the individual sport, the dissertation will aim to answer the same questions regarding nationality changes, minors and stateless athletes as are brought forward in the final comparison. In addition, close attention will be paid to the wording of the respective statutes and eligibility laws, eg. whether 'nationality' and 'citizenship' are used, which meaning is attributed to the terms, and whether an actual distinction is made between them Furthermore, the question of whether a 'sporting nationality' is mentioned will be answered, induding an attempt at a definition of what such a sporting national ity would entail.

Afterwards, theanalytical part of this dissertation (Chapter 15) will answer the first research question for all Olympic sports and compare the respective requirements with a spedific focus on the effect these requirements have on athletes wishing to change their nationality and represent another country. Here the focus will firstly be on the terminol ogy used by the different sports to see which different meanings are attributed to the terms such as 'nationality' or 'citizenship' (Chapter 15.1). Secondly, the aspects chosen for comparison will be whether a change of nationality is possible at all (Chapter 15.2.); the forms of acquisition of nationality that are accepted and which additional requirements need to be fulfilled (Chapter 15.3.); which residence

48 Parts of this were al ready published as "Towards a Sporting National ity?" by A. S. Wollmann, O. W. Vonk and G. R. deGroot published in 22 MJ 2 (2015), pp. 300 - 316. 
requirements exist in the respective cases (Chapter 15.4.); provisions on stateless athletes (Chapter 15.7.); the position of athletes after having competed for another country of which the athlete is a national (Chapter 15.6.); effect of changes of the territory of the country of representation (Chapter 15.8.); competing for the country of residence without being a national thereof (Chapter 15.9.); the question of minors and nationality changes (Chapter 15.10) and whether only a spedified number of changes is possible (Chapter 15.11.). Here al so the question of dual nationality comes into play, namely, for which country, of which he or she is a national, the athlete will be able to compete and if he or she might re decide and change the country of representation at some point in their career.

Following the comparison, the next part will answer the second research question: To what extent are these currently applicable eligibility criteria in accordance with international standards of nationality law? (Chapter 16). Firstly, the desiderata (desirable rules) that can be derived from the touchstone principles will be elaborated upon. In the following, therules in force at present will be compared to the individual desiderata. The core postulation is that sporting federations should recognise the athlete's national ity and should have provisions for stateless athl etes and refugees that allow them to continue to compete internationally (Chapter 16.1). Moreover, it can be derived from the principles of international law that changes of the country of representation have to be all owed and should not be limited by a maximum number of changes (Chapter 16.2). In this context also the special position of athletes with multiplenationality will be addressed, as well as those who were faced with territorial transfers. In the following, the focus will be on the genuine link between athl lete and country, which should be recognised by the sporting federations if established via i) ius soli, ius sanguinis or a combination thereof; ii) option rights; iii) facilitated naturalisation after marriage, or iv) naturalisation (Chapter 16.3). In this context, al so the current practice of imposing residence requirements (Chapter 16.3.4.1) and waiting periods (Chapter 16.3.4.2) will be examined. Following this, the issue of gender equality (Chapter 16.4) and non-discrimination (Chapters 16.6) will be addressed. Another desiderata is that sporting federations should provide rules for those who lost their nationality and allow them to continue their career (Chapter 16.5), which is closely connected to theissue of stateless athletes and refugees. Finally, the focus will be on minor athletes and how eligi bility rules should offer them additional protection (Chapter 16.7).

Finally, this dissertation will answer thethird research question of how thetensions that may exist between the criteria applied by the sporting federations and the international standards of nationality law can be solved (Chapter 17). Here, first the problems will be briefly recapitulated (Chapter 17.1), before three possible solutions will be examined. This will firstly be the free market approach (Chapter 17.2), which will be rejected. Secondly, the proposal brought forward by some authors of 
introducing a separate sporting nationality will be examined (Chapter 17.3$).{ }^{49}$ As al so this notion may be rejected, the third solution of crafting a sporting license in accordance with international principles of nationality law will be presented (Chapter 17.4). In this context, a draft artide aimed at providing a comprehensive approach to issues of nationality in the sporting context, while taking theinternational standards of nationality law into consideration, will be offered (Chapter 17.4.2). In the ensuing condusions and recommendations (Chapter 18), firstly a brief summary of the nationality laws essential for the analysis will be given (Chapter 18.1), before answering the research question of which eligibility criteria in Olympic Sports currently exist (Chapter. 18.2). In the following, the extent to which it may be problematic to align the eligibility criteria with international standards of nationality law will be elaborated upon (Chapter 18.3). Finally, it will be indicated how the tensions that exist between the criteria applied by the sporting federations and the international standards of nationality law can be solved (Chapter 18.4).

\subsection{Terminology}

Throughout this dissertation, the exact terminology used by the different federations will be considered important Not only can inconsistencies in the terms used in an eligibility code create confusion, but al so each term may have several connotations and should therefore be chosen with care The term used in this dissertation to describe the link between a person and a state will be 'nationality' as opposed to 'citizenship'. This choice was made as the focus for eligibility criteria is purely the link between a person and the state he or she represents and without the added notion of (divil) rights as implied by 'citizenship'. However, in chapters 4 to 14 , the terminol ogy used by the individual sporting federations will al so be used in theanal ytical text

The same applies to the use of 'federation' and 'association' to describe the bodies governing the sports on thenational and international level. While federation is the term chosen for this dissertation, for individual sports the terminol ogy used in the statutes will be also used to describe the sport Therefore, the wording may change between 'citizen' and 'national' as well as 'federation' and 'association'.

\subsection{Glossary}

In the following, a brief glossary will provide short definitions of the terms most frequently used in this dissertation. While there might be other definitions and usages of theterms in different contexts, theseare the meanings and connotations intended for thepurpose of this dissertation.

49 D. Oswald (2009a), p. 58; Y. Hafner (2008), p. 1; Y. Hafner (2009), p. 216; Y. Hafner (2012), p. 238. 

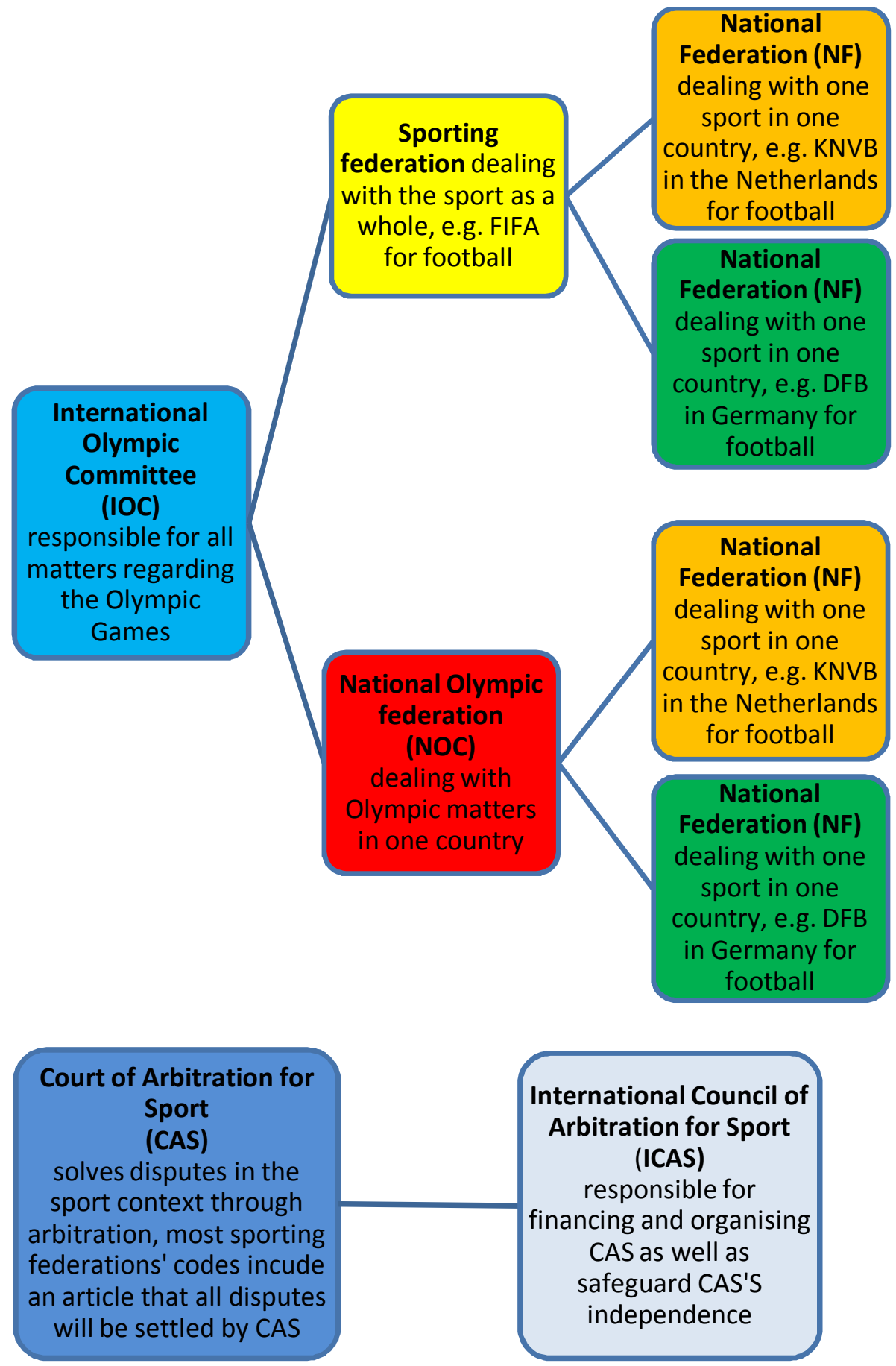

Figurel: Sport governing bodies 


\section{Sport governing bodies}

International Olympic TheIOC is a non-governmental organisation which has as Committee (IOC) its main aim to ensure that the Olympic Games are held every four years and that the Olympic spirit continues. It sets down its own rules regarding the organisation of the games and deals with all sporting and commercial matters.

National Olympic

Committee (NOC)

Sporting federation/ association

National federation/ association (NF or NA)
Most countries have established a separate committee that aims to further the countries' Olympic interests in that country, eg. by organising the athletes' travel to the games, promoting the Olympic sports, providing training facilities etc. National Olympic Committees also represent their states at Olympic level and are overseen by the $\rightarrow I O C$.

The body governing one sport, eg. FIFA is the body goveming all of football. They spell out all rules relevant to the sport from matters concerning protective gear and sports equipment, to commercial activities and antidoping. Sport federations/associations organise world championships as well as other international competitions and set down the qualification requirements athletes or teams need to meet to be digible for the Olympic Games. The eligi bility criteria for the Olympic Games need to be approved by the $\rightarrow$ IOC.

Body which govems an individual sport on national leve, eg. KNVB (Koninklijke Nederlandse Voetbalbond) governs football in the Netherlands as does the DFB (Deutscher Fußsball Bund) in Germany. These entities deal with the matters of one sport in an individual country and are thus responsible for national leagues, training and coaching, as well as sponsoring and other commercial matters of the national team In addition, they represent their country and its interests at meeting with the $\rightarrow$ sporting federation. 
Member

federation/association

H ost federation/ association

Court of Arbitration for Sport (CAS)
Another term for $\rightarrow$ national federation/association which is a member of the sporting federation governing the individual sport There are also non-member or nonassociated federations, which ladk official recognition.

The national federation of the country in which an athlete lives without having the nationality of the country. Some $\rightarrow$ national federationlassociation allow athletes to compete for their host federation in certain tournaments.

The Court of Arbitration for Sport (CAS) comprises an Ordinary Arbitration Division and an A ppeals Arbitration Division and maintains lists of arbitrators and mediators. Its main responsibility is dispute resolution in the sports context Such disputes may arise in the context of decisions taken by $\rightarrow$ national federations/associations and most of thesehavearbitration dauses in their rules or code book. The panels dealing with the disputes are usually composed of either oneor threearbitrators. Special, ad hoc divisions are set up prior to Olympic Games to deal with issues that need to be resolved speedily, such as questions regarding eligi bility.
International C ouncil of Arbitration for Sport (ICAS)

International Council of Arbitration for Sport ICAS is responsible for several things, such as the administration and financing of $\rightarrow$ CAS as well as facilitating the dispute resolution. Moreover, ICAS is to safeguard the independence of $\rightarrow$ CAS.

\section{Eligibility criteria}

Sporting licence
A licence given to an athlete by $a \rightarrow$ national federation/association, allowing the athlete to compete in official tournaments and leagues. Athletes may only obtain one if they follow the NF's code of conduct and other rules. Frequently, athletes may only obtain a licence from theNF of which they are nationals. 
Sporting nationality

Lex sportiva

A nationality for the sporting purposes. For some $\rightarrow$ national federation/association, the sporting nationality is considered unchangeable, thus for whichever country an athlete first competed intemationally will be the only country he or she can compete for, even if he or she acquires another nationality or already had multiple nationalities. Some authors wish to codify the sporting nationality for all sports.

Law governing sport and sport federations which is currently not one coherent body of law.

\section{Nationality law}

Nationality

Denominates a bond between the person and the state.

Citizenship

Denominates a bond between the person and the state and has the added connotation of civil rights granted to the person because of this bond.

Acquisition of nationality/citizenship

$\rightarrow$ Nationality and $\rightarrow$ citizenship are usually conferred upon children at their time of birth, either by $\rightarrow$ ius soli or $\rightarrow$ ius sanguinis. However, they may also acquire it through $\rightarrow$ naturalisation, if they have $a \rightarrow$ genuine link with the country.

Ius soli

The place of birth determines which $\rightarrow$ nationality or $\rightarrow$ citizenship a child acquires at birth. Traditionally used in immigrant countries to allow migrant children to become nationals.

lus sanguinis

The $\rightarrow$ nationality or $\rightarrow$ citizenship of the parents or one parent is automatically acquired by the child at birth. Rules differ among countries whether children may also acquire the nationality from the mother (a matre) or only through thepaternal line (a patre). 
Naturalisation

Genuine link

Residence

Statelessness
The process through which a person may acquire $\rightarrow$ nationality or $\rightarrow$ citizenship later in life, if they have $\rightarrow$ genuine link with the country. Usually conditional upon fulfilling several requirements, such as $\rightarrow$ residence Some countries have introduced facilitated natural isation procedures for non-national spouses of their own nationals.

If questions regarding the nationality or citizenship of a person arise, it is tested whether a genuine link between the person and the state in question exists. Such a genuine link may be established in different ways, eg. through $\rightarrow$ residence.

Residenceis deemed to exist if a person habitual ly resides in one country and has his or her centre of life there In many countries registration in the population registry may be revent. National laws and $\rightarrow$ sport governing bodies have different definitions and provide other requirements, such as $X$ out of $Y$ days per year, depending on the situation.

The status of a person who is not recogni sed by any state to bea national under theoperation of its laws. 


\section{Methodology}

As stated earlier, there are in principle three levels of rules which are relevant for the topic at hand. On the highest level, there are the rules of international law regarding nationality as well as the nationality laws of the individual states. Theseare applicable to everyone, athletes and non-athletes, when the nationality of an individual has to be determined. Although they are extremely important, elaborating on all of them would be outsidethescope of this dissetation.

The second level is that of the sport federations and their respective constitutions and codes of eligibility. They apply to athletes competing in the respective sports for national teams. Naturally, there is an interplay between the countries' laws on nationality and the codes of eligibility of the federations, since in most cases in order to become eligible for a national team an athl ete has to be recognised by the state as a national. ${ }^{50}$ The sport federations do, however, impose additional requirements, such as residence, in certain cases to decide on an athlete's eligibility.

The third level is that of the Olympic Charter, which al so has eligi bility criteria for athletes wishing to competein the Olympics. According to theartides and byelaws of the Olympic Charter, the sporting federations are free to determine the eligibility of athletes. However, there are several requirements for the representation of countries in the Olympic Games which areal ready stipulated in the IOC Charter itself. Thus, there is an interplay between these rules set by the IOC and those set by the sporting federations, which need to beapproved by the IOC.

Tablel: Levels of rules relevant to this dissertation

\begin{tabular}{|c|c|c|}
\hline Level & Documents & Applicable to \\
\hline $\begin{array}{l}\text { la } \\
\text { Rules of International } L \text { aw } \\
\text { on nationality }\end{array}$ & $\begin{array}{l}\text { - Treaties and Conventions, eg. } \\
\text { European Convention on } \\
\text { nationality }\end{array}$ & $\begin{array}{l}\text { - in principleto everyone, yet } \\
\text { the applicability of individual } \\
\text { documents depends on the } \\
\text { individual states (i.e } \\
\text { accession, ratification etc.) }\end{array}$ \\
\hline $\begin{array}{l}\text { l b } \\
\text { Nationality law of individual } \\
\text { states }\end{array}$ & - national rules on nationality & $\begin{array}{l}\text { - nationals of the individual } \\
\text { states and persons who aim to } \\
\text { acquirethenational ity of a } \\
\text { certain state }\end{array}$ \\
\hline $\begin{array}{l}2 \\
\text { International Sporting } \\
\text { federations }\end{array}$ & $\begin{array}{l}\text { - Eligibility codes for individual } \\
\text { sports and disciplines }\end{array}$ & - athletes of that particular sport \\
\hline $\begin{array}{l}3 \\
\text { Olympic Charter }\end{array}$ & - Olympic Charter & $\begin{array}{l}\text { - athletes competing in the } \\
\text { Olympic Games }\end{array}$ \\
\hline
\end{tabular}

50 In some sports, a separate sporting nationality is possible, i.a. in Wrestling: Introduction FILA international rules for the change of national ity approved by the Bureau on 15 J anuary 2015. 
The focus of this dissertation will be on the rules of the second and third level and the interplay between all threelevels. Consequently, the main method used to achieve this will be legal comparison. Therefore, a tertium comparationis, i.e a set of rules with respect to which the rules of the respective sports are compared, is needed. In addition, a tertiumval utationis is needed, meaning a set of criteria which enables an assessment of the rules involved and to identify the best practices.

\subsection{TetiumComparationis}

For the tertiumcomparationis one might consider the Olympic Charter itself; yet such a comparison would be faulty, considering that the Charter itself redi rects questions to the sporting associations and several sporting associations refer to the charter. ${ }^{51}$ Hence, an independent set of criteria is needed which has to either be chosen from an existing pool of criteria or created for this very purpose One might arguethat picking themost lenient set of rules provided by the sporting associations, or the strictest for that matter, would be a good tertium comparationis, but that would already include a value element in the pure comparison and lead to a onedimensional view. The best solution is thus to establish a mean or standard set of criteria, induding the average number of years for the residence requirement and the waiting period between participating for different countries. With regard to the non-numerical requirements, those mentioned most frequently will be considered to be the standard rule Consequently, all federations will becompared to this standard.

$Y e$, one particular problem arises with regard to this method, considering that some sporting federations change their rules and some, like tadkwondo, do so quite frequently. One has thus to pick a date that will count as day zero with regard to this study and which will be considered to be the basic standard. Sincel started writing this dissertation on $15^{\text {th }}$ October 2013, this will bethe date used for the first standard set of rules, which will be used as a tertium comparationis. In the course of the research, I reviewed changes in the rules twice a year, on $15^{\text {th }}$ A pril and $15^{\text {th }}$ October. From $25^{\text {th }}$ J une 2015 onwards, the federations' websites were checked weekly and the final day on which the website was checked for updates was $1^{\text {th }}$ May, 2016.

These eligibility rules and rule changes will be elaborated upon for the individual sports. In addition, the individual rules for each sporting federation will be compared to one another in the time span of $2005-2016$. Several problems arose in this context. Firstly, not all sporting federations were willing or able to provide previous rules for the purpose of this research. Secondly, not all topics which are of interest for the purpose of this dissertation were treated with equal detail among the federations. There are thus several aspects which were only dealt with by less than one third of the sporting federations. For those topics, therefore, one cannot draw conclusions that are applicable to the eligibility criteria of Olympic sports in their entirey. Thirdly, not all

51 E.g. weightifting Rule 113.2 IWF constitution and by-laws 2013 - 2016 - approved by IWF congress- Baku in effect with 01.01.2015. 
sports underwent a substantial change in their eligibility criteria within the examined timeframe

Consequently, there is a certain bias in the results, as developments could only be monitored in an extremely limited number of cases. While significant conclusions may be drawn for individual sports or individual topics, the big differences between the approaches used for the different spots makes formulating overall trends difficult.

\subsection{Tertiumvalutationis}

With regard to the tertium valutationis, the choice of a set of rules is significantly easier. The rules of the federations and the Olympic Charter have to respect the international standards regarding nationality law on the acquisition and loss of nationality. Consequently, the sporting federations may, for example, make no distindion with regard to eligibility for children born out of wedl ock or children who were adopted. In this regard, the focus of the FIFA rules on the country of birth of the biological parents is problematic. ${ }^{52}$ Going into more detail, thesituation becomes more complicated, because a genuine link between athlete and country of representation is required and different countries have different ways of determining the existence of such a link. This genuine link is of vital importance not only for the sporting federations, who wish to minimisethemercenary tendencies, but more so for countries that wish to confer their respective national ity only on those who genuinely bel ong to their community.

Starting from the situation of acquisition of nationality at birth, the practices of conferring nationality through the bloodlines, i.e ius sanguinis or on the ground of birth on a certain teritory, ius soli, provide states with a significantly different pool of potential athletes. However, nowadays the fault lines between the two are bluring, since many traditional ius soli countries have introduced additional requirements, such as the legal residence of a parent and several ius sanguinis countries haveincorporated elements of ius soli for migrant children. ${ }^{53}$ The use of ius soli or ius sanguinis in the patemal and/or maternal line influences the pool of athletes significantly. Most potential athletes are available to countries that make use of both ius soli and ius sanguinis in both the paternal and maternal line If only ius sanguinis a patre is used, meaning the child's nationality is determined soley on the basis of the nationality of the father, the pool of potential athletes is significantly smaller. However, states originally with a smaller pool of children that will be their nationals have introduced certain compensation mechanisms that all ow children born on their teritory to foreign parents or to children borm to a national to acquire the national ity of that state at a later stage, for example through the possibility of option or facilitated naturalisation, after

Art. 7(b) FIFA statutes: regulations governing the application of the statutes 2016.

K. Hail lbronner (2006), p. 54; P. Weis (1979), p. 95; T. A. Aleinikoff and D. B. Klusmeyer (2002), p. 2. 
having fulfilled additional requirements. Through these compensation mechanisms, theinequal ity between states with regard to their potential athletes is reduced. ${ }^{54}$

Sporting federations also incorporate additional requirements like the residency or nationality of the grandparents for those athletes who hold either dual nationality or who have acquired a new nationality and wish to change their country of representation. ${ }^{55}$ In case the athl ete has al ready fulfilled the requirements set by the state to become a national via the aforementioned compensation mechanisms, the sporting federations are reintroducing inequality. One can thus stipulate that additional requirements set by sporting federations should apply in general only to athletes who have not established their genuine link with a country through fulfilling thereasonable requirements set by the country, eg. residency. ${ }^{56}$

Otherwise the case could arise that an athlete was bom in country A that applies ius sanguinis, yet his or her parents are from country $B$ and are only legally residing in country $A$. The athlete grows up in country $A$ and, upon reaching the age of majority, makes use of the naturalisation or options procedure upon which the competent authority will take the aspects of birth in the country and residence etc. into consideration. The athlete could thus now in principle compete for country A; however, depending on the sporting federation, there might be further obstades, such as additional requirements regarding the birth place of the biological parents, a residencerequirement or a waiting period in his or her intemational career after having acquired thenew nationality. This enforced waiting period can range from one year in the case of athletics to four years in the case of ice hockey. ${ }^{57}$ Such requirements can impose unreasonable restrictions, because the athlete has al ready passed a certain set of additional requirements to become a national of country $A$ and - furthermore - if the country would have applied ius soli he would al ready have been a national.

The sporting federations' additional requirements are however very important in other places when countries are circumventing their own normal procedures for those athletes who do not have a genuine link but who would greatly enhance the countries' Olympic chances. Only through the additional requirements, such as the residency or the waiting period, can the balance between the countries in such cases be somewhat reestablished. In this way, more opportunistic changes of the country of representation are - if not entirely made impossible- at least discouraged, as was the case with rugby whereathl etes may in principlenot changetheir 'Rugby nationality'. ${ }^{58}$

\footnotetext{
$54 \quad$ G. R. deGroot \& J.J. Kuijpers (2006), pp. $145 f$.

55 E.g. Art. 28(1a) ITU constitution approved by the ITU congress, September 2015; Art. 21(b) book 3 chapter I FIBA rule book 2014 - 2019; Art. 5(1) FIFA statutes: regulations governing the appl ication of the statutes 2016.

$56 \quad$ G. R. deGroot \& J.J. Kuijpers (2006), pp. $147 f$.

57 Rule 5(2)(b) International Association of Athletics Federations competition rules 2016-2017 in Force as from $1^{\text {t }}$ November 2015; Art. 406(1.3) IIHF statutes and bylaws 2014 - 2018.

58

Art. 8.2 International Rugby Board handbook as framed by the International Rugby Board last updated: $1^{\text {st }}$ January, 2016; Question 4 explanatory guidelines on the implementation of regulation 8 Eligibility to play for national representative teams - book International Rugby Board handbook as framed by the International Rugby Board last updated: $1^{\text {st }}$ J anuary, 2016.
} 


\subsection{Data gathering}

The information on the respective eligibility criteria was initially gathered twice annually, on $15^{\text {th }}$ October and $15^{\text {th }}$ A pril. Each time, the official federations' websites were checked twice on the actual day and once on the day after to ensure that even changes occurring later in the day were taken into consideration. From $25^{\text {th }} \mathrm{J}$ une 2015 onwards, the federations' websites were chedked weekly. The final day on which the website was checked for updates was $1^{\text {th }}$ May 2016. One of the problems that occurred in this context was that federations do not immediately place their updated rules on their websites, eg. Athletics only uploaded the 2016-2017 Rules, which had been applicable since November 2015, on $6^{\text {th }}$ January, 2016. Furthermore, the federations were contacted for further information regarding the eligi bility criteria prior to 2013.

Looking at the changes that occurred within the set timeframe, from October 2013 until April 2015, there were 19 sports that did not have any substantial rule changes ${ }^{59}$ This means that half of the relevant sports did not alter their eligibility criteria. It is even more striking that there are nine sports that have not changed their eligibility rules since 2005, or earlier, namely: badminton, bobsleigh, fencing, gymnastics, judo, shooting, tabletennis, tennis, and triathl on. Hence, a quarter of the Olympic sports has been applying the same rules regarding national ity for the past decade Thanks to the various sporting federations, I received the rules that wereapplicablesince 2005 for 18 different sports and can consequently draw conclusions on the development or lack thereof regarding criteria for national teems. ${ }^{60}$

In order to ensure that all eligibility criteria were interpreted in the sense that the federations attribute to them and to provide the federations with the possibility to comment on their rules, the descriptions of the eligibility rules were sent to the federations' representatives on $29^{\text {th }}$ October, 2015. 18 federations replied to this email by $19^{\text {th }}$ November, ${ }^{61}$ when a first reminder was sent to theremaining federations. Over the next days, eight federations answered, ${ }^{62}$ and on $2^{\text {nd }}$ December a second reminder was sent to which four federations answered. ${ }^{63}$ As five federations ${ }^{64}$ had not replied by $8^{\text {th }}$ February 2016, a final reminder was sent, giving the federations the deadline of $22^{\text {nd }}$ February 2016, to which two federation replied. ${ }^{65}$

Namely: archery, badminton, basketball, biathlon, bobsleigh, canoe kayak, fencing, gymnastics, handball, hockey, judo, luge, shooting, skiing, tabletennis, tennis, triathl on, and weightlifting. Aquatics, athletics, bobsleigh, curling, cycling, equestrian, fencing, football, golf, gymnastics, ice hockey, judo, modern pentathl on, rowing, shooting, tabletennis, tennis, and triathlon.

61 Aquatics, archery, basketball, biathlon, canoe kayak, curling, equestrian, fencing, gymastics, handball, hockey, ice hockey, judo, modern pentathlon, rugby, shooting, skating, and skiing.

Athletics, badminton, bobsleigh, cycling, football, golf, luge, and weight ifting.

Rowing, tennis volleyball and wrestling.

Boxing, sailing, table tennis, taekwondo, and triathlon.

Boxing and rugby. 



\section{Principles of nationalitylaw}

Sovereign states are autonomous in nationality matters and may as such determine their national laws without interference from other states. ${ }^{66}$ Each state is free to determine who becomes a ditizen or a national. ${ }^{67}$ The only limits are those which states impose on themsel ves when acceding to treaties or conventions and general principles of law. Other states have to recognise the national laws of others, as long as these do not contravene

"intemational conventions, customary international law and the principles of law generally recognised with regard to nationality." ${ }^{\text {68 }}$

Should any state thus contravene principles such as non-discrimination on the basis of religion and make the transferral or possession of nationality conditional upon bel onging to a certain religion, other states would not need to recognise this law. The influence states can exercise over other states in such cases is however limited due to stateautonomy. Placing extemal pressure on states through diplomatic efforts or when negotiating trade and other economic relations is usual ly not successful in such cases.

Nationality and citizenship connote a significant re ationship between the state and a person. ${ }^{69}$ For the parties involved, the results are essentially two-fold: firstly, the individual's relationship to the state determines the scope of rights and duties the person has to the relevant state, ${ }^{70}$ eg. only citizens have unrestricted access to the state's teritory and have to be readmitted after sojoums abroad. ${ }^{71}$ Secondly, due to the special bond between a person and the state, it is the state's duty to protect the person. ${ }^{72}$ However, the amount of security derived from citizenship depends on the general outlook of the state, with democratic and well-governed states providing more security than corrupt states or those in which power vacuums have been filled by nonstateorganisations. ${ }^{73}$

The question to which state a person is linked and which state thus can offer its protection to the person is frequently at the heart of modem day conflicts ${ }^{74}$ and thus the distinction between citizens and foreigners remains of paramount importance for states. ${ }^{75}$ Consequently, access to nationality and citizenship is heavily regulated and

P. Weis (1979), pp. 31 and 67.

Art. 3(1) European Convention on Nationality; R. Bauböck, E. Ersboll, K. Groenendijk, and H. Waldrauch (2006), p. 15; O. W. Vonk (2012), p. 30.

Art. 3 (2) European Convention on Nationality.

P. Weis (1979), p. 29; R. Bauböck, E. Ersboll, K. Groenendijk, and H. Waldrauch (2006), p. 15.

K. Hail bronner (2006), p. 36; C. Joppke (2010), p. 27.

O. W. Vonk (2012), p. 34; M. P. Vink (2005), p. 9; P. Weis (1979), p. 45.

K. Hail bronner (2006), pp. 36f; E. Horváth (2008), p. 1.

R. Falk (2002), p. 22.

T. A. Aleinikoff and D. B. Klusmeyer (2002), p. 2; K. Hail lbronner (2006), pp. 36f; A. Shachar (2009), pp. 7ff.

S. W. Goodman and M. M. Howard (2013), p. 114. 
these barriers are frequently used to stop unwanted people from entering the community. ${ }^{76}$

In the beginning, nationality laws started out short and simple but, with increasing problems of migration, especially the first wave of mass migration after the Second World War, new rules were introduced, making everything more complex. ${ }^{77}$ Especially in European countries, such as Italy and Spain, which were traditionally emigrant countries and are now faced with many immigrants, thenationality laws have yet to catch up with the situation in practice ${ }^{78}$

Nationality or citizenship is usually confered upon children at birth, although later acquisition through naturalisation is possible ${ }^{79}$ Naturalisation, which is conditional upon having created a significant link with a country which is not the country of origin, eg. through permanent residence, has become increasingly important in the current age of globalisation and migration. ${ }^{80}$ Not only the laws themselves are important, but al so the practical implementation of nationality and naturalisation laws play an important role and could potentially become obstacles for those willing to acquirea new nationality. ${ }^{81}$

In the following, attention will be paid to the terminology and connotations invoked by the use of the terms ditizenship and nationality (Chapter 3.1), before turming to the importance of the genuine link between a person and the state (Chapter 3.2). Thereafter, the modes of acquisition (Chapter 3.3) and loss of nationality (Chapter 3.6) will be elaborated upon, including brief summaries of the respective historic relevance and developments. Finally, issues of dual national ity (Chapter 3.4), territorial transfers (Chapter 3.5), as well as the problematic aspects of nationality in the context of the refugees, asylum seckers and statelessness, as well as the issue of 'passports for sale' (Chapter 3.7), will be ind uded. Finally, the intemational standards of nationality law, as used in this dissetation, will be examined (Chapter 3.8).

\subsection{Nationality and citizenship}

3.1.1. National ity and citizenship - terminology and devel opment

What does national ity actually entail? Starting with the origins of the word, scholars generally consider its etymology to have its roots in the Latin terms ' natio' or 'nasci'. 'Natio' is said to include the connotation of the modern words 'nation', 'people', but al so 'state'. ${ }^{82}$ Some however suggest that it was initially used to refer to foreigners, which would be contrary to modem day usage ${ }^{83}$ 'Nasci' in turn meant 'to be born'

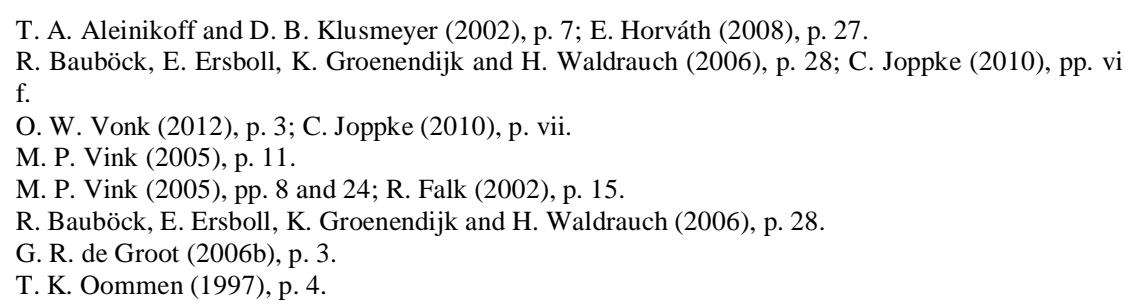


and thus has the connotation of descent and ethnic or tribal origins ${ }^{84}$ The modern concept of nationality was first introduced when the feudal system collapsed, ${ }^{85}$ while the idea of the nation state dates back to the Treaty of Westphalia. ${ }^{86}$ The connotations of both concepts vary depending on the focal point while in the course of Western history, nation and nationalism have both been unifying and destructive, for postcolonial countries, the surge of nationalisation has frequently been regarded as positive $^{87}$ Nowadays, regardless of the word's original usage, the terms used by modern states are dosely related to the Latin root and are therefore similar, eg. Nationalität (German), nationalité (French), nationaliteit (Dutch) or nazionalità (Italian) ${ }^{88}$

Another word that also is frequently used in order to express the connection between a certain state and a person is "ditizenship". ${ }^{89}$ This term usually has the connotation of full membership of a community, which guarantees the individual's right to fundamental principles such as faimess and justice ${ }^{90}$ Thus, it is distinctly more focussed on the complex and political dimensions. ${ }^{91}$ In general, the rights attached to modern citizenship arrived in three waves: the first, civil rights in the $18^{\text {th }}$ century; the second, political rights in $19^{\text {th }}$ century, and the third, social rights in the $20^{\text {th }}$ century. ${ }^{92}$ However, these waves did not reach all parts of society in all countries at the same time, as women in some countries arestill preduded from exercising voting rights and minorities are often excluded from social rights.

Looking at the advent of 'citizenship' most scholars point to ancient Rome or Greece ${ }^{93}$ Citizenship is often seen as dating back to the Greek polis of Athens and, as such, there seems to be an inherent link between democracy and citizenship. ${ }^{94}$ However, slaves and plebeians were not involved in the decision-making process. ${ }^{95}$ Greek citizenship was considered to transcend borders, although outside the border of the respective polis no legal rights were attached to it ${ }^{96}$ Contrarily, under Roman law citizenship status only gave the individual protection and not necessarily political rights, which were held exclusively by patricians. ${ }^{97}$ However, Roman citizenship was granted to those conquered by the Roman Empire ${ }^{98}$ Interestingly, deprivation of

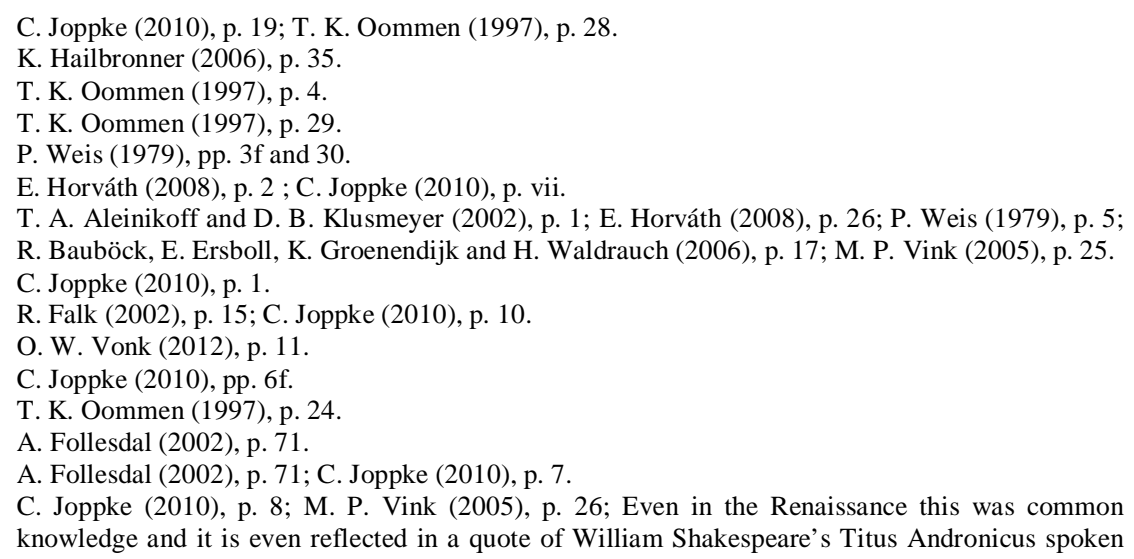


citizenship partially derives from the Roman law of a banishment, which meant that a previous citizen of Rome was forced to live outside the territory of the Roman Empire $^{99}$ The concept of citizenship lost its importance in feudal times and only the small city states of the Renaissance, such as Florence, maintained the political aspects in small participatory communities. ${ }^{100}$

Both Greek and Roman law relied solely on ius sanguinis, which lead to sons and daughters of slaves also being slaves ${ }^{101}$ Contrarily, in the Middle Ages, subjects were considered bound to the ground they were born on and, as such, property of the landholding dasses, i.e clergy and nobility. However, ius soli, the connection of birth on the soil of a particular country and belonging to the people of the country, is said to have first been explicitly advocated in the 1608 Cal vin case ${ }^{102}$ This Engl ish common law case concerned the question whether a person born in Scotland in 1606, Cal vin, ${ }^{103}$ after the Scottish King J ames I had al so become king of England in 1603, could be considered to be English and thus allowed to hold land in England. Seeing that Cal vin had been born after the J ames I was also King of England, hewas considered to have been born a subject to the King of England. ${ }^{104}$

A change from feudal structures and ius soli occurred with the French Revolution and, in its wake, everyone in France obtained the status of a 'citizen', whereas previously everyone had been a subject to the king. ${ }^{105}$ This also marked the re introduction of ius sanguinis, which becamethestandard way of attributing citizenship in the Code Napoleon. ${ }^{106}$ Due to the Napoleonic conquests and the subsequent applicability of the Code Napoleon in most of Westem Europe, this practice spread. A different picture presents itself when looking at the United States of America, traditionally immigrant country, where the adherence to ius soli citizenship was heavily debated and even challenged by the Southern States as it would grant citizenship to children of slaves. ${ }^{107}$

\subsubsection{Connotations of 'nationality' and 'citizenship'}

Whether 'citizenship' or 'nationality' is the appropriate term to use and which meaning and connotations are invol ved depends on the fiedd of study, discipline, legal system, and language used. ${ }^{108}$ It is stipulated that countries which previously referred to peopl eas subjects often now call them citizens to underlinethe change that occurred

by the Tamora, Queen of the conquered Goths: 'I am incorporate in Rome, A Roman now adopted happily' (William Shakespeare Titus Andronicus Act I, Scenel).

P. Weis(1979), p. 117.

E. Horváth (2008), p. 26.

P. J. Spiro (2013), p. 31.

P.J. Spiro (2013), p. 32

Calvin's guardians started the legal proceedings.

P. J. Spiro (2013), p. 32.

O. W. Vonk (2012), pp. 11 and 14f; E. Horváth (2008), p. 9; C. Joppke (2010), p. 11; K. Marx (2010), pp. 29ff.

E. Horváth (2008), p. 9; O. W. Vonk (2012), pp. 11 and $15 f f$.

P. J. Spiro (2013), p. 32.

O. W. Vonk (2012), p. 19; E. Horváth (2008), p. 3. 
in the social structure ${ }^{109}$ Likewise, some argue that nationality is perceived as having ethnic connotations and is thus not frequently used in Germany or Italy due to their history. ${ }^{110}$ In the Europeen context, the European Convention on Nationality defines theterms as follows:

"nationality" means the legal bond between a person and a State and does not indicate theperson's ethnic origin;

"multiple nationality" means the simultaneous possession of two or more nationalities by the same person; ${ }^{111}$

However, one needs to underscore that this convention was only signed by 29 European states and ratified by only 20 ; hence the abovementioned definitions cannot be used in all countries and in all contexts. ${ }^{112}$ For example, Croatia signed the Convention in 2005, but has not yet ratified it, while Belgium, Ireland, and Spain have not even signed it ${ }^{113}$

All in all, 'citizenship' and 'nationality' are used interchangeably in some countries, but other languages make a clear distinction, eg. German Staatsange hörigkeit (national ity) and Staatsbürgerschaft (citizenship). ${ }^{114}$ In German Nationalität (nationality) exists as a term, yet due to its ethnic connotation, it is less frequently used in legal context

The resulting distinction between 'nationals' and 'citizens' has frequently been at the heart of eligibility cases, as in the Perez I, II and III VIOC cases. ${ }^{115}$ In English the terms are confused the most, while on the continent nationality is generally used for the link between a person and the state and citizenship is used for the bond with political rights and political membership between a person and the state ${ }^{116}$ The issue becomes more complex as both concepts overlap and in most cases every citizen will al so be a national, but a national is not necessarily a citizen. ${ }^{117}$ Furthermore, thereare sub-categories with varying rights and definitions in some states, such as 'denizens', 'quasi-citizens', and 'nationals with less rights'. ${ }^{118}$ In some countries, there are al so large non-citizen minorities, eg. Russian migrants and their descendants in Latvia. This came about as Latvia granted citizenship to those who were Latvians before the occupation in the1940s. Yet, the Russian migrants were left in the lurch by both countries as they did not acquire Russian nationality either. ${ }^{119}$ Another example are Palestinians, who do not have Palestinian nationality, for a lack of a recognised

\footnotetext{
109 P. Weis (1979), p. 4.

$110 \quad$ O. W. Vonk (2012), p. 20.

111 Art. 2 European Convention on National ity.

112 European Convention on National ity Treaty Office.

113 As on $3^{\text {rd }}$ January, 2016 according to European Convention on Nationality Treaty Office

114 E. Horváth (2008), p. 3.

115 Perez I, II and III v IOC- CAS OG (Sydney) 00/001,00/005,00/009, Digest of CAS Awards II, pp. 595, 625 and 651; see Chapter 4.5.

116 O. W. Vonk (2012), p. 19.

117 P. Weis(1979), p. $5 f$.

118 R. Bauböck, E. Ersboll, K. Groenendijk, and H. Waldrauch (2006), pp. 19 and 28 .

119 O. W. Vonk, M. P. Vink, G. R. deGroot (2013), p. 11.
} 
Pal estinian state ${ }^{120}$ They often live in MiddleEastern and North African countries but cannot obtain the nationality of their host country due to the Casablanca Protocol, in which the League of Arab States agreed in 1965 to ensure the continuation of the Palestinians as a separateentity. ${ }^{121}$

In the following examples, the US and the UK will be examined, as the terminology used in this dissertation is in English and translations do not transmit the full meaning and connotations. For the UK, ${ }^{122}$ British nationality and citizenship are stipulated in the British National ity Act 1981 and the subsequent amending acts, such as British Nationality (Falkland Islands) Act 1983, ${ }^{123}$ or the Borders, Citizenship and Immigration Act 2009. ${ }^{124}$ In general, 'nationality' is used in the sense of a formal relationship between a person and the state ${ }^{125}$ However, with regard to 'citizenship', the term is used to indicate that the UK government has granted certain rights to the person. In this respect, the differentiation between actual "British Citizens" and "British Overseas Citizens" is important to underscore, since the respective groups enjoy different rights. ${ }^{126}$ In addition to the fact that the British National ity Act 1981 is entitled a 'nationality act' and then deals with a citizenship, there are also other interesting aspects: there is the general category of Commonwealth citizenship, which is the category applicable to British citizens, a British overseas territories citizen, a British national (overseas), a British overseas ditizen or a British subject ${ }^{127}$ In addition, there is the British protected person status. ${ }^{128}$ These six categories are determined as follows:

- British citizen: any person born in the UK will be a British citizen, provided that one parent was a British citizen or settled in the UK. ${ }^{129}$ This is the only category which al so provides automatic access to European Union citizenship.

- British overseas teritory citizen: any person born in a British overseas territory, e.g. Gibral $\operatorname{tar}^{130}$ will bea British overseas citizen, provided that one parent was a British overseas ditizen or settled in British overseas teritory. ${ }^{131}$ These persons have British passports but are not automatically European Union citizens. The position of Gibraltar is a special one, as Gibral tar is treated as part 2002, maintained the distinct citizenship categories while changing the status of some people so that they belonged to a different category, eg. the citizens of Hong Kong. Which introduced 'probationary citizenshi p'. For further information, see L. Fransman (2011). 
of the EU in several respects. ${ }^{132}$ Citizens of Gibraltar, as the only British overseas territory citizens, may however register as British citizens for the purpose of theEU treaties. ${ }^{133}$

- British national (overseas): A person who had a connection to Hong Kong as a British overseas teritories citizen and registered as a British national (overseas) before 1J uly 1997. ${ }^{134}$

- British overseas citizen: a person born on formerly British Hong Kong teritory after 1997 to a parent who was either a British national (overseas) or a British overseas ditizen, and who would have been stateless if British overseas citizenship had not been conferred upon him or her. ${ }^{135}$

- British subjects without ditizenship: any person who was so under the 1948 $\mathrm{Act}^{136}$, i.e prior to the Republic of I reland Act 1948, which ended theinfluence of the British Monarchy in the Republic of Ireland.

- British protected person: a person born after 1983 as a citizen or national of Brune or would otherwise have been bom stateless (without a country) in the UK or an overseas territory as one of the parents was a British protected person. ${ }^{137}$

Only fully fledged British citizens can travel fredy to the UK and are automatically European Union citizens, all others are subject to standard immigration rules, although they do have British passports.

With regard to the United States of America, nationality, citizenship and therights connected therewith (especially voting rights) can be even more problematic. This distinction between 'nationals' and 'citizens' has been at the heart of sport cases, such as the Perez I, II and III V IOC cases. ${ }^{138}$ In addition to the mainland States, there are several United States teritories that have a unique position with regard to citizenship and nationality. These territories are the inhabited teritories of American Samoa, Guam, Northern Marina Island, Puerto Rico, U.S. Virgin Islands, and Wake Island. Initially, inhabitants of these islands were U.S. nationals, but not U.S. citizens. This has changed for several of these teritories through different legislative acts and nowadays a person born in Pueto Rico, ${ }^{139} \mathrm{Guam}^{140}$ or the Virgin Islands, ${ }^{141}$ also becomes a U.S. national as well as a US citizen at birth. This is however not the case

Dedaration 55 Annexed to the Final Act of the Intergovernmental Conference which adopted the Treaty of Lisbon 2007; Art. 355(3) Treaty on the Functioning of the European Union. Section 5 British Nationality Act 1981 and British Overseas Territories Act 2002; Government of Gibraltar (1997).

134 British Nationality Hong Kong Act 1990.

135 Types of British nationality: https://www.gov.uk/types-of-british-nationality/british-overseascitizen.

136 Art.30 and 31 British Nationality Act 1981.

137 Types of British nationality: https://www.gov.uk/types-of-british-nationality/british-overseascitizen.

138 Perez I, II and III v IOC- CAS OG (Sydney) 00/001,00/005,00/009, Digest of CAS Awards II, pp. 595, 625 and 651; see Chapter 4.5.

$139 \S 302$ (US CodeTite 81402 ) Immigration and Nationality Act 2011.

$140 \S 307$ (US CodeTite 81407 ) Immigration and Nationality Act 2011.

$141 \S 306$ (US CodeTitel 8 1406) Immigration and Nationality Act 2011.
} 
for children bom in American Samoa, a US outlying possession, ${ }_{142}$ who become US nationals at birth, but do not automatical ly become US citizens. ${ }^{143}$ In order to become US citizens later in life, they will need to undergo the standard naturalisation procedureand pay the usual fees.

The historical roots of this problematic situation of citizens or nationals and their respective voting rights are evidenced in original insular cases, such as Downes v Bidwell ${ }^{144}$ dating back to 1901 . The reasoning was that:

"If those possessions are inhabited by alien races, differing from us in religion, customs, laws, methods of taxation, and modes of thought, the administration of government and justice, according to Anglo-Saxon principles, may for a time be impossible $[. .$.$] We dedine to hold that there is anything in the Constitution to$ forbid such action. Weare therefore of opinion that the island of Porto Rico is a territory appurtenant and belonging to the United States, but not a part of the United States within therevenuedauses of the Constitution [... ["145

Therefore, while the teritories were part of the United States, the United States' Constitution did not apply there and, consequently, inhabitants of these territories still lack essential voting rights. Despite the fact that this judgment clearly underlines that the impossibility of applying Anglo-Saxon principles is merely 'for a time', these cases and the reasoning justifying them still havenot been overnul ed. Regardl ess of the clearly racist tones of the original judgment, which in no way conforms to today's norms, theseinsular cases are even cited in current cases. ${ }^{146}$

\subsection{Nationality as a manifestation of a genuinelink}

Nationality in international law is the primary connecting factor between a person and a specific nation or, rather, a people or a particular state This tie is referred to as a 'genuine link', meaning that the connection between them is deemed to bestrong. ${ }^{147}$ In case of arising disputes such as in a sports context, it can be taken into consideration when deciding on the eligibility of an athlete for a certain team ${ }^{148}$ The concept of the 'genuine link' derives from the 1955 Nottebohm case In that case, Liechtenstein and Guatemala disputed the question whether Liechtenstein could grant diplomatic protection to Nottebohm, who had been living in Guatemala and had been expropriated there, after he had acquired the national ity of Liechtenstein only through naturalisation and without actually having lived in the country:

"[...] his actual connections with Liechtenstein were extremely tenuous. No settled abode, no prolonged residence in that country at the time of his application

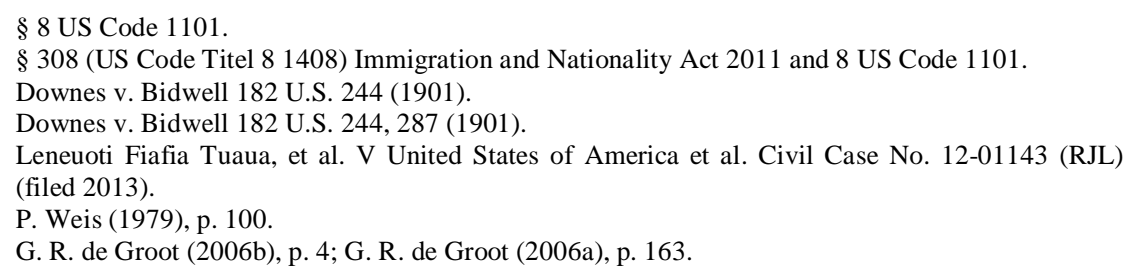


for naturalization: the application indicates that he was paying a visit there and confirms the transient character of this visit by its request that the naturalization proceedings shoul d beinitiated and cond uded without delay."149

The outcome was that Liechtenstein, as a sovereign state, could indeed give its nationality to a person who did not have a genuinelink with the country:

"It is for Liechtenstein, as it is for every sovereign State, to settle by its own legislation therules relating to the acquisition of its nationality, and to confer that nationality by naturalization granted by its own organs in accordance with that legislation." 150

However, protecting Nottenbohm's claim to property against Guatemala was not possible

"Guatemala is under no obligation to recognize a nationality granted in such circumstances. Liedhtenstein consequently is not entitled to extend its protection to Nottebohm vis-à-vis Guatemala and its daim must, for this reason, be held to beinadmissible"151

Ergo, the genuine link is not a factor preventing someone from acquiring a new nationality. However, in the case of new disputes, such as in a sports context, it can be taken into consideration when deciding on the eligibility of an athlete for a certain team ${ }^{152}$

\subsection{Acquisition of nationality}

\subsubsection{Acquisition at birth}

Having established the state's autonomy regarding the conferral of their nationality on indi viduals, it is important to takea doser look at how this conferral is generall y made This is primarily done at the time of birth, with factors like the place of birth (ius soli) or blood relations (ius sanguinis) determining which nationality a child acquires. ${ }^{153}$ The situation of foundlings is more problematic, although it is generally agreed that they, as well as children who would otherwise be stateless, should acquire the nationality of the country wherethey were bom or found respectively. ${ }^{154}$

Looking more closely at ius sanguinis, it is clear that this tradition was already employed in Ancient Greece and Rome, which had the effect that the children of

Art. 1, 2 and 4 Convention on the Reduction of Statelessness 1961; K. Hail lbronner (2006), p. 56; T. A. Aleinikoff and D. B. Klusmeyer (2002), p. 2; G. R. de Groot (2006b), pp. 5f; P. J. Spiro (2013), p. 31; M. P. Vink (2005), p. 11; O. W. Vonk (2012), p. 45; H. Waldrauch (2006a), pp. 121, 125 and 128; G. R. de Groot and J. J. Kuipers (2006), p. 144. 
slaves were unable to obtain ditizenship rights. ${ }^{155}$ Following the predominantly ius soli which applied in the Middle Ages, the French Revolution saw a return to ius sanguinis and, after the Napoleonic conquests and the subsequent spreading of the Code Napoleon, this practice became common place throughout the French Empire ${ }^{156}$ Traditionally ius sanguinis a patre, thus transferral through the paternal line, was used to reflect the patriarchal structure of society, but, nowadays, ius sanguinis a matre is also used. ${ }^{157}$ This was previously only possible for children born out of wedlock, as in these cases only the identity of the mother could be established beyond doubt Birth out of wedl ock may still be problematic in ius sanguinis countries, but most countries have recently introduced reforms to counter the discrimination of these children. ${ }^{158}$ However, with the increasing mobility and the occurrence of marriages between people holding different nationalities, new complex problems have arisen. ${ }^{159}$ One of the questions arising in the context of ius sanguinis is how parentage may be established, especially when one takes the new medical possibilities, for example surrogacy, into consideration. An answer may be found in Recommendation CM/Rec (2009)13, which underlines the high risk of statelessness in case of surrogacy, and, while noting that a child-parent relationship cannot be automatically assumed in the event of surrogacy, stipulates that:

"[i]f the child-parent family relationship is recognised in the state of nationality of the commissioning mother or father the provisions of that stateon the acquisition of nationality jure sanguinis have to be applicable The child will be fully integrated into the family of the commissioning parents, which justifies - as in

the case of adopted children - theacquisition of thenationality of the parents."160

It is hence the actual family relationship and not the process of birth that establishes the link between child and parent in such cases. Another issue of solely relying on ius sanguinis is that children of immigrant parents will remain non-nationals in the country in which they were bom and grew up in. In order to allow the indusion of second generation migrants, several countries have created medhanisms through which these people can acquire or chose the nationality of the country in which they were bom. ${ }^{161}$

\footnotetext{
155 P.J. Spiro (2013), p. 31.

156 E. Horváth (2008), p. 9; O. W. Vonk (2012), pp. $16 f$.

157 G. R. deGroot (2012), p. 610.

158 H. Waldrauch (2006a), p. 132; a discrimination which has been known to be unfair for centuries that is has already been bemoaned by Edmund in William Shakespeare's King Lear: "Why bastards? Wherefore base? [...] - why brand they us with base?[...]Our father's love is to the bastard Edmund as o th' legitimate. Fine word 'legitimate'![... ]Now, gods, stand up for bastards." (William Shakespeare, King Lear, Act I, Scenell).

159 K. Hailbronner (2006), p. 55.

160 Principle 12 Explanatory Memorandum Recommendation CM/Rec (2009)13.

161 Art. 17 Appendix to Recommendation CM/Rec(2009)13; For example in Germany, see $\S 4(3)$ Staatsangehörigkeitsesetz (StAG).
} 
Contrarily, ius soli, as previously outdined, relies on the placea person was born as the connecting factor to the country. ${ }^{162}$ The practice was first established in the Middle Ages when subjects were considered to be bound to the ground they were born on and, as such, property of thelandholding classes ${ }^{163}$

In recent years, in most countries a convergence has taken place, with ius soli countries adopting some ius sanguinis aspects and viceversa. ${ }^{164}$ That way, traditional ius soli countries grant their nationality to the children of their nationals born abroad under certain circumstances. ${ }^{165}$ Nowadays, most purely ius soli countries can be found in the Americas, ${ }^{166}$ such as the United States of America, ${ }^{167}$ Nicaragua, ${ }^{168}$ and Mexico. ${ }^{169}$ Others, such as Columbia, ${ }^{170}$ have included additional criteria for ius soli al ong the lines of:

“1) the parents' duration of residenceat thetime of the child's birth;

2) the parents' residencestatus and;

3) the parents' country of birth; as well as

4) the sex of the parent who has to meet conditions 1) and 3); and

5) whether the birth occurred in or out of wedl ock."171

Some ius sanguinis countries in turn have dedided to create the possibility to ind ude children bom to migrants living on their territory who would otherwise remain foreigners forever. ${ }^{172}$ Although practices vary depending on the country, most countries now facilitate the acquisition of nationality for children bom to foreigners on their territory. ${ }^{173}$

Nevertheless, there are frequently strong diasporic communities in both ius soli and ius sanguinis countries. One example would be the distinct Mexican and Indian communities in the United States, which, despite often having acquired US citizenship at birth, retain their identity and might be sent to school abroad. ${ }^{174}$ Another example is the strong Turkish community in Germany, whose ancestors were frequently guest workers and chose to stay in their host country. Before the

Art. 6(2) European Convention on Nationality; G. R. de Groot (2006b), pp. $5 f$.

Seealso the Calvin case described in Chapter 3.1.1.

G. R. de Groot (2012), p. 610f; K. Hailbronner (2006), p. 54; P. Weis (1979), p. 95; T. A. Aleinikoff and D. B. Klusmeyer (2002), p. 2.

165 K. Hailbronner (2006), p. 54; T. A. Aleinikoff and D. B. Klusmeyer (2002), p. 2.

166 For a detailed overview see O. W. Vonk (2014) and the individual country reports on eudocitzenship.eu.

167 P.J.Spiro (2015), p. $10 f$.

168 R. Courtney (2015), p. 4.

169 H. Hoyo (2015), p. 13.

170 C. Escobar (2015), p. 16.

171 H. Waldrauch (2006a). p. 128.

172 K. Hail bronner (2006), p. 39; T. A. Aleinikoff and D. B. Klusmeyer (2002), p. 2.

173 Art. 17 Appendix to Recommendation CM/Rec (2009)13; H. Waldrauch (2006a), pp. 128.

174 P.J. Spiro (2013), pp. $45 f$.
} 
advent of option rights, children of these workers remained non-citizens, despite being born in Germany. ${ }^{175}$

Also other problems remain, as the marital status of parents remains important and thus places children born outside of wedlock at a disadvantage in some countries. ${ }^{176}$

\subsubsection{Naturalisation}

Acquiring a national ity at a point after birth through a process called natural isation is usually significantly more difficult compared to acquisition at birth. ${ }^{177}$ Naturalisation mainly aims at including those into the political community that have spent a significant part of their lives there, such as children who migrated to the country at an early age and spent their formative years there, as well as second generation migrants in a ius sanguinis country. ${ }^{178}$ There are several reasons that a person may wish to acquirea new national ity, either for residence rights, rights to political participation in the place they live, to fadilitate employment, or to end administrative difficulties. ${ }^{179}$ Countries in turn val ue naturalisation as a means to integrate immigrants or to attract people who are important for the country economically, such as trained labourers, peopl ewho are otherwise considered beneficial, such as tal ented athl etes, or those who have rendered a particular service for the country. ${ }^{180}$

Naturalisation can only occur on the request of the individual and thus the compul sory conferral of nationality on an individual against their will is a violation of the basic principles of law and a violation of the individual's rights. ${ }^{181} Y$ et, while it is in principle impossible for states to force their nationality on those living outside their territory, the situation becomes more complex if disputed borders or territories come into play. ${ }^{182}$ However, compul sory conferal of nationality on people does not deprive thestate of origin of its protection rights. ${ }^{183}$

Naturalisation is mostly residence based, ${ }^{184}$ although the required duration and the definition of residence varies between countries. ${ }^{185}$ There are also modes of naturalisation which are based on socialisation, marriage and other family ties, or affinity ties to the country. ${ }^{186}$ Some citizenship for money possibilities are more controversial and do not require the usual residence periods or integration and

P. J. Spiro (2013), pp. $35 f$.

H. Waldrauch (2006a), p. 125.

H. Waldrauch (2006a), p. 135; P. Weis (1979), p. 99; T. A. Aleinikoff and D. B. Klusmeyer (2002), pp. 8f; H. Wal drauch (2006a), p. 158; see S. W. Goodman and M. M. Howard (2013), pp.

111 - 139 for recent developments.

T. A. Aleinikoff and D. B. Klusmeyer (2002), p. 10; M. P. Vink (2005), p. 139.

I. Chopin (2006), p. 256.

R. Bauböck, E. Ersboll, K. Groenendijk and H. Waldrauch (2006), p. 23; D. Owen (2014), p. 27;

H. Waldrauch (2006a), p. 176.

P. Weis (1979), p. 112; I. Chopin (2006), p. 245; O. W. Vonk (2014), pp. $28 f f$.

P. Weis (1979), pp. 102f.

P. Weis (1979), p. 107.

H. Waldrauch (2006a), pp. 134f; M. P. Vink (2005), p. 11; P. Weis (1979), p. 100.

H. Waldrauch (2006a), p. 148.

H. Wal drauch (2006a), pp. 158ff and 169f; P. Weis (1979), p. 96. 
language tests that others seeking naturalisation have to pass. ${ }^{187}$ The problem with naturalisation in sporting and other political contexts is that, while an official change of allegiance occurs, the underlying motives might be rather opportunistic, as in the aforementioned case of Hammon suggests. ${ }^{188}$ Consequently, states will circumvent their stricter rules in favour of fast-track naturalisations to bein time for major sporting events.

From a more European perspective, the European Convention on Nationality stipulates that each state should provide for the possibility of naturalisation, for which the required residence period should not exceed ten years. ${ }^{189}$ In addition, according to Article 6.4 of the European Convention on Nationality, the naturalisation for the foll lowing categories should befacilitated further:

"(a) spouses of its nationals,

(b) children of one of its nationals, falling under the exception of Artide 6, paragraph 1, sub-paragraph a;

(c) dhildren one of whose parents acqui res or has acquired its nationality;

(d) children adopted by one of its nationals;

(e) persons who were born on its teritory and reside there lawfully and habitually;

(f) persons who arelawful ly and habitually resident on its territory for a period of time beginning before the age of 18 , that period to be determined by the internal law of the State Party concerned;

(g) stateless persons and recognised refugees lawfully and habitually resident on its teritory."

The first four categories in this list fall into the broader category of family- or marriage based modes of naturalisation. Previously, women automatically acquired the nationality of the husband by marriage and, due to the impossibility of dual nationality, often lost ther original national ity in the process. ${ }^{190}$ Nowadays, spouses of national s are to be subject to a facilitated procedure ${ }^{191}$ However, obstad es may arise if the marriage is not recognised by the relevant country, for example in the case of a marriage between homosexuals conducted in a country that is not recognised in the respective country of origin. Frequently states impose additional requirements on marriages, such the duration of the marriage or a common household to prevent the recognition of 'marriages of convenience'. ${ }^{192}$ Minor children are usually included in thenaturalisation, due to the principle of family unity. ${ }^{193}$

See in A. Shachar and R. Bauböck (Eds.) (2014). Should Citizenship be for Sale? EUI Working Papers, for more information and discussion; Portugal only requires one week per year, see A. Shachar (2014), p. 3f; R. Barbulescu (2014), p. 16; This will be elaborated upon in Chapter 3.7. SeeIntroduction, p. 4, and A. Shachar (2011), p. 209f.

189 Art. 6(3) European Convention on National ity; seeal so S. W. Goodman (2010).

190 H. Waldrauch (2006a), p. 164.

191 H. Waldrauch (2006a), p. 159; I. Chopin (2006), p. 245.

192 H. Waldrauch (2006a), pp. 164- 168.

193 H. Waldrauch (2006a), pp. 167f. 
In addition to family ties, there is al so the factor of affinity, either through language, culture or religion, which can be taken into consideration. ${ }^{194}$ For an affinity-based naturalisation, the descendants of people from one particular country, who lived abroad and managed to maintain their language and culture, are re integrated into the country of origin. ${ }^{195}$ Another example are the so-called Aussiedler, descendants of those who were caught in the territories that belonged to Germany prior to WWII and who could not return to Germany after 1945 due to the Iron Curtain. Upon being proven to be a German ancestor, they are instantly recognised by Germany as being German. ${ }^{196}$ In that context one has to especially mention the Spätaussiedler, those of German affinity who had been residing in the states of the former USSR until its dissolution and migrated to Germany after $1992 .{ }^{197}$ While they remai ned separated far from Gemany for almost 50 years - although not through their own volition - their connection with Germany by descent is deemed extremely strong and thus sufficient. Those who were part of the fascist or communist regimes in those regions cannot rely on the Aussiedler or Spätaussiedler Article ${ }^{198}$ Another example is Italy, where
"[... ] even a person who can prove descent from an Ital ian who emigrated before the unification of Italy in 1861 is automatically entitled to Italian nationality, provided that the Italian ancestor was aliveat thetime of Ital y's unification". ${ }^{199}$

People who rely on such affinity to achieve naturalisation often have to take up residence in the country of which they arenewly integrated national s. ${ }^{200}$

Thus, another vital factor in naturalisation is residence, in addition to the declaration made by the person wishing to be naturalised. ${ }^{201}$ All countries stipulatethat this residence has to be legal. ${ }^{202}$ However, other definitions and requirements may differ between the countries and ther efore the residence may be referred to as 'main' and 'habitual' . ${ }^{203}$ One issue here is that residence sometimes has to be uninternupted, although in principle temporary absences, such as for vacations, should not be problematic for fulfilling the residence requirement ${ }^{204}$ Already the duration required by countries differs greatly, ranging from five years in Belgium ${ }^{205}$ to ten years in Italy and Austria, 15 years in the Former Yugoslav Republic of Macedonia or even 25 years in Qatar or Bahrain.206

H. Waldrauch (2006a), p. 169.

196 T.K. Oommen (1997) p. 17; H. Waldrauch (2006a), p. 173.

197 § 116 Grundgesez, § 4 and § 6 Bundesvertriebenengesetz; § 40a Staatsangehörigkeitsgesetz.

198 § 5 Bundesvertriebenengeset.

199 O. W. Vonk (2012), p. 333.

200 H. Wal drauch (2006a), p. $172 f$.

201 H. Wal drauch (2006a), p. 135; P. Weis (1979), p. 100.

202 G. R. deGroot and M. P. Vink (2013), p. 3.

203 H. Waldrauch (2006a), p. $147 f$.

204 T. A. Aleinikoff and D. B. Klusmeyer (2002), p. 18; H. Waldrauch (2006a), p. 147; G. R. de Groot and M. P. Vink (2013), p. 3.

205 Before 2013 only three years.

206 G. R. de Groot (2006b), p. 6; G. R. de Groot (2006a), p. 166; L. E. van Waas (2014), p. 11; see G. R. de Groot and M. P. Vink (2013) for an overview.
} 
There are often additional requirements, such as the command of the language, not posing a danger to society, and passing of an integration examination. ${ }^{207}$ The way this is applied however differs greatly, with some countries allowing for leniency depending on the applicants circumstances. ${ }^{208}$ Furthermore, some dauses remain undear and ill-defined, as 'good character' and no criminal record are often also conditions, al though the good character is defined differently in each country. ${ }^{209}$

As naturalisation is usual ly a lengthy procedure, the administrative aspects are of great importance and may be deterring applicants: documents might not be recognised, fees might be high or the procedure considered too long and strenuous. ${ }^{210}$ Having to renounce the former nationality, especially when dual nationality is not allowed, as in Malawi, ${ }^{211}$ or the Democratic Republic of Congo, ${ }^{212}$ or extremely restricted as in Zimbabwe ${ }^{213}$ might al so di ssuade applicants. ${ }^{214}$ Another problem can arise if the laws of the relevant countries are conflicting, especially if one country requires the renunciation of the applicant's former nationality and the country of origin does not allow for such renunciation or makes renunciation only possible at great $\cos ^{215}$ Furthermore, the possi bility to appeal against a negative decision al so varies, as well as the stages of appeal and, while sometimes there is an appeals procedure, the appeal might not actually be effective ${ }^{216}$

Hence, a person seeking naturalisation will face extremely different requirements, depending on the country in which it is sought Although which country is stricter and which more lenient cannot be deduced from the sole number of rules in place, a statistical evaluation has shown that the authorities can be effectively stricter. ${ }^{217}$ Overall, the general trend seems to be towards the acceptance of dual nationality and thus the deterring factor is reduced. However, moretests were introduced to check the person's knowledge of the country and language proficiency exams are increasingly important $^{218}$

\subsubsection{Option rights}

A third way of acqui ring nationality is through option rights, which areal so advocated for by theCouncil of Europe in their Recommendation CM/Rec (2009/13):

"[states should] facilitatetheacquisition of nationality, beforethe age of majority, by children born on their territory to a foreign parent lawfully and habitually

G. R. deGroot (2006b), p.6; G. R. de Groot (2006a), p. 166.

H. Waldrauch (2006a), pp. 139 and $151 f$.

H. Waldrauch (2006a), pp. 149 and 154.

I. Chopin (2006), pp. 245, 248 and 259; H. Wal drauch (2006a), p. 146.

B. Manby (2015), p. 145.

B. Manby (2015), p. 145.

B. Manby (2015), pp. 113 ff; p. 145, pp. $228 f f$.

I. Chopin (2006), p. 251; H. Wal drauch (2006a), p. 148.

I. Chopin (2006), p. 252.

H. Waldrauch (2006a), pp. 144f.

H. Waldrauch (2006a), p. 155.

H. Waldrauch (2006a), pp. $155 f$. 
residing there Enhanced facilitation should be offered in cases where that parent is al so born on their teritory." 219

While this procedureis different from naturalisation, it has some shared characteristics with thenaturalisation procedure Depending on therelevant national law, the number of shared characteristics may be so high that option rights amount to little more than a quick naturalisation. ${ }^{220}$ Generally, option rights are granted to those who have a strong tie with the country, eg. by birth on the territory and subsequently growing up there, but who did not acquire the national ity of the country, as the parents were immigrants and the country applies ius sanguinis. In such cases, the person having the option right needs to make a declaration to the effect that he or she wishes to be a national of the country. The relevant country's nationality law delineates at what time such a declaration may be made, eg. after reaching the age of majority, and in which form the dedaration needs to be made and reach ther evant authority. ${ }^{221}$ In some countries the procedure is similar to the naturalisation procedure, as a formal and written declaration is necessary and the relevant authority may reject the option. ${ }^{222}$ In other countries an oral and informal declaration is considered enough, provided that the relevant authority receives the declaration. Nationality is in such cases acquired if the declaration can be proven - although usually an official document is set up to that effect as well. ${ }^{223}$ Depending on the national ity law, the obstades and procedures for those with option rights vary.

\subsection{Dual nationality}

Improved travel possibilities and cross-border marriages havel ed to people devel oping ties to more than one country. ${ }^{224}$ People acquire a second nationality through naturalisation and many others might even acquire two nationalities at birth, due to cross-border marriages of nationals fromius sanguinis countries, automatically leading to children with dual nationalities, if ius sanguinis a matre et patre is possible $e^{225}$ While multi-nationality has become more accepted in recent years, there are still reasons why dual nationality is seen as problematic by some states ${ }^{226}$ The underlying issue is that dual national sare seen as having a divided loyalty, as they owe both states allegiance ${ }^{227}$ In tum, dual nationals might face double obligations, eg. regarding military service, but at the same time might enjoy rights in two countries, such as

Art. 17 Appendix to Recommendation CM/Rec (2009)13.

G. R. deGroot (2012), p. 612f.

G. R. deGroot (2012), p. $612 f$.

G. R. deGroot (2012), p. $612 f$.

G. R. deGroot (2012), p. $612 f$.

O. W. Vonk (2012), p. 7; T. A. Aleinikoff and D. B. Klusmeyer (2002), pp. $22 f f$.

T. A. Aleinikoff and D. B. Klusmeyer (2002), pp. 22ff.

R. Bauböck, E. Ersboll, K. Groenendijk and H. Waldrauch (2006), p. 28; O. W. Vonk (2012), pp. $58 f$.

O. W. Vonk (2012), pp. 59 and 74. 
voting rights. ${ }^{228}$ Moreover, they might result in difficulties between the states, especially when it comes to dipl omatic protection. 229

\subsection{Nationality and territorial transfers}

Having seen how nationality can be acquired and before turning to issues of loss of nationality, it is important to look at the changes a person's nationality can undergo through external circumstances. These circumstances occur when the state's territory changes - either by statesuccession, cession or decol oni sation;

"universal succession is theresult of total subjugation by annexation, secession or occupation, partial succession is the result of partial annexation, secession or occupation following dereliction or cession of teritory. In the case of partial succession some writers make a distinction between original and derivative modes of acquisition. Decolonisation may be either regarded as secession, dismemberment or even cession, or as a special mode of statesuccession."

All of these modes may be subject to some controversy. Moreover, countries once affected by them, such as the African ex-colonies, with particular nationality codes, frequently retain aspects of the former col onial power. ${ }^{231}$

A universal succession generally occurs if the old state ceases to exist and the new state is created, meaning that the relationship between the old state and the person ceases to exist as the old state no longer exists and the link between the new stateand the person takes its place ${ }^{232}$ However, sometimes the question of whether or not the old state ceased to exist is difficult to determine, as international opinions differ, which the case of Austria and Germany in 1938 illustrates. The question here was whether theannexation or occupation of Austria through theAnschl uss meant that Austria itself ceased to exist and only reemerged with the selting up of Austria in $1945 .{ }^{233}$ There has neither been consensus among writers nor among other countries courts. ${ }^{234} \mathrm{After}$ 1945, some German courts took the position that the deciding factor was the place of residence: if a person resided in what was now again Austrian territory, he or she was considered Austrian, but if a person lived in what was German territory at the date of the re establishment of the Austrian Republic, he or she was considered German. ${ }^{235}$ However, Austria aimed to regain its nationals and, according to Austrian law, these people were also considered Austrian and thus held dual nationality. ${ }^{236}$ While the German federal constitutional court dedared that all Austrians who had become German through the Anschluss lost German nationality when Austria was re-
O. W. Vonk (2012), pp. 75 and 81.
O. W. Vonk (2012), pp. 59 and 78 f.
P. Weis (1979), p. 136.
B. Manby (2010), p. 21 and 28ff, seeB. Manby (2015) for a detailed overview.
P. Weis (1979), pp. 136 and 144.
P. Weis (1979), pp. $136-151$.
P. Weis (1979), pp. 137 - 143.
P. Weis (1979), p. 150.
P. Weis (1979), p. 151. 
established in 1945, Austrians who wanted to retain their German national ity could do so by making a dedaration if they were resident in Germany territory after the reestablishment of Austria. ${ }^{237}$ Ultimately, state succession and re-succession is highly complex, as matters of recognition of theteritorial transfer play an important role

Partial succession in turn occurs between two states and is often regulated through a bilateral treaty. ${ }^{238}$ Here, as both states continue to exist and consequently both nationalities remain in existence, there needs to be a link between the person and the relevant territory, while people in other parts of the old state are not invol ved. ${ }^{239}$ Such a link is deemed to have been established if the people are habitual residents of the relevant territory. ${ }^{240} Y$ et, as with universal succession, difficulties can arise if the partial succession is not recognised or considered not in accordance with international law. ${ }^{241}$ Examples of this are the disputed territories of Crimea or the Isradi and Pal estinian teritories.

Cession, similar to partial succession, means part of one state's territory is given to another state This has to be in accordance with international law and is usually regulated by a treaty. In such cases, the ceding state has to withdraw nationality from thosein the ceded teritory, while the status of theremaining parts of the country is not changed. ${ }^{242}$

Contrarily, decolonisation means that the col onial power relinquishes its hold over a territory and a new state is created. ${ }^{243}$ Theresults for the nationality of those living in the new state depend largely on the colonial power and what is stipulated in the treaty. ${ }^{244}$ Taking the decolonisation from the UK as an example, where an Act of Parliament is required in these situations, usually British rule and nationality ends on an appointed day for people if they and their ancestors were born in the territory. ${ }^{245}$ The French nationality of former colonies is regulated in the Code Civil, the French civil Code, and onemay become French again by declaration if they live in Franceand receivetheauthorisation froma minister. ${ }^{246}$

Overall, teritorial transfers have inherently three distinct problems: firstly, the transfer has to be in accordance with international law and needs to be recognised. Secondly, people faced with partial territorial transfers should havetheright to choose whether to retain their old nationality or not ${ }^{247}$ And thirdly, statelessness can occur easily, ${ }^{248}$ for instance when people are left as minorities in newly minted states. This

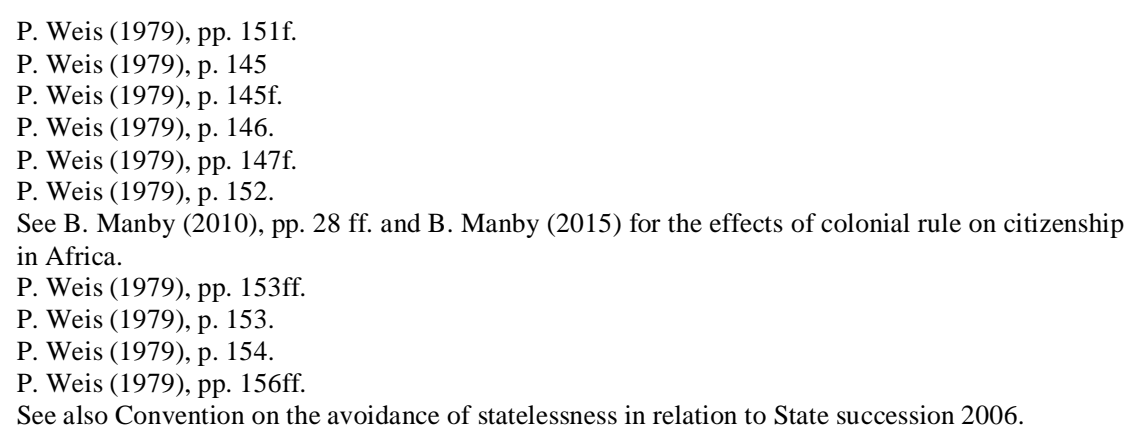


often occurs at the dissolution of multinational entities, such as Austria-Hungary, USSR, Y ugoslavia, or Czechoslovakia. ${ }^{249}$ Taking the case of theUSSR as an example, Latvia granted citizenship to those who were Latvians before the occupation in the1940s. Yet, Russian migrants were left in the lurch by both countries as they also did not acquire Russian nationality and thus a minority of stateless people of Russian descent areliving in Latvia today. ${ }^{250}$

\subsection{L oss of nationality}

One important aspect of the genuine link between a person and a state is that it is usually deemed to be permanent or at least stable and long lasting. As will be elaborated upon later, actions by either the state or the person may severe the bond. However, it is important to stress that no person should bearbitrarily deprived of his or her nationality. ${ }^{251}$ Furthermore, expulsion of the state's own nationals by the state is not in accordance with intemational law, as the state thus forces other states to allow its nationals to stay on their territory. 252

Historically the principle of non-deprivation has often been vidated. ${ }^{253}$ Depriving people of their nationality due to political reasons, i.e grounds of disloyalty, was common during and after the First World $W^{2}{ }^{254}$ In the following decades, deprivation of nationality on racial or national grounds occurred in the fascist regimes of Germany and Italy, frequently revoking previous naturalisations granted to Jews and others who were considered undesirables under the new regime ${ }^{255} Y \notin$, the denational isation of J ews was often not recognised by other states, as Lord Denning's statement in the Oppenheimer case shows:

"When the taxpayer came to England in 1939, he was a German national; and English law would regard him as such; notwithstanding that he was a refugee from the Nazi persecution of the J ews. When the German authorities passed the decree of November 25, 1941, the Engl ish courts would not recognise it as valid, by English law, to deprive him of his German nationality. Not only was it an objectionable and atrocious law. It was passed at a time when England and Gemany were at war: and English law will not recognise any decree of an enemy power which purports to deprive its ditizens of their enemy nationality in time of war."1256

K. Hail bronner (2006), pp. 60f; O. W. Vonk, M. P. Vink, G. R. deGroot (2013), p 11.

O. W. Vonk, M. P. Vink, G. R. deGroot (2013), p. 11.

Art. 4 c) European Convention on nationality.

P. Weis (1979), p. 47.

An in-depth description of the fascist regi mes and their atrocities is unfortunately outsi de the scope of this dissertation; see eg. Hannah Arendt (2015) for more information.

P. Weis (1979), p. 119.

P. Weis (1979), p. 119; for a detailed analysis see Hannah Arendt (2015), pp. 627 - 980.

Oppenheimer v Cattermole (Inspector of Taxes) [1972] 3 W.L.R. 815; p. 270. 
Consequently, the refugees were not recognised as such but were frequently seen as enemy national s by other European powers. ${ }^{257}$

\subsubsection{Loss of nationality ex lege or at theinitiative of the state}

Having mentioned the atrocious way in which people were deprived of their nationality during the fascist regime in Germany, one needs to stress that nowadays arbitrary deprivation of nationality should not happen. ${ }^{258}$ Nevertheless, people will find themsel ves deprived of their nationality under certain circumstances. ${ }^{259}$

Starting from a European perspective, there are several accepted principles regarding the loss of nationality as described in the European Convention on Nationality. ${ }^{260}$ In principle, nationality may be lost ex lege, at the initiative of the state party or at the initiative of the individual. Commenaing with the first category, Article 7 of the European Convention on Nationality is phrased in such a way that loss of nationality may only be provided for in a states' intemal laws in a limited number of situations:

"1. voluntary acquisition of another nationality;

2. acquisition of the nationality of theStateParty by means of fraudulent conduct, fal seinformation or concel ment of any relevant fact attributable to the applicant;

3. voluntary senvice in a foreign military force,

4. conduct seriously prejudicial to the vital interests of the StateParty;

5. lack of a genuine link between the State Party and a national habitually residing abroad;

6. where it is established during the minority of a child that the preconditions laid down by intemal law which led to theex legeacquisition of the national ity of the State Party are no longer fulfilled;

7. adoption of a child if the child acquires or possesses the foreign nationality of oneor both of theadopting parents."

These cases fall broadly into three categories. The first category includes cases in which the individual has sought to establish a connection with another country, eg. through the acquisition of another nationality. ${ }^{262}$ Here it should be noted that only voluntary acquisition counts and that states may not simply confer their nationality on all individuals living on their teritory. ${ }^{263}$ Furthemore, it can be noted that in most countries people no longer face an automatic loss of ther original nationality when another nationality is acquired. ${ }^{264}$

\footnotetext{
257 P. Weis (1979), p. 123.

$258 \quad$ K. Hail bronner (2006), p. 70.

259 L. E. van Waas (2008), p. 34.

260 Art. 7(1) European Convention on Nationality, eg. when entering the military force of another country voluntarily.

261 Art. 7(1) European Convention on Nationality.

262 H. Waldrauch (2006b), p. 195.

263 H. Waldrauch (2006b), p. 196.

264 H. Waldrauch (2006b), p. 212.
} 
The second category of cases ind udes those in which the individual has acted against the interest of the state, for instance through fraudul ently acquiring the nationality in the first place ${ }^{265}$ Conduct contrary to vital state interest also falls into that category, which is the case if the national was a spy for another country, was a member of a terrorist organisation or entered the service of another military force ${ }^{266}$

The third category includes cases in which there is no actual link between individual and the state This can either be because during their minority it was established that the requirements for acquisition were not fulfilled after all or that the 'genuine link' between the state and a national who lives abroad does not exist Thus, if someoneis a national of country $A$ and lives most of his life in country $B$, with very sparse occasional visits to country $A$, one can doubt whether the genuinelink exists.

Article 7 of the European Convention on Nationality further stipulates that:

"(2) A State Party may provide for the loss of its nationality by children whose parents lose that national ity except in cases covered by sub-paragraphs $c$ and $d$ of paragraph 1. However, children shall not losethat national ity if one of their parents retains it

(3) A State Party may not provide in its internal law for the loss of its nationality under paragraphs 1 and 2 of this article if the person concerned would thereby become stateless, with the exception of the cases mentioned in paragraph 1, subparagraph $b$, of this artide" 267

Thus, children are in principle protected from losing the nationality of a state if only one parent loses that nationality ${ }^{268}$ and if the parent loses the nationality based on voluntary service in a foreign military force ${ }^{269}$ or conduct seriously prejudicial to the vital interests of thestate party. ${ }^{270} \mathrm{Hence}$, children cannot losetheir nationality because their parents have acted against the state, and this provides for a certain degree of protection. Furthermore, everyone is to be protected from becoming stateless and, consequently, applying the laws on loss of nationality of one country if that would effectively render the person stateless is considered contrary to the European Convention on Nationality. There is one notable exception to that rule, namely if the person acquired the nationality fraudulently in the first place, he or she can become stateless. ${ }^{271}$

R. Bauböck, E. Ersboll, K. Groenendijk and H. Waldrauch (2006), p. 28; H. Waldrauch (2006b), pp. 201 and 212; see al so Case C-135/08 [2010] J anko Rottmann v Freistaat Bayern.

Art. 7 European Convention on National ity.

Art. 7(2) European Convention on National ity.

Art. 7(2) European Convention on Nationality and Art. 7(1) (c) European Convention on Nationality.

270 Art. 7(2) European Convention on Nationality and Art. 7(1) (d) European Convention on Nationality.

271 Art. 7(3) European Convention on Nationality. 


\subsubsection{Loss of nationality at the individual's initiative}

Voluntary loss of nationality is possible if the person renounces his or her nationality. ${ }^{272}$ International law does contain rules for the renunciation of nationality, provided the person would not become statel ess. ${ }^{273}$ However, whil estates should make it possible to renounce nationality, not all of them do so. ${ }^{274}$ Even if states allow for renunciation, the individual often has to fulfil certain conditions, i.e no criminal proceedings still in process before the renunciation can become effective ${ }^{275}$ Furthermore, as it is the general aim to avoid statelessness, states may not allow an individual to renouncehis or her national ity if this would render him or her stateless. ${ }^{276}$ Another safeguard may be provided by the state by stipulating in its laws that such a renunciation of nationality is only effective if the renouncing person is habitually resident abroad. ${ }^{277}$ As states have different definitions of 'permanency', 'residence' and 'abroad', there is no coherent picture ${ }^{278}$ Several states do however have a safeguard for those living abroad, so that their continued absence cannot be taken as a sign that the person wishes to renounce his or her nationality: usually a declaration to that effect or applying for a renewal of the passport are seen as sufficient ${ }^{279}$

Generally, an individual has to become very active in order to sever the ties with the country of which he or she is a national. While these are safeguards against statelessness, preventing a renunciation may however have adverse effects. This occurs if someone wishes to acquire a new national ity and renunciation of the previous nationality is a precondition for naturalisation. Several countries try to hinder those trying by imposing exorbitant fees or other obstades. ${ }^{280}$

\subsection{Nationality and its problems}

There are several problems related to nationality and citizenship. The most obvious one occurs when a person loses his or her national ity without having acquired another nationality and thus cannot rely on either state's protection. Asylum sedkers in turn often still have an official nationality tie with a spedific country, yet, due to circumstances, such as persecution by that state or strong para-military organisations, had to fle to another country. ${ }^{281}$ Their aim is to escape the truly dangerous situations in their home country and to gain protection from the country they fled to. ${ }^{282}$ Should

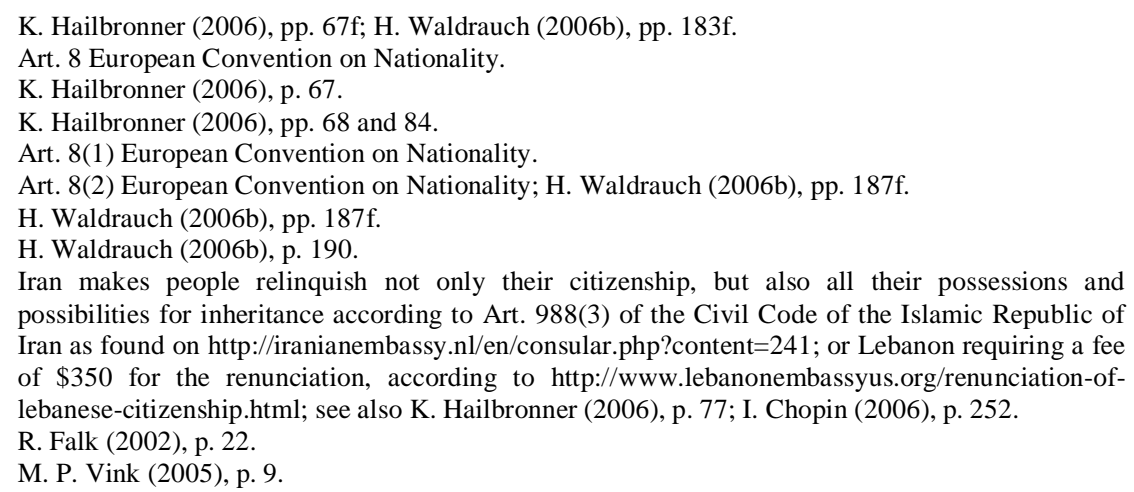
possibilities for inheritance according to Art. 988(3) of the Civil Code of the Islamic Republic of Iran as found on http://iranianembassy.nl/en/consular.php?content=241; or Lebanon requiring a fee of $\$ 350$ for the renunciation, according to http://www.lebanonembassyus.org/renunciation-oflebanese-citizenship.html; seeal so K. Hail lbronner (2006), p. 77; I. Chopin (2006), p. 252.

R. Falk (2002), p. 22.

M. P. Vink (2005), p. 9. 
the country they fled to recognisether peril, he or she will become an official refugee On the other side of the spectrum, cases may be observed in which people whose tie with the country is debateable achieve naturalisation through pecuniary or other means.

\subsubsection{Statelessness}

Starting with the issue of statelessness, it is first important to underscore that there is consensus among states that this negative conflict of national ities shoul $d$ beavoi ded. ${ }^{283}$ However, as the 'right to national ity' cannot be enforced against a particular state, statelessness occurs nevertheless. ${ }^{284}$ A distinction between de jure and de facto statelessness needs to be made, with the de facto statelessness being more difficult to prove and thus leading to different obstacles. De facto stateless persons possess a nationality nominally, but in fact they cannot rely on that nationality status as they belong to an ethnic, religious or political minority. ${ }^{285}$ In addition to not having protection intemationally, stateless people face several problems in their country of residence, as they are frequently not recognised by the administration, may not receive trave documents, and often have no standing in courts to redress violations of their rights. ${ }^{286}$

Dejure statel essness affects a high number of peopleas UNHCR statistics show. ${ }^{287}$ Currently, the UNCHR estimates that there are at least 10 million stateless people ${ }^{288}$ The number of countries reporting statistics on stateless people more than doubled within the last ten years. ${ }^{289}$ These numbers are especially appalling, when one takes into consideration that there has been a Convention on the Reduction of Statelessness since August $1961{ }^{290}$

Statelessness may arise in all countries of the world through problems with:

"birth registration, conflicting nationality legislation, state succession, migration and international law". 291

Statelessness resulting from problems with birth registration happens when it is factual ly or virtually impossi ble for the parents to register their child with the relevant authorities, either dueto thelocation of theauthorities or the political situation. Artide 1 of the Convention on the Reduction of Statelessness stipulates that contracting states should grant their nationality to children born in their territory if the child would

O. W. Vonk (2012), p. 38; E. Horváth (2008), p. 18.

E. Horváth (2008), p. 18.

R. Bauböck, E. Ersboll, K. Groenendijk and H. Waldrauch (2006), p. 28; see al so the argumentation in the Perez I, II and III VIOC cases.

E. Horváth (2008), p. 19; O. W. Vonk, M. P. Vink, G. R. deGroot (2013), p. 12.

UNHCR Global Trends 2013, p. 44.

UNHCR 2015 and Institute on Statelessness and Indusion (2014), pp. 7 - 11.

UNHCR Global trends 2013, p. 31.

Convention on the Reduction of Statelessness done at New York on $30^{\text {th }}$ August 1961; For examples of how European countries deal with this issue see O. W. Vonk, M. P. Vink, G. R. de Groot (2013), pp. 39 - 89.

O. W. Vonk, M. P. Vink, G. R. deGroot (2013), p. 7. 
otherwise be stateless ${ }^{292}$ Found ings, including those found on ships or aircrafts flying that are registered in the particular country or areflying the country's flag are deemed to have been born in the territory. ${ }^{293}$ These two artides apply the reasoning that the place of birth creates a val uable genuine link. It is further possible that children not bom on the teritory of the country nevertheless receive its nationality, provided that one parent was a national of the country at the time of birth. ${ }^{294}$ This is to prevent children of nationals of countries that usually adhere strictly to the ius soli rationale from being stateless when born abroad.

Examples of conflicting legislation occurs if ius sanguinis a matre is only possible if the father is stateless, as in the case of I raq, and the father stems from purely a ius soli country. ${ }^{295}$ In addition, the test for statelessness is often not effective and the overall focus on the child"s father is not like y to remedy the problem ${ }^{296}$

Loss of nationality due to an individual's actions or renunciation of nationality are to be conditional upon the acquisition of a new nationality. ${ }^{297}$ Consequently, even if a national voluntarily enters the military force of another country, which is considered a valid reason for loss of national ity, ${ }^{298}$ states should not al low the national to lose his or her nationality, unless heor sheal ready possesses another one Depriving a national of his or her nationality is also in principle forbidden if this would render the person stateless, ${ }^{299}$ yet, if the nationality was acquired in a fraudulent manner, it is admissible $\mathrm{e}^{300}$

State succession ${ }^{301}$ may leave unwanted minorities in newly minted states stateless. However, al ready under the 1961 Convention, in case of transfers of teritory or if borders redrawn due to geopolitics, such as the recent separation of Crimea from the Ukraine to Russia, the states involved need to undertake measures ensuring that nobody becomes stateless as a result $\mathrm{t}^{302}$

With regard to actions that a statemight undertakethat could result in statelessness for its people, one first has to underline that rendering groups of people statel ess based on their religion, ethnicity, race or political opinion is forbidden. ${ }^{303}$

\subsubsection{Asylum sedkers and refugees}

As previously described, asylum seekers often still have an official tie with a spedific country, yet, due to the circumstances, such as prosecution by state or strong para-

Art. 1(1) Convention on the Reduction of Statel essness 1961.

Art. 2 and Art. 3 Convention on the Reduction of Statelessness 1961.

Art. 4 Convention on the Reduction of Statel essness 1961.

L. E. van Waas (2014), p. 5f; O. W. Vonk, M. P. Vink, G. R. deGroot (2013), pp. $10 f$.

L. E. van Waas (2014), p. $5 f$.

Art. 5 and 7 Convention on the Reduction of Statel essness 1961.

Art. 7(1) European Convention on National ity.

Art. 8 Convention on the Reduction of Statelessness 1961.

Art. 8(2)(b) Convention on the Reduction of Statelessness 1961; see J anko Rottmann v Freistaat Bayern (Case C-135/08).

See Chapter 3.5.

Art. 10 Convention on the Reduction of Statelessness 1961.

Art. 9 Convention on the Reduction of Statelessness 1961. 
military organisations, can no longer continue to live in their home country. Often, they were forced to flee to another country in order to escape the dangerous situations in their home country. Should the country they fled to recognise their peril, he or she will become an official refugee A refugee is described in the Convention Relating to the Status of Refugees 1951 and the subsequent Protocol Relating to the Status of Refugees 1967 as someone who:

"As a result of events [....] and owing to well-founded feer of being persecuted for reasons of race, religion, nationality, membership of a particular social group or political opinion, is outside the country of his nationality and is unable or, owing to such fear, is unwilling to avail himself of the protection of that country; or who, not having a nationality and being outside the country of his former habitual residence as a result of such events, is unable or, owing to such ferr, is unwilling to retum to it

In the case of a person who has more than one nationality, theterm "the country of his nationality" shall mean each of the countries of which heis a national, and a person shall not be deemed to be lacking the protection of the country of his nationality if, without any valid reason based on well-founded feer, he has not availed himself of the protection of one of the countries of which he is a national." 304

According to UNHCR statistics there were 11,003,862 refugees in 2013 and an additional 699,317 who were in refugeelike situations but who had not been granted official refugee status. ${ }^{305}$ In June 2015, Amnesty International estimated that there were 50 million people who were forced to flee their homes. ${ }^{306}$ It is likely that, at the time of publication of this dissertation, this number has increased oncemore

Froma nationality law perspective, thosefleeing their country while retaining their nationality maintain a genuine link with the country. Consequently, the state should not only offer its protection, but it al so has to al ow them to reenter the territory. ${ }^{307}$ In a country were a (civil) war rages, protection by authorities is unlikely to occur and these people are often de facto stateless. The duty to readmit its citizens may lead to other scenarios, when those who fled are forced to return home by the countries they fled to and tried unsuccessfully to begiven asylum

\subsubsection{Current debate on 'passports for salle'}

Tuming to the other side of the spectrum of current problems connected to national ity, a small group of peopleis able to obtain nationality and citizenship rights fairly easily. While the problem is not new, seeing that Roman citizenship was al ready sold and in

\footnotetext{
304 Art. 1(A)(2) Convention Relating to the Status of Refugees 1951 and Art. 1(2) Protocol Relating to the Status of Refugees 1967.

UNHCR Global trends 2013, p. 44.

Amnesty International (2015).

K. Hailbronner (2006), pp. 36f; E. Horváth (2008), p. 1; O. W. Vonk (2012), p. 34; M. P. Vink (2005), p. 9; P. Weis (1979), p. 45.
} 
the sports context athletes change their country of representation frequently, eg. in rugby athletes are frequently lured over to Australia or New Zealand from other places, a new market for passports has opened up. ${ }^{308}$ Within Europe, there are investor citizenship programmes currently operating in countries such as Malta, Cyprus and Portugal. ${ }^{309}$ As these countries areall Member States of the European Union, the main incentive for non-EU citizens to obtain the nationality of one of these countries is considered to be visa free travel and entrance to Schengen area. ${ }^{310}$ This spiked a European Union-wide discussion on these practices, with the EU being strictly against European citizenship being sold as a commodity. ${ }^{311}$

The way citizenship can be acquired differs per country, with Malta asking a lot of money for a passport and Portugal giving out 'gol den residence permits' if the person invested heavily in real estate ${ }^{312}$ While this creates revenue for the governments, ${ }^{313}$ several scholars, such as A. Shachar, J. Dzankic, D. Owen, P. Spiro, P. Ochoa, and R. Bauböck, haveargued that ditizenship should not be for sal $\mathrm{e}^{314}$

One of the major points of critique against this practice is that al most no residence in the country is required. ${ }^{315}$ Portugal requires only seven days per year in first year and 14 days in following years. ${ }^{316}$ This is an extremely short period of time - even more so compared to the usually lengthy periods of residence required as a sign of the establishment of a genuine link. While investments can createa tie to a country's goals and economy, since investors might aim to adively contribute to the economy, scholars doubt that this is the case in Malta and Portugal. ${ }^{317}$ Especially the stark contrast between long-term residence and language requirements, which aim to ensure integration, and the quick cash-for-passport programmes have been underscored. ${ }^{318}$

Another aspect is that, by purchasing a passport, the people not only obtain visa and traved rights but also political rights in the communities. Citizenship is inherently political and thus bringing people into the polity without real ties to it can dangerous, al so because these people do not need to live in the country. ${ }^{319}$ For the other people, the situation is also difficult, as it is not made public who buys the passports; for example, in Malta the people do not know who counts as a fellow Maltese citizen. 320 In addition to the practical aspects, there is also the moral issue that wealth should no

R. Magni Bertin (2014), p. 11; D. Owen (2014), pp. 27 and 31; A. Shachar (2014), p. 3.

P. Spiro (2014), p. 9; For an overview seeS. Carrera (2014), p. 10ff.

P. Spiro (2014), p. 9; R. Bauböck (2014a), p. 1; J. Dzankic (2014), p. 18; S. Carrera (2014), pp. 2 and $6 \mathrm{ff}$.

S. Carrera (2014), p. $6 \mathrm{ff}$.

A. Shachar (2014), p. 3; P. Ochoa (2014), p. 23; H. Waldrauch (2006a), p. 176.

A. Shachar (2014), p. 5.

In A. Shachar and R. Bauböck (Eds.) (2014), Should Citizenship be for Sale? EUI Working Papers.

D. Owen (2014), p. 27; J. Dzankic (2014), p. 17; R. Bauböck (2014b), p. 19; S. Carrera (2014), p.

4.

A. Shachar (2014), pp. 3f.

J. Dzankic (2014), pp. 17f; P. Ochoa (2014), p. 24.

R. Barbulescu (2014), p. 16; R. Bauböck (2014b), p. 21.

A. Shachar (2014), p. 5; P. Ochoa (2014), p. 24.

A. Shachar (2014), p. 4. 
longer translate into political rights, as this would mark a retum to previous century practices ${ }^{321}$ Or as R. Bauböck cautions:

"Once they arecitizens, the votes of foreign investors will not formally count for more than everyone e Ise's. But it seems quite naïve to think that a dub that starts to sell its membership at a price that only the ultrarich can afford will keep treating its poorer members as equals."

At the same time, some scholars, such as R. Barbulescu and to some extent al so P. Spiro and D. Owen comment that this is just the tip of the iceberg and global inequality is the main problem ${ }^{323}$ Moreover, they argue that this market for passports shows how hollowed out the concept of citizenship has become and that it is an indicator that a meaningful discussion needs to take place now. ${ }^{324}$ Should this indeed bethe case, a change in our perception of citizenship and nationality might be brought about

Contrarily, authors such as R. Magni Bertin, D. Kochenov and C. Armstrong repudiate that there is actually a problem Considering that attributing citizenship at birth based on blood or place of birth can al so be considered rather arbitrary, the entire system can be seen as hypocritical and unfair. ${ }^{325}$ While there are claims that investments can actually be taking an interest in the country, ${ }^{326}$ some admit that the current methods lack democratic authorisation. ${ }^{327}$ Overall, these scholars claim that the problem lies not with the fast-track procedure but with the standard naturalisation process, which is too burdensome ${ }^{328}$

\subsection{Touchstone principles of nationality law}

Having elaborated on themodes of acquisition and loss of nationality, as well as on the problematic issues which may arise in this context, such as territorial transfers, dual national ity or statelessness, it is timeto draw some concl usions on generally applicable principles of nationality law. ${ }^{329}$ It is important to bear in mind that there is no unanimity regarding limits to state sovereignty among states, 330 but an enumeration of standards may nevertheless begiven. ${ }^{331}$ Thesetouchstone principles of nationality law, which will be used to examine the rules employed by sporting federations and the Olympic Committeeareas follows:

\footnotetext{
$321 \quad$ A. Shachar (2014), p. 6; R. Bauböck (2014b), p. 20.

R. Bauböck (2014b), p. 20.

R. Barbulescu (2014), p. 15.

P. Spiro (2014), p. 9; D. Owen (2014), p. 32.

D. Kochenov (2014), p. 27.

R. Magni Bertin (2014), p. 11; C. Armstrong (2014), p. 13.

C. Armstrong (2014), pp. $13 f$.

R. Magni Bertin (2014), p. 12.

P. Weis (1979), p. 97.

P. Weis (1979), p. 83.

O. W. Vonk (2012), p. 37.
} 
- No violation of fundamental human rights, in particular theright to nationality; ${ }^{332}$

- Statelessnessis to beavoi ded; 333

- Right to change one' snationality; 334

- Renunciation of nationality should beallowed, if it does not cause statelessness; ${ }^{335}$

- Attribution of national ity has to be based on a genuine link between a person and thestate ${ }^{336}$

- Birth right citizenship can be based on ius sanguinis or ius soli or a combination thereof; ${ }^{337}$

- Family unity should befacilitated; ${ }^{338}$

- Gender equality shoul d berespected; 339

- No arbitrary deprivation of nationality; ${ }^{340}$

- No discrimination. ${ }^{341}$

Furthermore, the position of children and minors is of paramount importance as they are in an especially vul nerable position and need additional protection. This protection is not only needed generally and can be found in their incapability to take legally binding decisions, but it also encompasses matters of nationality law. ${ }^{342}$ In that context, especial ly the problem of decisions taken by parents for their children arise, when such decisions do not necessarily reflect the will of the minor. These decisions thus need to be remedied later. ${ }^{343}$

These touchstone principles enumerated above will be used to assess the eligibility codes of the sporting federations (Chapter 16) with regard to their compatibility with legal standards. These concepts will al so al ready be induded in the chapters dealing with individual sports and the comparison between the sports (Chapters 5 to 15), where brief critical reflections on the examined eligibility codes will begiven.

\footnotetext{
332 K. Hail bronner (2006), pp. 53f; E. Horváth (2008), pp. 18f; O. W. Vonk (2012), p. 45; R. Bauböck, E. Ersboll, K. Groenendijk and H. Wal drauch (2006), p. 28.

333 K. Hailbronner (2006), pp. 53f; E. Horváth(2008), pp. 18f; R. Bauböck, E. Ersboll, K. Groenendijk and H. Waldrauch (2006), p. 28.

334 K. Hailbronner (2006), p. 38.

335 Art. 8 European Convention on Nationality.

336 R. Bauböck, E. Ersboll, K. Groenendijk and H. Waldrauch (2006), p. 28; T. A. Aleinikoff and D.

B. Klusmeyer (2002), p. 2.

337 O. W. Vonk (2012), p. 45; T. A. Aleinikoff and D. B. Klusmeyer (2002), p. 2.

338 R. Bauböck, E. Ersboll, K. Groenendijk and H. Wal drauch (2006), p. 28; P. Weis (1979), p. 97.

339 O. W. Vonk (2012), p. 45.

340 K. Hail bronner (2006), pp. 53f; P. Weis (1979), p. 57; E. Horváth (2008), pp. 18f; O. W. Vonk (2012), p. 45.

341 R. Bauböck, E. Ersboll, K. Groenendijk and H. Wal drauch (2006), p. 28; P. Weis (1979), p. 97.

342 See Recommendation CM/Rec (2009)13.

343 G. R. deGroot and E. P. J. Vrinds (2004), pp. 8ff, p. 15.
} 


\section{Lex sportiva and nationality}

Tuming from international standards of nationality law to sports law and nationality law, the problem of defining the exact concept of sports law arises. While, according to some scholars, it seems debateable whether sports law exists, ${ }^{344}$ this dissertation will assumethat it does, as will be briefly elaborated upon in Chapter 4.1. Afterwards, the use of theterms 'nationality' and 'citizenship' in thesporting context will be examined (Chapter 4.2), before turning to the issue of a genuine link in sports (Chapter 4.3). Afterwards sporting nationality, as proposed by some authors, will be briefly addressed (Chapter 4.4), before turning to the Court of Arbitration for Sports (CAS) (Chapter 4.5) and the national ity requirements as stipulated by the Olympic Charter (Chapter 4.6).

\subsection{The status of lex sportiva}

As previously stated, there is a debate among authors whether sports law actually exists as a separate entity. ${ }^{345}$ Thereare rul es spell led out by different stakeholders, such as the IOC, the sporting federation governing the sport as a whole, the national sporting federations and even countries delineating organisational and commercial rules around major sporting events. ${ }^{346}$ These rules neither solely form part of countries' national laws, nor were they established by international treaties or conventions. They do however affect people on a supra-national level.

Thus, it is justified to see them as a somewhat separate entity, although not a coherent one As there is currently no uniformity in the system and no single body establishing the rules, sports law is developed in several places, not only by the sporting federations, which have a monopoly on the respective sport, ${ }^{347}$ but al so by the $\mathrm{CAS}^{348}$ One should however note that through recent developments, such as the Pechstein case, ${ }^{349}$ the CAS's authority and the validity of its rulings have been questioned, as well be elaborated upon later (Chapter 4.5).

Sports law is often contrasted with or compared to lex mercatoria, the merchant law of the MiddleAges, as both are very autonomous and rely on principles of fairness and equity. ${ }^{350}$ This is further reflected in the terminology used, as neither the frequently used term 'lex sportiva' nor the less often used 'lex ludica' areactually pure Latin expressions. ${ }^{351}$ Both are neologisms, modelled after lex mercatoria, to

344

345

346

347

348

349

350

351
I. Blackshaw (2011), p. 140.

I. Blackshaw (2011), p. 140.

M. J. Mitten and H. Opie (2010), p. 272; See Chapter 1.5 Glossary for an overview of the stakehol ders involved.

D. P. Panagiotopoulos (2011), p. 122.

B. Kolev (2008), p. 57; J .A.R. Nafziger (2004), pp. 3ff; R. C. R Siekmann (2011a), pp. $153 f$.

Pechstein cases: CAS 2009/A/1912 \& 1913; CAS OG 10/04 and OLG München 15 January 2015

Az. U 1110/14 Kart.

I. Blackshaw (2011), p. 142; B. Kolev (2008), p. 57.

R. C. R Siekmann (2011a), p. 153. 
underscore that they are akin to these entities. ${ }^{352}$ For the purpose of this dissertation, theterm'lex sportiva' will beused.

\subsection{Usage of 'nationality' and 'citizenship' in the sporting context}

Having seen how both nationality and citizenship can have different connotations on a national level (Chapter 3.1), there needs to be a more general approach to be able to discuss nationality in a gl obal (sports) context.

Having addressed national definitions and requirements as well as the European Convention on Nationality, it is clear that 'nationality' can have different connotations. ${ }^{353}$ It can be interpreted differently to serve different groups of people, as the different national laws on nationality show.

With regard to the analysis of nationality requirements in a sporting context, this dissertation will thus use the 'nationality' of an athlete in the sense of a bond or link that was established between the state and the person according to the national ity laws of the respective state However, it will become clear that other concepts, such as the 'genuine link' will also come into play with regard to eligibility for a national team. Thus, it will be seen that in several sports being a national is not al ways sufficient to competefor the country.

\subsection{The genuinelinkin sports ${ }^{354}$}

4.3.1. Genuinelink in national leagues and national teams

Tuming to the genuine link in the sports context, one finds that the question of an athlete's nationality does not only come into play in international competitions, but it is also an important factor for national leagues and international dub competitions. ${ }^{355}$ Initiatives, such as the Home-grown Player Rule of the Union des Associations Européennes de Football (UEFA), limit the number of athletes from outside the EU and aim to reward clubs that invest in the training of young athl etes. ${ }^{356}$ As the political gains, such as the representational value of both hosting the Games and the number of medal lists, of the Olympic Games increase, ${ }^{357}$ athletes are being courted by the richer countries that can offer them not only better training facilities but al so other benefits. Consequently, if eligibility criteria were to be abolished, a free market situation of supply and demand would exist, enabling athletes to fredy choose for which country

352

R. C. R Siekmann (2011a), p. 153.

See Chapter 3.1 Nationality and Citizenship for a more in-depth explanation of the different connotations.

This chapter is largely based on the article "Towards a Sporting Nationality?" by A.S. Wollmann, O. W. Vonk and G. R. de Groot published in 22 MJ 2 (2015), pp. 300 - 316.

See Case C-415/93 Union Royale Belge Sociétés de Football Association and others v Bosman [1995] ECR I-4921; for further information and a detailed analysis see S. Van den Bogaert (2005) and S. van den Bogaert, A. Cuyvers, S. Gardiner, R. Parrish, S. Miettinen, J. Soek and R. Siekmann (2010).

European Uni on Study on the training of young sportsmen/women in Europe Extension - part II Home grown player rule A pril 2008. To be found at: http://ec.europa.eu/sport/documents/doc276_en.pdf.

D. Oswald (2009), p. 3. 
to compete Such a decision would be based on economic and other factors that the countries could offer therespectiveathlete

While there is sometimes a disjunction between sporting and state nationality, the principle of taking nationality as a basis for selecting national teams in general is not up for debate as the underlying notion of the genuine link remains. ${ }^{358} \mathrm{As}$ will be examined in greater detail later (Chapter 5 - 14), the eligibility codes of almost all Olympic sports are based on the assumption that it is the athlete's nationality that determines the deciding connecting factor between an athlete and a specific country. Consequently, changes to an athlete's national ity are problematic, as the link between athleteand country shifts. Notably, not all sporting federations all ow for such a change in the country of representation, meaning that sometimes the change in an athlete's nationality does not result in a change of the athlete's country of allegiance ${ }^{359}$ The respective federation's rules are strict in the sense that they aim to discourage athl etes from changing their country of representation in an opportunistic or mercenary fashion. ${ }^{360}$ The reasoning behind these rules, namely to ensure that only national s can compete for a national team, is certainly valid. However, it is important to recognise that changes to a person's nationality do happen more frequently in a globalising world and that people will haveties to more than one country.

Even if federations do in principle allow such changes, the athletes need to fulfil extra requirements before they are al lowed to change the country of representation. These requirements vary not only among the different sporting federations but, also within the same sport, athletes may be faced with different criteria. As many requirements can be waived or reduced, there is no legal certainty for an athlete who wishes to change his or her country of representation. In addition to the detrimental effect the lack of legal certainty can have on athletes, the possibility of the national federations agreeing among one another on the transfer of athletes without any publicity of the decision and the reasoning, could potentially lead to corruption. As also the reasoning behind the dedisions in case of disputes are frequently not made public, theentire mechanismand workings of the federations remain opaque.

\subsubsection{Genuinelink in sporting competitions- a debated topic}

Even countries with usually rather restrictive naturalisation procedures may offer athletes with promising careers passports. ${ }^{361}$ Contrarily, athletes from (civil) war stricken countries who do not change their nationality face the same perils as other civilians in these conflicts and are thus as like $y$ to become refugees or asylum seekers in order to escape ${ }^{362}$ Several scholars consider the fast-track naturalisations for

H. Andres (2009), p. 6; R. Sikmann(2006), p. 123.

Art. 5(2) FIFA statutes: regulations governing the application of the statutes 2016.

R. Siekmann (2006), p. 123.

K. Hail bronner (2006), p. 60; C. D. Hall (2012), p. 191.

BBC News (21 $1^{\text {st }}$ August 2012) Somalia Olympic Runner 'drowns trying to reach Europe'; Ben Quinn (The Guardian, $15^{\text {th }}$ August 2012) Eritrea's flag-carrying runner seeks asylum in UK to flee repressive regime - Olympic athlete and middle-distance runner is one of four from country seeking escape from repressive regime. 
athletes to be an 'abuse of naturalisation' ${ }^{363}$ In contrast, others actively campaign for even quicker naturalisations to improve the pool of athl etes of the respective country:

\begin{abstract}
"[... ] some countries, such as the United States, have strict immigration rules that put them a step behind in casting these intemational fre agents as members of their national team; therefore, the inconsistency evident in the immigration rules of individual countries is threatening innatecompetition of global football in light of the lenient FIFA regulations.[...] Due to this quandary, Congress should expedite naturalization procedures for select individuals who deserve a spot on theU.S. Men's National Teamjust as they have done for Olympic athletes such as Belbin." ${ }^{364}$
\end{abstract}

Whil le these fast tradk naturalisations do enable athletes to further their careers quickly and to compete at the highest level possible ${ }^{365}$ they have a negative effect not only on the devel opment of local tal ent, but they al so lead to a so-called 'muscle drain'. ${ }^{366}$ For instance, more and more tal ented African athletes come to Europe to play in national leagues and thus are sorely missed in their home leagues and often al so their home national teams. ${ }^{367}$

In addition, a third school of thought exists. These scholars favour the creation of a separate sporting nationality that is entire $y$ disconnected from the nationality granted by the state ${ }^{368}$ According to them, decoupling nationality and team representation would reduce the need for fast-track naturalisations and could lead to a freemarket approach. Such a solution is however opposed by scholars of the other schools of thought, as the basis of eligibility for a 'national' team should be having the relevant nationality. ${ }^{369}$ There is thus an on-going debate about nationality and citizenship in the context of sports and representative teams.

The overall tendency that weal thier countries attract athletes from poorer countries shows how international competitions have become more than mere sporting events and are now al so seen as profitable economic events. ${ }^{370}$

\title{
4.3.3. Sporting competitions and statelessness
}

Looking more closely at the aforementioned problems that may arise regarding nationality (Chapter 3.7) and placing them into the context of theOlympic Games, one notices that, while for some athletes the Olympics represent a chance beyond the mere sporting medals for others competing itself is dangerous, as countries try to prevent athl etes from competing by not all owing them to leave the country. The consequences of the latter can be illustrated by the case of Samia Y usuf Omar from Somalia She

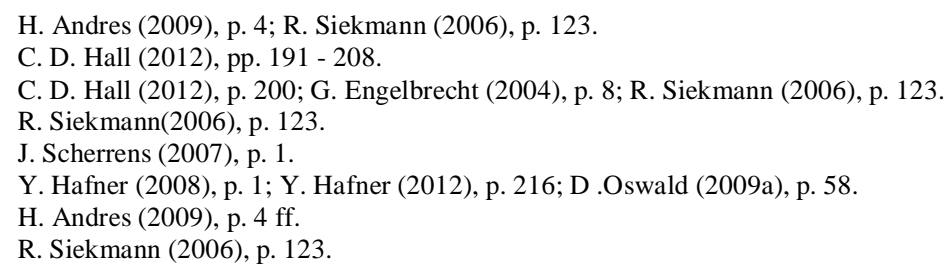


competed in the 2008 Olympics although she had not followed a careful ly elaborated training schedule like her compeitors from wealthier countries ${ }^{371}$ Facing repercussions and death threats upon her return home, she tried to reach Europe illegally via the Mediterraneen Sea. She drowned, like many others, when her boat sank. $^{372}$ Her story shows not only that femble athletes might endanger themselves through openly practicing their sport in countries that marginal ise women in society, but it al so demonstrates al so how difficult life can bein certain countries, even for an Olympic athl ete Thus, whilecalls for an Olympic Truceand cooperation among states are frequently voiced by the UN prior to the Games, actual cooperation allowing athletes to leave their country of origin and enter the country hosting the Olympics is not al ways achieved - with dire consequences for theathl letes.

Other athletes, such as the Eritrea's flag bearer or the entire Cuban football team used the Olympics as a means to leave their countries and sedk asylum elsewhere Athlete defections have occurred at major sporting events in the last decades. ${ }^{373}$ During the times of the Cold War, it was most notably the Eastem European athl etes who used events such as the Olympic Games to flee to the other side of the Iron Curtain. ${ }^{374}$ However, at the last Summer Olympics in London 2012, there were 82 asylum seekers who were connected to the Olympic Games and most of them hailed from A frican countries. ${ }^{375}$ Whilethe countries hosting the Olympic Games seem not to be concerned about the relatively small number of asylum sedkers, the countries of origin aim to combat athl lete defections. Eritrea now requires its athl etes to pay a bond prior to leaving the country for sporting competitions, which they will receive again upon returning home North Koree refuses to let its athletes stay at the Olympic Villages and, as an additional precaution, their family members back home are "kept close by government officials" ${ }^{376}$ An excessive amount of pressure is thus exercised by the countries fearing that their athletes seeintemational sporting competitions as an opportunity to seek asylum el sewhere ${ }^{377}$

One step has recently been taken by the IOC to improve the situation of athletes who are al ready refugees and seeking asylum in other countries. In light of the recent high number of people forced to flee from their home countries, the IOC will for the first time allow refugee athletes to compete during the 2016 Games. As they will not be able to compete for their country of origin, they will compete under the IOC flag

\footnotetext{
371 BBC News (21 ${ }^{\text {t }}$ August 2012) Somalia Olympic Runner 'drowns trying to reach Europe'.

372 Ibid.

373 Ben Quinn (The Guardian, $15^{\text {th }}$ August 2012) Eritrea's flag-carrying runner sedks asylum in UK to fle repressive regime - Olympic athlete and middle-distance runner is one of four from country seeking escape from repressive regi me; I lke Awgu $\left(08^{\text {th }} \mathrm{J}\right.$ une, 2012), For Some Olympians, Sedking Asylum Is Better Than Gold; J. Margolis (unknown publishing date), Winning Gold at Passport Control: Asylum-Sedking Olympians and theOlympic Passport J. Margolis (unknown publishing date), Winning Gold at Passport Control: Asylum-Seeking Olympians and the Olympic Passport.

Ibid.

376 J. Margolis (unknown publishing date) Winning Gold at Passport Control: Asylum-Seeking Olympians and the Olympic Passport; Ike Awgu (08 $8^{\text {th } J ~ u n e ~ 2012) . ~ F o r ~ S o m e ~ O l y m p i a n s, ~ S e d k i n g ~}$ Asylumls Better Than Gold. 
and the Olympic Anthem will be played during the ceremonies. ${ }^{378}$ So far, the IOC has not darified how the qualification for the individual disciplines will be handled, yet, through this measure, the IOC clearly reacts to circumstances athletes might find themselvesin.

\subsection{A proposed sporting nationality $y^{379}$}

As has been mentioned before and will be elaborated upon in greater detail later (Chapter 17.1), thereare some who advocate for theintroduction of a separatesporting nationality. ${ }^{380}$ When looking at the current eligibility codes, one finds that there are several sports that al ready work with the idea of a sporting passport or licence, namely:

- Aquatics (FINA) refers to 'sport nationality' ${ }^{381}$ and stipulates that athletes may only represent countries of which they are ditizens either by birth or by natural isation; ${ }^{382}$

- Gymastics (FIG) refers to a 'Gymastics passport' or license, that shows that the athl eteis a national of therevant country; 383

- Luge (FIL) (refers to a license, which is given if the athleteis a member of one of the FIL's member federations and has received the necessary training. ${ }^{384}$ Notably, national ity does not play a rolehere;

- Rugby (World Rugby) refers to a 'Rugby nationality' 385 and underlines that this will remain the same, regardless of their actual nationality once the athlete is called up for one country;

- Sailing (ISAF) - refers to 'ISAF eligibility', 386 meaning that either the athlete is registered with the ISAF by a national sailing authority or the athlete is a national of a member association.

- Skiing (FIS) refers to a license, which the national federations may only issue to those who arenationals of the country. ${ }^{387}$

378 T. Bach (2015), Speech on the occasion of the adoption of the resolution "Building a peaceful and better world through sport and the Olympic ideal" by IOC President Thomas Bach, UN General Assembly, New Y ork, 26 October 2015.

This chapter is largely based on the article "Towards a Sporting Nationality?" by A.S. Wollmann, O. W. Vonk and G. R. deGroot published in 22 MJ 2 (2015), pp. 300 - 316. Y. Hafner (2008), p. 1; Y. Hafner (2012), p. 216; D .Oswald (2009a), p. 58.

GR 2.5. FINA general rules 2013-2017 of August 2013.

If the athlete acquired citizenship through naturalisation, the FINA requires him or her to have lived in the country for at least two years.

Article 5.1 FIG technical regulations 2008; Article 5.1 FIG technical regulations 2004 from J une 2013; Art. 1 FIG Licence rules, Final version - last update September $25^{\text {th }} 2012 / \mathrm{mb} 1 / 5$.

Art. 3 International Luge regulations - Artificial Track - approved at the $62^{\text {nd }}$ FIL congress on J une $20^{\text {th }}, 2014$ in Innsbruck / Austria; Art 1.3 International Luge regulations - Natural Track - 2012 edition approved at the $60^{\text {th }} \mathrm{FIL}$ congress on J une $15^{\text {th }}, 2012$ in Riga / Latvia.

Question 4 explanatory guidelines on the implementation of regulation 8 eligibility to play for National representative teams - International Rugby Board handbook as framed by the International Rugby Board last updated: 1 September 2014. 
- Wrestling (UWW) refers to sports nationality that does not need to be based upon theathlete's nationality. ${ }^{388}$

Luge is particularly interesting, as thelicenceis not based on an athlete's nationality.

Thus, al so the approaches to the introduction of a sporting nationality or sporting licence differs depending on the Olympic sport Tuming from the sports approach to the theoretical approach taken by scholars, also no common ground has been reached yet. Nevertheless, theneed for better and deerer rules, which woul d lead to more legal certainty, has been recognised. ${ }^{389}$ Here, one of the major problems conceming the sporting national ity in particular and sports law or lex sportiva in general is that so far no clear and universal ly accepted definition exists. ${ }^{390}$

Some authors, such as Oswald or Hafner, have proposed the introduction of a separate sporting nationality, without however going into detail about what such a sporting nationality should entail. ${ }^{391}$ Overall, themain problems arising in this context are, firstly, the precise definition of 'sporting nationality' and, secondly, to what extent 'sporting nationality' should be dependent on an athlete's state nationality. ${ }^{392}$ Oswald proposed a concept

"that would be totally separate from state nationality, without losing the notion of national belonging. This would be known as 'Olympic nationality' or, even better 'Olympic membership' ". 393

The question arising from this suggestion is how such a notion of national belonging can be established without refering to nationality itself or without relying on the same criteria that the attribution of nationality usually relies upon. A genuine link between country and athlete usually has to re y either on bl ood relations (such as ius sanguinis), birth on the teritory (such as ius soli) or through prol onged residence in the country (as prescribed by natural isation mechanisms). Competing for a country internationally would show the athlete's intention of belonging to the country, yet this is a circular argument, as only those who bel ong to a country can compete for it intemationally. A further elaboration on this issue will be made in Chapter 17.1 when addressing possiblesolutions to theincoherent current system of eligibility criteria.

\subsection{The CAS and eligibility cases}

Coming to the eligibility criteria currently in place and the methods to solve disputes arising in this context, one first needs to underscore that the IOC has the exclusive right to allow entry to the Olympic Games. Legal disputes are settled by the Court of

\footnotetext{
388 Introduction FILA international rules for the change of national ity approved by the Bureau on $15^{\text {th }}$ January 2015. As the current rules are so varied and criteria can be set aside so easily; see Y. Hafner (2012), p. 238; R .C. R. Siekmann (2011b), p.87.

390 J. A. R. Nafziger (2011), p. 14; R. C. R. Siekmann (2011c), pp. $4 f f$.

391 Y. Hafner (2008), p. 1; Y. Hafner (2012), p. 216; D. Oswald (2009a), p. 58.

392 Y. Hafner (2012), p. 238; D. Oswal d (2009a), p. 58.

393 D. Oswald (2009a), p. 58.
} 
Arbitration for Sport (CAS), which was set up in 1982. It is a spedial arbitration body which is officially independent from any sporting federation. ${ }^{394}$ Through current devel opments, such as the Pechstein case, ${ }^{395}$ questions on the validity of this practice and applicability of the CAS rulings havearisen. ${ }^{396}$ Clauda Pechstein, a German speed skater was banned by the Skating Federation (ISU) as one of her blood samples was identified as containing doping traces. She contested the ban before CAS and the Swiss Federal Tribunal, which is the court responsible for appeals against CAS decisions under Swiss law, ${ }^{397}$ but lost. Maintaining that the result of the drugs test was faulty, she started proceedings in Germany and sued for damages. Eventually, after another appeal, the higher local court in Munich (Oberlandesgericht) held that the arbitration clause was invalid, as Pechstein had no choice but to accept the clause if shewanted to participatein ISU events. ${ }^{398}$

The CAS's independence has been questioned in recent times, seeing that International Council of Arbitration for Sport (ICAS), the body governing it is deemed to be overly tied to sport governing bodies ${ }^{399}$ These close ties are established as often people who held office in a sport governing body continue their career at CAS or ICAS. Furthermore, the composition of the arbitration pands leads to difficulties, as there is only a closed list of arbiters on which the sporting federations have a disproportionateinfluence ${ }^{400}$

Another issue of concern is whether athletes actually fredy consent to the arbitration dauses, as their respective sporting federation requires them to sign before they may participate in officially sanctioned competitions. ${ }^{401}$ Considering that an athlete's carer depends on participating in these sanctioned events, the extent to which the consent to the CAS arbitration dause is given fredy is doubtful at best. ${ }^{402}$ This forced arbitration can be harmful to athletes, yet, due to the short duration of an athl ete's career and themonopoly enjoyed by the sport governing bodies, most athl etes never challenge this. ${ }^{403}$ Furthermore, acceptance of a CAS judgment and relinquishing the possibility to go to ordinary courts, results in a situation in which there is no real means to redress. ${ }^{404}$

As previously mentioned, in principle CAS decisions can be appeel ed at the Swiss Federal tribunal. This judicial review is however severely limited, as the tribunal takes a 'hands-off' approach. ${ }^{405}$ Other problems include that CAS cases do not establish

M. J. Mitten and T. Davis (2008), p. 78; A. Duval and B. Van Rompuy (2015), p. $19 f$. Pechstein cases: CAS 2009/A/1912 \& 1913; CAS OG 10/04 and OLG München 15 January 2015 Az. U 1110/14 Kart; seeA. Duval (2015a) for a summary.

396 A. Duval (2015b), p. $249 f$.

397 Art. 191 Swiss International Arbitration Law.

398 Seealso A. Duval (2015a).

399 A. Duval and B. Van Rompuy (2015), pp. $25 \mathrm{f}$.

400 A. Duval and B. Van Rompuy (2015), pp. 22ff. and 27.

401 A. Duval and B. Van Rompuy (2015), p. 2; A. Duval (2015b), pp. $249 f$.

402 A. Duval and B. Van Rompuy (2015), pp. 2, $5 f$ and 8.

403 A. Duval and B. Van Rompuy (2015), pp. 10 and 17.

404 A. Duval (2015b), pp. $249 f$.

405 So far, few CAS awards have actually been struck down; see M. J. Mitten and T. Davis (2008), pp. 80 and 86; A. Duval and B. Van Rompuy (2015), p. 2; A. Duval (2015b), p. $246 f$.
} 
binding precedents and there is an overall lack of publicity. ${ }^{406}$ Thus, while CAS has shaped and does shape lex sportiva through its rulings, especially through the ad hoc divisions set up to solve issues speedily prior to major sporting events, ${ }^{407}$ several calls for reform have been voiced. ${ }^{408}$ However, the alternative of having national courts decide on sporting matters would create an extremely diverse picture and counteract all attempts at unifying sports law. ${ }^{409}$ Thus, while the current modus operandi is rightly criticised, the CAS remains an important body. ${ }^{410}$

Turning from the CAS and its problems to the relevant cases, one first needs to acknowl edge that the maj ority of CAS cases are doping re ated. ${ }^{411}$ Thereare, however, some interesting cases decided by the ad hoc divisions prior to Olympic Games dealing with eligibility issues and they shed light on the terminol ogy used by national legis ators and sporting federations. Looking at the Perez I, II and III v IOC ${ }^{412}$ and Miranda I and II $\vee I^{1 O C^{413}}$ cases, one finds several similarities but also stark differences.

Angel Perez was a Cuban national, born in 1971 who competed in canoe kayak competition for Cuba in the 1992 Olympics. Following a competition in Mexico in 1993, he fled to the USA and applied for asylum. He married a US citizen in 1994 and received a permanent residence permit in 1995, before becoming a citizen in 1999. Wishing to compete for the US in the 2000 Olympics, he had to prove that three years had passed since he became a US national. In the first case, Perez argued that he had become akin to a national, but a non-citizen, of the US when receiving his permanent residence permit and compared his situation to those stemming from Guam ${ }^{414}$ who also had to undergo a naturalisation procedure to become fully-fledged citizens. ${ }^{415}$ This was however dismissed. ${ }^{416}$ In the subsequent case it was argued that Perez had become de facto stateless when he defected from Cuba. It was further maintained that 'changing one's nationality' can also meen that a person becomes stateless, and the CAS held that a change had occurred in Perez's nationality status over three years prior to the Olympic games and thus all owed him to compete for the US ${ }^{417}$ The Cuban NOC challenged this dedision without success. ${ }^{418}$

Though since 2011 this situation has changed under $\S 307$ (US Code Title 8 1407) Immigration and Nationality Act 2011, making people from Guam now citizens from birth. 
Similarly, Arturo Miranda was a Cuban national, born in 1971 and had competed as a diver for Cuba in the Pan-American games in 1991. He however ended his diving career in 1992 and married a Canadian national in 1994 with whom he moved to Canada in 1995, where he became involved with diving again. Miranda became a Canadian citizen in 1999, but he retained his Cuban passport and visited Cuba annually. Wishing to compete for the Canadian diving team at the 2000 Olympics, he argued along the same lines as Perez that he had become akin to a national- noncitizen in Canada. While the Panel held that he had clearly not moved to Canada to further his diving carer, this application was dismissed ${ }^{419}$ In the subsequent case, Miranda al so tried to argue al ong the lines of de facto statelessness as Perez. However, Miranda had received permission from Cuba to emigrate, visited annually and maintained his Cuban passport, so that here there was no case of de facto statelessness. ${ }^{420}$

These five cases are interesting not only because they show how quick the CAS ad hoc divisions work, with CAS awards being given within 24 hours, but also the way the CAS deals with the underlying national laws becomes dear from these cases. For both athletes, the ad hoc divisions referred explicitly to distinctions made between nationals- non-citizens and citizens by countries and used this analogously when considering the athlete's situation in the context of the nationality criteria described in theIOC Charter.

\subsection{Nationality R equirements in the O lympic C harter}

As previously outlined, the Olympic Games are the pinnacle of sport competitions for most sports. ${ }^{421}$ The architectural and other changes brought to hosting dities are considered by some authors as akin to Olympics values, which enrich the city long after they the games took place there ${ }^{422}$ Special focus is al so placed on the Olympic Charter, which is seen as a:

"moral authority, based on the social, economic and sporting significance of the Olympic Games". ${ }^{223}$

As there have been controversies regarding not only the Olympics, but also other major sporting events and the effect they had on local communities, this seems debatable Looking more dosely at the rules applicable to the Olympic Games, some authors describetheOlympic Charter as follows:

"The functions of the Olympic Charter are essentially threefold: (i) it is the fundamental basic document of the Olympic Movement, with a legal status, which approximates that of a constitution; (ii) it defines therights and obligations of the component parts of the Olympic Movement, with a legal status which is

419
Miranda I v IOC - CAS OG (Sydney) 00/003, Digest of CAS Awards II, p. 607.

Miranda II vIOC - CAS OG (Sydney) 00/008, Digest of CAS Awards II, p. 645.

D. Oswald (2009b), p. 1.

D. Oswald (2009b), p. 3.

A. Mestre (2008), p. 101. 
similar to a contract; and (iii) it is the founding document of the IOC (i.e its byelaws goveming its intemal organisation - composition; membership rules; governing bodies, etc.)". 424

Tuming to the issue of eligibility, as termed by the IOC Charter, there are some problematic concems. For instance, trans-sexual athletes encounter obstades to competeas athl etes often have to identify their gender. ${ }^{425}$

Nationality Requirements and eligibility are described in the Olympic Charter of September 2013 in Artide 40 and 41 as well as in thetwo bye laws belonging to these artides. Rule 40 stipulates that the athlete, coach or other official must firstly comply with the Olympic Charter, also meaning the rules conceming fair play, anti-doping, and the conditions of eligibility of the IOC. In addition al so the eligibility rules of the respectiveinternational federation (IF) have to becomplied with, which in turn haveto be approved by the IOC again. ${ }^{426}$ The bye law to this rule further specifies that the IF may establish its own eligibility criteria in as far as these comply with the IOC rules and are approved by the IOC Board. ${ }^{427}$ Theactual application rests with the IF and the respectivenational federations, thus the $\mathrm{OC}$ does not actively concem itse $\mathrm{f}$ with these eligibility ariteria in general. ${ }^{428}$

Nationality is mentioned explicitly in Rule41, which states that:

"1. Any compeitor in the Olympic Games must be a national of the country of the NOC which is entering such competitor.

2. All matters relating to the determination of the country which a competitor may represent in the Olympic Games shall be resolved by the IOC Executive Board." 429

The reference here is to the nationality of the country of the NOC; although there might be countries in which there are several NOCs, eg. the UK with England, Scotland and Wales. At this stage no differentiation is made between athletes who wish to compete for the country of which they have been nationals since birth and athletes who have acquired a new national ity through naturalisation.

The bye law to this rule is more detailed and more to the point, since it al so deals with athletes with dual nationality, changes in theterritory of the country and changes in the country of representation. Here the first rule is that once an athlete chooses to represent one country in the Olympic Games or any compeition recognised by the relevant IF, he or she cannot change the country of representation. ${ }^{430}$ However, in certain situations, the acquisition or change of nationality can become effective for the sport Firstly, if an athlete with dual nationality or multiple nationality wishes to

\footnotetext{
$424 \quad$ A. Mestre (2008), p. 101.

425 R. Kopczyk (2012), p. 62.

426 Rule40 Olympic Charter September 2013.

427 Bye-law to rule 40(1) Olympic Charter September 2013.

428 Bye-law to rule 40(2) Olympic Charter September 2013.

429 Rule41 Olympic Charter September 2013.

430 Byelaw to Rule 41(1) Olympic Charter September 2013.
} 
changehis or her country of representation, this is possible only after a period of three years of non-competition, i.e not competing in championships recognised by the IF. ${ }^{431}$ However, this period may be reduced or waived if theNOCS, IF and the IOC agree, in case the circumstances at hand allow for such a deviation from the main rule ${ }^{432}$ The IOC further provides for the cases in which the teritory of the state has changed and thus has affected the question of nationality in a manner outsidetheordinary:

"3. If an associated State, province or overseas department, a country or colony acquires independence, if a country becomes incorporated within another country by reason of a change of border, if a country merges with another country, or if a new NOC is recognised by the IOC, a competitor may continue to represent the country to which he bel ongs or belonged. However, hemay, if heprefers, elect to represent his country or beentered in the Olympic Games by his new NOC if one exists. This particular choicemay bemadeonly once" ${ }^{\prime 433}$

The Olympic Charter underlines that it is the IOC Executive Board that takes the final decision in cases conceming athlete e ligi bility. ${ }^{434}$ Here cases conceming digibility are defined as those in which an athlete has qual ified for the Olympics when competing for a country of which he or she is not a national or has the choice between different countries which he or she could potentially represent ${ }^{435}$ It is interesting to note the way this is worded, sincethe Charter refers to:

"issues resulting from nationality, citizenship, domicile or residence of any competitor, including the duration of any waiting period."

A clear distinction is made between nationality and citizenship on the one hand and residence and domicile on the other hand. However, Rule 41 only referred to a national of the country of the NOC, not to a citizen of said country. ${ }^{437}$ The Charter hints at the differences existing in certain countries between residence and domicile ${ }^{438}$ and the differences between citizen and national, without further elaborating on the difference in concepts. One might thus deduce that while the IOC is aware of the differences, yet for the IOC's purpose eligibility, nationality and citizenship will be treated as synonyms. $^{439}$

Tablell. Overview of theIOC's eligibility requirements

\begin{tabular}{|l|l|}
\hline R equirements & IOC Olympic C harter October 2013 \\
\hline In force since & September 2013 \\
\hline C hange of nationality & Once \\
\hline
\end{tabular}

431 Byelaw to Rule 41(2) Olympic Charter September 2013.

432 Ibid.

433 Byelaw to Rule 41(3) Olympic Charter September 2013.

434 Byelaw to Rule 41(4) Olympic Charter September 2013.

435 Ibid.

436 Ibid.

437 Rule41(1) Olympic Charter September 2013.

438 Most notably the UK.

439 G. R. DeGroot (2003a), p. 6ff. 
LEX SPORTIVA AND NATIONALITY

\begin{tabular}{|l|l|}
\hline Residence requirements & None \\
\hline M inors and nationality change & Not specified \\
\hline Stateless athletes & Not specified \\
\hline $\begin{array}{l}\text { Position of athlete with multiple nationality } \\
\text { after having competed for another country of } \\
\text { which the athlete is a national }\end{array}$ & $\begin{array}{l}\text { Threyear period of non-competition, but might } \\
\text { bewaived }\end{array}$ \\
\hline E ffect of changes in territory of country & $\begin{array}{l}\text { Athlete may choose once whether heor she want } \\
\text { to continuerepresenting the old entity (if it still } \\
\text { exists) or wants to represent one of thenew entities }\end{array}$ \\
\hline Competing for the country of residence & Not specified \\
\hline Number of changes possible & Once, in thecase of changes in territorial reality. \\
\hline
\end{tabular}





\section{Classic Sports}

In the following part of the dissertation, 'classic sports' will be analysed. These sports date back to the Olympics in Ancient Greece, such as athletics, triathlon, modem pentathl on and weightlifting. Biathl on, although a relatively new sport, having become an Olympic sport in 1960, and a winter sport at that, is included here due to its structural proximity to triathl on and pentathl on, which require athletes to excel in more than onediscipline

Interestingly, in all of these sports, women have not been participating since the beginning. The earliest disciplineall owing women in their ranks was athletics in 1928. Thenext sport al lowing women was therelatively young sport biathl on, in 1992, while all other sports only allowed women to competeas of 2000.

TableIII: Topics dealt with in classic sports

\begin{tabular}{|c|c|c|c|c|c|}
\hline R equirements & Athletics & Biathlon & Triathlon & \begin{tabular}{|l} 
M odern \\
Pentathlon
\end{tabular} & Weightlifting \\
\hline In force since & 2014 & 2014 & 1989 & 2013 & 2013 \\
\hline $\begin{array}{l}\text { Versions since } \\
2005\end{array}$ & $\begin{array}{l}2005-2007 \\
2009-2011 \\
2011-2013 \\
\text { Since 2014 }\end{array}$ & Since2014 & Since 1989 & $\begin{array}{l}2005-2012 \\
2013-2015 \\
\text { Since } 2015\end{array}$ & Since 2013 \\
\hline $\begin{array}{l}\text { Substantial } \\
\text { C hanges made } \\
\text { since October } \\
2013\end{array}$ & $\begin{array}{l}\text { Previously two-year } \\
\text { non-competition } \\
\text { period or residence, } \\
\text { now changed to } \\
\text { threeyears both }\end{array}$ & na & na & $\begin{array}{l}\text { abolition of } \\
\text { residence } \\
\text { requirement, } \\
\text { waiting period } \\
\text { instead; } \\
\text { introduction of } \\
\text { teritorial transfer } \\
\text { rule }\end{array}$ & na \\
\hline $\begin{array}{l}\text { C hange of } \\
\text { nationality }\end{array}$ & Possible & $\begin{array}{l}\text { Possiblewith } \\
\text { two-year } \\
\text { waiting period }\end{array}$ & Possible & $\begin{array}{l}\text { Possible, after } \\
\text { threeyear } \\
\text { waiting period }\end{array}$ & \begin{tabular}{|l|} 
Possi ble, but \\
after first \\
changethereis a \\
waiting period \\
of four years
\end{tabular} \\
\hline \begin{tabular}{|l} 
Residence \\
requirements
\end{tabular} & $\begin{array}{l}\text { For athletes who } \\
\text { have not yet } \\
\text { competed } \\
\text { internationally: One } \\
\text { year (instead of } \\
\text { non-competition } \\
\text { period); for athletes } \\
\text { who had competed } \\
\text { internationally: } \\
\text { threyears (instead } \\
\text { of a threeyear } \\
\text { competition period) }\end{array}$ & None & $\begin{array}{l}\text { Three years, } \\
\text { may be waived } \\
\text { to one year }\end{array}$ & none & None \\
\hline $\begin{array}{l}\text { M inors and } \\
\text { nationality }\end{array}$ & Not specified & Not specified & Not specified & Not specified & Not specified \\
\hline
\end{tabular}


NATIONALITY REQUiREMENTS In OLy MPIC SPORTS

\begin{tabular}{|c|c|c|c|c|c|}
\hline change & & & & & \\
\hline \begin{tabular}{|l} 
Stateless \\
athletes
\end{tabular} & Not specified & \begin{tabular}{|l|} 
Can compete \\
for a \\
federation if \\
IBU Board \\
authorises it
\end{tabular} & Not specified & Not specified & Not specified \\
\hline \begin{tabular}{|l|} 
Position of \\
athlete with \\
multiple \\
nationality after \\
having \\
competed for \\
another \\
country of \\
which the \\
athlete is a \\
national
\end{tabular} & \begin{tabular}{|l|} 
For athletes who \\
had competed \\
internationally: \\
threeyears of \\
residence (instead \\
of threeyear \\
competition period); \\
Difference made for \\
dual citizenship \\
acquired at birth or \\
later in life
\end{tabular} & \begin{tabular}{|l|} 
Possi blewith \\
two-year \\
waiting period
\end{tabular} & $\begin{array}{l}\text { Threeyear } \\
\text { waiting period, } \\
\text { unless the } \\
\text { relevant } \\
\text { federations } \\
\text { agreeto reduce } \\
\text { it }\end{array}$ & $\begin{array}{l}\text { Possibleafter } \\
\text { threyear non- } \\
\text { competition } \\
\text { period }\end{array}$ & $\begin{array}{l}\text { May decide } \\
\text { with a waiting } \\
\text { period of } 12 \\
\text { months }\end{array}$ \\
\hline $\begin{array}{l}\text { E ffect of } \\
\text { changes in } \\
\text { territory of } \\
\text { country }\end{array}$ & $\begin{array}{l}\text { Change possible } \\
\text { and becomes } \\
\text { effectivedirectly for } \\
\text { the competitions }\end{array}$ & Not specified & $\begin{array}{l}\text { Athlete may } \\
\text { choose once, but } \\
\text { needs approval } \\
\text { of Executive } \\
\text { Committee }\end{array}$ & $\begin{array}{l}\text { Onechoice } \\
\text { allowed }\end{array}$ & Not specified \\
\hline $\begin{array}{l}\text { Competing for } \\
\text { the country of } \\
\text { residence }\end{array}$ & Not possible & Not possible & \begin{tabular}{|l||} 
Not exactly \\
specified, might \\
be possible, \\
depending on \\
how the \\
wording is \\
interpreted
\end{tabular} & Not specified & $\begin{array}{l}\text { Possibleif } \\
\text { approved by } \\
\text { federation }\end{array}$ \\
\hline $\begin{array}{l}\text { Number of } \\
\text { changes } \\
\text { possible }\end{array}$ & Not specified & Not specified & $\begin{array}{l}\text { No maximum } \\
\text { given }\end{array}$ & $\begin{array}{l}\text { No maximum } \\
\text { given }\end{array}$ & $\begin{array}{l}\text { One is easy, } \\
\text { afterwards it } \\
\text { becomes more } \\
\text { difficult }\end{array}$ \\
\hline $\begin{array}{l}\text { R eference to } \\
\text { Olympic } \\
\text { C harter }\end{array}$ & None & $\begin{array}{l}\text { Yes, } \\
\text { regarding } \\
\text { applicability } \\
\text { of rules }\end{array}$ & None & yes & $\begin{array}{l}\text { Yes, prevailsin } \\
\text { eligibility } \\
\text { questions }\end{array}$ \\
\hline $\begin{array}{l}\text { Uses } \\
\text { nationality/ } \\
\text { citizenship }\end{array}$ & \begin{tabular}{|l|} 
Citizenship by \\
virtue of having \\
been borm or by \\
virtue of having a \\
parent or \\
grandparent born in \\
the country
\end{tabular} & $\begin{array}{l}\text { Nationality in } \\
\text { the heading } \\
\text { and } \\
\text { citizenship/cit } \\
\text { izens in the } \\
\text { text }\end{array}$ & Citizenship & $\begin{array}{l}\text { Nationality \& } \\
\text { citizenship }\end{array}$ & citizenship \\
\hline $\begin{array}{l}\text { Uses residence/ } \\
\text { domicile }\end{array}$ & $\begin{array}{l}\text { Residenceis the } \\
\text { primary home\& } \\
\text { registration with } \\
\text { authorities }\end{array}$ & None & Residence & $\begin{array}{l}\text { Residence \& } \\
\text { domicile }\end{array}$ & Residence \\
\hline $\begin{array}{l}\text { Other } \\
\text { remarkable } \\
\text { peculiarity }\end{array}$ & \begin{tabular}{l|} 
Definitions of \\
Citizenship, \\
Residence and \\
Country provided at \\
the beginning;
\end{tabular} & & & $\begin{array}{l}\text { Distinction } \\
\text { Olympic \& Non- } \\
\text { Olympic } \\
\text { Competition }\end{array}$ & $\begin{array}{l}\text { Referenceto } \\
\text { UN as } \\
\text { institution, } \\
\text { which may rule } \\
\text { on the question }\end{array}$ \\
\hline
\end{tabular}


CLASSIC SPORTS

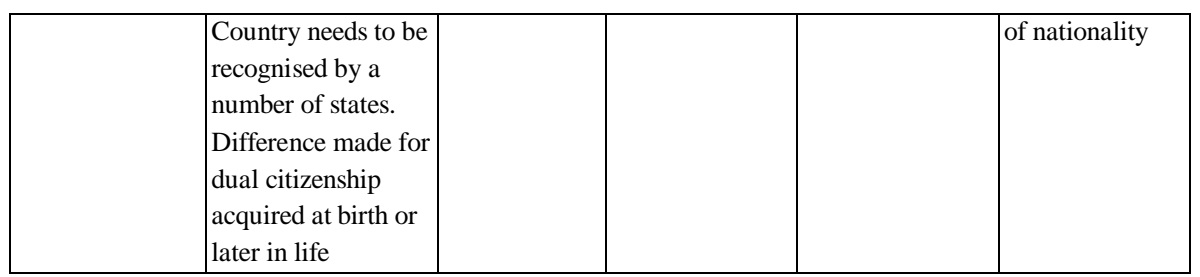




\subsection{Athletics ${ }^{440}$}

Athletics is one of the oldest Olympic sports in a dual sense of the word. Not only was it al ready included in the first modem Olympic Games in 1896, but it al so formed part of the Andient Gredk Games. ${ }^{441}$ There are records on champions dating back to 776 BC, although the set-up of those games were largely different from today, consisting of races on foot over a distance of 192 metres, while carrying shields or dressing up in infantry armour was sometimes added to increase the difficulty. ${ }^{442}$ Furthermore, competitions in long jump, disaus throwing, javelin throwing and wrestling were held. $^{443}$

The modem form of athletics, which indudes competitions in running, jumping, throwing, walking, and a combination thereof was already a feeture at the 1896 Games. ${ }^{444}$ Wrestling notably became its own individual discipline In 1912 the International Association of A thletics Federations (IAAF) was founded and has its seat in Monaco. ${ }^{445}$ Women have been competing at the Olympic level since $1928,{ }^{446}$ and nowadays the competitions for men and women areal most identical. ${ }^{447}$

At the Games themsel ves, there are track, field and road events and combinations thereof. Road events are held as marathons and long distance walks; field events indude discus and javelin throwing as well as the long jump competition; track events are any races from sprints to long distance races. Combinations are the decathl on or theheptathl on for men and women respectively. ${ }^{448}$

TableIV: Overview of the eligibility requirements for athletics

\begin{tabular}{|l|l|}
\hline R equirements I AAF & \\
\hline In force since & November 2013 \\
\hline C hange of nationality & Possi ble \\
\hline R esidence requirements & For athletes who have not yet competed internationally: One \\
& year (instead of non-competition period); \\
& For athletes who had competed internationally: threyears \\
& (instead of three-year non-competition period) \\
\hline M inors and nationality change & Not specified \\
\hline Stateless athletes & Not specified \\
\hline
\end{tabular}

440 The federation was contacted on $6^{\text {th }}$ August 2014 and asked to provide further insights into its eligibility criteria and older versions of the eligibility rules. On $19^{\text {th }}$ August 2014 the IAAF kindly replied and provided the previously applicable eligibility rules. On $29^{\text {th }}$ October 2015 , the federation was contacted again and asked for comments on this Chapter. As no reply was forthcoming, a first reminder was sent on $19^{\text {th }}$ November 2015, to which the federation replied on $30^{\text {th }}$ November 2015.

IOC Information ISAAF: for information on non-national athl etes in the European national leagues and competitions see S. van den Bogaert, A. Cuyvers, S. Gardiner, R. Parrish, S. Miettinen, J. Soek and R. Siekmann (2010), p. 135. IOC Information ISAAF; IOC Information A thletics Equipment and History.

443 IOC Information A thl etics Equi pment and History.

$444 \quad$ Ibid.

445 IOC Information ISAAF; IOC Information Athletics Equipment and History; IOC Reference document Athletics.

446 Ibid.

447 Information Athl etics Equi pment and History.

448 Ibid. 


\section{CLASSIC SPORTS}

\begin{tabular}{|l|l|}
\hline $\begin{array}{l}\text { Position of athletes with multiple } \\
\text { nationality after having competed for } \\
\text { another country of which the athlete } \\
\text { is a national }\end{array}$ & $\begin{array}{l}\text { For athletes who had competed internationally: threeyears } \\
\text { of residence (instead of threeyear non-competition period); } \\
\text { Difference made for dual citizenship acquired at birth or } \\
\text { later in life }\end{array}$ \\
\hline $\begin{array}{l}\text { E ffect of changes in territory of } \\
\text { country }\end{array}$ & $\begin{array}{l}\text { Change possibleand becomes directly effective for the } \\
\text { competitions }\end{array}$ \\
\hline $\begin{array}{l}\text { Competing for the country of } \\
\text { residence }\end{array}$ & Not possible \\
\hline Number of changes possible & Not specified \\
\hline R eference to Olympic Charter & None \\
\hline Uses nationality/ citizenship & $\begin{array}{l}\text { Citizenship by virtue of having been born or by virtue of } \\
\text { having a parent or grandparent born in the Country }\end{array}$ \\
\hline Uses residence/ domicile & $\begin{array}{l}\text { Residenceis the primary home\& registration with } \\
\text { authorities }\end{array}$ \\
\hline Other remarkable peculiarity & $\begin{array}{l}\text { Definitions of Citizenship, Residence and Country provided } \\
\text { at the beginning; Country needs to be recogni sed by a } \\
\text { number of states; } \\
\text { Difference made for dual citizenship acquired at birth or } \\
\text { later in life }\end{array}$ \\
\hline
\end{tabular}

\subsubsection{Athletics critical reflection}

Looking at the IAAF's eligibility criteria, one finds that changing the country of representation as a result of a change in the athlete's nationality is possible However, there are several problematic aspects: firstly, the IAAF refers primarily to dual national ity and does not take into account the possi bility for athl etes to have more than two nationalities ${ }^{449}$ Secondly, the IAAF does not seem to take the conferral of nationality after adoption or the less common surrogacy into consideration. ${ }^{450}$ And thirdly, the IAAF refers to states being recognised by other states, without providing a number of recognitions as a threshold, which can be problematic in case of border or territorial conflicts, ${ }^{451}$ i.e athletes wishing to compete for Palestine or Kosovo. Overall, the rules appear to be relatively strict with a threeyear residence or noncompeition period. ${ }^{452}$ However, as these requirements can be reduced or wai ved, ${ }^{453}$ thereis no legal security.

\subsubsection{Rules applicable since 2011}

With regard to the eligibility criteria that can be found in the Intemational Association of Athletics Federations Competition Rules 2016-2017 in force as of $1^{\text {th }}$ November

Rule 5(4)(e)(ii) International Association of Athletics Federations competition rules 2016-2017 in force as from $1^{\text {st }}$ November 2015.

450 Rule 5(2)(a) International Association of Athletics Federations competition rules 2016-2017 in force as from $1^{\text {st }}$ November 2015.

451 Definitions International Association of Athletics Federations competition rules 2016-2017 in force as from $1^{\text {st }}$ November 2015.

452 Rule 5(4)(e) International Association of Athletics Federations competition rules 2016-2017 in force as from $1^{\text {st }}$ November 2015.

453 Rule 5(4)(e)(ii) International Association of Athletics Federations competition rules 2016-2017 in force as from $1^{\text {st }}$ November 2015.
} 
2015, which are essentially identical to the 2014-2015 rules, these criteria dosely resembletherul es applicable previously and which devel oped in the foll owing stages:

Since 2008:

- The domestic competition in which athletes may participate after changing their country of representation may now ind udeathl etes from other Members. ${ }^{454}$

Since 2009:

- The deadline for submitting a request for the cancellation of a waiting period was added $^{455}$

Since 2011:

- a signature of both parties was no longer needed in cases of a transfer of dual citizenship. ${ }^{456}$

Since 2012:

- A more detailed approach to changing the country of representation after having competed internationality was introduced; ${ }^{457}$

- The introduction of a rule for athletes who wish to change their country of representation without having competed intemationally. ${ }^{458}$

Since 2013:

- A burden of proof clause was added; 459

- Three continuous years of residence al lowing for the reduction of the threeyear non-competition period in casean athl ete acquired a new national ity; ${ }^{460}$

- More differentiated rules for athl etes who havenever competed international ly and who wish to changether country of representation. ${ }^{461}$

The current IAAF rules start by providing definitions of the most important terms, such as citizen, citizenship and residence Residence, according to the meaning of the $I A A F$, is the place where the athletehas his or her primary homeand is registered with the authorities. ${ }^{462}$ A country means a geographical area which is recognised by

Rule5(3)(a) International Association of Athletics Federations competition rules 2008.

Rule (2)(c)(ii) and 5(2)(d)(ii) International Association of Athletics Federations competition rules 2009.

Rule5(2)(c)(i) International Association of Athl etics Federations competition rules 2010-2011.

Rule 5(4) International Association of Athletics Federations competition rules 2012-2013 in force as from $1^{\text {st }}$ November 2011.

Rule 5(2) International Association of Athletics Federations competition rules 2012-2013 in force as from $1^{\text {st }}$ November 2011.

Rule 5(5) International Association of Athletics Federations competition rules 2014-2015 in force as from $1^{\text {st }}$ November 2013.

Rule 5(4)(d)(ii) International Association of Athletics Federations competition rules 2014-2015 in force as from $1^{\text {st }}$ November 2013.

Rule 5(2) International Association of Athletics Federations competition rules 2012-2013 in force as from $1^{\text {st }}$ November 2011.

Definitions International Association of Athletics Federations competition rules 2016-2017 in force as from $1^{\text {st }}$ November 2015; Definitions International Association of Athletics Federations competition rules 2014-2015 in force as from $1^{\text {st }}$ November 2013; Definitions International Association of Athledics Federations competition rules $2012-2013$ in force as from $1^{\text {st }}$ November 2011. 
international law and intemational bodies as an independent state ${ }^{463}$ Since the definition does not give a minimum number of recognising states, this could potential ly be a matter of conflict Citizenship is to mean 'legal citizenship' and thus a citizen is someone who has such a legal ditizenship. ${ }^{464}$

The actual rules regarding eligibility to represent are stipulated in Rules 5, 20, 21 and 22, although only Rule 5 goes into greater detail conceming citizenship. However, the IAAF member associations may establish their own eligibility rules, which however need to conform to the IAAF eligi bility rules. ${ }^{465}$ In case of a conflict between the rules, the IAAF rules take precedence In general, an athlete is considered eligible to "compete if heagrees to abide by the Rules and has not been declared ineligible". ${ }^{466}$ More spedifically, this concerns athletes who are citizens of the country which they wish to represent and who comply with Rule $5{ }^{467}$ Regardless of their ditizenship, athl etes becomeineligible if they lose the eligi bility for the sport under theIAAF rules, specifically Rule22 and subsequent, for examplein the case of a violation of the AntiDoping Rules ${ }^{468}$ The burden of proof rests with the athlete and the relevant member federation. ${ }^{469}$ Consequently, the federations need to provide the IAAF with the necessary evidence conceming their athletes' citizenship status. ${ }^{470}$

463 Definitions International Association of Athletics Federations competition rules 2016-2017 in force as from $1^{\text {st }}$ November 2015; Definitions International Association of Athletics Federations competition rules 2014-2015 in force as from $1^{\text {st }}$ November 2013; Definitions International Association of Athletics Federations competition rules 2012-2013 in force as from $1^{\text {st }}$ November 2011.

464 Definitions International Association of Athletics Federations competition rules 2016-2017 in force as from $1^{\text {st }}$ November 2015; Definitions International Association of Athletics Federations competition rules 2014-2015 in force as from $1^{\text {st }}$ November 2013; Definitions International Association of Athletics Federations competition rules 2012-2013 in force as from $1^{\text {st }}$ November 2011.

465 Rule21(3) International Association of Athletics Federations competition rules 2016-2017 in force as from $1^{\text {ts }}$ November 2015; Rule 21(3) International Association of Athletics Federations competition rules 2014-2015 in force as from $1^{\text {st }}$ November 2013; Rule 21(3) International Association of Athletics Federations competition rules 2014-2015 in force as from $1^{\text {st }}$ November 2011.

466 Rule 20 International Association of Athletics Federations competition rules 2016-2017 in force as from $1^{\text {st }}$ November 2015; Rule 20 International Association of Athletics Federations competition rules 2014-2015 in force as from $1^{\text {st }}$ November 2013; Rule 20 International Association of Athl etics Federations competition rules 2014-2015 in force as from $1^{\text {th }}$ November 2011.

467 Rule 5(1) International Association of Athletics Federations competition rules 2016-2017 in force as from $1^{\text {st }}$ November 2015; Rule 5(1) International Association of Athletics Federations competition rules 2014-2015 in force as from $1^{\text {tt }}$ Novermber 2013; Rule 5(1) International Association of Athletics Federations competition rules 2014-2015 in force as from $1^{\text {st }}$ November 2011.

468 Rule 22(1)(e) International Association of Athletics Federations competition rules 2016-2017 in force as from $1^{\text {st }}$ November 2015; Rule 22(1)(e) International Association of Athletics Federations competition rules 2014-2015 in force as from $1^{\text {st }}$ Novermber 2013; Rule 22(1)(e) International Association of Athletics Federations competition rules 2014-2015 in force as from $1^{\text {st }}$ November 2011.

469 Rule 5(5) International Association of Athletics Federations competition rules 2016-2017 in force as from $1^{\text {st }}$ November 2015; Rule 5(5) International Association of Athletics Federations competition rules 2014-2015 in force as from $1^{\text {st }}$ November 2013.

470 Rule 5(5) International Association of Athletics Federations competition rules 2016-2017 in force as from $1^{\text {st }}$ November 2015; Rule 5(5) International Association of Athletics Federations competition rules 2014-2015 in forceas from $1^{\text {st }}$ November, 2013. 
The IAAF differentiates between athletes who have not yet competed on the international level and those who have ${ }^{471}$ In the case of the former, any citizen of the relevant country may represent a country in an international competition. ${ }^{472}$ TheIAAF refers to being a citizen "by virtue of having been born or by virtue of having a parent or grandparent born in the Country". ${ }^{473}$ The first requirement is undoubtedly inspired by national rules on the acquisition of nationality through the ius soli principle The second is more difficult; it has an ius sangui inis element, as the athletehas to be born to parents or grandparents who in turn fulfil theius soli requirement of having been born in the rel evant territory. Problems may arise with regard to adopted children - do their adopted parents country in this respect? Furthermore, the position of foundlings is precarious, sinceno official documentation about them will beavailable

Athletes who have acquired a new citizenship may in principle represent the new country of which they are citizens, but the need to respect a year of non-competition following the acquisition of citizenship, provided that they had not yet competed internationally. ${ }^{474}$ There are two possibilities to circumvent the waiting period, etther provided by the IAAF council in exceptional circumstances or if the athlete has resided in the country for one continuous year directly before the respective competition. ${ }^{475}$ One has to conclude that this rule does not take the standard naturalisation procedures into consideration, as usually a residence period is required before a person may acquire a new nationality. With regard to athletes who have already competed for a country on the international level, in principle the IAAF forbids any change of country of representation. ${ }^{476}$ There are however notable exceptions, namely if a change in the country's territory occurs, ${ }^{477}$ or there is no NOC in the country and the athl ete thus has to compete for the parent country. ${ }^{478}$

471 Rule 5 International Association of Athletics Federations competition rules 2016-2017 in force as from $1^{\text {st }}$ November 2015; Rule 5 International Association of Athletics Federations competition rules 2014-2015 in force as from $1^{\text {st }}$ November 2013; Rule 5 International Association of Athletics Federations competition rules 2014-2015 in forceas from $1^{\text {st }}$ November 2011.

Rule 5(2)(a) International Association of Athletics Federations competition rules 2016-2017 in force as from $1^{\text {st }}$ November 2015; Rule 5(2)(a) International Association of Athletics Federations competition rules 2014-2015 in force as from $1^{\text {tt }}$ November, 2013.

Rule 5(2)(a) International Association of Athletics Federations competition rules 2016-2017 in force as from $1^{\text {st }}$ November 2015; Rule 5(2)(a) International Association of Athletics Federations competition rules 2014-2015 in force as from $1^{\text {tt }}$ November, 2013.

Rule 5(2)(b) International Association of Athletics Federations competition rules 2016-2017 in force as from $1^{\text {st }}$ November 2015; Rule 5(2)(b) International Association of Athl etics Federations competition rules 2014-2015 in forceas from $1^{\text {st }}$ November 2013.

Rule 5(2)(b)(i) and Rule 5(2)(b)(ii) International Association of Athletics Federations competition rules 2016-2017 in force as from $1^{\text {st }}$ November 2015; Rule 5(2)(b)(i) and Rule 5(2)(b)(ii) International Association of Athletics Federations competition rules 2014-2015 in force as from $1^{\text {st }}$ November 2013.

476 Rule 5(3) International Association of Athletics Federations competition rules 2016-2017 in force as from $1^{\text {st }}$ November 2015; Rule 5(3) International Association of Athletics Federations competition rules 2014-2015 in force as from $1^{\text {tt }}$ Novermber 2013; Rule 5(3) International Association of Athletics Federations competition rules 2014-2015 in force as from $1^{\text {st }}$ November 2011.

477 Rule 5(4)(a) and Rule 5(4)(b) International Association of Athletics Federations competition rules 2016-2017 in force as from $1^{\text {st }}$ November 2015; Rule 5(4)(a) and Rule 5(4)(b) International Association of Athletics Federations competition rules 2014-2015 in force as from $1^{\text {st }}$ November 
Furthermore, athletes who acquired a new nationality after having competed on the international level may compete for the country of which they are now citizens following a threeyear waiting period after theacquisition of citizenship. ${ }^{479}$ This period can however be reduced or wai ved if the athlete fulfils one of the three requirements stipulated in Rule 5 (4) (d). Firstly, in exceptional circumstances, the IAAF coundil may decide to reduce or cancel the period upon application from the rel evant member federation. ${ }^{480}$ Secondly, heor shemay need to only wait for 12 months if an agreement between the member federations can be achieved. ${ }^{481}$ Thirdly, there will be no waiting period if the athlete has been a resident in the relevant country for three continuous years diredly before the competition in question. ${ }^{482}$

Athletes with dual nationality from birth may initially choose fredy which country they wish to represent, yet after they haverepresented one country on theintemational level they face a threeyear waiting period if they wish to change their country of

2013; Rule 5(4)(a) and Rule 5(4)(b) International Association of Athletics Federations competition rules 2014-2015 in force as from $1^{\text {st }}$ November 2011; Rule 5(2)(a) and Rule 5(2)(b) International Association of Athletics Federations competition rules 2010-2011; Rule 5(2)(a) and Rule 5(2)(b) International Association of Athletics Federations competition rules 2009; Rule 5(2)(a) and Rule 5(2)(b) International Association of Athletics Federations competition rules 2008; Rule 5(2)(a) and Rule5(2)(b) International Association of Athletics Federations competition rules 2006 - 2007.

Rule 5(4)(c) International Association of Athletics Federations competition rules 2016-2017 in force as from $1^{\text {st }}$ November 2015; Rule 5(4)(c) International Association of Athletics Federations competition rules 2014-2015 in force as from $1^{\text {st }}$ November 2013; Rule 5(4)(c) International Association of Athletics Federations competition rules 2014-2015 in force as from $1^{\text {st }}$ November 2011.

479 Rule 5(4)(d) International Association of Athletics Federations competition rules 2016-2017 in force as from $1^{\text {st }}$ November 2015; Rule 5(4)(d) International Association of Athl etics Federations competition rules 2014-2015 in force as from $1^{\text {st }}$ November 2013; Rule 5(4)(d) International Association of Athletics Federations competition rules 2014-2015 in force as from $1^{\text {st }}$ November 2011; Rule 5(2)(c) International Association of Athl etics Federations competition rules 2010-2011; Rule 5(2)(c) International Association of Athletics Federations competition rules 2009; Rule 5(2)(c) International Association of Athletics Federations competition rules 2008; Rule 5(2)(c) International Association of Athletics Federations competition rules 2006 - 2007.

480 Rule 5(4)(d)(iii) International Association of Athletics Federations competition rules 2016-2017 in force as from $1^{\text {st }}$ November 2015; Rule 5(4)(d)(iii) International Association of Athletics Federations competition rules 2014-2015 in force as from $1^{\text {st }}$ November, 2013; Rule 5(4)(d)(iii) International Association of Athletics Federations competition rules 2012-2013 in force as from ${ }^{\text {st }}$ November 2011.

481 Rule 5(4)(d)(i) International Association of Athletics Federations competition rules 2016-2017 in force as from $1^{\text {st }}$ November 2015; Rule 5(4)(d)(i) International Association of Athletics Federations competition rules 2014-2015 in force as from $1^{\text {st }}$ November 2013; Rule 5(4)(d)(i) International Association of Athletics Federations competition rules 2012-2013 in force as from $1^{\text {st }}$ November, 2011; Rule 5(2)(c) International Association of Athl etics Federations competition rules 2010-2011; Rule 5(2)(c) International Association of Athletics Federations competition rules 2009; Rule 5(2)(c) International Association of Athletics Federations competition rules 2008; Rule 5(2)(c) International Association of Athletics Federations competition rules 2006 - 2007.

Rule 5(4)(d)(ii) International Association of Athletics Federations competition rules 2016-2017 in force as from $1^{\text {st }}$ November 2015; Rule 5(4)(d)(ii) International Association of Athletics Federations competition rules 2014-2015 in force as from $1^{\text {st }}$ November 2013; Rule 5(2)(c) International Association of Athletics Federations competition rules 2010-2011; Rule 5(2)(c) International Association of Athletics Federations competition rules 2009; Rule 5(2)(c) International Association of Athletics Federations competition rules 2008; Rule 5(2) (c) International Association of Athletics Federations competition rules 2006 - 2007. 
representation. ${ }^{483}$ This waiting period may be waived in exceptional circumstances ${ }^{484}$ or reduced to 12 months if the relevant federations agree upon such a reduction. ${ }^{485}$ This only applies to athletes who acquire dual citizenship at birth and not to those who become citizens of a second country later without having to give up their first citizenship. Also, one has to wonder what happens if an athlete acquired more than two citizenships at birth.

Another interesting aspect is the position of adopted children or foundlings, since, in this case, dual citizenship at birth can neither be established, nor may it be effective Here one may observe a certain discriminatory element and holding dual citizenship prior to the first competition on the international level might have been the better solution. Minor Athletes and nationality changes or stateless athletes are not di scussed in theIAAF Rules.

483 Rule 5(4)(e) International Association of Athletics Federations competition rules 2016-2017 in force as from $1^{\text {st }}$ November 2015; Rule 5(4)(e) International Association of Athletics Federations competition rules 2014-2015 in force as from $1^{\text {st }}$ November 2013; Rule 5(4)(e) International Association of Athletics Federations competition rules 2014-2015 in force as from $1^{\text {st }}$ November 2011; Rule 5(2)(d) International Association of Athletics Federations competition rules 2010-2011; Rule 5(2)(d) International Association of Athletics Federations competition rules 2009; Rule 5(2)(d) International Association of Athletics Federations competition rules 2008; Rule 5(2)(d) International Association of Athletics Federations competition rules 2006 - 2007; Rule 5(2)(d) International Association of Athletics Federations competition rules 2010-2011; Rule 5(2)(d) International Association of Athletics Federations competition rules 2009; Rule 5(2)(d) International Association of Athletics Federations competition rules 2008; Rule 5(2)(d) International Association of Athletics Federations competition rules 2006 - 2007.

484 Rule 5(4)(e)(ii) International Association of Athl etics Federations competition rules 2016-2017 in force as from $1^{\text {st }}$ November 2015; Rule 5(4)(e)(ii) International Association of Athletics Federations competition rules 2014-2015 in force as from $1^{\text {st }}$ November 2013; Rule 5(4)(e)(ii) International Association of Athletics Federations competition rules 2014-2015 in force as from $1^{\text {st }}$ November, 2011; Rule 5(2)(d) International Association of Athl etics Federations competition rules 2010-2011; Rule 5(2)(d) International Association of Athletics Federations competition rules 2009; Rule 5(2)(d) International Association of Athletics Federations competition rules 2008; Rule 5(2)(d) International Association of Athletics Federations competition rules 2006 - 2007.

Rule 5(4)(e)(i) International Association of Athletics Federations competition rules 2016-2017 in force as of $1^{\text {st }}$ November 2015; Rule 5(4)(e)(i) International Association of Athletics Federations competition rules 2014-2015 in force as from $1^{\text {st }}$ November 2013; Rule 5(4)(e)(i) International Association of Athletics Federations competition rules 2014-2015 in force as from $1^{\text {st }}$ November 2013; Rule 5(2)(d) International Association of Athletics Federations competition rules 2010-2011; Rule 5(2)(d) International Association of Athletics Federations competition rules 2009; Rule 5(2)(d) International Association of Athletics Federations competition rules 2008; Rule 5(2)(d) International Association of Athletics Federations competition rules 2006 - 2007. 


\subsection{Biathlon 486}

Biathl on became an Olympic Sport in 1960, after being a demonstration sport at the 1948 Winter Games ${ }^{487}$ The women's event dates back to 1992 and the International Biathl on Union (IBU), which has its seat in Salzburg, Austria, was founded one year later. ${ }^{488}$ Nowadays the disciplines are sprint, pursuit, individual, mass start, and relay for both men and women. Although a combination of shooting and skiing, time is of the essence, meaning that the fastest athlete wins. In order to incorporate the shooting in the time, penalties for missing targets areinduded, taking either the form of an extra distance to ski or minutes added to the athlete's time ${ }^{489}$ While both genders need to shoot five targets during one stop at the shooting range, women have to cover less distancethan men.

Moreover, the number of times an athlete is required to stop at the shooting range varies. ${ }^{490}$ Sprinting events have women race $7.5 \mathrm{~km}$ and men $10 \mathrm{~km}$ with two stops at the firing range Here a $150 \mathrm{~m}$ penalty loop is added for each missed target ${ }^{491}$ Pursuit events are composed of four stops at the firing range, with men racing $12.5 \mathrm{~km}$ and women $10 \mathrm{~km}$ As with sprinting events, a $150 \mathrm{~m}$ penalty loop is added for missed targets. ${ }^{492}$ Individual events al so include four stops at the firing range, yet the racing distance is $15 \mathrm{~km}$ for women and $20 \mathrm{~km}$ for men. Contrary to the other disciplines, the athletes do not have to do a $150 \mathrm{~m}$ penalty loop for missed targets, but they receive an extra minute added to their time per missed shot ${ }^{493}$ The relay events are the only ones during which the athletes compete in teams - made up of four athletes each. Women race $6 \mathrm{~km}$ making the total distance covered $24 \mathrm{~km}$ while each male athlete races 7,5 $\mathrm{km}$ resulting in a $30 \mathrm{~km}$ total. Each athlete stops twice at the shooting range Again a penalty loop of $150 \mathrm{~m}$ is added for missed targets, but unlike in the other disciplines, each athlete is allowed to use three extra bulles per firing stop. Since these bull lets need to be loaded individually, the time lost for this might be more than the one lost through taking the penalty loop. ${ }^{494}$ The final event is the mass start in which all previous medal winners of the Olympic Games and the top World Cup athletes compete They start at the same time, have to stop four times at the firing range and recive a $150 \mathrm{~m}$ penalty loop per missed target The distances raced are $12.5 \mathrm{~km}$ for women and $15 \mathrm{~km}$ for

486

487

The federation was contacted on $6^{\text {th }}$ August 2014 and asked to provide further insights into its eligibility criteria and older versions of the eligibility rules. The IBU replied on $8^{\text {th }}$ August. On $29^{\text {th }}$ October 2015 the IBU was contacted again and asked for comments on this chapter, which the IBU provided on $4^{\text {th }}$ November 2015.

IOC Information Biathl on Equi pment and History; IOC I nformation IBU; for information on nonnational athletes in the European national leagues and competitions see $S$. van den Bogaert, $A$. Cuyvers, S. Gardiner, R. Parrish, S. Miettinen, J. Soek and R. Siekmann (2010), p. 141.

IOC Information IBU; IOC Reference Document Biathlon; IOC Information Biathl on Equipment and History IOC Reference Document Biathlon.

IOC Information IBU.

Ibid.

Ibid.

Ibid.

Ibid.

Ibid. 
men. 495

TableV: Overview of the eligibility requirements for biathlon

\begin{tabular}{|l|l|}
\hline R equirements IBU & \\
\hline In force since & 2012 \\
\hline C hange of nationality & Possiblewith 2-year waiting period \\
\hline R esidence requirements & None \\
\hline M inors and nationality change & Not specified \\
\hline Stateless athletes & $\begin{array}{l}\text { Can compete for a federation if IBU Board authorises } \\
\text { it }\end{array}$ \\
\hline $\begin{array}{l}\text { Position of athletes with multiple nationality } \\
\text { after having competed for another country of } \\
\text { which the athlete is a national }\end{array}$ & Possiblewith 2-year waiting period \\
\hline E ffect of changes in territory of country & Not specified \\
\hline C ompeting for the country of residence & Not possible \\
\hline Number of changes possible & Not specified \\
\hline R efer ence to Olympic C harter & Yes, regarding applicability of rules \\
\hline Uses nationality/ citizenship & $\begin{array}{l}\text { Nationality in the heading and citizenship/citizens in } \\
\text { thetext }\end{array}$ \\
\hline Uses residence/ domicile & None \\
\hline Other remarkable peculiarity & None \\
\hline
\end{tabular}

\subsubsection{Biathlon critical reflection}

Biathlon is one of the sports for which the eligibility criteria has not changed substantially in the past years. The underlying principle is that athletes need to be citizens of the country they wish to represent and that athl etes with multiplenationality may initially choose freely. ${ }^{496}$ Athl etes may change their country of representation to reflect a change in their nationality, yet they need to comply with a two-year noncompetition period. ${ }^{497}$ While these rules have been extremely stable in the past years, they do not go into great detail for specific cases such as minors. The non-competition period, which can be reduced or waived, is relatively short with only two years. The IBU thus takes a rather moderateapproach to eligibility criteria.

\subsubsection{Rules applicable since 2012}

The eligibility criteria are stipulated in the IBU Event and Competition Rules adopted by the 1998 IBU Congress with amendments by the 2000, 2002, 2004, 2006, 2008, 2010, 2012, and 2014 Congresses. These criteria are applicable to all official biathlon events, induding the Olympic Games, unless the IOC sets down other rules ${ }^{498}$ Compared to the previously applicable IBU Competition Rules adopted by the 1998

\footnotetext{
495 Ibid.

496 Art. 9 IBU rules adopted by the 2014 11th regular IBU congress.

497 Ibid.

498 Art. 1.1 IBU event and competition rules adopted by the 1998 IBU congress with amendments by the 2000, 2002, 2004, 2006, 2008, 2010, 2012, and 2014 congresses; Art 1.1 IBU event and competition rules adopted by the 1998 IBU congress with amendments by the 2000, 2002, 2004, 2006, 2008, 2010, and 2012 congresses.
} 
IBU Congress with amendments by the 2000, 2002, 2004, 2006, 2008, 2010, and 2012 Congresses, there are only minor aspects of the sentence structure were changed that did not amount to substantial changes. Only the wording has changed, with the previous version referring to an athlete 'representing' a country, ${ }^{499}$ whereas the new version refers to an athlete 'starting for' ${ }^{500}$ a country.

In general, eligibility for the biathlon events is made dependent upon compliance with the IBU rules, eg. those regarding anti-doping. ${ }^{501}$ In order to assure their compliance, athletes and staff sign an official dedaration and attach a copy of their passport. ${ }^{502}$ They further need to provide proof of their age, gender and nationality with the copy of their passport or other official document ${ }^{503}$

The rules regarding nationality are set out in the IBU Rules adopted by the 2014 $11^{\text {th }}$ Regular IBU Congress, Artide 2.6. Here it is stipulated that only those who are citizens may represent a country and athletes with dual citizenship need to decide for which country they wish to compete ${ }^{504}$ Such a decision is in principle binding for athletes who have competed in biathlon events in Olympic Games, Continental or Regional Games, or in World or Continental Championships. ${ }^{505}$ Interestingly, the statutes explicitly mention that the athletes have to compete "under the authority of the IBU" - meaning that if an athlete was to compete in both biathlon and skiing, he or she might beable to competefor a different country.

Athletes who acquired a new citizenship or who had multiple citizenships from birth and wishes to change their country of representation may do so only after a twoyear waiting period ${ }^{506}$ Such a period may be either reduced or annulled if the respective federations agreeand the IBU Board deems it acceptable in the case ${ }^{507}$

The IBU neither refers to teritorial transfers and resulting changes of citizenship, nor to minors and nationality changes. However, there is a provision on stateless athletes who "may participate for a member federation assigned by the IBU Executive

\footnotetext{
499 Art. 9 IBU rules adopted by the $201210^{\text {th }}$ regular IBU congress.

500 Art. 9 IBU rules adopted by the $201411^{\text {th }}$ regular IBU congress.

501 Art. 1.4.1 IBU event and competition rules adopted by the 1998 IBU congress with amendments by the 2000, 2002, 2004, 2006, 2008, 2010, 2012, and 2014 congresses; Art. 1.4.1 IBU event and competition rules adopted by the 1998 IBU congress with amendments by the 2000, 2002, 2004, 2006, 2008, 2010, and 2012 congresses.

Art. 1.4.1 IBU event and competition rules adopted by the 1998 IBU congress with amendments by the 2000, 2002, 2004, 2006, 2008, 2010, 2012, and 2014 congresses; Art. 1.4.1 IBU event and competition rules adopted by the 1998 IBU congress with amendments by the 2000, 2002, 2004, 2006, 2008, 2010, and 2012 congresses.

Art. 1.4.2 I BU event and competition rules adopted by the 1998 IBU congress with amendments by the 2000, 2002, 2004, 2006, 2008, 2010, 2012, and 2014 congresses; Art. 1.4.2 IBU event and competition rules adopted by the 1998 IBU congress with amendments by the 2000, 2002, 2004, 2006, 2008, 2010, and 2012 congresses.

Art. 9 IBU rules adopted by the $201411^{\text {th }}$ regular IBU congress; Art. 2.6 IBU rules adopted by the $201210^{\text {th }}$ regular IBU congress.

Art. 9 IBU rules adopted by the $201411^{\text {th }}$ regular IBU congress; Art. 2.6 IBU rules adopted by the $201210^{\text {th }}$ regular IBU congress.

Art. 9 IBU rules adopted by the $201411^{\text {th }}$ regular IBU congress; Art. 2.6 IBU rules adopted by the $201210^{\text {th }}$ regular IBU congress.

507 Art. 9 IBU rules adopted by the $201411^{\text {th }}$ regular IBU congress; Art. 2.6 IBU rules adopted by the $201210^{\text {th }}$ regular IBU congress.
} 
NATIONALITY REQUIREMENTS IN OLYMPIC SPORTS

Board upon the authorization of the IBU Executive Board and with that member federation's agreement"

508 Art. 9 IBU rules adopted by the $201411^{\text {th }}$ regular IBU congress; Art. 2.6 IBU rules adopted by the $201210^{\text {th }}$ regular IBU congress. 


\subsection{Triathlon ${ }^{509}$}

Triathlon is a relatively new sport, having been invented in the 1970s as an alternative to track training. The International Triathlon Union (ITU), with its seat in Vancouver, Canada, was founded in 1989 and nowadays there are over 120 national federations with the number steadily increasing since triathl on became Olympic in $2000{ }^{510}$ The Olympic parameters for triathlon are swimming $1.5 \mathrm{~km}$, cycling $40 \mathrm{~km}$ and running $10 \mathrm{~km}$ The transition time between each discipline is regulated, since athletes are supposed to preservetheir energy wisely and not to rest in between the different parts. The competition does not set men and women against each other, but it is distinct according to gender. ${ }^{511}$

TableVI: Overview of the eligibility requirements for triathl on

\begin{tabular}{|l|l|}
\hline R equirements ITU & \\
\hline In force since & 1989 \\
\hline C hange of nationality & Possible \\
\hline R esidence requirements & Threeyears, may bewaived to oneyear \\
\hline M inors and nationality change & Not specified \\
\hline Stateless athletes & Not specified \\
\hline $\begin{array}{l}\text { Position of athletes with multiple nationality } \\
\text { after having competed for another country of } \\
\text { which the athlete is a national }\end{array}$ & $\begin{array}{l}\text { Threeyear waiting period, unless therelevant } \\
\text { federations agreeto reduceit }\end{array}$ \\
\hline E ffect of changes in territory of country & $\begin{array}{l}\text { Athlete may choose once, but needs approval of } \\
\text { ExecutiveCommittee }\end{array}$ \\
\hline Competing for the country of residence & $\begin{array}{l}\text { Not exactly specified, might be possible, } \\
\text { depending on how the wording is interpreted }\end{array}$ \\
\hline Number of changes possible & No maximum given \\
\hline & None \\
\hline R efer ence to Olympic Charter & Citizenship \\
\hline Uses nationality/ citizenship & Residence \\
\hline Uses residence/ domicile & None \\
\hline Other remarkable peculiarity & \\
\hline
\end{tabular}

\subsubsection{Triathlon critical reflection}

The ITU eligibility criteria have remained unchanged for the longest period of time Since over two decades, the ITU allows for changes of the country of representation, which is conditional upon a threeyear non-competition period and fulfilling a

509 The federation was contacted on $6^{\text {th }}$ August 2014 and asked to provide further insights into its eligibility criteria and older versions of the eligibility rules, to which the ITU answered on $7^{\text {th }}$ August 2014 and stated that the eligibility rules for triathl on have remained the same since the founding of the ITU in 1989. On $29^{\text {th }}$ October 2015 the federation was contacted again and asked for comments on this Chapter. As no reply was forthcoming, a first reminder was sent on $19^{\text {th }}$ November 2015 and a second on $2^{\text {nd }}$ December 2015. No reply was received by the date of publication.

510 IOC Reference Document triathlon: for information on non-national athletes in the European national leagues and competitions see S. van den Bogaert, A. Cuyvers, S. Gardiner, R. Parrish, S. Miettinen, J. Soek and R. Siekmann (2010), p. 205.

511 IOC Information on Triathlon Equi pment and History. 
residence requirement ${ }^{512}$ In principle, an athlete needs to have resided in the relevant country for three years, yet this can be reduced to one year with the approval of the invol ved federations. ${ }^{513}$ The ITU addresses issues of teritorial transfers and all lows the athlete to dedide once for which country he or she wishes to compete ${ }^{514}$ Although matters of minors or stateless athletes are not addressed, the ITU goes into relatively great detail. The rules are strict, as a threeyear non-competition period will certainly affect an athlete's carer.

\subsubsection{Rules applicable since 1989}

Tuming to the question of eligibility, one finds that for triathlon thereare two main set of rules, the first is the ITU competition rules, which underscore the importance of 'good standing' between an athlete and the national federation. ${ }^{515}$ These competition rules were updated in 2015 and now also indude references to female athletes being questioned due to hyperandrogenism as well as to athletes wishing to continue their career after having undergonea sexual reassignment ${ }^{516}$ Overall, eligibility is set out in Chapter 6 of theITU Constitution, eg. that of February 2013:

"28.1 Wherean athlete:

a) Wishes to represent a NF other than the NF to which they original ly belonged, they must reside in the country of the subsequent NF for at leest three years after the date they last represented the original NF in any sanctioned event This period of residence can be reduced to one year if the two NFs concemed agree, and the Executive Board of ITU consents.

b) Holds or is legally entitled to hold citizenship of two or more countries, provided that it is at least three years since theathletelast represented the first NF in any compeition, the period of residencemay bereduced to oneyear, if the two NFs concerned agreeand if the Executive Board approves."

It is interesting that these artides do not first establish that athletes have to be nationals of the country in order to competefor thenational federation. Instead, the ITU directly refers to cases in which athletes wish to compete for another association than the one he or she bel onged to originally. ${ }^{518}$ Under these rules, an athl ete can only compete for the new country after having resided in the new country for at least three years since the last official compeition in which the athlete represented the original country. This period can however be reduced to only one year if the respective national federations

Art. 28(1a) ITU constitution approved by the ITU congress September, 2015.

Ibid.

Art. 28(2) ITU constitution approved by the ITU congress September, 2015.

Art. 2.5 ITU competition rules (approved by the ITU Executive Board, December 2014); Art. 2.5. ITU competition rules (approved by the ITU Executive Board, December 2013 and February 2014).

Art. 2.5 I) and m) ITU competition rul es (approved by the ITU Executive Board, September 2015). ITU constitution approved by the ITU congress.

Art. 28(1a) ITU constitution approved by the ITU congress, September 2015; Art. 28(1a) ITU constitution approved by the ITU congress, September 2013; Art. 28(1a) ITU constitution approved by theITU congress, Bejing, China, 7 September 2011. 
and the ITU Executive Board agre ${ }^{519}$ There is no prescribed timethat the athl etemay not compete - there is only the residence requirement. This however boils down to having the same effect, since the residence period is only counted from themoment of the last competition for the original country onwards and the athlete may not compete for thenew country until theresidence period is ful filled. It is further important to note that this part of the article does not refer to having the nationality of the country and therefore one could assumethat nationality is not important in that case

This became even further underscored, since the following article refers especially to athletes who 'hold or are legally entitled' to multiple national ities ${ }^{520}$ This, in itself, is an interesting formulation, since being entitled to a nationality is seen as distinct from actually holding that nationality. One possible explanation is that the athlete could have in principle registered, for example, with an embassy in another country to claim thenationality, but s/hedid not do so. Therefore, one could deduce from this that theITU all ows athl etes to compete for a country where they have merely been resident for three years without actually having been nationals of the country, which is nevertheless highly unlikely.

However, an athlete with multiple nationality who has not represented a country for at least three years is in a different position. In this case, the relevant national federations and the Executive Board can agree to reduce the residence requirement to one year. Here, there is a distinction to be made with regard to the first part of the artide in which the period of residence required could only be reduced to two years. Hence, the ITU seems to really make the distinction between athletes who wish to represent their country of residence and those who want to change between countries of which they al ready havethenationality. However, this is not explicitly stated.

In the following, the ITU turns to the question of what happens in the case of territorial transfers, either through independence or incorporation. In this case, the athlete can choose which country he or she wants to compete. However, this decision needs theapproval of the Executive Board and can only be doneonce ${ }^{521}$

Thus, the ITU's rules are not entirely clear, since definitions such as 'residence' and the differentiation between 'hol ding' a nationality and 'being entitled' to one are lacking. Furthermore, there seems to be no rule that an athl lete shoul d be a national of the country he represents. If one takes Artide 281 ITU of the Constitution literally, athletes could potential ly compete for their country of residence, after having fulfilled the residence requirement. This seems to be the correct interpretation, since the ITU differentiates between the possible reductions of the residence duration requirements set out in Artides 28(1a) and 28(1b). Yet again, this is not explicitly stated. The ITU does however directly refer to the teritorial transfers that can occur, although a

\footnotetext{
$519 \quad$ Ibid.

520 Art. 28(1b) ITU constitution approved by the ITU congress, September 2015; Art. 28(1b) ITU constitution approved by the ITU congress, September 2013; Art. 28(1b) ITU constitution approved by the ITU congress, Bejing, China, 7 September 2011.

521

Art. 28(2) ITU constitution approved by the ITU congress, September 2015; Art 28(2) ITU constitution approved by the ITU congress, September 2013; Art. 28(2) ITU constitution approved by the ITU congress, Beijing, China, 7 September 2011.
} 
resulting decision can only be made once by the athlete Overall, the residence requirement is relatively strict, with only a reduction and not a wai ver being possible Since the rules on eligibility are very concise, al so the questions of stateless athletes and minors are not addressed by the ITU. Thus these situations are not clear. Overall, therules seem quitestrict since the possi bility to reduce the residence period is limited. 


\subsection{M odern Pentathlon ${ }^{522}$}

Pentathl on dates back to the erliest Olympic Games in ancient Greece, yet its modern form deviates from the classic competitions of running, jumping, spear-throwing, discus, and wrestling. Since 1912, Olympiad men are competing in the disciplines of pistol shooting, fencing, swimming, horseriding, and running, whilewomen have only been competing at the Olympic level since $2000 .{ }^{523}$ In each discipline, the athlete collects points that are then added up to determine the overall score The competition starts with fencing - with the winner of each match being determined by a single touch. Afterwards, the athletes have to swim freestyle for $200 \mathrm{~m}$ This is followed by a 12-obstade show-jumping competition, which has to be completed in a given timeframe The rest of the competition is a combination of running and shooting. Athletes first have to run to the shooting range, hit at least 5 targets and then run 1000 mas fast as possi ble This last part is repeated threetimes, so the athletes have to run a total of $3000 \mathrm{~m}$ and hit 15 targets. ${ }^{524}$ Modern pentathlon is governed by the Union Internationale de Pentathlon Moderne (UIPM), which had its seat in Monte Carlo, Monaco and was founded in $1948 .{ }^{525}$

TableVII: Oveview of the eligibility requirements for modern pentathlon

\begin{tabular}{|l|l|}
\hline Requirements UIPM & \\
\hline In force since & 2015 \\
\hline C hange of nationality & Possible \\
\hline R esidence requirements & none \\
\hline M inors and nationality change & Not specified \\
\hline Stateless athletes & Not specified \\
\hline $\begin{array}{l}\text { Position of athletes with multiple nationality } \\
\text { after having competed for another country of } \\
\text { which the athlete is a national }\end{array}$ & $\begin{array}{l}\text { May do so after three-years no- competition } \\
\text { period }\end{array}$ \\
\hline Effect of changes in territory of country & Onechange possible \\
\hline Competing for the country of residence & Not specified \\
\hline Number of changes possible & No maximumgiven \\
\hline & \\
\hline R efer ence to Olympic Charter & None \\
\hline Uses nationality/ citizenship & Nationality and citizenship \\
\hline Uses residence/ domicile & Residenceand domicile \\
\hline Other remarkable peculiarity & Distinction Olympic \& Non-Olympic Competition \\
\hline
\end{tabular}

522 The federation was contacted on $6^{\text {th }}$ August 2014 and asked to provide further insights into its eligibility criteria and older versions of the eligibility rules. The UIPM kindly replied on $11^{\text {th }}$ August 2014 and provided the statutes of the previous years: On $29^{\text {th }}$ October 2015 the federation was contacted again and asked for comments on this to which the federation replied on $30^{\text {th }}$ October 2015. European national leagues and competitions see S. van den Bogaert, A. Cuyvers, S. Gardiner, R. Parrish, S. Miettinen, J. Soek and R. Siekmann (2010), p. 176. 


\subsubsection{Modem pentathlon critical reflection}

For the past three years, the rules for modem pentathl on have changed substantially. The most striking change was the abolition of the permanent residence requirements for athletes who changed their country of representation. Moreover, athletes with dual nationalities and territorial transfers are referred to nowadays. ${ }^{526}$ A thletes who al ready competed at theinternational level now only have to observe a non-competition period of three years, which can be reduced or entirely waived. ${ }^{527}$ These are all the nationality-related eligibility rules to be found in the UI PM statutes and they do not go into great detail. Considering that there is no maximum number of possible nationality changes, one can say that the UIPM is rather liberal in these regards. Overall, the UIPM has taken a more detail ed and codified approach lately and, at the same time, it has reduced therequi rements necessary to change the country of representation.

\subsubsection{Rules applicable since November 2015}

Tuming to the rules spelled out by the Union Intemationale de Pentathl on Modeme (UIPM), which unlike most associations has its seat in Monaco, one finds that that many dhanges occurred since 2013, as there is no longer a residence requirement in place and several rules have been added in 2015. The UIPM underscores that its nationality rules may not be contrary to the ones instituted by the IOC.528 The underlying principle is that the athlete is a national of the country he or she represents and athletes who are nationals of more than one country are initially free to choose which country they wish to represent 529 However, after having represented a country at an international tournament, athletes will have to undergo the standard procedure as athl etes wishing to changetheir country of representation.530 This procedure entails a threeyear waiting period, which can however be reduced or cancelled depending on the agreement of the relevant federations and the NOC and UI PM.531 Moreover, the UIPM underscores that the IOC may takeall decisions relating to the eigibility for the Olympic Games concerning pentathletes.532 Changes of the country of represented will only become effective for UIPM competitions after the next Olympic Games.533 Since 2015 theUIPM al so deal s with territorial transfers:

"3.5 If an associated State, province or overseas department, a country or col ony acquires independence, if a country becomes incorporated within another country by reason of a change of border, if a country merges with another country, or if a new NOC is recognised by the IOC, a pentathlete may continue to represent the country to which the pentathlete belongs or

Art. 3.3 and 3.5 UIPM Rules on Internal Organi sation Tapeo November 2015.

Art. 3.4 UI PM Rules on Internal Organisation Tapeo November 2015.

Art. 3. 2 UIPM Rules on Internal Organisation Tapeo November 2015.

Art. 3.3 UI PM Rules on Internal Organi sation Tapeo November 2015.

Art. 3.3 UI PM Rules on Internal Organi sation Tapeo November 2015.

Art. 3.4 UI PM Rules on Internal Organi sation Tapeo November 2015.

Art. 3.6 UIPM Rules on Internal Organi sation Tapeo November 2015.

Art. 3.7 UI PM Rules on Internal Organi sation Tapeo November 2015. 
bel onged. However, a pentathlete may elect to represent the newly formed or recognised country or be entered in the Ol ympic Games by the relevant new NOC if one exists. This particular choice may be made only once"

This is interesting, as not only the country but al so the relevant NOC are mentioned. The question however emerges what is meant with a 'recogni sed' country. Is there a specific number of states that need to recognise the new country or the cession? If so, thethreshold will be of utmost importance.

\subsubsection{Rules applicable $2013-2015$}

Prior to 2015, there were few eligibility rules. However, UIPM underscored that its eligibility rules must not contradict the Rules and ByeLaws on digibility of the International Olympic Committee (IOC). ${ }^{535}$

According to UIPM, a pentathl ete could not in principle change which country he competes for in the Olympic Games after he had competed for another country on an ' $A$ ' level. The only possibilities here were that he or she acquired a new nationality and had his or her permanent residence in this new country. Thus, there was a distinct and strict residence requirement - although the UIPM did not specify what was to be considered a permanent residence. Furthermore, the athlete had to wait for three years before he or she could represent the new country at the Olympic Games - unless the IOC, UIPM and the respectivenational federations agreed on something else ${ }^{536}$

With regard to non-Olympic competitions, the athlete who acquired a new national ity al so had to establ ish his or her permanent residence in the country of which he or she was a national. It was not possible for the athlete to compete in any nonOlympic competition in the samecal endar year as the change was undertaken. ${ }^{537}$ Thus, if an athlete acquired a new nationality and took up permanent residence in the new country on $31^{\text {s }}$ December, he was able to compete for the new country from $1^{\text {t }}$

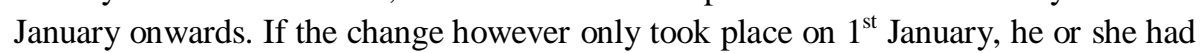
to wait 365 days before being able to compete agai $n$. This rule was certai nly ai med to deter athletes from changing nationality too often, but the time requirement of 'a cal endar year' could be easily circumvented. However, this was only for non-Olympic competitions and most athletes at the Olympic level would potentially be faced with a threeyear break - unless, IOC, UIPM, and the national federations agreed on a shorter time

\footnotetext{
534 Art. 3.5 UIPM Rules on Internal Organi sation Tapeo November 2015.

535 Art. 4.2 Union Internationale de Pentathlon Moderne (International Union of the Modern Pentathl on) statutes season 2013.

Art. 4.3 Union Internationale de Pentathlon Modeme (International Union of the Modern Pentathlon) statutes season 2013.

537 Art. 4.4 Union Internationale de Pentathlon Moderne (International Union of the Modern Pentathlon) statutes season 2013.
} 
5.4.4. Rules applicable $2005-2012$

Prior to the rule changes in 2013, the UIPM Statutes contained only one artide on eligibility:

"4.1 Only competitors and officials who are eligible according to the Union's eligibility rules are allowed to take part in competitions organised by the UIPM or its Members.

4.2 Specific eligibility rules are included in the Competition Rules. They are confirmed by the Congress and may in no way be contradictory to Rules and Bye Laws on eligibility of the International Olympic Committee (IOC)." ${ }^{\prime 33}$

This rule is remarkable, as it underlines the importance of the compatibility of the UIPM rules and theIOC eligibility laws.

$538 \quad$ Art. 4.1 and Art. 4.2 Union Internationale de Pentathlon Moderne(International Union of the Modern Pentathl on) statutes - UIPM rules on internal organisation chapter IV - eligibility rules 2012; Art. 4.1 and 4.2 Union Internationale de Pentathl on Moderne (International Union of the Modern Pentathl on) statutes - UIPM rules on internal organisation chapter IV - eligibility rules 2011; Art 4.1 and Art. 4.2 Union International e de Pentathl on Moderne (International Union of the Modern Pentathlon) statutes - UIPM rules on internal organisation chapter IV - eligibility rules 2010; Art 4.1 and Art. 4.2 Uni on International e de Pentathl on Moderne (International Union of the Modern Pentathlon) statutes - UIPM rules on internal organisation chapter IV - eligibility rules 2009; Art 4.1 and Art. 4.2 Union International e de Pentathl on Moderne (International Union of the Modern Pentathl on) statutes - UIPM rules on internal organisation chapter IV - eligibility rules 2008; Art. 4.1 and 4.2 Union Internationale de Pentathl on Moderne (International Union of the Modern Pentathlon) statutes - UIPM rules on internal organisation chapter IV - eligibility rules 2007; Art 4.1 and Art. 4.2 Uni on International e de Pentathl on Moderne (International Union of the Modern Pentathl on) statutes - UIPM rules on internal organi sation chapter I - eligibility rules 2005. 


\subsection{Weightlifting ${ }^{539}$}

Weightifting already existed in ancient Greece and Egypt and has featured in the modern Olympic Games since $1896 .{ }^{540}$ However, weightlifting has not had an unbroken run, being absent from the 1900, 1908 and 1912 Games $^{541}$ The women's events have only been part of the Olympic Games since $2000 .{ }^{542}$

In 1905, the International Weightlifting Federation (IWF) was founded and has its seat in Budapest, Hungary. ${ }^{543}$ Nowadays, the competitions are in the snatch and the clean and jerk, with the athlete's results being combined to determine the final ranking. ${ }^{544}$ The snatch is performed by raising the bar straight over the head in one fluid motion. ${ }^{545}$ The clean and jerk motion is divided into two movements, with the athlete first raising the bar to shoulder level before raising it straight above the head. ${ }^{546}$ Men and women compete according to their weight category. There are eight weighting categories for men ranging from under $56 \mathrm{~kg}$ to the over $105 \mathrm{~kg}$. Women's events are divided accordingly into seven categories, from the under 48kgs weightgroup to the over $75 \mathrm{kgs}^{547}$

TableVIII: Ovenview of the eligibility requirements for weightlifting

\begin{tabular}{|l|l|}
\hline R equirements IWF & \\
\hline In force since & 1st anuary 2013 \\
\hline C hange of nationality & $\begin{array}{l}\text { Possi ble, but after a changethere is a waiting period of } \\
\text { four years }\end{array}$ \\
\hline R esidence requirements & None \\
\hline M inors and nationality change & Not specified \\
\hline Stateless athletes & Not specified \\
\hline $\begin{array}{l}\text { Position of athletes with multiple nationality } \\
\text { after having competed for another country of } \\
\text { which the athlete is a national }\end{array}$ & May decide with a waiting period of 12 months \\
\hline E ffect of changes in territory of country & Not specified \\
\hline Competing for the country of residence & Possibleif approved by federation \\
\hline Number of changes possible & Oneis easy, afterwards it becomes moredifficult \\
\hline & \\
\hline
\end{tabular}

The federation was contacted on $6^{\text {th }}$ August 2014 and asked to provide further insights into its eligibility criteria and older versions of the eligibility rules. As no answer was forthcoming, a reminder e-mail was send on $18^{\text {th }}$ September to which the IWF replied. On $29^{\text {th }}$ October 2015 the federation was contacted again and asked for comments on this Chapter. As no reply was forthcoming, a first reminder was sent on $19^{\text {th }}$ November 2015 to which the federation replied on $19^{\text {th }}$ November 2015.

IOC Information on Weightlifting Equipment and History; IOC Information IWF; IOC Reference Document Weightlifting.

IOC Information on Weightlifting Equipment and History; IOC Reference Document Weightifting: for information on non-national athletes in the European national leagues and competitions see S. van den Bogaert, A. Cuyvers, S. Gardiner, R. Parrish, S. Miettinen, J. Soek and R. Siekmann (2010), p. 209.

Ibid

543 IOC Information IWF; IOC Reference Document Weightlifting. IOC Information on Weightlifting Equipment and History; IOC I nformation IWF. IOC Information IWF.

Ibid.

IOC Information IWF; IOC Information on Weightifting Equipment and History. 
NATIONALITY REQUiREMENTS IN OLYMPIC SPORTS

\begin{tabular}{|l|l|}
\hline R efer ence to O lympic C harter & Yes, prevails in eligibility questions ${ }^{48}$ \\
\hline Uses nationality/ citizenship & Citizenship \\
\hline Uses residence/ domicile & Residence \\
\hline Other remarkable peculiarity & $\begin{array}{l}\text { Reference to UN as institution, which may rule on the } \\
\text { question of national ity }\end{array}$ \\
\hline
\end{tabular}

5.5.1. Weightifting critical reflection

For weight ifting, the eigi bility rules specify that theathletes need to be citizens of the country they represent ${ }^{549}$ Changes are possible in principle and, for the first change, the waiting period is only one year. ${ }^{550}$ In addition, athletes with multiple citizenships may change their country of representation relatively frequently, as only a 12-month period needs to be observed. ${ }^{551}$ Contrarily, should an athlete wish to change his or her country of representation for a second or third time, a four-year non-competition period is required ${ }^{52}$ Whereas the one-year period and the frequent changes possible for athletes with dual nationality are extremely lenient, the four-year period is significantly stricter compared to other eligibility criteria. The IWF thus offers athletes an initially easy access to changes, yet, to combat openly mercenary tendencies, the subsequent criteria are stricter.

\subsubsection{Rules applicablesince 2013}

The rules governing eligibility in weightlifting are set out in the IWF Technical \& Competition rules \& Regulations 2013 - 2016 approved by the IWF Congress - Baku - 2012 Updated by IWF Congress - Kazan - 2014 updated in Almaty - 2014 in effect as of 01.01.2015 and the IWF Constitution and By-laws 2013- 2016 approved by the IWF Congress - Baku - modified by IWF Congress - Almaty 2014 in effect as of $1.1 .2015^{553}$

The technical rules stipulate the need for an Athlete's Card, on which the declarations, nationality, body weight, weight category, and other technical details relevant for competitions are recorded. ${ }^{554}$ These are especially checked for the

548 Rule 13.2 IWF constitution and by-laws 2013-2016 - approved by IWF congress - Baku in effect with 01.01.2013.

549 By-law to Rule 13.1 IWF constitution and by-laws 2013 - 2016 approved by the IWF congress Baku - modified by IWF congress - Almaty 2014 in effect with 1.1.2015.

550 By-law to Rule 13.3 IWF constitution and by-laws 2013 - 2016 approved by the IWF congress Baku - modified by IWF congress - Almaty 2014 in effect with 1.1.2015.

551 By-law to Rule 13.1 IWF constitution and by-laws 2013 - 2016 approved by the IWF congress Baku - modified by IWF congress - Almaty 2014 in effect with 1.1.2015.

552 By-law to Rule 13.3 IWF constitution and by-laws 2013 - 2016 approved by the IWF congress Baku - modified by IWF congress - Almaty 2014 in effect with 1.1.2015.

553 Which are identical to the previously applicable IWF technical and competition rules \& regulations 2013- 2016 - approved by the IWF congress - Baku in effect with 01.01.2013 and the IWF constitution and by-laws 2013-2016 - approved by IWF congress - Baku in effect with 01.01.2013. Art. 3.4.6 IWF technical \& competition rules \& regulations 2013 - 2016 approved by the IWF congress - Baku - 2012 updated by IWF congress - Kazan - 2014 updated in Almaty - 2014 in effect with 01.01.2015; Art. 3.4.6 IWF technical and competition rules \& regulations 2013- 2016 approved by the IWF congress- Baku in effect with 01.01.2013. 
Olympics and need to comply with further regulations issued by the IOC or NOCs. ${ }^{555}$ The question regarding eligibility is answered in the IWF Constitution, where Artide 13.1 stipulates that the IWF rules generally apply to IWF events and are only superseded in case of the Olympic Games by thel OC Eligi bility Rules. ${ }^{556}$ The bye law to this rule requires athl etes to be a citizen of the country they want to compete for and to prove their citizenship by possessing a valid document to that effect ${ }^{557}$ In case a country does not provide its citizens with such a document, the UN or IOC may rule on the nationality of the athlete ${ }^{558}$ The IOC is set on the same leved regarding the determination of nationality as the UN for thesepurposes.

Athletes with dual citizenship may decide which country to represent and may change their country of representation if there is a period of 12 months between the representations of the different countries. ${ }^{559}$ Hence, athletes with dual or multiple citizenships may changetheir country of representation rather frequently.

If an athlete wishes to compete for another country without having dual citizenship, therearein principle two requirements.

"(i) the athleteobtains thecitizenship of that new country, and

(ii) the athlete gets the approval of the Member Federation helshe is currently representing, the approval of the Member Federation helshe wishes to represent and theapproval of theIWF." ${ }^{\prime \prime 50}$

In case such an approval is not forthcoming, thereis to bea waiting period of oneyear, which is cal cul ated from the day the athlete requested his or her current federation to

555 Art. 5.3 and Art. 6.2 IWF technical \& competition rules \& regulations 2013 - 2016 approved by the IWF congress - Baku - 2012 updated by IWF congress - Kazan - 2014 updated in Almaty 2014 in effect with 01.01.2015; Art 5.3 and Art. 6.2 IWF technical and competition rules \& regulations 2013- 2016 - approved by the IWF congress - Baku in effect with 01.01.2013. Art. 13.1 and Art. 13.2 IWF constitution and by-laws 2013 - 2016 approved by the IWF congress Baku - modified by IWF congress - Almaty 2014 in effect with 1.1.2015; Art. 13.1 and Art 13.2 IWF constitution and By-laws 2013-2016 - approved by IWF congress - Baku in effect with 01.01.2013.

By-law to Rule 13.1 IWF constitution and by-laws 2013 - 2016 approved by the IWF congress Baku - modified by IWF congress - Almaty 2014 in effect with 1.1.2015; By-law to Rule 13.1 IWF constitution and by-laws 2013-2016 - approved by IWF congress - Baku in effect with 01.01.2013.

By-law to Rule 13.1 IWF constitution and by-laws 2013 - 2016 approved by the IWF congress Baku - modified by IWF congress - Almaty 2014 in effect with 1.1.2015; By-law to Rule 13.1 IWF constitution and by-laws 2013-2016 - approved by IWF congress - Baku in effect with 01.01.2013.

By-law to Rule 13.1 IWF constitution and by-laws 2013 - 2016 approved by the IWF congress Baku - modified by IWF congress - Almaty 2014 in effect with 1.1.2015; By-law to Rule 13.1 IWF constitution and by-laws 2013-2016 - approved by IWF congress - Baku in effect with 01.01.2013.

By-law to Rule 13.3 (i) and (ii) IWF constitution and by-laws 2013 - 2016 approved by the IWF congress - Baku - modified by IWF congress - Almaty 2014 in effect with 1.1.2015; By-law to Rule 13.3 (i) and (ii) IWF constitution and by-laws 2013-2016 - approved by IWF congress - Baku in effect with 01.01.2013. 
approve of the change ${ }^{561}$ If the athlete wishes to change his or her country of representation a second or further time, the by-law stipulates that:

"In the case of a second or further change of citizenship, the condition of participation in intemational events is four (4) years' of new citizenship, induding one Olympic Games [sic]." ${ }^{\text {562 }}$

It is sightly unclear whether this condition is a generally applicable one or only applicable if the Member federation does not approve. However, from the wording, onemay deducethat it is a general one

Competing for the country of residence is a possibility, however, the athlete needs the approval of his or her national weightlifting federation. ${ }^{563}$ There are no provisions regarding stateless athl etes, athletes faced with changes in theteritory of their country or minors.

The IWF published extra guidelines conceming nationality changes in September 2014. This document revolves around the question of how an athlete can change his nationality and represent another country. ${ }^{564}$ The answer is that the athlete needs to hold the citizenship of the country, which seems to imply that, to be a national, one needs to also be a citizen. In the following, five different scenarios are elaborated upon, the first of which being that athletes who acquire a new citizenship and who have not yet competed internationally may compete directly for the new country. ${ }^{565}$

Case two and three are connected, as they stipulate that those who hold neither double nor multiple citizenships need to acquire the new citizenship and then obtain the approval of all relevant federations and the IWF in order to compete for the new federation. ${ }^{566}$ If the approval of the former federation is not forthcoming, the IWF advises the athleteto:

"1. submit a written request to the IWF that you wish to represent a new country and then you have to wait one year from the date of the request submission to be automatically digible to compete on behalf of your new Federation.

2. obtain thecitizenship of thenew country

3. submit a written approval from your new Federation

561

By-law to Rule 13.3 IWF constitution and by-laws 2013 - 2016 approved by the IWF congress Baku - modified by IWF congress - Almaty 2014 in effect with 1.1.2015; By-law to Rule 13.3 IWF constitution and by-laws 2013-2016 - approved by IWF congress - Baku in effect with 01.01.2013.

562

By-law to Rule 13.3 IWF constitution and by-laws 2013 - 2016 approved by the IWF congress Baku - modified by IWF congress - Almaty 2014 in effect with 1.1.2015; By-law to Rule 13.3 IWF constitution and by-laws 2013-2016 - approved by IWF congress - Baku in effect with 01.01.2013.

By-law to Rule 13.2 IWF constitution and by-laws 2013 - 2016 approved by the IWF congress Baku - modified by IWF congress - Almaty 2014 in effect with 1.1.2015; By-law to Rule 13.2 IWF constitution and by-laws 2013-2016 - approved by IWF congress - Baku in effect with 01.01.2013.

IWF guidelines for national ity change September 2014.

Case 1 IWF guidelines for nationality change September 2014.

Case 2 IWF guidelines for national ity change September 2014. 


\section{CLASSIC SPORTS}

4. and lastly obtain an approval from theIWF." 567

Consequently, athletes who have difficulty to obtain the approval of their current federation, for whatever reason, may still manage to change their country of representation. In general, a change in the country of representation can only occur after a time period of 12 months has lapsed. ${ }^{568}$ If the attempted change of citizenship is however not the first one, then the athletes have to have held thenew citizenship for at least four years, including the time of one Olympic Games. ${ }^{569}$ 



\section{Sports focussing on body control}

In this chapter, the focus will be on the sports that require a special command over all the human musde groups. The aim of these sports is to show the possibilities the human body has with regard to movement and the athletes' strive to perfect their actions in the prescribed way. Both sports have several sub-disciplines and in both sports there is one discipline for which there are no men's events - synchronised swimming and rhythmic gymastics respectively, which were both introduced in 1984. Regarding theage of the di sci plines, both swimming and artistic gymnastics have been Olympic disciplines since the first Olympics in 1896, while trampoline has been Olympic only since 2000. As with most sports, women's events were introduced later than men's, with water polo being the discipline in which women had to wait the longest before being al lowed to al so partici pate- over 100 years.

TableIX: Topics dealt with in sports that focus on body control

\begin{tabular}{|c|c|c|}
\hline Requirements & Aquatics & Gymnastics \\
\hline In force since & 2009 & 2005 \\
\hline Versions since 2005 & $\begin{array}{l}2005-2009 \\
\text { Since } 2009\end{array}$ & Since 2005 \\
\hline $\begin{array}{l}\text { Substantial C hanges made since } \\
\text { O ctober } 2013\end{array}$ & n/a & n/a \\
\hline C hange of nationality & Possible & $\begin{array}{l}\text { Possiblethrough if consent is } \\
\text { given or a waiting period is } \\
\text { observed }\end{array}$ \\
\hline R esidence requirements & 1 year & None \\
\hline M inors and nationality change & Not specified & Not specified \\
\hline Stateless athletes & Not specified & Not specified \\
\hline $\begin{array}{l}\text { Position of athletes with multiple } \\
\text { nationality after having competed } \\
\text { for another country of which the } \\
\text { athlete is a national }\end{array}$ & $\begin{array}{l}\text { Possi ble change after one } \\
\text { year of non-competition } \\
\text { Haveto choose sport } \\
\text { nationality }\end{array}$ & $\begin{array}{l}\text { Treated likean athlete who } \\
\text { wishes to acquire a new } \\
\text { nationality }\end{array}$ \\
\hline $\begin{array}{l}\text { E ffect of changes in territory of } \\
\text { country }\end{array}$ & Not specified & $\begin{array}{l}\text { Athlete may decideto compete } \\
\text { for either of the new entities }\end{array}$ \\
\hline $\begin{array}{l}\text { Competing for the country of } \\
\text { residence }\end{array}$ & Not specified & $\begin{array}{l}\text { If athletewas born in the } \\
\text { country to parents who were } \\
\text { legally residing there, but were } \\
\text { not citizens }\end{array}$ \\
\hline Number of changes possible & No maximum & No maximum specified \\
\hline R eference to Olympic C harter & none & Yes \\
\hline U ses nationality/ citizenship & $\begin{array}{l}\text { Citizen in thetext, but } \\
\text { memorandumon } \\
\text { nationality and reference } \\
\text { to sport nationality }\end{array}$ & Nationality \\
\hline Uses residence/ domicile & residence & none \\
\hline Other remarkable peculiarity & $\begin{array}{l}\text { Reference to sporting } \\
\text { nationality }\end{array}$ & Use of 'official nationality' \\
\hline
\end{tabular}




\subsection{Aquatics ${ }^{570}$}

Aquatics comprises six disciplines and one programme, namely swimming, open water swimming, diving, high diving, water polo, synchronized swimming, and the Masters programme / activity. Of these, five are Olympic and will be present at the 2016 Games in Rio: swimming, swimming marathon through open water, diving, water polo, and synchronised swimming. Its goveming association, the Fédération International e de Natation (FINA), was founded in 1908 and has its seat in Lausanne, Switzerland. ${ }^{571}$

Having been discovered as a means to trave through water in the Stone Age, swimming was only practised as a sport in the $19^{\text {th }}$ century. ${ }^{572}$ At first solely the breaststroke method was used, until the crawl was discovered in the 1880s by an Englishman who saw the native South Americans usethis technique ${ }^{573}$ Swimming has been an Olympic Sport since the first Olympic Games in 1896, when it was still rather risky. ${ }^{574}$ The first Olympic Games were in freestyle and breaststroke with backstroke being added in $1904 .{ }^{575}$ The Butterfly was initially a variation on breaststroke, which was at first banned, but then given its own official rank as a strokein $1956 .{ }^{576}$ The first women's events were held in $1912^{577}$ and nowadays the swimming events for men and women feature four different techniques across various di stances. ${ }^{578}$ These techniques aretheaforementioned crawl, butterfly, backstroke, and breaststrokewhich are used to race $100 \mathrm{~m}$ and $200 \mathrm{~m}^{579}$ There are al so freestyle events with distances of $50 \mathrm{~m}, 100$ $\mathrm{m}, 200 \mathrm{~m}, 400 \mathrm{~m}, 800 \mathrm{~m}, 1,500 \mathrm{~m}, 10,000 \mathrm{~m}$ - although the 800m and 1,500m are only for women and men respectively. ${ }^{580}$ In addition there are medley events with $200 \mathrm{~m}$ and $400 \mathrm{~m}$ for individuals in all four stroke techniques, plus a four times 100 medley. ${ }^{581}$ For freestyle, there are also four times 100 and four times $200 \mathrm{~m}$ medl eys. ${ }^{582}$ In each of these races, no more than eight swimmers can compete against oneanother. ${ }^{583}$ The swimming marathon takes placein open water over $10 \mathrm{~km}^{584}$

\footnotetext{
570 The federation was contacted on $6^{\text {th }}$ August 2014 and asked to provide further insights into its eligi bility criteria and ol der versions of the eligibility rules. The FINA replied on $6^{\text {th }}$ August 2014 and provided the necessary documents. On $29^{\text {th }}$ October 2015 the FINA was contacted again and asked for comments on this Chapter, which theFINA provided on $16^{\text {th }}$ November 2015.

IOC Information FINA IOC Information FINA - diving; IOC Information FINA - synchronisedswimming; IOC Information FINA - water-polo; IOC Reference Document Aquatics: for information on non-national athletes in the European national leagues and competitions see $S$. van den Bogaert, A. Cuyvers, S. Gardiner, R. Parrish, S. Miettinen, J. Soek and R. Siekmann (2010), p. 127.

Ibid.

Ibid.

Ibid.

Ibid.

Ibid.

IOC Information on Swimming Equipment and History.

IOC Information FINA IOC Information FINA - diving; IOC Information FINA - synchronisedswimming; IOC Information FINA - water-polo.

Ibid.

Ibid.

Ibid.

Ibid.

Ibid.
} 
Diving developed in the $18^{\text {th }}$ century from gymastics, when gymasts practiced tumbling into water. ${ }^{585}$ It became an Olympic event in 1904 with the modern springboards and platforms used since 1908. ${ }^{586}$ Since 1912, women have been participating in the diving competitions and in 2000 the discipline of synchronised diving was introduced. ${ }^{587}$ The points for diving are given based on the elegance of the performance ${ }^{588}$ Contestants arejudged on a ten point-scale, with adjustments made for the degree of difficulty of themoves performed. ${ }^{59}$

Synchronised swimming does not rely on speed, but on technique and artistic merit ${ }^{590}$ It was invented by Annette Kellerman, who performed water acrobatics and it was developed further by Katherine Curtis who combined the water acrobatics with music in $1933{ }^{591}$ Synchronised swimming became Olympic in 1984 and features a team and a duet event ${ }^{592}$ Contestants are judged on a ten point-scale according to the technique and artistic merit of the figures performed..$^{593}$ Until 2015, it was a women's only event, but now it al so features a mixed duet ${ }^{594}$

Water polo traditionally invol ved players riding on floating barres and hitting the ball with sticks like in equestrian polo - hence the name- and fighting with the other players was common until the introduction of rules at the end of the $19^{\text {th }}$ century, which resulted in a change in the outlook of the game ${ }^{595}$ While an American and European style had developed simultaneously, the European style became predominant ${ }^{596}$ Water polo was introduced in the 1900 Olympic Games, but it was absent in 1904 and has feetured again since the 1908 Games $^{597}$ Women's water polo became Olympic in 2000,598 and nowadays there are eight women's teams and 12 men's teams compeing against oneanother respectively. ${ }^{599}$

Rio 2016 Swimming Marathon information.

IOC Information on Diving Equipment and History.

IOC Information on Diving Equipment and History; IOC Reference Document Aquatics.

IOC Information on Diving Equipment and History.

IOC Information FINA IOC Information FINA- diving; IOC Information FINA - synchronisedswimming; IOC Information FINA - water-polo.

Ibid.

Ibid.

IOC Information on Synchroni sed Swimming Equi pment and History.

IOC Information on Synchronised Swimming Equipment and History; IOC Reference Document Aquatics.

IOC Information FINA IOC Information FINA- diving; IOC Information FINA - synchronisedswimming; IOC Information FINA - water-polo.

IOC Information on Synchronised Swimming Equipment and History; Kazan 2015 synchronised swimming.

IOC Information on Water Polo Equipment and History.

Ibid.

IOC Information on Water Polo Equi pment and History; IOC Reference Document Aquatics.

IOC Information on Water Polo Equipment and History.

IOC Information FINA IOC Information FINA - diving; IOC Information FINA - synchronisedswimming; IOC Information FINA - water-polo.
} 


\section{NATIONALITY REQUIREMENTS IN OLy MPIC SPORTS}

TableX: Overview of the eligibility requirements for aquatics

\begin{tabular}{|c|c|}
\hline Requirements FINA & \\
\hline In force & since 2005 \\
\hline Change of nationality & Possible \\
\hline R esidence requirements & 1 year \\
\hline M inors and nationality change & Not specified \\
\hline Stateless athletes & Not specified \\
\hline $\begin{array}{l}\text { Position of athletes with multiple nationality } \\
\text { after having competed for another country of } \\
\text { which the athlete is a national }\end{array}$ & $\begin{array}{l}\text { Possi ble change after oneyear of non-competition; } \\
\text { athl etes } \\
\text { have to choose sport nationality }\end{array}$ \\
\hline E ffect of changes in territory of country & Not specified \\
\hline Competing for the country of residence & Not specified \\
\hline Number of changes possible & No maximum \\
\hline R eference to Olympic C harter & None \\
\hline Uses nationality/ citizenship & $\begin{array}{l}\text { Citizen in the text, but memorandum on national ity } \\
\text { and referenceto sport nationality }\end{array}$ \\
\hline Uses residence/ domicile & residence \\
\hline Other remarkable peculiarity & Referenceto sporting nationality \\
\hline
\end{tabular}

\subsubsection{Aquatics citical reflection}

One of the most striking characteristics of the FINA eligibility rules is the reference to a 'sporting nationality'. ${ }^{600}$ With regard to changes of nationality, the FINA requires that naturalised athl etes have to have lived in the relevant country for at least one year prior to the competition. ${ }^{601}$ Thus, changes are not only possible, but the requirement of residence and one year of non-competition are relatively easy to fulfil for athletes. ${ }^{602}$ The rules do not go into great detail, for example territorial transfers are not mentioned and are rather lenient, with only one year of non-competition prescribed.

\subsubsection{Rules applicable since 2005}

Eligibility for all aquatic sports are set down in the FINA General Rules, which are identical in the 2009- 2013 and the 2013-2017 versions of August 2013, 29 $9^{\text {th }}$ January 2015 and of $25^{\text {th }}$ November 2015. The core of today's rules is identical to those in force between 2005 and 2009, however, since 2009, the FINA rules contain explicit artides regarding proof of residenceand proof of jurisdiction. ${ }^{603}$

\footnotetext{
600 GR 2.5 FINA general rules 2013-2017 of November, 2015.

601 GR 2.5 FINA general rules 2013-2017 of November, 2015.

602 GR 2.6.2(4) FINA general rules 2013-2017 of November 2015.

603 GR 2.6.1 FINA general rules 2013-2017 of November 2015; GR 2.6.1 FINA general rules 20132017 of January 2015; GR 2.6.1 FINA general rules 2013-2017 of August 2013; GR 2.6.1 FINA general rules 2009 - 2013; GR 2.6.2 FINA general rules 2013-2017 of November 2015; GR 2.6.2 FINA general rules 2013-2017 of January 2015; GR 2.6.2 FINA general rules 2013-2017 of August 2013; GR 2.6.2 FINA general rules2009 - 2013.
} 
Here the first rul eis that athletes are to be registered with their respective federation in order to be eligible for official FINA competitions. ${ }^{604}$ With regard to the athletes representing their country in official compeitions, the FINA stipulates that athletes may only compete for countries of which there are citizens. ${ }^{605}$ The FINA further elaborates that the acquisition of citizenship may be either by birth or naturalisation with the added requirement that any naturalised citizen has lived in the relevant country for at least oneyear prior to the competition. ${ }^{606}$

Athletes who have more than one nationality have to decide on one "Sport Nationality" and may not be affiliated to more than onefederation. ${ }^{607}$ This provision is especially interesting, since it not only refers to a 'sport nationality' in the sense of a nationality establ ishing a genuine link only for sporting matters, but al so sincethetext changes from a reference to 'citizen' to 'nationality'. It remains unclear which implications such a sporting nationality are intended by the FINA.

The topic of athletes with multiple nationality was further addressed by a Memorandum on $9^{\text {th }}$ February 2011. Here the FINA stated that, in order to avoid a violation of FINA rules, the federations should require their athletes to disclose the following information upon registration:

"- The athlete shall disd ose any other sport nationality that helshe is eligible to represent (or has been able to represent in case of a change of citizenship);

- The athlete shall dedare whether helshe has previously represented another sport country in any international competition and in any age leve;

- In the event the athlete has al ready represented another sport country, the athlete shall declarehe/shehas complied with the FINA Rules regarding the change of sport nationality (FINA GR 2.5 ff)." ${ }^{\prime 608}$

Hereagain, nationality and citizenship are used interchangeably. The responsi bility for the nationality change remains with the athlete who has to dedare his or her compliance with the FINA rules. The federation is not required to ask for any proof of this compliance, eg. the document stating the FINA's approval of the change Thus, this requirement becomes less effective, as the federation does not have to check the validity of the athlete's statements.

GR 1.1 FINA general rules 2013-2017 of November 2015; GR 1.1 FINA general rules 2013-2017 of January 2015; GR 1.1 FINA general rules 2013-2017 of August 2013; GR 1.1 FINA general rules 2009 - 2013; GR 1.1 FINA general rules 2005 - 2009. of January, 2015; GR 2.5 FINA general rules 2013-2017 of August 2013; GR 2.5 FINA general rules 2009 - 2013; GR 2.5 FINA general rules 2005 - 2009. of January, 2015; GR 2.5 FINA general rules 2013-2017 of August 2013; GR 2.5 FINA general rules 2009 - 2013; GR 2.5 FINA general rules 2005 - 2009. 
With regard to athletes who change their sporting allegiance, the FINA needs to approve the change ${ }^{609}$ and thus requires them to reside in the territory or the country they wish to represent for a oneyear prior to the first competition for this country. ${ }^{610}$ In addition to the residence in the federation's territory, the athl ete should have spent at least 12 months under the jurisdiction of there levant federation ${ }^{611}$ - meaning thathe or she has been competing for one of the dubs falling within the jurisdiction of the federation. ${ }^{612}$ During these twel ve months the athl ete may not compete for any of the countries ${ }^{613}$

Since 2009, the FINA provides criteria with which both the residence and the jurisdiction requirement aretested. For residencethe definition is as follows:

"Residence means the place/country wherethe competitor or compeition official 'lives and sleeps' and where helshe can be found in the majority of days of the year."

Evidence of this is provided by official registration and providing evidence through documents such as employment contracts in the new country. ${ }^{615}$ Providing proof of jurisdiction is in tum a matter of showing that the athlete was a member of a club in the new country, ${ }^{616}$ induding proof that the athlete has competed for this club during the revant period, ${ }^{617}$ and a confirmation from the relevant federation. ${ }^{618}$ The FINA does not refer to any occasions in which athletes might be faced with changing territorial realities or might berendered stateless.

609 GR 2.7 FINA general rules 2013-2017 of November, 2015; GR 2.7 FINA general rules 2013-2017 of January 2015; GR 2.7 FINA general rules 2013-2017 of August 2013; C 14.5.2 FINA constitution 2013 - 2017; GR 2.7 FINA general rules 2009 - 2013; GR 2.7. FINA general rules 2005 - 2009.

610

GR 2.6 FINA general rules 2013-2017 of November, 2015; GR 2.6 FINA general rules 2013-2017 of January 2015; GR 2.6 FINA general rules 2013-2017 of August 2013; GR 2.6 FINA general rules 2009 - 2013; GR 2.6 FINA general rules 2005 - 2009.

611 GR 2.6 FINA general rules 2013-2017 of November, 2015; GR 2.6 FINA general rules 2013-2017 of January 2015; GR 2.6 FINA general rules 2013-2017 of August 2013; GR 2.6 FINA general rules 2009 - 2013; GR 2.6 FINA general rules 2005 - 2009.

612 GR 2.6.2 FINA general rules 2013-2017 of November, 2015; GR 2.6.2 FINA general rules 20132017 of January 2015; GR 2.6.2 FINA general rules 2013-2017 of August 2013 and GR 2.6.2 FINA general rules 2009 - 2013.

613 GR 2.6.2(4) FINA general rules 2013-2017 of November, 2015; GR 2.6.2(4) FINA general rules 2013-2017 of August 2013 and GR 2.6.2(4) FINA general rules 2009 - 2013.

614 GR 2.6(1) FINA general rules 2013-2017 of November, 2015; GR 2.6(1) FINA general rules 20132017 of January 2015; GR 2.6(1) FINA general rules 2013-2017 of August 2013 and GR 2.6(1) FINA general rules 2009 - 2013.

615 GR 2.6.1(2) and GR 2.6.1(3) FINA general rules 2013-2017 of November, 2015; GR 2.6.1(2) and GR 2.6.1(3) FINA general rules 2013-2017 of J anuary 2015; GR 2.6.1(2) and GR 2.6.1(3) FINA general rules 2013-2017 of August 2013 and GR 2.6.1(2) FINA general rules 2009 - 2013.

616 GR 2.6.2(1) FINA general rules 2013-2017 of November, 2015; GR 2.6.2(1) FINA general rules 2013-2017 of January 2015; GR 2.6. 2(1) FINA general rules 2013-2017 of August 2013 and GR 2.6. 2(1) FINA general rules 2009 - 2013.

617 GR 2.6.2(3) FINA general rules 2013-2017 of November, 2015; GR 2.6.2(3) FINA general rules 2013-2017 of January 2015; GR 2.6.2(3) FINA general rules 2013-2017 of August 2013 and GR 2.6.2(3) FINA general rules 2009 - 2013.

618 GR 2.6.2(2) FINA general rules 2013-2017 of November, 2015; GR 2.6.2(2) FINA general rules 2013-2017 of January 2015; GR 2.6.2(2) FINA general rules 2013-2017 of August 2013 and GR 2.6.2(2) FINA general rules 2009 - 2013. 


\subsection{Gymnastics ${ }^{619}$}

Gymnastics is the heading given to the disciplines of gymnastics artistic, rhythmic gymastics and trampoline Its governing federation, the Fédération Internationale de Gymastique (FIG), was founded in 1881, meaning that it is the ol dest organised sport at an international level. ${ }^{620}$ Since 1896, gymnastics has been an Olympic sport, with trampoline events being introduced in $2000 .^{621}$ Gymastics feature one of the few women only events in the Olympic Games, namely rhythmic gymnastics. ${ }^{622}$

Gymnastics-artistic evolved in the $19^{\text {th }}$ century, although al ready in ancient Greece gymastic events were popular as they seemed to perfect the balance between body and mind. ${ }^{623}$ Interestingly, first editions of the events also included dimbing and acrobatics. ${ }^{624}$ Initially only men could compete, but women's events were ind uded in $1952 .{ }^{625}$ Nowadays, gymastics artistic is an event for both women and men, although the disciplines vary with regard to the apparatus used ${ }^{626}$ Both compete on floor and vault; Men compete on the pormmd horse, paralle bars, horizontal bar and rings, while women al so compete on the uneven bars and bal ance beam ${ }^{627}$

Trampolines had initially been used to train astronauts in the 1930s, but it soon became an independent sport ${ }^{628}$ While several variations, such as spaceball, were invented, they never gained wide interest. ${ }^{629}$ An Olympic discipline since 1984, rhythmic gymastics invol ves the contestants performing routines with a rope, hoop, ball, dubs, and ribbon to music. ${ }^{630}$ There are group events and individual ones, with groups consisting of five women. ${ }^{631}$ These groups perform twice, with the apparatus used changing every two years. ${ }^{632}$ Currently, during one event two members perform

619 The federation was contacted on $6^{\text {th }}$ August 2014 and asked to provide further insights into its eligibility criteria and older versions of the eligibility rules. On $8^{\text {th }}$ August 2014 the FIG replied that the Gymastics eligi bility rules had been unchanged since 2005. On $29^{\text {th }}$ October 2015 the FIG was contacted again and asked for comments on this Chapter, which the FIG provided on $5^{\text {th }}$ November 2015.

IOC Information FIG Artistic Gymmastics, IOC Information FIG Rhythmic Gymnastics; IOC Information FIG Trampoline for information on non-national athletes in the European national leagues and competitions see S. van den Bogaert, A. Cuyvers, S. Gardiner, R. Parrish, S. Miettinen, J. Soek and R. Siekmann (2010), p. 163.

IOC Information FIG Artistic Gymastics, IOC Information FIG Rhythmic Gymnastics; IOC Information FIG Trampoline; IOC Reference Document Gymastics. IOC Information FIG Artistic Gymastics, IOC Information FIG Rhythmic Gymnastics; IOC Information FIG Trampoline

IOC Information Gymnastics Artistic Equi pment and History.

Ibid.

Ibid.

IOC Information FIG Artistic Gymastics, IOC Information FIG Rhythmic Gymnastics; IOC Information FIG Trampoline

Ibid.

IOC Information Trampoline Equipment and History.

IOC Information TrampolineEqui pment and History.

IOC Information FIG Artistic Gymastics, IOC Information FIG Rhythmic Gymnastics; IOC Information FIG Trampoline; IOC Information Rhythmic Gymastics Equi pment and History; IOC Reference Document Gymastics.

IOC Information FIG Artistic Gymastics, IOC Information FIG Rhythmic Gymnastics; IOC Information FIG Trampoline 
the routine with hoops, while three use a pair of clubs each and during the other event all teammembers useribbon. ${ }^{633}$

TableXI: Overview of the eligibility requirements for gymnastics

\begin{tabular}{|l|l|}
\hline Requirements FIG & 2005 \\
\hline In force since & $\begin{array}{l}\text { Possi blethrough if consent is given or a waiting } \\
\text { period is observed }\end{array}$ \\
\hline C hange of nationality & None \\
\hline R esidence requirements & Not specified \\
\hline M inors and nationality change & Not specified \\
\hline Stateless athletes & $\begin{array}{l}\text { Treated likean athlete who wishes to acquirea new } \\
\text { national ity }\end{array}$ \\
\hline $\begin{array}{l}\text { Position of athletes with multiple nationality } \\
\text { which the athlete is a national }\end{array}$ & $\begin{array}{l}\text { Athlete may decideto compete for either of the } \\
\text { new countries }\end{array}$ \\
\hline E ffect of changes in territory of country & $\begin{array}{l}\text { If athletewas born in the country to parents who } \\
\text { werelegally residing there, but werenot citizens }\end{array}$ \\
\hline Competing for the country of residence & No maximum specified \\
\hline Number of changes possible & Yes \\
\hline R efer ence to Olympic C harter & Nationality \\
\hline Uses nationality/ citizenship & None \\
\hline Uses residence/ domicile & Use of 'official nationality' \\
\hline Other remarkable peculiarity & \\
\hline
\end{tabular}

\subsubsection{Gymastics critical reflection}

Gymnastics, as governed by the FIG, has had the same eligibility rules for the past decade Athletes require a 'Gymastics Passport', which they can only receive from the federation of which they are nationals ${ }^{634}$ A thletes wishing to change their country of representation after having acquired a new citizenship can do so rather easily. ${ }^{635}$ In case the FIG and relevant federations agree, the athlete can compete directly for the new country, otherwise a oneyear non-competition period is necessary. ${ }^{636}$ Athletes with multiple nationality can decide for which country they wish to compete, yet if they wish to re decide after having starred internationally for a country, they need to undergo the same procedure as an athlete who acquired a new nationality and wishes to change their country of representation. ${ }^{637}$ Competing for the country of residenceis possible if the athlete was bom in the country to parents who resided in his or her

633 FIG e-mail of $5^{\text {th }}$ November 2015.

634 Article 5.1 FIG technical regulations 2008; Article 5.1 FIG technical regulations 2004 from J une 2013; Art. 1 FIG Licence Rules Final version - last update September 25th 2012/mb 1/5.

635 Art. 36.2.1 Fédération Internationale de Gymnastique statutes edition 2015 in effect from J anuary $1^{\text {st }} 2015$.

636 Art. 36.2.1 Fédération Internationale de Gymnastique statutes edition 2015 in effect from J anuary $1^{\text {st }} 2015$.

637 Art. 36.2.2 Fédération Internationale de Gymnastique statutes edition 2015 in effect from J anuary $1^{\text {st }} 2015$. 
country of birth legally, but they were not nationals of the country. ${ }^{638}$ The FIG's rules arethus rather lenient

\subsubsection{Rules applicable since 2005}

The FIG prescribes eligibility criteria in the different qualification system documents for the respective disciplines. All three of these stipulate that the athl etes must comply with the provisions of the Olympic Charter at all times and need to have achieved a minimum technical standard as set for the respective discipline by the FIG. ${ }^{639}$ Gymmasts need to havea licence or 'Gymastics Passport', which proves that they are members of a federation of which they are nationals. ${ }^{640}$ In addition, the FIG published rules for the qualification systems for the Olympic Games in Rio. These underscore that athletes need to comply with the Olympic Charter and especially the nationality requirements therein. ${ }^{641}$ In the appendix to the technical regulations, eligibility is further elaborated upon. Here it is first stated that in general all athletes abiding by the eligibility rules are eligi ble ${ }^{642}$ Athletes are considered not to be abiding by the rules if they:

“a) have been expelled from any National or International Sports Federation for theuseof drugs

b) take part in any gymnastic competition or exhibition which is not sanctioned by theFIG or his/her National Federation

c) bear on his/her sportswear or his/her sports equipment any advertising trademarks during the Olympic Games or any compeition sanctioned by the FIG or National Federation, except for themenufacturing trademarks on equi pment or sportswear in accordance with the spedifications of the IOC, FIG or National Federation." 643

Art. 36.2.3 Fédération Internationale de Gymnastique statutes edition 2015 in effect from J anuary $1^{\text {st }} 2015$.

639 Art. C Qualification System - Games of the XXX Olympiad FIG Original version: English April 2011 - Federation Internationale De Gymnastique - Artistic Gymastics April, 2011; Art. C Qualification System - Games of the XXX Olympiad FIG Original version: English April 2011 Federation International e De Gymastique - Rhythmic Gymastics; Art. C Qualification SystemGames of the XXX Olympiad FIG Original version: English April, 2011 - Federation InternationaleDeGymastique- Trampoline.

640 Article 5.1 FIG technical regulations 2008; Article 5.1 FIG technical regulations 2004 from June 2013; Art. 1 FIG Licence Rules Final version - last update September $25^{\text {th }} 2012 / \mathrm{mb} 1 / 5$.

641 C. Athlete eligibility Fédération International e De Gymnastique - Qualification System - games of the XXXI Olympiad - Rio 2016 - Artistic Gymastics; C. Athlete eligibility Fédération International e De Gymnastique- Qualification System- games of the XXXI Olympiad - Rio 2016 - Rhythmic Gymnastics and C. Athlete eligibility Fédération Internationale De Gymastique Qualification System - games of the XXXI Olympiad - Rio 2016 - Trampoline

Art. 1 Appendix B rules of eligibility for the International Gymnastics Federation to technical regulations version 2015; Art. 1 Appendix B rules of eligibility for the International Gymnastics Federation to technical regulations version 2014.

Art. 5 Appendix B rules of eligibility for the International Gymnastics Federation to technical regulations version 2015; Art. 5 A ppendix B rules of eligibility for the International Gymnastics Federation to technical regulations version 2014. 
It is the respective federations' duty to certify that an athlete is eligible ${ }^{644}$ The FIG executive committeemay decide whether or not a rul ehas been violated. ${ }^{645}$

The main eligibility criteria for gymastics are described in Artide 36 of the Fédération Internationale De Gymastique Statutes Edition 2013 in effect from 1st J anuary 2013. Here it is stipulated that gymasts wishing to represent their country on an intermational level must hold the 'nationality (citizenship)' of the country. ${ }^{646}$ The FIG refers to both terms in this case and thus does not seem to want to differentiate regarding connotations. Athletes who wish to dhange their discipline within the framework of gymnastics may do so, but they need the approval of both the FIG and therevevant federation. ${ }^{647}$

In the following artides, the FIG elaborates on cases in which the question of nationality or citizenship is more difficult to answer. The FIG underscores that these rules apply to all FIG competitions, but that for the Olympic Games the IOC Charter is applicable

If an athlete acquires a new citizenship - or official nationality as the FIG terms it - he or she may represent the country of which he or she has newly acquired citizenship. ${ }^{648}$ It now depends on whether or not the federations concerned and the executive committee of the FIG agree to this move - then the athlete may start compeing for the new country directly after the consent is given. ${ }^{649}$ If such an agreement cannot be made, the athletehas to wait for one year after the acquisition of the nationality and may not compete internationally before the change of nationality becomes effective for the sport. ${ }^{650}$

Art. 2 Appendix B rules of eligibility for the International Gymnastics Federation to technical regulations version 2015; Art. 2 Appendix B rules of eligibility for the International Gymnastics Federation to technical regulations version 2014.

Art. 7 Appendix B rules of eligibility for the International Gymastics Federation to technical regulations version 2015; Art. 7 Appendix B rules of eligibility for the International Gymnastics Federation to technical regulations version 2014.

Art. 36.1 Fédération International e de Gymnastique statutes edition 2013 in effect from J anuary $1^{\text {st }}$ 2013; Art 35.1 Fédération Intermationale De Gymnastique statutes edition 2009 in effect from January $1^{\text {st }}$ 2009; Art. 35.1 Federation Internationale De Gymnastique statutes edition 2007 in effect from J anuary $1^{\text {st }}$ 2007; Art. 35.1 Federation International e De Gymnastique statutes edition 2004 in effect fromJ anuary $1^{\text {t }} 2005$.

Art. 36.2.5 Fédération Internationale de Gymnastique statutes edition 2015 Fédération Internationale de Gymnastique; statutes edition 2013 in effect from January 1st, 2015; Art. 36.2.5 Fédération Internationale de Gymastique statutes edition 2013 Fédération Internationale de Gymnastique; statutes edition 2013 in effect from January $1^{\text {st }}$ 2013; Art. 35.2.5 Federation Internationale De Gymastique statutes edition 2009 in effect from J anuary $1^{\text {st }}$ 2009; Art. 35.2.5 Federation International e De Gymnastique statutes edition 2007 in effect from J anuary $1^{\text {st }} 2007$; Art. 35.2.5 Federation Internationale De Gymastique statutes edition 2004 in effect fromJ anuary $1^{\text {t }} 2005$.

Art. 36.2.1 Fédération Internationale de Gymnastique statutes edition 2015 in effect from J anuary $1^{\text {tt }}$ 2015; Art. 36.2.1 Fédération International e de Gymnastique statutes edition 2013 in effect from January $1^{\text {st }}$ 2013; Art. 35.2.1 Federation Internationale De Gymnastique statutes edition 2009 in effect from J anuary $1^{\text {st }}$ 2009; Art. 35.2.1 Federation International e De Gymnastique statutes edition 2007 in effect from January $1^{\text {st }}$ 2007; Art. 35.2.1 Federation Internationale De Gymnastique statutes edition 2004 in effect from J anuary $1^{\text {st }} 2005$.

Ibid.

Ibid. 
If an athlete has multiple nationalities, he or she in principle has to choose one ${ }^{651}$ In case the athl ete wishes to compete for another country of which he or sheis a national, in general it not easily possible ${ }^{652}$ The athlete has to go through the aforementioned process as if the nationality or ditizenship was newly acquired ${ }^{653}$ Athletes who have not yet competed internationally and then acquire a new nationality may compete directly for their new country of representation. ${ }^{654}$

If an athlete was born to legal immigrant parents in an ius sanguinis country, the athlete may represent this country, even if he or she did not acquire the citizenship of the country through option rights. ${ }^{655}$ For this, the athlete will need the approval of the FIG's executive committee ${ }^{656}$ If a country is split into several parts, the athletes previously representing that country may decideto compete for either one of thenewly independent parts or represent a country he or she has moved to. ${ }^{657}$ In other unforeseen cases, the exearitive committee will dedide on a case by-case basis. ${ }^{658}$

651 Art. 36.2.2 Fédération Internationale de Gymnastique statutes edition 2015 in effect from J anuary $1^{\text {st }}$ 2015; Art. 36.2.2 Fédération International e de Gymnastique statutes edition 2013 in effect from January $1^{\text {st }}$ 2013; Art 35.2.2 Federation Internationale De Gymnastique statutes edition 2009 in effect from J anuary $1^{\text {st }}$ 2009; Art. 35.2.2 Federation International e De Gymnastique statutes edition 2007 in effect from January 1 1 statutes edition 2004 in effect from J anuary $1^{\text {st }}, 2005$. Ibid.

Art. 36.2.3 Fédération Internationale de Gymnastique statutes edition 2015 in effect from J anuary

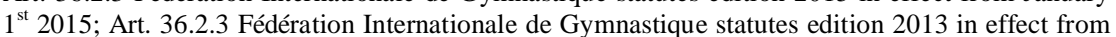
January $1^{\text {st }}$ 2013; Art 35.2.3 Federation Internationale De Gymnastique statutes edition 2009 in

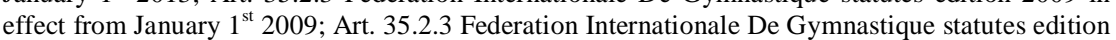
2007 in effect from January $1^{\text {st }}$ 2007; Art. 35.2.3 Federation Internationale De Gymnastique statutes edition 2004 in effect fromJ anuary $1^{\text {st }} 2005$. Ibid.

656 Ibid.

657 Art. 36.2.4 Fédération Internationale de Gymnastique statutes edition 2015 in effect from J anuary

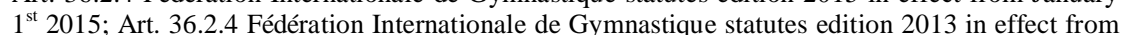
January $1^{\text {st }}$ 2013; Art 35.2.4 Federation Internationale De Gymnastique statutes edition 2009 in effect from J anuary $1^{\text {th }}$ 2009; Art. 35.2.4 Federation Internationale De Gymnastique statutes edition 2007 in effect from January $1^{\text {st }}$ 2007; Art. 35.2.4 Federation Internationale De Gymnastique statutes edition 2004 in effect from J anuary $1^{\text {st }} 2005$.

Art. 36.2.7 Fédération Internationale de Gymnastique statutes edition 2015 in effect from J anuary $1^{\text {st }}$ 2015; Art 36.2.7 Fédération International e de Gymnastique statutes edition 2013 in effect from January $1^{\text {st }}$ 2013; Art 35.2.7 Federation Internationale De Gymnastique statutes edition 2009 in effect from J anuary $1^{\text {st }}$ 2009; Art. 35.2.7 Federation International e De Gymnastique statutes edition 2007 in effect from January $1^{\text {st }}$ 2007; Art. 35.2.7 Federation Internationale De Gymnastique statutes edition 2004 in effect fromJ anuary $1^{\text {st }} 2005$. 



\section{M artial Arts without bodily contact between contestants}

With regard to the martial arts, this chapter will deel with those that do not require any physical contact between the contestants. These are archery, fencing and shooting, as none of them allow for an athlete to voluntary or involuntary touch a competitor's body during the competition. Therefore, although a martial arts move is made towards a target, which in the case of fencing is the opponent's sody, it is less about physically overpowering an opponent. Hence, a differentiation is made between these sports and wrestling, boxing or judo.

Both fencing and shooting have been Olympic since 1896 and archery was introduced at the next Olympiad. However, archery and shooting have not made an appearance at all games. Fencing in turn has never been absent from the Olympic Games until now. With regard to women's participation, archery was the first sport introducing events for female athletes in 1904, while ladies' fencing was only introduced in 1924. Shooting was a mixed event between 1968 and 1992.

TableXII: Topics dealt with in Martial Arts without bodily contact

\begin{tabular}{|c|c|c|c|}
\hline Requirements & Archery & Fencing & Shooting \\
\hline In force since & 2012 & 2005 & 2000 \\
\hline Versions since 2005 & Since 2012 & Since 2005 & Since 2000 \\
\hline $\begin{array}{l}\text { Substantial C hanges } \\
\text { made since October } \\
2013\end{array}$ & n/a & $n / a$ & $n / a$ \\
\hline C hange of nationality & Possible & $\begin{array}{l}\text { Possible after a three } \\
\text { year waiting period if } \\
\text { the athletehas } \\
\text { competed for another } \\
\text { country }\end{array}$ & $\begin{array}{l}\text { Possible after non- } \\
\text { competition for three } \\
\text { years }\end{array}$ \\
\hline $\begin{array}{l}\text { Residence } \\
\text { requirements }\end{array}$ & $\begin{array}{l}\text { None, unless } \\
\text { competing for country } \\
\text { of residence }\end{array}$ & None & None \\
\hline $\begin{array}{l}\text { M inors and } \\
\text { nationality change }\end{array}$ & Not specified & Not specified & Not specified \\
\hline Stateless athletes & Not specified & $\begin{array}{l}\text { Legally stateless } \\
\text { athl etes registered with } \\
\text { therelevant national } \\
\text { federation may } \\
\text { compete for their } \\
\text { country of residence }\end{array}$ & Not specified \\
\hline $\begin{array}{l}\text { Position of athletes } \\
\text { with multiple } \\
\text { nationality after } \\
\text { having competed for } \\
\text { another country of } \\
\text { which the athlete is a } \\
\text { national }\end{array}$ & $\begin{array}{l}\text { One-year waiting } \\
\text { period needed }\end{array}$ & $\begin{array}{l}\text { Possible after three } \\
\text { year waiting period }\end{array}$ & $\begin{array}{l}\text { May change after a } \\
\text { threyear waiting } \\
\text { period }\end{array}$ \\
\hline $\begin{array}{l}\text { E ffect of changes in } \\
\text { territory of country }\end{array}$ & Not specified & Not specified & $\begin{array}{l}\text { May chooseto } \\
\text { represent either entity }\end{array}$ \\
\hline
\end{tabular}


NATIONALITY REQUIREMENTS IN OLYMPIC SPORTS

\begin{tabular}{|l|l|l|l|}
\hline $\begin{array}{l}\text { Competing for the } \\
\text { country of residence }\end{array}$ & $\begin{array}{l}\text { Possible after one year } \\
\text { of residenceand with } \\
\text { written approval }\end{array}$ & $\begin{array}{l}\text { Possibleonly for } \\
\text { legally stateless } \\
\text { athletes registered with } \\
\text { therdevant national } \\
\text { federation }\end{array}$ & Not specified \\
\hline $\begin{array}{l}\text { Number of changes } \\
\text { possible }\end{array}$ & No maximumgiven & Once & No maximumgiven \\
\hline $\begin{array}{l}\text { R eference to Olympic } \\
\text { Charter }\end{array}$ & Yes & None \\
\hline $\begin{array}{l}\text { Uses nationality/ } \\
\text { citizenship }\end{array}$ & Nationality & None & Nationality \\
\hline $\begin{array}{l}\text { Uses residence/ } \\
\text { domicile }\end{array}$ & None & None \\
\hline $\begin{array}{l}\text { Other remarkable } \\
\text { peculiarity }\end{array}$ & $\begin{array}{l}\text { Passport sufficient to } \\
\text { med nationality } \\
\text { requirement }\end{array}$ & & \\
\hline
\end{tabular}




\subsection{Archery 659}

Archery is one of the ol dest sports and has been Olympic since 1900 (thus the second Olympiad), although there were years in which there was no Olympic archery competition, namely 1912, 1924, 1928, 1932, 1936, 1948, 1852, 1956, 1960, 1964, and $1968 .{ }^{660}$ The World Archery Federation was founded in 1931, although it was first named FITA (Fédération Internationale de Tir à l'Arc) and has it seat in Lausanne, Switzerland. ${ }^{661}$ Archery refers to a competition in which an athlete tries to hit a target with an arrow that is shot froma bow. The bow's draw weight, i.e theamount of force needed to draw it, as well as the distance to the target and the diameter of the arrows are regulated. Typical arrows havea maximum diameter of 9.3 millimetres and have to be marked in such a way as to make it clear to which competitor it belongs, i.e with the athlete's name or initials. The bow's draw weight differs for the genders, with typical draw weights at the Olympics being 22 kilograms (i.e 48 pounds) for men and 17 kilograms (i.e 38 pounds) for women. Compound bows used for other competitions havea maximum draw weight of 60 pounds. ${ }^{662}$

The distance to the target is 70 meters and the target itself is 1.22 meters in diameter. On the target there are 10 concentric rings drawn, with the centre ring 12.2 centimetres in diameter. The closer the arrow is to this centre ring, the higher the points awarded to the archer, who has between 9 and 15 arrows per round depending on the competition. ${ }^{63}$ In case of a team competition, each team is made up of threearchers. ${ }^{664}$

TableXIII: Overview of the eligibility requirements for archery

\begin{tabular}{|l|l|}
\hline R equirements WA & \\
\hline In force since & $1^{\text {s }}$ April 2012 \\
\hline C hange of nationality & Possible \\
\hline R esidence requirements & None, unless competing for country of residence \\
\hline M inors and nationality change & Not specified \\
\hline Stateless athletes & Not specified \\
\hline $\begin{array}{l}\text { Position of athletes with multiple nationality } \\
\text { after having competed for another country of } \\
\text { which the athlete is a national }\end{array}$ & Oneyear waiting period needed \\
\hline Effect of changes in territory of country & Not specified \\
\hline Competing for the country of residence & $\begin{array}{l}\text { Possibleafter one year of residenceand with written } \\
\text { approval }\end{array}$ \\
\hline Number of changes possible & No maximum given \\
\hline & \\
\hline
\end{tabular}

659 The federation was contacted on $6^{\text {th }}$ August 2014 and asked to provide further insights into its eligibility criteria and older versions of the eligibility rules. As no reply was forthcoming, a reminder email was sent on $18^{\text {th }}$ September. On $29^{\text {th }}$ October 2015 the WA was contacted again and asked for comments on this Chapter, which the WA provided on $31^{\text {st }}$ October 2015.

IOC Reference Document Archery: for information on non-national athletes in the European national leagues and competitions see S. van den Bogaert, A. Cuyvers, S. Gardiner, R. Parrish, S. Miettinen, J. Soek and R. Siekmann (2010), p. 131. Ibid.

662 WA E-mail of $31^{\text {st }}$ October 2015.

663 WA E-mail of $31^{\text {st }}$ October 2015.

664 IOC Information on Archery Equi pment and History. 
NATIONALITY REQUiREMENTS IN Oly MPIC SPORTS

\begin{tabular}{|l|l|}
\hline R efer ence to Olympic C harter & Yes \\
\hline Uses nationality/ citizenship & Nationality \\
\hline Uses residence/ domicile & None \\
\hline Other remarkable peculiarity & Passport sufficient to meet nationality requirement \\
\hline
\end{tabular}

7.1.1. Archery critical reflection

For the WA, an athlete has to have a valid passport from the relevant country. ${ }^{665}$ This is an interesting way of phrasing the requirement, since it only refers to the ownership of a valid passport and not to the status as a national directly. ${ }^{666}$ Thus athl etes hailing from American Samoa, who are nationals but not US citizens, could compete for the US archery team ${ }^{667}$

Changing between national teams is only possi ble if the athlete does not compete for the period of one year in between the changes. ${ }^{668} \mathrm{~A}$ maximum number of changes is not stated, however the one-year period does slightly reduce the attraction of frequent changes. In case an athlete with multiple national ity wishes to compete for the other national team instead, the aforementioned period of one year between the representations also has to be observed. ${ }^{669}$ Consequently, archers do have a certain freedom in their choice of national team they wish to compete for if they have more than one nationality.

Overall, the rules seem to be very liberal, given that changes are possible often and the one-year period al so seems to be within a reasonable time frame. Questions of stateless athletes and minors are not addressed by the eligibility code, yet, since there no specified age at which an athlete has to decide for which national team he or she wants to compete, this does not seem to be overly problematic. The position of stateless athletes is somewhat more difficult. On the one hand, there is this extraordinary possibility to compete for the country of residence, after one year of residence and the permission of the home archery association. On the other hand, this would not real ly apply to archers who lose their nationality and thus might lack a home archery association. The problem of stateless athl etes thus remains unsol ved. However, one has to underscore that the possibility to compete for the country of residence without actual ly being a national of that country is very liberal.

\subsubsection{Rules applicable sinceApril 2012}

Tuming to the eligibility rules for archery, one finds that they are spelled out in Chapter 2 of the World Archery Constitution and Rules 2012 effective since $1^{\text {st }}$ April 2012 and which were updated on $1^{\text {t }}$ A pril 2013, 25 September 2013, $1^{\text {th }}$ A pril 2014,

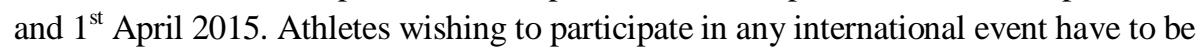

Art. 2.4.1 World Archery constitution and rules 2015 effective since $1^{\mathrm{st}} \mathrm{A}$ pril 2015. $\S 308$ (US Code Title 8 1408) Immigration and Nationality Act 2011 and 8 USC 1101. See Chapter 3.2 on national ity and citizenship.

Art. 2.4.1 and Art. 2.4.3 World Archery constitution and rules 2015 effective since $1^{\text {st }}$ A pril 2015. Art. 2.4.3 World Archery constitution and rules 2015 effective since $1^{\text {tt }}$ A pril 2015. 
members of an archery association which is affiliated with theWA. ${ }^{670}$ To compete for a country, the athletes al ways need to comply with the WA's eligibility code and, in the case of the Olympic Games, need to also comply with the Olympic Charter. ${ }^{671}$ A thl etes furthermore are to respect anti-betting and corruption rules, fair-play and nonviolence rules, as well as the WA's anti-doping rules and the advertising and sponsorship rules. ${ }^{672}$

In order to compete for a national team at any international event, the athlete has to have a valid passport of the relevant country. ${ }^{673}$ Notably the phrasing is interesting, since it only refers to the ownership of a valid passport and not to the status as a national directly. ${ }^{674}$ Thus athletes hailing from American Samoa, who are nationals but not US citizens, could compete for the US archery team ${ }^{675}$ Another requirement is that the athlete has not competed for another national team for at least one year. Hencea change between national teams is only possible if the athlete does not compete for the period of one year in between the changes. ${ }^{676} \mathrm{~A}$ maximum number of changes is not stated, however the oneyear period does reduce the attraction of frequent changes slightly.

It is furthermore a possibility to compete for a country of which one does not possess a valid passport and hence is not a national. This is only an option if the athlete has resided for at least one year in the country for which he or she wants to compete without being a national. In addition, the written permission of the Archery Association of the country of which he is a national is needed. ${ }^{677}$ It is somewhat

Art. 2.1.1 World Archery constitution and rules 2015 effective since $1^{\text {st }}$ April 2015; Art 2.1.1 World Archery constitution and rules 2014 effective since 1 April 2014; Art. 2.1.1 World Archery constitution and rules 2012 effective since $1^{\text {st }}$ A pril 2012 updated $1^{\text {st }}$ A pril 2013 and $25^{\text {th }}$ September 2013.

671 Art. 2.1.2 and Art. 2.1.3 World Archery constitution and rules 2015 effective since $1^{\text {st }}$ A pril 2015; Art. 2.1.2 and Art. 2.1.3 World Archery constitution and rules 2014 effective since $1^{\text {st }}$ A pril 2014; Art. 2.1.2 and Art. 2.1.3 World Archery constitution and rules 2012 effective since $1^{\text {st }}$ A pril 2012 updated $1^{\text {st }}$ A pril 2013 and $25^{\text {th }}$ September 2013.

Art. 2.2.1, Art. 2.2.1.1, Art. 2.2.2, Art. 2.2.3, Art. 2.2.4, Art. 2.2.5, Art.2.2.6, Art 2.2.7, Art. 2.2.7.1, Art. 2.2.7.2, Art. 2.2.7.3 and Art 2.2.8 World Archery constitution and rules 2015 effective since $1^{\text {st }}$ April 2015; Art. 2.2.1, Art. 2.2.1.1, Art. 2.2.2, Art. 2.2.3, Art. 2.2.4, Art. 2.2.5, Art.2.2.6, Art. 2.2.7, Art. 2.2.7.1, Art. 2.2.7.2, Art. 2.2.7.3 and Art 2.2.8 World Archery constitution and rules 2014 effective since $1^{\text {st }}$ A pril 2014; Art. 2.2.1, Art. 2.2.1.1, Art. 2.2.2, Art. 2.2.3, Art. 2.2.4, Art. 2.2.5, Art.2.2.6, Art. 2.2.7, Art. 2.2.7.1, Art 2.2.7.2, Art 2.2.7.3 and Art 2.2.8 World Archery constitution and rules 2012 effective since $1^{\text {th }}$ A pril 2012 updated $1^{\text {st }}$ A pril 2013 and $25^{\text {th }}$ September 2013.

Art. 2.4.1 World Archery constitution and rules 2015 effective since $1^{\text {st }}$ April 2015; Art 2.4.1 World Archery constitution and rules 2014 effective since $1^{\text {st }}$ A pril 2014; Art. 2.4.1 World Archery constitution and rules 2012 effective since $1^{\text {st }}$ A pril 2012 updated $1^{\text {st }}$ A pril 2013 and $25^{\text {th }}$ September 2013.

$674 \S 308$ (US Code Titte 81408 ) Immigration and Nationality Act 2011 and 8 USC 1101.

675 See Chapter 3.2 on national ity and citizenship.

676 Art. 2.4.1 and Art. 2.4.3 World Archery constitution and rules 2015 effective since $1^{\text {st }}$ A pril 2015; Art. 2.4.1 and Art. 2.4.3 World Archery constitution and rules 2014 effective since $1^{\text {st }}$ A pril 2014; Art. 2.4.1 and Art 2.4.3 World Archery constitution and rules 2012 effective since $1^{\text {st }}$ April 2012 updated $1^{\text {st }}$ A pril 2013 and $25^{\text {th }}$ September 2013.

677 Art. 2.4.2 World Archery constitution and rules 2015 effective since $1^{\text {st }}$ A pril 2015; Art. 2.4.2 World Archery constitution and rules 2014 effective since $1^{\text {st }}$ A pril 2014; Art. 2.4.2 World Archery 
difficult to assess the likeliness of such a permission given to top athletes on a purely theoretical basis. This rule does not answer the question of what happens to athletes who become stateless. If their nationality is revoked in a discriminatory way, eg. based on their membership of an ethnic minority, there would technically be no archery association of a country of which they hold a valid passport - since that has been revoked.

Tuming to athletes with more than one val id passport, i.e multiple nationalities, the eligi bility code stipulates that a choice for either of them can be made In casean athlete wants to change and compete for the other national team instead, there has to be the aforementioned period of one year between the representations. ${ }^{678}$ Therefore, archers do have a certain freedom in their choice of the national team they wish to compete for if they have more than onenationality.

constitution and rules 2012 effective since $1^{\text {st }}$ A pril 2012 updated $1^{\text {st }}$ A pril 2013 and $25^{\text {th }}$ September 2013. 


\subsection{Fencing ${ }^{679}$}

The modem sport fencing devel oped from the art of duelling and the main aim during a match remains to hit the opponent with the weapon to score a point. Three different weapons with al so different target areas on the opponent's s body are used nowadays:

- Epée, with theentire body being the possible target;

- Sabre, with thetorso, arms and head as target;

- Foil, whereonly the hits to thetorso are counted.

Another differentiating aspect is the 'right of way' requirement when fencing foil or sabre, meaning that simultaneous hits are not counted, but only the points for the fencer who started the attack first or made a defensive action prior to making a counter-attack are valid. Contrarily, epée fencing recognises the possibility to scorea 'double', meaning that both fencers can score a point at the sametime ${ }^{680}$ The official rules are spelled out by the FIE, the Federation International d'Escrime, founded in 1913 and having its seat in Lausanne, Switzerland. ${ }^{681}$ With regard to the Olympics, men's fencing was first included in the 1896 Games in Athens and women's fencing was introduced in 1924 in Paris. ${ }^{682}$ Nowadays, men and women fence in separate competitions - with teemand individual events for both. ${ }^{683}$

TableXIV: Overview of the digibility requirements for fencing

\begin{tabular}{|l|l|}
\hline R equirements FIE & $\mathbf{0}$ ctober $\mathbf{2 0 1 3}$ \\
\hline In force since & 2005 \\
\hline C hange of nationality & $\begin{array}{l}\text { Possi bleafter a threeyear waiting period if the } \\
\text { athletehas compeded for another; this may } \\
\text { however be reduced or wai vered by the Executive } \\
\text { Board }\end{array}$ \\
\hline R esidence requirements & None \\
\hline M inors and nationality change & Not specified \\
\hline Stateless athletes & $\begin{array}{l}\text { Legally stateless athletes registered with the } \\
\text { relevant national federation may competefor their } \\
\text { country of residence }\end{array}$ \\
\hline $\begin{array}{l}\text { Position of athletes with multiple nationality } \\
\text { after having competed for another country of } \\
\text { which the athlete is a national }\end{array}$ & Possibleafter threeyear waiting period \\
\hline E ffect of changes in territory of country & Not specified \\
\hline Competing for the country of residence & Possi bleonly for legally stateless athletes \\
\hline
\end{tabular}

679 The federation was contacted on $6^{\text {th }}$ August 2014 and asked to provide further insights into its eligibility criteria and older versions of the eligibility rules. As no reply was forthcoming, a reminder email was sent on $18^{\text {th }}$ September, to which the FIE replied directly, stating that there had been no rule changes since 2005 with regard to athl ete nationality. On $29^{\text {th }}$ October 2015 the FIE was contacted again and asked for comments on this Chapter, which the FIE provided on $29^{\text {th }}$ October 2015.

680 Deutscher Fechtbund.

681 IOC ReferenceDocument Fencing.

682 Ibid.

683 IOC Information on Fencing Equipment and History: for information on non-national athletes in the European national leagues and competitions see S. van den Bogaert, A. Cuyvers, S. Gardiner, R. Parrish, S. Miettinen, J. Soek and R. Siekmann (2010), p. 163. . 
NATIONALITY REQUiREMENTS In OLy MPIC SPORTS

\begin{tabular}{|l|l|}
\hline & registered with therelevant national federation \\
\hline Number of changes possible & Once \\
\hline & \\
\hline R efer ence to Olympic Charter & Yes \\
\hline Uses nationality/ citizenship & Nationality \\
\hline Uses residence/ domicile & None \\
\hline Other remarkable peculiarity & None \\
\hline
\end{tabular}

\subsubsection{Fending critical reflection}

Fencing has employed the same eligi ibility criteria since 2005. Rules are strict as only national s may competein a national team ${ }^{684}$ and a change of country of representation forces the fencer to take a threeyear brek fromintemational competitions. ${ }^{685} \mathrm{Athl}$ etes with multiple national ity may initially decide freely, but afterwards they are bound by the same requirements as the other athl etes. ${ }^{686}$ Stateless athl etes may compete for their country of residence, provided they are registered with the relevant federation. ${ }^{687}$ Overall, the FIE is extremely strict, since only one change is admissible, ${ }^{688}$ and the Executive Committee's ruling that is asked in case of dispute, cannot be appeel ed. ${ }^{689}$ Ergo, in case of a dispute that is decided not in favour of a fencer, it is impossible to ask for a reevaluation of the situation. Also, the duration of the prescribed waiting period is rather long.

\subsubsection{Rules applicable since 2005}

Thenationality requirements in fencing are set out in Chapter 9 of theFIE Statures and Chapter 1 of the FIE Administrative rules. It is important to underscore that for the Olympic Games athlete eligibility is determined by the IOC Charter, to which the FIE rules must comply. ${ }^{690}$ In turn, Artide 9.2 of the FIE statues stipulates that in officially sanctioned FIE competitions fencers may only represent the country of which they are nationals. ${ }^{691}$ This means that for fending players with multiple nationality have to choose for either country. ${ }^{692}$ In case the fencer wants to represent another country, he may in principle only do so after taking a threeyear break from fencing compeitions. ${ }^{693}$ While this would effectively lead to a serious break in a fencer's carer, there is the possibility for FIE Executive Committee to reduce or wai ve this period, provided that the respective federations al so agree ${ }^{694}$ If a fencer acquires a new nationality, either through naturalisation or after being stateless, the same threeyear

\footnotetext{
684 Art. 9.2.2 FIE statutes of December 2014 (wording unchanged since 2005).

${ }^{685}$ Art. 9.2.2.a FIE statues of December 2015 (wording unchanged since 2005).

$686 \quad$ Art. 9.2.2.a FIE statues of December 2015 (wording unchanged since 2005).

687 Art. 9.2.3 FIE statutes of December 2015 (wording unchanged since 2005).

688 Art. 9.2.2.f) FIE statutes of December 2015 (wording unchanged since 2005).

689 Art. 9.2.2.g) FIE Statues of December 2015 (wording unchanged since2005).

690 Art. 9.2.1 FIE statutes of December 2015 (wording unchanged since 2005).

691 Art. 9.2.2 FIE statutes of December 2015 (wording unchanged since 2005).

692 Art. 9.2.2.a FIE statues of December 2015 (wording unchanged since 2005).

${ }^{693}$ Art. 9.2.2. a FIE statues of December 2015 (wording unchanged since 2005).

694 Art. 9.2.2. d FIE statutes of December 2015 (wording unchanged since2005).
} 
break after the last competition for previous country is prescribed. ${ }^{695}$ This provision, however, does not specify for which country a stateless fencer could have fenced before. One can thus deduce that that the mentioning of stateless fencers in this artide is primarily aimed at fencers who, after representing their country at an international competition, become stateless and then acquire a new nationality. In case such a loss of nationality was triggered by an act of the fencer, this situation would be understandable However, in cases of involuntary loss of nationality, the threeyear period seems somewhat unfair.

Contrarily, fencers who acquire an additional nationality by marriage are not faced with a threeyear waiting period. ${ }^{696}$ Even if the three year waiting period should in principle apply, the FIE Executive Committee may reduce or waive this period, provided that the respective federations al so agree ${ }^{697}$ In case of the fencer who became statel ess without any intention or criminal act, this would probably not help his or her cause, since the national federation of the previous nationality of the fencer is not likely to be very accommodating.

An exception to these rules is provided under 9.2.2. sub e) namely for fencers who have not yet participated in an official competition, the change of nationality is not subject to perquisites and can be done without causing a waiting period.

Tuming to the Administrative Rules of the FIE of February 2014, on the possibility for changes of nationality, they stipulate that any change regarding the country of representation is definitive, and thus no new changes will be allowed afterwards. ${ }^{698}$

The overall stance on the change of country of the FIE is very strict, since only one change is admissible and the Executive Committee's ruling that is requested in the case of a dispute, cannot be appeal ed against ${ }^{699}$ Ergo, in case of a dispute that is not decided in favour of a fencer, it is impossible to ask for a reevaluation of the situation.

A more lenient stance is taken for stateless fencers who may compete for their country of residence, provided that they are legally stateless and are registered with the relevant national federation. ${ }^{700}$ The question arises whether the FIE would al so take de facto stateless athletes into consideration, meaning those that do nominally possess a nationality, but can in truth not rely thereon as they belong to an ethnic, religious or political minority. From the wording 'legally stateless', this does not seem to be the case. Should a stateless athlete acquire a new national ity, he or she would have to undergo the standard procedure, meaning the change of nationality is only possible after a threeyear waiting period. However, the FIE Executive Committee might reduce or waive this period. A more problematic aspect is that the

\footnotetext{
695 Art. 9.2.2.b FIE statutes of December 2015 (wording unchanged since 2005).

696 Art. 9.2.2. C FIE statutes of December 2015 (wording unchanged since 2005).

697 Art. 9.2.2.d FIE statutes of December 2015 (wording unchanged since 2005).

698 Art. 1.4.2 Administrativerules of the FIE of December 2015 (wording unchanged since 2005).

699 Art. 9.2.2. $f$ and g) FIE Statues of December 2015 (wording unchanged since 2005).

700 Art. 9.2.3 FIE statutes of December 2015 (wording unchanged since2005).
} 
decisions taken by the FIE are final and only one change is admissible, the question arises how the FIE would deal with a factual change of nationality, eg. through the independence of the part of the country in which the fencer lives and a subsequent further splitting up of the country, as no rules exist so far.

Tuming to the more technical part of changing a fencer's nationality, one has to consult the Administrative Rules of the FIE, which divides the potential cases into 'regular' and 'non-regular' cases. The non-regular cases, which concern athletes competing at the highest possible level, or transfers of multiple athletes between federations, are decided by the FIE Executive Committee al one ${ }^{701}$ Contrary to this, the regular cases are dealt with by the Legal Commission's Executive Committee representative and the FIE's CEO upon the request of theathl ete's new federation. ${ }^{702}$ Such a request needs to be in writing and the following documents need to be provided:

"- a letter from the new federation accepting the transfer and requesting the cancel lation or reduction of the 3 year period only for just reasons;

- a letter from the athleterequesting the change of nationality;

- a letter from the former federation accepting the transfer and requesting the cancel lation or reduction of the 3 year period only for just reesons;

- a copy of the athlete's passport indicating his/her new nationality;

- if the athlete is a minor, a leter from his/her parents requesting the change of nationality, and a photocopy of their passports;

- if the new nationality has been dbtained by marriage, a copy of the marriage certificate" ${ }^{\prime 703}$

This is the only time that the FIE statues address the issue of minor athletes with regard to changes of nationality.

Art. 1.4 Administrative rules of the FIE, December 2011, February 2014 and September 2014 (wording unchanged since 2005).

${ }^{702}$ Art. 1.4.1 Admini strative rules of theFIE, December 2015 (wording unchanged since 2005).

${ }^{703} \mathrm{Art}$. 1.4.3 Admini strativerules of the FIE, December 2015 (wording unchanged since2005). 


\subsection{Shooting ${ }^{704}$}

Shooting has been an Olympic sport since the first Olympiad in 1896, although there were years without shooting competitions, namely 1904 and $1928{ }^{705}$ Women have had their own events since 1984, yet there were mixed gender events between 1968 and $19922^{706}$ In principle, three different firearms are used in the 15 Olympic shooting events: rifle, pistol and shotgun. In the rifle and pistol compeitions competitors have to hit a bull's-eye from distances of 10,25 or 50 meters. ${ }^{707}$ In shotgun competitions, the athletes aim at day targets which are propelled in different directions and angles. ${ }^{708}$ Rules on participation in shooting events are laid down in the official statues rules and regulations of the International Sport Shooting Federation (ISSF). It was founded in 1907 and, unlike most international sports associations, does not have it seat in Switzerland, but in Munich, Germany. ${ }^{709}$

TableXV: Overview of the eligibility requirements for shooting

\begin{tabular}{|l|l|}
\hline R equirements ISSF & \\
\hline In force since & November 2000 \\
\hline C hange of nationality & Possi ble after non-compeition for threeyears \\
\hline R esidence requirements & None \\
\hline M inors and nationality change & Not specified \\
\hline Stateless athletes & Not specified \\
\hline $\begin{array}{l}\text { Position of athletes with multiple nationality } \\
\text { after having competed for another country of } \\
\text { which the athlete is a national }\end{array}$ & May change after a threeyear waiting period \\
\hline E ffect of changes in territory of country & May chooseto represent either entity \\
\hline Competing for the country of residence & Not specified \\
\hline Number of changes possible & No maximum given \\
\hline & \\
\hline R efer ence to Olympic Charter & None \\
\hline Uses nationality/ citizenship & Nationality \\
\hline Uses residence/ domicile & None \\
\hline Other remarkable peculiarity & None \\
\hline
\end{tabular}

\subsubsection{Shooting critical reflection}

For over 15 years, theISSF's eligi bility criteria have stipulated that only those who are nationals of a country can be called upon to compete for the national team in

The federation was contacted on $6^{\text {th }}$ August 2014 and asked to provide further insights into its eligibility criteria and older versions of the eligibility rules. The ISSF replied on $7^{\text {th }}$ August and stated that the rules have remained unchanged since 2000. On $29^{\text {th }}$ October 2015 the ISSF was contacted again and asked for comments on this Chapter, which the ISSF provided on $4^{\text {th }}$ November 2015.

IOC Reference Document Shooting: for information on non-national athletes in the European national leagues and competitions see S. van den Bogaert, A. Cuyvers, S. Gardiner, R. Parrish, S. Miettinen, J. Soek and R. Siekmann (2010), p. 185.

Ibid.

IOC Information on Shooting Equipment and History.

IOC Reference Document Shooting. 
international competitions. ${ }^{710}$ For dhanges of the country of representation, a thre year waiting period is prescribed. ${ }^{711}$ The ISSF has a detailed approach to all the possibilities of national ity changes due to a territorial transfer and shows that the ISSF aims at providing solutions for all possi ble situations. ${ }^{712}$ However, the athl ete only has theoption to choose once, which could potentially be difficult for an athlete to do at an early stage Overall, the ISSF seems to be rather moderate in its approach - allowing for nationality changes more than once, however in principle only after a period of threeyears of non-competition. ${ }^{713}$

\subsubsection{Rules applicable since 2000}

The current rules on eligibility on shooting can be found in the 2013 edition of the ISSF official statutes rules and regulations, although the content of these rules have remained unchanged since 2000. National shooting associations have to declare an athlete eligible for the relevant team under those rules, which in principle stipulates that athletes must be national s of the countries for which they compete ${ }^{714}$ In case of multiple nationality, the athlete has to choose for which country he or she wishes to compete and stay with this decision. ${ }^{715}$ However, athletes who initially had multiple nationalities or those who change or acquire a new nationality may compete for another country than the one they originally chose $Y$ et, this is only possible if they have not competed for the first country for a period of three years. ${ }^{716}$ This seems to be a relatively long period, since it also encompasses the time in which athletes could qualify for the Olympic Games and could thus act as an obstade to nationality changes. Nevertheless, whether or not such a period will actually be required depends on the circumstances in the individual cases, since these are reviewed by the ISSF Executive Committee Hence, in case the national associations involved agree, the period may either be reduced or entirely cancelled. ${ }^{717}$ The ISSF Executive Committee

\footnotetext{
710 Art. 3.6.3 ISSF official statutes rules and regulations edition 2013 (first print, 11/2012; second print, 01/2014; third print, 01/2015; fourth print 03/2016).

711 3.6.3.3 ISSF official statutes rules and regulations edition 2013 (first print, 11/2012; second print, 01/2014; third print, 01/2015; fourth print 03/2016); 3.6.4. ISSF official statutes rules and regulations edition 2013 (first print, 11/2012; second print, 01/2014; third print, 01/2015; fourth print 03/2016). 3.6.3.4 ISSF official statutes rules and regulations edition 2013 (first print, 11/2012; second print, 01/2014; third print, 01/2015; fourth print 03/2016).

713 3.6.3.3 ISSF official statutes rules and regulations edition 2013 (first print, 11/2012; second print, 01/2014; third print, 01/2015; fourth print 03/2016); Art. 3.6.4. ISSF official statutes rules and regulations edition 2013 (first print, 11/2012; second print, 01/2014; third print, 01/2015; fourth print 03/2016).

Art. 3.6.3 and Art 3.6.5 ISSF official statutes rules and regulations edition 2013 (first print, 11/2012; second print, 01/2014; third print, 01/2015; fourth print 03/2016).

Art. 3.6.3.2 ISSF official statutes rules and regulations edition 2013 (first print, 11/2012; second print, 01/2014; third print, 01/2015; fourth print 03/2016).

716 Art. 3.6.3.2 ISSF official statutes rules and regulations edition 2013 (first print, 11/2012; second print, 01/2014; third print, 01/2015; fourth print 03/2016); Art. 3.6.3.3 ISSF official statutes rules and regulations edition 2013 (first print, 11/2012; second print, 01/2014; third print, 01/2015; fourth print 03/2016).

717 3.6.3.3 ISSF official statutes rules and regulations edition 2013 (first print, 11/2012; second print, 01/2014; third print, 01/2015; fourth print 03/2016); Art. 3.6.4. ISSF official statutes rules and
} 
furthermore has the power to intervene and take decisions conceming periods of noncompetition in all cases in which an athlete has the choice between representing several countries. ${ }^{718}$ It is thus a very powerful institution and the ISSF dearly wants to keep track of thenationality changes of the competing athletes.

Turning to the question of possible stateless athletes or athletes whose home state itself changes; the ISSF has included a specific provision for such occasions:

"3.6.3.4 If an associated State, province or overseas department, a country or colony acquires independence, if a country becomes incorporated within another country by reason of a change of border, if a country merges with another country, or if a new NOC is recognised by the IOC, an athlete may continue to represent the country to which he belongs or belonged. However, he may, if he prefers, elect to represent his country or beentered in ISSF Championships by his new Federation when recognized by the ISSF. This particular choice may be madeonly once"

Threethings areimportant for this article firstly, the ISSF clearly pays close attention to the possible scenarios, referring both theindependence of col onies, border changes, mergers or incorporations within other countries; secondly, the athlete is given a choice - however only once; and thirdly, the ISSF plays an important roleagain, since such a choice is only admissible, if the ISSF recognises the new national shooting federation. Questions of stateless athletes or minors are not addressed in the statutes. However, the detail led approach to all the possibilities of nationality changes through a change in the athlete's country shows that the ISSF aims at providing solutions for all possible situations. The athlete only has the option to choose once, which could potential ly makeit difficult for the athl eteto makea choiceat an early stage

regulations edition 2013 (first print, 11/2012; second print, 01/2014; third print, 01/2015; fourth print 03/2016). 



\section{Martial Arts with direct bodily contact between contestants}

In the following section, the martial arts which require bodily contact between contestants will be described and analysed. These sports originated at different times during the Olympic history, with wrestling and boxing dating back to ancient times and becoming Olympic early on, while judo and taekwondo gained wide popularity only later. Taekwondo has been Olympic since 2000 for both men and women. Contrarily, in most other sports there is a significant difference between the time when the sport first became Olympic and the first women's events. For freestyle wrestling, the difference is exactly 100 years and for Greco-Roman wrestling there still is no women's event Boxing, while being introduced in the 1904 Olympics, has only allowed women since 2012 and for judo there was a men's only event between 1964 and 1992.

TableXVI: Topics dealt with in Martial Arts with direct bodily contact

\begin{tabular}{|c|c|c|c|c|}
\hline R equirements & Boxing & Judo & Taekwondo & W restling \\
\hline In force since & 2015 & 2005 & 2013 & 2015 \\
\hline $\begin{array}{l}\text { Versions since } \\
2005\end{array}$ & $\begin{array}{l}2013-2014 \\
\text { Since } 2015\end{array}$ & Since 2005 & $\begin{array}{l}2010-2012 \\
\text { Since } 2013\end{array}$ & $\begin{array}{l}2011-2012 \\
2012-2015 \\
\text { Since } 2015\end{array}$ \\
\hline $\begin{array}{l}\text { Substantial } \\
\text { Changes made } \\
\text { since October } \\
2013\end{array}$ & $\begin{array}{l}\text { Previously not } \\
\text { rules specified on } \\
\text { AIBA level }\end{array}$ & n/a & $n / a$ & $\begin{array}{l}\text { Introduction of } \\
\text { sport nationality, } \\
\text { residence } \\
\text { requirement and } \\
\text { waiting period }\end{array}$ \\
\hline $\begin{array}{l}\text { C hange of } \\
\text { nationality }\end{array}$ & $\begin{array}{l}\text { Possibleafter two } \\
\text { years of non- } \\
\text { competition }\end{array}$ & Possible & $\begin{array}{l}\text { Not mentioned, } \\
\text { thus not possible }\end{array}$ & $\begin{array}{l}\text { Possi ble, although } \\
24 \text { month waiting } \\
\text { period if } \\
\text { federations do not } \\
\text { agree }\end{array}$ \\
\hline $\begin{array}{l}\text { Residence } \\
\text { requirements }\end{array}$ & None & None & None & $\begin{array}{l}\text { Holding a } \\
\text { residence permit }\end{array}$ \\
\hline $\begin{array}{l}\text { M inors and } \\
\text { nationality } \\
\text { change }\end{array}$ & $\begin{array}{l}\text { Not specified on } \\
\text { AlBA level }\end{array}$ & Not specified & $\begin{array}{l}\text { Artide not } \\
\text { applicableto } \\
\text { minors } \\
\end{array}$ & $\begin{array}{l}\text { Minors are treated } \\
\text { as fully-fledged } \\
\text { athletes here }\end{array}$ \\
\hline Stateless athletes & $\begin{array}{l}\text { Not specified on } \\
\text { AIBA level }\end{array}$ & Not specified & Not specified & \\
\hline $\begin{array}{l}\text { Position of } \\
\text { athletes with } \\
\text { multiple } \\
\text { nationality after } \\
\text { having competed } \\
\text { for another } \\
\text { country of which } \\
\text { the athlete is a } \\
\text { national }\end{array}$ & $\begin{array}{l}\text { 2-year non- } \\
\text { competition } \\
\text { period }\end{array}$ & $\begin{array}{l}\text { Need to comply } \\
\text { with threeyear } \\
\text { waiting period } \\
\text { that can be } \\
\text { reduced or } \\
\text { annulled }\end{array}$ & $\begin{array}{l}\text { Possibleafter } \\
\text { threeyear period }\end{array}$ & $\begin{array}{l}\text { Initially freto } \\
\text { choose, then usual } \\
\text { changing } \\
\text { mechanism i.e } \\
24 \text { month waiting } \\
\text { period if } \\
\text { federations do not } \\
\text { agree }\end{array}$ \\
\hline E ffect of changes & Not specified on & Not specified & Not specified & Not specified \\
\hline
\end{tabular}


NATIONALITY REQUIREMENTS IN OLYMPIC SPORTS

\begin{tabular}{|c|c|c|c|c|}
\hline $\begin{array}{l}\text { in territory of } \\
\text { country }\end{array}$ & AIBA level & & & \\
\hline $\begin{array}{l}\text { Competing for } \\
\text { the country of } \\
\text { residence }\end{array}$ & Not possible & Not possible & Not possible & Not possible \\
\hline $\begin{array}{l}\text { Number of } \\
\text { changes possible }\end{array}$ & $\begin{array}{l}\text { No maximum } \\
\text { given }\end{array}$ & $\begin{array}{l}\text { No maximum } \\
\text { given }\end{array}$ & Not specified & Once \\
\hline $\begin{array}{l}\text { R eference to } \\
\text { Olympic } \\
\text { C harter }\end{array}$ & None & $\begin{array}{l}\text { Yes, to Rule42 } \\
\text { and theByelaw } \\
\text { to Rule42 }\end{array}$ & None & Yes \\
\hline $\begin{array}{l}\text { Uses nationality/ } \\
\text { citizenship }\end{array}$ & None & $\begin{array}{l}\text { Both } \\
\text { interchangeably }\end{array}$ & $\begin{array}{l}\text { Both - stating that } \\
\text { national ity is } \\
\text { decided by } \\
\text { citizenship }\end{array}$ & $\begin{array}{l}\text { Nationality \& } \\
\text { sport nationality }\end{array}$ \\
\hline $\begin{array}{l}\text { Uses residence/ } \\
\text { domicile }\end{array}$ & None & Residence & None & $\begin{array}{l}\text { Residence } \\
\text { (including permit, } \\
\text { if necessary) }\end{array}$ \\
\hline $\begin{array}{l}\text { Other } \\
\text { remarkable } \\
\text { peculiarity }\end{array}$ & & & $\begin{array}{l}\text { Just refers to } \\
\text { athletes with } \\
\text { multiple } \\
\text { nationality }\end{array}$ & $\begin{array}{l}\text { 'Sport nationality' } \\
\text { that is entirely } \\
\text { disconnected } \\
\text { fromathlete's } \\
\text { nationality } \\
\text { introduced }\end{array}$ \\
\hline
\end{tabular}




\section{1. $\quad$ B oxing ${ }^{719}$}

Boxing dates back to ancient times and was already a sport in Egypt, Greece and Rome - although in Rome gladiators later on wore gloves that were studded with metal, making that variant of boxing a deadly sport ${ }^{720}$ The overall aim remains to hit the opponent in such a way that he or she ends up on the ground for a given time or gives up. Boxing became an Olympic discipline in 1904 and was featured in all Games, except at the 1912 Stockholm Games, due to a ban of boxing under Swedish law. $^{721}$ In 1904, the US won all boxing medals, being the only country which sent contestants. ${ }^{722}$ The Association Internationale de Boxe Amateur (AIBA) was founded in 1920 and has its seat in Lausanne, Switzerland. ${ }^{723}$ It changed its name to Association International de Boxe in 2007. ${ }^{724}$ Women were only been induded in 2012 at the Olympics, though they had been competing at AIBA events since $2001 .^{725}$ Traditionally there were five weight classes, ${ }^{726}$ yet nowadays there are ten weight classes ranging from the under $48 \mathrm{~kg}$, the light flyweights, to the super heavwweights of over $91 \mathrm{kgs}^{727}$ Over the years, there have been significant changes introduced, likethe compul sory wearing of protective helmets in 1984, which was reversed in 2013 for men, ${ }^{728}$ the electronic scoring system in 1992 and the point scoring system in 2007. ${ }^{729}$

TableXVII: Overview of the eligibility requirements for boxing

\begin{tabular}{|l|l|}
\hline Requirements AIBA & \\
\hline In force since & $1^{\text {s }}$ February 2015 \\
\hline C hange of nationality & Possibleafter 2 years of non-competition \\
\hline R esidence requirements & None \\
\hline M inors and nationality change & Not specified on AIBA leve \\
\hline Stateless athletes & Not specified on AIBA leve \\
\hline $\begin{array}{l}\text { Position of athletes with multiple nationality } \\
\text { after having competed for another country of } \\
\text { which the athlete is a national }\end{array}$ & 2 -ear non-competition period \\
\hline E ffect of changes in territory of country & Not specified on AIBA leve \\
\hline Competing for the country of residence & Not possible \\
\hline Number of changes possible & No maximumgiven \\
\hline
\end{tabular}

719 The federation was contacted on $6^{\text {th }}$ August 2014 and asked to provide further insights into its eligibility criteria and older versions of the eligibility rules. As no reply was forthcoming, a reminder e-mail was sent on $18^{\text {th }}$ September. On $29^{\text {th }}$ October 2015 the federation was contacted again and asked for comments on this Chapter to which AIBA replied on $2^{\text {nd }}$ March, 2016. IOC Information Boxing, Equi pment and History.

721 IOC Information AIBA; IOC Information Boxing, Equipment and History; IOC Reference Document Boxing: for information on non-national athletes in the European national leagues and competitions see S. van den Bogaert, A. Cuyvers, S. Gardiner, R. Parrish, S. Miettinen, J. Soek and R. Siekmann (2010), p. 185.

IOC Information Boxing, Equi pment and History.

IOC Reference Document Boxing.

IOC Information AIBA.

IOC Information Boxing, Equipment and History. IOC Reference Document Boxing; AIBA E-mail of $2^{\text {nd }}$ March, 2016.

726 IOC Information Boxing, Equi pment and History.

727 IOC Information AIBA.

728 AIBA E-mail of $2^{\text {nd }}$ March, 2016.

729 IOC Information AIBA; IOC Information Boxing, Equipment and History. 


\begin{tabular}{|l|l|}
\hline & \\
\hline R eference to Olympic Charter & None \\
\hline Uses nationality/ citizenship & None \\
\hline Uses residence/ domicile & None \\
\hline Other remarkable peculiarity & None \\
\hline
\end{tabular}

8.1.1. Boxing critical reflection

Since 2015, AIBA deals with eligibility matters and nationality related issues ${ }^{730}$ The underlying principle is that athl etes need to be either licensed or otherwise authorised by a national federation. ${ }^{731}$ Changes regarding country of representation are now possible after a two-year non-competition period. ${ }^{732}$ Boxers who hold dual nationality may initially decide fredy which country they wish to represent ${ }^{733}$ If they wish to change their country of representation, they will be treated like boxers who changed their nationality at a later stage and face a period of non-competition of two years. ${ }^{734}$ These rules are relatively lenient, as the period of non-competition is only two years and no maximum number of changes is stipulated.

\subsubsection{Rules applicable since 2015}

The newest rules are set down in AIBA tednnical rules effective as of $1^{\text {t }}$ February 2015, which differ considerably from the previously applicable rules. The underlying concept that athletes need to be either licensed or otherwise authorised by a national federation remained the same ${ }^{735}$ However, the AIBA rules now deal spedifically with eligi bility and national ity related issues, induding change of national ity, as well as the sport related eligibility. ${ }^{736}$ The later focusses on the relationship of athletes to the AIBA $^{737}$ and especially on the distinction between professional and amateur athletes. ${ }^{738}$ Athletes who have previously competed professionally in any physical contact sport that is fought on an individual basis, will never be all owed to competein AIBA events. ${ }^{739}$ This rule is extremely strict, as any professionalism in a physical contact sport leads to an exdusion from AIBA events. Turning to the question of nationality, the AIBA is responsible for verifying the athlete's nationality and eligibility by checking the passport of the boxer prior to any event. ${ }^{740}$ Should there be issues regarding the boxer's nationality, the AIBA may require the boxer and the federation to provide

\footnotetext{
730 Art. 2.2.1 AIBA technical rules effectiveas of February $1^{\text {st }}, 2015$.

Art. 2.2 AIBA technical rules effective as of February $1^{\text {st }}, 2015$.

Art. 2.2.1.4.1 AIBA technical rules effectiveas of February $1^{\text {st }}, 2015$.

Art. 2.2.1.4.2 AIBA technical rules effectiveas of February $1^{\text {st }}, 2015$.

Art. 2.2.1.4.2 AIBA technical rules effectiveas of February $1^{\text {st }}, 2015$.

Art. 2.2 AIBA technical rules effectiveas of February $1^{\text {st }}, 2015$.

Art. 2.2.1, Art. 2.2.1.4 and Art. 2.2.2 AIBA technical rules effective as of February $1^{\text {st }}, 2015$.

Art. 2.2.2.1.1 AIBA technical rules effectiveas of February $1^{\text {st }}, 2015$.

Art. 2.2.2.1.3 and Art. 2.2.2.1.4 AIBA technical rul es effective as of February $1^{\text {th }}, 2015$.

Art. 2.2.2.1.3 AIBA technical rules effectiveas of February $1^{\text {st }}, 2015$.

Art. 2.2.1.1 and Art 2.2.1.3 AIBA technical rules effectiveas of February $1^{\text {st }}, 2015$
} 


\section{"2.2.1.3.1 Birth Certificate}

\subsection{Citizenship I dentity Papers;}

\subsection{Nationality I dentity Document;}

2.2.1.3.4Confirmation Letter from the NOC., ${ }^{7741}$

It is interesting that the AIBA differentiates between citizenship papers and a nationality identity document Notably, neither a definition nor a reason for differentiating is provided here

With regard to changes of nationality, the AIBA prescribes a waiting period of two years in which the boxer may not compete ${ }^{742}$ Athletes with dual nationality have to initially decide on one country they wish to represent. ${ }^{743}$ If they wish to changetheir country of representation, they will be treated like boxers who changed their nationality and face a period of non-competition of two years. ${ }^{744}$

\subsubsection{Rules applicable $2013-2014$}

The previous rules were set out in the AIBA Technical Rules, effective as of $31^{\text {t }}$ August 2014 and the AIBA Technical Rules, which were effective on $23^{\text {rd }}$ August 2013, but which did not differ considerably regarding content ${ }^{745}$ Here, the first rule was that all involved in the boxing sport need to have a license ${ }^{746}$ or could otherwise beexcluded from AIBA competitions. ${ }^{747}$ Eligi bility could berefused on thegrounds of the athlete's sport carer, eg. those having boxed professionally at non-AIBA events werenot eligible ${ }^{748} A s$ in the previous rules, nationality did not play a role with regard to boxing, as passports are only required as proof of identity. ${ }^{749}$

Hence, it was left to the National Federations to provide the requirements for boxers to acquire their licences, but national ity or citizenship was not regulated for the boxers themselves on the AIBA leve..$^{750}$

Art. 2.2.1.3 AIBA technical rules effectiveas of February $1^{\text {st }}, 2015$.

Art. 2.2.1.4.1 AIBA technical rules effectiveas of February $1^{\text {th }}, 2015$.

Art. 2.2.1.4.2 AIBA technical rules effectiveas of February $1^{\text {st }}, 2015$.

Art. 2.2.1.4.2 AIBA technical rules effectiveas of February $1^{\text {th }}, 2015$.

Thereare other eligi bility rules for officials of the AIBA set down in statutes and by-laws.

Rule 1.3.1 AIBA technical rules effective as of August 31 ${ }^{\mathrm{st}}, 2014$; Definitions AIBA technical rules. Effective on August 23 $3^{\text {rd }}$, 2013; Rule 1.1 AIBA technical rules. Effective on August 23 2013. 


\subsection{J udo ${ }^{751}$}

Judo is a Japanese martial art that developed from ancient samurai combat techniques with its main aim being to bring the opponent to the ground and hold him there ${ }^{752}$ It was developed in the late $19^{\text {th }}$ century, when features of various sports where combined by Dr. Jigoro Kano. ${ }^{753}$ J udo first becamean Olympic sport in 1964, 13 years after the Intemational Judo Federation had been founded in $1951 .{ }^{754}$ It was only absent from the 1968 Olympics. ${ }^{75}$ Women's events were added in 1992 and today maleand female competitors, called J udoka, compete in seven weight classes, each in singleelimination rounds. ${ }^{756}$

TableXVIII: Overview of the eligibility requirements for judo

\begin{tabular}{|l|l|}
\hline R equirements IJ F & \\
\hline In force since & 2005 \\
\hline C hange of nationality & Possi ble \\
\hline R esidence requirements & None \\
\hline M inors and nationality change & Not specified \\
\hline Stateless athletes & Not specified \\
\hline $\begin{array}{l}\text { Position of athletes with multiple nationalities } \\
\text { after having competed for another country of } \\
\text { which the athlete is a national }\end{array}$ & $\begin{array}{l}\text { Need to comply with threeyear waiting period } \\
\text { that can be reduced or annulled }\end{array}$ \\
\hline E ffect of changes in territory of country & Not specified \\
\hline Competing for the country of residence & No possible \\
\hline Number of changes possible & No maximumgiven \\
\hline & \\
\hline R efer ence to Olympic Charter & Yes, to Rule42 and theByelaw to Rule42 \\
\hline Uses nationality/ citizenship & Both interchangeably \\
\hline Uses residence/ domicile & Residence \\
\hline Other remarkable peculiarity & None \\
\hline
\end{tabular}

\subsubsection{Judo critical reflection}

The IJF's judo rules have remained the same for the past decade Athletes may only compete for the countries of which they are nationals. ${ }^{757}$ Like in most sports, athl etes with dual citizenship are initially free to choose ${ }^{758}$ All athletes that al ready competed

751 The federation was contacted on $6^{\text {th }}$ August 2014 and asked to provide further insights into its eligibility criteria and older versions of the eligibility rules. The IJF replied on $12^{\text {th }}$ August 2014 that the rules have been complying with the ones of the Olympic Comity since 2005 . On $29^{\text {th }}$ October 2015 the IJ F was contacted again and asked for comments on this chapter, which the IJ F provided on $30^{\text {th }}$ October 2015. IOC Information J udo Equipment and History.

Ibid.

IOC Information IJ F: for information on non-national athl etes in the European national leagues and competitions see S. van den Bogaert, A. Cuyvers, S. Gardiner, R. Parrish, S. Miettinen, J. Soek and R. Siekmann (2010), p. 185.

755 IOC Reference DocumentJ udo.

756 IOC Information IJF; IOC Reference Document Judo; IOC Information J udo Equipment and History.

757 Art. 13.3.1 Sports and organization rules of the International Judo Federation 2015.

758 Art. 13.3.1(b) Sports and organization rules of the International J udo Federation 2015. 
in official IJF or national federation events and wish to compete for a different country need to fulfil a waiting and non-competition period of three years. ${ }^{759}$ These rules are rather strict as three years is a rather long timein an athl ete's carer.

\subsubsection{Rules applicablesince 2005}

According to the IJ F, the rul es have not changed in essence since 2005 and the current judo eligibility rules are set out in the Sports and Organization Rules of the International Judo Federation 2015. These rules are almost identical to those previously set out in the 2013 version, with only the wording changing from 'compeitor' to 'athlete' and the singular cases changed to 'they'. Furthermore, there was an additional document added by the IJF General Secretary on 24/01/2014 concerning the Procedure of Participation in IJ F Competitions for Athletes* who want to represent another country. This document refers to Article 13.3.1 of the IJF Sport Organization Rules 2013 and underlines that no reduction to or waiver for the waiting period is possible without the written agreement of the concerned federations. ${ }^{760}$ It further details that, for Olympic Games, thethreeyear waiting period applies. ${ }^{761}$

Minors are explicitly mentioned under Article 1.7 with regard to the permissions needed for the guardian of the respective minor with regard to anti-doping testing and general participation in the events. ${ }^{762}$ During the competitions, athletes and team officials need an accreditation card from the IJ $F$, which serves as their main identity document. ${ }^{763}$ Information such as the competitor's name, weight category and country he or she is competing for is included in this document. ${ }^{764}$ Regarding nationality, the IJF stipulates that athletes may only compete for the countries of which they are national $\mathrm{s}^{765}$ This is ensured by checking theathletes' passports. ${ }^{766}$

Athletes with multiple citizenships have to choose for which country they wish to compete ${ }^{767}$ If an athlete has already competed in official IJF or national federations' events and wishes to compete for a different country after acquiring or changing his or her nationality, s/he needs to fulfil a waiting and non-competition

759

Art. 13.3.1(b) Sports and organization rules of the International Judo Federation 2015; Art. 2.1 Annex 1 to Sports and organization rules of the International J udo Federation 2015.

Procedure of participation in IJF competitions for the Athletes* who want to represent another country. Additional document by the IJ F general Secretary published on 24/01/2014.

Procedure of participation in IJF competitions for the Athletes* who want to represent another country. Additional document by the IJF general Secretary published on 24/01/2014.

Art. 1.7 Sports and organization rules of the International Judo Federation 2015; Art. 12.6 Sports and organization rules of the International Judo Federation 2013.

Art. 1.9 Sports and organization rules of the International Judo Federation 2015; Art 13.3 Sports and organization rules of the International Judo Federation 2013.

Art. 1.9 Sports and organization rules of the International Judo Federation 2015; Art 13.3 Sports and organization rules of the International Judo Federation 2013.

Art. 1.9 Sports and organization rules of the International Judo Federation 2015; Art. 13.3.1 Sports and organization rules of the International Judo Federation 2013.

Art. 1.9 Sports and organization rules of the International Judo Federation 2015; Art. 13.3.1 Sports and organization rules of the International Judo Federation 2013.

Art. 1.9 Sports and organization rules of the International Judo Federation 2015; Art. 13.3.1(b) Sports and organization rules of the International J udo Federation 2013. 
period of three years. ${ }^{768}$ The IJF only refers to an athlete "who has changed his nationality or acquired a new nationality", ${ }^{769}$ which, if taken literally, means that those who already have had dual citizenship do not fall under this provision. However, in Annex 1 to the Sports and Organization Rules, it is stipulated that athletes who have dual citizenship and initially compete for one country and then wish to change their country of representation al so need to comply with the three year waiting and non-competition period. ${ }^{770}$ The aforementioned waiting period can be reduced or annulled in case the national federations agree to such a change of procedure if the athlete requested it formal ly. ${ }^{771}$ In addition, the IJ $\mathrm{F}$ rules make an explicit reference to the Olympic Charter, namely Rule 42 and the Byelaw to Rule 42. The IJF however also recognises particular cases that provide evidence of citizenship:

“a) where the competitions are being held in a country in which theresidents do nothold passports while in that country, ${ }^{772}$

b) where there is a possible problem of "joint citizenship", eg. Dutch Antilles and the Netherlands an acceptable substitute for the passport will be a letter or certificate from the compeitor's National Olympic Committee or, if there is no such body, from the National Sports Authority confirming the compeitor's residence in that country and thecitizenship."773

Therefore, there is a certain degree of flexibility when it comes to technicalities and thelJ F seems to aimat delineating all possible scenarios to avoid confusion.

768 Art. 1.9 Sports and organization rules of the International Judo Federation 2015; Art 13.3.1(b) Sports and organization rules of the International J udo Federation 2013.

769 Art. 1.9 Sports and organization rules of the International Judo Federation 2015; Art 13.3.1(b) Sports and organization rules of the International J udo Federation 2013.

770 Art. 1.9 Sports and organization rules of the International Judo Federation 2015; Art 2.1 Annex 1 to Sports and organization rules of the International J udo Federation 2013.

771 Art. 1.9 Sports and organization rules of the International Judo Federation 2015; Art 13.3.1(b) Sports and organization rules of the International J udo Federation 2013; Art. 2.1 Annex 1 to Sports and organization rules of the International J udo Federation 2013.

772 Art. 1.9 Sports and organization rules of the International Judo Federation 2015; Art. 13.3.1(a) Sports and organization rules of the International J udo Federation 2013.

773 Art. 1.9 Sports and organization rules of the International Judo Federation 2015; Art 13.3.1(b) Sports and organization rules of the International J udo Federation 2013. 


\subsection{Taekwondo ${ }^{774}$}

Taekwondo is a Korean martial art which dates back to $50 \mathrm{BC}$ and involves a combination of punch and most notably kick movements to bring an opponent down. ${ }^{775}$ In 1973, the World Takwondo Federation (WTF) was founded and takwwondo became a demonstration sport at the Olympic Games in $1988 .{ }^{776} 12$ years later, taekwondo became an official Olympic sport in $2000 .{ }^{777}$ Nowadays men and women competein four weight dasses in single elimination rounds. ${ }^{778}$

TableXIX: Overview of the eligibility requirements for taekwondo

\begin{tabular}{|l|l|}
\hline R equirements WTF & $7^{\text {th }}$ October 2010 \\
\hline In force since & Not mentioned, thus not possible \\
\hline C hange of nationality & None \\
\hline R esidence requirements & Articlenot applicableto minors \\
\hline M inors and nationality change & Not specified \\
\hline Stateless athletes & Possi bleafter thre-year period \\
\hline $\begin{array}{l}\text { Position of athletes with multiple nationality } \\
\text { after having competed for another country of } \\
\text { which the athlete is a national }\end{array}$ & \\
\hline Effect of changes in territory of country & Not specified \\
\hline Competing for the country of residence & Not possible \\
\hline Number of changes possible & Not specified \\
\hline & None \\
\hline R efer ence to Olympic Charter & $\begin{array}{l}\text { Both- stating that nationality is decided by } \\
\text { citizenship }\end{array}$ \\
\hline Uses nationality/ citizenship & None \\
\hline Uses residence/ domicile & Just refers to athletes with multiplenationality \\
\hline Other remarkable peculiarity & \\
\hline
\end{tabular}

\subsubsection{Taekwondo critical reflection}

The WTF changes its rules bi-annually, yet no substantial change has occurred to the eligibility criteria since 2013. The underlying principle is that the athlete has to be a national of the country he or she represents. ${ }^{779}$ Here the term citizenship is used as a sort of sub-category to nationality, as nationality can be determined based on citizenship according to the WTF. Changing the country of representation is only

774 The federation was contacted on $6^{\text {th }}$ August 2014 and asked to provide further insights into its eligibility criteria and older versions of the eligibility rules. As no reply was forthcoming, a reminder e-mail was sent on $18^{\text {th }}$ September. On $29^{\text {th }}$ October 2015 the federation was contacted again and asked for comments on this Chapter. As no reply was received, a first reminder was sent on $19^{\text {th }}$ November 2015 and a second on $2^{\text {nd }}$ December 2015. No reply was received by the time of publication. IOC Information Taekwondo Equi pment and History.

776 IOC Information WTF; IOC Reference Document Taekwondo: for information on non-national athl etes in the European national leagues and competitions see S. van den Bogaert, A. Cuyvers, S. Gardiner, R. Parrish, S. Miettinen, J. Soek and R. Siekmann (2010), p. 185.

777 IOC Information WTF, IOC Information Taekwondo Equipment and History. IOC Reference Document Taekwondo.

778 IOC Information WTF.

779 Explanation 1 to Art. 4.1.1 World Tadkwondo Federation rules \& interpretation in force as of $11^{\text {th }}$ May 2015. 
elaborated upon for athletes with multiple nationality who need to comply with a noncompetition period of three years. ${ }^{780}$ This period may be reduced or completely wai ved in case the respective national federations and the WTF agree on it ${ }^{781}$ There are no provisions on athletes who acquire another nationality without holding multiple nationalities at the sametime Hence, one can deduce that this is not possible These rules are thus extremely strict as, for the majority of cases, a change of country of representation is not possible.

\subsubsection{Rules applicable since 2010}

For taekwondo, the eligibility rules are set out in the World Tadwondo Federation Rules \& Interpretation in force as of $11^{\text {th }}$ May 2015, which are identical to the version amended on $1^{\text {tt }}$ January $2015,1^{\text {tt }}$ July 2014 and $14^{\text {th }}$ J uly 2013 . In the core of their content, theserules areal so identical to those applicablein the years 2010 - 2012, with the updates of $26^{\text {th }}$ December 2012, $4^{\text {th }}$ October 2011 and $7^{\text {th }}$ October 2010. Here Article 4.1.1 spedifies that the contestant should hold the nationality of the team he or she competes for ${ }^{782}$ and hold a WTF certificate ${ }^{783}$ and, since 2012, a WTF license ${ }^{784}$ The biggest changes over the years occurred in Explanation 1 to Artide 4.1.1, which goes into more detail regarding nationality requirements.

Here it is said that an athlete's "nationality is decided by citizenship of the country he/she is representing" and that this is verified by checking the athlete's passport ${ }^{785}$ In this case, the term citizenship is used as a sort of sub-category to

\section{$780 \quad$ Ibid.}

781 Ibid.

782 Art. 4.1.1 World Takwondo Federation rules \& interpretation in force as of $11^{\text {th }}$ May 2015; Art. 4.1.1 World Taekwondo Federation rules \& interpretation in force as of $1^{\text {st }}$ J anuary 2015; Art 4.1.1 World Taekwondo Federation competition rules \& interpretation in force as of J uly 1 ${ }^{\mathrm{s}}$, 2014; Art. 4.1.1 World Taekwondo Federation rules $\&$ interpreation amended $14^{\text {th }}$ July, 2013; Art 4. 1.1 World Taekwondo Federation competition rules $\&$ interpretation in force as of December $26^{\text {th }}$, 2012; Art. 4. 1.1 World Taekwondo Federation competition rules $\&$ interpretation in force as of October $4^{\text {th }}, 2011$; Art. 4. 1.1 World Taekwondo Federation competition rules \& interpretation amended: October $7^{\text {th }}, 2010$.

Art. 4.1.3 World Taekwondo Federation rules \& interpretation in force as of $11^{\text {th }}$ May 2015; Art. 4.1.3 World Taekwondo Federation rules \& interpretation in force as of $1^{\text {st }}$ J anuary 2015; Art 4.1.3 World Taekwondo Federation competition rules $\&$ interpretation in force as of J uly $1^{\text {st }} 2014$; Art. 4.1.3 World Taekwondo Federation rules $\&$ interpretation amended $14^{\text {th }}$ July, 2013; Art 4. 1.3 World Taekwondo Federation competition rules $\&$ interpretation in force as of December $26^{\text {th }}$, 2012; Art. 4. 1.3 World Taekwondo Federation competition rules $\&$ interpretation in force as of October $4^{\text {th }}, 2011$; Art. 4. 1.3 World Taekwondo Federation competition rules $\&$ interpretation amended: October $7^{\text {th }}, 2010$.

Art. 4.1.4 World Taekwondo Federation rules $\&$ interpretation in force as of $11^{\text {th }}$ May 2015; Art. 4.1.4 World Taekwondo Federation rules \& interpretation in force as of $1^{\text {st }}$ January 2015; Art 4.1.4 World Tadkwondo Federation competition rules $\&$ interpretation in force as of J uly $1^{\mathrm{st}}, 2014$; Art. 4.1.4 World Taekwondo Federation rules \& interpretation amended $14^{\text {th }}$ July, 2013; Art 4. 1.4 World Taekwondo Federation competition rules $\&$ interpretation in force as of December $26^{\text {th }}$, 2012; Explanation 1 to Art 4.1.1. World Taekwondo Federation competition rules \& interpretation in force as of December 26 $6^{\text {th }}, 2012$; Art 4. 1.1 World Taekwondo Federation competition rules \& interpretation in force as of October $4^{\text {th }}, 2011$; Explanation 1 to Art. 4. 1.1 World Taekwondo Federation competition rules \& interpretation amended: October $7^{\text {th }}, 2010$.

785 Explanation 1 to Art. 4.1.1 World Tadkwondo Federation rules \& interpretation in force as of $11^{\text {th }}$ May 2015; Explanation 1 to Art. 4.1.1 World Taekwondo Federation rules \& interpretation in force 
nationality, as nationality can be determined based on citizenship according to the WTF. Regarding athletes with dual nationality, they need to decide which country they wish to represent and, since 2011, may only change their country of representation after a period of non-competition of three years. ${ }^{786}$ This period may be reduced or completely waived in case the respective national federations and the WTF agree on it. 787

There are no provisions on athletes who acquire another nationality without hol ding multiple nationalities at the same time One can thus deduce that this is not possible. Athletes who find themselves stateless and athletes faced with changes in the territory are also not mentioned in this article However, since 2013, the article explicitly states that it is not applicable to athletes younger than 16 years. ${ }^{788}$ Ergo, this article effectively only deals with athletes with dual or multiple nationality wishing to change their country of representation.

as of $1^{\text {st }}$ January 2015; Explanation 1 to Art. 4.1.1 World Taekwondo Federation competition rules $\&$ interpretation in force as of July $1^{\text {st }}, 2014$; Explanation 1 to Art 4.1.1 World Taekwondo Federation rules \& interpretation amended $14^{\text {th }} \mathrm{July}$, 2013; Explanation 1 to Art. 4.1.1. World Tadkwondo Federation competition rules \& interpretation in force as of December 26 $6^{\text {th }}, 2012$; Art. 4. 1.1 World Taekwondo Federation competition rules $\&$ interpretation in force as of October $4^{\text {th }}$, 2011.

Ibid.

Ibid.

Explanation 1 to Art. 4.1.1 World Taekwondo Federation rules $\&$ interpretation in force as of $11^{\text {th }}$ May 2015; Explanation 1 to Art. 4.1.1 World Tadkwondo Federation rules \& interpretation in force as of $1^{\text {st }}$ J anuary 2015; Explanation 1 to Art. 4.1.1 World Taekwondo Federation competition rules $\&$ interpretation in force as of $1^{\text {st }}$ July 2014; Explanation 1 to Art. 4.1.1 World Taekwondo Federation rules \& interpretation amended $14^{\text {th }}$ July 2013. 


\subsection{Wrestling ${ }^{789}$}

Wrestling dates back to the dassical times, when this sport was first popular in ancient Rome and Greece ${ }^{790}$ It became an Olympic Sport in 1896 with only the ancient Greco-Roman style being used. ${ }^{791}$ The freestyle wrestling events were added in 1904, but they were absent from the Olympics in $1912 .{ }^{792}$ It's goveming association, the United World Wrestling (UWW), known until September 2014 as the Fédération Internationale des Luttes Associées (FILA) was founded in 1905, but it al so ind uded weightlifting at that time ${ }^{793}$ Wrestling was shortly governed by the International Ring Verband between 1912 until 1953, when this association dhanged its nameto FILA. ${ }^{794}$ Nowadays, wrestling is divided into the categories of freestyle and Greco-Roman wrestling with seven weight divisions each for themen's events. ${ }^{795}$ Women have been competing in the discipline of wrestling since 2004 and are divided into four weight divisions in freestyle ${ }^{796}$ In the ancient Greco-Roman style, contestants may only use ther upper bodies and arms. ${ }^{797}$ Freestyle wrestling was only introduced in 1904 and allows contestants to also use their legs in the fight and grab their opponents both aboveand below the waist - although with limitations. ${ }^{798}$

TableXX: Overview of the eligibility requirements for wrestling

\begin{tabular}{|l|l|}
\hline R equirements UWW & \\
\hline In force since & January 2015 \\
\hline C hange of nationality & $\begin{array}{l}\text { Possi ble, although 24 month waiting period if } \\
\text { federations do not agree }\end{array}$ \\
\hline R esidence requirements & Holding a residence permit \\
\hline M inors and nationality change & Minors aretreated as full-fledged athl etes here \\
\hline Stateless athletes & $\begin{array}{l}\text { Pofition of athletes with multiple nationality } \\
\text { which the athlete is a national }\end{array}$ \\
\hline E ffect of changes in territory of country & $\begin{array}{l}\text { Inechanism i.e } 24 \text { month waiting period if } \\
\text { federations do not agree }\end{array}$ \\
\hline
\end{tabular}

789 The federation was contacted on $6^{\text {th }}$ August 2014 and asked to provide further insights into its eligi iility criteria and ol der versions of the eligibility rules and the FILA replied on $8^{\text {th }}$ September, stating that the rules only changed in 2012 and provided the previously applicable rules in the 2011 version. On $29^{\text {th }}$ October 2015 the federation was contacted again and asked for comments on this Chapter. As no reply was forthcoming, a first reminder was sent on $19^{\text {th }}$ November 2015 and a second on $2^{\text {nd }}$ December 2015, to which the federation replied on $8^{\text {th }}$ December 2015. IOC Information FILA; IOC Information Wrestling Greco-Roman Equipment and History; IOC Information Wrestling Freestyle Equipment and History.

791 IOC Information FILA; IOC Information Wrestling Greco-Roman Equi pment and History.

792 IOC Information FILA; IOC Information Wrestling Freestyle Equipment and History; IOC Reference Document Wrestling.

793 IOC Information FILA: for information on non-national athletes in the European national leagues and competitions see S. van den Bogaert, A. Cuyvers, S. Gardiner, R. Parrish, S. Miettinen, J. Soek and R. Siekmann (2010), p. 185. Ibid.

Ibid.

Ibid.

Ibid.

IOC Information FILA; IOC Information Wrestling Freestyle Equipment and History; IOC Information Wrestling Greco-Roman Equi pment and History. 


\begin{tabular}{|l|l|}
\hline Competing for the country of residence & Not possible \\
\hline Number of changes possible & Once \\
\hline & \\
\hline R efer ence to Olympic Charter & Yes \\
\hline Uses nationality/ citizenship & Nationality \& sport nationality \\
\hline Uses residence/ domicile & Residence (induding permit, if necessary) \\
\hline Other remarkable peculiarity & 'Sport nationality' that is entirely disconnected \\
& froman athl ete's nationality introduced; \\
& Administrative charge of CHF 5,000 payableto \\
& theFILA for a nationality change by thenew \\
& federation; appeals against decisions either \\
& impossibleor combined with high costs. \\
\hline
\end{tabular}

\subsubsection{Wrestling critical reflection}

Since January 2015, UWW has introduced a 'sport nationality' that may be disconnected from the actual nationality the athlete has. ${ }^{799}$ Overall, changes of a sporting nationality are possible but only once ${ }^{800}$ Athletes with dual nationality are initially free to choose for which country they wish to compete; afterwards the procedure to change to competefor another country is the same regard ess of whether the athlete is a dual national or not ${ }^{801}$ For this, the UWW requires the athl ete to be legally residing in the country and in possession of a work permit As residence is one of the indi cators of a connection with the country, this is aimed at reducing the mercenary tendencies. However, to what extent the UWW checks whether the official residence permit is actually used to reside in the relevant country is not known. Another problem arises with regard to dual nationals who do not need a work or residence permit for a country of which they are nationals and thus cannot show one to fulfil the requirements of the procedure Should the federation of origin not wish to let the respective athlete go to another one federation, the athl ete has to wait for 24 months, before the change becomes effective ${ }^{802}$ Overall, while the 'sport nationality' does not rely on the athlete's actual national ity, the reference to residence underlines that there still needs to be a genuine link between athlete and country of representation.

\subsubsection{Rules applicable since 2015}

The current rules for wresting are set down in the UWW international rules for the change of nationality approved by the Bureau on $13^{\text {th }}$ December 2015 which are almost identical to the those of $15^{\text {th }}$ January 2015 and deal with this topic in 14 very detailed articles. The only change which occurred is that the federations do not need to supply an athlete's old and new passports when requesting a change of sporting

\footnotetext{
799 Introduction UWW international rules for the change of nationality approved by the Bureau on $13^{\text {th }}$ December 2015.

800 Art. 6 UWW international rules for the change of nationality approved by the Bureau on $13^{\text {th }}$ December 2015.

801 Ibid.

802 Art. 7 UWW international rules for the change of nationality approved by the Bureau on $13^{\text {th }}$ December 2015.
} 
nationality. ${ }^{803}$ The UWW stresses that, for the Olympic Games, the IOC Charter applies ${ }^{804}$ The introduction the UWW stipulates that, in principle, athletes may only compete for a country of which he or she is a national. ${ }^{805}$ However, since January 2015, the UWW does all ow athletes to al so represent countries of which they are not nationals, provided that they have the 'sports nationality' of that country:

"The sports nationality is defined as the right granted to a wrestler by United World Wrestling to represent a country of which he/she does not necessarily hold thenationality." ${ }^{\prime 806}$

As proof of a sports nationality, the wrestler needs a license issued by United World Wrestling ${ }^{807}$ Athletes with dual nationality are freeto choose for which country they wish to compete ${ }^{808}$ Once chosen, the procedure to change the country of representation is the same regardless of whether the athlete is a dual national or not ${ }^{809}$ If any athlete wishes to compete for another country, he or she can changethe respective sporting nationality. ${ }^{810}$ In order to do so, the wrestler's federation needs to submit an official request between $1^{\mathrm{st}}$ and $31^{\mathrm{st}}$ December and a successful application will be effective as of $1^{\text {st }}$ January of the following year. ${ }^{811}$ This official request must contain:

"A) Official attestation by the left federation (signed by its president, on a letter with official header and seal) agreeing with the applicant's change of sports nationality;

Art. 4 UWW international rules for the change of nationality approved by the Bureau on $13^{\text {th }}$ December 2015.

Art. 2 UWW international rules for the change of nationality approved by the Bureau on $13^{\text {th }}$ December 2015; Art. 2 UWW international rules for the change of nationality approved by the Bureau on $15^{\text {th }}$ J anuary 2015. December 2015; Introduction UWW international rules for the change of national ity approved by the Bureau on $15^{\text {th }}$ J anuary 2015.

Introduction UWW international rules for the change of nationality approved by the Bureau on $13^{\text {th }}$ December, 2015; Introduction UWW international rules for the change of national ity approved by the Bureau on $15^{\text {th }}$ J anuary 2015.

Art. 1 UWW international rules for the change of nationality approved by the Bureau on $13^{\text {th }}$ December 2015; Art. 1 UWW international rules for the change of nationality approved by the Bureau on $15^{\text {th }}$ J anuary 2015.

Art. 6 UWW international rules for the change of nationality approved by the Bureau on $13^{\text {th }}$ December 2015; Art. 6 UWW international rules for the change of nationality approved by the Bureau on $15^{\text {th }}$ J anuary 2015.

Art. 6 UWW international rules for the change of nationality approved by the Bureau on $13^{\text {th }}$ December 2015; Art. 6 UWW international rules for the change of nationality approved by the Bureau on $15^{\text {th }}$ J anuary 2015.

810 Art. 1 UWW international rules for the change of nationality approved by the Bureau on $13^{\text {th }}$ December 2015; Art. 1 UWW international rules for the change of nationality approved by the Bureau on $15^{\text {th }}$ J anuary 2015.

811 Art. 4 UWW international rules for the change of nationality approved by the Bureau on $13^{\text {th }}$ December 2015; Art 4 UWW international rules for the change of nationality approved by the Bureau on $15^{\text {th }}$ January 2015.

812 Art. 4 a) UWW international rules for the change of nationality approved by the Bureau on $13^{\text {th }}$ December 2015; 4 a) UWW international rules for the change of nati onal ity approved by the Bureau on $15^{\text {th }}$ J anuary 2015. 
B) Official attestation by the host federation (signed by its president, on a letter with official header and seal) agreeing with the applicant's change of sports nationality; ${ }^{813}$

C) Copy of the wrestler's original passport (corresponding to the sports nationality waived by thewrestler);

D) Copy of wrestler's new passport or his/her country's official residence permit where the applicant lives and for which he/she applies for the sports nationality;

E) Copy of the country's official work permit where the applicant lives and for which helshe applies for thesports nationality; ${ }^{816}$

F) Proof of payment to United World Wrestling of the fee for the change of sports nationality set to 5.000 Swiss Francs ${ }^{817}$

G) A parental authorization for minors (under 18 years old). ${ }^{818}$

While this sporting nationality is not connected to the athlete's legal nationality, the FILA requires the athlete to be legally residing in the country and in possession of a work permit As residence is an indicator of a connection with the country, there seems to be less of a chance of mercenary tendencies. However, the question is to what extent the UWW checks whether the official residence permit is actual ly used to reside in the relevant country. Should the federation of origin not wish to let the respective athl ete go to another one, the athlete has to wait for 24 months before the change becomes effective ${ }^{819}$ During this time, the wrestler may in principle compete for the original federation. ${ }^{820}$

813 Art. 4 b) UWW international rules for the change of nationality approved by the Bureau on $13^{\text {th }}$ December, 2015; Art. 4 b) UWW international rules for the change of nationality approved by the Bureau on $15^{\text {th }}$ J anuary 2015. Art. 4 c) UWW international rules for the change of national ity approved by the Bureau on $13^{\text {th }}$ December 2015.

Art. 4 d) UWW international rules for the change of nationality approved by the Bureau on $13^{\text {th }}$ December 2015; Art 4 c) UWW international rules for the change of nationality approved by the Bureau on $15^{\text {th }}$ J anuary 2015.

Art. 4 e) UWW international rules for the change of nationality approved by the Bureau on $13^{\text {th }}$ December 2015; Art 4 d) UWW international rules for the change of nationality approved by the Bureau on $15^{\text {th }}$ J anuary 2015.

817 Art. $4 \mathrm{f}$ ) UWW international rul es for the change of nationality approved by the Bureau on $13^{\text {th }}$ December 2015; 4 e) UWW international rules for the change of national ity approved by the Bureau on $15^{\text {th }}$ J anuary 2015.

818 Art. 4 g) UWW international rules for the change of nationality approved by the Bureau on $13^{\text {th }}$ December 2015; Art $4 \mathrm{f}$ ) UWW international rules for the change of nationality approved by the Bureau on $15^{\text {th }}$ J anuary 2015.

Art. 7 UWW international rules for the change of nationality approved by the Bureau on $13^{\text {th }}$ December 2015; Art. 7 UWW international rules for the change of nationality approved by the Bureau on $15^{\text {th }}$ January 2015.

Art. 7 UWW international rules for the change of nationality approved by the Bureau on $13^{\text {th }}$ December 2015; Art 7 UWW international rules for the change of nationality approved by the Bureau on $15^{\text {th }}$ J anuary 2015. 
The monetary aspect is al so of utmost importance as United World Wrestling receives money for the nationality change ${ }^{821}$ and the federation of origin can ask up to 300,000 Swiss Francs for a gold medal ist athlete leaving their ranks. ${ }^{822}$ This underscores that pecuniary aspects are often at the forefront of national ity changes. These requirements are aimed at dissuading federations from reaping the benefits of another federations' training, yet, thericher federations will not beas dissuaded as qui ckly as the less welloff federations.

Such a change is only possible once during the wrestler's carer and per country only one change per year is admissible per age category. ${ }^{823} \mathrm{Y}$ et, no differentiation between adult and minor athletes is made regarding the maximum number of changes possible ${ }^{824}$ Changes cannot be revoked for any reason, yet there is the possibility for an annulment if the sports nationality was granted due to a deception. ${ }^{825}$ In case of disputes, the United World Wrestling's Secretary General can be called upon to decide ${ }^{826}$ An appeals procedure is possible against such a decision, ${ }^{827}$ although only within the first 21 days after the decision was made ${ }^{828}$

\subsubsection{Rules applicable since $2012-2015$}

Wrestling previous regulations on eligibility and nationality changes were set out in the International Regulations for the Change of Nationality - effective $3^{\text {rd }}$ August 2012. Several of theserules arestill applicabletoday:

- athletes shoul d in prina ple benational sof the country they represent: ${ }^{829}$

- dual national s may choose for which country they wish to compete, ${ }^{830}$

821 Art. 4 e) UWW international rules for the change of nationality approved by the Bureau on $13^{\text {th }}$ December 2015; Art 4 e) UWW international rules for the change of nationality approved by the Bureau on $15^{\text {th }}$ J anuary, 2015.

Art. 5 UWW international rules for the change of nationality approved by the Bureau on $13^{\text {th }}$ December 2015; Art 5 UWW international rules for the change of nationality approved by the Bureau on $15^{\text {th }}$ J anuary 2015.

Art. 1 and Art. 3 UWW international rules for the change of nationality approved by the Bureau on $13^{\text {th }}$ December 2015; Art. 1 and Art. 3 UWW international rules for the change of nationality approved by the Bureau on $15^{\text {th }}$ J anuary 2015 .

Art. 1 UWW international rules for the change of nationality approved by the Bureau on $13^{\text {th }}$ December 2015; Art. 1 UWW international rules for the change of nationality approved by the Bureau on $15^{\text {th }}$ January, 2015.

Art. 13 UWW international rules for the change of nationality approved by the Bureau on $13^{\text {th }}$ December, 2015; Art. 13 UWW international rules for the change of nationality approved by the Bureau on $15^{\text {th }}$ J anuary 2015.

Art. 8 UWW international rules for the change of nationality approved by the Bureau on $13^{\text {th }}$ December 2015; Art. 8 UWW international rules for the change of nationality approved by the Bureau on $15^{\text {th }}$ J anuary 2015.

Art. 10 UWW international rules for the change of nationality approved by the Bureau on $13^{\text {th }}$ December 2015; Art. 10 UWW international rules for the change of nationality approved by the Bureau on $15^{\text {th }}$ J anuary 2015.

Art. 12 UWW international rules for the change of nationality approved by the Bureau on $13^{\text {th }}$ December 2015; Art. 12 UWW international rules for the change of nationality approved by the Bureau on $15^{\text {th }}$ J anuary 2015.

829 General conditions (a) FILA international regulations for the change of nationality - effective $3^{\text {rd }}$ August 2012. 
- changing the country of representation is possible once ${ }^{831}$ under certain conditions; ${ }^{832}$

- Transfer window was between the $1^{\text {t }}$ and $31^{\star \star}$ of December of a given year; 833

- the procedureand the required documents are the same ${ }^{834}$

- copies of old and new passport;

- new contract;

- certificated from theinvol ved federations;

- Therewas al so a CHF 5,000 fe payable by the wrestlers' new federation for a national ity change ${ }^{835}$

- And a payment for the education or promotion of the wrestler becomes payable e36 $^{836}$

- "For Junior and Senior (but not for Cadet), the payment to the former Federation of the following training compensations, $10 \%$ thembeing paid to FILA:

- Olympic Gold Medal list or World Champion CHF 300'000.-

- Olympic or World Silver \& Bronze Medallist CHF 200'000.-

- Continental Gold Medallist CHF 100'000.-

- Continental Silver or BronzeMedallist and others CHF 50'000.-" 837

Previously, the FILA focussed explicitly on the manner of acquisition of the new nationality:

"A wrestler who has obtained a new national ity by naturalization may participate, for his/her new country, in all competitions entered in the FILA calendar (tournaments, championships, cups, games, etc.) only after having obtained his/her new nationality which shall be proved by a new passport and upon agreement by FILA within the period between 1 and 31 December. He/she shall be only eligible to participate in the above mentioned compeition the year following the request for the change of nationality. For Olympic Games qualifying tournaments and for the Olympic Games, the provisions of the

General conditions (b) FILA international regulations for the change of nationality - effective $3^{\text {rd }}$ August 2012.

General conditions (d) FILA international regulations for the change of nationality - effective $3^{\text {rd }}$ August 2012.

General conditions (d) FILA international regulations for the change of nationality - effective $3^{\text {rd }}$ August 2012.

General Conditions (d) FILA international regulations for the change of nationality - effective $3^{\text {rd }}$ August 2012; Art 1 FILA international regulations for the change of nationality - effective $3^{\text {rd }}$ August 2012; Annex FILA International regulations for the change of nationality - effective $3^{\text {rd }}$ August 2012.

Appendix (1) FILA international regulations for the change of nationality - effective $3^{\text {rd }}$ August 2012.

Art. 3 FILA international regulations for the change of nationality - effective $3^{\text {rd }}$ August 2012; A ppendix (5) International regulations for the change of national ity - effective $3^{\text {rd }}$ August 2012.

Art. 5 FILA international regulations for the change of nationality - effective $3^{\text {rd }}$ August 2012;

Appendix (6) International regulations for the change of national ity - effective $3^{\text {rd }}$ August 2012.

Appendix (6) FILA international regulations for the change of nationality - effective $3^{\text {rd }}$ August 2012. 
Olympic Charter are applied. A change of nationality is accepted only once by

FILA and thewrestler cannot retum to his/her previous nationality. ${ }^{\prime 838}$

This artide was applicable to wrestlers of all ages and all levels. ${ }^{839}$ Such a change is only possible once Furthermore, only an acquisition through naturalisation was accepted by the FILA. In the Annex to theseregulations, the procedure of a nationality change was explained. It induded a list of items the wrestler him or herself had to submit to the FILA, namely the copies of both the old and the new passport, the new contract with thenew federation and certificates from both federations invol ved. ${ }^{840}$

The other time requirement was a year of non-competition between the application and the first competition for the new country of representation. In addition to the conditions spelled out in the general conditions, Article 1 al so listed conditions under which a wrestler could not compete for another federation following a nationality change. These conditions related to the contract between athlete and federation, which may neither expire within six months or be terminated by mutual agreement or on a right ground. ${ }^{841}$

These prices al ready indicate that the more successful an athlete has al ready proven to be, the more expensive he or she will be for the new federation. This naturally made acquiring such a successful athlete slightly less alluring for federations. Moreover, the specification that any federation could only request the FILA to admit one athlete per style and per year who changed his or her nationality into its ranks limits the federation's possibilities. ${ }^{842}$ Also taking into consideration the fees payable for such a change, it becomes clear that federations were clearly to be discouraged from acquiring wrestlers from other countries into their ranks.

All these requirements and the procedures made it very difficult for wrestlers to change between federations, although admittedly, the waiting period of only one year was relatively easy to fulfil. Stateless athletes or athl etes faced with a changein the territory of their country were not explicitly mentioned, but under Article 13 the Executive Committee is given the power to settle any cases that do not fall within therules set down at the time ${ }^{843}$

\subsubsection{Rules applicable $2009-2012$}

Prior to the 2012 rule change, the FILA rules applicable were the FILA international regulations for the change of nationality, which werein force sinceMarch 2009.

Several aspects of theserules arestill applicable today such as:

838

839

General conditions (d) FILA international regulations for the change of nationality - effective $3^{\text {rd }}$ August 2012.

General conditions (d) FILA international regulations for the change of nationality - effective $3^{\text {rd }}$ August 2012.

Appendix (1), (2) and (3) FILA International regulations for the change of nationality - effective $3^{\text {rd }}$ August 2012.

Art. 1(a), (b) and (c) FILA international regulations for the change of nationality - effective $3^{\text {rd }}$ August 2012.

A ppendix FILA international regulations for the change of nationality - effective $3^{\text {rd }}$ August 2012. Art. 13 FILA international regulations for the change of nationality - effective $3^{\text {rd }}$ August 2012. 
- Only nationals of a country can compete for it in FILA compeitions; ${ }^{844}$

- Athletes with multiple nationality have to pick one and stay with their choice $^{845}$

- Only onechange of country of allegianceis admissible, ${ }^{846}$

- Thetransfer window between the $1^{\mathrm{a}}$ and $31^{\mathrm{s}}$ December of each yeer; ${ }^{847}$

- The procedure of changing a nationality requirements and the monetary and document requirements; 848

- An al lowance is charged to the new federation upon the change of an athl ete to which both federations had to agree ${ }^{849}$

The conditions for a change of country of representation were different firstly, the wrestler had to obtain a new national ity by naturalisation; ${ }^{850}$ secondly he or she had to prove this new nationality by holding a passport of the country; 851 and thirdly the wrestler had a period of non-competition of two years regarding Olympic Qualification Tournaments or Olympic Games, World Championships and World Cups, University Championships and Games, Military Championships and Games, Continental Championships and Games. ${ }^{852}$ Competing in other international toumaments was possibleif theathletehad thenecessary passport ${ }^{853}$

Incomplete applications were not taken into consideration. Such a transfer could thus be difficult due to the additional requirements, as it was not only the wrestler's contracts with the federation that were taken into consideration, ${ }^{854}$ and there was only a small transfer window between the $1^{\text {t }}$ and $31^{\text {tt }}$ December of each year. ${ }^{855}$ Consequently, even if an athlete had fulfilled the requirements of the two-year period, the change could only be truly made in December. Combined with the fees payable to both FILA and the federation of origin, the federations were effectively discouraged from transfers.

\footnotetext{
844 General conditions a) FILA international regulations for the change of nationality 2011.

845 General conditions b) FILA international regulations for the change of nationality 2011.

General conditions d) FILA international regulations for the change of nationality 2011.

Ibid.

848 Appendix I compul sory procedure to follow for the change of national ity to the FILA international regulations for the change of nationality.

849 Art. 3 and Art. 4 FILA international regulations for the change of nationality 2011.

850 General conditions d) FILA international regulations for the change of nationality 2011.

851 General conditions d) FILA international regulations for the change of nationality 2011; Appendix I compulsory procedure to follow for the change of nationality to the FILA international regulations for the change of nationality 2011.

Art. 1 FILA international regulations for the change of nationality 2011; Appendix I compul sory procedure to follow for the change of nationality to the FILA international regulations for the change of nationality 2011. 



\section{Team sports involving a ball}

In this section, team sports involving a ball will be examined. Football, basketball, handball, hockey, ice hockey, and rugby all have a similar playing fiedd setup of a goal, goal area or basket, which, in the cases of football, handball, hockey, and ice hockey is guarded by a player whose main responsibility is to prevent the other team from scoring. Volleyball is different in that respect, as no specifically marked goal area exists and physical contact between athletes is made impossible by the net which is situated between the two hal ves of the field. Icehockey is a particular case, sinceit is a sport at the winter Olympics, yet, it seems more logical to compare ice hockey to hockey than icehockey to bobsleigh or luge.

Football is the sport with the longest Olympic history, having started in 1900 and having been absent only in 1932. Women's football has however only been Olympic since 1996, which makes it one of the latest additions in this category. Hockey became Olympic in 1908 and ice hockey followed in 1924, with women's events being added in 1980 and 1998 respectively. Volleyball is a retatively new sport at the Olympics, as it becameOlympic in 1960 for both men and women and both beach voll eyball events were added in 1996. Rugby is the youngest sport in this category and will make its Olympic debut at the 2016 Rio Olympic Games.

TableXXI: Topics dealt with in Teamsports involving a ball

\begin{tabular}{|c|c|c|c|c|c|c|c|}
\hline $\begin{array}{l}\text { Requirem } \\
\text { ents }\end{array}$ & B asketball & Football & Handball & Hockey & $\begin{array}{l}\text { Ice } \\
\text { H ockey }\end{array}$ & Rugby & Volleyball \\
\hline $\begin{array}{l}\text { In force } \\
\text { since }\end{array}$ & 2010 & 2008 & 2011 & 2010 & 2014 & 2013 & 2015 \\
\hline $\begin{array}{l}\text { Versions } \\
\text { since } 2005\end{array}$ & Since 2010 & $\begin{array}{l}2005- \\
2007 \\
2007 \\
\text { Since 2008 }\end{array}$ & Since 2011 & Since 2011 & $\begin{array}{l}2003- \\
2012 \\
2012- \\
2014 \\
\text { Since 2014 }\end{array}$ & $\begin{array}{l}2013 \\
\text { Since } \\
\text { December } \\
2013\end{array}$ & $\begin{array}{l}2013- \\
2014 \\
\text { Since 2015 }\end{array}$ \\
\hline $\begin{array}{l}\text { substantial } \\
\text { changes } \\
\text { made } \\
\text { since } \\
\text { October } \\
2013\end{array}$ & $n / a$ & $n / a$ & $n / a$ & $\begin{array}{l}\text { No } \\
\text { residence } \\
\text { period } \\
\text { required } \\
\text { since 2012; } \\
\text { special } \\
\text { masters } \\
\text { category } \\
\text { introduced } \\
\text { in } 2015\end{array}$ & $\begin{array}{l}\text { Waiting } \\
\text { period } \\
\text { reduced; } \\
\text { differentiat } \\
\text { ion male } \\
\text { and femble } \\
\text { athletes }\end{array}$ & $\begin{array}{l}\text { Stricter, } \\
\text { even } \\
\text { minors } \\
\text { cannot } \\
\text { change } \\
\text { country of } \\
\text { representati } \\
\text { on now }\end{array}$ & $\begin{array}{l}\text { Differentiat } \\
\text { ion native } \\
\text { and } \\
\text { naturalised } \\
\text { athlete } \\
\text { introduced }\end{array}$ \\
\hline $\begin{array}{l}\text { C hange of } \\
\text { nationality }\end{array}$ & Possible & $\begin{array}{l}\text { Not } \\
\text { possible } \\
\text { after an 'A' } \\
\text { match, but } \\
\text { possible } \\
\text { before that }\end{array}$ & $\begin{array}{l}\text { Possible } \\
\text { onceafter } \\
\text { three years } \\
\text { of non- } \\
\text { competitio } \\
\mathrm{n}\end{array}$ & $\begin{array}{l}\text { Possible } \\
\text { with } \\
\text { permission } \\
\text { and three } \\
\text { year } \\
\text { waiting } \\
\text { period }\end{array}$ & $\begin{array}{l}\text { Possible, } \\
\text { although } \\
\text { different } \\
\text { rules } \\
\text { depending } \\
\text { on whether } \\
\text { the athlete } \\
\text { has } \\
\text { competed } \\
\text { before; if } \\
\text { so: four }\end{array}$ & $\begin{array}{l}\text { Not } \\
\text { possible }\end{array}$ & $\begin{array}{l}\text { Possible } \\
\text { once, after } \\
\text { two years } \\
\text { of } \\
\text { residence } \\
\& \text { non- } \\
\text { competitio } \\
n\end{array}$ \\
\hline
\end{tabular}




\begin{tabular}{|c|c|c|c|c|c|c|c|}
\hline & & & & & $\begin{array}{l}\text { years } \\
\text { waiting } \\
\text { period and } \\
\text { four years } \\
\text { competing } \\
\text { in national } \\
\text { league } \\
\text { necessary, } \\
\text { otherwise } \\
\text { just two } \\
\text { hockey } \\
\text { seasons }\end{array}$ & & \\
\hline $\begin{array}{l}\text { Residence } \\
\text { requireme } \\
\text { nts }\end{array}$ & $\begin{array}{l}\text { In case of } \\
\text { dependent } \\
\text { territories }\end{array}$ & $\begin{array}{l}\text { Five years } \\
\text { in casea } \\
\text { new } \\
\text { nationality } \\
\text { is acquired, } \\
\text { otherwise } \\
\text { two }\end{array}$ & $\begin{array}{l}24 \text { months } \\
\text { in case of } \\
\text { multiple } \\
\text { nationality }\end{array}$ & $\begin{array}{l}\text { Oneyear } \\
\text { for masters } \\
\text { players, } \\
\text { nonefor } \\
\text { the others }\end{array}$ & $\begin{array}{l}\text { Legal } \\
\text { residence, } \\
\text { duration } \\
\text { depends on } \\
\text { case }\end{array}$ & $\begin{array}{l}36 \\
\text { consecutiv } \\
\text { emonths } \\
\text { as a } \\
\text { perquisite } \\
\text { to compete } \\
\text { for national } \\
\text { team; } \\
\text { athletes } \\
\text { should stay } \\
10 \text { months } \\
\text { a year ina } \\
\text { country }\end{array}$ & Two years \\
\hline $\begin{array}{l}\text { Minors } \\
\text { and } \\
\text { nationality } \\
\text { change }\end{array}$ & $\begin{array}{l}\text { Under } 17 \\
\text { year olds } \\
\text { may } \\
\text { choose }\end{array}$ & $\begin{array}{l}\text { May } \\
\text { change } \\
\text { until they } \\
\text { competein } \\
\text { their first } \\
\text { 'A' match }\end{array}$ & $\begin{array}{l}\text { Not } \\
\text { specified }\end{array}$ & $\begin{array}{l}\text { May } \\
\text { choose } \\
\text { prior to } \\
\text { becoming } \\
\text { senior } \\
\text { athletes, } \\
\text { meaning } \\
\text { competing } \\
\text { on senior } \\
\text { leve }\end{array}$ & $\begin{array}{l}\text { Not } \\
\text { mentioned, } \\
\text { but living } \\
\text { in the } \\
\text { country } \\
\text { since } 12^{\text {th }} \\
\text { birthday } \\
\text { important }\end{array}$ & $\begin{array}{l}\text { Minors } \\
\text { cannot } \\
\text { change } \\
\text { their } \\
\text { country of } \\
\text { representati } \\
\text { on }\end{array}$ & $\begin{array}{l}\text { Not } \\
\text { specified }\end{array}$ \\
\hline $\begin{array}{l}\text { Stateless } \\
\text { athletes }\end{array}$ & $\begin{array}{l}\text { Stateless } \\
\text { persons or } \\
\text { asylum } \\
\text { seekers } \\
\text { dealt with } \\
\text { on a case- } \\
\text { by-case } \\
\text { basis, } \\
\text { special } \\
\text { FIBA } \\
\text { nationality } \\
\text { possible }\end{array}$ & $\begin{array}{l}\text { May ask } \\
\text { permission } \\
\text { to compete } \\
\text { for another } \\
\text { federation, } \\
\text { if he or she } \\
\text { was not at } \\
\text { fault for } \\
\text { becoming } \\
\text { stateless }\end{array}$ & $\begin{array}{l}\text { Not } \\
\text { specified }\end{array}$ & $\begin{array}{l}\text { Not } \\
\text { specified }\end{array}$ & $\begin{array}{l}\text { Not } \\
\text { specified }\end{array}$ & $\begin{array}{l}\text { Not } \\
\text { specified }\end{array}$ & $\begin{array}{l}\text { Not } \\
\text { specified }\end{array}$ \\
\hline $\begin{array}{l}\text { Position of } \\
\text { athletes } \\
\text { with } \\
\text { multiple } \\
\text { nationality } \\
\text { after } \\
\text { having } \\
\text { competed } \\
\text { for } \\
\text { another } \\
\text { country of } \\
\text { which the } \\
\text { athlete is a }\end{array}$ & $\begin{array}{l}\text { Haveto } \\
\text { decide } \\
\text { onceand } \\
\text { can only } \\
\text { decide } \\
\text { again } \\
\text { under } \\
\text { special } \\
\text { circumstan } \\
\text { ces }\end{array}$ & $\begin{array}{l}\text { Only } \\
\text { possible } \\
\text { prior to } \\
\text { first 'A' } \\
\text { match, and: } \\
\text { hewas } \\
\text { bom on the } \\
\text { teritory of } \\
\text { the relevant } \\
\text { Associatio } \\
\text { n; or his } \\
\text { biological } \\
\text { mother or }\end{array}$ & $\begin{array}{l}\text { The athlete } \\
\text { was bom in } \\
\text { the } \\
\text { teritory of } \\
\text { the } \\
\text { federation } \\
\text { concemed } \\
\text { or his } \\
\text { biologica } \\
\text { mother or } \\
\text { biol ogical } \\
\text { father were } \\
\text { bom in the }\end{array}$ & $\begin{array}{l}\text { Three-year } \\
\text { waiting } \\
\text { period } \\
\text { needed }\end{array}$ & $\begin{array}{l}\text { Four-year } \\
\text { non- } \\
\text { internation } \\
\text { a } \\
\text { competitio } \\
\text { n period } \\
\text { whilefour } \\
\text { years spent } \\
\text { competitio } \\
\text { n on } \\
\text { national } \\
\text { level }\end{array}$ & $\begin{array}{l}\text { Nationality } \\
\text { change not } \\
\text { possible }\end{array}$ & $\begin{array}{l}\text { Considered } \\
\text { a } \\
\text { naturalised } \\
\text { athlete, per } \\
\text { team there } \\
\text { may be } \\
\text { only one; } \\
\text { Possible } \\
\text { after two- } \\
\text { year } \\
\text { residence } \\
\text { and two- } \\
\text { year }\end{array}$ \\
\hline
\end{tabular}


TEAM SPORTS INVOLVING A BALL

\begin{tabular}{|c|c|c|c|c|c|c|c|}
\hline national & & $\begin{array}{l}\text { biological } \\
\text { father was } \\
\text { bom on the } \\
\text { teritory of } \\
\text { therelevant } \\
\text { Associatio } \\
\mathrm{n} \text {; or his } \\
\text { grandmoth } \\
\text { er or } \\
\text { grandfather } \\
\text { was bom } \\
\text { on the } \\
\text { teritory of } \\
\text { the relevant } \\
\text { Associatio } \\
\text { n; or he has } \\
\text { lived } \\
\text { continuousl } \\
\text { y on the } \\
\text { teritory of } \\
\text { the relevant } \\
\text { Associatio } \\
\text { nfor at } \\
\text { least two } \\
\text { years }\end{array}$ & $\begin{array}{l}\text { teritory of } \\
\text { the } \\
\text { federation } \\
\text { concermed } \\
\text { or hehas } \\
\text { been living } \\
\text { in the } \\
\text { teritory of } \\
\text { the } \\
\text { federation } \\
\text { concermed } \\
\text { for more } \\
\text { than } 24 \\
\text { monthsin } \\
\text { any period } \\
\text { of his life }\end{array}$ & & & & $\begin{array}{l}\text { waiting } \\
\text { period }\end{array}$ \\
\hline $\begin{array}{l}\text { E ffect of } \\
\text { changes in } \\
\text { territory } \\
\text { of country }\end{array}$ & $\begin{array}{l}\text { Not } \\
\text { specified }\end{array}$ & $\begin{array}{l}\text { Not } \\
\text { specified }\end{array}$ & $\begin{array}{l}\text { Not } \\
\text { specified }\end{array}$ & $\begin{array}{l}\text { Choose } \\
\text { which } \\
\text { entity they } \\
\text { wish to } \\
\text { represent, } \\
\text { but only } \\
\text { once; the } \\
\text { three-year } \\
\text { period does } \\
\text { not apply }\end{array}$ & $\begin{array}{l}\text { Not } \\
\text { specified }\end{array}$ & $\begin{array}{l}\text { Not } \\
\text { specified }\end{array}$ & $\begin{array}{l}\text { Not } \\
\text { specified }\end{array}$ \\
\hline $\begin{array}{l}\text { Competin } \\
\mathrm{g} \text { for the } \\
\text { country of } \\
\text { residence }\end{array}$ & $\begin{array}{l}\text { Not } \\
\text { possible }\end{array}$ & $\begin{array}{l}\text { Not } \\
\text { possible }\end{array}$ & $\begin{array}{l}\text { Not } \\
\text { possible }\end{array}$ & $\begin{array}{l}\text { Possible } \\
\text { for masters } \\
\text { players or } \\
\text { of athlete } \\
\text { has a } \\
\text { passport } \\
\text { fromthe } \\
\text { country of } \\
\text { residence } \\
\text { and has not } \\
\text { competed } \\
\text { for another } \\
\text { country }\end{array}$ & $\begin{array}{l}\text { Not } \\
\text { possible }\end{array}$ & $\begin{array}{l}\text { Possible, if } \\
36 \text { months } \\
\text { of } \\
\text { consecutiv } \\
\text { eresidence }\end{array}$ & $\begin{array}{l}\text { Possible } \\
\text { after } 8 \\
\text { years of } \\
\text { residence }\end{array}$ \\
\hline $\begin{array}{l}\text { Number of } \\
\text { changes } \\
\text { possible }\end{array}$ & $\begin{array}{l}\text { Once, } \\
\text { unless } \\
\text { special } \\
\text { interest of } \\
\text { basketball } \\
\text { is at stake }\end{array}$ & $\begin{array}{l}\text { None after } \\
\text { competing } \\
\text { in A match }\end{array}$ & Once & $\begin{array}{l}\text { No } \\
\text { maximum } \\
\text { given }\end{array}$ & $\begin{array}{l}\text { No } \\
\text { maximum } \\
\text { given }\end{array}$ & None & Once \\
\hline $\begin{array}{l}\text { R eference } \\
\text { to } \\
\text { Olympic } \\
\text { Charter }\end{array}$ & None & None & None & Yes & $\begin{array}{l}\text { Complianc } \\
\text { eexplicitly } \\
\text { mentioned }\end{array}$ & $\begin{array}{l}\text { Yes, } \\
\text { reference } \\
\text { to IOC } \\
\text { rules for } \\
\text { Olympic } \\
\text { Games }\end{array}$ & None \\
\hline
\end{tabular}


NATIONALITY REQUiREMENTS In OLy MPIC SPORTS

\begin{tabular}{|c|c|c|c|c|c|c|c|}
\hline $\begin{array}{l}\text { Uses } \\
\text { nationality } \\
\text { / } \\
\text { citizenship }\end{array}$ & $\begin{array}{l}\text { Legal } \\
\text { nationality }\end{array}$ & $\begin{array}{l}\text { 'Permanent } \\
\text { nationality }\end{array}$ & Nationality & Both & $\begin{array}{l}\text { Mostly } \\
\text { citizen and } \\
\text { citizenship, } \\
\text { but also } \\
\text { nationality } \\
\text { and } \\
\text { national } \\
\text { eligibility }\end{array}$ & $\begin{array}{l}\text { Nationality } \\
\text { and rugby } \\
\text { nationality }\end{array}$ & citizenship \\
\hline $\begin{array}{l}\text { Uses } \\
\text { residence/ } \\
\text { domicile }\end{array}$ & $\begin{array}{l}\text { Permanent } \\
\text { Residency } \\
\text { and 'living } \\
\text { ina } \\
\text { country' }\end{array}$ & Residence & Residence & Both & Residence & $\begin{array}{l}\text { Residence, } \\
\text { meaning } \\
\text { primary } \\
\text { and } \\
\text { permanent } \\
\text { home }\end{array}$ & Residence \\
\hline $\begin{array}{l}\text { Other } \\
\text { remarka- } \\
\text { ble } \\
\text { peculiarity }\end{array}$ & $\begin{array}{l}\text { 'significant } \\
\text { link' } \\
\text { mentioned; } \\
\text { adopted } \\
\text { children } \\
\text { placed at a } \\
\text { great } \\
\text { disadvanta } \\
\text { gefor } \\
\text { dependent } \\
\text { teritories }\end{array}$ & $\begin{array}{l}\text { Difficult } \\
\text { position of } \\
\text { adopted } \\
\text { athletes; } \\
\text { use of } \\
\text { 'permanent } \\
\text { nationality' }\end{array}$ & $\begin{array}{l}\text { Reference } \\
\text { to asylum } \\
\text { sedkers and } \\
\text { refugees }\end{array}$ & $\begin{array}{l}\text { special } \\
\text { masters } \\
\text { category }\end{array}$ & $\begin{array}{l}\text { Differentiat } \\
\text { ion } \\
\text { between } \\
\text { maleand } \\
\text { femde } \\
\text { athletes, } \\
\text { with } \\
\text { female } \\
\text { athletes } \\
\text { having to } \\
\text { fulfil less } \\
\text { citeria }\end{array}$ & $\begin{array}{l}\text { ‘genuine, } \\
\text { close, } \\
\text { credible } \\
\text { and } \\
\text { established } \\
\text { link' } \\
\text { explicitly } \\
\text { mentioned }\end{array}$ & $\begin{array}{l}\text { Definitions } \\
\text { of native, } \\
\text { naturdised } \\
\text { players and } \\
\text { citizenship } \\
\text { provided; } \\
\text { native } \\
\text { athlete= } \\
\text { nationality } \\
\text { acquired } \\
\text { prior to } \\
\text { sporting } \\
\text { debut }\end{array}$ \\
\hline
\end{tabular}




\subsection{Basketball 856}

Basketball is one of the newer sports, being invented only in $1891 .{ }^{857}$ Its goveming association, the Intemational Basketball Federation (FIBA), was founded in 1932 and has its seat in Mies, Switzerland. ${ }^{858}$ Basketball becamean Olympic Sport in 1936, with a women's event coming 40 years later in $1976 .{ }^{859}$ There are 12 women's and 12 men's teams competing in four periods of ten minutes. ${ }^{860}$ Most notably, also professional players areall lowed to participatein theOlympics. ${ }^{861}$

TableXXII: Overview of the eligibility requirements for basketball

\begin{tabular}{|l|l|}
\hline Requirements FIBA & \\
\hline In force since & $3^{\text {rd }}$ September 2010 \\
\hline C hange of nationality & Possi ble \\
\hline R esidence requirements & In case of dependent teritories \\
\hline M inors and nationality change & Under 17 year olds may chose \\
\hline Stateless athletes & $\begin{array}{l}\text { Stateless persons or asylumsedkers dealt with on a } \\
\text { case by-case basis, special FIBA national ity } \\
\text { possible }\end{array}$ \\
\hline $\begin{array}{l}\text { Position of athletes with multiple nationalities } \\
\text { after having competed for another country of } \\
\text { which the athlete is a national }\end{array}$ & $\begin{array}{l}\text { Haveto decide onceand can only decideagain } \\
\text { under special circumstances }\end{array}$ \\
\hline E ffect of changes in territory of country & Not specified \\
\hline Competing for the country of residence & Not possible \\
\hline Number of changes possible & $\begin{array}{l}\text { Once, unless special interest of basketball is at } \\
\text { stake }\end{array}$ \\
\hline R efer ence to Olympic C harter & None \\
\hline Uses nationality/ citizenship & Legal nationality \\
\hline Uses residence/ domicile & Permanent Residency and 'living in a country' \\
\hline Other remarkable peculiarity & $\begin{array}{l}\text { 'Significant link' mentioned; adopted children } \\
\text { placed at great disadvantagefor dependent } \\
\text { territories }\end{array}$ \\
\hline
\end{tabular}

\subsubsection{Basketball critical reflection}

Basketball has had the samerules set out by the FIBA since 2010. Athletes need to be nationals of the country they represent ${ }^{862}$ Those who are nationals of more than one country may decide for which country they wish to competeand athl etes under 21 may redecide until their $21^{\text {st }}$ birthday. ${ }^{863}$ However, if the athlete is asked to compete for an

856 The federation was contacted on $6^{\text {th }}$ August 2014 and asked to provide further insights into its eligibility criteria and ol der versions of the eligibility rules. The FIBA replied on $19^{\text {th }}$ August. On $29^{\text {th }}$ October 2015, the federation was contacted again and asked for comments on this chapter to which the FIBA replied on $16^{\text {th }}$ November 2015, supplying the previously applicable rules and commenting on the chapter on $19^{\text {th }}$ February 2016.

857 IOC Information Basketball Equipment and History.

858 IOC Reference Document Basketball.

859 IOC Information FIBA; IOC Reference Document Basketball.

860 IOC Information FIBA.

861 Ibid.

862 Art. 13, Art. 14 and Art. 15 book 3 chapter I FIBA rul e book 2014 - 2019.

${ }^{863}$ Art. 16 and Art. 20 book 3 chapter I FIBA rule book 2014 - 2019. 
adult team after their $18^{\text {th }}$ birthday and accepts the summons, this choice is irrevocable ${ }^{864}$ The FIBA also provides rules for players who are from dependent territories and can decide on a caseby-case basis in special circumstances ${ }^{865}$ The same hol ds true for stateless athletes or those seeking asylum ${ }^{866}$ An interesting aspect is that residence only comes into play for athletes living in dependent teritories. ${ }^{867}$ The overall FIBA rules arerather strict as a change of country of representation is only possibleonce

\subsubsection{Rules applicablesince 2004}

The current eligibility rules for basketball are set down in Book 3 of the FIBA Rule Book 2014 - 2019 approved by the FIBA Central Board on 27 August 2014, which are identical to the FIBA Rule Book 2010 - 2014. The FIBA Internal Regulations of 2004, 2006 and 2009 also closely resemble the later ones, with only some artides added or amended over time Most notably, in 2004 the FIBA provided a list of definitions and principles prior to delving into the topic of nationality laws. ${ }^{868}$ Moreover, while nowadays age is the important factor, in 2004 and 2006, FIBA focussed especially on athletes having competed in U-19 and U-21 toumaments ${ }^{89}$ and, since 2006, al so U-17 events. ${ }^{870}$ Thenewly introduced rules are the foll lowing:

\section{Since 2006:}

- Athletes from dependent teritories are deal t with. ${ }^{871}$

Since 2009:

- Exceptions given to youth player transfers, al lowing them to choose again for which country they wish to compete, ${ }^{872}$

- Focus on $17^{\text {th }}$ birthday for distinction between athletes who may re decide for which country to competeand those who may do so under special circumstances; ${ }^{873}$

- Elaboration on athletes from dependent teritories, also requiring them to have the legal nationality. ${ }^{874}$

Since 2010:

- Introduction of limits for the constellation of national teams, allowing only one athleteper team who acqui red a legal nationality after theage of $16^{875}$

Art. 17 and Art. 19 book 3 chapter I FIBA rule book 2014 - 2019.

Art. 34 book 3 chapter I FIBA rule book 2014 - 2019.

Ibid.

Art. 26 book 3 chapter I FIBA rule book 2014 - 2019.

Art. 3.1 Book 3 Regulations governing the National Status of Players - FIBA Internal Regulations 2004.

Art. 3.3.4 Book 3 Regulations governing the National Status of Players - FIBA Internal Regulations 2004.

870 H 2.3.4 FIBA Internal Regulations 2006.

871 H 2.3.7 FIBA Internal Regulations 2006.

872 H.2.3.2.1 and H.2.3.2.5 FIBA Internal Regulations 2009.

873 H.2.3.4 and H.2.3.5 FIBA Internal Regulations 2009.

$874 \quad$ H.2.3.7.1 and H.2.3.7.2 FIBA Internal Regulations 2009.

875 Art. 21 book 3 chapter I FIBA rule book 2014 - 2019; Art. 21 book 3 chapter I FIBA rule book 2010 - 2014.
} 
Since the early, versions the underlying principles have been the respect for fair play and submission to medical tests and respect for anti-doping rules. ${ }^{876}$ Afterwards, the general principles regarding the national status of players are listed, stating that the FIBA rules apply at all levels and to both genders. ${ }^{877}$ In order to be eligible to play for a national teem - in addition to the compliance to the aforementioned general rules, the athlete must have the legal national ity of the country concemed and must be able to provehis or her nationality by submitting an appropriate document at the request of theFIBA. ${ }^{878}$

With regard to the position of athletes with two or more legal nationalities, the FIBA does not explicitly differentiate between athletes who have acquired two national ities at birth, those who have done so by naturalisation or athletes who had the right to acquire another nationality at birth, but only claimed that right until later. ${ }^{879}$ They all may choose at any point in time for which country they want to compete, yet they need to provide a written declaration to the FIBA. ${ }^{880}$ There are however exceptions to that rule, namely players who transferred between federations as youth players, for reasons linked to basketball (as opposed to family relocations or educational moves) may only decide to play for another country than the country from which they transferred after their $21^{\text {st }}$ birthday. ${ }^{881}$

If such an athlete with multiple nationality is summoned to compete for a national team, it is important how old he or she is at that time. If the age is still under 17, he or she may decide later on to compete for the other country of which he or she is a national - in case the two federations can agree ${ }^{882}$ If the call for the national team comes after the $18^{\text {th }}$ birthday, the athlete can either decline or accept the country's summons. ${ }^{883}$ Such an acceptance is irrevocable ${ }^{884}$ If he or she dedines

Art. 3(a), (b) and (c) book 3 chapter I FIBA rule book 2014 - 2019; Art. 3(a),(b) and (c) book 3 chapter I FIBA rule book 2010 - 2014.

Art. 10 and Art. 11 book 3 chapter I FIBA rule book 2014 - 2019; Art. 10 and 11 book 3 chapter I FIBA rule book 2010 - 2014; H.2.1.1 and H.2.1.2 FIBA Internal Regulations 2009; H.2.1.1 and H.2.1.2 FIBA Internal Regulations 2006; Art.3.1.1 and Art. 3.1.2 Book 3 Regulations governing the National Status of Players - FIBA Internal Regulations 2004.

Art. 13, Art. 14 and Art. 15 book 3 chapter I FIBA rule book 2014 - 2019; Art. 13, Art. 14 and Art. 15 book 3 chapter I FIBA rule book 2010 - 2014; H.2.2.1, H.2.2.2 and H.2.3.1 FIBA Internal Regulations 2009; H.2.2.1, H.2.2.2 and H.2.3.1 FIBA Internal Regulations 2006; Art. 3.2.1, Art. 3.2.2 and Art. 3.3.1 Book 3 Regulations governing the National Status of Players - FIBA Internal Regulations 2004.

879 Art. 16 book 3 chapter I FIBA rule book 2014 - 2019; Art. 16 book 3 chapter I FIBA rule book 2010 - 2014; H.2.3.2 FIBA Internal Regulations 2009; H.2.3.2 FIBA Internal Regulations 2006; Art. 3.3.2 Book 3 Regulations governing the National Status of Players - FIBA Internal Regulations 2004. Ibid.

881 Art. 20 book 3 chapter I FIBA rule book 2014 - 2019; Art. 20 book 3 chapter I FIBA rule book $2010-2014$. Art. 22 book 3 chapter I FIBA rule book 2014 - 2019; Art. 22 book 3 chapter I FIBA rule book $2010-2014$.

Art. 17 book 3 chapter I FIBA rule book 2014 - 2019; Art. 17 book 3 chapter I FIBA rule book 2010 - 2014; H.2.3.2 FIBA Internal Regulations 2009; H.2.3.2 FIBA Internal Regulations 2006; Art. 3.3.2 Book 3 Regulations governing the National Status of Players - FIBA Internal Regulations 2004. 
the summons, he or she has to choose the country of which he or she is a national, but from which the athlete has not received a summons yet ${ }^{885}$ The only option is to declare in writing that he or she is actually choosing to compete for the country which summoned him or her first within 15 days of receiving the second request ${ }^{886}$ Either decision is also in principle irrevocable ${ }^{887}$ There is however a notable exception: if a player may not return to his country of origin but wishes to do so, the FIBA Secretary General may al low this change if it is considered to be in theinterest of the development of and after the payment of a fee $e^{888}$

A decision to the effect of the country of representation is al so deemed to have been made in case the athlete competes for one of the countries of which he or she is a national. ${ }^{889}$ Again this choice is generally deemed to be irrevocable ${ }^{890}$ There are two exceptions; firstly the FIBA's Secretary General may allow this after the payment of a fee if it is in the interest of basketball in the player's country of origin. ${ }^{891}$ Secondly, if a player wishes to change to another member federation of which he or she is a national, the new federation has to request a written declaration from the old federation that the player has never competed for it on FIBA level. ${ }^{892}$ If

Art. 19 and Art. 17 book 3 chapter I FIBA rule book 2014 - 2019; Art. 19 and Art 17 book 3 chapter I FIBA rule book 2010 - 2014; H.2.3.2 FIBA Internal Regulations 2009; H.2.3.2 FIBA Internal Regulations 2006; Art. 3.3.2 Book 3 Regulations governing the National Status of Players - FIBA Internal Regulations 2004.

Art. 17 book 3 chapter I FIBA rule book 2014 - 2019; Art. 17 book 3 chapter I FIBA rule book 2010 - 2014; H.2.3.2 FIBA Internal Regulations 2009; H.2.3.2 FIBA Internal Regulations 2006; Art. 3.3.2 Book 3 Regulations governing the National Status of Players - FIBA Internal Regulations 2004.

Art. 17 book 3 chapter I FIBA rule book 2014 - 2019; Art. 17 book 3 chapter I FIBA rule book 2010 - 2014; H.2.3.2 FIBA Internal Regulations 2009; H.2.3.2 FIBA Internal Regulations 2006; Art. 3.3.2 Book 3 Regulations governing the National Status of Players - FIBA Internal Regulations 2004.

Art. 19 book 3 chapter I FIBA rule book 2014 - 2019; Art. 19 book 3 chapter I FIBA rule book 2010 - 2014; H.2.3.2.4 FIBA Internal Regulations 2009; H.2.3.2.4 FIBA Internal Regulations 2006; Art 3.3.2 Book 3 Regulations governing the National Status of Players - FIBA Internal Regulations 2004.

Art. 23 book 3 chapter I FIBA rule book 2014 - 2019; Art. 23 book 3 chapter I FIBA rule book 2010 - 2014; H.2.3.4 FIBA Internal Regulations 2009 according to FIBA E-mail of 19 ${ }^{\text {th }}$ February, 2016 the fee does not apply automatically or in all cases, though it may at times be used as a deterent for federations to request a change.

Art. 18 book 3 chapter I FIBA rule book 2014 - 2019; Art. 18 book 3 chapter I FIBA rule book 2010 - 2014; H.2.3.2.3 FIBA Internal Regulations 2009; H.2.3.2.3.4 FIBA Internal Regulations 2006; Art 3.3.2 Book 3 Regulations governing the National Status of Players - FIBA Internal Regulations 2004.

Art. 19 book 3 chapter I FIBA rule book 2014 - 2019; Art. 19 book 3 chapter I FIBA rule book 2010 - 2014; H.2.3.2.4 FIBA Internal Regulations 2009; H.2.3.2 FIBA Internal Regulations 2006; Art. 3.3.2.4 Book 3 Regulations governing the National Status of Players - FIBA Internal Regulations 2004.

Art. 23 book 3 chapter I FIBA rule book 2014 - 2019; Art. 23 book 3 chapter I FIBA rule book 2010 - 2014; H.2.3.4 FIBA Internal Regulations 2009.

892 Art. 24 book 3 chapter I FIBA rule book 2014 - 2019; Art. 24 book 3 chapter I FIBA rule book 2010 - 2014; H.2.3.6 FIBA Internal Regulations 2009; H.2.3.6 FIBA Internal Regulations 2006; Art. 3.3.6 Book 3 Regulations governing the National Status of Players - FIBA Internal Regulations 2004. 
such a declaration is not forthcoming, the FIBA may issue a provisional authorisation, which will become final and irrevocable after one year. ${ }^{893}$

In addition, the FIBA prohibits teams form having more than one player who acquired the nationality of the team after the age of 16 by any means, even if he or she had the right to the nationality at birth, but did not claim it until later. ${ }^{894}$ If an athletehas claimed thenationality before his 16th birthday, but fails to provide proof of this, the FIBA Secretary General may decide that the athlete falls within the restriction. ${ }^{895}$ The Secretary General will base his judgment on the foll lowing ariteria:

"- The number of years during which the player has lived in the country, for the national team of which hewishes to play;

- The number of seasons during which the player has participated in domestic competitions in the country of the national team for which he wishes to play;

- Any other criteria capable of establishing a significant link between the player and thecountry, for thenational team of which he wishes to play." ${ }^{\prime 896}$

This provision is interesting sincea 'significant link' between a player and the country of representation is to be established, which is a direct reference to the 'genuine link' concept employed in nationality law. Furthermore, the number of years during which the athlete has been living in the country is taken into consideration - although the FIBA neither specifies what constitutes 'living in a country' for their purposes nor how a year is counted, eg. by cal endar year or otherwise

Coming to another special case, the FIBA al so provides rules for the players who are from dependent territories. These are territories which are their own entities, yet they are still dependent on the main teritory or mainland. To athletes who have the main territory's nationality but wish to compete for one of those dependent territories the foll owing applies that they:

"a. Have been bom in the dependent territory; or

b. Have

i. been born in the main teritory of at least one parent who was born in the dependent teritory; or

ii. been born of parents both of whom were born in the dependent teritory, regardl ess of the place of birth of the player; or

iii. at least one grandparent born in the dependent teritory, regardless of the place of birth of the player." 897

\footnotetext{
893 Ibid.

894 Art. 21(a) book 3 chapter I FIBA rule book 2014 - 2019; Art. 21(a) book 3 chapter I FIBA rule book 2010 - 2014.

895 Art. 21(b) book 3 chapter I FIBA rule book 2014 - 2019; Art. 21(b) book 3 chapter I FIBA rule book 2010 - 2014.

896 Ibid.

897 Art. 26 book 3 chapter I FIBA rule book 2014 - 2019; Art. 26 book 3 chapter I FIBA rule book 2010 - 2014; H.2.3.7.1 FIBA Internal Regulations 2009.
} 
These provisions aim at establishing a real link between the athl ete and the dependant territory. This artide refers to 'being born of parent', which would meen that only biological parents are taken into consideration. Hence, adopted children would be placed at a significant disadvantage. Additionally, if an athlete cannot satisfy these birthplace requirements, Artide 27 stipulates that players acquiring the nationality of the main teritory through naturalisation, and can prove a minimum of four years of permanent residence in the dependent teritory, may also compete for the dependent territory. ${ }^{898}$ This does not however help the adopted athletes, since he or she will not have acquired the nationality through naturalisation but at the moment of adoption. Also the definition of permanent residence is not given and the rules thus remain undear.

According to FIBA's email the issue of adopted athletes is taken on a case by case basis. Should an athlete be adopted by someone from a dependent teritory, the FIBA will carefully examine the link the athlete has established with the dependent territory, either by living there, having placed basketball there or - if the language deviated from the language spoken on the main land - whether he or she has mastered the language specific to the dependent territory. 899

In the case of stateless athletes or those seeking asylum, the Secretary General will decide on a case-by-case basis. ${ }^{900}$ Even a special FIBA nationality may be granted to players under specific circumstances. ${ }^{901}$ Although the FIBA does not deal explicitly with athletes whose dependent teritories become independent countries, the Secretary General has the possi bi lity to decide on marginal cases. ${ }^{902}$ Hence, these cases are al so to some extent covered by the FIBA rules.

Art. 27 book 3 chapter I FIBA rule book 2014 - 2019; Art. 27 book 3 chapter I FIBA rule book $2010-2014$.

899 FIBA E-mail of $19^{\text {th }}$ February, 2016.

900 Art. 34 book 3 chapter I FIBA rule book 2014 - 2019; Art. 34 book 3 chapter I FIBA rule book 2010 - 2014; H.2.7 FIBA Internal Regulations 2009; H.2.7 FIBA Internal Regulations 2006; Art. 3.7 Book 3 Regulations governing the National Status of Players - FIBA Internal Regulations 2004. 


\subsection{Football ${ }^{903}$}

In football, or as it is known in the US 'soccer', the main aim is to place the ball in the opponent team's goal through the use of al most any limbs except the hands of the field players. On the fiedd, there are usually 22 players, 11 per team which indudeten field players and one goal keeper who is the only player allowed to touch the ball with his or her hands. In addition, more sophisticated rules like ' offside' and the ensuing use of the 'offside trap' are applied, resulting in not only a referee on the field but al so two referees al ong the side lines necessary. In the course of a 90 minute game- plus extra time- there is a compul sory break of 15 minutes after the first half of 45 minutes and the coach of each side has the chance to substitute three players with fresh ones from the bench during the game ${ }^{904}$ Football's status as an Olympic sport is somewhat difficult to ascertain, since there was allegedly a football game in 1896, although football was not really a recognised sport at that time ${ }^{905}$ The first official Olympic appearance came in 1900 for men's football and in 1996 for women's football. ${ }^{906}$ Internationally, football is regulated by the Fédération Internationale de Football Association (FIFA) which was founded in 1904 and has its seat in Zürich, Switzerland. ${ }^{907}$ Interestingly professional football players are allowed for the men's Olympic teams, yet the majority of the players has to be under 23 years of age ${ }^{908}$ For women thereareno such restrictions. ${ }^{909}$

TableXXIII: Overview of the eligibility requirements for football

\begin{tabular}{|l|l|}
\hline R equirements FIFA & 2008 \\
\hline In force since & $\begin{array}{l}\text { Not possible after an 'A' match, but possi ble } \\
\text { beforethat }\end{array}$ \\
\hline C hange of nationality & $\begin{array}{l}\text { Fiveyears in case a new nationality is acquired, } \\
\text { otherwise two }\end{array}$ \\
\hline R esidence requirements & $\begin{array}{l}\text { May change until they competein their first ' } A \text { ' } \\
\text { match }\end{array}$ \\
\hline M inors and nationality change & $\begin{array}{l}\text { May ask permission to competefor other } \\
\text { federation, if he or shewas not at fault for } \\
\text { becoming stateless }\end{array}$ \\
\hline Stateless athletes & $\begin{array}{l}\text { Only possible prior to first 'A' match, and: he was } \\
\text { born on the territory of therelevant Association; or } \\
\text { his biological mother or biological father was born } \\
\text { on theterritory of therelevant Association; or his }\end{array}$ \\
\hline $\begin{array}{l}\text { Position of athletes with multiple nationality } \\
\text { after having competed for another country of } \\
\text { which the athlete is a national }\end{array}$
\end{tabular}

The federation was contacted on $6^{\text {th }}$ August 2014 and asked to provide further insights into its eligi bility criteria and older versions of the eligibility rules. The FIFA replied on $11^{\text {th }}$ August 2014 and kindly provided all old rule books. On $29^{\text {th }}$ October 2015 the federation was contacted again and asked for comments on this chapter as no reply was forthcoming a first reminder was sent on $19^{\text {th }}$ November 2015 to which the federation replied on $30^{\text {th }}$ November. FIFA laws of the Game 2011/2012.

905 B. Mallon \& T. Widlund (1998), p. 118.

906 IOC Information FIFA; IOC Information Football Equipment and History; IOC Reference Document Football.

907 IOC Information FIFA; IOC Reference Document Football.

908 IOC Information FIFA.

909 IOC Information FIFA. 


\begin{tabular}{|l|l|}
\hline & $\begin{array}{l}\text { grandmother or grandfather was born on the } \\
\text { territory of the relevant Association; or he has } \\
\text { lived continuously on theteritory of the relevant } \\
\text { Association for at least two years }\end{array}$ \\
\hline E ffect of changes in territory of country & Not specified \\
\hline Competing for the country of residence & Not possible \\
\hline Number of changes possible & Noneafter competing in A match \\
\hline & \\
\hline R eference to Olympic Charter & None \\
\hline Uses nationality/ citizenship & 'Permanent' nationality \\
\hline Uses residence/ domicile & residence \\
\hline O ther remarkable peculiarity & $\begin{array}{l}\text { Difficult position of adopted athletes; use of } \\
\text { 'permanent nationality' }\end{array}$ \\
\hline
\end{tabular}

\subsubsection{Football critical reflection}

The FIFA eligibility criteria have not changed substantially since 2008. Athletes have to be nationals of the country they represent. ${ }^{910}$ Athletes with multiple national ity need to fulfil additional criteria if they wish to choose one particular country. ${ }^{911}$ Here the fact that bi ol ogical parents or grandparents are mentioned is problematic, as this places adopted children at a great disadvantage Changing the country of representation is difficult and only possible before the athlete has competed in the first ' $A$ ' match for a national side, meaning the country's main national team ${ }^{912}$ The only exception arises if a government authority deprives the athl ete of his nationality. Then the athl ete may ask permission of the FIFA to become eligible for another association, provided that he has (acquired) the respective nationality. ${ }^{913}$ Overall, these rules are strict and - as they di sadvantage adopted athl etes - al so di scriminatory.

\subsubsection{Rules applicable since 2008}

Themain rules deal ing with player eligi bility can befound in theFIFA statutes and the regulations governing the application of the statutes, subpart 'eligibility to play for respective teams'. Looking at the changes over time, one notices that since 2008 only one substantive change was made - prior to 2009. According to Article 18 (1) - now Article 8 (1), athletes could ask for a change of country of representation once prior to their $21^{\text {s }}$ birthday. ${ }^{914}$ Since 2009, the reference to the athlete's birthday and the resulting limitation have been left out ${ }^{915}$ Another change has been made to the layout in 2011, changing thenumbering on the rules, resulting in Article 15 becoming Artide

910

Art. 5(1) FIFA statutes: regulations governing the appl ication of the statutes 2016.

Art. 6(1) FIFA statutes: regulations governing the application of the statutes 2016.

Art. 5(2) FIFA statutes: regulations governing the application of the statutes 2016.

Art. 8(2) FIFA statutes: regulations governing the application of the statutes 2016.

Art. 18 (1) FIFA statutes: regulations governing the application of the statutes 2008.

Art. 8(1) FIFA statutes: regulations governing the application of the statutes 2016; Art 8(1) FIFA statutes: regulations governing the application of the statutes 2014; Art 8(1) FIFA statutes: regulations governing the application of the statutes 2013; Art. 8(1) FIFA statutes: regulations governing the application of the statutes 2012; Art. 8(1) FIFA statutes: regulations governing the application of the statutes 2011; Art. 18(1) FIFA statutes: regulations governing the application of the statutes 2010; Art. 18(1) FIFA statutes: regulations governing the application of the statutes 2009. 
5; Artide 16 becoming Artide 6, Artide 17 turning to Article 7 and Artide 18 to Article 8 . Since the wording of these artides has remained identical, they will be examined as one, with the in-text reference made to the currently applicable artide numbers.

Starting with the FIFA rules for the World Cup 2014, Article 8 on the eligibility of the players stipulates in Paragraph 1 sub a that the players need to be of the nationality of the country they are called up for and are furthermore eligible for selection as spelled out by the FIFA statutes. ${ }^{916}$ These in turn specify under Article 5 (1) of the Regulations Governing the Application of the Statutes A pril 2016 that:

"Any person holding a permanent nationality that is not dependent on residence in a certain Country is eligible to play for the representative teams of the Association of that Country."

It is important to underscore the qual ification added to the athlete's national ity, namely that is needs to be permanent and not dependant on a residence requirement ${ }^{918}$ In case a player has multiple nationalities, the athlete needs to fulfil one of the additional requirements under Artide6(1) to be eligible to play for one of the associations:

“a) Hewas born on the teritory of therelevant Association;

b) His biological mother or biological father was born on the territory of the relevant Association;

c) His grandmother or grandfather was born on the teritory of the relevant Association;

d) He has lived continuously on the teritory of the relevant Association for at least two years."

However, there is an exception to Artide 6(1), which provides the possibility for associations that share one nationality to either waive Artide 6(1)(d) or to amend it with regard to the residence time that is required. ${ }^{920}$ In the aforementioned case of

916 FIFA regulations 2014 World Cup Brazil.

Art. 5(1) FIFA statutes: regulations governing the application of the statutes 2016; Art 5(1) FIFA statutes: regulations governing the application of the statutes 2014; Art. 5(1) FIFA statutes: regulations governing the application of the statutes 2013; Art. 5(1) FIFA statutes: regulations governing the application of the statutes 2012 Art. 5(1) FIFA statutes: regulations governing the application of the statutes 2011; Art. 15(1) FIFA statutes: regulations governing the application of the statutes 2010; Art. 15(1) FIFA statutes: regulations governing the application of the statutes 2009; Art. 15(1) FIFA statutes: regulations governing the application of the statutes 2008. See Chapter 3.4 on the permanent character of nationality.

919 Art. 6(1) FIFA statutes: regulations governing the application of the statutes 2016; Art 6(1) FIFA statutes: regulations governing the application of the statutes 2014; Art. 6(1) FIFA statutes: regulations governing the application of the statutes 2013; Art. 6(1) FIFA statutes: regulations governing the application of the statutes 2012; Art. 6(1) FIFA statutes: regulations governing the application of the statutes 2011; Art. 16(1) FIFA statutes: regulations governing the application of the statutes 2010; Art. 16(1) FIFA statutes: regulations governing the application of the statutes 2009; Art. 16(1) FIFA statutes: regulations governing the application of the statutes 2008. 
Argentinian Camoranesi, who could rely on acquiring Italian nationality ius sanguinis in thepaternal line due to his Italian grandfather, was able to be eligi ble for playing for Italy. ${ }^{921}$

Tuming to the question of whether it is possible to change an athlete's nationality, under Article 5 (2), Regulations Governing the Application of the Statutes it is in principle not possible for an athlete to change his or her association after having participated in an " $A$ " international match for one association. ${ }^{922}$ This means that international matches for the national U-18 or U-21 are not taken into consideration if an athlete wishes to change the country of representation. Given that an athlete fulfils the requirements of Article 5, there are further prerequisites stipulated in Article 7, namely:

a) Hewas bom on the teritory of therelevant Association; 923

b) His biological mother or biological father was bom on the territory of the relevant Association; 924

c) His grandmother or grandfather was born on the territory of the relevant Association; ${ }^{925}$

d) Hehas lived continuously for at least five years after reaching the age of 18 on theteritory of therevant Association. ${ }^{926}$

appl ication of the statutes 2011; Art. 16(2) FIFA statutes: regulations governing the appl ication of the statutes 2010; Art. 16(2) FIFA statutes: regulations governing the application of the statutes 2009; Art. 16(2) FIFA statutes: regulations governing the application of the statutes 2008.

Since under Italian law (legge n. 91 of 5.12.1992) there is no limit to the generations for the acquisition of nationality.

Art. 5(2) FIFA statutes: regulations governing the application of the statutes 2016; Art 5(2) FIFA statutes: regulations governing the application of the statutes 2014; Art. 5(2) FIFA statutes: regulations governing the application of the statutes 2013; Art. 5(2) FIFA statutes: regulations governing the application of the statutes 2012; Art. 5(2) FIFA statutes: regulations governing the appl ication of the statutes 2011; Art. 15(2) FIFA statutes: regulations governing the application of the statutes 2010; Art. 15(2) FIFA statutes: regulations governing the application of the statutes 2009; Art. 15(2) FIFA statutes: regulations governing the application of the statutes 2008.

Art. 7(a) FIFA statutes: regulations governing the application of the statutes 2016; Art 7(a) FIFA statutes: regulations governing the application of the statutes 2014; Art. 7(a) FIFA statutes: regulations governing the application of the statutes 2013; Art 7(a) FIFA statutes: regulations governing the application of the statutes 2012; Art 7(a) FIFA statutes: regulations governing the application of the statutes 2011; Art. 17(a) FIFA statutes: regulations governing the application of the statutes 2010; Art. 17(a) FIFA statutes: regulations governing the application of the statutes 2009; Art. 17(a) FIFA statutes: regulations governing the application of the statutes 2008.

Art. 7(b) FIFA statutes: regulations governing the application of the statutes 2016; Art. 7(b) FIFA statutes: regulations governing the application of the statutes 2014; Art. 1(b) FIFA statutes: regulations governing the application of the statutes 2013; Art. 7(b) FIFA statutes: regulations governing the application of the statutes 2012; Art. 7(b) FIFA statutes: regulations governing the application of the statutes 2011; Art. 17(b) FIFA statutes: regulations governing the application of the statutes 2010; Art 17(b) FIFA statutes: regulations governing the application of the statutes 2009; Art. 17(b) FIFA statutes: regulations governing the appl ication of the statutes 2008.

Art. 7(c) FIFA statutes: regulations governing the application of the statutes 2016; Art 7(c) FIFA statutes: regulations governing the application of the statutes 2014; Art. 7(c) FIFA statutes: regulations governing the application of the statutes 2013; Art 7(c) FIFA statutes: regulations governing the application of the statutes 2012; Art 7(c) FIFA statutes: regulations governing the application of the statutes 2011; Art. 17(c) FIFA statutes: regulations governing the application of the statutes 2010; Art. 17(c) FIFA statutes: regulations governing the application of the statutes 2009; Art. 17(c) FIFA statutes: regulations governing theapplication of the statutes 2008. 
In this case, the biggest difference between making use of another nationality and acquiring a new one is that, for the former, only two years of residence are required, while five are necessary for the latter and only the years after reaching the age of majority are counted. Additionally, a waiver of the requirement under sub d) is not possiblein the case of a change of nationality. However, it will be possibleto fulfil the residence requirement of five years only after the athl ete reached the age of majority. This means that a naturalised player who cannot rely on either Article 7(b) or (c) has a waiting period of five years prior to the first possibleintemational competition.

In addition to changing the nationality, a player needs to change the association of which he is a member as stipulated in Article 8(1) of the Regulations Governing the Application of the Statutes 2016. However, such a change is possible only once, if he has not played for another Association an " $A$ " international match and al ready has the nationality of his new association prior to being first fielded in an intemational competition. ${ }^{927}$ The athlete cannot play for a new association in a competition in which he or she al ready represented another Association. ${ }^{928}$ Hence, in case an athlete at the age of 18 changes association and wants to compete at the U21 level after having participated in this competition for his old Association, he is not eligible.

An exception to this strict rule is provided in the next paragraph, which deals with cases of permanent loss of nationality against the will of the athlete If a government authority deprives the athlete of his nationality, he may ask permission of the FIFA to become eligible for another association, provided that he has (acquired) the respectivenationality. ${ }^{929}$

Art. 7(d) FIFA statutes: regulations governing the application of the statutes 2016; Art 7(d) FIFA statutes: regulations governing the application of the statutes 2014; Art. 7(d) FIFA statutes: regulations governing the application of the statutes 2013; Art. 7(d) FIFA statutes: regulations governing the application of the statutes 2012; Art. 7(d) FIFA statutes: regulations governing the application of the statutes 2011; Art. 17(d) FIFA statutes: regulations governing the application of the statutes 2010; Art. 17(d) FIFA statutes: regulations governing the application of the statutes 2009; Art. 17(d) FIFA statutes: regulations governing the application of the statutes 2008.

Art. 8(1a) FIFA statutes: regulations governing the application of the statutes 2016; Art. 8(1a) FIFA statutes: regulations governing the application of the statutes 2015; Art. 8(1a) FIFA statutes: regulations governing the application of the statutes 2014; Art. 8(1a) FIFA statutes: regulations governing the application of the statutes 2013; Art 8(1a) FIFA statutes: regulations governing the application of the statutes 2012; Art 8(1a) FIFA statutes: regulations governing the application of the statutes 2011;Art 18(1a) FIFA statutes: regulations governing the application of the statutes 2009; Art. 18(1a) FIFA statutes: regulations governing the application of the statutes 2010; Art. 8(1a) FIFA statutes: regulations governing the application of the statutes 2009; Art 18(1a) FIFA statutes: regulations governing the application of the statutes 2008.

Art. 8(1b) FIFA statutes: regulations governing the application of the statutes 2016; Art 8(1b) FIFA statutes: regulations governing the application of the statutes 2014; Art. 8(1b) FIFA statutes: regulations governing the application of the statutes 2013; Art 8(1b) FIFA statutes: regulations governing the application of the statutes 2012; Art. 8(1b) FIFA statutes: regulations governing the application of the statutes 2011; Art 18(1b) FIFA statutes: regulations governi ng the application of the statutes 2010; Art. 18(1b) FIFA statutes: regulations governing the application of the statutes 2009; Art. 18(1b) FIFA statutes: regulations governing the application of the statutes 2008. 


\subsubsection{Rules applicable 2007}

Prior to the 2008 changes, there was only oneartidein the FIFA Statutes: Regulations Governing the Application of the Statutes 2007 in section 'VII. Eligibility top for association teams'. Some of today's core rules wereal ready in placethen:

- Athletes have to benationals of thecountry they represented; 930

- Athletes in principle cannot dhange their country of al legiance after having represented onecountry in an official match; ${ }^{931}$

- Athletes with dual or multiple nationality may change their country of representation once, ${ }^{932}$

- Such a change is only possibleif s/hehas not competed in an 'A' match; ${ }^{933}$

- Athl etes who losetheir nationality may compete for another country of which they have becomenationals; ${ }^{934}$

- The FIFA Executive's Committee deals with these issues on a case by-case basis. $^{935}$

Contrary to modem rules, there was focus on the athlete's $21^{\text {t }}$ birthday as a threshold for changing the country of representation.

\subsubsection{Rules applicable 2005 - 2007}

Tuming to the FIFA Statutes: Regulations Governing the Application of the Statute 2005, subpart VII. Eligibility to play for Association Teems, one finds that they have littlein common with the current rules. The underlying principleis that:

- Athletes should only compete for the country of which they arenationals, ${ }^{936}$

- After competing in an ' $A$ ' match, an athlete may in principle not change the country of representation; 937

- Spedial rules apply to those athletes who havemore than one national ity. ${ }^{938}$

The content of these special rules however largely differs from what they are today: these days, Artide 15 focussed even more on the $21^{\text {st }}$ birthday provision:

“(a) Up to his 21st birthday, a player may only once request dhanging the Association for which he is eligible to play international matches. A Player may exercise this right to change Associations only if he has not played at " $\mathrm{A}$ " international level for his current Association and if at the time of his first full or

appl ication of the statutes 2011; Art. 18(2) FIFA statutes: regulations governing the application of the statutes 2010; Art. 18(2) FIFA statutes: regulations governing the application of the statutes

2009; Art. 18(2) FIFA statutes: regulations governing the application of the statutes 2008.

Art. 15(1) FIFA statutes: regulations governing the application of the statutes 2007.

Art. 15(2) FIFA statutes: regulations governing the application of the statutes 2007.

Art. 15(3) FIFA statutes: regulations governing the application of the statutes 2007.

Art. 15(3)(a) FIFA statutes: regulations governing the application of the statutes 2007.

Art. 15(4) FIFA statutes: regulations governing the application of the statutes 2007.

Art. 15(1) FIFA statutes: regulations governing the application of the statutes 2007.

Art. 15(1) FIFA statutes: regulations governing the application of the statutes 2005.

Art. 15(2) FIFA statutes: regulations governing the application of the statutes 2005.

Art. 15(3) FIFA statutes: regulations governing the application of the statutes 2005. 
partial appeerance in an international match in an official competition of any other category, he al ready had such nationalities. Changing Associations is not permitted during the preliminary competition of a FIFA competition, continental championship or Olympic Tournaments if a player has already been fielded in a match of one of thesecompetitions.

(b) Any Player who has already acquired eligibility to play for one Association but has another nationality imposed upon him by a government authority, is al so entitled to changeassociations. This provision is not subject to any age limits." ${ }^{\prime 939}$

Thus, the FIFA basically distinguished between athletes who were forced to have another nationality - notably, this is exactly opposed to the wording of the later version, wherethe rules deal with deprivation of nationality - who could at any time changethe country of representation and those actively seeking to changetheir country of representation. ${ }^{940}$ The latter may do so once until their $21^{\text {ts }}$ birthday and only if they have not yet competed for another country in an ' $A$ ' match. The focus on the $21^{\text {st }}$ birthday sems arbitrary. Contrarily, the conditions that the athlete may not have competed in a fully-fledged match and should not be all owed to change the country of representation during a tournament or the qualification for a tournament is entirely reasonable

The FIFA further stipulated that all athletes, to whom the aforementioned possibilities to change the country of representation did not apply, could ask the Executive Committee to decide on their eligibility on a case-by-case basis. ${ }^{941}$ Thus, while in principle changes were not allowed, athlete specific circumstances were taken into consideration.

The athlete's $21^{\text {st }}$ birthday was relevant for another provision as well:

"Any Players who have already had their 21st birthday at the time of implementation of these provisions and who fulfil the requirements in par. 3 (a) areal so entitled to submit such a request to changeAssociations. This entitlement will expire definitivel y twe vemonths after implementation of this provision. ${ }^{\prime \prime 42}$

This not only underlines that these provisions were new and thus a transition period was needed, but it al so shows the focus on a specific age- which is absent in the later versions. At that time, the principle rule was that only those who were nationals of a country could represent that country at a football tournament and that as a general rule no changes were permitted oncean athl etehad participated in any official competition for one country. ${ }^{943}$ This meant that also participation in any youth match counted, making it impossi bl eto changethe country of representation at any time

Art. 15(3)(a) and (b) FIFA statutes: regulations governing the application of the statutes 2005.

Art. 15(3)(b) FIFA statutes: regulations governing the application of the statutes 2005.

Art. 15(1) FIFA statutes: regulations governing the application of the statutes 2005.

Art. 15(5) FIFA statutes: regulations governing the application of the statutes 2005.

Art. 15(1) and 15(2) FIFA statutes: regulations governing the application of the statutes 2005. 


\subsection{Handball ${ }^{944}$}

At the Olympic Games only indoor handball has been played continuously since 1972 by men and since 1976 by women. ${ }^{945}$ In handball teams of seven players - either men or women since mixed teams cannot compete - try to throw a ball in the goal of the opposing team Circumferenceand weight of the ball depends on the gender - for men it is 58 to $60 \mathrm{~cm}$ and 425 to $475 \mathrm{grams}$ and for women 54 to $56 \mathrm{~cm}$ and 325 to 400 grams respectively. The goal is shaped like $\mathrm{D}$ and is situated on the shorter side of the 40 times 20 m court $^{946}$ At international level handball is regulated by the International Handbal I Federation (IHF) founded in 1946 with its Headquarters in Base, Switzerland. ${ }^{947}$

TableXXIV Overview of the eligibility requirements for handball

\begin{tabular}{|c|c|}
\hline Requirements IHF & \\
\hline In force since & $1^{\mathrm{s}}$ July 2011 \\
\hline C hange of nationality & Possi ble once after threeyears of non-competition \\
\hline R esidence requirements & 24 months in case of multiplenationality \\
\hline M inors and nationality change & Not specified \\
\hline Stateless athletes & Not specified \\
\hline $\begin{array}{l}\text { Position of athletes with multiple nationality } \\
\text { after having competed for another country of } \\
\text { which the athlete is a national }\end{array}$ & $\begin{array}{l}\text { The athlete was born in the territory of the } \\
\text { federation concerned or his biol ogical mother or } \\
\text { biological father were born in theterritory of the } \\
\text { federation concerned or he has been living in the } \\
\text { territory of the federation concerned for more than } \\
24 \text { months in any period of his life }\end{array}$ \\
\hline E ffect of changes in territory of country & Not specified \\
\hline Competing for the country of residence & Not possible \\
\hline Number of changes possible & Once \\
\hline R eference to Olympic C harter & None \\
\hline Uses nationality/ citizenship & Nationality \\
\hline Uses residence/ domicile & residence \\
\hline Other remarkable peculiarity & Reference to asylum seekers and refugees \\
\hline
\end{tabular}

\subsubsection{Handbal a critical reflection}

The IHF eligibility criteria stipulate that athletes are to be citizens of the country they represent internationally. ${ }^{948}$ In case of multiple nationality, the player has to fulfil additional requi rements to beable to choose to represent one of the countries, i.e place of birth, place of birth of the biological parent or residence of over 24 months ${ }^{949}$ Here, the reference to biological parents is problematic, as adopted children have a great

944 The federation was contacted on $6^{\text {th }}$ August 2014 and asked to provide further insights into its eligibility criteria and older versions of the eligibility rules. As no reply was forthcoming a reminder email was sent on $18^{\text {th }}$ September. On $29^{\text {th }}$ October 2015 the IHF was contacted again and asked for comments on this chapter, which the IHF provided on $30^{\text {th }}$ October 2015. IOC Information on Handball equipment and History; IOC Reference Document Handball .

946 IOC Information on Handball equipment and History.

947 IOC Information IHF; IOC Reference Document Handball.

948 Art. 6.1 a) Player eligi bility code of the International Handball Federation (IHF) of $8^{\text {th }}$ J uly 2014. 
disadvantage in that case Changing the country of representation is possible onceafter a period of three years of non-competing for another national team ${ }^{950}$ Nevertheless, should the national federation dissolve or otherwise circumstances change drastically, thelHF will deel with theresulting problems on a case by-case basis. ${ }^{951}$

Overall, the IHF seems rather strict, since nationality changes are only possible once and a player wishing to compete for another country has to prove a real connection to that country. However, the residence requirement, which is the only one attainable later in life, is rather liberal, since the player has to have lived in the territory of the country for more than 24 months at any time in his or her life. The statutes do not stipul ate that these 24 months have to be uninterrupted, so even more flexibility may be possible In addition, the possibility to decide on a case-by-case basis how to deal with the dissolution of a country and its federation gives the IHF more leeway to address all kinds of circumstances.

\subsubsection{Rules applicable since 2011}

Tuming to the question of nationality requirements, one first has to note that all handball players are subject to the Player Eligibility Code of the International Handball Federation (IHF). ${ }^{952}$ The IHF stipulates that players participating in the Olympics may not make use of illegal substances or lent themselves for advertising purposes during that time ${ }^{953}$ In principle, players can compete for a country of which they are citizens. ${ }^{954}$ In case of multiple nationality, the player has to fulfil additional requirements to be abl eto choose to represent one of the countries:

“a) hewas bom in the territory of thefederation concerned or

b) his biological mother or biological father were born in the territory of the federation concemed or

c) he has been living in the territory of the federation concemed for more than 24 months in any period of his life"

It is thus not possible to compete for a national team if the player has no substantial connection to the relevant country. Changes are in principle admissible under Artide 6.3 Player Eligibility Code of the International Handball Federation (IHF) of $1^{\text {t }}$ July 2011. However, this is only possible onceand only after a period of threyears of noncompetition. ${ }^{956}$ Thus, the IHF is very strict with regard to nationality changes. In case

Art. 6.1 b) Player eligibility code of the International Handball Federation (IHF) of $8^{\text {th }}$ July 2014. Art. 6.3 Player eligibility code of the International Handball Federation (IHF) of $8^{\text {th }} \mathrm{July} 2014$.

Art. 1 Player eligi bility code of the International Handball Federation (IHF) of $8^{\text {th }}$ July 2014; Art 1 Player eligibility code of the International Handball Federation (IHF) of $1^{\text {st }}$ J uly 2011.

Art. 8 Player eligibility code of the International Handball Federation (IHF) of $8^{\text {th }}$ July 2014; Art. 8 Player eligibility code of the International Handball Federation (IHF) of $1^{\text {st } J ~ u l y ~} 2011$.

Art. 6.1 a) Player eligibility code of the International Handball Federation (IHF) of $8^{\text {th }}$ July 2014; Art. 6.1 a) Player eligibility code of the International Handball Federation (IHF) of $1^{\text {st }}$ July 2011. Art. 6.2 Player eligibility code of the International Handball Federation (IHF) of $8^{\text {th }}$ July 2014; Art. 6.2 Player eligibility code of the International Handball Federation (IHF) of $1^{\text {st }}$ July 2011.

Art. 6.1 b) Player eligibility code of the International Handball Federation (IHF) of $8^{\text {th }}$ July 2014; Art. 6.1 b) Player eligibility code of the International Handball Federation (IHF) of $1^{\text {st }}$ J uly 2011. 
NATIONALITY REQUIREMENTS IN OLYMPIC SPORTS

an existing federation dissolves for whatever changes in the setup of the respective country of representation, the IHF will solve arising problems on a case-by-case basis. ${ }^{957}$

The position of stateless athletes is not elaborated upon, but the IHF makes clear references to refugees and asylum seekers.

957 Art. 6.2 Player eligibility code of the International Handball Federation (IHF) of $8^{\text {th }}$ July 2014; Art. 6.3 Player eligibility code of the International Handball Federation (IHF) of $1^{\text {st }}$ July 2011. 


\subsection{Hockey 958}

Hockey is one of the ol dest games involving a ball and sticks, since it allegedly was al ready played in 2000 BC. It has been an Olympic sport since 1908, although it was notably not included in the 1912 and 1924 Olympiads. ${ }^{959}$ Nowadays, a hockey teem consists of 18 players of whom a maximum of 11 players are on the pitch and aim to bring the hard plastic ball in the goal of the opposing team The ball has a circumference of $230 \mathrm{~mm}$ and is usually white and the sticks used by the players are Jshaped to enable them to better hit and ster the ball. ${ }^{960}$ Hockey is regulated by the International Hockey Federation (FIH) founded in 1924 which has its seat in Lausanne, Switzerland. ${ }^{961}$

TableXXV: Overview of the ligibility requirements for hockey

\begin{tabular}{|c|c|}
\hline Requirements FIH & \\
\hline In force since & $13^{\text {th }}$ November 2010 \\
\hline C hange of nationality & $\begin{array}{l}\text { Possible with permission and three-year waiting } \\
\text { period }\end{array}$ \\
\hline R esidence requirements & One year for masters players, none for the others \\
\hline M inors and nationality change & $\begin{array}{l}\text { May choose prior to becoming senior athletes, } \\
\text { meaning competing on a seni or level }\end{array}$ \\
\hline Stateless athletes & Not specified \\
\hline $\begin{array}{l}\text { Position of athletes with multiple nationality } \\
\text { after having competed for another country of } \\
\text { which the athlete is a national }\end{array}$ & Threeyear waiting period needed \\
\hline E ffect of changes in territory of country & $\begin{array}{l}\text { Choose whi ch entity they wish to represent, but } \\
\text { only once; the threeyear period does not apply }\end{array}$ \\
\hline Competing for the country of residence & $\begin{array}{l}\text { Possi ble for masters players or of athlete has a } \\
\text { passport from the country of residence and has not } \\
\text { competed for another country }\end{array}$ \\
\hline Number of changes possible & No maximumgiven \\
\hline R eference to O lympic C harter & Yes \\
\hline Uses nationality/ citizenship & Both \\
\hline Uses residence/ domicile & Both \\
\hline Other remarkable peculiarity & Special masters category \\
\hline
\end{tabular}

\subsubsection{Hockey critical reflection}

In its eligibility rules, theFIH pays considerableattention to details, eg. differentiating between junior, senior and masters athletes. ${ }^{962}$ In principle, athletes need to be

958 The federation was contacted on $6^{\text {th }}$ August 2014 and asked to provide further insights into its eligi bility criteria and older versions of the eligibility rules. The IHF replied on $7^{\text {th }}$ August 2014. On $29^{\text {th }}$ October, 2015 the federation was contacted again and asked for comments on this chapter to which the federation replied on $29^{\text {th }}$ October 2015. IOC Information FIH; IOC Reference Document Hockey.

960 IOC Information on Hockey Equipment and History.

961 IOC Information FIH; IOC Reference Document Hockey.

962 Respectively Art 2, Art. 3 and Art 4 FIH Regulations governing the Eligibility of a Player to Play International Hockey for a country/ National Association $3^{\text {rd }}$ July, 2015. 
nationals of the country they represent ${ }^{963} Y$ et, a change of the country of representation is possible, although it is considerably easier for junior or masters athletes compared to senior athletes. ${ }^{964} \mathrm{~A}$ case-by-case approach by the Executive Board is possible in difficult situations, allowing players that acquire another nationality, either by choice or by circumstance to al ways have the possibility to represent the country of their choice ${ }^{965}$ The possibility to rededide after having competed in a junior competition is highly liberal as is the non-restricted number of nationality changes (with the exception of teritorial transfers). Stateless athletes are however not mentioned, but one would presume that their cases fall within the scope of the Executive Board's decisions on a case-by-case basis.

\subsubsection{Rules applicable since 2010}

The current eligibility criteria for Hockey can be found in the FIH Regulations governing the Eligibility of a Player to Play International Hockey for a Country / National Association of July 2015, which for junior and senior players mostly resemble the 2010 and 2012 rul eversions. Onenotabl e exception is that since 2012 the artide concerning athl etes recognised by more than one country has been scrapped and that since 2015 the category of master players has been introduced.

Prior to 2012, athletes with multiple nationality could only represent the country in which he or she was a bona fide resident, ${ }^{966}$ meaning that the athlete had been a resident in the country for a period of 210 days in each of the three years leading up to the initial selection. ${ }^{967}$ Special provisions applied when countries share common nationality and residency within one intemational border and in such cases the eligibility depended on the place of birth of either the player or the player's parents. In addition, players could select to play for the country in which they were bona fide residents. ${ }^{968}$

Tuming to the currently applicable eligibility criteria, the FIH underscores that for the Olympic Games the IOC's rules take precedence ${ }^{969}$ For FIH competitions, junior or senior players need in principle to have the nationality of the country they wish to represent ${ }^{970}$ Nationality is considered to be given in case the athlete hol ds a

963 Art. 1.1. FIH Regulations governing the Eligibility of a Player to Play International Hockey for a country/ National Association $3^{\text {rd }} \mathrm{July} 2015$.

Art. 2.4; Art. 3.4 and Art. 4.3 FIH Regulations governing the Eligibility of a Player to Play International Hockey for a country/ National Association $3^{\text {rd }}$ July 2015. Art. 3.5 and Art. 4.4 FIH Regulations governing the Eligibility of a Player to Play International Hockey for a country/ National Association $3^{\text {rd }}$ July 2015.

966 Art. 5.2.4.1 International Hockey Federati on statutes updated $13^{\text {th }}$ November 2010.

967 Art. 5.2.4.3 International Hockey Federati on statutes and bye-laws updated $13^{\text {th }}$ November 2010.

968 Art. 5.2.4.2 International Hockey Federati on statutes updated $13^{\text {th }}$ November 2010.

Art. 1.1 FIH Regulations governing the Eligibility of a Player to Play International Hockey for a country/ National Association $3^{\text {rd }}$ July 2015; Art 1.1 FIH Regulations governing the Eligibility of a Player to Play International Hockey for a country/ National Association 29 $9^{\text {th }}$ March 2012; Art. 5.2.1.3 International Hockey Federation statutes updated $13^{\text {th }}$ November 2010.

Art. 1.1 FIH Regulations governing the Eligibility of a Player to Play International Hockey for a country/ National Association $3^{\text {rd }}$ July 2015; Art 1.1 FIH Regulations governing theEligibility of a Player to Play International Hockey for a country/ National Association 29 $9^{\text {th }}$ March 2012; Art. 5.2.1.1 International Hockey Federation statutes updated $13^{\text {th }}$ November 2010. 
valid passport of a country. ${ }^{971}$ Athletes may also compete for their country of residence, provided that they have a passport of this country - even if it is not their country of origin. ${ }^{972}$

Senior players, meaning all athletes competing in senior toumaments regardless of their age ${ }^{973}$ cannot change their country of representation with direct effect if they have al ready competed internationally. ${ }^{974}$ Such a change is only possible after the athlete has waited for three years after having represented another country and if the athlete has received the written permission of the involved associations and the FIH Executive Board. ${ }^{975}$ This applies not only to athletes who acquired a new nationality, but also to those who had multiple nationality before embarking on an intemational carer. The FIH underscores that the acquisition of a new nationality does not need to lead to a change of country of representation, provided that the athlete continues to be a national of the original country. ${ }^{976}$

The FIH pays special attention to cases where the athlete's national ity is subject to change due to territorial transfers - e.g. because the country gai ns is independence or becomes incorporated into another. In such cases, athletes can choose once for which country they wish to compete without the threyear waiting period or permission necessary. ${ }^{977}$ This allows athletes to continue their career with only minor interruptions.

Furthermore, the FIH states that all cases not falling under the statutes or bye laws will be decided by the Executive Board if brought before them Such decisions, especially those that focus on nationality, citizenship, domicile, or residence of players can then either be decided for the individual case or in a general matter for

Art. 1.2 FIH Regulations governing the Eligibility of a Player to Play International Hockey for a country/ National Association $3^{\text {rd }}$ July 2015; Art 1.1 FIH Regulations governing the Eligibility of a Player to Play International Hockey for a country/ National Association 29 $9^{\text {h }}$ March 2012; Art. 5.2.1.2 International Hockey Federation statutes updated $13^{\text {th }}$ November 2010. FIH e-mail of $8^{\text {th }}$ February 2016.

Art. 3.1 FIH Regulations governing the Eligibility of a Player to Play International Hockey for a country/ National Association $3^{\text {rd }}$ J uly 2015; Art 3.1 FIH Regulations governing the Eligibility of a Player to Play International Hockey for a country/ National Association 29 $9^{\text {th }}$ March 2012; Art. 5.2.3.1 International Hockey Federation statutes updated $13^{\text {th }}$ November 2010.

Art. 3.3 FIH Regulations governing the Eligibility of a Player to Play International Hockey for a country/ National Association $3^{\text {rd }}$ July 2015; Art 3.3 FIH Regulations governing the Eligibility of a Player to Play International Hockey for a country/ National Association 29 ${ }^{\text {th }}$ March 2012; Art. 5.2.3.2 International Hockey Federation statutes and bye-laws updated $13^{\text {th }}$ November 2010.

Art. 3.4 FIH Regulations governing the Eligibility of a Player to Play International Hockey for a country/ National Association $3^{\text {rd }}$ J uly 2015; Art 3.4 FIH Regulations governing the Eligibility of a Player to Play International Hockey for a country/ National Association 29 $9^{\text {th }}$ March 2012; Art. 5.2.3.4 International Hockey Federation statutes and byelaws updated $13^{\text {th }}$ November 2010.

Art. 3.3 FIH Regulations governing the Eligibility of a Player to Play International Hockey for a country/ National Association $3^{\text {rd }}$ J uly 2015; Art 3.3 FIH Regulations governing the Eligibility of a Player to Play International Hockey for a country/ National Association 29 th $^{\text {th }}$ March 2012; Art. 5.2.3.2 International Hockey Federation statutes and bye-laws updated $13^{\text {th }}$ November 2010.

Art. 3.5 FIH Regulations governing the Eligibility of a Player to Play International Hockey for a country/ National Association $3^{\text {rd }}$ July 2015; Art 3.5 FIH regulations governing the eligibility of a player to play International Hockey for a country / National Association 29 $9^{\text {th }}$ March 2012; Art. 5.2.3.4 International Hockey Federation statutes and bye-laws updated $13^{\text {th }}$ November 2010. 
all similar cases. ${ }^{978}$ Here the FIH refers to nationality and citizenship while having mentioned only nationality before The fact that these four terms were listed individually shows that the $\mathrm{FIH}$ considers them distinct concepts - otherwise nationality and residence would have been sufficient. However, no further information is provided on the FIH's definition or the FIH's intention in mentioning these concepts additional ly, which is especial ly interesting as, prior to 2012, the FIH did provide a definition of the then required bona fide residence in Article 4.3 International Hockey Federation Statutes.

With regard to minors, one finds that the FIH considers all players under the age of 21 to be a junior player. ${ }^{979}$ However, if the athlete has participated in what is considered a senior tournament he or she will be considered a senior player from then on. ${ }^{980}$ In principle, junior players with multiple nationality have to choose which country they want to represent. ${ }^{981} \mathrm{Y}$ et, junior athletes who acquire a new nationality or al ready had several nationalities may change their country of representation, provided they can obtain the approval of the Executive Board. ${ }^{982}$ Another choice is possible when the athlete proceeds from being a junior to competing as a senior player. ${ }^{983}$ However, if the player has represented one country at a senior leve, he or she may only represent another country after not having competed for a country for three years. This requirement can be set aside in case the athlete receives the approval of the national association of the first country and the Executive Board. ${ }^{984}$ Overall, these rules place junior athletes in a good situation and allow them to re decide upon reaching theage of majority.

978 Art. 3.6 FIH Regulations governing the Eligibility of a Player to Play International Hockey for a country/ National Association $3^{\text {rd }}$ July 2015; Art 3.6 FIH regulations governing the eligi bility of a player to play International Hockey for a country / National Association 29 $9^{\text {th }}$ March 2012; Art. 5.2.3.5. International Hockey Federation statutes and byelaws updated $13^{\text {th }}$ November 2010.

Art. 2.1 FIH Regulations governing the Eligibility of a Player to Play International Hockey for a country/ National Association $3^{\text {rd }}$ J uly 2015; Art 2.1 FIH regulations governing the eligi bility of a player to play International Hockey for a country/ National Association 29 ${ }^{\text {th }}$ March 2012; Art. 5.2. 2.1 International Hockey Federation statutes and bye-laws updated $13^{\text {th }}$ November 2010.

Art. 2.5 FIH Regulations governing the Eligibility of a Player to Play International Hockey for a country/ National Association $3^{\text {rd }}$ July 2015; Art 2.5 FIH regulations governing the eligibility of a player to play International Hockey for a country/ National Association 29 ${ }^{\text {th }}$ March, 2012; Art. 5.2.2.5 International Hockey Federation statutes and bye-laws updated $13^{\text {th }}$ November, 2010.

Art. 2.2 FIH Regulations governing the Eligibility of a Player to Play International Hockey for a country/ National Association $3^{\text {rd }}$ J uly 2015; Art 2.2 FIH regulations governing the eligibility of a player to play International Hockey for a country / National Association 29 $9^{\text {th }}$ March 2012; Art. 5.2.2.2 International Hockey Federation statutes and byelaws updated $13^{\text {th }}$ November 2010.

Art. 2.2 and Art. 2.3 FIH Regulations governing the Eligibility of a Player to Play International Hockey for a country/ National Association $3^{\text {rd }}$ July 2015; Art 2.2 and Art 2.3 FIH regulations governing the eligibility of a player to play International Hockey for a Country / national Association 29 $9^{\text {th }}$ March 2012; Art 5.2.2.2 and Art. 5.2.3 International Hockey Federation statutes and bye-laws updated $13^{\text {th }}$ November 2010.

Art. 2.4 FIH Regulations governing the Eligibility of a Player to Play International Hockey for a country/ National Association $3^{\text {rd }}$ July 2015; Art 2.4 FIH regulations governing the eligibility of a player to play International Hockey for a country / National Association 29 $9^{\text {th }}$ March 2012; Art. 5.2.2.4 International Hockey Federation statutes and bye-laws updated $13^{\text {th }}$ November 2010. Ibid. 
Since 2015, there is the additional category of 'masters athletes' to whom different rules apply, eg. in masters toumaments or events they may also compete for their country of residence, provided they have been living there 12 months directly prior to the tournament ${ }^{985}$ Such a masters tournament or event is any FIH sanctioned event which is either labelled 'masters' or has an age restriction, meaning a minimum age requirement ${ }^{986}$ At the masters level, athletes may compete for countries of which they are nationals or where they have been residents prior to the event for at least 12 months. ${ }^{987}$ Akin to junior and senior athletes, they should choose for which country they want to compete in the case of dual or multiple nationality. ${ }^{988}$ However, contrary to the other competitions, masters players can change their country of representation after only a one year waiting period or with the approval of the Board. ${ }^{989}$ This is significantly quicker than the three years usually applicable Moreover, the FIH allows the relevant Board to take decisions regarding nationality, citizenship, domicile and residence on an individual or general basis. ${ }^{990}$ Thus, while this category is generally very much akin to the senior and junior players, the highly reduced waiting period is remarkable

\footnotetext{
985 Art. 1.1 FIH Regulations governing the Eligibility of a Player to Play International Hockey for a country/ National Association $3^{\text {rd }}$ July 2015. Art. 4.1 FIH Regulations governing the Eligibility of a Player to Play International Hockey for a country/ National Association $3^{\text {rd }}$ July 2015. Art. 4.2 FIH Regulations governing the Eligibility of a Player to Play International Hockey for a country/ National Association $3^{\text {rd }}$ July 2015. Ibid.

Art. 4.3 FIH Regulations governing the Eligibility of a Player to Play International Hockey for a country/ National Association $3^{\text {rd }}$ July 2015.

990 Art. 4.4 FIH Regulations governing the Eligibility of a Player to Play International Hockey for a country/ National Association $3^{\text {rd }}$ July 2015.
} 


\subsection{Ice Hockey ${ }^{991}$}

Ice hockey was first devel oped in the erly $19^{\text {th }}$ century in Canada, although the first rules were only laid down in $1879 .{ }^{992}$ In 1908 the Intemational Ice Hockey Federation (IIHF) was founded and ice hockey was included in the summer Olympics in 1920 as a men's only event ${ }^{993}$ Since 1924, icehockey was part of the Winter Olympic Games programme, while women's ice hockey has featured in the Games since 1998, after having been accepted as an Olympic Sport in 1992. ${ }^{994}$ The main difference between the women's and the men's game is that, in the former, body-checks are not allowed. ${ }^{995}$ I ce hockey games last an hour plus a 15 minuteintermission, with the hour being divided into three periods of 20 minutes ${ }^{996}$ Theintermission occurs between the first and second period. ${ }^{977}$ The teams of six players each change sides on the ice ring between the periods. ${ }^{998}$ There are additional overtimes possible if at the end of the regular time the score is a draw between the teams - this means five minutes after standard games and 20 minutes after a second intermission of 15 minutes for a gold medal game ${ }^{999}$ In case no team scored a winning goal during the overtime, a penalty shoot takes place ${ }^{1000}$

TableXXVI: Overview of the eligibility requirements for ice hockey

\begin{tabular}{|c|c|}
\hline Requirements IIHF & \\
\hline In force since & May 2014 \\
\hline C hange of nationality & $\begin{array}{l}\text { Possible, al though different rules depending on } \\
\text { whether the athlete has competed before: if so: } \\
\text { four years waiting period and four years } \\
\text { competing in national league necessary, otherwise } \\
\text { just two hockey seasons }\end{array}$ \\
\hline Residence requirements & Legal residence, duration depends on case \\
\hline M inors and nationality change & $\begin{array}{l}\text { Not mentioned, but living in the country since } 10^{\text {th }} \\
\text { birthday important (previously } 12^{\text {th }} \text { birthday) }\end{array}$ \\
\hline Stateless athletes & $\begin{array}{l}\text { Not specified, but would fall under exceptional } \\
\text { circumstances }\end{array}$ \\
\hline $\begin{array}{l}\text { Position of athletes with multiple nationality } \\
\text { after having competed for another country of } \\
\text { which the athlete is a national }\end{array}$ & $\begin{array}{l}\text { Four-year non-international competition period } \\
\text { while four years spent competition on national } \\
\text { leve }\end{array}$ \\
\hline
\end{tabular}

991 The federation was contacted on $6^{\text {th }}$ August 2014 and asked to provide further insights into its eligibility criteria and older versions of the eligibility rules. The IIHF replied on $22^{\text {nd }}$ August and kindly supplied all the necessary documents. On $29^{\text {th }}$ October 2015, the federation was contacted again and asked for comments on this chapter to which the federation replied on $3^{\text {rd }}$ November 2015.

992 IOC Information on I ce Hockey Equipment and History.

993 IOC Information on Ice Hockey Equipment and History. IOC Information IIHF; IOC Reference Document I ceHockey.

994 IOC Information on I ce Hockey Equi pment and History.

995 IOC Information IIHF; IOC Reference Document I ce Hockey.

996 IOC Information IIHF.

997 Ibid.

998 Ibid.

999 Ibid.

1000 lbid. 


\begin{tabular}{|l|l|}
\hline E ffect of changes in territory of country & $\begin{array}{l}\text { Not specified Application to IIHF needed, choice } \\
\text { can be made only once, but no waiting period will } \\
\text { beneeded }\end{array}$ \\
\hline Competing for the country of residence & Not possible \\
\hline Number of changes possible & No maximum given, since2014 \\
\hline R efer ence to Olympic Charter & Compliance explicitly mentioned \\
\hline Uses nationality/ citizenship & $\begin{array}{l}\text { Mostly citizen and citizenship, but al so nationality } \\
\text { and national eligi bility }\end{array}$ \\
\hline Uses residence/ domicile & residence \\
\hline Other remarkable peculiarity & $\begin{array}{l}\text { Differentiation between male and femaleathletes, } \\
\text { with female athl etes having to fulfil less criteria }\end{array}$ \\
\hline
\end{tabular}

9.5.1. Ice Hockey critical reflection

Since May 2014, the IIHF rules have changed sightly, although the underlying principle is that athletes need to be nationals of the country they represent ${ }^{1001}$ All in all, the criteria seem to have become easier to meet and the possibility to change one's nationality more than once certainly is a huge step towards a more flexible rule, while the four-year period of non-competition required remains applicable and should deter mercenary tendencies. ${ }^{1002}$ The rules for athletes who have not yet made their international debut areal so significantly changed to be more accommodating, as this is now possi ble after just two hockey seasons spent in the relevant country. ${ }^{1003}$ However, the new rule regarding female athletes is quite a curiosity, as it allows for female athletes to change their country of representation easier. ${ }^{1004}$ The differentiation between male and female athletes regarding eligibility criteria is discriminatory. Taking this and the four-year waiting period for a nationality change into consideration, one nevertheless has to draw the condusion that ice hodkey rules are rather strict.

\subsubsection{Rules applicable since 2003}

The current eligi bility rules are set out in thell HF Statutes and Bylaws 2014- 2018 of May 2014. These are in most core aspects identical to the ones before IIHF Statutes and Bylaws applicable in 2012 - 2014; 2008 - 2012 and 2003 until 2008. Y et, they do differ considerably in the numbering, eg. Artide 204 (1)(f) in the 2003-2008 version has become Artide 205 (1.6) in the 2008-2012 and 406 (1.6) since 2012. Since the 2014 the most important rule change meant that there is no longer a maximum number of dhanges of the country of representation. ${ }^{1005}$

Other devel opments wereas follows:

1001 Art. 406 IIHF statutes and bylaws 2014 - 2018 of May 2014.

1002 Art. 406(1.3) IIHF statutes and bylaws 2014 - 2018 of May 2014.

1003 Art. 406(1.7) IIHF statutes and bylaws 2014 - 2018 of May 2014.

1004 Art. 406(1.8) IIHF statutes and bylaws 2014 - 2018 of May 2014.

1005 Art. 406(1.3) IIHF statutes and bylaws 2014 - 2018 of May 2014. 
Since2008:

- Surrender of citizenship is explicitly mentioned; 1006

- Residence requirement for athl etes with multiple nationality or who have acqui red a new national ity and wish to change the country of representation introduced. ${ }^{1007}$

Since2012:

- Referenceto thelOC Charter made, ${ }^{1008}$

- Explicit referenceto citizensinduded; 1009

- Athletes who al ready competed internationally and wish to change their country of representation have to have competed for an explicit number of days (1460) in the national competitions of therevant country, ${ }^{1010}$

- Athletes with multiple nationality or who have acquired a new nationality and wish to change the country of representation had to haveto:

- compete at least two years (730 days) in national competitions of the relevant country

- after their $12^{\text {th }}$ birthday. ${ }^{1011}$

Since 2014:

- Change of the country of representation is possible more often than once ${ }^{1012}$

- Athletes with multiple nationality or who have acquired a new nationality and wish to changethe country of representation now haveto:

- have competed at least two hockey seasons; and

- 16 consecutive months (480 days) in national competitions of the relevant country;

- after their $10^{\text {th }}$ birthday. ${ }^{1013}$

- A distinction between maleand femal eathletes is made, with female athletes having to ful fil less stringent requirements. ${ }^{1014}$

Looking at the rules more dosely, one finds that, since 2008, the IIHF explicitly states that it will comply with the Olympic Charter, which will also take precedence over IIHF regulations regarding Olympic eligibility. ${ }^{1015}$ The IIHF requires the participants of the national teams to be citizens of the country they represent ${ }^{1016}$ In order to prove

\footnotetext{
1006 Art. 205(1.6) IIHF statutes and bylaws 2008-2012 with 2011 Amendments.

1007 Art. 205(1.6)(a) and Art. 205(1.7)(b) IIHF statutes and bylaws 2008-2012 with 2011 Amendments.

1008 Art. 405 IIHF statutes and bylaws 2012 - 2014.

1009 Art. 405 IIHF statutes and bylaws 2012 - 2014.

1010 Art. 406(1.3) IIHF statutes and bylaws 2012-2014.

1011 Art. 406(1.6)(a)and 406 (1.7)(a) IIHF statutes and bylaws 2012 - 2014.

1012 Art. 406(1.3) IIHF statutes and bylaws 2014 - 2018 of May 2014.

1013 Art. 406(1.6) and Art. 406(1.7) IIHF statutes and bylaws 2014 - 2018 of May 2014.

1014 Art. 406(1.8) IIHF statutes and bylaws 2014 - 2018 of May 2014.

1015 Art. 405 IIHF statutes and bylaws 2014 - 2018 of May 2014; Art. 405 IIHF statutes and bylaws 2012 - 2014; Art 204 IIHF statutes and bylaws 2008-2012 with 2011 Amendments; Art. 203 IIHF statutes and bylaws 2003-2008.

1016 Art. 406 IIHF statutes and bylaws 2014 - 2018 of May 2014; Art. 406 IIHF statutes and bylaws 2012 - 2014; Art 205 IIHF statutes and bylaws 2008-2012 with 2011 Amendments; Art. 204 IIHF statutes and bylaws 2003-2008.
} 
their status, athl letes need to submit a val id passport ${ }^{1017}$ Whereas previously a choice for a country was limited, the new rules no longer ind ude a reference that changing the country of representation is a once in a life time chance ${ }^{1018}$ The previous rules regarding the application for a nationality changearehowever still in place

"A) heis a citizen of that country;

B) he has an intemational transfer that was approved by the IIHF and dated at least four years before the start of the IIHF competition in which he wishes to participate;

C) he has participated, on a consistent basis, for at least four consecutive years (1460 days) in the national competitions of his new country during which period he has neither transferred to another country nor played ice hockey for a team registered/located within any other country: and

D) he has not played for his previous country in an IIHF compeition either during this four year period or between completion of this four-year period and thestart of thellHF championshiphewishes to compete"1019

Hence, the necessary four-year period is still in force, which in itself should deter athletes from changing their country of representation often. If an athlete acquired or surrendered a citizenship and consequently would like to participate in the IIHF championship or theOlympics for this new country without having represented the old country in either of those competitions, heneeds to:

"A) prove that he has participated on a consistent basis, for at least two consecutive hockey seasons and 16 consecutive months (480 days) after his $10^{\text {th }}$ birthday in the national competitions of and having resided in his new country during which period he has neither transfered to another country nor played ice hockey for a teamregistered/located within any other country; and

B) if the country of his choice is one to which the player has transferred then he must have had an international transfer that was approved by the IIHF and dated at least 16 months (480 days) to his proposed participation."1020

The same criteria areapplicable to athl etes who have multiple citizenships and want to compete for one of the countries for the first time ${ }^{1021}$ This is a significant change

1017 Art. 406(1.2) IIHF statutes and bylaws 2014 - 2018 of May 2014; Art. 406(1.2) IIHF statutes and bylaws 2012 - 2014; Art. 205(1.2) IIHF statutes and bylaws 2008-2012 with 2011 Amendments; Art. 204(b) IIHF statutes and bylaws 2003-2008.

1018 Art. 406(1.3) IIHF statutes and bylaws 2014 - 2018 of May 2014; Art. 406(1.3) IIHF statutes and bylaws 2012 - 2014; Art. 205(1.3) IIHF statutes and bylaws 2008-2012 with 2011 Amendments; Art. 204(c) IIHF statutes and bylaws 2003-2008.

1019 Art. 406(1.3) IIHF statutes and bylaws 2014 - 2018 of May 2014; Art. 406(1.3) IIHF statutes and bylaws 2012 - 2014; Art. 205(1.3) IIHF statutes and bylaws 2008-2012 with 2011 Amendments; Art. 204(c) IIHF statutes and bylaws 2003-2008.

1020 Art. 406(1.6) IIHF statutes and bylaws 2014 - 2018 of May 2014; Art. 406(1.6) IIHF statutes and bylaws 2012 - 2014; Art. 205(1.6) IIHF statutes and bylaws 2008-2012 with 2011 Amendments; Art. 205(1.6) IIHF statutes and bylaws 2008-2012 with 2011 Amendments; Art. 204 (f) IIHF statutes and bylaws 2003-2008. 
compared to the earlier versions, which stipulated two years of participation in the national league. Furthermore, the earlier rules focussed not on the $10^{\text {th }}$ but on the $12^{\text {th }}$ birthday of the athlete as a significant date, making thenew rules easier to satisfy as a bigger time frame is taken into consideration. The change from the required 730 days in earlier versions to mere 480 days al so shows a development towards an easier set of rules. Since 2014, the IIHF differentiates between male and female athletes for the purpose of the eligi bility criteria. Whereas, prior to the 2014 rules, both had to face the same additional criteria if they had multiple citizenships or acquired a new citizenship and wanted to participate for the first time in the IIHF championships or the Olympic Games, the current rules saw theintroduction of Article406 (1.8):

"1.8 In the case of Female Hockey, the eligibility requirement described in 1.6 and 1.7 of this By-Law will be met if a player has participated on a consistent basis for at least one (1) hockey season in the competitions of the Member National Association (MNA) of that country, and was a member of that MNA for at least twelve (12) consecutivemonths during that period." 1022

Thus, while the criteria in general have become broader, the rules for female athletes have lowered the threshold even further. Onehas to wonder why the IIHF has decided to distingui ish between the genders in such a way, as no explanation is evident from the textitseff.

As stipulated in previous versions, should there be a teritorial transfer, the athletes may change their country of representation - subject to an application to the IIHF and proof that the athlete is a ditizen of the new country. ${ }^{1023}$ Contrary to the earlier mentioned change of nationality, this change remains irrevocable and can only betaken once ${ }^{1024}$ Exceptional cases, as in earlier versions, will be decided by thellHF Coundil upon application by the concemed athl ete $\mathrm{e}^{1025}$

1021 Art. 406(1.7) IIHF statutes and bylaws 2014 - 2018 of May 2014; Art. 406(1.7) IIHF statutes and bylaws 2012 - 2014; Art. 205(1.7) IIHF statutes and bylaws 2008-2012 with 2011 Amendments; Art. 204(g) IIHF statutes and bylaws 2003-2008.

1022 Art. 406(1.8) IIHF statutes and bylaws 2014 - 2018 of May 2014.

1023 Art. 406(1.5) IIHF statutes and bylaws 2014 - 2018 of May 2014; Art. 406(1.5) IIHF statutes and bylaws 2012 - 2014; Art. 205(1.5) IIHF statutes and bylaws 2008-2012 with 2011 Amendments; Art. 204(e) IIHF statutes and bylaws 2003-2008.

1024 Art. 406(1.5) IIHF statutes and bylaws 2014 - 2018 of May 2014; Art. 406(1.5) IIHF statutes and bylaws 2012 - 2014; Art. 205(1.5) IIHF statutes and bylaws 2008-2012 with 2011 Amendments; Art. 204(e) IIHF statutes and bylaws 2003-2008.

1025 Art.406(1.10) IIHF statutes and bylaws 2014 - 2018 of May 2014; Art. 406(1.9) IIHF statutes and bylaws 2012 - 2014; Art. 205(1.8) IIHF statutes and bylaws 2008-2012 with 2011 Amendments; Art. 204(h) IIHF statutes and bylaws 2003-2008. 


\subsection{Rugby ${ }^{1026}$}

Rugby has al legedly been played since 1823, when William Webb Elis ran over the goal line hol ding the ball in his hands during a football match. ${ }^{1027}$ In the subsequent years therules of nugby were codified and the International Rugby Board was founded in 1886 and renamed itself World Rugby (WR) in 2014. ${ }^{1028}$ Different variations of the sport are still practiced today, although the rugby union and the rugby sevens are the most common types. ${ }^{1029}$ The rugby union of 15 players per team was an Olympic discipline at the Games in 1900, 1908, 1920, and 1924. ${ }^{1030}$ In 2016, rugby sevens will be played at the Rio Games and feature men's and women's events. ${ }^{1031}$ This means that there will be seven players per team with each team having five substitute players on the bench. ${ }^{1032}$ However, each team may only use a maximum of three substitutes per game ${ }^{1033} \mathrm{~A}$ game is remarkably short with half-times lasting only seven minutes, making the entire match last 14 minutes plus eventual extra time ${ }^{1034}$ The final match in a competition has ten minute half-times and thus lasts 20 minutes plus extra time ${ }^{1035}$ Points are scored by bringing the ball on the ground behind the opposing team's goal line in their goal area. ${ }^{1036}$ Placing the ball there by hand earns the team five points, kicking it so that it lands there eams two points. ${ }^{1037}$ Throwing the ball forward to scorea 'try' or passing it to another person is forbidden. ${ }^{1038}$

TableXXVII: Overview of the eligibility requirements for rugby

\begin{tabular}{|l|l|}
\hline R equirements World R ugby & December 2013 \\
\hline In force since & Not possible \\
\hline C hange of nationality & $\begin{array}{l}36 \text { consecutive months as a perquisite to compete } \\
\text { for a national team, athletes should stay } 10 \text { months } \\
\text { a year in a country }\end{array}$ \\
\hline R esidence requirements & $\begin{array}{l}\text { Minors cannot changetheir country of } \\
\text { representation }\end{array}$ \\
\hline M inors and nationality change & Not specified \\
\hline Stateless athletes & Nationality change not possible \\
\hline $\begin{array}{l}\text { Position of athletes with multiple nationality } \\
\text { after having competed for another country of }\end{array}$ & \\
\hline
\end{tabular}

1026 The federation was contacted on $6^{\text {th }}$ August 2014 and asked to provide further insights into its eligibility criteria and older versions of the eligibility rules. The IRB replied on $12^{\text {th }}$ August 2014. On $29^{\text {th }}$ October 2015 the federation was contacted again and asked for comments on this chapter to which at first only an automated reply e-mail was received, before World Rugby replied on $3^{\text {rd }}$ March, 2016.

1027 IOC Information Rugby Equi pment and History.

1028 IOC Information Rugby Equi pment and History; IOC Information IRB.

1029 IOC Information Rugby Equi pment and History.

1030 IOC Information Rugby Equipment and History; IOC Information IRB; IOC Reference Document Rugby.

1031 Ibid.

1032 IOC Information IRB.

1033 IOC Information IRB; OC Information Rugby Equipment and History.

1034 Ibid.

1035 Ibid.

1036 IOC Information Rugby Equi pment and History.

1037 Ibid.

1038 Ibid. 
NATIONALITY REQUiREMENTS IN OLYMPIC SPORTS

\begin{tabular}{|l|l|}
\hline which the athlete is a national & \\
\hline E ffect of changes in territory of country & Not specified \\
\hline Competing for the country of residence & Possi ble, if 36 month of consecutive residence \\
\hline Number of changes possible & None \\
\hline R efer ence to Olympic Charter & $\begin{array}{l}\text { Yes, referenceto IOC rules for Olympic Games } \\
\text { (sinceDecember 2013) }\end{array}$ \\
\hline Uses nationality/ citizenship & Nationality and rugby nationality \\
\hline Uses residence/ domicile & Residence, meaning primary and permanent home \\
\hline Other remarkable peculiarity & $\begin{array}{l}\text { 'genuine, close, credibleand established link' } \\
\text { explicitly mentioned; explicit inclusion of adoptive } \\
\text { parents }\end{array}$ \\
\hline
\end{tabular}

9.6.1. Rugby critical reflection

Rugby eligibility criteria are very detailed. They refer not only to an athlete's nationality, but al so to his or her 'nugby nationality' which is unchangeable ${ }^{1039}$ This also indudes athletes who competed for one country as a minor and then wished to compete for another country of which he or she is a national later in life - it is impossible ${ }^{1040}$ Thus, once 'the rugby nationality' is established, ${ }^{1041}$ it will remain stable regardless of the changes to the athlete's actual nationality. This is extremely strict and contrary to the rule that a genuine link should exist between a person and a state

\subsubsection{Rules applicable since 2013}

The rugby rules currently in force are set down in the International Rugby Board Handbook as framed by the International Rugby Board with the last updates stemming from $8^{\text {th }}$ March 2016, $1^{\text {t }}$ January 2016, $11^{\text {th }}$ September 2015, $1^{\text {th }}$ August 2015, $15^{\text {th }}$ May 2015, 22 ${ }^{\text {nd }}$ March 2015, $1^{\text {ts }}$ September 2014, and $1^{\text {st }}$ December 2013. Theserules are further elaborated upon in the Explanatory Guidelines on the Implementation of Regulation 8 Eligibility to Play for National Representative Teams Handbook. The biggest changes in the recent years was the addition of Olympic eligibility rules in December 2013. ${ }^{1042}$ In September 2014, only Regulation 8.3 (d) was added and, in the

1039 Regulation. 8.2 International Rugby Board handbook as framed by the International Rugby Board last updated: $8^{\text {th }}$ March 2016.

1040 Question 4 explanatory guidelines on the implementation of regulation 8 eligibility to play for national representative teams - International Rugby Board handbook as framed by the International Rugby Board last updated: $8^{\text {th }}$ March 2016.

1041 Regulation 8.1 International Rugby Board handbook as framed by the International Rugby Board last updated: $8^{\text {th }}$ March 2016 and Question 3 explanatory guidelines on the implementation of regulation 8 eligibility to play for national representative teams - International Rugby Board handbook as framed by the International Rugby Board last updated: $8^{\text {th }}$ March 2016.

1042 Regulation 8.6 - 8.16 International Rugby Board handbook as framed by the International Rugby Board last updated: $8^{\text {th }}$ March 2016; Regulation 8.6 - 8.16 International Rugby Board handbook as framed by the International Rugby Board last updated: $1^{\text {st }}$ January 2016; Regulation $8.6-8.16$ International Rugby Board handlbook as framed by the International Rugby Board last updated: $11^{\text {th }}$ September 2015; Regulation 8.6 - 8.16 International Rugby Board handbook as framed by the International Rugby Board last updated: $1^{\text {st }}$ August 2015; Regulation 8.6 - 8.16 International Rugby Board handbook as framed by the International Rugby Board last updated: $15^{\text {th }}$ May 2015. Regulation 8.6 - 8.16 International Rugby Board handbook as framed by the International Rugby 
explanatory guidelines, Question 6 received the sub-part c), which both deel with Unions Under-20s national representative teams. Changes made in 2015 were minor, with 'World Rugby' substituting the 'IRB' in the text ${ }^{1043}$ Since 2016, Questions 22, 23 and 24 as well as Regulation 8.5.3 were added, which deal with the athlete's duty to be in compliance with theregulations and the sanctions for breaches. As all other rules remained equal, these rule versions will be examined together in the following. The rugby rules prescribethat only an athletemay competefor a national team if:

"(a) hewas born; or

(b) one parent or grandparent was born; or

(c) he has completed thirty six conseautive months of Residence immediately preceding thetime of playing." ${ }^{\prime 1044}$

Board last updated: $22^{\text {nd }}$ March 2015; Regulation 8.6 - 8.16 International Rugby Board handbook as framed by the International Rugby Board last updated: $1^{\text {st }}$ September 2014; Regulation 8.6 8.16 International Rugby Board handbook as framed by the International Rugby Board last updated: $1^{\text {st }}$ December 2013.

1043 Regulation 8.1 International Rugby Board handbook as framed by the International Rugby Board last updated: $8^{\text {th }}$ March 2016; Regulation 8.1 International Rugby Board handbook as framed by the International Rugby Board last updated: $1^{\text {t }}$ J anuary 2016; Regulation 8.1 International Rugby Board handbook as framed by the International Rugby Board last updated: $11^{\text {th }}$ September 2015, Regulation 8.1 International Rugby Board handbook as framed by the International Rugby Board last updated: $1^{\text {st }}$ August 2015, Regulation 8.1 International Rugby Board handbook as framed by the International Rugby Board last updated: $15^{\text {th }}$ May 2015. Regulation 8.1 International Rugby Board handbook as framed by the International Rugby Board last updated: $22^{\text {nd }}$ March 2015.

Regulation 8.1 International Rugby Board handbook as framed by the International Rugby Board last updated: $8^{\text {th }}$ March 2016 and Question 3 explanatory guidelines on the implementation of regulation 8 eligibility to play for national representative teams - International Rugby Board handbook as framed by the International Rugby Board last updated: $8^{\text {th }}$ March 2016; Regulation 8.1 International Rugby Board handbook as framed by the International Rugby Board last updated:

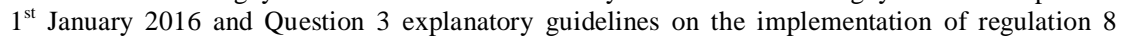
eligibility to play for national representative teams - International Rugby Board handbook as framed by the International Rugby Board last updated: $1^{\text {st }}$ January 2016; Regulation 8.1 International Rugby Board handbook as framed by the International Rugby Board last updated: $11^{\text {th }}$ September 2015 and Question 3 explanatory guidelines on the implementation of regulation 8 eligibility to play for national representative teams - International Rugby Board handbook as framed by the International Rugby Board last updated: $11^{\text {th }}$ September 2015; Regulation 8.1 International Rugby Board handbook as framed by the International Rugby Board last updated: $1^{\text {st }}$ August 2015 and Question 3 explanatory guidelines on the implementation of regulation 8 eligibility to play for national representative teams - International Rugby Board handbook as framed by the International Rugby Board last updated: $1^{\text {st }}$ August 2015; Regulation 8.1 International Rugby Board handbook as framed by the International Rugby Board last updated: $15^{\text {th }}$ May 2015 and Question 3, explanatory guidelines on the impl ementation of regulation 8 eligibility to play for national representative teams - International Rugby Board handbook as framed by the International Rugby Board last updated: $15^{\text {th }}$ May 2015; Regulation 8.1 International Rugby Board handbook as framed by the International Rugby Board last updated: 22 $2^{\text {nd }}$ March 2015 and Question 3 explanatory guidelines on the implementation of regulation 8 eligibility to play for national representative teams - International Rugby Board handbook as framed by the International Rugby Board last updated: 22 ${ }^{\text {nd }}$ March 2015; Regulation 8.1 International Rugby Board handbook as framed by the International Rugby Board last updated: $1^{\text {st }}$ September 2014 and Question 3 explanatory guidelines on the implementation of regulation 8 eligibility to play for national representative teams - International Rugby Board handbook as framed by the International Rugby Board last updated: $1^{\text {st }}$ September 2014; Regulation 8.1 International Rugby Board handbook as framed by the International Rugby Board last updated: $1^{\text {st }}$ December 2013 and Question 3 explanatory guidelines on the implementation of regulation 8 eligibility to play for national representative teams - International Rugby Board handbook as framed by the International Rugby 
This provision clearly does not mention actual national ity, but a genuine link between athl ete and country through birth, blood relations or residence Themain reason behind these requirements is that there has to be a 'genuine, dose, credible and established link' between athlete and country of representation. ${ }^{1045}$ This is close to the wording empl oyed in national ity law in general.

However, in Article 8.6 it is stated that an athlete does indeed need to be a national of the relevant country in order to compete ${ }^{1046}$ It is important to underscore that parents in such a situation also explicitly includes adoptive parents, provided that the adoption was legal. ${ }^{1047}$ The fulfilment of the residence requirement will not

Board last updated: $1^{\text {st }}$ December 2013; Regulation 8.1 International Rugby Board handbook as framed by the International Rugby Board last updated: $1^{\text {st }}$ August 2013 and Question 3, explanatory guidelines on the implementation of regulation 8 eligibility to play for national representative teams - International Rugby Board handbook as framed by the International Rugby Board last updated: $31^{\text {st }}$ J uly 2013.

1045 Question 1 explanatory guidelines on the implementation of regulation 8 eligibility to play for national representative teams - International Rugby Board handbook as framed by the International Rugby Board last updated: $8^{\text {th }}$ March 2016; Question 1 explanatory guidelines on the implementation of regulation 8 eligibility to play for national representative teams - International

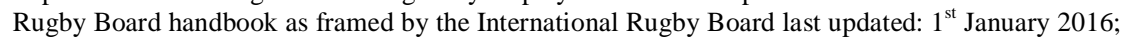
Question 1 explanatory guidelines on the implementation of regulation 8 eligibility to play for national representative teams - International Rugby Board handbook as framed by the International Rugby Board last updated: $11^{\text {th }}$ September 2015; Question 1 explanatory guidelines on the implementation of regulation 8 eligibility to play for national representative teams - International Rugby Board handbook as framed by the International Rugby Board last updated: $1^{\text {st }}$ August 2015; Question 1 explanatory guidelines on the implementation of regulation 8 eligibility to play for national representative teams - International Rugby Board handbook as framed by the International Rugby Board last updated: $15^{\text {th }}$ May 2015; Question 1 explanatory guidelines on the implementation of regulation 8 eligi bility to play for national representative teams - International Rugby Board handbook as framed by the International Rugby Board last updated: $22^{\text {nd }}$ March 2015; Question 1 explanatory guidelines on the implementation of regulation 8 eligibility to play for national representative teams - International Rugby Board handbook as framed by the International Rugby Board last updated: $1^{\text {st }}$ September 2014; Question 1 explanatory guidelines on the implementation of regulation 8 eligibility to play for national representative teams International Rugby Board handbook as framed by the International Rugby Board last updated: $1^{\text {st }}$ December 2013; Question 1 explanatory guidelines on the implementation of regulation 8 eligibility to play for national representative teams - International Rugby Board handbook as framed by the International Rugby Board last updated: $31^{\text {st }}$ July 2013.

1046 Regulation 8.6 International Rugby Board handbook as framed by the International Rugby Board last updated: $8^{\text {th }}$ March 2016; Regulation 8.6 International Rugby Board handbook as framed by the International Rugby Board last updated: $1^{\text {st }}$ January 2016; Regulation 8.6 International Rugby Board handbook as framed by the International Rugby Board last updated: $11^{\text {th }}$ September 2015; Regulation 8.6 International Rugby Board handbook as framed by the International Rugby Board last updated: $1^{\text {st }}$ August 2015; Regulation 8.6 International Rugby Board handbook as framed by the International Rugby Board last updated: $15^{\text {th }}$ May 2015; Regulation 8.6 International Rugby Board handbook as framed by the International Rugby Board last updated: $22^{\text {nd }}$ March 2015; Regulation 8.6 International Rugby Board handbook as framed by the International Rugby Board last updated: $1^{\text {st }}$ September 2014; Regulation 8.6 International Rugby Board handbook as framed by the International Rugby Board last updated: $1^{\text {st }}$ December 2013; Regulation 8.6 International

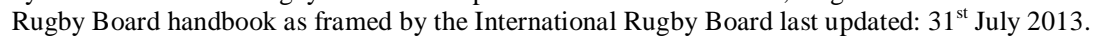
Question 12 explanatory guidelines on the implementation of regulation 8 eligibility to play for national representative teams - International Rugby Board handbook as framed by the International Rugby Board last updated: $8^{\text {th }}$ March 2016; Question 12 explanatory guidelines on the implementation of regulation 8 eligibility to play for national representative teams - International Rugby Board handbook as framed by the International Rugby Board last updated: $1^{\text {st }}$ January 2016; Question 12 explanatory guidelines on the implementation of regulation 8 eligibility to play for national representative teams - International Rugby Board handbook as framed by the International 
be endangered by an athlete's visit to family members living abroad or holidays, yet the athlete shoul d not stay less than ten months a year in the country. ${ }^{1048}$

Oncean athletehas competed for a national team, including the times when he or shereceived a call for the national team and answered it positivel $y_{1}^{1049}$ heor she may

Rugby Board last updated: $11^{\text {th }}$ September 2015; Question 12 explanatory guidelines on the implementation of regulation 8 eligi bility to play for national representative teams - International Rugby Board handbook as framed by the International Rugby Board last updated: $1^{\text {st }}$ August 2015; Question 12 explanatory guidelines on the implementation of regulation 8 eligibility to play for national representative teams - International Rugby Board handbook as framed by the International Rugby Board last updated: 15 ${ }^{\text {th }}$ May 2015; Question 12 explanatory guidelines on the implementation of regulation 8 eligi bility to play for national representative teams - International Rugby Board handbook as framed by the International Rugby Board last updated: $22^{\text {nd }}$ March, 2015; Question 12 explanatory guidelines on the implementation of regulation 8 eligi bility to play for national representative teams - International Rugby Board handbook as framed by the International Rugby Board last updated: $1^{\text {st }}$ September 2014; Question 12 explanatory guidelines on the implementation of regulation 8 eligibility to play for national representative teams International Rugby Board handbook as framed by the International Rugby Board last updated: $1^{\text {st }}$ December 2013; Question 12 explanatory guidelines on the implementation of regulation 8 eligibility to play for national representative teams - International Rugby Board handbook as framed by the International Rugby Board last updated: 31 ${ }^{\text {st }}$ J uly 2013.

Question 16 explanatory guidelines on the implementation of regulation 8 eligibility to play for national representative teams - International Rugby Board handbook as framed by the International Rugby Board last updated: $8^{\text {th }}$ March 2016; Question 16 explanatory guidelines on the implementation of regulation 8 eligi bility to play for national representative teams - International Rugby Board handbook as framed by the International Rugby Board last updated: $1^{\text {st }}$ J anuary 2016; Question 16 explanatory guidelines on the implementation of regulation 8 eligibility to play for national representative teams - International Rugby Board handbook as framed by the International Rugby Board last updated: $11^{\text {th }}$ September 2015; Question 16 explanatory guidelines on the implementation of regulation 8 eligi bility to play for national representative teams - International Rugby Board handbook as framed by the International Rugby Board last updated: $1^{\text {st }}$ August 2015; Question 16 explanatory guidelines on the implementation of regulation 8 eligibility to play for national representative teams - International Rugby Board handbook as framed by the International Rugby Board last updated: 15 ${ }^{\text {th }}$ May 2015; Question 16 explanatory guidelines on the implementation of regulation 8 eligi bility to play for national representative teams - International Rugby Board handbook as framed by the International Rugby Board last updated: $22^{\text {nd }}$ March 2015; Question 16 explanatory guidelines on the implementation of regulation 8 eligi bility to play for national representative teams - International Rugby Board handbook as framed by the International Rugby Board last updated: $1^{\text {st }}$ September 2014; Question 16 explanatory guidelines on the implementation of regulation 8 eligibility to play for national representative teams International Rugby Board handbook as framed by the International Rugby Board last updated: $1^{\text {st }}$ December 2013; Question 16 explanatory guidelines on the implementation of regulation 8 eligibility to play for national representative teams - International Rugby Board handbook as framed by the International Rugby Board last updated: $31^{\mathrm{st}}$ July 2013.

1049 Regulation 8.3 and Regulation 8.4 International Rugby Board handbook as framed by the International Rugby Board last updated: $8^{\text {th }}$ March 2016; Question 5 explanatory guidelines on the implementation of regulation 8 eligi bility to play for national representative teams - International Rugby Board handbook as framed by the International Rugby Board last updated: $8^{\text {th }}$ March 2016; Regulation 8.3 and Regulation 8.4 International Rugby Board handbook as framed by the International Rugby Board last updated: $1^{\text {st }}$ J anuary 2016; Question 5 explanatory guidel ines on the implementation of regulation 8 eligi bility to play for national representative teams - International Rugby Board handbook as framed by the International Rugby Board last updated: $1^{\text {st }}$ J anuary 2016; Regulation. 8.3 and Regulation 8.4 International Rugby Board handbook as framed by the International Rugby Board last updated $11^{\text {th }}$ September 2015; Question 5 explanatory gui delines on the implementation of regulation 8 eligibility to play for national representative teams International Rugby Board handbook as framed by the International Rugby Board last updated: $11^{\text {th }}$ September 2015; Regulation. 8.3 and Regulation 8.4 International Rugby Board handbook as framed by the International Rugby Board last updated $1^{\text {st }}$ August 2015; Question 5 explanatory guidelines on the implementation of regulation 8 eligibility to play for national representative 
in principle not compete for another country. ${ }^{1050}$ As it is stressed since $1^{\text {st }}$ September 2014, this also includes an athlete who is selected by a Unions Under-20s team and has reached the age of majority when the Under-20s team is designated as the next senior team ${ }^{1051}$ Consequently, their 'rugby nationality' will remain the same, regardless of their actual nationality. ${ }^{1052}$

teams - International Rugby Board handbook as framed by the International Rugby Board last updated: $1^{\text {st }}$ August 2015; Regulation. 8.3 and Regulation 8.4 International Rugby Board handbook as framed by the International Rugby Board last updated 15 guidelines on the implementation of regulation 8 eligibility to play for national representative teams - International Rugby Board handbook as framed by the International Rugby Board last updated: $15^{\text {th }}$ May 2015; Regulation. 8.3 and Regulation 8.4 International Rugby Board handbook as framed by the International Rugby Board last updated 22 $2^{\text {nd }}$ March 2015; Question 5 explanatory guidelines on the implementation of regulation 8 eligibility to play for national representative teams - International Rugby Board handbook as framed by the International Rugby Board last updated: 22 $2^{\text {nd }}$ March 2015; Regulation. 8.3 and Regulation 8.4 International Rugby Board handbook as framed by the International Rugby Board last updated: $1^{\text {st }}$ September, 2014; Question 5 explanatory guidelines on the implementation of regulation 8 eligibility to play for national representative teams - International Rugby Board handbook as framed by the International Rugby Board last updated: $1^{\text {st }}$ September 2014; Regulation. 8.3 and Regulation 8.4 International Rugby Board handbook as framed by the International Rugby Board last updated: $1^{\text {st }}$ December 2013; Question 5 explanatory guidelines on the implementation of regulation 8 eligibility to play for national representative teams - International Rugby Board handbook as framed by the International Rugby Board last updated: $1^{\text {st }}$ December 2013; 8. 3 and Regulation 8.4 International Rugby Board handbook as framed by the International Rugby Board last updated: 31 July 2013; Question 5 explanatory guidelines on the implementation of regulation 8 eligibility to play for national representative teams - International Rugby Board handbook as framed by the International Rugby Board last updated: $31^{\text {st }}$ J uly 2013.

1050 Regulation 8.2 International Rugby Board handbook as framed by the International Rugby Board last updated: $8^{\text {th }}$ March 2016; Regulation 8.2 International Rugby Board handbook as framed by the International Rugby Board last updated: $1^{\text {st }}$ January 2016; Regulation. 8.2 International Rugby Board handbook as framed by the International Rugby Board last updated: $11^{\text {th }}$ September 2015; Regulation. 8.2 International Rugby Board handbook as framed by the International Rugby Board last updated: $1^{\text {st }}$ August 2015; Regulation. 8.2 International Rugby Board handbook as framed by the International Rugby Board last updated: $15^{\text {th }}$ May 2015; Regulation. 8.2 International Rugby Board handbook as framed by the International Rugby Board last updated: $22^{\text {nd }}$ March 2015; Regulation. 8.2 International Rugby Board handbook as framed by the International Rugby Board last updated: $1^{\text {st }}$ September 2014; Regulation. 8.2 International Rugby Board handbook as framed by the International Rugby Board last updated: $1^{\text {th }}$ December 2013; 8.2 International Rugby Board handbook as framed by the International Rugby Board last updated: 31 J Jul 2013.

Regulation 8.3 d) International Rugby Board handbook as framed by the International Rugby Board last updated: $8^{\text {th }}$ March 2016; Regulation 8.3 d) International Rugby Board handbook as framed by the International Rugby Board last updated: $1^{\text {st }}$ January 2016; Regulation.8.3 d) International Rugby Board handbook as framed by the International Rugby Board last updated: $11^{\text {th }}$ September, 2015; Regulation.8.3 d) International Rugby Board handbook as framed by the International Rugby Board last updated: $1^{\text {st }}$ August, 2015; Regulation.8.3 d) International Rugby Board handbook as framed by the International Rugby Board last updated: $15^{\text {th }}$ May 2015; Regulation.8.3 d) International Rugby Board handbook as framed by the International Rugby Board last updated: 22 ${ }^{\text {nd }}$ March 2015; Regulation.8.3 d) International Rugby Board handbook as framed by the International Rugby Board last updated: $1^{\text {st }}$ September 2014.

Question 4 explanatory guidelines on the implementation of regulation 8 eligibility to play for national representative teams - International Rugby Board handbook as framed by the International Rugby Board last updated: $8^{\text {th }}$ March 2016; Question 4 explanatory guidelines on the implementation of regulation 8 eligi bility to play for national representative teams - International Rugby Board handbook as framed by the International Rugby Board last updated: $1^{\text {st }}$ J anuary 2016; Question 4 explanatory guidelines on the implementation of regulation 8 eligibility to play for national representative teams - International Rugby Board handbook as framed by the International Rugby Board last updated: $11^{\text {th }}$ September, 2015; Question 4 explanatory guidelines on the 
With regard to the question of Olympic eligibility, it is dear that athletes have to be nationals of the country for which they compete, due to the IOC's rules. ${ }^{1053}$ Athletes who also have another nationality may apply to compete in an Olympic event for the other country, if the athlete has informed his own federation in due time, ${ }^{1054}$ and has observed a period of non-competition of three years. ${ }^{1055}$ The athlete may not compete

implementation of regulation 8 eligi bility to play for national representative teams - International Rugby Board handbook as framed by the International Rugby Board last updated: $1^{\text {st }}$ August 2015; Question 4 explanatory guidelines on the implementation of regulation 8 eligibility to play for national representative teams - International Rugby Board handbook as framed by the International Rugby Board last updated: 15 ${ }^{\text {th }}$ May 2015; Question 4 explanatory guidelines on the implementation of regulation 8 eligi bility to play for national representative teams - International Rugby Board handbook as framed by the International Rugby Board last updated: $22^{\text {nd }}$ March 2015; Question 4 explanatory guidelines on the implementation of regulation 8 eligibility to play for national representative teams - International Rugby Board handbook as framed by the International Rugby Board last updated: $1^{\text {st }}$ September 2014; Question 4 explanatory gui delines on the implementation of regulation 8 eligibility to play for national representative teams International Rugby Board handbook as framed by the International Rugby Board last updated: $1^{\text {st }}$ December 2013; Question 4 explanatory guidelines on the implementation of regulation 8 eligibility to play for national representative teams - International Rugby Board handbook as framed by the International Rugby Board last updated: $31^{\text {st }}$ July 2013. Question 2 explanatory guidelines on the implementation of regulation 8 - Olympic eligibility International Rugby Board handbook as framed by the International Rugby Board last updated: $1^{\text {st }}$ J anuary 2016; Question 2 explanatory guidelines on the implementation of regulation 8 - Olympic eligibility - International Rugby Board handbook as framed by the International Rugby Board last updated: $1^{\text {st }}$ anuary 2016; Question 2 explanatory guidelines on the implementation of regulation 8 - Olympic eligibility - International Rugby Board handbook as framed by the International Rugby Board last updated: $11^{\text {th }}$ September 2015; Question 2 explanatory gui delines on the implementation of regulation 8 - Olympic eligibility - International Rugby Board handbook as framed by the International Rugby Board last updated: $1^{\text {st }}$ August 2015; Question 2 explanatory guidelines on the implementation of regulation 8 - Olympic eligibility - International Rugby Board handbook as framed by the International Rugby Board last updated: 15 ${ }^{\text {th }}$ May 2015; Question 2 explanatory guidelines on theimplementation of regulation 8 - Olympic eligibility - International Rugby Board handbook as framed by the International Rugby Board last updated: $22^{\text {nd }}$ March 2015; Question 2 explanatory guidelines on the implementation of regulation 8 - Olympic eligibility - International Rugby Board handbook as framed by the International Rugby Board last updated: $1^{\text {st }}$ September 2014; Question 2 explanatory guidelines on the implementation of regulation 8 - Olympic eligibility - International Rugby Board handbook as framed by the International Rugby Board last updated: $1^{\text {st }}$ December 2013.

1054 Regulation 8.7.1 International Rugby Board handbook as framed by the International Rugby Board last updated: $8^{\text {th }}$ March 2016; Regulation 8.7.1 International Rugby Board handloook as framed by the International Rugby Board last updated: $1^{\text {t }}$ January 2016; Regulation 8.7.1 International Rugby Board handbook as framed by the International Rugby Board last updated: $11^{\text {th }}$ September 2015; Regulation 8.7.1 International Rugby Board handbook as framed by the International Rugby Board last updated: $1^{\text {ts }}$ August 2015; Regulation 8.7.1 International Rugby Board handbook as framed by the International Rugby Board last updated: $15^{\text {th }}$ May 2015; Regulation 8.7.1 International Rugby Board handbook as framed by the International Rugby Board last updated: $22^{\text {nd }}$ March 2015; Regulation 8.7.1 International Rugby Board handbook as framed by the International Rugby Board last updated: $1^{\text {st }}$ September 2014; Regulation 8.7.1 International Rugby Board handbook as framed by the International Rugby Board last updated: $1^{\text {st }}$ December 2013.

1055 Regulation 8.7.2 International Rugby Board handbook as framed by the International Rugby Board last updated: $8^{\text {th }}$ March 2016; Question 8 explanatory guidelines on the implementation of regulation 8 - Olympic eligibility - International Rugby Board handbook as framed by the International Rugby Board last updated: $8^{\text {th }}$ March 2016; Regulation 8.7.2 International Rugby Board handbook as framed by the International Rugby Board last updated: $1^{\text {st }}$ January 2016; Question 8 explanatory guidelines on the implementation of regulation 8 - Olympic eligibility International Rugby Board handbook as framed by the International Rugby Board last updated: $1^{\text {st }}$ January 2016; Regulation 8.7.2 International Rugby Board handbook as framed by the 
for thenew country prior to competing for it at an Olympic event ${ }^{1056}$ Thereis however a specific rule regarding the Rio Olympic Games in 2016, which requires only a period of 18 months of non-competition for an athlete who wishes to represent another country of which he or sheis a national at these games ${ }^{1057}$ It is explicitly not possible for an athleteto competefor two sides during theOlympic Games. ${ }^{1058}$

International Rugby Board last updated: $11^{\text {th }}$ September 2015; Question 8 explanatory guidelines on the implementation of regulation 8 - Olympic eligibility - International Rugby Board handbook as framed by the International Rugby Board last updated: $11^{\text {th }}$ September 2015; Regulation 8.7.2 International Rugby Board handbook as framed by the International Rugby Board last updated: $1^{\text {st }}$ August 2015; Question 8 explanatory guidelines on the impl ementation of regulation 8 - Olympic eligi bility - International Rugby Board handbook as framed by the International Rugby Board last updated: $1^{\text {st }}$ August, 2015; Regulation 8.7.2 International Rugby Board handbook as framed by the International Rugby Board last updated: $15^{\text {th }}$ May 2015; Question 8 explanatory guidelines on the implementation of regulation 8 - Olympic eligibility - International Rugby Board handbook as framed by the International Rugby Board last updated: $15^{\text {th }}$ May 2015; Regulation 8.7.2 International Rugby Board handbook as framed by the International Rugby Board last updated: $22^{\text {nd }}$ March 2015; Question 8 explanatory guidelines on the implementation of regulation 8 Olympic eligibility - International Rugby Board handbook as framed by the International Rugby Board last updated: $22^{\text {nd }}$ March 2015; Regulation 8.7.2 International Rugby Board handbook as framed by the International Rugby Board last updated: $1^{\text {st }}$ September, 2014; Question 8 explanatory guidelines on the implementation of regulation 8 - Olympic eligi bility - International Rugby Board handbook as framed by the International Rugby Board last updated: $1^{\text {st }}$ September 2014; Regulation 8.7.2 International Rugby Board handbook as framed by the International Rugby Board last updated: $1^{\text {st }}$ December 2013; Question 8 explanatory guidelines on the implementation of regulation 8 - Olympic eligibility - International Rugby Board handbook as framed by the International Rugby Board last updated: $1^{\text {st }}$ December 2013.

Regulation 8.7.2 International Rugby Board handbook as framed by the International Rugby Board last updated: $8^{\text {th }}$ March 2016; Regulation 8.7.2 International Rugby Board handbook as framed by the International Rugby Board last updated: $1^{\text {s }}$ J anuary 2016; Regulation 8.7.2 International Rugby Board handbook as framed by the International Rugby Board last updated: $11^{\text {th }}$ September 2015; Regulation 8.7.2 International Rugby Board handbook as framed by the International Rugby Board last updated: $1^{\text {st }}$ August 2015; Regulation 8.7.2 International Rugby Board handbook as framed by the International Rugby Board last updated: $15^{\text {th }}$ May 2015; Regulation 8.7.2 International Rugby Board handbook as framed by the International Rugby Board last updated: $22^{\text {nd }}$ March 2015; Regulation 8.7.2 International Rugby Board handbook as framed by the International Rugby Board last updated: $1^{\text {st }}$ September 2014; Regulation 8.7.2 International Rugby Board handbook as framed by the International Rugby Board last updated: $1^{\text {st }}$ December 2013.

1057 Regulation 8.7.2 a) International Rugby Board handbook as framed by the International Rugby Board last updated: $8^{\text {th }}$ March 2016; Regulation 8.7.2 a) International Rugby Board handbook as framed by the International Rugby Board last updated: $1^{\text {t }}$ January 2016; Regulation 8.7.2 a) International Rugby Board handbook as framed by the International Rugby Board last updated: $11^{\text {th }}$ September 2015; Regulation 8.7.2 a) International Rugby Board handbook as framed by the International Rugby Board last updated: $1^{\text {st }}$ August 2015; Regulation 8.7.2 a) International Rugby Board handbook as framed by the International Rugby Board last updated: $15^{\text {th }}$ May 2015; Regulation 8.7.2 a) International Rugby Board handbook as framed by the International Rugby Board last updated: $22^{\text {nd }}$ March 2015; Regulation 8.7.2 a) International Rugby Board handbook as framed by the International Rugby Board last updated: $1^{\text {st }}$ September 2014; Regulation 8.7.2 a) International Rugby Board handbook as framed by the International Rugby Board last updated: $1^{\text {tt }}$ December 2013.

1058 Regulation 8.11 International Rugby Board handbook as framed by the International Rugby Board last updated: $8^{\text {th }}$ March 2016; Question 5 explanatory guidelines on the implementation of regulation 8 - Olympic eligibility - International Rugby Board handbook as framed by the International Rugby Board last updated: $8^{\text {th }}$ March 2016; Regulation 8.11 International Rugby Board handbook as framed by the International Rugby Board last updated: $1^{\text {st }}$ January 2016; Question 5 explanatory guidelines on the implementation of regulation 8 - Olympic eligibility International Rugby Board handbook as framed by the International Rugby Board last updated: $1^{\text {st }}$ January 2016; Regulation 8.11 International Rugby Board handbook as framed by the International 
Athletes who fulfil the Olympic criteria may compete for the country of which they are nationals, even if competing for another country would lead to them becoming eligible for the Olympics. ${ }^{1059}$ They do however need to satisfy the requirement of a period of non-competition. ${ }^{1060}$ If an athlete was to be eligible to play at the Olympics, but his

Rugby Board last updated: $11^{\text {th }}$ September 2015; Question 5 explanatory guidelines on the implementation of regulation 8 - Olympic eligibility - International Rugby Board handbook as framed by the International Rugby Board last updated: $11^{\text {th }}$ September 2015; Regulation 8.11 International Rugby Board handbook as framed by the International Rugby Board last updated: $1^{\text {st }}$ August 2015; Question 5 explanatory guidelines on the implementation of regulation 8 - Olympic eligi bility - International Rugby Board handbook as framed by the International Rugby Board last updated: $1^{\text {st }}$ August 2015; Regulation 8.11 International Rugby Board handbook as framed by the International Rugby Board last updated: $15^{\text {th }}$ May 2015; Question 5 explanatory guidelines on the implementation of regulation 8 - Olympic eligibility - International Rugby Board handbook as framed by the International Rugby Board last updated: 15 ${ }^{\text {th }}$ May 2015; Regulation 8.11 International Rugby Board handbook as framed by the International Rugby Board last updated: $22^{\text {nd }}$ March 2015; Question 5 explanatory guidelines on the implementation of regulation 8 Olympic eligibility - International Rugby Board handbook as framed by the International Rugby Board last updated: 22 ${ }^{\text {nd }}$ March 2015; Regulation 8.11 International Rugby Board handbook as framed by the International Rugby Board last updated: $1^{\text {st }}$ September 2014; Question 5 explanatory guidel ines on theimplementation of regulation 8 - Olympic eligibility - International Rugby Board handbook as framed by the International Rugby Board last updated: $1^{\text {st }}$ September 2014; Regulation 8.11 International Rugby Board handbook as framed by the International Rugby Board last updated: $1^{\text {st }}$ December 2013; Question 5 explanatory guidelines on the implementation of regulation 8 - Olympic eligibility - International Rugby Board handbook as framed by the International Rugby Board last updated: $1^{\text {st }}$ December 2013.

Regulation 8.8 International Rugby Board handbook as framed by the International Rugby Board last updated: $8^{\text {th }}$ March 2016; Regulation 8.8 International Rugby Board handbook as framed by the International Rugby Board last updated: 1 January 2016; Regulation 8.8 International Rugby Board handbook as framed by the International Rugby Board last updated: $11^{\text {th }}$ September 2015; Regulation 8.8 International Rugby Board handbook as framed by the International Rugby Board last updated: $1^{\text {st }}$ August 2015; Regulation 8.8 International Rugby Board handbook as framed by the International Rugby Board last updated: $15^{\text {th }}$ May 2015; Regulation 8.8 International Rugby Board handbook as framed by the International Rugby Board last updated: $22^{\text {nd }}$ March 2015; Regulation 8.8 International Rugby Board handbook as framed by the International Rugby Board last updated: $1^{\text {st }}$ September 2014; Regulation 8.8 International Rugby Board handbook as framed by the International Rugby Board last updated: $1^{\text {st }}$ December 2013.

Regulation 8.8 International Rugby Board handbook as framed by the International Rugby Board last updated: $8^{\text {th }}$ March 2016; Question 8 explanatory guidelines on the implementation of regulation 8 - Olympic eligibility - International Rugby Board handbook as framed by the International Rugby Board last updated: $8^{\text {th }}$ March 2016; Regulation 8.8 International Rugby Board handbook as framed by the International Rugby Board last updated: $1^{\text {st }}$ J anuary 2016; Question 8 explanatory guidelines on the implementation of regulation 8 - Olympic eligibility - International Rugby Board handbook as framed by the International Rugby Board last updated: $1^{\text {st } J}$ anuary 2016; Regulation 8.8. International Rugby Board handbook as framed by the International Rugby Board last updated: $11^{\text {th }}$ September, 2015; Question 8 explanatory guidelines on the implementation of regulation 8 - Olympic eligibility - International Rugby Board handbook as framed by the International Rugby Board last updated: $11^{\text {th }}$ September 2015; Regulation 8.8. International Rugby Board handbook as framed by the International Rugby Board last updated: $1^{\text {st }}$ August 2015; Question 8 explanatory guidelines on the implementation of regulation 8 - Olympic eligibility International Rugby Board handbook as framed by the International Rugby Board last updated: $1^{\text {st }}$ August 2015; Regulation 8.8. International Rugby Board handbook as framed by the International Rugby Board last updated: $15^{\text {th }}$ May 2015; Question 8 explanatory guidelines on the implementation of regulation 8 - Olympic eligibility - International Rugby Board handbook as framed by the International Rugby Board last updated: 15 ${ }^{\text {th }}$ May 2015; Regulation 8.8. International Rugby Board handbook as framed by the International Rugby Board last updated: $22^{\text {nd }}$ March 2015; Question 8 explanatory guidelines on the implementation of regulation 8 Olympic eligibility - International Rugby Board handbook as framed by the International Rugby Board last updated: 22 $2^{\text {nd }}$ March, 2015; Regulation 8.8. International Rugby Board handbook as 
Union is not, he may compete for another team as long as this is not from one Union. ${ }^{1061}$ Thus, an Italian rugby player could not play for France, for instance, but for a sort of all-star team This is conditional upon the following requirements:

"8.9.1 Where the Player has been captured under Regulation 8.2 for a Union he shall remain captured for such Union notwithstanding the Player's representation for the Olympic Sevens Team of a National Olympic Committee in an Olympic Event;

8.9.2 Where the Player has not previously been captured under Regulation 8.2 and he represents the Olympic Sevens Team of a National Olympic Committee in an Olympic Event he will be deemed to be captured for one of the underlying Unions which support the Olympic Sevens Team of the relevant National Olympic Committee, and the Player must dect which of those underlying Unions heshall becaptured by for thepurposes of Regulation 8."1062

framed by the International Rugby Board last updated: $1^{\text {st }}$ September 2014; Question 8 explanatory guidel ines on theimplementation of regulation 8 - Olympic eligibility - International Rugby Board handbook as framed by the International Rugby Board last updated: $1^{\text {th }}$ September 2014; Regulation 8.8. International Rugby Board handbook as framed by the International Rugby Board last updated: $1^{\text {st }}$ December 2013; Question 8 explanatory guidelines on the implementation of regulation 8 - Olympic eligibility - International Rugby Board handbook as framed by the International Rugby Board last updated: 1 December 2013.

Regulation 8.9 International Rugby Board handbook as framed by the International Rugby Board last updated: $8^{\text {th }}$ March 2016; Regulation 8.9 International Rugby Board handbook as framed by the International Rugby Board last updated: 1 January 2016; Regulation 8.9 International Rugby Board handbook as framed by the International Rugby Board last updated: $11^{\text {th }}$ September 2015; Regulation 8.9 International Rugby Board handbook as framed by the International Rugby Board last updated: $1^{\text {st }}$ August 2015; Regulation 8.9 International Rugby Board handbook as framed by the International Rugby Board last updated: $15^{\text {th }}$ May 2015; Regulation 8.9 International Rugby Board handbook as framed by the International Rugby Board last updated: $22^{\text {nd }}$ March 2015; Regulation 8.9 International Rugby Board handbook as framed by the International Rugby Board last updated: $1^{\text {st }}$ September 2014; Regulation 8.9 International Rugby Board handbook as framed by the International Rugby Board last updated: $1^{\text {st }}$ December 2013.

Regulation 8.9.1 and Regulation 8.9.2 International Rugby Board handbook as framed by the International Rugby Board last updated: $8^{\text {th }}$ March 2016; Question 13 explanatory gui delines on the implementation of regulation 8 - Olympic eligibility - International Rugby Board handbook as framed by the International Rugby Board last updated: $8^{\text {th }}$ March 2016; Regulation 8.9 .1 and Regulation 8.9.2 International Rugby Board handbook as framed by the International Rugby Board last updated: $1^{\text {st }}$ January 2016; Question 13 explanatory guidelines on the implementation of regulation 8 - Olympic eligibility - International Rugby Board handbook as framed by the International Rugby Board last updated: $1^{\text {st }}$ January 2016; Regulation 8.9.1 and Regulation 8.9.2 International Rugby Board handbook as framed by the International Rugby Board last updated: $11^{\text {th }}$ September 2015; Question 13 explanatory guidelines on the implementation of regulation 8 Olympic eligibility - International Rugby Board handbook as framed by the International Rugby Board last updated: $11^{\text {th }}$ September 2015; Regulation 8.9.1 and Regulation 8.9.2 International Rugby Board handbook as framed by the International Rugby Board last updated: $1^{\text {st }}$ August 2015; Question 13 explanatory guidelines on the implementation of regulation 8 - Olympic eligibility International Rugby Board handbook as framed by the International Rugby Board last updated: $1^{\text {st }}$ August, 2015; Regulation 8.9.1 and Regulation 8.9.2 International Rugby Board handbook as framed by the International Rugby Board last updated: 15 $5^{\text {th }}$ May 2015; Question 13 explanatory guidelines on theimplementation of regulation 8 - Olympic eligibility - International Rugby Board handbook as framed by the International Rugby Board last updated: $15^{\text {th }}$ May 2015; Regulation 8.9.1 and Regulation 8.9.2 International Rugby Board handbook as framed by the International Rugby Board last updated: $22^{\text {nd }}$ March 2015; Question 13 explanatory guidelines on the implementation of regulation 8 - Olympic eligibility - International Rugby Board handbook as 
World Rugby thus differentiates between athletes who have already competed internationally, who will thus remain connected to that country, and those for whom the participation in such an all-star team will bethe first international experience The latter will need to decide for which sideheor shewants to competein the future

Although in principle an athlete who has represented a country at the Olympic Games may not compete for another country, there is a provision regarding athletes who have changed their nationality or acquired a new one ${ }^{1063}$ In such a case, they may apply to the relevant IOC bodies and the World Rugby to be allowed to compete for their new country. ${ }^{1064}$ The IOC Executive board will take the specific

framed by the International Rugby Board last updated: $22^{\text {nd }}$ March 2015; Regulation 8.9.1 and Regulation 8.9.2 Intemational Rugby Board handbook as framed by the International Rugby Board last updated: $1^{\text {st }}$ September 2014; Question 13 explanatory guidelines on the implementation of regulation 8 - Olympic eligibility - International Rugby Board handbook as framed by the International Rugby Board last updated: $1^{\text {st }}$ September 2014; Regulation 8.9.1 and Regulation 8.9.2 International Rugby Board handbook as framed by the International Rugby Board last updated: $1^{\text {st }}$ December 2013; Question 13 explanatory guidelines on the implementation of regulation 8 Olympic eligibility - International Rugby Board handbook as framed by the International Rugby Board last updated: $1^{\text {st }}$ December 2013.

1063 Regulation 8.12 International Rugby Board handbook as framed by the International Rugby Board last updated: $8^{\text {th }}$ March 2016; Regulation 8.12 International Rugby Board handbook as framed by the International Rugby Board last updated: $1^{\text {st }}$ anuary 2016; Regulation 8.12 International Rugby Board handlbook as framed by the International Rugby Board last updated: $11^{\text {th }}$ September 2015; Regulation 8.12 International Rugby Board handbook as framed by the International Rugby Board last updated: $1^{\text {st }}$ August 2015; Regulation 8.12 International Rugby Board handbook as framed by the International Rugby Board last updated: $15^{\text {th }}$ May 2015; Regulation 8.12 International Rugby Board handbook as framed by the International Rugby Board last updated: $22^{\text {nd }}$ March 2015; Regulation 8.12 International Rugby Board handbook as framed by the International Rugby Board last updated: $1^{\text {t }}$ September 2014; Regulation 8.12 International Rugby Board handbook as framed by the International Rugby Board last updated: $1^{\text {st }}$ December 2013.

1064 Regulation 8.10 International Rugby Board handbook as framed by the International Rugby Board last updated: $8^{\text {th }}$ March 2016; Question 6 explanatory guidelines on the implementation of regulation 8 - Olympic eligibility - International Rugby Board handbook as framed by the International Rugby Board last updated: $8^{\text {th }}$ March 2016; Regulation 8.10 International Rugby Board handbook as framed by the International Rugby Board last updated: $1^{\text {st }}$ January 2016; Question 6 explanatory guidelines on the implementation of regulation 8 - Olympic eligibility International Rugby Board handbook as framed by the International Rugby Board last updated: $1^{\text {st }}$ January - 2016; Regulation 8.10 International Rugby Board handbook as framed by the International Rugby Board last updated: $11^{\text {th }}$ September 2015; Question 6 explanatory guidelines on the implementation of regulation 8 - Olympic eligibility - International Rugby Board handbook as framed by the International Rugby Board last updated: $11^{\text {th }}$ September 2015; Regulation 8.10 International Rugby Board handbook as framed by the International Rugby Board last updated: $1^{\text {st }}$ August 2015; Question 6 explanatory guidelines on the implementation of regulation 8 - Olympic eligibility - International Rugby Board handbook as framed by the International Rugby Board last updated: $1^{\text {st }}$ August 2015; Regulation 8.10 International Rugby Board handbook as framed by the International Rugby Board last updated: $15^{\text {th }}$ May 2015; Question 6 explanatory guidelines on the implementation of regulation 8 - Olympic eligibility - International Rugby Board handbook as framed by the International Rugby Board last updated: 15 ${ }^{\text {th }}$ May 2015; Regulation 8.10 International Rugby Board handbook as framed by the International Rugby Board last updated: $22^{\text {nd }}$ March 2015; Question 6 explanatory guidelines on the implementation of regulation 8 Olympic eligibility - International Rugby Board handbook as framed by the International Rugby Board last updated: 22 ${ }^{\text {nd }}$ March 2015; Regulation 8.10 International Rugby Board handbook as framed by the International Rugby Board last updated: $1^{\text {st }}$ September 2014; Question 6 explanatory guidel ines on theimplementation of regulation 8 - Olympic eligibility - International Rugby Board handbook as framed by the International Rugby Board last updated: $1^{\text {st }}$ September 2014; Regulation 8.10 International Rugby Board handbook as framed by the International Rugby Board last updated: $1^{\text {st }}$ December 2013; Question 6 explanatory guidelines on the implementation of 
circumstances into account, nevertheless, the threyear period of non-competition should be observed. ${ }^{1065}$

regulation 8 - Olympic eligibility - International Rugby Board handbook as framed by the International Rugby Board last updated: $1^{\text {st }}$ December 2013.

1065 Regulation 8.10 International Rugby Board handbook as framed by the International Rugby Board last updated: $8^{\text {th }}$ March 2016; Regulation 8.10 International Rugby Board handbook as framed by the International Rugby Board last updated: $1^{\text {st }}$ J anuary 2016; Regulation 8.10 International Rugby Board handbook as framed by the International Rugby Board last updated: $11^{\text {th }}$ September 2015; Regulation 8.10 International Rugby Board handbook as framed by the International Rugby Board last updated: $1^{\text {st }}$ August 2015; Regulation 8.10 International Rugby Board handbook as framed by the International Rugby Board last updated: $15^{\text {th }}$ May 2015; Regulation 8.10 International Rugby Board handbook as framed by the International Rugby Board last updated: $22^{\text {nd }}$ March 2015; Regulation 8.10 International Rugby Board handbook as framed by the International Rugby Board last updated: $1^{\text {st }}$ September 2014; Regulation 8.10 International Rugby Board handbook as framed by the International Rugby Board last updated: $1^{\text {st }}$ December 2013. 


\subsection{Volleyball ${ }^{1066}$}

Volleyball is a team sport in which no physical contact between opposing teams is foreseen. It was initially intended as the easier alternative to basketball in $1895 .{ }^{1067}$ Its international governing body, the Fédération Internationale de Volleyball (FIVB) was founded in 1947 and has its seat in Lausanne, Switzerland. ${ }^{1068}$ In 1964 volleyball became an Olympic discipline, with beach voll eyball following in $1996 .{ }^{1069}$ The latter had been developed in the 1920s in Cal ifornia and had quickly gained popularity. ${ }^{1070}$ Nowadays there are men's and women's events for both volleyball and beach volleyball. ${ }^{1071}$ The same rules apply to both sports, although in beach volleyball the added difficulty of moving quickly in the sand and with the variables of sun and wind give the gameits distinct character. ${ }^{1072}$ Each voll leyball match consists of fivesets with the first four sets being played to 25 and the last set being played to 15 points. ${ }^{1073}$ However, as a team must win with a two point advantage, the sets are continued until such an advantage is reached. ${ }^{1074}$ In beach voll eyball, thereare three sets with the first two consisting of 21 points and the final set up to 15 points. ${ }^{1075}$ Also here sets are played on even after reaching the hall-marks of the sets in case the leading team cannot win by a two point advantage ${ }^{1076}$

TableXXVIII: Overview of the eligibility requirements for volleyball

\begin{tabular}{|l|l|}
\hline Requirements FIVB & \\
\hline In force since & $14^{\text {th }}$ May 2014 \\
\hline C hange of nationality & Possi ble once, after \\
\hline R esidence requirements & Two years \\
\hline M inors and nationality change & Not specified \\
\hline Stateless athletes & Not specified \\
\hline $\begin{array}{l}\text { Position of athletes with multiple nationality } \\
\text { after having competed for another country of } \\
\text { which the athlete is a national }\end{array}$ & $\begin{array}{l}\text { Considered a naturalised athlete, per team there } \\
\text { may be only one; Possibleafter two-year residence } \\
\text { and two year waiting period }\end{array}$ \\
\hline E ffect of changes in territory of country & Not specified \\
\hline Competing for the country of residence & Possi bleafter 8 years of residence \\
\hline Number of changes possible & Once \\
\hline
\end{tabular}

1066 The federation was contacted on $6^{\text {th }}$ August 2014 and asked to provide further insights into its eligibility criteria and older versions of the eligibility rules. As no reply was forthcoming a reminder e-mail was sent on $18^{\text {th }}$ September to which the FIVB replied on $22^{\text {nd }}$ October, sending the relevant documents. On $29^{\text {th }}$ October, 2015 the federation was contacted again and asked for comments on this Chapter, as no reply was forthcoming, a first reminder was sent on $19^{\text {th }}$ November 2015 and a second on $2^{\text {nd }}$ December 2015, to which the federation replied on $2^{\text {nd }}$ December.

1067 IOC Information Volleyball Equipment and History.

1068 IOC Information FIVB; IOC Reference Document Voll eyball.

1069 IOC Information FIVB; IOC Information Volleyball Equipment and History; IOC Information Beach Volleyball Equipment and History. IOC ReferenceDocument Volleyball.

1070 IOC Information Beach Voll eyball Equipment and History.

1071 IOC Information FIVB.

1072 Ibid.

1073 Ibid.

1074 Ibid.

1075 Ibid.

1076 Ibid. 


\begin{tabular}{|l|l|}
\hline & None \\
\hline R efer ence to Olympic C harter & Citizenship \\
\hline Uses nationality/ citizenship & Residence \\
\hline Uses residence/ domicile & $\begin{array}{l}\text { Definitions of native, naturalised players and } \\
\text { citizenship provided; native athlete = nationality } \\
\text { acquired prior to sporting debut }\end{array}$ \\
\hline Other remarkable peculiarity & \\
\hline
\end{tabular}

\subsubsection{Volleyball critical reflection}

The FIVB stipulates that only citizens any represent a country at international volleyball toumaments. ${ }^{1077}$ Themost striking feature of the FIVB is the differentiation between native and naturalised players. Here, native does not have the usual connotation of having acquired the relevant citizenship at birth only, but also encompasses those who acquired the citizenship later. ${ }^{1078}$ The main point of differentiation between native and naturalised players for the FIVB is the time of acquisition relative to the athlete's debut for a national side If the citizenship was acquired before this point, the athlete will be considered as a native player. ${ }^{1079}$ If the athlete has al ready competed for another federation and acquirea new citizenship will be considered a naturalised player. ${ }^{1080}$ Changing the country of representation is possible only once in an athlete's career, ${ }^{1081}$ and requires the approval of both the FIVB. ${ }^{1082}$ The FIVB rules are relatively strict and different from the other sports regarding the federation of origin criteria.

\subsubsection{Rules applicablesince 2013}

The current rules are set out by theFIVB sports regulations voll eyball version: 15 May 2015, which are identical to the 15 May 2014 version and almost identical to the 15 May 2013 version.

The main change which occurred in 2014 are

- Reference to native players acquiring citizenship of a country at birth or later was added. ${ }^{1083}$

- Reference to all players who have acquired a new citizenship (naturalised players) being able play in national teams of their new country was del eted. ${ }^{1084}$

- Aspects of special cases were added. ${ }^{1085}$

\footnotetext{
1077 Art. 5.2 Sports regulations Voll eyball version: 15

1078 Art.41.1 Sports regulations Volleyball version: 15 $5^{\text {th }}$ May 2015.

1079 Art. 41.1 Sports regulations Volleyball version: 15

1080 Art. 41.2 Sports regulations Volleyball version: $15^{\text {th }}$ May 2015.

1081 Art. 44.1 Sports regulations Volleyball version: $15^{\text {th }}$ May 2015.

1082 Art. 44.1 Sports regulations Volleyball version: $15^{\text {th }}$ May 2015.

1083 Art.41.1 Sports regulations Volleyball version: 15 Volleyball version: $15^{\text {th }}$ May 2014.

1084 Art. 41.2.1 Sports regulations Volleyball version: 15 $5^{\text {th }}$ May 2013.

1085 Art. 44.4 Sports regulations Volleyball version: 15 $5^{\text {th }}$ May 2015; Art. 44.4 Sports regulations Voll eyball version: $15^{\text {th }}$ May 2014.
} 
Theseare definitions of eligibleand natural ised players, citizenship and the exceptions thereto. Here Artide 5.2 underscores that only citizens who can prove that status by showing their passport are eligible to compete for a country. ${ }^{1086}$ Eligi bility is governed by Chapter 9 of the FIVB Sports regulations, which indudes special provisions for naturalised players to compete for a country. ${ }^{1087}$ While the FIVB has the highest authority to deal with all issues relating to eligibility, it is up to the respective national federations to decide on a player's eligibility within the framework of the FIVB rules ${ }^{1088}$ Consequently, the national federations can base their decisions mainly on age, gender and citizenship. ${ }^{1089}$

The FIVB distinguishes between native and naturalised players. Since 2014, native does not have the usual connotation of having acquired the relevant citizenship at birth only, but also encompasses those who acquired the citizenship later. ${ }^{1090}$ Themain point of differentiation between native and naturalised players for the FIVB is the time of acquisition relative to the athlete's debut for a national side If the citizenship was acquired before this debut, the athlete will be considered to be a native player. ${ }^{1091}$ If the athlete has al ready competed for another federation and thereafter acquires a new citizenship, he or she will be considered a naturalised player. ${ }^{1092}$ Being a naturalised athl ete does not create a disadvantage for the athlete per se as, in principle, naturalised athletes are just as eligible for teams as native athletes. However, regarding the composition of the national teams, the FIVB stipul ates that per team only one natural ised player may compete ${ }^{1093}$

Another important concept is the one of federation of origin, meaning the federation which first registered the athlete as one of its own or issued the athlete's first license ${ }^{1094}$ For this, the athlete does not need to be a citizen of the country of the federation. Thus, the registration does not make the athlete directly eligible to compete for the federation - only after the acquisition of the citizenship of the

1086 Art. 5.2 and Art. 41.5 Sports regulations Volleyball version: 15 $5^{\text {th }}$ May 2015; Art. 5.2 and Art. 41.5 Sports regulations Volleyball version: $15^{\text {th }}$ May 2014: Art. 5.2 and Art. 41.5 Sports regulations Volleyball version: $15^{\text {th }}$ May 2013.

Art. 5.1 and Art. 5.4 Sports regulations Volleyball version: $15^{\text {th }}$ May 2015; Art 5.1 and Art. 5.4 Sports regulations Volleyball version: $15^{\text {th }}$ May 2014; Art. 5.1 and Art. 5.5 Sports regulations Volleyball version: $15^{\text {th }}$ May 2013.

Art. 40.1 and Art. 40.2 Sports regulations Volleyball version: 15 $5^{\text {th }}$ May 2015; Art 40.1 and Art. 40.2 Sports regulations Volleyball version: 15 regulations Volleyball version: $15^{\text {th }}$ May 2013.

1089 Art. 40.3 Sports regulations Volleyball version: $15^{\text {th }}$ May 2015; Art. 40.3 Sports regulations Volleyball version: 15 $5^{\text {th }}$ May 2014; Art. 40.3 Sports regulations Volleyball version: $15^{\text {th }}$ May 2013.

1090 Art. 41.1 Sports regulations Volleyball version: 15 $5^{\text {th }}$ May 2015; Art.41.1 Sports regulations Volleyball version: $15^{\text {th }}$ May 2014.

1091 Art. 41.1 Sports regulations Volleyball version: 15 $5^{\text {th }}$ May 2015; Art. 41.1 Sports regulations Volleyball version: $15^{\text {th }}$ May 2014.

1092 Art. 41.2 Sports regulations Volleyball version: 15 $5^{\text {th }}$ May 2015; Art. 41.2 Sports regulations Volleyball version: $15^{\text {th }}$ May 2014.

1093 Art. 41.2.2 Sports regulations Volleyball version: 15 $5^{\text {th }}$ May 2015; Art. 41.2.2 Sports regulations Volleyball version: $15^{\text {th }}$ May 2014.

1094 Art. 41.4. Sports regulations Volleyball version: 15 ${ }^{\text {th }}$ May 2015; Art. 41.4. Sports regulations Volleyball version: 15 $5^{\text {th }}$ May 2014; Art. 41.4 Sports regulations Voll eyball version: $15^{\text {th }}$ May 2013. 
country may he or she compete for this federation. ${ }^{1095}$ Consequently, if an athlete wishes to compete for another federation, there needs to be a change in the federation of origin, which is possible only once in an athlete's carer, and needs the approval of both the FIVB, as well as the relevant federations'. ${ }^{1096}$ In order to achieve this, the athlete needs to have been residing in the territory of the new federation for at least two continuous years ${ }^{1097}$ and must have acquired the citizenship of the country. ${ }^{1098}$ Proof that the athlete fulfils these requirements must be submitted to the FIVB, and in addition, a fee needs to be paid. ${ }^{1099}$ If the athlete was al ready a national of the new federation, the two-year residence period does not apply. ${ }^{1100}$ Athletes who have been residents in the country of the new federation for at least eight years can change their federation of origin without having to comply with the requirements of citizenship, payment of fees or the approval of the federations. ${ }^{1101}$ This is possible if athletes file such a request in the calendar year during which they turn 38 in the case of men or 35 for women. ${ }^{1102}$ This differentiation between the genders and the ages could be considered discriminatory, as no reason is given why a male athlete has to be 38 in contrast to a female's 35 years. In exceptional circumstances the Board of Administration could rule on the eligibility of an athlete ${ }^{1103}$

1095 Art. 41.1 and 41.4.2 Sports regulations Volleyball version: 15 41.4.2 Sports regulations Volleyball version: $15^{\text {th }}$ May 2014; Art. 41.1 and Art. 41.4.2 Sports regulations Volleyball version: $15^{\text {th }}$ May 2013. Art. 44.1, Art. 44.2.3 and Art. 44.2.4 Sports regulations Volleyball version: $15^{\text {th }}$ May 2015; Art. 44.1, Art. 44.2.3 and Art. 44.2.4 Sports regulations Volleyball version: $15^{\text {th }}$ May 2014; Art 44.1 and Art 44.2.3 Sports regulations Voll eyball version: $15^{\text {th }}$ May 2013. Volleyball version: $15^{\text {th }}$ May 2014; Art. 44.2.2 Sports regulations Volleyball version: $15^{\text {th }}$ May 2013.

Art. 44.2.1 Sports regulations Volleyball version: 15 $5^{\text {th }}$ May 2015; Art. 44.2.1 Sports regulations Volleyball version: $15^{\text {th }}$ May, 2014; Art 44.2.1 Sports regulations Volleyball version: $15^{\text {th }}$ May 2013. Art. 44.3.1, Art. 44.2.5 and Art. 44.3.2 Sports regulations Volleyball version: $15^{\text {th }}$ May 2015; Art. 44.3.1, Art. 44.2.5 and Art. 44.3.2 Sports regulations Voll eyball version: 15 $5^{\text {th }}$ May 2014.

1100 Art. 44.4 Sports regulations Volleyball version: 15 $5^{\text {th }}$ May 2015; Art. 44.4 Sports regulations Volleyball version: $15^{\text {th }}$ May 2014; 44.4 Sports regulations Voll eyball version: 15 $5^{\text {th }}$ May 2013.

1101 Art. 44.4.2 Sports regulations Volleyball version: $15^{\text {th }}$ May 2015; Art 44.4.2 Sports regulations Volleyball version: $15^{\text {th }}$ May 2014.

1102 Art. 44.4.2 Sports regulations Volleyball version: 15 $5^{\text {th }}$ May 2015; Art 44.4.2 Sports regulations Volleyball version: $15^{\text {th }}$ May 2014.

1103 Art. 5.3 and Art. 43.3 Sports regulations Volleyball version: 15 $5^{\text {th }}$ May 2015; Art. 5.3 and Art. 43.3 Sports regulations Volleyball version: $15^{\text {th }}$ May 2014; Art. 5.3 and Art. 43.3 Sports regulations Volleyball version: $15^{\text {th }}$ May 2013. 


\section{Ball sports with rackets}

In this section the focus will be on sports with rackes, namely badminton, tennis and table tennis - although the design of the rackets differs depending on the individual demands of the sports.

Of these three tennis is the one with the longest Olympic history, making its debut in 1896 and having women's events since 1900. Y et, between 1928 and 1984, both were absent from the Olympic Games. Table tennis and badminton started out with both men's and women's events in 1988 and 1992 respectively. They have been Olympic disciplines ever since.

Table XXIX: Topics dealt with in sports involving rackets

\begin{tabular}{|c|c|c|c|}
\hline Requirements & Badminton & Tennis & Table Tennis \\
\hline In force since & 2005 & 2005 & 2005 \\
\hline Versions since 2005 & Since 2005 & Since 2005 & Since 2005 \\
\hline $\begin{array}{l}\text { Substantial C hanges } \\
\text { made since October } \\
2013\end{array}$ & $n / a$ & $\begin{array}{l}\text { n/a } \\
2015 \text { - C hange in the } \\
\text { Fed and Davis } C \text { up } \\
\text { rules, but not the } \\
\text { main constitution }\end{array}$ & n/a \\
\hline C hange of nationality & possible & $\begin{array}{l}\text { Constitution: possible } \\
\text { In Fed and Davis Cup } \\
\text { Rules: not possible }\end{array}$ & $\begin{array}{l}\text { Possi ble until the age } \\
\text { of } 21 \text { with effect for all } \\
\text { compeitions, } \\
\text { afterwards only for } \\
\text { Olympic Games }\end{array}$ \\
\hline $\begin{array}{l}\text { Residence } \\
\text { requirements }\end{array}$ & none & $\begin{array}{l}\text { In Constitution: None } \\
\text { In Fed and Davis Cup } \\
\text { Rules } 5 \text { years and } \\
\text { unlimited residence } \\
\text { permit. }\end{array}$ & $\begin{array}{l}\text { In case a country has } \\
\text { more than one } \\
\text { association }\end{array}$ \\
\hline $\begin{array}{l}\text { M inors and } \\
\text { nationality change }\end{array}$ & $\begin{array}{l}\text { Minors competein the } \\
\text { U19 competitions }\end{array}$ & $\begin{array}{l}\text { In Constitution: Not } \\
\text { specified. } \\
\text { For Fed Cup: no } \\
\text { athletes younger than } \\
14 \text { are ligible } \\
\text { In Fed and Davis Cup } \\
\text { Rules: only one nation } \\
\text { may berepresented at } \\
\text { senior level. }\end{array}$ & $\begin{array}{l}\text { Waiting period } \\
\text { depends on age of } \\
\text { athlete and age at the } \\
\text { time of registration. } \\
\text { Theol der an athletethe } \\
\text { longer the waiting } \\
\text { period and after the age } \\
\text { of } 21 \text { no change will } \\
\text { have effect for world } \\
\text { cup, world team cup, } \\
\text { world championships }\end{array}$ \\
\hline Stateless athletes & Not specified & $\begin{array}{l}\text { In Constitution: Not } \\
\text { specified. } \\
\text { In Fed and Davis Cup } \\
\text { Rules: may compete } \\
\text { for country of } \\
\text { residence after } 5 \text { years } \\
\text { if in possession of } \\
\text { unlimited residence } \\
\text { permit. }\end{array}$ & Not mentioned \\
\hline
\end{tabular}




\begin{tabular}{|c|c|c|c|}
\hline $\begin{array}{l}\text { Position of athletes } \\
\text { with multiple } \\
\text { nationality after } \\
\text { having competed for } \\
\text { another country of } \\
\text { which the athlete is a } \\
\text { national }\end{array}$ & $\begin{array}{l}\text { Threyear waiting } \\
\text { period }\end{array}$ & $\begin{array}{l}\text { In Constitution: Three } \\
\text { year waiting period, } \\
\text { which may be reduced } \\
\text { or wai ved. } \\
\text { In Fed and Davis Cup } \\
\text { Rules: cannot change } \\
\text { country of } \\
\text { representation. }\end{array}$ & $\begin{array}{l}\text { Change possible under } \\
\text { certain conditions, } \\
\text { depending on age and } \\
\text { registration for most } \\
\text { competitions }\end{array}$ \\
\hline $\begin{array}{l}\text { E ffect of changes in } \\
\text { territory of country }\end{array}$ & $\begin{array}{l}\text { Athletes may choose } \\
\text { which entity to } \\
\text { compete for and this } \\
\text { decision will be } \\
\text { effective directly }\end{array}$ & $\begin{array}{l}\text { In Constitution, Fed } \\
\text { and Davis Cup Rules } \\
\text { Athletes may choose } \\
\text { once which entity to } \\
\text { represent, no waiting } \\
\text { period is needed. }\end{array}$ & $\begin{array}{l}\text { Athlete may choose } \\
\text { any of the new or old } \\
\text { entities once }\end{array}$ \\
\hline $\begin{array}{l}\text { Competing for the } \\
\text { country of residence }\end{array}$ & $\begin{array}{l}\text { Not possible for non- } \\
\text { passport hol ders }\end{array}$ & $\begin{array}{l}\text { In Constitution: Not } \\
\text { possible } \\
\text { In Fed and Davis Cup } \\
\text { Rules: Possibleafter } 5 \\
\text { years and with } \\
\text { unlimited residence } \\
\text { permit. }\end{array}$ & Not possible \\
\hline $\begin{array}{l}\text { Number of changes } \\
\text { possible }\end{array}$ & No maximumgiven & $\begin{array}{l}\text { In Constitution: Once } \\
\text { after changein } \\
\text { territorial reality, no } \\
\text { maximumgiven for } \\
\text { normal change with } \\
\text { waiting period. } \\
\text { In Fed and Davis Cup } \\
\text { Rules: none. }\end{array}$ & $\begin{array}{l}\text { Depends on } \\
\text { competition, nonefor } \\
\text { over } 21 \text { year ol ds for all } \\
\text { except Olympic games }\end{array}$ \\
\hline $\begin{array}{l}\text { R eference to O lympic } \\
\text { C harter }\end{array}$ & Yes & $\begin{array}{l}\text { In Constitution: } \\
\text { Several. } \\
\text { In Fed and Davis Cup } \\
\text { Rules: None }\end{array}$ & Yes \\
\hline $\begin{array}{l}\text { Uses nationality/ } \\
\text { citizenship }\end{array}$ & Neither & $\begin{array}{l}\text { Constitution: Both } \\
\text { In Fed and Davis Cup } \\
\text { Rules: nation and } \\
\text { citizen }\end{array}$ & $\begin{array}{l}\text { Nationality \& } \\
\text { citizenship for Olympic } \\
\text { Games }\end{array}$ \\
\hline $\begin{array}{l}\text { Uses residence/ } \\
\text { domicile }\end{array}$ & Neither & $\begin{array}{l}\text { Constitution: Both. } \\
\text { In Fed and Davis Cup } \\
\text { Rules: residence }\end{array}$ & $\begin{array}{l}\text { Both in relation to the } \\
\text { eligibility for the } \\
\text { Olympic Games }\end{array}$ \\
\hline $\begin{array}{l}\text { Other remarkable } \\
\text { peculiarity }\end{array}$ & & $\begin{array}{l}\text { In Constitution: Very } \\
\text { focussed on IOC } \\
\text { Executive committee }\end{array}$ & $\begin{array}{l}\text { Different rules for } \\
\text { competitions with the } \\
\text { Olympic Games being } \\
\text { themost lenient ones }\end{array}$ \\
\hline
\end{tabular}




\subsection{Badminton ${ }^{1104}$}

Badminton was invented by the Duke of Beaufort at his home, Badminton house, when he adapted a version of an Indian game ${ }^{1105}$ After its invention in 1873 , the game quickly became very popular and the first set of rules was devised in $1877 .{ }^{1106}$ The Badminton World Federation was founded in 1934 and badminton became an Olympic Sport in 1992 after being a demonstration sport in $1972 .{ }^{1107}$ Nowadays there are five events, singles and doubles for both men and women as well as mixed doubles. ${ }^{1108}$ Each match consists of threegames that go up to 21 points. ${ }^{1109}$

TableXXX: Overview of the eligibility requirements for badminton

\begin{tabular}{|l|l|}
\hline R equirements BWF & \\
\hline In force since & 2005 \\
\hline C hange of nationality & possible \\
\hline R esidence requirements & none \\
\hline M inors and nationality change & Minors competein the U19 competitions \\
\hline Stateless athletes & Not specified \\
\hline $\begin{array}{l}\text { Position of athletes with multiple nationality } \\
\text { after having competed for another country of } \\
\text { which the athlete is a national }\end{array}$ & Threeyear waiting period \\
\hline $\begin{array}{l}\text { E ffect of changes in territorial reality of } \\
\text { country }\end{array}$ & $\begin{array}{l}\text { Athletes may choose which entity to compete for } \\
\text { and this decision will beeffectivedirectly }\end{array}$ \\
\hline Competing for the country of residence & Not possiblefor non-passport holders \\
\hline Number of changes possible & No maximumgiven \\
\hline & \\
\hline R efer ence to Olympic C harter & Yes \\
\hline Uses nationality/ citizenship & Neither \\
\hline Uses residence/ domicile & Neither \\
\hline Other remarkable peculiarity & None \\
\hline
\end{tabular}

\subsubsection{Badminton critical reflection}

Badminton is one of the sports that has had the same eligibility criteria for the past decade Athletes need to hold a passport of the country they wish to represent ${ }^{1110} \mathrm{It}$ is interesting that holding a passport is seen as sufficient proof of nationality. Changing the country of representation is possible, but only after a non-representation period of

1104 The federation was contacted on $6^{\text {th }}$ August 2014 and asked to provide further insights into its eligibility criteria and older versions of the eligibility rules. The BWF replied on $7^{\text {th }}$ August and kindly replied that the eligi bility rules have been the same since 2005, with the exception of Art. 8.5 which was added in 2008. On $29^{\text {th }}$ October 2015 the federation was contacted again and asked for comments on this Chapter. As no reply was forthcoming, a first reminder was sent on $19^{\text {th }}$ November 2015 to which the BWF replied on $27^{\text {th }}$ November 2015.

IOC Information Badminton Equi pment and history: for information on non-national athl etes in the European national leagues and competitions see S. van den Bogaert, A. Cuyvers, S. Gardiner, R. Parrish, S. Miettinen, J. Soek and R. Siekmann (2010), p. 139.

1107 IOC Information Badminton Equipment and history, IOC Information BWF; IOC Reference Document Badminton.

1108 IOC Information Badminton Equipment and history, IOC Information BWF.

1109 IOC Information BWF.

1110 Art. 8.2 and Art. 8.2.1 part III - section 1A BWF general competition regulations updated $9^{\text {th }}$ November 2015. 
three years. ${ }^{1111}$ In case the territory of the country and thus the badminton federation changes, the athletes will deemed not to have competed for any federation previously and may thus compete directly for any federation they wish to represent ${ }^{1112}$ All in all, while the three year non-representation period is rather strict, there is the possibility for those who fall victim to circumstances beyond their sphere of influence to directly competefor a new country.

\subsubsection{Rules applicable since 2005}

Tuming to the question of eligibility, which is addressed in Part III - Section $1 \mathrm{~A}$ General Competition Regulations Updated: $1^{\text {tt }} J$ une 2015; $8^{\text {th }}$ December 2014; $5^{\text {th }}$ J une 2014; $3^{\text {rd }}$ December 2013 and $1^{\text {td }}$ June 2013 Badminton General Competition Regulations, the responsibility for the management of the players lies with their respective federation. ${ }^{1113}$ Athletes in turn need to have a good standing with their federation. ${ }^{1114}$ These rules take precedence over any rules adopted especially for sporting events, except over the Olympic Charter for the Olympic Games, which overulestheBWF's laws. ${ }^{1115}$

Representing a country at the intemational leve is only possible at official BWF events, eg. Continental Championships, the World Championships and Olympic Games. ${ }^{1116}$ In order to participate in one of these, an athlete needs to fulfil the sporting qual ification requirement and has to hold a passport of the country he or she

1111 Art. 8.2 and Art. 8.2.2 part III - section 1A BWF general competition regulations updated $9^{\text {th }}$ November 2015.

1112 Art. 8.4 part III - section 1A BWF general competition regulations updated $9^{\text {th }}$ November 2015.

1113 Art. 7.2 part III - section 1A BWF general competition regulations updated $9^{\text {th }}$ November 2015; Art. 7.2 part III - section 1A BWF general competition regulations updated $1^{\text {st }}$ June 2015; Art 7.2 part III - section IA BWF general competition regulations updated $8^{\text {th }}$ December 2014; Art. 7.2 part III - section IA BWF general competition regulations updated $5^{\text {th }}$ J une 2014; Art 7.2 part III section 1A BWF general competition regulations updated $3^{\text {rd }}$ December 2013; Art 7.2 part III section 1A BWF general competition regulations updated $1^{\text {st }}$ J une 2013.

1114 Art. 7.2.1 part III - section IA BWF general competition regulations updated $9^{\text {th }}$ November 2015; Art. 7.2.1 part III - section IA BWF general competition regulations updated $1^{\text {st }}$ J une 2015; Art. 7.2.1 part III - section 1A BWF general competition regulations updated $8^{\text {th }}$ December 2014; Art. 7.2.1 part III - section IA BWF general competition regulations updated $5^{\text {th }}$ J une 2014; Art. 7.2.1 part III - section IA BWF general competition regulations updated $3^{\text {rd }}$ December 2013; Art 7.2.1 part III - section 1A BWF general competition regulations updated $1^{\text {st }}$ J une 2013.

1115 Art. 8.5 part III - section IA BWF general competition regulations updated $9^{\text {th }}$ November 2015; Art. 8.5 part III - section 1A BWF general competition regulations updated $1^{\text {st }}$ June 2015; Art 8.5 part III - section IA BWF general competition regulations updated $8^{\text {th }}$ December 2014; Art. 8.5 part III - section 1A BWF general competition regulations updated $5^{\text {th }}$ J une 2014; Art. 8.5 part III section 1A BWF general competition regulations updated $3^{\text {rd }}$ December 2013; Art. 8.5 part III section 1A BWF general competition regulations updated $1^{\text {st }}$ J une 2013.

1116 Art. 8.1, Art 8.1.1 and Art. 8.1.2 part III - section IA BWF general competition regulations updated $9^{\text {th }}$ November 2015; Art 8.1, Art. 8.1.1 and Art. 8.1.2 part III - section 1A BWF general competition regulations updated $1^{\text {st }}$ J une 2015; Art. 8.1, Art 8.1.1 and Art 8.1.2 part III - section 1A BWF general competition regulations updated $8^{\text {th }}$ December 2014; Art. 8.1, Art. 8.1.1 and Art. 8.1.2 part III - section IA BWF general competition regulations updated $5^{\text {th }}$ J une 2014; Art. 8.1, Art. 8.1.1 and Art 8.1.2 part III - section IA BWF general competition regulations updated $3^{\text {rd }}$ December 2013; Art. 8.1, Art 8.1.1 and Art. 8.1.2 part III - section 1A BWF general competition regulations updated $1^{\text {st }}$ June 2013. 
wishes to represent. ${ }^{1117}$ It is interesting that hol ding a passport is seen as sufficient proof of nationality. In addition to holding a passport, which is a very formal requirement, the athlete has either last competed for the country he or she wants to compete for now, or has not represented another country for three years. ${ }^{1118}$ Consequently, athletes wishing to change their country of representation have to have a threeyear period of non-representation. Competing for a country is defined as receiving a countries official invitation and the athlete's acceptance thereof. ${ }^{1119}$ In case of territorial transfers and a change in the badminton federation, either through dissolution, division or absorption, the athletes will be deemed not to have competed for any federation previously and may thus compete directly for any federation they wish to represent ${ }^{1120}$

1117 Art. 8.2 and Art. 8.2.1 part III - section 1A BWF general competition regulations updated $9^{\text {th }}$ November 2015; Art. 8.2 and Art. 8.2.1 part III - section IA BWF general competition regulations updated $1^{\text {st }}$ J une 2015; Art. 8.2 and Art. 8.2.1 part III - section 1A BWF general competition regulations updated $8^{\text {th }}$ December 2014; Art. 8.2 and Art. 8.2.1 part III - section 1A BWF general competition regulations updated $5^{\text {th }}$ J une 2014; Art 8.2 and Art 8.2.1 part III - section 1A BWF general competition regulations updated $3^{\text {rd }}$ December 2013; Art. 8.2 and Art. 8.2.1 part III section 1A BWF general competition regulations updated $1^{\text {st }}$ J une 2013.

1118 Art. 8.2, Art 8.2.2 and Art. 8.2.3 part III - section IA BWF general competition regulations updated $9^{\text {th }}$ November 2015; Art 8.2, Art 8.2.2 and Art. 8.2.3 part III - section 1A BWF general competition regulations updated $1^{\text {st }}$ J une 2015; Art. 8.2, Art. 8.2.2 and Art 8.2.3 part III - section 1A BWF general competition regulations updated $8^{\text {th }}$ December 2014; Art. 8.2, Art. 8.2.2 and Art. 8.2.3 part III - section 1A BWF general competition regulations updated $5^{\text {th }}$ J une 2014; Art. 8.2, Art. 8.2.2 and Art 8.2.3 part III - section IA BWF general competition regulations updated $3^{\text {rd }}$ December 2013; Art. 8.2, Art 8.2.2 and Art. 8.2.3 part III - section IA BWF general competition regulations updated $1^{\text {st }}$ J une 2013.

1119 Art. 8.3 part III - section 1A BWF general competition regulations updated $9^{\text {th }}$ November 2015; Art. 8.3 part III - section 1A BWF general competition regulations updated $1^{\text {st } J ~ u n e ~ 2015 ; ~ A r t ~} 8.3$ part III - section 1A BWF general competition regulations updated $8^{\text {th }}$ December 2014; Art. 8.3 part III - section 1A BWF general competition regulations updated $5^{\text {th }}$ J une 2014; Art 8.3 part III section IA BWF general competition regulations updated $3^{\text {rd }}$ December 2013; Art. 8.3 part III section $1 \mathrm{~A}$ BWF general competition regulations updated $1^{\text {st }}$ J une 2013 .

1120 Art. 8.4 part III - section IA BWF general competition regulations updated $9^{\text {th }}$ November 2015; Art. 8.4 part III - section 1A BWF general competition regulations updated $1^{\text {st }}$ J une 2015; Art 8.4 part III - section 1A BWF general competition regulations updated $8^{\text {th }}$ December 2014; Art. 8.4 part III - section 1A BWF general competition regulations updated $5^{\text {th }}$ J une 2014; Art 8.4 part III section IA BWF general competition regulations updated $3^{\text {rd }}$ December 2013; Art. 8.4 part III section $1 \mathrm{~A}$ BWF general competition regulations updated $1^{\mathrm{st}} \mathrm{J}$ une 2013 . 


\subsection{Tennis ${ }^{1121}$}

Tennis developed from the French 'jeu de paume' and quickly became popular in England. ${ }^{1122}$ As in this older sport, the aim is to hit a ball in such a way that it crosses the net which is dividing the court and lands in the other player's half in such a way that the opponent is unable to reach it in time to hit it back. By 1913 tennis had become very popular all over the world and the national ternis associations held an international conference in Paris in 1924 and founded the first international tennis federation, the International Lawn Tennis Federation (ILTF). ${ }^{1123}$ This federation changed its name in 1977 and became the International Tennis Federation. ${ }^{1124}$ Tennis was an Olympic discipline between 1896 and 1924, when the requirement that no professionals were to compete at the Olympics caused the federation to withdraw. ${ }^{1125}$ In 1988 tennis returned and now includes competitions for both men and women in singles and doubles. ${ }^{1126}$ Matches are played in three sets and the best athlete or couple during these matches wins. ${ }^{1127}$ The finals for men in the single and double categories for which matches are comprised of five sets. ${ }^{1128}$ Professionals are now again al lowed to participate ${ }^{1129}$

TableXXXI: Overview of the eligibility requirements for tennis

\begin{tabular}{|l|l|}
\hline Requirements ITF & \\
\hline In force since & 2005 \\
\hline Change of nationality & $\begin{array}{l}\text { Constitution: possible } \\
\text { In Fed and Davis Cup Rules: }{ }^{1130} \text { not possible }\end{array}$ \\
\hline Residence requirements & $\begin{array}{l}\text { In Constitution: None } \\
\text { In Fed and Davis Cup Rules fiveyears and } \\
\text { unlimited residence permit }\end{array}$ \\
\hline M inors and nationality change & $\begin{array}{l}\text { In Constitution: Not specified. } \\
\text { For Fed Cup: no athletes younger than } 14 \text { are } \\
\text { eligible }\end{array}$ \\
\hline
\end{tabular}

1121 The federation was contacted on $6^{\text {th }}$ August 2014 and asked to provide further insights into its eligibility criteria and ol der versions of the eligibility rules. The ITF kindly replied on $14^{\text {th }}$ August 2014 and said that there had been no rule changes since 2005. The ITF further underlined that in order to be able to compete for a country at the Olympics the player needs to have met the Davis Cup or Fed Cup eligi bility requirements. Till 2016 these regulations stipulated that a player can represent a different country after a period of three years, provided that the athlete in question holds the relevant passport and has resided there for 24 consecutive months at some period. On $29^{\text {th }}$ October 2015 the federation was contacted again and asked for comments on this Chapter. As no reply was forthcoming, a first reminder was sent on $19^{\text {th }}$ November 2015 and a second on $2^{\text {nd }}$ December 2015 to which the ITF replied on $9^{\text {th }}$ December.

1122 IOC Information Tennis Equipment and History.

1123 IOC Information ITF; IOC Information Tennis Equi pment and History.

1124 IOC Information ITF.

1125 IOC Information ITF; IOC Information Tennis Equi pment and History. IOC Reference Document Tennis: for information on non-national athletes in the European national leagues and competitions see S. van den Bogaert, A. Cuyvers, S. Gardiner, R. Parrish, S. Miettinen, J. Soek and R. Siekmann (2010), p. 139.

1126 IOC Information ITF; IOC Information Tennis Equi pment and History.

1127 IOC Information ITF.

1128 Ibid.

1129 IOC Information ITF; IOC Information Tennis Equi pment and History.

1130 Fed and Davis Cup rules changed in 2015. 


\begin{tabular}{|c|c|}
\hline & $\begin{array}{l}\text { In Fed and Davis Cup Rules: only one nation may } \\
\text { be represented at senior leve. }\end{array}$ \\
\hline Stateless athletes & $\begin{array}{l}\text { In Constitution: Not specified. } \\
\text { In Fed and Davis Cup Rules: may competefor } \\
\text { country of residenceafter fiveyears if in } \\
\text { possession of unlimited residence permit }\end{array}$ \\
\hline $\begin{array}{l}\text { Position of athletes with multiple nationality } \\
\text { after having competed for another country of } \\
\text { which the athlete is a national }\end{array}$ & $\begin{array}{l}\text { In Constitution: Threyear waiting period, which } \\
\text { may be reduced or waived. } \\
\text { In Fed and Davis Cup Rules: cannot change } \\
\text { country of representation. }\end{array}$ \\
\hline E ffect of changes in territory of country & $\begin{array}{l}\text { In Constitution, Fed and Davis Cup Rules Athletes } \\
\text { may choose once which entity to represent, no } \\
\text { waiting period is needed. }\end{array}$ \\
\hline Competing for the country of residence & $\begin{array}{l}\text { In Constitution: Not possible } \\
\text { In Fed and Davis Cup Rules: Possible after five } \\
\text { years and with unl imited residence permit. }\end{array}$ \\
\hline Number of changes possible & $\begin{array}{l}\text { In Constitution: Once after changein territorial } \\
\text { real ity, no maximum given for normal change with } \\
\text { waiting period. } \\
\text { In Fed and Davis Cup Rules: none }\end{array}$ \\
\hline R eference to Olympic C harter & $\begin{array}{l}\text { In Constitution: Several. } \\
\text { In Fed and Davis Cup Rules: None }\end{array}$ \\
\hline Uses nationality/ citizenship & $\begin{array}{l}\text { Constitution: Both } \\
\text { In Fed and Davis Cup Rules: nation and citizen }\end{array}$ \\
\hline Uses residence/ domicile & $\begin{array}{l}\text { Constitution: Both. } \\
\text { In Fed and Davis Cup Rules: residence }\end{array}$ \\
\hline Other remarkable peculiarity & $\begin{array}{l}\text { In Constitution: Very focussed on IOC Executive } \\
\text { committee }\end{array}$ \\
\hline
\end{tabular}

\subsubsection{Tennis critical reflection}

The ITF eligibility criteria enshrined in the Constitution have not undergone any substantial changes since 2005. The underlying rule is that athletes have to be nationals of the country they want to represent ${ }^{1131}$ Athl etes with multiple nationality are initially free to choose ${ }^{1132}$ All athletes who have al ready represented a country internationally need to undergo the same procedure, ${ }^{1133}$ which requires a threeyear waiting period. ${ }^{1134}$ In case of a teritorial transfer, the athl etes may decide to continue

1131 Rule 41(1) Constitution of ITF limited 2016 trading as International Tennis Federation memorandum articles of association and byelaws of ITF limited trading as the International Tennis Federation (unchanged since 2005).

1132 Bye Law to Rule 41(1) Constitution of ITF limited 2016 trading as International Tennis Federation memorandum articles of association and byelaws of ITF limited trading as the International Tennis Federation (unchanged since 2005).

1133 Bye-Law to Rule 41(1) Constitution of ITF limited 2016 trading as International Tennis Federation memorandum articles of association and byelaws of ITF limited trading as the International Tennis Federation (unchanged since 2005).

1134 Bye Law to Rule 41(2) Constitution of ITF limited 2016 trading as International Tennis Federation memorandum articles of association and bye-laws of ITF limited trading as the International Tennis Federation (unchanged since 2005). 
representing the country they represented before ${ }^{1135}$ Should they however wish to compete for a new country, they can decide to do so once and will not face a waiting period. ${ }^{1136}$ Although the topics of minors or stateless athletes are not addressed in the Constitution, the ITF has a rather comprehensive approach to the problems that can arise from nationality changes in the field of sport Especially the last paragraph refering to the Byelaw to Rule 41 underscores that any issues will be dealt with not by the ITF itself, but the IOC. The threyear waiting period is rather strict and certainly deters athletes from changing their country of representation due to mercenary tendencies. The Fed and Davis Cup rules are al so applicable and go into greater detail and also deal with stateless athletes and those faced with territorial change ${ }^{1137}$ The most striking aspect of these rules is that since 2016 no changes of the country of representation are allowed under Fed and Davis Cup rule, while the Constitution still allows for them. Thereis thus a conflict of rules within the ITF.

\subsubsection{Rules applicable since 2005}

The main eligibility rules for tennis are spelled out in the Constitution of the ITF trading as intemational tennis federation Memorandum Articles of Association and Bye laws of the ITF limited trading as the International Ternis Federation. Theserules have not changed since 2005 according to the ITF. In the context of eligi bility Rule 41 on the Nationality of Competitors and the Byelaw to this rule are the most important. However, as tennis players need to have been part of a final nominated teem in either the Davis Cup, the men's only competition, or the Fed Cup, the women's only competition, on a minimum of three occasions in the four-year Olympic cycle, these eligibility rules al so havean impact upon Olympic eligi bility.

Regarding the rules stipulated in the ITF Constitution, it can be seen that the underlying rule is that athletes have to be nationals of the country they want to represent ${ }^{1138}$ In case an athlete's country of representation has to be determined for the purpose of the Olympic Games, the IOC Executive Board will take the necessary

1135 Bye-Law to Rule 41(3) Constitution of ITF limited 2016 trading as International Tennis Federation memorandum articles of association and byelaws of ITF limited trading as the International Tennis Federation (unchanged since 2005).

1136 Bye Law to Rule 41(3) Constitution of ITF limited 2016 trading as International Tennis Federation memorandum articles of association and byelaws of ITF limited trading as the International Tennis Federation (unchanged since 2005).

1137 Rule 31 b) iii) b) ITF Fed Cup Regulations 2016; Rule 35 a) iii) b) ITF Davis Cup Regulation 2016; Rule 31 c) i) and Rule 31 c) ii) ITF Fed Cup Regulations 2016; Rule 35 b) i) and Rule 35 b) ii) ITF Davis Cup Regulation 2016.

1138 Rule 41(1) Constitution of ITF limited 2016 trading as International Tennis Federation memorandum articles of association and byelaws of ITF limited trading as the International Tennis Federation; Rule 41(1) Constitution of ITF limited 2015 trading as International Tennis Federation memorandum, articles of association and bye-laws of ITF limited trading as the International Tennis Federation; Rule 41(1) Constitution of ITF limited 2014 trading as International Tennis Federation memorandum, articles of association and byelaws of ITF limited trading as the International Tennis Federation; Rule 41(1) Constitution of ITF limited 2013 trading as International Tennis Federation memorandum articles of association and bye-laws of ITF limited trading as the International Tennis Federation (unchanged since 2005). 
decisions. ${ }^{1139}$ In addition to these underlying rules, the Bye Law to Rule 41 deals with the cases of dual national ity, athletes wishing to represent other countries than the ones they have al ready represented and territorial transfers.

Starting with multiple nationality of athletes, the ITF prescribes that athletes have to choose to compete for one of the countries of which they are nationals. ${ }^{1140}$ After having represented one country intemational ly, the athlete can only change his or her country of representation in the same way athletes can change their country of representation after changing or acquiring an entirely new nationality. ${ }^{1141}$ This procedure requires a threeyear waiting period during which the athlete cannot compete internationally. ${ }^{1142}$ This period may however be waived or entirely cancelled if the relevant federations, national Olympic committees and the IOC Executive Board agree ${ }^{1143}$ The decision is made on a case-by-case basis, with the

1139 Rule 41(2) Constitution of ITF limited 2016 trading as International Tennis Federation memorandum articles of association and byelaws of ITF limited trading as the International Tennis Federation; Rule 41(2) Constitution of ITF limited 2015 trading as International Tennis Federation memorandum articles of association and byelaws of ITF limited trading as the International Tennis Federation; Rule 41(2) Constitution of ITF limited 2014 trading as International Tennis Federation memorandum, articles of association and byelaws of ITF limited trading as the International Tennis Federation; Rule 41(2) Constitution of ITF limited 2013 trading as International Tennis Federation memorandum articles of association and bye-laws of ITF limited trading as the International Tennis Federation (unchanged since 2005).

Bye Law to Rule 41(1) Constitution of ITF limited 2016 trading as International Tennis Federation memorandum articles of association and bye-laws of ITF limited trading as the International Tennis Federation; Bye-Law to Rule 41(1) Constitution of ITF limited 2015 trading as International Tennis Federation memorandum articles of association and byelaws of ITF limited trading as the International Tennis Federation; Bye-Law to Rule 41(1) Constitution of ITF limited 2014 trading as I nternational Tennis Federation memorandum, articles of association and bye-laws of ITF limited trading as the International Tennis Federation; Bye-Law to Rule 41(1) Constitution of ITF limited 2013 trading as International Tennis Federation memorandum, articles of association and byelaws of ITF limited trading as the International Tennis Federation (unchanged since 2005).

1141 Bye Law to Rule 41(1) Constitution of ITF limited 2016 trading as International Tennis Federation memorandum articles of association and byelaws of ITF limited trading as the International Tennis Federation; Bye-Law to Rule 41(1) Constitution of ITF limited 2015 trading as International Tennis Federation memorandum, articles of association and bye laws of ITF limited trading as the International Tennis Federation; Bye Law to Rule 41(1) Constitution of ITF limited 2014 trading as I nternational Tennis Federation memorandum, articles of association and bye-laws of ITF limited trading as the International Tennis Federation; Bye-Law to Rule 41(1) Constitution of ITF limited 2013 trading as International Tennis Federation memorandum, articles of association and byelaws of ITF limited trading as the International Tennis Federation (unchanged since 2005).

1142 Bye Law to Rule 41(2) Constitution of ITF limited 2016 trading as International Tennis Federation memorandum articles of association and byelaws of ITF limited trading as the International Tennis Federation; ByeLaw to Rule 41(2) Constitution of ITF limited 2015 trading as International Tennis Federation memorandum, articles of association and bye-laws of ITF limited trading as the International Tennis Federation; Bye-Law to Rule 41(2) Constitution of ITF limited 2014 trading as International Tennis Federation memorandum, articles of association and bye-laws of ITF limited trading as the International Tennis Federation; Bye-Law to Rule 41(2) Constitution of ITF limited 2013 trading as International Tennis Federation memorandum, articles of association and byelaws of ITF limited trading as the International Tennis Federation (unchanged since 2005).

1143 Bye Law to Rule 41(2) Constitution of ITF limited 2016 trading as International Tennis Federation memorandum articles of association and byelaws of ITF limited trading as the International Tennis Federation; ByeLaw to Rule 41(2) Constitution of ITF limited 2015 trading as 
IOC Executive Board looking at the special circumstances of each case to come to a conclusion. ${ }^{1144}$

In case of territorial transfers, either through independence, incorporation or any territorial transfer, the athletes may decide to continue representing the country they represented before ${ }^{1145}$ Athletes may, however, al so decide to compete for one of the new entities and will not need to undergo a waiting period. ${ }^{1146}$ Such a choice may only be made once ${ }^{1147}$ This means that athletes may not simply switch between several countries for which there are eligible - after the choice is made once, he or she can however rely on the other procedure involving the threyear waiting period.

International Tennis Federation memorandum articles of association and byelaws of ITF limited trading as the International Tennis Federation; Bye Law to Rule 41(2) Constitution of ITF limited 2014 trading as International Tennis Federation memorandum, articles of association and bye-laws of ITF limited trading as the International Tennis Federation; Bye-Law to Rule 41(2) Constitution of ITF limited 2013 trading as International Tennis Federation memorandum, articles of association and byelaws of ITF limited trading as the International Tennis Federation (unchanged since 2005).

1144 Bye-Law to Rule 41(2) Constitution of ITF limited 2016 trading as International Tennis Federation memorandum articles of association and byelaws of ITF limited trading as the International Tennis Federation; Bye-Law to Rule 41(2) Constitution of ITF limited 2015 trading as International Tennis Federation memorandum, articles of association and byelaws of ITF limited trading as the International Tennis Federation; Bye Law to Rule 41(2) Constitution of ITF limited 2014 trading as International Tennis Federation memorandum, articles of association and bye-laws of ITF limited trading as the International Tennis Federation; Bye-Law to Rule 41(2) Constitution of ITF limited 2013 trading as International Tennis Federation memorandum, articles of association and byelaws of ITF limited trading as the International Tennis Federation (unchanged since 2005).

1145 Bye-Law to Rule 41(3) Constitution of ITF limited 2016 trading as International Tennis Federation memorandum articles of association and byelaws of ITF limited trading as the International Tennis Federation; ByeLaw to Rule 41(3) Constitution of ITF limited 2015 trading as International Tennis Federation memorandum, articles of association and bye laws of ITF limited trading as the International Tennis Federation; Bye Law to Rule 41(3) Constitution of ITF limited 2014 trading as International Tennis Federation memorandum, articles of association and bye-laws of ITF limited trading as the International Tennis Federation; Bye-Law to Rule 41(3) Constitution of ITF limited 2013 trading as International Tennis Federation memorandum, articles of association and byelaws of ITF limited trading as the International Tennis Federation (unchanged since 2005).

1146 Bye Law to Rule 41(3) Constitution of ITF limited 2016 trading as International Tennis Federation memorandum articles of association and byelaws of ITF limited trading as the International Tennis Federation; Bye-Law to Rule 41(3) Constitution of ITF limited 2015 trading as International Tennis Federation memorandum, articles of association and byelaws of ITF limited trading as the International Tennis Federation; Bye Law to Rule 41(3) Constitution of ITF limited 2014 trading as International Tennis Federation memorandum, articles of association and bye-laws of ITF limited trading as the International Tennis Federation; Bye-Law to Rule 41(3) Constitution of ITF limited 2013 trading as International Tennis Federation memorandum, articles of association and bye-laws of ITF limited trading as the International Tennis Federation (unchanged since 2005).

1147 Bye Law to Rule 41(3) Constitution of ITF limited 2016 trading as International Tennis Federation memorandum articles of association and byelaws of ITF limited trading as the International Tennis Federation; Bye-Law to Rule 41(3) Constitution of ITF limited 2015 trading as International Tennis Federation memorandum, articles of association and byelaws of ITF limited trading as the International Tennis Federation; Bye-Law to Rule 41(3) Constitution of ITF limited 2014 trading as International Tennis Federation memorandum, articles of association and bye-laws of ITF limited trading as the International Tennis Federation; Bye-Law to Rule 41(3) Constitution of ITF limited 2013 trading as International Tennis Federation memorandum, articles of association and byelaws of ITF limited trading as the International Tennis Federation (unchanged since 2005). 
In any case in which an athlete's country of representation could be problematic and which is involving the Olympic Games, the IOC Executive Board may:

"takeall decisions of a general or individual nature with regard to issues resulting from nationality, citizenship, domicile or residence of any competitor, induding the duration of any waiting period."1148

The way this is worded is interesting, since it indudes all possible terms that may be used relating to theissue of establishing a genuine link between the countries and their athletes. It al so underlines that the final decision rests with theIOC.

\subsubsection{Fed and Davis Cup}

Looking briefly at therules applicable in the Fed and Davis Cup, it is first important to underline that their eligi bility rules are almost identical, with the exception of an age limit ind uded for the Fed Cup, pred uding athl etes younger than 14 from competing in the tournament ${ }^{1149}$ While this still allows young teenagers to compete in adult toumaments, thereis a certain level of protection of minors here

Generally, at Fed and Davis Cup competitions, athletes may only compete for nations for which they are citizens and have held a passport for at least 24 months. ${ }^{1150}$ Should such a passport not be issued by the nation, the athlete needs to have a document proving his or her birth place was in that nation. ${ }^{1151}$ The focus on the birthplace and thus ius soli returns in the paragraph deal ing with athletes who are unable to hold a valid passport, but have been resident in a nation for five consecutive years. ${ }^{1152}$ If such a ius soli link is given or if an ancestor was born in that nation, the athlete may compete for the nation without having the necessary passport ${ }^{1153}$ Moreover, the focus on competing for a nation is interesting as it goes beyond the more frequently used phrase of representing a country. In that respect, al so the use of 'citizen' in contrast to 'nation' has to be mentioned, as one would have expected the ITF to use 'national'.

Athletes with multiple nationality may be nominated by either association. This association then has to notify the ITF Executive, who will then notify all other

1148 Bye Law to Rule 41(4) Constitution of ITF limited 2016 trading as International Tennis Federation memorandum articles of association and byelaws of ITF limited trading as the International Tennis Federation; ByeLaw to Rule 41(4) Constitution of ITF limited 2015 trading as International Tennis Federation memorandum, articles of association and byelaws of ITF limited trading as the International Tennis Federation; Bye Law to Rule 41(4) Constitution of ITF limited 2014 trading as International Tennis Federation memorandum, articles of association and bye-laws of ITF limited trading as the International Tennis Federation; Bye-Law to Rule 41(4) Constitution of ITF limited 2013 trading as International Tennis Federation memorandum, articles of association and byelaws of ITF limited trading as the International Tennis Federation (unchanged since 2005).

1149 Rule31 a) ITF Fed Cup Regulations 2016.

1150 Rule31 b) i) ITF Fed Cup Regulations 2016; Rule 35 a) i) ITF Davis Cup Regulation 2016.

1151 Rule31 b) ii) ITF Fed Cup Regulations 2016; Rule 35 a) ii) ITF Davis Cup Regulation 2016.

1152 Rule 31 b) iii) and Rule 31 b) iii) a) ITF Fed Cup Regulations 2016; Rule 35 a) iii) and Rule 35 a) iii) a) ITF Davis Cup Regulation 2016.

1153 Rule 31 b) iii) a) ITF Fed Cup Regulations 2016; Rule 35 a) iii) a) ITF Davis Cup Regulation 2016. 
associations that have a connection with the athlete. These other associations may comment on the athlete's nomination and the ITF will give a final ruling. ${ }^{1154}$ When an athlete accepts a nomination, he or she will be deemed to have represented that nation. ${ }^{1155}$ It is important to note that, since 2016, athletes may only compete for one nation at a senior leve ${ }^{1156}$ and that thus changes of the country of representation are not possible under the Davis and Fed Cup rules - though they do feature in the ITF Constitution. These rules are thus extremely contradictory.

The ITF al so deal s with stateless athletes or refugees in Davis and Fed Cup rul es, as athl etes who have has obtained or procured the right to remain permanently or has been granted humanitarian protection in that nation and have been residents there for five years may al so compete for the nation. ${ }^{1157}$ In addition, those athletes faced with territorial transfers may compete directly for a new country. ${ }^{1158}$

\footnotetext{
1154 Rule 31 b) ITF Fed Cup Regulations 2016; Rule 35 a) ITF Davis Cup Regulation 2016.

1155 Rule31 d) ITF Fed Cup Regulations 2016; Rule 35 d) ITF Davis Cup Regulation 2016.

1156 Rule31 b) ITF Fed Cup Regulations 2016; Rule 35 a) ITF Davis Cup Regulation 2016.

1157 Rule 31 b) iii) b) ITF Fed Cup Regulations 2016; Rule 35 a) iii) b) ITF Davis Cup Regulation 2016.

1158 Rule 31 c) i) and Rule 31 c) ii) ITF Fed Cup Regulations 2016; Rule 35 b) i) and Rule 35 b) ii) ITF Davis Cup Regulation 2016.
} 


\subsection{Table Tennis ${ }^{1159}$}

Table tennis was invented in England as an al temative to the popular lawn tennis in the late $19^{\text {th }}$ century. ${ }^{1160}$ As in lawn tennis, the aim is to hit the ball in such a way that the opponent on the other side of the table is unable to reach it when it comes down in his or her half. In 1926 the Intemational Table Tennis Federation (ITTF) was founded in London and has its seat in Lausanne ${ }^{1161}$ Its Olympic debut came in 1988 and nowadays thereareteam and single events for men and women. ${ }^{1162}$ Per team, thereare three players and three is al so the maximum number of players per gender that an NOC may send to the Olympics. ${ }^{1163}$

TableXXII: Overview of the eligibility requirements for tabletennis

\begin{tabular}{|c|c|}
\hline Requirements ITTF & \\
\hline In force since & 2005 \\
\hline C hange of nationality & $\begin{array}{l}\text { Possi ble until the age of } 21 \text { with effect for all } \\
\text { competitions, afterwards only for Olympic Games }\end{array}$ \\
\hline Residence requirements & In case a country has more than one association \\
\hline M inors and nationality change & $\begin{array}{l}\text { Waiting period depends on age of athleteand age at the } \\
\text { time of registration. the ol der an athl ete the longer the } \\
\text { waiting period and after the age of } 21 \text { no change will have } \\
\text { effect for world cup, world team cup, world } \\
\text { championships }\end{array}$ \\
\hline Stateless athletes & Not mentioned \\
\hline $\begin{array}{l}\text { Position of athletes with multiple } \\
\text { nationality after having competed for } \\
\text { another country of which the athlete is a } \\
\text { national }\end{array}$ & $\begin{array}{l}\text { Change possible under certain conditions, depending on } \\
\text { age and registration for most competitions }\end{array}$ \\
\hline E ffect of changes in territory of country & Athlete may chooseany of thenew or old entities once \\
\hline Competing for the country of residence & Not possible \\
\hline Number of changes possible & $\begin{array}{l}\text { Depends on competition, none for over } 21 \text { year olds for } \\
\text { all except Olympic games }\end{array}$ \\
\hline R eference to O lympic C harter & Yes \\
\hline Uses nationality/ citizenship & National ity \& citizenship for Olympic Games \\
\hline Uses residence/ domicile & Both in relation to the eligibility for theOlympic Games \\
\hline Other remarkable peculiarity & $\begin{array}{l}\text { Different rules for competitions with the Olympic Games } \\
\text { being the most lenient ones }\end{array}$ \\
\hline
\end{tabular}

1159 The federation was contacted on $6^{\text {th }}$ August 2014 and asked to provide further insights into its eligibility criteria and older versions of the eligibility rules. The ITTF replied on $7^{\text {th }}$ August 2014 and kindly supplied all necessary handbooks. On $29^{\text {th }}$ October 2015 the federation was contacted again and asked for comments on this Chapter. As no reply was forthcoming, a first reminder was sent on $19^{\text {th }}$ November 2015 and a second on $2^{\text {nd }}$ December 2015. No reply was received by the time of publication.

1160 IOC Information TableTennis Equipment and History.

1161 IOC Information ITTF; IOC Information Table Tennis Equipment and History; IOC Reference Document TableTennis.

1162 IOC Information ITTF; IOC Information Table Tennis Equipment and History; IOC Reference Document Table Tennis: for information on non-national athletes in the European national leagues and competitions see S. van den Bogaert, A. Cuyvers, S. Gardiner, R. Parrish, S. Miettinen, J. Soek and R. Siekmann (2010), p. 139. 


\subsubsection{TableTennis critical reflection}

Since 2005, the ITTF eligibility criteria have remained identical. The underlying principle is that an athlete can only represent a country of which he or she is a national. ${ }^{1164}$ However, if an athlete has represented another country due to previously applicable rules, he or shemay continueto do so. ${ }^{1165}$ As in most federations, the ITTF stipulates that athl etes with more than onenationality are initial ly freeto choose which association to represent ${ }^{1166}$ Such a choice is in principle binding. ${ }^{1167} Y$ et, athl etes who acqui re a new nationality may represent the new country following a threeyear noncompetition period. ${ }^{1168}$ For athletes affected by territorial transfers, the ITTF stipulates that they may either choose to continue to compete for the original country or may decide to compete for one of the new entities ${ }^{1169}$ This choice is only possible once ${ }^{1170}$ All in all, the ITTF has very detailed rules, which include rules addressing a lot of possible situations. Changing the country of representation is possible, but only after a rather long period of non-competition.

\subsubsection{Rules applicable since 2005}

In the last years, there have been six different rule books dealing with the eligibility criteria in tabl etennis, spanning from 2005 to 2008, 2008 to 2009; 2009 to 2010; 2010 to 2012 and most recently the ones spelled out in the ITTF Handbooks of 2013-2014, 2014 - 2015 and the one of 2016. These rules differ minimally in their wording, eg. since September 2012 athletes are referred to as 'he or she' in the artides, ${ }^{1171}$ and a reference to the Paralympic Games is made ${ }^{1172}$ Another difference is the reference to an athlete being a national on $1^{\text {t }}$ September 2004, which is present in the 2005 - 2008 and 2010- 2012 versions. ${ }^{1173}$ Hence, the rules of 3.8 dealing with International eligibility will be considered as not having changed with regard to their substance Article 3.8.1 delineates where the individual provisions can be found. Questions regarding eligibility are dealt with by theEligibility Commission. ${ }^{1174}$

In general, an athlete wishing to represent an association has to be a national of the country over which the association has jurisdiction. ${ }^{1175}$ However, it is possible that an athlete:

1164 Art. 3.8.3 ITTF handbook 2016.

1165 Art. 3.8.3 ITTF handbook 2016.

1166 Art. 3.8.3.2 ITTF handbook 2016.

1167 Art. 4.5.1.3.2 ITTF handbook 2016.

1168 Art. 4.5.1.3.3 ITTF handbook 2016

1169 Art. 4.5.1.3.5 ITTF handbook 2016.

1170 Art. 4.5.1.3.5 ITTF handbook 2016

1171 Art. 3.8.2 ITTF handbook 2012 - 2013.

1172 Art. 3.8.1 ITTF handbook 2012 - 2013.

1173 Art. 3.8.3 ITTF handbook 2005 - 2008; Art. 3.8.3 ITTF handbook 2010 -2012.

1174 Art. 3.8.8 ITTF handbook 2014 - 2015; Art 3.8.8 ITTF handbook 2013 - 2014; Art 3.8.8 ITTF handbook 2012 - 2013; Art. 3.8.8 ITTF handbook 2010 - 2012; Art. 3.8.8 ITTF handbook 20092010; Art. 3.8.8 ITTF handbook 2008-2009; Art. 3.8.8 ITTF handbook 2005 - 2008.

1175 Art. 3.8.3 ITTF handbook 2016; Art 3.8.3 ITTF handbook 2014 - 2015; Art. 3.8.3 ITTF handbook 2013 - 2014; Art. 3.8.3 ITTF handbook 2012 - 2013; Art. 3.8.3 ITTF handbook 2010 - 2012; Art. 3.8.3 ITTF handbook 2009 - 2010; Art. 3.8.3 ITTF handbook 2008 - 2009; Art. 3.8 .3 ITTF handbook 2005 - 2008. 
"who has already represented an Association of which he or she was not a national in accordance with previous rules may retain that eligibility."

This means that athletes who used to compete for a country of which they were not national s prior to 2004 may continue to compete for there levant association.

In case a country's athletic pool is governed by more than one association, eg. in the case of the Welsh Table Tennis Association whose athletes have British passports as do the athl etes representing Scotland, the athlete has to ful fil additional requirements to pick one of the associations. ${ }^{1177}$ They need to either have been bom on this particular territory or need to have their residence in it. ${ }^{1178}$ Thus anyone wishing to compete for Wales not only has to to have a British passport, but should have either been born on Welsh territory or should maintain his or her main residence there Athletes with more than one nationality are free to choose which association they wish to represent ${ }^{1179}$ Athletes may not represent two different associations within three years. ${ }^{1180}$ Representing in this case means that an athlete accepts an official nomination from the association and competes in one of the officially sanctioned competitions. ${ }^{1181} \mathrm{An}$ athlete may be requested to "provide documentary evidence of his or her eligibility and his or her passport". ${ }^{1182}$ This indicates that a passport in itself does not constitute sufficient evidence of eligibility.

Tuming to the individual competitions, the ITTF stipulates that for World Cup, team world cup and world championship eligibility criteria, a player needs to fulfil

1176 Art. 3.8.3 ITTF handbook 2016; Art. 3.8.3 ITTF handbook 2014 - 2015; Art. 3.8.3 ITTF handbook 2013 - 2014; Art. 3.8.3 ITTF handbook 2012 - 2013; Art. 3.8.3 ITTF handbook 2010 - 2012; Art. 3.8.3 ITTF handbook 2009-2010; Art. 3.8.3 ITTF handbook 2008 - 2009; Art. 3.8.3 ITTF handbook 2005 - 2008.

1177 Art. 3.8.3.1 ITTF handbook 2016; Art 3.8.3.1 ITTF handbook 2014 - 2015; Art 3.8.3.1 ITTF handbook 2013 - 2014; Art. 3.8.3.1 ITTF handbook 2012 - 2013; Art 3.8.3.1 ITTF handbook 2010 - 2012; Art. 3.8.3.1 ITTF handbook 2009 - 2010; Art. 3.8.3.1 ITTF handbook 2008 - 2009; Art. 3.8.3.1 ITTF handbook 2005 - 2008.

1178 Art. 3.8.3.1 ITTF handbook 2016; Art 3.8.3.1 ITTF handbook 2014 - 2015; Art 3.8.3.1 ITTF handbook 2013 - 2014; Art. 3.8.3.1 ITTF handbook 2012 - 2013; Art 3.8.3.1 ITTF handbook 2010 - 2012; Art. 3.8.3.1 ITTF handbook 2009 - 2010; Art. 3.8.3.1 ITTF handbook 2008 - 2009; Art. 3.8.3.1 ITTF handbook 2005 - 2008.

1179 Art. 3.8.3.2 ITTF handbook 2016; Art 3.8.3.2 ITTF handbook 2014 - 2015; Art 3.8.3.2 ITTF handbook 2013 - 2014; Art. 3.8.3.2 ITTF handbook 2012 - 2013; Art 3.8.3.2 ITTF handbook 2010 - 2012; Art. 3.8.3.2 ITTF handbook 2009 - 2010; Art. 3.8.3.2 ITTF handbook 2008 - 2009; Art. 3.8.3.2 ITTF handbook 2005 - 2008.

1180 Art. 3.8.5 ITTF handbook 2016; Art. 3.8.5 ITTF handbook 2014 - 2015; Art. 3.8.5 ITTF handbook 2013 - 2014; Art. 3.8.5 ITTF handbook 2012 - 2013; Art. 3.8.5 ITTF handbook 2010 - 2012; Art. 3.8.5 ITTF handbook 2009 - 2010; Art. 3.8.5 ITTF handbook 2008 - 2009; Art. 3.8.5 ITTF handbook 2005 - 2008.

1181 Art. 3.8.2 ITTF handbook 2016; Art 3.8.2 ITTF handbook 2014 - 2015; Art. 3.8.2 ITTF handbook 2013 - 2014; Art. 3.8.2 ITTF handbook 2012 - 2013; Art. 3.8.2 ITTF handbook 2010 - 2012; Art. 3.8.2 ITTF handbook 2009 - 2010; Art. 3.8.2 ITTF handbook 2008 - 2009; Art. 3.8.2 ITTF handbook 2005 - 2008.

1182 Art. 3.8.7 ITTF handbook 2016; Art 3.8.7 ITTF handbook 2014 - 2015; Art. 3.8.7 ITTF handbook 2013 - 2014; Art. 3.8.7 ITTF handbook 2012 - 2013; Art. 3.8.7 ITTF handbook 2010 - 2012; Art. 3.8.7 ITTF handbook 2009 - 2010; Art. 3.8.7 ITTF handbook 2008 - 2009; Art. 3.8.7 ITTF Handbook 2005 - 2008. 
different waiting periods prior to competing for the new association, depending on the age at which he or she first registered. ${ }^{1183}$

These rul es are very strict as theathletes may have to wait up to seven years for a nationality change to become effective ${ }^{1184}$ Furthermore, World Championships, World Cup and World Team Cup competition rules state that any player aged 21 or over may not change their country of representation with effect for these competitions. ${ }^{1185}$

In addition to these very strict rules for the 'adult' competitions, the world junior championship also prescribes a threy year wait for those who have acquired a new nationality and wish to represent the other country now. ${ }^{1186}$ This is however only possible if the athlete was younger than 15 upon registration. ${ }^{1187}$ Hence, youth athletes will face a significantly long wait upon changing their country of representation, which might lead to themrestarting their career only as adults.

With regard to the Olympic Games, the ITTF firstly underscores the need for compliance with the IOC Rules, ${ }^{1188}$ such as the Anti-Doping Code, ${ }^{1189}$ and the spirit of fair play. ${ }^{1190}$ Regarding nationality, the ITTF states that the athlete who is to represent a country is to bea national of that country. ${ }^{1191}$

Athletes with multiple nationality may select which one he or she wants to represent ${ }^{1192}$ Such a choice is in principle binding, unless the athl ete acquires a new nationality and complies with a threeyears non-competition period prior to competing for the new country in the Olympic Games. ${ }^{1193}$ Furthermore, the time of non-competition of three years is significantly shorter than the postulated seven years and may even be reduced or cancel led given the circumstances of individual cases. $^{1194}$

1183

Art. 4.1.3.3; Art. 4.3.6.2; 4.4.6.2 ITTF handbook 2016; Art. 4.1.3.3; Art. 4.3.6.2; Art. 4.4.6.2 ITTF handbook 2014 - 2015; Art. 4.1.3.3; Art 4.3.6.2; 4.4.6.2 ITTF handbook 2013 - 2014.

Art. 4.1.3.3.3; Art. 4.3.6.2.3; Art 4.4.6.2.3 ITTF handbook 2016; Art 4.1.3.3.3; Art 4.3.6.2.3; Art. 4.4.6.2.3 ITTF handbook 2014 - 2015; Art 4.1.3.3.3; Art. 4.3.6.2.3; Art. 4.4.6.2.3 ITTF handbook $2013-2014$.

Art. 4.1.3.4; Art 4.3.6.3; Art 4.4.6.3 ITTF handbook 2014- 2014; Art. 4.1.3.4; Art 4.3.6.3; Art. 4.4.6.3 ITTF handbook 2013- 2014.

Art. 4.2.3.4 ITTF handbook 2016; Art 4.2.3.4 ITTF handbook 2014 - 2015; Art 4.2.3.4 ITTF handbook 2013-2014.

Art. 4.2.3.5 ITTF handbook 2016; Art 4.2.3.5 ITTF handbook 2014 - 2015; Art 4.2.3.5 ITTF handbook 2013 - 2014.

Art. 4.5.1.1 ITTF handbook 2016; Art 4.5.1.1 ITTF handbook 2014 - 2015; Art 4.5.1.1 ITTF handbook 2013 - 2014.

Art. 4.5.1.1.3 ITTF handbook 2016; Art. 4.5.1.1.3 ITTF handbook 2014 - 2015; Art. 4.5.1.1.3 ITTF handbook 2013 - 2014.

Art. 4.5.1.1.2 ITTF handbook 2016; Art. 4.5.1.1.2 ITTF handbook 2014 - 2015; Art. 4.5.1.1.2 ITTF handbook 2013 - 2014.

Art. 4.5.1.3 ITTF handbook 2016; Art 4.5.1.3 ITTF handbook 2014 - 2015; Art 4.5.1.3 ITTF handbook 2013- 2014.

Art. 4.5.1.3.1 ITTF handbook 2016; Art. 4.5.1.3.1 ITTF handbook 2014 - 2015; Art. 4.5.1.3.1 ITTF handbook 2013 - 2014.

Art. 4.5.1.3.2 and Art 4.5.1.3.3 ITTF handbook 2016; Art 4.5.1.3.2 and Art 4.5.1.3.3 ITTF handbook 2014 - 2015; Art. 4.5.1.3.2 and Art 4.5.1.3.3 ITTF handbook 2013 - 2014.

Art. 4.5.1.3.4 ITTF handbook 2016; Art. 4.5.1.3.4 ITTF handbook 2014 - 2015; Art. 4.5.1.3.4 ITTF handbook 2013 - 2014. 
In case of territorial transfers, the athletes of the country may either chooseto continue to compete for the original country or may decide to compete for one of the new entities. ${ }^{1195}$ This choice is only possible once ${ }^{1196}$ - although onecan presumethat, if in the aftermath of such a change in teritory the borders are redrawn again, an athlete would begiven a choice again, since this should count as another teritorial transfer. In any case, the IOC Executive board will deal with any disputes regarding "nationality, citizenship, domicile or residence of the player". ${ }^{1197}$ It is interesting that all theseterms are enumerated here - showing that really all issues relating to an athlete's eligibility will be dealt with.

1195 Art. 4.5.1.3.5 ITTF handbook 2016; Art. 4.5.1.3.5 ITTF handbook 2014 - 2015; Art. 4.5.1.3.5 ITTF handbook 2013 - 2014.

1197 Art. 4.5.1.4 ITTF handbook 2016; Art 4.5.1.4 ITTF handbook 2014 - 2015; Art 4.5.1.4 ITTF handbook 2013 - 2014. 



\section{Aiming with an object for a goal}

The following two sports, curling and golf, are rather different in their execution, while the general aim of moving one object so that it reaches a goal on - or respectively in the ground - is very similar. Interestingly, both sports originate from Scottish games. Curling first became Olympic in 1924, but then was not present again until 1998. In turn, 2016 will mark golf's Olympic debut

Table: XXXIII: Topics dealt with in sports ai ming with an object for a goal

\begin{tabular}{|c|c|c|}
\hline Requirements & Curling & Golf \\
\hline In force since & 2010 & J une 2014 \\
\hline Versions since 2005 & $\begin{array}{l}2005-2010 \\
\text { Since } 2010\end{array}$ & $\begin{array}{l}\text { 2010-2014 } \\
\text { Since J une } 2014\end{array}$ \\
\hline $\begin{array}{l}\text { Substantial changes made } \\
\text { since October } 2013\end{array}$ & n/a & $\begin{array}{l}\text { No nationality requirements } \\
\text { prior to J une } 2014\end{array}$ \\
\hline C hange of nationality & Possible & Possible \\
\hline Residence requirements & $\begin{array}{l}\text { Two years if athlete wishes to } \\
\text { compete for country of } \\
\text { residence }\end{array}$ & $\begin{array}{l}\text { May beused in special } \\
\text { circumstances }\end{array}$ \\
\hline M inors and nationality change & Not specified & $\begin{array}{l}\text { Not specified, but falls under } \\
\text { catch-call article }\end{array}$ \\
\hline Stateless athletes & $\begin{array}{l}\text { Not specified, but may compete } \\
\text { for country of residence }\end{array}$ & $\begin{array}{l}\text { Not specified, but falls under } \\
\text { catch-call article }\end{array}$ \\
\hline $\begin{array}{l}\text { Position of athletes with } \\
\text { multiple nationality after } \\
\text { having competed for another } \\
\text { country of which the athlete is } \\
\text { a national }\end{array}$ & $\begin{array}{l}\text { Not specified, change of country } \\
\text { of representation al ways } \\
\text { possibleafter a two-year waiting } \\
\text { timeand fulfilling either the } \\
\text { national ity or residence } \\
\text { requirement }\end{array}$ & $\begin{array}{l}\text { Possible after non-competition } \\
\text { for four years }\end{array}$ \\
\hline $\begin{array}{l}\text { E ffect of changes in territory } \\
\text { of country }\end{array}$ & Not specified & $\begin{array}{l}\text { Athletes can choose oncefor } \\
\text { which country they wish to } \\
\text { compete }\end{array}$ \\
\hline $\begin{array}{l}\text { Competing for the country of } \\
\text { residence }\end{array}$ & $\begin{array}{l}\text { Possibleafter two-year } \\
\text { residence }\end{array}$ & $\begin{array}{l}\text { Not specified, but falls under } \\
\text { catchall article }\end{array}$ \\
\hline Number of changes possible & No maximumgiven & No maximumgiven \\
\hline R efer ence to O lympic C harter & Yes & None \\
\hline U ses nationality/ citizenship & Nationality & $\begin{array}{l}\text { Both, athlete has to be a citizen } \\
\text { to be considered a national }\end{array}$ \\
\hline Uses residence/ domicile & Residence & Residenceand domicile \\
\hline Other remarkable peculiarity & $\begin{array}{l}\text { Focus on residence and genuine } \\
\text { link }\end{array}$ & $\begin{array}{l}\text { Non-competition period can be } \\
\text { extended }\end{array}$ \\
\hline
\end{tabular}




\subsection{C urling ${ }^{1198}$}

Curling devel oped from a Scottish Game, which was al ready played in the early $16^{\text {th }}$ century. ${ }^{1199}$ During the course of the $20^{\text {th }}$ century, the rules and equipment were standardi sed. ${ }^{1200}$ Teams consist of four players who each deliver two stones al ternating with their opponents. ${ }^{1201}$ The aim is to let the delivered stone glide over the ice to reach one of the concentric cirdes (called the house) - a point is scored for every stone nearer to the centre of the house than any stone of the opposing team Only stones in the house count towards the score and only one team can score per end. ${ }^{1202}$ Each player delivers two stones and two of theteam's players sweep theice before the stone to influence the stone's speed and direction. ${ }^{1203}$ The temperature of the ice is controlled and fine water droplets are sprinkled over it (pebbling). ${ }^{1204}$ There are ten rounds during which the players deliver the stones, which are called 'ends'. ${ }^{2005}$ The score of such an 'end' is determined when each team has thrown its eight stones and the team that scores best during the overall match wins. ${ }^{1206}$ The World Curling Federation was founded as the International Curling Federation in 1966 - interestingly after the sport became Olympic in $1924 .{ }^{1207}$ However, curling was not an Olympic sport in 1928 1932, 1936, 1952, 1956, 1960, 1964, 1968, 1972, 1976, 1980, 1984, 1988, 1992, and 1994. ${ }^{1208}$ Curling was a demonstration sport in 1988 and 1992, before becoming an Olympic discipline again in $1998 .{ }^{1209}$ Since 1998, there have been men's and women's compeitions at all the Olympic Winter Games. ${ }^{1210}$

TableXXXIV: Ovenview of the eligibility requirements for curling

\begin{tabular}{|l|l|}
\hline Requirements & \\
\hline In force since & $1^{\mathrm{s}}$ June2011 \\
\hline C hange of nationality & Possible \\
\hline R esidence requirements & $\begin{array}{l}\text { Two years if athletewishes to compete for country } \\
\text { of residence }\end{array}$ \\
\hline M inors and nationality change & Not specified \\
\hline Stateless athletes & $\begin{array}{l}\text { Not specified, may compete for country of } \\
\text { residence }\end{array}$ \\
\hline
\end{tabular}

1198 The federation was contacted on $6^{\text {th }}$ August 2014 and asked to provide further insights into its eligibility criteria and ol der versions of the eligibility rules. The WCF replied on $7^{\text {th }}$ August 2014, providing a comparison of the different rules and stating that the only rul e change occurred in 2010 and the rules between 2010 and 2005 had been identical. On 29th October 2015, the WCF was contacted again and asked for comments on this chapter, which the WCF provided on $29^{\text {th }}$ October 2015.

1199 IOC Information Curling Equipment and History.

1200 Ibid.

1201 IOC Information WCF.

1202 Ibid.

1203 Ibid.

1204 Ibid.

1205 Ibid.

1206 Ibid.

1207 IOC Information WCF; IOC I nformation Curling Equi pment and History.

1208 IOC Reference Document Curling; IOC Reference Document Curling.

1209 IOC Information Curling Equipment and History; IOC Reference Document Curling.

1210 IOC Information WCF; IOC Information Curling Equipment and History; IOC Reference Document Curling. 


\begin{tabular}{|l|l|}
\hline $\begin{array}{l}\text { Position of athletes with multiple nationality } \\
\text { after having competed for another country of } \\
\text { which the athlete is a national }\end{array}$ & $\begin{array}{l}\text { Not specified, change of country of representation } \\
\text { always possibleafter a two-year waiting timeand } \\
\text { fulfilling either thenationality or residence } \\
\text { requirement }\end{array}$ \\
\hline E ffect of changes in territory of country & Not specified \\
\hline Competing for the country of residence & Possi bleafter two-year residence \\
\hline Number of changes possible & No maximumgiven \\
\hline & \\
\hline R efer ence to Olympic Charter & Yes \\
\hline Uses nationality/ citizenship & Nationality \\
\hline Uses residence/ domicile & Residence \\
\hline Other remarkable peculiarity & Focus on residenceand genuinelink \\
\hline
\end{tabular}

\subsubsection{Curling critical reflection}

TheWCF has rather liberal rules, as athletes may compete for a country either if they arenationals of the country or if they have been residents in the relevant country for at least two years. ${ }^{1211}$ Changing the country of representation is possi ble efter a two-year non-compeition period. ${ }^{1212}$ These rules are extremely lenient, as competing for the country of residence is envisioned. Furthermore, the two-year non-competition period is not extremely long and, although this time will affect the athlete's carer, it is less intrusivethan a four-year period.

\subsubsection{Rules applicable since 2010}

Eligibility rules for curling are set down in the Rules of Curling and Rules of Competition of J une 2011, which in the case of the artides relating to eligibility have

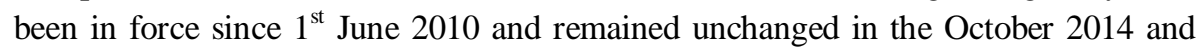
October 2015 document updates. These rules do not apply to Olympic Compeitions, since they are subject to the IOC's rules. ${ }^{1213}$ In order to be eligible to compete for a country, the athlete has to either be a national of the country or a resident in the country for at least two years prior to the competition. ${ }^{1214}$ Nationals might explicitly have their residence anywhere and competing for the country of residence is a possibility. If an athlete has al ready competed in an official curling competition and wishes to change the country of representation, he or she needs to either acquire the nationality of the relevant country or be a resident thereof for two consecutive years. ${ }^{1215}$ In any case, the athlete will have to wait for two years between the

\footnotetext{
1211 Art. 1 eligibility the rules of Curling and rules of competition of October 2015.

1212 Art. 2 eligibility the rules of Curling and rules of competition of October 2015.

1213 Art. 3 eligibility the rules of Curling and rules of competition of October 2015; Art. 3 eligibility the rules of Curling and rules of competition of October 2014; Art 3 eligibility the rules of Curling and rules of competition of J une 2011.

1214 Art. 1 eligibility the rules of Curling and rules of competition of October 2015; Art. 1 eligibility the rules of Curling and rules of competition of October 2014; Art 1 eligibility the rules of Curling and rules of competition of J une 2011.

1215 Art. 2 eligibility the rules of Curling and rules of competition of October 2015; Art. 2 eligibility the rules of Curling and rules of competition of October 2014; Art. 2 eligibility the rules of Curling and rules of competition of J une 2011.
} 
compeitions for the different countries. ${ }^{1216}$ In case a problem arises with regard to eligibility, the athlete or association in question must go to the WCF Executive Board which will decide on thesituation. ${ }^{1217}$

\subsubsection{Rules applicable $2005-2010$}

According to the WCF's email of $7^{\text {th }}$ August 2014 and the subsequent emails the rules beforethechange on 2010 werethe sameand as foll ows:

June2007 RuleBook p 40:

“(1) Eligibility: is based on curlers who are qualified nationally to represent their country either by birth, being children of parents bom in that country, or by permanent residence in that country for a consecutive period of at least two years before the first of April in the year of the World Championships. A person is qualified to play for a spouse's country if resident in that country. It should be noted that this eligibility and qualification will not apply to playing in the Olympic Winter Games, which will be governed by the regulations of the Intemational Olympic Committee"1218

This very concise rule thus all lowed for athletes who were nationals of the country to represent that country. Those who were permanent residents for a consecutive period of two years could al so represent their country of residence, provided that this period was completed prior to $1^{\text {st }}$ April of the World Championships year. The question remaining is however, why it had to be the $1^{\text {st }}$ April and not for example the $6^{\text {th }}$ October. The text did not provide any answers on this matter. Also, the provision that an athlete might compete for the country of which his or her spouse was a national provided that the athl ete was resident there- is interesting. Would an athl ete lose this right in case of a divorce or death of a spouse? And did a residency period apply? The WCF stressed that for the purpose of Olympic Games the IOC Charter applied to all questions regarding eligibility.

\footnotetext{
1216 Art. 2 eligibility the rules of Curling and rules of competition of October 2015; Art. 2 eligibility the rules of Curling and rules of competition of October 2014; Art. 2 eligibility the rules of Curling and rules of competition of J une 2011.

1217 Art. 4 eligibility the rules of Curling and rules of competition of October 2015; Art. 4 eligibility the rules of Curling and rules of competition of October 2014; Art 4 eligibility the rules of Curling and rules of competition of J une 2011.

1218 June2007 Rule book p. 40 according to WCF E-mail of $6^{\text {th }}$ August 2014.
} 


\subsection{G olf ${ }^{1219}$}

Golf developed simultaneously in the Netherlands and in Scotland. ${ }^{1220}$ The first rules were laid down in 1754 and remain hardly changed. ${ }^{1221}$ The aim is to use as few strokes as possible to navigate the ball over obstacles such as lakes, trees, sand filled bunkers, rivers, or hills. ${ }^{1222}$ Depending on the ground, wind direction and strength and the position of the ball on the ground, the players use different clubs to strike the ball. ${ }^{1223}$ Golf has only recently become an Olympic discipline and will have its debut at the 2016 Games after being an Olympic Sport shortly in 1900 and 1904, 2224 although back in 1904 only the US and Canada were contestants. ${ }^{1225}$ In 1958 the International Golf Federation was founded. ${ }^{1226}$ In 2016 there will be two 72-hole individual stroke play events, one for men and onefor women, who will play the same golf course of several times. ${ }^{1227}$

TableXXXV: Overview of the eligibility requirements for golf

\begin{tabular}{|l|l|}
\hline R equirements IG F & \\
\hline In force since & June2014 \\
\hline C hange of nationality & Possible \\
\hline R esidence requirements & May be used in special circumstances \\
\hline M inors and nationality change & Not specified, but falls under catchall article \\
\hline Stateless athletes & Not specified, but falls under catchall article \\
\hline $\begin{array}{l}\text { Position of athletes with multiple nationality } \\
\text { after having competed for another country of } \\
\text { which the athlete is a national }\end{array}$ & Possi bleafter non-competition for four years \\
\hline E ffect of changes in territory of country & $\begin{array}{l}\text { Athletes can choose oncefor which country they } \\
\text { wish to compete }\end{array}$ \\
\hline C ompeting for the country of residence & Not specified, but falls under catchall article \\
\hline Number of changes possible & No maximumgiven \\
\hline & None \\
\hline R eference to Olympic Charter & $\begin{array}{l}\text { Both, athletehas to bea citizen to beconsidered a } \\
\text { national }\end{array}$ \\
\hline Uses nationality/ citizenship & Residenceand domicile \\
\hline U ses residence/ domicile & Non-competition period can be extended \\
\hline Other remarkable peculiarity &
\end{tabular}

1219 The federation was contacted on $6^{\text {th }}$ August 2014 and asked to provide further insights into its eligibility criteria and older versions of the eligibility rules. As no reply was forthcoming, a reminder e-mail was sent on $18^{\text {th }}$ September and a reply with the newly implemented nationality rules applicable as of J une 2014 was sent on $29^{\text {th }}$ October 2015 the federation was contacted again and asked for comments on this Chapter. As no reply was forthcoming, a first reminder was sent on $19^{\text {th }}$ November 2015 to which the IGF replied on $24^{\text {th }}$ November 2015. IOC Information Golf Equipment and History.

1221 Ibid.

1222 Ibid.

1223 IOC Information Golf Equipment and History.

1224 IOC Information IGF; IOC Information Golf Equipment and History; IOC Reference Document Golf.

1225 IOC Information IGF; IOC I nformation Golf Equi pment and History.

1226 Ibid.

1227 Ibid. 


\subsubsection{Golf critical reflection}

Golf is new to the Olympics and its nationality rules have only been in place since J une 2014. The underlying principle is that athletes need to be nationals of the country they wish to represent ${ }^{1228}$ Athletes with multiple nationality can choose for which country to compete ${ }^{1229}$ Changes are only possible after four years of noncompetition. ${ }^{1230}$ This results in the athlete facing an extremely long break from international toumaments and it can even be extended, which is unique among the Olympic sports. ${ }^{1231}$ If a teritorial transfer occurs, the athletes concerned may choose to either remain with their old federation or compete for the new one Such a choice however is only possible once ${ }^{1232}$ Overall, the newly introduced rules are rather strict, as a four year or longer non-competition period will have a severe influence on an athlete's career.

\subsubsection{Rules applicable since J une 2014}

Since June 2014 the IGF has its own nationality policy. Therein the IGF stipulates that theathletes need to benational s of the country they represent. ${ }^{1233}$ For the purpose of theIGF:

"A compeitor will be considered a National of a country if the competitor is a citizen of the country, as defined by thelaws of such country."1234

Thus the IGF not only stresses that the national rules of the respective countries apply, but it also makes citizenship a condition for nationality. Athletes with multiple nationality can select to compete for either country, but they can only change their country of representation after having had a non-competition period of four years. ${ }^{1235}$ Such a period al so applies to athletes who competed for one country and then acquired a new nationality. ${ }^{1236}$ It important to notice that this period can not only be reduced and cancelled if the revant federations agree, as it is customary with the other sports, but it can al so potentially beextended. ${ }^{1237}$ Therefore, athletes could in principlefacean even longer enforced break fromintemational competitions.

Should a territorial transfer occur, the athletes concerned may choose to either remain with their old federation or compete for the new country. Such a choice is however only possible once ${ }^{1238}$ In all other cases in which gol fers could compete for a country, the IGF may take decisions on issues revolving around residence,

\footnotetext{
1228 Art. III. IGF national ity policy J une 2014.

1229 Ibid.

1230 Ibid.

1231 Ibid.

1232 Ibid.

1233 Art. I. IGF national ity policy J une 2014.

1234 Art. III. IGF nationality policy June 2014.

1235 Ibid.

1236 Ibid.

1237 Ibid.

1238 Ibid.
} 
domicile, citizenship, or nationality. ${ }^{1239}$ The fact that all these terms are enumerated shows that the IGF really aims at dealing with all issues that could be at stake and could allow for a certain flexibility.

11.2.3. Rules applicable2005 - 2014

Prior to June 2014, there were two documents on the official website of the IGF, one dealing with the anti-doping rules and the other the Constitution of International Golf Federation, the 2010 Version. Neither of these documents contained eligibility criteria pertaining to nationality. 



\section{Movement over ground}

In the following, cycling and equestrian sports will be examined. These sports share one common characteristic, namely, the aim to move over ground without the athletes' feet actually touching the ground. Although a bike and a horse are very different, the main idea is to 'ride' on something to cover distances ${ }^{1240}$ Road and track cycling are the oldest Olympic sports, having their Olympic debut in 1986, with equestrian entering in 1900. Mountain biking and BMX came later, in 1996 and 2008 respectively. Interestingly, equestrian was the first of the sports to allow women to participate and since 1952 there have only been mixed events. Road cycling had its first women's events in 1984 and track cycling in 1988. Thenewer cycling disciplines allowed both men and women from the start

TableXXXVI: Topics dealt with in sports that focus on movement over ground

\begin{tabular}{|c|c|c|}
\hline Requirements & Cycling & Equestrian \\
\hline In force since & 2014 & 2014 \\
\hline Versions since 2005 & $\begin{array}{l}2005 \text { - } 2011 \\
2011 \text { - } 2014 \\
\text { Since } 2014\end{array}$ & $\begin{array}{l}2005-2006 \\
2007-2008 \\
2009 \\
\text { Since } 2010\end{array}$ \\
\hline $\begin{array}{l}\text { Substantial changes made } \\
\text { since October } 2013\end{array}$ & $\begin{array}{l}\text { Reference to loss of nationality } \\
\text { introduced }\end{array}$ & $\mathrm{Wa}$ \\
\hline C hange of nationality & Possibleonce & $\begin{array}{l}\text { The way through which the } \\
\text { nationality was acquired only } \\
\text { matters with regard to the } \\
\text { residence requirement and } \\
\text { possible exceptions }\end{array}$ \\
\hline R esidence requirements & $\begin{array}{l}\text { None, except for stateless } \\
\text { athletes }\end{array}$ & $\begin{array}{l}\text { Many exceptions possible, in } \\
\text { general the residence } \\
\text { requirement can either be } \\
\text { fulfilled through two } \\
\text { uninterrupted years of legal } \\
\text { residence or fivenon- } \\
\text { consecutive years of legal } \\
\text { residence }\end{array}$ \\
\hline M inors and nationality change & $\begin{array}{l}\text { May change upon reaching age } \\
\text { of majority }\end{array}$ & Possible annually \\
\hline Stateless athletes & $\begin{array}{l}\text { Can compete for country of } \\
\text { residence after five years }\end{array}$ & $\begin{array}{l}\text { May compete for new } \\
\text { association directly }\end{array}$ \\
\hline $\begin{array}{l}\text { Position of athletes with } \\
\text { multiple nationality after } \\
\text { having competed for another } \\
\text { country of which the athlete is } \\
\text { a national }\end{array}$ & $\begin{array}{l}\text { Possible if first appearance was } \\
\text { when still a minor }\end{array}$ & $\begin{array}{l}\text { Change directly possible, with } \\
\text { the exception of some } \\
\text { tournaments for which a two- } \\
\text { year break is necessary }\end{array}$ \\
\hline $\begin{array}{l}\text { E ffect of changes in territory } \\
\text { of country }\end{array}$ & Not specified & $\begin{array}{l}\text { Possible to choose once for } \\
\text { either entity old or new }\end{array}$ \\
\hline
\end{tabular}

1240 Though a bicycle is coll loquial referred to as 'Drahtesel', literally translated as wire mule or metal mulein German. 
NATIONALITY REQUiREMENTS In OLy MPIC SPORTS

\begin{tabular}{|l|l|l|}
\hline $\begin{array}{l}\text { Competing for the country of } \\
\text { residence }\end{array}$ & Possiblefor stateless athletes & $\begin{array}{l}\text { Possiblewith permission of } \\
\text { national federation }\end{array}$ \\
\hline Number of changes possible & Once & No maximum specified \\
\hline R eference to Olympic Charter & Yes & Yes \\
\hline Uses nationality/ citizenship & National ity & Nationality and citizen \\
\hline Uses residence/ domicile & Residence & Residence \\
\hline Other remarkable peculiarity & Refers to loss of nationality & $\begin{array}{l}\text { Very flexible; Horses need to } \\
\text { have samenationality }\end{array}$ \\
\hline
\end{tabular}




\subsection{C ycling ${ }^{1241}$}

Cycling was first invented in the mid-18 $18^{\text {th }}$ century and developed further with the invention of gears in $1885 .{ }^{1242}$ The main aim of the cycling competitions is to reach a certain goal ahead of the other cyclists. Depending on the terrain over which the athletes have to cycle, the difficulties with which the cyclists are faced vary and thus their bikes will have different characteristics adapted to the obstades. Cycling is governed by the Union Cycliste Internationale (UCI), which was founded in 1900 and a form of cycling has been at all Olympic Games except in 1900 to 1908, although there are significant differences. ${ }^{1243}$ There are currently track racing, road racing, BMX, and Mountain Biking events. ${ }^{1244}$ At the first Olympics, road racing cyclists had to cycle the marathon course twice in $1896 .{ }^{1245}$ It was notably not induded in the programme of the 1900, 1904 and 1908 Olympics. ${ }^{1246}$ Nowadays, there are events for men and women with the men's racing distance being over $200 \mathrm{~km}$ and the women's over $120 \mathrm{~km}^{1247}$ The races are either set up as mass starts (for road races) or interval starts (for time trials during which athletes have to cover a set distance in a set time). ${ }^{1248}$

Track racing is one of the oldest of the cycling disciplines, with the first races being recorded in 1870 and nowadays includes both team and individual racing events. ${ }^{1249}$ It was featured in all Olympic Games since its debut in 1896, with the sole exception of $1912 .{ }^{1250}$ The modes of the races are either sprint, individual or team pursuit, or time trial and take place in oval-shaped tracks. ${ }^{1251}$ Women have been participating since 1988 in their individual events. ${ }^{1252}$

1241 The federation was contacted on $6^{\text {th }}$ August 2014 and asked to provide further insights into its eligibility criteria and older versions of the eligibility rules. The UCI replied on $26^{\text {th }}$ August 2014 and kindly supplied all the necessary documents. On $29^{\text {th }}$ October 2015 the federation was contacted again and asked for comments on this Chapter. As no reply was forthcoming, a first reminder was sent on $19^{\text {th }}$ November 2015 to which the $\mathrm{UCl}$ replied on $27^{\text {th }}$ Novermer and $4^{\text {th }}$ December 2015.

1242 IOC Information Road Cyding Equipment and History.

1243 IOC Information UCI Cycling BMX; IOC Information UCI Cycling Road; IOC Information UCI Cycling Track; IOC Reference Document Cycling: for information on non-national athletes in the European national leagues and competitions see S. van den Bogaert, A. Cuyvers, S. Gardiner, R. Parrish, S. Miettinen, J. Soek and R. Siekmann (2010), p. 139.

IOC Information UCI Cycling BMX; IOC Information UCI Cyding Road; IOC Information UCI Cycling Track.

1245 IOC Information UCI Cycling BMX; IOC Information UCI Cycling Road; IOC Information UCI Cycling Track; IOC Information BMX Cycling Equipment and History.

1246 Ibid.

1247 IOC Information UCI Cycling BMX; IOC Information UCI Cycling Road; IOC Information UCI Cycling Track.

1248 Ibid.

1249 IOC Information UCI Cycling BMX; IOC Information UCI Cycling Road; IOC Information UCI Cycling Track; IOC Information Track Cycling Equi pment and History.

1250 IOC Information Track Cycling Equipment and History.

1251 IOC Information UCI Cycling BMX; IOC Information UCI Cycling Road; IOC Information UCI Cycling Track.

1252 IOC Information Track Cycling Equipment and History. 
BMX cycling developed from motorcross in the late 1960s and thus its cycling course features several obstades and jumps. ${ }^{1253}$ Since 2008, men and women compete in individual events. ${ }^{1254}$

Mountain biking has been an Olympic discipline since $1996 .{ }^{1255}$ This cycling discipline features a course over mountainous or rocky terrain with trees, rivers or other natural obstacles. ${ }^{1256}$ It dates back to the 1970 s, when the advent of sturdier bikes made it possible to cover more difficult terrain at higher speed. ${ }^{1257}$ The distance is $5 \mathrm{~km}$ and men's racing times are approximately two hours while women's times are onehour and 45 minutes. ${ }^{1258}$

TableXXXVII: Overview of the eligibility requirements for cycling

\begin{tabular}{|l|l|}
\hline R equirements UCI & \\
\hline In force since & March 2014 \\
\hline C hange of nationality & Once \\
\hline R esidence requirements & None, except for stateless athletes \\
\hline M inors and nationality change & May change upon reaching age of majority \\
\hline Stateless athletes & Can compete for country of residence after 5 years \\
\hline $\begin{array}{l}\text { Position of athletes with multiple nationality } \\
\text { after having competed for another country of } \\
\text { which the athlete is a national }\end{array}$ & Possi ble if first appearance was when still a minor \\
\hline E ffect of changes in territory of country & Not specified \\
\hline Competing for the country of residence & Possiblefor stateless athletes \\
\hline Number of changes possible & Once \\
\hline & \\
\hline R efer ence to Olympic Charter & Yes \\
\hline Uses nationality/ citizenship & Nationality \\
\hline Uses residence/ domicile & Residence \\
\hline Other remarkable peculiarity & Refers to loss of nationality \\
\hline
\end{tabular}

\subsubsection{Cycling critical reflection}

According to UCl statutes, athletes may only compete for a country of which they are national s. ${ }^{1259}$ Statel ess athl letes may compete for a country after having been a resident there for five years. ${ }^{1260}$ The $\mathrm{UCl}$ is one of the few federations that refer explicitly to stateless athletes and whil e five years of residenceis relatively long, it at least provides for a possibility for athletes who would otherwise not have a chance to compete

1253 IOC Information UCI Cycling BMX; IOC Information UCI Cycling Road; IOC Information UCI Cycling Track.

1254 IOC Information UCI Cycling BMX; IOC Information UCI Cycling Road; IOC Information UCI Cycling Track; IOC Information BMX Cycling Equipment and History.

1255 Ibid.

1256 IOC Information UCI Cycling BMX; IOC Information UCI Cycling Road; IOC Information UCI Cyding Track.

1257 IOC Information Mountain Bike Equi pment and History.

1258 IOC Information UCI Cycling BMX; IOC Information UCI Cycling Road; IOC Information UCI Cyding Track.

1259 Art. 1.1.033 $\$ 1 \mathrm{UCl}$ Cyding regulations general organisation of E0116 Cycling as a sport part 1 general organi sation of Cycling as a sport (version of 15.03.2016).

1260 Art. 1.1.033 §1 UCl Cycling regulations general organi sation of E0116 Cycling as a sport part 1 general organi sation of Cycling as a sport (version of 15.03.2016). 
internationally. Athletes with multiple nationality have to choose for which country they wish to compete, but they do not need to fulfil any additional criteria. ${ }^{1261}$ Changing the country of representation is possible once ${ }^{1262} \mathrm{All}$ in all, UCI rules are rather detailed. While the possibility of changing the country of representation is only given once, therest of the criteria arerather lenient

\subsubsection{Rules applicable since 2005}

The newest UCI rules are those of $15^{\text {th }}$ March 2016, which are identical to the rules of $1^{\text {st }}$ January 2016, $13^{\text {th }}$ March 2015, 25 September 2014 and $1^{\text {th }}$ May 2014. Theserules are very similar to thoseapplicabl e earlier. The changes occurred in these phases:

Since 2011:

- Changing of national ity introduced in a separatearticle ${ }^{1263}$ Since May 2014: : $^{1264}$

- Exceptional cases in which a rider may choose a country of representation, after his choice had been al ready viewed as final was added. ${ }^{1265}$

- Detailed list of documents needed for the procedures was added. ${ }^{1266}$

All versions underscore that it does not matter which country gave the athlete the license, but of which country the athlete is a national. ${ }^{1267}$ The UCl further stipulates

1261 Art. 1.1.033 §2 UCl Cycling regulations general organisation of E0116 Cycling as a sport part 1 general organi sation of Cycling as a sport (version of 15.03.2016).

1262 Art. 1.1.033 §2a) and §2c) UCl Cycling regulations general organisation of E0116 Cycling as a sport part 1 general organi sation of Cycling as a sport (version of 15.03.2016).

Art. 1.1.033 §4 UCl Cycling regulations - general organisation of E1014 Cycling as a sport part 1 general organisation of Cydling as a sport (versions of March 2014; October 2013 and October 2011).

1264 Thearticle was re-structured, with the previous Art. 1.1.033 § 2, receiving label led subparagraphs.

1265 Art. 1.1.033 §2d) UCl Cycling regulations general organisation of E0115 Cycling as a sport part 1 general organi sation of Cycling as a sport (version of 13.03.2015); Art 1.1.033 §2d) UCl Cycling regulations general organisation of E0914 Cyding as a sport part 1 general organi sation of Cycling As A sport version of 25.09.2014; Art. 1.1.033 §2d) UCl Cycling regulations general organisation of E0514 Cyding as a sport part 1 general organisation of Cyding as a sport (version of 01.05.2014).

1266 Art. 1.1.033 §2e) UCl Cycling regulations general organisation of E0115 Cycling as a sport part 1 general organisation of Cycling as a sport (version of 13.03.2015); Art. 1.1.033 §2e) UCl Cycling regulations general organi sation of E0914 Cyding as a sport part 1 general organi sation of Cyding As A sport version of 25.09.2014; Art 1.1.033 §2e) UCI Cycling regulations general organisation of E0514 Cyding as a sport part 1 general organisation of Cyding as a sport (version of 01.05.2014); Art. 1.1.033 §3 UCl Cycling regulations general organisation of E0115 Cyding as a sport part 1 general organi sation of Cycling as a sport (version of 13.03.2015); Art 1.1.033 $\$ 3 \mathrm{UCl}$ Cycling regulations general organi sation of E0914 Cycling as a sport part 1 general organi sation of Cycling As A sport version of 25.09.2014; Art. 1.1.033 \$3 UCl Cycling regulations general organisation of E0514 Cycling as a sport part 1 general organisation of Cycling as a sport (version of 01.05.2014).

1267 Art. 1.1.033 \$1 UCl Cycling regulations general organisation of E0116 Cycling as a sport part 1 general organisation of Cyding as a sport (version of 15.03.2016); Art. 1.1.033 §1 UCl Cycling regulations general organi sation of E0116 Cyding as a sport part 1 general organi sation of Cycling as a sport (version of 01.01.2016); Art. 1.1.033 \$1 UCl Cycling regulations general organi sation of E0115 Cycling as a sport part 1 general organi sation of Cycling as a sport (version of 13.03.2015); Art. 1.1.033 §1 UCl Cyding regulations general organisation of E0914 Cycling as a sport part 1 general organisation of Cydling as a sport (version of 25.09.2014); Art. 1.1.033 §1 UCl Cycling 
that the Olympic Games are governed by the Olympic Charter. ${ }^{1268}$ Stateless athletes may compete for a country after having been a resident there for five years. ${ }^{1269}$ Athletes with multiple nationality have to choose for which country they wish to compete and need to apply for a license in the country in which they have their main residence ${ }^{1270}$ This decision is binding, unless the athlete was a minor at the point the decision was taken. In such a case, a new decision can be made upon reaching the age of majority. ${ }^{1271}$ The UCl further provides for cases of the loss and acquisition of

regulations general organi sation of E0514 Cyding as a sport part 1 general organi sation of Cycling as a sport (version of 01.05.2014); Art. 1.1.033 § $1 \mathrm{UCl}$ Cycling regulations - general organisation of E1014 Cyding as a sport part 1 general organisation of Cycling as a sport (versions of March 2014; October 2013 and October 2011); Art. 1.1.033 §1 UCl Cycling regulations - general organisation of E0105 Cycling as a sport part 1 general organi sation of Cycling as a sport 2005.

Art. 1.1.033 §5 UCl Cycling regulations general organisation of E0116 Cycling as a sport part 1 general organisation of Cycling as a sport (version of 15.03.2016); Art. 1.1.033 §5 UCl Cyding regulations general organisation of E0116 Cyding as a sport part 1 general organi sation of Cycling as a sport (version of 01.01.2016); Art 1.1.033 $\$ 5 \mathrm{UCl}$ Cyding regulations general organi sation of E0115 Cycling as a sport part 1 general organi sation of Cycling as a sport (version of 13.03.2015); Art. 1.1.033 $\$ 5 \mathrm{UCl}$ Cycling regulations general organisation of E0914 Cycling as a sport part 1 general organisation of Cydling As A sport version of 25.09.2014; Art. 1.1.033 §5 UCl Cycling regulations general organi sation of E0514 Cyding as a sport part 1 general organi sation of Cycling as a sport (version of 01.05.2014); Art. 1.1.033 § $5 \mathrm{UCl}$ Cycling regulations - general organisation of E1014 Cyding as a sport part 1 general organisation of Cyding as a sport (versions of March 2014; October 2013 and October 2011); Art. 1.1.033 §4 UCl Cycling regulations - general organi sation of E0105 Cycling as a sport part 1 general organi sation of Cycling as a sport 2005.

Art. 1.1.033 $\$ 1 \mathrm{UCl}$ Cydling regulations general organisation of E0116 Cycling as a sport part 1 general organisation of Cycling as a sport (version of 15.03.2016); Art. 1.1.033 §1 UCl Cycling regulations general organi sation of E0116 Cyding as a sport part 1 general organi sation of Cyding as a sport (version of 01.01.2016); Art. 1.1.033 \$1 UCl Cycling regulations general organi sation of E0115 Cyding as a sport part 1 general organi sation of Cycling as a sport (version of 13.03.2015); Art. 1.1.033 $\$ 1 \mathrm{UCl}$ Cycling regulations general organisation of E0914 Cycling as a sport part 1 general organisation of Cycling As A sport version of 25.09.2014; Art. 1.1.033 §1 UCl Cycling regulations general organi sation of E0514 Cyding as a sport part 1 general organi sation of Cycling as a sport (version of 01.05.2014); Art. 1.1.033 §1 UCl Cycling regulations - general organisation of E1014 Cyding as a sport part 1 general organisation of Cycling as a sport (versions of March 2014; October 2013 and October 2011); Art. 1.1.033 §1 UCl Cycling regulations - general organisation of E0105 Cycling as a sport part 1 general organi sation of Cycling as a sport 2005.

Art. 1.1.033 \$2 and Art. 1.1.011 UCl Cycling regulations general organi sation of E0116 Cycling as a sport part 1 general organisation of Cycling as a sport (version of 15.03.2016); Art 1.1.033 §2 and Art. 1.1.011 UCl Cyding regulations general organisation of E0116 Cycling as a sport part 1 general organi sation of Cycling as a sport (version of 01.01.2016); Art 1.1.033 §2 and Art. 1.1.011 $\mathrm{UCl}$ Cyding regulations general organisation of E0115 Cyding as a sport part 1 general organisation of Cycling as a sport (version of 13.03.2015); Art 1.1.033 §2 and Art. 1.1.011 UCl Cyding regulations general organi sation of E0914 Cycling as a sport part 1 general organi sation of Cycling As A sport version of 25.09.2014; Art 1.1.033 \$2 and Art. 1.1.011 UCl Cycling regulations general organi sation of E0514 Cyding as a sport part 1 general organisation of Cycling as a sport (version of 01.05.2014); Art. 1.1.033 §2 and Art 1.1.011 UCl Cycling regulations general organisation of E1014 Cycling as a sport part 1 general organi sation of Cycling as a sport (versions of March 2014; October 2013 and October 2011); Art. 1.1.033 §2 and Art. 1.1.011 UCl Cycling regulations - general organi sation of E0105 Cycling as a sport part 1 general organi sation of Cycling as a sport 2005.

Art. 1.1.033 §2b) UCI Cycling regulations general organisation of E0116 Cycling as a sport part 1 general organisation of Cycling as a sport (version of 15.03.2016); Art 1.1.033 §2b) UCl Cycling regulations general organi sation of E0116 Cyding as a sport part 1 general organi sation of Cycling as a sport (version of 01.01.2016); Art. 1.1.033 §2b) UCl Cycling regulations general organi sation of E0115 Cycling as a sport part 1 general organisation of Cycling as a sport (version of 13.03.2015); Art. 1.1.033 §2b) UCl Cycling regulations general organisation of E0914 Cyding as a sport part 1 general organisation of Cycling As A sport version of 25.09.2014; Art. 1.1.033 §2b) 
nationality. In the case of the former, the athlete may choose to compete for the country of which he or sheis al so a national. ${ }^{1272}$ In the case of the latter, the athletehas two years to decide whether to compete for the new federation. Within these two years, he or she needs to have establ ished his or her main residence in this country and has to apply for the new license with the new federation. ${ }^{1273}$ In these cases, the athl lete cannot compete in the world championships for a year. ${ }^{1274}$ The UCl provides an example for such cases, with the relevant dates updated according to the version of the rulebook:

UCI Cycling regulations general organisation of E0514 Cycling as a sport part 1 general organi sation of Cycling as a sport (version of 01.05.2014); Art. 1.1.033 \$2 UCl Cycling regulations - general organi sation of E1014 Cycling as a sport part 1 general organi sation of Cycling as a sport (versions of March 2014; October 2013 and October 2011); Art 1.1.033 \$2 UCl Cycling regulations - general organisation of E0105 Cyding as a sport part 1 general organisation of Cycling as a sport 2005.

Art. 1.1.033 §2 a) and Art. 1.1.011 UCI Cycling regulations general organi sation of E0116 Cycling as a sport part 1 general organi sation of Cycling as a sport (version of 15.03.2016); Art. 1.1.033 §2 a) and Art. 1.1.011 UCl Cycling regulations general organi sation of E0116 Cycling as a sport part 1 general organisation of Cycling as a sport (version of 01.01.2016); Art. 1.1.033 §2a) and Art. 1.1.011 UCl Cyding regulations general organisation of E0115 Cycling as a sport part 1 general organisation of Cycling as a sport (version of 13.03.2015); Art. 1.1.033 §2a) and Art 1.1.011 UCI Cycling regulations general organi sation of E0914 Cycling as a sport part 1 general organi sation of Cycling As A sport version of 25.09.2014; Art. 1.1.033 §2a) and Art. 1.1.011 UCl Cycling regulations general organisation of E0514 Cyding as a sport part 1 general organi sation of Cycling as a sport (version of 01.05.2014); Art 1.1.033 §2 and Art. 1.1.011 UCl Cycling regulations general organisation of E1014 Cycling as a sport part 1 general organisation of Cycling as a sport (versions of March 2014; October 2013 and October 2011); Art. 1.1.033 §2 and Art. 1.1.011 UCl Cycling regulations - general organisation of E0105 Cycling as a sport part 1 general organisation of Cycling as a sport 2005.

Art. 1.1.033 §2 c) UCl Cycling regulations general organisation of E0116 Cycling as a sport part 1 general organisation of Cycling as a sport (version of 15.03.2016); Art. 1.1.033 §2 c) UCl Cycling regulations general organi sation of E0116 Cyding as a sport part 1 general organi sation of Cyding as a sport (version of 01.01.2016); Art 1.1.033 §2c) UCl Cycling regulations general organisation of E0115 Cyding as a sport part 1 general organisation of Cyding as a sport (version of 13.03.2015); Art. 1.1.033 §2c) UCl Cycling regulations general organisation of E0914 Cycling asa sport part 1 general organisation of Cycling As A sport version of 25.09.2014; Art. 1.1.033 §2c) $\mathrm{UCl}$ Cycling regulations general organisation of E0514 Cycling as a sport part 1 general organisation of Cycling as a sport (version of 01.05.2014); Art. 1.1.033 §3 UCl Cycling regulations - general organisation of E1014 Cycling as a sport part 1 general organi sation of Cycling as a sport (versions of March 2014; October 2013 and October 2011); Art 1.1.033 §3 UCl Cyding regulations - general organisation of E0105 Cyding as a sport part 1 general organisation of Cycling as a sport 2005.

1274 Art. 1.1.033 §2e) UCI Cycling regulations general organisation of E0116 Cycling as a sport part 1 general organi sation of Cyding as a sport (version of 15.03.2016); Art. 1.1.033 §2e) UCI Cyding regulations general organisation of E0116 Cyding as a sport part 1 general organi sation of Cycling as a sport (version of 01.01.2016); Art. 1.1.033 §2e) UCl Cycling regulations general organisation of E0115 Cycling as a sport part 1 general organisation of Cycling as a sport (version of 13.03.2015); Art. 1.1.033§2e) and Art. 1.1.033 $\$ 3 \mathrm{UCl}$ Cyding regulations general organisation of E0914 Cycling As A sport part 1 general organisation of Cyding as a sport version of 25.09.2014; Art. 1.1.033 §2e) UCl Cycling regulations general organisation of E0514 Cycling as a sport part 1 general organisation of Cycling as a sport (version of 01.05.2014); Art 1.1.033 §3 UCl Cycling regulations - general organisation of E1014 Cyding as a sport part 1 general organisation of Cycling as a sport (versions of March 2014; October 2013 and October 2011); Art. 1.1.033 §3 UCl Cycling regulations - general organisation of E0105 Cycling as a sport part 1 general organisation of Cycling as a sport 2005. 
"Example: a rider hol ding nationality A acquires nationality B on 1 J uly 2013 and wishes to henceforth represent nation $B$. The change of nationality is approved by the $\mathrm{UCl}$ on 5 October 2013. The rider may not represent nation $\mathrm{B}$ at the world championships of 2013 (i) or 2014 (ii). However, the rider may immediately represent nation $B$ at other competitions, in particular continental championships and as a member of the national team for world cup events. A rider who has never represented nation $A$ at the world championships, continental championships or as a member of the national team competing in world cup events, shall not be subject to any restrictions and may immediately represent nation $B$ at the world championships." 1275

It should be noted that the athlete is not barred fromany other competitions during this period. The UCl also provides for changes under other circumstances, however this is only possible with the agreement of the relevant federations and the UCI. ${ }^{1276}$ Thus, the $\mathrm{UCI}$ has the possibility to react on a case-by-case basis to changes in an athlete's situation.

1275 Art. 1.1.033 §2e) UCl Cycling regulations general organisation of E0116 Cycling as a sport part 1 general organisation of Cycling as a sport (version of 15.03.2016); Art 1.1.033 §2e) UCI Cycling regulations general organi sation of E0116 Cyding as a sport part 1 general organi sation of Cycling as a sport (version of 01.01.2016); Art 1.1.033 §2e) UCI Cycling regulations general organisation of E0115 Cycling as a sport part 1 general organisation of Cycling as a sport (version of 13.03.2015).

Art. 1.1.033 §2d) UCl Cycling regulations general organisation of E0116 Cycling as a sport part 1 general organisation of Cycling as a sport (version of 15.03.2016); Art. 1.1.033 §2d) UCl Cycling regulations general organisation of E0116 Cyding as a sport part 1 general organi sation of Cycling as a sport (version of 01.01.2016); Art. 1.1.033 §2d) UCl Cycling regulations general organisation of E0115 Cycling as a sport part 1 general organisation of Cyding as a sport (version of 13.03.2015); Art. 1.1.033 §2d) UCl Cycling regulations general organisation of E0914 Cyding as a sport part 1 general organisation of Cycling As A sport version of 25.09.2014; Art. 1.1.033 §2d) UCl Cycling regulations general organisation of E0514 Cycling as a sport part 1 general organisation of Cyding as a sport (version of 01.05.2014). 


\subsection{Equestrian ${ }^{1277}$}

Equestrian has been an Olympic sport since 1900, but it was notably absent from the Olympiads in 1904 and 1908. Its rules are set out by Fédération Equestre Internationale (FEI) which was founded in 1921 and has its seat in Lausanne, Switzerland. ${ }^{1278}$ Interestingly, it is a sport in which men and women both compete in the same event. ${ }^{1279}$ The disciplines recognised by the FEI are jumping, dressage, eventing, driving, endurance, vaulting, reining, and paraequestrian. ${ }^{1280}$ However, only three of these, namely dressage, eventing and jumping are also Olympic disciplines. ${ }^{1281}$ The major aim behind equestrian competitions is to see which riders manage to evoke the best responsive behaviour from their horses in previously known and practised tasks, such as going backwards through a spedific form or jumping over obstades of a specific height and in set combinations.

For the discipline of 'dressage' riders are required to let their horses go through complicated movement pattems, such as pirouettes. This dates back to the military drills battle horses in Ancient Greece were trained in, which aimed at improving the horses' responses and agility during military operations. ${ }^{1282}$ These techniques were refined over the course of time until the peak of classical dressage art was reached in the Spanish Riding School situated in Vienna. ${ }^{1283}$ Eventing stems from the preparation of cavalry horses. ${ }^{1284}$ It combines jumping as well as dressage over cross-country courses. ${ }^{1285}$ For jumping, the goal is to jump over various combinations of jumps including obstacles of varying heights and lengths without making a mistake. Here 'mistakes' are considered the physical contact of horse and obstacle or thehorse's refusal to jump. ${ }^{1286}$

TableXXXVIII: Overview of the eligibility requirements for equestrian

\begin{tabular}{|l|l|}
\hline Requirements FEI & 2010 \\
\hline In force since & $\begin{array}{l}\text { The way through which the nationality was } \\
\text { acquired only matters with regard to the residence } \\
\text { requirement and possibleexceptions }\end{array}$ \\
\hline C hange of nationality & Many exceptions are possible, in general the \\
\hline R esidence requirements
\end{tabular}

1277 The federation was contacted on $6^{\text {th }}$ August 2014 and asked to provide further insights into its eligi bility criteria and ol der versions of the eligibility rules. The FEI replied on $7^{\text {th }}$ August 2014 and sent the eligibility rules electronically. On $29^{\text {th }}$ October 2015 the FEI was contacted again and asked for comments on this chapter, which theFEl provided on $2^{\text {nd }}$ November 2015. IOC Reference Document Equestrian: for information on non-national athletes in the European national leagues and competitions see S. van den Bogaert, A. Cuyvers, S. Gardiner, R. Parrish, S. Miettinen, J. Soek and R. Siekmann (2010), p. 139. IOC Information FEI dressage; IOC Information FEI jumping; IOC Reference Document Equestrian.

1280 IOC Information FEI dressage; IOC Information FEI jumping.

1281 Ibid.

1282 IOC Information Equestrian Dressage Equipment and History.

1283 Ibid.

1284 Ibid.

1285 Ibid.

1286 FEI guidelines for the evaluation of pirouettes as well as contact and mouth problems and FEI Jumping rules 2012. 


\begin{tabular}{|c|c|}
\hline & $\begin{array}{l}\text { residence requirement can either be fulfilled } \\
\text { through two uninterupted years of legal residence } \\
\text { or fivenon-consecutive years of legal residence }\end{array}$ \\
\hline M inors and nationality change & Possibleannually \\
\hline Stateless athletes & May competefor new federation directly \\
\hline $\begin{array}{l}\text { Position of athletes with multiple nationality } \\
\text { after having competed for another country of } \\
\text { which the athlete is a national }\end{array}$ & $\begin{array}{l}\text { Changedirectly possible, with the exception of } \\
\text { sometournaments for which a two-year break is } \\
\text { necessary }\end{array}$ \\
\hline E ffect of changes in territory of country & Possi ble to choose once for either entity old or new \\
\hline C ompeting for the country of residence & $\begin{array}{l}\text { Possiblefor minors only with permission of } \\
\text { national federation }\end{array}$ \\
\hline Number of changes possible & No maximum specified \\
\hline R eference to Olympic C harter & Yes \\
\hline Uses nationality/ citizenship & Nationality and citizen \\
\hline Uses residence/ domicile & $\begin{array}{l}\text { Residence, which is understood as "legal } \\
\text { residence" (the residence where you have your } \\
\text { permanent homeor principal establ ishment and to } \\
\text { where, whenever you areabsent, you intend to } \\
\text { return; every person is compelled to have one and } \\
\text { only one domicileat a time }\end{array}$ \\
\hline Other remarkable peculiarity & $\begin{array}{l}\text { Very detailed; for the Olympic Games the } \\
\text { nationality of the owners of the horses is important } \\
\text { as well. }\end{array}$ \\
\hline
\end{tabular}

12.2.1. Equestrian critical reflection

The FEI is one of the most lenient federations. Its rules stipulate that only nationals should compete for a national team ${ }^{1288}$ and consequently athletes with dual nationality have to choose one country at the age of majority. ${ }^{1289}$ Nevertheless, nationality changes are allowed. ${ }^{1290}$ Minors with dual nationality can even choose annually for which country they wish to compete ${ }^{1291}$ For the others, changing the country of representation is only allowed if the residence criteria of either two consecutive or five non-consecutive years are met. ${ }^{1292}$ The possibility to al so met the residence criteria through non-consecutive years is very lenient, as it is easier for athletes with an international tournament schedule The FEI also deals with athletes faced with territorial transfers, and they can choose for which of the (potentially new) entities they wish to compete ${ }^{1293}$ Athletes who lost their nationality, became refugees or

1287 FEI E-mail of $2^{\text {nd }}$ November 2015.

1288 Exceptions are provided for in paragraphs 4, 5, 6.2, and 6.3, of the samearticle

1289 Art. $119(2) \mathrm{FEI}$ general regulations $23^{\text {rd }}$ edition, $1^{\text {t }}$ January 2009 , updates effective $1^{\text {st }}$ J anuary 2016.

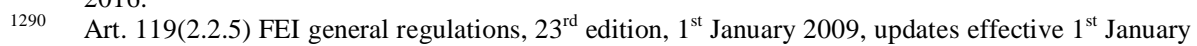
2016.

1291 Art. 119(3.1) FEI general regulations, $23^{\text {rd }}$ edition, $1^{\text {st }}$ January 2009 , updates effective $1^{\text {st }}$ J anuary 2016.

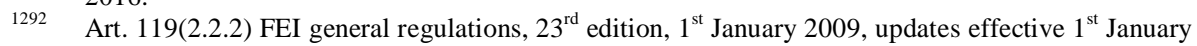
2016.

1293 Art. 119(4) FEl general regulations, $23^{\text {rd }}$ edition, $1^{\text {st }}$ January 2009 , updates effective $1^{\text {st }}$ January 2016. 
whose national federation ceased to exist, can compete in international tournaments nevertheless and will be deemed to compete for their host country, i.e the one in which they live, at some tournaments. ${ }^{1294}$ The FEI has extremely detailed and nuanced rules that aim to al low athletes the greatest possibleflexibility, whileal so contravening mercenary tendencies.

\subsubsection{Rules applicable since 2005}

The current rules regarding eligibility are spelled out in the FEI General Regulations $23^{\text {rd }}$ edition, $1^{\text {t }}$ J anuary 2009, updates effective $1^{\text {t }}$ January, 2016. ${ }^{1295}$ Since 2005 these rules have undergoneseveral changes and have become even more detailed.

\section{Since 2007:}

- Referenceto multiplenationality was added; ${ }^{1296}$

- Proof of citizenshi p becamenecessary, ${ }^{1297}$

- Change of nationality. residencerequirements was mentioned; ;298

- Possibility for special cases introduced; ${ }^{1299}$

- ReferencetoIOC made ${ }^{1300}$

Since 2009: 1301

- Special Olympic Games Ruleind uded. ${ }^{1302}$

Since 2010:

- Differentiation between adult and minor athletes with separate rules for minor athletes added; ${ }^{1303}$

- Exceptions to residence requirements becamepossible ${ }^{1304}$

- Reduction of requirements for married athletes ind uded. ${ }^{1305}$

Since 2011:

1294 Art. 119(5) FEl general regulations, $23^{\text {rd }}$ edition, $1^{\text {st }}$ January 2009 , updates effective $1^{\text {st }}$ January 2016.

1295 And which did not differ from the $1^{\text {st }} J$ anuary 2014 and $1^{\text {st }} J$ anuary 2015 updates.

1296 Art. 123(4) FEl general regulations, $22^{\text {nd }}$ edition, $1^{\text {st }}$ June 2007 and $22^{\text {nd }}$ edition with 2008 amendments.

1297 Art. 123(5) FEl general regulations, $22^{\text {nd }}$ edition, $1^{\text {st }}$ June 2007 and $22^{\text {nd }}$ edition with 2008 amendments.

1298 Art. 123(5) FEl general regulations, $22^{\text {nd }}$ edition, $1^{\text {st }}$ June 2007 and $22^{\text {nd }}$ edition with 2008 amendments.

1299 Art. 123(6) FEl general regulations, $22^{\text {nd }}$ edition, $1^{\text {st }}$ June 2007 and $22^{\text {nd }}$ edition with 2008 amendments.

1300 Art. 123(7) FEl general regulations, $22^{\text {nd }}$ edition, $1^{\text {st }}$ June 2007 and $22^{\text {nd }}$ edition with 2008 amendments.

1301 Renumbering: The rules under Art. 123 were moved to Art. 119 and a new Art.123 was introduced that dealt with the Olympic Games.

1302 Art. 123(1) FEI general regulations, $23^{\text {rd }}$ edition, $1^{\text {st }}$ January 2009 and Art 119(7) FEI general regulations, $23^{\text {rd }}$ edition, $1^{\text {st }}$ January 2009.

1303 Art. $119(2)$ and $119(3)$ were added as well as $119(6.3)$ FEI general regulations $23^{\text {rd }}$ edition, $1^{\text {st }}$ January 2009, updates effective $1^{\text {st }}$ J anuary 2010.

1304 Art. 119 (2.2.3) FEl general regulations $23^{\text {rd }}$ edition, $1^{\text {st } J ~ a n u a r y ~} 2009$, updates effective $1^{\text {st }}$ J anuary 2010.

1305 Art. 119(2.2.4) FEl general regulations $23^{\text {rd }}$ edition, $1^{\text {st }}$ January 2009 , updates effective $1^{\text {st }}$ January 2010. 
- Athletes who live in a country that does not have a national federation and cannot rely on any other FEI provision may apply for special authorisation and compete under theFEl flag;,

- 'Biological parents' ${ }^{1307}$ was replaced with 'acquired by virtue of descent or through other means related to family heritage', ${ }^{1308}$ thus broadening the applicability of this provision, putting an end to the potential exd usion of adopted children;

- waiting periods were prescribed by the IOC Charter also applicable to athletes wishing to compete at the Olympics after having changed their country of representation. ${ }^{1309}$

Since 2012:

- Artide 123.2 was added, stating that everyone invol ved in the Olympic Games is to begoverned by the IOC rules. ${ }^{1310}$

Tuming to the rules currently applicable, it is firstly important to underline that al so thenationality of the horses' owners is important and that horses have to be registered like the athletes with the FEI and their own NF. ${ }^{1311}$ At the Olympic Games athletes may only compete with horses which have been owned by a person of the same nationality since $15^{\text {th }}$ J anuary of the Olympic year. ${ }^{1312}$ Secondly, the FEI underscores that for Olympic competitions the Olympic Charter applies, while other FEI competitions are governed solely by over FEI rules. ${ }^{1313}$ Consequently, only those who

1306 Art. 119.5.1 FEl general regulations $23^{\text {rd }}$ edition, $1^{\text {st }}$ January 2009 , updates effective $1^{\text {st J January }}$ 2013 and Art. 119.5.1 FEl general regulations $23^{\text {rd }}$ edition, $1^{\text {st }}$ January 2009, updates effective $1^{\text {st }}$ January 2012.

1307 Art. 119.2.2.3 FEl general regulations $23^{\text {rd }}$ edition, $1^{\text {st }}$ J anuary 2009 , updates effective $1^{\text {st }}$ J anuary 2010.

1308 Art. 119.2.2.3 FEI general regulations $23^{\text {rd }}$ edition, $1^{\text {st }}$ January 2009 , updates effective $1^{\text {st }}$ January 2012 and Art 119.2.2.3 FEI general regulations $23^{\text {rd }}$ edition, $1^{\text {st }}$ J anuary 2009 , updates effective $1^{\text {st }}$ January 2011.

1309 Art. 119.2.2.8 FEl general regulations $23^{\text {rd }}$ edition, $1^{\text {st }} J$ anuary 2009 , updates effective $1^{\text {st }}$ January 2012 and Art. 119.2.2.8 FEl general regulations $23^{\text {rd }}$ edition, $1^{\text {st } J ~ a n u a r y ~} 2009$, updates effective $1^{\text {st }}$ January 2011.

1310 Art. $123.2 \mathrm{FEI}$ general regulations $23^{\text {rd }}$ edition, $1^{\text {st }}$ January 2009 , updates effective $1^{\text {st }}$ January 2013; Art. $123.2 \mathrm{FEI}$ general regulations $23^{\text {rd }}$ edition, $1^{\text {st }}$ January 2009 , updates effective $1^{\text {st }}$ January 2012.

1311 Art. 113(1) and Art. 113(2) FEI general regulations $23^{\text {rd }}$ edition, $1^{\text {st }} J$ anuary 2009, updates effective

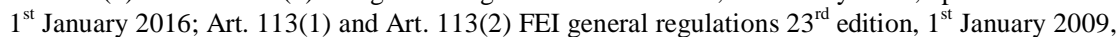
updates effective $1^{\text {st }}$ January 2015; Art. $113(1)$ and (2) FEl general regulations $23^{\text {rd }}$ edition, $1^{\text {st }}$ January 2009, updates effective 2014; Art. $113.1 \mathrm{FEl}$ general regulations, $23^{\text {rd }}$ edition, $1^{\text {td }} \mathrm{J}$ anuary 2009, updates effective ${ }^{\text {st }}$ J anuary 2013.

1312 Art. 139(4) FEl general regulations, $23^{\text {rd }}$ edition, $1^{\text {st }}$ January 2009 , updates effective $1^{\text {st }} J$ anuary 2016; Art 139(4) FEl general regulations, $23^{\text {rd }}$ edition, $1^{\text {st }}$ January 2009 , updates effective $1^{\text {st }}$ January 2015.

1313 Art. $119(2.2 .8) \mathrm{FEI}$ general regulations, $23^{\text {rd }}$ edition, $1^{\text {st }}$ anuary 2009 , updates effective $1^{\text {st }}$ January 2016; Art. 119(2.2.8) FEl general regulations, $23^{\text {rd }}$ edition, $1^{\text {st }}$ January 2009 , updates effective $1^{\text {st }}$ January 2015; Art 119(2.2.8) FEl general regulations, $23^{\text {rd }}$ edition, $1^{\text {st }} J$ anuary 2009 , updates effective $1^{\text {t }}$ J anuary 2014; Art. 119(2.2.8) FEI general regulations, $23^{\text {rd }}$ edition, $1^{\text {st }}$ January 2009 , updates effective $1^{\text {th }} \mathrm{J}$ anuary 2013; Art. 119(2.2.8) FEI general regulations $23^{\text {rd }}$ edition, $1^{\text {st }}$ J anuary 2009, updates effective $1^{\text {st } J ~ a n u a r y ~} 2012$ and Art. 119(2.2.8) FEI general regulations $23^{\text {rd }}$ edition, $1^{\mathrm{s}} \mathrm{J}$ anuary 2009, updates effective $1^{\mathrm{s}}$ January 2011; Art 119(7) FEl general regulations $23^{\text {rd }}$ edition, $1^{\text {st }}$ January 2009, updates effective $1^{\text {st }}$ January 2010; Art 119(7) FEl general regulations, 
fulfil the requirements of the Olympic Charter and other IOC rules can competeat the Olympic Games. ${ }^{1314}$

With regard to the nationality requirements in equestrian, it becomes clear that in principle an athlete can only compete for the national federation of the country of which he is a national. ${ }^{1315}$ With respect to dual nationality, the FEI requires athletes to choose for one country at the age of majority. ${ }^{1316}$ Nevertheless, nationality changes are admissi ble under Article 1192(2) if the new nationality was acquired by $31^{\mathrm{st}}$ December of the preceding year and if the necessary formal requirements are fulfilled. ${ }^{1317}$ However, special requirements are in place for more upscale tournaments. ${ }^{1318}$

"(i) Subject to the exceptions set forth in paragraph 2.2.3 below, the Athl etemust have had legal residence in his new country prior to the first competition he wishes to competein under his new sport nationality, for either:

$23^{\text {rd }}$ edition, $1^{\text {st }}$ January 2009; Art. 123(7) FEl general regulations, $22^{\text {nd }}$ edition, $1^{\text {st }}$ June 2007 and $22^{\text {nd }}$ edition with 2008 amendments.

1314 Art. 123 FEI general regulations $23^{\text {rd }}$ edition, $1^{\text {tt }}$ January, 2009, updates effective $1^{\text {st }}$ anuary, 2016;

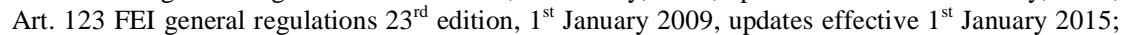
Art. $123 \mathrm{FEl}$ general regulations $23^{\text {rd }}$ edition, $1^{\text {st }}$ January 2009 , updates effective $1^{\text {st }}$ J anuary 2014; Art. $123 \mathrm{FEI}$ general regulations $23^{\text {rd }}$ edition, $1^{\text {st }}$ January 2009, updates effective $1^{\text {st }}$ January 2013;

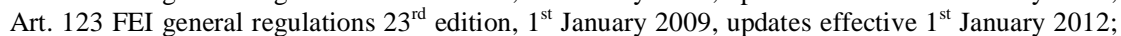
Art. 123 FEl general regulations $23^{\text {rd }}$ edition, $1^{\text {st }}$ January 2009, updates effective $1^{\text {st }}$ January 2011 and Art $123 \mathrm{FEl}$ general regulations $23^{\text {rd }}$ edition, $1^{\text {st }}$ January 2009 , updates effective $1^{\text {st }}$ January 2010.

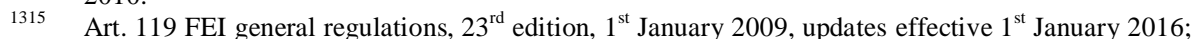
Art. $119 \mathrm{FEl}$ general regulations, $23^{\text {rd }}$ edition, $1^{\text {st }}$ January 2009 , updates effective $1^{\text {st }}$ January 2015 ;

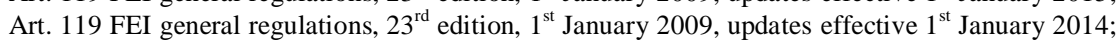
Art. $119 \mathrm{FEl}$ general regulations, $23^{\text {rd }}$ edition, $1^{\text {st }}$ January 2009 , updates effective $1^{\text {st }}$ J anuary 2013 ; Art. $119 \mathrm{FEI}$ general regulations $23^{\text {rd }}$ edition, $1^{\text {st }}$ January 2009 , updates effective $1^{\text {t }}$ J anuary 2012; Art. $119 \mathrm{FEl}$ general regulations $23^{\text {rd }}$ edition, $1^{\text {st }}$ J anuary 2009, updates effective $1^{\text {st }}$ J anuary 2011 and Art $119 \mathrm{FEl}$ general regulations $23^{\text {rd }}$ edition, $1^{\text {st }}$ J anuary 2009, updates effective $1^{\text {st }}$ January 2010; Exceptions are provided for in paragraphs 4, 5, 6.2, and 6.3, of the same article.

1316 Art. $119(2) \mathrm{FEI}$ general regulations $23^{\text {rd }}$ edition, $1^{\text {ts }}$ anuary 2009 , updates effective $1^{\text {st } J \text { anuary }}$ 2016; Art 119(2) FEI general regulations $23^{\text {rd }}$ edition, $1^{\text {st }}$ January 2009, updates effective $1^{\text {st }}$ January 2015; Art. 119(2) FEI general regulations $23^{\text {rd }}$ edition, $1^{\text {st }}$ January 2009, updates effective

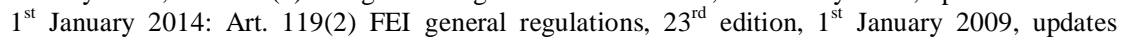
effective $1^{\text {st }}$ January 2013; Art. 119 (2) FEl general regulations $23^{\text {rd }}$ edition, $1^{\text {st }}$ January 2009, updates effective $1^{\text {st }}$ January 2012; Art. 119(2) FEI general regulations $23^{\text {rd }}$ edition, $1^{\text {st }}$ January

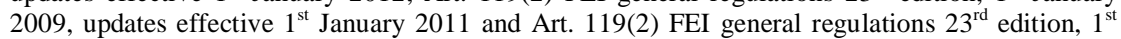
January 2009, updates effective $1^{\mathrm{st}}$ January 2010; Art 119(4) FEl general regulations, $23^{\text {rd }}$ edition, $1^{\text {st }}$ January 2009.

1317 Art. 119(2.2.5) FEI general regulations, $23^{\text {rd }}$ edition, $1^{\text {st } J ~ a n u a r y ~} 2009$, updates effective $1^{\text {st }}$ January 2016; Art. 119(2.2.5) FEI general regulations, $23^{\text {rd }}$ edition, $1^{\text {st }}$ January 2009 , updates effective $1^{\text {st }}$ January 2015; Art. 119(2.2.5) FEl general regulations, $23^{\text {rd }}$ edition, $1^{\text {st }}$ January 2009, updates effective $1^{\text {st }}$ January 2014; Art. 119(2.2.5) FEl general regulations, $23^{\text {rd }}$ edition, $1^{\text {st }}$ January 2009 , updates effective $1^{\text {st }}$ January 2013; Art. $119(2.2 .5)$ FEl general regulations $23^{\text {rd }}$ edition, $1^{\text {st }}$ January 2009, updates effective $1^{\text {st }}$ January 2012; Art. 119(2.2.5) FEl general regulations $23^{\text {rd }}$ edition, $1^{\text {st }}$ January 2009, updates effective $1^{\text {st }}$ January 2011 and Art. 119(2.2.5) FEl general regulations $23^{\text {rd }}$

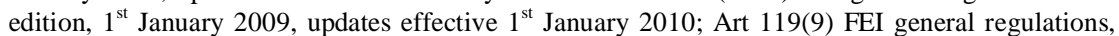
$23^{\text {rd }}$ edition, $1^{\text {st }}$ January 2009; Art 123(9) FEl general regulations, $22^{\text {nd }}$ edition, $1^{\text {td }} J$ une 2007 and $22^{\text {nd }}$ edition with 2008 amendments; Art. 123(5) FEl general regulations $21^{\text {st }}$ edition, effective $1^{\text {st }}$ January 2005 revision May 2006; Art. 123(5) FEI general regulations $21^{\text {st }}$ edition, effective $1^{\text {st }}$ January 2005.

1318 Such as FEl Championships, FEI World Cup Series, CIOs. 
(a) a minimum of two (2) uninterrupted years; or

(b) a total of five (5) years of non-consecutive periods.

(ii) The Athlete shall not have taken part in any of the competitions set forth in Artide 2.2.2. above for his previous NF in the two (2) years prior to the first competition hewishes to competein under his new sport nationality."

The abovementioned subparagraph stipulates under which circumstances the resident requirement can bewaived. Thoseindude:

“(i) the Athlete's entitlement to his new nationality was established by his birth in that country;

(ii) The Athlete's entitlement to his new nationality was acquired by virtue of descent or through other means related to family heritage

(iii) the naturalized Athlete was a former national whose loss of nationality was neither voluntary or due to criminal acts, or

(iv) the naturalized Athlete had to renounce his former nationality as a condition of acquiring anew one"1320

These perquisites combine in just one artide the aspects of acquisition of nationality, notably ius sanguinis (ii) and ius soli (i), with loss of nationality. Since 2011 adopted children are no longer put at a di sadvantage, as for them 'family heritage' could al so mean that non-biological parents and the links made through them. The qual ification that loss of national ity does not lead to a waiver in case the loss was brought about by the commission of a criminal act is furthermore noteworthy, since these regulations show that the writers aimed keep therul es closeto the legal aspects.

A further reduction of the nationality requirement is provided in Article 119 2.2.4, which allows naturalised athletes with a spouse of the new nationality to compete for the new federation after one year of uninterupted legal residence or three years of non-consecutive periods of legal residence In addition, the FEI recognises special circumstances in which the FEI has the discretion not to apply aforementioned rules after prior consultation with the relevant national federations.

1319 Art. 119(2.2.2) FEI general regulations, $23^{\text {rd }}$ edition, $1^{\text {st }}$ January 2009 , updates effective $11^{\text {st }}$ January 2016; Art 119(2.2.2) FEl general regulations, $23^{\text {rd }}$ edition, $1^{\text {st }}$ January 2009 , updates effective $1^{\text {st }}$ January 2015; Art. 119(2.2.2) FEl general regulations, $23^{\text {rd }}$ edition, $1^{\text {st }}$ J anuary 2009 , updates effective $1^{\text {st }}$ January 2014; Art. 119(2.2.2) FEI general regulations, $23^{\text {rd }}$ edition, $1^{\text {st }}$ January 2009, updates effective $1^{\text {st }}$ January 2013; Art. 119(2.2.2) FEl general regulations $23^{\text {rd }}$ edition, $1^{\text {st }}$

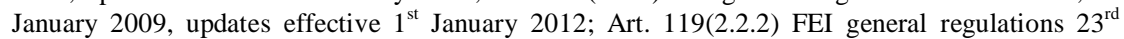
edition, $1^{\text {st }}$ January 2009, updates effective $1^{\text {st }}$ January 2011 and Art. 119(2.2.2) FEI general regulations $23^{\text {rd }}$ edition, $1^{\text {st }}$ January 2009, updates effective $1^{\text {st }}$ January 2010; Art 119(5) FEI general regulations, $23^{\text {rd }}$ edition, $1^{\text {st }}$ January 2009; Art 123(5) FEl general regulations, $22^{\text {nd }}$ edition, $1^{\text {st } J ~ u n e ~} 2007$ and $22^{\text {nd }}$ edition with 2008 amendments.

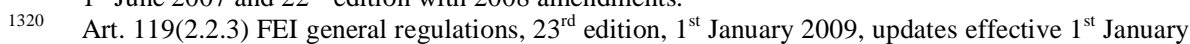
2016; Art. 119(2.2.3) FEl general regulations, $23^{\text {rd }}$ edition, $1^{\text {st }}$ January 2009 , updates effective $1^{\text {st }}$ January 2015; Art. 119(2.2.3) FEl general regulations, $23^{\text {rd }}$ edition, $1^{\text {st }}$ January 2009, updates effective $1^{\text {st }}$ January 2014; Art. 119(2.2.3) FEI general regulations, $23^{\text {rd }}$ edition, $1^{\text {st }}$ January 2009, updates effective $1^{\text {st }}$ January 2013; Art. 119(2.2.3) FEl general regulations $23^{\text {rd }}$ edition, $1^{\text {st }}$ January 2009, updates effective $1^{\text {st }}$ January 2012 and Art. 119(2.2.3) FEI general regulations $23^{\text {rd }}$ edition, $1^{\text {t }}$ January 2009 , updates effective $1^{\text {t }}$ J anuary 2011. 
With regard to residence, theFEI al so in principleallows athletes who do not live in a country of which they were a national to compete for the host country at certain tournaments, ${ }^{1321}$ in casehis own national federations agreed. ${ }^{1322}$ Another exceptional circumstance is also provided namely for the position of an athlete whose country was subject to teritorial transfers. In principle the athlete does not need to change to the new federation. He or she can choose to do so, however, but then the choice is deemed to be final. ${ }^{1323}$ Athletes who lost their national ity, became refugees or whose national federation ceased to exist could compete in international tournaments nevertheless. In that case, however, he or she can be considered a national of the host country of the tournament ${ }^{1324}$

Having spoken of adult athletes, it is necessary to turn to the FEI's regulation on minor athletes. It stipulates that:

"A Minor Athlete who is a citizen of more than one country can choose each calendar year which NF hewants to represent" $" 1325$

1321 CNs, CIMsas well as Cls.

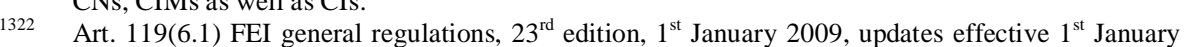
2016; Art. 119(6.1) FEl general regulations, $23^{\text {rd }}$ edition, $1^{\text {st }}$ January 2009, updates effective $1^{\text {st }}$ January 2015; Art. 119(6.1) FEI general regulations, $23^{\text {rd }}$ edition, $1^{\text {s }}$ January 2009, updates

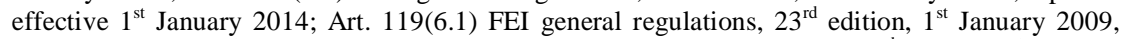
updates effective $1^{\text {st }}$ anuary 2013; Art. 119(6.1) FEl general regulations $23^{\text {rd }}$ edition, $1^{\text {tt }}$ anuary 2009, updates effective $1^{\text {st }}$ January 2012; Art. 119(6.1) FEl general regulations $23^{\text {rd }}$ edition, $1^{\text {st }}$ January 2009, updates effective $1^{\text {st }}$ January 2011 and Art 119(6.1) FEI general regulations $23^{\text {rd }}$ edition, $1^{\text {st }}$ J anuary 2009, updates effective $1^{\text {st }} J$ anuary 2010; Art 119(11) FEI general regulations, $23^{\text {rd }}$ edition, $1^{\text {st } J ~ a n u a r y ~ 2009 ; ~ A r t ~ 123(11) ~ F E l ~ g e n e r a l ~ r e g u l a t i o n s, ~} 22^{\text {nd }}$ edition, $1^{\text {st }} J$ une 2007 and $22^{\text {nd }}$ edition with 2008 amendments; Art. 123(8) FEI general regulations $21^{\text {st }}$ edition, effective $1^{\text {st }}$ January 2005 revision May 2006; Art. 123(8) FEl general regulations $21^{\text {ts }}$ edition, effective $1^{\text {st }}$ January 2005.

1323 Art. 119(4) FEl general regulations, $23^{\text {rd }}$ edition, $1^{\text {st }}$ January 2009 , updates effective $1^{\text {st }}$ January 2016; Art 119(4) FEl general regulations, $23^{\text {rd }}$ edition, $1^{\text {st }}$ January 2009 , updates effective $1^{\text {st }}$ January 2015; Art. 119(4) FEl general regulations, $23^{\text {rd }}$ edition, $1^{\text {st } J ~ a n u a r y ~} 2009$, updates effective $1^{\text {t }}$ January 2014; Art 119(4) FEl general regulations, $23^{\text {rd }}$ edition, $1^{\text {ts }}$ January 2009, updates effective $1^{\text {st }}$ January 2013; Art. 119(4) FEI general regulations $23^{\text {rd }}$ edition, $1^{\text {st }}$ January 2009 , updates effective $1^{\text {st }}$ January 2012; Art. 119(4) FEI general regulations $23^{\text {rd }}$ edition, $1^{\text {st }}$ January 2009, updates effective $1^{\text {st }}$ January 2011 and Art. 119(4) FEl general regulations $23^{\text {rd }}$ edition, $1^{\text {st }}$ January 2009, updates effective $1^{\mathrm{st}}$ J anuary 2010; Art 119(8) FEI general regulations, $23^{\text {rd }}$ edition, $1^{\text {t }}$ January 2009. Art 123(8) FEI general regulations, $22^{\text {nd }}$ edition, $1^{\text {st }} J$ une 2007 and $22^{\text {nd }}$ edition with 2008 amendments; Art 123(4) FEI general regulations $21^{\text {st }}$ edition, effective $1^{\text {st }}$ January 2005 revision May 2006; Art. 123(4) FEI general regulations $21^{\text {st }}$ edition, effective $1^{\text {st }}$ January 2005.

Art. 119(5) FEl general regulations, $23^{\text {rd }}$ edition, $1^{\text {st }}$ January 2009 , updates effective $1^{\text {st }}$ January

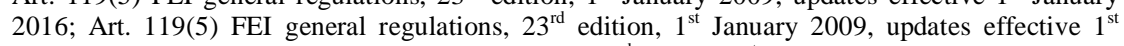

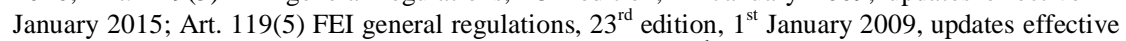
$1^{\text {ts }}$ January 2014; Art $119(5)$ FEl general regulations, $23^{\text {rd }}$ edition, $1^{\text {st } J a n u a r y ~} 2009$, updates effective $1^{\text {ts }}$ January 2013; Art. 119(5) FEI general regulations $23^{\text {rd }}$ edition, $1^{\text {tt }}$ January 2009, updates effective $1^{\text {st }}$ January 2012; Art. 119(5) FEI general regulations $23^{\text {rd }}$ edition, $1^{\text {st }}$ January 2009, updates effective $1^{\text {st }}$ January 2011 and Art 119(5) FEI general regulations $23^{\text {rd }}$ edition, $1^{\text {st }}$ January 2009, updates effective $1^{\text {st }}$ January 2010; Art 119(12) FEI general regulations, $23^{\text {rd }}$ edition, $1^{\text {st }}$ January 2009; Art 123(12) FEl general regulations, $22^{\text {nd }}$ edition, $1^{\text {st }}$ June 2007 and $22^{\text {nd }}$ edition with 2008 amendments; Art 123(9) FEl general regulations $21^{\text {st }}$ edition, effective $1^{\text {st }}$ January 2005 revision May 2006; Art. 123(9) FEl general regulations $21^{\text {st }}$ edition, effective $1^{\text {st }}$ January 2005.

1325 Art. 119(3.1) FEI general regulations, $23^{\text {rd }}$ edition, $1^{\text {st }}$ January 2009, updates effective $1^{\text {st }}$ January 2016; Art. 119(3.1) FEl general regulations, $23^{\text {rd }}$ edition, $1^{\text {st }}$ January 2009 , updates effective $1^{\text {th }}$ 
While in the provisions on adult athletes, the terms "nationality" and "national" were used, the term chosen in this case is "citizen" for minor athletes. The reason for this choice of words cannot be deduced from the FEI statutes. Generally, a minor athlete may decide each year for which country he or she wants to compete, provided that he or she is a national of the country. ${ }^{1326}$ If the minor athletehas al ready competed on an international level during the year and wishes to again change the country of representation, he or she needs the FEI's and the relevant national federations' approval to do $50 .{ }^{1327}$ In case a minor resides in a country of which heis not a citizen, he could compete in certain tournaments, ${ }^{1328}$ after informing the national federation and theFEI ${ }^{1329}$ Thereare internal FEI guide ines in place for such cases and the rules are applied conservative $y .{ }^{1330}$ If the minor athlete never competed for his own NF, it is possible for the athlete, upon reaching the age of majority, to ask the FEI to regard the country of residenceas the country of thenational federation if:

(i) hehas never competed under the flag of his own NF;

(ii) the country of residence, in the FEI's opinion, qualifies as a country where obtaining nationality is overly burdensome;

(iii) the Minor Athlete has a valid identity card or residence permit for the country of residence, or other equival ent document; and

January 2015; Art 119(3.1) FEl general regulations, $23^{\text {rd }}$ edition, $1^{\text {st }}$ January 2009, updates effective $1^{\text {st }}$ January 2014; Art. 119(3.1) FEl general regulations, $23^{\text {rd }}$ edition, $1^{\text {st }}$ January 2009, updates effective $1^{\text {st }}$ January 2013; Art 119(3.1) FEl general regulations $23^{\text {rd }}$ edition, $1^{\text {t }}$ January 2009, updates effective $1^{\text {st }}$ January 2012; Art. 119(3.1) FEl general regulations $23^{\text {rd }}$ edition, $1^{\text {st }}$ January 2009, updates effective $1^{\text {st }}$ January 2011 and Art 119(3.1) FEI general regulations $23^{\text {rd }}$

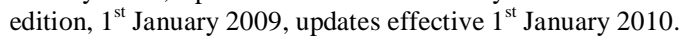

FEI email of $2^{\text {nd }}$ November 2015; Art. 119(3.2.) FEl general regulations, $23^{\text {rd }}$ edition, $1^{\text {st }}$ January 2009, updates effective $1^{\text {st }}$ January 2016; Art. 119(3.2.) FEl general regulations, $23^{\text {rd }}$ edition, $1^{\text {st }}$ January 2009, updates effective $1^{\text {st }}$ January 2015; Art. 119(3.2.) FEl general regulations, $23^{\text {rd }}$ edition, $1^{\text {st }}$ anuary 2009, updates effective $1^{\text {st }}$ January 2014; Art. 119(3.2.) FEl general regulations, $23^{\text {rd }}$ edition, $1^{\text {st }}$ January 2009, updates effective $1^{\text {st }}$ January 2013; Art 119(3.2.) FEl general

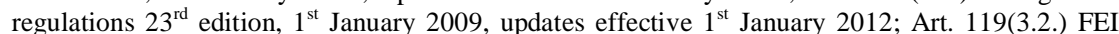
general regulations 23rd edition, $1^{\mathrm{tt}}$ January 2009, updates effective $1^{\text {tt }}$ January 2011 and Art. 119 (3.2.) FEI general regulations $23^{\text {rd }}$ edition, $1^{\text {st }}$ J anuary 2009 , updates effective $1^{\text {ts } J}$ anuary 2010. Cls for Pony Riders, Juni or Riders and Y oung Riders (which excludes $\mathrm{ClO}$ s and Championships), and senior CIMS.

1329 Art. 119(6.2) FEI general regulations, $23^{\text {rd }}$ edition, $1^{\text {ts }}$ January 2009 , updates effective $1^{\text {st }}$ January 2016; Art. 119(6.2) FEl general regulations, $23^{\text {rd }}$ edition, $1^{\text {st }}$ January 2009 , updates effective $1^{\text {st }}$ January 2015; Art. 119(6.2) FEl general regulations, $23^{\text {rd }}$ edition, $1^{\text {st }}$ January 2009, updates effective $1^{\text {st }}$ January 2014; Art. 119(6.2) FEl general regulations, $23^{\text {rd }}$ edition, $1^{\text {s }}$ January 2009 , updates effective $1^{\mathrm{t}}$ January 2013; Art. 119(6.2) FEl general regulations $23^{\text {rd }}$ edition, $1^{\mathrm{t}}$ J anuary 2009, updates effective $1^{\text {st }}$ January 2012; Art. 119(6.2) FEl general regulations $23^{\text {rd }}$ edition, $1^{\text {st }}$ January 2009, updates effective $1^{\text {st }}$ January 2011 and Art 119(6.2) FEI general regulations $23^{\text {rd }}$ edition, $1^{\text {st }}$ January 2009, updates effective $1^{\text {st } J ~ a n u a r y ~ 2010 ; ~ A r t ~ 119(11) ~ F E I ~ g e n e r a l ~ r e g u l a t i o n s, ~}$ $23^{\text {rd }}$ edition, $1^{\text {st }}$ January 2009; Art. 123(11) FEl general regulations, $22^{\text {nd }}$ edition, $1^{\text {st } J ~ u n e ~} 2007$ and $22^{\text {nd }}$ edition with 2008 amendments; Art. 123(8) FEI general regulations $21^{\text {st }}$ edition, effective $1^{\text {st }}$ January 2005 revision May 2006; Art. 123(8) FEI general regulations $21^{\text {st }}$ edition, effective $1^{\text {st }}$ J anuary 2005.

1330 FEl e-mail of $2^{\text {nd }}$ November 2015. 
(iii) the Minor Athlete has been a resident of the country of residence for at least thelast five (5) consecutive years. ${ }^{1331}$

However, what constitutes an overly burdensome procedure to acquire nationality for the FEI? The statutes do not darify which standards are to be applied, however there are internal guidelines and the rules is applied conservatively. ${ }^{1332}$ The stipul ation that theminor athletedid not compete under another flag are in line with the conditions for adult athletes, yet point (ii) is difficult to ascertain. Since 2012, if an athlete is nether stateless, refugee nor faced with a territorial transfer, but is living in a country without a recognised NF, the FEI may decide to le him or her participate under the FEI flag. Such a decision is taken conservatively on a case-by-case basis according to the internal guidelines, with particular attention paid to the specific and exceptional circumstances of the case ${ }^{1333}$ In conclusion, the FEI has a very detailed approach and even with rules that are usually applied conservatively it allows for changes in the country of representation under several circumstances.

\footnotetext{
1331 Ibid.

1332 FEl email of $2^{\text {nd }}$ November 2015.

1333 FEI e-mail of $2^{\text {nd }}$ November 2015; Art. 119(5.2) FEl general regulations, $23^{\text {rd }}$ edition, $1^{\text {st }}$ January 2009, updates effective $1^{\text {st }}$ January 2016; Art. 119(5.2) FEl general regulations, $23^{\text {rd }}$ edition, $1^{\text {st }}$ January 2009, updates effective $1^{\text {st }}$ January 2015; Art. 119(5.2) FEl general regulations, $23^{\text {rd }}$

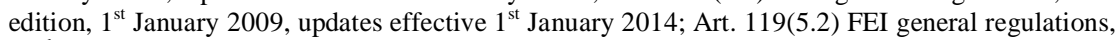

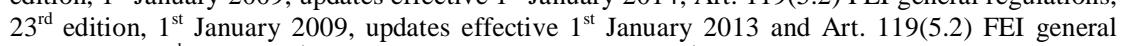

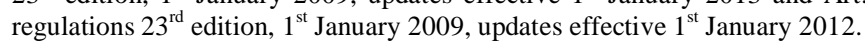





\section{Movement over water}

In the following, sports that aim at the swiftest movement over water will be examined. The sport that should be the oldest with regard to Olympic presence is sailing, as it was supposed to make its debut in 1896, yet, due to bad weather conditions in 1896, sailing and rowing both madether first appearance at the Olympic Games in 1900.

Sailing interestingly allowed women to partake in the sport from the very beginning, since the teams were mixed gender. Separate women and men only events were added in 1988 and the 2008 Games saw the end of the mixed events. Rowing, in tum, only had Olympic women's events introduced in 1976. Canoe is by far the youngest of these sports, with sprint being introduced in 1936 and stal om only in 1972. Interestingly, in both categories women were allowed to participate earlier than in rowing, with the women's events being introduced in 1948 and 1972 respectively. Regarding the continuity of presence, rowing and canoe sprint were featured at all Olympic Games sincetheir debut, whilesail ling missed out in 1904.

Table XXXIX: Topics dealt with in Sports that focus on movement over water

\begin{tabular}{|c|c|c|c|}
\hline Requirements & C anoe K ayak & Rowing & Sailing \\
\hline In force since & 2011 & 2013 & 2013 \\
\hline Versions since 2005 & Since 2011 & $\begin{array}{l}2005-2012 \\
\text { Since } 2012\end{array}$ & $\begin{array}{l}2012-2013 \\
\text { Since } 2013\end{array}$ \\
\hline $\begin{array}{l}\text { Substantial C hanges } \\
\text { made since October } \\
2013\end{array}$ & $n / a$ & $n / a$ & n/a \\
\hline C hange of nationality & Possible & $\begin{array}{l}\text { Possible after a two- } \\
\text { year waiting period }\end{array}$ & Possible \\
\hline $\begin{array}{l}\text { Residence } \\
\text { requirements }\end{array}$ & $\begin{array}{l}\text { two years for } \\
\text { competing for country } \\
\text { of domicile without } \\
\text { needing prior } \\
\text { permission }\end{array}$ & None & Ordinary residence \\
\hline $\begin{array}{l}\text { M inors and } \\
\text { nationality change }\end{array}$ & $\begin{array}{l}\text { J unior athletes are } \\
\text { those aged } 15 \text { to } 18 \text {, } \\
\text { samerules apply }\end{array}$ & Not specified & Not specified \\
\hline Stateless athletes & $\begin{array}{l}\text { Not specified on ICF } \\
\text { level }\end{array}$ & Not specified & Not specified \\
\hline $\begin{array}{l}\text { Position of athletes } \\
\text { with multiple } \\
\text { nationality after } \\
\text { having competed for } \\
\text { another country of } \\
\text { which the athlete is a } \\
\text { national }\end{array}$ & $\begin{array}{l}\text { Permission from } \\
\text { federation and two-year } \\
\text { residencein relevant } \\
\text { country needed }\end{array}$ & $\begin{array}{l}\text { Possi ble after two-year } \\
\text { waiting period }\end{array}$ & $\begin{array}{l}\text { Threeyear waiting } \\
\text { period }\end{array}$ \\
\hline $\begin{array}{l}\text { E ffect of changes in } \\
\text { territory of country }\end{array}$ & $\begin{array}{l}\text { Not specified on ICF } \\
\text { leve }\end{array}$ & Not specified & $\begin{array}{l}\text { Have to acquire } \\
\text { nationality of new } \\
\text { entity first }\end{array}$ \\
\hline Competing for the & Possiblewith & Possible, if exception is & Possibleafter three \\
\hline
\end{tabular}


NATIONALITY REQUIREMENTS IN OLYMPIC SPORTS

\begin{tabular}{|l|l|l|l|}
\hline country of residence & $\begin{array}{l}\text { permission of } \\
\text { federation of origin or } \\
\text { after two years of } \\
\text { domicile }\end{array}$ & granted & $\begin{array}{l}\text { years of ordinary } \\
\text { residence }\end{array}$ \\
\hline $\begin{array}{l}\text { Number of changes } \\
\text { possible }\end{array}$ & No maximumgiven & No maximumgiven & \\
\hline $\begin{array}{l}\text { R efer ence to Olympic } \\
\text { Charter }\end{array}$ & Yes & Yes & None \\
\hline $\begin{array}{l}\text { Uses nationality/ } \\
\text { citizenship }\end{array}$ & Nationality & Nationality & Both \\
\hline $\begin{array}{l}\text { Uses residence/ } \\
\text { domicile }\end{array}$ & Domicile & Neither & Both \\
\hline
\end{tabular}




\subsection{C anoe Kayak ${ }^{1334}$}

Canoeing became Olympic in the 1936 Games in Berlin, ${ }^{1335}$ while the current International Canoe Federation (ICF) was founded in 1946 and has its seat in Lausanne, Switzelland. Canœe Slal om was first introduced in 1972, yet it was absent from the Games in 1976, 1980, 1984, and 1988. ${ }^{1336}$

The main difference between canoes and kayaks lies in the athlete's paddling position and theamount of cover used on top of the boat to keep the water out. In the case of kayaks, the athlete paddles in a sitting position and the top of the boat is closed. Contrarily, athletes who use canoes paddle in a kneding position in an open boat. ${ }^{1337}$ Nowadays, both canoes and kayaks are used at the main events, which feature races over distances of $200 \mathrm{~m}, 500 \mathrm{~m}$ or $1,000 \mathrm{~m}$ The main disciplines here are either sprint or slalom. For the former, cal $m$ water is needed and the aim is to cross the surface as fast as possible, while the latter was modelled after ski slalom and thus the athletes have to brace flowing water and navigate their canoe or kayak through a slal om course as fast as possible

The different disciplines al so require slightly different crafts. Canoe sprint boats tend to be longer and more streamlined, while those for slalom are smaller and lighter to allow for easier maneuverers. Tuming to the rules regarding athlete eligibility, there are nominally different rules for canoe slalom and canoe sprint. However, with regard to athlete eligi bility, they do not differ in their content.

TableXL: Overview of the eligibility requirements for Canoe Kayak

\begin{tabular}{|l|l|}
\hline R equirements ICF - C anoe K ayak & \\
\hline In force since & 2011 \\
\hline C hange of nationality & Possi ble \\
\hline R esidence requirements & $\begin{array}{l}\text { two years for competing for country of domicile } \\
\text { without needing prior permission }\end{array}$ \\
\hline M inors and nationality change & $\begin{array}{l}\text { Junior athletes are those aged 15 to 18, samerules } \\
\text { apply }\end{array}$ \\
\hline Stateless athletes & Not specified on ICF leve \\
\hline $\begin{array}{l}\text { Position of athletes with multiple nationality } \\
\text { after having competed for another country of } \\
\text { which the athlete is a national }\end{array}$ & $\begin{array}{l}\text { Permission from federation and two-year residence } \\
\text { in relevant country needed }\end{array}$ \\
\hline E ffect of changes in territory of country & Not specified on ICF leved \\
\hline C ompeting for the country of residence & $\begin{array}{l}\text { Possi blewith permission of federation of origin or } \\
\text { after two years of domicile }\end{array}$ \\
\hline
\end{tabular}

1334 The federation was contacted on $6^{\text {th }}$ August 2014 and asked to provide further insights into its eligibility criteria and older versions of the eligibility rules. As no reply was forthcoming a reminder e-mail was sent on $18^{\text {th }}$ September. On $29^{\text {th }}$ October 2015 the federation was contacted again and asked for comments on this Chapter, to which the federation replied on $29^{\text {th }}$ October 2015.

1335 IOC Reference Document Canoe Sprint.

1336 IOC Reference Document Canoe Slal om for information on non-national athletes in the European national leagues and competitions see S. van den Bogaert, A. Cuyvers, S. Gardiner, R. Parrish, S. Miettinen, J. Soek and R. Siekmann (2010), p. 139.

1337 IOC Information on Canoe/ Kayak Slal omEqui pment and History. 
NATIONALITY REQUiREMENTS IN OLYMPIC SPORTS

\begin{tabular}{|l|l|}
\hline Number of changes possible & No maximumgiven \\
\hline & \\
\hline R eference to Olympic Charter & Yes \\
\hline Uses nationality/ citizenship & Nationality \\
\hline Uses residence/ domicile & Domicile \\
\hline O ther remarkable peculiarity & Rules split between different parts of the rule book \\
\hline
\end{tabular}

\subsubsection{CanoeKayak critical reflection}

The rules on ICF level are split in two - one dealing with eligibility for the Olympics and thus focussing only on the IOC Charter ${ }^{1338}$ and the other dealing with competitors in all ICF competitions. Athletes al ways need the permission of their federation of origin to competeinternationally, ${ }_{13}^{1339}$ which might betedious, but, through this system, competing for the country of domicile becomes easily possibl $e^{1340}$ Stateless athletes and territorial transfers are not explicitly mentioned and there are no rules for minors except those delineating an age limit for junior competitions, namely between 15 and $18 .{ }^{1341}$

\subsubsection{Rules applicable since 2011}

Eligibility rules for Canœe Slalom and Canœe Sprint may be found in the separate compeition rules. Within the compeition rules, there are two articles, one titled 'Eligibility' and dealing with Olympic eligibility, which is closely connected to the IOC's rules, and the other titled 'Competitors', which sets down rules for all ICF compeitions.

Starting with the eligibility criteria described in the 'Eligibility' article, one finds that these rules, under the current heading $C$ of both the International Canoe Federation Canoe Slalom Competition Rules and International Canoe Federation Canoe Sprint Competition Rules 2015, are basically identical to those previously applied and which were described in Article C of the Intemational Canœe Federation Canoe Slalom Competition Rules 2011 and Article C of the International Canoe Federation Canoe Sprint Competition Rules 2013. The underlying postulation is that only athletes who have complied with the Olympic Charter may participate in the Olympics. ${ }^{1342}$ The only difference regarding the 2015 version and the previous versions is that since 2015 the eligibility Article 41 of the IOC Charter is mentioned

1338 Art. C International Canoe Federation Canoe Slal om competition rules 2015; Art. C International Canoe Federation - Canoe Sprint competition rules 2015.

1339 Art. 3.2 International Canoe Federation Canoe Slalom competition rules 2015; Art. 3.2 International Canoe Federation - CanoeSprint competition rules 2015.

1340 Art. 3.3.1 International Canoe Federation Canoe Slalom competition rules 2015; Art 3.3 International Canoe Federation - Canoe Sprint competition rules 2015.

1341 Art. 3.4 International Canoe Federation Canoe Slalom competition rules 2015; Art. 3.6 International Canoe Federation - Canoe Sprint competition rules 2015.

1342 Art. C International Canoe Federation Canoe Slal om competition rules 2015; Art. C International Canoe Federation - Canoe Sprint competition rules 2015; Art. C International Canoe Federation Canoe Slalom competition rules 2011; Art. C International Canoe Federation - Canoe Sprint competition rules 2013. 
explicitly. ${ }^{1343}$ This is further clarified to mean that athletes have to comply with the Olympic Charter currently in force for the period of the Olympic Games. ${ }^{1344}$ No reference is made to an athlete's nationality and its connection to eligibility at this point

Significantly more information can be found under the heading 'Competitors', wherein the ICF stipulates that athletes should have a good standing with their federation and may only compete for one federation per calendar year. ${ }^{1345}$ It is important to note that, until 2015, an exemption was granted to athletes who moved their domicile due to marriage, as they could di rectly compete for thenew country of domicile ${ }^{1346}$

In order to compete internationally, the athlete has to obtain the written permission of his or her federation of origin. ${ }^{1347}$ Such a permission may also be obtained if the athlete wishes to compete for his or her country of domicile, if this is not also the country of origin. ${ }^{1348}$ In this case, the ICF headquarters also need to receive this authorisation by $30^{\text {th }}$ November of the year prior to which the change would become effective ${ }^{1349}$ Should the athlete wish to change back to his or her federation of origin, the same procedure applies. ${ }^{1350}$ Athletes who have been domiciled in a country for over two years do not need to ask for permission from their federation of origin. ${ }^{1351}$

J unior athletes are those between 15 and 18 years of age - al though it is not the exact birthday that is taken into consideration but just the year of birth. ${ }^{1352}$ Thus, an

1343 Art. C International Canoe Federation Canoe Slal om competition rules 2015; Art. C International Canoe Federation - Canoe Sprint competition rules 2015.

1344 Art. C International Canoe Federation Canoe Slal om competition rules 2015; Art. C International Canoe Federation - Canoe Sprint competition rules 2015; Art. C International Canoe Federation Canoe Slalom competition rules 2011; Art. C International Canoe Federation - Canoe Sprint competition rules 2013.

1345 Art. 3.1 and Art. 3.3.3 International Canoe Federation Canoe Slal om competition rules 2015; Art. 3.1 and Art. 3.5 International Canoe Federation - Canoe Sprint competition rules 2015; Art. 3.1 and Art. 3.3.3 International Canoe Federation Canoe Slal om competition rules 2011; Art. 3.1 and Art. 3.5 International Canoe Federation - Canoe Sprint competition rules 2013.

1346 Art. 3.3.3 International Canoe Federation Canoe Slalom competition rules 2011; Art 3.5 International Canoe Federation - CanoeSprint competition rules 2013.

1347 Art. 3.2 International Canoe Federation Canoe Slalom competition rules 2015; Art. 3.2 International Canoe Federation - Canoe Sprint competition rules 2015; Art. 3.2 International Canoe Federation Canoe Slal om competition rules 2011; Art. 3.2 International Canoe Federation - Canoe Sprint competition rules 2013.

1348 Art. 3.3.1 International Canoe Federation Canoe Slalom competition rules 2015; Art 3.3 International Canoe Federation - Canoe Sprint competition rules 2015; Art. 3.3.1 International Canoe Federation Canoe Slal om competition rules 2011; Art. 3.3 International Canoe Federation Canoe Sprint competition rules 2013. Ibid.

1350 Ibid.

1351 Art. 3.3.2 International Canoe Federation Canoe Slalom competition rules 2015; Art 3.4 International Canoe Federation - Canoe Sprint competition rules 2015; Art. 3.3.2 International Canoe Federation Canoe Slal om competition rules 2011; Art. 3.4 International Canoe Federation Canoe Sprint competition rules 2013.

1352 Art. 3.4 International Canoe Federation Canoe Slalom competition rules 2015; Art. 3.6 International Canoe Federation - Canoe Sprint competition rules 2015; Art. 3.4 International Canoe 
athlete whose birthday is on $10^{\text {th }}$ December will be able to compete in a junior tournament from $1^{\mathrm{st}}$ J anuary of the year he or she turns 15 , despite being only 14 at that point. There are no rules providing these athletes with extra protection regarding changes of the country of representation, but, as the general rules are rather lenient, this does not seem necessary.

The ICF does not specify which rules apply in case of territorial transfers and statel ess athletes are al so not explicitly addressed. 


\subsection{R owing ${ }^{1353}$}

Rowing has been an Olympic Sport since the Olympic Games in Paris in 1900, with women being admitted in 1976. ${ }^{1354}$ The Fédération Internationale des Sociétés d'Aviron (FISA) was founded in 1922 and has its seat in Lausanne, Switzerland. Nowadays the competitions are divided according to sculling and sweep oar. In sweep oar competitions, every athl letehas only one oar held in both hands and the position of the oars alternates between the sides of the boat Rowers using sculling oars use two oars. ${ }^{1355}$ There is a further division into heavyweight and lightweight, on top of which the number of competing athletes per team varies. There are competitions in which there is only one athl ete rowing; thereareteams of two, four or eight athletes. Men and women do not competein mixed teems. ${ }^{1356}$

TableXLI: Overview of the eligibility requirements for rowing

\begin{tabular}{|l|l|}
\hline R equirements FISA & \\
\hline In force since & February 2013 \\
\hline C hange of nationality & Possi bleafter two-year waiting period \\
\hline R esidence requirements & None \\
\hline M inors and nationality change & Not specified \\
\hline Stateless athletes & Not specified \\
\hline $\begin{array}{l}\text { Position of athletes with multiple nationality } \\
\text { after having competed for another country of } \\
\text { which the athlete is a national }\end{array}$ & Possibleafter two-year waiting period \\
\hline Effect of changes in territory of country & Not specified \\
\hline Competing for the country of residence & Possible, if exception is granted \\
\hline Number of changes possible & No maximumgiven \\
\hline & \\
\hline R efer ence to Olympic Charter & Yes \\
\hline Uses nationality/ citizenship & Nationality \\
\hline Uses residence/ domicile & Neither \\
\hline Other remarkable peculiarity & None \\
\hline
\end{tabular}

\subsubsection{Rowing critical reflection}

The FISA stipulates that only athletes who are nationals of a country can represent the country during rowing tournaments, but in exceptional circumstances a dedision may be taken by the Exeative Committee to circumvent this rule ${ }^{1357}$ Athletes with

1353 The federation was contacted on $6^{\text {th }}$ August 2014 and asked to provide further insights into its eligi bility criteria and ol der versions of the eligibility rules. On $7^{\text {th }}$ August, the FISA replied that there had been no rule changes between 2005 and 2012. On $29^{\text {th }}$ October 2015, the federation was contacted again and asked for comments on this Chapter. As no reply was forthcoming a first reminder was sent on $19^{\text {th }}$ November 2015 and a second on $2^{\text {nd }}$ December 2015, to which the federation replied on $2^{\text {nd }}$ December 2015.

1354 IOC Information FISA; IOC Reference Document Rowing: for information on non-national athl etes in the European national leagues and competitions see S. van den Bogaert, A. Cuyvers, S. Gardiner, R. Parrish, S. Miettinen, J. Soek and R. Siekmann (2010), p. 139.

1355 IOC Information FISA; IOC Information on Rowing Equipment and History.

1356 IOC Information on Rowing Equipment and History.

1357 Rule19 FISA rule book February 2013. 
multiple nationality may choose which country to represent ${ }^{1358}$ Later, wishes to compete for a different country will be honoured following a two-year waiting period. ${ }^{1359}$ In conclusion, the FISA's rules are not very detailed. They are however rather lenient, as the two-year non-compeition period is not as intrusive as the criteria prescribed by other sports.

\subsubsection{Rules applicable sinceOctober 2013}

Eligibility for rowing competitions is spelled out in rules 18 and 19 of the FISA rule book of February 2013. Rule 18 stipulates that, for all official competitions, the athletes need to fulfil the sporting requirements of the relevant category. ${ }^{1360}$ In order for an individual athlete to compete at an event, the rules depend on the compeition. For the world rowing championship, world rowing cup, continental championship and international regattas, the athl ete needs the authorisation of his or her federation. ${ }^{1361}$ For the World Championships, competing for a country is possible on the condition that the athlete is a national of the relevant country and may prove so by providing a valid passport or identity card. ${ }^{1362}$ In certain cases, exceptions can be granted by the Executive Committee 1363

With regard to the representation of a country in the Olympic Games, the athletes first of all need to fulfil the eligibility criteria prescribed by the IOC. ${ }^{1364}$ In principle, athletes may represent the country of which they are nationals and, in the case of multiple nationality they may select one country for which they want to compete ${ }^{1365}$ Athletes who have al ready competed for a country on the international level and wish to reverse their choice and those who acquired another nationality need to wait for two years before competing for the new country. ${ }^{1366}$ Again, exceptions can be made by the Executive Committee under special circumstances. ${ }^{1367}$

\subsubsection{Rules applicable $2005-2012$}

Tuming to therules spel led out by the Fédération Internationale des Sociétés d'Aviron (FISA) in the years 2005 to 2012, the eligi bility rules were rather concise, as Rule 43 stipulates that a crew may only be authorised by a member federation to the FISA. ${ }^{1368}$ Concerning the individual athl ete, theFISA stipul ated that he or shehad to bea citizen of the country he or she wished to represent ${ }^{1369}$ In order to fulfil this criterion, the

\footnotetext{
1358 Ibid.

1359 Ibid.

1360 Rule 18 FISA rule book February 2013.

1361 Rule 19 FISA rule book February 2013.

1362 Ibid.

1363 Ibid.

1364 Ibid.

1365 Ibid.

1366 Ibid.

1367 Ibid.

1368 Rule43(a) FISA rules applicable 2005 to 2012

1369 Rule43(b) FISA rules applicable 2005 to 2012.
} 
possession of an official document such as a passport or ID card was sufficient ${ }^{1370}$ Thus, there were no further rules regarding the acquisition of nationality or any residence requirements. Furthermore, the FISA executive Committee could make exceptions to the aforementioned rule, depending on the case ${ }^{1371}$

Giving the brevity of the FISA rules, one cannot go into great analytical depths. Overall, the rules requiring only the possession of a passport seems to be rather liberal, due to the absence of a residence period requirement and allowed for nationality changes in an easy and uncomplicated manner. Stateless athletes and minors were not especially addressed - however, the possibility for the Executive Committee to make exceptions to the general rule should ensure that adequate measures are taken in unforeseen circumstances. One could potentially deduce that the FISA did place less emphasis on the nationality of an athlete, but focussed more on the athlete's connection to the respective member association. 


\subsection{Sailing ${ }^{1372}$}

The general aim of sailing - or yachting as it used to becalled - is to makethe best use of the weather conditions, such as wind, to navigate the water faster than the other boats. It has been an Olympic sport since 1896, although the International Sailing Federation (ISAF) was only founded in 1907 - then still under the old name of International Yacht Rading Union - and has its seat in London, United Kingdom ${ }^{1373}$ Sailing was at first a gender independent sport and teams consisted of both men and women. ${ }^{1374}$

Nowadays teams compete in ten races in which they collect points depending on their finishing positions. Interestingly, the aim is to have the lowest possible scoresince finishing first gives the team one point, coming in second two points etc. Only the boats with the lowest scores will compete in the race for the Olympic medals. In the ensuing 30-minute race the points are counted double and added up to the points acquired in the first ten matches to determine the final score. Again, the team with the lowest score wins. There is, however, also the possibility of match racing, meaning that whichever team comes in first wins the match. ${ }^{1375}$

TableXLII: Overview of the eligibility requirements for sailing

\begin{tabular}{|l|l|}
\hline R equirements ISAF & \\
\hline In force since & May 2013 \\
\hline C hange of nationality & Possible \\
\hline R esidence requirements & Ordinary residence \\
\hline M inors and nationality change & Not specified \\
\hline Stateless athletes & Not specified \\
\hline $\begin{array}{l}\text { Position of athletes with multiple nationality } \\
\text { after having competed for another country of } \\
\text { which the athlete is a national }\end{array}$ & Threeyear waiting period \\
\hline E ffect of changes in territory of country & Haveto acquirethenationality of new entity first \\
\hline C ompeting for the country of residence & Possi bleafter threeyears of ordinary residence \\
\hline Number of changes possible & None \\
\hline & \\
\hline R eference to Olympic Charter & None \\
\hline Uses nationality/ citizenship & Both \\
\hline Uses residence/ domicile & Both \\
\hline O ther remarkable peculiarity & $\begin{array}{l}\text { Possibleto compete for country of which an } \\
\text { athl etehas competed for threeyears for that } \\
\text { national league; membership sufficient }\end{array}$ \\
\hline
\end{tabular}

1372 The federation was contacted on $6^{\text {th }}$ August 2014 and asked to provide further insights into its eligibility criteria and older versions of the eligibility rules. As no reply was forthcoming, a reminder e-mail was sent on $18^{\text {th }}$ September. On $29^{\text {th }}$ October 2015 the federation was contacted again and asked for comments on this chapter as no reply was forthcoming.

1373 IOC Information ISAF: for information on non-national athletes in the European national leagues and competitions see S. van den Bogaert, A. Cuyvers, S. Gardiner, R. Parrish, S. Miettinen, J. Soek and R. Siekmann (2010), p. 139.

1375 IOC Information on Sailing Equipment and History. 


\subsubsection{Sailing citical reflection}

The ISAF rules are particularly interesting as they differentiate between competition eligi bility and ISAF eligi bility. ${ }^{1376}$ Competition eligibility is granted unless the athlete has violated the ISAF code ${ }^{1377}$ ISAF eligibility can be obtained by those who are members of their relevant federation, abide by the ISAF rules, and are registered with the ISAF. ${ }^{1378}$ For national teams, the sail or needs to be a national of the country heor she represents. ${ }^{1379}$ There are however exceptions that might be granted to those who have been resident for at least three consecutive years in the relevant country. ${ }^{1380}$ Changing the country of representation is possible if the athl ete observes a threeyear non-competition period. ${ }^{1381}$ These rules are rather strict, due to the thre-year noncompeition period which can rather hinder an athlete's carer.

\subsubsection{Rules applicable since 2012}

Initially the ISAF eligibility code only dealt with matters of ISAF eligibility, i.e the need for a correct license ${ }^{1382}$ Nationality criteria and matters of changing the country of representation were only introduced in $2013 .{ }^{1383}$ Currently the ISAF distinguishes between two forms of eligibility - the first being competition eligi bility and the second ISAF eligibility. ${ }^{1384}$ The former is held by anyone unless it is revoked due to a violation of the code ${ }^{1385}$ The latter is needed in addition to the competition eligibility for all official ISAF events and the Olympics ${ }^{1386}$ and is granted if the athlete is registered with the ISAF as a sai lor, ${ }^{1387}$ abides by the ISAF rules, ${ }^{1388}$ and is a member of therelevant federation: ${ }^{1389}$

1376

Art. 19.1 and Art. 19.4 ISAF regulations 2015 - Annex 3 - eligi bility code- November 2014. Art. 19.1. and Art 19.2 ISAF regulations 2015 - Annex 3 - eligibility code - November 2014. Art. 19.4(a), Art. 19.4(b) and Art 19.4(c) ISAF regulations 2015 - Annex 3 - eligibility code November 2014.

Art.19. 8ISAF regulations 2015 - Annex 3- digi bility code- November 2014.

Art. 19.12(a), Art. 19.12(b) and Art. 19.12(c) ISAF regulations 2015 - Annex 3 - eligi bility codeNovember 2014.

Art. 19.13(b) ISAF regulations 2015 - Annex 3 - eligibility code - November 2014.

Art. 19.1 and Art. 19.2. ISAF regulations 2012 Appendix 3 - eligi bility code.

Art. 19.8 - 19.13 ISAF regulations 2015 - Annex 3 - eligibility code - November 2014; Art 19.8 - 19.13 ISAF regulations 2014 - Annex 3 - eligibility code - November 2013; Art. 19.8 - 19.13 ISAF regulations 2014 - Annex 3 - eligibility code- May 2013.

Art. 19.1 and Art 19.4 ISAF regulations 2015 - Annex 3 - eligi bility code - November 2014; Art. 19.1 and Art. 19.4 ISAF regulations 2014 - Annex 3 - eligibility code- November 2013; Art. 19.1 and Art 19.4 ISAF regulations 2014 - Annex 3 - eligibility code- May 2013.

Art. 19.1. and Art. 19.2 ISAF regulations 2015- Annex 3 - eligi bility code - November 2014; Art. 19.1. and Art 19.2 ISAF regulations 2014 - Annex 3 - eligibility code - November 2013; Art. 19.1. and Art. 19.2 ISAF regulations 2014 - Annex 3 - eligibility code- May 2013.

Art. 19.6(a) and Art. 19.6 (c) ISAF regulations 2015- Annex 3 - eligibility code - November 2014; Art. 19.6(a) and Art. 19.6(c) ISAF regulations 2014 - Annex 3 - eligibility code November 2013; Art. 19.6(a) and Art 19.6(c) ISAF regulations 2014 - Annex 3 - eligibility code - May 2013.

Art. 19.4(b) ISAF regulations 2015- Annex 3 - eligibility code - November 2014; Art. 19.4(b) ISAF regulations 2014 - Annex 3 - eligibility code - November 2013; Art. 19.4(b) ISAF regulations 2014 - Annex 3 - digibility code - May 2013; Art. 19.2 ISAF regulations 2012 Appendix 3 - eligibility code

Art. 19.4(c) ISAF regulations 2015 - Annex 3 - eligibility code - November 2014; Art. 19.4(c) ISAF regulations 2014 - Annex 3 - eligibility code - November 2013; Art 19 4(c) ISAF 
" $(\mathrm{i})$ by being entered by a national authority of the country of which the compeitor is a national or ordinarily a resident; or

(ii) by presenting a valid membership card or certificate, or other satisfactory evidence of identity and membershi p;"

The wording here is interesting, since either being a national or being a member of the association is sufficient in order to have ISAF eligibility. Furthermore, the Executive Committee may grant an athlete ISAF eligibility under spedial circumstances if he or she is not able to fulfil the requirements. ${ }^{1391}$ Regarding the nationality criteria and the gui delines thereof, the ISAF underscores the need for an athlete to be a national of the country he or she represents. ${ }^{1392}$ Disputes are settled by the Executive Committee, which takes the IOC and ISAF rules into consideration, and may al so grant exceptions to theabovementioned rules. ${ }^{1393}$ This is the case when:

“(a) a compeitor must have been an ordinary resident of the country for more than three (3) consecutive years and must be able to establish his residency for this period;

(b) a competitor must have been member of the relevant Member National Authority, or a dub or other organization affiliated to the relevant national authority for at least three(3) consecutive years;

(c) a competitor who has represented one country in the Olympic Games, in continental or regional games or in world or regional dhampionships recognized by the Federation (ISAF), and who wants to represent another country, may represent this country provided that at least thre (3) consecutive years have passed since the competitor last represented a different country in the events referred to above or theExeative Committee has reduced this period." 1394

regulations 2014 - Annex 3 - eligi bility code - November 2013; Art. 19.2 ISAF regulations 2012 Appendix 3 - eligibility code.

Art. 19.4(a) ISAF regulations 2015 - Annex 3 - eligibility code - November 2014; Art. 19.4(a) ISAF regulations 2014 - Annex 3 - eligibility code - November 2013; Art. 19.4(a) ISAF regulations 2014 - Annex 3 - eligibility code - May 2013; Art. 19.2 ISAF regulations 2012 Appendix 3 - eligibility code.

1390 Art. 19.4(a)(i) and Art. 19.4(a)(ii) ISAF regulations 2015 - Annex 3 - eligibility code - November 2014; Art. 19.4(a)(i) and Art. 19.4(a)(ii) ISAF regulations 2014 - Annex 3 - eligibility code November 2013; Art. 19.4(a)(i) and Art. 19.4(a)(ii) ISAF regulations 2014 - Annex 3 - eligibility code- May 2013; Art. 19.2 ISAF regulations 2012 Appendix 3 - eligibility code

Art. 19.5 ISAF regulations 2015 - Annex 3 - eligibility code - November 2014; Art. 19.5 ISAF regulations 2014 - Annex 3 - eligibility code- November 2013; Art. 19.5 ISAF regulations 2014 Annex 3 - eligibility code- May 2013.

1392 Art.19.8 ISAF regulations 2015 - Annex 3 - eligibility code - November 2014; Art.19. 8 ISAF regulations 2014 - Annex 3 - eligibility code- November 2013; Art.19.8 ISAF regulations 2014 Annex 3 - eligi bility code- May 2013.

1393 Art. 19.10, Art. 19.12 and Art 19.13 ISAF regulations 2015 - Annex 3 - eligibility code November 2014; Art. 19.10, Art. 19.12 and Art 19.13 ISAF regulations 2014 - Annex 3 eligibility code - November 2013; Art. 19.10, Art.19.12 and Art 19.13 ISAF regulations 2014 Annex 3 - eligi bility code- May 2013.

1394 Art. 19.12(a), Art. 19.12(b) and Art. 19.12(c) ISAF regulations 2015 - Annex 3 - eligi bility codeNovember 2014; Art. 19.12(a), Art. 19.12(b) and Art. 19.12(c) ISAF regulations 2014 - Annex 3 - 
What is striking about these rules is that either threyears residency or membership of a relevant entity can lead the Executive Committeeto allow an athlete to competefor a country. Thus, compeing for the country of ordinary residence is possible after three years. Moreover, athl etes who have been competing for a club in a national league for at least three years becomes eligible for this country's national team Thus, a convergence between national and dub teams becomes possible

Coming to the third case in which an exception may be given, one finds that changing the country of representation is possible after three years of noncompetition. There is however no additional requirement mentioned in this part of the statutes, eg. the athlete does not seem to need to acquire the nationality of the new country. Such an additional requirement can only be found in the following Article 19.13, which deals with the nationality criteria guidelines. Here it is spelled out that the athlete indeed has to have acquired the nationality or changed his nationality to the one of the country he or she wishes to represent. ${ }^{1395}$ The aforementioned period of three years of non-competition may be reduced or even waived by the Executive Committee ${ }^{1396}$ These guidelines furthermore refer to the cases in which athletes hold multiple nationalities as well as those situations in which a territorial transfer occurred. Athletes with multiple nationality should in principle select one country for which they want to compete ${ }^{1397}$ If they wish to change their country of representation, they need to undergo the same procedure as those who acquired a new nationality, meaning they must fulfil the threeyear noncompetition period. ${ }^{1398}$ With regard to athletes who are faced with teritorial transfers, the ISAF allows them to choose once ${ }^{1399}$ They can choose whether to compete for one of the new entities after acquiring the relevant nationality ${ }^{1400}$ or continue to compete for the original country if s/he remains a national thereof. ${ }^{1401}$

eligibility code - November 2013; Art. 19.12(a), Art. 19.12(b) and Art. 19.12(c) ISAF regulations 2014 - Annex 3 - eligibility code- May 2013.

Art. 19.13(b) ISAF regulations 2015 - Annex 3 - eligibility code - November 2014; Art. 19.13(b) ISAF regulations 2014 - Annex 3 - eligibility code - November 2013; Art. 19.13(b) ISAF regulations 2014 - Annex 3 - eligibility code- May 2013.

Art. 19.13(b) ISAF regulations 2015 - Annex 3 - eligi bility code - November 2014; Art. 19.13(b) ISAF regulations 2014 - Annex 3 - eligibility code - November 2013; Art. 19.13(b) ISAF regulations 2014 - Annex 3 - eligibility code- May 2013.

1397 Art. 19.13(a) ISAF regulations 2015 - Annex 3 - eligibility code - November 2014; Art. 19.13(a) ISAF regulations 2014 - Annex 3 - eligibility code - November 2013; Art 19.13(a) ISAF regulations 2014 - Annex 3- eligibility code- May 2013.

Art. 19.13(a) and Art. 19.13(b) and Art. 19.12 ISAF regulations 2015 - Annex 3 - eligibility code - November 2014; Art. 19.13(a) and Art. 19.13(b) and Art. 19.12 ISAF regulations 2014 - Annex 3 - eligibility code - November 2013; Art. 19.13(a) and Art. 19.13(b) and Art. 19.12 ISAF regulations 2014 - Annex 3 - eligibility code- May 2013.

1399 Art. 19.13(c)(iii) ISAF regulations 2015 - Annex 3 - digibility code - November 2014; Art. 19.13(c)(iii) ISAF regulations 2014 - Annex 3 - eligibility code - November 2013; Art. 19.13(c)(iii) ISAF regulations 2014 - Annex 3 - eligibility code- May 2013.

1400 Art. 19.13(c)(ii) ISAF regulations 2015 - Annex 3 - eligibility code - November 2014; Art. 19.13(c)(ii) ISAF regulations 2014 - Annex 3 - eligibility code- November 2013; Art. 19.13(c)(ii) ISAF regulations 2014 - Annex 3 - eligibility code- May 2013.

1401 Art. 19.13(c)(i) ISAF regulations 2015 - Annex 3 - eligibility code - November 2014; Art. 19.13(c)(i) ISAF regulations 2014 - Annex 3 - eligibility code - November 2013; Art. 19.13(c)(i) ISAF regulations 2014 - Annex 3 - eligibility code- May 2013. 
However, in such a case, the Executive Committee is able to take decisions on "nationality, citizenship, domicile or residence" for either individual athletes or in general. ${ }^{1402}$ Such decisions will always be based on the IOC Charter when the eligibility for the Olympic Games is an issue ${ }^{1403}$ If a quick decision is needed, two individuals will be tasked with the decision-taking by the Executive Committee ${ }^{1404}$ Such a decision will only be valid for the event at stake and a more thorough decision is taken by the Executive Committee afterwards. ${ }^{1405}$

1402 Art. 19.13(d) ISAF regulations 2015 - Annex 3 - eligibility code - November 2014; Art. 19.13(d) ISAF regulations 2014 - Annex 3 - eligibility code - November 2013; Art. 19.13(d) ISAF regulations 2014 - Annex 3 - eligibility code- May 2013. regulations 2014 - Annex 3 - eligibility code- November 2013; Art 19.13 ISAF regulations 2014 - Annex 3 - eligibility code- May 2013.

1404 Art. 19.13(e) ISAF regulations 2015 - Annex 3 - digibility code - November 2014; Art. 19.13(e) ISAF regulations 2014 - Annex 3 - eligibility code - November 2013; Art 19.13(e) ISAF regulations 2014 - Annex 3 - eligibility code- May 2013.

1405 Art. 19.13(e) ISAF regulations 2015 - Annex 3 - eligibility code - November 2014; Art. 19.13(e) ISAF regulations 2014 - Annex 3 - eligibility code - November 2013; Art 19.13(e) ISAF regulations 2014 - Annex 3 - eligibility code- May 2013. 


\section{M ovement over ice and snow}

In the following, the sports that aimat the swiftest or most elegant movement over ice or snow will be focussed upon, namely bobsleigh, luge, skating, and skiing. Interestingly, only the International Skating Union has its seat in Lausanne, where most of the other sports have their international headquarters. The FIS governs skiing matters from Oberhofen am Thunersee in Switzerland, while the FIL for luge and the IBSF for bobsleigh are situated in Berchtesgaden, Germany and Milan, Italy respectively. Most of these sports and their individual disciplines were introduced in the Olympics in 1924, with luge becoming an Olympic sport in 1964 and freestyle skiing and short track speed skating were introduced in 1992. The youngest discipline by far is snowboarding, which joined in 1998. Regarding women's events, somesports were introduced relative y late, with bobsleigh introducing women's events only in 2002 and ski jumping only in 2014. Only figure skating and al pine skiing had men's and women's events from the start in 1924 and 1936 respectively. The newer sports started out with events for both men and women. All sports, with the exception of the skeleton bobsleigh, have been present at all the Olympic Games since their Olympic Debut.

TableXLIII. Topics dealt with in sports that focus on movement over ice and snow

\begin{tabular}{|c|c|c|c|c|}
\hline Requirements & Bobsleigh & L uge & Skating & Skiing \\
\hline In force since & 2005 & 1998 & 2012 & 2012 \\
\hline $\begin{array}{l}\text { Versions since } \\
2005\end{array}$ & Since 2005 & Since 1998 & Since 2012 & Since 2012 \\
\hline $\begin{array}{l}\text { C hanges made } \\
\text { since October } \\
2013\end{array}$ & na & na & na & $\mathrm{na}$ \\
\hline $\begin{array}{l}\text { Change of } \\
\text { nationality }\end{array}$ & $\begin{array}{l}\text { Possible, } \\
\text { acceptance of old } \\
\text { and new } \\
\text { association } \\
\text { needed }\end{array}$ & Not specified & $\begin{array}{l}\text { Possible, although } \\
\text { not strictly } \\
\text { necessary }\end{array}$ & $\begin{array}{l}\text { Possiblein } \\
\text { combination with } \\
\text { residenceand/or } \\
\text { ancestry in the } \\
\text { country }\end{array}$ \\
\hline $\begin{array}{l}\text { Residence } \\
\text { requirements }\end{array}$ & Official residence & Not specified & Oneyear & Not specified \\
\hline $\begin{array}{l}\text { M inors and } \\
\text { nationality } \\
\text { change }\end{array}$ & Not specified & Not specified & Not specified & Not specified \\
\hline Stateless athletes & Not specified & Not specified & Not specified & Not specified \\
\hline $\begin{array}{l}\text { Position of } \\
\text { athletes with } \\
\text { multiple } \\
\text { nationality after } \\
\text { having competed } \\
\text { for another } \\
\text { country of which } \\
\text { the athlete is a } \\
\text { national }\end{array}$ & $\begin{array}{l}\text { Possible, } \\
\text { acceptance of old } \\
\text { and new } \\
\text { association } \\
\text { needed }\end{array}$ & Not specified & $\begin{array}{l}\text { Depends on type } \\
\text { of international } \\
\text { competition, } \\
\text { between } 1 \text { year } \\
\text { and } 18 \text { months of } \\
\text { non-competition } \\
\text { period and either } \\
\text { a oneyear } \\
\text { residence and } \\
\text { acceptance of the }\end{array}$ & $\begin{array}{l}\text { Need to fulfil the } \\
\text { normal } \\
\text { requirements of } \\
\text { nationality and } \\
\text { residency/ancestr } \\
\text { y plus a year of } \\
\text { non-competition }\end{array}$ \\
\hline
\end{tabular}


NATIONALITY REQUIREMENTS IN OLYMPIC SPORTS

\begin{tabular}{|c|c|c|c|c|}
\hline & & & $\begin{array}{l}\text { change by former } \\
\text { member } \\
\text { association or } \\
\text { one-year or } \\
\text { residence and } \\
\text { application for } \\
\text { citizenship }\end{array}$ & \\
\hline $\begin{array}{l}\text { Effect of changes } \\
\text { in territory of } \\
\text { country }\end{array}$ & Not specified & Not specified & Not specified & Not specified \\
\hline $\begin{array}{l}\text { Competing for } \\
\text { the country of } \\
\text { residence }\end{array}$ & $\begin{array}{l}\text { Possible, if } \\
\text { official residence }\end{array}$ & Not specified & $\begin{array}{l}\text { Possible, after one } \\
\text { year or residence } \\
\text { and either } \\
\text { application for } \\
\text { citizenship or } \\
\text { permission by old } \\
\text { federation }\end{array}$ & $\begin{array}{l}\text { Principal legal } \\
\text { and effective } \\
\text { residence for two } \\
\text { years }\end{array}$ \\
\hline $\begin{array}{l}\text { Number of } \\
\text { changes possible }\end{array}$ & $\begin{array}{l}\text { No maximum } \\
\text { given }\end{array}$ & Not specified & $\begin{array}{l}\text { No maximum } \\
\text { given }\end{array}$ & $\begin{array}{l}\text { No maximum } \\
\text { given }\end{array}$ \\
\hline $\begin{array}{l}\text { R eference to } \\
\text { Olympic } \\
\text { Charter }\end{array}$ & None & None & Yes & None \\
\hline $\begin{array}{l}\text { Uses nationality/ } \\
\text { citizenship }\end{array}$ & $\begin{array}{l}\text { Citizenship \& } \\
\text { nation }\end{array}$ & None & Citizen & Citizenship \\
\hline $\begin{array}{l}\text { Uses residence/ } \\
\text { domicile }\end{array}$ & Official residence & None & Residence & $\begin{array}{l}\text { Principal legal } \\
\text { and fffective } \\
\text { residence }\end{array}$ \\
\hline $\begin{array}{l}\text { Other } \\
\text { remarkable } \\
\text { peculiarity }\end{array}$ & $\begin{array}{l}\text { The use of nation } \\
\text { seems to differ } \\
\text { between the two } \\
\text { rules }\end{array}$ & None & $\begin{array}{l}\text { Possi bility to } \\
\text { compete for } \\
\text { country where } \\
\text { thereis no } \\
\text { member } \\
\text { federation }\end{array}$ & $\begin{array}{l}\text { Refusal to allow } \\
\text { change possible, } \\
\text { even if all criteria } \\
\text { arefulfilled }\end{array}$ \\
\hline
\end{tabular}




\subsection{B obsleigh ${ }^{1406}$}

Bobsleigh was invented in the late $18^{\text {th }}$ century becamean Olympic discipline in 1924 and its governing organi sation, the IBSF, which was named Fédération Internationale de Bobsleigh et de Tobogganing (FIBT) until June 2015, was founded the year before ${ }^{1407}$ There are two main disciplines, the bobsleigh discipline with either two or four people per team, and the skeleton, which is an individual athlete's compeition. ${ }^{1408}$ In bobsleigh, the two-person teams consist of a brakeman and a pilct, while the four-person teamal so ind udes two pushers. ${ }^{1409}$ For the skeleton races, which only became regular features at the Olympics in 2002, the athl ete is facing forward on the bobsleigh when racing downwards. ${ }^{1410}$ Women compete in the indi vidual skeleton or in the two-person team bobsleigh competition, while men compete in individual skeleton, two and four people bobsleigh. ${ }^{1411}$ The compeitions take place over two days, with each team rading twice a day. ${ }^{1412}$ The eligibility criteria for bobsleigh and skeleton are very much alike in their content, yet the wording differs, with bobsleigh focussing on the Member or Associate Member to the IBSF while the skeleton rules focus on 'nation'. Therefore, these two will be discussed separately in the following. In either case, the teams competing during the Olympics have to stem from Member associations or associated member associations. ${ }^{1413}$ However, during the qualification rounds, a driver could potentially compete with brakemen who are not citizens of the same country and qualify for the Olympics with them, yet during the Olympics other brakemen who are citizens of the country would need to taketheir place ${ }^{1414}$

1406 The federation was contacted on $6^{\text {th }}$ August 2014 and asked to provide further insights into its eligibility criteria and older versions of the eligibility rules. The FIBT replied on $7^{\text {th }}$ August 2014 and stated that only the format of the rules had changed, being formerly labelled a), b) and c), whereas there are only bullet points nowadays. Furthermore, in 2008 an additional rule regarding the athlete's ranking was introduced: "When athletes switch Nations, they keep their Scores/Ranking in the F.I.B.T. Ranking List, as well as the number of competitions in which they have participated; however, they do not keep the right to the previous quotas for participation, which remains tied to the nation of origin." No further changes have occurred. On $29^{\text {th }}$ October 2015 the IBSF was contacted again and asked for comments on this chapter, which the IBSF provided on $9^{\text {th }}$ November 2015.

IOC Information FIBT Sketen; IOC Information FIBT Bobsleigh; IOC Information Bobsleigh Equi pment and History: for information on non-national athletes in the European national leagues and competitions see S. van den Bogaert, A. Cuyvers, S. Gardiner, R. Parrish, S. Miettinen, J. Soek and R. Siekmann (2010), p. 139. IOC Information FIBT Skeleton; IOC I nformation FIBT Bobsleigh.

1409 IOC Information FIBT Skeleton; IOC Information FIBT Bobsleigh.

1410 IOC Information FIBT Sketen; IOC Information FIBT Bobsleigh; IOC Information Bobsleigh Skeleton Equi pment and History; IOC Reference Document Bobsleigh Skeleton.

1411 IOC Information FIBT Skeleton; IOC Information FIBT Bobsleigh; IOC Reference Document Bobsleigh Skeleton; IOC Reference Document Bobsleigh.

1412 IOC Information FIBT Skeleton; IOC I nformation FIBT Bobsleigh.

1413 Art. 3. Admission International Bobsleigh rules 2014 October 2014; Art. 3. Admission Skeleton rules 2014 (valid from October 2014); Art. 3. Admission International Bobsleigh rules 2013 October 2013; Art. 3. Admission Skeleton rules 2013 (valid from October $1^{\text {st }}$ of 2013). 


\subsubsection{Bobsleigh aritical reflection}

The IBSF's (formerly FIBT) rules on athletes' eligibility are not very specific. Whilea change of the country of representation is in principle possible, ${ }^{1415}$ the main rationale is still that only citizens can compete for the country's national team ${ }^{1416}$ More problematic is the fact that athletes need to receive the approval of the relevant federation to make the change effective, eg. if an athl ete has previously competed for oneassociation and now has either changed his or her official place of residence or has acquired the citizenship of a new association. In both cases the previous association needs to haver reeased the athlete and thenew association needs to have accepted him - this latter is not as problematic as the former. If an association does not accept that theathl ete wishes to compete for a new association of which he or sheis now a citizen, a conflict will arise

\subsubsection{B obsleigh}

TableXLIV: Overview of the ligibility requirements for bobsleigh

\begin{tabular}{|c|c|}
\hline R equirements IBSF - Bobsleigh & \\
\hline In force since & October 2005 \\
\hline C hange of nationality & $\begin{array}{l}\text { Possible, acceptance of old and new association } \\
\text { needed }\end{array}$ \\
\hline Residence requirements & Official residence \\
\hline M inors and nationality change & Not specified \\
\hline Stateless athletes & Not specified \\
\hline $\begin{array}{l}\text { Position of athletes with multiple nationality } \\
\text { after having competed for another country of } \\
\text { which the athlete is a national }\end{array}$ & $\begin{array}{l}\text { Possible, acceptance of old and new association } \\
\text { needed }\end{array}$ \\
\hline E ffect of changes in territory of country & Not specified \\
\hline Competing for the country of residence & Possible, if official residence \\
\hline Number of changes possible & No maximumgiven \\
\hline R eference to Olympic C harter & None \\
\hline Uses nationality/ citizenship & Citizenship \& nation \\
\hline Uses residence/ domicile & Residence \\
\hline Other remarkable peculiarity & $\begin{array}{l}\text { The use of nation seems to differ between the two } \\
\text { rules }\end{array}$ \\
\hline
\end{tabular}

\subsubsection{Rules applicable since 2005}

Since 2005 the content of the rules has remained unchanged, yet in J une 2015 the federation changed its name from FIBT to IBSF. Coming to the criteria which athletes need to fulfil, one finds that there are essentially three possibilities to qualify for one country:

" -They must hold citizenship of the nation of the Member or Associate Member concerned, and may not have taken part in intemational IBSF competitions on behalf of another Member /AssociateMember, or

\footnotetext{
1415 Ibid.

1416 Art. 3. Admission I nternational Bobsleigh rules 2015, June 2015; Art. 3. Admission Sket eton rules 2015 (valid fromJ une 2015).
} 
- They must have their official residence in the Member/Associate Member concerned, and may not have taken part in intemational IBSF compeitions on behalf of another Member/AssociateMember, or

- They must have changed their citizenship or their official residence, and have been releesed by their former Member/Associate Member and accepted by their member. In this case, the athlete may represent one of the two members, but not both."1417

It is interesting that the IBSF uses the phrase "hol ding citizenship of a nation", while one would expect the use of citizenship of a country, sincenation seems linguistically more dosely tied to national and not to citizen.

Official residence is the second possibility for an athlete to qual ify for a national team, although the duration of that residence is not prescribed. Residence in this case is not defined in the official documents, but only internally and means actually living/residing in the country. It may be proven by letters from the local council to the athlete, eg. about garbage collection. ${ }^{1418}$

The only additional requirement is that the athlete has not yet competed for another association. If an athlete has previously competed for one association and now has either changed his or her official place of residence or has acquired the citizenship of a new association, the previous association needs to rel ease the athlete and the new association needs to have accepted him While the latter is not as problematic as the former, if an association does not accept that the athl ete wishes to compete for a new association of which he or she is now a citizen, conflicts will arise The athletes' choice to compete for another nation than the one they competed for initially will only take effect after one season ends on $30^{\text {th }}$ September of any given year. ${ }^{1419}$ Through this rule, the ongoing championships and leagues are not disrupted by any changes.

\subsubsection{B obsleigh Skeleton}

TableXLV: Overview of the eligibility requirements for bobsleigh skeleton

\begin{tabular}{|l|l|}
\hline R equirements IBSF - Skeleton & \\
\hline In force since & $1^{\text {s }}$ October 2005 \\
\hline C hange of nationality & $\begin{array}{l}\text { Possi ble, acceptance of old and new association } \\
\text { needed }\end{array}$ \\
\hline R esidence requirements & Official residence \\
\hline M inors and nationality change & Not specified \\
\hline Stateless athletes & Not specified \\
\hline $\begin{array}{l}\text { Position of athletes with multiple nationality } \\
\text { after having competed for another country of }\end{array}$ & $\begin{array}{l}\text { Possi ble, acceptance of old and new association } \\
\text { needed }\end{array}$ \\
\hline
\end{tabular}

1417 Art. 3. Admission International Bobsleigh rules 2015 J une 2015; Prior to 2015 the federation was called FIBT; Art. 3. Admission International Bobsleigh rules 2014 October 2014; Art 3. Admission I nternational Bobsleigh rules 2013 October 2013.

1418 IBSF E-mail of $19^{\text {th }}$ November 2015

1419 Art. 3. Admission International Bobsleigh rules 2015 J une 2015; Prior to 2015 the federation was called FIBT; Art. 3. Admission International Bobsleigh rules 2014 October 2014; Art 3. Admission International Bobsleigh rules 2013 October 2013. 
NATIONALITY REQUiREMENTS IN Oly MPIC SPORTS

\begin{tabular}{|l|l|}
\hline which the athlete is a national & \\
\hline E ffect of changes in territory of country & Not specified \\
\hline Competing for the country of residence & Possi ble, if official residence \\
\hline Number of changes possible & No maximumgiven \\
\hline & \\
\hline R eference to Olympic Charter & None \\
\hline Uses nationality/ citizenship & Citizenship \& nation \\
\hline Uses residence/ domicile & Residence \\
\hline Other remarkable peculiarity & $\begin{array}{l}\text { Theuse of nation seems to differ between the two } \\
\text { rules }\end{array}$ \\
\hline
\end{tabular}

\subsubsection{Rules applicable since 2005}

As previously mentioned, since 2005 the content of therules has remained unchanged, yet in J une 2015 the federation dhanged its name from FIBT to IBSF. As in the case of bobsleigh, al so for the skeleton the teams have to stem from Member associations or associated member associations. ${ }^{1420}$ With regard to the criteria which athl etes need to fulfil, one finds that there are three essential possibilities to qualify for competing for onecountry:

\footnotetext{
"•they must hold citizenship of the nation of the Member or Associate Member concerned, and may not have taken part in intemational IBSF competitions on behalf of another nation, or

- they must have their official residence in the nation concemed, and may not havetaken part in intemational IBSF competitions on behalf of another nation, or - they must have changed their citizenship or their official residence, and have been releesed by their former Member / Associate Member and accepted by their new federation. In this case, the athlete may represent one of the two Members, but not both."1421
}

Although, content wise, these rules seem to be identical to the ones of bobsleigh, one notes several differences, eg. where the bobsleigh rules referred to competing for an association, the skeleton rules refer to nation in the first two cases. One can thus presume that the emphasis here lies not so much on competing for a federation, but on competing for a nation. An interesting aspect is the wording of 'official residence in a nation', which is presumably to mean residence on a nation's teritory. The concept which is attributed to the word 'nation' in the skeleton rules seems to be overall more encompassing than in the rules for bobsleigh, where it is "residence in the member association". As in the bobsleigh rules, residence and citizenship are the ways to qualify for a national team in general. Again, residence is not defined in the official

1420 Art. 3. Admission International Bobsleigh rules 2015 J une 2015; Art. 3. Admission Skeleton rules 2015 (valid from June 2015); Art. 3. Admission International Bobsleigh rules 2014 October 2014; Art. 3. Admission Skeleton rules 2014 (valid from October 2014); Art. 3. Admission International Bobsleigh rules 2013 October 2013; Art. 3. Admission Skeleton rules 2013 (valid from October $1^{\text {st }}$ of 2013).

1421 Art. 3. Admission Skeleton rules 2015 (valid from J une 2015); Art. 3. Admission Skeleton rules 2014 (valid from October 2014); Art. 3. Admission Skeleton rules 2013 (valid from October 1st of 2013). 
documents, but only internally, and means actually living/residing in the country. It may be proven by letters from the local coundil to the athlete, eg. about garbage collection. ${ }^{1422}$

In case an athlete has al ready competed for another nation in the wording of the text, the residence or citizenship of the athlete has to have changed in order for him or her to become eligible for another country. ${ }^{1423}$ In addition, the relevant member federations - not the nations - have to consent Such a change is not possible during a season which runs from $1^{\text {st }}$ October until $30^{\text {th }}$ September of the following year. ${ }^{1424}$

1422 IBSF E-mail of $19^{\text {th }}$ November, 2015.

1423 Art. 3. Admission Skeleton rules 2015 (valid from J une 2015); Art. 3. Admission Skeleton rules 2014 (valid from October 2014); Art. 3. Admission Skeleton rules 2013 (valid from October 1st of 1424 2013). Ibid. 


\subsection{L uge $^{1425}$}

Luge was invented in Switzerland and dates back to the $16^{\text {th }}$ century, ${ }^{1426}$ but the first luge course was only built in the $19^{\text {th }}$ century. ${ }^{1427}$ Unlike in other sledge sports, the athletes lie on their backs and can thus only rely on reflexes to ster the luge down the ice track. ${ }^{1428}$ Nowadays there are singleand double events, di vided into events for men and women, although it would in general be possible to have a mixed double $e^{1429}$ Competitions last two days, with athletes doing two runs a day. ${ }^{1430}$ The time of each run is added up to create a total run time, with the fastest athlete or athlete team winning. ${ }^{1431}$ The governing body, the Fédération Internationale de Luge de Course (FIL) was founded in 1957 and in 1964 luge becamean Olympic sport ${ }^{1432}$

\subsubsection{Luge critical reflection}

Thereare no spedific FIL national ity criteria currently in force

\subsubsection{Artificial Track}

TableXLVI: Overview of the ligibility requirements for luge- artificial track

\begin{tabular}{|l|l|}
\hline Requirements FIL - Artificial T rack & \\
\hline In force since & $7^{\text {th }}$ une 1998 \\
\hline C hange of nationality & Not specified \\
\hline R esidence requirements & Not specified \\
\hline M inors and nationality change & Not specified \\
\hline Stateless athletes & Not specified \\
\hline $\begin{array}{l}\text { Position of athletes with multiple nationality } \\
\text { after having competed for another country of } \\
\text { which the athlete is a national }\end{array}$ & Not specified \\
\hline E ffect of changes in territory of country & Not specified \\
\hline Number of changes possible & Not specified \\
\hline & \\
\hline R eference to Olympic Charter & None \\
\hline Uses nationality/ citizenship & None \\
\hline Uses residence/ domicile & None \\
\hline Other remarkable peculiarity & None \\
\hline
\end{tabular}

1425 The federation was contacted on $6^{\text {th }}$ August 2014 and asked to provide further insights into its eligibility criteria and older versions of the eligibility rules. As no reply was forthcoming, a reminder e-mail was sent on $18^{\text {th }}$ September 2014. On $29^{\text {th }}$ October 2015, the federation was contacted again and asked for comments on this Chapter. As no reply was forthcoming, a first reminder was sent on $19^{\text {th }}$ November 2015 to which the FIL replied on $30^{\text {th }}$ November 2015 providing the old versions.

1426 IOC Information FIL.

1427 IOC Information FIL

1428 IOC Information Luge Equi pment and History.

1429 IOC Information FIL; IOC Information LugeEqui pment and History.

1430 IOC Information FIL.

1431 IOC Information FIL.

1432 IOC Information FIL; IOC Reference Document Luge: for information on non-national athletes in the European national leagues and competitions see S. van den Bogaert, A. Cuyvers, S. Gardiner, R. Parrish, S. Miettinen, J. Soek and R. Siekmann (2010), p. 139. 


\subsubsection{Rules applicable since 1998}

The FIL regulations regarding eligibility are set up for natural and artificial track events individual ly. Both current nules were approved at the $62^{\text {nd }}$ FIL Congress on $20^{\text {th }}$ June 2014 in Innsbruck / Austria. The 2014 artificial track rules on digibility are identical to those approved of at the $60^{\text {th }}$ FIL Congress on $15^{\text {th }}$ June 2012 in Riga, Latvia, $58^{\text {th }}$ FIL Congress on $18^{\text {th }}$ J une 2010 in Sochi / Russian Federation, $56^{\text {th }}$ FIL Congress on $28^{\text {th }}$ June 2008 in Cal gary / Canada and $54^{\text {th }}$ FIL Congress on $29^{\text {th }}$ June 2006 in Berchtesgaden / Germany.

Prior to 2006, the luge eligibility rules underwent minor changes and the core requirement that athletes haveto obtain a licenceand need to undergo themedical tests has remained unchanged since $1998 .{ }^{1433}$ Similarly, licences have al ways been issued by the athlete's national federation, requiring the signature of the NF's president and the athlete's written dedaration of adhering to the FIL and IRO rules and regulations. ${ }^{1434}$

In 2004, the requirement that the medical examination should have been conducted in the past 12 months and that the outcome must have been positive was added, thus ensuring an up-to date fitness check. ${ }^{1435}$ The major change occurred in

1433 Art. 3 International Luge regulations - Artificial Track - approved at the 62nd FIL congress on June $20^{\text {th }}$, 2014 in Innsbruck / Austria; Art. 3 International Luge regulations - Artificial Track approved at the 60th FIL congress on J une 15 $5^{\text {th }}, 2012$ in Riga / Latvia; Art. 3 IRO International Luge regulations - Artificial Track - 2010 Edition approved at the $58^{\text {th }}$ FIL Congress on J une $18^{\text {th }}$, 2010 in Sochi / Russian Federation; Art 3 IRO International Luge regulations - Artificial Track 2008 Edition approved at the $56^{\text {th }}$ FIL Congress on J une $28^{\text {th }}, 2008$ in Cal gary / Canada; Art. 3 IRO International Lugeregulations - Artificial Track - 2006Edition approved at the $54^{\text {th }}$ FIL Congresson J une $29^{\text {th }}, 2006$ inBerchtesgaden/Germany; Art. 3 IRO International Luge regulations - Artificial Track-2004 Edition approved at the $52^{\text {nd }}$ FIL Congress onJ une $11^{\text {th }}, 2004$ in Rio deJ aneiro/ Brazil; Art. 3 IRO International Luge regulations - Artificial Track -2002 Edition approved at the $50^{\text {th }} \mathrm{FIL}$ Congress on J une 28 $8^{\text {th }}, 2002$ in St. Wol fgang / AUT; Art. 3 IRO I nternationale Rennrodel ordnung Kunstbahn - Ausgabe 2000 beschlossen beim 48. FIL-Kongress am 17.6.2000 in Oberhof / GER; Art. 3 IRO International Luge regulations - Artificial Track - 1998 Edition approved at the $46^{\text {th }} \mathrm{FIL}$ Congress on J une $7^{\text {th }}, 1998$ in Colorado Springs.

1434 Art. 3 International Luge regulations - Artificial Track - approved at the $62^{\text {nd }}$ FIL congress on J une $20^{\text {th }}, 2014$ in Innsbruck / Austria; Art. 3 International Luge regulations - Artificial Track approved at the $60^{\text {th }}$ FIL congress on June 15 $15^{\text {th }}, 2012$ in Riga / Latvia; Art. 3 IRO International Luge regulations - Artificial Track - 2010 Edition approved at the $58^{\text {th }}$ FIL Congress on J une 18, 2010 in Sochi / Russian Federation; Art. 3 IRO International Luge regulations - Artificial Track 2008 Edition approved at the $56^{\text {th }}$ FIL Congress on J une 28 ${ }^{\text {th }}, 2008$ in Cal gary / Canada; Art. 3 IRO International Lugeregulations - Artificial Track - 2006Edition approved at the $54^{\text {th }}$ FIL Congresson June 29 $9^{\text {th }}, 2006$ inBerchtesgaden/Germany; Art. 3 IRO International Luge regulations - Artificial Track -2004 Edition approved at the 52 ${ }^{\text {nd }}$ FIL Congress on J une 11 ${ }^{\text {th }}, 2004$ in Rio deJ aneiro/ Brazil; Art. 3 IRO International Luge regulations - Artificial Track -2002 Edition approved at the $50^{\text {th }} \mathrm{FIL}$ Congress on J une 28 ${ }^{\text {th }}, 2002$ in St. Wolfgang / AUT; Art. 3 IRO Internationale Rennrodel ordnung Kunstbahn - Ausgabe 2000 beschl ossen beim 48. FIL-Kongress am 17.6.2000 in Oberhof / GER; Art. 3 IRO International Luge regulations - Artificial Track - 1998 Edition approved at the $46^{\text {th }}$ FIL Congress on J une $7^{\text {th }}, 1998$ in Col orado Springs.

1435 Art. 3 International Luge regulations - Artificial Track - approved at the $62^{\text {nd }}$ FIL congress on J une $20^{\text {th }}, 2014$ in Innsbruck / Austria; Art. 3 International Luge regulations - Artificial Track approved at the $60^{\text {th }}$ FIL congress on June 15 $5^{\text {th }}, 2012$ in Riga / Latvia; Art. 3 IRO International Luge regulations - Artificial Track - 2010 Edition approved at the $58^{\text {th }}$ FIL Congress on J une $18^{\text {th }}$, 2010 in Sochi / Russian Federation; Art 3 IRO International Luge regulations - Artificial Track 2008 Edition approved at the $56^{\text {th }}$ FIL Congress on J une $28^{\text {th }}, 2008$ in Cal gary / Canada; Art. 3 IRO International Lugeregulations - Artificial Track - 2006Edition approved atthe $54^{\text {th }}$ FIL Congresson 
2006 with insurances also having to be valid in foreign countries and training becoming important as the current conditions which need to be fulfilled in order to acquirea licence reflect:

"a) the athleteis a member of his/her federation or one of its associated dubs,

b) the athl eteis insured for practicing the sport of lugeal so in foreign countries,

c) the athlete has a medical certificate that is based on a medical examination conducted during the last 12 months or a subsequent medical examination in the event of a serious injury, and states that from a point of view of sports medicine, helsheis fit for practicing the sport of luge,

d) the athlete has received such a basic training that one could expect the athlete to be able to master lugetracks used for competitions in a safe way." ${ }^{1436}$

With regard to the partici pation in training, the athletes need to be able to participatein luge competitions. ${ }^{1437}$ Furthermore a valid license as well as compliance with the relevant age groupings are perquisites ${ }^{1438}$ Nationality is not a requirement to participate or to train, yet the FIL requires an athlete to compete only for one nation during one sporting year. ${ }^{1439}$ One can thus deduce that the FIL does not require an athlete to be a national of the federation for which he or she competes and thus does

June $29^{\text {th }}, 2006$ inBerchtesgaden/Germany; Art. 3 IRO International Luge regulations - Artificial

Track-2004 Edition approved at the 52 $2^{\text {nd }}$ FIL Congress onJ une $11^{\text {th }}, 2004$ in Rio deJ aneiro/ Brazil.

Art. 3 International Luge regulations - Artificial Track - approved at the $62^{\text {nd }}$ FIL congress on J une $20^{\text {th }}, 2014$ in Innsbruck / Austria; Art. 3 International Luge regulations - Artificial Track approved at the $60^{\text {th }}$ FIL congress on J une 15 $5^{\text {th }}, 2012$ in Riga / Latvia; Art. 3 IRO International Luge regulations - Artificial Track - 2010 Edition approved at the $58^{\text {th }}$ FIL Congress on June $18^{\text {th }}$, 2010 in Sochi / Russian Federation; Art 3 IRO International Luge regulations - Artificial Track 2008 Edition approved at the $56^{\text {th }}$ FIL Congress on J une $28^{\text {th }}, 2008$ in Cal gary / Canada; Art. 3 IRO International Lugeregulations - Artificial Track - 2006Edition approved at the $54^{\text {th }}$ FIL Congresson J une2 $9^{\text {th }}, 2006$ inBerchtesgaden/Germany.

1437 Art. 3 International Luge regulations - Artificial Track - approved at the $62^{\text {nd }}$ FIL congress on J une $20^{\text {th }}, 2014$ in Innsbruck / Austria; Art. 8 International Luge regulations - Artificial Track approved at the $60^{\text {th }}$ FIL congress on June 15 1 th 2012 in Riga / Latvia; Art. 3 IRO International Luge regulations - Artificial Track - 2010 Edition approved at the $58^{\text {th }}$ FIL Congress on June $18^{\text {th }}$, 2010 in Sochi / Russian Federation; Art. 3 IRO International Luge regulations - Artificial Track 2008 Edition approved at the $56^{\text {th }}$ FIL Congress on J une $28^{\text {th }}, 2008$ in Cal gary / Canada; Art. 3 IRO International Lugeregulations - Artificial Track - 2006Edition approved at the $54^{\text {th }}$ FIL Congress on June29 $9^{\text {th }}, 2006$ inBerchtesgaden/Germany.

1438 Art. 3 International Luge regulations - Artificial Track - approved at the $62^{\text {nd }}$ FIL congress on J une $20^{\text {th }}, 2014$ in Innsbruck / Austria; Art. 8 International Luge regulations - Artificial Track approved at the $60^{\text {th }}$ FIL congress on J une 15 1 th, 2012 in Riga / Latvia; Art. 3 IRO International Luge regulations - Artificial Track - 2010 Edition approved at the $58^{\text {th }}$ FIL Congress on June $18^{\text {th }}$, 2010 in Sochi / Russian Federation; Art 3 IRO International Luge regulations - Artificial Track 2008 Edition approved at the $56^{\text {th }}$ FIL Congress on J une $28^{\text {th }}, 2008$ in Cal gary / Canada; Art. 3 IRO International Lugeregulations - Artificial Track - 2006Edition approved at the $54^{\text {th }}$ FIL Congresson June29 $9^{\text {th }}, 2006$ inBerchtesgaden/Germany.

1439 Art. 3 International Luge regulations - Artificial Track - approved at the $62^{\text {nd }}$ FIL congress on J une $20^{\text {th }}, 2014$ in Innsbruck / Austria; Art. 8 International Luge regulations - Artificial Track approved at the $60^{\text {th }}$ FIL congress on J une 15, 2012 in Riga / Latvia; Art. 3 IRO International Luge regulations - Artificial Track - 2010 Edition approved at the $58^{\text {th }}$ FIL Congress on J une $18^{\text {th }}, 2010$ in Sochi / Russian Federation; Art. 3 IRO International Luge regulations - Artificial Track - 2008 Edition approved at the $56^{\text {th }}$ FIL Congress on J une 28 2008 in Cal gary / Canada; Art. 3 IRO International Lugeregulations - Artificial Track - 2006Edition approvedatthe $54^{\text {th }}$ FIL Congresson June29 $9^{\text {th }}, 2006$ inBerchtesgaden/Germany. 
not deal with changes in the country of representation as long as the change does not disrupt an ongoing sporting year.

\subsubsection{Natural Track}

TableXLVII: Overview of the eligibility requirements for luge- natural track

\begin{tabular}{|l|l|}
\hline R equirements FIL - Natural Track & \\
\hline In force since & $7^{\text {th June } 1998}$ \\
\hline C hange of nationality & Not specified \\
\hline Residence requirements & Not specified \\
\hline M inors and nationality change & Not specified \\
\hline Stateless athletes & Not specified \\
\hline $\begin{array}{l}\text { Position of athletes with multiple nationalities } \\
\text { after having competed for another country of } \\
\text { which the athlete is a national }\end{array}$ & Not specified \\
\hline E ffect of changes in territory of country & Not specified \\
\hline Number of changes possible & Not specified \\
\hline & \\
\hline R eference to Olympic Charter & None \\
\hline Uses nationality/ citizenship & None \\
\hline Uses residence/ domicile & None \\
\hline Other remarkable peculiarity & None \\
\hline
\end{tabular}

\subsubsection{Rules applicable since 1998}

As for artificial tradk, the natural track rules were approved at the $62^{\text {nd }}$ FIL Congress on $20^{\text {th }}$ J une 2014 in Innsbruck / Austria. While the wording has changed in some parts, the content of these rules is still identical to that approved of by the 60th FIL Congress on $15^{\text {th }}$ June 2012 in Riga, Latvia, 58 $8^{\text {th }}$ FIL Congress on $18^{\text {th }}$ June 2010 in Sochi / Russian Federation, 56 5 th FIL Congress on $28^{\text {th }}$ J une 2008 in Cal gary / Canada and $54^{\text {th }}$ FIL Congress on $29^{\text {th }}$ J une 2006 in Berchtesgaden / Germany. Moreover, the core aspect of the FIL, requiring all its athletes to have a licence which is issued by the relevant federation, has been in force since $1998 .{ }^{1440}$ Several requirements have remained unchanged since then, namely that the athleteneeds to declare that he or she will adhere to the FIL and IRO rules and regulations and that an official signature is

1440 Art. 1.3 IRO International Luge regulations - Natural Track -2014 Edition approved at the $62^{\text {nd }} \mathrm{FIL}$ Congress on June $20^{\text {th }}, 2014$ in Innsbruck / Austria; Art 1.3 International Luge regulations Natural Track - 2012 edition approved at the $60^{\text {th }}$ FIL congress on J une 15 ${ }^{\text {th }}, 2012$ in Riga / Latvia; Art. 1.3 IRO International Lugeregulations - Natural Track - 2010 Edition approved at the $58^{\text {th }}$ FIL Congress on June $18^{\text {th }}, 2010$ in Sochi / Russian Federation; Art 1.3 IRO International Luge regulations - Natural Track - 2008 Edition approved at the $56^{\text {th }}$ FIL Congress on J une $28^{\text {th }}, 2008$ in Calgary / Canada; Art 1.3 IRO International Luge regulations - Natural Track - 2006 Edition approved at the $54^{\text {th }}$ FIL Congress on J une 29 2006 in Berchtesgaden / Germany; Art. 1.3 IRO International Luge regulations - Natural Track -2004 Edition approved at the $52^{\text {nd }}$ FIL Congress on June $11^{\text {th }}, 2004$ in Rio de Janeiro / Brazil; Art. 1.3 IRO International Luge regulations - Natural Track -2002 Edition approved at the $50^{\text {th }}$ FIL Congress on J une $28^{\text {th }}, 2002$ in St. Wolfgang / AUT; Art. 1.3 IRO International Luge regulations - Natural Track - 2000 Edition approved at the $48^{\text {th }}$ FIL Congress on June $17^{\text {th }}, 2000$ in Oberhof / GER; Art. 1.3 IRO International Luge regulations Natural Track - 1998 Edition approved at the $46^{\text {th }}$ FIL Congress on June $7^{\text {th }}, 1998$ in Colorado Springs. 
needed to make the licence valid. ${ }^{1441}$ In addition, athletes have al ways had to havean insurance and have to undergo a medical check-up, although only since 2004 the FIL stipulates that this check-up has to have occurred within the past 12 months and that the outcome must have been positive ${ }^{1442}$ Furthermore, since 2006 an athl ete needs to havesufficient training in order to safel y participatein luge competitions. ${ }^{1443}$

In order to be admitted to official luge training, the athletenot only needs to have a valid licence and be of the right age for the respective groups, but also s/he may not have competed for another nation during the sport year in question. ${ }^{1444}$ This is interesting, since it not only refers to competing for a nation, but al so since the rules do not go into greater detail regarding national ity changes. One can thus deduce that the FIL does not require an athlete to be a national of the federation for which he or she competes and thus does not deal with changes in the country of representation as long as the change does not disrupt an ongoing sporting year.

1441 Art. 1.3 IRO International Luge regulations - Natural Track -2014 Edition approved at the $62^{\text {nd }} \mathrm{FIL}$ Congress on June $20^{\text {th }}, 2014$ in Innsbruck / Austria; Art 1.3 International Luge regulations Natural Track - 2012 edition approved at the $60^{\text {th }}$ FIL congress on J une $15^{\text {th }}, 2012$ in Riga / Latvia; Art. 1.3 IRO International Luge regulations - Natural Track - 2010 Edition approved at the $58^{\text {th }} \mathrm{FIL}$ Congress on June 18 $8^{\text {th }}, 2010$ in Sochi / Russian Federation; Art. 1.3 IRO International Luge regulations - Natural Track - 2008 Edition approved at the $56^{\text {th }}$ FIL Congress on J une $28^{\text {th }}, 2008$ in Cal gary / Canada; Art 1.3 IRO International Luge regulations - Natural Track - 2006 Edition approved at the $54^{\text {th }}$ FIL Congress on J une $29^{\text {th }}, 2006$ in Berchtesgaden / Germany; Art. 1.3 IRO International Luge regulations - Natural Track -2004 Edition approved at the $52^{\text {nd }}$ FIL Congress on June $11^{\text {th }}, 2004$ in Rio de Janeiro / Brazil; Art. 1.3 IRO International Luge regulations - Natural Track -2002 Edition approved at the 50 $50^{\text {th }}$ FIL Congress on J une 28 2002 in St. Wolfgang / AUT; Art. 1.3 IRO International Luge regulations - Natural Track - 2000 Edition approved at the $48^{\text {th }} \mathrm{FIL}$ Congress on J une $17^{\text {th }}, 2000$ in Oberhof / GER; Art. 1.3 IRO International Luge regulations Natural Track - 1998 Edition approved at the $46^{\text {th }}$ FIL Congress on June $7^{\text {th }}, 1998$ in Colorado Springs.

1442 Art. 1.3 IRO International Luge regulations - Natural Track -2014 Edition approved at the $62^{\text {nd }} \mathrm{FIL}$ Congress on June $20^{\text {th }}, 2014$ in Innsbruck / Austria; Art 1.3 International Luge regulations Natural Track - 2012 edition approved at the $60^{\text {th }}$ FIL congress on J une $15^{\text {th }}, 2012$ in Riga / Latvia; Art. 1.3 IRO International Luge regulations - Natural Track - 2010 Edition approved at the $58^{\text {th }}$ FIL Congress on June $18^{\text {th }}, 2010$ in Sochi / Russian Federation; Art. 1.3 IRO International Luge regulations - Natural Track - 2008 Edition approved at the $56^{\text {th }}$ FIL Congress on J une $28^{\text {th }}, 2008$ in Cal gary / Canada; Art. 1.3 IRO International Luge regulations - Natural Track - 2006 Edition approved at the $54^{\text {th }}$ FIL Congress on J une 29 $9^{\text {th }}, 2006$ in Berchtesgaden / Germany; Art. 1.3 IRO International Luge regulations - Natural Track -2004 Edition approved at the $52^{\text {nd }}$ FIL Congress on J une $11^{\text {th }}, 2004$ in Rio deJ aneiro/ Brazil.

Art. 1.3 IRO International Luge regulations - Natural Track - 2014 Edition approved at the $62^{\text {nd }} \mathrm{FIL}$ Congress on June $20^{\text {th }}, 2014$ in Innsbruck / Austria; Art. 1.3 International Luge regulations Natural Track - 2012 edition approved at the $60^{\text {th }}$ FIL congress on J une $15^{\text {th }}, 2012$ in Riga / Latvia; Art. 1.3 IRO International Luge regulations - Natural Track - 2010 Edition approved at the $58^{\text {th }} \mathrm{FIL}$ Congress on June $18^{\text {th }}, 2010$ in Sochi / Russian Federation; Art. 1.3 IRO International Luge regulations - Natural Track - 2008 Edition approved at the $56^{\text {th }}$ FIL Congress on J une $28^{\text {th }}, 2008$ in Calgary / Canada; Art 1.3 IRO International Luge regulations - Natural Track - 2006 Edition approvedat the $54^{\text {th }}$ FIL CongressonJ une $29^{\text {th }}, 2006$ inBerchtesgaden/Germany.

1444 Art. 6 International Luge regulations - Natural Track - 2012 edition approved at the $60^{\text {th }}$ FIL congress on J une $15^{\text {th }}, 2012$ in Riga / Latvia. 


\subsection{Skating ${ }^{1445}$}

Skating was first developed in the Netherlands in the $13^{\text {th }}$ century, when people used the frozen canals to travel between places in winter. ${ }^{1446}$ Nowadays, skating encompasses three categories and is governed by the International Skating Union (ISU), which was founded in 1892 and has its seat in Lausanne, Switzerland. ${ }^{1447}$ Skating had been an Olympic sport since 1924, with the competitions being held in the categories of figure skating and speed skating. ${ }^{1448}$ Women were participating in figure skating since the beginning, yet speed skating has only had a women's event since 1960. ${ }^{1449}$ Short track speed skating was introduced in 1992 as both a women's and a men's event ${ }^{1450}$

Figure skating, is one of the ol der categories and comprises three subcategories, namely the ice dance, singles and pairs. ${ }^{1451}$ For the singles men and women have to compete in the short programme, which consists of eight elements including jumps and spins and free skating, during which the skater shows his or her abilities to music of his or her choice ${ }^{1452}$ The same two categories of the short programme and free skating apply to the pairs, although the elements of the pairs category involves throw-jumps and overhead lifts. ${ }^{1453}$ Ice dance consists of three categories, the compul sory dance set by the committee, an original dance and a free dance ${ }^{1454}$

In speed skating, individual skaters race against one opponent over distances of $500 \mathrm{~m}, 1,000 \mathrm{~m}, 1,500 \mathrm{~m}$ or $5,000 \mathrm{~m}$ on an oval ice rink, with additional distances of $10,000 \mathrm{~m}$ for men and $3,000 \mathrm{~m}$ for women. ${ }^{1455}$ The aim is to complete the race is as littletime as possible ${ }^{1456}$ There areal so team pursuit events. ${ }^{1457}$

In turn, short track events have men and women compete over distances of $500 \mathrm{~m}, 1,000$ and $1,500 \mathrm{~m}$ with extra relays of $5,000 \mathrm{~m}$ for men and $3,000 \mathrm{~m}$ for women. ${ }^{1458}$ This type of skating was first developed in North America in the early

1445 The federation was contacted on $6^{\text {th }}$ August 2014 and asked to provide further insights into its eligibility criteria and older versions of the eligibility rules. As no reply was forthcoming, a reminder email was sent on $18^{\text {th }}$ September, to which the ISU replied on $19^{\text {th }}$ September. On $29^{\text {th }}$ October 2015 the federation was contacted again and asked for comments on this chapter, to which the federation replied on $17^{\text {th }}$ November 2015.

1446 IOC Information Figure Skating Equipment and History: for information on non-national athletes in the European national leagues and competitions see S. van den Bogaert, A. Cuyvers, S. Gardiner, R. Parrish, S. Miettinen, J. Soek and R. Siekmann (2010), p. 188. IOC Reference Document Skating; IOC Information ISU Figure Skating; IOC Information ISU Short track speed skating; IOC Information ISU Speed Skating.

IOC Reference Document Speed Skating; IOC Reference Document Figure Skating.

IOC Reference Document Short Track Speed Skating.

IOC Information ISU Figure Skating; IOC Information ISU Short track speed skating; IOC Information ISU Speed Skating; IOC Information Figure Skating Equipment and History.

IOC Information ISU Figure
Information ISU Speed Skating. Information ISU Speed Skating; IOC Information Speed Skating Equipment and History. 
$20^{\text {th }}$ century. ${ }^{1459}$ Being officially recognised by the ISU in 1967, it took until 1988 to become a demonstration sport at the Olympics, until 1992 it became an official Olympic discipline ${ }^{1460}$

TableXLVIII: Overview of the eligibility requirements for skating

\begin{tabular}{|l|l|}
\hline R equirements ISU & \\
\hline In force since & June2012 \\
\hline C hange of nationality & Possi ble, though not strictly necessary \\
\hline R esidence requirements & 1 year \\
\hline M inors and nationality change & Not specified \\
\hline Stateless athletes & Not specified \\
\hline $\begin{array}{l}\text { Position of athletes with multiple nationality } \\
\text { after having competed for another country of } \\
\text { which the athlete is a national }\end{array}$ & $\begin{array}{l}\text { Depends on thetype of international competition, } \\
\text { between oneyear and 18 months of non- } \\
\text { competition period and either a oneyear residence } \\
\text { and acceptance of the change by former member } \\
\text { association or oneyear or residenceand } \\
\text { application for citizenship }\end{array}$ \\
\hline E ffect of changes in territory of country & Not specified \\
\hline Competing for the country of residence & $\begin{array}{l}\text { Possi ble, after one year or residenceand either } \\
\text { application for citizenship or permission by old } \\
\text { federation }\end{array}$ \\
\hline Number of changes possible & No maximum given \\
\hline & Yes \\
\hline R eference to Olympic Charter & Citizen \\
\hline Uses nationality/ citizenship & Residence \\
\hline Uses residence/ domicile & $\begin{array}{l}\text { Possibility to compete for country wherethere is } \\
\text { no member federation }\end{array}$ \\
\hline Other remarkable peculiarity & \\
\hline
\end{tabular}

\subsubsection{Skating critical reflection}

The underlying principle of the ISU eligibility criteria is that it is a privilege to compete internationally in ice skating. ${ }^{1461}$ For national teams, only citizens may compete, unless the athlete has not competed for another federation for at least twelve months and has been a resident in the country for at least a year and applies for this country's citizenship. ${ }^{1462}$ Hereal ready applying for the citizenship of a country is seen as sufficient - provided that the athlete has been a resident for at least a year, which is very little compared to what most countries require $Y$ et, such an application will not necessarily result in the conferral of citizenship upon the athlete Thus, this oneyear of residence and theintention of the athleteto become a citizen of the relevant country is regarded as sufficient to establish the genuine link by the ISU. Should an athlete wish to change his or her country of representation, the non-competition period is between

\footnotetext{
1459 Ibid.

1460 Ibid.

1461 Rule 102(1)(a)(i) International Skating Union general regulations 2014 as accepted by the $55^{\text {th }}$ Ordinary Congress J une, 2014.

1462 Rule 109(2)(a), Rule 109(2)(b)(i), Rule 109(2)(b)(ii), Rule 109(2)(b)(iii) and Rule 109(2)(b)(iv) International Skating Union general regulations 2014 as accepted by the $55^{\text {th }}$ Ordinary Congress June, 2014.
} 
12 and 18 months, depending on the level of international competition. ${ }^{1463}$ One interesting aspect regarding the ISU rules is that under Rule 109(6) an athlete may compete for a country in which there is no ISU member federation if he or she can get the consent form theISU Council. ${ }^{1464}$

Tuming to the ISU rules regarding the Olympic Games, one finds that the ISU underscores that these are govemed not only by the ISU rules and regulations, but al so by the Olympic Charter. ${ }^{1465}$ In conclusion, these rules are rel atively lenient, as a 12- or 18-month period during which an athlete cannot compete internationally is not extremely long and thus less intrusive.

\subsubsection{Rules applicable since 2012}

While there was a new rule introduced in June 2014, the only difference with the previously applicable rules was that the numbering in case of Article 102(2) was changed from (i) - (iv) to (a) - (d). The ISU starts its eligibility code by underlining that it is indeed a "privilege to take part in the activities and competitions under the jurisdiction of the ISU". ${ }^{1466}$ Consequently, those who wish to have that privilege need to respect the ISU rules, regulations and the prinaiples on which they rest ${ }^{1467}$ The reasoning is al so made dear in thefoll owing paragraph:

"the condition of eligibility is made for the adequate protection of the economic and other interests of the ISU, which uses its financial revenues for the administration and development of the ISU sport disciplines and for the support and benefit of the Members and their Skaters."1468

Eligibility is lost if an athlete participates in events which are not sanctioned by the ISU or a member association. ${ }^{1469}$ An athlete can further loose eligibility in case he or

\footnotetext{
1463 Rule 109(2)(b)(ii) and Rule 109(2)(b)(iii) International Skating Union general regulations 2014 as accepted by the $55^{\text {th }}$ Ordinary Congress] une, 2014.

1464 Rule 109(6) International Skating Uni on general regulations 2014 as accepted by the $55^{\text {th }}$ Ordi nary Congress] une, 2014.

1465 Rule 126(1) and Rule 126(2) International Skating Union general regulations 2014 as accepted by the $55^{\text {th }}$ Ordi nary Congress] une, 2014.

1466 Rule 102(1)(a)(i) International Skating Union general regulations 2014 as accepted by the $55^{\text {th }}$ Ordinary Congress June 2014; Rule 102(1)(a)(i) International Skating Union constitution and general regulations 2012 as accepted by the $54^{\text {th }}$ ordi nary congress J une, 2012.

1467 Rule 102(1)(a)(i) International Skating Union general regulations 2014 as accepted by the $55^{\text {th }}$ Ordinary Congress June, 2014; Rule 102(1)(a)(i) International Skating Union constitution and general regulations 2012 as accepted by the $54^{\text {th }}$ ordinary congress J une, 2012.

1468 Rule 102(1)(a)(ii) International Skating Union general regulations 2014 as accepted by the $55^{\text {th }}$ Ordinary Congress June 2014; Rule 102(1)(a)(ii) International Skating Union constitution and general regulations 2012 as accepted by the $54^{\text {th }}$ ordinary congress J une, 2012.

1469 Rule 102(1)(b) and Rule 102(2) International Skating Union general regulations 2014 as accepted by the $55^{\text {th }}$ Ordinary Congress J une, 2014; Rule 102(1)(b) and Rule 102(2) International Skating Union constitution and general regulations 2012 as accepted by the $54^{\text {th }}$ ordinary congress June, 2012.
} 
she breaches any of theISU rules, and thus may no longer participate in ISU Events or theOlympic Games, as this is the privilege of an eligible person. ${ }^{1470}$

The actual participation in competitions is described in Rule 109, with the exception of the Olympic Winter Games which are dealt with in Rule $126 .{ }^{1471}$ The general principle underlying the competition and eligibility rules is that an athlete has to be a citizen of the country for which he or she competes. ${ }^{1472}$ Competing for another country is possible, if the athlete fulfils the perquisites:

“i) he has resided for at least one year in that country and has been permitted to compete for that Member by the National Association of the country of which he is a citizen, or he has resided for at least one year in that country and he (or his parents if heis not of age) has applied for citizenship in that country;

ii) before July Ist immediately prior to his first International Compeition as a member of the Member, hehas not competed in any International Competition or ISU Championship for another Member during the twelve (12) preceding months;

iii) before J uly 1st immediately prior to his first ISU Championship as a member of the Member, he has not competed in any International Competition or ISU Championship for another Member during theeighteen (18) preceding months; iv) Any denial of a request for permit by the Member submitted in accordance with sub-paragraph (i) above may be the subject of a request to the Council by the involved Skater or any involved Member for exceptional permission as provided in paragraph 5 of this Rule"11473

The first condition offers two possibilities, either the athl ete has resided in the country for which heor shewishes to competeand is in the process of acquiring the citizenship of that country or the athl ete fulfils the residence requirement and is competing for the other country with the permission of the federation of which he is a ditizen. For the ISU, al ready applying for the citizenship of a country is seen as sufficient - provided that the athl ete has been a resident for at least a year. Here one has to note that such an application will not necessarily result in the conferral of citizenship upon the athlete With regard to the underlying assumption that a genuine link should exist between athlete and the country, the application for citizenship would be insufficient. It is thus

1470 Rule 102(3) and Rule 102(7) International Skating Union general regulations 2014 as accepted by the $55^{\text {th }}$ Ordinary Congress J une 2014; Rule 102(3) and Rule 102(7) International Skating Union constitution and general regulations 2012 as accepted by the $54^{\text {th }}$ ordi nary congress J une, 2012.

1471 Rule 109(1) International Skating Union general regulations 2014 as accepted by the $55^{\text {th }}$ Ordi nary Congress J une 2014; Rule 109(1) International Skating Union constitution and general regulations 2012 as accepted by the 54 ${ }^{\text {th }}$ ordi nary congress J une, 2012.

1472 Rule 109(2)(a) International Skating Union general regulations 2014 as accepted by the $55^{\text {th }}$ Ordinary Congress J une 2014; Rule 109(2)(a) International Skating Union constitution and general regulations 2012 as accepted by the $54^{\text {th }}$ ordinary congress J une, 2012.

1473 Rule 109 (2)(b)(i), Rule 109 (2)(b)(ii), Rule 109 (2)(b)(iii) and Rule 109 (2)(b)(iv) International Skating Union general regulations 2014 as accepted by the $55^{\text {th }}$ Ordinary Congress June, 2014; Rule 109 (2)(b)(i), Rule 109 (2)(b)(ii), Rule 109 (2)(b)(iii) and Rule 109 (2)(b)(iv) International Skating Union constitution and general regulations 2012 as accepted by the $54^{\text {th }}$ ordinary congress June, 2012. 
this one year of residence and the intention of the athlete to become a citizen of the relevant country that is regarded as sufficient to establish the genuinelink for the ISU. Most countries would not see such a genuine link as being establ ished in such a case

The other possibility, that the athletereceives the permission from the federation, seems relatively unlikely, but there is an exception to the rule: in these cases, the ISU Council may take a decision that effectively overrides the Association's decision. ${ }^{1474}$ However, the council may also stop an athlete from competing for a country if therelevant association has in fact given its consent if

"a Member tries to "import" several athletes with foreign a itizenship, in particular when such athletes should form a new national team of such Member or its substantial part'. ${ }^{1475}$

These rules are thus designed to stop federations from accumulating athletes form other federations through a 'shopping spree'. Rule 109 (2) (b) (ii) and (iii) deal with the cases in which athletes have previously competed for a country. ${ }^{1476}$ Here a differentiation is made between general international competitions, which requirea $12-$ month period of non-competition, and ISU championships, which requirean 18-month period of non-competition, before the athl ete may compete for a country of which he

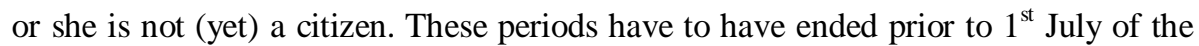
year in which the athlete wishes to compete for his or her new country. ${ }^{1477}$ Consequently, it is not possible for skaters to change their country of representation during the course of a season. ${ }^{1478}$

There are special rules in place for pair skating and ice dance couples, as well as for synchronised skating teams. For pair skating or ice dance, at least one of the two athletes has to be a citizen of the country for which the pair competes. ${ }^{1479}$ Residence and waiting periods of the previous articles do not apply to the partner who is not a

1474 Rule 109(5) International Skating Uni on general regulations 2014 as accepted by the $55^{\text {th }}$ Ordi nary Congress J une, 2014; Rule 109(5) International Skating Union constitution and general regulations 2012 as accepted by the $54^{\text {th }}$ ordi nary congress J une, 2012.

1475 Rule 109(5) International Skating Union general regulations 2014 as accepted by the $55^{\text {th }}$ Ordi nary Congress J une, 2014; Rule 109(5) International Skating Uni on constitution and general regulations 2012 as accepted by the $54^{\text {th }}$ ordi nary congress J une, 2012.

1476 Rule 109(3) International Skating Union general regulations 2014 as accepted by the $55^{\text {th }}$ Ordi nary Congress J une, 2014; Rule 109(3) International Skating Union constitution and general regulations 2012 as accepted by the $54^{\text {th }}$ ordi nary congress J une, 2012.

1477 Rule 109(2)(b)(ii) and Rule 109(2)(b)(iii) International Skating Union general regulations 2014 as accepted by the $55^{\text {th }}$ Ordinary Congress June, 2014; Rule 109(2)(b)(ii)and Rule 109(2)(b)(iii) International Skating Union constitution and general regulations 2012 as accepted by the $54^{\text {th }}$ ordinary congress] une, 2012.

1478 Rule 109(4) International Skating Uni on general regulations 2014 as accepted by the $55^{\text {th }}$ Ordi nary Congress J une, 2014; Rule 109(4) International Skating Union constitution and general regulations 2012 as accepted by the $54^{\text {th }}$ ordi nary congress J une, 2012.

1479 Art. 109(2)(c) International Skating Union general regulations 2014 as accepted by the $55^{\text {th }}$ Ordinary Congress J une, 2014; Art 109(2)(c) International Skating Union constitution and general regulations 2012 as accepted by the $54^{\text {th }}$ ordinary congress J une, 2012. 
citizen of the country for which the pair competes. ${ }^{1480}$ There is however the added requirement that if the partner has previously represented another country, he or she has to wait 12 months before being able to represent the new country. ${ }^{1481}$ For synchronised skating, the quota of non-citizens per team is $25 \%$ at a maximum, meaning that if 12 skaters form a team, three may be from a country which is not the one the team represents. ${ }^{1482}$ These skaters need the permission of the country of which they are citizens and may not change their country of representation within the course of a season. ${ }^{1483}$ Since there are no further requirements, these rules allow for more flexibility in the team skating events.

One interesting aspect regarding the ISU rules is that, under Rule 109(6), an athl ete may compete for a country in which there is no ISU member federation if he or she is able to get the consent of the ISU Council.. ${ }^{1484}$ Tuming to the ISU rules regarding the Olympic Games, the ISU underlines that these are governed not only by the ISU rules and regulations, but al so by the Olympic Charter. ${ }^{1485}$

1480 Art. 109(2)(c) International Skating Union general regulations 2014 as accepted by the $55^{\text {th }}$ Ordinary Congress June, 2014; Rule 109(2)(c) International Skating Union constitution and general regulations 2012 as accepted by the $54^{\text {th }}$ ordinary congress J une, 2012.

1481 Art. 109(2)(c) International Skating Union general regulations 2014 as accepted by the $55^{\text {th }}$ Ordinary Congress June, 2014; Rule 109(2)(c) International Skating Union constitution and general regulations 2012 as accepted by the $54^{\text {th }}$ ordinary congress J une, 2012.

1482 Rule 109(2)(d) International Skating Union general regulations 2014 as accepted by the $55^{\text {th }}$ Ordinary Congress June, 2014; Rule 109(2)(d) International Skating Union constitution and general regulations 2012 as accepted by the $54^{\text {th }}$ ordinary congress J une, 2012. Rule 109(2)(d) International Skating Union general regulations 2014 as accepted by the $55^{\text {th }}$ Ordinary Congress June, 2014; Rule 109(2)(d) International Skating Union constitution and general regulations 2012 as accepted by the $54^{\text {th }}$ ordinary congress J une, 2012. Congress J une, 2014; Rule 109(6) International Skating Union constitution and general regulations 2012 as accepted by the $54^{\text {th }}$ ordi nary congress J une, 2012. constitution and general regulations 2012 as accepted by the $54^{\text {th }}$ ordi nary congress J une, 2012. 


\subsection{Skiing ${ }^{1486}$}

Skiing as a means of transportation dates back to ancient times, as ski fragments from 8,000 to 7,000 BC have been found. ${ }^{1487}$ Skiing has been an Olympic discipline since the Olympic Winter Games in $1924^{1488}$ and is the Olympic Sport with the most disciplines, namely six: al pine, cross country, ski jumping, nordic combined, freestyle, and snowboarding, with several sub-categories existing in snowboarding. ${ }^{1489}$ All of these di sci plines are governed by one association, the Fédération I nternationale de Skj (FIS), which was founded in 1924 and has its seat in Oberhofen am Thunersee in Switzerland. ${ }^{1490}$

Cross country skiing was initially used as a means of transportation in the countries with heavy snow during winter periods. ${ }^{1491}$ As a sport, it was first featured at the 1924 Olympic Games, when only men were competing. ${ }^{1492}$ The aim of cross country skiing is to cover a distance on even ground as quickly as possible Men, and since 1952 also women, compete in the sprint and team sprint ${ }^{1493}$ Women's events al so include the $10 \mathrm{~km}$ individual start, $15 \mathrm{~km}$ pursuit, $30 \mathrm{~km}$ mass start, and the four times $5 \mathrm{~km}$ relay. ${ }^{1494}$ Men have the events of $15 \mathrm{~km}$ individual start, $30 \mathrm{~km}$ pursuit, $50 \mathrm{~km}$ mass start, and the four times $10 \mathrm{~km}$ relay. ${ }^{1495}$

Ski Jumping was first practiced in 1808 by Ole Rye in Norway and in the subsequent times different styles were developed. ${ }^{1496}$ It has been an Olympic discipline since 1924 and since the Winter Olympics in 2014 women are also competing in this category. ${ }^{1497}$ Athletes ski down a ramp and then jump through the air to land as far down the hill as possible. During their jump they keep their skis in a ' $V$ ' shape and lean extremely forward, while holding their arms stretched to their

1486 The federation was contacted on $6^{\text {th }}$ August 2014 and asked to provide further insights into its eligi bility criteria and ol der versions of the eligibi lity rules. TheFIS replied on $7^{\text {th }}$ August 2014. On $29^{\text {th }}$ October 2015 the FIS was contacted again and asked for comments on this chapter, which the FIS provided on $30^{\text {th }}$ October 2015.

1487 IOC Information Alpine Skiing Equipment and History; IOC Information Cross Country Skiing Equi pment and History; IOC I nformation Nordic Combi ned Equi pment and History.

1488 IOC Information FIS Al pine Skiing; IOC Information FIS Cross-Country Skiing; IOC Information FIS Freestyle-skiing; IOC Information FIS Nordic-Combined; IOC Information FIS Ski-J umping; IOC Information FIS Snowboard; IOC Reference Document Skiing: for information on nonnational athletes in the European national leagues and competitions see $\mathrm{S}$. van den Bogaert, A. Cuyvers, S. Gardiner, R. Parrish, S. Miettinen, J. Soek and R. Siekmann (2010), p. 191.

1490 lbid.

1491 IOC Information Cross Country Skiing Equipment and History.

1492 IOC Information FIS Al pine Skiing; IOC Information FIS Cross-Country Skiing; IOC Information FIS Freestyle-skiing; IOC Information FIS Nordic-Combined; IOC Information FIS Ski-Jumping; IOC Information FIS Snowboard; IOC Reference Document Cross-Country Skiing; IOC Information Cross Country Skiing Equipment and History. Ibid.

1494 IOC I nformation FIS A l pineSkiing; IOC Information FIS Cross-Country Skiing; IOC I nformation FIS Freestyle-skiing; IOC Information FIS Nordic-Combined; IOC Information FIS Ski-Jumping; IOC Information FIS Snowboard; Ibid.

IOC Information Ski J umping Equipment and History. IOC I nformation FIS Al pine Skiing; IOC Information FIS Cross-Country Skiing; IOC Information FIS Freestyle-skiing; IOC Information FIS Nordic-Combined; IOC Information FIS Ski-J umping; IOC Information FIS Snowboard; IOC Reference Document Ski J umping. 
backs to improve their flying. ${ }^{1498}$ This is done either on an individual basis with €ach athletejumping twice and his or her distance being added up or in a team event with teams consisting of four athletes. ${ }^{1499}$

Alpine skiing was al ready a competitive sport in the 1840 s. ${ }^{1500}$ Introduced in 1936 for both men and women, Alpine skiing has five events: the downhill, the super giant slalom giant slalom, slalom, and super combined. ${ }^{1501}$ In all alpine disciplines, the athlete is skiing downhill at high speed and obstacles are added depending on the focus of the sport In downhill, theathlete's aim is to reach the end of the course as quickly as possible ${ }^{1502}$ Slalom adds obstacles to the downhill course, which have to be navigated by short and quick turns. ${ }^{1503}$ The giant slal om's obstacles are placed further apart, enabling the athlete to make wider and smoother turns. ${ }^{1504}$ The super-giant slalom has the obstacles set furthest apart so that the athletes can race through the slal om, thus combining the speed of the downhill with the turns of the slalom ${ }^{1505}$ The super combined consists of two events, first the athletes have to go through a downhill race, then through a slalom, with their times being added up to come to the end result $t^{1506}$

Freestyle has been a feature for men and women at the Olympic Games since ${ }^{1992 .}{ }^{1507}$ It encompasses the disciplines of aerial, mogul and ski cross, half pipe, and slope style ${ }^{1508}$ What makes freestyle skiing so particular is the combination of acrobatic tricks, eg. likethose done by skateboarders on a half-pipe and skiing. ${ }^{1509}$

Snowboarding is a rather recent invention from the US in the 1960 s. $^{1510}$ Borrowing from surfing and skateboarding techniques, snowboarding quickly

1498 IOC Information Ski Jumping Equipment and History.

1499 IOC Information FIS Al pine Skiing; IOC I nformation FIS Cross-Country Skiing; IOC I nformation FIS Freestyle-skiing; IOC Information FIS Nordic-Combined; IOC Information FIS Ski-J umping; IOC Information FIS Snowboard.

1500 IOC Information A I pi ne Skiing Equipment and History.

1501 IOC Information FIS Alpine Skiing; IOC I nformation FIS Cross-Country Skiing; IOC I nformation FIS Freestyle-skiing; IOC Information FIS Nordic-Combined; IOC Information FIS Ski-J umping; IOC Information FIS Snowboard; IOC Reference Document Alpine Skiing; IOC Information Alpine Skiing Equipment and History.

IOC I nformation FIS AI pine Skiing; IOC I nformation FIS Cross-Country Skiing; IOC I nformation FIS Freestyle-skiing; IOC Information FIS Nordic-Combined; IOC Information FIS Ski-J umping; IOC Information FIS Snowboard.

1504 Ibid.

1505 Ibid.

1506 Ibid.

IOC I nformation FIS AI pine Skiing; IOC I nformation FIS Cross-Country Skiing; IOC I nformation FIS Freestyle-skiing; IOC Information FIS Nordic-Combined; IOC Information FIS Ski-J umping; IOC Information FIS Snowboard; IOC ReferenceDocument Skiing.

1507 IOC Information FIS Alpi ne Skiing; IOC I nformation FIS Cross-Country Skiing; IOC I nformation FIS Freestyle-skiing; IOC Information FIS Nordic-Combined; IOC Information FIS Ski-J umping; IOC Information FIS Snowboard; IOC Reference Document Freestyle Skiing; IOC Information Freestyle Skiing Equipment and History. FIS Freestyle-skiing; IOC Information FIS Nordic-Combined; IOC Information FIS Ski-J umping; IOC Information FIS Snowboard;

1509 IOC Information Frestyle Skiing Equi pment and History

1510 IOC Information Snowboard Equi pment and History. 
became popular. ${ }^{1511}$ It becamean Olympic Sport in $1998^{1512}$ and features five events per gender, namely half pipe, paralle slal om, giant parallel slal om snowboard cross, and slope style since 2014 . $^{1513}$

Nordic combined consists of ski jumping and cross country skiing. ${ }^{1514}$ It becamean Olympic discipline in 1924 and remains a men's only event to date ${ }^{1515}$ There arethree different events, namely thenormal hill Gundersen, large hill Gundersen and the team event. For the small hill Gundersen, athletes ski jump froma $90 \mathrm{~m}$ hill and race $10 \mathrm{~km}$ cross-country style, while the large hill Gundersen event has the same racing distance, yet the ski jumping takes place from a $120 \mathrm{~m} \mathrm{hill.}{ }^{1516}$ Theteam event al so makes use of thelarger hill, yet the raceis on a four times $5 \mathrm{~km}$ on relay basis. ${ }^{1517}$

TableXLIX: Overview of the eligibility requirements for skiing

\begin{tabular}{|l|l|}
\hline R equirements FIS - Skiing & \\
\hline In force since & $48^{\text {th }}$ Congress, 2013 \\
\hline C hange of nationality & $\begin{array}{l}\text { Possiblein combination with residence and/or } \\
\text { ancestry in the country }\end{array}$ \\
\hline R esidence requirements & Not specified \\
\hline M inors and nationality change & Not specified \\
\hline Stateless athletes & Not specified \\
\hline $\begin{array}{l}\text { Position of athletes with multiple nationality } \\
\text { after having competed for another country of } \\
\text { which the athlete is a national }\end{array}$ & $\begin{array}{l}\text { Need to fulfil the normal requirements of } \\
\text { national ity and residency/ancestry plus a year of } \\
\text { non-competition }\end{array}$ \\
\hline E ffect of changes in territory of country & Not specified \\
\hline Competing for the country of residence & $\begin{array}{l}\text { Principal legal and effectiveresidence for two } \\
\text { years }\end{array}$ \\
\hline Number of changes possible & No maximumgiven \\
\hline R efer ence to Olympic Charter & None \\
\hline Uses nationality/ citizenship & Citizenship \\
\hline Uses residence/ domicile & Principal legal and effectiveresidence \\
\hline Other remarkable peculiarity & $\begin{array}{l}\text { Refusal to allow change possible, even if all } \\
\text { criteria arefulfilled }\end{array}$ \\
\hline
\end{tabular}

1511 Ibid.

1512 IOC I nformation FIS Al pine Skiing; IOC I nformation FIS Cross-Country Skiing; IOC I nformation FIS Freestyle-skiing; IOC Information FIS Nordic-Combined; IOC Information FIS Ski-J umping; IOC Information FIS Snowboard; IOC Reference Document Snowboard; IOC Information Snowboard Equipment and History.

1513 IOC I nformation FIS Al pine Skiing; IOC I nformation FIS Cross-Country Skiing; IOC I nformation FIS Freestyle-skiing; IOC Information FIS Nordic-Combined; IOC Information FIS Ski-J umping; IOC Information FIS Snowboard.

1514 IOC Information FIS Al pine Skiing; IOC Information FIS Cross-Country Skiing; IOC I nformation FIS Freestyle-skiing; IOC Information FIS Nordic-Combined; IOC Information FIS Ski-J umping; IOC Information FIS Snowboard; IOC I nformation Nordic Combi ned Equipment and History.

1515 IOC I nformation FIS A l pine Skiing; IOC I nformation FIS Cross-Country Skiing; IOC I nformation FIS Freestyle-skiing; IOC Information FIS Nordic-Combined; IOC Information FIS Ski-J umping; IOC Information FIS Snowboard; IOC Reference Document Nordic Combined.

1516 IOC I nformation FIS Al pine Skiing; IOC Information FIS Cross-Country Skiing; IOC I nformation FIS Freestyle-skiing; IOC Information FIS Nordic-Combined; IOC Information FIS Ski-J umping; IOC Information FIS Snowboard.

1517 Ibid. 


\subsubsection{Skiing critical reflection}

The FIS eligibility criteria prescribe that athletes need to have licenses from the country of which they are nationals in order to be allowed to compete internationally. ${ }^{1518}$ Athletes wishing to change their country of representation need to show that they have a genuine link with the new country. ${ }^{1519}$ The FIS establishes such a genuine link by requiring the athlete's ditizenship of the country concemed and at least two years 'principal legal and effective residence' in the country. ${ }^{1520}$ In addition, the rel evant federations need to agree and an athlete might need to wait an entire year, starting from the last season during which he or she represented a country, if the approval is not forthcoming. ${ }^{1521}$ Overall, theFIS criteria are very explicit regarding the genuine link that is required between athleteand state Thus, skiing is one of the sports that has the most specific rules and takes themost ariteria into consideration.

\subsubsection{Rules applicable since 2013}

The FIS eligibility rules are set out in the Intemational Ski Competition Rules (ICR), with the different disciplines described in the different books. ${ }^{1522}$ Nevertheless, the content and wording does not differ among the various FIS disciplines. Furthermore, the rules approved by the $48^{\text {th }}$ International Ski Congress, Kangwonland (KOR) in 2012 are identical to those approved by the $49^{\text {th }}$ International Ski Congress in Barcelona (Spa) 2014 and those dating fromsummer and autumn 2015.

1518 Art. 203.3. International Ski Compeition Rules (ICR) book II Cross-Country approved by the $49^{\text {th }}$ International Ski congress, Barcelona (Spa) ind. Changes and precisions 2015 November, 2015; Art. 203.3 International Ski Competition Rules (ICR) book III Ski Jumping approved by the 49th International Ski congress, Barcelona (Spa) ind. changes and precisions 2015 Edition July, 2015; Art. 203.3 International Ski Competition Rules (ICR) book IV J oi nt regulations for Al pine Skiing, Downhill Slal om, Giant Slalom, Super-G, Combined Events, Team Events, Parallel Events, Ko Events approved by the $49^{\text {th }}$ International Ski congress, Barcelona (Spa),Web Version July, 2015; Art. 203.3 International Freestyle Skiing Competition Rules (ICR) book V J oint regulations for Freestyle Skiing, Aerials Moguls, Dual Moguls, Ski Cross, Ski Halfpipe, Ski Slopestyle approved by the $49^{\text {th }}$ International Ski congress, Barcelona (Spa) incl. changes and precisions 2015 Oberhofen, Edition August, 2015; Art 203.3 International Snowboard Competition Rules (ICR) book VI Joint regulations for Snowboarding, Slalom / Giant Slalom, Triple-S, Paralle Events, Snowboard Cross, Snowboard Halfpipe, Snowboard Big Air, Snowboard Slopestyle approved by the 49th I nternati onal Ski congress, Barcel ona (Spa) incl. changes and precisions 2015 web edition December, 2015 Oberhofen, December, 2015; Art203.3 International Ski Competition Rules (ICR) book VII Nordic Combined approved by the $49^{\text {th }}$ International Ski congress, Barcelona (Spa) ind. changes and precisions 2015 October, 2015. Ibid.

1520 Ibid.

1521 Ibid.

1522 Book II is for Cross-Country events, while book III delineates the rules for Ski J umping; book IV deals with joint regulations for Al pi neSkiing Downhill, Slal om, Giant Slal om, Super-G, Combined Events, Team Events, Paralle Events, Ko Events, while book $V$ focuses on thejoint regulations for Freestyle Skiing Aerials Moguls, Dual Moguls, Ski Cross, Ski Halfpipe, Ski Slopestyle book VI covers the joint regulations for Snowboarding Slalom / Giant Slalom, Triple-S, Parallel Events, Snowboard Cross, Snowboard Halfpi pe, Snowboard Big Air, Snowboard Slopestyle and book VII contains the rules for Nordic Combined. 
In all FIS regulated sports, the athletes need to have a license to participate in the official events. ${ }^{1523}$ The license is issued by the re levant national federation and is valid

1523 Art. 203 and Art. 203. 4 International Ski Competition Rules (ICR) book II Cross-Country approved by the $49^{\text {th }}$ International Ski congress 2014, Barcelona (Spa) incl. Changes and precisions 2015 Edition July, 2015 and November, 2015 Edition; Art. 203 and Art. 203. 4. International Ski Competition Rules (ICR) book II Cross-Country approved by the $49^{\text {th }}$ International Ski congress 2014, Barcelona (Spa) July, 2014; Art. 203 and Art. 203. 4 International Ski Competition Rules (ICR) book II Cross-Country approved by the $48^{\text {th }}$ International Ski congress 2012, Kangwonland (Kor) ind. marked up changes and precisions 2013 web edition October 2013; Art. 203 and Art. 203. 4 International Ski Competition Rules (ICR) book III Ski Jumping approved by the 49th International Ski congress 2014, Barcelona (Spa) ind. changes and precisions 2015 Edition July 2015; Art. 203 and Art. 203. 4 International Ski Competition Rules (ICR) book III Ski Jumping approved by the 49th International Ski congress 2014, Barcelona (Spa) July 2014; Art 203 and Art. 203.4 International Ski Competition Rules (ICR) book III Ski Jumping approved by the $48^{\text {th }}$ International Ski congress 2012, Kangwonland (Kor) web edition October, 2013; Art. 203 and Art. 203. 4 International Ski Competition Rules (ICR) book IV Joint regulations for Alpine Skiing, Downhill Slal om, Giant Slalom, Super-G, Combined Events, Team Events, Paralle Events, Ko Events approved by the $49^{\text {th }}$ International Ski congress 2014, Barcelona (Spa), Web Version J uly 2015; Oberhofen, July 2015; Art 203 and Art. 203. 4 International Ski Competition Rules (ICR) book IV J oint regulations for Al pine Skiing, Downhill Slalom, Giant Slal om Super-G, Combined Events, Team Events, Paralle Events, Ko Events approved by the $49^{\text {th }}$ International Ski congress 2014, Barcelona (Spa), July 2014; Art. 203 and Art. 203.4 International Ski Competition Rules (ICR) book IV Joint regulations for Alpine Skiing Downhill, Slalom, Giant Slalom Super-G, Combined Events, Team Events, Parallel Events, Ko Events approved by the $48^{\text {th }}$ International Ski congress 2012, Kangwonland (Kor) web edition J uly 2013; Art. 203 and Art. 203. 4 International Freestyle Skiing Competition Rules (ICR) book V J oint regulations for Freestyle Skiing, Aerials Moguls, Dual Moguls, Ski Cross, Ski Halfpipe, Ski Slopestyle approved by the $49^{\text {th }}$ International Ski congress 2014, Barcelona (Spa) ind. changes and precisions 2015 Oberhofen, Edition August 2015; Art. 203 and Art. 203.4 International Freestyle Skiing Competition Rules (ICR) book V J oint regulations for Freestyle Skiing, Aerials Moguls, Dual Moguls, Ski Cross, Ski Halfpipe, Ski Slopestyle approved by the $49^{\text {th }}$ International Ski congress 2014, Barcelona (Spa) November 2014; Art. 203 and Art. 203.4 International Freestyle Skiing Competition Rules (ICR) book V J oint regulations for Freestyle Skiing Aerials Moguls, Dual Moguls, Ski Cross, Ski Halfpipe, Ski Slopestyle approved by the $48^{\text {th }}$ International Ski congress 2012, Kangwonland (Kor) web edition November 2013; Art. 203 and Art. 203. 4 International Freestyle Skiing Competition Rules (ICR) book V J oint regulations for Freestyle Skiing Aerials Moguls, Dual Moguls, Ski Cross, Ski Halfpi pe, Ski Slopestyle approved by the $48^{\text {th }}$ International Ski congress 2012, Kangwonland (Kor) web edition J uly 2013; Art. 203 and Art. 203. 4 International Snowboard Competition Rules (ICR) book VI Joint regulations for Snowboarding, Slalom / Giant Slalom, Triple-S, Paralle Events, Snowboard Cross, Snowboard Halfpipe, Snowboard Big Air, Snowboard Slopestyle approved by the 49th International Ski congress 2014, Barcelona (Spa)ind. changes and precisions 2015 web edition September 2015 Oberhofen, September 2015 and December 2015 Edition; Art. 203 and Art. 203. 4 International Snowboard Competition Rules (ICR) book VI Joint regulations for Snowboarding, Slal om / Giant Slalom, Triple-S, Paralle Events, Snowboard Cross, Snowboard Halfpipe, Snowboard Big Air, Snowboard Slopestyle approved by the 49th International Ski congress 2014, Barcelona (Spa) October 2014; Art 203 and Art. 203. 4 International Snowboard Competition Rules (ICR) book VI Joint regulations for Snowboarding Slalom / Giant Slalom, Triple-S, Paralle Events, Snowboard Cross, Snowboard Halfpipe, Snowboard Big Air, Snowboard Slopestyle approved by the $48^{\text {th }}$ International Ski congress 2012, Kangwonland (Kor) web edition November 2013; Art. 203 and Art 203. 4 International Snowboard Competition Rules (ICR) book VI Joint regulations for Snowboarding Slalom / Giant Slalom, TripleS, Paralle Events, Snowboard Cross, Snowboard Halfpipe, Snowboard Big Air, Snowboard Slopestyle approved by the 48 ${ }^{\text {th }}$ International Ski congress 2012, Kangwonland (Kor) web edition August 2013; Art. 203 and Art. 203. 4 International Ski Competition Rules (ICR) book VII Nordic Combined approved by the $49^{\text {th }}$ International Ski congress 2014, Barcelona (Spa) incl. changes and precisions 2015 October 2015; Art. 203 and Art. 203. 4 International Ski Competition Rules (ICR) book VII Nordic Combined approved by the $49^{\text {th }}$ International Ski congress 2014, Barcelona (Spa) incl. changes and precisions 2015 July 2015; Art. 203 and Art. 203. 4 International Ski Competition Rules (ICR) book VII Nordic Combined approved by the $49^{\text {th }}$ International Ski congress 2014, Barcel ona (Spa) 
for one FIS season, lasting from $1^{\text {t }}$ J uly until $30^{\text {th }}$ J une of the following calendar year. ${ }^{1524}$ In order to be eligible for such a license, the athlete must dedare that he or

November 2014; Art. 203 and Art. 203. 4 International Ski Competition Rules (ICR) book VII Nordic Combined approved by the $49^{\text {th }}$ International Ski congress 2014, Barcelona (Spa) August 2014; Art. 203 and Art. 203. 4 International Ski Competition Rules (ICR) book VII Nordic Combined approved by the $48^{\text {th }}$ International Ski congress 2012, Kangwonland (Kor) web edition October 2013.

1524 Art. 203.1and Art 203.2. International Ski Competition Rules (ICR) book II Cross-Country approved by the $49^{\text {th }}$ International Ski congress 2014, Barcelona (Spa) incl. Changes and precisions 2015 Edition J uly 2015 and November 2015 Edition; Art. 203.1. and Art. 203.2. International Ski Competition Rules (ICR) book II Cross-Country approved by the $49^{\text {th }}$ International Ski congress 2014, Barcelona (Spa) July 2014; Art. 203.1 and Art. 203.2. International Ski Competition Rules (ICR) book II Cross-Country approved by the $48^{\text {th }}$ International Ski congress 2012, Kangwonland (Kor) incl. marked up changes and precisions 2013 web edition October 2013; Art. 203.1 and Art. 203.2. International Ski Competition Rules (ICR) book III Ski Jumping approved by the 49th International Ski congress 2014, Barcelona (Spa) ind. changes and precisions 2015 Edition July 2015; Art. 203.1 and Art. 203.2. International Ski Competition Rules (ICR) book III Ski Jumping approved by the 49th International Ski congress 2014, Barcelona (Spa) July 2014; Art. 203.1 and Art. 203.2. International Ski Competition Rules (ICR) book III Ski Jumping approved by the $48^{\text {th }}$ International Ski congress 2012, Kangwonland (Kor) web edition October 2013; Art. 203.1 and Art. 203.2. International Ski Competition Rules (ICR) book IV J oint regulations for Al pine Skiing, Downhill Slalom, Giant Slalom, Super-G, Combined Events, Team Events, Parallel Events, Ko Events approved by the $49^{\text {th }}$ International Ski congress 2014, Barcelona (Spa), Web Version July 2015; Oberhofen, July 2015; Art. 203.1 and Art. 203.2. International Ski Competition Rules (ICR) book IV J oint regulations for Al pine Skiing, Downhill Slalom, Giant Slal om Super-G, Combined Events, Team Events, Parallel Events, Ko Events approved by the $49^{\text {th }}$ International Ski congress 2014, Barcelona (Spa), July 2014; Art. 203.1 and Art. 203.2. International Ski Competition Rules (ICR) book IV Joint regulations for Alpine Skiing Downhill, Slalom, Giant Slalom, Super-G, Combined Events, Team Events, Paralle Events, Ko Events approved by the $48^{\text {th }}$ International Ski congress 2012, Kangwonland (Kor) web edition J uly 2013; Art. 203.1 and Art. 203.2. International Freestyle Skiing Competition Rules (ICR) book V J oint regulations for Freestyle Skiing, Aerials Moguls, Dual Moguls, Ski Cross, Ski Halfpipe, Ski Slopestyle approved by the $49^{\text {th }}$ International Ski congress 2014, Barcel ona (Spa) ind. changes and precisions 2015 Oberhofen, Edition August 2015; Art. 203.1 and Art. 203.2. International Freestyle Skiing Competition Rules (ICR) book V J oint regulations for Freestyle Skiing, Aerials Moguls, Dual Moguls, Ski Cross, Ski Halfpipe, Ski Slopestyle approved by the $49^{\text {th }}$ International Ski congress 2014, Barcelona (Spa) November 2014; Art. 203.1 and Art. 203.2. International Freestyle Skiing Competition Rules (ICR) book V J oint regulations for Freestyle Skiing Aerials Moguls, Dual Moguls, Ski Cross, Ski Halfpipe, Ski Slopestyle approved by the $48^{\text {th }}$ International Ski congress 2012, Kangwonland (Kor) web edition November 2013; Art. 203.1 and Art. 203.2. International Freestyle Skiing Competition Rules (ICR) book V Joint regulations for Freestyle Skiing Aerials Moguls, Dual Moguls, Ski Cross, Ski Halfpi pe, Ski Slopestyle approved by the $48^{\text {th }}$ International Ski congress 2012, Kangwonland (Kor) web edition July 2013; Art 203.1 and Art. 203.2. International Snowboard Competition Rules (ICR) book VI Joint regulations for Snowboarding, Slalom / Giant Slalom, TripleS, Parallel Events, Snowboard Cross, Snowboard Halfpipe, Snowboard Big Air, Snowboard Slopestyle approved by the 49th International Ski congress 2014, Barcel ona (Spa)incl. changes and precisions 2015 web edition September 2015 Oberhofen, September 2015 and December 2015 Edition; Art. 203.1 and Art. 203.2. International Snowboard Competition Rules (ICR) book VI J oint regulations for Snowboarding, Slal om/ Giant Slal om, TripleS, Parallel Events, Snowboard Cross, Snowboard Halfpipe, Snowboard Big Air, Snowboard Slopestyle approved by the 49th International Ski congress 2014, Barcel ona (Spa) October 2014; Art. 203.1 and Art. 203.2. International Snowboard Competition Rules (ICR) book VI Joint regulations for Snowboarding Slalom / Giant Slalom, Triple-S, Parallel Events, Snowboard Cross, Snowboard Halfpipe, Snowboard Big Air, Snowboard Slopestyle approved by the $48^{\text {th }}$ International Ski congress 2012, Kangwonland (Kor) web edition November 2013; Art. 203.1 and Art. 203.2. International Snowboard Competition Rules (ICR) book VI J oint regulations for Snowboarding Slalom / Giant Slalom, Triple-S, Paralle Events, Snowboard Cross, Snowboard Halfpipe, Snowboard Big Air, Snowboard Slopestyle approved by the $48^{\text {th }}$ International Ski congress 2012, Kangwonland (Kor) web edition August 2013; Art203.1 and Art. 203.2. International Ski Competition Rules (ICR) book VII Nordic Combined approved 
she submits him or herseff to the FIS rules and the jurisdiction of the Court of Arbitration for Sport ${ }^{1525}$

by the $49^{\text {th }}$ International Ski congress 2014, Barcelona (Spa) ind. changes and precisions 2015 October 2015Art203.1 and Art. 203.2. International Ski Competition Rules (ICR) book VII Nordic Combined approved by the $49^{\text {th }}$ International Ski congress 2014, Barcelona (Spa) incl. changes and precisions 2015 July 2015; Art.203.1 and Art. 203.2. International Ski Competition Rules (ICR) book VII Nordic Combined approved by the $49^{\text {th }}$ International Ski congress 2014, Barcelona (Spa) November 2014; Art. 203.1 and Art. 203.2. International Ski Competition Rules (ICR) book VII Nordic Combined approved by the $49^{\text {th }}$ International Ski congress 2014, Barcelona (Spa) August 2014; Art 203.1 and Art. 203.2. International Ski Competition Rules (ICR) book VII Nordic Combined approved by the $48^{\text {th }}$ International Ski congress 2012, Kangwonland (Kor) web edition October 2013.

Art. 203.2.1 International Ski Competition Rules (ICR) book II Cross-Country approved by the $49^{\text {th }}$ International Ski congress 2014, Barcelona (Spa) ind. Changes and precisions 2015 Edition July 2015 and November 2015 Edition; Art. 203.2.1. International Ski Competition Rules (ICR) book II Cross-Country approved by the $49^{\text {th }}$ International Ski congress 2014, Barcelona (Spa) J uly 2014; Art. 203.2.1 International Ski Competition Rules (ICR) book II Cross-Country approved by the $48^{\text {th }}$ International Ski congress 2012, Kangwonland (Kor) ind. marked up changes and precisions 2013 web edition October 2013; Art. 203.2.1 International Ski Competition Rules (ICR) book III Ski J umping approved by the 49th International Ski congress 2014, Barcelona (Spa) ind. changes and precisions 2015 Edition July 2015; Art. 203.2.1 International Ski Competition Rules (ICR) book III Ski J umping approved by the 49th International Ski congress 2014, Barcel ona (Spa) July 2014; Art. 203.2.1 International Ski Competition Rules (ICR) book III Ski Jumping approved by the $48^{\text {th }}$ International Ski congress 2012, Kangwonland (Kor) web edition October 2013; Art. 203.2.1 Intemational Ski Competition Rules (ICR) book IV Joint regulations for Alpine Skiing, Downhill Slal om, Giant Slalom, Super-G, Combined Events, Team Events, Paralle Events, Ko Events approved by the $49^{\text {th }}$ International Ski congress 2014, Barcelona (Spa),Web Version July 2015; Oberhofen, July 2015; Art. 203.2.1 International Ski Competition Rules (ICR) book IV J oint regulations for Alpine Skiing, Downhill Slal om, Giant Slal om, Super-G, Combined Events, Team Events, Paralle Events, Ko Events approved by the $49^{\text {th }}$ International Ski congress 2014, Barcelona (Spa), J uly 2014; Art. 203.2.1 International Ski Competition Rules (ICR) book IV J oint regulations for Alpine Skiing Downhill, Slalom Giant Slalom Super-G, Combined Events, Team Events, Paralle Events, Ko Events approved by the $48^{\text {th }}$ International Ski congress 2012 , Kangwonland (Kor) web edition J uly 2013; Art. 203.2.1 International Freestyle Skiing Competition Rules (ICR) book V Joint regulations for Freestyle Skiing, Aerials Moguls, Dual Moguls, Ski Cross, Ski Halfpipe, Ski Slopestyle approved by the $49^{\text {th }}$ International Ski congress 2014, Barcelona (Spa) ind. changes and precisions 2015 Oberhofen, Edition August 2015; Art. 203.2.1 International Freestyle Skiing Competition Rules (ICR) book V Joint regulations for Freestyle Skiing, Aerials Moguls, Dual Moguls, Ski Cross, Ski Halfpipe, Ski Slopestyle approved by the $49^{\text {th }}$ International Ski congress 2014, Barcelona (Spa) November 2014; Art. 203.2.1 International Freestyle Skiing Competition Rules (ICR) book V J oint regulations for Freestyle Skiing Aerials Moguls, Dual Moguls, Ski Cross, Ski Halfpipe, Ski Slopestyle approved by the $48^{\text {th }}$ International Ski congress 2012, Kangwonland (Kor) web edition November 2013; Art. 203.2.1 International Freestyle Skiing Competition Rules (ICR) book V J oint regulations for Freestyle Skiing Aerials Moguls, Dual Moguls, Ski Cross, Ski Halfpipe, Ski Slopestyle approved by the $48^{\text {th }}$ International Ski congress 2012, Kangwonland (Kor) web edition July 2013; Art. 203.2.1 International Snowboard Competition Rules (ICR) book VI Joint regulations for Snowboarding, Slalom / Giant Slalom, Triple-S, Paralle Events, Snowboard Cross, Snowboard Halfpipe, Snowboard Big Air, Snowboard Slopestyle approved by the 49th I nternational Ski congress 2014, Barcel ona (Spa)ind. changes and precisions 2015 web edition September 2015 Oberhofen, September 2015 and December 2015 Edition; Art. 203.2.1 International Snowboard Competition Rules (ICR) book VI J oint regulations for Snowboarding, Slal om/ Giant Slal om Triple-S, Paralle Events, Snowboard Cross, Snowboard Halfpipe, Snowboard Big Air, Snowboard Slopestyle approved by the 49th International Ski congress 2014, Barcelona (Spa) October 2014; Art. 203.2.1 International Snowboard Competition Rules (ICR) book VI J oi nt regulations for Snowboarding Slalom/ Giant Slal om, Triple-S, Paralle Events, Snowboard Cross, Snowboard Halfpipe, Snowboard Big Air, Snowboard Slopestyle approved by the $48^{\text {th }}$ International Ski congress 2012, Kangwonland (Kor) web edition November 2013; Art 203.2.1 International Snowboard Competition Rules (ICR) book VI J oint regulations for Snowboarding Slalom / Giant Slalom, TripleS, Parallel Events, Snowboard Cross, Snowboard 
Regarding nationality as a criterion, the FIS requires the respective national associations to only provide nationals of their own country with the licence ${ }^{1526}$ The

Halfpipe, Snowboard Big Air, Snowboard Slopestyle approved by the $48^{\text {th }}$ International Ski congress 2012, Kangwonland (Kor) web edition August 2013; Art.203.2.1 International Ski Competition Rules (ICR) book VII Nordic Combined approved by the $49^{\text {th }}$ International Ski congress 2014, Barcelona (Spa) incl. changes and precisions 2015 October 2015; Art.203.2.1 International Ski Competition Rules (ICR) book VII Nordic Combined approved by the $49^{\text {th }}$ International Ski congress 2014, Barcelona (Spa) incl. changes and precisions 2015 July 2015; Art.203.2.1 International Ski Competition Rules (ICR) book VII Nordic Combined approved by the $49^{\text {th }}$ International Ski congress 2014, Barcelona (Spa) November 2014; Art 203.2.1 International Ski Competition Rules (ICR) book VII Nordic Combined approved by the $49^{\text {th }}$ International Ski congress 2014, Barcelona (Spa) August 2014; Art 203.2.1 International Ski Competition Rules (ICR) book VII Nordic Combined approved by the $48^{\text {th }}$ International Ski congress 2012, Kangwonland (Kor) web edition October 2013.

1526 Art. 203.3. International Ski Competition Rules (ICR) book II Cross-Country approved by the $49^{\text {th }}$ International Ski congress 2014, Barcelona (Spa) incl. Changes and precisions 2015 Edition J uly 2015 and November 2015 Edition; Art. 203.3. International Ski Competition Rules (ICR) book II Cross-Country approved by the $49^{\text {th }}$ International Ski congress 2014, Barcelona (Spa) July 2014; Art. 203.3 International Ski Competition Rules (ICR) book II Cross-Country approved by the $48^{\text {th }}$ International Ski congress 2012, Kangwonland (Kor) incl. marked up changes and precisions 2013 web edition October 2013; Art 203.3 International Ski Competition Rules (ICR) book III Ski J umping approved by the 49th International Ski congress 2014, Barcel ona (Spa) incl. changes and precisions 2015 Edition J uly 2015; Art 203.3 International Ski Competition Rules (ICR) book III Ski Jumping approved by the 49th International Ski congress 2014, Barcelona (Spa) July 2014; Art. 203.3 International Ski Competition Rules (ICR) book III Ski J umping approved by the $48^{\text {th }}$ International Ski congress 2012, Kangwonland (Kor) web edition October 2013; Art. 203.3 International Ski Competition Rules (ICR) book IV J oint regulations for Alpine Skiing, Downhill Slalom, Giant Slalom, Super-G, Combined Events, Team Events, Parallel Events, Ko Events approved by the $49^{\text {th }}$ International Ski congress 2014, Barcelona (Spa),Web Version July 2015; Oberhofen, July 2015; Art. 203.3 International Ski Competition Rules (ICR) book IV Joint regulations for Alpine Skiing, Downhill Slal om, Giant Slal om, Super-G, Combined Events, Teem Events, Paralle Events, Ko Events approved by the $49^{\text {th }}$ International Ski congress 2014, Barcelona (Spa), July 2014; Art. 203.3 International Ski Competition Rules (ICR) book IV J oint regulations for Alpine Skiing Downhill, Slalom, Giant Slalom Super-G, Combined Events, Team Events, Paralle Events, Ko Events approved by the $48^{\text {th }}$ International Ski congress 2012, Kangwonland (Kor) web edition July 2013; Art 203.3 International Freestyle Skiing Competition Rules (ICR) book V Joint regulations for Freestyle Skiing, Aerials Moguls, Dual Moguls, Ski Cross, Ski Halfpipe, Ski Slopestyle approved by the $49^{\text {th }}$ International Ski congress 2014, Barcelona (Spa) ind. changes and precisions 2015 Oberhofen, Edition August 2015; Art. 203.3 International Freestyle Skiing Competition Rules (ICR) book V J oint regulations for Freestyle Skiing, Aerials Moguls, Dual Moguls, Ski Cross, Ski Halfpipe, Ski Slopestyle approved by the $49^{\text {th }}$ International Ski congress 2014, Barcelona (Spa) November 2014; Art. 203.3 International Freestyle Skiing Competition Rules (ICR) book V J oint regulations for Freestyle Skiing Aerials Moguls, Dual Moguls, Ski Cross, Ski Halfpipe, Ski Slopestyle approved by the $48^{\text {th }}$ International Ski congress 2012, Kangwonland (Kor) web edition November 2013; Art. 203.3 International Freestyle Skiing Competition Rules (ICR) book V J oint regulations for Freestyle Skiing Aerials Moguls, Dual Moguls, Ski Cross, Ski Halfpipe, Ski Slopestyle approved by the $48^{\text {th }}$ International Ski congress 2012, Kangwonland (Kor) web edition July 2013; Art. 203.3 International Snowboard Competition Rules (ICR) book VI J oint regulations for Snowboarding, Slal om/ Giant Slalom, Triple-S, Parallel Events, Snowboard Cross, Snowboard Halfpipe, Snowboard Big Air, Snowboard Slopestyle approved by the 49th International Ski congress 2014, Barcel ona (Spa)incl. changes and precisions 2015 web edition September 2015 Oberhofen, September 2015 and December 2015 Edition; Art. 203.3 International Snowboard Competition Rules (ICR) book VI Joint regulations for Snowboarding, Slalom / Giant Slalom, Triple-S, Paralle Events, Snowboard Cross, Snowboard Halfpipe, Snowboard Big Air, Snowboard Slopestyle approved by the 49th International Ski congress 2014, Barcelona (Spa) October 2014; Art 203.3 International Snowboard Competition Rules (ICR) book VI J oint regulations for Snowboarding Slalom / Giant Slalom, Triple-S, Paralle Events, Snowboard Cross, Snowboard Halfpipe, Snowboard Big Air, Snowboard Slopestyle approved by the $48^{\text {th }}$ International Ski congress 2012, Kangwonland (Kor) web edition November 
athletes have to prove their nationality by submitting a copy of their passports to the federations. ${ }^{1527}$ Minors, need to have the permission of their guardians to apply for the licenses. ${ }^{1528}$

Athletes wishing to change the association from which they have received a license will depend on the decision taken by the FIS Council in the spring of every year. ${ }^{1529}$ It is important to note that:

2013; Art. 203.3 International Snowboard Competition Rules (ICR) book VI J oint regulations for Snowboarding Slalom / Giant Slalom Triple-S, Parallel Events, Snowboard Cross, Snowboard Halfpipe, Snowboard Big Air, Snowboard Slopestyle approved by the $48^{\text {th }}$ International Ski congress 2012, Kangwonland (Kor) web edition August 2013; Art203.3 International Ski Competition Rules (ICR) book VII Nordic Combined approved by the $49^{\text {th }}$ International Ski congress 2014, Barcelona (Spa) ind. changes and precisions 2015 October 2015; Art.203.3 International Ski Competition Rules (ICR) book VII Nordic Combined approved by the $49^{\text {th }}$ International Ski congress 2014, Barcelona (Spa) ind. changes and precisions 2015 July 2015; Art.203.3 International Ski Competition Rules (ICR) book VII Nordic Combined approved by the $49^{\text {th }}$ International Ski congress 2014, Barcelona (Spa) November 2014; Art. 203.3 International Ski Competition Rules (ICR) book VII Nordic Combined approved by the $49^{\text {th }}$ International Ski congress 2014, Barcelona (Spa) August 2014; Art. 203.3 International Ski Competition Rules (ICR) book VII Nordic Combined approved by the $48^{\text {th }}$ International Ski congress 2012, Kangwonland (Kor) web edition October 2013.

1528 Ibid.

1529 Art. 203.5. International Ski Compeition Rules (ICR) book II Cross-Country approved by the $49^{\text {th }}$ International Ski congress 2014, Barcelona (Spa) incl. Changes and precisions 2015 Edition J uly 2015 and November 2015 Edition; Art. 203.5. International Ski Competition Rules (ICR) book II Cross-Country approved by the $49^{\text {th }}$ International Ski congress 2014, Barcelona (Spa) July 2014; Art. 203.5 International Ski Competition Rules (ICR) book II Cross-Country approved by the $48^{\text {th }}$ International Ski congress 2012, Kangwonland (Kor) incl. marked up changes and precisions 2013 web edition October 2013; Art 203.5 International Ski Competition Rules (ICR) book III Ski Jumping approved by the 49th International Ski congress 2014, Barcel ona (Spa) ind. changes and precisions 2015 Edition July 2015; Art 203.5 International Ski Competition Rules (ICR) book III Ski J umping approved by the 49th International Ski congress 2014, Barcel ona (Spa) July 2014; Art. 203.5 International Ski Competition Rules (ICR) book III Ski J umping approved by the $48^{\text {th }}$ International Ski congress 2012, Kangwonland (Kor) web edition October 2013; Art. 203.5 International Ski Competition Rules (ICR) book IV J oint regulations for Alpine Skiing, Downhill Slalom, Giant Slalom, Super-G, Combined Events, Team Events, Parallel Events, Ko Events approved by the $49^{\text {th }}$ International Ski congress 2014, Barcel ona (Spa),Web Version July 2015; Oberhofen, July 2015; Art. 203.5 International Ski Competition Rules (ICR) book IV Joint regulations for Alpine Skiing, Downhill Slal om, Giant Slal om, Super-G, Combined Events, Team Events, Paralle Events, Ko Events approved by the $49^{\text {th }}$ International Ski congress 2014, Barcelona (Spa), July 2014; Art. 203.5 International Ski Competition Rules (ICR) book IV J oint regulations for Alpine Skiing Downhill, Slalom Giant Slalom Super-G, Combined Events, Team Events, Paralle Events, Ko Events approved by the $48^{\text {th }}$ International Ski congress 2012, Kangwonland (Kor) web edition July 2013; Art. 203.5 International Freestyle Skiing Competition Rules (ICR) book V Joint regulations for Freestyle Skiing, Aerials Moguls, Dual Moguls, Ski Cross, Ski Halfpipe, Ski Slopestyle approved by the $49^{\text {th }}$ International Ski congress 2014, Barcelona (Spa) ind. changes and precisions 2015 Oberhofen, Edition August 2015; Art. 203.5 International Freestyle Skiing Competition Rules (ICR) book V J oint regulations for Freestyle Skiing, Aerials Moguls, Dual Moguls, Ski Cross, Ski Halfpipe, Ski Slopestyle approved by the $49^{\text {th }}$ International Ski congress 2014, Barcelona (Spa) November 2014; Art. 203.5 International Freestyle Skiing Competition Rules (ICR) book V J oint regulations for Freestyle Skiing Aerials Moguls, Dual Moguls, Ski Cross, Ski Halfpi pe, Ski Slopestyle approved by the $48^{\text {th }}$ International Ski congress 2012, Kangwonland (Kor) web edition November 2013; Art. 203.5 International Freestyle Skiing Competition Rules (ICR) book V J oint regulations for Freestyle Skiing Aerials Moguls, Dual Moguls, Ski Cross, Ski Halfpipe, Ski Slopestyle approved by the $48^{\text {th }}$ International Ski congress 2012, Kangwonland (Kor) web edition J uly 2013; Art. 203.5 International Snowboard Competition Rules (ICR) book VI J oint regulations for Snowboarding, Slal om / Giant Slalom Triple-S, Paralle 
"an application to change licence registration will not be granted unless the competitor demonstrates his personal association with thenew nation." ${ }^{1530}$

This is a direct reference to the concept of the genuine link which needs to exist between the athl ete and the country he or she represents. The FIS establishes such a genuine link by requiring the athl ete's citizenship of the country concemed and at least two years "principal legal and effectiveresidence" therein. ${ }^{1531}$ Here the FIS underlines that, for a change, not only the citizenship of the country is relevant but, that for such a purpose, the link has to be supported by another factor, such as residence The residence requirement may be wai ved if either the athlete was bom in the country or the parents are nationals of the country. ${ }^{1532}$ It does not suffice that the parents of the athlete acquire a passport, but they also must need to be resident in the country. ${ }^{1533}$ This requirement places found ings at a di sadvantage, sincetheir place of birth or their parents' nationality cannot be proven. The further requirement that the athl ete needs to have ancestry in the rel evant country is al so problematic, as this is something which an adopted child or foundling might be hard pressed to prove ${ }^{1534}$ In all cases, the athlete will have to explain thoroughly the reasons why he or she wishes to change the country for which he or she has a licence ${ }^{1535}$

If the athlete has multiple nationality or has al ready participated in an official FIS event, he or she needs to comply with the aforementioned criteria of having a passport, residency, and possi bly ancestry but, in addition, needs to acquire a rel ease

Events, Snowboard Cross, Snowboard Halfpipe, Snowboard Big Air, Snowboard Slopestyle approved by the 49th International Ski congress 2014, Barcel ona (Spa)incl. changes and precisions 2015 web edition September 2015 Oberhofen, September 2015 and December 2015 Edition; Art. 203.5 International Snowboard Competition Rules (ICR) book VI Joint regulations for Snowboarding, Slalom / Giant Slal om Triple-S, Paralle Events, Snowboard Cross, Snowboard Halfpipe, Snowboard Big Air, Snowboard Slopestyle approved by the 49th International Ski congress 2014, Barcelona (Spa) October 2014; Art 203.5 International Snowboard Competition Rules (ICR) book VI J oint regulations for Snowboarding Slalom/ Giant Slal om, TripleS, Paralle Events, Snowboard Cross, Snowboard Halfpipe, Snowboard Big Air, Snowboard Slopestyle approved by the $48^{\text {th }}$ International Ski congress 2012, Kangwonland (Kor) web edition November 2013; Art. 203.5 International Snowboard Competition Rules (ICR) book VI J oint regulations for Snowboarding Slalom / Giant Slalom Triple-S, Parallel Events, Snowboard Cross, Snowboard Halfpipe, Snowboard Big Air, Snowboard Slopestyle approved by the $48^{\text {th }}$ International Ski congress 2012, Kangwonland (Kor) web edition August 2013; Art203.5 International Ski Competition Rules (ICR) book VII Nordic Combined approved by the $49^{\text {th }}$ International Ski congress 2014, Barcelona (Spa) ind. changes and precisions 2015 October 2015; Art.203.5 International Ski Competition Rules (ICR) book VII Nordic Combined approved by the $49^{\text {th }}$ International Ski congress 2014, Barcelona (Spa) incl. changes and precisions 2015 July 2015; Art.203.5 International Ski Competition Rules (ICR) book VII Nordic Combined approved by the $49^{\text {th }}$ International Ski congress 2014, Barcel ona (Spa) November 2014; Art. 203.5 International Ski Competition Rules (ICR) book VII Nordic Combined approved by the $49^{\text {th }}$ International Ski congress 2014, Barcelona (Spa) August 2014; Art. 203.5 International Ski Competition Rules (ICR) book VII Nordic Combined approved by the $48^{\text {th }}$ International Ski congress 2012, Kangwonland (Kor) web edition October 2013.

1531 Ibid.

1532 Ibid.

1533 Ibid.

1534 Ibid.

1535 Ibid. 
agreement from the former association. ${ }^{1536}$ In case therelevant association refuses to release the athlete, he or she needs to wait an entire year, starting from the last

1536 Art. 203.5.1 International Ski Competition Rules (ICR) book II Cross-Country approved by the $49^{\text {th }}$ International Ski congress 2014, Barcelona (Spa) ind. Changes and precisions 2015 Edition July 2015 and November 2015 Edition; Art. 203.5.1. International Ski Competition Rules (ICR) book II Cross-Country approved by the $49^{\text {th }}$ International Ski congress 2014, Barcelona (Spa) July 2014; Art. 203.5.1 International Ski Competition Rules (ICR) book II Cross-Country approved by the $48^{\text {th }}$ International Ski congress 2012, Kangwonland (Kor) ind. marked up changes and precisions 2013 web edition October 2013; Art. 203.5.1 International Ski Competition Rules (ICR) book III Ski J umping approved by the 49th International Ski congress 2014, Barcelona (Spa) ind. changes and precisions 2015 Edition July 2015; Art. 203.5.1 International Ski Competition Rules (ICR) book III Ski J umping approved by the 49th International Ski congress 2014, Barcelona (Spa) July 2014; Art. 203.5.1 International Ski Competition Rules (ICR) book III Ski Jumping approved by the $48^{\text {th }}$ International Ski congress 2012, Kangwonland (Kor) web edition October 2013; Art. 203.5.1 International Ski Competition Rules (ICR) book IV Joint regulations for Alpine Skiing, Downhill Slal om, Giant Slalom, Super-G, Combined Events, Team Events, Paralle Events, Ko Events approved by the $49^{\text {th }}$ International Ski congress 2014, Barcelona (Spa),Web Version July 2015; Oberhofen, July 2015; Art. 203.5.1 International Ski Competition Rules (ICR) book IV J oint regulations for Alpine Skiing, Downhill Slal om Giant Slal om Super-G, Combined Events, Team Events, Paralle Events, Ko Events approved by the $49^{\text {th }}$ International Ski congress 2014, Barcelona (Spa), July 2014; Art. 203.5.1 International Ski Competition Rules (ICR) book IV J oint regulations for Alpine Skiing Downhill, Slalom Giant Slalom Super-G, Combined Events, Team Events, Paralle Events, Ko Events approved by the $48^{\text {th }}$ International Ski congress 2012, Kangwonland (Kor) web edition J uly 2013; Art. 203.5.1 International Freestyle Skiing Competition Rules (ICR) book V Joint regulations for Freestyle Skiing, Aerials Moguls, Dual Moguls, Ski Cross, Ski Halfpipe, Ski Slopestyle approved by the $49^{\text {th }}$ International Ski congress 2014, Barcelona (Spa) ind. changes and precisions 2015 Oberhofen, Edition August 2015; Art. 203.5.1 International Freestyle Skiing Competition Rules (ICR) book V J oint regulations for Freestyle Skiing, Aerials Moguls, Dual Moguls, Ski Cross, Ski Halfpipe, Ski Slopestyle approved by the $49^{\text {th }}$ International Ski congress 2014, Barcelona (Spa) November 2014; Art. 203.5.1 International Freestyle Skiing Competition Rules (ICR) book V J oint regulations for Freestyle Skiing Aerials Moguls, Dual Moguls, Ski Cross, Ski Halfpipe, Ski Slopestyle approved by the $48^{\text {th }}$ International Ski congress 2012, Kangwonland (Kor) web edition November 2013; Art. 203.5.1 International FreestyleSkiing Competition Rules (ICR) book V J oint regulations for Freestyle Skiing Aerials Moguls, Dual Moguls, Ski Cross, Ski Halfpipe, Ski Slopestyle approved by the $48^{\text {th }}$ International Ski congress 2012, Kangwonland (Kor) web edition July 2013; Art 203.5.1 International Snowboard Competition Rules (ICR) book VI Joint regulations for Snowboarding, Slal om / Giant Slalom, Triple-S, Paralle Events, Snowboard Cross, Snowboard Halfpi pe, Snowboard Big Air, Snowboard Slopestyle approved by the 49th I nternational Ski congress 2014, Barcel ona (Spa)ind. changes and precisions 2015 web edition September 2015 Oberhofen, September 2015 and December 2015 Edition; Art. 203.5.1 International Snowboard Competition Rules (ICR) book VI Joint regulations for Snowboarding, Slal om / Giant Slal om, Triple-S, Parallel Events, Snowboard Cross, Snowboard Halfpipe, Snowboard Big Air, Snowboard Slopestyle approved by the 49th International Ski congress 2014, Barcelona (Spa) October 2014; Art. 203.5.1 International Snowboard Competition Rules (ICR) book VI J oint regulations for Snowboarding Slalom/ Giant Slalom, Triple-S, Paralle Events, Snowboard Cross, Snowboard Halfpipe, Snowboard Big Air, Snowboard Slopestyle approved by the $48^{\text {th }}$ International Ski congress 2012, Kangwonland (Kor) web edition November 2013; Art 203.5.1 International Snowboard Competition Rules (ICR) book VI J oint regulations for Snowboarding Slalom / Giant Slalom, Triple-S, Parallel Events, Snowboard Cross, Snowboard Halfpipe, Snowboard Big Air, Snowboard Slopestyle approved by the $48^{\text {th }}$ International Ski congress 2012, Kangwonland (Kor) web edition August 2013; Art.203.5.1 International Ski Competition Rules (ICR) book VII Nordic Combined approved by the $49^{\text {th }}$ International Ski congress 2014, Barcelona (Spa) incl. changes and precisions 2015 October 2015; Art.203.5.1 International Ski Competition Rules (ICR) book VII Nordic Combined approved by the $49^{\text {th }}$ International Ski congress 2014, Barcelona (Spa) incl. changes and precisions 2015 July 2015; Art.203.5.1 International Ski Competition Rules (ICR) book VII Nordic Combined approved by the $49^{\text {th }}$ International Ski congress 2014, Barcelona (Spa) November 2014; Art 203.5.1 International Ski Competition Rules (ICR) book VII Nordic Combined approved by the $49^{\text {th }}$ International Ski congress 2014, Barcelona (Spa) August 2014; Art. 203.5.1 International Ski 
season during which he or she represented a country. ${ }^{1537}$ The FIS Council has a very important role in these procedures as they can grant a change in license, even if the athlete does not meet the aforementioned criteria. ${ }^{1538}$ This is however only possi ble

1537

1538

Competition Rules (ICR) book VII Nordic Combined approved by the $48^{\text {th }}$ International Ski congress 2012, Kangwonland (Kor) web edition October 2013.

Ibid.

Art. 203.5.3 International Ski Competition Rules (ICR) book II Cross-Country approved by the $49^{\text {th }}$ International Ski congress 2014, Barcelona (Spa) ind. Changes and precisions 2015 Edition July 2015 and November 2015 Edition; Art. 203.5.3. International Ski Competition Rules (ICR) book II Cross-Country approved by the $49^{\text {th }}$ International Ski congress 2014, Barcelona (Spa) July 2014; Art. 203.5.3 International Ski Competition Rules (ICR) book II Cross-Country approved by the $48^{\text {th }}$ International Ski congress 2012, Kangwonland (Kor) ind. marked up changes and precisions 2013 web edition October 2013; Art. 203.5.3 International Ski Competition Rules (ICR) book III Ski J umping approved by the 49th International Ski congress 2014, Barcelona (Spa) ind. changes and precisions 2015 Edition July 2015; Art. 203.5.3 International Ski Competition Rules (ICR) book III Ski J umping approved by the 49th Internati onal Ski congress 2014, Barcel ona (Spa) July 2014; Art 203.5.3 International Ski Competition Rules (ICR) book III Ski Jumping approved by the $48^{\text {th }}$ International Ski congress 2012, Kangwonland (Kor) web edition October 2013; Art. 203.5.3 International Ski Competition Rules (ICR) book IV Joint regulations for Alpine Skiing, Downhill Slalom, Giant Slalom, Super-G, Combined Events, Team Events, Paralle Events, Ko Events approved by the $49^{\text {th }}$ International Ski congress 2014, Barcelona (Spa),Web Version July 2015; Oberhofen, July 2015; Art. 203.5.3 International Ski Competition Rules (ICR) book IV J oint regulations for Alpine Skiing, Downhill Slal om, Giant Slal om, Super-G, Combined Events, Team Events, Paralle Events, Ko Events approved by the $49^{\text {th }}$ International Ski congress 2014, Barcelona (Spa), J uly 2014; Art. 203.5.3 International Ski Competition Rules (ICR) book IV J oint regulations for Alpine Skiing Downhill, Slalom Giant Slalom Super-G, Combined Events, Team Events, Paralle Events, Ko Events approved by the $48^{\text {th }}$ International Ski congress 2012, Kangwonland (Kor) web edition July 2013; Art. 203.5.3 International Freestyle Skiing Competition Rules (ICR) book V Joint regulations for Freestyle Skiing, Aerials Moguls, Dual Moguls, Ski Cross, Ski Halfpipe, Ski Slopestyle approved by the $49^{\text {th }}$ International Ski congress 2014, Barcelona (Spa) ind. changes and precisions 2015 Oberhofen, Edition August 2015; Art. 203.5.3 International Freestyle Skiing Competition Rules (ICR) book V J oint regulations for Freestyle Skiing, Aerials Moguls, Dual Moguls, Ski Cross, Ski Halfpipe, Ski Slopestyle approved by the $49^{\text {th }}$ International Ski congress 2014, Barcelona (Spa) November 2014; Art. 203.5.3 International Freestyle Skiing Competition Rules (ICR) book V J oint regulations for Freestyle Skiing Aerials Moguls, Dual Moguls, Ski Cross, Ski Halfpipe, Ski Slopestyle approved by the $48^{\text {th }}$ International Ski congress 2012, Kangwonland (Kor) web edition November 2013; Art. 203.5.3 International FreestyleSkiing Competition Rules (ICR) book V J oint regulations for Freestyle Skiing Aerials Moguls, Dual Moguls, Ski Cross, Ski Halfpipe, Ski Slopestyle approved by the $48^{\text {th }}$ International Ski congress 2012, Kangwonland (Kor) web edition July 2013; Art 203.5.3 International Snowboard Competition Rules (ICR) book VI J oint regulations for Snowboarding, Slalom / Giant Slalom, Triple-S, Paralle Events, Snowboard Cross, Snowboard Halfpi pe, Snowboard Big Air, Snowboard Slopestyle approved by the 49th I nternational Ski congress 2014, Barcel ona (Spa)ind. changes and precisions 2015 web edition September 2015 Oberhofen, September 2015 and December 2015 Edition; Art. 203.5.3 International Snowboard Competition Rules (ICR) book VI J oint regulations for Snowboarding, Slal om/ Giant Slal om Triple-S, Parallel Events, Snowboard Cross, Snowboard Halfpipe, Snowboard Big Air, Snowboard Slopestyle approved by the 49th International Ski congress 2014, Barcelona (Spa) October 2014; Art. 203.5.3 International Snowboard Competition Rules (ICR) book VI J oint regulations for Snowboarding Slalom/ Giant Slalom, Triple-S, Paralle Events, Snowboard Cross, Snowboard Halfpipe, Snowboard Big Air, Snowboard Slopestyle approved by the $48^{\text {th }}$ International Ski congress 2012, Kangwonland (Kor) web edition November 2013; Art 203.5.3 International Snowboard Competition Rules (ICR) book VI J oint regulations for Snowboarding Slalom / Giant Slalom Triple-S, Parallel Events, Snowboard Cross, Snowboard Halfpipe, Snowboard Big Air, Snowboard Slopestyle approved by the $48^{\text {th }}$ International Ski congress 2012, Kangwonland (Kor) web edition August 2013; Art.203.5.3 International Ski Competition Rules (ICR) book VII Nordic Combined approved by the $49^{\text {th }}$ International Ski congress 2014, Barcelona (Spa) incl. changes and precisions 2015 October 2015; Art.203.5.3 International Ski Competition Rules (ICR) book VII Nordic Combined approved by the $49^{\text {th }}$ 
if the athlete can prove that there are exceptional circumstances. ${ }^{1539}$ It is furthermore conceivable that, even if the athlete does fulfil all the relevant criteria, the FIS Council may still refuse to all ow the change:
"where it deems it is contrary to the spirit of the rule and in the best interests of the International Ski Federation to do so (eg. to dedine to grant a change of licenceif a member National Ski Association tries to "import" a competitor)".

International Ski congress 2014, Barcelona (Spa) incl. changes and precisions 2015 July 2015; Art.203.5.3 International Ski Competition Rules (ICR) book VII Nordic Combined approved by the $49^{\text {th }}$ International Ski congress 2014, Barcelona (Spa) November 2014; Art 203.5.3 International Ski Competition Rules (ICR) book VII Nordic Combined approved by the $49^{\text {th }}$ International Ski congress 2014, Barcelona (Spa) August 2014; Art 203.5.3 International Ski Competition Rules (ICR) book VII Nordic Combined approved by the $48^{\text {th }}$ International Ski congress 2012, Kangwonland (Kor) web edition October 2013.

Ibid.

Art. 203.5.2 International Ski Competition Rules (ICR) book II Cross-Country approved by the $49^{\text {th }}$ International Ski congress 2014, Barcelona (Spa) ind. Changes and precisions 2015 Edition July 2015 and November 2015 Edition; Art. 203.5.2. International Ski Competition Rules (ICR) book II Cross-Country approved by the $49^{\text {th }}$ International Ski congress 2014, Barcelona (Spa) July 2014; Art. 203.5.2 International Ski Competition Rules (ICR) book II Cross-Country approved by the $48^{\text {th }}$ International Ski congress 2012, Kangwonland (Kor) ind. marked up changes and precisions 2013 web edition October 2013; Art. 203.5.2 International Ski Competition Rules (ICR) book III Ski Jumping approved by the 49th Intemational Ski congress 2014, Barcel ona (Spa) ind. changes and precisions 2015 Edition July 2015; Art. 203.5.2 International Ski Competition Rules (ICR) book III Ski J umping approved by the 49th I nternational Ski congress 2014, Barcelona (Spa) July 2014; Art. 203.5.2 International Ski Competition Rules (ICR) book III Ski Jumping approved by the $48^{\text {th }}$ International Ski congress 2012, Kangwonland (Kor) web edition October 2013; Art. 203.5.2 International Ski Competition Rules (ICR) book IV Joint regulations for Alpine Skiing, Downhill Slalom, Giant Slalom, Super-G, Combined Events, Team Events, Parallel Events, Ko Events approved by the $49^{\text {th }}$ International Ski congress 2014, Barcelona (Spa), Web Version July 2015; Oberhofen, July 2015; Art. 203.5.2 International Ski Competition Rules (ICR) book IV J oint regulations for Alpine Skiing, Downhill Slal om, Giant Slal om Super-G, Combined Events, Team Events, Paralle Events, Ko Events approved by the $49^{\text {th }}$ International Ski congress 2014, Barcelona (Spa), J uly 2014; Art. 203.5.2 International Ski Competition Rules (ICR) book IV J oint regulations for Alpine Skiing Downhill, Slalom Giant Slalom Super-G, Combined Events, Team Events, Paralle Events, Ko Events approved by the $48^{\text {th }}$ International Ski congress 2012, Kangwonland (Kor) web edition J uly 2013; Art. 203.5.2 International Freestyle Skiing Competition Rules (ICR) book V Joint regulations for Freestyle Skiing, Aerials Moguls, Dual Moguls, Ski Cross, Ski Halfpipe, Ski Slopestyle approved by the $49^{\text {th }}$ International Ski congress 2014, Barcelona (Spa) ind. changes and precisions 2015 Oberhofen, Edition August 2015; Art. 203.5.2 International Freestyle Skiing Competition Rules (ICR) book V J oint regulations for Freestyle Skiing, Aerials Moguls, Dual Moguls, Ski Cross, Ski Halfpipe, Ski Slopestyle approved by the $49^{\text {th }}$ International Ski congress 2014, Barcelona (Spa) November 2014; Art. 203.5.2 International Freestyle Skiing Competition Rules (ICR) book V J oint regulations for Freestyle Skiing Aerials Moguls, Dual Moguls, Ski Cross, Ski Halfpi pe, Ski Slopestyle approved by the $48^{\text {th }}$ International Ski congress 2012, Kangwonland (Kor) web edition November 2013; Art. 203.5.2 International FreestyleSkiing Competition Rules (ICR) book V J oint regulations for Freestyle Skiing Aerials Moguls, Dual Moguls, Ski Cross, Ski Halfpipe, Ski Slopestyle approved by the $48^{\text {th }}$ International Ski congress 2012, Kangwonland (Kor) web edition July 2013; Art 203.5.2 International Snowboard Competition Rules (ICR) book VI J oint regulations for Snowboarding, Slal om / Giant Slal om Triple-S, Paralle Events, Snowboard Cross, Snowboard Halfpipe, Snowboard Big Air, Snowboard Slopestyle approved by the 49th I nternational Ski congress 2014, Barcel ona (Spa)ind. changes and precisions 2015 web edition September 2015 Oberhofen, September 2015 and December 2015 Edition; Art. 203.5.2 International Snowboard Competition Rules (ICR) book VI J oint regulations for Snowboarding, Slal om/ Giant Slal om, Triple-S, Parallel Events, Snowboard Cross, Snowboard Halfpipe, Snowboard Big Air, Snowboard Slopestyle approved by the 49th International Ski congress 2014, Barcelona (Spa) October 2014; Art. 203.5.2 International Snowboard Competition 
There are thus safeguards in place both to prevent countries from simply acquiring tal ented athletes as well as still al lowing for more leniency in special cases.

Rules (ICR) book VI J oint regulations for Snowboarding Slalom/ Giant Slalom, TripleS, Paralle Events, Snowboard Cross, Snowboard Halfpipe, Snowboard Big Air, Snowboard Slopestyle approved by the $48^{\text {th }}$ International Ski congress 2012, Kangwonland (Kor) web edition November, 2013; Art 203.5.2 International Snowboard Competition Rules (ICR) book VI J oint regulations for Snowboarding Slalom / Giant Slalom, TripleS, Parallel Events, Snowboard Cross, Snowboard Halfpipe, Snowboard Big Air, Snowboard Slopestyle approved by the $48^{\text {th }}$ International Ski congress 2012, Kangwonland (Kor) web edition August 2013; Art.203.5.2 International Ski Competition Rules (ICR) book VII Nordic Combined approved by the $49^{\text {th }}$ International Ski congress 2014, Barcelona (Spa) incl. changes and precisions 2015 October, 2015; Art203.5.2 International Ski Competition Rules (ICR) book VII Nordic Combined approved by the $49^{\text {th }}$ International Ski congress 2014, Barcelona (Spa) incl. changes and precisions 2015 July, 2015; Art.203.5.2 International Ski Competition Rules (ICR) book VII Nordic Combined approved by the $49^{\text {th }}$ International Ski congress 2014, Barcelona (Spa) November, 2014; Art 203.5.2 International Ski Competition Rules (ICR) book VII Nordic Combined approved by the $49^{\text {th }}$ International Ski congress 2014, Barcelona (Spa) August, 2014; Art. 203.5.2 International Ski Competition Rules (ICR) book VII Nordic Combined approved by the $48^{\text {th }}$ International Ski congress 2012, Kangwonland (Kor) web edition October, 2013. 


\section{Comparison}

In the following, the statutes of all Olympic sports will be compared with one another with regard to the nationality requirements and the prerequisites under which the athletes may change their country of representation. For this, the terminol ogy used by the different federations must first be addressed (Chapter 15.1), before turning to the respectivestatutes, which will be compared with regard to ten important aspects:

1. Is changing the country of representation possible? (Chapter 15.2)

2. Which forms of acquisition of nationality are accepted and which additional requirements need to be fulfilled? (Chapter 15.3)

3. What is the position of athletes with dual or multiple nationality after having competed for one of the countries? (Chapter 15.4)

4. Which residence requirements exist and when arethey applicable? (Chapter 15.5)

5. Which waiting or non-competition periods are applicable and under which circumstances? (Chapter 15.6)

6. For which country may stateless athletes compete and under which circumstances? (Chapter 15.7)

7. How do territorial transfers affect the athletes' choices regarding country of representation? (Chapter 15.8)

8. Is compeing for the country of residence possible under certain circumstances? (Chapter 15.9)

9. What is the situation for minors regarding changes of the country of representation? (Chapter 15.10)

10. Is the number of changes of the country of representation limited in any way? (Chapter 15.11)

Looking at the changes that occurred within the set timeframefrom October 2013 until February 2016, there were 16 sports that did not have any substantial rule changes. ${ }^{1541}$ This means that half of the relevant sports did not alter their eligibility criteria. It is even more striking that there are eight sports that have not changed their eligibility rules since 2005 or earlier, namely: badminton, bobsleigh, fencing, gymastics, judo, shooting, tabletennis, and triathlon. Hence, almost a quarter of the Olympic sports has been applying the samenul es regarding national ity for the past decade

For the tertium comparationis as envisioned in Chapter 2.1, this meant that the plan of establishing a mean or standard set of criteria encountered several problems: firstly, not all sporting federations were willing or able to provide the previous rules for the purpose of this research. Secondly, not all topics which are of interest for the purpose of this dissertation were elaborated upon in equal detail among the federations. There are thus several aspects which were only dealt with in less than a

1541 Namely: archery, badminton, basketball, biathlon, bobsleigh, canoe kayak, fencing, gymnastics, handball, judo, shooting, skiing, tabletennis, triathl on, and weightlifting. 
third of the sporting federations. For those topics, one can thus not draw conclusions that are applicable to eligibility criteria in Olympic sports in their entirely. Thirdly, not all sports underwent a substantial change in their eligibility criteria within the examined time frame

Consequently, there is a certain bias in the results, as developments could only be monitored in an extremely limited number of cases. Whilesignificant conclusions may be drawn for individual sports or individual topics, the big differences between the approaches in the different sports makes determining overall trends difficult.

Table L: The mean/ standard eligibility criteria of October $2013^{1542}$

\begin{tabular}{|c|c|c|}
\hline Requirements & Standard rule 2013 & Comment \\
\hline C hange of nationality & Possible & $\begin{array}{l}2 \text { out of } 35 \text { federations did not allow } \\
\text { this. }{ }^{1543}\end{array}$ \\
\hline $\begin{array}{l}\text { Waiting period necessary for } \\
\text { change of nationality }\end{array}$ & 2 to 3 years & $\begin{array}{l}4 \text { years provided by } 1 \text { out of } 35^{1544} \\
3 \text { years provided by } 12 \text { out of } 35^{1545} \\
2 \text { years provided by } 6 \text { out of } 35^{1546} \\
1 \text { year provided by } 7 \text { out of } 35^{1547} \\
\text { No rule set by } 10 \text { out of } 35^{1548}\end{array}$ \\
\hline R esidence requirements & 2 year & $\begin{array}{l}5 \text { years provided by } 2 \text { out of } 35^{1549} \\
4 \text { years provided by } 0 \text { out of } 35 . \\
3 \text { years provided by } 5 \text { out of } 35^{1550} \\
2 \text { years provided by } 6 \text { out of } 35^{1551} \\
1 \text { year provided by } 4 \text { out of } 35^{1552} \\
\text { No ruleset by } 17 \text { out of } 35 .^{1553}\end{array}$ \\
\hline M inors and nationality change & Not specified & $\begin{array}{l}\text { Only } 7 \text { out of } 35 \text { federations addressed } \\
\text { this issue }\end{array}$ \\
\hline Stateless athletes & Not specified & $\begin{array}{l}\text { Only } 7 \text { out of } 35 \text { federations addressed } \\
\text { this issue }\end{array}$ \\
\hline $\begin{array}{l}\text { Position of athletes with } \\
\text { multiple nationality after } \\
\text { having competed for another }\end{array}$ & $\begin{array}{l}\text { 3-year waiting period } \\
\text { applicablethat can however } \\
\text { bewaivered }\end{array}$ & $\begin{array}{l}\text { Only } 8 \text { out of } 35 \text { federations did not } \\
\text { have any rules. }{ }^{1556}\end{array}$ \\
\hline
\end{tabular}

1542 Notably in October 2013 golf had not adopted any nationality based eligibility criteria. Moreover, some federations have different requirements depending on the circumstances, and therefore they feature twice in the table. Rugby and football.

Weight ifting (under special circumstances).

Athl etics, badminton, fencing, handball, hockey, judo, modern pentathlon, sailing, shooting, taekwondo, tennis, triathlon.

Biathlon, curling, equestrian, rowing, skating (under special circumstances), volleyball.

Aquatics, archery, gymnastics, skating, skiing, (under special circumstances), weightlifting (under special circumstances), wrestling.

Basketball, bobsleigh, boxing, canoe kayak, football, golf, luge, rugby, table tennis.

Cycling (for competing for country of residence), football (under special circumstances).

Athl etics, fencing, rugby, sailing (for competing for country of residence), triathlon.

Canoe Kayak (for competing for country of residence), curling (for competing for country of residence), football (under special circumstances), handball, skiing, volleyball.

Aquatics, archery, ice hockey, skating.

Badminton, basketball, biathl on, bobsleigh, boxing, golf, gymnastics, judo, luge, modern pentathl on, rowing, shooting, tabletennis, takwondo, tennis, weightlifting, wrestling. Basketball, cyding, equestrian, football, hockey, rugby and taekwondo.

Archery, basketball, biathlon, cyding, equestrian, fencing and football.

Badminton, bobslejgh, canoekayak, curling, golf, luge, skating and volleyball. 


\begin{tabular}{|l|l|l|}
\hline $\begin{array}{l}\text { country of which the athlete is } \\
\text { a national }\end{array}$ & \\
\hline $\begin{array}{l}\text { E ffect of changes in territory } \\
\text { of country }\end{array}$ & Not specified & $\begin{array}{l}\text { Only 8 out of 35 federations stipulated } \\
\text { that athletes may choose once which } \\
\text { entity to represent, no waiting period } \\
\text { was needed. }\end{array}$ \\
\hline $\begin{array}{l}\text { Competing for the country of } \\
\text { residence }\end{array}$ & Not specified & $\begin{array}{l}\text { Only } 9 \text { out of 35 federations dealt with } \\
\text { thetopic. }\end{array}$ \\
\hline Number of changes possible & No maximum given & $\begin{array}{l}\text { 6 out of 35 federations gavea } \\
\text { maximum of one changeina } \\
\text { career. }\end{array}$ \\
\hline
\end{tabular}

Making use of those few federations that address the issues, the standard shown above can be determined: changes of the country of representation were generally allowed after a two-year non-compeition period. No maximum number of changes was provided for and athletes with multiple nationality faced a 2- to 3-year noncompetition period, if they had already competed internationally and then wished to change

However, as can be seen from the comment colum, this standard is not very elaborate, as many issues are left unspecified by the majority of the 35 sports.

\subsection{Terminology}

Before delving into a comparison of the different sports it must be underlined that the terms and definitions used by the federations vary greatly and that thus a comparison is made difficult This also gives rise to the main question of what is meant with 'national', 'citizen' and 'residence' in the individual federations' rules and regulations. As can be seen from the tables below, several sports use the terms interchangeably or do not provideany definition.

\subsubsection{Nationality/Citizenship}

The 35 Olympic sports have their eligibility criteria set out in 42 different rule books or codes and, of these, only three that refer neither to 'citizenship' nor to 'nationality'. It will be seen that nationality and citizenship are used interchangeably 14 times, which represents slightly more than one third of the cases. In more than half of the cases, namely 18 times, the federation chose to refer to only 'nationality' or 'citizenship'. ' Nationality' is used ten times exclusively, whilecitizenship is used eight times. Most striking are those cases in which citizenship is used as a condition for nationality, as in the cases of golf and taekwondo. These two federations seem to consider citizenship as merely a condition that needs to be fulfilled to acquire nationality, yet do not provide a differentiating definition of these terms. As seen

1557 Equestrian, hockey, modern pentathlon, sailing, shooting, table tennis, tennis and triathl on.

1558 Archery, curling, cycling, equestrian, gymmastics, rowing, sailing, skiing and triathlon.

1559 Basketball, fencing, handball, volleyball and wrestling. 
previously, it is usually the case that all citizens areal so nationals, but not all nationals arecitizens. $^{1560}$

Colour-coding was used as follows:

\begin{tabular}{|l|l|l|}
\hline Sport & & Citizenship or nationality is used exclusively \\
\hline Sport & & Citizenship and nationality used interchangeably \\
\hline Sport & & Reference is madeto neither citizenship nor nationality \\
\hline Sport & & One is considered a requirement for the other \\
\hline
\end{tabular}

TableLI: Usage of 'citizenship' and 'nationality' in Olympic Sports

\begin{tabular}{|c|c|c|c|}
\hline $\begin{array}{l}\text { Sport \& } \\
\text { Discipline }\end{array}$ & $\begin{array}{l}\text { Usage of } \\
\text { "citizenship/citizen" or } \\
\text { "nationality/national" }\end{array}$ & $\begin{array}{l}\text { Definitions provided and other } \\
\text { remarks }\end{array}$ & Conclusion \\
\hline Aquatics & $\begin{array}{l}\text { Mixed: } \\
\text { - Athleteneeds to bea } \\
\text { "citizen" } \\
\text { - Uses "nationality" in } \\
\text { memorandum } \\
\text { - } \quad \text { Refers to "double } \\
\text { citizenship" }\end{array}$ & & $\begin{array}{l}\text { Citizenship and } \\
\text { nationality used } \\
\text { interchangeably }\end{array}$ \\
\hline Archery & Nationality & Holding the passport of the country & $\begin{array}{l}\text { Nationality used } \\
\text { exclusively }\end{array}$ \\
\hline Athletics & "citizen" and "citizenship" & $\begin{array}{l}\text { Citizen } \\
\text { A person who has legal Citizenship } \\
\text { of a Country or, in the case of a } \\
\text { Teritory, legal Citizenship of the } \\
\text { Territory's parent Country and } \\
\text { appropriatelegal status in the } \\
\text { Teritory under applicable laws. } \\
\text { Citizenship } \\
\text { Legal citizenship of a Country or, } \\
\text { in the case of a Territory, legal } \\
\text { citizenship of theTerritory's parent } \\
\text { Country and appropriatelegal } \\
\text { status in the Teritory under } \\
\text { applicablelaws. }\end{array}$ & $\begin{array}{l}\text { Citizenship used } \\
\text { exclusively }\end{array}$ \\
\hline Badminton & Neither & $\begin{array}{l}\text { "hol ding a valid passport" is the } \\
\text { criterion }\end{array}$ & $\begin{array}{l}\text { No reference made } \\
\text { to either }\end{array}$ \\
\hline Basketball & Nationality & & $\begin{array}{l}\text { Nationality used } \\
\text { exclusively }\end{array}$ \\
\hline Biathlon & $\begin{array}{l}\text { Mixed: } \\
\text { - Uses "nationality" in } \\
\text { theheading } \\
\text { - } \quad \text { Athletes need to be } \\
\text { "citizens" of the } \\
\text { country } \\
\text { - } \quad \text { Refers to "changing } \\
\text { citizenship" }\end{array}$ & & $\begin{array}{l}\text { Citizenship and } \\
\text { nationality used } \\
\text { interchangeably }\end{array}$ \\
\hline
\end{tabular}

1560 See Chapter 3.1. 


\section{COMPARISON}

\begin{tabular}{|c|c|c|c|}
\hline Bobsleigh & Citizenship & & $\begin{array}{l}\text { Citizenship used } \\
\text { exclusively }\end{array}$ \\
\hline $\begin{array}{l}\text { Bobsleigh } \\
\text { Skeleton }\end{array}$ & Citizenship & & $\begin{array}{l}\text { Citizenship used } \\
\text { exclusively }\end{array}$ \\
\hline Boxing & $\begin{array}{l}\text { Mixed: } \\
\text { - Uses "nationality } \\
\text { identity document" } \\
\text { - Uses "citizenship } \\
\text { identity papers" }\end{array}$ & $\begin{array}{l}\text { Passport needed as proof of } \\
\text { identity only }\end{array}$ & $\begin{array}{l}\text { Predominant use of } \\
\text { "nationality", but } \\
\text { also referenceto } \\
\text { citizenship }\end{array}$ \\
\hline C anoe K ayak & Nationality & $\begin{array}{l}\text { Only in referenceto Olympic } \\
\text { Charter }\end{array}$ & $\begin{array}{l}\text { Nationality used } \\
\text { exclusively }\end{array}$ \\
\hline Curling & National & & $\begin{array}{l}\text { Nationality used } \\
\text { exclusively }\end{array}$ \\
\hline Cycling & Nationality & & $\begin{array}{l}\text { Nationality used } \\
\text { exclusively }\end{array}$ \\
\hline Equestrian & $\begin{array}{l}\text { Mixed: } \\
\text { - } \quad \text { Use of nationality for } \\
\text { adult athletes } \\
\text { - } \quad \text { Use of citizenship for } \\
\text { minor athletes }\end{array}$ & & $\begin{array}{l}\text { Citizenship and } \\
\text { nationality used } \\
\text { interchangeably }\end{array}$ \\
\hline Fencing & Nationality & & $\begin{array}{l}\text { Nationality used } \\
\text { exclusively }\end{array}$ \\
\hline Football & Nationality & & $\begin{array}{l}\text { Nationality used } \\
\text { exclusively }\end{array}$ \\
\hline Golf & $\begin{array}{l}\text { Mixed: } \\
\text { - } \quad \text { Being a national is } \\
\text { conditional upon } \\
\text { being a citizen of the } \\
\text { country }\end{array}$ & $\begin{array}{l}\text { A compeitor will be considered a } \\
\text { National of a country if the } \\
\text { competitor is a citizen of the } \\
\text { country, as defined by the laws of } \\
\text { such country. }\end{array}$ & $\begin{array}{l}\text { Citizenship isa } \\
\text { requirement for } \\
\text { nationality }\end{array}$ \\
\hline Gymnastics & $\begin{array}{l}\text { Mixed: } \\
\text { - } \quad \text { Nationality and } \\
\text { citizenship al ways } \\
\text { mentioned together }\end{array}$ & $\begin{array}{l}\text { Citizenship enumerated al ongside } \\
\text { national ity }\end{array}$ & $\begin{array}{l}\text { Citizenship and } \\
\text { nationality used } \\
\text { interchangeably }\end{array}$ \\
\hline H andball & $\begin{array}{l}\text { Mixed: } \\
\text { - } \quad \text { Athletes need to be } \\
\text { citizens to be all lowed } \\
\text { in national team } \\
\text { - } \quad \text { Referenceto dual } \\
\text { nationality and } \\
\text { hol ding multiple } \\
\text { nationality made }\end{array}$ & & $\begin{array}{l}\text { Citizenship and } \\
\text { nationality used } \\
\text { interchangeably }\end{array}$ \\
\hline Hockey & Nationality & $\begin{array}{l}\text { Nationality is determined by the } \\
\text { hol ding of a valid passport of the } \\
\text { country the player is selected to } \\
\text { represent. }\end{array}$ & $\begin{array}{l}\text { Nationality used } \\
\text { exclusively }\end{array}$ \\
\hline Ice Hockey & Citizenship & & $\begin{array}{l}\text { Citizenship used } \\
\text { exclusively }\end{array}$ \\
\hline Judo & $\begin{array}{l}\text { Mixed: } \\
\text { - } \quad \text { Nationality is set as } \\
\text { requirement } \\
\text { - } \quad \text { Federations need to }\end{array}$ & & $\begin{array}{l}\text { Citizenship and } \\
\text { nationality used } \\
\text { interchangeably }\end{array}$ \\
\hline
\end{tabular}


NATIONALITY REQUiREMENTS In OLy MPIC SPORTS

\begin{tabular}{|c|c|c|c|}
\hline & $\begin{array}{l}\text { check theathlete's } \\
\text { citizenship }\end{array}$ & & \\
\hline $\begin{array}{l}\text { Luge- } \\
\text { Artificial } \\
\text { Track }\end{array}$ & Neither & A licenseisissued & $\begin{array}{l}\text { No reference made } \\
\text { to either }\end{array}$ \\
\hline $\begin{array}{l}\text { Luge- } \\
\text { Natural } \\
\text { Track }\end{array}$ & Neither & A licenseis issued & $\begin{array}{l}\text { No reference made } \\
\text { to either }\end{array}$ \\
\hline $\begin{array}{l}\text { Modern } \\
\text { Pentathlon }\end{array}$ & Nationality and citizenship & & $\begin{array}{l}\text { Citizenship and } \\
\text { nationality used } \\
\text { interchangeably }\end{array}$ \\
\hline Rowing & Nationality & & $\begin{array}{l}\text { Nationality used } \\
\text { exclusively }\end{array}$ \\
\hline Rugby & $\begin{array}{l}\text { Mixed: } \\
\text { - } \quad \text { Referenceto national } \\
\text { in therules } \\
\text { - } \quad \text { Referenceto } \\
\text { citizenship in the } \\
\text { explanatory guide }\end{array}$ & & $\begin{array}{l}\text { Citizenship and } \\
\text { nationality used } \\
\text { interchangeably }\end{array}$ \\
\hline Sailing & $\begin{array}{l}\text { Mixed } \\
\text { - } \quad \text { Headings and most } \\
\text { rules refer to } \\
\text { nationality } \\
\text { - Citizenship } \\
\text { enumerated al ongside } \\
\text { nationality in some } \\
\text { cases }\end{array}$ & $\begin{array}{l}\text { Citizenship enumerated al ongside } \\
\text { national ity }\end{array}$ & $\begin{array}{l}\text { Citizenship and } \\
\text { nationality used } \\
\text { interchangeably }\end{array}$ \\
\hline Shooting & $\begin{array}{l}\text { Mixed } \\
\text { - } \quad \text { most rules refer to } \\
\text { nationality } \\
\text { - } \quad \text { Citizenship } \\
\text { enumerated al ongside } \\
\text { nationality in some } \\
\text { cases }\end{array}$ & $\begin{array}{l}\text { Citizenship enumerated al ongside } \\
\text { national ity }\end{array}$ & $\begin{array}{l}\text { Citizenship and } \\
\text { nationality used } \\
\text { interchangeably }\end{array}$ \\
\hline Skating & Citizenship & $\begin{array}{l}\text { A license is issued based on the } \\
\text { athl ete's citizenship }\end{array}$ & $\begin{array}{l}\text { Citizenship used } \\
\text { exclusively }\end{array}$ \\
\hline Skiing & Citizenship & $\begin{array}{l}\text { A license is issued based on the } \\
\text { athlete's citizenship }\end{array}$ & $\begin{array}{l}\text { Citizenship used } \\
\text { exclusively }\end{array}$ \\
\hline Table Tennis & $\begin{array}{l}\text { Mixed: } \\
\text { - } \quad \text { Rules based on } \\
\text { nationality } \\
\text { - } \quad \text { Citizenship } \\
\text { enumerated al ongside } \\
\text { nationality in some } \\
\text { cases }\end{array}$ & $\begin{array}{l}\text { Citizenship enumerated al ongside } \\
\text { national ity }\end{array}$ & $\begin{array}{l}\text { Citizenship and } \\
\text { nationality used } \\
\text { interchangeably }\end{array}$ \\
\hline Taekwondo & $\begin{array}{l}\text { Mixed: } \\
\text { Being a national is } \\
\text { conditional upon being a } \\
\text { citizen of the country }\end{array}$ & $\begin{array}{l}\text { When a contestant is a } \\
\text { representative of a national team, } \\
\text { his/her nationality is decided by } \\
\text { citizenship of the country he/sheis } \\
\text { representing before submission of } \\
\text { the application to partici pate. } \\
\text { Verification of citizenship is done }\end{array}$ & $\begin{array}{l}\text { Citizenship isa } \\
\text { requirement for } \\
\text { nationality }\end{array}$ \\
\hline
\end{tabular}




\begin{tabular}{|c|c|c|c|}
\hline & & by inspection of the passport & \\
\hline Tennis & $\begin{array}{l}\text { Mixed: } \\
\text { - } \quad \text { Rules based on } \\
\text { nationality } \\
\text { - } \quad \text { Citizenship } \\
\text { enumerated al ongside } \\
\text { nationality in some } \\
\text { cases }\end{array}$ & $\begin{array}{l}\text { Citizenship enumerated al ongside } \\
\text { nationality }\end{array}$ & $\begin{array}{l}\text { Citizenship and } \\
\text { national ity used } \\
\text { interchangeably }\end{array}$ \\
\hline Triathlon & Citizenship & & $\begin{array}{l}\text { Citizenship used } \\
\text { exclusively }\end{array}$ \\
\hline Volleyball & Citizenship & & $\begin{array}{l}\text { Citizenship used } \\
\text { exclusively }\end{array}$ \\
\hline Weightlifting & $\begin{array}{l}\text { Mixed: } \\
\text { - Uses "national ity" in } \\
\text { the heading } \\
\text { - Athletes need to be } \\
\text { "citizens" of the } \\
\text { country }\end{array}$ & $\begin{array}{l}\text { - Introduced "sports national ity" } \\
\text { in } 2015\end{array}$ & $\begin{array}{l}\text { Citizenship and } \\
\text { nationality used } \\
\text { interchangeably }\end{array}$ \\
\hline Wrestling & Nationality & & $\begin{array}{l}\text { Nationality used } \\
\text { exclusively }\end{array}$ \\
\hline
\end{tabular}

\subsubsection{Domicile/Residence}

In addition to nationality and citizenship, federations also deal differently with residence and domicile 11 sports refer to neither domicilenor residence, which is less than a third of the Olympic sports. This al so means that in those sports no residence requirements are in place and that a genuine link between a person and a state thus cannot rely thereon. Interestingly, no federation solely refers to domicile, but 17 federations, which represent approximately half of the Olympic sports, do refer to 'residence' in one way or another. While this seems to be a significant number at first glance, the reality is more complex, as hardly any federation provides a definition of what is meant with residence in their eligibility codes. Therearefive definitions given and these vary largely in their detail, ranging from 'living in a territory' to 'being registered with the relevant authorities'. Therefore, even if the same word is used, the connotations and the way residencemay be checked depends on the federation.

In conclusion, the variations of the terms and the different definitions do not only make comparing the different sports difficult, but they al so greatly hinder any analysis. Moreover, if definitions are set by a federation, different officials and committees may interpret the terms differently even within the same national federation. Hence, the same federation could have more than one approach to the same term and thus to eligibility ariteria. 
NATIONALITY REQUiREMENTS In OLy MPIC SPORTS

Colour-coding was used as follows:

\begin{tabular}{|l|l|l|}
\hline Sport & & Residence or domicileis used exclusively \\
\hline Sport & & residence and domicile are both mentioned \\
\hline Sport & & Reference is madeto neither residence nor domicile \\
\hline
\end{tabular}

Table LII: Usage of 'residence' and 'domicile' in Olympic Sports

\begin{tabular}{|c|c|c|}
\hline Sport \& Discipline & $\begin{array}{l}\text { Usage of 'residence/ } \\
\text { domicile' }\end{array}$ & Definitions provided and other remarks \\
\hline Aquatics & Residence & $\begin{array}{l}\text { Residence means the place/country where the } \\
\text { competitor or competition official "lives and sleps" } \\
\text { and where he/she can be found in the majority of } \\
\text { days of the year. }\end{array}$ \\
\hline Archery & Neither & N.A. \\
\hline Athletics & Residence & $\begin{array}{l}\text { Residence is the place or location in which the } \\
\text { athl ete is registered with relevant authorities as } \\
\text { having his primary and permanent home. }\end{array}$ \\
\hline Badminton & Neither & N.A. \\
\hline Basketball & Neither & N.A. \\
\hline Biathlon & Neither & N.A. \\
\hline Bobsleigh & official residence & N.A. \\
\hline Boxing & Residence & N.A. \\
\hline Canoe Kayak - & Domicile & Refers to "living" in a place \\
\hline Curling & Residence & N.A. \\
\hline Cycling & Residence & N.A. \\
\hline Equestrian & Legal residence & N.A. \\
\hline Fencing & neither & N.A. \\
\hline Football & Residence & Refers also to having "lived in theterritory" \\
\hline Golf & Domicileand residence & N.A. \\
\hline Gymnastics & neither & N.A. \\
\hline H andball & 'Residence permit' & Refers to living in a territory \\
\hline Hockey & Domicileand Residence & Since 2012 no explanation of residence given \\
\hline Ice Hockey & Neither & N.A. \\
\hline J udo & Residence & N.A. \\
\hline Luge & Neither & N.A. \\
\hline $\begin{array}{l}\text { M odern } \\
\text { Pentathlon }\end{array}$ & Residence and domicile & N.A. \\
\hline Rowing & Neither & N.A. \\
\hline Rugby & Residence & N.A. \\
\hline Sailing & Domicileand residence & N.A. \\
\hline Shooting & Domicile and residence & N.A. \\
\hline Skating & Residence & N.A. \\
\hline
\end{tabular}




\begin{tabular}{|l|l|l|}
\hline Skiing & $\begin{array}{l}\text { Principal legal and effective } \\
\text { placeof residence }\end{array}$ & N.A. \\
\hline Table Tennis & Main residence & N.A. \\
\hline Taekwondo & Domicileand residence & N.A. \\
\hline Tennis & Neither & N.A. \\
\hline Triathlon & Residence & N.A. \\
\hline Volleyball & Continuous residence & N.A. \\
\hline Weightlifting & Neither & N.A. \\
\hline Wrestling & Official residence & N.A. \\
\hline
\end{tabular}

\subsection{Is changing the country of representation possible?}

Starting with the question whether changes in an athlete's nationality will be reflected in the athlete's country of representation and how this has developed over the past decade, it can be seen that the general trend here is towards allowing changes, even after an athlete competed internationally. In 2012, athletics introduced such a rule for athletes who wish to change their country of representation in 2012 and since 2013 ther approach is even more detail ed. ${ }^{1561}$ Similarly, boxing has added the possi bility to change the country of representation in $2015,{ }^{1562}$ as did golf in $2014 .{ }^{1563}$ This liberal trend was continued when ice hockey abol ished the maximum number of changes of the country of representation in 2014. ${ }^{1564}$ On the other side of the spectrum wresting introduced a sporting nationality in 2015, ${ }^{1565}$ although this remains changeable unlike therugby one Interestingly, prior to 2008, al FIFA decisions were taken on a case-bycase basis. ${ }^{1566}$ This is the first discernible trend is towards a codification of rules. The second development is towards allowing changes of the country of representation, although different additional criteria wereintroduced by the various federations.

Looking at the current rules, it must first be underlined that one sport does not include any rules on that topic, namely luge. There are furthermore two sports that do not al low for any change at all. The first one is football, where a player has to decide for which country he or she wishes to compete prior to the first ' $A$ ' match, ${ }^{1567}$ and the second one is rugby, in which the players' rugby nationality remains the same, regardless of their actual nationality. ${ }^{1568}$ These three sports thus diverge greatly from the standard set of rules. For all other sports, the underlying principle is that athletes should have a connection with the country they represent and that this

1561 Rule 5(2) International Association of Athletics Federations competition rules 2012-2013 in force as from $1^{\text {st }}$ November 2011.

1562 Art. 2.2.1, Art. 2.2.1.4 and Art. 2.2.2 AIBA technical rules effectiveas of February $1^{\text {st }}, 2015$.

1563 Art. III. IGF national ity policy J une 2014.

1564 Art. 406(1.3) IIHF statutes and bylaws 2014 - 2018 of May 2014.

1565 Introduction UWW international rules for the change of nationality approved by the Bureau on $15^{\text {th }}$ J anuary 2015.

1566 Art. 15(1) FIFA statutes: regulations governing the application of the statutes 2005.

1567 Art. 5(2) FIFA statutes: regulations governing the application of the statutes 2016.

1568 Regulation 8.2 International Rugby Board handbook as framed by the International Rugby Board last updated: $8^{\text {th }}$ March 2016. 
connection is defined by nationality or citizenship. ${ }^{1569}$ There are thus 31 out of 35 sports that allow for some flexibility and changes of national ity. They do, however, greatly differ regarding the conditions that need to be fulfilled and the circumstances that will be taken into consideration. In conclusion, it is clear that changing national ity is considered a possi bi lity among Olympic sports, if not a desirable one

\subsection{Which forms of acquisition of nationality are accepted and which additional requirements need to be fulfilled?}

Over the last years, the way a nationality was acquired lost its importance for sporting federations, as the recent abolition of such requirements by wrestling in 2015 shows. ${ }^{1570}$ Similarly, since 2011, equestrian has replaced the terms 'biological parents' ${ }^{\prime 271}$ with 'acquired by virtue of descent or through other means related to family heritage', ${ }^{1572}$ thus broadening the applicability of this provision and putting an end to the potential exclusion of adopted children. Hence, the number of federations explicitly mentioning matters of the acquisition of nationality has been decreasing recently.

Moreover, when examining the rules currently in place, it can be seen that 10 out of 35 sports, namely aquatics, athletics, basketball, equestrian, fencing, football, handball, rugby, skiing, and volleyball in principle follow two approaches. While some sports refer to the acquisition of nationality by birth or naturalisation, ${ }^{1573}$ the majority refers to aspects of ius soli and ius sanguinis, ${ }^{1574}$ notably without using these terms. They refer to an athlete being born in the territory of a certain country or by virtue of having parents from the country.

Some federations do however combine these aspects, as athletics also refers to naturalisation and equestrian even explicitly mentions the loss and revocation of national ity. ${ }^{1575}$ Fencing in turn only deals with acquisition through marriage or after

\footnotetext{
1569 Depending on the wording chosen by the federation.

1570 General conditions (d) FILA international regulations for the change of nationality - effective $3^{\text {rd }}$ August 2012.

1571 Art. 119.2.2.3 FEI general regulations $23^{\text {rd }}$ edition, $1^{\text {tt }}$ January 2009 , updates effective $1^{\text {st }}$ January 2010.

1572 Art. 119.2.2.3 FEI general regulations $23^{\text {rd }}$ edition, $1^{\text {st }}$ January 2009 , updates effective $1^{\text {st }}$ January 2012 and Art 119.2.2.3 FEI general regulations $23^{\text {rd }}$ edition, $1^{\text {t }}$ J anuary 2009 , updates effective $1^{\text {st }}$ January 2011.

1573 Aquatics: GR 2.5. FINA general rules 2013-2017 of November, 2015; Basketball: Art. 16 book 3 chapter I FIBA rule book 2014 - 2019.

1574 Athletics: Rule 5(2) (a) International Association of Athletics Federations competition rules 20162017 in force as from $1^{\text {st }}$ November 2015; Equestrian: Art. 119 (2.2.3) FEl general regulations, $23^{\text {rd }}$ edition, $1^{\text {st } J a n u a r y ~ 2009, ~ u p d a t e s ~ e f f e c t i v e ~} 1^{\text {st }}$ January 2016; Football: Art. 6(1) FIFA statutes: regulations governing the application of the statutes 2016; Art. 7(1) FIFA statutes: regulations governing the application of the statutes 2016; Handball: Art. 6.2 Player eligibility code of the International Handball Federation (IHF) of $8^{\text {th }}$ July 2014; Rugby: Regulation. 8.1 International Rugby Board handbook as framed by the International Rugby Board last updated: $8^{\text {th }}$ March 2016; and skiing: eg. Art. 203.5. International Ski Competition Rules (ICR) book II Cross-Country approved by the $49^{\text {th }}$ International Ski congress, Barcelona (Spa) November, 2015.

1575 Athletics: Rule 5(2) (a) International Association of Athl etics Federations competition rules 20162017 in force as from $1^{\text {st }}$ November, 2015; Equestrian: Art. 119 (2.2.3) FEl general regulations, $23^{\text {rd }}$ edition, $1^{\text {st }}$ J anuary 2009, updates effective $1^{\text {t }}$ J anuary 2016.
} 
statelessness. $^{1576}$

Contrarily, volleyball differentiates between naturalised and native athletes. Here, the definitions do however starkly differ from the standard ones, as a native athlete does not have the usual connotation of having acquired the relevant citizenship at birth only, but also encompasses those who acquired the citizenship later. ${ }^{1577}$ The main point of differentiation between native and naturalised players for the FIVB is the time of acquisition relative to the athlete's debut for a national side If the citizenship was acquired before this debut, the athlete will be considered as a native player. ${ }^{1578}$ One can thus conclude that the way an athlete acquires a national ity is not a priority issue for most Olympic sports.

\subsection{What is the position of athletes with dual or multiple nationality after having competed for one of the countries?}

Seeing how the federations' stance on multiple nationality has developed since 2005, one first has to underscore that it has become significantly more important in the years since equestrian first made a reference to it in 2007. ${ }^{1579}$ The general trend is in favour of treating athletes with dual nationality akin to athletes who acquired a new nationality, meaning that they also face waiting periods: four years for golf since $2014,{ }^{1580}$ three years for modern pentathlon since $2015 ;{ }^{1581}$ two years for rowing since $2013,{ }^{1582}$ two years for boxing since $2015 .{ }^{1583}$ Treating them akin to those who acquired a new nationality is the recent trend in Olympic sports. As these rules can be rather strict, athletes who al ready have a genuine link with a country are placed at a disadvantage

However, the residence requirement that ice hockey introduced in 2008 for athletes with multiple nationality has become subsequently easier to meet throughout the past four years, shifting the focus from the $12^{\text {th }}$ birthday in 2012 , to the $10^{\text {th }}$ birthday in 2014 (see Chapter 15.5). ${ }^{1584}$ Athletics in tum has undertaken a more detailed approach since $2012{ }^{1585}$ Hence, while requirements have become more specific and detailed, they have al so become easier to meet.

Currently, only seven federations do not discuss the issue of athletes with multiple nationality, namely badminton, bobsleigh, canoe kayak, curling, luge, skating, and volleyball. While the vast majority of the 35 Olympic sports thus deals with the issue of multiplenationality, some federations have particular requirements for athletes who

1576

Art. 9.2.2. a FIE statues of December 2015 (wording unchanged since 2005). Art.41.1 Sports regulations Volleyball version: 15 $5^{\text {th }}$ May 2015.

Art. 41.1 Sports regulations Volleyball version: $15^{\text {th }}$ May 2015.

Art. 123 (4) FEl general regulations, $22^{\text {nd }}$ edition, $1^{\text {st }}$ June 2007 and $22^{\text {nd }}$ edition with 2008 amendments.

Art. III. IGF national ity policy J une 2014.

Art. 3.3 UIPM Rules on Internal Organi sation Tapeo November 2015.

Rule 19FISA rule book February 2013.

Art. 2.2.1.4.2 AIBA technical rules effective as of February $1^{\text {st }}, 2015$.

Art. 406(1.6) and Art. 406(1.7) IIHF statutes and bylaws 2014 - 2018 of May 2014.

Rule 5(4) International Association of Athl etics Federations competition rules 2012-2013 in force as from 1st November 2011. 
have multiplenationality and wish to changetheir country of representation: handball, ice hockey and football. ${ }^{1586}$ The other sports ${ }^{1587}$ all refer to athletes with multiple nationality and allow them to initially choose freely for which country they wish to compete ${ }^{1588}$ Contrarily, rugby refers to multiple nationality, but it does not have additional requirements. ${ }^{1589}$ Generally, once an athlete with multiple national ity has competed for one country and then wishes to compete for another country, of which he or sheis a national, the same procedure applies, as the nationality was newly acquired. Consequently, residencerequi rements or waiting periods will be in place

\subsection{Which residence requirements exist and when are they applicable?}

Paying closer attention to the actual residence requirements, one finds that these can be either in place for athletes who have multiple nationality and wish to select one country; for athletes who changed their national ity; or for those wishing to competefor the country of residence without having the nationality of this country - when possible

Examining how these have devel oped over the past decade, it is clear that only five federations changed their residence requirements. Ice hockey first introduced a

1586 Art. 6.2 Player eligibility code of the International Handball Federation (IHF) of $8^{\text {th }}$ J uly 2014; Art. 406(1.7) IIHF statutes and bylaws 2014 - 2018 of May 2014; Art. 6(1) FIFA statutes: regulations governing the application of the statutes 2015; Art. 6(2) FIFA statutes: regulations governing the application of the statutes 2015.

Namely: aquatics, archery, athletics, basketball, biathlon, boxing, cycling, equestrian, fencing, golf, gymnastics, hockey, judo, modern pentathlon, rowing, sailing, shooting, skiing, table tennis, taekwondo, tennis, triathlon, weightlifting, and wresting.

GR 2.5 FINA general rules 2013 - 2017 of November, 2015; Art. 2.4.4 World Archery constitution and rules 2015 effective since $1^{\text {st }}$ April, 2015; Rule 5(4)(e)(ii) International Association of Athletics Federations competition rules 2016-2017 in force as from $1^{\text {st }}$ November 2015; Art 16 book 3 chapter I FIBA rule book 2014 - 2019; Art. 9 IBU rules adopted by the $201411^{\text {th }}$ regular IBU congress; Art. 2.6 IBU rules adopted by the $201210^{\text {th }}$ regular IBU congress; Art 2.2.1.4.2 AIBA technical rules effective as of February $1^{\text {st }} 2015$; Art. 1.1.033 $\$ 2$ UCl Cyding regulations general organisation of E0116 Cycling as a sport part 1 general organisation of Cycling as a sport (version of 15.03.2016); Art. 119(2) FEI general regulations $23^{\text {rd }}$ edition, $1^{\text {st }}$ January 2009, updates effective $1^{\text {st }}$ January, 2016; Art. 9.2.2. a FIE statues of December 2015 (wording unchanged since 2005); Art III. IGF nationality policy June 2014; Art 36.2.2 Fédération Internationale de Gymmastique statutes edition 2015 in effect from January 1 ${ }^{\text {st }}$, 2015; Art. 13.3.1(b) Sports and organization rules of the International Judo Federation 2015; Art. 3.3 UIPM Rules on Internal Organisation Tapeo November 2015; Rule 19 FISA rule book February 2013; Art 19.13 ISAF regulations 2015 - Annex 3 - eligibility code - November 2014; Art. 3.6.3.2 ISSF official statutes rules and regulations edition 2013 (third version 2015); skiing: eg. Art 203.5.1 the International Ski Competition Rules (ICR) book II Cross-Country approved by the $49^{\text {th }}$ International Ski congress, Barcel ona (Spa) November2015; Art 3.8.3.2 ITTF handbook 2016; Explanation 1 to Art. 4.1.1 World Taekwondo Federation rules \& interpretation in force as of $11^{\text {th }}$ May 2015; Bye Law to Rule 41 Constitution of ITF limited 2016 trading as International Tennis Federation memorandum articles of association and byelaws of ITF limited trading as the International Tennis Federation(unchanged since 2005); Art. 28 ITU constitution approved by the ITU congress, September 2013; By-law to Rule 13 IWF constitution and by-laws 2013 - 2016 approved by the IWF congress - Baku - modified by IWF congress - Almaty 2014 in effect with 1.1.2015; Art 6 UWW international rules for the change of nationality approved by the Bureau on $13^{\text {th }}$ December 2015.

1589 Questions 4 and 5 explanatory guidelines on the implementation of regulation 8 eligibility to play for national representative teams - International Rugby Board handbook as framed by the International Rugby Board last updated: $8^{\text {th }}$ March 2016. 
residence requirement in 2008, ${ }^{1590}$ one year after equestrian did the same ${ }^{1591}$ However, while equestrian has allowed exceptions to the rule since 2010, ${ }^{1592}$ ice hockey has taken a different approach, focussing on the time an athlete was legally resident in a country after a given birthday. While this was the $12^{\text {th }}$ birthday in 2012, the 2014 rule change saw this reduced to the $10^{\text {th }}$ birthday, ${ }^{1593}$ rendering the requirement easier to meet. The devel opment in hockey is more striking, since, prior to 2012, athletes with multiple nationality were required to be bona fide residents, ${ }^{1594}$ meaning that the athlete had been a resident in the country for a period of 210 days in each of the three years leading up to the initial selection. ${ }^{1595}$ This rule was abolished in 2012 and since 2015 resi dence only matters for master athletes who wish to compete for their country of residence ${ }^{1596}$

While for these sports the importance of residence seems to have lessened, or at least the requirements have become easier to meet, athletics relies more on such requirements since 2013. Following this rule change, a threeyear continuous residence period may now help to reduce the threeyear non-competition period. ${ }^{1597}$ Although these are only four sports and one cannot extrapolate trends from this and apply them to all the Olympic sports, there seems to be a development towards more exceptions and criteria which are easier to meet. This can also be seen from the fact that now residence may be used to avoid thenon-competition period.

Currently, only 14 of the 35 sports impose residence requirements. ${ }^{1598}$ The duration varies greatly from only one year for aquatics, archery and skating, ${ }^{1599}$ to two years for volleyball, curling, handball, and football under some circumstances, ${ }^{1600}$ and even five years that cycling prescribes for stateless athletes wishing to compete for the country of residence ${ }^{1601}$ Equestrian is among the most

1590 Art. 205(1.6)(a) and Art 205(1.7)(b) IIHF statutes and bylaws 2008 - 2012 with 2011 Amendments.

1591 Art. 123(5) FEl general regulations, $22^{\text {nd }}$ edition, $1^{\text {st }}$ June 2007 and $22^{\text {nd }}$ edition with 2008 amendments.

1592 Art. $119(2.2 .3)$ FEl general regulations $23^{\text {rd }}$ edition, $1^{\text {st }}$ January 2009 , updates effective $1^{\text {st }} J$ anuary 2010.

1593 Art. 406(1.6) and Art. 406(1.7) IIHF statutes and bylaws 2014 - 2018 of May 2014.

1594 Art. 5.2.4.1 International Hockey Federation statutes updated $13^{\text {th }}$ November 2010.

1595 Art. 5.2.4.3 International Hockey Federati on statutes and bye-laws updated $13^{\text {th }}$ November 2010.

1596 Art. 1.1 FIH Regulations governing the Eligibility of a Player to Play International Hockey for a country/ National Association $3^{\text {rd }}$ July 2015.

1597 Rule 5(4)(d)(ii) International Association of Athletics Federations competition rules 2014 - 2015 in forceas from $1^{\text {st }}$ November 2013.

1598 Namely aquatics, archery, athletics, basketball, curling, cycling, equestrian, football, handball, rugby, skating, triathl on, volleyball, wrestling.

1599 GR 2.5. FINA general rules 2013 - 2017 of November 2015; In case of competing for country of residence: Art. 2.4.2 World Archery constitution and rules 2015 effective since $1^{\text {st }}$ April 2015; Rule 109(2)(b)(i), Rule 109(2)(b) (ii), Rule 109(2)(b)(iii) and Rule 109(2)(b)(iv) International Skating Uni on general regulations 2014 as accepted by the $55^{\text {th }}$ Ordi nary Congress] une 2014.

1600 Art. 44.2.2 Sports regulations Volleyball version: 15 th May 2015; Art. 1 eligibility the rules of Curling and rules of competition of October 2015; Art 6.2 Player eligibility code of the International Handball Federation (IHF) of $8^{\text {th }}$ July 2014; Art 6(1) FIFA statutes: regulations governing the application of the statutes 2015.

1601 Art. 1.1.033 $\$ 1$ UCl Cycling regulations general organisation of E0116 Cycling as a sport part 1 general organi sation of Cycling as a sport (version of 15.03.2016). 
detailed sports, requiring two uninterrupted years of legal residence or five nonconsecutive years of legal residence ${ }^{1602}$ Looking at some of the federations in more detail, one sees that the IHF stipulates that a player is able to choose a country if:

“a) hewas bom in the territory of thefederation concerned or

b) his biological mother or biological father were born in the territory of the federation concemed or

c) he has been living in the teritory of thefederation concemed for more than 24 months in any period of his life"1603

Hence, the 24 months of residence are not the only possibility to establish a sufficient link with the country the athlete wants to represent. Also, the IHF does not stipulate that the 24 months should be continuous and the addition of 'in any period of his life' makes this rul eappear even more lenient.

\subsubsection{Residencerequirements after acqui sition of a new nationality}

Tuming to cases in which residence is a requirement added after to make a nationality change al so effective for the country of representation, it can be seen that the FIFA specifies residence as one of the additional requirements that an athlete with a new nationality needs to fulfil in order to become eligible for the new association. However, a distinction is made between a player who al ready had the national ity when starting his football career and players who only acquired another national ity at a later point in time In case of the former, the athlete needs to fulfil a requirement of two conseautive years of residence, ${ }^{1604}$ whereas for thelatter the FIFA prescribes fiveyears of residence after reaching the age of majority. Nevertheless, these residence requirements are not mandatory in case the link with the new country can be established in a different way. The ITU in contrast just refers to residence, with the prescribed period being three years, yet a reduction to one year is possible ${ }^{1605}$ Contrarily, the FEI in principle has an additional residence requirement applicable to all athletes, unless they are exempted through special circumstances. ${ }^{1606}$ However, the residence requirements can be fulfilled by either two uninterrupted years of legal residence or five years of non-consecutive legal residence. When comparing this to the FIFA's rules, one first notices the stress placed on the legal residence by the FEI, while the FIFA just requires 'residence'. Nevertheless, it is unlikely that any time of illegal residence in a country would be recognised by the FIFA to fulfil the residence

\footnotetext{
1602 Art. 119 (2.2.2) FEl general regulations, $23^{\text {rd }}$ edition, $1^{\text {st }}$ January 2009 , updates effective $1^{\text {st }} J$ anuary 2016.

1603 Art. 6.3 Player eligibility code of the International Handball Federation (IHF) of $8^{\text {th }}$ J uly 2014.

1604 Which can also be waived, Art. 6(1) FIFA statutes: regulations governing the application of the statutes 2015; Art 6(2) FIFA statutes: regulations governing the application of the statutes 2015.

1605 Art. 28.1 ITU constitution September 2015.

1606 Art. 119(2.2.3) FEl general regulations, $23^{\text {rd }}$ edition, $1^{\text {st }}$ January 2009 , updates effective $1^{\text {st }}$ J anuary 2016.
} 
requirement ${ }^{1607}$ Furthermore the $\mathrm{FEI}$ is the only association that also accepts nonconsecutive periods of legal residence as fulfilling the requirements. This provision grants athl etes considerably more freedom and flexibility, since prol onged periods of absence are also allowed within a fiveyear span. On top of that, the residence requirements can be substantially reduced in case the naturalised athl ete is married to a national of thenew country for which he or she wants to compete ${ }^{1608}$

\subsubsection{Residencerequirements for minors}

Residence is furthermore important with regard to minor athletes. The FEI allows minor athletes to compete for the country of residence and allows this athlete to continue competing for his or her country of residence after reaching the age of majority even if he or sheis not a national of that country, provided that he or she has a valid residence permit and has lived there for five conseative years. ${ }^{1609}$ However, the subsequent requirements are more difficult to meet, especially the requirement stating that the country of residence must qualify as a country where obtaining nationality is overly burdensome $Y \in$, no definition of what constitutes overly burdensomeis given by theFEI in its eligibility code.

\subsection{Which waiting or non-competition periods are applicable and under which circumstances?}

In addition to a required residence period, several federations also require the athlete who has acquired a new nationality and wishes to compete for the new country - or respectively an athlete with multiplenational ity willing to compete for another country - to cease competing intemationally for a certain period of time in order to curb mercenary tendencies.

Over the past years, several non-competition periods have been introduced, such as two years for boxing in 2015 or rowing since $2013{ }^{1610}$ Golf went further in 2014 requiring a four-year non-competition period. ${ }^{1611}$ Additionally, since 2011, equestrian especially aligned its rules with the IOC's required non-competition period for the Olympics. ${ }^{1612}$ While these four examples show a trend towards more and stricter non-competition periods, on the other side of the spectrum, wrestling only imposes a two-year period since 2012 if the federations do not agree to the

\footnotetext{
1607 And since naturalisation also typically does require at least legal residence at the time of application such a scenario is highly unlikely.

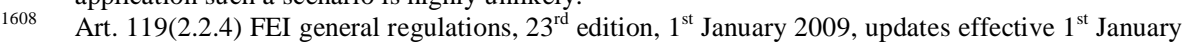
2016.

1609 Art. 119(6.3) FEl general regulations, $23^{\text {rd }}$ edition, $1^{\text {st }}$ January 2009 , updates effective $1^{\text {st }} J$ anuary 2016.

1610 Art. 2.2.1.4.1 AIBA technical rules effective as of February $1^{\text {th }} 2015$; Rule 19 FISA rule book February 2013.

1611 Art. III. IGF nationality policy June 2014.

1612 Art. 119.2.2.8 FEI general regulations $23^{\text {rd }}$ edition, $1^{\text {st }}$ January 2009 , updates effective $1^{\text {st }} J$ anuary 2012 and Art 119.2.2.8 FEl general regulations $23^{\text {rd }}$ edition, $1^{\text {st }}$ January 2009 , updates effective $1^{\text {st }}$ J anuary 2011.
} 
change ${ }^{1613}$ and, since 2013 , athletics offers the possibility to reduce the threyear non-competition period by proving three continuous years of residence in the relevant country. ${ }^{1614} Y \in$, the overall trend goes towards limiting changes of the country of representation by means of non-competition periods.

Currently, there are 22 federations that do require such a period and the durations largely differ. Skating in particular is interesting as it features varying lengths of non-competition periods, depending on the circumstances. ${ }^{1615}$ Some federations, only impose a oneyear waiting period, such as aquatics, archery and skiing. ${ }^{1616} \mathrm{It}$ is important to note, however, that the FIS may waive the waiting period in case the relevant federations agree Six other federations require a two-year non-competition period ${ }^{1617}$ and nine require a three year non-competition period. ${ }^{1618}$ One example of this is judo:

"A competitor who has represented one country in the Olympic Games, World Championships, in continental, regional games and/or Championships or International Tournaments organized by IJF or under its auspices, and who has changed his nationality or acquired a new nationality may participate to represent his new country provided that at least three years have passed since the compeitor last represented his former country. If the two National Federations concerned agreethey may request the Intemational J udo Federation to shorten the period of three years, even to cancel theduration."1619

This artide also underlines one of the major problems of this type of requirement it can be rather easily circumvented and as no official mechanisms are in place to check the reasons for thesereductions and to ensure that similar cases are treated equal.

1613 Art. 7 UWW international rules for the change of nationality approved by the Bureau on $13^{\text {th }}$ December 2015; General conditions d) FILA international regulations for the change of nationality 2011; Appendix I compulsory procedure to follow for the change of nationality to the FILA international regulations for the change of nationality 2011.

Rule 5(4)(d)(ii) International Association of Athletics Federations competition rules 2014 - 2015 in forceas from $1^{\text {th }}$ November 2013.

Rule 109(2)(b)(ii) and Rule 109(2)(b)(iii) International Skating Union general regulations 2014 as accepted by the $55^{\text {th }}$ Ordinary Congress] une 2014.

1616 GR 2.6.2(4) FINA general rules 2013 - 2017 of November, 2015; Art. 2.4.1 and Art. 2.4.3 World Archery constitution and rules 2015 effective since $1^{\text {st }}$ April 2015; skiing: eg. Art 203.5.1 International Ski Competition Rules (ICR) book II Cross-Country approved by the $49^{\text {th }}$ International Ski congress, Barcelona (Spa) November, 2015.

1617 Biathl on: Art. 9 IBU rules adopted by the $201411^{\text {th }}$ regular IBU congress; Boxing: Art. 2.2.1.4.2 AIBA technical rules effective as of February $1^{\mathrm{st}}, 2015 ; 11^{\text {th }}$ regular IBU congress; Curling, Art. 2 eligibility the rules of Curling and rules of competition of October 2015; Equestrian, Art. $119(2.2 .2)$ FEI general regulations, $23^{\text {rd }}$ edition, $1^{\text {st }}$ January 2009 , updates effective $1^{\text {st }}$ January 2016; Rowing, Rule 19 FISA rule book February 2013: Wrestling (unl ess federations agree): Art. 7 FILA international rules for the change of nationality approved by the Bureau on $15^{\text {th }}$ January 2015.

1618 Badminton, fencing, handball, hockey, judo, sailing, shooting, taekwondo, and tennis.

1619 Art. 13.3.1 Sports and organization rules of the International Judo Federation 2015. 
Ice hockey and golf require four years of non-competition and in the case of golf this can even be extended. ${ }^{1620}$ Weightlifting at first requires only a oneyear period of noncompeition, but after the first change this period is four years. ${ }^{1621}$ This approach is certainly the most nuanced, as it will allow an athlete to change his or her nationality once with only a minor forced break period. In order to contravene mercenary tendencies, which a second or third change is more likely to be, the rules are stricter. Overall, the non-compeition period is the best tool federations have to ensure that athletes are at least dissuaded from changing nationalities qui ckly.

\subsection{For which country may stateless athletes compete and under which circumstances?}

In total, only seven federations deal with stateless athletes, refugees or asylum seekers which is only one fifth of 35 Olympic Sports. FIBA and FIFA deal with athletes who are stateless on a case by case basis. ${ }^{1622}$ The FIE allows stateless athletes to compete for their country of residence, provided that they are registered with the relevant national federation. ${ }^{1623}$ The same goes for equestrian, where athletes who lost their nationality became refugees or whose national federation ceased to exist could compete in international toumaments nevertheless and will be deemed to compete for the country they live in. ${ }^{1624}$ The IBU takes a different approach as it will assign a stateless biathlete to one country. ${ }^{1625}$ The handball statutes do not refer to stateless athletes, but to refugees and asylum seekers. They can compete for their host country if they havea valid residence permit ${ }^{1626}$ Whil lethese are relatively quick solutions, the $\mathrm{UCl}$ stipulates that:

"A stateless rider may be selected only by the national federation of a country where hehas been continuously in residence for at least five years."

This is an extremely long time and might thus not be very hel pful to athletes who are suddenly faced with statelessness. Other federations, such as the ISSF do not explicitly mention stateless athletes either; however, it provides for a case by-case solution in case of unforeseen circumstances. ${ }^{1628}$ Equally, the WA does not mention stateless archers explicity, but since competing for the country of residence is possible, it goes

\footnotetext{
1620 Art. 406(1.3) IIHF statutes and bylaws 2014 - 2018 of May, 2014; Art. III. IGF nationality policy June 2014.

1621 By-law to Rule 13.3 IWF constitution and by-laws 2013 - 2016 approved by the IWF congress Baku - modified by IWF congress - Almaty 2014 in effect with 1.1.2015.

1622 Art. 34 book 3 chapter I FIBA rule book 2014 - 2019; Art. 8(2) FIFA statutes: regulations governing the application of the statutes 2015.

1623 Art. 9.2.3 FIE statutes of December 2015 (wording unchanged since 2005).

1624 Art. 119(5) FEl general regulations, $23^{\text {rd }}$ edition, $1^{\text {st }}$ January 2009 , updates effective $1^{\text {st }}$ January 2016.

1625 Art. 9 IBU rules adopted by the $201411^{\text {th }}$ regular IBU congress.

1626 Art. 5.3.a) Player eligibility code of the International Handball Federation (IHF) of $8^{\text {th }}$ J uly 2014.

1627 Art. 1.1.033 §1 UCl Cyding regulations general organisation of E0116 Cycling as a sport part 1 general organi sation of Cycling as a sport (version of 15.03.2016).

1628 Art. 3.6.3.5 ISSF Official statutes rul es and regulations edition 2013 (fourth print 03/2016).
} 
in the same direction as the FEI's rules. ${ }^{1629}$ The same can be said for the ISAF, which allows for a wai ver in thenational ity requirements for ' good reasons'. ${ }^{1630}$

Thus, in conclusion, the position of stateless athletes is not given much importance by the federations. This can either be because they do not see it as an important problem or because they wish to decide it in such cases themselves on a case-by-cases basis. Moreover, no changes have occurred with regard to the rules of stateless athletes since 2013. This is bound to change for the upcoming Olympics, the IOC will for the first timeal ow refugee athletes to compete. ${ }^{1631}$ So far it remains unclear how the qualification for the individual disciplines will be handled, yet, through this measure, the IOC clearly reacts to circumstances athletes might find themselves in. It can expect that the federations will soon follow suit and will include similar rules in their own eligibility codes.

\subsection{How do territorial transfers affect the athletes' choice regarding the country of representation?}

Since 2013, trends regarding territorial transfers have been limited to the introduction of a rule dealing with the aftermath of state succession by golf in $2014^{1632}$ and the modern pentathlon in 2015. ${ }^{1633}$ However, one has to keep in mind that, prior to 2014, golf did not have any eligibility rules concerning nationality. On the one hand, most sporting federations thus still do not concem themselves with these issues. On the other hand, the fact that such a provision was ind uded in the first ever eligibility rules written by the IGF shows that this aspect is deemed important by at least federations newly drafting their eligibility codes. Overall, there are currently nine federations that refer to territorial transfers. ${ }^{1634}$ Most of them havean artide that is similar to this one

"If an associated State, province or overseas department, a country or colony acquires independence, if a country becomes incorporated within another country by reason of a change of border, if a country merges with another country, or if a new NOC is recognised by the IOC, an athlete may continue to represent the country to which hebel ongs or bel onged. However, hemay, if heprefers, elect to represent his country or be entered in ISSF Championships by his new Federation when recognized by the ISSF. This particular dhoice may be made only once" 1635

1630 Art. 19.2.1 ISAF regulations 2015 Appendi $x 3$ - eligibility code.

1631 T. Bach (2015). Speech on the occasion of the adoption of the resolution "Building a peaceful and better world through sport and the Olympic ideal" by IOC President Thomas Bach, UN General Assembly, New Y ork, 26 $6^{\text {th }}$ October 2015.

1632 Art. III. IGF nationality policy J une 2014.

1633 Art. 3.5 UIPM Rules on Internal Organisation Tapeo November 2015.

1634 Equestrian, golf, hockey, modern pentathl on sailing, shooting, table tennis, tennis, triathlon.

1635 3.6.3.4 ISSF official statutes rul es and regulations edition 2013 (fourth print 03/2016).
} 
All these federations allow the athlete to choose fredy, yet he or she may only do so once $^{1636}$ These articles are interesting, as they try to cover all aspects of teritorial transfers. There may still be problematic situations as a choice can only be made once and frequently tensions remain after a teritorial transfer, rendering the political and social situation unstable

Interestingly, badminton has a different approach to teritorial transfers:

"If a player has represented a Member Association and such Member Association is subsequently di vided into two or more Member Associations or is absorbed by another Member Association, either politically or by recognition of the BWF, such player shall, for the purposes of these Regul ations, be deemed from the date of such alteration not to have represented any Member Association."1637

Here the federation not the country itself is important This may be problematic, if part of a country becomes incorporated into another one without the main federations being affected.

\subsection{Is competing for the country of residence possible and if so under certain circumstances?}

While most associations strictly lay down that an athlete can only compete for a country of which he or she is a national, there are ten federations that al ow athletes to compete for the countries they live in. ${ }^{1638}$ However, fencing only does this for stateless fencers registered with thenational federation. Contrarily, theFEl allows non-stateless athletes residing outside of the country of nationality to compete for the "host" association, i.e the onein which the athl etelives, in certain tournaments. ${ }^{1639}$ However, these rules are applied conservatively and the permission of the national federation is needed. The same holds true for minor athletes, with the difference that whilean adult athlete will in principle remain a member of his or her national association, the minor is able to tum the federation of his or her country of residence into his or her home association upon reaching the age of majority (subject to conditions). Rowers also haveto ask theFISA to grant theman exception. ${ }^{1640}$

Other associations that allow athletes to compete for their country of residence make it conditional upon the duration of residence. For the WA it takes one year of

1636 Hockey = Art 3.5 FIH Regulations governing the Eligibility of a Player to Play International Hockey for a country / National Association $3^{\text {rd }}$ July 2015; Tennis: Bye-Law to Rule 41(3) Constitution of ITF limited 2016 trading as International Tennis Federation memorandum articles of association and byelaws of ITF limited trading as the International Tennis Federation); Table Tennis = Art 4.5.1.3.5 ITTF handbook 2016; Golf = Art. III. IGF nationality policy June 2014; Equestrian: Art. 119(4) FEl general regulations, $23^{\text {rd }}$ edition, $1^{\text {st }}$ January, 2009, updates effective $1^{\text {st }}$ January 2016; Sailing Art 19.13(c) ISAF regulations 2015 - Annex 3 - eligibility code November 2014; Triathlon Art. 28(2) ITU constitution approved by the ITU congress, September 2015.

1637 Art. 8.4 part III - section IA BWF general competition regulations updated J une 2015.

1638 Archery, curling, cycling, equestrian, fencing gymastics, rowing, sailing, skiing, triathlon.

1639 Art. $119(6.1)$ FEI general regulations, $23^{\text {rd }}$ edition, $1^{\text {st }}$ January 2009 , updates effective $1^{\text {st }}$ January 2016.

1640 Rule19FISA rule book February 2013. 
residence before the athlete can compete, ${ }^{1641}$ while curling and skiing ask for two years. ${ }^{1642}$ Both ITU and ISAF allow athletes to compete for their country of residence after having been resident for three years, ${ }^{1643}$ while cycling asks for five years. ${ }^{1644}$ Gymnastics in tum takes a different stance:

"Wherea gymnast moves to another country, and has not represented his former country, he may immediately after receiving citizenship (official nationality) represent his new country with the consent of the ExeativeCommittee In the case of a gymnast -bom in a country in which his parents are "bona fide" residents but have not received citizenship (official nationality), the federation of the country in which hewas bom may indude him in its national team subject to the consent of the Exeative Committee"1645

It is the residence of the parents and the link of being bom in a country that uses ius sanguinis and therefore did not all ow the athl ete to acquire the nationality based on ius soli that needs to be ful filled here

One can thus see that, while 24 of 35 sports do not allow competition for the country of residence at all, the other associations areall owing it to varying degrees with differences in residence requirements being the most obvious ones. The IHF's stance, with its focus on asylum seekers and refugees is unique, but it also underlines the special situation those people are in. However, being recognised as refugee or asylum secker does tend to be rather tedious and so the acquisition of a residence permit might actually be more difficult to achieve than any of the other requirements.

Interestingly, only one change occurred since 2013 regarding this topic and, since 2015, tennis requires five years of residence for those wishing to compete for their country of residence in the Fed and Davis Cups, which are essential for players to qual ify for the Olympics. ${ }^{1646}$ However, akin to stateless athletes, this issue has not been at the forefront of the debate regarding eligibility criteria. This is bound to change with the current mass migration movements and the new stance taken by the IOC on refugee athletes.

1641 Art. 2.4 World Archery constitution and rules 2015 effective since $1^{\text {st }}$ A pril 2015.

1642 Art. 1 eligibility the rules of Curling and rules of competition of October 2015; Skiing: e.g. Art. 203.5. International Ski Compeition Rules (ICR) book II Cross-Country approved by the $49^{\text {th }}$ International Ski congress, Barcelona (Spa) November, 2015.

1643 Art. 28(1a) ITU constitution approved by the ITU congress, September, 2015; Art 19.12(a), Art. 19.12(b) and Art. 19.12(c) ISAF regulations 2015 - Annex 3 - eligi bility code - November 2014.

1644 Art. 1.1.033 $\$ 1$ UCl Cycling regulations general organisation of E0116 Cycling as a sport part 1 general organi sation of Cycling as a sport (version of 15.03.2016).

1645 Art. 36.2.3 Fédération Internationale de Gymnastique statutes edition 2015 in effect from J anuary $1^{\text {t }}, 2016$.

1646 Rule 31 b) iii) and Rule 31 b) iii) a) ITF Fed Cup Regulations 2016; Rule 35 a) iii) and Rule 35 a) iii) a) ITF Davis Cup Regulation 2016. 


\subsection{What is the situation for minors regarding changes of the country of representation?}

Over the past years, few changes have occurred with regard to minor athletes. While, on the one hand, since 2008 the $21^{\text {st }}$ birthday of the athlete lost its importance for the FIFA, ${ }^{1647}$ on the other hand, since 2014 ice hockey focusses on the $10^{\text {th }}$ birthday as a hallmark after which an athleteneeds to have lived and competed in a country, without dealing further with minor athletes themsel ves. ${ }^{1648}$ There is thus no di scernibletrend in either direction. The only other remarkable rule change occurred in 2010 in equestrian, when the differentiation between adult and minor athletes was first added. ${ }^{1649}$ While this marks an increase in interest of sporting federations in minor athletes, the total number of those dealing with this vital topic remains extremely small.

Examining the position minor athletes find themselves in at the moment more into depth, it can be seen that several intemational associations do not provide specific rules on their position with regard to nationality. Only basketball, cycling, equestrian, football, hockey, rugby, and tadkwondo refer at all to minors and rugby only does so to underline that there are no separate rules applicable ${ }^{1650}$ Hence the majority of the Olympic Sports remain mute on this point.

Looking at some examples, one finds that the FIFA does not concern itself with matters of age but focusses on who has not played a match in an " $\mathrm{A}$ " competition. Those who have not may still decide to play for another association. This means that players competing in the junior competitions can rethink their choice for which country they would like to play. ${ }^{1651}$ Equestrian eligibility rules provide even more choices for minor athletes with multiple nationality, enabling them to choose annually for which country they want to compete These rules, however, are applied conservatively and this relative freedom changes as soon as the athlete reaches the age of majority. ${ }^{1652}$

1647

Art. 15(3)(a) and Art. 15(3)(b) FIFA statutes: regulations governing the application of the statutes 2005.

Art. 406(1.6) and Art. 406(1.7) IIHF statutes and bylaws 2014 - 2018 of May 2014.

Art. $119(2)$ and $119(3)$ were added as well as $119(6.3)$ FEl general regulations $23^{\text {rd }}$ edition, $1^{\text {st }}$ January 2009, updates effective $1^{\text {st }}$ J anuary 2010.

Art. 16 and 20 book 3 chapter I FIBA rule book 2014 - 2019; Art 1.1 .033 §2 b) UCl Cyding regulations general organisation of E0116 Cyding as a sport part 1 general organi sation of Cycling as a sport (version of 15.03.2016); Art. 119(3.1) FEl general regulations, $23^{\text {rd }}$ edition, $1^{\text {st }}$ January 2009, updates effective $1^{\text {st }}$ January 2016; Art. 5(2) FIFA statutes: regulations governing the application of the statutes 2015; Art. 2 FIH Regulations governing the Eligibility of a Player to Play International Hockey for a country / National Association $3^{\text {rd }}$ July 2015; Question 4 explanatory guidelines on the implementation of regulation 8 eligibility to play for national representative teams - International Rugby Board handbook as framed by the International Rugby Board last updated: $8^{\text {th }}$ March 2016; Explanation 1 to Art. 4.1.1 World Taekwondo Federation rules $\&$ interpretation in force as of $11^{\text {th }}$ May 2015.

Art. 5(2) FIFA statutes: regulations governing the application of the statutes 2015.

Art. 119(3.1) FEl general regulations, $23^{\text {rd }}$ edition, $1^{\text {st }}$ January 2009 , updates effective $1^{\text {st }}$ January 2016. 


\subsection{Is the number of changes of the country of representation limited in any way?}

Tuming to the last aspect, namely how often an athlete can actual ly change his or her nationality with an effect for his or her country of representation, the general trend seems thus to be that no limits are imposed and athletes are free to choose which country they wish to represent, as the recent abolition of the limit of one change of country of representation by ice hockey shows. ${ }^{1653}$ Although this is only one sport that lifted the restriction, the overall majority of Olympic sports do currently not impose any maximum number of changes of the country of representation. They do however have to fulfil the additional criteria set down in the eligibility codes. Contrarily, for tennis, theFed and Davis Cup al low no changes of the country of representation since 2016, while the Constitution still allows for them ${ }^{1654}$ There is thus a conflict of rules within the ITF. The few sports imposing a restriction are football, where, after an ' $A$ ' match, the athlete is considered to have chosen for life, ${ }^{1655}$ although redediding beforehand is possi ble, and rugby, where a rugby nationality is seen as set in stone ${ }^{1656}$ As previously mentioned, luge does not have any rules on eligibility and cannot be classifiable in this respect This leaves 31 federations that do allow for changes to a certain extent All those dealing with teritorial transfers in their rule books al low an athlete to decide for which entity he or she wishes to compete just once ${ }^{1657}$ For the standard procedure that is triggered if an athlete wishes to compete for another country after having acquired a new nationality, there are six federations that only allow for one change These are cycling, basketball, fencing, handball, volleyball, and wrestling. ${ }^{1658}$ Thesearethestrictest federations in that regard.

1653 Art. 406(1.3) IIHF statutes and bylaws 2014 - 2018 of May 2014.

1654 Rule 31 b) ITF Fed Cup Regulations 2016; Rule 35 a) ITF Davis Cup Regulation 2016.

1655 Art. 5(2) FIFA statutes: regulations governing the appl ication of the statutes 2015.

1656 Regulation. 8.2 International Rugby Board handbook as framed by the International Rugby Board last updated: $8^{\text {th }}$ March 2016.

1657 Equestrian, golf, hockey, sailing, shooting, table tennis, tennis, triathlon.

1658 Art. 1.1.033 §2a) UCl Cyding regulations general organi sation of E0116 Cycling as a sport part 1 general organisation of Cycling as a sport (version of 15.03.2016); Art 17 book 3 chapter I FIBA rule book 2014 - 2019; Art 9.2.2.f) FIE statutes of December, 2015 (wording unchanged since 2005); Art 6.1 b) Player eligibility code of the International Handball Federation (IHF) of $8^{\text {th }}$ July, 2014; Art. 44.1 Sports regulations Volleyball version: 15 $5^{\text {th }}$ May 2015; Art. 6 FILA international rules for the change of nationality approved by the Bureau on $15^{\text {th }} \mathrm{J}$ anuary 2015. 


\section{Compatibility of eligibility criteria and nationality law}

Having answered thequestion of which eligibility criteria exist in Chapters 5 - 15, it is now time to turn to the second research question: to what extent are the currently applicable eligi bility criteria problematic in light of therelevant international standards in the field of nationality law? The principles of international law as established in the touchstone principles (Chapter 3.8) are

- No violation of fundamental human rights, in particular theright to nationality;

- Statelessness is to beavoided;

- Right to change one's nationality,

- Renunciation of national ity should beal lowed, if it does not causestatelessness,

- Attribution of national ity has to be based on a genuine link between a person and the state:

- Birth right citizenship can be based ius sanguinis or ius soli or a combination thereof;

- Family unity should be uphedd;

- Gender equality should be respected;

- No arbitrary deprivation of nationality,

- No discrimination.

Additionally, the position of children and minors is of paramount importance, as they are in an especially vulnerable position and need additional protection. As outlined in Chapter 3.8, not all of these standards are applied by countries throughout the world and especially gender equality and non-discrimination are often problematic.

From these principles, several desiderata, i.e desirable rules, have been established, according to which the previously compared criteria (Chapter 15) will be analysed. The desiderata can be summarised as foll lows:

a) Sporting federations should recognise the athlete's nationality and should have provisions for stateless athl etes and refugees that allow them to continue to compete intemationally (Chapter 16.1);

b) Changes of country of representation haveto beallowed and should not belimited by a maximumnumber of changes (Chapter 16.2);

c) The genuine link between athlete and country should be recognised by the sporting federations if established via i) ius soli, ius sanguinis or a combination thereof; ii) option rights, iii) facilitated naturalisation after marriage or iv) naturalisation (Chapter 16.3);

d) Gender equal ity should be respected (Chapter 16.4);

e) Sporting federations should provide rules for those who lost their nationality and al low them to continuether carer (Chapter 16.5);

f) Thereshould beno discriminatory rules (Chapter 16.6);

g) Rules conceming minor athletes should offer additional protection (Chapter 16.7). 
While fundamental human rights and the principle of non-discrimination should play an important role in all aspects of law, for the purpose of eligibility criteria the attribution of national ity based on a genuine link between a person and the state is the most important one The current eligibility criteria aim at establishing a link between an athlete and a state either by reying on ius soli, ius sanguinis or residence, with residenceand waiting periods being important secondary factors to ensure that thelink is actually genuine.

\subsection{Sporting federations should recognise the athlete's nationality and should have provisions for stateless athletes and refugees that allow them to continue to compete inter nationally}

Firstly, the core touchstone principle is that there should be no violation of fundamental human rights, in particular the right to nationality, ${ }^{1659}$ and statelessness should be avoided. ${ }^{1660}$ Consequently, the first desideratum is that sporting federations should not only recognise an athl ete's national ity but should al so incorporate measures for those who are stateless. This leads to another desideratum, namely that athletes in situations similarly precarious as statelessness should betreated with similar care

Generally, refugees as well as stateless athletes should beallowed to compete for a country. For stateless athletes this cannot be the country of nationality for they have none and thus a country with which the stateless person has a significant link, eg. through residence, might be considered appropriate In case of refugees who hold a national ity but cannot compete for their country of nationality a similar way needs to be found.

Looking at how this is in practice, there are only seven federations, namely archery, basketball, biathlon, cycling, equestrian, fencing, and football, which deal with stateless athletes, refugees or asylum seekers, which is only one fifth of the 35 Olympic Sports. Moreover, it might be debatable who is considered stateless by a federation, as some federations ask for the loss to be permanent, but also few federations actually deal with the problem. This should be remedied, as all federations should include provisions on stateless athletes and refugees. While there is a difference between de jure and de facto statelessness, and sporting federations might not be able or willing to include de facto statelessness in the general rules, a case-by-case option for dealing with these problems should be available, as well as an appeal procedure ${ }^{1661}$

Furthermore, the current approaches taken by those seven federations differ greatly, with some al ready dealing with the circumstances on a case-by-case basis, eg. basketball, others like biathlon, assigning athletes to a country, or letting them

\footnotetext{
1659 K. Hail bronner (2006), pp. 53f; E. Horváth (2008), pp. 18f; O. W. Vonk (2012), p. 45; R. Bauböck, E. Ersboll, K. Groenendijk and H. Wal drauch (2006), p. 28.

1660 K. Hail bronner (2006), pp. 53f; E. Horváth (2008), pp. 18f; R. Bauböck, E. Ersboll, K. Groenendijk and H. Waldrauch (2006), p. 28.

1661 R. Bauböck, E. Ersboll, K. Groenendijk and H. Waldrauch (2006), p. 28; see also the argumentation in the Perez I, II and III VIOC cases.
} 
compete for their country of residence, as equestrian does, or the country hosting the tournament, as al lowed in fencing. Out of these options the case-by-case approach is the most individual and can take the athl ete's circumstances best into consideration. However, such a procedure might be lengthy and it is not sure, from the current modus operandi, that similar cases will betreated equally. This should thus be a fallback option, supporting a general approach to statel ess athletes. Simply assigning an athlete to a country may be problematic, as the athlete will not necessarily have a link with the country in question, if such an assignment was done at random Should the assignment be based on objective requirements, such as residence, this would not be a problem, as allowing stateless athletes to compete for their country of residence is already an option favoured by some federations. Here, it is important how residence is defined and which duration is deemed sufficient. The current approach taken by some that stipulate long periods of residence may be considered extremely burdensome for athletes. Interestingly, currently only archery, curling, cycling, equestrian, gymnastics, rowing, sailing, skiing and triathlon, thus nine federations, allow athletes who are not stateless to compete for the countries they live in, provided that they fulfil certain requirements. This is usually a residence requirement, with a duration ranging between one and five years. This is logical, sinceresidence is the factor determining the link between the athlete and the country for which he or she competes. However, there should be one standard duration of residence required. Permission by either the Executive Board or the national federation is certainly al so a useful requirement, although at least the approval of the national federation would be problematic in cases of stateless athletes who wish to compete for their country of residence Ergo, a combination between a certain length of residence and the approval of the Executive Board - since it is likely to be more objective than theinvolved national federation - would be the best solution.

In addition to stateless athletes, also athletes who become refugees are in a difficult situation as they cannot compete for a country whence they have fled. This problem has been recognised by the IOC and during the 2016 Games, refugee athletes will be allowed to compete for the first time As they will not be able to compete for the country from which they have fled, they will compete under theIOC flag and the Olympic Anthem will be played during the ceremonies. ${ }^{1662}$ So far it remains unclear how the qualification for the individual disciplines will be handled, yet through this measure the IOC clearly reacts to circumstances athletes might find themselves in. One can thus expect that changes will soon be included by the national federations.

In conclusion, the current eligibility criteria of all sports should be amended in such a way to include provisions on stateless athletes and refugees, which allow them to continue their carer. The main rule should be to allow stateless athletes to

1662 T. Bach (2015), Speech on the occasion of the adoption of the resolution "Building a peaceful and better world through sport and the Olympic ideal" by IOC President Thomas Bach, UN General Assembly, New Y ork, 26 October 2015. 
compete for their country of residence. However, should they have a genuine link with another country, athletes may apply to compete for it. Such a decision should then betaken on a case-by-case basis.

\subsection{Changes of the country of representation have to be allowed and should not be limited by a maximum number of changes}

There is a right to change one's nationality ${ }^{1663}$ and, consequently, renunciation of nationality should be al lowed, if it does not cause statelessness. ${ }^{1664}$ As the underlying assumption of all representative teams is that an athlete should have a connection with the country he or she represents, sporting federations should allow for changes in the country of representation if the link with the country changes. This should not only be allowed for athletes who have acquired a new nationality, but al so for those with dual or multiple nationality and it should thus be possible for all athletes to al so change their country of representation.

Special attention should be paid by the federations to cases of state succession and under these circumstances athletes should be allowed to choose for whichever new entity they wish to compete There should be no maximum number limiting the changes of the country of representation. However, safeguards to combat mercenary tendencies should be in place and federations should check whether a genuine link exists between the athlete and the country he or she represents. In practice, this is well reflected in the current eligibility criteria, as there are only two instances where changing an athlete's nationality and country of representation are impossible, as it is in rugby or in football.

\subsubsection{Maximumnumber of changes}

One can understand that sporting federations do not wish to have their athletes changing constantly between the countries they compete for. Too many changes and too lax restrictions would again lead to a distortion of competition. Is it however prudent to set a specific number of changes that may in no circumstance be surpassed? The answer has to be no, since circumstances, such as state successions, political developments, eg. in the cases for refugees and asylum seekers, and also personal circumstances will not conform to the dean-aut provisions. Moreover, such a restriction would be contrary to thegeneral principles of international law.

In practice, the majority of sports do not specify any maximum number of changes, but some only allow for one change of country of representation in an athlete's career, namely cycling, basketball, fencing, handball, volleyball and wrestling. This maximum is not only extremely strict and contrary to the principles of nationality law, but it also leads to situations in which the country of representation and the athlete's national ity are not congruent. As the underlying aim was to ensure that athletes have a genuine link with the country they represent, these

\footnotetext{
1663 K. Hail bronner (2006), p. 38.

1664 Art. 8 European Convention on Nationality.
} 
rules achieve the exact opposite of what they were instituted for. An interesting other approach is taken by one sport, namely weightlifting, which differentiates between the first and any subsequent changes of the country of representation. Initially a oneyear period of non-competition is sufficient, but, later, up to four years are necessary. Thus, while the further federation changes are not impossible, they are significantly more difficult to achieve and can thus contravene mercenary tendencies.

In conclusion, not allowing athletes to change their country of representation or limiting the number of changes to only one change in a lifetime does not only contravene international principles of national ity law, but it al so does not take reallife situations into consideration. Therefore, these limits should no longer be included in eligibility catalogues and other means to combat overly mercenary tendencies should be chosen.

\subsubsection{Changes in case of multiple nationality}

With the increasing acceptance of dual national ity in recent decades (see Chapter 3.4), also in the sporting context, dual or multiple nationality has been dealt with more frequently, namely in all sports except badminton, bobsleigh, canoe kayak, curling, luge, modern pentathlon, skating, and volleyball.

\subsubsection{Multiplenationality from birth}

At the start of their careers, athl etes with multiple nationality are free to choose for which country they wish to compete, yet if an athlete wishes to change the country of representation later in life usually the same procedure applies as if the nationality was newly acquired. Consequently, residence requirements or waiting periods will be in place to establish a genuine link between the athlete and the country. The athlete already had more than one nationality to begin with, meaning that through the application of ius sanguinis or ius soli there already was a link with the teritory. Nevertheless, the federations want additional circumstances to show that the link is genuine The aim of these requirements is to prevent athletes from changing their allegiance depending on how well the national team is faring. $Y$ et, there is a rel difference to the aforementioned case of players acquiring new nationalities as these athl etes al ready had the national ity to begin with. They did thus not necessarily acquire a new national ity at their own volition. The important aspect in such a case is more the choice of the athlete to compete for either of the countries for which he or she is a national - which dearly is distinct from an athlete acquiring another nationality while al ready engaging in a sporting career. Ergo, the requirements to establish a real genuine link in such a case should be more lenient or at least different from cases where the athlete acquired another national ity at a later stage

\subsubsection{Multiplenationality acquired later in life}

It is thus the point of acquisition of a nationality in an athlete's life that matters - yet a mere age distinction is not the best solution as carer paths differ. The differentiation 
between an 'A' match and a match at another level of competition is certainly necessary, since training, for example as a minor at the place of residence, should not al ready constitute a conscious choice for one country or another. Representing a country at an official ' $A$ ' match carries more weight $Y \notin$, as younger athletes are nowadays also called up for ' $A$ ' matches, the protection of minors comes into play (seeChapter 16.7 for a detail ed approach to this topic).

The question remains how one should ensure that the link between the athlete and the country of which he or she al ready was a national is genuine On the one hand, one could say that, since the state recognises the athlete as one of its nationals, this should be sufficient also for the federations to say that there is a genuine link. On the other hand, as the abovementioned actual cases have shown, such a link might be considered weak.

However, does a residence requirement solve the problem of athletes who re decide after having competed at an ' $A$ ' level? That depends on the form - if it is continuous residence, then the athlete might not be able to fulfil this requirement if he or she is playing in another national league. Thus, the best option if a residence requirement was chosen, would be something al ong the lines of $X$ days per year in the last $Y$ years. This approach has al ready been advocated by hockey. With regard to a break period, as also in place for athletes who acquired a new nationality vol untarily, it seems rather strange to treat those two kinds the same

Hence, if such a requirement was indeed to remain in place, there should be different durations for athletes with multiple nationality and those who acquired a new one The possibility of having to wait a certain period together with the residence requirement would still have a detering effect and would still not be as strict. Requirements like having the biological parents' birth place in the respective country, as envisioned by FIFA, would seriously affect athletes who were adopted as children or who were foundlings and are as such discriminatory. ${ }^{1665}$

\subsubsection{Changes in case of territorial transfers}

As previously outlined, teritorial transfers can bring about changes to an athlete's nationality (seeChapter 3.5). Such a possibility is dealt with by nine of the 35 Olympic sports, namely equestrian, golf, hockey, modern pentathlon, sailing, shooting, table tennis, tennis and triathlon, which is a small number, seeing that teritorial disputes and transfers can affect a lot of peopleat the sametimeand are by no means a thing of the distant past In circumstances such as state successions these sports provide athletes with the possi bility to choose fredy. $Y$ e, as this choicecan only be made once and because the dissolution or independence of countries will not be directly clear aut and easy to assess, the athlete may make the wrong decision in a time of immense political stress. Changes in the geo-political order of countries can potentially lead to moreexcluding social policies that might only show themsel ves after a while.

1665 See Chapter 16.3. 
As previously described (see Chapters 3.5), borders usually are not redrawn in a way to takeall different populations on the territory into consideration. Consequently, some minorities with ties to other states will remain within each new state. Such a minority might find itself marginalised and placed in a worse politically and socially situation. Thus, if one country $R$ with a multi-ethnic population is divided into countries $S$ and $Q$, athletes will be faced with the choice between the two new countries. Athlete $Z$ choses to compete for country $Q$, but, after a while, it becomes clear that $Z$ is part of a minority in that country and would be part of the majority in country $S$. Should country $Q$ now start marginalising the minority to which $Z$ belongs, $Z$ will face problems due to the minority status in the country. In addition to the social, economic and political aspects of this situation, Z' s career is al so jeopardised as he or she cannot redecide The only solution for the sporting aspect then is that $Z$ acquires the nationality of country $S$ the usual way and facea waiting period.

Also, the approach taken by one sport, namely badminton, which focusses on the sporting federation itself, is problematic. As the federations will not always be forced to split or converge, the federations might not be representing the reality of the state the athlete would represent Consequently, an athlete from Crimea who previously competed for the Ukraine, but now that Crimea might be considered part of Russia would have to competefor Russia, would not fall under this article Hence, he or she would not have a choice.

The problematic aspect here is that so few sports have adopted rules for the case of territorial transfers. This should be remedied as, in case of changes of circumstances beyond the control of the athletes, they should be able to quickly adapt to the new situation without al so jeopardising their career. Hence, while there should be one generally applicable rule, eg. in case of territorial transfers, athletes may fredy decide once for which country they wish to compete, athletes should have the opportunity to re-decide under special circumstances. In that situation, a case-by-case decision with special focus on the individual athlete's circumstances should be taken. One example of such special circumstances would be if the athlete was either openly or effectively hindered from exercising the sport for the new country.

\subsection{The genuinelink between athlete and country should be recognised by the sporting federations if established via i) ius soli, ius sanguinis or a combination thereof ii) option rights; iii) facilitated naturalisation after marriage; or iv) naturalisation}

According to the third core principle, attribution of nationality has to be based on a genuine link between a person and the state, ${ }^{1666}$ which for birth right citizenship can be based ius sanguinis, ius soli or a combination thereof. ${ }^{1667}$ Furthermore, the possibility

\footnotetext{
1666 R. Bauböck, E. Ersboll, K. Groenendijk and H. Waldrauch (2006), p. 28; T. A. Aleinikoff and D. B. Klusmeyer (2002), p. 2.

1667 O. W. Vonk (2012), p. 45; T. A. Aleinikoff and D. B. Klusmeyer (2002), p. 2.
} 
of family unity should be upheld, meaning that all family members should be facilitated to have the samenationality if they want ${ }^{1668}$

\subsubsection{Eligibility codes and ius sanguinis and/or ius soli or a combination thereof}

The use of birth right ditizenship based on ius sanguinis and/or ius soli is one of the principles of nationality law. ${ }^{1669}$ For the sporting federation, this means that no preference should begiven to either ius sanguinis or ius soli.

However, it has been seen that only ten sports, namely aquatics, athletics, basketball equestrian, fencing, football, handball, rugby, skiing, and volleyball, deal with this issue and they have two different approaches, boiling down to ius soli or ius sanguinis and which are thus in line with the international standards. However, some have introduced additional requirements, eg. that the biological mother or father were born on the territory of the relevant country, which may prove problematic as it places adopted children at a disadvantage and is as such discriminatory. Moreover, the biological aspect, i.e the DNA link, is not conclusive for the acquisition iure sanguinis and should not be postulated by sporting federations. Foundlings in turn will face the sher impossibility of providing documentation of where they were born and where their ancestors were born. Moreover, thesituation of children born to parents whose family was originally from a ius sanguinis country, but are living abroad in another country will be difficult. If their parents were also born in another country, they cannot fulfil this requirement Nevertheless, as second or further generation expats, they still have correctly acquired the nationality of the original country through ius sanguinis. These additional requirements can thus lead to discriminatory outcomes and are contrary to the general principles of nationality law.

\subsubsection{Eligibility codes and option rights}

Option rights currently do not feature in any sporting federation's eligibility code. Athletes who make use of their option rights are therefore treated like those who acquired nationality through naturalisation. This is in itself a problem as option rights are usually only granted to those who al ready have a strong tie with the country (see Chapter 3.3.3). To have them face the same additional requirements as those who underwent the standard naturalisation procedure places them at a great di sadvantage, as they haveal ready proven that they havea genuinelink with the country.

Under the current rules, the case could arise that an athletewas bom in country $A$ that applies ius sanguinis, yet his or her parents are from country $B$ and are only legally residing in country $A$. The athlete grows up in country $A$ and upon reaching the age of majority makes use of options procedure or facilitated naturalisation procedure upon which the competent authority will take the aspects of birth in the country and residence into consideration. The athlete could thus now in principle

\footnotetext{
1668 R. Bauböck, E. Ersboll, K. Groenendijk and H. Wal drauch (2006), p. 28; P. Weis (1979), p. 97.

1669 O. W. Vonk (2012), p. 45; T. A. Aleinikoff and D. B. Klusmeyer (2002), p. 2.
} 
compete for country A. However, depending on the sporting federation there might be further obstacles, eg. additional requirements such as the birth place of the biological parents, a residence requirement or waiting period in his or her intemational carer after having acquired the new national ity. Such requirements can impose unreasonable difficulties, because the athlete has al ready passed a certain set of additional requirements to become a national of country $A$ and - furthermore - if the country woul d have applied ius soli he would al ready have been a national.

In conclusion, if states with more restrictive domestic laws themselves aim to counterbalance the negative effects thereof by providing option rights or facilitated naturalisation procedures, there should not be additional requirements set by sporting federations reimposing the imbalance. Hence, sporting federations should include provisions that exempt those having made use of option rights from additional requirements.

\subsubsection{Eligi bility codes and facilitated natural isation after marriage}

It is a principle in international law that family unity should be facilitated, which leads to the possibility of the acquisition of nationality based on family unity policies. Such an attribution is based on a genuine link, eg. based on marriage or a registered partnership and no unreasonable extra requirements should be in place $Y$ et, marriage can be difficult to ascertain, eg. when the bond between two samesex partners is not recognised by the relevant country. Furthermore, acqui sition of national ity by marriage is not provided for in all countries or, if it is, there are significant differences between provisions for men and women. ${ }^{1670}$ Another question arises with regard to the terminology: is acquisition of a nationality only by a bond between two people which by the country is labelled 'marriage' recognised? If so, those who enter into civil partnerships where possible eare severely di sadvantaged.

However, attention has to be paid in this context to gender equality and there should be no automatic acquisition of nationality by marriage for women. For sporting federations this means that nationality acquired through fast-track procedures after marriage should be recognised. However, if a woman acquired the nationality of a state automatically upon marriage, extra additional conditions are acceptable.

Yet, facilitated acquisition of nationality upon marriage, akin to option rights, does not feature prominently in current eligibility codes. Currently, only one sport, namely fencing, does not require those who underwent the facilitated naturalisation procedure to fulfil the same extra requi rements as those who followed the standard procedure Not paying special attention to this issue and not allowing for more lenient requirements after facilitated naturalisation procedures is problematic, as there is a strong family unity-based link between the person and the state if national ity was acquired subsequent to a marriage or registered partnership. Placing these athletes at a disadvantage, even if the countries they wish to represent have

E.g. in MiddleEaster Countries, seeL. E. van Waas (2014), p. 14. 
been forthcoming and facilitating the natural isation procedure seems not only unfair, but it is also contrary to the principle of facilitation of family unity. Consequently, sporting federations should pay close attention to those athletes who acquired nationality later in life and should not introduce additional requirements to those who made use of facilitated naturalisation procedures after marriage

\subsubsection{Eligibility codes and naturalisation:}

Naturalisation procedures as set down in national laws are often extremely lengthy, requiring residence periods and integration and language tests. However, there are instances in which countries themselves have applied less strict criteria to fast-track the naturalisation of persons of interest In order to combat mercenary tendencies and to ensure that there is a genuine link between the athlete and the country of representation, sporting federations have introduced additional requirements al ong the samelines of timeand residence

\subsubsection{Residence as a factor for the genuinelink}

Residence requirements can be either in place for athletes who have multiple nationality and wish to select one country; athletes who changed their nationality; or athletes who wish to compete for the country of residence without having the nationality of this country. Only 14 of the 35 sports impose residence requirements, namely aquatics, archery, athletics, basketball, curling, cycling, equestrian, football, handball, rugby, skating, triathlon, volleyball and wresting. The duration largedy varies from only one year imposed by aquatics, archery and skating to five years required by cycling. Moreover, one finds that the terms diverge greatly, which creates a diverse picture and since no clear definitions are given, there is greet (legal) uncertainty here Again, the differences in duration and wai ver possibilities can lead to a distortion of competition, with national associations circumventing stricter rules in case they both agree

In general, residence is only one of the ways a genuine link can be demonstrated between an athlete and a country. Furthermore, while there needs to be a threshold for residence, the reasoning behind the number of days or months set by the federations is not clear and appears arbitrary. Will someone who lives only 209 out of 365 days in a country have a significantly less genuine link than someone who lives there 210 out of 365 ? Furthermore, do these 210 days really need to be continuous? On the European continent, where one can cross several borders when travelling only two or three hours, does an overnight trip from Paris to Brussels eliminate the athlete's connection to France? Does a family holiday hiking in Austria for one week sever the connection an originally Bulgarian fencer has with Sweden where he had been living for 200 continuous days? If a football player was living in the Netherlands close to the German border, but competing for a German Bundestiga team and coming to the Netherlands only to sleep, is this sleepingresidence sufficient? 
Thus, although residence can certainly indi cate a link between a person and a country, it seems that a certain degree of flexibility is needed. Seeing especially that athletes do not only compete in national competitions, but al so in leagues for clubs in different countries, a differentiation between continuous and non-consecutive residence would be in order. ${ }^{1671}$ Taking the example of a small country A which does not have a great football league itself but which has several players who are playing at the top dubs in country $B$, one finds that those players would not fulfil the residence requirements if only continuous residence was recognised. In addition, there are supranational leagues, such as the Champions League in football, where clubs from different countries compete against one another and thus the athletes at this sporting level will trave frequently.

Overall, the manner in which the eligibility codes connoteand deal with residence raises more questions than it answers. Not only does the prescribed time period seem to have been selected arbitrarily, an actual definition of how residence can be established is al so missing in most cases. Moreover, the frequently problematic aspect of waivers comes into play. While granting exceptions to rules in special circumstances is certainly necessary, there are currently no easily accessi ble guidelines for the conditions under which wai vers may be granted. Since these decisions are not published, there is al so no possibility to see whether the establishing of a genuine link may under certain circumstances be scrutini sed less by the federations involved. As no precedents are created by the waivers and the rules are generally not dear, waivers may lead to a lack of legal certainty.

\subsubsection{Timeas a factor for the genuinelink}

In addition to the aforementioned residence requirements, several sports have enshrined waiting or non-competition periods for athletes wishing to change their country of representation. The aim of waiting or non-competition periods is to discourage easy and frequent changes between national teams. However, in the case of previously stateless athletes it al so harms people who might not have actively sought a transfer to another country. Hence a strict waiting period would be in order only if there was the possibility for a waiver if the athlete can ether prove a previously existent genuine link with the new country or if the athlete was in a special situation, eg. stateless. Yet, waivers are generally difficult with regard to the aurrent modus operandi, as the reasoning behind them are not dear and should be advocated with caution.

Overall, there are 22 federations whose eligibility codes feature periods of noncompetition, namely aquatics, archery, badminton, biathlon, boxing, curling, equestrian, fencing, golf, handball, hockey, ice hockey, judo, rowing, sailing, shooting, skating, skiing, tadkwondo, tennis, weightlifting, and wrestling. As

1671 For problematic aspects thereof, compare al so S. van den Bogaert, A. Cuyvers, S. Gardiner, R. Parrish, S. Miettinen, J. Soek and R. Siekmann (2010), p. $219 f f$. 
outlined, the duration can vary from four years of non-competition prescribed by golf or ice hockey to only one year required by others, such as archery or skiing. This requirement is one of the most intrusive and potentially destructive ones for an athlete's career, as the athlete will not be all owed to qual ify for or compete in major tournaments.

From a legal point of view, introducing the element of time is in order - as most countries' naturalisation laws include aspects of a certain duration of legal residence. However, merely waiting and biding one's time does not establ ish a genuinelink per se The question arises whether a waiting period should be applicable at all if an athlete has undergone the standard naturalisation procedure. Having complied with all domestic laws in place, which usually involve lengthy residence periods, waiting an additional period of time will not strengthen a genuine link.

Furthermore, these additional requirements should not be significantly stricter than those required by the states. For example, an athlete who acquired German national ity through the normal natural isation procedure and thus has al ready been a resident in Germany for eight years should not be faced with a sporting association which stipulates an additional five years waiting period. However, if a state reduced the required residence period for athletes to only six months, then an additional period from the federations would be in order to discourage Olympic opportunism Federations cannot deal with issues of national nationality laws on a case by case basis and analyse to what extent preferential treatment might have occurred, as they do not have the capacity for it This would be especially difficult as there are situations as envisioned by Article 6(4) European Convention on nationality in which facilitated naturalisations should be possible. For other cases, when such a preferential treatment cannot be justified, a general waiting period might best be instituted, although a waiver possibility should be given under special circumstances.

This can however not be akin to the current situation with eligibility codes al lowing national federations to agree between themselves on reductions or wai vers of the non-competition periods in case of a change of country of representation. As a consequence, athletes faced with the decision of whether to change the country of representation will not be able to correctly assess the influence the decision will have on their career. And it is thus not al ways certain that equal cases will be treated equally. Furthermore, the relevant federations need to agree on a reduction of the waiting period and it is not unlikely that the federation that is to be left by the athlete might receive some monetary incentives to let him or her go more quickly.

These rules should thus be changed and waivers should only be allowed according to strict, and openly accessible guidelines. Furthermore, decisions on waivers should be published and create precedents in order to improve the legal certainty. 


\subsection{Gender equality should be respected}

In all eigibility codes gender equality should be respected. ${ }^{1672}$ Hence, there should be no different rules in place for male or female athletes. Currently, this principle is breached by only ice hockey that offers more favourable conditions to femal eathl etes. While affirmative action may be seen as positive, there is no reason why female athletes should face significantly better conditions upon changing their country of representation.

\subsection{Sporting federations should provide rules for those who lost their nationality and allow them to continue their career}

One underlying principle of nationality law is that there should be no arbitrary deprivation of nationality. ${ }^{1673}$ This does not only mean that states cannot deprive parts of their population of their nationality, but it al so refers to current issues connected to the status of women. Traditionally, women acquired the nationality of their husband upon marriage, resulting in the loss of their own nationality, which could lead to a complete loss of nationality and thus statel essness upon divorce. This is connected to the issue of gender equality, as men's nationality usually does not depend on their marital status, yet it makes issues of family unity more difficult. Loss of nationality is currently not a primary concem of sporting federations, yet, akin to the issue of statel essness and refugees, it is extremely important Should an athlete lose his or her nationality, there should be rules in place that al low the athl ete to continue his or her career. Hence, along with matters of stateless and refuge athletes, all sporting federations should incorporate terms under which those athletes are able to continue their carer. It should be done, either, as previously stipulated, by allowing them to compete for their country of residence, or as the IOC has al ready all owed for the 2016 Olympics, by allowing them to compete under a neutral flag, such as the IOC's.

\subsection{There should be no discriminatory rules}

The principle of non-discrimination is one of the paramount rules both in law in general and in nationality law. ${ }^{1674}$ For sporting federations, this means that an eligibility rule should neither be discriminatory nor have a potentially discriminatory effect.

Starting with the directly discriminatory rules, few of the current rules are openly disadvantaging athletes. Yet, as previously described, there are some, eg. placing an undue focus on biological parents or their place of birth, such as handball or football. As previously pointed out, this places adopted children as well as foundlings at a great disadvantage and should thus no longer be included in eligibility rules. The same is applicable for the previously described case of ice hockey, which has less stringent requirements for femal e athletes.

\footnotetext{
1672 O. W. Vonk (2012), p. 45.

1673 K. Hailbronner (2006), pp. 53f; P. Weis (1979), p. 57; E. Horváth (2008), pp. 18f; O. W. Vonk (2012), p. 45.

1674 R. Bauböck, E. Ersboll, K. Groenendijk and H. Waldrauch (2006), p. 28; P. Weis (1979), p. 97.
} 
In turn, some rules can have discriminatory outcomes without being discriminatory themselves, which is the case with most residence periods or non-competition periods. Introducing such non-competition or residence periods is not contrary to standards of international law, yet the fact that these can be waived or reduced is problematic. There are no official or easily accessible guidelines under which such reductions or waivers are possible and thus athletes cannot judge beforehand which effect a change can have on their career. Moreover, as decisions aretaken internal ly and few means of appeal are available in some sports, it is possible that similar cases are not treated equally. While it is not possible to say that discrimination is currently happening, one is not given sufficient insights into the workings of the federations and their decisionmaking process to entirely rule out discriminatory practices. Hence, the conditions which need to be met to achieve reductions or wai vers should either be made public and should be similar for all sports, or the entire system should be abandoned and replaced with a better controlled one

\subsection{R ules concerning minor athletes should offer additional protection}

Moreover, special attention should be paid to the position of children and those who start their athletic careers at a very young age. Minors are in an especially vulnerable position and are generally presumed to need special protection, not only in the fiedd of nationality laws. Children are deemed incapable of taking legally binding decisions and are as such protected from being bound by unwise decisions. In addition, children are in principle protected from losing the nationality of a state if only one parent loses said national ity, ${ }^{1675}$ and if the parent loses thenational ity based on voluntary service in a foreign military force, ${ }^{1676}$ or conduct seriously prejudicial to the vital interests of the state party. ${ }^{1677}$

\subsubsection{Minors competing internationally}

As previously examined, there are only a few federations, namely: basketball, cycling, equestrian, football, hockey, rugby, and taekwondo, which deal with the position of minors. This is in itself a problem as minors should receive more protection than adult athletes. A child who is al ready an accomplished athl ete does not need less protection, but rather more protection, as monetary interests could be prioritised above the best interests of the child. Only the abovementioned sports address the aspect of minors at all and rugby only does so to underline that there are no separate rules applicable. Hencethemajority of the Olympic Sports remain muteon this point

The few regulations that deal with minor athletes recognise that minors are not able to make full decisions on which country they want to represent in international competitions and hence apply a degree of flexibility. Yet, the definition of who can

1675

1676

1677
Art. 7(2) European Convention on Nationality.

Art. 7(2) European Convention on Nationality and Art. 7(1)(c) European Convention on Nationality.

Art. 7(2) European Convention on Nationality and Art. 7(1)(d) European Convention on Nationality. 
be considered a minor largely differs, with federations such as FIFA not dealing with a particular age, but focussing on who has not played a match in an " $A$ " competition. Those who have not, may still decide play for another association. This means that players competing in the junior competitions can rethink their choice for which country they would like to play. Others, such as equestrian, in turn focus on the age of majority, before which athletes are free to decide.

It is true that a clear age distinction between minor and adult athletes might be problematic, as sometimes even young athletes are al ready competing at the highest international level. Hence, a distinction based on the level of the competitions the athlete participates in is more useful and easiest to handle However, seeing that continuously younger children are called up for different youth national teams, it is important to maintain a minimum level of protection for the youngest athletes al ready competing at that level. This includes that minors who are not capable of taking legally binding decisions cannot be held accountable for those decisions regarding their nationality and for which state they wish to compete. Furthermore, in most cases, it will be the athlete's parents exerting an influence on the minor and one would thus hold an athlete accountable for a decision his or her parents made years ago.

\subsubsection{Transition from minor athl ete to adult athl ete}

For sporting federations, the special position of minor athletes means that not only should there be provisions protecting these talented children from exploitation, but also the transition from minor athlete to adult athlete should be better controlled. Minor athletes are not able to decide for themselves for which country they wish to compete, their parents make such decisions for them However, children should never be bound by their or their parent's decisions made during their minority. They must also be given a reasonable period after having attained majority to change their position. This period might be established analogously to the one prescribed in the 1961 Convention on the Reduction of Statel essness for those who were born stateless and seek to obtain the national ity of a state through an application:

"that the application is lodged during a period, fixed by the Contracting State, beginning not later than at the age of eighteen years and ending not earlier than at the age of twenty-one years, so, however, that the person concerned shall be allowed at least one year during which he may himself make the application without having to obtain legal authorization to do 50."1678

There is thus a period of at least three years between the age of 18 and the age of 21 during which, if applied akin to this rule, an athlete should beallowed to redecide for which country heor shewishes to compete

1678 Art. 1(2)(a) Convention on the Reduction of Statel essness 1961. 



\section{Solutions}

Having answered the first two research questions, the following chapter will aim at providing answers to the question of how tensions that exist between the criteria applied by the sporting federations and the intemational standards of nationality law can be solved. After quickly recapitulating the problems that were unearthed in the previous chapters (Chapter 17.1), three different approaches will be presented. Firstly, the free market approach (Chapter 17.2) will be discussed. Secondly, a separate 'sporting nationality', as advocated by some scholars, will be examined, including the question of how such a sporting nationality could be put into practice (Chapter 17.3). This solution would seethe creation of a separate system of 'nationalities' only for the purpose of sports. Finally, rejecting both the free market approach and the notion of a sporting nationality that is entirely disconnected from the athlete's nationality, a third solution will be presented. Here a system of sporting licences that follows the desiderata and is in accordance with international standards of nationality law will be proposed (Chapter 17.3).

\subsection{Problems}

Having looked at the different eligi bility codes and how they can be eval uated against the desiderata, it has become apparent that several tensions exist between the sporting federations' eligibility criteria and the international standards of nationality law. The main problems arising from the tensions between eligibility criteria and the international standards of nationality law can be summarised as follows:

- Firstly, the terminology used and the definitions of the various terms are inconsistent and contradictory;

- Secondly, the issue of stateless athletes and asylum seckers is being inadequately addressed by most federations; better rules are needed that provide fast solutions and allow athletes to continuetheir carer;

- Thirdly, allowing only a set number of changes of the country of representation, or noneat all, is contrary to theright of changing one's nationality;

- Fourthly, additional requirements may have discriminatory elements, such as focussing on the biological parents and thus placing adopted children and foundlings at a di sadvantage;

- Fifthly, waiving or reducing residence and waiting periods leads to similar cases not being treated equally. Consequently, there is no legal certainty and, what is even more problematic, discriminatory practices cannot be counter-acted;

- Finally, minors who do not have the legal capacity to make binding decisions are expected to make binding decisions concerning their nationality and country of representation.

These tensions need to be addressed, while taking the aforementioned principles of international law and the previously established desiderata into consideration. In 
addition to the difficulties arising from the friction between the standards of national ity law and the eligibility criteria, there are problems inherent to the eligibility codes, which one should bear in mind. One major factor is that one needs to dive into each particular sport and its rules in order to find out who can compete for which national team at the Olympics. This is not a problem per se, as one could argue that different sports merit different requirements. However, for the purpose of the unifying Olympics movement, a common ground should be reached. In the context of the Olympic Games where the overall aim is to win as many medals for one country, differences in nationality requirements can lead to a distortion of competition.

\subsection{Solution 1: A free market approach}

One way of reaching a common ground would be to do away with the current codes and allow for a freemarket approach. Under this regime, supply and demand would be the determining factors in international sports. Countries offering the best sporting facilities and other benefits could easily attract and select the athletes they want In tum, athl etes could freely choose for which country they want to compete Due to fasttrack naturalisation procedures they might quickly acquire the nationality of the country and changes between countries could be immediately effective. For practical reasons, changes within a toumament could not be al lowed but, for therest of the time, athlete transfers between countries could be handled akin to the ones between the top sporting dubs.

\subsubsection{Implementing the freemarket approach}

While this approach would require the least intrusive rules, there are several problematic aspects. Firstly, this approach would lead to an increase in the fast-track naturalisation procedures which are currently debated heavily. ${ }^{1679}$ With the calls from scholars to limit the applicability of such procedures, this is unlike y to happen without a public outory. Secondly, with only fast-track naturalisation procedures, the underlying genuine link between the person and the state might be tenuous at best. While according to the desiderata, the genuine link between athlete and country should be recognised by the sporting federations if established by the naturalisation procedure, but thesefast-track options are often circumventing the standard nationality law. Altematively, the principle of taking nationality as a basis for selecting national teams might also be reconsidered. However, in that case, the whole matter of representative national teams becomes a moot point

\subsubsection{Desirability of the freemarket approach}

In addition to the workability of this solution, the question is whether a free market approach is desirable in the context of national representativeteams. The answer has to be no for several reasons. Such an approach would lead to a situation akin to themajor sports leagues with athletes transferring between clubs frequently. While this is not

See Chapter 3.7.3. Current debate on 'passports for sale'. 
inherently a bad situation, it could potentially createan al ignment between thenational leagues and the national teams, as richer dubs are situated in the countries in which more money is allocated to sporting issues. Such an alignment would render the distinction between international clubs and international competitions obsolete If one wants to maintain the compeitions between national teems in a more meaningful way, athl etes representing a country do need to have a genuine link therewith. And to ensure this link, the current scrutiny exercised by the federations regarding nationality changes does serve an important goal, as it may prevent opportunistic changes of the country of representation, especially before the Olympic Games. Thus, totally abolishing therules is not an option.

\subsection{Solution 2: A separate sporting nationality 1680}

As previously discussed, (see Chapter 4) not much common ground has been reached regarding a sporting nationality. However, the underlying principle is that the athl ete should have one connection or other with the country he or she represents. In most cases, this connection is referred to as nationality or citizenship. ${ }^{1681}$ Due to the huge differences in eligibility criteria, the question that arises is whether the introduction of a separate sporting nationality could solve the problem When looking at the current eligibility codes, one finds that there are several sports that al ready work with the idea of a sporting passport or licence, namely:

- Aquatics (FINA) refers to 'sport nationality ${ }^{1682}$ and stipulates that athletes may only represent countries of which they are citizens either by birth or by naturalisation; ${ }^{1683}$

- Gymnastics (FIG) refers to a 'Gymastics passport' or license, that shows that the athleteis a national of therevent country; ${ }^{1684}$

- Luge(FIL) (refers to a license, which is given if theathleteis a member of one of the FIL's member federations and has received the necessary training. ${ }^{1685}$ Notably, nationality does not play a rolehere,

- Rugby (World Rugby) refers to a 'Rugby nationality ${ }^{1686}$ and underlines that this will remain the same, regardless of their actual nationality once the athl ete was call led up for one country;

1680 This chapter is largely based on the article "Towards a Sporting Nationality?" by A.S. Wollmann, O. W. Vonk and G. R. deGroot published in 22 MJ 2 (2015), pp. 300 - 316.

1681 SeeTable L chapter 15.1.

1682 GR 2.5. FINA general rules 2013 - 2017 of November, 2015.

1683 If the athlete acquired citizenship through naturalisation, the FINA requires him or her to have lived in the country for at least two years.

1684 Article 5.1 FIG technical regulations 2008; Article 5.1 FIG technical regulations 2004 from J une 2013.

1685 Art. 3 International Luge regulations - Artificial Track - approved at the $62^{\text {nd }}$ FIL congress on J une $20^{\text {th }}, 2014$ in Innsbruck / Austria.

1686 Question 4 explanatory guidelines on the implementation of regulation 8 eligibility to play for National representative teams - International Rugby Board handbook as framed by the International Rugby Board last updated: $8^{\text {th }}$ March 2016. 
- Sailing (ISAF) - refers to 'ISAF eligibility', ${ }^{1687}$ meaning that either the athlete is registered with the ISAF by a national sailing authority or the athleteis a national of a member association;

- Skiing (FIS) refers to a license, which the national federations may only issue to those who are nationals of the country; ${ }^{1688}$

- Wrestling (UWW) refers to sports nationality that does not need to be based upon the athlete's nationality. ${ }^{1689}$

Luge is particularly interesting, as the license is not based on an athlete's nationality.

Thus, also the approaches to the introduction of a sporting licence differ depending on the Olympic sport Tuming from the sports approach to the theoretical approach taken by scholars, one finds that al so no common ground has been reached yet. Here, one of the major problems concerning the sporting nationality in particular and sport law or lex sportiva in general is that, so far, no clear and universally accepted definition exists. ${ }^{1690}$ Nevertheless, the need for better and clearer rules which would lead to more legal certainty has been recognised. ${ }^{1691}$

Some authors have proposed the introduction of a separate sporting nationality ${ }^{1692}$ without, however, going into detail about what such a sporting nationality should entail. ${ }^{1693}$ Overall, the main problems arising in this context are, firstly, the precise definition of 'sporting nationality' and, secondly, to what extent 'sporting nationality' should be dependent on an athlete's state nationality. ${ }^{1694}$ As described in Chapter 4, Oswald proposed a concept:

"that would be totally separate from state nationality, without losing the notion of national belonging. This would be known as 'Olympic nationality' or, even better 'Olympic membership'."1695

The question arising from this suggestion is how such a notion of national belonging can be established without referring to nationality itself or without relying on thesame criteria that the attribution of nationality usually relies upon.

\subsubsection{Granting a'sporting nationality'}

Technical questions come into play at this point, namely which institution could introduce such a sporting nationality. Should the IOC replace its existing rules with

1687 Art. 19.1 and Art. 19.4 ISAF regulations 2015 - Annex 3 - Eligibility code- November, 2014.

1688 Art. 203.3 International Ski competition rules (ICR) book IV Joint regulations For Al pine Skiing, Downhill Slal om Giant Slalom Super-G, Combined Events Team Events Paralle Events Ko Events approved by the $49^{\text {th }}$ internati onal Ski congress, Barcelona (Spa) Oberhofen, July 2015. Introduction UWW international rules for the change of nationality approved by the Bureau on $13^{\text {th }}$ December, 2015.

1690 SeeChapter 4.1; J.A.R. Nafziger (2011), p. 14; R. C. R. Siekmann (2011c), pp. 4ff.

1691 As the current rules are so varied and criteria can be set aside so easily; see $Y$. Hafner (2012), $p$. 238; R. C. R. Siekmann (2011b), p. 87.

1692 D. Oswal d (2009a), p. 58.

1693 Y. Hafner (2008), p. 1; Y. Hafner (2012), p. 216; D .Oswald (2009a), p. 58.

1694 Y. Hafner (2012), p. 238; D. Oswald (2009a), p. 58.

1695 D. Oswald (2009a), p. 58. 
one sporting nationality? As seen in the previous chapters, several federations have eligibility criteria that are contradicting those set down by the IOC, so this would not be a solution. Having all federations establish an eligibility code similar to the antidoping code would be extremdy complex, as matters of national belonging are more open to debate than banning illegal performance enhanaing methods. It is thus likely that each individual sporting federation would be called upon to introduce its own sporting nationality rules al ong (potentially) general guidelines. With this scenario, there would however be no improvement compared to the current situation of individual sports' eligibility codes. Also, if a sporting nationality was not directly linked to a state nationality, a non-state body would have to confer this sporting national ity on an athlete The fact that this concept is label led 'nationality' makes it a tricky proposal, as it is in itself contrary to the current concept of nationality as a bond between a person and a state

Considering for a moment that a new body was founded and was imbued with the powers to confer a national ity - al beit only a sporting one- there is another issue that arises, as even in that scenario disputes will happen. There thus needs to be an additional judicial body that allows for procedures in accordance with generally accepted standards of justice to challenge these decisions. The possibility to appeal against the verdict should al so be given and any verdict and reasoning would need to be published and made available to the public. Should the Court of Arbitration for Sport (CAS), which is a very likely candidate, be called, it would increase the workload of the CAS immensely. Consequently, a separate chamber might have to be introduced that deals exclusively with nationality issues. Furthermore, current developments, such as the Pechstein case, ${ }^{1696}$ have recently questioned the validity and applicability of the CAS rulings (see Chapter 4.5).

\subsubsection{Eligibility criteria for a sporting nationality}

Regardless of which body confers the sporting nationality, it would have to do so according to a set of criteria and in accordance with the principles of intemational law, as elaborated upon in the desiderata (Chapter 16.1). The basis remains a genuine link between country and athlete $Y$ et, in addition to the previously mentioned criteria of ius sanguinis and ius soli as well as the respective option rights or naturalisation procedures, which do not feature prominently in the current eligibility rules, ${ }^{1697}$ there needs to be something entirely inherent to the sporting context to establish a sporting nationality.

Should one follow the line of argument of Oswald and Hafner and create an 'Olympic nationality', the criteria applied would neither refer to an athlete's nationality nor make use of the criteria normally employed to establish such a nationality. As the usually used conditions refer to matters of birth, adoption or

\footnotetext{
1696 Pechstein cases: CAS 2009/A/1912 \& 1913; CAS OG 10/04 and OLG München 15 $5^{\text {th }}$ January 2015 Az. U 1110/14 Kart.

1697 See Chapter 15. 3.
} 
residence, these criteria could not be part of those standards that define the Olympic national ity. ${ }^{1698}$ As Hafner and Oswald do not specify which criteria would be used in contrast to those employed by domestic national law, one has to wonder how else such a link between athlete and state could be established. Moreover, this is contrary to one of the established desiderata, namely that the genuine link between athlete and country should be recognised by the sporting federations if established via i) ius soli, ius sanguinis or a combination thereof ii) option rights iii) facilitated naturalisation after marriage or iv) naturalisation.

Some sports consider a link between the athlete and the national league he or she competes in as sufficient. ${ }^{1699}$ Athletes who are involved in the training and practice of the sport in a particular country certainly have an inherently sporting link with this country. Using this link as the basis for the sporting nationality is problematic, however, as top clubs attract top athletes and have very international teams as a result. Yet, an athlete will not necessarily wish to compete for the national team of the country the club is situated in. Otherwise, a German football player who transfers to J uventus Turin would suddenly be eligible for the Italian national team This option would lead to an alignment between the top-leagues and the national teams, rendering the distinction between club and national teams superfluous.

Another possibility would be the focus on the country that has most invested both financially and otherwise - in the athlete's development. Here problems regarding the classification and qualification of the non-monetary investment will arise and a detai led catal ogue would be necessary. While it might be a fair approach in some respects, it would again benefit the richer countries or a system of categorising the time spent on an athlete as opposed to solely the money had to be introduced. All in all, this procedure would not constitute a simplification of the previous eligibility criteria and might only shift the focus of the discussion.

\subsubsection{Sporting nationality and dual nationals}

Should a separate sporting nationality be introduced, there is an additional complication as the position of dual nationals would need to be taken into consideration. Currently, athletes holding dual nationality could potentially be called up for the national teams of either country and each individual athlete does need to choose which nationality he or she favours in a sporting context ${ }^{1700}$ As such, a free choice can usually only be made once several criteria are met, such as a period of

\footnotetext{
1698 D. Oswal d (2009a), p. 58; Y. Hafner (2012), p. 238.

1699 Art. 406(1.3c) IIHF statutes and bylaws 2014 - 2018 of May 2014.

1700 Rule 5(4)(e) International Association of Athletics Federations competition rules 2016-2017 in force as from 1st November 2015; By law to Rule 13(1) IWF constitution and by-laws 2013 - 2016 - approved by IWF congress - Baku in effect with 01.01.2015; Art. 36.2.2 Fédération Internationale de Gymnastique statutes edition 2015 in effect from January 1 ${ }^{\text {st }}$, 2015; Art. 2.4.3 World Archery constitution and rules 2014 effective since $1^{\text {st }}$ A pril 2015.
} 
residence, ${ }^{1701}$ ancestry, ${ }^{1702}$ competition in national leagues, ${ }^{1703}$ and a period of noncompetition for international matches, if an athlete wishes to change the country of representation later in his or her career. Should a separate sporting nationality be introduced, the question is how this current system woul d be changed in order to fit in with thenew rules.

\subsubsection{Sporting nationality and therights it might entail}

A person who is a national of a given country receives not only the country's protection, but also rights and duties. An athlete who is called up to compete for a national team has a more specific connection to the sporting federation of the particular country in addition to being a national of the country. Again, the devil is in the details of thenomenclature By calling it a sporting nationality, one would createa national ity without any rights and duties usually associated with it, and therefore this would be a hollow concept Through the introduction of a paralle system of nationalities which are inherently different concepts, the entire system would need to be re defined. Such a system of two different concepts under closely connected terms is neither feasi ble, not desirable.

Another practical aspect is that twel ve out of 35 federations requirea passport as proof of nationality. ${ }^{1704}$ These sports would either need to change their eligibility criteria, or a separate sporting passport proving an athlete's sporting nationality. Naming the document passport would in turn lead to a two-level passport system, with the sporting passport not functioning as a travel document, which would add to the confusing terminology.

\subsubsection{Changing a sporting nationality}

As previous y outlined, the right to change one's nationality is a touchstone principle of nationality law. If one was to introduce a separate sporting nationality, there would thus need to be a possibility to change the sporting nationality. While one might consider the change of a sporting nationality that is entirely disconnected from the athlete's real nationality should in principle be easier, there are several problems. Firstly, the underlying difficulty of mercenary tendencies would continueto exist The solution to current problems cannot be to water down all the rules that are in place for

1701 Art. 28(1a) ITU constitution approved by the ITU congress, September 2015; Art. 21(b) book 3 chapter I FIBA rule book 2014 - 2019; Art 5(1) FIFA statutes: regulations governing the application of the statutes 2015.

1702 Art. 5(1) FIFA statutes: regulations governing the application of the statutes 2015; Art 6.2 Player Eligibility code of the International Handball Federation (IHF) of $8^{\text {th }}$ J uly 2014.

1703 Regulation 8.1 International Rugby Board handbook as framed by the International Rugby Board last updated: $8^{\text {th }}$ March 2016 and Question 3 explanatory guidelines on the implementation of regulation 8 eligibility to play for national representative teams - International Rugby Board handbook as framed by the International Rugby Board last updated: $8^{\text {th }}$ March 2016.

1704 Art. 2.41 World Archery constitution and rules 2015 effective since $1^{\text {st }}$ A pril 2015; Badminton general competition regulations November 2015; Art. 13, Art 14 and Art 15 book 3 chapter I FIBA rule nook 2014 - 2019; Art. 406(1.2) IIHF statutes and bylaws 2014 - 2018 of May 2014; as well as basketball, hockey, judo, rowing, skiing, table tennis, takwondo, volleyball, and weightlifting. 
a very valid reason. There would thus be a need for very detai led criteria that delineate under which circumstances a change is admissible in order to contravene the aforementioned fast-track naturalisation procedures before international competitions. Secondly, the aforementioned criteria for establishing a genuine link in the sporting context, without relying on elements used for the attribution of legal nationality, would also need to be tailored in such a way to allow for a change Thirdly, as previously outlined, a body would need to be established to assess and decide on applications and it must subsequently again be possi ble to chal lenge decisions in court.

One thus has to cond ude that introducing a separate sporting nationality does not have major benefits, as only additional procedures and criteria would be needed to grant and verify such a nationality. Moreover, the separation between the sporting national ity and national ity of an athl ete would be contrary to standards of international nationality law.

\subsection{Solution 3: A sporting licencein accordance with international standards of nationality law}

One solution to the aforementioned problem might be to introduce a separate sporting licence issued by the national federations. This would notably not be a sporting nationality. Contrary to the two solutions presented before, the focus of a sporting licence would be to align the eligibility criteria for national teams with the international standards of nationality law:

a) Sporting federations should recognise the athlete's nationality and should have provisions for stateless athl etes and refugees that allow them to continue to compete intemationally;

b) Changes of the country of representation have to be allowed and should not be limited by a maximumnumber of changes;

c) The genuine link between athlete and country should be recognised by the sporting federations if established via i) ius soli, ius sanguinis or a combination thereof ii) option rights iii) facil itated naturalisation after mariageor iv) natural isation;

d) Gender equality should be respected;

e) Sporting federations should provide rules for those who lost their nationality and al low them to continuether carer;

f) Thereshould beno discriminatory rules;

g) Rules conceming minor athletes should offer additional protection;

Several of these elements are induded at least in part in current eligibility codes. However, to create a standard set of rules, all of these issues need to be addressed. Consequently, the criteria applied need to be very detailed and have to guarantee that there is indeed a genuine link between athletes and the state they represent in order to prevent fast track naturalisations prior to major sporting events. The underlying principle for these rules has to be that such a sporting licence cannot be given to athl letes who do not have a genuinelink with the state In general, one can presumethat an athlete who hol ds the nationality of a state does have a genuine link with this state. 
If, however, as in the case of dual nationals, additional requirements are introduced to ensure or select the link which is to be deemed the strongest, these requirements have to be chosen very carefully. Caution is needed because countries establish different rules regarding the acquisition and loss of nationality. Consequently, there is al ready an inherent imbal ance between states based on their domestic nationality rules. ${ }^{1705} \mathrm{~A}$ country applying ius soli and ius sanguinis a patre and a matre will have a much bigger pool of athletes to choose from than a country using exclusively ius sanguinis a patre Chances to have better athletes - provided that the necessary investments in talent scouting, training and training facilities are made- arefar higher for states with the most inclusive domestic national ity laws. If states with more restrictive domestic laws aim to counterbalance this through providing option rights or facilitate naturalisation procedures, there should not be additional requirements re-imposing the imbalance

Nevertheless, the federation's scrutiny does serve an important goal, as it may prevent opportunistic changes of the country of representation. Yet, this scrutiny may never disadvantage those who make use of compensation mechanisms such as option rights by imposing additional requirements. In case an athlete does not make use of compensation mechanisms, additional rules are to be applied. These may not, however, be too restrictive and should be firmly applied without random possibilities for waivers. I am of the opinion that such an article should not only be included in the IOC's Olympic Charter, but also in all sporting federations' eligibility rules catal ogues.

\subsubsection{Calling it a 'licence' instead of 'nationality'}

As previously stated, terminology is of the essence, due to different connotations words may have Speaking of attributing a 'nationality' purely for the sporting context - even if it was based on the athlete's nationality - has to be rejected. Nationality not only denominates the bond between a person and the state, but also may only be granted by a state authority. A non-state organisation cannot for both legal and political reasons claim to confer a 'nationality' on a person, regardless of the rights attributed to that status.

Moreover, what eligibility in international competitions actually entails is that the body goveming one particular sport grants an athlete the right to represent one country at intemational level in that particular sport. A 'licence' is generally accepted to mean an authority's official permission to do something, provided one fulfils the criteria set by the authority. This word and its connotations thus best capture the essence of eligibility criteria and should thus be used.

\subsubsection{Draft article}

Having seen all these problems and possible solutions, the following draft artide aims at providing a more comprehensive approach. In addition, a dear set of definitions and 
an explanatory memorandum would need to be delineated by each individual sport as well as the IOC. Each individual sport will naturally further adopt its own code of conduct and refer to the anti-doping and anti-betting codes. While a breach of those codes usually leads to an athlete's ineligibility, this aspect of eligibility criteria is disconnected from the nationality aspect and is, as such, outside the scope of this dissertation.

\section{Article 1: Athlete eligibility and sporting licences}

1.1. Any athlete competing internationally should be affiliated with a country of which he or sheis a national.

1.2. To mark the connection between the country and the athlete, the relevant national sporting federation shall issuea sporting licence, after:

1.2.1. Theathlete provided proof of his or her nationality by submitting a copy of the passport The sporting federation recognises the acquisition of nationality and the establishment of a genuinelink:

1.2.1.1. at birth through ius soli or ius sanguinis;

1.2.1.2. through compensation medhanisms such as option rights;

1.2.1.3. through facilitated natural isation offered by countries for:

- spouses of their nationals;

- children of one of their nationals;

- children, one of whose parents acquires or has acquired its nationality;

- children adopted by one of their nationals,

- persons who were born on their territory and reside there lawfully and habitually;

- persons who are lawfully and habitually resident on their territory for a period of time beginning before the age of 18 , that period to be determined by the internal law of the respectivestateconcerned;

- stateless persons and recognised refugees lawfully and habitually resident in theteritory;

\subsubsection{Naturalisation.}

1.2.2. In case of naturalisation, the national federation needs to verify that the relevant country's standard procedure was complied with.

1.2.3. Automatic acquisition of nationality upon marriage will not be immediatel y recognised.

1.2.4. Theathletesigned the code of conduct agreement

1.3. Athletes holding dual or multiple nationality are initially free to choose for which country they wish to compete and will thus only hold one sporting licence of their country of choice

1.4. In case an athlete acquires a new national ity or wishes to compete for a country of which he or she is a national, but he or she has not yet competed for, the athlete needs to acquire the sporting licence of the new country. The athlete 
wishing to acquire a new licence has to notify the sporting federation and the relevant national federations in writing of his or her wish and the competent authority needs to take a decision within 30 working days upon receiving the request

1.5. For such an acquisition of a new sporting licence a two-year non-competition period is applicabl e for athl etes who have al ready competed internationally.

1.5.1. An automatic exception to the waiting period is granted in the following cases:

1) The athlete has made use of option rights or other facilitated procedures to naturalisation as set down under the relevant country's domestic law of the state He or she can then competediredty for the new country; or

2) The changein theathlete's national ity was brought about by external circumstances on which the athlete had no influence, eg. teritorial transfer. The athlete may then directly compete for the new country; or

3) The athlete is stateless or a refugee He or she may then directly compete for the country of residence or under the flag of thesporting federation.

1.5.2. An athlete may apply for a waiver of the waiting period if he or she can show that the athl ete's naturalisation procedure was in accordance with the naturalisation procedure generally applicable for people in the same position as the athlete in the athlete's new country of representation. Decisions will be taken on a caseby-case basis and apped procedures shall beopen beforean independent body.

1.6. Changes cannot be made within one tournament or during a qualification round for a toumament

1.7. If the athlete with multiple nationality al ready competed internationally prior to theage of majority, he or shemay redecide for which country he or shewants to compete once within the first three years after reaching the age of majority without having to observea non-competition period.

1.8. Junior athletes, meaning those who have not yet reached the age of majority, may choose fredy for which country of nationality they wish to compete. They may al so decide to compete for another country, given that they are a national thereof, without prior waiting period.

1.9. In case of State succession, meaning the replacement of one State by another in the responsibility for the international relations of teritory; or if a new national federation is recognised by the International sporting federation, an athlete may continue to represent the country to which he bel ongs or bel onged if that country continues to have a national federation. However, he or she may, if he or she prefers, choose to represent his or her new national federation. This particular choice must receivetheapproval of theinternational federation. 
1.9.1. Should the athl ete afterwards wish to re decide for which of the entities he or she wishes to compete, he or she needs to ask permission from the international federation and has to prove that special circumstances apply in his or her case Such a decision will betaken on a case by case basis and appeal s procedures shall be open beforean independent body.

1.10. Stateless athletes, regardless of whether they have been stateless from birth or lost their nationality later, may compete for their country of residence Should they wish to compete for another country, a decision will betaken on a case bycase basis and appeals procedures shall be open before an independent body.

1.11. Refugees who can no longer compete for their country of origin may compete for their country of residence Should they wish to compete for another country, a decision will be taken on a case-by-case basis and appeals procedures shall be open.

1.12. Disputes are to be settled by a competent and independent authority and the verdicts as well as the reasoning leading to them are to be published and easily accessibleetectronically for all.

1.13. No additional eligibility criteria that might have effects contrary to the rules stipulated above shall beincorporated by any federation.

17.4.3 How is this draft artide in accordance with standards of international nationality law?

This artide was written with the desiderata and the standards of intemational law in mind. Stateless athl etes and refugees are explicitly addressed and the solution akin to the one currently favoured by the IOC for the Rio 2016 Games was taken on board. Minors are especiall ly mentioned and may decide fred y for which country they wish to compete before they reach the age of majority. After their $18^{\text {th }}$ birthday they have a chance to redecide within the next three years without facing a non-competition period.

Moreover, the genuine link and the modes acquisition of nationality are explicitly elaborated upon as they are not in current eligibility codes. In addition, changes of nationality are allowed without any limits and the required waiting period of two years is not too strict. There are several automatic exceptions that will be granted when it is clear that an athlete has a genuine link with the country he or she wishes to represent While the general waiving possibilities are extremely limited, athletes may apply for a waiver and will need to show that the procedure through which they became nationals of the country was not unduly hurried along. As with all decisions that are to be taken on a case-by-case basis, appeals procedures before an independent body have to be in place to ensure faimess.

\subsubsection{How does this draft artide solve the current problems inherent in eligibility codes?}

The above-elaborated draft artide should not only be included in the IOC's Olympic Charter, but also in all sporting federations' eligibility rules catalogues, as it would 
ensure legal certainty, not only for athletes wishing to compete at the Olympics, but for all athletes of one particular sport Moreover, comparability of themanner in which athletes are treated by their federations and when independent bodies decide on issues such as eligi bility based on nationality, will hep to ensure that similar cases are treated equally. 



\section{Conclusions and Recommendations}

This dissertation explored the terra incognita of nationality requirements in Olympic sports. The exploration began with the legal concept and regulation of nationality (Chapter 3), which led to the establishment of the touchstone principles of nationality for the purpose of this dissertation, i.e the principles according to which the sports' eligibility criteria were examined (Chapter 3.8.). Afterwards, nationality was placed in the context of lex sportiva (Chapter 4) and special attention was paid to the concept of the genuine link in the sports context (Chapter 4.3). Having thus set the scene, the following chapters deal $t$ with threeresearch questions:

1) What are the eligibility ariteria aurently employed by theOlympic Sports? (Chapter 5- 15)

2) To what extent is it problematic to align these currently applicable eligi bility criteria with intemational standards of national ity law? (Chapter 16)

3) How can tensions that may exist between the criteria applied by the sporting federations and the intemational standards of nationality law besol ved? (Chapter 17).

\subsection{Nationality law and the touchstone principles thereof}

Before looking at the eligibility codes of Olympic sports and the way they sometimes conflict with the international standards of nationality law, one should briefly recapture the essence of nationality law (see Chapter 3 for an daborate description). The terms 'nationality' and 'citizenship' are used in intemational law to describe the legal link between an individual and a state. While in the common usage both terms may be used interchangeably, from a legal perspective the exact term chosen is important, as 'citizenship' has the additional connotation of political membership of a state

For such a relationship between a person and the state to be effective under international law, a 'genuinelink' has to exist This concept is derived from the 1955 Nottebohm case In case of disputed nationality or citizenship, the tie between state and person is put to the test to determine whether a genuine link can be established. The existence of such a link leads to several rights and duties both for the state and the individual, eg. the individual has the right to unrestricted access to the state's territory and has to be re admitted after sojourns abroad.

National ity or citizenship is usual lyconferred upon children at birth, with factors like the place of birth (ius soli) or blood relations (ius sanguinis) determining which nationality a child acquires. The situation of foundlings is more problematic, al though it is generally agreed that they, as well as children who would otherwise be stateless, should acquire the nationality of the country where they were bom or found respectively. 
Acquiring a national ity at a point after birth through a process called natural isation is usually significantly more difficult compared to acquisition at birth. For this, an individual needs to have created a significant link with a country which is not the country of origin, eg. through permanent residence This process mainly aims at ind uding those into the political community that have spent a significant part of their lives there, such as children who migrated to the country at an early ageand spent their formative years there or second generation migrants in a ius sanguinis country and to whom option rights or facilitated naturalisation procedures are available There are several reasons why a person might wish to acquire a new nationality, either for residence rights, rights to political participation in a place they live, to facilitate employment or to end administrative difficulties. Countries in tum valuenaturalisation as a means to integrate immigrants or to attract people who are important for the country economically, such as trained labourers, are otherwise considered beneficial, such as tal ented athletes, or those who haverendered the country a particular service

Improved trave possibilities and cross-border marriages have led to people developing ties to more than one country. While some people acquire a second nationality through naturalisation, others may acquire two nationalities at birth, as cross-border marriages of nationals from ius sanguinis countries can lead to dual national ity for the children. While having multiple nationalities has become more accepted in recent years, there are still reasons why it can be seen as problematic. The underlying issue is that dual nationals are seen as having a divided loyalty as they owe al legiance to more than one state.

A person's nationality may be subject to changes throughout their lifetime, eg. through external circumstances. These circumstances occur when the state's teritory changes - either by state succession, cession or decol onisation. In such a situation, the states involved will often draft treaties with rules tailored to the circumstances. Furthermore, while the genuine link between a person and a state is that it is usual ly deemed to be permanent or at least stable and long lasting, actions by either the state or the person may sever the bond. However, it is important to stress that no person should be arbitrarily deprived of his or her nationality, especially if this would leave the person stateless. Overall, there is consensus among states that statelessness should be avoided. However, as the 'right to nationality' cannot be enforced against a particular state, statel essness occurs nevertheless.

From the above, the following touchstone principles of nationality law were distilled (see Chapter 3.8):

- No violation of fundamental human rights, in particular theright to nationality;

- Statelessness is to beavoided;

- Right to change one's nationality

- Renunciation of national ity should beal lowed, if it does not causestatel essness,

- Attribution of nationality has to be based on a genuine link between a person and the state

- Birth right citizenship can be based ius sanguinis or ius soli or a combination thereof; 
- Family unity should be uphedd;

- Gender equality should be respected;

- No arbitrary deprivation of nationality;

- No discrimination.

Additionally, the position of children and minors is of paramount importance as they arein an especially vul nerable position and need additional protection.

These principles were used in the analysis and evaluation of the eligibility criteria set by theOlympic sports.

\subsection{What are the eligibility criteria currently employed by the Olympic Sports?}

To answer this question, the eligibility codes of the following sports were examined in Chapters 5-15: FINA (Aquatics), WA (Archery), IAAF (Athletics), BWF (Badminton), FIBA (Basketball), IBU (Biathlon), IBSF (Bobsleigh), AIBA (Boxing), ICF (Canoe Kayak), WCF (Curling), UCl (Cycling), FEl (Equestrian), FIE (Fencing), FIFA (Football), IGF (Golf), FIG (Gymastics), IHF (Handball), FIH (Hockey), IIHF (Ice Hockey), IJF (Judo), FIL (Luge) UIPM (Modem Pentathlon), FISA (Rowing), World Rugby (Rugby), ISAF (Sailing), ISSF (Shooting), ISU (Skating), FIS (Skiing), ITTF (Table Tennis), WTF (Takkwondo), ITF (Tennis), ITU (Triathlon), FIVB (Volleyball), IWF (Weightlifting), and UWW (Wrestling).

It became clear that the 35 Olympic sports present a very diverse picture On the one hand, some sports went into great detail on several aspects, while on the other hand others only briefly mentioned problematic points, while some remained rather unspecific in their rules. Furthermore, there were great differences regarding the federations' approaches to the question of eligibility. By looking at all the Olympic sports, an overview of the different possible requirements athletes are faced with was gained. The most striking observation is that, while the sports differ greatly regarding the details, most sports have rules in force that require athletes to have a genuine link with the country they represent, either through residence or by being a national of the country.

The standard that was to be used as a tertiumcomparationis was thus difficult to establish and several problems arose. Firstly, rules applicable prior to 2013 were not al ways forthcoming from the federations. Secondly, not all topics which are of interest for the purpose of this dissertation were treated in equal detail among the federations' current eligibility codes. As for several aspects, only less than a third of all Olympic sports have rules in place, it is not possible to draw conclusions on this topic for all 35 Olympic sports. Thirdly, not all sports experienced a substantial change in their eligibility criteria within the examined time frame.

Consequently, there is a certain bias in the results, as developments could only be monitored in an extremely limited number of cases. One should first mention that no changes have occurred with regard to the rules of stateless athletes and those competing for the country of residence. However, this is bound to change as, for the 
upcoming Olympics, the IOC will for the first time allow refugee athletes to compete Similarly, since 2013, trends regarding teritorial transfers have been limited to the introduction of a rule deal ing with the aftermath of state successi on by golf in 2014 and modern pentathlon in 2015. The important topic of minor athletes al so has not been brought up by many sports and while, on the one hand since 2008 FIFA no longer focuses on an athlete's $21^{\text {st }}$ birthday, on the other hand since 2014 ice hockey now places importance on the $10^{\text {th }}$ birthday and the country in which an athlete has lived since. There is thus al so no discernible trend in either direction. Ice hockey is also the only sport that had a significant change in policy regarding a maximum number of changes, as the limit of one change of country of representation was abolished in 2014. These aspects of eligibility criteria were thus not subject to changes so far.

There was, however, a discernible trend towards allowing changes of the country of representation, even after an athlete competed internationally. In 2012 athletics introduced such a rule for athletes who wish to change their country of representation and, since 2013, their approach is even more detailed. Similarly, boxing has added the possi bility to change the country of representation in 2015, as did golf in 2014. On the other side of the spectrum, wrestling introduced a sporting nationality in 2015. Furthermore, athletes with multiple nationality have become more important and most federations have chosen to treat them like those having changed their national ity and they face the same waiting periods: four years for golf since 2014; three for modern pentathl on since 2015; two years for rowing since 2013; as well as two for boxing since 2015. Thus, the first discernible trend is towards a codification of rules. The second development is towards allowing changes of the country of representation, although different additional criteria were introduced by the various federations.

The opposite held true regarding the federations' take on modes of acquisition of nationality, which do not feature prominently in most eligibility codes. Similarly, while residence periods are still used by many federations, recently three federations changed this aspect of their eligibility criteria. In 2007, equestrian first introduced a residence requirement and a year later ice hockey followed suit However, while equestrian has al ready allowed exceptions to the rule since 2010, ice hockey has taken a different approach, focussing on the time legal ly resident in a country after a given birthday. While this was the $12^{\text {th }}$ birthday in 2012, the 2014 rule change saw this reduced to the $10^{\text {th }}$ birthday, making the requirement easier to meet. While for these two sports the importance of residence seems to have reduced, or at least the requirements have become easier to meet, athletics relies more for such requirements since 2013, as currently a threyear continuous residence period may help to reduce the three year non-competition period.

Non-competition periods have become more important and new requirements were recently introduced, e.g. two years for boxing in 2015 or rowing since 2013. Golf went further in 2014 requiring a four-year non-competition period. Additionally, since 2011, equestrian especially al igned with the IOC's required non- 
competition period for the Olympics. While these four examples show a trend towards more and stricter non-competition periods, there has been trend in the other direction as well. On the other side of the spectrum, wrestling only imposes a twoyear period since 2012 if the federations do not agree and, since 2013, athletics offers the possibility to reduce the threeyear non-competition period by proving three continuous years of residence in the relevant country. $Y$ et, the overall trend goes towards limiting changes of the country of representation by means of noncompetition periods.

18.3 To what extent are these currently applicable eligibility criteria in accordance with the international standards of nationality law?

When examining the extent to which eligibility codes and touchstone principles of nationality law dash, themain focus is on the genuine link between the athl ete and the statehe or she represents in a sporting competition. Here it is important to note that the definitions the sporting federations give for a genuine link should not be at odds with the principles of intemational law. From the above enumerated principles, one can formulate several desiderata, i.e desirableaspects of eligibility criteria:

a) Sporting federations should recognise the athlete's nationality and should have provisions for stateless athl etes and refugees that allow them to continue to compete intermationally;

b) Changes of country of representation haveto beallowed and should not belimited by a maximumnumber of changes;

c) The genuine link between the athlete and the country should be recognised by the sporting federations if established via i) ius soli, ius sanguinis or a combination thereof ii) option rights iii) facilitated naturalisation after mariage or iv) naturalisation;

d) Gender equality should berespected;

e) Sporting federations should provide rules for those who lost their nationality and al low them to continuether carer;

f) Thereshould beno discriminatory rules;

g) Rules conceming minor athletes should offer additional protection.

\subsubsection{Terminology}

In addition to the content of the rules, the way they are phrased is important As previously explained, words have different connotations and using terms with different connotations interchangeably leads to confusion and undear rules. This is contrary to an underlying assumption in law that the same word should mean the same within the same code Confusingly, as seen in Chapter 15.1, 13 federations use nationality and citizenship interchangeably13 times. Moreover, golf and takwondo consider citizenship as merely a condition that needs to be fulfilled to acquire nationality, yet they do not provide a differentiating definition of these terms. As seen previously, it is usually the case that all citizens are al so nationals, but not all nationals are citizens. 
The federations are thus dearly using the terms contrary to generally established principles.

Moreover, most federations do not provide clear definitions of nationality or citizenship, which makes comparing their respective concepts difficult. The same can be said for 'residence' which is not al ways defined. Thus it might be better for future clarity to either provide a definition in the rule book itself or for all Olympic sports to agree on a particular set of terms to allow for easier communication between the sports.

18.3.2 Sporting federations should recognise the athl ete's national ity and should have provisions for stateless athletes and refugees that allow them to continue to competeintemationally

Currently, the UNHCR estimates that there are at least ten million stateless people in the world. Ammesty International estimates that more than 50 million people were forced to fle from their home country and sedk asylum essewhere To adapt to this current situation and to address problems that are largely ignored by the federations, the IOC will for the first time allow refugee athletes to compete during the 2016 Games. As they will not be able to compete for the country from which they havefled, they will compete under the IOC flag and the Olympic Anthem will be played during the ceremonies. So far, it remains undear how the qualification for the individual disciplines will be handled, yet through this measure the IOC clearly reacts to circumstances athletes might find themsel ves in.

It is likely that sporting federations will soon follow, as currently there are only seven out of 35 federations which deal with stateless athletes, refugees or asylum seekers. The approaches taken by those seven largel y differ.

Allowing stateless athletes or refugees to compete for the county of residence is more in line with the general principles of nationality law, as residence helps to forge a genuine link between the athlete and the country. $Y \notin$, the criteria with which residence is assessed should not be too strict. Generally, in order to address the pressing issue of statelessness and refugees and in order to be in line with the touchstone principles of nationality law, as the IOC has recently done, all federations should indude provisions on stateless or refugee athl etes.

18.3.3 Changes of the country of representation have to beall owed and should not be limited by a maximum number of changes

Changing one's country of representation, which is one of themost complex aspects of the eligibility codes, is usually possible with either residence or waiting period requirements having to be ful filled. Overall, there are only two sports that do not al low for any change at all and whose provisions are thus contrary to the touchstone principles of nationality law. The first one is football, wherea player has to decide for which country he or she wishes to compete prior to the first ' $A$ ' match. The samegoes for rugby players whose rugby nationality remains the same, regardl ess of their actual nationality. All other Olympic sports rely on the assumption that a person should have 
a genuine link with the country he or sherepresents and that this connection is defined by nationality or citizenship.

In order to avert situations in which athletes change their country of representation frequently and might thus cause a difficult situation within one international tournament, sporting federations have included several provisions in their codes with additional criteria for such changes. These provisions largely differ regarding the conditions that need to be fulfilled and the circumstances that will be taken into consideration. Including aspects such as residence is in line with the touchstone principles of nationality law, since residence is used as a criterion for naturalisation.

Furthermore, some federations, namely cycling, basketball, fencing, handball, voll eyball, and wrestling specify that only one change can occur during an athlete's career. Not only do circumstances such as state successions, political devel opments, or personal circumstances not conform to the clean-cut provisions; this provision is also contrary to the touchstone principles of nationality law, as changing one's national ity is a human right.

With the increasing acceptance of dual nationality in recent decades, al so in the sporting context dual or mult tiplenational ity has been dealt with more frequently and most sports nowadays include articles on dual nationals in their eligibility codes. The majority of these al low athletes to initially choose fred y for which country they wish to compete Once an athlete with multiple nationality has competed for one country and then wishes to compete for another country of which he or she is a national, usually the same procedure applies as when the nationality was newly acquired. Consequently, residence requirements or waiting periods will be in place to counter-act mercenary tendencies.

Other sports, likehandball, ice hockey and football approach the issue differently and have additional requirements in place to decide with which of the countries the genuine link is strongest. While determining whether or not a genuine link exists with the help of ius soli or ius sanguinis criteria is in line with the touchstone principles of nationality law, some of the criteria used are not. One example of a discriminatory requirement is having the biological parents' birth place in the respective country as the determining factor, as it seriously affects athl etes who were adopted as children or who were foundlings. This provision should thus be changed to al so include foster or adopted parents.

Finally, some sports, like rugby or football, limit the choices for athletes with dual nationality and distinguish between ' $A$ ' matches and those matches in lower level competitions. After an athl ete competed for a national team in an ' $A$ ' match, he or she can no longer change the country of representation. While limiting mercenary tendencies is necessary for the sake of the sport and continuity in competitions, this is not in accordance with the right to change one's nationality.

In tum, decolonialisation, state succession and cession lead to situations in which an athlete's nationality may be subject to change without him or her having initiated the change This topic is not dealt in detail with by the Olympic federations, 
as only nine out of 35 sports refer to territorial transfers in their codes. Interestingly, most of these articles are phrased in the same way and can thus not only be compared easily, but they al so show that one general approach is taken by thesenine sports. In such cases, the athlete is left to choose which country he or she wants to represent This is in line with the touchstone principles of nationality law that al low for changing one's nationality as well as the principle that a genuine link should exist between a person and the state.

18.3.4 Thegenuinelink between an athleteand a country should berecognised by the sporting federations if established via i) ius soli, ius sanguinis or a combination thereof ii) option rights iii) facilitated naturalisation after marriage or iv) naturalisation

As previously described, the conferral of nationality usually happens at birth through either ius soli or ius sanguinis. Themajority of the Olympic sports do not deal with the question of how exactly a nationality is acquired. The few that do have two different approaches, which all boil down to ius soli or ius sanguinis and are thus in line with the international standards. Some have additional requirements in place that are more problematic as they refer to the biological mother or father, thereby placing adopted children at a disadvantage Foundlings in tum will be faced with the sher impossibility of providing documentation of where they were bom and where their ancestors were bom.

Another difficult aspect is 'residence', as the federations' definitions, if any are given, vary grealy. Nevertheless, most Olympic sports focus on residence when examining whether a genuine link between a person and a state exists. This is done either to verify a genuine link in case of a change of nationality or to establish a connection if an athlete wishes to compete for a country of which he or she is not a national. As residence is usually one of the conditions that needs to be met when a person seeks naturalisation, this is in line with the principles of national ity law.

However, the way in which residence is quantified in most eligibility codes raises several questions and the number of days seems to have been picked arbitrarily.

Time and especially a waiting or non-competition period is frequently used by sports as an additional requirement if athletes wish to change their country of representation. Some have these requirements in addition to the residence requirement, while others only have non-competition periods. Overall, there are 22 federations whose el igibility codes feature a period of non-competition. The duration of this differs and ranges from four years required by ice hockey and golf to only one year required by aquatics, archery, and skiing.

From a legal point of view, introducing an element of time is in itself not contrary to the touchstone principles of nationality law and most countries' naturalisation laws include aspects of a certain duration of legal residence. However, this waiting period is not directly linked to residence Merely waiting and biding one's time does not establish a genuine link per se and while it discourages easy and 
frequent changes between national teams, it does not contribute much to fostering a genuinelink.

Furthermore, any additional requirements should not be significantly stricter than those required by the states. If an athl ete has fulfilled the standard requirements for a naturalisation procedure, made use of option rights or was a dual national from birth, the fact that the state considers him or her as a national should be sufficient for a genuinelink.

\subsubsection{Gender equality should berespected}

In all eligi bility codes, gender equal ity should be respected. Hence, there should be no different rules in place for male or femal eathletes. Currently, this principleis breached by only one federation, namely ice hockey, which offers morefavourable conditions to female athl etes. While affirmative action may be seen as positive, there is no reason why female athletes should be subject to more favourable conditions upon changing their country of representation.

18.3.6 Sporting federations should provide rules for those who lost their nationality and al ow them to continuether carer

Along with matters of stateless and refugee athletes, all sporting federations should incorporate terms under which athletes who lost their nationality are able to continue their career. It should either be done by all owing them to compete for their country of residence or, as the IOC has al ready allowed for the 2016 Olympics, by allowing them to compete under a neutral flag, such as the IOC's. This is connected not only to the issue of gender equality and family unity, as it is usually female athletes whose nationality is made dependent on their marital status. Loss of national ity is currently not a primary concern of sporting federations, yet, akin to theissue of statel essness and refugees, it is extremely important Should an athlete lose his or her nationality there should be rules in place that allow the athlete to continue his or her carer. An exception to this rulemust certainly be the case if thenationality was lost due to fraud on the part of the athlete or if thenational ity is lost at the application of theathlete, i.e by renunciation or release

\subsubsection{There should beno discriminatory rules}

Eligibility requirements should not be discriminatory and few of the current rules are openly disadvantaging certain athletes. However, there are some that place an undue focus on biological parents or their place of birth. Nevertheless, some rules can have discriminatory outcomes, which is the case with most residence periods or noncompeition periods, prescribed for athletes wishing to change their country of representation. Introducing non-competition or residence periods is not contrary to the standards of international law, yet the fact that these can be waived or reduced is problematic. There are no official guidelines under which such reductions or waivers are possibleand thus athletes cannot judge beforehand which effect a change can have on their career. Moreover, as decisions are taken internally and few means of appeal 
are available in some sports, it is possible that similar cases are not treated equally. While it is not possible to say that discrimination is currently happening, one is not given sufficient insights into the workings of the federations and their decision-making processes to rule out discriminatory practices entirely. Hence, the conditions which need to be met to achieve reductions or waivers should either be made public and should besimilar for all sports, or the entire system should be abandoned and replaced with a better controlled one

\subsubsection{Rules conceming minor athletes should offer additional protection}

Minors are in an especially vulnerable position and are generally presumed to need special protection, not only in the fiedd of nationality law. Yet, there are only a few federations that deal with the position of minors and the majority of Olympic sports remains mute on that point Even if minors arementioned, the provisions largel y differ as only basketball, cycling, equestrian, football, hockey, rugby, and taekwondo refer at all to minors and rugby only does so to underline that there are no separate rules applicable This is in itself a problem as minors should receive more protection than adult athletes. A child who is al ready an accomplished athlete does not need less, but rather more, protection. The underlying problemis that minors who are not recogni sed as legally capable to make legally binding decisions cannot be expected to make binding decisions regarding their nationality and for which statethey wish to compete Thus, those federations who either contain no spedial rules for minors or those who explicity state that minors will be treated as adults are acting contrary to generally accepted legal principles.

The few regulations that deal with minor athletes recognise that minors are not able to make fully-informed decisions on which country they want to represent in international competitions and hence apply a degree of flexibility. Others such as FIFA do not concem themselves with matters of age, but they focus on who has played a match in an " $A$ " competition. Those who have not may still decide to play for another association. This means that players competing in the junior competitions can rethink their choice for which country they would like to play. The problem arising from a clear age distinction between minor and adult athletes is that sometimes even younger athletes are al ready competing at the highest international level. Hence, a distinction based on the leve of the competitions the athlete participates in is more useful and easiest to handle However, seeing that more and more younger dhildren are called up for different youth national teams, it is important to maintain a minimumlevel of protection for the young athletes.

\subsubsection{Waiving eligi bility requirements}

One of the major problems with the current eligibility criteria set by the sporting federations is that they may be reduced or wai ved. This leads to athletes deciding on whether to change the country of representation being faced with different obstacles within the samefederation. It is thus not certain that equal cases will betreated equally and thus discriminatory practices become possible 
Moreover, reductions or wai vers are often subject to the federations agreement, which might mean that the establishing of a genuine link could under certain circumstances bescrutinised less by the federations involved.

\subsection{How can tensions that may exist between the criteria applied by the sporting federations and the international standards of nationality law be solved?}

The main problems arising from the tensions between eligibility criteria and the international standards of nationality law can be summarised as follows:

- Firstly, theterminol ogy and definitions used are inconsistent and contradictory;

- Secondly, theissue of statel ess athl etes and asylum seekers is not being addressed adequately by most federations; better rules are needed that provide fast solutions and all ow athletes to continuether carer;

- Thirdly, allowing only a set number of changes of the country of representation or none at all, is contrary to theright to change one's nationality;

- Fourthly, additional requirements havediscriminatory elements, such as focussing on the biological parents and thus placing adopted children and foundlings at a disadvantage

- Fifthly, waiving or reduaing residence and waiting periods leads to similar cases not being treated equally. Consequently, there is no legal certainty and discriminatory practices cannot be counter-acted;

- Finally, minors who do not have the legal capacity to make binding decisions are expected to make binding decisions conceming their nationality and country of representation.

These tensions need to be addressed, while taking the aforementioned principles of international law and the previously established desiderata into consideration.

\subsubsection{Option one a freemarket approach}

One way of reducing the tensions between the standards of intemational law and the eligibility criteria would be to simply further reduce the artides of the eligibility codes - as some sports do not go into great detail - and adopt a free market approach. Without the often contradictory and sometimes even discriminatory rules, supply and demand would be the determining factors in international sports. The countries demanding the best athletes would need to invest in the best facilities and other benefits to the athletes. Sport development would see new investments and sport as a whole could benefit In turn, athletes could freely choose for which country they want to compete. Due to fast-track natural isation procedures, they might quickly acquire the nationality of a country and changes between countries could be immediately effective. For practical reasons changes within a tournament would not be all owed but, for the rest, athlete transfers between countries could be hand ed akin to those between thetop sporting dubs. 
Heren lies one of the main problems of this approach, as fast-track naturalisation schemes have recently fuel led heated debates on citizenship as a whole Examples of this were the investor citizenship programmes currently operating in some European Union member states such as Malta, Cyprus and Portugal. As almost no residence requirements are in place for rich investors who are thus able to buy a European passport from one of these countries and consequently gain free access to the Schengen area, an EU-wide discussion on these practices has arisen. Furthermore, while the genuine link between an athlete and the country should be recognised by the sporting federations if established by naturalisation, these fast-track options often circumvent the standard nationality law. Altematively, also the principle of taking nationality as a basis for selecting national teams might bere-considered. However, in that case, the wholematter of representativenational teams becomes a moot point

Another problem might arise as creating a market akin to the market for athletes for national leagues could lead to an alignment between the national leagues and the national teams, as richer dubs are situated in the countries in which more money is allocated to sporting issues. Such an alignment would render the distinction between international clubas and international competitions obsolete If one wants to maintain the compeitions between national teams in a more meaningful way, athletes representing a country do need to have a genuine link therewith. And to ensure this link, the current scrutiny exercised by the federations regarding nationality changes does servean important goal, as it may prevent opportunistic changes of the country of representation, especially before the Olympic Games. Totally abolishing the rules is therefore not an option.

\subsubsection{Option two: a separate sporting nationality}

Having established that a set of eligibility rules would have to be applicable to all federations and their intemational competitions, the next question is how lenient or strict the rules should be The preliminary question one has to ask in this respect is whether one wants to give athl etes the most liberty in choosing which country they can compete for to further their careers, or whether one's primary aim is to ensure that athletes have a genuine link with the country they compete for. The problems arising from stringent rules are, however, that certain residence or non-competition requirements will hinder athletes who have not actively changed their nationality but who are forced to do so dueto statesuccession.

Some authors have proposed the introduction of a separate sporting nationality without, however, going into detail about what such a sporting nationality should entail. Overall, the main problems arising in this context are, firstly, the precise definition of 'sporting nationality' and, secondly, to what extent sporting nationality should be dependent on an athlete's state national ity. Oswal d proposed a concept in which the sporting nationality would be entirely disconnected from the athlete's nationality, which begs the question how such a notion of national belonging can be established without referring to nationality itself or without relying on the same criteria on which the attribution of nationality usually relies. Examining all 
possibilities to establish a genuine link between an athlete and the country of representation and seeing that this proposal would only shift the focus of the problem, one has to conclude that introducing a separate sporting nationality does not have major benefits. Moreover, the term sporting nationality should al so not be chosen, because any workable definition of this link is at odds with the generally accepted use of the term 'national ity'.

Having examined nationality law not only in general, but also more specifically the concept of sporting national ity, one finds that whil e greater simplicity for athlete eligibility in international competitions is certainly desirable, the introduction of a sporting nationality is not.

\subsubsection{Option three A sporting licencein accordance with theintemational standards of nationality law}

The solution favoured in this dissertation is to introduce a separate sporting licence issued by thenational federations, as presented in a 'Draft article' (seeChapter 17.4.2). This sporting licence would notably not be a sporting nationality as advocated by some scholars. The citeria for granting a sporting licence needs to be very detailed and should guarantee that there is indeed a genuine link between athletes and the country of representation in order to prevent fast-track naturalisations prior to major sporting events. The underlying principles determining these criteria have to be in line with the general standards of intemational nationality law, and such a sporting licence cannot be given to athl etes who do not have a genuine link with the state In general, one can presume that an athl lete who holds the nationality of a state does have such a link. If, however, as in the case of dual nationals, additional requirements are introduced to ensure or select the link created by the nationality, these requirements have to be selected very carefully. Caution is required because- as al ready mentioned above - countries set down different rules regarding the acquisition and loss of nationality. Consequently, there is al ready an inherent imbalance between states based on their domestic nationality rules. A country applying ius soli and ius sanguinis a patre and a matre will have a much bigger pool of athletes to choose from than a country using exdusively ius sanguinis a patre. Chances to have better athletes provided that the necessary investments in talent scouting, training and training facilities are made - are far higher for states with the most indusive domestic nationality laws. If states with more restrictive domestic laws themselves aim to counterbalance this through providing option rights or facilitating naturalisation procedures, there should not be additional requirements reimposing theimbal ance

The problems encountered by stateless and refugee athletes need to be explicitly addressed and a solution like the one currently favoured by the IOC for the Rio 2016 Games needs to be provided. Furthermore, the position of minors needs special attention and they should be able to decide fredy for which country they wish to compete before they reach the age of majority. After their $18^{\text {th }}$ birthday they need to have a chance to redecide within the next three years without facing a noncompetition period. For this sporting license, the rules need to explicitly refer to all 
modes of acquisition of nationality, ensuring that option rights and facilitated naturalisation procedures are recognised and treated akin to acquisition of nationality at birth. In addition, changes of national ity are to beallowed without any limits and the proposed waiting period of two years is not too strict. Moreover, as the waiting period cannot be waived, legal certainty is ensured. Since terms and terminology have been a large issue with current codes, the definitions and explanations should be spelled out before the article to clarify all issues. 


\section{Bibliography}

\subsection{Literature}

\section{T. A. Aleinikoff and D. B. K lusmeyer (2002)}

T. A. Aleinikoff and D. B. Klusmeyer (2002). Citizenship policies for an age of migration Washington, DC: CamegieEndowment for International Peace.

\section{H. Andres (2009)}

H. Andres (2009). Les problèmes éthiques dela national ité dans lesport Colloque international Ethiqueet sport en Europe, Université Rennes II, Rennes: France Retrieved from: https:/hal shs.archives-ouvertes.fr/hal shs-00389324v2/document.

\section{Amnesty International (2015)}

Amnesty International (2015). Global refugee crisis in numbers. Retrieved from: https://www.amnesty.org/en/press-releases/2015/06/gl obal-refugeecrisis-in-numbers/

\section{H. Arendt (2015)}

H. Arendt (2015). Elementeund Ursprüngetotaler Herrschaft Antisemitismus. Imperialismus. Totale Herrschaft, $18^{\text {th }}$ edition. München: Piper

\section{Armstrong (2014)}

C. Armstrong (2014). The Price of Selling Citizenship. In A. Shachar and R. Bauböck (Eds.) Should Citizenship be for Sale? EUI Working Papers, pp. 13- 14. Retrieved from http://cadmus evi.eu/bitstream/handle/1814/29318/RSCAS 2014 01.pdf?sequence=1. On $6^{\text {th }}$ August, 2015.

\section{R. Barbulescu (2014)}

R. Barbulescu (2014). Global mobility corridors for theultrarich. Theneoliberal transformation of citizenship. In A. Shachar and R. Bauböck (Eds.) Should Citizenship be for Sal e? EUI Working Papers, pp. 15 - 16. Retrieved from http://cadmus eui.eu/bitstream/handl e/1814/29318/RSCAS_2014_01.pdf?sequence=1. On $6^{\text {th }}$ August, 2015.

\section{R. Bauböck, E. Ersboll, K. G roenendijk and H. Waldrauch (2006)}

R. Bauböck, E. Ersboll, K. Groenendijk and H. Wal drauch (2006). Introduction. In R. Bauböck, E. Ersboll, K. Groenendijk and H. Waldrauch (Eds). Acquisition and Loss of nationality - polidies and trends in 15 European states - Volume 1: Comparative Analysis. Amsterdam AmsterdamUniversity Press, pp. 15- 34.

\section{R. Bauböck (2014a)}

R. Bauböck (2014a). Summary: gl dbal, European and National Questions about the Price of Citizenship. In A. Shachar and R. Bauböck (Eds.) Should Citizenship be for Sale? EUI Working Papers, pp. 1-2. Retrieved from http://cadmus eui.eu/bitstream/handl e/1814/29318/RSCAS_2014_01.pdf?sequence=1. On $6^{\text {th }}$ August, 2015. 


\section{R. Bauböck (2014b)}

R. Bauböck (2014b). What is wrong with selling citizenship? It cornupts democracy! In A. Shadhar and R. Bauböck (Eds) Should Citizenship befor Sale? EUI Working Papers, pp. 19 - 21. Retrieved from

http://cadmus aui.eu/bitstream/handle/1814/29318/RSCAS_2014_01.pdf?sequence=1. On $6^{\text {th }}$ August, 2015.

\section{B lackshaw (2011)}

I. Blackshaw (2011). Towards a ‘Lex Sportiva. Theinternational sports lawjournal 2011 3\& 4 Retrieved from

http://uww.asser.n//Defaultaspx?site_id=11\&level 1=13908\&level2=13941\&level3= 15266

\section{S. Van den Bogaert (2005)}

S. Van den Bogaert (2005). Practical regulation of themobility of sportsmen in theEU post Bosman. The Hague Kluwer Law International

\section{S. van den B ogaert, A. C uyvers, S. G ardiner, R. Parrish, S. M iettinen, J . Soek} and R. Siekmann (2010)

S. van den Bogaert, A. Cuyvers, S. Gardiner, R. Parrish, S. Miettinen, J. Soek and R. Siekmann (2010). Study on the equal treatment of non-nationals in individual sports competitions. Commissioned by the European commission, Directorate-General for education and culture T.M.C. Asser Instituut, Edge Hill University, Leiden University.

\section{S. Carrera (2014)}

S. Carrera (2014). How much does EU citizenship cost? The Maltesecitizenship-forsale-affair: A breakthrough for sincere cooperation in citizenship of the union? CEPS Paper in Liberty and security in Europe No64/2014. Retrieved from https://www.ceps.eu/system/files/LSE\%20No\%2064\%20Price\%20of\%20EU\%20Citiz enship\%20final2.pdf

\section{Chopin (2006)}

I. Chopin (2006). Administrative practices in the acquisition of nationality. In R. Bauböck, E. Ersboll, K. Groenendijk and H. Waldrauch (Eds). Acquisition and Loss of nationality - policies and trends in 15 European states - Volume 1: Comparative Analysis, Amsterdam Amsterdam University Press, pp. 221 - 264.

\section{R. Courtney (2015)}

R. Courtney (2015). Report on Citizenship Law: Nicaragua. EUDO Citizenship Country Report, RSCAS/EUDO-CIT-CR 2015/9. Retrieved from:http://cadmus eui.eu/bitstream/handle/1814/35996/Eudo_CIT_2015_09.pdf?sequ ence $=1$ 
J. Dzankic (2014)

J. Dzankic (2014). The MalteseFal con, or: my Porsche for a Passport In A. Shachar and R. Bauböck (Eds.) Should Citizenship be for Sale? EUI Working Papers, pp. 17 18. Retrieved from

http://cadmus eui. eu/bitstream/handl e1814/29318/RSCAS_2014_01.pdf?sequence=1. On $6^{\text {th }}$ August, 2015.

\title{
A. Duval (2015a)
}

A. Duval (2015a). The Pechstein ruling of the Oberlandesgericht München - Timefor a new reform of CAS? Retrieved from http://www. asser.nl/SportsLaw/Blog/post/the pechstein-ruling-of-the-oberlandesgericht-munchen-timefor-a-new-reform-of-cas.

\section{A. Duval (2015b)}

A. Duval (2015b). The Court of Arbitration for Sport and EU Law: Chronide of an Encounter. 22 MJ 2, pp. 224 - 256.

A.Duval and B. Van Rompuy (2015)

A.Duval and B. Van Rompuy (2015). The Compatibility of Forced CAS Arbitration with EU Competition Law: Pechstein Reloaded. Retrieved from: http://ssrn.com/abstract=2621983 or http://dx.doi.org/10.2139/ssrn.2621983

\section{G. Engelbrecht (2004)}

G. Engel brecht (2004). The Individual Right to Participatein theOlympic Games. The international sports law journal $20041 \& 2$ Retrieved from

http://wnw.asser.nl/Defaultaspx?site_id=11\&leve1 1=13908\&level2=13941\&level3= 14052

\section{E scobar (2015)}

C. Escobar (2015). Report on Citizenship Law: Columbia. EUDO Citizenship Country Report, RSCAS/EUDO-CIT-CR 2015/10. Retrieved from: http://cadmus eui.eu/bitstream/handl e/1814/35997/EUDO-CIT_2015_10Colombia.pdf?sequence $=3$

\section{E uropean Union Study on training of young sportsmen/women in E urope} Extension - Part I H ome grown player rule A pril 2008.

European Union Study on training of young sportsmen/women in Europe ExtensionPart I Homegrown player rule April 2008 Retrieved from http://ec.europa.ev/sport/documents/doc272_en.pdf_And last visited on $3^{\text {rd }}$ July 2013.

\author{
R. Falk (2002) \\ R. Falk (2002). An emergent matrix of citizenship: complex, uneven, and fluid. In \\ N.Dower and J. Williams (Eds.). Global citizenship- a critical reader. Edinburgh: \\ Edinburgh University Press, pp. 15- 29.
}

\section{A. Follesdal (2002)}

A. Follesdal (2002). An emergent matrix of citizenship: complex, uneven, and fluid. In N.Dower andJ. Williams (Eds.). Global citizenship- a critical reader. Edinburgh: Edinburgh University Press, pp. $71-83$. 


\section{Fransman (2011)}

L. Fransman (2011). Fransman's British National ity Law ( $3^{\text {rd }}$ Edition). Hayward's Heath: Bloomsbury Publishing.

\section{S. W. Goodman (2010)}

S. W. Goodman (2010). Naturalization Policies in Europe expl oring patterns of indusion and exclusion. Retrieved from http://eudo-citizenship.eu/docs/7-

Naturalisation\%20Policies\%20in\%20Europepdf

\section{S. W. G oodman and M. M. H oward (2013)}

S. W. Goodman and M. M. Howard (2013). Eval uating and explaining the restrictive backlash in citizenship policy in Europe In A. Sarat (Ed). (2013). Special issue: who belongs?: immigration, citizenship and the constitution of legal ity. Bingley [etc.]: Emerald, pp. 111 - 139.

\section{G. R. de G root (2003a)}

G. R. deGroot (2003a).Towards a European nationality law =Vers un droit européen denationalité Maastricht: Universiteit Maastricht

\section{G. R. de G root (2003b)}

G. R. deGroot (2003b). Handboek nieuw nationaliteitsrecht Deventer: Kluwer

\section{G. R. de Groot and E. P. J Vrinds (2004)}

Gerard-RenédeGroot and Erik P. J Vrinds (2004). The position of children in respect of decisions made by their parents regarding their nationality. Report for the $3 r d$ European conference on national ity, Strasbourg 2004, 16. Retrieved from: http://www.coeint/t/dghl/standardsetting/nationality/3_WEB\%20E\%20Rep.\%208.pdf.

\section{G. R. de G root (2006a)}

G. R. deGroot (2006a). Sports and unfair competition via nationality law. Maastricht J ournal of European and Comparative Law, 161-171.

\section{G. R. de G root (2006b)}

G. R. deGroot (2006b). Remarks on therelationship between the general legal nationality of a person and his 'sporting national ity'. International Sports Law J ournal $20061 \&$ 2. Retrieved from http://www.asser.nl/Defaultaspx?site id =11\&level 1=13908\&leve 2=13941\&leve 3=1 4013. And last visited on 15h January, 2014

\section{G. R. de G root and J . J . K uipers (2006)}

G. R. deGroot and J. J. Kuipers (2006). Sport en Nationaliteit Retrieved from http://arno.unimaas.nl/show.cgi ffid=7601.

\section{G. R. de G root (2008)}

G. R. deGroot (2008). Nationaliteit en rechtszekerhed. Den Haag: BoomJ uridische uitgevers 
G. R. de G root and M. P. Vink (2008)

G. R. de Groot and M. P. Vink (2008). Meervoudigenationaliteit in Europees perspectief: en landenvergelijkend overzicht. Den Haag: Adviescommissievoor Vreemdelingenzaken

G. R. de G root and M. P. Vink (2010)

G. R. deGroot and M. P. Vink (2010). Loss of Citizenship- Trends and regulations in Europe EUDO Citizenship Observatory. Retrieved fromhttp://eudocitizenship.eu/docs/Loss.poff

\section{G. R. de G root (2012)}

G. R. deGroot (2012). Nationality Law. InJ an M. Smits (Ed). Elgar Encyclopedia of Comparative Law ( $2^{\text {nd }}$ Edition). Cheltenham Edward Elgar Publishing House

\section{G. R. de G root and M. P. Vink (2013)}

G. R. deGroot and M. P. Vink (2013).The relationship between citizenship and residence inthe citizenship laus of the Merber States of the European Union. CARIM-India RR 2013/25. Robert Schuman Centrefor Advanced Studies, San Domenico di Fiesole (FI): European University Institute, 2013/25. Retrieved from: http://www.india-eurmigration.eu/media/CARIM-India-2013-25.pdf.

Y. Hafner (2008)

Y. Hafner (2008) Changein nationality: the next Bosman? Olympic Capital Quarterly (October 2008, Volume3, Number 4), pp. 1-3

\section{Y. Hafner (2009)}

Y. Hafner (2009). Sporting national ity in the ancient and modern Olympic Games. Paper Published In Report on International Seminar On Olympic Studies For PostgraduateStudents 1 - 30 J uly 2009. Published by the International Olympic Academy and thel nternational Olympic Committee Retrieved from http://www.ioa.org.gr/?lang=en\& item $=94 \&$ view $=9 \&$ pro_id=5

\section{Y. Hafner (2012)}

Y. Hafner (2012). Athletes eligibility in national teams and EU law: What can we learn from two doped swimmers? Antonio Rigozzi / Dominique Sprumont/Yann Hafner (éd.)Retrieved from

https:/www.academia.edv/2288313/Athletes_eligibility_in_national_teams_and_EU_ law_What_can_we_leam_from_two_dopped_swimmers

\section{K. Hailbronner (2006)}

K. Hailbronner (2006). National ity in public international lawand european law. In

R. Bauböck, E. Ersboll, K. Groenendijk and H. Wal drauch (Eds). Acquisition and Loss of national ity - policies and trends in 15 European states-Volume 1:

ComparativeAnal ysis. Amsterdam: Amsterdam University Press, pp. 35 - 104.

\section{D. Hall (2012)}

C. D. Hall (2012). Fishing for All-Stars in a Time of Global FreA Agency:

Understanding FIFA Eligibility Rules and the Impact on the U.S. Men's National Team, MarquetteSports Law Review, pp. 191 


\author{
E. H orváth (2008) \\ E. Horváth (2008). Mandating identity: citizenship, kinship laws and plural nationality \\ in theEuropeen Union. Al phen aan den Rijn: Kl uwer Law Intemational
}

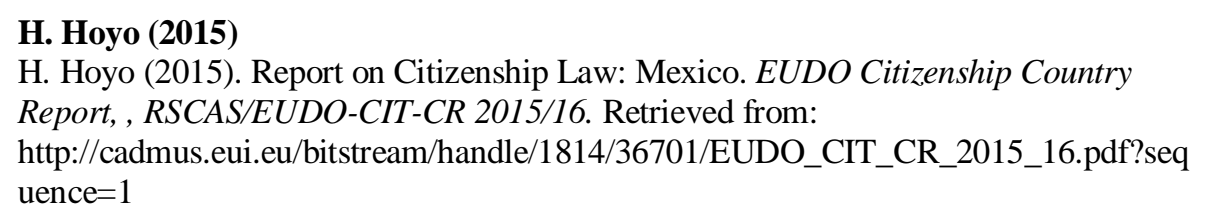

\title{
B. K olev (2008)
}

B. Kolev (2008). Lex Sportiva And Lex Mercatoria. Theinternational sports law journal $20081 \& 2$ Retrieved from

http://wnw.asser.nl/Defaultaspx?site id=11\&level1=13908\&/ evel2=13941\&level 3= 14042

\section{R. K opczyk (2012)}

R. Kopczyk (2012). Legal Problems of the Olympic Movement The international sports lawjournal $20121 \& 2$. Retrieved from

http://www.asser.nl/Defaultaspx?site_id=11\&level1=13908\&level2=13941\&level 3= 15438

\section{H. T. Kruijt (2006)}

H. T. Kruijt (2006). Sport Law and Nationality - A Field of Competition. Unpublished paper.

\section{R. Magni Berton (2014)}

R. Magni Betton (2014). Citizenship for those who invest into the future of the state is not wrong, the priceis the problem In A. Shachar and R. Bauböck (Eds.) Should Citizenship be for Sal e? EUI Working Papers, pp. 11 - 12. Retrieved from http://cadmus eui.eu/bitstream/handl e/1814/29318/RSCAS_2014_01.pdf?sequence=1. On $6^{\text {th }}$ August, 2015.

\section{B. M allon \& T. Widlund (1998)}

B. Mallon \& T. Widlund (1998). The 1896 Olympic Games. Results for All Competitors in All Events, with Commentary. J efferson: McFarland. 


\section{B. M anby (2010) \\ B. Manby (2010). Citizenship and Statelessness in Africa: A Comparative Study. Retrieved from: \\ https:/www.opensodietyfoundations.org/sites/default/files/ditizenship- africa_20101118.pdf \\ B. M anby (2015) \\ B. Manby (2015). Citizenship and Statelessness in Africa: Thelawand politics of belonging. Oijsterwijk: Wolf Legal Publishers}

\section{K. Marx (2010)}

K. Marx (2010). Zur Kritik der Hegel schen Rechtsphilosophie[Kritik des Hegelschen Staatsredhts §§ 261 - §§313]. Bellin: Contumax GmbH \& Co. KG

J. M argolis (unknown publishing date)

J. Margolis (unknown publishing date). Winning Gold at Passport Control: AsylumSeeking Olympians and the Olympic Passport Retrieved from https://www.academia.edu/11000201/Winning_Gold_at_Passport_Control_Asylum_S eeking_Olympians_and_the_Olympic_Passport

\section{A. Mestre (2008)}

A. Mestre(2008). The Legal Basis of theOlympic Charter. Theinternational sports lawjournal $20081 \& 2$ Retrieved from

http://www.asser.nl/Defaultaspx?site_id=11\&level1=13908\&/evel2=13941\&level3= 14042

\section{M. . . Mitten and T. Davis (2008)}

M. J. Mitten and T. Davis (2008). "AthleteEligi bility Requirements and Legal Protedion of Sports Participation Opportunities". Faculty Publications. Paper 546. Retrieved from: http://scholarship.law.marquetteedu/facpub/546

\section{J . Mitten and H. O pie (2010)}

M. J. Mitten and H. Opie (2010). "Sports Law": Implications for the Development of Intemational, Comparative, and National Law and Global Dispute Resolution. Marquette Law Scholarly commons Faculty Publications. Paper 519. Retrieved from http://scholarship.law.marquetteedu/facpub/519

\section{J. A. R. Nafziger (2004) \\ J. A .R. Nafziger (2004). Lex Sportiva. Theinternational sports law journal 2004 1\& 2 Retrieved from http://unw.asser.nl/Defaultaspx?site id=11\&level1=13908\&level2=13941\&level3= 14052}

\footnotetext{
J. A. R. Nafziger (2011)

J. A. R. Nafziger (2011). Defining theScopeand Structure of Intemational Sports Law: Four Conceptual Issues. Theinternational sports law journal 2011 3\& 4 Retrieved from http://uww.asser.nl/Defaultaspx?site id=11\&level1=13908\&level2=13941\&level 3= 15266
} 
P. Ochoa (2014)

P. Ochoa (2014) What Money Can't Buy: Face-to-Face cooperation and Local Democratic Life. In A. Shachar and R. Bauböck (Eds.) Should Citizenship be for Sal e? EUI Working Papers, pp. 22 - 23. Retrieved from

http://cadmus ai .eu/bitstream/handle/1814/29318/RSCAS_2014_01.pdf?sequence=1. On $6^{\text {th }}$ August, 2015.

\section{T. K. Oommen (1997)}

T. K. Oommen (1997). Citizenship, nationality and ethnicity: reconciling competing identities Cambridge[etc.]: Polity Press

D. 0 swald (2009a)

D. Oswald (2009a). Nationalitédans le sport Rerrieved from http://www. olympic.org/Documents/Congress_2009/XIIIE\%20CONGRES\%200LY MPIQUE\%20-\%20CONTRIBUTIONS.pdf

\section{D.0swald (2009b)}

D.Oswald (2009b). Les Jeux Olympiques. Retrieved from:

http://www.olympic.org/Assets/XIII\%200LYMPIC\%20CONGRESS/PDF/ACTES_2 .0/DENIS_OSWALD_FR.pdf

\section{O wen (2014)}

D. Owen (2014). Trading citizenship, human capital and the European Union. In A. Shachar and R. Bauböck (Eds.) Should Citizenship befor Sal e? EUI Working Papers pp. 31 - 32. Rerieved from

http://cadmus, eui.eu/bitstream/handle/1814/29318/RSCAS 2014 01.pdf?sequence=1. On $6^{\text {th }}$ August, 2015.

\section{P. Panagiotopoulos (2011)}

D. P. Panagi otopoul os (2011). Lex Sportiva And Intemational Legitimacy Goveming: Protection Of Professional Players. US-CHINA LAWREVIEWVol. 8, pp. 121- 136

\section{Panagiotopoulos (2012)}

D. Panagiotopoul os (2012). Lex Olympia: From the Inter-StateAncient Greek Law to the Rul e of Participation in the Modern Olympic Games. The international sports law journal $20121 \& 2$. Retrieved from

http://uww.asser.nl/Defaultaspx?site id=11\&level1=13908\&/ evel2=13941\&level 3= 15438

\section{Sawyer and H. W ray (2014)}

C. Sawyer and H. Wray (2014). Report on Citizenship Law: United Kingdom EUDO Citizenship Country Report, RSCAS/EUDO-CIT-CR 2014/1. Retrieved from: http://cadmus eui. eu/bitstream/handl e/1814/33839/EUDO-

CIT_2014_01_UK.pdf?sequence=1. 


\section{J. Scherrens (2007)}

J. Scherrens (2007). Themusdedrain of African football players to Europe trade or trafficking? Master Thesis. Rerieved from http://www. etcgraz.at/typo3/fileadmin/user upload/ETC-

Hauptseite/Programm/Aktuelles/the_human_trade_of_african_football_players.pdf

\section{A. Shachar (2009)}

A .Shachar (2009). The birthright lottery: ditizenship and gl obal inequality.

Cambridge, MA [ecc]: Harvard University Press

\section{A. Shachar (2011)}

A. Shachar (2011). Picking Winners: Olympic Citizenship and the Global Racefor Talent TheYale Law J oumal. 20YaleL.J. 2088, pp. 2088- 2139

\section{A. Shachar (2014)}

A. Shachar (2014). Dangerous Lai sons: Moen and Citizenship. In A. Shachar and R. Bauböck (Eds.) Should Citizenship be for Sale? EUI Working Papers, pp. 3-8.

Retrieved from

http://cadmus eui.eu/bitstream/handl e1814/29318/RSCAS_2014_01.pdf?sequence=1. On $6^{\text {th }}$ August, 2015.

\section{R. Siekmann(2006)}

R. Siekmann(2006) Nationality and Sport The international sports law journal 2006 $1 \& 2$ Retrieved from http://unw.asser.nl/Defaultaspx?site_id=11\&level $1=13908 \&$ level2=13941\&level 3= 14013

\section{R. C. R. Siekmann (2011a)}

R. C. R. Siekmann (2011a). TheEtymology of the Termini Technici Lex Sportiva and Lex Ludica: Where Do They ComeFrom? The international sportslaw journal 2011 3\& 4 Retrieved from http://www.asser.nl/Defaultaspx?site id=11\&level1=13908\&level2=13941\&level3= 15266

\section{R. C. R. Siekmann (2011b)}

R. C. R. Siekmann (2011b). Sport and National ity: "Accelerated" Natural isation for National Representative Purposes and Discrimination Issues in Individual and Team Competitions under EU Law. The international sports law journal 2011 3\& 4 Retrieved from http://www.asser.nl/Defaultaspx?site id=11\&leve1 1=13908\&level2=13941\&leve 3= 15266

\section{R. C. R. Siekmann (2011c)}

R. C. R. Siekmann (2011c). What is Sports Law? Lex Sportiva and Lex Ludica: a Reassessment of Content and Terminology. Theinternational sports lawjournal 2011 3\& 4 Retrieved from http://uww.asser.nl/Defaultaspx?site id=11\&level1=13908\&/evel2=13941\&level3= 15266 


\author{
P. J. Spiro (2011) \\ P. J. Spiro (2011). TheEnd if Olympic Nationality. Legal Study Research Papers \\ TempleUniversity.
}

\title{
P. J. Spiro (2013) \\ P. J. Spiro. (2013). 'Interrogating birth right citizenship'. In A. Sarat (Ed). (2013).
}

Spedial issue who belongs?: immigration, citizenship and the constitution of legal ity.

Bingley [etc]: Emerald, pp. 29- 53.

\section{P. J. Spiro (2014)}

P. J. Spiro (2014). Cash-for-passports and the end of citizenship. In A. Shachar and R.

Bauböck (Eds.) Should Citizenship be for Sale? EUI Working Papers, pp. 9 - 10.

Retrieved from

http://cadmus eui.eu/bitstream/handle/1814/29318/RSCAS_2014_01.pdf?sequence=1. On $6^{\text {th }}$ August, 2015.

\author{
P. J. Spiro (2015) \\ P. J. Spiro (2015). Report on Citizenship Law: United States of America. EUDO \\ Citizenship Country Report, RSCAS/EUDO-CIT-CR 2015/13. Retrieved from \\ http://cadmus.eui .eu/bitstream/handl e/1814/36498/EUDO_CIT_CR_2015_13_USA.p \\ df?sequence $=1$
}

Study on training of young sportsmen/women in E urope Extension - Part II H omegrown players rule A pril 2008

Study on training of young sportsmen/women in Europe Extension - Partll Home grown players ruleA pril 2008. Retrieved from

http://ec.europa.eu/sport/documents/doc276_en.pdf. And last visited on $3^{\text {rd }}$ July 2013.

\section{UDHR}

Universal Dedaration of Human Rights.

UNHCR 2015

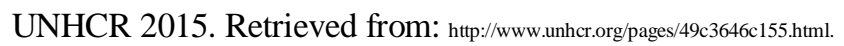

UNH C R G lobal trends 2013

UNHCR Global trends 2013. Retrieved from http://www.unher.org/546e01319.html

\section{P. Vink (2005)}

M. P. Vink (2005). Limits of European ditizenship: European integration and domestic immigration policies. Basingstoke[đc.]: Pal grave Macmillan

\section{P. Vink and G. R. de Groot (2010a)}

M. P. Vink and G. R.deGroot (2010a). Birthright Citizenship: Trends and Regulations in Europe EUDO Citizenship Observatory. Rérieved from http://eudocitizenship.eu/docs/birthright_comparativepaper.pdf 
M. P. Vink \& G. R.de Groot (2010b)

M. P. Vink \& G.-R. deGroot (2010b). Citizenship Attribution in Western Europe International Framework and Domestic Trends. J ournal of Ethnic and Migration Studies, 36:5, pp. 713-734

O. W. Vonk (2012)

O. W. Vonk (2012). Dual nationality in theEuropean Union: a study on changing norms in public and privateinternational law and in themunicipal laws of four EU member states. Leiden [etc.]: Nijhoff

O. W. Vonk, M. P. Vink, G. R. de Groot (2013)

O. W. Vonk, M. P. Vink, G. R. de Groot (2013). Protection against Statelessness Trends and regulations in Europe EUDO Citizenship Observatory. Retrieved from http://eudo-citizenship.ev/images/docs/eudocit_vink_degroot_statelessness_final.pdf

O. W. Vonk (2014)

O. W. Vonk (2014). Nationality Law in the Western Hemisphere- A Study on Grounds for Acquisition and Loss of Citizenship in theAmericas and the Caribbean. Leiden: Brill.

\section{E. van Waas (2008)}

L .E.van Waas (2008). National ity matters: statelessness under international law. Antwerp [etc.]: Intersentia

\section{E. van Waas (2010)}

L. E. van Waas (2010). The situation of stateless persons in the Middl eEast and North Africa. UNHCR. Retrieved from http://www.unhar.org/cgi-

bin/texis/vt//home/opendocPDFViewer.html?docid=4ce63e079\&query=syria\%20decr e\%20no\%2093.

\section{E. van Waas (2014)}

L. E. van Waas (2014). A ComparativeAnalysis of Nationality Laws in the MENA Region. Retrieved from: http://ssrn.com/abstract=2493718 and http://dx. doi.org/10.2139/ssin.2493718

\section{H. W aldrauch (2006a)}

H. Waldrauch. (2006a). Acquisition of nationality. In R. Bauböck, E. Ersboll, K. Groenendijk and H. Wal drauch (Eds). Acquisition and Loss of nationality - policies and trends in 15 European states - Volume1: ComparativeAnal ysis, Amsterdam Amsterdam University Press, pp. 121 - 182.

\section{H. W aldrauch (2006b)}

H. Waldrauch. (2006b). Loss of nationality. In R. Bauböck, E. Ersboll, K. Groenendijk and $\mathrm{H}$. Waldrauch (Eds.). Acquisition and Loss of nationality - policies and trends in 15 European states - Volume 1: ComparativeAnal ysis, Amsterdam: Amsterdam University Press, pp. 183- 219. 
P. Weis (1979)

P. Weis. (1979). National ity and statelessness in international law. Alphen aan den

Rijn [ec.]: Sijthoff \& Noordhoff

M. W ells-G reco (2015)

M. Wells-Greco (2015). Thestatus of children arising frominter-country surrogacy arrangements. Den Haag: Eleven Intenrational Publishing.

A. S. W ollmann, O. Vonk and G. R. de Groot (2015)

A. S. Wollmann, O. Vonk and G. R. de Groot (2015). Towards a Sporting Nationality? 22 MJ 2, pp. $300-316$. 


\subsection{C ase law}

\section{B osman}

Case C-415/93 Union Royale Belge Sociétés deFootbal I Association and others v Bosman[1995] ECR I-4921

\section{Dowes v Bidwell}

Downes v Bidwell 182 U.S. 244 (1901).

\section{Leneuoti Fiafia T uaua etc.}

Leneuoti Fiafia Tuaua, etal. V United States of America et al. Civil Case No. 12$01143(\mathrm{RJ} L)$.

\section{Miranda I and II v IOC}

MirandaI and II v IOC - CAS OG (Sydney) 00/003 and 00/008; Digest of CAS

Awards II, p. 607 and 645. Retrieved from: http://jurisprudencetas-

cas.org/sites/Caselaw/Shared\%20Documents/OG\%2000-003.pdf and

http://jurisprudencetas-cas.org/sites/Casel_aw/Shared\%20Documents/OG\%2000-

008.pdf

\section{New Zeeland v SLOC, FIS, IOC}

New Zeeland v SLOC, FIS, IOC - CAS OG (Salt LakeCity) 02/006, Award of 20

February 2002. Retrieved from http://jurisprudencetas-

cas.org/sites/Caselaw/Shared\%20Documents/OG\%2002-006.pdf

\section{Nottebohm}

1955 I.C.J. 4 (Liechtenstein v. Guatemala)

\section{O ppenheimer v Cattermole (Inspector of T axes)}

Oppenheimer v Cattermole (Inspector of Taxes). [1972] 3W.L.R. 815; [1973] Ch. 264

\section{Pechstein}

CAS 2009/A/1912 \& 1913 and CAS OG 10/04 and OLG München · 15J anuary 2015 - Az. U 1110/14 Kart

\section{Perez I, II and III vIOC-CAS}

Perez I, II and III v IOC- CAS OG (Sydney) 00/001,00/005,00/009, Digest of CAS Awards II, p. 595, 625 and 651. Retrievd from: http://jurisprudencetas cas.org/sites/Caselaw/Shared\%20Documents/OG\%2000-001.pdf; , http://jurisprudencetas-cas.org/sites/Caselaw/Shared\%20Documents/OG\%2000005.poff and http://jurisprudencetascas.org/sites/Casel aw/Shared\%20Documents/OG\%2000-009.pdf.

\section{R ottmann}

Case C-135/08 [2010] Janko Rottmann v Freistaat Bayern. 
US Swimming v FINA

US Swimming v FINA - CAS OG (Atlanta) 001/1996 A ward of 22 July 1996, Digest of CAS A wards I, p. 337. Retrieved from: http://jurisprudencetas cas.org/sites/Caselaw/Shared\%20Documents/OG\%2096-001.pdf 


\subsection{Conventions and recommendations}

Convention on the avoidance of statelessness in relation to State succession 2006 Convention on theavoidance of statel essness in relation to State succession 2006. Retrieved from:: http://www.coeint/de/web/conventions/full-list//conventions/ms/0900001680083747

Convention on the Reduction of Statelessness 1961

Convention on the reduction of Statelessness 1961. Retrieved from: http://www.unhar.org/3bbb286d8.html.

Convention Relating to the Status of Refugees 1951

Convention Relating to the Status of Refugees 1951. Retrieved from http://www.unhar.org/3b66c2aa10.html

E uropean Convention on Nationality (1997)

European Convention on Nationality (1997). Retrieved from

http://conventions. coeint/Treaty/en/Treaties/Html/166.htmAnd last visited on $3^{\text {rd }}$ July 2013.

\section{E uropean C onvention on Nationality Treaty Office}

European Convention on National ity Treaty Office Retrieved from http://conventions, coeint/Treaty/Commun/ChercheSig.asp?NT $=166 \& C M=\& D F=\& C$ $L=E N G$.

Protocol Relating to the Status of R efugees 1967

Protocol Relating to the Status of Refugees 1967. Retrieved from:

http://www.unhar.org/3b66c2aa10.html

Recommendation CM/Rec (2009)13.

Recommendation CM/Rec(2009)13. adopted by the Committee of Ministers of the Coundil of Europe on 9 December 2009, on the proposal of the European Committee on Legal Co-operation (CDCJ). Retrieved from

http://www.coeint/t/dghl/standardsetting/cdcj/CDCJ\%20Recommendations/CMRec\% 282009\%2913E_NationaliteDesEnfants.pdf 


\subsection{National Laws}

\section{B ritish Nationality Act 1981}

B ritish Nationality H ong K ong Act 1990

Civil C ode of the Islamic Republic of Iran

Civil Code of thelslamic Republic of Iran. Retrieved from

http://iranianembassy.nl/en/consular.php?content=241.

Information on L ebanese citizenship

Information on Lebanesecitizenship. Retrieved from

http://www.lebanonembassyus.org/renunciation-of-lebanesecitizenship.html.

Information on the connection Argentina-Italy with regard to citizenship

Information on the connection Argentinal taly with regard to citizenship. -Retrieved from

http://www.ambbuenosaires.esteri.it/Ambasciata_BuenosAires/Menu/lnformazioni_e servizi/Servizi_consolari/Cittadinanza/Cittadinanza.htmand last visited on $3^{\text {rd }}$ July $\underline{2013}$

Staatsangehörigkeitsesetz (StAG).

Staatsangehörigkeitsesez (StAG). Rerieved from http://uww.gesetzeiminternet de/bundesrecht/rustag/gesamt.pdf

U.S. Code: Title 8 - AL IE NS AND NATIONALITY.

U.S. Code Title8- ALIENS AND NATIONALITY. Retrieved from

https://www.law.cornell.edu/uscode/text/8 


\subsection{Sport information}

\section{Aquatics}

\section{IOC Information FINA}

IOC Information FINA. Retrieved fromhttp://www. olympic. org/fina and last visited on: $3^{\text {rd }}$ July 2013.

\section{IOC Information FINA - Diving}

IOC Information on FINA - Diving. Retrieved fromhttp://www. olympic.org/fina diving and last visited on: $3^{\text {rd }}$ July 2013.

IOC Information FINA - Synchronised Swimming

IOC Information FINA - Synchronised Swimming. Retrieved from

$\mathrm{h}$ ttp://hww. olympic.org/fina-synchroni sed-swimming and last visited on: $3^{\text {rd }} \mathrm{J}$ uly 2013.

IOC Information FINA - water polo

IOC Information FINA - water pol o. Retrieved from http://www. ol ympic. org/finawater-polo and last visited on: $3^{\text {rd }}$ J uly 2013.

IOC Information Diving E quipment and History IOC Information on Diving. Retrieved from http://www. olympic.org/divingequi pment-and-history_and last visited on: $3^{\text {rd }}$ July 2013.

IOC Information Swimming Equipment and History IOC Information Swimming. Retrieved fromhttp://www.olympic.org/swimmingequi pment-and-history and last visited on: $3^{\text {rd }}$ July 2013.

IOC Information Synchronised Swimming Equipment and History IOC Information Synchronised Swimming . Retrieved from http://www. olympic.org/synchronized-swimming-equi pment-and-history and last visited on: $3^{\text {rd }}$ July 2013.

IOC Information Water Polo Equipment and History IOC Water Polo. Rerieved from http://www. olympic. org/water-pol o-equipment-andhistory and last visited on: $3^{\text {rd }}$ July 2013.

IOC R eference Document Aquatics Diving 2011

IOC Reference Document Aquatics Diving 2011. Retrived from $\mathrm{http} / / / \mathrm{ww}$. ol ympic.org/di ving-equi pment-and-history?tab=history and last visited on: $3^{\text {rd }}$ July 2013.

IOC R eference Document Aquatics Swimming 2011

IOC Reference Document Aquatics Swimming 2011. Retrieved from http://www. olympic.org/swimming-equipment-and-history?tab=history_and last visited on: $3^{\text {rd }}$ July 2013. 
IOC R eference Document Aquatics: Synchronised Swimming 2011 IOC Reference Document Syndhronised Swimming 2011. Reerieved from $\mathrm{http://www.} \mathrm{olympic.org/syndhronized-swimming-equi} \mathrm{pment-and-history?tab=history}$ and last visited on: $3^{\text {rd }}$ July 2013.

IOC R eference Document Aquatics: Water Polo 2011 IOC Reference Document Water Polo 2011. Retrieved from http://www. olympic.org/water-polo-equi pment-and-history?tab=history_and last visited on: $3^{\text {rd }}$ July 2013.

\section{Archery}

IOC Information Archery E quipment and History Archery Equipment and History retrieved from http://www.olympic.org/archeryequi pment-and-history?tab=equi pment and last visited on: $3^{\text {rd }}$ J uly 2013.

\section{IOC Information FITA}

IOC Information FITA. Retrieved from http://www. ol ympic.org/fita and last visited on: $3^{\text {rd }}$ July 2013.

IOC R eference Document Archery 2011

IOC Reference documentArchery 2011. Retrieved from

http://www. olympic.org/archery-equi pment-and-history?tab=history and last visited on: $3^{\text {rd }}$ July 2013.

\section{Athletics}

IOC Information Athletics E quipment and History

IOC Information Athl etics. Retrieved from http://www. olympic.org/athletics-roadequi pment-and-history and last visited on: $3^{\text {rd }}$ July 2013.

\section{IOC Information ISAAF}

IOC Information ISAAF. Retrieved from http://www. olympic.org/iaaf-athletics-road and last visited on: $3^{\text {rd }}$ July 2013.

IOC Reference Document Athletics 2011

IOC Reference Document Athl etics 2011. Retrieved from

$\mathrm{http} / / \mathrm{www}$. ol ympic.org/athl etics-road-equipment-and-history?tab=history and last visited on: $3^{\text {rd }}$ July 2013.

\section{Badminton}

\section{IOC Information Badminton}

IOC Information Badminton. Retrieved from http://www. olympic. org/badmintonequi pment-and-history and last visited on: $3^{\text {rd }} \mathrm{J}$ uly 2013.

IOC Information BWF.

IOC Information BWF. Retrieved from http://www.olympic.org/bwf and last visited on: $3^{\text {rd }}$ July 2013. 
IOC R eference Document Badminton 2011

IOC Reference Document Badminton 2011. Reerieved from

http://www. olympic. org/badminton-equipment-and-history?tab=history and last

visited on: $3^{\text {rd }}$ July 2013.

Basketball

IOC Information on Basketball.

IOC Information on Basketbal I. Retrieved from http://www. olympic. org/basketball-

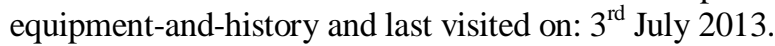

\section{IOC Information on FIBA}

IOC Information on FIBA. Retrieved from http://www.olympic. org/fiba and last visited on: $3^{\text {rd }}$ July 2013.

IOC R eference document Basketball 2011

IOC Basketball Reference document (2011). Retrieved from

$\mathrm{http} / / / \mathrm{ww}$. ol ympic.org/basketball -equipment-and-history?tab=history and last visited on: $3^{\text {rd }}$ July 2013.

\section{Biathlon}

\section{IOC Information IBU}

IOC Information IBU. Retrieved from http://www. olympic. org/i bu and last visited on: $3^{\text {rd }}$ July 2013.

IOC Information Biathlon Equipment and History

IOC Information Biathl on Equipment and History. Retrieved from

http://www. olympic. org//biathl on-equi pement-and-hi story and last visited on: $3^{\text {rd }} \mathrm{July}$ 2013.

IOC R eference Document Biathlon 2011

IOC Reference Document Biathlon 2011. Rerieved from

$\mathrm{http}: / / \mathrm{ww} w$.ol ympic. org/biathl on-equi pement-and-history?tab=history_and last visited on: $3^{\text {rd }}$ July 2013.

\section{Bobsleigh}

IOC Information FIBT - Bobsleigh

IOC Information FIBT - Bobsleigh. Retrieved from http://www.olympic.org/fibtbobsleigh and last visited on: $3^{\text {rd }}$ July 2013.

\section{IOC Information FIBT - Bobsleigh Skeleton}

IOC Information FIBT - Skeleton. Retrieved from http://www. olympic.org/fibtskeleton and last visited on: $3^{\text {rd }}$ July 2013.

\section{IOC Information B obsleigh}

IOC Information Bobsleigh. Retrieved from http://www. olympic. org/bobsleighequi pment-and-history and last visited on: $3^{\text {rd }}$ July 2013. 
IOC Information B obsleigh Skeleton

IOC Information Bobsleigh Skeleton Retrieved from

http://www. olympic.org/sketeton-equi pment-and-history and last visited on: $3^{\text {rd }} \mathrm{J}$ uly

2013.

IOC R eference Document B obsleigh 2011

IOC Reference Document Bobsleigh 2011. Retrieved from

http://www. olympic.org/bobsle igh-equi pment-and-history?tab=history and last visited on: $3^{\text {rd }}$ July 2013.

\section{IOC R eference Document B obsleigh Skeleton 2011}

IOC Reference Document Bobsleigh Skeleton 2011. Retrieved from

$\mathrm{http} / / / \mathrm{ww}$. ol ympic. org/skel eton-equi pment-and-history?tab=history and last visited on: $3^{\text {rd }}$ July 2013.

\section{Boxing}

\section{IOC Information AIBA}

IOC Information AIBA. Retrieved from http://www. olympic.org/aiba and last visited on: $3^{\text {rd }}$ July 2013.

\section{IOC Information B oxing}

IOC Information Boxing. Retrieved from http://www. olympic.org/boxing-equi pmentand-history and last visited on: $3^{\text {rd }} \mathrm{J}$ uly 2013.

IOC R eference Document B oxing 2011

IOC Reference Document Boxing 2011. Rerieved from

http://www. olympic.org/boxing-equi pment-and-history?tab=history and last visited on: $3^{\text {rd }}$ July 2013.

\section{CanoeKayak}

IOC Information C anoe / Kayak Slalom E quipment and History

Canoe/ Kayak Slal om Equipment and History. Rerieved from

http://www. olympic.org/canoekayak-slal om-equi pment-and-history and

$\mathrm{http}: / / \mathrm{ww} w$. ol ympic.org/canoekayak-sprint-equi pment-and-history_and last visited on: $3^{\text {rd }}$ July 2013.

IOC R eference Document CANOE - Slalom 2011

IOC Reference Document CANOE - Slal om 2011. Rerieved from

http://www. olympic.org/canoekayak-slal om-equi pment-and-history?tab=history and last visited on: $3^{\text {rd }}$ J uly 2013.

IOC R eference Document CANOE - Sprint 2011

IOC Reference Document CANOE - Sprint 2011. Retrieved from

http://www. olympic.org/canoekayak-sprint-equi pment-and-history?tab=history and last visited on: $3^{\text {rd }}$ July 2013. 


\section{Curling}

IOC Information C urling

IOC Information Curling. Retrieved from http://www. olympic. org/curling-equipmentand-history and last visited on: $3^{\text {rd }} \mathrm{J}$ uly 2013.

\section{IOC Information WCF}

IOC Information WCF. Retrieved from http://www.olympic.org/wcf and last visited on: $3^{\text {rd }}$ July 2013.

\section{IOC R eference Document C urling 2011}

IOC Reference Document Curling 2011. Retrieved from

http://www. olympic.org/curling-equi pment-and-history?tab=history and last visited on $3^{\text {rd }}$ July 2013.

\section{Cycling}

\section{IOC Information UCI - Cycling}

IOC Information UCl - Cycling. Retrieved from http://www.olympic.org/uci-cyclingbmx and last visited on $3^{\text {rd }}$ July 2013.

\section{IOC Information UCI - Cycling road}

IOC Information UCl - Cycling road. Retrieved from http://www.olympic.org/udcycling-road and last visited on $3^{\text {rd J July } 2013 .}$

\section{IOC Information UCI -Cycling Track}

IOC Information UCl -Cycling Track. Retrieved from http://umw. olympic.org/udicycling-track and last visited on $3^{\text {rd }}$ J uly 2013.

\section{IOC Information UCI - M ountain Bike}

IOC Information UCl - Mountain Bike Retrieved from http://www. olympic.org/ucimountain-bikeand last visited on $3^{\text {rd }}$ J uly 2013.

\section{IOC Information Cycling - BMX}

IOC Information Cycling- BMX. Retrieved from http://www. olympic.org/cyclingbmx-equi pment-and-history and last visited on $3^{\text {rd }}$ July 2013.

IOC Information Cycling - M ountain Bike

IOC Information Cycling-Mountain Bike Retrieved from

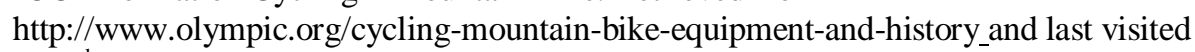
on $3^{\text {rd }}$ July 2013.

IOC Information Cycling - R oad

IOC Information Cycling- Road. Retrieved from http://www.olympic.org/cyclingroad-equipment-and-history and last visited on $3^{\text {rd }}$ July 2013.

IOC Information Cycling - Track

IOC Information Cycling-Track. Retrieved from http://www.olympic.org/cyclingtradk-equipment-and-history_and last visited on $3^{\text {rd }} \mathrm{J}$ uly 2013. 
IOC R eference Document Cycling - BMX 2011

IOC Reference Document Cycling-BMX 2011. Retrieved from

$\mathrm{http} / / / \mathrm{www}$.olympic.org/cycling-bmx-equi pment-and-history?tab=history and last

visited on $3^{\text {rd }}$ July 2013.

IOC R eference Document Cycling - M ountain Bike 2011

IOC Reference Document Cycling-Mountain Bike2011. Rerieved from

http://www. olympic.org/cycling-mountain-bike equipment-and-history?tab=history

and last visited on $3^{\text {rd }}$ July 2013.

IOC R eference Document Cycling - Road 2011

IOC Reference Document Cycling- Road 2011. Retrieved from

$\mathrm{http} / / / \mathrm{www}$. ol ympic.org/cycling-road-equi pment-and-history?tab=history and last visited on $3^{\text {rd }}$ July 2013.

\section{Equestrian}

IOC Information E questrian - Dressage

IOC Information Equestrian - Dressage Retrieved from

$\mathrm{http}: / / \mathrm{wmw}$. olympic.org/equestrian-dressage equipment-and-history and last visited on $3^{\text {rd }}$ July 2013.

\section{IOC Information Equestrian - J umping}

IOC Information Equestrian - Jumping. Retrieved

fromhttp://www.olympic. org/equestrian-jumping-equi pment-and-history and last visited on $3^{\text {rd }}$ July 2013.

\section{IOC Information FE I - Dressage}

IOC Information FEI - Dressage Retrieved fromhttp://www.olympic.org/feiequestrian-dressageand last visited on $3^{\text {rd }}$ July 2013.

IOC Information E questrian - E venting

IOC Information Equestrian - Eventing. Retrieved from

http://www. ol ympic.org/equestrian-eventing-equipment-and-history and last visited on $3^{\text {rd }}$ July 2013.

IOC Information FE I - J umping

IOC Information FEI - J umping. Retrieved from http://www.olympic.org/feiequestrian-jumping and last visited on $3^{\text {td }} \mathrm{J}$ uly 2013.

IOC R eference Document Equestrian 2011

IOC Reference Document Equestrian 2011. Retrieved from

http://hww. olympic.org/equestrian-dressage equipment-and-history?tab=history and last visited on $3^{\text {rd }}$ J uly 2013. 


\section{Fencing}

Deutscher Fechtbund

Deutscher Fechtbund. Retrieved from

http://www.fechten.org/ueber_uns/fechter/waffen.html and

$h$ ttp://www.fechten.org/ueber_uns/fechter/trefferanzeigewertung.html. And last

visited on: $3^{\text {rd }}$ July 2013.

IOC Information on Fencing E quipment and History.

Fencing Equi pment and History. Retrieved from http://www.olympic.org/fencingequi pment-and-history?tab=history and last visited on: $3^{\text {rd }} \mathrm{J}$ uly 2013.

IOC Information FIE

IOC Information FIE. Retrieved from http://www.olympic.org/fieand last visited on $3^{\text {rd }}$ July 2013.

IOC R eference Document Fencing 2011

IOC Reference Document Fencing 2011. Rerieved from

http://www. olympic.org/fending-equi pment-and-history?tab=history and last visited on $3^{\text {rd }}$ July 2013.

\section{Football}

\section{IOC Information FIFA}

IOC Information FIFA. Refrieved from http://www. olympic.org/fifa and last visited on $3^{\text {rd }}$ July 2013.

\section{IOC Information Football}

IOC Information Football. Retrieved from http://www. olympic.org/football-

equi pment-and-history and last visited on $3^{\text {td }} \mathrm{J}$ uly 2013.

IOC R eference Document Football 2011

IOC Reference Document Football 2011. Retrieved from

http://www. olympic.org/football-equi pment-and-history?tab=history and last visited on $3^{\text {rd }}$ July 2013.

\section{Golf}

IOC Information IG F

IOC Information IGF. Rerieved from http://www.olympic.org/igf and last visited on $3^{\text {rd }}$ July 2013.

\section{IOC Information G olf}

IOC Information Golf. Retrieved from http://www. olympic.org/content/sports/allsports/golf/equipment-and-history/and last visited on $3^{\text {rd }}$ J uly 2013.

\section{Gymnastics}

IOC Information FIG - Artistic G ymnastics

IOC Information FIG - Artistic Gymnastics. Retrieved from

http://www. olympic.org/fig-artistic-gymnastics and last visited on $3^{\text {rd }}$ July 2013. 
IOC Information FIG - R hythmic G ymnastics

IOC Information FIG - Rhythmic Gymastics. Retrieved from

http://www.olympic.org/fig-rhythmic-gymastics_and last visited on $3^{\text {rd }}$ J uly 2013.

IOC Information FIG - Trampoline Gymnastics

IOC Information FIG - Trampoline Gymastics. Retrieved from

http://www.olympic.org/fig-trampolineand last visited on $3^{\text {rd }}$ July 2013.

IOC Information G ymnastics - Artistic

IOC Information Gymastics - Artistic. Retrieved from

$\mathrm{http} / / / \mathrm{www}$. olympic.org/artistic-gymastics-equipment-and-history and last visited on $3^{\text {rd }}$ July 2013.

IOC Information G ymnastics - R hythmic

IOC Information Gymastics - Rhythmic. Retrieved from

http://mww. olympic.org/rhythmic-gymnastics-equi pment-and-history_and last visited on $3^{\text {rd }}$ July 2013.

IOC Information G ymnastics - Trampoline

IOC Information Gymnastics - Trampoline Retrieved from

http://www. ol ympic. org/trampoline equi pment-and-history_and last visited on $3^{\text {rd }} \mathrm{July}$

2013.

IOC R eference Document G ymnastics - Artistic 2011

IOC Reference Document Gymnastics - Artistic 2011. Retrieved from

http://www. olympic.org/artistic-gymnastics-equi pment-and-history?tab=history and last visited on $3^{\text {rd }}$ July 2013.

IOC R eference Document G ymnastics - R hythmic 2011

IOC Reference Document Gymnastics - Rhythmic 2011. Retrieved

fromhttp://www. olympic.org/rhythmic-gymnasticsequi pment-and-history?tab=history and last visited on $3^{\text {rd }}$ July 2013.

IOC R eference Document G ymnastics - Trampoline 2011

IOC Reference Document Gymastics - Trampoline2011. Rerieved from

http://www. olympic.org/trampoline equi pment-and-history?tab=historyand last visited on $3^{\text {rd }}$ July 2013.

\section{Handball}

IOC Information on H andball equipment and History

Handball equi pment and History. Retrieved from http://www. olympic. org/handballequi pment-and-history and last visited on: $3^{\text {rd }}$ July 2013.

\section{IOC Information IHF}

IOC Information IHF. Rerieved from http://www.olympic.org/ihf and last visited on $3^{\text {rd }}$ July 2013. 
IOC R eference Document Handball 2011

IOC Reference Document Handball 2011. Retrieved from

http://www. olympic.org/handball-equi pment-and-history?tab=history and last visited on $3^{\text {rd }}$ July 2013.

Hockey

IOC Information FIH

IOC Information FIH. Rerieved from http://www.olympic.org/fih and last visited on $3^{\text {rd }}$ July 2013.

\section{IOC Information on H ockey Equipment and H istory}

Hockey Equi pment and History. Retrieved from http://www.olympic.org/hockey-

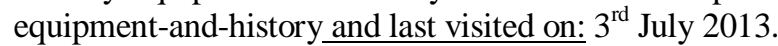

IOC R eference Document H ockey 2011

IOC Reference Document Hockey 2011. Retrieved from

http://www. olympic.org/hockey-equipment-and-history?tab=history and last visited on $3^{\text {rd }}$ July 2013.

\section{IceHockey}

IOC Information on Ice H ockey Equipment and History

IOC Information on I ce Hockey Equi pment and History. Retrieved from

http://www. olympic.org/ice hockey-equipment-and-history and last visited on: $3^{\text {rd }}$ July 2013.

\section{IOC Information IIHF}

IOC Information IIHF. Retrieved from http://www. olympic.org/iihf and last visited on $3^{\text {rd }}$ July 2013.

IOC R eference Document Ice H ockey 2011

IOC Reference Document Ice Hockey 2011. Retrieved from

http://www. ol ympic.org/icehockey-equipment-and-history?tab=history and last

visited on $3^{\text {rd }}$ July 2013.

Judo

IOC Information IJ F

IOC Information IJ F. Retrieved from http://www. olympic.org/ijf and last visited on $3^{\text {rd }}$ July 2013.

IOC Information J udo

IOC Information J udo. Retrieved from http://www. ol ympic.org/judo-equi pment-andhistory and last visited on $3^{\text {rd }} \mathrm{July} 2013$.

IOC R eference Document J udo 2011

IOC Reference Document J udo 2011. Retrieved from htto://www. olympic. org/judo-

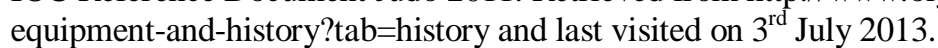


Luge

IOC Information FIL

IOC Information FIL. Retrieved from http://www.olympic.org/fil and last visited on $3^{\text {rd }}$ July 2013.

IOC Information L uge

IOC Information Luge Rerieved from http://www. olympic.org/luge equi pment-andhistory and last visited on $3^{\text {rd }}$ July 2013.

IOC Reference Document L uge 2011

IOC Reference Document Luge2011. Retrieved from http://www. olympic. org/luge equi pment-and-history?tab=historyand last visited on $3^{\text {rd }}$ J uly 2013.

\section{Modern Pentathlon}

IOC Information on M odern Pentathlon Equipment and History

Modern Pentathlon Equi pment and History. Retrieved from

http://www. ol ympic.org/modem-pentathl on-equipment-and-history and last visited on: $3^{\text {rd }}$ July 2013.

\section{IOC Information UIPM}

IOC Information UIPM. Retrieved from http://www.olympic.org/uipmand last visited on $3^{\text {rd }}$ July 2013.

IOC R eference Document M odern Pentathlon 2011

IOC Reference Document Modern Pentathl on 2011. Retrieved from

http://www. olympic.org/modem-pentathl on-equipment-and-history?tab=history and last visited on $3^{\text {rd }}$ July 2013.

Rowing

IOC Information FISA

IOC Information FISA. Rerieved from http://www.olympic.org/fisa and last visited on $3^{\text {rd }}$ July 2013.

IOC Information on R owing Equipment and History

Rowing Equi pment and History. Rerrieved from http://www.olympic.org/rowingequipment-and-history and last visited on: $3^{\text {rd }}$ July 2013.

IOC R eference Document R owing 2011

IOC Reference Document Rowing 2011. Retrieved from

$\mathrm{http}: / / \mathrm{ww}$. olympic.org/rowing-equi pment-and-history?tab=historyand last visited on $3^{\text {rd }}$ July 2013.

\section{Rugby}

IOC Information IR B

IOC Information IRB. Retrieved from http:///www.olympic. org/irb and last visited on $3^{\text {rd }}$ July 2013. 
IOC R eference Document R ugby 2011

IOC Reference Document Rugby 2011. Retrieved from

http://www. olympic.org/content/sports/all-sports/rugby/equi pement-and-history/and last visited on $3^{\text {rd }}$ July 2013.

Sailing

IOC Information ISAF

IOC Information ISAF. Retrieved from http://www. olympic.org/isaf_and last visited on $3^{\text {rd }}$ July 2013.

IOC Information on Sailing Equipment and History

Sailing Equipment and History. Rerieved fromhttp://www. olympic.org/sailingequi pment-and-history?tab=equi pment and last visited on: $3^{\text {rd }}$ J uly 2013.

IOC R eference Document Sailing 2011

IOC Reference Document Sailing 2011. Retrieved from

http://www. ol ympic. org/sailing-equi pment-and-history?tab=history and last visited on $3^{\text {rd }}$ July 2013.

\section{Shooting}

IOC Information ISSF

IOC Information ISSF. Rerieved from http://www.olympic.org/issf_and last visited on $3^{\text {rd }}$ July 2013.

IOC Information on Shooting E quipment and History

Shooting Equi pment and History. Rerrieved from http://www. olympic. org/shootingequi pment-and-history?tab=history and last visited on: $3^{\text {rd }} \mathrm{J}$ uly 2013.

\section{IOC R eference Document Shooting 2011}

IOC Reference Document Shooting 2011. Rerieved

fromhttp://www.olympic. org/shooting-equipment-and-history?tab=history and last visited on $3^{\text {rd }}$ July 2013.

Skating

IOC Information ISU - Figure Skating

IOC Information ISU - Figure Skating. Refrieved from http://nww. olympic.org/isufigure skating and last visited on $3^{\text {rd }}$ July 2013.

IOC Information ISU - Short Track Speed Skating

IOC Information ISU- Short Track Speed Skating. Reerieved from

http://www. ol ympic.org/isu-short-track-speed-skating and last visited on $3^{\text {rd }}$ Jul y 2013.

IOC Information ISU - Speed Skating

IOC Information ISU- Speed Skating. Retrieved from http://www. olympic.org/isur speed-skatingand last visited on $3^{\text {rd }}$ July 2013. 
IOC Information Skating - Figure Skating

IOC Information Skating - Figure Skating. Retrieved from

http://www. olympic.org/figure skating-equipment-and-history and last visited on $3^{\text {rd }}$ July 2013.

IOC Information Skating - Short Track Speed Skating

IOC Information Skating- Short Track Speed Skating. Retrieved from

http://www. olympic.org/short-track-speed-skating-equi pment-and-history and last visited on $3^{\text {rd }}$ July 2013.

\section{IOC Information Skating - Speed Skating}

IOC Information Skating - Speed Skating. Rerieved from

$\mathrm{http} / / / \mathrm{ww}$. ol ympic.org/speed-skating-equi pment-and-history and last visited on $3^{\text {rd }}$ July 2013.

\section{IOC R eference Document Skating- Figure Skating 2011}

IOC Reference Document Skating- FigureSkating 2011. Retrieved from

$\mathrm{http}: / / \mathrm{ww}$. olympic.org/figure skating-equipment-and-history?tab=history and last visited on $3^{\text {rd }}$ July 2013.

IOC R eference Document Skating- Short Track Speed Skating 2011

IOC Reference Document Skating - Short Track Speed Skating 2011. Retrieved from http://www. ol ympic.org/short-track-speed-skating-equi pment-and-history?tab=history and last visited on $3^{\text {rd }}$ July 2013.

\section{IOC R eference Document Skating - Speed Skating 2011}

IOC Reference Document Skating- Speed Skating 2011. Rerieved from

$\mathrm{http} / / / \mathrm{ww}$. ol ympic.org/speed-skating-equi pment-and-history?tab=history and last visited on $3^{\text {rd }}$ July 2013.

Skiing

IOC Information FIS - Alpine Skiing

IOC Information FIS- AlpineSkiing. Retrieved from http://www. olympic.org/fis al pine-skiing and last visited on $3^{\text {rd }}$ July 2013.

IOC Information FIS - Cross Country Skiing

IOC Information FIS - Cross Country Skiing. Rerieved from

http://www. olympic.org/fis-cross-country-skiing and last visited on $3^{\text {rd }}$ J uly 2013.

IOC Information FIS - F reestyle Skiing

IOC Information FIS - FreestyleSkiing. Retrieved from http://www.olympic.org/fis freestyleskiing and last visited on $3^{\text {rd }}$ July 2013.

IOC Information FIS - Nordic Combined

IOC Information FIS - Nordic Combined. Rerieved from http://uww.olympic.org/fisnordic-combined and last visited on $3^{\text {rd }} \mathrm{July} 2013$. 
IOC Information FIS - Ski J umping

IOC Information FIS - Ski J umping. Retrieved from http://uww. ol ympic. org/fis-skijumping and last visited on $3^{\text {rd }}$ July 2013.

\section{IOC Information FIS - Snowboard}

IOC Information FIS - Snowboard. Retrieved from http://www. olympic.org/fissnowboard and last visited on $3^{\text {rd }}$ July 2013.

IOC Information Skiing - Alpine Skiing

IOC Information Skiing- Al pine Skiing. Retrieved from

$\mathrm{http}: / / \mathrm{ww}$. ol ympic. org/al pine-skiing-equi pment-and-history and last visited on $3^{\text {rd }}$ July 2013.

IOC Information Skiing - Cross C ountry Skiing

IOC Information Skiing-Cross Country Skiing. Retrieved from

$\mathrm{http} / / / \mathrm{ww}$. olympic.org/cross-country-skiing-equi pment-and-history and last visited on $3^{\text {rd }}$ July 2013.

IOC Information Skiing - Freestyle Skiing

IOC Information Skiing - FreestyleSkiing. Retrieved from

$\mathrm{http://www.} \mathrm{olympic.org/freestyle-skiing-equipment-and-history} \mathrm{and} \mathrm{last} \mathrm{visited} \mathrm{on} 3^{\text {rd }}$ July 2013.

IOC Information Skiing - Nordic Combined

IOC Information Skiing- Nordic Combined. Retrieved from

http://www. olympic.org/nordic-combined-equi pment-and-history and last visited on $3^{\text {rd }}$ July 2013.

\section{IOC Information Skiing - Ski J umping}

IOC Information Skiing - Ski Jumping. Retrieved from http://www.olympic.org/skijumping-equi pment-and-history and last visited on $3^{\text {rd }} \mathrm{J}$ uly 2013.

IOC Information Skiing - Snowboard

IOC Information Skiing - Snowboard. Retrieved from

http://www. olympic.org/snowboard-equi pment-and-history and last visited on $3^{\text {rd }} \mathrm{July}$ 2013.

IOC R eference Document Skiing - Alpine Skiing 2011

IOC Reference Document Skiing - Al pineSkiing 2011. Retrieved from

$\mathrm{http}: / / \mathrm{ww}$. olympic.org/al pine-skiing-equi pment-and-history?tab=history and last visited on $3^{\text {rd }}$ July 2013.

IOC R eference Document Skiing - Cross C ountry Skiing 2011

IOC Reference Document Skiing - Cross Country Skiing 2011. Rerieved from http://www. olympic.org/cross-country-skiing-equi pment-and-history?tab=history and last visited on $3^{\text {rd }}$ J uly 2013. 
IOC R eference Document Skiing - Freestyle Skiing 2011

IOC Reference Document Skiing- FreestyleSkiing 2011. Retrieved from

http://www. olympic.org/freestyl eskiing-equi pment-and-history?tab=history and last visited on $3^{\text {rd }}$ July 2013.

IOC R eference Document Skiing - Nordic Combined 2011

IOC Reference Document Skiing - Nordic Combined 2011. Rerieved from

http://www. olympic.org/nordic-combined-equipment-and-history?tab=history and last visited on $3^{\text {rd }}$ July 2013.

IOC R eference Document Skiing - Ski J umping 2011

IOC Reference Document Skiing - Ski Jumping 2011. Retrieved

fromnhttp://www.olympic.org/ski-jumping-equipment-and-history?tab=history and last visited on $3^{\text {rd }}$ J uly 2013.

IOC R eference Document Skiing - Snowboard 2011

IOC Reference Document Skiing-Snowboard 2011. Retrieved from

http://www.olympic.org/snowboard-equi pment-and-history?tab=history and last

visited on $3^{\text {rd }}$ July 2013.

TableTennis

IOC Information ITTF

IOC Information ITTF. Retrieved from http://www.olympic. org/iitf and last visited on $3^{\text {rd }}$ July 2013.

IOC Information Table Tennis

IOC Information TableTennis. Rerieved from http://www.olympic.org/tabletennisequipment-and-history_and last visited on $3^{\text {rd }}$ J uly 2013.

IOC R eference Document Table Tennis 2011

IOC Reference Document Table Tennis 2011. Retrieved from

$\mathrm{http://www.} \mathrm{ol} \mathrm{ympic.org/tabl} \mathrm{etennis} \mathrm{equi} \mathrm{pment-and-history?tab=history} \mathrm{and} \mathrm{last}$ visited on $3^{\text {rd }}$ July 2013.

Taekwondo

IOC Information Taekwondo

IOC Information Tadkwondo. Retrieved from http://www. olympic.org/taekwondoequi pment-and-history and last visited on $3^{\text {rd }} \mathrm{Jul}$ y 2013.

IOC Information WTF

IOC Information WTF. Retrieved from http://www.olympic.org/wtf and last visited on $3^{\text {rd }}$ July 2013.

IOC R eference Document Taekwondo 2011

IOC Reference Document Taekwondo 2011. Retrieved from

http://www. ol ympic.org/taekwondo-equi pment-and-history?tab=hi story and last

visited on $3^{\text {rd }}$ July 2013. 
Tennis

IOC Information ITF

IOC Information ITF. Retrieved from http://www.olympic.org/itf and last visited on $3^{\text {rd }}$ July 2013.

IOC Information Tennis

IOC Information Tennis. Retrieved http://www. olympic.org/tennis equi pment-andhistory_and last visited on $3^{\text {rd }}$ J uly 2013.

IOC R eference Document Tennis 2011

IOC Reference DocumentTennis 2011. Retrieved from

$\mathrm{http} / / / \mathrm{www}$. ol ympic. org/tennis-equi pment-and-history?tab=history and last visited on $3^{\text {rd }}$ July 2013.

\section{Triathlon}

\section{IOC Information ITU}

IOC Information ITU. Retrieved from http://www. ol ympic.org/itu and last visited on $3^{\text {rd }}$ July 2013.

\section{IOC Information on Triathlon E quipment and $\mathrm{H}$ istory}

Triathl on Equi pment and History. Retrieved from http://www. olympic.org/triathl onequi pment-and-history and last visited on: $3^{\text {rd }}$ July 2013.

IOC R eference Document Triathlon 2011

IOC Reference Document Triathl on 2011. Rerieved from

$\mathrm{h}$ ttp://www. ol ympic.org/triathl on-equipment-and-history?tab=history_and last visited on $3^{\text {rd }}$ July 2013.

\section{Volleyball}

IOC Information FIVB - V olleyball

IOC Information FIVB - Volleyball. Retrieved from http://uwww. olympic.org/fivbvolleyball and last visited on $3^{\text {rd }}$ July 2013.

IOC Information Beach Volleyball

IOC Information Beach Voll eyball. Retrieved from http://www. ol ympic. org/beachvolleyball-equipment-and-history and last visited on $3^{\text {rd }}$ July 2013.

\section{IOC Information Volleyball}

IOC Information Volleyball. Rerieved from http://www. olympic.org/volleyballequi pment-and-history_and last visited on $3^{\text {rd }} \mathrm{July} 2013$.

IOC R eference Document B each V olleyball 2011

IOC Reference Document Beach Volleyball 2011. Retrieved from http://www. ol ympic.org/beach-voll leyball-equi pment-and-history?tab=history and last visited on $3^{\text {rd }}$ July 2013. 
IOC R eference Document V olleyball 2011

IOC Reference Document Volleyball 2011. Retrieved from

http://uww. olympic.org/voll eyball-equipment-and-history?tab=history and last visited on $3^{\text {rd J July } 2013 .}$

Weightifting

IOC Information IWF

IOC Information IWF. Retrieved from http://www.olympic.org/i wf and last visited on $3^{\text {rd }}$ July 2013.

\section{IOC Information Weightlifting}

IOC Information Weightlifting. Retrieved from http://www. olympic.org/weightliftingequi pment-and-history and last visited on $3^{\text {rd }} \mathrm{J}$ uly 2013.

IOC R eference Document W eightlifting 2011

IOC Reference Document Weightlifting 2011. Retrieved from

http://www. ol ympic.org/weightlifting-equipment-and-history?tab=historyand last

visited on $3^{\text {rd }}$ July 2013.

Wrestling

IOC Information FILA - Freestyle

IOC Information FILA - Freestyle Retrieved from http://www. olympic.org/fila wrestling-freestyleand last visited on $3^{\text {rd }}$ J uly 2013.

IOC Information W restling - Freestyle

IOC Information Wrestling - Freestyle Retrieved from

$\mathrm{http://www.olympic.org/wrestling-freestyle} \mathrm{equipment-and-history} \mathrm{and} \mathrm{last} \mathrm{visited} \mathrm{on}$ $3^{\text {rd }}$ July 2013.

IOC Information W restling - G reco-R oman

IOC Information Wrestling- Greco-Roman. Retrieved from

$\mathrm{http} / / / \mathrm{w} w \mathrm{w}$. ol ympic.org/wrestling-greco-roman-equi pment-and-history_and last visited on $3^{\text {rd }}$ July 2013.

IOC R eference Document W restling - Freestyle 2011

IOC Reference Document Wrestling - Freestyle 2011. Retrieved from

http://www. olympic.org/wrestling-freestyle equipment-and-history?tab=history_and last visited on $3^{\text {rd }}$ J uly 2013.

IOC R eference Document W restling - G reco-R oman 2011

IOC Reference Document Wrestling - Greco-Roman 2011. Retrieved from

http://www. olympic.org/wrestling-greco-roman-equi pment-and-history?tab=history

and last visited on $3^{\text {rd }}$ July 2013. 


\subsection{Sport statutes}

Olympic Charter J uly 2011

Olympic Charter July 2011. Retrieved from http://www. olympic.org/olympic-

charter/documents-reports-studies-publications and last visited on $7^{\text {hh }}$ September, 2013.

Olympic Charter September 2013

Olympic Charter September 2013. Retrieved from http://www. olympic.org/olympiccharter/documents-reports-studies-publications and last visited on $21^{\text {ț }}$ October, 2013.

Aquatics

FINA general rules 2013-2017 of J anuary 2015

FINA general rules 2013-2017 of January 2015. Retrieved from http://www.fina.org/H2O/docs/rules/2015/FINA_generalrules.pdf

FINA General Rules 2013-2017

FINA General Rules 2013-2017 (effective from September 26, 2013). Retrieved from http://www. fina.org/H2O/index.php?option=com_content\& view=artide\&id=4161\&/t emid $=184$ and last visited on $21^{\text {t }}$ October, 2013

FINA general rules $2009-2013$.

FINA general rules 2009 - 2013. Received viaremail. Seeappendix.

FINA memorandum on Athletes' Sport Nationality 2011

FINA memorandum on Athletes' Sport National ity (2011). Retrieved from

$\mathrm{http} / / / \mathrm{ww}$.swimireland.ie/high-pefformanceswimming/elegibility/ and last visited on $21^{\star}$ October, 2013

FINA general rules 2005 - 2009.

FINA general rules 2005 - 2009. Received viaremail. Seeappendix.

\section{Archery}

W orld Archery constitution and rules 2015 effective since 1 A pril 2015 World Archery constitution and rules 2015 effective since 1 April 2015. Retrieved from http://rul ebook. worldarchery.org/PDF/Official/2015-04-01/EN-Book1.pdf

W orld Archery constitution and rules 2014 effective since 1 A pril 2014 World Archery constitution and rules 2014 effectivesince 1 April 2014. Received from: http://rul ebook.worldarchery.org/PDF/Official/2015-04-01/EN-Book1.pdf

W orld Archery constitution and rules 2012 effective since 1 A pril 2012 updated 1 A pril 2013 and 25 September 2013.

World Archery constitution and rules 2012 effective since 1 April 2012 updated 1 A pril 2013 and 25 September 2013. Received from http://rul ebook. worl darchery.org/ 
Constitution and Rules of the W orld Archery Association Since 1 A pril 2012 Constitution and Rules of theWorld Archery Association Since 1 A pril 2012. Retrieved from

http://www.archery.org/UserFiles/Document/FITA\%2Owebsite/05\%20Rules/01\%20C \&R\%20Book/Book_2012/EN-Book1.pdf_And last visited on $3^{\text {rd }}$ J uly 2013.

Athletics

International Association of Athletics Federations competition rules 2016-2017 in force as from 1st November 2015

International Assodiation of Athletics Federations competition rules 2014-2015 in force as from 1st November 2013. Retrieved from http://www.iaaf.org/aboutiaaf/documents.

International A ssociation of A thletics Federations competition rules 2014-2015 in force as from 1st November 2013

International Assodiation of Athletics Federations competition rules 2014-2015 in force as from 1st November 2013. Retrieved from http://wwww. iaaf.org/aboutiaaf/documents.

International Association Of Athletics Federations C hanges of Allegiance as of 22 August 2013.

International Association Of Athletics Federations Changes of All egianceas of 22 August 2013.Rerieved from http://www.iaaf.org/about-iaaf/documents/transfer-ofal legiance tethl etetransfer-of-allegianceand last visited on $21^{\text {t }}$ October, 2013

International Association Of Athletics Federations Competition R ules 2012-1013 International Association Of Athletics Federations Competition Rules 2012-1013. Retrieved from http://www.iaaf.org/about-iaaf/documents/rul es-regulations and last visited on $21^{\text {st }}$ October, 2013

International A ssociation of A thletics Federations competition rules 2010-2011 International Association of Athl etics Federations competition rules 2010-2011; Received via-email. See appendix.

International A ssociation of A thletics Federations competition rules 2009 International Association of Athletics Federations compeition rules 2009. Received via-e-mail. Seeappendix.

International A ssociation of A thletics Federations competition rules 2008 Intemational Association of Athletics Federations competition rules 2008. Received viaremail. Seeappendix.

International A ssociation of A thletics Federations competition rules 2006 - 2007 International Association of Athletics Federations competition rules 2006- 2007. Received via-email. See appendix. 
International Association Of Athletics Federations C hanges of Allegiance 1998 to 2011

International Association Of Athletics Federations Changes of Allegiance 1998 to 2011. Retrieved from http://www.iaaf.org/about-iaaf/documents/transfer-ofallegiancethl ete-transfer-of-all legianceand last visited on $21^{\text {\$d }}$ October, 2013

International A ssociation Of Athletics Federations Changes of Allegiance 2009 / $2010 / 2011$

International Association Of Athletics Federations Changes of Allegiance 2009 / 2010 / 2011. Retrieved from

http://www.iaaf.net/mm/Document/06/35/78/63578_PDF_English.pdf and last visited on $21^{\text {st }}$ October, 2013.

International Association Of Athletics Federations C hanges as at 17 December 2012

International Assodiation Of Athletics Federations Changes as at 17 December 2012. Retrieved fromhttp://www.iaaf.org/about-iaaf/documents/transfer-of-

allegiancethl ete-transfer-of-allegianceand last visited on $21^{\star \pm}$ October, 2013

International A ssociation Of Athletics Federations C onstitution 2011

International Association Of Athletics Federations Constitution 2011. Retrieved from http://hww. iaaf.org/about-iaaf/documents/constitution and last visited on $21^{\text {ts }}$ October, 2013

Badminton

BW F general competition regulations updated 9 November 2015

BWF general competition regulations updated 9 November 2015. Retrieved from http://www.bufbadminton.org

BW F general competition regulations updated $1 \mathrm{~J}$ une 2015 BWF general competition regulations updated 1 J une2015. Retrieved from http://www. bwfbadminton.org

BW F general competition regulations updated 8 December 2014 BWF general compeition regulations updated 8 December 2014. Rerieved from http://www. buffbadminton.org

BW F general competition regulations updated $5 \mathrm{~J}$ une 2014 BWF general competition regulations updated 5J une 2014. Retrieved from http://www. bwfbadminton.org/file aspx?id $=558275 \& d=1$.

BWF general competition regulations updated $1 \mathrm{~J}$ une, 2013

BWF general competition regulations updated 1 J une, 2013. Retrieved from: $\mathrm{http}: / / \mathrm{ww} w$. bwfbadminton. org/fileaspx?id=608510\&dl=1

Badminton H andbook 2013/2014

Badminton Handbook 2013/2014. Retrieved from http://www. bufbadminton.org/pageaspx?id=14915 and last visited on $21^{\mathrm{s}}$ October, 2013 
Badminton W orld Federation Constitution 2013

Badminton World Federation Constitution 2013. Retrieved from

http://www. bufbadminton.org/pageaspx?id=15520 and last visited on $21^{\text {t }}$ October, 2013

Basketball

FIBA rule book 2010 - 2014.

FIBA rule book 2010 - 2014. Rerieved from:

http://www. fiba.com/pages/eng/fc/FIBA/rul eRegu/p/openNodelDs/897/selNodelD/89 7/baskOffiRulehtml

Official Basketball Rules \& Official Interpretations 2012

Official Basketball Rules \& Official Interpretations 2012. Retrieved from

http://www.fiba.com/pages/eng/fc/FIBA/ruleRegu/p/openNodelDs/897/selNodelD/89 7/baskOffiRulehtml and last visited on $21^{\text {ț }}$ October, 2013

Official Basketball Rules 2012

Official Basketball Rules 2012. Retrieved from

http://www.fiba.com/pages/eng/fc/FIBA/ruleRegu/p/openNodel Ds/897/selNodelD/89 7/baskOffiRulehtml and last visited on $21^{\star \star}$ October, 2013

FIBA Internal Regulations 2010 - Players and Officials - B ook 2

FIBA Internal Regulations 2010 - Players and Officials- Book 2. Retrieved from http://www.fiba.com/pages/eng/fc/FIBA/ruleRegu/p/openNodel Ds/916/selNodelD/91 6/fibaRegu.html and last visited on $21^{\text {t }}$ October, 2013

FIBA Internal Regulations 2010 - Players and Officials - Book 3

FIBA Internal Regulations 2010 - Players and Officials- Book 3. Retrieved from http://www.fiba.com/pages/eng/fc/FIBA/rul eRegu/p/openNodel Ds/916/selNodelD/91 6/fibaRegu.html and last visited on $21^{\text {t }}$ October, 2013

FIB A Internal Regulations 2009

FIBA Internal Regulations 2009. Received via email.

FIB A Internal Regulations 2006

FIBA Internal Regulations 2006. Received via email.

FIBA Internal Regulations 2004

FIBA Internal Regulations 2004. Received via email.

Biathlon

IBU event and competition rules 2012

IBU event and competition rules 2012. Retrieved from

http://www. biathl onworld.com/en/downl oads.html and last visited on $21^{\text {st }}$ October, 2013 
IBU event and competition rules adopted by the 1998 IB U congress with amendments by the 2000, 2002, 2004, 2006, 2008, 2010, 2012 and 2014 congresses IBU event and competition rules adopted by the 1998 IBU congress with amendments by the 2000, 2002, 2004, 2006, 2008, 2010, 2012 and 2014 congresses. Reerieved from:

http://www5.biathlonworld.com/media/files/rules_2014/IBU_Rules_2014_e_cap3.pdf.

IBU event and competition rules adopted by the 1998 IB U congress with amendments by the 2000, 2002, 2004, 2006, 2008, 2010 and 2012 congresses. IBU event and compeition rules adopted by the 1998 IBU congress with amendments by the 2000, 2002, 2004, 2006, 2008, 2010 and 2012 congresses. Retrieved from http://www. biathl onworld.com/en/downl oads.html.

\section{Bobsleigh}

\section{FIBT STATUTE S 2007}

FIBT STATUTES 2007. Rerieved from http://www. fibt.com/fibt-

federation/organization.html and last visited on $21^{\mathrm{s}}$ October, 2013

FIBT International B obsleigh R ules 2012

FIBT International Bobsleigh Rules 2012. Retrieved from

http://www. fibtcom/bobsleigh/rules.html and last visited on $21^{\text {st }}$ October, 2013

FIBT International Skeleton R ules 2012

FIBT International Skeleton Rules 2012. Retrieved from

http://www.fibtcom/skeletor/rul es.html and last visited on $21^{\star \pm}$ October, 2013

Admission International B obsleigh rules 2015 J une 2015

Admission International Bobsleigh rules 2015 J une 2015. Retrieved from

http://www.fibtcom/

Admission International B obsleigh rules 2014 October 2014

Admission International Bobsleigh rules 2014 October 2014. Retrieved from

http://www.fibtcom/uploads/media/2014_International_Rules_BOBSLEIGH_final.pd f

Admission Skeleton rules 2015 (valid from J une 2015).

Admission Skeleton rules 2015 (valid from J une 2015). Retrieved from:

http://www. fibtcom/

Admission Skeleton rules 2014 (valid from 0 ctober 2014).

Admission Skeleton rules 2014 (valid from October 2014). Retrieved from:

http://uww.fibtcom/uploads/media/2014_International_Rules_SKELETON_final.pdf

Boxing

AIBA technical rules effective as of February 1, 2015

AIBA technical rules effective as of February 1, 2015. Retrieved from

http://www. ai ba.org/documents/common/AIBA\%20Technical\%20Rules\%20-

\%2001.02.2015\%20bbbb.pdf 
AIB A technical rules effective as of August 31, 2014

AIBA technical rules effective as of August 31, 2014. Retrieved from:

http://uww. ai ba. org/documents/common/AIBA\%20Technical\%20Rules\%20-

\%20August\%2031,\%202014.pdf\#

AIB A technical rules. E ffective on A ugust 23, 2013.

AIBA technical rules. Effective on August 23, 2013.

. Retrieved from http://www. ai ba.org/defaul taspx?pl d=3565\#and last visited on $21^{\text {t }}$

October, 2013

AIB A STAT UTE S 2010 (amended 2011)

AIBA STATUTES 2010 (amended 2011). Rerieved from

http://hww. ai ba.org/defaul taspx?pl d=3565\#and last visited on $21^{\text {st }}$ October, 2013

\section{CanoeKayak}

International C anoe Federation Canoe Slalom competition rules 2015

Intermational Canoe Federation CanoeSlal om competition rules 2015. Rerrieved

fromhttp://www.canoeicf.com/icf/AboutlCF/Rules-and-Statutes.html

International C anoe Federation - C anoe Sprint competition rules 2015

International Canoe Federation - CanoeSprint competition rules 2015. Retrieved from: http://www.canoeicf.com/icf/AboutdCF/Rules-and-Statutes.html

International C anoe Federation - C anoe Slalom Competition R ules 2011 Intemational Canoe Federation - CanoeSlal om Competition Rules 2011. Retrieved from http://www.canoeicf.com/icf/AboutlCF/Rules-and-Statutes.html and last visited on $3^{\text {rd }}$ July 2013.

International C anoe Federation - C anoe Sprint Competition R ules 2013

International Canoe Federation - CanoeSprint Competition Rules 2013. Retrieved from http://www. canoeicf.com/icf/A boutd CF/Rules-and-Statutes.htmland last visited on $3^{\text {rd }}$ July 2013.

\section{Curling}

The rules of $C$ urling and rules of competition of $O$ ctober 2015

Therules of Curling and rules of competition of October 2015. Retrieved from: http://www. worldaurling.org/rul es-and-regul ations-downl oads.

The rules of $C$ urling and rules of competition of 0 ctober 2014

Therules of Curling and rules of competition of October 2014. Retrieved from: http://www. worldaurling.org/rules-and-regul ations-downl oads.

The rules of curling and rules of competition 2011

Therules of curling and rules of competition 2011. Retrieved from $\mathrm{http} / / / \mathrm{www}$. worldaurling.org/rul es-and-regul ations and last visited on $21^{\text {st }}$ October, 2013 
W orld C urling Federation C onstitution and Bylaws 2009

World Curling Federation Constitution and Bylaws 2009. Rerieved from

$\mathrm{http}: / / \mathrm{ww}$. worldarling.org/rul es-and-regul ations and last visited on $21^{\text {st }}$ October,

2013

J une 2007 C urling R uling R ule book

J une2007 Curling Ruling Rule book. Received vizemail. Seappendix.

Cycling

UCI Cycling regulations - general organisation of E 0116 Cycling as a sport part 1 general organisation of Cycling as a sport (versions of 15.03.16)

UCI Cycling regulations- general organisation of E0116 Cycling as a sport part 1 general organisation of Cycling as a sport (versions of 01.05.2014) Rerieved from http://www.ud.ch/

UCI Cycling regulations - general organisation of E 0116C ycling as a sport part 1 general organisation of Cycling as a sport (versions of 01.01.16)

$\mathrm{UCl}$ Cycling regulations - general organi sation of E0116 Cycling as a sport part 1 general organisation of Cycling as a sport (versions of 01.01.2016) Refrieved from http://www.ud.dV

UCI Cycling regulations general organisation of E 0115 Cycling as a sport part 1 general organisation of Cycling as a sport (version of 13.03.2015)

$\mathrm{UCl}$ Cycling regulations general organisation of E0115 Cycling as a sport part 1 general organisation of Cycling as a sport (version of 13.03.2015) Retrieved from http://www.udi.ch/mm/Document/News/Rul esandregulation/16/80/73/1-GEN20150313-E_English.pdf

UCI Cycling regulations general organisation of E 0914 Cycling as a sport part 1 general organisation of Cycling As A sport version of 25.09.2014.

$\mathrm{UCl}$ Cycling regulations general organisation of E0914 Cycling as a sport part 1 general organisation of Cycling As A sport version of 25.09.2014. Rerrieved from http://mww.uai.ch/

UCI Cycling regulations - general organisation of E 0514 Cycling as a sport part 1 general organisation of Cycling as a sport (versions of 01.05.14)

UCI Cycling regulations - general organisation of E0514 Cycling as a sport part 1 general organisation of Cycling as a sport (versions of 01.05.2014) Rerieved from http://www.udi.ch/

UCI Cycling regulations - general organisation of E 1014 Cycling as a sport part 1 general organisation of Cycling as a sport (versions of M arch 2014; October 2013 and October 2011)

UCI Cycling regulations - general organi sation of E1014 Cycling as a sport part 1 general organisation of Cycling as a sport (versions of March 2014; October 2013 and October 2011) Retrieved from http://www.uci.dV 
UCI Cycling regulations - general organisation of E 0105 Cycling as a sport part 1 general organisation of Cycling as a sport 2005.

UCI Cycling regulations - general organi sation of E0105 Cycling as a sport part 1 general organisation of Cycling as a sport 2005. Received viae-mail. Seeappendix.

UCI Constitution 2010

$\mathrm{UCl}$ Constitution 2010. Rerieved from

http://www.ud.ch/templates/UCl/UCl 3/layoutasp?Menuld=MTY 4MzM\&Langl d=1 and last visited on $21^{\text {st }}$ October, 2013

UCI Regulations Part I G eneral Organisation Cycling 2013

UCI Regulations Part I General Organi sation Cycling 2013. Retrieved from http://Www.udi.ch/templates/BUILTIN-

NOFRAMES/Templatel/layout.asp?Menul d=MTY2NjU\&Langl d=1 and last visited on $21^{\text {\} } \text { October, } 2013$

\section{UCI Regulations Part XI O lympic G ames 2013}

UCI Regulations PartXI Olympic Games 2013. Rerieved

fromhttp://www.uci.d/templates/BUILTIN-

NOFRAMES/Templatel/layout.asp?Menul d=MTY2NjU\&Langl d=1 and last visited on $21^{\text {s }}$ October, 2013

\section{Equestrian}

FEI G uidelines for the evaluation of pirouettes as well as contact and mouth problems

FEI Guidelines for the eval uation of pirouettes as well as contact and mouth problems. Retrieved from

http://www.fei.org/sites/default/files/file/DISCIPLINES/DRESSAGE/Rules/FEI\%20G uidelines\%20for\%20the\%20evaluation\%20of\%20pirouettes\%20\%20contac\%20and \%20mouth\%20problems_01july2011.pdf and last visited on 23 $3^{\text {rd }}$ March 2012

FEI J umping rules of 24th edition, effective $1 \mathrm{~J}$ anuary 2012.

FEI J umping rules of 24th edition, effective 1 January 2012. Retrieved from http://www.fei.org/sites/default/files/file/DISCIPLINES/J UMPING/Rul es/] umpRules _24thEd_2012_full-mark-up.pdf and last visited on 23 $3^{\text {rd }}$ March 2012

FEI rules on nationality (2010)

FEI rules on nationality (2010) Retrieved from http://studforlifecom/presse/photo/2010-01/Rul es2010.pdf and last visited on $3^{\text {rd }} \mathrm{July}$ $\underline{2013}$

FE I general regulations $23^{\text {rd }}$ edition, $1 \mathrm{~J}$ anuary 2009 , updates effective $1 \mathrm{~J}$ anuary 2016

FEl general regulations $23^{\text {rd }}$ edition, 1 J anuary 2009, updates effective 1J anuary 2015. Retrieved from: http://www.fei.org. 
FEI general regulations $23^{\text {rd }}$ edition, 1 J anuary 2009, updates effective $1 \mathrm{~J}$ anuary 2015

FEI general regulations $23^{\text {rd }}$ edition, 1 J anuary 2009, updates effective 1 J anuary 2015. Retrieved from:

http://www.fei.org/sites/default/files/GENERAL\%20REGULATIONS\%20\%20-

\%20Effective\%201\%20] anuary\%202015.pdf

FEI general regulations $23^{\text {rd }}$ edition, 1 J anuary 2009, updates effective 1 J anuary 2014.

FEl general regulations $23^{\text {rd }}$ edition, 1 J anuary 2009, updates effective 1 J anuary 2014.

Retrieved fromhttp://www.fei.org

FEI general regulations $23^{\text {rd }}$ edition, 1 J anuary 2009, updates effective $1 \mathrm{~J}$ anuary 2013

FEI general regulations $23^{\text {rd }}$ edition, 1 J anuary 2009, updates effective 1J anuary 2013 Retrieved from http://www.fei.org

FE I general regulations $23^{\text {rd }}$ edition, $1 \mathrm{~J}$ anuary 2009 , updates effective $1 \mathrm{~J}$ anuary 2012.

FEl general regulations $23^{\text {rd }}$ edition, 1 J anuary 2009, updates effective 1 J anuary 2012. Retrieved from http://uww.fei.org

FE I general regulations $23^{\text {rd }}$ edition, $1 \mathrm{~J}$ anuary 2009 , updates effective $1 \mathrm{~J}$ anuary 2011

FEl general regulations $23^{\text {rd }}$ edition, 1 January 2009, updates effective 1 J anuary 2011. Retrieved from http://www.fei.org

FEI general regulations, $23^{\text {rd }}$ edition, $1 \mathrm{~J}$ anuary 2009.

FEl general regulations, $23^{\text {rd }}$ edition, 1 January 2009. Received via-email. See appendix.

FE I general regulations, $22^{\text {nd }}$ edition, $1 \mathrm{~J}$ une 2007 and $22^{\text {nd }}$ edition with 2008 amendments.

FEl general regulations, $22^{\text {nd }}$ edition, 1 J une 2007 and $22^{\text {nd }}$ edition with 2008 amendments. Received vize-mail. Seeappendix.

FE I general regulations $21^{\text {st }}$ edition, effective $1 \mathrm{~J}$ anuary 2005

FEl general regulations $21^{ \pm}$edition, effective 1J anuary 2005. Received via-email.

See appendix.

FE I general regulations $21^{\text {st }}$ edition, effective $1 \mathrm{~J}$ anuary 2005 revision May 2006

FEl general regulations $21^{\text {t }}$ edition, effective 1 J anuary 2005 revision May 2006.

Received via-email. See appendix.

\section{Fenaing}

Administrative rules of the FIE of March 2012.

Administrativerules of theFIE of March 2012. Retrieved from

http://fiech/downl oad/status/en/ADMINISTRATIVE\%2ORULES-ANG.pdf and last

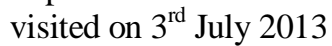


FIE Statutes of December 2011

FIE Statutes of December 2011 Retrieved from

http://uww.fiedh/downl oad/status/er/FIE\%20Statutes\%20ang.pdf and last visited on $3^{\text {rd }}$ July 2013.

FIE Statutes of December 2014

FIE Statutes of December 2014 Retrieved from: http://static9.fie org/upl oads/5/28808FIE\%20Statutes\%20ang.pdf

\section{FIE Statutes of December 2016}

FIE Statutes of December 2016 Rerrieved from: http://static9.fie org/upl oads/5/28808FIE\%20Statutes\%20ang.pdf

\section{Football}

FIFA statutes: regulations governing the application of the statutes 2015

FIFA statutes: regulations governing theapplication of the statutes 2015. Retrieved from:

http://www.fifa.com/mm/document/affederation/generic/02/58/14/48/2015fifastatutese n_neutral.pdf

FIFA statutes: regulations governing the application of the statutes 2014

FIFA statutes: regulations governing theapplication of thestatutes 2014. Retrieved from: http://www.fifa.com

\section{FIFA Statutes 2013}

FIFA Statutes 2013. Retrieved from

http://www.fifa.com/aboutfifa/organisation/statutes.html and last visited on $21^{\text {t }}$

October, 2013

FIFA Laws of the Game 2013/2014

FIFA Laws of the Game2013/2014. Retrieved from

$\mathrm{http}: / / \mathrm{ww} w$. fifa.com/aboutfifa/footbal Idevelopment/technical support/refereeing/lawsof-the-game/index.html land last visited on $21^{\text {st }}$ October, 2013

FIFA statutes: regulations governing the application of the statutes 2012

FIFA statutes: regulations governing theapplication of thestatutes 2012. Retrieved from: http://www.fifa.com

FIFA statutes: regulations governing the application of the statutes 2011 FIFA statutes: regulations governing theapplication of thestatutes 2011. Retrieved from http://www.fifa.com

FIFA Laws of the Game 2011/2012.

FIFA Laws of the Game2011/2012. Retrieved from

$\mathrm{http}: / / \mathrm{www}$.fifa.com/mm/document/affederation/generic/81/42/36/lawsofthegame_201 1_12_en.pdf and last visited on $3^{\text {rd }}$ July 2013. 
Declaration of the UEFA Congress on the Subject of L ocal Training of Players (2005)

Declaration of the UEFA Congress on the Subject of Local Training of Players (2005). Retrieved from

http://www.uefa.com/MultimediaFiles/Download/uefa/UEFAMedia/297202_DOWN LOAD.pdf and last visited on $3^{\text {rd } J}$ uly 2013.

FIFA Regulations 2014 W orld C up Brazil.

FIFA Regulations 2014 World Cup Brazil. Retrieved from

http://www. fifa.com/mm/document/toumament/competition/01/47/38/17/regulationsf wcbrazil2014_en.pdf and last visited on $3^{\text {rd }}$ July 2013.

FIFA Regulations G overning the Application of the Statutes (A ugust 2010). FIFA Regulations Governing the Application of theStatutes (August 2010). Retrieved from

http://www.fifa.com/mm/document/affederation/generic/01/29/85/71/fifastatuten2010 _epdf and last visited on $3^{\text {rd }}$ July 2013.

UE FA Investing in L ocal Training of Players $Q \& A$ UEFA Investing in Local Training of Players Q \& A. Retrieved from http://www.uefa.com/multimediafiles/downl oad/uefa/uefamedia/273606_downl oad.pd f and last visited on $3^{\text {rd }}$ July 2013.

FIFA statutes: regulations governing the application of the statutes 2009 FIFA statutes: regulations governing theapplication of the statutes 2009. Retrieved from: http://www.fifa.com

FIFA statutes: regulations governing the application of the statutes 2008 FIFA statutes: regulations governing theapplication of the statutes 2008. Retrieved from: http://www.fifa.com

FIFA statutes: regulations governing the application of the statutes 2007 FIFA statutes: regulations governing theapplication of the statutes 2007. Retrieved from: http://www.fifa.com

FIFA statutes: regulations governing the application of the statutes 2005 FIFA statutes: regulations governing theapplication of thestatutes 2005. Retrieved from: http://www.fifa.com

Golf

IG F Constitution 2010

IGF Constitution 2010. Retrieved from http://www.igfgolf.org/documents/ and last visited on $21^{\text {ț }}$ October, 2013

I G F nationality policy J une 2014

IGF nationality policy J une2014. Retrieved from http://igfederation.s3.amazonaws.com/wp-content/upl oads/2014/06//GF-NationalityPolicy.pdf. 
Gymastics

Athlete eligibility Fédération Internationale De G ymnastique- $Q$ ualification System - games of the XXXI Olympiad - Rio 2016 -Artistic G ymnastics Athlete eligibility Fédération International e De Gymastique Qualification Systemgames of the XXXI Olympiad - Rio 2016-Artistic Gymastics. Retrieved from http://www.fig-gymnastics.com/publicdir/rules/files/olympic/Rio\%202016Qualification-systempdf

A thlete eligibility Fédération Internationale De G ymnastique - Q ualification System - games of the XXXI Olympiad - Rio 2016-R hythmic G ymnastics Athlete eligi bility Fédération International e De Gymnastique- Qualification Systemgames of the XXXI Olympiad - Rio 2016- Rhythmic Gymastics. Retrieved from http://www.fig-gymmastics.com/publicdir/rules/files/olympic/Rio\%202016Qualification-systempdf

Athlete eligibility Fédération Internationale De G ymnastique - Q ualification System - games of the XXXI Olympiad - Rio 2016-Trampoline. Athletee ligi bility Fédération International e De Gymnastique- Qual ification Systemgames of the XXXI Olympiad - Rio 2016- Trampoline Retrieved from http://www.fig-gymmastics.com/publicdir/rules/files/olympic/Rio\%202016Qualification-systempdf

\section{FIG Statutes 2013}

FIG Statutes 2013. Retrieved fromhttp://www.figgymnastics.com/vsite/vnavsite/page/directory/0,10853,5187-188050-205272-nav-

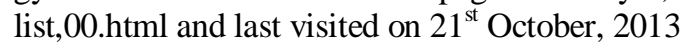

FIG Olympic Games Q ualification 2012

FIG Olympic Games Qualification 2012. Retrieved from http://uww.figgymastics.com/vsite/vnavsite/page/di rectory/0,10853,5187-188050-205272-navlist,00.html and last visited on $21^{ \pm}$October, 2013

Fédération Internationale De G ymnastique statutes edition 2009 in effect from J anuary $1^{\text {st }} 2015$

Fédération Internationale De Gymnastique statutes edition 2009 in effect fromJ anuary $1^{\text {st } 2015 . ~ R e r i e v e d ~ f r o m ~ h t t p: / / w w w . f i g-g y m m a s t i c s . c o m / ~}$

Fédération Internationale De G ymnastique statutes edition 2009 in effect from J anuary $1^{\text {st }} 2009$

Fédération Internationale De Gymnastique statutes edi tion 2009 in effect fromJ anuary $1^{\text {st }} 2009$. Received viaremail. Seeappendix.

Federation Internationale De G ymnastique statutes edition 2007 in effect from J anuary $1^{\text {st }}, 2007$

Federation Internationale De Gymastique statutes edition 2007 in effect fromJ anuary $1^{\text {st }}$, 2007. Received viazemail. Seeappendix. 
Federation Internationale De G ymnastique statutes edition 2004 in effect from $J$ anuary $1^{\text {st }}, 2005$.

Federation International e De Gymastique statutes edition 2004 in effect fromJ anuary $1^{\text {st }}, 2005$. Received viazemail. Seeappendix.

Handball

Player Eligibility C ode of the International H andball Federation (IHF) of J uly 2014

Player Eligibility Code of the International Handball Federation (IHF) of J uly 2014.

Retrieved from http://ams.eurohandball.com/

Player Eligibility C ode of the International Handball Federation (IHF) of J uly 2011

Player Eligi bility Code of the International Handball Federation (IHF) of July 201.

Retrieved from

http://cms eurohandball.com/Portal Data/1/Resources/1_enf main/11_downl oadsregul ations_forms/1_regulations/5_transfer/03___player_eligibility.pdf_And last visited on $3^{\text {rd }}$ July 2013.

Regulations for Transfer Between Federations E dition: 1 J uly 2011

Regulations for Transfer Between Federations Edition: 1 J uly 2011

http://cms.eurohandball.com/Portal Data/1/Resources/1_ehf_main/11_downl oadsregul ations_forms/1_regulations/5_transfer/Regulations_for_Transfers_Bétween_Federatio ns_E. $\overline{p d f}$. And last visited on $\overline{3}^{\text {rd }}$ July 2013.

Hockey

International H ockey Federation Statutes updated $3^{\text {rd } \mathrm{J}}$ uly, 2014

International Hockey Federation Statutes updated $3^{\text {rd }} \mathrm{J}$ uly, 2014. Retrieved from http://www.fih.ch.

International H ockey Federation Statutes updated $29^{\text {th }}$ M arch, 2013 International Hockey Federation Statutes updated 29 $9^{\text {th }}$ March, 2013. Reerieved from http://www.fih.ch.

International H ockey Federation Statutes updated 13 November, 2010 International Hockey Federation Statutes updated 13 November, 2010. Retrieved from http://www.fih.ch/en/fih/statutesan last visited on $3^{\text {rd }}$ J uly 2013.

FIH R egulations G overning the Eligibility of a Player to Play International H ockey for a Country / National A ssociation

FIH Regulations Governing theEligi bility of a Player to Play International Hockey for a Country / National Association. Retrieved from http://www. fih.dV/en/fih/statutesand last visited on $3^{\text {rd }}$ J uly 2013.

Ice Hockey

IIHF eligibility for Sochi M en and IIHF eligibility for Sochi Women.

IIHF eligibility for Sochi Men and IIHF eligibility for Sochi Women. Retrieved from http://sochi2014.iihf.com/ 
IIHF statutes and bylaws 2014 - 2018 of M ay 2014

IIHF statutes and bylaws 2014 - 2018 of May 2014. Retrieved from:

http://www.iihf.com/fil eadmin/use__upl oad/PDF/The_IIHF/2014

2018_IIHF_Statutes_and_Bylaws.podf

IIHF Statutes and Bylaws 2012-2014

IIHF Statutes and Bylaws 2012-2014. Retrieved from http://www.iihf.com/iihfhome/theiihf/statutes-bylaws.html and last visited on $21^{ \pm}$October, 2013

IIHF statutes and bylaws 2008-2012 with 2011 Amendments

IIHF statutes and bylaws 2008-2012 with 2011 Amendments. Received via-email.

See appendix.

IIHF statutes and bylaws 2003-2008

IIHF statutes and bylaws 2003-2008. Received via-email. Seeappendix.

Judo

Sports and organization rules of the International J udo Federation 2015

Sports and organization rules of thelntemational Judo Federation 2015. Reerieved fromhttp://www.intiudo.eu.

Sports and organization rules of the International J udo Federation 2013 Sports and organization rules of the International Judo Federation 2013. Retrieved fromhttp://www.intiudo.eu.

IJ F Statutes 2013

IJF Statutes 2013. Rerrieved from http://www.intjudo.ev/akk66 I and last visited on $21^{\text {st }}$ October, 2013

IJ F Statutes 2011

IJ F Statutes 2011. Rerieved from http://mww.intiudo.ev/cikk66 and last visited on 7th September, 2013

Luge

International L uge regulations - Artificial Track - approved at the 62nd FIL congress on J une 20, 2014 in Innsbruck / A ustria.

International Lugeregulations - Artificial Track - approved at the 62nd FIL congress on J une 20, 2014 in Innsbruck / Austria. Retrieved from http://www. fil-

luge org/fil eadmin/user_upl cad/Documents/IRO/IRO_2014_AT_English_complete_w eb.pdf

International L uge regulations - Artificial Track - approved at the 60th FIL congress on J une 15, 2012 in Riga / L atvia

International Lugeregulations - Artificial Track - approved at the 60th FIL congress on J une 15, 2012 in Riga/ Latvia. Retrieved from http://www.filluge org/index. php?id=416 and last visited on $21^{\ddagger}$ October, 2013 
IRO International $L$ uge regulations - Artificial Track - 2010 E dition approved at the $58^{\text {th }}$ FIL C ongress on J une 18, 2010 in Sochi / R ussian Federation. IRO International Luge regulations - Artificial Track - 2010 Edition approved at the $58^{\text {th }}$ FIL Congress on June 18, 2010 in Sochi / Russian Federation. Retrieved via e mail. Seeappendix.

IRO International L uge regulations - Artificial Track - 2008 E dition approved at the $56^{\text {th }}$ FIL C ongress on J une $28^{\text {th }}, 2008$ in Calgary / C anada IRO Intemational Lugeregulations - Artificial Tradk - 2008 Edition approved at the $56^{\text {th }}$ FIL Congress on J une $28^{\text {th }}$, 2008 in Cal gary / Canada Retrieved via email. See appendix.

IRO International L uge regulations - Artificial Track - $2006 \mathrm{E}$ dition approved at the $54^{\text {th }}$ FIL Congress on J une $29^{\text {th }}, 2006$ in Berchtesgaden / G ermany IRO International Luge regulations - Artificial Track - 2006 Edition approved at the $54^{\text {th }}$ FIL Congress on June 29 $9^{\text {th }}, 2006$ in Berchtesgaden / Germany. Rerieved via e mail. Seeappendix.

I RO International L uge regulations - Artificial Track -2004 E dition approved at the $52^{\text {nd }}$ FIL Congress on J une $11^{\text {th }}, 2004$ in Rio de J aneiro / B razil. IRO Intemational Luge regulations - Artificial Track -2004 Edition approved at the $52^{\text {nd }}$ FIL Congress on June $11^{\text {th }}, 2004$ in Rio de Janeiro / Brazil. Retrieved via email. See appendix.

I RO International L uge regulations - Artificial Track -2002 E dition approved at the $50^{\text {th }}$ FIL Congress on J une $28^{\text {th }}, 2002$ in St. W olfgang / AUT.

IRO Intemational Luge regulations - Artificial Track -2002 Edition approved at the $50^{\text {th }}$ FIL Congress on June $28^{\text {th }}, 2002$ in St. Wolfgang / AUT. Retrieved via email. See appendix.

I RO Internationale R ennrodelordnung - K unstbahn - A usgabe 2000 beschlossen beim 48. FIL -K ongress am 17.6.2000 in O berh of / G E R.

IRO International e Rennrodel ordnung - Kunstbahn - Ausgabe 2000 beschl ossen beim 48. FIL-Kongress am 17.6.2000 in Oberhof / GER. Retrieved via email. Se appendix.

IRO International L uge regulations - Artificial Track - $1998 \mathrm{E}$ dition approved at the $46^{\text {th }}$ FIL Congress on $\mathrm{J}$ une $7^{\text {th }}, 1998$ in Colorado Springs.

IRO Intemational Luge regulations - Artificial Track - 1998 Edition approved at the $46^{\text {th }}$ FIL Congress on June $7^{\text {th }}, 1998$ in Colorado Springs. Retrieved via email. See appendix.

I RO International L uge regulations - Natural Track -2014 E dition approved at the $62^{\text {nd }}$ FIL Congress on J une $20^{\text {th }}, 2014$ in Innsbruck / Austria IRO International Luge regulations - Natural Track -2014 Edition approved at the $62^{\text {nd }}$ FIL Congress on J une $20^{\text {th }}$, 2014 in Innsbruck / Austria. Rerieved from http://www.fil-lugeorg/ 
International L uge regulations - Natural T rack - 2012 edition approved at the 60th FIL congress on J une 15, 2012 in Riga / L atvia.

International Lugeregulations - Natural Track - 2012 edition approved at the 60th FIL congress on J une 15, 2012 in Riga / Latvia. Retrieved from http://uww. fil-

lugeorg/index.php?id=416 and last visited on $21^{\text {tt }}$ Odtober, 2013

IRO International L uge regulations - Natural Track - $2010 \mathrm{E}$ dition approved at the $58^{\text {th }}$ FIL C ongress on J une $18^{\text {th }}, 2010$ in Sochi / R ussian Federation IRO International Luge regulations - Natural Track - 2010 Edition approved at the $58^{\text {th }}$ FIL Congress on J une 18 1 , 2010 in Sochi / Russian Federation. Retrieved via email. See appendix.

IRO International L uge regulations - Natural Track - $2008 \mathrm{E}$ dition approved at the $56^{\text {th }}$ FIL C ongress on J une $28^{\text {th }}, 2008$ in C algary / C anada

IRO International Luge regulations - Natural Track - 2008 Edition approved at the $56^{\text {th }}$ FIL Congress on J une 28 ${ }^{\text {th }}, 2008$ in Cal gary / Canada. Retrieved via email. See appendix.

IRO International L uge regulations - Natural Track - 2006 E dition approved at the $54^{\text {th }}$ FIL C ongress on J une $29^{\text {th }}, 2006$ in Berchtesgaden / Germany IRO International Luge regulations - Natural Track - 2006 Edition approved at the $54^{\text {th }}$ FIL Congress on J une 29 $9^{\text {th }}, 2006$ in Berchtesgaden / Germany. Retrieved via email. See appendix.

IRO International L uge regulations - Natural Track -2004 E dition approved at the $52^{\text {nd }}$ FIL C ongress on J une $11^{\text {th }}, 2004$ in Rio de J aneiro / B razil IRO International Lugeregulations - Natural Track -2004 Edition approved at the $52^{\text {nd }}$ FIL Congress on J une 11 $11^{\text {th }}, 2004$ in Rio de Janeiro / Brazil. Retrieved via email. See appendix.

IRO International L uge regulations - Natural Track -2002 E dition approved at the $50^{\text {th }}$ FIL C ongress on J une $28^{\text {th }}, 2002$ in St. W olfgang / AUT IRO International Luge regulations - Natural Track -2002 Edition approved at the $50^{\text {th }}$ FIL Congress on June 28 $8^{\text {th }}, 2002$ in St Wolfgang / AUT. Retrieved via email. See appendix.

I RO International L uge regulations - Natural Track - 2000 E dition approved at the $48^{\text {th }}$ FIL C ongress on J une $17^{\text {th }}, 2000$ in 0 berhof / G E R

IRO International Luge regulations - Natural Track - 2000 Edition approved at the $48^{\text {th }}$ FIL Congress on J une $17^{\text {th }}, 2000$ in Oberhof / GER. Refrieved via email. See appendix.

I RO International L uge regulations - Natural Track - 1998 E dition approved at the $46^{\text {th }}$ FIL C ongress on J une $7^{\text {th }}, 1998$ in Colorado Springs

IRO International Luge regulations - Natural Track - 1998 Edition approved at the $46^{\text {th }}$ FIL Congress on J une $7^{\text {th }}$, 1998 in Col orado Springs. Retrieved via e-mail. See appendix. 
Modern Pentathlon

UIPM Rules on Internal O rganisation T apeo November 2015

UIPM Rules on Internal Organisation Tapeo November 2015. Retrieved from

http://www. pentathlon.org/.

Union Internationale de Pentathlon M oderne (International Union of the M odern Pentathlon) ST AT UTE S Season 2013

Union International ede Pentathl on Modeme (International Union of the Modern

Pentathl on) STATUTES Season 2013. Retrieved from

http://www.pentathl on.org/images/Rul es/i\%20ui pm\%20constitutional\%20rul es\%2020 13.pdfAnd last visited on: $3^{\text {rd }}$ J uly, 2013.

Union Internationale de Pentathlon M oderne (I nternational Union of the M odern Pentathlon) statutes - UIPM rules on internal organisation chapter I. - eligibility rules 2012.

Union International ede Pentathl on Modeme (Intemational Union of the Modern Pentathl on) statutes - UIPM rules on internal organisation dhapter I. - eligi bility rules 2012. Received via-email. Seeappendix.

Union Internationale de Pentathlon M oderne (International Union of the M odern Pentathlon) statutes - UIPM rules on internal organisation chapter IV - eligibility rules 2011

Union International ede Pentathl on Modeme (International Union of the Modern Pentathlon) statutes- UIPM rules on intemal organisation chapter IV - eligibility rules 2011. Received via-email. Seeappendix.

Union Internationale de Pentathlon M oderne (International Union of the M odern Pentathlon) statutes - UIPM rules on internal organisation chapter IV - eligibility rules 2010

Union International ede Pentathl on Modeme (International Union of the Modern Pentathl on) statutes- UIPM rules on intemal organisation chapter IV - eligibility rules 2010. Received viaremail. Seeappendix.

Union Internationale de Pentathlon M oderne (International Union of the M odern Pentathlon) statutes - UIPM rules on internal organisation chapter IV - eligibility rules 2009

Union Internationale de Pentathlon Modeme(International Union of the Modern Pentathlon) statutes - UIPM rules on internal organisation chapter IV - eligi bility rules 2009. Received vize-mail. Seeappendix.

Union Internationale de Pentathlon M oderne (International Union of the M odern Pentathlon) statutes - UIPM rules on internal organisation chapter IV. eligibility rules 2008

Union International ede Pentathl on Modeme (International Union of the Modern Pentathl on) statutes - UIPM rules on internal organisation chapter IV. - digibility rules 2008. Received viaemail. Seeappendix. 
Union Internationale de Pentathlon M oderne (International Union of the M odern Pentathlon) statutes - UIPM rules on internal organisation chapter IV - eligibility rules 2007

Union International ede Pentathl on Modeme (International Union of the Modern Pentathl on) statutes - UIPM rules on internal organisation chapter IV - eligibility rules 2007. Received viaemail. Seeappendix.

Union Internationale de Pentathlon M oderne (International Union of the M odern Pentathlon) statutes - UIPM rules on internal organisation chapter IV - eligibility rules 2005

Union International ede Pentathl on Modeme (International Union of the Modern Pentathl on) statutes - UIPM rules on internal organisation chapter IV - eligi bility rules 2005. Received vizemail. Seeappendix.

Rowing

FISA rule book February 2013.

FISA rulebook February 2013. Received from

http://www.worldrowing.com/fisa/publications/rul e-book

FISA R ule Book March 2011

FISA RuleBook March 2011. Retrieved from

http://www.worldrowing.com/fisa/resources/rule booksand last visited on $3^{\text {rd }} \mathrm{July}$ 2013.

FISA R ules applicable 2005 to 2011

FISA Rules applicable 2005 to 2011. Received via-email. Seeappendix.

\section{Rugby}

International R ugby B oard handbook as framed by the International R ugby B oard last updated: 8 M arch 2016

Intemational Rugby Board handbook as framed by the International Rugby Board last updated: 8 March 2016. Received from http://www.worldrugby.org/

International R ugby B oard handbook as framed by the International R ugby B oard last updated: 1 J anuary 2016

International Rugby Board handbook as framed by the International Rugby Board last updated: 1J anuary 2016. Received from http://www. worldrugby. org/

International R ugby B oard handbook as framed by the International R ugby B oard last updated: 11 September 2015

International Rugby Board handbook as framed by the International Rugby Board last updated: 11 September 2015. Received from http://www. worldrugby.org/

International R ugby B oard handbook as framed by the International R ugby B oard last updated: 1 A ugust 2015

International Rugby Board handbook as framed by the International Rugby Board last updated: 1 August 2015. Received from http://www.worldrugby.org/ 
International R ugby B oard handbook as framed by the International R ugby B oard last updated: 15 M ay 2015

International Rugby Board handbook as framed by the International Rugby Board last updated: 15 May 2015. Received from http://www.worldrugby.org/

International R ugby B oard handbook as framed by the International R ugby B oard last updated: 22 M arch 2015

Intermational Rugby Board handbook as framed by the International Rugby Board last updated: 22 March 2015. Received from http://www. worldrugby. org/wrresources/WorldRugbyDIR/Handbook/English/pubData/source/150320\%20GF\%20Ha ndbook\%20English\%20Web\%20Version.pdf

International R ugby B oard handbook as framed by the International R ugby B oard last updated: 1 September, 2014

Intermational Rugby Board handbook as framed by the International Rugby Board last updated: 1 September, 2014. Received from:

http://www. irb.com/irbupl oader/ePubs/Handbook/Website Content/140701 English/p ubData/source/140901\%20GF\%20I RB\%20Handbook\%20W'Website\%20Version.pdf

International R ugby B oard handbook as framed by the International R ugby B oard last updated: 1 December, 2013

Intermational Rugby Board handbook as framed by the International Rugby Board last updated: 1 December, 2013. Received from: http://www.irb.com/

IRB Handbook J uly 2013

IRB Handbook July 2013. Retrieved from

http://wwww. irb.com/aboutirb/constitution/index.html and last visited on $21^{\text {st }}$ October, 2013

Sailing

ISAF regulations 2015 - A nnex 3 - eligibility code - November 2014

ISAF regulations 2015 - Annex 3- eligibility code- November 2014. Retrieved from http://www.sailing.org/

ISAF regulations 2014 - A nnex 3 - eligibility code - November 2013

ISAF regulations 2014 - Annex 3- eligibility code- November 2013. Retrieved from http://www.sailing.org/documents/index.php

ISAF regulations 2014 - A nnex 3 - eligibility code - M ay 2013.

ISAF regulations 2014 - Annex 3- eligibility code- May 2013. Retrieved from: http://www.sailing.org/documents/index.php

ISAF regulations 2012 A ppendix 3 - Eligibility C ode

ISAF regulations 2012 Appendix 3 - Eligibility Code Retrieved from

http://www. sailing.org/documents/index.php.And last visited on: $3^{\text {rd }}$ July 2013. 
Shooting

ISSF 0 fficial Statutes R ules and Regulations E dition 2013 (fourth print 03/2016) ISSF Official Statutes Rules and Regulations Edition 2013 (fourth print 03/2016). Retrieved from http://uww.issf-sports.org.

ISSF 0 fficial Statutes R ules and Regulations E dition 2013 (Third print, 01/2015) ISSF Official Statutes Rules and Regulations Edition 2013 (Third print, 01/2015). Rerieved from http://www.issf-sports.org.

ISSF 0 fficial Statutes R ules and Regulations E dition 2013 (Second print, 01/2014) ISSF Official Statutes Rules and Regulations Edition 2013 (Second print, 01/2014). Retrieved from http://uww.issf-sports.org.

ISSF 0 fficial Statutes R ules and Regulations E dition 2013 (First Print, 11/2012) ISSF Official Statutes Rules and Regulations Edition 2013 (First Print, 11/2012). Retrieved from http://www.issf-sports.org/theissf/rul es/english_rul ebook.ashxand last visited on $3^{\text {rd }}$ July 2013.

Skating

International Skating Union general regulations 2014 as accepted by the $55^{\text {th }}$ Ordinary Congress

International Skating Union general regulations 2014 as accepted by the $55^{\text {th }}$ Ordinary Congress. Retrieved from http://static.isu.org/media/165642/constitution-and-generalregulations-version-july-31-2014.pdf

ICU Constitution and General R ules 2012

ISU Constitution and General Rules 2012. Retrieved from

http://www.isu.org/vsite/vnavsite/page/directory/0,10853,4844-153889-171105-navlist, 00.html and last visited on $21^{\text {st }}$ October, 2013

Special R ules and R egulations Speed Skating and Short Track 2012

Special Rulesand Regulations Speed Skating and Short Track 2012. Rerieved from http://www.isu.org/vsite/vnavsite/page/directory/0,10853,4844-153889-171105-navlist, 00.htm and last visited on $21^{\mathrm{s}}$ October, 2013

Synchronized Skating Regulations Single and Pair and Ice Dance 2012 Synchronized Skating Regul ations Singleand Pair and I ceDance 2012. Retrieved from http://www.isu.org/vsite/ mavsite/page/directory/0,10853,4844-153889-171105nav-list,00.htm and last visited on $21^{\text {st }}$ October, 2013

Synchronized Skating Regulations Synchronized Skating R egulations 2012 Synchronized Skating Regul ations Synchronized Skating Regulations 2012. Retrieved from http://www.isu.org/vsite/vnavsite/page/directory/0,10853,4844-153889-171105nav-list,00.htm and last visited on $21^{\mathrm{t}}$ October, 2013

Skiing

FIS Statutes 2012

FIS Statutes 2012. Retrieved from http://uww. fis-ski.com/inside fis/documentlibrary/statutes/index.html and last visited on $21^{\text {\$ }}$ October, 2013 


\section{FIS 2014 Q ualifications}

FIS 2014 Qualifications. Rerrieved from http://uww.fis-ski.com/inside-fis/documentlibrary/olympics/index.html and last visited on $21^{\mathrm{t}}$ October, 2013

International C ompetition rules Alpine Skiing 2013

Intemational Competition rules AlpineSkiing 2013. Retrieved from http://www.fisski.com/insidefis/document-library/al pineskiing/index.html and last visited on $21^{\text {t }}$ October, 2013

\section{International Competition rules C ross C ountry 2013}

Intemational Competition rules Cross Country 2013. Retrieved from http://www. fisski.com/insidefis/document-library/cross-country/index.html and last visited on $21^{\text {t }}$ October, 2013

International Competition rules Nordic Combined 2012

International Competition rul es Nordic Combined 2012. Retrieved from http://www. fis-ski.com/inside-fis/document-library/nordic-combined/index.html and last visited on $21^{\text {tt }}$ October, 2013

International C ompetition rules Ski J umping 2012 Intemational Compeition rules Ski J umping 2012. Retrieved from http://uww.fisski.com/insidefis/document-library/ski-jumping/index.html and last visited on $21^{\text {s }}$ October, 2013

International Ski Competition R ules (ICR) book II C ross-C ountry approved by the $49^{\text {th }}$ International Ski congress, Barcelona (Spa) E dition J uly 2015 and November 2015

International Ski Competition Rules (ICR) book II Cross-Country approved by the $49^{\text {th }}$ International Ski congress, Barcelona (Spa) Edition July 2015 and November 2015. http://www.fis-ski.com/inside-fis/document-library/cross-country/index.html

International Ski Competition R ules (IC R ) book II C ross-C ountry approved by the $49^{\text {th }}$ International Ski congress, Barcelona (Spa) J uly 2014

International Ski Competition Rules (ICR) book II Cross-Country approved by the $49^{\text {th }}$ International Ski congress, Barcelona (Spa) J uly 2014. http://www.fis-ski.com/insidefis/document-library/cross-country/index.html

International Ski Competition R ules (ICR ) book II C ross-C ountry approved by the $48^{\text {th }}$ International Ski congress, $K$ angwonland (K OR) incl. marked up changes and precisions 2013 web edition O ctober 2013 International Ski Competition Rules (ICR) book II Cross-Country approved by the $48^{\text {th }}$ Intemational Ski congress, Kangwonland (KOR) ind. marked up changes and precisions 2013 web edition October 2013. http://www. fis-ski.com/insidefis/document-library/cross-country/index.html 
International Ski Competition R ules (ICR) book III Ski J umping approved by the 49th International Ski congress, Barcelona (Spa) J uly 2015;

International Ski Compeition Rules (ICR) book III Ski Jumping approved by the 49th International Ski congress, Barcelona (Spa) J uly 2015. from http://uww. fisski.com/insidefis/document-library/ski-jumping/index.html

International Ski C ompetition R ules (ICR ) book III Ski J umping approved by the 49th International Ski congress, Barcelona (Spa) J uly 2014;

International Ski Competition Rules (ICR) book III Ski J umping approved by the 49th International Ski congress, Barcelona (Spa) J uly 2014. from http://www.fisski.com/insidefis/document-library/ski-jumping/index.html

International Ski Competition R ules (ICR) book III Ski J umping approved by the $48^{\text {th }}$ International Ski congress, K angwonland (K OR) web edition October 2013

International Ski Competition Rules (ICR) book III Ski Jumping approved by the $48^{\text {th }}$ Intermational Ski congress, Kangwonland (KOR) web edition October 2013. from http://uww. fis-ski.com/inside-fis/document-library/ski-jumping/index.html

International Ski Competition R ules (ICR) book IV J oint regulations for A lpine Skiing, Downhill Slalom Giant Slalom Super-G, Combined E vents Team E vents Parallel Events $K$ o E vents approved by the $49^{\text {th }}$ International Ski congress, Barcelona (Spa), J uly 2015 International Ski Competition Rules (ICR) book IV J oint regulations for Al pine Skiing, Downhill Slal om Giant Slal om Super-G, Combined Events TeamEvents Paralle Events Ko Events approved by the $49^{\text {th }}$ Intemational Ski congress, Barcelona (Spa), J uly 2015. Retrieved from http://www. fis-ski.com/insidefis/documentlibrary/al pineskiing/index.html

International Ski C ompetition Rules (ICR) book IV J oint regulations for Alpine Skiing, Downhill Slalom Giant Slalom Super-G, Combined E vents Team E vents Parallel E vents $K$ o E vents approved by the $49^{\text {th }}$ International Ski congress, Barcelona (Spa), J uly 2014

International Ski Competition Rules (ICR) book IV J oint regulations for Alpine Skiing, Downhill Slal om Giant Slal om Super-G, Combined Events Team Events Paralle Events Ko Events approved by the $49^{\text {th }}$ Intemational Ski congress, Barcel ona (Spa), J uly 2014. Retrieved from http://www. fis-ski.com/inside fis/documentlibrary/al pineskiing/index.html

International Ski Competition R ules (ICR) book IV J oint regulations for Alpine Skiing Downhill, Slalom, Giant Slalom, Super-G, Combined E vents, Team E vents, Parallel E vents, $K$ o E vents approved by the $48^{\text {th }}$ International Ski congress, K angwonland (K O R) web edition J uly 2013

International Ski Competition Rules (ICR) book IV J oint regulations for Alpine Skiing Downhill, Slal om Giant Slal om, Super-G, Combined Events, Team Events, Paralle Events, Ko Events approved by the $48^{\text {th }}$ International Ski congress, Kangwonland (KOR) web edition J uly 2013. Retrieved from http://www. fis-ski.com/insidefis/document-library/al pineskiing/index.html 
International Freestyle Skiing Competition R ules (ICR) book V J oint regulations for Freestyle Skiing, Aerials M oguls, Dual M oguls Ski Cross Ski H alfpipe, Ski Slopestyle approved by the $49^{\text {th }}$ International Ski congress, Barcelona (Spa) August 2015

International FreestyleSkiing Competition Rules (ICR) book V J oint regulations for Freestyle Skiing, Aerials Moguls, Dual Moguls Ski Cross Ski Halfpipe, Ski Slopestyle approved by the $49^{\text {th }}$ Intemational Ski congress, Barcelona (Spa) August

2015. Retrieved from: http://www. fis-ski.com/inside fis/document-library/freestyle skiing/index.htwl

International Freestyle Skiing Competition R ules (ICR) book V J oint regulations for Freestyle Skiing, Aerials M oguls, Dual M oguls Ski Cross Ski H alfpipe, Ski Slopestyle approved by the $49^{\text {th }}$ International Ski congress, Barcelona (Spa) November 2014

International FreestyleSkiing Competition Rules (ICR) book V J oint regulations for Freestyle Skiing, Aerials Moguls, Dual Moguls Ski Cross Ski Halfpipe, Ski Slopestyle approved by the $49^{\text {th }}$ International Ski congress, Barcel ona (Spa) November 2014. Rerrieved from: http://uww. fis-ski.com/inside fis/document-library/freestyle skiing/index.htm

International Freestyle Skiing Competition R ules (ICR) book V J oint regulations for Freestyle Skiing Aerials M oguls, Dual M oguls, Ski Cross, Ski H alfpipe, Ski Slopestyle approved by the $48^{\text {th }}$ International Ski congress, K angwonland ( $K$ or) web edition November 2013

International FreestyleSkiing Competition Rules (ICR) book V J oint regulations for Freestyle Skiing Aerials Moguls, Dual Moguls, Ski Cross, Ski Halfpipe, Ski Slopestyleapproved by the $48^{\text {th }}$ International Ski congress, Kangwonland (Kor) web edition November 2013. Reerieved from: http://www.fis-ski.com/inside fis/documentlibrary/freestyleskiing/index.html

International Freestyle Skiing Competition R ules (ICR ) book V J oint regulations for Freestyle Skiing Aerials M oguls, Dual M oguls, Ski Cross, Ski H alfpipe, Ski Slopestyle approved by the $48^{\text {th }}$ International Ski congress, K angwonland ( $K$ or) web edition J uly 2013

International FreestyleSkiing Competition Rules (ICR) book V J oint regulations for Freestyle Skiing Aerials Moguls, Dual Moguls, Ski Cross, Ski Halfpipe, Ski

Slopestyleapproved by the $48^{\text {th }}$ International Ski congress, Kangwonland (Kor) web edition July 2013. Retrieved from: http://www.fis-ski.com/inside-fis/documentlibrary/freestyle-skiing/index.html 
International Snowboard Competition R ules (ICR) book VI J oint regulations for Snowboarding Slalom / G iant Slalom Triple-S, Parallel E vents Snowboard Cross Snowboard Halfpipe Snowboard Big Air, Snowboard Slopestyle approved by the 49th International Ski congress, B arcelona (Spa) September and December 2015 E dition

International Snowboard Competition Rules (ICR) book VI J oint regulations for Snowboarding Slal om/Giant Slal omTripleS, Parallel Events Snowboard Cross Snowboard Hal fpipeSnowboard Big Air, Snowboard Sl opestyle approved by the 49th Intemational Ski congress, Barcelona (Spa) September and December 2015 Edition. Retrieved from http://www. fis-ski.com/inside fis/documentlibrary/snowboard/index.html

International Snowboard Competition R ules (ICR ) book VI J oint regulations for Snowboarding Slalom / G iant Slalom Triple-S, Parallel E vents Snowboard Cross Snowboard Halfpipe Snowboard Big Air, Snowboard Slopestyle approved by the 49th International Ski congress, B arcelona (Spa) October 2014 International Snowboard Competition Rules (ICR) book VI J oint regulations for Snowboarding Slal om/Giant Slal om TripleS, Paralle Events Snowboard Cross Snowboard Hal fpipe Snowboard Big Air, Snowboard Slopestyle approved by the 49th International Ski congress, Barcelona (Spa) October 2014. Retrieved from http://www.fis-ski.com/inside-fis/document-library/snowboard/index.html

International Snowboard Competition R ules (ICR) book VI J oint regulations for Snowboarding Slalom / G iant Slalom, Triple-S, Parallel Events, Snowboard Cross, Snowboard H alfpipe, Snowboard Big Air, Snowboard Slopestyle approved by the $48^{\text {th }}$ International Ski congress, Kangwonland (K OR) web edition November 2013

International Snowboard Competition Rules (ICR) book VI J oint regulations for Snowboarding Slalom/ Giant Slal om TripleS, Paralle Events, Snowboard Cross, Snowboard Hal fpipe, Snowboard Big Air, Snowboard Slopestyle approved by the $48^{\text {th }}$ Intemational Ski congress, Kangwonland (KOR) web edition November 2013. Retrieved from http://www. fis-ski.com/inside fis/documentlibrary/snowboard/index.html

International Snowboard Competition R ules (ICR) book VI J oint regulations for Snowboarding Slalom / Giant Slalom, Triple-S, Parallel Events, Snowboard Cross, Snowboard H alfpipe, Snowboard Big Air, Snowboard Slopestyle approved by the $48^{\text {th }}$ International Ski congress, Kangwonland (K OR) web edition A ugust 2013

International Snowboard Competition Rules (ICR) book VI J oint regulations for Snowboarding Slalom/ Giant Slal om TripleS, Paralle Events, Snowboard Cross, Snowboard Hal fpipe, Snowboard Big Air, Snowboard Sl opestyle approved by the $48^{\text {th }}$ International Ski congress, Kangwonland (KOR) web edition August 201. Retrieved from http://www.fis-ski.com/inside fis/document-library/snowboard/index.html 
International Ski Competition R ules (ICR) book VII Nordic Combined approved by the $4^{\text {th }}$ International Ski congress, Barcelona (Spa) October 2015. Intemational Ski Competition Rules (ICR) book VII Nordic Combined approved by the $49^{\text {th }}$ International Ski congress, Barcelona (Spa) October 2015. Retrieved from http://www.fis-ski.com/inside-fis/document-library/nordic-combined/index.html

International Ski C ompetition R ules (ICR) book VII Nordic Combined approved by the $49^{\text {th }}$ International Ski congress, B arcelona (Spa) J uly 2015.

International Ski Compeition Rules (ICR) book VII Nordic Combined approved by the $49^{\text {th }}$ Intemational Ski congress, Barcelona (Spa) July 2015. Retrieved from http://www.fis-ski.com/insidefis/document-library/nordic-combined/index.html

International Ski C ompetition R ules (ICR) book VII Nordic Combined approved by the $4^{\text {th }}$ International Ski congress, B arcelona (Spa) November 2014.

Intemational Ski Competition Rules (ICR) book VII Nordic Combined approved by the $49^{\text {th }}$ International Ski congress, Barcelona (Spa) November 2014. Retrieved from http://wwww.fis-ski.com/insidefis/document-library/nordic-combined/index.html

International Ski C ompetition R ules (ICR) book VII Nordic Combined approved by the $49^{\text {th }}$ International Ski congress, B arcelona (Spa) August 2014;

International Ski Competition Rules (ICR) book VII Nordic Combined approved by the $49^{\text {th }}$ International Ski congress, Barcelona (Spa) August 2014. Retrieved from http://www.fis-ski.com/insidefis/document-library/nordic-combined/index.html

International Ski Competition R ules (ICR) book VII Nordic Combined approved by the $48^{\text {th }}$ International Ski congress, K angwonland (KOR) web edition October 2013

Intemational Ski Competition Rules (ICR) book VII Nordic Combined approved by the 48 Intemational Ski congress, Kangwonland (KOR) web edition October 2013. Retrieved from http://www. fis-ski.com/inside fis/document-library/nordiccombined/index.html

TableTennis

ITTF handbook 2016

ITTF handbook 2016. Retrieved from http://www.itf.com/

ITTF handbook 2014-2015

ITTF handbook 2014-2015. Retrieved from

http://www.ittf.com/ittf_handbook/2014/2014_EN_HBK_CHPT_3.pdf 2014-2015

ITTF Constitution 2013/2014

ITTF Constitution 2013/2014. Retrieved from

http://www.ittf.com/stories/full_story.asp?title=\%3E\%3E\%20Regul ations and last visited on $21^{\star}$ October, 2013

ITTF Constitution 2012/2013

ITTF Constitution 2012/2013. Rerieved from

http://www.ittf.com/stories/full_story.asp?title=\%3E\%3E\%20Regul ations and last

visited on $7^{\text {th }}$ September, 2013 
ITTF handbook 2010-2012

ITTF handbook 2010-2012. Received via-email. Seeappendix.

ITTF handbook 2009-2010

ITTF handbook 2009-2010 Received via-email. Seappendix.

ITTF handbook 2008-2009

ITTF handbook 2008-2009. Received via-email. Seeappendix.

ITTF handbook 2005-2008

ITTF handbook 2005-2008. Received via-email. Seeappendix.

ITTF Regulations for International Competitions 2013

ITTF Regulations for International Competitions 2013. Rerrieved from

http://www.ittf.com/stories/full_story.asp?title=\%3E\%3E\%20Regulations and last visited on $21^{\text {st }}$ October, 2013

ITTF Regulations for International Competitions 2012

ITTF Regulations for International Compeitions 2012. Rerrieved from

$\mathrm{http} / / / \mathrm{ww}$.ittf.com/stories/full_story.asp?title=\%3E\%3E\%2ORegul ations and last visited on $7^{\text {th }}$ September, 2013

\section{ITTF Regulations for Olympics 2013}

ITTF Regulations for Olympics 2013. Retrieved from

http://www.ittf.com/stories/full_story.asp?tite=\%3E\%3E\%20Regulations and last visited on $21^{\text {tf }}$ October, 2013

\section{ITTF Regulations for Olympics 2012}

ITTF Regulations for Olympics 2012. Retrieved from

http://www.ittf.com/stories/full_story.asp?title=\%3E\%3E\%20Regulations and last visited on $7^{\text {th }}$ September, 2013

Taekwondo

WTF Ethics Code 0 ctober 2011

WTF Ethics CodeOctober 2011. Retrieved from

$\mathrm{http} / / / \mathrm{ww}$. worldtadkwondofederation. ne/rul es-and-documents and last visited on $21^{ \pm}$October, 2013

\section{WTF Statutes J uly 2013}

WTF Statutes J uly 2013. Rerieved from

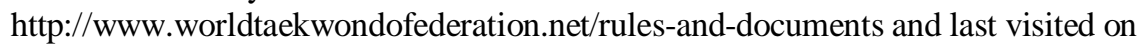
$21^{\mathrm{s}}$ October, 2013

WTF Statutes December 2012

WTF Statutes December 2012. Rerieved from

http://www. worldtadkwondofederation. net/rules-and-documents and last visited on $21^{ \pm}$October, 2013 
WTF Statutes A pril 2012

WTF Statutes April 2012. Retrieved from

http://www. worldtadkwondofederation. net/rules-and-documents and last visited on $21^{\text {t }}$ October, 2013

W orld Taekwondo Federation rules $\&$ interpretation in force as of $11^{\text {th }} M$ ay 2015. World Taekwondo Federation rules \& interpretation in forceas of $11^{\text {th }}$ May 2015. Retrieved from: http://www.worldtadkwondofederation.net/

W orld Taekwondo Federation rules \& interpretation in force as of $1^{\text {st }} \mathrm{J}$ anuary 2015.

World Taekwondo Federation rules \& interpretation in force as of $1^{\text {t } J ~ J a n u a r y ~} 2015$. Retrieved from:

http://www.worldtadkwondofederation.net/images/Final_Competition_Rules_Amend ments_E-Voting_2014_copy_copy.pdf

W orld Taekwondo Federation competition rules \& interpretation in force as of J uly 1, 2014

World Tadwondo Federation competition rules \& interpretation in forceas of J uly 1 , 2014. Retrieved from

http://www.worldtadkwondofederation.net/images/Final_Competition_Rules_amende d_in_Taipei_2014.pdf

W orld Taekwondo Federation rules \& interpretation in force as of $14^{\text {th }} \mathrm{J}$ uly 2013. World Taekwondo Federation rules \& interpretation in forceas of $14^{\text {th }}$ July 2013. Retrieved from: http://www.worldtadkwondofederation.ne/

W orld Taekwondo Federation rules \& interpretation in force as of $26^{\text {th }}$ December 2012.

World Taekwondo Federation rules \& interpretation in forceas of $26^{\text {th }}$ December 2012. Retrieved from: http://www.worldtaekwondofederation.net/

W orld Taekwondo Federation rules $\&$ inter pretation in force as of $4^{\text {th }} 0$ ctober 2012.

World Taekwondo Federation rules \& interpretation in forceas of $4^{\text {th }}$ October 2012. Retrieved from: http://www.worldtadkwondofederation.net/

W orld Taekwondo Federation competition rules \& interpretation amended: October 7, 2010

World Taekwondo Federation competition rules \& interpretation amended: October 7 , 2010. Retrieved from: http://www.worldtaekwondofederation.net/rules-and-documents

Tennis

Constitution of ITF limited 2016 trading as International Tennis Federation memorandum, articles of association and bye-laws of ITF limited trading as the International Tennis Federation

Constitution of ITF limited 2016 trading as International Tennis Federation memorandum artides of association and bye laws of ITF limited trading as the International Tennis Federation. Received from http://www.itftennis.com/ 
Constitution of ITF limited 2015 trading as International Tennis Federation memorandum, articles of association and bye-laws of ITF limited trading as the International Tennis Federation

Constitution of ITF limited 2015 trading as International Tennis Federation memorandum artides of association and bye laws of ITF limited trading as the International Tennis Federation. Received from: http://www.itfternis.com/media/194732/194732.pdf

C onstitution of ITF limited 2014 trading as International Tennis Federation memorandum, articles of association and bye-laws of ITF limited trading as the International Tennis Federation

Constitution of ITF limited 2014 trading as International Tennis Federation memorandum artides of association and bye laws of ITF limited trading as the International Ternis Federation. Received from: http://www.itftennis.com/

\section{ITF Constitution 2013}

ITF Constitution 2013. Retrieved from

http://www.itfternis. com/about/organisation/constitution.aspx and last visited on $21^{\text {t }}$ October, 2013

Constitution of ITF limited 2013 trading as International Tennis Federation memorandum, articles of association and bye-laws of ITF limited trading as the International Tennis Federation (unchanged since 2005).

Constitution of ITF limited 2013 trading as International Tennis Federation memorandum, artides of association and bye laws of ITF limited trading as the International Tennis Federation (unchanged since2005). Received via-email. Se appendix.

\section{Triathlon}

ITU constitution approved by the ITU congress, September 2015

ITU constitution approved by thelTU congress, September 2015. Received from: http://uww.triathl on.org/upl oads/

ITU constitution approved by the ITU congress, September 2013

ITU constitution approved by the ITU congress, September 2013. Received from $\mathrm{h}$ ttp://www. triathl on.org/upl oads/docs/itusport_competition-rules_december20141.pdf

ITU Competition Rules 21/02/2012 E dition (Approved by the ITU Executive B oard, February 2012)

ITU Competition Rules 21/02/2012 Edition (Approved by thelTU Exeative Board, February 2012) Retrieved from http://www.triathl on. org/about/documents.And last visited on $3^{\text {rd }}$ July 2013.

ITU Constitution 2011

ITU Constitution Approved by the ITU Congress, Beijing, China, 7 September 2011. Retrieved from http://www.triathl on.org/about/documents_and last visited on $3^{\text {rd }} \mathrm{J}$ uly 2013. 
Volleyball

FIVB G eneral regulations 2013

FIVB General regulations 2013. Retrieved from

http://uww. fivb.org/EN/FIVB/Legal .asp and last visited on 21 $21^{\text {st }}$ October, 2013

FIV B Sports Regulations 2013

FIVB Sports Regulations 2013. Retrieved from

http://www. fivb.org/EN/FIVB/Legal .asp and last visited on 21 $21^{\text {st }}$ October, 2013

FIVB Constitution 2012

FIVB Constitution 2012. Retrieved from http://wwww.fivb.org/EN/FIVB/Legal .asp and last visited on $21^{\text {t }}$ October, 2013

Sports regulations V olleyball version: $15 \mathrm{M}$ ay 2015

Sports regulations Volleyball version: 15 May 2015. Received from:

http://www.fivb.org

Sports regulations V olleyball version: 15 M ay 2014

Sports regulations Voll eyball version: 15 May 2014. Received from:

http://www.fivb.org/EN/FIVB/Document/Legal/FIVB_Sports_Regulations_en_20140

516_V3.pdf

Weightifting

IWF technical \& competition rules \& regulations 2013 - 2016 approved by the IW F congress - Baku - 2012 updated by IW F congress - K azan - 2014 updated in Almaty - 2014 in effect with 01.01.2015

IWF technical \& competition rules \& regulations 2013 - 2016 approved by the IWF congress - Baku - 2012 updated by IWF congress - Kazan - 2014 updated in Almaty

- 2014 in effect with 01.01.2015. Retireved from http://www.iwf.net/wpcontent/upl oads/downl oads.

IW F guidelines for nationality change September 2014.

IWF guidelines for nationality change September 2014. Retrieved from:

http://www.iwf.net/wp-content/upl oads/downl oads/2014/09/GUIDELINES-FOR-

NATIONALITY-CHANGE.pdf

IWF Constitution and Bylaws 2013- 2016

IWF Constitution and Bylaws 2013- 2016. Retrieved from

http://www. iwf.net/devel opment-program/downl oads/ and last visited on $21^{\text {t }}$ October, 2013

Wrestling

FIL A Constitution 2013

FILA Constitution 2013. Retrieved from http://www.fila official. com/index.php?option=com content\&view=artide\&id=31\&Itemid $=100265 \&$ I ang=en and last visited on $21^{\text {st }}$ Octōerer, 2013 
FIL A Regulation for the change of nationality 2012

FILA Regulation for the change of nationality 2012. Retrieved from http://www.fila official.com/index. php?option=com content\& view=artide\&id=31\&Itemid=100265\&l ang=en and last visited on $21^{\text {st }}$ October, 2013

Fila Wrestling R ules 2013

Fila Wresting Rules 2013. Retrieved from http://www.fila official.com/index. php?option=com content\& view=artidesid=31\&Itemid $=100265 \&$ I ang=en and last visited on $21^{\text {st }}$ Octōerer, 2013

FIL A international rules for the change of nationality approved by the B ureau on 15J anuary 2015.

FILA international rules for the change of nationality approved by the Bureau on 15 January 2015.

Retrieved from:

https://unitedworldwrestling.org/sites/default/files/media/document/intemational_rules _for_the_change_of_nationality_jan15_eng.pdf

FIL A international regulations for the change of nationality 2011. FILA international regulations for the change of nationality 2011.Retried from: http://www.fila-official.com/

UWW international rules for the change of nationality approved by the B ureau on $13^{\text {th }}$ December 2015

UWW international rules for the change of national ity approved by the Bureau on $13^{\text {th }}$ December 2015 Retrieved from https://unitedworldwrestling.org/ 


\subsection{Other}

I ke A wgu (08 ${ }^{\text {th }} J$ une, 2012)

I ke Awgu (08 ${ }^{\text {th }}$ J une, 2012). For SomeOlympians, Seeking Asylum Is Better Than Gold. Retrieved from http://www.huffingtonpostca/ike-awgy/olympics2012_b_1738691.html

\section{T. Bach (2015)}

T. Bach (2015). Speech on the occasion of theadoption of the resolution "Building a peaceful and better world through sport and theOlympic ideal" by IOC President Thomas Bach, UN General Assembly, New Y ork, 26 October 2015. Rerieved from http://www. olympic.org/Documents/Olympic_Truce/UN-General-Assembly-2015Olympic-Truce-Resolution-26-Oct.pdf

\section{B BC News (21 $1^{\text {st }}$ A ugust 2012)}

BBC News (21 ${ }^{\text {st }}$ August 2012). Somalia Olympic runner 'drowns trying to reach Europe'. Retrieved from: http://www.bbc.com/news/world-africa-19323535

\section{Camoranesi: Argentina's my anthem}

On Camoranesi: Argentina's my anthem Camoranesi taken from http://soccernet.espn.go.com/news/story?id $=371118 \& c c=5739$ and last visited on $3^{\text {rd }}$ July 2013.

\section{J. Dzankic (2012)}

J. Dzankic (2012) London's Olympics show that the links between sports, citizenship, politics, and national identity areas tangi bleas ever. Blog written on $30^{\text {th }} \mathrm{J} \mathrm{uly,} 2012$. Rerieved from blogs. Iseac.uk http://blogs.Iseac.uk/europpblog/2012/07/30/olympics citizenship/

\section{G overnment of Gibraltar (1997)}

Government of Gibraltar (1997). Speech delivered by theChief Minister, The Hon P R Caruana to theEuropean Atlantic Group, House of Commons, England on Monday 24th November 1997. Retrieved from: http://www.gi bnetcom/press/speech20.htm

IOC Information on London Summer Olympics 2012

London Summer Olympics 2012. Retrieved from http://www. olympic.org/london2012-summer-olympics and last visited on: $3^{\text {rd }} \mathrm{J}$ uly 2013.

IOC Information on Sydney Summer Olympics 2000

Sydney Summer Olympics 2000. Retrieved from http://www. olympic.org/sydney2000-summer-olympics and last visited on: $3^{\text {rd }} \mathrm{J}$ ul y 2013.

\section{Ben Q uinn (The G uardian, 15th A ugust 2012)}

Eritrea's flag-carrying runner seeks asylumin UK to flerepressiveregime- Olympic athl ete and middl edistancerunner is one of four from country sedking escapefrom repressive regime Retrieved from http://www.theguardian.com/uk/2012/aug/15/eritrearunner-sedks-asylum-uk 
Frankfurter Allgemeine Zeitung. (3rd August 2015). DSOB will in Rio mindestens 44 Medaillen.

Frankfurter AllgemeineZeitung. (3rd August 2015). DSOB will in Rio mindestens 44 Medaillen. Retrieved from: http://www.faz.ne/aktuel/sport/sportpolitik/dosb-will-beiolympia-2016-in-rio-mindestens-44-medaillen-13732457.html

Süddeutsche Zeitung (11 ${ }^{\text {th }}$ A ugust, 2012) Zielvorgaben für Olympia: Politiker kritisieren überzogene Medaillen-Erwartung

SüddeutscheZeitung (11 ${ }^{\text {th }}$ August, 2012). Ziel vorgaben für Olympia: Politiker kritisieren überzogeneM Medaillen-Erwartung. Rerieved from

http://www. sueddeutsche de/sport/zie vorgaben-fuer-olympia-pol itiker-kritisieren-

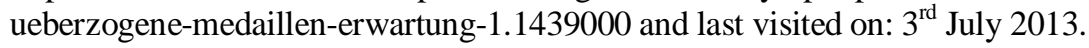

\section{W. Shakespeare}

W.Shakespeare Titus Andronicus. In: The Complete Works of WilliamShakespeare Magnus Verlag: Haper Collins Publishers.

\section{W. Shakespeare}

W.Shakespeare King Lear. In: The Complete Works of WilliamShakespeare Magnus Verlag: Haper Collins Publishers.

\section{L ondon Olympics 20120 pening Ceremony: Happy and G lorious (2012 Video)} The London Olympics 2012 Opening Ceremony: Happy and Glorious. Retrieved from: http://www.youtubecom/watch?v=1AS-dCdY Zbo and last visited on $3^{\text {rd }} \mathrm{J}$ uly 2013. 
20. List of A bbreviations

Table LIII Sport Associations and their abbreviations

\begin{tabular}{|c|c|c|c|c|c|c|c|c|c|}
\hline$\frac{2}{6}$ & $\begin{array}{l}8 \\
8 \\
8 \\
8 \\
8 \\
8\end{array}$ & $\begin{array}{l}\overline{8} \\
\frac{8}{8} \\
8 \\
4\end{array}$ & 8 & $\begin{array}{l}\frac{y}{2} \\
\frac{2}{8} \\
\frac{0}{0} \\
\frac{8}{8} \\
\frac{8}{4}\end{array}$ & 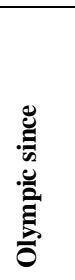 & 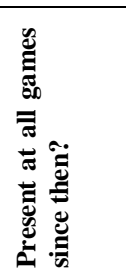 & 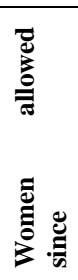 & 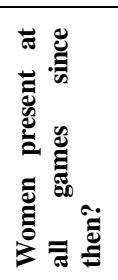 & $\frac{y}{\frac{8}{2}}$ \\
\hline \multirow[b]{4}{*}{$\begin{array}{l}\frac{y}{2} \\
\frac{0}{0} \\
\frac{3}{4} \\
\end{array}$} & \multirow[b]{4}{*}{$\frac{\pi}{4}$} & \multirow[b]{4}{*}{ \&్̊ㅁ } & \multirow{4}{*}{ 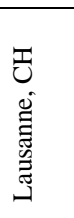 } & Water Polo & 1900 & Not 1904 & 2000 & Yes & \\
\hline & & & & Diving & 1904 & yes & 1912 & yes & \\
\hline & & & & Swimming & 1896 & yes & 1912 & yes & \\
\hline & & & & $\begin{array}{l}\text { Synchronised } \\
\text { Swimming }\end{array}$ & 1984 & Yes & 1984 & yes & $\begin{array}{l}\text { No } \\
\text { men's } \\
\text { event }\end{array}$ \\
\hline 这 & 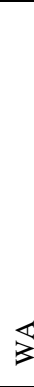 & बु & 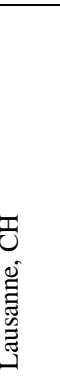 & & 1900 & $\begin{array}{l}\text { Not } \\
1912 \\
1924 \\
1928 \\
1932 \\
1936 \\
1948 \\
1952 \\
1956 \\
1960 \\
1964 \\
1968 \\
\end{array}$ & 1904 & $\begin{array}{l}\text { Not } \\
1912 \\
1924 \\
1928 \\
1932 \\
1936 \\
1948 \\
1852 \\
1956 \\
1960 \\
1964 \\
1968 \\
\end{array}$ & $\begin{array}{l}\text { First } \\
\text { named } \\
\text { FITA }\end{array}$ \\
\hline$\frac{y}{\frac{y}{0}}$ & $\stackrel{u}{4}$ & Эี & $\mid \begin{array}{l}U \\
\Sigma \\
0 \\
\delta \\
\check{O} \\
\Sigma \\
\Sigma\end{array}$ & & 1896 & yes & 1928 & yes & \\
\hline D్ & $\sum_{0}^{u}$ & 范 & 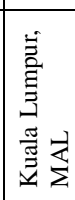 & & 1992 & yes & 1992 & yes & \\
\hline \begin{tabular}{|l}
$\overline{\bar{\pi}}$ \\
$\frac{3}{0}$ \\
总 \\
$\infty$
\end{tabular} & $\frac{\Phi}{\frac{\Phi}{4}}$ & ర్తి & $\begin{array}{l}\text { I } \\
\frac{\hat{y}}{\Sigma}\end{array}$ & & 1936 & yes & 1976 & yes & \\
\hline$\frac{\delta}{\frac{5}{5}}$ & $\stackrel{?}{\underline{m}}$ & @̆ & 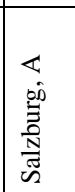 & & 1960 & yes & 1992 & yes & \\
\hline \multirow{2}{*}{$\begin{array}{l}\frac{\bar{\delta}}{\mathbb{D}} \\
\frac{0}{0} \\
\frac{0}{0} \\
\infty\end{array}$} & \multirow{2}{*}{ 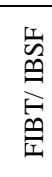 } & \multirow[b]{2}{*}{ ฮ } & \multirow[b]{2}{*}{ 竞 } & Bobsleigh & 1924 & Not 1960 & 2002 & yes & \\
\hline & & & & Skeleton & 1928 & $\begin{array}{l}\text { Not 1932 } \\
1936 \\
1952\end{array}$ & 2002 & yes & \\
\hline
\end{tabular}


NATIONALITY REQUIREMENTS IN OlYMPIC SPORTS

\begin{tabular}{|c|c|c|c|c|c|c|c|c|c|}
\hline & & & & & & $\begin{array}{l}1956 \\
1960 \\
1964 \\
1968 \\
1972 \\
1976 \\
1980 \\
1984 \\
1988 \\
1992 \\
1994 \\
1998\end{array}$ & & & \\
\hline - & $\frac{\overleftarrow{a}}{\frac{a}{\alpha}}$ & 过 & 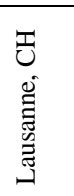 & & 1904 & Not 1912 & 2012 & yes & \\
\hline \multirow[t]{2}{*}{$\begin{array}{l}\frac{.}{0} \\
\text { बे } \\
\frac{1}{d} \\
\text { c } \\
\text { U. }\end{array}$} & \multirow{2}{*}{$\underline{\underline{u}}$} & \multirow{2}{*}{ 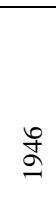 } & \multirow[t]{2}{*}{ 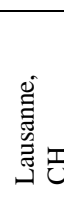 } & Slalom & 1972 & $\begin{array}{l}\text { Not } 1976 \\
1980 \\
1984 \\
1988\end{array}$ & 1972 & $\begin{array}{l}\text { Not } \\
1976 \\
1980 \\
1984 \\
1988 \\
\end{array}$ & \\
\hline & & & & Sprint & 1936 & yes & 1948 & yes & \\
\hline 影 & $\stackrel{u}{u}$ & \& & 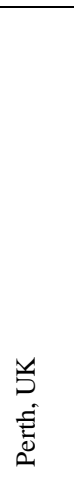 & & 1924 & $\begin{array}{l}\text { Not } 1928 \\
1932 \\
1936 \\
1952 \\
1956 \\
1960 \\
1964 \\
1968 \\
1972 \\
1976 \\
1980 \\
1984 \\
1988 \\
1992 \\
1994\end{array}$ & 1998 & yes & \\
\hline \multirow{4}{*}{ 衽 } & \multirow[b]{4}{*}{$\overline{\mathrm{J}}$} & \multirow[b]{4}{*}{8} & \multirow{4}{*}{$\begin{array}{l}\frac{T}{U} \\
\frac{v}{\sigma} \\
\frac{O}{\mathbb{Z}}\end{array}$} & BMX & 2008 & yes & 2008 & yes & \\
\hline & & & & Road & 1896 & $\begin{array}{l}\text { Not } 1900 \\
1904 \\
1908\end{array}$ & 1984 & yes & \\
\hline & & & & Track & 1896 & Not 1902 & 1988 & yes & \\
\hline & & & & $\begin{array}{l}\text { Mountain } \\
\text { Bike }\end{array}$ & 1996 & yes & 1996 & yes & \\
\hline 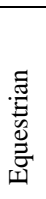 & 岀 & สิ & 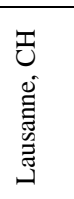 & & 1900 & $\begin{array}{l}\text { Not } 1904 \\
1908\end{array}$ & 1952 & yes & $\begin{array}{l}\text { Since } \\
1952 \\
\text { only } \\
\text { mixed } \\
\text { event }\end{array}$ \\
\hline - & $\frac{\omega}{\bar{\psi}}$ & $\stackrel{m}{g}$ & 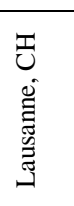 & & 1896 & yes & 1924 & yes & \\
\hline
\end{tabular}


APPENDICES

\begin{tabular}{|c|c|c|c|c|c|c|c|c|c|}
\hline $\begin{array}{l}\overline{\overline{0}} \\
\overline{8} \\
\\
\end{array}$ & 芯 & ष्ठ & 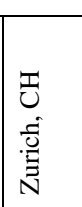 & & 1900 & Not 1932 & 1996 & yes & \\
\hline 㐘 & 峛 & \begin{tabular}{|l|}
$\stackrel{\infty}{\circ}$ \\
$\stackrel{\circ}{\sigma}$
\end{tabular} & 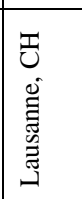 & & 2016 & & & & \\
\hline \multirow{3}{*}{ 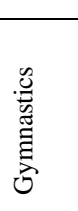 } & \multirow{3}{*}{$\frac{0}{\Psi}$} & \multirow{3}{*}{$\begin{array}{l}\overrightarrow{0} \\
\stackrel{\infty}{\sigma} \\
\sim\end{array}$} & \multirow{3}{*}{ 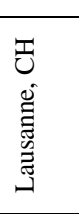 } & Artistic & 1896 & yes & 1928 & $\begin{array}{l}\text { Not } \\
1932\end{array}$ & \\
\hline & & & & Rhythmic & 1984 & yes & 1984 & yes & $\begin{array}{l}\text { No } \\
\text { men's } \\
\text { event }\end{array}$ \\
\hline & & & & Trampoline & 2000 & yes & 2000 & yes & \\
\hline $\begin{array}{l}\overline{\frac{\delta}{0}} \\
\frac{\bar{c}}{\bar{\tau}} \\
\overline{1}\end{array}$ & 堊 & 过 & 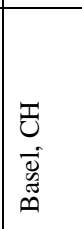 & & 1936 & $\begin{array}{l}\text { Not } 1948 \\
1952 \\
1956 \\
1960 \\
1964 \\
1968 \\
1972\end{array}$ & 1976 & yes & \\
\hline $\begin{array}{l}\frac{\widehat{v}}{\mathrm{v}} \\
\frac{\mathrm{o}}{\mathrm{T}}\end{array}$ & $\frac{I}{\bar{L}}$ & ఫั & 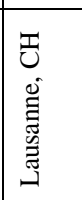 & & 1908 & $\begin{array}{l}\text { Not } 1912 \\
1924\end{array}$ & 1980 & yes & \\
\hline 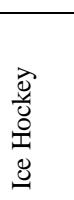 & 堊 & \&్̊ㅁ & 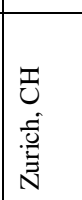 & & 1924 & yes & 1998 & yes & \\
\hline$\frac{8}{2}$ & 岂 & 롱 & 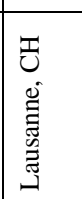 & & 1964 & Not 1968 & 1992 & yes & \\
\hline 乌্త & $\vec{\Delta}$ & ถู & 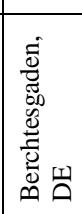 & & 1964 & yes & 1964 & yes & \\
\hline 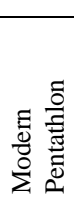 & $\sum_{0}$ & 吅 & 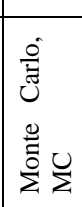 & & 1912 & yes & 2000 & yes & \\
\hline
\end{tabular}


NATIONALITY REQUIREMENTS IN OlYMPIC SPORTS

\begin{tabular}{|c|c|c|c|c|c|c|c|c|c|}
\hline 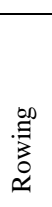 & $\frac{\mathbb{n}}{\mathbb{L}}$ & สู & 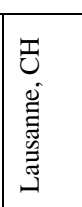 & & 1900 & yes & 1976 & yes & \\
\hline 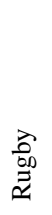 & 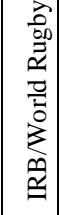 & 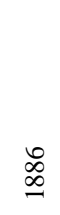 & 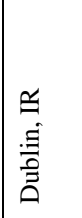 & & & & & & \\
\hline 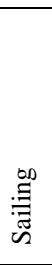 & \begin{tabular}{|l}
$u$ \\
$\underline{\underline{x}}$ \\
$\underline{\underline{n}}$ \\
\end{tabular} & ᄋ్ & 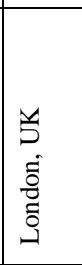 & & $\begin{array}{l}1900 \\
(1896 \\
\text { not } \\
\text { possi } \\
\text { ble } \\
\text { due to } \\
\text { weath } \\
\text { er) }\end{array}$ & Not 1904 & $\begin{array}{l}\text { Since } \\
1900\end{array}$ & yes & $\begin{array}{l}\text { Mixed } \\
\text { events } \\
\text { till 2008, } \\
\text { separate } \\
\text { men and } \\
\text { women } \\
\text { since } \\
1988\end{array}$ \\
\hline $\begin{array}{l}\frac{8}{n} \\
\frac{8}{n}\end{array}$ & 岕 & ồ & 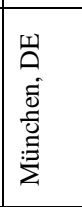 & & 1896 & $\begin{array}{l}\text { Not 1904 } \\
1928 \\
1968 \\
1972 \\
1976 \\
1980\end{array}$ & 1984 & yes & $\begin{array}{l}\text { Mixed } \\
\text { events } \\
1968 \\
1992\end{array}$ \\
\hline \multirow{9}{*}{ 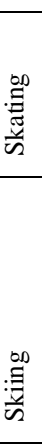 } & \multirow{3}{*}{$\underline{\underline{m}}$} & \multirow{3}{*}{ Љ్ } & \multirow{3}{*}{ 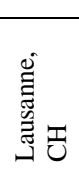 } & $\begin{array}{l}\text { Figure } \\
\text { Skating }\end{array}$ & 1924 & yes & 1924 & yes & \\
\hline & & & & $\begin{array}{l}\text { Short track } \\
\text { speed skating }\end{array}$ & 1992 & Yes & 1992 & yes & \\
\hline & & & & Speed Skating & 1924 & yes & 1960 & yes & \\
\hline & \multirow{6}{*}{$\frac{\Omega}{4}$} & \multirow{6}{*}{ ఫิ } & \multirow{6}{*}{ 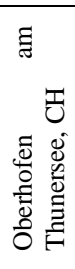 } & Alpine & 1936 & yes & 1936 & yes & \\
\hline & & & & Cross Country & 1924 & yes & 1952 & yes & $\square$ \\
\hline & & & & $\begin{array}{l}\text { Freestyle } \\
\text { Nordic }\end{array}$ & $\begin{array}{l}1992 \\
1924\end{array}$ & $\begin{array}{l}\text { yes } \\
\text { yes }\end{array}$ & 1992 & $\frac{y e s}{-}$ & No \\
\hline & & & & Combined & & & & & $\begin{array}{l}\text { women's } \\
\text { event }\end{array}$ \\
\hline & & & & Ski Jumping & 1924 & yes & 2014 & yes & \\
\hline & & & & Snowboard & 1998 & yes & 1998 & yes & \\
\hline$\frac{\frac{n}{\tilde{C}}}{\frac{0}{\frac{0}{0}}}$ & 亗 & ఝ̆ & 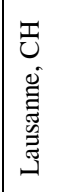 & & 1988 & yes & 1988 & yes & \\
\hline 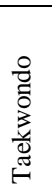 & 岁 & $\stackrel{\mathrm{m}}{\mathrm{g}}$ & 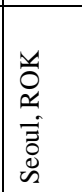 & & 2000 & yes & 2000 & yes & \\
\hline
\end{tabular}




\section{APPENDICES}

\begin{tabular}{|c|c|c|c|c|c|c|c|c|c|}
\hline 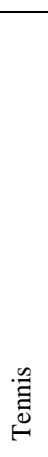 & $\stackrel{\text { 㫐 }}{\underline{E}}$ & ํㅗㄱ & 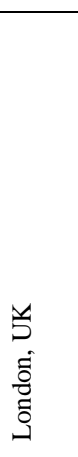 & & 1896 & $\begin{array}{l}\text { Not } \\
1928 \\
1932 \\
1936 \\
1952 \\
1956 \\
1960 \\
1964 \\
1968 \\
1972 \\
1976 \\
1980 \\
1984\end{array}$ & 1900 & $\begin{array}{l}\text { Not } \\
1904 \\
1928 \\
1932 \\
1936 \\
1952 \\
1956 \\
1960 \\
1964 \\
1968 \\
1972 \\
1976 \\
1980 \\
1984\end{array}$ & \\
\hline$\frac{\delta}{\frac{\delta}{\frac{1}{7}}}$ & $\underline{P}$ & $\begin{array}{l}\text { ஜ } \\
\text { 의 }\end{array}$ & 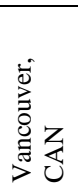 & & 2000 & yes & 2000 & yes & \\
\hline \multirow{2}{*}{$\begin{array}{l}\overline{\overline{0}} \\
\frac{\sqrt{0}}{\overline{0}} \\
\frac{\overline{0}}{>}\end{array}$} & \multirow[b]{2}{*}{$\sum_{\amalg}^{\infty}$} & \multirow[b]{2}{*}{ 今 } & \multirow{2}{*}{ 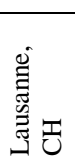 } & $\begin{array}{l}\text { Beach } \\
\text { Volleyball }\end{array}$ & 1996 & yes & 1996 & yes & \\
\hline & & & & Volleyball & 1960 & yes & 1960 & yes & \\
\hline 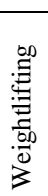 & $\stackrel{\text { 岁 }}{\underline{3}}$ & 농 & $\begin{array}{l}I \\
\frac{1}{0} \\
\frac{8}{80} \\
\frac{0}{0}\end{array}$ & & 1896 & $\begin{array}{l}\text { Not } 1900 \\
1908 \\
1912\end{array}$ & 2000 & yes & \\
\hline \multirow[b]{2}{*}{ 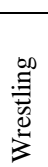 } & \multirow[b]{2}{*}{$\sum_{\supset}^{3}$} & \multirow[b]{2}{*}{ ิㅡㄱ } & \multirow[b]{2}{*}{ 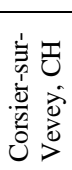 } & Freestyle & 1904 & Not 1912, & 2004 & yes & \\
\hline & & & & Greco-Roman & 1896 & $\begin{array}{l}\text { Not } 1900 \\
1904\end{array}$ & - & - & $\begin{array}{l}\text { No } \\
\text { women's } \\
\text { event }\end{array}$ \\
\hline
\end{tabular}

Other:

- EU: European Union

- TCN: Third country national

- UEFA: Union of European Football Associations

o Founded in 1954

- Seat in Nyon, Switzerland 



\section{Appendices ${ }^{x}$}

\subsection{IOC Charter \\ E ligibility Olympic C harter September 2013}

\section{E ligibility Code*}

To be eligible for participation in the Olympic Games, a competitor, coach, trainer or other team official must comply with the Olympic Charter, including the conditions of eligibility established by the IOC, as well as with the rules of the IF concerned as approved by the IOC, and the compeitor, coach, trainer or other team official must beentered by his NOC.

The abovenoted persons must:

- respect the spirit of fair play and non violence, and behave accordingly; and

- respect and comply in all aspects with theWorld Anti-Doping Code

\section{Byelawto Rule 40}

1. Each IF establishes its sport's own eligibility criteria in accordance with the Olympic

Charter. Such criteria must be submitted to the IOC Executive Board for approval.

2. The application of the eligibility criteria lies with the IFs, their affiliated national federations and the NOCs in the fields of their respective responsibilities.

3. Except as permitted by the IOC Executive Board, no competitor, coach, trainer or official who participates in the Olympic Games may allow his person, name, picture or sports performances to be used for advertising purposes during the Olympic Games.

4. The entry or participation of a competitor in the Olympic Games shall not be conditional on any financial consideration.

\section{Nationality of Competitors*}

1. Any competitor in the Olympic Games must be a national of the country of the NOC which is entering such competitor.

2. All matters relating to the determination of the country which a competitor may represent in the Olympic Games shall be resolved by theIOC Executive Board.

Byelaw to Rule 41

1. A competitor who is a national of two or more countries at the same time may represent either one of them as he may elect. However, after having represented one country in the Olympic Games, in continental or regional games or in world or regional championships recognised by the relevant IF, he may not represent another country unless he meets the conditions set forth in paragraph 2 below that apply to persons who have changed their nationality or acquired a new nationality.

2. A competitor who has represented one country in the Olympic Games, in continental or regional games or in world or regional championships recognised by the relevant IF, and who has changed his nationality or acquired a new nationality, may participate in the Olympic Games to represent his new country provided that at least three years have passed since the competitor last represented his former country. This period may be reduced or even cancelled, with the agreement of the NOCs and IF concerned, by the IOC Executive Board, which takes into account the circumstances of each case.

3. If an associated State, province or overseas department, a country or colony acquires independence, if a country becomes incorporated within another country by reason of a change of border, if a country merges with another country, or if a new NOC is recognised by the IOC, a competitor may continue to represent the country to which he belongs or belonged. However, he may, if he prefers, elect to represent his country or be entered in the Olympic Games by his new NOC if one exists. This particular choicemay bemade only once. 4. Furthermore, in all cases in which a competitor would be eligible to participate in the Olympic Games, either by representing another country than his or by having the choice as to the country which such competitor intends to represent, the IOC Executive Board may take all decisions of a general or individual nature with regard to issues resulting fromnationality, citizenship, domicile or residence of any competitor, including the duration of any waiting period.

x Any spelling mistakes found in the appendices are due to spelling mistakes in the source material, meaning the federations' rulebooks. 


\section{NATIONALITY REQUIREMENTS IN OLY MPIC SPORTS}

\subsection{Sport federation rules and statutes}

In the following sel ected articles from the respective international sport association statutes can be found. All articles not concerning eligibility or players' nationality were omitted.

\section{Aquatics}

\section{FINA GENERAL RULES valid as of $25^{\text {th }}$ November 2015}

\section{GR 1ELIGIBILITY}

GR 1.1 All competitors shall be registered with their National Federation to be eligible to compete

\section{GR 2 INTERNATIONAL RELATIONS}

\section{[... ]}

G R 2.5 When a competitor or competition official represents his/her country in a competition, he/she shall be a citizen, whether by birth or naturalisation, of the nation he/she represents, provided that a naturalised citizen shall have lived in that country for at least one year prior to that competition. Competitors, who have more than one national ity according to the laws of the respective nations must choose one "Sport Nationality" and be affiliated to one Member only.

G R 2.6 Any competitor or competition official changing his affiliation from one national governing body to another must have resided in the territory of and been under the jurisdiction of the latter for at least twelve months prior to his first representation for the country.

GR 2.6.1 Proof of Residence

1) Residence means the place/country where the competitor or competition official "lives and sleeps" and wherehe/she can be found in the majority of days of theyear.

2) The proof of residence must include documentation establishing the applicant resides in the country. In this regard the official school or university confirmation or employment contract or any other relevant documentation may constitute evidence.

3) Certified registration of an address in the «new» country for at least twelve (12) months prior to first representation of the competitor or competition official for the «new» country must besent to FINA.

GR 2.6.2 Proof of J urisdiction

1) Certified membership in a club of the new country

2 ) Confirmation from the FINA Member of that country

3) Official result lists from national championships, national, regional or international club competitions in which the applicant has participated for his/her "new" club during the GR2.6 requested time

4) Applicants cannot represent any of the countries during the "transfer period"

G R 2.7 Any application for change of affiliation must be approved by FINA.

\section{FINA GE NE RAL RULES valid as of 29] anuary 2015}

\section{GR 1ELIGIBILITY}

GR 1.1 All compeitors shall be registered with their National Federation to be ligibleto compete.

\section{GR 2 INTERNATIONAL RELATIONS}

[... ]

G R 2.5 When a competitor or competition official represents his/her country in a competition, he/she shall be a citizen, whether by birth or natural isation, of the nation he/she represents, provided that a naturalised citizen shall have lived in that country for at least one year prior to that competition. Competitors, who have more than one national ity according to the laws of the respective nations must choose one "Sport Nationality" and be affiliated to one Member only.

GR 2.6 Any competitor or competition official changing his affiliation from one national governing body to another must have resided in the territory of and been under the jurisdiction of the latter for at least twelve months prior to his first representation for the country.

GR 2.6.1 Proof of Residence

1) Residence means the place/country where the competitor or competition official "lives and sleeps" and where he/she can be found in the majority of days of theyear.

2) The proof of residence must include documentation establishing the applicant resides in the country. In this regard the official school or university confirmation or employment contract or any other relevant documentation may constitute evidence.

3) Certified registration of an address in the «new» country for at least twelve (12) months prior to first representation of the competitor or competition official for the «new» country must besent to FINA.

GR 2.6.2 Proof of J urisdiction

1) Certified membership in a dub of the new country

2 ) Confirmation from the FINA Member of that country

3) Official result lists from national championships, national, regional or international club competitions in which the applicant has participated for his/her "new" club during the GR2.6 requested time

4) Applicants cannot represent any of the countries during the "transfer period" 


\section{APPENDICES}

G R 2.7 Any application for change of affiliation must be approved by FINA.

FINA GE NE RAL RULE S 2013-2017 of August 2013

GR 1ELIGIBILITY

GR 1.1 All competitors shall be registered with their National Federation to be eligible to compete.

GR 2 INTERNATIONAL RELATIONS

[... ]

G R 2.5 When a competitor or competition official represents his/her country in a competition, he/she shall be a citizen, whether by birth or naturalisation, of the nation he/she represents, provided that a natural ised citizen shall have lived in that country for at least one year prior to that competition. Competitors, who have more than one nationality according to the laws of the respective nations must chose one "Sport Nationality" and beaffiliated to one Member only.

GR 2.6 Any competitor or competition official changing his affiliation from one national governing body to another must have resided in the territory of and been under the jurisdiction of the latter for at least twelve months prior to his first representation for the country.

\section{GR 2.6.1 Proof of Residence}

1) Residence means the place/country where the competitor or competition official "lives and sleeps" and where he/she can be found in the majority of days of theyear.

2) The proof of residence must include documentation establishing the applicant resides in the country. In this regard the official school or university confirmation or employment contract or any other relevant documentation may constitute evidence

3) Certified registration of an address in the "new" country for at least twelve (12) months prior to first representation of the competitor or competition official for the "new" country must be sent to FINA.

GR 2.6.2 Proof of J urisdiction

1) Certified membership in a club of thenew country

2) Confirmation from theFINA Member of that country

3) Official result lists from national championships, national, regional or international club competitions in which the applicant has participated for his/her "new" club during the GR 2.6 requested time

4) Applicants cannot represent any of the countries during the "transfer period"

GR 2.7 Any application for change of affiliation must beapproved by FINA.

\section{FINA M emorandum on Athlete's Nationality 9 February 2011}

\section{"Dear Sirs,}

Considering the latest cases audited by the FINA Disciplinary Pane, FINA would like to draw the attention of all FINA Member Federations to the problem that the double citizenship of athletes can cause In order to avoid the risk of FINA Rules violations, FINA deems that all FINA Member Federations should get knowledge on the sport nationality of the athletes when they register by including a paragraph in their registration form in which the athletes are required to inform on the following points:

- The athlete shall discl ose any other sport nationality that he/she is eligible to represent (or has been able to represent in case of a change of citizenship);

- The athlete shall declare whether he/she has previously represented another sport country in any international competition and in any ageleve;

- In the event the athlete has al ready represented another sport country, the athlete shall declare helshe has complied with the FINA Rules regarding the change of sport nationality (FINA GR $2.5 \mathrm{ff}$ ).

This requirement would avoid the participation in international events of athletes that do not comply with the FINA GR $2.5 \mathrm{ff}$ and thus prevent the National Federations and the athletes to be sanctioned with regard to the Rules on Sport Nationality.

Thank you for your kind attention and your support in this important issue

Yours sincerely,

Cornel Marculescu"

FINA Constitutions $2013-2017$

C 3.17 Sport Country - means a geographical territory or region which, though not recognized as a country, has certain aspects of self-government at least to the extent in being autonomous in the control of its sports, and is recognized as such by FINA.

C 14.5.2 The approval shall include the conditions and requirements in accordance with the FINA Rules, whilst the appointment of FINA delegate(s) shall be granted by the FINA Executive. All Competitors must comply with FINA eligibility rules. 


\section{NATIONALITY REQUiREMENTS In Olympic SPORTS}

FINA CONSTITUTION AND RULES 2009 - 2013

\section{GENERAL RULES}

GR 1 ELIGIBILITY

GR 1.1 All competitors shall be registered with their National Federation to be eligible to compete.

GR 2 INTERNATIONAL RELATIONS

[...]

G R 2.5 When a competitor or competition official represents his/her country in a competition, he/she shall be a citizen, whether by birth or natural isation, of the nation he/she represents, provided that a naturalised citizen shall have lived in that country for at least one year prior to that competition. Competitors, who have more than one nationality according to the laws of the respective nations must chose one "Sport Nationality" and be affiliated to one Member only.

GR 2.6 Any competitor or competition official changing his affiliation from one national governing body to another must have resided in the territory of and been under the jurisdiction of the latter for at least twelve months prior to his first representation for the country.

\section{GR 2.6.1 Proof of R esidence}

1) Residence means the place/country where the competitor or com petition official "lives and sleeps" and wherehe/she can be found in the majority of days of theyear.

2) The proof of residence must include documentation establishing the applicant resides in the country. In this regard the official school or uni- versity confirmation or employment contract or any other relevant documentation may constituteevidence

3) Certified registration of an address in the "new" country for at least twelve (12) months prior to first representation of the competitor or competition official for the "new" country must be sent to FINA.

GR 2.6.2 Proof of J urisdiction

1) Certified membership in a dub of the new country

2) Confirmation from the FINA Member of that country

3) Official result lists from national championships, national, regional or international club competitions in which the applicant has participated for his/her "new" club during the GR 2.6 requested time

4) Applicants cannot represent any of the countries during the "transfer period"

G R 2.7 Any application for change of affiliation must be approved by FINA.

\section{FINA General Rules 2005}

\section{GR 1ELIGIBILITY}

GR 1.1 All competitors shall be registered with their National Federation to beeligible to compete

GR 2 INTERNATIONAL RELATIONS

\section{[...]}

G R 2.5 When a competitor represents his/her country in a competition, he/she shall be a citizen, whether by birth or naturalisation, of the nation he/she represents, provided that a naturalised citizen shall have lived in that country for at least one year prior to that competition. Competitors, who have more than one nationality according to the laws of the respective nations must chose one "Sport Nationality" and be affiliated to one Member only.

GR 2.6 Any competitor changing his affiliation from one national governing body to another must have resided in the territory of and been under the juris- diction of the latter for at least twelve months prior to his first representation for the country.

G R 2.7 Any application for change of affiliation must be approved by FINA.

\section{Archery}

World Archery Constitution and R ules 2015 effective since 1 A pril 2015

Book 1 C hapter 2 E ligibility Code for Athletes and Team Officials

\subsection{Admission}

2.1.1. Athletes who wish to participate in Championships, Games, International and National Tournaments, which are recognised or controlled by World Archery or a Member Association, in one or more of the various disciplines recogni sed by World Archery, shall be affiliated with a Member Association.

2.1.2 .To be eligible to participate in the World Championships, World Record and Performance Award Tournaments and such other events as World Archery may recognise and specify, athletes shall comply with the Eligibility Code

2.1.3. To be eligible to participate in the Olympic Games, Paralympic Games and Regional or Area Games, an athlete shall comply with the Olympic Charter (see Appendix 1-Congress Procedures, Appendix 6Olympic Charter) and the Eligibility Code.

[...]

2.2. Eligibility Code

(SeeAppendix 1-Congress Procedures, Appendix 6-Olympic Charter.) 


\section{APPENDICES}

2.2.1. Athletes and officials shall respect the spirit of fair play and non-violence, and behave accordingly on the field of play.

2.2.1.1. Athletes and all other members of the World Archery Family shall comply with the betting and anticorruption rules set forth in Appendix 9

2.2.2. Athletes shall refrain from using substances and procedures prohi bited by the laws of World Archery, IOC, IPC and WADA, and together with the officials shall respect and comply in all aspects with the World Archery Anti-Doping Rules and the World Anti-Doping Code

2.2.3 An athlete may allow his person, name, picture or sport performances to be used for advertising purposes and may accept prizes or money without any restriction or limit (see Appendix 1-Congress Procedures, Appendix 6-Olympic Charter).

2.2.4. Athletes shall comply with the requirements of World Archery sponsorship contracts during World Championships.

2.2.5. Tobacco and al cohol advertising and sponsorship are forbidden at World Championships.

2.2.6. Athletes may wear advertising in addition to the normal manufacturer trademarks of the articles worn. The manufacturer's trademark is the registered mark of the company which produced the item If a company has an item made for it under contract, the label of the item, if appropriate to the item, shall correspond to its trademark.

2.2.7. Athletes may have advertising on their personal and technical equipment (eg. bows, bags, etc.) in addition to the item's normal trademark.

2.2.7.1. All advertising referred to Article2.2.6. and Article2.2.7. above shall not exceed $400 \mathrm{~cm} 2$ per item Athletes' numbers are not covered by this article.

2.2.7.2. All trademarks referred to in Article 2.2.6. and Article 2.2.7. above shall not exceed $30 \mathrm{~cm} 2$ except trademarks on bows and stabilizers.

2.2.7.3. The official insignia, flag or emblem of the country or Member Association they represent has no restriction as to size and is not counted as advertising.

2.2.8.Provisions under Article 2.2.5. , Article 2.2.6. , Article 2.2.7. , Article 2.2.7.1. and Article 2.2.7.2. are al so to be observed by all team officials present on the field of play.

2.2.9. For eligibility rules applicable to Para-Archery events, see21. Chapter 21-Para-Archery in Book 3.

[...]

2.4. National Teams

2.4.1. To be eligible to participate as a member of a National Team in International Events, an athlete shall have a valid passport from the country of which he is a National Team Member and shall not have represented any other Member Association as a National Team Member for at least one year before the date of the competition.

2.4.2. If an athlete wants to compete for a National Team other than the one for which he holds a valid passport, he shall have resided in the new country for at least one year before the date of the competition and shall have the written permission of the Member Association, if any, of the country from which he has a valid passport.

2.4.3. An athlete who has changed his nationality, or acquired a new nationality, may not represent the National Team of his new Member Association until one year after such a change or acquisition.

2.4.4. An athlete who has a valid passport of two or more countries at the same time may represent either of them, as he chooses. He shall, however, meet the conditions laid down in Article 2.4.1. to Article 2.4.3. above

2.5. Athletes are not eligible to compete in World Archery events if they do not meet the requirements laid down above

World Archery R ules 2014

World Archery C onstitution and R ules 2014 effective since 1 April 2014

Chapter 2

E ligibility Code for Athletes and Team 0 fficials

2.1. Admission

2.1.1. Athletes who wish to participate in Championships, Games, International and National Tournaments, which are recognised or controlled by World Archery or a Member Association, in one or more of the various di sciplines recogni sed by World Archery, shall be affiliated with a Member Association.

2.1.2. To be eligible to participate in the World Championships, World Record and Performance Award Tournaments and such other events as World Archery may recognise and specify, athletes shall comply with the Eligibility Code

2.1.3. To be eligible to participate in the Olympic Games, Paralympic Games and Regional or Area Games, an athlete shall comply with the Olympic Charter (see Appendix 1-Congress Procedures, Appendix 6Olympic Charter) and the Eligibility Code.

$[\ldots]$ 


\section{NATIONALITY REQUiREMENTS IN Oly mpic SPORTS}

\subsection{E ligibility Code}

(SeeAppendix 1-Congress Procedures, A ppendix 6-Olympic Charter.)

2.2.1. Athletes and officials shall respect the spirit of fair play and non-violence, and behave accordingly on thefiedd of play.

2.2.1.1. Athletes and all other members of the World Archery Family shall comply with the betting and anticorruption rules set forth in Appendix 9

2.2.2. Athletes shall refrain from using substances and procedures prohi bited by the laws of World Archery, IOC, IPC and WADA, and together with the officials shall respect and comply in all aspects with the World Archery Anti-Doping Rules and the World Anti-Doping Code

2.2.3. An athlete may allow his person, name, picture or sport performances to be used for advertising purposes and may accept prizes or money without any restriction or limit (see Appendix 1-Congress Procedures, A ppendix 6-Olympic Charter).

2.2.4. Athletes shall comply with the requirements of World Archery sponsorship contracts during World Championships.

2.2.5. Tobacco and al cohol advertising and sponsorship are forbidden at World Championships.

2.2.6. Athletes may wear advertising in addition to the normal manufacturer trademarks of the articles worn. The manufacturer's trademark is the registered mark of the company which produced the item If a company has an item made for it under contract, the label of the item, if appropriate to the item, shall correspond to its trademark.

2.2.7. Athletes may have advertising on their personal and technical equipment (eg. bows, bags, etc.) in addition to the item's normal trademark.

2.2.7.1. All advertising referred to Article2.2.6. and Article 2.2.7. above shall not exceed $400 \mathrm{~cm} 2$ per item Athletes' numbers are not covered by this article.

2.2.7.2. All trademarks referred to in Article 2.2.6. and Article 2.2.7. above shall not exceed $30 \mathrm{~cm} 2$ except trademarks on bows and stabilizers.

2.2.7.3. The official insignia, flag or emblem of the country or Member Association they represent has no restriction as to size and is not counted as advertising.

2.2.8. Provisions under Article 2.2.5. , Article 2.2.6. , Article 2.2.7. , Article2.2.7.1. and Article 2.2.7.2. are also to be observed by all team officials present on the field of play.

2.2.9. For eligibility rules applicable to Para-Archery events, see21. Chapter 21-Para-Archery in Book 3.

[...]

2.4. National Teams

2.4.1. To be eligible to participate as a member of a National Team in International Events, an athlete shall have a valid passport from the country of which he is a National Teem Member and shall not have represented any other Member Association as a National Team Member for at least one year before the date of the competition.

2.4.2. If an athlete wants to compete for a National Team other than the one for which he holds a valid passport, he shall have resided in the new country for at least one year before the date of the competition and shall have the written permission of the Member Association, if any, of the country from which he has a valid passport.

2.4.3. An athlete who has changed his nationality, or acquired a new nationality, may not represent the National Team of his new Member Association until one year after such a change or acquisition.

2.4.4. An athlete who has a valid passport of two or more countries at the sametime may represent either of them, as he chooses. He shall, however, meet the conditions laid down in Article 2.4.1. to Article 2.4.3. above

2.5. Athletes are not eligible to compete in World Archery events if they do not meet the requirements laid down above

World Archery Rules 2013

World Archery Constitution and Rules 2012 effective since 1 April 2013 with Updated: 25 September

$\underline{2013}$

Chapter 2

E ligibility Code for Athletes and Team 0 fficials

\subsection{Admission}

2.1.1. Athletes who wish to participate in Championships, Games, International and National Tournaments, which are recognised or controlled by World Archery or a Member Association, in one or more of the various disciplines recognised by World Archery, shall be affiliated with a Member Association.

2.1.2. To be eligible to participate in the World Championships, World Record and Performance Award Tournaments and such other events as World Archery may recognise and specify, athletes shall comply with theEligibility Code. 


\section{APPENDICES}

2.1.3. To be eligible to participate in the Olympic Games, Paralympic Games and Regional or Area Games, an athlete shall comply with the Olympic Charter (see Appendix 1-Congress Procedures, Appendix 6Olympic Charter) and the Eligibility Code.

[...]

2.2. E ligibility Code

(SeeAppendix 1-Congress Procedures, A ppendix 6-Olympic Charter.)

2.2.1. Athletes and officials shall respect the spirit of fair play and non-violence, and behave accordingly on the field of play.

2.2.1.1. Athletes and all other members of the World Archery Family shall comply with the betting and anticorruption rules set forth in Appendix 9

2.2.2. Athletes shall refrain from using substances and procedures prohibited by the laws of World Archery, IOC, IPC and WADA, and together with the officials shall respect and comply in all aspects with the World Archery Anti-Doping Rules and the World Anti-Doping Code

2.2.3. An athlete may allow his person, name, picture or sport performances to be used for advertising purposes and may accept prizes or money without any restriction or limit (see Appendix 1-Congress Procedures, Appendix 6-Olympic Charter).

2.2.4. Athletes shall comply with the requirements of World Archery sponsorship contracts during World Championships.

2.2.5. Tobacco and al cohol advertising and sponsorship are forbidden at World Championships.

2.2.6. Athletes may wear advertising in addition to the normal manufacturer trademarks of the articles worn. The manufacturer's trademark is the registered mark of the company which produced the item If a company has an item made for it under contract, the label of the item, if appropriate to the item, shall correspond to its trademark.

2.2.7. Athletes may have advertising on their personal and technical equipment (eg. bows, bags, etc.) in addition to the item's normal trademark.

2.2.7.1. All advertising referred to Article2.2.6. and Article 2.2.7. above shall not exceed $400 \mathrm{~cm} 2$ per item Athletes' numbers are not covered by this article.

2.2.7.2. All trademarks referred to in Article 2.2.6. and Article 2.2.7. above shall not exceed $30 \mathrm{~cm} 2$ except trademarks on bows and stabilizers.

2.2.7.3. The official insignia, flag or emblem of the country or Member Association they represent has no restriction as to size and is not counted as advertising.

2.2.8. Provisions under Article 2.2.5. , Article 2.2.6. , Article 2.2.7. , Article 2.2.7.1. and Article 2.2.7.2. are al so to be observed by all team officials present on the field of play.

2.2.9. For eligi bility rules applicable to ParaArchery events, see21. Chapter 21-Para-Archery in Book 3.

$[\ldots]$

2.4. National Teams

2.4.1. To be eligible to participate as a member of a National Team in International Events, an athlete shall have a valid passport from the country of which he is a National Team Member and shall not have represented any other Member Association as a National Team Member for at least one year before the date of the competition.

2.4.2. If an athlete wants to compete for a National Team other than the one for which he holds a valid passport, he shall have resided in the new country for at least one year before the date of the competition and shall have the written permission of the Member Association, if any, of the country from which he has a valid passport.

2.4.3. An athlete who has changed his nationality, or acquired a new nationality, may not represent the National Team of his new Member Association until one year after such a change or acquisition.

2.4.4. An athlete who has a valid passport of two or more countries at the same time may represent either of them, as he chooses. He shall, however, meet the conditions laid down in Article 2.4.1. to Article 2.4.3. above

2.5. Athletes are not eligible to compete in World Archery events if they do not meet the requirements laid down above

\section{World Archery Rules 2012}

\section{Eligibility code for athletes and team officials}

2.1. Admission

2.1.1. Athletes who wish to participate in Championships, Games, International and National Tournaments, which are recognised or controlled by World Archery or a Member Association, in one or more of the various disciplines recognised by World Archery, shall be affiliated with a Member Association.

2.1.2. To be eligible to participate in the World Championships, World Record and Performance Award Tournaments and such other events as World Archery may recognise and specify, athletes shall comply with the Eligibility Code. 


\section{NATIONALITY REQUiREMENTS IN Oly mpic SPORTS}

2.1.3. To be eligible to participate in the Olympic Games, Paralympic Games and Regional or Area Games, an athlete shall comply with the Olympic Charter (see Appendix 1-Congress Procedures, Appendix6Olympic Charter) and the Eligibility Code.

[...]

2.2. E ligibility Code

(SeeAppendix 1-Congress Procedures, A ppendix 6-Olympic Charter.)

2.2.1. Athletes and officials shall respect the spirit of fair play and non-violence, and behave accordingly on the field of play.

2.2.1.1. Athletes and all other members of the World Archery Family shall comply with the betting and anticorruption rules set forth in Appendix 9

2.2.2. Athletes shall refrain from using substances and procedures prohibited by the laws of World Archery, IOC, IPC and WADA, and together with the officials shall respect and comply in all aspects with the World Archery Anti-Doping Rules and the World Anti-Doping Code

2.2.3. An athlete may allow his person, name, picture or sport performances to be used for advertising purposes and may accept prizes or money without any restriction or limit (see Appendix 1-Congress Procedures, Appendix 6-Olympic Charter).

2.2.4. Athletes shall comply with the requirements of World Archery sponsorship contracts during World Championships.

2.2.5. Tobacco and al cohol advertising and sponsorship are forbidden at World Championships.

2.2.6. Athletes may wear advertising in addition to the normal manufacturer trademarks of the articles worn. The manufacturer's trademark is the registered mark of the company which produced the item If a company has an item made for it under contract, the label of the item, if appropriate to the item, shall correspond to its trademark.

2.2.7. Athletes may have advertising on their personal and technical equipment (eg. bows, bags, etc.) in addition to the item's normal trademark.

2.2.7.1. All advertising referred to Article 2.2.6. and Article2.2.7. above shall not exceed $400 \mathrm{~cm} 2$ per item Athletes' numbers are not covered by this article.

2.2.7.2. All trademarks referred to in Article 2.2.6. and Article 2.2.7. above shall not exceed $30 \mathrm{~cm} 2$ except trademarks on bows and stabilizers.

2.2.7.3. The official insignia, flag or emblem of the country or Member Association they represent has no restriction as to size and is not counted as advertising.

2.2.8. Provisions under Article 2.2.5. , Article 2.2.6. , Article 2.2.7. , Article 2.2.7.1. and Article 2.2.7.2. are also to beobserved by all team officials present on the field of play.

2.2.9. For eligibility rules applicable to Para-Archery events, see 21. Chapter 21-Para-Archery in «Book 3».

\subsection{National Teams}

2.4.1. To be eligible to participate as a member of a National Team in International Events, an athlete shall have a valid passport from the country of which he is a National Team Member and shall not have represented any other Member Association as a National Team Member for at least one year before the date of the competition.

2.4.2. If an athlete wants to compete for a National Team other than the one for which he holds a valid passport, he shall have resided in the new country for at least one year before the date of the compeition and shall have the written permission of the Member Association, if any, of the country from which he has a valid passport.

2.4.3. An athlete who has changed his nationality, or acquired a new nationality, may not represent the National Team of his new Member Association until one year after such a change or acquisition.

2.4.4. An athlete who has a valid passport of two or more countries at the sametime may represent either of them, as he chooses. He shall, however, meet the conditions laid down in Article 2.4.1. to Article 2.4.3. above

2.5. Athletes are not eligible to compete in World Archery events if they do not meet the requirements laid down above

\section{Athletics \\ INTERNATIONAL ASSOCIATION OF ATHLETICS FEDERATIONS COMPETITION RULES 2016-2017 IN FORCE AS FROM 1ST NOVEMBER 2015 \\ DEFINITIONS \\ Citizen}

A person who has legal Citizenship of a Country or, in the case of a territory, legal Citizenship of the territory's parent Country and appropriate legal status in the territory under applicable laws.

Citizenship

I egal citizenship of a Country or, in the case of a territory, legal citizenship of the teritory's parent Country and appropriate legal status in the territory under applicable laws. 


\section{APPENDICES}

\section{Country}

A self-governing geographical area of the world recognised as an independent state by international law and international governmental bodies.

\section{Residence}

Residence is the place or location in which the athlete is registered with relevant authorities as having his primary and permanent home

the major international Competitions in theiAAF's four-yearly official competition programme

Note (i): The above definitions apply to all Rules except where the same terms are also defined in Chapter 3 (Anti-Doping and Medical) e.g., International Competition, in which case the above definitions apply to all Rules except Chapter 3. The definitions in Chapter 3 apply to the Anti-Doping and Medical Rules only.

Note (ii): All references in the Rules to the masculine gender shall also include references to the feminine and all references to thesingular shall also include references to the plural.

Note (iii): IAAF publications "The Referee" and "Le J uge Arbitre", in English and French respectively, provide interpretation to the Competition Rules and practical guidance for their implementation.

Note (iv): Amendments (other than editorial amendments) to the corresponding Rules in the IAAF Competition Rules, 2016-2017 approved by the 2015 Congress or by the Council, are marked by double lines in the margin and are applicable from 1st November 2015 unless otherwise stated.

\section{RULE 5 Eligibility to Represent a M ember}

1. in international Competitions held under Rules 1.1(a), (b), (c), (f) or (g), Members shall be represented only by athletes who are Citizens of the Country (or territory) which the affiliated Member represents and who comply with the eligibility requirements of this Rule 5.

2. An athlete who has never competed in an international Competition under Rules 1.1(a), (b), (c), (f) or (g) shall be eligible to represent a Member in an international Competition under Rules 1.1(a), (b), (c), (f) or (g) if heis:

(a) a Citizen of the Country (or territory) by virtue of having been born or by virtue of having a parent or grandparent born in the Country (or territory); or

(b) a Citizen of the Country (or territory) through the acquisition of a new Citizenship but, in such a case, he may represent his new Member no earlier than one year following the date of acquisition of new Citizenship pursuant to the athlete's application. this period of one year may be reduced or cancelled as set out below:

(i) the period shall be cancelled if the athletehas completed one continuous year of Residence in the Country (or territory) immediately preceding theinternational Competition in question;

(ii) the period may be reduced or cancelled in exceptional cases by the Council. An application for a reduction or cancellation must be submitted by the relevant Member in writing to the iAAF Office at least 30 days before theinternational Competition in question.

3. Subject to Rule 5.4, an athlete who has represented a Member in an international Competition held under Rules 1.1(a), (b), (c), (f) or (g) shall not be eligible to represent another Member in an international Competition held under Rules 1.1(a), (b), (c), (f) or (g).

4. An athlete who has represented a Member in an international Competition under Rules 1.1(a), (b), (c), (f) or (g) shall be eligible to represent another Member in an international Competition under Rules 1.1(a), (b), (c), (f) or (g) (with immediate effect unless otherwise stated) in the foll owing circumstances only:

(a) if the Country (or territory) of the Member is subsequently incorporated in another Country that is or subsequently becomes a Member;

(b) if the Country (or territory) of the Member ceases to exist and the athlete becomes a Citizen as of right of a newly formed Country ratified by treaty or otherwise recognised at international level that subsequently becomes a Member;

(c)if the territory of the Member does not have a National Olympic Committee and an athlete qualifies to compete at the Olympic games for the territory's parent Country. in such a case, the athlete's representation of the territory's parent Country at the Olympic games shall not affect his eligibility to continue to compete for therelevant Member territory in other international Competitions under Rules 1.1(a), (b), (c), (f) or (g);

(d)Acquisition of new Citizenship: if the athlete acquires a new Citizenship, he may represent his new Member in an international Competition under Rules 1.1(a), (b), (c), (f) or (g), but no earlier than three years following the date of acquisition of new Citizenship pursuant to the athlete's application. this period of three years may be reduced or cancelled as set out below:

(i) the period may be reduced to 12 months with the agreement of the Members concerned. the reduction shall be effective upon receipt by theiAAF Office of a written notification of the Members' agreement;

(ii) the period shall be cancelled if the athlete has completed three continuous years of Residence in the Country (or territory) of his new membership immediately preceding the international Competition in question;

(iii) the period may be reduced or cancelled in exceptional cases by the Council. An application for a reduction or cancellation must be submitted by the relevant Member in writing to the iAAF Office at least 30 days before the international Competition in question. 
(e) Dual Citizenship: if an athlete holds Citizenship of two (or more) Countries (or territories), he may represent the Member of either (or any) of them as he may elect However, having once represented his elected Member in an international Competition under Rules 1.1(a), (b), (c), (f) or (g), he shall not represent another Member of which he is a Citizen for a period of thre years from the date that he last represented the first elected Member. this period may be reduced or cancel led as set out below:

(i) the period may be reduced to 12 months with the agreement of the Members concerned. the reduction shall be fffective upon receipt by theiAAF Office of a written notification of the Members' agreement;

(ii) the period may be reduced or cancelled in exceptional cases by the Council. An application for a reduction or cancel lation must be submitted by the relevant Member in writing to the iAAF Office at least 30 days before theinternational Competition in question.

the application of Rule 5.4(e) is limited to athletes who were born with dual citizenship. An athlete who holds Citizenship of two or more Countries (or territories) by virtue of the fact that he has acquired a new Citizenship (for example, through marriage) without relinquishing his Citizenship of birth is subject to the provisions of Rule $5.4(\mathrm{~d})$.

5. in accordance with Rule 21.2, the eligibility of an athlete competing under these Rules shall at all times be guaranteed by the Member to which the athlete is affiliated. the burden of proof in establishing whether an athlete is eligible in accordance with this Rule 5 rests with the Member and the athlete concerned. the Member must provide the iAAF with valid / authentic documentation demonstrating the athlete's eligibility and such other evidence as may be necessary to provethe athlete's eligibility on a definitive basis. if required by the iAAF, Members shall provide a certified copy of all documentation on which it seeks to rely in demonstrating the athlete's eligibility under this Rule

RULE 20 Definition of Eligible Athlete

An athleteis eligible to compete if he agrees to abide by the Rules and has not been dedared ineligible

RULE 21 Restriction of Competition to E ligible Athletes

1. Competition under these Rules is restricted to athletes who are under the jurisdiction of a Member and who are eligibleto compete under the Rules.

2. in any competition under the Rules, the eligibility of an athlete competing shall be guaranteed by the Member to which the athleteis affiliated.

3. the eligibility rules of Members shall be strictly in conformity with those of the iAAF and no Member may pass, promul gate or retain in its constitution or regulations any eligibility rule or regulation which is in direct conflict with a Rule or Regulation. where there is a conflict between the eligibility rules of the iAAF and the eligibility rules of a Member, the eligibility rules of theiAAF shall apply.

INTERNATIONAL ASSOCIATION OF ATHLETICS FEDERATIONS COMPETITION RULES 2014-2015

\section{IN FORCE AS FROM 1ST NOVEMBER 2013 DEFINITIONS \\ Citizen}

A person who has legal Citizenship of a Country or, in the case of a Territory, legal Citizenship of the Territory's parent Country and appropriate legal status in the Teritory under applicable laws.

\section{Citizenship}

Legal citizenship of a Country or, in the case of a Teritory, legal citizenship of the Territory's parent Country and appropriate legal status in the Territory under applicable laws.

\section{Country}

A self-governing geographical area of the world recognised as an independent state by international law and international governmental bodies.

\section{Residence}

Residence is the place or location in which the athlete is registered with relevant authorities as having his primary and permanent home

\section{Rule 5 E ligibility to Represent a M ember}

1. In International Competitions held under Rules 1.1(a), (b), (c), (f) or (g), Members shall be represented only by athletes who are Citizens of the Country (or Teritory) which the affiliated Member represents and who comply with the eligibility requirements of this Rule 5.

2. An athlete who has never competed in an International Competition under Rules 1.1(a), (b), (c), (f) or (g) shall be eligible to represent a Member in an International Competition under Rules 1.1(a), (b), (c), (f) or (g) if heis:

(a) a Citizen of the Country (or Territory) by virtue of having been born or by virtue of having a parent or grandparent born in the Country (or Territory); or

(b) a Citizen of the Country (or Territory) through the acquisition of a new Citizenship but, in such a case, he may represent his new Member no earlier than one year following the date of acquisition of new Citizenship pursuant to the athlete's application. This period of oneyear may be reduced or cancel led as set out bel ow: 
(i) the period shall be cancelled if the athletehas completed one continuous year of Residence in the Country (or Teritory) immediately preceding the International Competition in question;

(ii) the period may be reduced or cancelled in exceptional cases by the Council. An application for a reduction or cancel lation must besubmitted by the rel evant Member in writing to the IAAF Office at least 30 days before the International Competition in question.

3. Subject to Rule 5.4, an athlete who has represented a Member in an International Competition held under Rules 1.1(a), (b), (c), (f) or (g) shall not be eligible to represent another Member in an International Competition held under Rules 1.1(a), (b), (c), (f) or (g).

4. An athl ete who has represented a Member in an International Competition under Rules 1.1(a), (b), (c), (f) or (g) shall be eligible to represent another Member in an International Competition under Rules 1.1(a), (b), (c), (f) or (g) (with immediate effect unless otherwise stated) in the foll owing circumstances only:

(a) if the Country (or Teritory) of the Member is subsequently incorporated in another Country that is or subsequently becomes a Member;

(b) if the Country (or Teritory) of the Member ceeses to exist and the athlete becomes a Citizen as of right of a newly formed Country ratified by Treaty or otherwise recognised at international level that subsequently becomes a Member;

(c) if the Teritory of theMember does not have a National Olympic Committee and an athlete qualifies to compete at the Olympic Games for the Territory's parent Country. In such a case, theathlete's representation of the Territory's parent Country at the Olympic Games shall not affect his eligibility to continue to compete for the relevantMember Territory in other International Competitions under Rules 1.1(a), (b), (c), (f) or (g);

(d) Acquisition of new Citizenship: if the athlete acquires a new Citizenship, he may represent his new Member in an International Competition under Rules 1.1(a), (b), (c), (f) or (g), but no earlier than thre years following the date of acquisition of new Citizenship pursuant to theathlete's application. This period of three years may be reduced or cancel led as set out below:

(i) the period may be reduced to 12 months with the agreement of theMembers concerned. The reduction shall be effective upon receipt by the IAAF Office of a written notification of the Members' agreement;

(ii) the period shall be cancelled if the athlete has completed three continuous years of Residence in the Country (or Teritory) of his new membership immediately preceding the International Competition in question;

(iii) the period may be reduced or cancelled in exceptional cases by the Council. An application for a reduction or cancel lation must besubmitted by the rel evant Member in writing to theIAAF Officeat least 30 days before the International Competition in question.

(e) Dual Citizenship: if an athlete holds Citizenship of two (or more) Countries (or Territories), he may represent the Member of either (or any) of them as he may elect. However, having once represented his elected Member in an International Competition under Rules 1.1(a), (b), (c), (f) or (g), he shall not represent another Member of which he is a Citizen for a period of thre years from the date that he last represented the first elected Member. This period may be reduced or cancel led as set out below:

(i) the period may be reduced to 12 months with the agreement of the Members concerned. The reduction shall be effective upon receipt by the IAAF Office of a written notification of the Members' agreement;

(ii) the period may be reduced or cancelled in exceptional cases by the Council. An application for a reduction or cancel lation must be submitted by the re evant Member in writing to theIAAF Office at least 30 days before the International Competition in question.

The application of Rule 5.4(e) is limited to athletes who were born with dual citizenship. An athlete who holds Citizenship of two or more Countries (or Territories) by virtue of the fact that he has acquired a new Citizenship (for example, through marriage) without relinquishing his Citizenship of birth is subject to the provisions of Rule 5.4(d).

5. In accordance with Rule 21.2, the eligibility of an athlete competing under these Rules shall at all times be guaranteed by the Member to which the athlete is affiliated. The burden of proof in establishing whether an athlete is eligible in accordance with this Rule 5 rests with the Member and the athlete concerned. The Member must provide the IAAF with valid / authentic documentation demonstrating the athlete's eligibility and such other evidence as may be necessary to provethe athlete's eligi bility on a definitive basis. If required by the IAAF, Members shall provide a certified copy of all documentation on which it seeks to rely in demonstrating the athlete's eligibility under this Rule

RULE 20 Definition of E ligible Athlete

An athlete is eligible to competeif he agrees to abide by the Rules and has not been dedared ineligible RULE 21 Restriction of Competition to E ligible A thletes

1. Competition under these Rules is restricted to athletes who are under the jurisdiction of a Member and who are eligibleto compete under the Rules.

2. In any competition under the Rules, the eligibility of an athlete competing shall be guaranteed by theMember to which the athleteis affiliated. 


\section{NATIONALITY REQUIREMENTS IN OLYMPIC SPORTS}

3. The eligibility rules of Members shall be strictly in conformity with those of the IAAF and no Member may pass, promul gate or retain in its constitution or regulations any eligibility rule or regulation which is in direct conflict with a Rule or Regulation. Where there is a conflict between the eligibility rules of the IAAF and the eligibility rules of a Member, the ligibility rules of theIAAF shall apply.

RULE 22 Ineligibility for International and Domestic Competitions

1. The following persons shall beineligible for competitions, whether

held under these Rules or the rules of an Area or a Member. Any athlete, athlete support personnel or other person:

(a) whose National Federation is currently suspended by the IAAF. This does not apply to national competitions organised by the currently suspended Member for the Citizens of that Country or Territory;

(b) who has been provisionally suspended or dedared ineligible under the rules of his National Federation from competing in competitions under the jurisdiction of that National Federation, in so far as such suspension or ineligibility is consistent with these Rules;

(c) who is currently serving a period of provisional suspension from competition under these Rules;

(d) who does not meet the eligibility requirements set out in Rule 141 or the Regulations thereunder;

(e) who has been declared ineligible as a result of a breach of the Anti-Doping Rules in Chapter 3;

(f) who has been declared indigible as a result of a breach of any other Ruleor Regulation under Rule60.4.

2. If an athlete competes in a competition when not eligible to do so under Rule 141 or the Regulations thereunder, without prejudice to any other disciplinary action that may be taken under the Rules, the athlete and any team for which the athlete competed shall be disqualified from the competition with all resulting consequences for the athlete and the team, including the forfeiture of all titles, awards, medals, points and prizeand appearance money.

3. If an athlete competes (or an athlete support personnel or other person participates) in a competition, whether held under these Rules or the rules of an Area or Member, whilst ineligible to do so under the AntiDoping Rules in Chapter 3, the consequences set out in Rule 40.11 shall apply.

4. If an athlete competes (or an athlete support personnel or other person participates) in a competition, whether held under these Rules or the rules of an Area or Member, whilst ineligible to do so under any other Rule, the period of his ineligibility shall recommence from the time he last competed as though no part of a period of ineligibility had

been served.

\section{INTER NATIONAL ASSOCIATION OF ATHLETICS FEDERATIONS COM PETITION RULES 2012-2013IN FORCE AS FROM 1ST NOVEM BER 2011 \\ Definitions \\ Citizen}

A person who has legal Citizenship of a Country or, in the case of a Territory, legal Citizenship of the Territory's parent Country and appropriate legal status in the Teritory under applicable laws.

\section{Citizenship}

Legal citizenship of a Country or, in the case of a Teritory, legal citizenship of the Territory's parent Country and appropriate legal status in the Territory under applicable laws.

\section{Country}

A self-governing geographical area of the world recognised as an independent state by international law and international governmental bodies.

\section{Residence}

Residence is the place or location in which the athlete is registered with relevant authorities as having his primary and permanent home

Note (i): The above definitions apply to all Rules except where the same terms are also defined in Chapter 3 (Anti-Doping and Medical) eg., International Competition, in which case the above definitions apply to all Rules except Chapter 3. The definitions in Chapter 3 apply to the Anti- Doping and Medical Rules only.

\section{RULE 5 Eligibility to Represent a M ember}

1. In International Competitions held under Rules 1.1(a), (b), (c), (f) or (g), Members shall be represented only by athletes who are Citizens of the Country (or Teritory) which the affiliated Member represents and who comply with the eligibility requirements of this Rule 5.

2. An athlete who has never competed in an International Competition

under Rules 1.1(a), (b), (c), (f) or (g) shall be eligible to represent a Member in an International Competition under Rules 1.1(a), (b), (c), (f) or (g) if he:

(a) is a Citizen of the Country and has been a Citizen for the two year period immediately preceding the International Competition in question; or

(b) is a Citizen of the Territory and has completed two continuous years of Residence in the Territory immediately preceding the International Competition in question. The period of two years in either case may exceptionally be reduced or cancelled by the Council. An application for a reduction or cancellation of the 


\section{APPENDICES}

two-year period must be submitted by the relevant Member in writing to the IAAF Office at least 30 days before the International Competition in question.

3. Subject to Rule 5.4, an athlete who has represented a Member in an International Competition held under Rules 1.1(a), (b), (c), (f) or (g) shall not be eligible to represent another Member in an International Competition held under Rules 1.1(a), (b), (c), (f) or (g).

4. An athlete who has represented a Member in an International Competition under Rules 1.1(a), (b), (c), (f) or (g) shall be eligible to represent another Member in an International Competition under Rules 1.1(a), (b), (c), (f) or (g) (with immediate effect unless otherwise stated) in the foll owing circumstances only:

(a) if the Country (or Teritory) of the Member is subsequently incorporated in another Country that is or subsequently becomes a Member;

(b) if the Country (or Teritory) of the Member ceases to exist and the athlete becomes a Citizen as of right of a newly formed Country ratified by Treaty or otherwise recognised at international level that subsequently becomes a Member;

(c) if the Territory of the Member does not have a National Olympic Committee and an athlete qualifies to compete at the Olympic Games for the Territory's parent Country. In such a case, the athl ete's representation of the Territory's parent Country at the Olympic Games shall not affect his eligibility to continue to compete for the relevant Member Territory in other International Competitions under Rules 1.1(a), (b), (c), (f) or (g);

(d) Acquisition of new Citizenship: if the athlete acquires a new Citizenship, he may represent his new Member in an International Competition under Rules 1.1(a), (b), (c), (f) or (g), but no earlier than thre years following the date of acquisition of new Citizenship pursuant to the athlete's application. This period of three years may be reduced or cancel led as set out below:

(i) the period may be reduced to 12 months with the agreement of the Members concerned. The reduction shall be effective upon receipt by the IAAF Office of a written notification of the Members' agreement;

(ii) the period may be reduced or cancelled in exceptional cases by the Council. An application for a reduction or cancel lation must be submitted by the relevant Member in writing to the IAAF Office at least 30 days before the International Competition in question; or

(e) Dual Citizenship: if an athlete holds Citizenship of two (or more) Countries (or Territories), he may represent the Member of either (or any) of them as he may elect. However, having once represented his elected Member in an International Competition under Rules 1.1(a), (b), (c), (f) or (g), he shall not represent another Member of which he is a Citizen for a period of three years from the date that he last represented the first elected Member. This period may be reduced or cancelled as set out below:

(i) the period may be reduced to 12 months with the agrement of the Members concerned. The reduction shall be effective upon receipt by the IAAF Office of a written notification of the Members' agreement;

(ii) the period may be reduced or cancelled in exceptional cases by the Council. An application for a reduction or cancel lation must be submitted by the rel evant Member in writing to the IAAF Office at least 30 days before the International Competition in question.

The application of Rule 5.4(e) is limited to athletes who were born with dual citizenship. An athlete who holds Citizenship of two or more Countries (or Teritories) by virtue of the fact that he has acquired a new Citizenship (for example, through marriage) without relinquishing his Citizenship of birth is subject to the provisions of Rule 5.4(d).

\section{RULE 20 Definition of Eligible Athlete}

An athlete is eligible to competeif he agrees to abide by the Rules and has not been dedared ineligible

\section{RULE 21 Restriction of C ompetition to E ligible Athletes}

1. Competition under these Rules is restricted to athletes who are under the jurisdiction of a Member and who are eligible to compete under the Rules.

2. In any competition under the Rules, the eligibility of an athlete competing shall be guaranteed by the Member to which the athlete is affiliated.

3. The eligibility rules of Members shall be strictly in conformity with those of the IAAF and no Member may pass, promul gate or retain in its constitution or regulations any eligibility rule or regulation which is in direct conflict with a Rule or Regulation. Where there is a conflict between the eligibility rules of the IAAF and the ligibility rules of a Member, the eligibility rules of theIAAF shall apply.

\section{RULE 22 Ineligibility for International and Domestic Competitions}

1. The following persons shall be ineligible for competitions, whether held under these Rules or the rules of an Area or a Member. Any athlete, athletesupport personnel or other person:

(a) whose National Federation is currently suspended by the IAAF. This does not apply to national competitions organised by the currently suspended Member for the Citizens of that Country or Territory;

(b) who has been provisionally suspended or declared ineligible under the rules of his National Federation from competing in competitions under the jurisdiction of that National Federation, in so far as such suspension or ineligibility is consistent with these Rules;

(c) who is currently serving a period of provisional suspension from competition under these Rules;

(d) who does not meet the eligibility requirements set out in Rule 141 or the Regulations thereunder; 
(e) who has been dedared ineligible as a result of a breach of the Anti-Doping Rules in Chapter 3;

(f) who has been declared indigible as a result of a breach of any other Rule or Regulation under Rule60.4.

2. If an athlete competes in a competition when not eligible to do so under Rule 141 or the Regulations thereunder, without prejudice to any other disciplinary action that may be taken under the Rules, the athlete and any team for which the athlete competed shall be disqualified from the competition with all resulting consequences for the athlete and the team, including the forfeiture of all titles, awards, medals, points and prizeand appearance money.

3. If an athlete competes (or an athlete support personnel or other person participates) in a competition, whether held under these Rules or the rules of an Area or Member, whilst ineligible to do so under the AntiDoping Rules in Chapter 3, the consequences set out in Rule40.11 shall apply.

4. If an athlete competes (or an athlete support personnel or other person participates) in a competition, whether held under these Rules or the rules of an Area or Member, whilst ineligible to do so under any other Rule, the period of his ineligibility shall recommence from the time he last competed as though no part of a period of ineligibility had been served.

INTERNATIONAL ASSOCIATION OF ATHLETICS FEDERATIONS COMPETITION RULES 2010-2011

\section{RULE 5 Citizenship and C hanges in Citizenship}

1. In International Competitions under Rules 1.1(a), (b) or (f), Members shall be represented only by Citizens of the Country or Territory which the affiliated Member represents.

2. Having once represented a Member in an International Competition under Rules 1.1(a), (b) or (f), no athlete may thereafter represent another Member in an International Competition under Rules 1.1(a), (b) or (f), except in the following circumstances:

(a)Theincorporation of one Country or Territory in another.

(b) The creation of a new Country ratified by Treaty or otherwise recognised at international level.

(c) Acquisition of a new Citizenship. In this case, the athlete shall not represent his new Member in an International Competition under Rules 1.1(a), (b) or (f), for a period of three years following the date of acquisition of new Citizenship pursuant to the athlete's application. This period of three years may however be reduced or cancelled as set out below:

(i)the period may be reduced to 12 months with the agreement of the Members concerned. The reduction shall be effective upon receipt by the IAAF Office of a written notification of the Members' agreement;

(ii) the period may be reduced or cancelled in truly exceptional cases by the Council. This matter should be submitted to the Council for its dealing at least 30 days before the International Competition which the change concerns.

(d)Dual Citizenship: In this case, an athlete who holds Citizenship of two (or more) Countries or Teritories, may represent the Member of either (or any) of them, as he may elect. However, having represented the Member in an International Competition under Rules 1.1(a), (b) or (f), he shall not represent another Member of which he is a Citizen in an International Competition under Rules 1.1(a), (b) or (f), for a period of three years from the date he last represented the first Member. This period of three years may be reduced or cancelled as set out below:

(i)the period may be reduced to 12 months with the agreement of the Members concerned. The reduction shall be effective upon receipt by the IAAF Office of a written notification of the Members' agreement which has been signed by both parties;

(ii) the period may be reduced or cancelled in truly exceptional cases with the approval of the Council. This matter should be submitted to the Council for its dealing at least 30 days before the International Competition which the change concerns.

3.(a) When a Citizen of a Country or Territory of a Member which is suspended from the IAAF is seeking to become a Citizen of a Country or Territory of a Member which is not suspended, he may compete in domestic competition organised by the Member which is not suspended on condition that:

(i)he renounces his former nationality in the process of applying for Citizenship of the Country or Territory of the Member which is not suspended and he publicly states this fact by advising the relevant Members concerned;

(ii)he completes at least one year's continuous residence in his new Country or Teritory;

(b) An athlete who has complied with the requirements of Rule 5.3(a) may compete in International Competitions under Rules 1.1(i) and (j) only after completing a period of two years' continuous residence in his new Country or Teritory.

(c)An athlete who has complied with the requirements of Rule 5.3(a) may represent his new National Federation in International Competitions under Rules 1.1(a) to (f) only after completing a period of three years' continuous residence in his new Country or Teritory and after he has acquired new Citizenship.

(d)The period(s) of continuous residence shall be computed on the basis of a year of 365 days, starting from the day after a person lands in the Country or Teritory where he sedks to acquire new citizenship. 
(e)In any continuous 365 day period, an athlete may not spend more than a total of 90 days in the foreign Country or Territory of the Member under suspension.

(f)An athlete seeking to qualify under this Rule must refrain from any athletics activities, which shall ind ude, but not be restricted to, exhibition races, training, coaching, officiating, lecturing, giving interviews and publicity interviews, with any representatives of a Member which is under suspension.

4. Members and their officials, coaches and athletes are not to conduct any activities, as defined in Rule 5.3(f) or otherwise, associated with any representative of a suspended Member, its officials, coaches, judges, athletes, etc. In case of any infringement of this Rule, the provisions for suspensions and sanctions laid down in the Constitution shall apply.

\section{INTERNATIONAL ASSOCIATION OF ATHLETICS FEDERATIONS COMPETITION RULES}

\section{$\underline{2009}$}

\section{RULE 5 Citizenship and Changes in Citizenship}

1. In International Competitions under Rules 1.1(a), (b) or (f), Members shall be represented only by Citizens of the Country or Territory which the affiliated Member represents.

2. Having once represented a Member in an International Competition under Rules 1.1(a), (b) or (f), no athlete may thereafter represent another Member in an International Competition under Rules 1.1(a), (b) or (f), except in the following circumstances:

(a) The incorporation of one Country or Territory in another.

(b) The creation of a new Country ratified by Treaty or otherwise recognised at international level.

(c) Acquisition of a new Citizenship. In this case, the athlete shall not represent his new Member in an International Competition under Rules 1.1(a), (b) or (f), for a period of three years following the date of acquisition of new Citizenship pursuant to the athlete's application. This period of three years may however be reduced or cancelled as set out below:

(i) the period may be reduced to 12 months with the agreement of the Members concerned. The reduction shall be effective upon receipt by the IAAF Office of a written notification of the Members' agreement;

(ii) the period may be reduced or cancelled in truly exceptional cases by the Council. This matter should be submitted to the Council for its dealing at least 30 days before the International Competition which the change concerns.

(d)Dual Citizenship: In this case, an athlete who holds Citizenship of two (or more) Countries or Teritories, may represent the Member of either (or any) of them as he may elect However, having represented the Member in an International Competition under Rules 1.1(a), (b) or (f), he shall not represent another Member of which he is a Citizen in an International Competition under Rules 1.1(a), (b) or (f), for a period of three years from the date he last represented the first Member. This period of three years may be reduced or cancelled as set out below:

(i) the period may be reduced to 12 months with the agreement of the Members concerned. The reduction shall be effective upon receipt by the IAAF Office of a written notification of the Members' agreement which has been signed by both parties;

(ii) the period may be reduced or cancelled in truly exceptional cases with the approval of the Council. This matter should besubmitted to the Council for its dealing at least 30 days before the International Competition which the change concerns.

3. (a)When a Citizen of a Country or Territory of a Member which is suspended from the IAAF is seeking to become a Citizen of a Country or Territory of a Member which is not suspended, he may compete in domestic competition organised by the Member which is not suspended on condition that:

(i) he renounces his former nationality in the process of applying for Citizenship of the Country or Territory of the Member which is not suspended and he publicly states this fact by advising the relevant Members concerned;

(ii) he completes at least one year's continuous residence in his new Country or Teritory;

(b) An athlete who has complied with the requirements of Rule 5.3(a) may compete in International Competitions under Rules 1.1(i) and (j) only after completing a period of two years' continuous residence in his new Country or Territory.

(c)An athlete who has complied with the requirements of Rule 5.3(a) may represent his new National Federation in International Competitions under Rules 1.1(a) to (f) only after completing a period of three years' continuous residence in his new Country or Territory and after he has acquired new Citizenship.

(d) The period(s) of continuous residence shall be computed on the basis of a year of 365 days, starting from the day after a person lands in the Country or Teritory where he sedks to acquire new citizenship.

(e) In any continuous 365 day period, an athlete may not spend more than a total of 90 days in the foreign Country or Territory of the Member under suspension.

(f) An athlete sedking to qualify under this Rule must refrain from any athletics activities, which shall include, but not be restricted to, exhibition races, training, coaching, officiating, lecturing, giving interviews and publicity interviews, with any representatives of a Member which is under suspension. 
4. Members and their officials, coaches and athletes are not to conduct any activities, as defined in Rule 5.3(f) or otherwise, associated with any representative of a suspended Member, its officials, coaches, judges, athletes, etc. In case of any infringement of this Rule, the provisions for suspensions and sanctions laid down in the Constitution shall apply.

\section{INTERNATIONAL ASSOCIATION OF ATHLETICS FEDERATIONS COMPETITION RULES 2008}

In the event of a negative response to a request for authorisation under this Rule, which response must be supported by reasons, the athlete or the National Federation of the Country or Territory in which the athleteis residing may appeal against any such decision to the IAAF. The IAAF shall publish guidelines for the filing of an appeal under this Rule and these guidelines shall be available on the IAAF website To facilitate compliance with this Rule, the IAAF shall maintain on its web site a list of National Federations with such authorisation requirements.

Note: Rule 4.3 concerns athletes aged 18 or over as at the 31st of December of the year in question. The Rule does not apply to athletes who are not Citizens of a Country or Territory or to political refugees.

\section{RUL 5 Citizenship and Changes in Citizenship}

1. In International Competitions under Rules 1.1(a) and (b), Members shall be represented only by Citizens of the Country or Territory which the affiliated Member represents.

2. Having once represented a Member in an International Competition under Rules 1.1(a) and (b), no athlete may thereafter represent another Member in an International Competition under Rules 1.1(a) and (b), except in the following circumstances:

(a) Theincorporation of one Country or Teritory in another.

(b) The creation of a new Country ratified by Treaty or otherwise recogni sed at international level.

(c) Acquisition of a new citizenship. In this case, the athlete shall not represent his new Member in an International Competition under Rules 1.1(a) and (b), for a period of three years following the date of acquisition of new Citizenship pursuant to the athlete's application. This period of three years may however be reduced or cancelled as set out below:

(i) the period may be reduced to 12 months with the agreement of the Members concerned. The reduction shall be effective upon receipt by the IAAF Office of a written notification of the Members' agreement;

(ii) the period may be reduced or cancelled in truly exceptional cases by the Council.

(d) Dual Citizenship: In this case, an athlete who holds Citizenship of two (or more) Countries or Teritories, may represent the Member of either (or any) of them, as he may elect. However, having represented the Member in an International Competition under Rules 1.1(a) and (b), he shall not represent another Member of which he is a Citizen in an International Competition under Rules 1.1(a) and (b), for a period of thre years from the date he last represented the first Member. This period of three years may be reduced or cancelled as set out below:

(i) the period may be reduced to 12 months with the agreement of the Members concerned. The reduction shall be effective upon receipt by the IAAF Office of a written notification of the Members' agreement which has been signed by both parties;

(ii) the period may be reduced or cancelled in truly exceptional cases with the approval of the Council.

3. (a) When a Citizen of a Country or Territory of a Member which is suspended from theIAAF is seeking to become a Citizen of a Country or Territory of a Member which is not suspended, he may compete in domestic competition organised by the Member which is not suspended on condition that:

(i) herenounces his former nationality in the process of applying for citizenship of the Country or Territory of the Member which is not suspended and he publicly states this fact by advising the relevant Members concerned;

(ii)he completes at least one year's continuous residence in his new Country or Territory;

(b)An athlete who has complied with the requirements of Rule 5.3(a) may compete in International Competitions under Rules 1.1(i) and (j) only after completing a period of two years' continuous residence in his new Country or Teritory.

(c)An athlete who has complied with the requirements of Rule 5.3(a) may represent his new National Federation in International Competitions under Rules 1.1(a) to (f) only after completing a period of three years' continuous residence in his new Country or Teritory and after he has acquired new citizenship.

(d)The period(s) of continuous residence shall be computed on the basis of a year of 365 days, starting from the day after a person lands in the Country or Territory where he sedks to acquire new citizenship.

(e) In any continuous 365 day period, an athlete may not spend more than a total of 90 days in the foreign Country or Teritory of the Member under suspension.

(f) An athl ete seeking to qualify under this Rulemust refrain fromany athletics activities, which shall indude, but not be restricted to, exhibition races, training, coaching, officiating, lecturing, giving interviews and publicity interviews, with any representatives of a Member which is under suspension.

4. Members and ther officials, coaches and athletes are not to conduct any activities, as defined in Rule 5.3(f) 


\section{APPENDICES}

or otherwise, associated with any representative of a suspended Member, its officials, coaches, judges, athletes, etc. In case of any infringement of this Rule, the provisions for suspensions and sanctions laid down in the Constitution shall apply.

INTERNATIONAL ASSOCIATION OF ATHLETICS FEDERATIONS COMPETITION RULES 2006- 2007

RULE 5 Citizenship and Changes in Citizenship

1. In International Competitions under Rule 1(a), (b), (c)(i) and (d), Members shall be represented only by Citizens of the Country or Territory which the affiliated Member represents.

2. Having once represented a Member in an International Competition under Rule 1(a), (b), (c)(i) or (d),, no athl ete may thereafter represent another Member in an International Competition under Rule 1(a), (b), (c)(i) or (d), except in the following circumstances:

(a) The incorporation of one Country or Territory in another.

(b) The creation of a new Country ratified by Treaty or otherwise recognised at international level.

(c) Acquisition of a new citizenship. In this case, the athlete shall not represent his new Member in an International Competition under Rule 1(a), (b), (c)(i) or (d) for a period of 3 years foll lowing the acquisition of new Citizenship pursuant to the athlete's application. This period of 3 years may however be reduced or cancelled as set out below:

(i) the period may be reduced to 12 months with the agreement of the Members concerned. The reduction shall be effective upon receipt by the IAAF Office of a written notification of the Members' agreement which has been signed by both parties;

(ii) the period may be reduced or cancelled in truly exceptional cases with the approval of the Council.

(d) Dual Citizenship: In this case, an athlete who holds Citizenship of two (or more) Countries or Territories, may represent the Member of either (or any) of them, as he may elect However, having represented the Member in an International Competition under Rule 1(a), (b),(c)(i) or (d), he shall not represent another Member of which he is a Citizen in an International Competition under Rule 1(a), (b), (c)(i) or (d) for a period of 3 years from the date he last represented the first Member. This period of 3 years may however be reduced or cancelled as set out below:

(i) the period may be reduced to 12 months with the agreement of the Members concerned. The reduction shall be effective upon receipt by the IAAF Office of a written notification of the Members' agreement which has been signed by both parties;

(ii)the period may be reduced or cancelled in truly exceptional cases with the approval of the Council.

3.(a)When a Citizen of a Country or Territory of a Member which is suspended from the IAAF is seeking to become a Citizen of a Country or Territory of a Member which is not suspended, he may compete in domestic competition organised by the Member which is not suspended on condition that:

-he renounces his former nationality in the process of applying for citizenship of the Country or Territory of the Member which is not suspended and he publicly states this fact by advising the relevant Members concerned;

-he completes at least one year's continuous residence in his new Country or Teritory;

-the domestic compeition in which he participates does not include athl etes from other Members.

(b) An athlete who has complied with the requirements of Rule 5.3(a) above may compete in International Competitions under Rule $1(\mathrm{f}),(\mathrm{g})$ and (h) only after completing a period of two years' continuous residence in his new Country or Territory.

(c) An athlete who has complied with the requirements of Rule 5.3(a) above may represent his new National Federation in International Competitions under Rule 1(a)-(e) only after completing a period of three years' continuous residence in his new Country or Teritory and after he has acquired new citizenship.

(d) The period(s) of continuous residence shall be computed on the basis of a year of 365 days, starting from the day after a person lands in the Country or Teritory where he sedks to acquirenew citizenship.

(e) In any continuous 365 day period, an athlete may not spend more than a total of 90 days in the foreign Country or Territory of the Member under suspension.

(f) An athlete sedking to qualify under this Rule must refrain from any athletics activities, which shall indude, but not be restricted to, exhibition races, training, coaching, officiating, lecturing, giving interviews and publicity interviews, with any representatives of a Member which is under suspension.

4. Members and their officials, coaches and athletes are not to conduct any activities, as defined in Rule 5.3(f) above or otherwise, associated with any representative of a suspended Member, its officials, coaches, judges, athletes, etc. In case of any infringement of this Rule, the provisions for suspensions and sanctions laid down in the Constitution shall apply. 


\section{Badminton}

Badminton General Competition Regulation PART III SECTION 1 A GENERAL COM PETITION RE GULATIONS [U pdated 9 November 2015]

7. MEM BER ASSOCIATIONS' RESPONSIBILITIES FOR TOURNAMENTS AND PLAYERS

7.1 Each Member Association shall be responsible for the conduct of all tournaments held under its jurisdiction and in particular for ensuring compliance by the organisers with all the relevant Competition Regulations in BWF-sanctioned tournaments.

7.2 Each Member Association shall beresponsible for the control and management of all players under its jurisdiction.

7.2.1 To be eligible to enter and compete in tournaments, all players must be in good standing with their Member Association. A Member Association may declare a player under its jurisdiction to be ineligible to compete, but the reasons for such declaration and the period of ineligibility must be reported to theBWF.

7.2.2 Member Associations shall have full responsibility for any support (financial or otherwise) received by players under their jurisdiction for the puposes of preparation and competition.

7.2.3 Member Associations shall accept and deal with all prizes paid in cash under Regulations 27.1 and 27.2.

7.2.4 Member Associations shall also supervise or administer any sponsorship, contractual or other arrangements entered into, or involving, players under their jurisdiction.

7.2.5Member Associations shall ensure that players adhere to the Players' Code of Conduct [Part III Section 1B, Appendix 4].

7.3 A Member Association shall be responsible for the management and control of all coaches and team officials sunder its jurisdiction at any tournament.

7.3.1 For all leve 1 to 3 tournaments, every Member Association shall appoint a Team Manager before thetournament.

7.3.2 In default of such appointment, the players present at the tournament shall choose their own Manager.

7.3.3 The Referee of the Tournament shall be notified of the name of the Team Manager as soon as he is appointed.

7.3.4 From the time of arrival at the venue, the Manager shall assume all administrative and other responsibilities on behalf of the relevant Member Association and all the players and team officials in connection with the conduct of the toumament.

7.3.5 The Team Manager must attend any briefing meeting called by the Referee and / or by the Committee of Management. Where there is a failure to comply, regulation 31 shall beapplied.

7.3.6 Member Associations shall ensure that their coaches and team officials adhere to the Code of Conduct for coaches and team officials [Part III - Section 1 B, Appendix 9].

\section{INTERNATIONAL REPRESENTATION*}

8.1 Representing a Member Association is defined as accepting a nomination to be a member of that Association's team in any Badminton toumament where the competition is between teams. However, playing as an individual in a tournament does not count as representation, unl ess the tournament has been specifically nominated by theBWF (Regulation 8.1.2).

8.1.1 Competition between teams includes, but is not limited to, the Thomas, Uber and Sudirman Cups, Continental team championshi ps, theA sian Games team championships, the Commonwealth Games team championships, and other international matches or competitions involving two or more Member Associations' teams.

8.1.2 Currently, the BWF has also specified that the World Championships (see World Championships Regulation 9.2), the World Senior Championships and the individual events at the Olympic Games, Youth Olympic Games, the Asian Games, the Commonweal th Games, Continental Championships, Eye Level Cups, Continental Junior Championships and Continental Senior Championships shall count as international representation. Where players in a doubles pair are from di fferent Member Associations it shall count as international representation for each player.

8.2 A player shall be qualified to represent a Member Association providing the player is in good standing with that Member Association and satisfies Regulations 8.2.1 and either 8.2.2 or 8.2.3:

8.2.1 holds a passport of a country whose teritory the Member Association has jurisdiction over;

8.2.2 has not represented any other Member Association for thre years immediately preceding the date of the tournament;

8.2.3 last represented that Member Association; 


\section{APPENDICES}

8.3 A player shall be deemed to have represented a Member Association if he or she shall have been officially nominated to represent that Member Association and shall have accepted such nomination.

8.4 If a player has represented a Member Association and such Member Association is subsequently divided into two or more Member Associations or is absorbed by another Member Association, either politically or by recognition of the BWF, such player shall, for the purposes of these Regulations, be deemed from the date of such alteration not to have represented any Member Association.

8.5 Notwithstanding the foregoing Regulations, in the case of any officially-recognised competitive multi-sport games in which Badminton is included, the qual ifications for the representation of a Member Association shall be in full accordance with the conditions laid down by such a multi- sport international games. However, BWF eligibility regulations take precedence and should not be contravened (Regulations 8.2 to 8.4 ) with the exception of the Olympic Games, wherethe Olympic Charter takes precedence.

* See Part III Section 1 Appendix 1, page 1, International representation for explanatory chart

\section{JURISDICTION}

9.1 A player comes under the jurisdiction of all Member Associations to which the player is directly or indirectly affiliated.

9.2 Duration

9.2.1 A player comes under continued jurisdiction of a Member Association for a period of three months after ceasing to reside in the country of that Member Association, unless the player explicitly renounces this jurisdiction.

9.2.2 After the three-month period, jurisdiction shall lapse unless the player implicitly (eg. by participation in the Member Association's activities) continues to accept that jurisdiction, or explicitly declares a wish to accept that jurisdiction.

9.2.3 A player who represents a Member Association (see Regulation 8.3) automatically comes under the jurisdiction of that Member Association for threemonths thereafter (as in Regulation 9.2.1).

9.3 Where a sanction is imposed that affects a player's participation beyond the jurisdiction of the Member Association concerned, then such sanction shall be notified immediately to the BWF, who shall notify all Member Associations of such sanction.

9.4 Where sanctions affect a player who comes under the jurisdiction of more than one Member Association, the BWF shall have power to receive representations and to amend such sanctions, if felt necessary.

Badminton General Competition Regulation PART III SECTION 1 A GENERAL COM PETITION REGULATIONS [Updated 1] une 2015]

7. MEM BER ASSOCIATIONS' RESPONSIBILITIES FOR TOURNAMENTS AND PLAYERS

7.2. Each Member Association shall be responsible for the control and management of all players under its jurisdiction.

7.2.1 To be eligible to enter and compete in toumaments, all players must be in good standing with their Member Association. A Member Association may declare a player under its jurisdiction to be ineligible to compete, but the reasons for such declaration and the period of ineligi bility must be reported to the BWF.

7.2.2 Member Associations shall have full responsibility for any support (financial or otherwise) received by players under their jurisdiction for the purposes of preparation and competition.

7.2.3 Member Associations shall accept and deal with all prizes paid in cash under Regulations 27.1 and 27.2 .

7.2.4. Member Associations shall also supervise or administer any sponsorship, contractual or other arrangements entered into, or involving, players under their jurisdiction.

7.2.5 Member Associations shall ensure that players adhere to the Players' Code of Conduct [Part III Section 1B, Appendix 4].

\section{INTERNATIONAL REPRESENTATION*}

8.1. Representing a Member Association is defined as accepting a nomination to be a member of that Association's team in any Badminton toumament where the competition is between teams. However, playing as an individual in a tournament does not count as representation, unl ess the tournament has been specifically nominated by the BWF (Regulation 8.1.2).

8.1.1.Competition between teams includes, but is not limited to, the Thomas, Uber and Sudirman Cups, Continental team championships, the Asian Games team championships, the Commonweal th Games team championships, and other international matches or competitions involving two or more Member Associations' teams. 
8.1.2. Currently, the BWF has also specified that the World Championships (see World Championships Regulation 9.2), the World Senior Championships and the individual events at the Olympic Games, Y outh Olympic Games, the Asian Games, the Commonwealth Games, Continental Championships, Eye Level Cups, Continental J unior Championships and Continental Senior Championships shall count as international representation. Where players in a doubles pair are from different Member Associations it shall count as international representation for each player.

8.2. A player shall be qualified to represent a Member Association providing the player is in good standing with that Member Association and satiffies Regulations 8.2.1 and either 8.2.2 or 8.2.3:

8.2.1 holds a passport of a country whose teritory the Member Association has jurisdiction over;

8.2.2. has not represented any other Member Association for three years immediately preceding the date of thetournament;

8.2.3. last represented that Member Association;

8.3. A player shall be deemed to have represented a Member Association if he or she shall have been officiall ly nominated to represent that Member Association and shall have accepted such nomination.

8.4. If a player has represented a Member Association and such Member Association is subsequently divided into two or more Member Associations or is absorbed by another Member Association, either politically or by recognition of the BWF, such player shall, for the purposes of these Regulations, be deemed from the date of such alteration not to have represented any Member Association.

8.5. Notwithstanding the foregoing Regulations, in the case of any officially-recognised competitive multisport games in which Badminton is included, the qualifications for the representation of a Member Association shall be in full accordance with the conditions laid down by such a multi- sport international games. However, BWF eligibility regulations take precedence and should not be contravened (Regulations 8.2 to 8.4) with the exception of the Olympic Games, where the Olympic Charter takes precedence.

9. JURISDICTION

9.1 A player comes under the jurisdiction of all Member Associations to which the player is directly or indirectly affiliated.

* See Part III Section 1 Appendix 1, page 1, International representation for explanatory chart

\subsection{Duration}

9.2.1 A player comes under continued jurisdiction of a Member Association for a period of three months after ceasing to reside in the country of that Member Association, unless the player explicitly renounces this jurisdiction.

9.2.2 After the threemonth period, jurisdiction shall lapse unless the player implicitly (eg. by participation in the Member Association's activities) continues to accept that jurisdiction, or explicitly dedares a wish to accept that jurisdiction.

9.2.3 A player who represents a Member Association (see Regulation 8.3) automatically comes under the jurisdiction of that Member Association for three months thereafter (as in Regulation 9.2.1).

9.3 Where a sanction is imposed that affects a player's participation beyond the jurisdiction of the Member Association concerned, then such sanction shall be notified immediately to the BWF, who shall notify all Member Associations of such sanction.

9.4 Where sanctions affect a player who comes under the jurisdiction of more than one Member Association, theBWF shall have power to receive representations and to amend such sanctions, if felt necessary.

Part III - Section 1A Badminton General Competition Regulations Updated: 8 December 2014[unchanged since 2005, with the exception of 8.5 which was added in 2008]

\section{MEM BER ASSOCIATIONS' RESPONSIBILITIES FOR TOURNAMENTS AND PLAYERS}

7.2 Each Member Association shall be responsible for the control and management of all players under its jurisdiction.

7.2.1 To be eligible to enter and compete in toumaments, all players must be in good standing with their Member Association. A Member Association may declare a player under its jurisdiction to be ineligible to compete, but the reasons for such declaration and the period of ineligi bility must be reported to the BWF.

8. INTERNATIONAL REPRESENTATION*

8.1 Representing a Member Association is defined as accepting a nomination to be a member of that Association's team in any Badminton toumament where the competition is between teams. However, playing as an individual in a tournament does not count as representation, unl ess the tournament has been specifically nominated by the BWF (Regulation 8.1.2).

8.1.1 Competition between teams includes, but is not limited to, the Thomas, Uber and Sudirman Cups, Continental team championships, the Asian Games team championships, the Commonwealt th Games team championships, and other international matches or competitions involving two or more Member Associations' teams. 
8.1.2 Currently, the BWF has also specified that the World Championships (see World Championships Regulation 9.2), the World Senior Championships and the individual events at the Olympic Games, Y outh Olympic Games, the Asian Games, the Commonwealth Games, Continental Championships, World J unior Championships, Continental J unior Championships and Continental Senior Championships shall count as international representation. Where players in a doubles pair are from different Member Associations it shall count as international representation for each player.

8.2 A player shall be qualified to represent a Member Association providing the player is in good standing with that Member Association and satisfies Regulations 8.2.1 and either 8.2.2 or 8.2.3:

8.2.1 holds a passport of a country whose territory the Member Association has jurisdiction over;

8.2.2 has not represented any other Member Association for three years immediately preceding the date of thetournament;

8.2.3 last represented that Member Association;

8.3 A player shall be deemed to have represented a Member Association if he or she shall have been officiall ly nominated to represent that Member Association and shall have accepted such nomination.

8.4 If a player has represented a Member Association and such Member Association is subsequenty divided into two or more Member Associations or is absorbed by another Member Association, either politically or by recognition of theBWF, such player shall, for the purposes of these Regulations, be deemed fromthe date of such alteration not to have represented any Member Association.

8.5 Notwithstanding the foregoing Regulations, in the case of any officially-recognised competitive multisport games in which Badminton is included, the qualifications for the representation of a Member Association shall be in full accordance with the conditions laid down by such a multi-sport international games. However BWF eligibility regulations take precedence and should not be contravened (Regulations 8.2 to 8.4 ) with the exception of theOlympic Games, wheretheOlympic Charter tokes precedence.

[... ]

Badminton General Competition Regulations Part III - Section 1A General Competition Regulations Updated:1 J une 2013

Part III - Section 1A Badminton General Competition Regulations U pdated:1 J une 2013[unchanged since 2005, with the exception of 8.5 which was added in 2008]

\section{MEM BER ASSOCIATIONS' RESPONSIBILITIES FOR TOURNAMENTS AND PLAYERS}

7.2 Each Member Association shall be responsible for the control and management of all players under its jurisdiction.

7.2.1 To be eligible to enter and compete in tournaments, all players must be in good standing with their Member Association. A Member Association may declare a player under its jurisdiction to be ineligible to compete, but the reasons for such declaration and the period of ineligi bility must be reported to the BWF.

8. INTERNATIONAL REPRESENTATION*

8.1 Representing a Member Association is defined as accepting a nomination to be a member of that Association's team in any Badminton tournament where the competition is between teams. However, playing as an individual in a tournament does not count as representation, unl ess the tournament has been specifically nominated by theBWF (Regulation 8.1.2).

8.1.1 Competition between teams includes, but is not limited to, the Thomas, Uber and Sudirman Cups, Continental team championships, the Asian Games team championships, the Commonwealth Games team championships, and other international matches or competitions involving two or more Member Associations' teams.

8.1.2 Currently, the BWF has also specified that the World Championships (see World Championships Regulation 9.2), the World Senior Championships and the individual events at the Olympic Games, Y outh Olympic Games, the Asian Games, the Commonwealth Games, Continental Championships, World J unior Championships, Continental J unior Championships and Continental Senior Championships shall count as international representation. Where players in a doubles pair are from different Member Associations it shall count as international representation for each player.

8.2 A player shall be qualified to represent a Member Association providing the player is in good standing with that Member Association and satisfies Regulations 8.2.1 and either 8.2.2 or 8.2.3:

8.2.1 holds a passport of a country whose teritory the Member Association has jurisdiction over;

8.2.2 has not represented any other Member Association for three years immediately preceding the date of thetournament;

8.2.3 last represented that Member Association;

8.3 A player shall be deemed to have represented a Member Association if he or she shall have been officially nominated to represent that Member Association and shall have accepted such nomination.

8.4 If a player has represented a Member Association and such Member Association is subsequently divided into two or more Member Associations or is absorbed by another Member Association, either politically or 
by recognition of the BWF, such player shall, for the purposes of these Regulations, be deemed from the date of such al teration not to have represented any Member Association.

8.5 Notwithstanding the foregoing Regulations, in the case of any officially-recognised competitive multisport games in which Badminton is included, the qualifications for the representation of a Member Association shall be in full accordance with the conditions laid down by such a multi-sport international games. However BWF eligibility regulations take precedence and should not be contravened (Regulations 8.2 to 8.4 ) with the exception of the Olympic Games, where the Olympic Charter takes precedence [...]

\section{Basketball}

\section{FIBA 2014-2019}

These Internal Regulations have been approved by theFIBA Central Board on 27 August 2014

[These Internal Regulations are divided into four volumes, Books 1 to 4 . Referencing and cross-referencing are done by inserting the Book Number first (eg 1) followed by therelevant article (eg 213); article1-213].

\section{B ook 3 - Players and Officials}

Chapter I. - Eligibility and National Status of Players

\section{Eligibility of Players}

1. To be entitled to participatein FIBA competitions, a player must observethe General Statutes and Internal Regulations of FIBA.

2. The national member federation is responsible for the eligibility of its players at all times and will bear the consequences of any infractions of the Regulations governing Eligibility, National Status, International Transfer, and Age of Players.

3. All players who participate in Competitions of FIBA and/or those of its national member federations must:

A) Respect the Code of Conduct and Fair Play and act accordingly at all times on and off the court;

B) Refrain from using substances and methods prohibited by the regulations of FIBA and those of the International Olympic Committee (IOC) and World Anti-Doping Agency (WADA);

C) Agree to submit at any time to medical tests and controls, particularly doping controls, carried out in compliance with the regulations of FIBA, the International Olympic Committee, and WADA.

4. A national member federation or FIBA is authorised to deny participation in Competitions of FIBA to players who do not respect the provisions provided for in article 3-3 above Permission to play may be refused also to any player who does not provide the entry form as required for Compeitions of FIBA, in which he agrees to accept inter alia:

A) The conditions in forcefor doping control.

B) The jurisdiction of the Court of Arbitration for Sport, Lausanne, to the exclusion of any recourse to ordinary courts, in the event of a dispute with FIBA which cannot be settled within FIBA.

5. Players in breach of the principles set out in article 3-3 may not be eligible to participate in the Competitions of FIBA - see articles 1-142 to 1-151.

6. Player contracts shall have a maximum duration of four (4) years. It is recommended that the parties to a player contract state their agreement in writing.

7. Players who participate in professional leagues must be registered with organisations which are affiliated to a national member federation; otherwise they will not be able to participate in the Competitions of FIBA.8. No financial remuneration for the performance of a player or a team is permitted during the Olympic Games.

9. It is within the spirit of all FIBA Regulations that players make themselves available for compeitions of both their club and their national team The national member federations are encouraged to enact regulations securing the participation of all players under their jurisdiction in their respectivenational teams. (see articles 3-78 to 3-96)

\section{National Status of Players}

General Principles

10. These regulations apply to all Competitions of FIBA. They apply at national team level and at international club level.

11. These Regulations apply to both genders.

12. If necessary for reasons of mandatory international law, the Zones are authorised to draw up specific regulations applicable to club competitions within the Zone in question. Such regulations are subject to the prior approval of the FIBA Central Board prior to their implementation.

\section{Proof of Legal Nationality}

13. FIBA may ask that evidence be provided to verify the legal nationality (or nationalities) of any player by requesting any documents it deems appropriate

14. Proof of legal nationality of a country by itself does not constitute sufficient evidence to guarantee a player's right to play as a national for the national team of that country- see article3-15.

National Teams

15. In order to play for the national team of a country, a player must hold the legal nationality of that country, 


\section{APPENDICES}

and have fulfilled al so the conditions of eligibility according to the FIBA Internal Regulations.

Players with $\mathrm{T}$ wo or M ore Nationalities

16. Any player with two legal nationalities or more, by birth or by naturalisation, may choose at any age the national team for which he wishes to play. Any such choice must be made in a written declaration to FIBA. This provision applies also to any player having acquired legal nationality by birth, or having the right to acquirea second nationality at birth, but who does not lay claim to this right until a given timein the future [Note: for exceptions see articles 3-20 and 3-21].

17. However, if a player having two (2) or more nationalities is summoned by a national member federation after reaching the age of eighteen (18), he is obliged to choose for which national team he wishes to play. If he has dedined the summons, the player may choose only the national team of the other country/one of the other countries, unless he declares, in writing, within fifteen (15) days of receiving the summons that he has chosen the country that summoned himfirst

[Note: for exception see article3-23].

18. Any player having played in a main official competition of FIBA for a national team for which he is eligible is considered as having chosen the national team of that country, with the exception of cases provided for under articles 3-23 and 3-34.

19. Choices made under articles 3-16, 3-17, and 3-18 are irrevocable

20. A player who has transferred as a young player according to article 3-52 may not choose until he has reached the age of twenty-one (21) the national team of any country other that the country from which he transferred.

21. a. A national team participating in a Competition of FIBA may have only one player on its team who has acquired the legal nationality of that country by naturalisation or by any other means after having reached the age of sixteen (16). This provision applies al so to any player having the right to acquire a second nationality at birth but who did not lay claim to this right until after having reached the age of sixteen (16).

b. For purposes of letter (a) above, in the event that a player claims to have acquired a legal nationality before having reached the age of sixteen (16), without presenting the respective passport with a date of issue before the player's sixteenth birthday, the Secretary General may decide in his sole discretion that the player falls under the restriction of Ietter (a) above In taking this decision the Secretary General shall take into account thefollowing criteria:

-The number of years during which the player has lived in the country, for the national team of which he wishes to play;

-The number of seasons during which the player has participated in domestic competitions in the country of the national teamfor which hewishes to play;

-Any other criteria capable of establishing a significant link between the player and the country, for the national team of which he wishes to play."

22. A player who has played in a main official competition (see article 2-1) of FIBA before reaching his seventeenth (17) birthday may play for a national team of another country if both national member federations agree; in the absence of an agreement the Secretary General decides.

23. A player who has played in a main official competition of FIBA (see article2-1) after having reached his seventeenth (17) birthday may not play for a national team of another country. However, in exceptional circumstances the Secretary General may authorise such a player to play for the national team of his country of origin if heis ineligible to play for such country according to this article3-23 and if this is in the interest of the development of basketball in this country. An administrative fe as stipulated in article3-305 and decided by the Secretary General is payable to FIBA.

24. For any player who has two or more legal nationalities by birth or by naturalisation, the national member federation for which the player wishes to play must obtain written certification from the national member federation of the country(-ies) corresponding to the player's other nationality(-ies), in which it is stated that he has not taken part in a main official competition of FIBA as a member of its national team

If the request for this certification remains unanswered, FIBA may issue provisional authorisation to the national member federation making the request. After a period of one year, this authorisation shall be considered final.

Special Provisions for Players from Dependent Teritories

25. Article 3-15 does not apply to players who wish to represent FIBA-recognised national member federations of dependent territories, i.e territories whose citizens have the legal nationality of the country on which the territory is dependent (the "main" teritory). However, with a view to ensuring equitable treatment of players and safeguarding a level playing field in national team competitions, national member federations of dependent territories shall comply with the following provisions in addition to all other provisions of the regulations governing the national status of players.

26. In order to represent a dependent territory in the Competitions of FIBA, a player must have the legal nationality of the main teritory and additionally fall within one of the following categories:

A) Have been born in the dependent territory; or 


\section{NATIONALITY REQUiREMENTS In Oly mpic SPORTS}

\section{B) Have:}

I)been born in the main territory of at least one parent who was born in the dependent territory; or

II)been born of parents both of whom were born in the dependent territory, regardless of the place of birth of the player; or

III)at least one grandparent born in the dependent territory, regardless of the place of birth of the player.

27. A player who does not satisfy the provisions of article 3-26 but obtains the legal nationality of the main territory by way of naturalisation and can demonstrate permanent residency of the dependent territory for at least four (4) years is eligible to represent the dependent territory, on the same conditions as apply in 3-21.

28. Articles 3-21, 3-22, and 3-23 apply mutatis mutandis.

[... ]

M arginal C ases

34. Decisions on marginal cases are the responsibility of the Secretary General following consultation with the Chairperson of theFIBA Legal Commission.

The same shall apply with respect to refugees enjoying asylum rights and displaced persons (UN Conventions).

In certain cases, FIBA nationality may begranted to a player.

\section{Appeals}

35. An appeal against decisions made under the foregoing provisions shall be submitted to the FIBA Appeals' Panel in accordance with the Regulations governing Appeals (see Book 1, Chapter VII).

36. If and when an appeal hearing is organised under these Regulations involving member federations, clubs or players, FIBA shall be authorised to make the organisation of such hearing dependent upon the parties paying to FIBA reasonable administrative costs.

\section{Official Basketball Rules 2012}

As approved by FIBA Central Board Rio de Janeiro, Brazil, 29th April 2012.Valid as of 1st October 2012

Art. 4 Teams

4.1 Definition

4.1.1 A team member is eligible to play when he has been authorised to play for a team according to the regulations, including regulations governing age limits, of theorganising body of the competition.

4.1.2 A team member is entitled to play when his name has been entered on the score sheet before the start of the gameand as long as he has neither been di squalified nor committed five (5) fouls.

4.1.3 During playing time, a team member is:

- A player when heis on the playing court and is entitled to play.

- A substitute when heis not on the playing court but heis entitled to play.

-An excluded player when he has committed five (5) fouls and is no longer entitled to play.

4.1.4 During an interval of play, all teammembers entitled to play are considered as players.

\section{FIBA RULE BOOK}

These Internal Regulations have been approved by theFIBA Central Board on 3 September 2010.

\section{B ook 3 - Players and O fficials}

Chapter I. - E ligibility and National Status of Players E ligibility of Players

1. To beentitled to participate in FIBA competitions, a player must observethe General Statutes and Internal Regulations of FIBA.

2. The national member federation is responsible for the eligibility of its players at all times and will bear the consequences of any infractions of the Regulations governing Eligibility, National Status, International Transfer, and Age of Players.

3. All players who participate in Competitions of FIBA and/or those of its national member federations must: a. Respect the Code of Conduct and Fair Play and act accordingly at all times on and off the court;

b. Refrain from using substances and methods prohibited by the regulations of FIBA and those of the International Olympic Committee (IOC) and World Anti-Doping Agency (WADA);

c. Agree to submit at any time to medical tests and controls, particularly doping controls, carried out in compliance with the regulations of FIBA, the International Olympic Committee, and WADA.

[...]

National Status of Players - General Principles

10. These regulations apply to all Competitions of FIBA. They apply at national team leve and at international clubleve.

11. These Regulations apply to both genders.

$[\ldots]$

Proof of Legal Nationality

13. FIBA may ask that evidence be provided to verify the legal nationality (or nationalities) of any player by requesting any documents it deems appropriate 


\section{APPENDICES}

14. Proof of legal nationality of a country by itself does not constitute sufficient evidence to guarantee a player's right to play as a national for the national team of that country- see article 3-15.

National Teams

15. In order to play for the national team of a country, a player must hold the legal national ity of that country, and have fulfilled al so the conditions of eligibility according to theFIBA Internal Regulations.

\section{Players with T wo or M ore Nationalities}

16. Any player with two legal nationalities or more, by birth or by naturalisation, may choose at any age the national team for which he wishes to play. Any such choice must be made in a written dedaration to FIBA. This provision applies also to any player having acquired legal nationality by birth, or having the right to acquirea second nationality at birth, but who does not lay claim to this right until a given timein the future.

[Note: for exceptions see articles 3-20 and 3-21].\#

17. However, if a player having two (2) or more nationalities is summoned by a national member federation after reaching the age of eighteen (18), he is obliged to choose for which national team he wishes to play. If he has dedined the summons, the player may choose only the national team of the other country/one of the other countries, unless he declares, in writing, within fifteen (15) days of receiving the summons that he has chosen the country that summoned himfirst [Note: for exception see article 3-23].

18. Any player having played in a main official competition of FIBA for a national team for which he is eligible is considered as having chosen the national team of that country, with the exception of cases provided for under articles 3-23 and 3-34.

19. Choices made under articles 3-16, 3-17, and 3-18 are irrevocable

20. A player who has transferred as a young player according to article 3-52 may not choose until he has reached the age of twenty-one (21) the national team of any country other that the country from which he transferred.

21. a. A national team participating in a Competition of FIBA may have only one player on its team who has acquired the legal national ity of that country by naturalisation or by any other means after having reached the age of sixteen (16). This provision applies al so to any player having the right to acquire a second nationality at birth but who did not lay claim to this right until after having reached the age of sixteen (16).

b. For purposes of letter (a) above, in the event that a player claims to have acquired a legal nationality before having reached the age of sixteen (16), without presenting the respective passport with a date of issue before the player's sixteenth birthday, the Secretary General may decide in his sole discretion that the player falls under the restriction of letter (a) above In taking this decision the Secretary General shall take into account thefollowing criteria:

- The number of years during which the player has lived in the country, for the national team of which he wishes to play;

- The number of seasons during which the player has participated in domestic competitions in the country of the national teamfor which hewishes to play;

- Any other criteria capable of establishing a significant link between the player and the country, for the national team of which hewishes to play."

22. A player who has played in a main official competition (see article 2-1) of FIBA before reaching his seventeenth (17) birthday may play for a national team of another country if both national member federations agree, in the absence of an agreement the Secretary General decides.

23. A player who has played in a main official competition of FIBA (see article2-1) after having reached his seventeenth (17) birthday may not play for a national team of another country. However, in exceptional circumstances the Secretary General may authorise such a player to play for the national team of his country of origin if heis ineligible to play for such country according to this article $3-23$ and if this is in theinterest of the development of basketball in this country. An administrative fee as stipulated in article 3-305 and decided by the Secretary General is payable to FIBA. decided by the Secretary General is payable to FIBA.

24. For any player who has two or more legal nationalities by birth or by naturalisation, the national member federation for which the player wishes to play must obtain written certification from the national member federation of the country(-ies) corresponding to

the player's other nationality(-ies), in which it is stated that he has not taken part in a main official competition of FIBA as a member of its national team If the request for this certification remains unanswered, FIBA may issue provisional authorisation to the national member federation making the request. After a period of oneyear, this authorisation shall be considered final.

Special Provisions for Players from Dependent Territories

25. Article 3-15 does not apply to players who wish to represent FIBA-recognised national member federations of dependent territories, i.e territories whose citizens have the legal nationality of the country on which the territory is dependent (the "main" teritory). However, with a view to ensuring equitable treatment of players and safeguarding a level playing field in national team competitions, national member federations of dependent territories shall comply with the following provisions in addition to all other provisions of the regulations governing the national status of players. 


\section{NATIONALITY REQUiREMENTS IN Oly mpic SPORTS}

26. In order to represent a dependent territory in the Competitions of FIBA, a player must have the legal nationality of the main teritory and additionally fall within one of the following categories:

a. Have been born in the dependent teritory; or

b. Have:

i. been born in the main territory of at least one parent who was born in the dependent teritory; or

ii. been born of parents both of whom were born in the dependent territory, regardl ess of the place of birth of the player; or

iii. at least one grandparent born in the dependent territory, regardless of the place of birth of the player.

27. A player who does not satisfy the provisions of article 3-26 but obtains the legal nationality of the main territory by way of naturalisation and can demonstrate permanent residency of the dependent teritory for at least four (4) years is eligibleto represent the dependent territory, on the same conditions as apply in 3-21.

[...]

\section{$M$ arginal $C$ ases}

34. Decisions on marginal cases are the responsibility of the Secretary General following consultation with the Chairman of the FIBA Legal Commission. The same shall apply with respect to refugees enjoying asylum rights and displaced persons (UN Conventions). In certain cases, FIBA nationality may be granted to a player.

\section{Appeals}

35. An appeal against decisions made under the foregoing provisions shall be submitted to the FIBA Appeals' Panel in accordance with the Regulations governing Appeals (seeBook 1, Chapter VII).

36. If and when an appeal hearing is organised under these Regulations involving member federations, clubs or players, FIBA shall be authorised to make the organisation of such hearing dependent upon the parties paying to FIBA reasonable administrative costs.

\section{License Restrictions}

66. A player may not belicensed by more than one national member federation at the sametime $[\ldots]$

\section{FIBA Internal Regulations 2009}

Regulation $\mathrm{H}$ : rules governing players, coaches, support officials and players' agents

H.1 E ligibility of Players

H.1.1. To be entitled to participate in FIBA competitions, a player must observe the General Statutes and Internal Regulations of FIBA.

H.1.2. The national member federation is responsible for the eligibility of its players at all times and will bear the consequences of any infractions of the Regulations governing Eligibility, National Status, International Transfer, and Age of Players.

H .1.3. All players who participate in competitions of FIBA and/ or those of its national member federations must:

a) Respect the spirit of fair play and non violence and act accordingly at all times on the court.

b) Refrain from using substances and from practices prohibited by the regulations of FIBA and those of the International Olympic Committee (IOC) and World Anti-Doping Agency (WADA).

c) Agree to submit at any time to medical tests and controls, particularly doping controls, carried out on compliance with the regulations of FIBA, the International Olympic Committee, and WADA.

[...]

H.2 National status of players

H.2.1 General Principles

H.2.1.1 There regulations apply to all competitions of FIBA. They apply at national team level and at international dub level.

H .2.1.2. These regulations apply to both genders.

$[\ldots]$

H.2.2 Proof of nationality

H.2.2.1 FIBA may ask that evidence be provided to verify the legal nationality (or nationalities) of any player by requesting any documents it deems appropriate

H .2.2.2. Proof of legal nationality of a country by itself does not constitute sufficient evidence to guaranteea player's right to play as a national for the national team of that country- seeH.2.3.1.

H.2.3. National Teams

H.2.3.1. In order to play for the national team of a country, a player must hold the legal nationality of that country, and havefulfilled al so the conditions of eligibility according to the Internal Regulations.

\section{H.2.3.2 Players with two or more nationalities}

H 2.3.2.1 Any player with two legal nationalities or more, by birth or by naturalization, may choose at any age the national team for which he wishes to play. Any such choice must be made in a written dedaration to FIBA. This provision applies also to any player having acquired legal nationality by birth or by having the 


\section{APPENDICES}

right to acquire a second nationality at birth, but who does not lay daim to this right until a given time in the future (Note for exception seeH.2.3.2.5).

H 2.3.2.2. However, if a player having two (2) or more nationalities is summoned by a national member federation after reaching the age if eighteen (18), he is obliged to choose for which national team he wishes to play. If he has declined the summons, the player may choose only the national team of the other country/one of the other countries, unless he declares, in writing, within fifteen (15) days of receiving the summons that he has chosen the country that summoned him first. (Note: for exception seeH H.2.3.2.5)

H .2.3.2.3.Any player having played in a main official competition of FIBA for a national team for which he is eligible is considered as having chosen the national team of that country, which the exception of cases provided for under H.2.3.5 and H.2.7.

H.2.3.2.4. Choices made under H.2.3.2.1, H.2.3.2.2 and H.2.3.2.3 areirrevocable

H.2.3.2.5 A player who transferred as a young player according to H.3.4.1.1b may not choose until he has reached the age of twenty-one (21) the national team of any country other than the country from which he transferred

H.2.3.3. A national team participating in an international competition of FIBA may have only one player in its team who has acquired the legal nationality of that country by naturalization or by any other means after having reached the age of sixten (16).

H 2.3.4. A player who played in a main official competition of FIA before reaching his seventeenth (17) birthday may play for a national team of another country if both national member federations agree; in the absence of an agreement the Secretary General decides.

H.2.3.5. A player who has played in a main official competition of FIBA after having reached his seventeenth (17) birthday ay not play for a national team of another country.

However, in exceptional circumstances the Secretary General may authorise such a player to play for the national team of his country of origin if he is ineligible to play for such country according to this regulation H.2.3.5. and if this is in the interest of the development of basketball of this country. An administrative feeas stipulated in $\mathrm{O} .3$ and decided by the Secretary General is payable to FIBA.

H.2.3.6. For any player who has two or more legal nationalities by birth or by naturalization, the national member federation for which the player wishes to play must obtain written certification from the national member federation of the country(-ies) corresponding to the player's other nationality(-ies), in which it is stated that he has not taken part in a main official competition of FIBA as a member of its national team

If the request for this certification remains unanswered, FIBA may issue provisional authorisation to the national member federation making the request. After a period of one year, this authorisation shall be considered final.

H .2.3.7. Special provision concerning the eligibility of players from dependent territories.

H .2.3.7.1. In order to represent the territory in the official competitions of FIBA or in other international competitions organised within their Zones, subject to other following provisions, a player must fulfil the following conditions:

a) Have the legal nationality of the country on which the territory is dependent ( the 'main territory'); and

b) Have:

i. been born in the dependent territory; or

ii. been born in the main territory of at least one parent born in the dependent territory, regardless of the place of birth of the player; or

iii. been bon of parents both of whome were born in the dependent territory, regardless of the place of birth of the player; or

iv. at least one grandparent who was born in the dependent teritory, regardless of the place of birth of the player.

H .2.3.7.2. A player who does not satisfy the provisions of H.2.3.7.1.b) but obtains the legal nationality of the main territory and can demonstrate permanent residency of the dependent territory for at least four years is eligible to represent the dependent territory, subject to thefollowing:

a. if the player obtains the legal nationality before reaching the age of sixteen (16) years, he will be ineligible to represent the dependent territory without restriction.

b. if the player obtains the legal nationality of the main teritory after the age of sixteen (16) years, then he will be considered in the same way as a natural ised player and the provisions of H.2.3.3. arein effect.

H.2.3.7.3. Regulations H.2.3.3, H.2.3.4 and H.2.3.5. arein effect.

$[\ldots]$

FIB A Internal Regulations 2006

Regulation H: rules governing players, coaches, support officials and players' agents

H.1 E ligibility of Players

H.1.1. To be entitled to participate in FIBA competitions, a player must observe the General Statutes and Internal Regulations of FIBA. 


\section{NATIONALITY REQUiREMENTS In Olympic SPORTS}

H.1.2. The national member federation is responsible for the eligibility of its players at all times and will bear the consequences of any infractions of the Regulations governing Eligibility, National Status, International Transfer, and Age of Players.

H.1.3. All players who participate in competitions of FIBA and/ or those of its national member federations must:

a) Respect the spirit of fair play and non violence and act accordingly at all times on the court.

b) Refrain from using substances and from practices prohibited by the regulations of FIBA and those of the International Olympic Committee (IOC) and World Anti-Doping Agency (WADA).

c) Agree to submit at any time to medical tests and controls, particularly doping controls, carried out on compliance with the regulations of FIBA, the International Olympic Committee, and WADA.

[...]

H.2 National status of players

H.2.1 General Principles

H.2.1.1 There regulations apply to all competitions of FIBA. They apply at national team level and at international dub level.

H.2.1.2. These regulations apply to both genders.

$[\ldots]$

H.2.2 Proof of legal nationality

H.2.2.1 FIBA may ask that evidence be provided to verify the legal nationality (or nationalities) of any player by requesting any documents it deems appropriate

H.2.2.2. Proof of legal nationality of a country by itself does not constitute sufficient evidence to guaranteea player's right to play as a national for the national team of that country- seeH.2.3.1.

\section{H.2.3. National Teams}

H 2.3.1. In order to play for the national team of a country, a player must hold the legal nationality of that country, and have fulfilled al so the conditions of eligibility according to the Internal Regulations.

\section{H 2.3.2 Players with two or more nationalities}

H 2.3.2.1 Any player with two legal nationalities or more, by birth or by naturalization, may choose at any age the national team for which he wishes to play. Any such choice must be made in a written dedaration to FIBA. This provision applies also to any player having acquired legal nationality by birth or by having the right to acquire a second national ity at birth, but who does not lay claim to this right until a given time in the future

H 2.3.2.2. However, if a player having two (2) or more nationalities is summoned by a national member federation after reaching the age if eighteen (18), he is obliged to choose for which national team he wishes to play. If he has declined the summons, the player may choose only the national team of the other country/one of the other countries, unless he declares, in writing, within fifteen (15) days of receiving the summons that he has chosen the country that summoned him first. (Note for exception seeH.2.3.2.5)

H .2.3.2.3.Any player having played in a main official competition of FIBA for a national team for which he is eligible is considered as having chosen the national team of that country, which the exception of cases provided for under H.2.3.5 and H.2.7.

H.2.3.2.4. Choices made under H.2.3.2.1, H.2.3.2.2 and H.2.3.2.3 are irrevocable

H 2.3.2.5 A player who transferred as a young player according to H.3.4.1.1b may not choose until he has reached the age of twenty-one (21) the national team of any country other than the country from which he transferred

H.2.3.3. A national team participating in an international competition of FIBA may have only one player in its team who has acquired the legal nationality of that country by naturalization or by any other means after having reached the age of sixteen (16).

H .2.3.4. After having played in the U-17, U-19, U-21 or for a men's or women's national team of a country in a main official competition of FIBA, a player may not, under any circumstances, play for any national team of another country.

H .2.3.5. With the agreement of the two member federations concerned, FIBA may authorise a player who has played on a U-14 team of a country in a main official competition of FIBA, to play for a national team of a new country of which he has acquired legal nationality. A player thus authorised to change national teams may do this only once in his lifetime and may not, after this change, play again for the team of his first country. H.2.3.3. applies al so in this case

H.2.3.6. For any player who has two or more legal nationalities by birth or by naturalization, the national member federation for which the player wishes to play must obtain written certification from the national member federation of the country(-ies) corresponding to the player's other nationality(-ies), in which it is stated that he has not taken part in a main official competition of FIBA as a member of its national team

If the request for this certification remains unanswered, FIBA may issue provisional authorisation to the national member federation making the request. After a period of one year, this authorisation shall be considered final. 


\section{APPENDICES}

$H$.2.3.7. Special provision concerning the eligibility of players from dependent territories.

H .2.3.7.1. The following players are eligibleto play for a dependent territory:

a. Players born in the dependent territory;

b. Players born in the respective main territory of at least one person born in the dependent territory; and

c. Players, regardless of their place of birth, born of parents both of whom were born in the dependent territory.

$[\ldots]$

\section{FIBA Internal Regulations 2004}

\section{Regulations governing the National Status of Players}

1 There regulations apply to all competitions of FIBA as defined I $n$ the International Regulations of FIBA

(1.1.1 and 1.1.2). They apply at national teamlevel and at international club level.

2. These regulations apply to both genders.

[...]

3.2 Proof of nationality

1. FIBA may ask that evidence be provided to verify the legal nationality (or nationalities) of any player by requesting any documents it deems appropriate

2. Proof of legal nationality of a country by itself does not constitute sufficient evidence to guarantee a player's right to play as a national for the national team of that country- seeH.2.3.1.

\subsection{National Teams}

1. Only a player holding the legal nationality of that country and having fulfilled al so the terms of eligibility according to the appropriate Internal Regulations may play for the national team of that country.

2. Any player with two legal nationalities or more, by birth or by naturalization, may choose at any age the national teamfor which he wishes to play. Any such choice must be made in a written dedaration to FIBA.

This provision applies al so to any player having acquired legal nationality by birth or by having the right to acquirea second national ity at birth, but who does not lay claim to this right until a given timein the future

However, if a player having two (2) or more nationalities is summoned by a national member federation after reaching the age if eighteen (18), he is obliged to choose for which national team he wishes to play. If he has declined the summons, the player may choose only the national team of the other country/one of the other countries, unless he declares, in writing, within fifteen (15 days of receiving the summons that he has chosen the country that summoned himfirst.

Any player having played in a main official competition of FIBA for a national team for which he is eligible is considered as having chosen the national team of that country, which the exception of cases provided for under article 3.3.5.

These choices areirrevocable

3. A national team participating in an international competition of FIBA may have only one player in its team who has acquired the legal nationality of that country by naturalization or by any other means after having reached the age of sixteen (16). This does not apply to those players whose eligibility was defined prior to the new regulations coming into force

4. After having played in the junior (U- 19), young people's (U-21) or senior age categories for a national team of a country in a main official competition of FIBA, a player may not, under any circumstances, play for any national team of another country.

5. With the agreement of the two national federations concemed, FIBA may authorisea player having played on a national cadet team of a country in a main official competition of FIBA, to play for a national team of a new country of which he has acquired legal nationality. A player thus authorised to change national teams may do this only once in his lifetime and may not, after this change, play again for the team of his first country. Article 3.3.3 al so applies in this case

6. For any player who has two or more legal nationalities by birth or by naturalization, the national member federation for which the player wishes to play must obtain written certification from the national member federation of the country(-ies) corresponding to the player's other nationality(-ies), in which it is stated that hehas not taken part in a main official competition of FIBA as a member of its national team.

If the request for this certification remains unanswered, FIBA may issue provisional authorisation to the national member federation making the request. After a period of one year, this authorisation shall be considered final.

$[\ldots]$

\section{Biathlon}

IBU EVENT AND COM PETITION RULES Adopted by the 1998 IBU Congress with amendments by the 2000, 2002, 2004, 2006, 2008, 2010, 2012 and 2014 Congresses

1. General Regulations

1.1 Application 


\section{NATIONALITY REQUiREMENTS In Olympic SPORTS}

These rules must be applied at all IBU events. At the Olympic Winter Games (OWG) these rules must be used accordingly, except when otherwise stipulated by the IOC. In other international events (as defined in the IBU Constitution) these rules will be applied unless changes, which have been authorized by theIBU, are specified in theinvitation.

1.4 E ligibility rules for competitors and team staff

1.4.1 General

Only such competitors and team staff who comply with the following IBU regulations will be ligible to take part in biathlon events and competitions organized by an IBU member federation. In order to be eligible to participate in an IBU event, biathletes and team staff must sign the IBU Declaration of Obligations, the Court of Arbitration Declaration and the Dedaration to Fight Doping in Sport, signifying agreement to abide by and follow all IBU rules and policies. Competitors and team staff members must sign these declarations prior to taking part in their first IBU competition and must include a copy of their passport with their signed declaration.

Each signed dedaration will remain in effect until terminated by either party.

1.4.2. Responsi bility of Competitors and Team Staff

Competitors and team staff may only participate in an IBU event or competition with materials, equipment, clothing and advertising that are in compliance with the pertinent IBU rules, including the IBU Rules for Advertising. It is the competitors' and team staff's responsibility to ensure that all rules regarding material and advertising are followed and that they undergo materials, equipment and clothing inspections before the start and after the finish. All competitors participating in IBU competitions are requested to certify their nationality, age and gender with their national passport or official photo identification document.

\section{IBU RULES}

Adopted by the 11th Regular IBU Congress 2014. WADA CODE compliant. 1. CONSTITUTION OF THE INTERNATIONAL BIATHLON UNION (IBU)

The general reformulation was made by the 2014 Congress.

The Constitution was made subject to Austrian law at the establishment of the seat of the IBU by the Congress at the 1999 Constituent General Assembly in Minsk/BLR.

\section{Nationality of Athletes}

The sphere of responsibility of the member federations is restricted to the territory of the country they represent. The respective member federation may only enter athletes who are citizens of the respective country. Athletes who are citizens of two or more countries at the sametime may start either for one of them, as they may elect. However, after having started for one country in the Olympic Games, in Continental or Regional Games or in World or Continental Championships under the authority of the IBU, they may not start for another country, unless they met the conditions for athletes who have changed their citizenship or acquired a new citizenship. Athletes who have started for one country in the Olympic Games, in Continental or Regional Games and/or World or Continental Championships under the authority of the IBU, and who have changed their citizenship or assumed a new citizenship may not participate in IBU competitions representing their new country until at least two years have passed since they last started for their former country. This period may be reduced or even annulled, with the agreement of the IBU member federations concerned, by the Executive Board of the IBU, which will take into account the circumstances of each case Stateless persons may participate for a member federation assigned by the IBU Executive Board upon the authorization of the IBU Executive Board and with that member federation's agreement.

IBU EVENT AND COM PETITION RULES Adopted by the 1998 IBU Congress with amendments by the 2000, 2002, 2004, 2006, 2008, 2010 and 2012 Congresses

1.1 APPLICATION

These rules must be applied at all IBU events. At the Olympic Winter Games (OWG) these rules must be used accordingly, except when otherwise stipulated by the IOC. In other international events (as defined in Art 1.4.2 of the IBU Constitution) these rules will be applied unless changes, which have been authorized by the IBU, are specified in the invitation.

\subsection{ELIGIBILITY RULES FOR COM PETITORS AND TEAM STAFF \\ 1.4.1 General}

Only such competitors and team staff who comply with the following IBU regulations will be eligible to take part in biathl on events and competitions organized by an IBU member federation. In order to be eligible to participate in an IBU event, biathletes and team staff must sign the IBU Declaration of Obligations and the Court of Arbitration Declaration and the Declaration to Fight Doping in Sport, signifying agreement to abide by and follow all IBU rules and policies. These declarations must be signed prior to starting in the first IBU competition in which a competitor or staff member takes part. In addition, a copy of the passport must be attached. Each signed dedaration will remain in effect until terminated by either party. 


\section{APPENDICES}

\subsubsection{R esponsibility of Competitors and Team Staff}

Competitors and team staff may only participate in an IBU event or competition with materials, equipment, clothing and advertising that are in compliance with the IBU Materials Catalogue It is the competitors and team staff's responsibility to ensure that all rules regarding materials and advertising are followed and that they undergo material, equipment and clothing inspections before the start and after the finish. All competitors participating in IBU competitions are requested to certify their nationality, age and gender with their national passport or official photo identification document.

\section{IBU RULE S Adopted by the 2012 10th Regular IBU Congress.}

\subsection{Nationality of Athletes}

The sphere of responsibility of the member federations is restricted to the territory of the country they represent. The respective member federation may only enter athletes who are citizens of the respective country. Athletes who are citizens of two or more countries at the same time may represent either one of them, as they may elect. However, after having represented one country in the Olympic Games, in Continental or Regional Games or in World or Continental Championships under the authority of the IBU, they may not represent another country, unless they meet the conditions for athletes who have changed their citizenship or acquired a new citizenship. Athletes who have represented one country in the Olympic Games in Continental or Regional Games or in World or Continental Championships under theauthority of the IBU, and who have changed their citizenship or assumed a new citizenship may not participate in IBU competitions representing their new country until at least two years have passed since they last represented their former country. This period may be reduced or even annulled, with the agreement of the IBU member federations concerned, by the Executive Board of the IBU, which will take into account circumstances of each case Stateless persons may participate for a member federation assigned by the IBU Executive Board upon the authorization of the IBU Executive Board and with that member federation's agreement.

\section{B obsleigh}

Unchanged since 2005, with only minor change in 2008

\section{Bobsleigh}

International Bobsleigh Rules 2015 R elease Date: J une 2015

3. ADMISSION

Theright to participatein championships and official IBSF competitions is reserved only for teams registered by Members, i.e teams from

-MEMBERS or

-ASSOCIATE MEMBERS.

The athletes must fulfill one of the following conditions:

-They must hold citizenship of the nation of the Member or Associate Member concerned, and may not have taken part in international IBSF competitions on behalf of another Member/AssociateMember, or -They must have their official residence in the Member/Associate Member concerned, and may not have taken part in international IBSF competitions on behalf of another Member/AssociateMember, or

-They must have changed their citizenship or their official residence, and have been released by their former Member/Associate Member and accepted by their member. In this case, the athlete may represent one of the two members, but not both.

An athlete may represent only one nation during any competition season, which lasts from October 1 to September 30 of the following year. Applications to change Member may only be submitted between A pril 01 and September 30 of each year. When athletes switch Nations, they keep their Scores/Ranking in the IBSF Ranking List, as well as the number of competitions in which they have participated; however, they do not keep the right to the previous quotas for participation, which remains tied to the nation of origin.

\section{International Bobsleigh R ules 2014 R elease Date: O ctober 2014}

\section{ADMISSION}

The right to participate in championships and official FIBT competitions is reserved only for teams registered by Members, i.e teams from

- MEMBERS or

- ASSOCIATE MEMBERS.

The athletes must fulfill one of the following conditions:

- They must hold citizenship of the nation of the Member or Associate Member concerned, and may not have taken part in international FIBT competitions on behalf of another Member /Associate Member, or

- They must have their official residence in the Member/Associate Member concerned, and may not 


\section{NATIONALITY REQUIREMENTS IN OLy MPIC SPORTS}

havetaken part in international FIBT competitions on behalf of another Member/AssociateMember, or

- They must have changed their citizenship or their official residence, and have been released by their former Member/Associate Member and accepted by their member. In this case, the athlete may represent one of the two members, but not both.

An athlete may represent only one nation during any competition season, which lasts from October 1 to September 30 of the following year.

Applications to change Member may only be submitted between A pril 01 and September 30 of each year. When athletes switch Nations, they keep their Scores/Ranking in the FIBT Ranking List, as well as the number of competitions in which they have participated; however, they do not keep the right to the previous quotas for participation, which remains tied to the nation of origin

\section{International Bobsleigh R ules 2013}

\section{ADMISSION}

The right to participate in championships and official FIBT competitions is reserved only for teams registered by Members, i.e teams from

- MEMBERS or

-ASSOCIATE MEMBERS.

The athletes must fulfill one of the following conditions:

- They must hold citizenship of the nation of the Member or AssociateMember concerned, and may not have taken part in international FIBT competitions on behalf of another Member /Associate Member, or

- They must have their official residence in the Member/Associate Member concemed, and may not have taken part in international FIBT competitions on behalf of another Member/Associate Member, or

- They must have changed their citizenship or their official residence, and have been released by their former Member/Associate Member and accepted by their member. In this case, the athlete may represent one of the two members, but not both.

An athlete may represent only one nation during any competition season, which lasts from October 1 to September 30 of the following year. Applications to change Member may only be submitted between April 01 and September 30 of each year. When athletes switch Nations, they keep their Scores/Ranking in the FIBT Ranking List, as well as the number of competitions in which they have participated; however, they do not keep theright to the previous quotas for participation, which remains tied to the nation of origin.

\section{B obsleigh skeleton}

\section{International Skeleton R ules 2015 R elease Date: J une 2015}

\section{3, ADMISSION}

The right to participate in championships and official IBSF competitions is reserved only for athletes registered by Members, i.e athletes from

-MEMBERS or-ASSOCIATE MEMBERS .

The athletes must fulfill one of the following conditions:

- they must hold citizenship of the nation of the Member or Associate Member concerned, and may not have taken part in international IBSF competitions on behalf of another nation, or

-they must have their official residence in the nation concerned, and may not have taken part in international IBSF competitions on behalf of another nation, or

-they must have changed their citizenship or their official residence, and have been released by their former Member / Associate Member and accepted by their new federation. In this case, the athlete may represent one of thetwo Members, but not both.

An athlete may represent only one nation during any competition season, which lasts from October 1 to September 30 of the following year.

Applications to change federations may only be submitted between March 31 and September 30 of each year.

When athletes switch nations, they keep their scores and ranking in the IBSF Ranking List, as well as the number of competitions in which they have participated; however, they do not keep the right to the previous quotas for participation, which remains tied to the nation of origin.

\section{International Skeleton R ules 2014 R elease Date: October 2014}

\section{ADMISSION}

The right to participate in championships and official FIBT competitions is reserved only for athletes registered by Members, i.e athletes from

- MEMBERS or

- ASSOCIATE MEMBERS.

The athletes must fulfill one of thefollowing conditions: 


\section{APPENDICES}

- they must hold citizenship of the nation of the Member or Associate Member concerned, and may not have taken part in international FIBT competitions on behalf of another nation, or

- they must have their official residence in the nation concerned, and may not have taken part in international FIBT competitions on behalf of another nation, or

- they must have changed their citizenship or their official residence, and have been released by their former Member / Associate Member and accepted by their new federation. In this case, the athlete may represent one of the two Members, but not both.

An athlete may represent only one nation during any competition season, which lasts from October 1 to September 30 of the following year.

Applications to change federations may only be submitted between March 31 and September 30 of each year.

When athletes switch nations, they keep their scores and ranking in the FIBT Ranking List, as well as the number of competitions in which they have participated; however, they do not keep the right to the previous quotas for participation, which remains tied to the nation of origin.

\section{International Bobsleigh R ules Skeleton 2013 (valid from October 1st of 2013) \\ 3. ADMISSION}

The right to participate in championships and official FIBT competitions is reserved only for athletes registered by Members, i.e athletes from

- MEMBERS or

-ASSOCIATE MEMBERS.

The athletes must fulfill one of the following conditions:

- they must hold citizenship of the nation of the Member or Associate Member concerned, and may not have taken part in international FIBT competitions on behalf of another nation, or

- they must have their official residence in the nation concerned, and may not havetaken part in international FIBT competitions on behalf of another nation, or

- they must have changed their citizenship or their official residence, and have been released by their former Member / Associate Member and accepted by their new federation. In this case, the athlete may represent one of the two Members, but not both.

An athlete may represent only one nation during any competition season, which lasts from October 1 to September 30 of the following year. Applications to change federations may only be submitted between March 31 and September 30 of each year.

When athletes switch nations, they keep their scores and ranking in the FIBT Ranking List, as well as the number of competitions in which they have participated; however, they do not keep the right to the previous quotas for participation, which remains tied to the nation of origin.

\section{Boxing}

AIBA TECHNICAL RULES Effective as of February 1,2015

RULE 2. MEMBERSHIP AND ELIGIBILITY

\subsection{M embership}

2.1.1 All Boxers, Coaches, Officials, National Federation Office Holders must be members of or licensed and/or authorized by their National Federation, Confederation and AIBA to participate in national and international AIBA Competitions, unless AIBA otherwise consents.

2.2 E ligibility

2.2.1 Eligibility on Nationality related Issues

2.2.1.1 Prior to any AOB Competition and APB Cyde or during WSB Registration Period, AIBA must confirm the nationality and eligibility of all Boxers. However, if a complaint on the eligibility of a Boxer is received during any AIBA Competition, the Supervisor must immediately report to the AIBA Headquarters. If an ineligibility case is proved, the Supervisor must immediately disqualify the Boxer and inform all parties.

2.2.1.2 For all disputes on eligibility taking place outside an AIBA Competition, the final decision on determining the nationality lies with the AIBA Executive Committee If it is believed that nationality rules have been violated, the matter will be submitted to the AIBA Disciplinary Commission for review and sanctions may beimposed on the Boxer and/or his/her National Federation.

2.2.1.3 Nationality shall be confirmed by the Boxer's passport. When the nationality is in question, AIBA has the right to request the following documents as a proof:

2.2.1.3.1 Birth Certificate

2.2.1.3.2 Citizenship I dentity Papers;

2.2.1.3.3 Nationality I dentity Document;

2.2.1.3.4 Confirmation Letter from the NOC.

2.2.1.4 C hange of Nationality 
2.2.1.4.1 If a Boxer wishes to change nationality, this Boxer can enter any AIBA Competition as a participant of the changed National Federation after two (2) years from this Boxer's change of nationality.

2.2.1.4.2 If a Boxer having represented one National Federation in any AIBA Competition is al so a national of two or more countries simultaneously, this Boxer must select only one National Federation to enter AIBA Competitions. In this case, once the Boxer selects one National Federation, this Boxer must not enter any AIBA Competition as a participant of the changed National Federation for two (2) years.

\subsubsection{E ligibility on Sport related Issues}

2.2.2.1 Participation in Professional Boxing or Individual Physical Contact Sport

2.2.2.1.1 Any Boxer who enters into a contract, memorandum of understanding, pre agreement or any other form of agreement, with an entity or individual other than AIBA (or any entity that is an affiliate or subsidiary of AIBA), related to such Boxer's future participation in professional boxing or any other professional Individual Physical Contact Sport than boxing, will not be eligible to participate in any AIBA Competition at any level including, for the avoidance of doubt, the Olympic Games.

2.2.2.1.2. If a Boxer who has previously competed in AOB, APB or WSB competes in any Bout or Event organized or promoted by any non-AIBA professional boxing organization, then such B oxer will not be eligible to compete in any AIBA Competition at any level ever again.

2.2.2.1.3. Any Boxer who has competed professionally in any Individual Physical Contact Sport will not be eligibleto competein any AIBA Competition at any level.

2.2.2.1.4. A Boxer who has competed at an amateur level in any Individual Physical Contact Sport is eligible to competein an AIBA Competition, at any level, under the foll lowing conditions:

2.2.2.1.5. When a National Federation wishes to register an amateur athlete from any Individual Physical Contact Sport as a Boxer, this National Federation shall complete the Application Form in Appendix B and submit the same to AIBA for acceptance and registration. The registration will be approved by AIBA in consultation with the AIBA Technical \& Rules Commission. The National Federation may specify a longer period depending on the history of the athlete and circumstances of registration. If there is any issue in this regard, the case will be reviewed by the AIBA Technical \& Rules Commission for a final decision.

2.2.2.1.6 If the amateur athlete applying for registration has competed in another Individual Physical Contact Sport for:

2.2.2.1.6.1. less than a cumulative period of three (3) years, then this amateur athlete shall not be allowed to participate in any AIBA Sanctioned National Leve Competition, including National Championships, until at least one (1) year after the date of the acceptance of the athlete's registration

2.2.2.1.6.2. morethan a cumulative period of three (3) years, then this amateur athleteshall not be all lowed to participate in any AIBA Sanctioned National Leve Competition, including National Championships, until at least two (2) years after the date of the acceptance of the athl ete's registration.

2.2.2.1.7 In addition, theBoxer may not partici pate in any other Individual Physical Contact Sport during this time

2.2.2.1.8. The Boxer must have competed in at least one (1) National Championships organized by the National Federation the Boxer is representing before being eligible to participate in any AIBA Compeition.

AIBA TE CHNICAL RULE S effective as of August 31, 2014

RULE 1.CLASSIFICATION, MEMBERSHIP AND ELIGIBILITY

$1.3 \mathrm{M}$ embership and Eligibility

1.3.1 All Boxers, Coaches, Officials, National Federation Office Holders must be members of or licensed and/or authorized by their National Federation, Confederation and AIBA to participate in national and international AIBA Competitions, unless AIBA otherwise consents.

1.4 When registering for any AIBA Competition, all Boxers and Team Officials must provide a copy of their current passport. No other proof of identity will beaccepted.

1.5 Except in cases where Rule 1.3 of the APB Competition Rules applies, any Boxer who has participated in any Bout or Event organized or promoted by any professional boxing organization or promoter (other than any AIBA, APB or WSB) will not be permitted to competein any AIBA Competition at any level.

1.6 If a Boxer, having competed in AOB, APB or WSB competes in any Bout or Event organized or promoted by any professional boxing organization or promoter (other than any AIBA, APB or WSB), then such Boxer will not be eligibleto competein any AIBA Competition at any level ever again.

1.7 Any Boxer who has competed professionally in any Individual Physical Contact Sport will not be eligible to competein any AIBA Competition at any level.

1.8 A Boxer who has competed at an amateur level in any Individual Physical Contact Sport is eligible to competein an AIBA Competition, at any level, under the foll lowing conditions:

1.8.1.1 When an amateur athlete from any Individual Physical Contact Sport turns to Boxing, his/her National Federation shall inform AIBA officially in a written letter and AIBA will then register this information in the AIBA Database 


\section{APPENDICES}

1.8.1.2 The National Federation is responsible for ensuring that the amateur athlete will only start participating in all official sanctioned National Level Competitions including National Championships a minimum of at least one (1) year after the amateur athlete has registered in boxing from another Individual Physical Contact Sport based on the history of the athlete in the concerned sport(s). If there is any issue in this regard, the case will be reviewed by the AIBA Technical \& Rules Commission for a final decision.

1.8.1.3 In addition, the Boxer may not participate in any other Individual Physical Contact Sport during this time

1.8.1.4 TheBoxer must have competed in at least one (1) National Championships organized by the National Federation the Boxer is representing before being eligibleto participatein any AIBA Competition.

AIBA Bylaws Adopted ] uly 17, 2013

\section{CHAPTER 3 MAINTENANCE OF MEMBERSHIP AND VOTING RIGHTS}

Article 11 Membership

11.1 A National Federation can only be responsible for governing the sport of boxing. It is prohibited for a National Federation and/or its President to be responsible for governing any other sporting activity, including mixed martial arts (MMA), UFC, Kickboxing, K-1 and other similar combat sports as may be determined by AIBA.

11.2 A National Federation President and Executive Committee members must be national passport holders of the National Federation country. In the event the President or Executive Committee member holds dualnationality, he or she must decide upon one country they wish to represent and provide proof that it is his or her country of residence if requested to do so.

\section{CHAPTER 11EXECUTIVE COMMITTEE MEMBER ELIGIBILITY}

\section{Article 35 E ligibility}

35.1 Upon election as an EC Member, each EC Member must continue to fulfill all of the eligibility criteria set out in Art. 35 of theAIBA Statutes.

35.2 For the avoidance of doubt, where an EC Member no longer fulfills all of the eligibility criteria set out in Art. 35 of the AIBA Statutes, or, if a National Federation removes their nomination for an EC Member or a National Federation informs AIBA that the EC member is no longer a member of the National Federation, the President shall have the power to removesuch EC Member and appoint a replacement in accordance with Art $37.3(A)$ and $(B)$ of the AIBA Statutes.

35.3 The replacement EC Member will receive full EC Member status immediately after the EC meeting at which that EC Member's appointment is approved by theEC.

35.4 The President has the power to remove any AIBA EC Member should he or she be absent (without any valid reason) from two (2) EC meetings and appoint a replacement in accordance with Art. 37.3 (A) and (B) of the AIBA Statutes.

\section{AIBA TECH NICAL RULES Effectiveon August23, 2013}

Definitions: "Boxer" means any Boxer who participates in a competition and who is a member of or licensed by a National Federation that is a member of AIBA; the term Boxer refers to Boxers of both genders;

\section{RULE 1. MEMBERSHIP AND ELIGIBILITY}

1.1. All Boxers, Coaches, Officials, National Federation Office Holders must be members of or licensed and/or authorized by their National Federation, Confederation and AIBA to participate in national and international AIBA Competitions.

1.2. When registering for any AIBA Competition, all Boxers and Team Officials must providea copy of their current passport. No other proof of identity will be accepted.

1.3. Except in cases where Rule 1.2.1. of the APB Competition Rules applies, any Boxer who has participated in any Bout or Event organized or promoted by any professional boxing organization or promoter (other than any AIBA, WSB, BMA Bout or Event) will not be permitted to compete in any AIBA Competition at any level.

1.4. If a Boxer, having competed in AOB, APB or WSB, competes in any Bout or Event organized or promoted by any professional boxing organization or promoter (other than any AIBA, WSB, BMA Bout or Event), then such Boxer will not be eligible to competein any AIBA Competition at any level ever again.

1.5. Any Boxer who has competed professionally in any Individual Physical Contact Sport will not be eligible to competein any AIBA Competition at any leve.

1.6. In order to be eligible to competein an AIBA Competition, at any leve, a Boxer who has competed at an amateur leve in any Individual Physical Contact Sport must submit an application to the AIBA Eligibility Committee The AIBA Eligibility Committee will review each application based on the information submitted and the guidelines and criteria developed by the Committee. The applying Boxer will only be eligible to compete in an AIBA Competition where the AIBA Eligibility Committee has deemed that Boxer 
to be eligible The decision of the AIBA Eligibility Committee will be final and not subject to appeal or challenge (either by the Boxer or by any third party).

1.7. If any Boxer having received an authorization from the AIBA Eligibility Committee, in accordance with Rule 1.6 of these Rules, participates again in an Individual Physical Contact Sport, at any level, such Boxer will automatically be ineligible to compete in any AIBA Competition at any level and will not be permitted to reapply to theAIBA Eligibility Committee

\section{Canoe Kayak}

INTERNATIONAL CANOE FEDERATION CANOE SLALOM COM PETITION RULES 2015

Taking effect from 1 J anuary, 2015

3. Competitors

3.1 Only the members of clubs or associations affiliated with an ICF Federation have the right to participate in an international competition.

3.2 A competitor having satisfied 3.1 and al so having first obtained the (written) consent of the competitors Federation, is permitted to competeindividual ly in an International Competition.

3.3.1 A competitor may compete on behalf of the Federation in a foreign country in which helshe is domiciled, if the competitor obtains the authorisation of their Federation of origin. This authorisation has to be sent before $30^{\text {th }}$ November prior to the year concerned to the ICF Headquarters with a copy to the CSL Technical Committee Chair. The same procedure applies, should the competitor revert to their original Federation.

3.3.2 If he/she has lived for 2 years or more in a foreign country, the approval of his/her Federation of origin is no longer required.

3.3.3 A competitor may not compete for more than one Federation in any one cal endar year in the sport of Canoeing.

3.4 The first year a competitor can compete in an ICF or International competition is the year that their $15^{\text {th }}$ birthday falls in. The last year they can compete in a J unior category is the year that their $18^{\text {th }}$ birthday falls in. The last year he/she can compete in Under 23 category is theyear that their 23rd birthday falls in.

3.5 Master(s) compeitors can compete in a Masters event in the year that he/she reaches the lower limit of the age categories, i.e in the 35-39 age group they are eligible to compete the year of their $35^{\text {th }}$ birthday. In events that have two competitors in the boat, the age of the younger competitor will control the category in which the pair can compete. Age group categories will commence from age 35-39 and increase upwards in 5 year age intervals.

3.6 Each Federation shall ensure that their compeitors are in a good state of heal th and fitness which all lows them to compete at a level commensurate with the competition level of the particular event. Each Federation must also ensure that their compeitors, team officials, as well as the Federation itself, carries appropriate health, accident and property insurance covering their persons, equipment and property.

$[\ldots]$

APPENDIX 1 - QUALIFICATION SYSTEM GAMES OF THE XXXI OLY MPIAD

\section{RIO 2016}

\section{C.ATHLETE ELIGIBILITY}

All athletes must comply with the provisions of the Olympic Charter currently in force and only those athletes who have complied with the Olympic Charter may participate in the Olympic Games. This indudes Rule41 of the Olympic Charter (Nationality of Competitors).

\section{Additional IF Requirements:}

To be eligible to participate in the Rio 2016 Olympic Games, all eligible NOCs must participate in at least one

Olympic event at the 2015 CanoeSlal om World Championships.

To be eligible for a Tripartite Commission Invitation Place an NOC must also be listed on the ICF Canoe SlalomRanking by 1 J une 2016.

A minimum of three (3) NOCs must contest each athlete quota place at the Olympic Qualifying Events for the event to be valid. If there are less than three (3) NOCs in any Olympic event then the athlete quota place will be returned to theICF CanoeSlal om Ranking for reallocation as outlined in sectionF.

\section{INTERNATIONAL CANOE FEDERATION CANOE SLALOM COM PETITION RULES 2011}

\section{COM PETITORS}

3.1 Only the members of clubs or associations affiliated with an ICF National Federation have the right to participate in an international competition.

3.2 A competitor having satisfied 3.1 and al so having first obtained the (written) consent of the competitors National Federation, is permitted to compete individually in an International Compeition.

3.3.1 A competitor may compete on behalf of the National Federation in a foreign country in which he/she is domiciled, if the competitor obtains the authorisation of their Federation of origin. This authorisation has to 


\section{APPENDICES}

be sent before 30th November prior to the year concerned to the ICF Headquarters with a copy to the CSL Technical Committee Chair. The sameprocedure applies, should the competitor revert to their original National Federation.

3.3.2 If he/she has lived for 2 years or more in a foreign country, the approval of his/her Federation of origin is no longer required.

3.3.3 A competitor may not compete for more than one Federation in any one cal endar year in the sport of Canoeing. This rule does not apply in the case of a competitor who leaves their country of origin to marry and live in another country. He/she can, in this case, compete for their new Federation without awaiting the delay of 2 years.

3.4 The first year a competitor can compete in a J unior competition is the year in that their 15th birthday falls in. The last year they can compete in a J unior category is the year that their 18th birthday falls in. The last year he/she can compete in Under 23 category is the year that their 23 rd birthday falls in.

3.5 Master(s) competitors can compete in a Masters event in the year that he/she reaches the lower limit of the age categories, i.e in the 35-39 age group they are eligible to compete the year of their 35th birthday. In events that have two compeitors in the boat, the age of the younger competitor will control the category in which the pair can compete Age group categories will commence from age 35-39 and increase upwards in 5 year ageintervals.

3.6 Each National Federation shall ensure that their competitors are in a good state of health and fitness which allows them to compete at a level commensurate with the competition level of the particular event. Each Federation must also ensure that their competitors, team officials, as well as the Federation itself, carries appropriate heal th, accident and property insurance covering their persons, equipment and property.

[...]

C. ATHLETE ELIGIBILITY

Only those athletes who have complied with the Olympic Charter (at all times) may participate in the Olympic Games. For the sake of darity, all athletes must comply with the provisions of the Olympic Charter in force during the qual ification period for the Olympic Games up until the end of the period of the Olympic Games.

An NOC must participate in at least one event at the 2011 CanoeSlal om World Championships to be eligi ble for an Athlete Quota Place in the canoeing events at the Olympic Games.

\section{INTER NATIONAL CANOE FEDERATION CANOE SPRINT COM PETITION RULES 2015}

\section{Taking effect from 1 J anuary, 2015}

\section{COM PETITORS}

3.1 Only the members of clubs or associations affiliated with an ICF National Federation have the right to participatein an international competition.

3.2 A competitor is al ways all lowed to take part individually in an international compeition but must in each case obtain special permission fromhis/her National Federation.

3.3 A Compeitor may take part on behalf of the Federation in a foreign country in which he/she is domiciled, if he/she obtains the authorisation of his/her Federation of origin. This authorisation has to be sent before $30^{\text {th }}$ November prior to the year concerned to the ICF Headquarters with a copy to the Chair of the Canoe Sprint Committee. The same procedure applies, should the Competitor change back his/her starting right to the Federation of origin.

3.4 If he/she has lived for 2 (two) years or more in (this) a foreign country, the approval of his/her Federation of origin is no longer required.

3.5 A competitor may not compete for more than one Federation in any calendar year in the sport of canoeing.

3.6 The first year a competitor can compete in a junior category is the year that his/her $15^{\text {th }}$ birthday falls in and the last year he/she can compete, as a junior is the year that his/her $18^{\text {th }}$ birthday falls in. Last year he/she can competein Under 23 category is the year that his/her 23th birthday falls in.

3.7 A competitor can competein a Masters event in the year in which he or she reaches the lower limit of the age categories i.e for the 35 - 39 age group, athlete is eligible in the year of his or her $35^{\text {th }}$ birthday. In K2/C2 or K4/C4 events the average age of the competitors will determine the category in which a crew can compete

3.8 Each National Federation shall ensure that their competitors are in a good state of health and fitness which allows them to compete at a level commensurate with the competition level of the particular event and ensure each compeitor, team official and the National Federation carries appropriate health, accident and property insurance covering their persons, equipment and property.

$[\ldots]$

\section{C.ATHLETE ELIGIBILITY}

All athletes must comply with the provisions of the Olympic Charter currently in force, including but not 
limited to, Rule 41 (Nationality of Competitors). Only those athletes who have complied with the Olympic Charter may participate in the Olympic Games.

Additional Requirements:

To be eligible to participate in the Rio 2016 Olympic Games, all eligible NOCs must participate in at least one (1) Olympic event at the 2015 Canoe Sprint World Championships to be eligible for an Athlete Quota Place in the Canoe Sprint events at the Olympic Games.

To be eligible for a Tripartite Commission Invitation Place the athlete must have participated in at least one (1) Olympic Qualification Event in Canoe Sprint.

\section{INTER NATIONAL CANOE FEDERATION CANOE SPRINT COM PETITION RULES 2013}

Taking effect from 1 January, 2013

\section{COM PETITORS}

3.1 Only the members of clubs or associations affiliated with an ICF National Federation have the right to participate in an international competition.

3.2 A competitor is al ways allowed to take part individually in an international competition but must in each case obtain special permission from his/her National Federation.

3.3 A Competitor may take part on behalf of the Federation in a foreign country in which he/she is domiciled, if he/she obtains the authorisation of his/her Federation of origin. This authorisation has to be sent before $30^{\text {th }}$ November prior to the year concerned to the ICF Headquarters with a copy to the Chair of the Canoe Sprint Committee The same procedure applies, should the Competitor change back his/her starting right to theFederation of origin.

3.4 If he/she has lived for 2 (two) years or more in (this) a foreign country, the approval of his/her Federation of origin is no longer required.

3.5 A competitor may not compete for more than one Federation in any calendar year in the sport of canoeing. This rule does not apply in the case of a competitor who leaves his/her country of origin to marry and livein another country. He/shecan, in this case, compete for his/her new Federation without awaiting the delay of 2 years.

3.6 The first year a competitor can compete in a junior category is the year that his/her $15^{\text {th }}$ birthday falls in and the last year he/she can compete, as a junior is the year that his/her $18^{\text {th }}$ birthday falls in. Last year he/she can compete in Under 23 category is the year that his/her 23th birthday falls in.

3.7 A competitor can competein a Masters event in the year in which he or she reaches the lower limit of the age categories i.e for the 35 - 39 age group, athlete is eligible in the year of his or her $35^{\text {th }}$ birthday. In K2/C2 or $\mathrm{K} 4 / \mathrm{C} 4$ events the average age of the competitors will determine the category in which a crew can compete

3.8 Each National Federation shall ensure that their competitors are in a good state of health and fitness which all lows them to compete at a level commensurate with the competition level of the particular event and ensure each competitor, team official and the National Federation carries appropriate health, accident and property insurance covering their persons, equipment and property.

[...]

APPENDIX 3 - QUALIFICATION SY STEM - GAMES OF THE XXX OLYM PIAD LONDON 2012 C.ATHLETE ELIGIBILITY

Only those athletes who have complied with the Olympic Charter (at all times) may participate in the Olympic Games. For the sake of darity, all athletes must comply with the provisions of the Olympic Charter in force during the qualification period for the Olympic Games up until the end of the period of the Olympic Games. All NOCs (including those who receive Tripartite Commission Places) must participate in at least one event at the 2011 Canoe Sprint World Championships to be eligible for an Athlete Quota Place in the canoeing events at the Olympic Games.

\section{Curling}

\section{THE RULES OF CURLING and Rules of Competition October 2015}

E L I G I B I LITY

1. Athletes area national of the country they are representing - their residence can be anywhere

or

Athletes are a resident of the country they are representing for a period of at least two consecutive years immediately prior to the start of the competition.

2. If an athlete has represented a country in any WCF competition, or played in an international qual ifier for a WCF competition, that athlete may not represent another country in any WCF competition or WCF international qualifier until the athlete fulfills one of the above criteria AND a period of two consecutive years has elapsed.

3. This eligibility does not apply to competing in the Olympic / Paralympic Winter Games, which are governed by the regulations of the International Olympic / Paralympic Committee 
4. The WCF Executive Board shall resolve any dispute relating to the determination of the WCF Member Association that an athletemay represent in a WCF competition.

\section{THE RULE S OF CURLING and Rules of Competition October 2014}

Eligibility (effective 1J une 2010)

1. Athletes area national of the country they are representing - their residence can be anywhere

or

Athletes are a resident of the country they are representing for a period of at least two consecutive years immediately prior to the start of the competition.

2. If an athlete has represented a country in any WCF competition, or played in an international qualifier for a WCF competition, that athlete may not represent another country in any WCF competition or WCF international qualifier until the athlete fulfills one of the above criteria AND a period of two consecutive years has elapsed.

3. This eligibility does not apply to competing in the Olympic / Paralympic Winter Games, which are governed by the regulations of the International Olympic / Paralympic Committee.

4. Any dispute relating to the determination of the WCF Member Association which an athlete may represent in a WCF competition, shall beresolved by theWCF ExecutiveBoard.

\section{THE RULES OF CURLING and Rules of Competition / une 2011}

\section{ELIG IBIL ITY (effective 1J une 2010)}

1. Athletes are a national of the country they are representing - their residence can be anywhere

or

Athletes are a resident of the country they are representing for a period of at least two consecutive years immediately prior to the start of the competition.

2. If an athlete has represented a country in any WCF competition, or played in an international qual ifier for a WCF competition, that athlete may not represent another country in any WCF competition or WCF international qualifier until the athlete fulfills one of the above criteria AND a period of two consecutive years has elapsed.

3. This eligibility does not apply to competing in the Olympic / Paralympic Winter Games, which are governed by the regulations of the International Olympic / Paralympic Committee.

4. Any disputerelating to the determination of the WCF Member Association which an athlete may represent in a WCF competition, shall beresolved by theWCF ExecutiveBoard.

\section{Cycling}

UCI CYCLING REGULATIONS GENERAL ORGANISATION OF E0116 CYCLING ASA SPORT PART 1 GENERAL ORGANISATION OF CYCLING ASA SPORT (Version on 05.03.2016) PART 1 GENERAL ORGANISATION OF CYCLING AS A SPORT

1.1.33 §1F or the world championships, continental championships and for teams participating in $\mathrm{UCl}$ world cup events, a rider may only be selected by the federation of his nationality, regardless of the federation that issued his licence. A rider shall be subject to the regulations and disciplinary procedures of the national federation of his nationality in all matters conceming his selection for the national team A stateless rider may be selected only by the national federation of a country where he has been continuously in residence for at least five years.

\$2 A rider holding multiple nationalities shall be required to choose between them on theoccasion of first applying for a licence The nationality chosen will then betherider's nationality for all matters regarding the UCI regulations.

The first application for a licence permanently defines a rider's nationality for the whole of his career, except in the following cases:

a. If the national ity in question is lost for any reason, and without prejudice to paragraph $b$, therider may choose one of the nationalities to which heis entitled in accordance with his civil status;

b.If the rider was a minor at the time of first applying for a licence in accordance with the relevant laws of each of the nations in question, the rider may choose a different nationality - to which he is entitled in accordance with his civil status - when making a a first application for a licence after he reaches the age of majority, in accordance with the laws of each of the nations in question;

c.If a rider acquires an additional nationality, the rider may choosethis nationality. This choicemust be made, at the latest, when applying for a licence for the second year following the year of acquisition of the new national ity. This choice is final unless the rider loses the nationality in question ( $\$ 2$ a) or if a gl obal agreement intervenes $(\$ 2 \mathrm{~d})$;

d.In exceptional cases and in the event of the agreement of the national federations concerned (thenations in question) and the $\mathrm{UCl}$, a rider may chooseanother national ity to which heis eligible in accordance with 


\section{NATIONALITY REQUiREMENTS IN Oly mpic SPORTS}

his civil status, even if he had al ready made an initial choice that had been considered final in principle. A change of this kind is only allowed oncein a rider's caree;

eln the cases described in $\$ 2 c$ and d and insofar as the rider has al ready represented the former national ity in the events described in $\S 1$, a rider who has validly chosen a new nationality may not be selected nor participatein:

i. the world championships held in theyear in which therider's change of national ity is approved by the UCl;

ii. the world championships held in theyear after the change of nationality.

Example a rider holding nationality $A$ acquires nationality $B$ on $1 J$ uly 2013 and wishes to henceforth represent nation $\mathrm{B}$. The change of nationality is approved by the UCl on 5 October 2013. Therider may not represent nation B at the world championships of 2013 (i) or 2014 (ii). However, the rider may immediately represent nation $B$ at other competitions, in particular continental championships and as a member of the national teamfor world cup events. A rider who has never represented nation $A$ at the world championships, continental championships or as a member of the national teamcompeting in world cup events, shall not be subject to any restrictions and may immediately represent nation B at the world championships.

The rider must send the UCI Legal Services the foll owing documents in order to formalisehis choice of nationality:

-Proof of eligi bility for thenationality chosen, which may beillustrated by a certificateissued by a competent authority (ministry, consulate, embassy, etc.) attesting to the date of acquisition of the nationality.

-A formal statement by the rider, signed and dated, expressing the choice of nationality and the fact that the rider is aware that this choice is final for his entire career in accordance with $\mathrm{UCl}$ regulations.

§ 3 A rider who changes national ity may not be selected to participate in the world championships held in theyear in which the change was approved by the $\mathrm{UCl}$, nor in the world championships of theyear following the change of nationality.

Comment: a change of nationality means that a person of nationality $A$ loses this nationality upon acquiring nationality $B$. There is thus no need to makea choice of nationality as described in $\$ 2 c$. The rider must send the UCI Legal Services the foll owing documents in order to formalise his change of nationality:

-Proof of acquisition of the new nationality, which may beillustrated by a certificateissued by a competent authority (ministry, consulate, embassy, etc.) attesting to the date of acquisition of the nationality.

-A formal statement by therider, signed and dated, expressing the new nationality and acknowl edging the fact that the rider is aware that this change is final for his entire career in accordance with $\mathrm{UCl}$ regulations. $\S 4$ Participation in national championships is governed by Art 1.2.028 of these regulations. \$5 The determination of a country that a rider can represent at the Olympic and Paralympic Games is governed by the Olympic Charter.

(text modified on 8.06.00; 1.01.04; 1.10.11; 1.05.14).

UCI CYCLING REGULATIONS GENERAL ORGANISATION OF E0116 CYCLING AS A SPORT PART 1 GENERAL ORGANISATION OF CYCLING AS A SPORT (Version on 01.01.2016) PART 1 GENERAL ORGANISATION OF CYCLING AS A SPORT

1.1.33 §1For the world championships, continental championships and for teams participating in UCI world cup events, a rider may only be selected by the federation of his nationality, regardless of the federation that issued his licence. $A$ rider shall be subject to the regulations and disciplinary procedures of the national federation of his nationality in all matters concerning his selection for the national team

A stateless rider may be selected only by the national federation of a country where he has been continuously in residence for at least fiveyears.

\$2 A rider holding multiple nationalities shall be required to choose between them on the occasion of first applying for a licence. The national ity chosen will then be the rider's nationality for all matters regarding the UCI regulations.

The first application for a licence permanently defines a rider's nationality for the whole of his carer, except in the following cases:

a. If the nationality in question is lost for any reason, and without prejudice to paragraph $b$, the rider may choose one of the nationalities to which heis entitled in accordance with his civil status;

b.If the rider was a minor at the time of first applying for a licence in accordance with the relevant laws of each of the nations in question, the rider may choose a different nationality - to which he is entitled in accordance with his civil status- when making a a first application for a licence after he reaches the age of majority, in accordance with the laws of each of thenations in question; 
c.If a rider acquires an additional nationality, the rider may choose this nationality. This choice must be made, at the latest, when applying for a licence for the second year following the year of acquisition of the new nationality. This choice is final unless the rider loses the nationality in question (\$2a) or if a global agreement intervenes $(\$ 2 \mathrm{~d})$;

d.In exceptional cases and in the event of the agreement of the national federations concerned (the nations in question) and the $\mathrm{UCl}$, a rider may choose another national ity to which he is eligible in accordance with his civil status, even if he had al ready made an initial choice that had been considered final in principle. A change of this kind is only allowed once in a rider's carer;

eln the cases described in $\$ 2 c$ and $d$ and insofar as the rider has al ready represented the former nationality in the events described in §1, a rider who has validly chosen a new national ity may not be selected nor participatein:

i. the world championships held in the year in which the rider's change of nationality is approved by theUCl;

ii. the world championships held in theyear after the change of national ity.

Example a rider holding nationality A acquires nationality B on $1 \mathrm{~J} \mathrm{uly} 2013$ and wishes to henceforth represent nation $\mathrm{B}$. The change of nationality is approved by the $\mathrm{UCl}$ on 5 October 2013. The rider may not represent nation B at the world championships of 2013 (i) or 2014 (ii). However, the rider may immediately represent nation $B$ at other competitions, in particular continental championships and as a member of the national team for world cup events. A rider who has never represented nation $A$ at the world championships, continental championships or as a member of the national teamcompeting in world cup events, shall not be subject to any restrictions and may immediately represent nation B at the world championships.

The rider must send the UCI Legal Services the following documents in order to formalise his choice of nationality:

-Proof of eligibility for the nationality chosen, which may be illustrated by a certificate issued by a competent authority (ministry, consulate, embassy, etc.) attesting to the date of acquisition of the nationality.

-A formal statement by the rider, signed and dated, expressing the choice of nationality and the fact that the rider is aware that this choice is final for his entire career in accordance with $\mathrm{UCl}$ regulations.

§ 3 A rider who changes national ity may not be sel ected to participate in the world championshi ps held in the year in which the change was approved by the $\mathrm{UCI}$, nor in the world championships of the year following the change of nationality.

Comment: a change of nationality means that a person of nationality $\mathrm{A}$ loses this nationality upon acquiring nationality $B$. There is thus no need to makea choice of nationality as described in $\S 2 c$.

The rider must send the UCI Legal Senvices the following documents in order to formalise his change of nationality:

-Proof of acquisition of the new nationality, which may beillustrated by a certificateissued by a competent authority (ministry, consulate, embassy, etc.) attesting to the date of acquisition of the nationality.

-A formal statement by the rider, signed and dated, expressing the new national ity and acknowledging the fact that the rider is aware that this change is final for his entire career in accordance with $\mathrm{UCl}$ regulations. \$4 Participation in national championships is governed by Art 1.2.028 of these regulations.

$\S 5$ The determination of a country that a rider can represent at the Olympic and Paralympic Games is governed by the Olympic Charter.

(text modified on 8.06.00; 1.01.04; 1.10.11; 1.05.14).

UCI CYCLING REGULATIONS GENERAL ORGANISATION OF E0115 CYCLING AS A SPORT PART 1 GENERAL ORGANISATION OF CYCLING AS A SPORT (Version on 13.03.2015) Chapter I LICENCE-HOLDERS

1.1.33 §1 For the world championships, continental championships and for teams participating in UCI world cup events, a rider may only be selected by the federation of his nationality, regardless of the federation that issued his licence A rider shall be subject to the regulations and disciplinary procedures of the national federation of his nationality in all matters concerning his selection for the national team

A stateless rider may be selected only by the national federation of a country where he has been continuously in residence for at least five years.

\$2 A rider hol ding multiple nationalities shall be required to choose between them on the occasion of first applying for a licence. The national ity chosen will then be the rider's nationality for all matters regarding theUCl regulations.

The first application for a licence permanently defines a rider's nationality for the whole of his carer, except in thefollowing cases:

A) If the nationality in question is lost for any reason, and without prejudice to paragraph $b$, the rider may choose one of the nationalities to which he is entitled in accordance with his civil status; 
B) If the rider was a minor at the time of first applying for a licence in accordance with the relevant laws of each of the nations in question, the rider may choose a different nationality - to which he is entitled in accordance with his civil status - when making a a first application for a licence after he reaches the age of majority, in accordance with the laws of each of the nations in question;

C) If a rider acquires an additional nationality, the rider may choose this nationality. This choice must be made, at the latest, when applying for a licence for the second year foll lowing the year of acquisition of the new nationality. This choice is final unless the rider loses the nationality in question (\$2a) or if a global agreement intervenes (\$2d);

D) In exceptional cases and in the event of the agreement of the national federations concerned (the nations in question) and the $\mathrm{UCl}$, a rider may choose another nationality to which he is eligible in accordance with his civil status, even if he had already made an initial choice that had been considered final in principle A change of this kind is only all lowed once in a rider's career;

E) In the cases described in $\$ 2 c$ and $d$ and insofar as the rider has already represented the former nationality in the events described in $\S 1$, a rider who has validly chosen a new nationality may not be selected nor participatein:

I) the world championships held in the year in which the rider's change of nationality is approved by the UCl;

II) the world championships held in the year after the change of nationality.

Example: a rider holding nationality A acquires nationality B on $1 \mathrm{~J}$ uly 2013 and wishes to henceforth represent nation $\mathrm{B}$. The change of nationality is approved by the UCl on 5 October 2013 . The rider may not represent nation B at the world championships of 2013 (i) or 2014 (ii). However, the rider may immediately represent nation $B$ at other competitions, in particular continental championships and as a member of the national team for world cup events. A rider who has never represented nation $A$ at the world championships, continental championships or as a member of the national team competing in world cup events, shall not be subject to any restrictions and may immediately represent nation B at the world championships.

The rider must send the UCI Legal Services the following documents in order to formalise his choice of nationality:

- Proof of eligibility for the nationality chosen, which may be illustrated by a certificate issued by a competent authority (ministry, consulate, embassy, etc.) attesting to the date of acquisition of the nationality.

- A formal statement by the rider, signed and dated, expressing the choice of nationality and the fact that the rider is aware that this choice is final for his entire career in accordance with $\mathrm{UCl}$ regulations.

§ $3 \mathrm{~A}$ rider who changes national ity may not be sel ected to partici pate in the world championships held in the year in which the change was approved by the UCI, nor in the world championships of the year following the change of nationality.

Comment: a change of nationality means that a person of nationality $A$ loses this nationality upon acquiring nationality $\mathrm{B}$. There is thus no need to make a choice of national ity as described in $\S 2 \mathrm{c}$.

The rider must send the UCl Legal Services the following documents in order to formalise his change of nationality:

- Proof of acquisition of the new nationality, which may be illustrated by a certificate issued by a competent authority (ministry, consulate, embassy, etc.) attesting to the date of acquisition of the national ity.

- A formal statement by the rider, signed and dated, expressing the new national ity and acknowl edging the fact that the rider is aware that this change is final for his entire career in accordance with $\mathrm{UCl}$ regulations. §4 Participation in national championships is governed by Art 1.2.028 of these regulations.

$\$ 5$ The determination of a country that a rider can represent at the Olympic and Paralympic Games is governed by theOlympic Charter.

(text modified on 8.06.00; 1.01.04; 1.10.11; 1.05.14).

UCI CYCLING REGULATIONS GENERAL ORGANISATION OF E0914 CYCLING AS A SPORT PART 1 GENERAL ORGANISATION OF CYCLING AS A SPORT (Version of 25.09.2014) 1.1.033 §1 For the world championships, continental championships and for teams participating in UCI world cup events, a rider may only be selected by the federation of his nationality, regardless of the federation that issued his licence A rider shall be subject to the regulations and disciplinary procedures of the national federation of his national ity in all matters concerning his sel ection for the national team

A stateless rider may be selected only by the national federation of a country where he has been continuously in residence for at least five years.

\$2 A rider holding multiple nationalities shall be required to choose between them on the occasion of first applying for a licence. The national ity chosen will then be the rider's national ity for all matters regarding the UCI regulations.

The first application for a licence permanently defines a rider's national ity for the whole of his carer, except in thefollowing cases: 


\section{APPENDICES}

A. If the nationality in question is lost for any reason, and without prejudice to paragraph $b$, the rider may choose one of the nationalities to which he is entitled in accordance with his civil status;

B. If the rider was a minor at the time of first applying for a licence in accordance with the relevant laws of each of the nations in question, the rider may choose a different nationality - to which he is entitled in accordance with his civil status - when making a a first application for a licence after he reaches the age of majority, in accordance with the laws of each of the nations in question;

C. If a rider acquires an additional nationality, the rider may choose this nationality. This choice must be made, at the latest, when applying for a licence for the second year following the year of acquisition of the new nationality. This choice is final unless the rider loses the nationality in question (\$2a) or if a global agrement intervenes ( $\$ 2 \mathrm{~d})$;

D. In exceptional cases and in the event of the agreement of the national federations concemed (the nations in question) and the $\mathrm{UCl}$, a rider may choose another national ity to which he is eligible in accordance with his civil status, even if he had al ready made an initial choice that had been considered final in principle A change of this kind is only all lowed once in a rider's carer;

$\mathrm{E}$. In the cases described in $\S 2 \mathrm{c}$ and $d$ and insofar as the rider has al ready represented the former national ity in the events described in $\S 1$, a rider who has validly chosen a new nationality may not be selected nor participatein:

(i) the world championships held in the year in which the rider's change of nationality is approved by the $\mathrm{UCl}$;

(ii) the world championships held in the year after the change of nationality.

Example: a rider holding nationality A acquires nationality B on 1 J uly 2013 and wishes to henceforth represent nation $\mathrm{B}$. The change of nationality is approved by the UCl on 5 October 2013. The rider may not represent nation B at the world championships of 2013 (i) or 2014 (ii). However, the rider may immediately represent nation $B$ at other competitions, in particular continental championships and as a member of the national teamfor world cup events. A rider who has never represented nation $A$ at the world championships, continental championships or as a member of the national team competing in world cup events, shall not be subject to any restrictions and may immediately represent nation $B$ at the world championships.

The rider must send the UCI Legal Services the following documents in order to formalise his choice of nationality:

Proof of eligibility for the nationality chosen, which may be illustrated by a certificate issued by a competent authority (ministry, consulate, embassy, etc.) attesting to the date of acquisition of the nationality.

- A formal statement by the rider, signed and dated, expressing the choice of nationality and the fact that the rider is aware that this choice is final for his entire career in accordance with $\mathrm{UCI}$ regulations.

§ $3 \mathrm{~A}$ rider who changes national ity may not be sel ected to participate in the world championships held in the year in which the change was approved by the $\mathrm{UCl}$, nor in the world championships of the year following the change of nationality.

Comment: a change of nationality means that a person of nationality A loses this nationality upon acquiring nationality $B$. There is thus no need to make a choice of nationality as described in \$2c.

The rider must send the UCI Legal Services the following documents in order to formalise his change of nationality:

- Proof of acquisition of the new nationality, which may be illustrated by a certificate issued by a competent authority (ministry, consulate, embassy, etc.) attesting to the date of acquisition of the nationality.

- A formal statement by the rider, signed and dated, expressing the new nationality and acknowledging the fact that the rider is aware that this change is final for his entire career in accordance with $\mathrm{UCl}$ regulations.

§4 Participation in national championships is governed by Art. 1.2.028 of these regulations.

\$5 The determination of a country that a rider can represent at the Olympic and Paralympic Games is governed by the Olympic Charter.

(text modified on 8.06.00; 1.01.04; 1.10.11; 1.05.14).

UCI CYCLING REGULATIONS GENERAL ORGANISATION OF E 1014 CYCLING AS A SPORT PART 1 GENERAL ORGANISATION OF CYCLING AS A SPORT (version on 7.03.14) Chapter LICENCE-HOLDERS

Licences

Definition

1.1.001 The licence is an identity document confirming that its hol der undertakes to respect the constitution and regulations and which authorise him to participatein cycling events.

[...]

1.1.008 The licence shall be valid for one year, from 1 January to 31 December. It shall be valid in all countries wherethere is a UCI member national federation.

1.1.009 A licence holder may hold the licence of only onenational federation.

[... ] 


\section{NATIONALITY REQUiREMENTS In Oly mpic SPORTS}

\section{Issuing procedure}

1.1.011 The licenceshall be issued by the federation of the country where, according to the legislation of that country, the applicant has his main residence at the time of application. He shall remain affiliated to that federation until the expiry of thelicence, even if he changes country of residence.

[... ]

1.1.020 Any member federation of which a licence holder possesses the nationality shall be informed within one month of thelicence hol der's application and the issuing of thelicence in the following cases:

a) if the applicant does not hold the nationality of the federation to which he applied;

b) if the applicant holds the nationality of the federation to which he applied but also of one or more other national federations;

c) if thelicence application is made to the $\mathrm{UCI}$.

(text modified on 1.01.00).

[...]

1.1.033 § 1 A rider may be selected solely by the federation of his nationality to participate in world championships, continental championships, and regional games or to be part of teams participating in UCl world cup events, regardless of the federation that issued his licence The rider shall be subject to the regulations and the discipline of the national federation of his nationality in all matters concerning his selection for the national team A stateless rider may be selected only by the national federation of a country where he has been continuously in residence for at least five years.

§ 2 A rider holding multiple nationalities shall be required to choose between them on the occasion of first applying for a licence This choice of nationality shall be final for the rider's entirecarer unless heloses that nationality for any reason, without prejudice to the application of the third paragraph below. The rider shall be deemed to hold the nationality thus chosen for any matter regarding the UCI regulations. Such a rider may choose another nationality which he legitimately holds, if when first electing a nationality the rider was a minor under the relevant laws of each of the nationalities in question, and the choice is made on the first application for a licence after he reaches the age of majority under the laws of each nationality in question. § $3 \mathrm{~A}$ rider who acquires an additional nationality may choose this nationality. Such a choice must be made at the latest by the application for a licence for the second year following the one of the acquisition of the new nationality. This choice is final. The rider who validly chose his new nationality can be selected by the national federation of his new nationality and represent it in events mentioned in $\S 1$ as from the second calendar year he chose his new nationality.

Example a rider holding nationality A also acquires nationality B on 1st J uly 2011 . Should he wish to ride under nationality $B$, he must choose nationality $B$ at the latest when requesting his licence for the year 2013. Otherwise, he will be definitely considered as a rider holding nationality $A$. In case he chooses nationality $B$ when requesting his licence for the year 2012, he may ride for his new national teamas from the year 2013. By choosing the nationality $B$ when requesting his licence for the year 2013 , he may ride for his new national teamas from the year 2014. He may be selected by the national teamA until 2012, respectively 2013.

\$ $4 \mathrm{~A}$ rider who changes his nationality can be selected by the national federation of his new nationality and represent it in events mentioned in $\S 1$ as from the second calendar year following the one during which the change of nationality took place.

Comment: the change of nationality implies that a person holding the A nationality loses that nationality when acquiring nationality $B$. A choice of a nationality, as in the case mentioned in $\S 3$ does therefore not take place. For example, a rider who changes his nationality on 1st J uly 2011 may ride for his new national teamB as from the year 2013. Until 31 December 2012, he may be selected by the national teamA.

§ 5 The determination of a country that a rider can represent at the Olympic and Paralympic Games is governed by the Olympic Charter.

(text modified on 8.06.00; 1.01.04; 1.10.11).

\section{National team}

1.1.044 A national teamis a team of riders selected by thenational federation of their nationality.

(article introduced on 1.01.05).

\section{UCI Cycling Regulations PART 11 OL Y M PIC GAM E S (version on 1.02.13)}

11.1.001 Participation in cycling competitions at the Olympic Games shall be governed by the rules of the International Olympic Committee (IOC) and of the UCl. Participation in the Olympics shall imply acceptance and respect of the IOC and UCI rules by the rider and any other licence holder.

\section{Participation}

11.1.003 To take part in the Olympics, each rider shall:

- hold a licenceissued by a National Federation

- beat least 18 years ol d for track events, 19 years old for road, mountain bi keand BMX events or reach this age in the year of the Olympics.

- bein the J unior category for competitions in theY outh Olympic Games. 
UCI CYCLING REGULATIONS GENERAL ORGANISATION OF E 1013 CYCLING AS A SPORT PART 1 GENERAL ORGANISATION OF CYCLING AS A SPORT (version on 1.10.13)

Art. 1 Licences

Definition

1.1.001 The licence is an identity document confirming that its holder undertakes to respect the constitution and regulations and which authorise him to participate in cycling events.

$[\ldots]$

1.1.008 The licence shall be valid for one year, from 1 January to 31 December. It shall be valid in all countries where there is a UCI member national federation.

1.1.009 A licence holder may hold the licence of only onenational federation.

[... ] Issuing procedure

1.1.011 Thelicenceshall beissued by the federation of the country where, according to the legislation of that country, the applicant has his main residence at the time of application. He shall remain affiliated to that federation until the expiry of thelicence, even if he changes country of residence.

[...]

1.1.020 Any member federation of which a licence holder possesses the nationality shall be informed within one month of thelicence hol der's application and the issuing of thelicence in the following cases:

a) if the applicant does not hold the nationality of the federation to which he applied;

b) if the applicant holds the nationality of the federation to which he applied but also of one or more other national federations;

c) if thelicence application is made to the $\mathrm{UCI}$.

[...]

1.1.033 § 1 A rider may be selected solely by the federation of his nationality to participate in world championships, continental championships, and regional games or to be part of teams participating in UCI world cup events, regardless of the federation that issued his licence The rider shall be subject to the regulations and the discipline of the national federation of his nationality in all matters concerning his selection for the national team A stateless rider may be selected only by the national federation of a country where he has been continuously in residence for at least five years.

§ $2 \mathrm{~A}$ rider holding multiple nationalities shall be required to choose between them on the occasion of first applying for a licence This choice of nationality shall be final for the rider's entirecarer unless heloses that nationality for any reason, without prejudice to the application of the third paragraph below. The rider shall be deemed to hold the nationality thus chosen for any matter regarding the UCI regulations. Such a rider may choose another nationality which he legitimately holds, if when first electing a nationality the rider was a minor under the relevant laws of each of the nationalities in question, and the choice is made on the first application for a licence after he reaches the age of majority under the laws of each nationality in question.

§ 3 A rider who acquires an additional nationality may choose this nationality. Such a choice must be made at the latest by the application for a licence for the second year following the one of the acquisition of the new nationality. This choice is final.

The rider who validly chose his new nationality can be selected by the national federation of his new nationality and represent it in events mentioned in $\S 1$ as from the second calendar year he chose his new nationality.

Example: a rider holding nationality $A$ also acquires nationality $B$ on 1 st J uly 2011 . Should he wish to ride under nationality B, he must choose nationality B at the latest when requesting his licence for the year 2013. Otherwise, he will be definitely considered as a rider holding nationality $A$. In case he chooses nationality $B$ when requesting his licence for the year 2012, he may ride for his new national teamas from the year 2013. By choosing the nationality $B$ when requesting his licence for the year 2013 , he may ride for his new national teamas from the year 2014. Hemay be selected by the national teamA until 2012, respectively 2013.

\$ $4 \mathrm{~A}$ rider who changes his nationality can be selected by the national federation of his new nationality and represent it in events mentioned in $\S 1$ as from the second calendar year following the one during which the change of nationality took place.

Comment: the change of nationality implies that a person holding the A nationality loses that nationality when acquiring nationality $B$. A choice of a nationality, as in the case mentioned in $\S 3$ does therefore not take place. For example, a rider who changes his nationality on 1st J uly 2011 may ride for his new national teamB as from the year 2013. Until 31 December 2012, he may be selected by the national teamA.

§ 5 The determination of a country that a rider can represent at the Olympic and Paralympic Games is governed by the Olympic Charter.

(text modified on 8.06.00; 1.01.04; 1.10.11).

National team

1.1.044 A national teamis a team of riders selected by the national federation of their nationality.

UCI C ycling Regulations PART 11 OLYM PIC GAM ES (version on 1.02.13) 


\section{NATIONALITY REQUiREMENTS IN Oly mpic SPORTS}

11.1.001 Participation in cyding competitions at the Olympic Games shall be governed by the rules of the International Olympic Committee (IOC) and of the UCl. Participation in the Olympics shall imply acceptance and respect of the IOC and $\mathrm{UCl}$ rules by the rider and any other licence holder.

\section{Participation}

11.1.003 To take part in the Olympics, each rider shall:

- hold a licence issued by a National Federation

- beat least 18 years old for track events, 19 years old for road, mountain bikeand BMX events or reach this age in the year of the Olympics.

- bein the J unior category for competitions in the Y outh Olympic Games.

\section{UCI 2011 Version}

$1.1 .033 \S$ I A rider may be selected solely by the federation of his nationality to participate in world championships, continental championships, and regional games or to be part of teams participating in UCI world cup events, regardless of the federation that issued his licence The rider shall be subject to the regulations and the discipline of the national federation of his nationality in all matters concerning his selection for the national team

A stateless rider may be selected only by the national federation of a country where he has been continuously in residence for at least five years.

§ 2 A rider holding multiple nationalities shall be required to choose between them on the occasion of first applying for a licence This choice of nationality shall be final for the rider's entire carer unl ess he loses that national ity for any reason, without prejudice to the application of thethird paragraph below.

Therider shall be deemed to hold the nationality thus chosen for any matter regarding the UCI regulations. Such a rider may choose another nationality which he legitimately holds, if when first electing a nationality the rider was a minor under the relevant laws of each of the nationalities in question, and the choice is made on the first application for a licence after he reaches the age of majority under the laws of each nationality in question.

§ $3 \mathrm{~A}$ rider who acquires an additional nationality may choose this nationality. Such a choice must be made at the latest by the application for a licence for the second year following the one of the acquisition of the new nationality. This choice is final.

The rider who validly chose his new nationality con be selected by the national federation of his new nationality and represent it in events mentioned in $\S 1$ as from the second calendar year he chose his new nationality.

Example a rider holdlilg nationality $A$ al so acquires nationality B nationality B on Ist J uly 2011 . Should he wish to ride under nationality $B$, he must choose 1latiollolity $B$ at the latest when requesting his licellce for the year 20 I 3. Otherwise, he will be definitely considered as a rider holding nationality A. In case he chooses nationality $B$ when requestillg his license for the year $20 \mathrm{I} 2$, he may ride for his new national team as from the year 20 / 3. By choosing the nationality $B$ when requesting his license for the year 20 / 3 , he may ride for this new national teamas from the year 2014. Hemay beselected by the national teamA until 2012 , respectively 2013.

§ 4 A rider who changes his national ity can be sel ected by the national federation of his new nationality and represent it in events mentioned in $\S 1$ as from the second cal endar year following the one during which the change of nationality took place

Comment: the change of nationality implies that a person holding the $A$ nationality loses that nationality when acquiring nationally $\mathrm{B}$. A choice of o nationality as in the case mentioned in $\S 3$ does therefore not take place. For example, a rider who changes his nationality on $1^{\text {\$ }} \mathrm{J}$ uly 2011 may ride For his new national team $\mathrm{B}$ as from the year 2013 . Until 31 December 2012, he may be selected by the natiollal teamA.

§ 5 The determination of a country that a rider can represent at the Olympic and Paralympic Games is governed by the Olympic Charter.

(text modified on B.06.00; 1.01.04; 1.10.11).

\section{UCI 2005 Version}

1.1 .033 § I A rider may be selected solely by the federation of his nationality to participate in world championships, continental championships, and regional games or to be port of teams porticipot. ing in cyclo cross world cup and mountain bike world cup events, regardless of the federation that issued his licence The rider shall be subject to the regulations and the discipline of the notional federation of his nationality in all matters concerning his selection for the national team

A stateless rider may be selected only by the national federation of a country where he has been continuously in residence for at least five years.

§ 2 A rider holding multiple nationalities shall be required to choose between them on the occasion of first applying for a licence This choice of nationality shall be final for the rider's entire career unless he loses that nationality for any reason, without prejudice to the application of the third paragraph below. 


\section{APPENDICES}

The rider shall be deemed to hold the nationality thus chosen for any molter regarding the UCI regulations.

Such a rider may choose another nationality which he legitimately holds, if when first electing a nationality the rider was a minor under the rel evant laws of each of the national ities in ques. tion, and the choice is made on the first application for a licence after he reaches the age of majority under the laws of each nationality in question.

§ 3 A rider who acquires an additional nationality moy choose this nationality. Such a choice shall be final, and shall be made at the latest by the second application for a licence following the acquisition of the new nationality.

§ 4 The determination of a country that a rider can represent at the Olympic Games is governed by the Olympic Charter.

(text modified on 8.06.00; 1.01.04).

\section{Equestrian}

FEI GE NERAL RE GUL ATIONS 23rd edition, 1 J anuary 2009, updates effective 1 J anuary 2016

Article 113 - Registration and E ligibility of Athletes and Horses

1. All Athletes and Horses must be registered with the FEI, and their own NF, or whereappropriate with their host NF, before they can be entered and permitted to take part in an Intemational Event, unless otherwise specified by the Sport Rules. (Se also Article 119- Sport Nationality Status of Athletes and Chapter V Horses).

2. NFs are responsible for registering all Athletes and Horses and shall ensure that such Athletes have the appropriate corresponding sport nationality pursuant to Article 119. NFs are also responsible for unregistering any Athleteand/or Horse that are not competing anymore for any reason.

3. Any Athlete and/or any Horse not registered with the FEl and/or not fulfilling an eligibility requirement shall beautomatically disqualified, unless compel ling circumstances warrant otherwise

4. An Athlete and/or Horse, even if registered with the FEI, is not eligible to participate in an International Event or National Event (and so may not be invited by an OC to such Event or entered by an NF in such Event) if that Athlete and/or Horse has participated, in the six (6) months prior to the first day of the International Event or National Event in question, in an Unsanctioned Event.

5. For purposes of Article 113.4, an 'Unsanctioned Event' is an event and/or a competition that is neither published in the official Calendar nor authorised by an NF and/or a National Event authorised or organised by a NF that is suspended by the FEI.

6. An Athlete, Chef d'Equipe, Owner, or NF may challengethe application of Article 113.4, or sedk a waiver thereof in exceptional circumstances, by application to the Secretary General. A denial of that application may be appeal ed to the FEI Tribunal, such appeal to be heard on the papers without a live hearing unl ess the FEI Tribunal orders otherwise

\section{Article 119- Sport Nationality Status of Athletes}

1. General principles:

1.1. The NF of a country where an Athlete has his nationality is his "own" NF. Proof of nationality is necessary for an Athleteto competefor a country.

1.2 Except as provided in paragraphs 4, 5, 6.2, and 6.3, an Athletemay only compete, at International Events, for his "own NF", as defined in paragraph 1.1.

2. Sport national ity and sport national ity changes: Adult Athletes

2.1 An Athlete who is a national of more than one (1) country must decide as of the age of (eighteen) 18 years which of his countries of nationality will be his own NF for international competition purposes. Thereafter, subject to paragraph 2.2.1, he can only represent that NF in international competition. Further changes to his sport nationality can only be accomplished through a sport nationality change process, subject to the conditions outlined in this paragraph 2.

\subsection{Sport nationality changes:}

2.2.1 Basic requirement: an Adult Athlete who is or who becomes the national of more than one country and wishes to compete for his new/other country of nationality may apply for a sport nationality change to the FEI. In the case of a new nationality, this nationality must have been acquired by 31st December of the preceding year.

2.2.2 Additional requirements prior to participation in FEI Championships (except FEI Championships for Y oung Horses), FEI World Cup ${ }^{\text {TM }}$ Series, and team competitions at CIOs:

(i)Subject to the exceptions set forth in paragraph 2.2.3 below, the Athlete must have had legal residence in his new country prior to the first competition he wishes to compete in under his new sport nationality, for either: (a) a minimum of two (2) unintemupted years; or (b) a total of five (5) years of non-consecutive periods. 


\section{NATIONAlity ReQuirements in Olympic SPORTS}

(ii)The Athlete shall not have taken part in any of the competitions set forth in Article 2.2.2. above for his previous NF in the two (2) years prior to the first competition he wishes to compete in under his new sport nationality.

2.2.3 The residency requirement set out in paragraph 2.2.2 (i) shall be mandatory, except where the Athlete can establish one of the following:

(i)the Athlete's entitlement to his new nationality was established by his birth in that country;

(ii)The Athlete's entitlement to his new nationality was acquired by virtue of descent or through other means related to family heritage

(iii)the naturalized Athlete was a former national whose loss of nationality was neither voluntary or due to criminal acts; or

(iv)the natural ized Athl ete had to renounce his former nationality as a condition of acquiring a new one

2.2.4 Where the natural ized Athl ete can establ ish that he is legal ly married to a national of the new country of nationality, the residency requirement set out in paragraph 2.2.2 (i) shall be reduced to one (1) year of uninterrupted legal residence or three (3) years of non- consecutive periods of legal residence

2.2.5 An application for an Athlete's change of sport nationality must be filed with the FEI Secretary General, through his new NF, stating the reason for the change and supported by the Athlete's passport or equivalent document for the new country that he wishes to represent. The FEI must inform the current NF that a request for change of sport nationality has been filed.

2.2.6 An Athlete shall only be entitled to compete for his new NF once theFEI has given its written approval of the change in sport nationality.

2.2.7 In special and exceptional circumstances, the FEI has the discretion to grant exceptions, with the agreement of the NFs concerned.

2.2.8 Participation in the Olympic and Paralympic Games is also subject to Olympic and Paralympic Regulations (Byelaw to Rule 42, Olympic Charter) and in particular to any waiting period imposed by these regulations. Similarly, participation in Regional and Continental Games is also subject to the regulations of the relevant governing body.

\section{Sport nationality and sport nationality changes: M inor Athletes}

3.1 A Minor Athlete who is a citizen of more than one country can choose each calendar year which NF he wants to represent.

3.2 A Minor Athlete may subsequently change his NF (only once per calendar year). Such change of NF is subject to the previous NF's, the new NF's and the FEl's approvals if the Minor Athlete has already participated in an international event for another NF since 1 J anuary of that calendar year.

3.3 As of the Minor Athlete's 18th birthday, paragraph 2 above applies. At such time, the Athlete will register with the chosen NF who will, in turn, register the Athlete with theFEI.

4. If an associate state, province or overseas department, a country or a colony acquires independence; if a country becomes incorporated within another country by reason of a change of border; or if a new NF is recognized by the FEI, an Athl ete may continue to represent the country to which he belongs or belonged if that country continues to have an NOC. However, he may, if he prefers, choose to represent his new NF. This particular choice must receive the Approval of theFEI and may bemade only once

5.

5.1An Athlete Living outside his country of nationality who: (i) loses his nationality; (ii) becomes a refugee; or (iii) whose home country does not have an NF which is a member of the FEI, can compete internationally as if he were a national of the host country in all International Events including Championships, until such time as his home country has an NF which is a member of theFEI.

5.2 Athletes whose country of citizenship does not have an NF which is a member of the FEI, and whose situation does not qualify under paragraphs 4 and 5.1 above, may receive special authorisation from the FEI to compete in FEI Events under theFEI flag, in exceptional circumstances and on a case by case basis.

6. Athletes L iving outside their country of nationality:

6.1 An Adult Athlete Living outside his country of nationality can have his entries processed by his "hostNF" for participation in CNs, CIMs as well as Cls if he is given permission of his own NF and the FEI. The Athlete, while keeping his own NF, comes under the jurisdiction of the host NF for the above-mentioned Events and must take part according to the relevant Sport Rules. This administrative facility is not a change of sport nationality. The Athlete will in all circumstances keep his "own NF", and al ways compete under its flag.

6.2 A Minor Athlete may compete for his country of residence in the following Events, and regardless of the country wherethe Event is organised: Cls for Children, Pony Riders, J unior Riders and Y oung Riders (which excludes $\mathrm{ClO}$ s and Championships), and senior CIMs as defined in Appendix E, GRs. In such circumstances, the Athletewill becompelled to informhis "own NF" as well as the FEl.

6.3 A Minor Athlete who has always competed for his country of residence and not his own NF, may apply to the FEI to establish his country of residence as his own NF once heturns eighteen (18), even though he is not a national of such country, only if: (i) he has never competed under the flag of his own NF; (ii) the 


\section{APPENDICES}

country of residence, in the FEI's opinion, qualifies as a country where obtaining nationality is overly burdensome; (iii) the Minor Athlete has a valid identity card or residence permit for the country of residence, or other equival ent document; and (iii) the Minor Athlete has been a resident of the country of residence for at least the last five (5) consecutive years. The FEI shall have sole discretion to grant or deny an application presented under this provision, weighing the best interests of equestrian sport against the best interests of the Minor Athlete

Article 123 - Olympic and Regional Games under the Patronage of the IOC, and Paralympic Games under the patronage of the IPC

1. Only Athletes who satisfy the applicable conditions set forth in the GRs, the Olympic Regulations, the Olympic Charter, its Bylaws and the regulations of the relevant governing bodies may be entered for the Olympic and Regional Games under the patronage of the IOC (see Appendix B). Only Athletes who satisfy the conditions set forth in the GRs and applicable Paralympic Regulations may be entered for the Paralympic Games.

2. All Athletes, Officials, Persons Responsible, grooms, veterinarians, trainers, Chefs de Mission, Chefs d'Equipes, National Federation representatives, and/or any other member of the Athlete's support personnel or entourage participating in, or accredited to the Olympic, Paralympic, and/or Regional Games are subject, by virtue of such participation and/or accreditation, to any IOC, IPC, and/or applicable Regional Organisations' Rules.

\section{FE I GE NERAL RE GUL ATIONS 23rd edition, 1 J anuary 2009, updates effective 1 J anuary 2015 CHAPTER II - PARTICIPATION OF ATHLETES AND HOR SES \\ Article 113 - Registration and Eligibility of Athletes and Horses}

1. All Athletes and Horses must be registered with the FEI, and their own NF, or where appropriate with their host NF, before they can be entered and permitted to take part in an International Event, unless otherwise specified by the Sport Rules. (See also Article 119- Sport Nationality Status of Athletes and Chapter V Horses).

2. NFs are responsible for registering all Athletes and Horses and shall ensure that such Athl etes have the appropriate corresponding sport nationality pursuant to Article 119. NFs are also responsible for unregistering any Athlete and/or Horse that are not competing anymore for any reason.

3. Any Athlete and/or any Horse not registered with the FEI and/or not fulfilling an eligibility requirement shall beautomatically disqualified, unless compel ling circumstances warrant otherwise

4. An Athlete and/or Horse, even if registered with the FEI, is not eligible to participate in an International Event or National Event (and so may not be invited by an OC to such Event or entered by an NF in such Event) if that Athlete and/or Horse has participated, in the six (6) months prior to the first day of the International Event or National Event in question, in an Unsanctioned Event.

5. For purposes of Article 113.4, an 'Unsanctioned Event' is an event and/or a competition that is neither published in the official Calendar nor authorised by an NF.

6. An Athlete, Chef d'Equipe, Owner, or NF may challengetheapplication of Article 113.4, or seek a waiver thereof in exceptional circumstances, by application to the Secretary General. A denial of that application may be appeal ed to the FEI Tribunal, such appeal to be heard on the papers without a live hearing unl ess the FEI Tribunal orders otherwise.

\section{Article 119- Sport Nationality Status of Athletes}

1. General principles:

1.1. The NF of a country where an Athlete has his nationality is his "own" NF. Proof of nationality is necessary for an A thl ete to compete for a country.

1.2. Except as provided in paragraphs $4,5,6.2$, and 6.3 , an Athlete may only compete, at International Events, for his "own NF", as defined in paragraph 1.1.

2. Sport national ity and sport national ity changes: Adult Athletes

2.1. An Athlete who is a national of more than one (1) country must decide as of the age of (eighteen) 18 years which of his countries of nationality will be his own NF for international competition purposes. Thereafter, subject to paragraph 2.2.1, he can only represent that NF in international competition. Further changes to his sport nationality can only be accomplished through a sport nationality change process, subject to the conditions outlined in this paragraph 2.

\subsection{Sport nationality changes:}

2.2.1. Basic requirement: an Adult Athl ete who is or who becomes the national of more than one (1) country and wishes to compete for his new/other country of nationality may apply for a sport nationality change to the FEI. In the case of a new nationality, this national ity must have been acquired by 31st December of the preceding year.

2.2.2. Additional requirements prior to participation in FEI Championships (except FEI Championships for Y oung Horses), FEI World Cup ${ }^{\mathrm{TM}}$ Series, and team competitions at CIOs: 
(i) Subject to the exceptions set forth in paragraph 2.2.3 below, the Athlete must have had legal residence in his new country prior to the first competition he wishes to compete in under his new sport nationality, for either: (a) a minimum of two (2) unintemupted years; or (b) a total of five (5) years of non-consecutive periods.

(ii) The Athlete shall not have taken part in any of the competitions set forth in Article 2.2.2. above for his previous NF in the two (2) years prior to the first competition he wishes to compete in under his new sport nationality.

2.2.3 The residency requirement set out in paragraph 2.2.2 (i) shall be mandatory, except where the Athlete can establish one of the following:

(i) theAthl ete's entitlement to his new national ity was established by his birth in that country;

(ii) TheAthlete's entitlement to his new national ity was acquired by virtue of descent or through other means related to family heritage

(iii) the natural ized Athlete was a former national whose loss of nationality was neither voluntary or due to criminal acts; or

(iv) the naturalized A thl ete had to renounce his former national ity as a condition of acquiring a new one

2.2.4. Where the naturalized A thl ete can establish that he is legally married to a national of the new country of nationality, the residency requirement set out in paragraph 2.2.2 (i) shall be reduced to one (1) year of uninternupted legal residence or three (3) years of non-consecutive periods of legal residence.

2.2.5. An application for an Athlete's change of sport nationality must be filed with the FEI Secretary General, through his new NF, stating the reason for the change and supported by the Athlete's passport or equivalent document for the new country that he wishes to represent. The FEI must inform the current NF that a request for change of sport nationality has been filed.

2.2.6. An Athlete shall only be entitled to compete for his new NF once the FEI has given its written approval of the changein sport nationality.

2.2.7. In special and exceptional circumstances, the FEI has the discretion to grant exceptions, with the agreement of the NFs concerned.

2.2.8. Participation in the Olympic and Paralympic Games is also subject to Olympic and Paralympic Regulations (Byelaw to Rule 42, Olympic Charter) and in particular to any waiting period imposed by these regulations. Similarly, participation in Regional and Continental Games is also subject to the regulations of therelevant governing body.

\section{Sport nationality and sport nationality changes: $M$ inor Athletes}

3.1. A Minor Athlete who is a citizen of more than one country can choose each calendar year which NF he wants to represent.

3.2. A Minor Athl ete may subsequently change his NF (only once per cal endar year). Such change of NF is subject to the previous NF's, the new NF's and the FEI'S approvals if the Minor Athlete has already participated in an international event for another NF since $1 \mathrm{~J}$ anuary of that cal endar year.

3.3. As of the Minor Athlete's 18th birthday, paragraph 2 above applies. At such time, the Athlete will register with the chosen NF who will, in turn, register the Athlete with theFEI.

4. If an associate state, province or overseas department, a country or a colony acquires independence; if a country becomes incorporated within another country by reason of a change of border; or if a new NF is recognized by the FEI, an Athl ete may continue to represent the country to which he bel ongs or belonged if that country continues to have an NOC. However, he may, if he prefers, choose to represent his new NF. This particular choice must receive the Approval of theFEI and may bemade only once

5.

5.1. An Athlete Living outsidehis country of national ity who: (i) loses his nationality; (ii) becomes a refugee; or (iii) whose home country does not have an NF which is a member of the FEI, can compete internationally as if he were a national of the host country in all International Events including Championships, until such time as his home country has an NF which is a member of theFEI.

5.2. Athletes whose country of citizenship does not have an NF which is a member of the FEI, and whose situation does not qualify under paragraphs 4 and 5.1 above, may receive special authorisation from the FEI to compete in FEI Events under theFEI flag, in exceptional circumstances and on a case by case basis.

6. Athletes L iving outside their country of nationality:

6.1. An Adult Athlete Living outside his country of nationality can have his entries processed by his "hostNF" for participation in CNs, CIMs as well as Cls if he is given permission of his own NF and the FEI. The Athlete, while keeping his own NF, comes under the jurisdiction of the host NF for the above-mentioned Events and must take part according to the relevant Sport Rules. This administrative facility is not a change of sport nationality. The Athlete will in all circumstances keep his "own NF", and al ways compete under its flag.

6.2. A Minor Athlete may compete for his country of residence in the following Events, and regardless of the country where the Event is organised: Cls for Pony Riders, J unior Riders and Y oung Riders (which excludes 


\section{APPENDICES}

CIOs and Championships), and senior CIMs as defined in Appendix E, GRs. In such circumstances, the Athlete will becompelled to inform his "own NF" as well as the FEl.

6.3. A Minor Athlete who has al ways competed for his country of residence and not his own NF, may apply to the FEI to establish his country of residence as his own NF once heturns eighteen (18), even though he is not a national of such country, only if: (i) he has never competed under the flag of his own NF; (ii) the country of residence, in the FEl's opinion, qualifies as a country where obtaining nationality is overly burdensome; (iii) the Minor Athlete has a val id identity card or residence permit for the country of residence, or other equival ent document; and (iii) the Minor Athlete has been a resident of the country of residence for at least the last five (5) consecutive years. The FEI shall have sole discretion to grant or deny an application presented under this provision, weighing the best interests of equestrian sport against the best interests of the Minor Athlete

Article 123 - Olympic and Regional Games under the Patronage of the IOC, and Paralympic Games under the patronage of the IPC

1. Only Athletes who satisfy the applicable conditions set forth in the GRs, the Olympic Regulations, the Olympic Charter, its Bylaws and the regulations of the relevant governing bodies may be entered for the Olympic and Regional Games under the patronage of the IOC (see Appendix B). Only Athletes who satisfy the conditions set forth in the GRs and applicable Paralympic Regulations may be entered for the Paralympic Games.

2. All Athletes, Officials, Persons Responsible, grooms, veterinarians, trainers, Chefs de Mission, Chefs d'Equipes, National Federation representatives, and/or any other member of the Athlete's support personne or entourage participating in, or accredited to the Olympic, Paralympic, and/or Regional Games are subject, by virtue of such participation and/or accreditation, to any IOC, IPC, and/or applicable Regional Organisations' Rules.

Article 124 - Y oung R iders, J uniors, Pony R iders, C hildren and Veterans

1. Athletes of the appropriate age may take part in FEI Competitions and FEI Championships of more than one (1) Category for Y oung Riders, J uniors and Pony Riders, but in each Discipline only in one (1) of these FEI Championships in any one (1) cal endar year.

2. Athletes may take part in FEI Senior Competitions and Championships from the beginning of the year they reach the age of (eighteen) 18 but they may only take part either in a J unior or a Y oung Rider or a FEI Championship for Seniors in the same Discipline in any calendar year. Further exceptions regarding age limits are set forth in the Sport Rules of the rel evant Disciplines.

3. In exceptional cases, Technical Committees may with the approval of the Bureau vary any of the ages set out in the definitions for specific Events or regions.

4. Rules regarding Veteran Athletes are set forth in the Sport Rules of each Discipline.

FEI GE NE RAL RE GULATIONS 23rd edition, 1] anuary 2009, updates effective 1J anuary 2014

Article 119- Sport Nationality Status of Athletes

1. General principles:

1.1 The NF of a country where an Athlete has his nationality is his "own" NF. Proof of nationality is necessary for an Athleteto compete for a country.

1.2 Except as provided in paragraphs 4, 5, 6.2, and 6.3, an Athletemay only compete, at International Events, for his "own NF", as defined in paragraph 1.1.

2. Sport nationality and sport nationality changes: Adult Athletes

2.1 An Athlete who is a national of more than one (1) country must decide as of the age of (eighteen) 18 years which of his countries of nationality will be his own NF for international competition purposes. Thereafter, subject to paragraph 2.2.1, he can only represent that NF in international competition. Further changes to his sport nationality can only be accomplished through a sport nationality change process, subject to the conditions outdined in this paragraph 2.

\subsection{Sport nationality changes:}

2.2.1 Basic requirement: an Adult A thlete who is or who becomes the national of more than one (1) country and wishes to compete for his new/other country of nationality may apply for a sport nationality change to the FEI. In the case of a new nationality, this national ity must have been acquired by 31st December of the preceding year.

2.2.2 Additional requirements prior to participation in FEI Championships (except FEI Championships for Y oung Horses), FEI World Cup ${ }^{T M}$ Series, and team competitions at CIOs:

(i) Subject to the exceptions set forth in paragraph 2.2.3 below, the Athlete must have had legal residence in his new country prior to the first competition he wishes to compete in under his new sport nationality, for either: (a) a minimum of two (2) unintemupted years; or (b) a total of five (5) years of non-consecutive periods. 


\section{NATIONALITY REQUiREMENTS In Oly mpic SPORTS}

(ii) The Athlete shall not have taken part in any of the competitions set forth in Article 2.2.2. above for his previous NF in the two (2) years prior to the first competition he wishes to compete in under his new sport nationality.

2.2.3 The residency requirement set out in paragraph 2.2.2 (i) shall be mandatory, except where the Athlete can establish one of the following:

(i) the Athlete's entitlement to his new national ity was established by his birth in that country;

(ii) The Athlete's entitlement to his new nationality was acquired by virtue of descent or through other means related to family heritage

(iii) the naturalized Athlete was a former national whose loss of nationality was neither voluntary or due to criminal acts; or

(iv) the naturalized Athlete had to renounce his former nationality as a condition of acquiring a new one

2.2.4 Where the naturalized Athl ete can establ ish that he is legally married to a national of the new country of nationality, the residency requirement set out in paragraph 2.2.2 (i) shall be reduced to one (1) year of uninterrupted legal residence or three (3) years of non-consecutive periods of legal residence.

2.2.5 An application for an Athlete's change of sport nationality must be filed with the FEI Secretary General, through his new NF, stating the reason for the change and supported by the Athlete's passport or equivalent document for the new country that he wishes to represent. The FEI must inform the current NF that a request for change of sport nationality has been filed.

2.2.6 An Athlete shall only be entitled to compete for his new NF once theFEI has given its written approval of the change in sport nationality.

2.2.7 In special and exceptional circumstances, the FEI has the discretion to grant exceptions, with the agreement of the NFs concerned.

2.2.8 Participation in the Olympic and Paralympic Games is also subject to Olympic and Paralympic Regulations (Byelaw to Rule 42, Olympic Charter) and in particular to any waiting period imposed by these regulations. Similarly, participation in Regional and Continental Games is also subject to the regulations of the relevant governing body.

\section{Sport nationality and sport nationality changes: M inor Athletes}

3.1 A Minor Athlete who is a citizen of more than one country can choose each calendar year which NF he wants to represent.

3.2 A Minor Athlete may subsequently change his NF (only once per calendar year). Such change of NF is subject to the previous NF's, the new NF's and the FEl's approvals if the Minor Athlete has already participated in an international event for another NF since 1 J anuary of that calendar year.

3.3 As of the Minor Athlete's 18th birthday, paragraph 2 above applies. At such time, the Athlete will register with the chosen NF who will, in turn, register the Athlete with theFEI.

4. If an associate state, province or overseas department, a country or a colony acquires independence; if a country becomes incorporated within another country by reason of a change of border; or if a new NF is recognized by the FEI, an Athlete may continue to represent the country to which he belongs or belonged if that country continues to have an NOC. However, he may, if he prefers, choose to represent his new NF. This particular choice must receive the Approval of theFEI and may bemade only once 5.

5.1. An Athlete Living outside his country of national ity who: (i) loses his nationality; (ii) becomes a refugee; or (iii) whose home country does not have an NF which is a member of the FEI, can compete internationally as if he were a national of the host country in all International Events including Championships, until such time as his home country has an NF which is a member of theFEI.

5.2 Athletes whose country of citizenship does not have an NF which is a member of the FEI, and whose situation does not qualify under paragraphs 4 and 5.1 above, may receive special authorisation from the FEI to compete in FEI Events under theFEI flag, in exceptional circumstances and on a case by case basis.

6. Athletes L iving outside their country of nationality:

6.1. An Adult Athlete Living outside his country of nationality can have his entries processed by his "hostNF" for participation in CNs, CIMs as well as Cls if he is given permission of his own NF and the FEI. The Athlete, while keeping his own NF, comes under the jurisdiction of the host NF for the above-mentioned Events and must take part according to the relevant Sport Rules. This administrative facility is not a change of sport nationality. The Athlete will in all circumstances keep his "own NF", and al ways compete under its flag.

6.2 A Minor Athlete may compete for his country of residence in the following Events, and regardless of the country where the Event is organised: Cls for Pony Riders, J unior Riders and Y oung Riders (which excludes CIOs and Championships), and senior CIMs as defined in Appendix E, GRs. In such circumstances, the Athlete will becompelled to inform his "own NF" as well as the FEI.

6.3 A Minor Athlete who has al ways competed for his country of residence and not his own NF, may apply to the FEI to establish his country of residence as his own NF once heturns eighteen (18), even though he is not a national of such country, only if: (i) he has never competed under the flag of his own NF; (ii) the 


\section{APPENDICES}

country of residence, in the FEI's opinion, qualifies as a country where obtaining nationality is overly burdensome; (iii) the Minor Athlete has a valid identity card or residence permit for the country of residence, or other equival ent document; and (iii) the Minor Athlete has been a resident of the country of residence for at least the last five (5) consecutive years. The FEI shall have sole discretion to grant or deny an application presented under this provision, weighing the best interests of equestrian sport against the best interests of the Minor Athlete

Article 123 - Olympic and Regional Games under the Patronage of the IOC, and Paralympic Games under the patronage of the IPC

1. Only Athletes who satisfy the applicable conditions set forth in the GRs, the Olympic Regulations, the Olympic Charter, its Bylaws and the regulations of the relevant governing bodies may be entered for the Olympic and Regional Games under the patronage of the IOC (see Appendix B). Only Athletes who satisfy the conditions set forth in the GRs and applicable Paralympic Regulations may be entered for the Paralympic Games.

2. All Athletes, Officials, Persons Responsible, grooms, veterinarians, trainers, Chefs de Mission, Chefs d'Equipes, National Federation representatives, and/or any other member of the Athlete's support personnel or entourage participating in, or accredited to the Olympic, Paralympic, and/or Regional Games are subject, by virtue of such participation and/or accreditation, to any IOC, IPC, and/or applicable Regional Organisations' Rules.

\section{FEI GE NE RAL RE GULATIONS 23rd edition, 1] anuary 2009, updates effective 1] anuary 2013}

\section{Article 119- Sport Nationality Status of Athletes}

1.General principles:

1.1 The NF of a country where an Athlete has his nationality is his "own" NF. Proof of nationality is necessary for an Athleteto competefor a country.

1.2 Except as provided in paragraphs 4, 5, 6.2, and 6.3, an Athletemay only compete, at International Events, for his "own NF", as defined in paragraph 1.1.

\section{Sport nationality and sport nationality changes: Adult Athletes}

2.1 An Athlete who is a national of more than one (1) country must decide as of the age of (eighteen) 18 years which of his countries of nationality will be his own NF for international competition purposes. Thereafter, subject to paragraph 2.2.1, he can only represent that NF in international competition. Further changes to his sport nationality can only be accomplished through a sport nationality change process, subject to the conditions outlined in this paragraph 2.

\subsection{Sport nationality changes:}

2.2.1 Basic requirement: an Adult A thlete who is or who becomes the national of more than one (1) country and wishes to compete for his new/other country of nationality may apply for a sport nationality change to the FEI. In the case of a new nationality, this nationality must have been acquired by 31st December of the preceding year.

2.2.2. Additional requirements prior to participation in FEI Championships (except FEI Championships for Y oung Horses), FEI World Cup ${ }^{T M}$ Series, and CIOS:

(i)Subject to the exceptions set forth in paragraph 2.2.3 below, the Athlete must have had legal residence in his new country prior to the first competition he wishes to compete in under his new sport nationality, for either: (a) a minimum of two (2) uninternupted years ; or (b) a total of five (5) years of non-consecutive periods.

(ii)The Athlete shall not have taken part in any of the competitions set forth in Article 2.2.2. above for his previous NF in the two (2) years prior to the first competition he wishes to compete in under his new sport nationality.

2.2.3 The residency requirement set out in paragraph 2.2.2 (i) shall be mandatory, except where the Athlete can establish one of thefollowing:

(i)the Athlete's entitlement to his new national ity was established by his birth in that country;

(ii)The Athlete's entitlement to his new nationality was acquired by virtue of descent or through other means related to family heritage

(iii)the naturalized Athlete was a former national whose loss of nationality was neither voluntary or due to criminal acts; or

(iv)the naturalized A thl ete had to renounce his former national ity as a condition of acquiring a new one 2.2.4 Where the natural ized A thl ete can establish that he is legall ly married to a national of the new country of nationality, the residency requirement set out in paragraph 2.2.2 (i) shall be reduced to one (1) year of uninternupted legal residence or three (3) years of non-consecutive periods of legal residence.

2.2.5 An application for an Athlete's change of sport nationality must be filed with the FEI Secretary General, through his new NF, stating the reason for the change and supported by the Athlete's passport or equivalent document for the new country that he wishes to represent. The FEI must inform the current NF that a request for change of sport nationality has been filed. 


\section{NATIONALITY REQUIREMENTS IN OLY MPIC SPORTS}

2.2.6 Athlete shall only be entitled to compete for his new NF once the FEI has given its written approval of the change in sport nationality.

2.2.7 In special and exceptional circumstances, the FEl has the discretion to grant exceptions, with the agreement of the NFs concerned.

2.2.8 .Participation in the Olympic and Paralympic Games is also subject to Olympic and Paralympic Regulations (Byelaw to Rule 42, Olympic Charter) and in particular to any waiting period imposed by these regulations. Similarly, participation in Regional and Continental Games is also subject to the regulations of therelevant governing body.

\section{Sport nationality and sport nationality changes: $M$ inor Athletes}

3.1 A Minor Athlete who is a citizen of more than one country can choose each cal endar year which NF he wants to represent.

3.2 A Minor Athlete may subsequently change his NF (only once per calendar year). Such change of NF is subject to the previous NF's, the new NF'S and the FEl's approvals if the Minor Athlete has already participated in an international event for another NF since $1 \mathrm{~J}$ anuary of that calendar year.

3.3 As of the Minor Athlete's 18th birthday, paragraph 2 above applies. At such time, the Athlete will register with the chosen NF who will, in turn, register the Athlete with theFEI.

4. If an associate state, province or overseas department, a country or a colony acquires independence; if a country becomes incorporated within another country by reason of a change of border; or if a new NF is recognized by the FEI, an Athl ete may continue to represent the country to which he belongs or belonged if that country continues to have an NOC. However, he may, if he prefers, choose to represent his new NF. This particular choice must receive the Approval of theFEI and may be made only once

5. An Athlete Living outside his country of nationality who: (i) loses his nationality; (ii) becomes a refugee; or (iii) whose home country does not have an NF which is a member of the FEI, can compete internationally as if he were a national of the host country in all International Events including Championships, until such timeas his home country has an NF which is a member of theFEI.

5.2 Athletes whose country of citizenship does not have an NF which is a member of the FEI, and whose situation does not qualify under paragraphs 4 and 5.1 above, may receive special authorisation from the FEI to compete in FEI Events under theFEI flag, in exceptional circumstances and on a case by case basis.

6. Athletes L iving outside their country of nationality:

6.1 An Adult Athlete Living outside his country of nationality can have his entries processed by his "hostNF" for participation in CNs, CIMs as well as Cls if he is given permission of his own NF and the FEI. The Athlete, while keeping his own NF, comes under the jurisdiction of the host NF for the above-mentioned Events and must take part according to the relevant Sport Rules. This administrative facility is not a change of sport nationality. The Athlete will in all circumstances keep his "own NF", and al ways compete under its flag.

6.2 A Minor Athlete may compete for his country of residence in the following Events, and regardless of the country where the Event is organised: Cls for Pony Riders, J unior Riders and Y oung Riders (which excludes CIOs and Championships), and senior CIMs as defined in Appendix E, GRs. In such circumstances, the Athlete will becompelled to informhis "own NF" as well as the FEl.

6.3 A Minor Athlete who has al ways competed for his country of residence and not his own NF, may apply to the FEI to establish his country of residence as his own NF once he turns 18, even though he is not a national of such country, only if: (i) he has never competed under the flag of his own NF; (ii) the country of residence, in the FEI's opinion, qualifies as a country where obtaining nationality is overly burdensome; (iii) the Minor Athlete has a valid identity card or residence permit for the country of residence, or other equivalent document; and (iii) the Minor Athlete has been a resident of the country of residence for at least the last five (5) consecutive years. The FEI shall have sole discretion to grant or deny an application presented under this provision, weighing the best interests of equestrian sport against the best interests of the Minor Athlete

$[\ldots]$

Article 123 - Olympic and Regional Games under the Patronage of the IOC, and Paralympic Games under the patronage of the IPC

1. Only Athletes who satisfy the applicable conditions set forth in the GRs, the Olympic Regulations, the Olympic Charter, its Bylaws and the regulations of the relevant governing bodies may be entered for the Olympic and Regional Games under the patronage of the IOC (see Appendix B). Only Athletes who satisfy the conditions set forth in the GRs and applicable Paralympic Regulations may be entered for the Paralympic Games.

2. All Athletes, Officials, Persons Responsible, grooms, veterinarians, trainers, Chefs de Mission, Chefs d'Equipes, National Federation representatives, and/or any other member of the Athlete's support personnel or entourage participating in, or accredited to the Olympic, Paralympic, and/or Regional Games are subject, by virtue of such participation and/or accreditation, to any IOC, IPC, and/or applicable Regional Organisations' Rules. 


\section{APPENDICES}

FE I GE NE RAL RE GULATIONS 23rd edition, 1] anuary 2009, updates effective 1] anuary 2012

Article 119- Sport Nationality Status of Athletes

1. General principles:

1.1 The NF of a country where an Athlete has his nationality is his "own" NF. Proof of nationality is necessary for an Athl ete to compete for a country.

1.2 Except as provided in paragraphs 4, 5, 6.2, and 6.3, an Athlete may only compete, at International Events, for his "own NF", as defined in paragraph 1.1.

2.Sport nationality and sport nationality changes: Adult Athletes

2.1 An Athlete who is a national of more than one (1) country must decide as of the age of (eighteen) 18 years which of his countries of nationality will be his own NF for international competition purposes. Thereafter, subject to paragraph 2.2.1, he can only represent that NF in international competition. Further changes to his sport nationality can only be accomplished through a sport nationality change process, subject to the conditions outlined in this paragraph 2.

2.2 Sport nationality changes:

2.2.1 Basic requirement: an Adult Athlete who is or who becomes the national of more than one (1) country and wishes to compete for his new/other country of nationality may apply for a sport nationality change to the FEI. In the case of a new nationality, this nationality must have been acquired by 31st December of the preceding year.

2.2.2 Additional requirements prior to participation in FEI Championships, FEI World Cup ${ }^{\text {TM }}$ Series, and FEI Nations Cup Series:

(i) Subject to the exceptions set forth in paragraph 2.2.3 below, the Athlete must have had legal residence in his new country prior to the first competition he wishes to compete in under his new sport nationality, for either: (a) a minimum of two (2) uninterrupted years ; or (b) a total of five (5) years of non-consecutive periods.

(ii) The Athlete shall not have taken part in any of the competitions set forth in Artide 2.2.2. above for his previous NF in the two (2) years prior to the first competition he wishes to compete in under his new sport nationality.

2.2.3 The residency requirement set out in paragraph 2.2 .2 (i) shall be mandatory, except where the Athlete can establish one of the following:

(i) the Athlete's entitlement to his new nationality was established by his birth in that country;

(ii)The Athlete's entitlement to his new nationality was acquired by virtue of descent or through other means related to family heritage

(iii) the naturalized Athlete was a former national whose loss of nationality was neither voluntary or due to criminal acts; or

(iv)the naturalized A thlete had to renounce his former national ity as a condition of acquiring a new one 2.2.4 Where the natural ized Athlete can establ ish that he is legally married to a national of the new country of nationality, the residency requirement set out in paragraph 2.2.2 (i) shall be reduced to one (1) year of uninternupted legal residence or three(3) years of non-consecutive periods of legal residence.

2.2.5 An application for an Athlete's change of sport nationality must be filed with the FEl Secretary General, through his new NF, stating the reason for the change and supported by the Athlete's passport or equivalent document for the new country that he wishes to represent. The FEI must inform the current NF that a request for change of sport nationality has been filed.

2.2.6 An Athlete shall only be entitled to compete for his new NF once theFEI has given its written approval of the change in sport nationality.

2.2.7 In special and exceptional circumstances, the FEI has the discretion to grant exceptions, with the agreement of the NFs concerned.

2.2.8 Participation in the Olympic and Paralympic Games is also subject to Olympic and Paralympic Regulations (Byelaw to Rule 42, Olympic Charter) and in particular to any waiting period imposed by these regulations. Similarly, participation in Regional and Continental Games is also subject to the regulations of the relevant governing body.

3. Sport nationality and sport nationality changes: Minor Athletes

3.1 A Minor Athlete who is a citizen of more than one country can choose each calendar year which NF he wants to represent.

3.2 A Minor Athlete may subsequently change his NF (only once per calendar year). Such change of NF is subject to the previous NF's, the new NF's and the FEl's approvals if the Minor Athlete has already participated in an international event for another NF since 1 J anuary of that calendar year.

3.3 As of the Minor Athlete's 18th birthday, paragraph 2 above applies. At such time, the Athlete will register with the chosen NF who will, in turn, register the Athlete with theFEI.

4. If an associate state, province or overseas department, a country or a colony acquires independence; if a country becomes incorporated within another country by reason of a change of border; or if a new NF is recognized by the FEI, an Athl ete may continue to represent the country to which he belongs or belonged if 
that country continues to have an NOC. However, he may, if he prefers, choose to represent his new NF. This particular choice must receive the Approval of theFEI and may be made only once

5. An Athlete Living outside his country of nationality who: (i) loses his nationality; (ii) becomes a refugee; or (iii) whose home country does not have an NF which is a member of the FEI, can compete internationally as if he were a national of the host country in all International Events including Championships, until such time as his home country has an NF which is a member of theFEI.

5.1 Athletes whose country of citizenship does not have an NF which is a member of the FEI, and whose situation does not qualify under paragraphs 4 and 5 above, may receive special authorization from the FEI to compete in FEI Events under theFEI flag, in exceptional circumstances and on a case by case basis.

6. Athletes L iving outside their country of nationality:

6.1 An Adult Athlete Living outside his country of nationality can have his entries processed by his "hostNF" for participation in CNs, CIMs as well as Cls if he is given permission of his own NF and the FEI. The Athlete, while keeping his own NF, comes under the jurisdiction of the host NF for the above-mentioned Events and must take part according to the relevant Sport Rules. This administrative facility is not a change of sport nationality. The Athlete will in all circumstances keep his "own NF", and al ways compete under its flag.

6.2 A Minor Athlete may compete for his country of residence in the following Events, and regardless of the country where the Event is organized: Cls for Pony Riders, J unior Riders and Y oung Riders (which exdudes $\mathrm{CIOs}$ and Championships), and senior CIMs as defined in Appendix E, GRs. In such circumstances, the Athlete will be compelled to informhis "own NF" as well as the FEI.

6.3 A Minor Athlete who has al ways competed for his country of residence and not his own NF, may apply to the FEI to establish his country of residence as his own NF once he turns 18, even though he is not a national of such country, only if: (i) he has never competed under the flag of his own NF; (ii) the country of residence, in the FEl's opinion, qualifies as a country where obtaining nationality is overly burdensome; (iii) the Minor Athlete has a valid identity card or residence permit for the country of residence, or other equivalent document; and (iii) the Minor Athlete has been a resident of the country of residence for at least the last five (5) consecutive years. The FEI shall have sole discretion to grant or deny an application presented under this provision, weighing the best interests of equestrian sport against the best interests of the Minor Athlete

Article 123 - Olympic and Regional Games under the Patronage of the IOC, and Paralympic Games under the patronage of the IPC

1. Only Athletes who satisfy the applicable conditions set forth in the GRs, the Olympic Regulations, the Olympic Charter, its Bylaws and the regulations of the relevant goveming bodies may be entered for the Olympic and Regional Games under the patronage of the IOC (see Appendix B). Only Athletes who satisfy the conditions set forth in the GRs and applicable Paralympic Regulations may be entered for the Paralympic Games.

2. All Athletes, Officials, Persons Responsible, grooms, veterinarians, trainers, Chefs de Mission, Chefs d'Equipes, National Federation representatives, and/or any other member of the Athlete's support personnel or entourage participating in, or accredited to the Olympic, Paralympic, and/or Regional Games are subject, by virtue of such participation and/or accreditation, to any IOC, IPC, and/or applicable Regional Organisations' Rules.

FEI GE NERAL RE GULATIONS 23rd edition, 1J anuary 2009, updates effective 1J anuary 2011 Article 119- Sport Nationality Status of Athletes

1.General principles:

1.1 The NF of a country where an Athlete has his nationality is his "own" NF. Proof of nationality is necessary for an Athleteto competefor a country.

1.2 Except as provided in paragraphs 4, 5, 6.2, and 6.3, an Athletemay only compete, at International Events, for his "own NF", as defined in paragraph 1.1.

2.Sport nationality and sport nationality changes: Adult Athletes

2.1 An Athlete who is a national of more than one (1) country must decide as of the age of (eighteen) 18 years which of his countries of nationality will be his own NF for international competition purposes. Thereafter, subject to paragraph 2.2.1, he can only represent that NF in international competition.

Further changes to his sport nationality can only be accomplished through a sport nationality change process, subject to the conditions outlined in this paragraph 2 .

\subsection{Sport nationality changes:}

2.2.1 Basic requirement: an Adult A thlete who is or who becomes the national of more than one (1) country and wishes to compete for his new/other country of nationality may apply for a sport nationality change to the FEI. In the case of a new nationality, this national ity must have been acquired by 31st December of the preceding year.

2.2.2 Additional requirements prior to participation in FEI Championships, FEI World Cup ${ }^{\text {TM }}$ Series, and 
FEI Nations Cup Series:

(i) Subject to the exceptions set forth in paragraph 2.2.3 below, the Athlete must have had legal residence in his new country prior to the first competition he wishes to compete in under his new sport nationality, for either: (a) a minimum of two (2) uninternupted years ; or (b) a total of five (5) years of non-consecutive periods.

(ii)The Athlete shall not have taken part in any of the competitions set forth in Article 2.2.2. above for his previous NF in the two (2) years prior to the first competition he wishes to compete in under his new sport nationality.

2.2.3 The residency requirement set out in paragraph 2.2.2 (i) shall be mandatory, except where the Athlete can establish one of the following:

(i) the Athlete's entitlement to his new national ity was established by his birth in that country;

(ii) The Athlete's entitlement to his new nationality was acquired by virtue of descent or through other means related to family heritage-

(iii) the natural ized Athlete was a former national whose loss of nationality was neither voluntary or due to criminal acts; or

(iv) the naturalized Athl ete had to renounce his former national ity as a condition of acquiring a new one

2.2.4 Where the naturalized Athl ete can establish that he is legall ly married to a national of thenew country of nationality, the residency requirement set out in paragraph 2.2.2 (i) shall be reduced to one (1) year of uninternupted legal residence or three (3) years of non-consecutive periods of legal residence.

2.2.5 An application for an Athlete's change of sport nationality must be filed with the FEI Secretary General, through his new NF, stating the reason for the change and supported by the Athlete's passport or equivalent document for the new country that he wishes to represent. The FEI must inform the current NF that a request for change of sport national ity has been filed.

2.2.6 Athlete shall only be entitled to compete for his new NF once the FEI has given its written approval of the change in sport nationality.

2.2.7 In special and exceptional circumstances, the FEI has the discretion to grant exceptions, with the agreement of the NFs concerned.

2.2.8 Participation in the Olympic and Paralympic Games is also subject to Olympic and Paralympic Regulations (Byelaw to Rule 42, Olympic Charter) and in particular to any waiting period imposed by these regulations. Similarly, participation in Regional and Continental Games is also subject to the regulations of therelevant governing body.

3. Sport nationality and sport nationality changes: M inor Athletes

3.1 A Minor Athlete who is a citizen of more than one country can choose each calendar year which NF he wants to represent.

3.2 A Minor Athlete may subsequently change his NF (only once per calendar year). Such change of NF is subject to the previous NF's, the new NF's and the FEl's approvals if the Minor Athlete has already participated in an international event for another NF since $1 \mathrm{~J}$ anuary of that calendar year.

3.3 As of the Minor Athlete's 18th birthday, paragraph 2 above applies. At such time, the Athlete will register with the chosen NF who will, in tum, register the Athlete with the FEI.

4. If an associate state, province or overseeas department, a country or a colony acquires independence; if a country becomes incorporated within another country by reason of a change of border; or if a new NF is recognized by the FEI, an Athl ete may continue to represent the country to which he belongs or belonged if that country continues to have an NOC. However, he may, if he prefers, choose to represent his new NF. This particular choice must receive the Approval of theFEI and may be made only once

5. An Athlete Living outside his country of nationality who: (i) loses his nationality; (ii) becomes a refugee; or (iii) whose home country does not have an NF which is a member of the FEI, can compete internationally as if he were a national of the host country in all International Events including Championships, until such timeas his home country has an NF which is a member of theFEI.

\section{Athletes L iving outside their country of nationality:}

6.1 An Adult Athlete Living outside his country of nationality can have his entries processed by his "hostNF" for participation in CNs, CIMs as well as Cls if he is given permission of his own NF and the FEI. The Athlete, while keeping his own NF, comes under the jurisdiction of the host NF for the above mentioned Events and must take part according to the relevant Sport Rules. This administrative facility is not a change of sport national ity. The Athlete will in all circumstances keep his "own NF", and al ways compete under its flag.

6.2 A Minor Athlete may compete for his country of residence in the foll lowing Events, and regardless of the country where the Event is organized: Cls for Pony Riders, J unior Riders and Y oung Riders (which excludes CIOs and Championships), and senior CIMs as defined in Appendix E, GRs. In such circumstances, the Athlete will becompelled to informhis "own NF" as well as theFEI.

6.3 A Minor Athlete who has al ways competed for his country of residence and not his own NF, may apply to the FEI to establish his country of residence as his own NF once he turns 18, even though he is not a 
national of such country, only if: (i) he has never competed under the flag of his own NF; (ii) the country of residence, in the FEl's opinion, qualifies as a country where obtaining nationality is overly burdensome; (iii) the Minor Athlete has a valid identity card or residence permit for the country of residence, or other equivalent document; and (iii) the Minor Athlete has been a resident of the country of residence for at least the last five (5) consecutive years. The FEI shall have sole discretion to grant or deny an application presented under this provision, weighing the best interests of equestrian sport against the best interests of the Minor Athlete

Article 123 - Olympic and Regional Games under the Patronage of the IOC, and Paralympic Games under the patronage of the IPC

1. Only Athletes who satisfy the applicable conditions set forth in the GRs, the Olympic Regulations, the Olympic Charter, its Bylaws and the regulations of the relevant goveming bodies may be entered for the Olympic and Regional Games under the patronage of the IOC (see Appendix B). Only Athletes who satisfy the conditions set forth in the GRs and applicable Paralympic Regulations may be entered for the Paralympic Games.

FEI GE NE RAL RE GULATIONS 23rd edition, 1J anuary 2009, updated 1J anuary 2010

Article 119- Sport Nationality Status of Athletes

1. General principles:

1.1 The NF of a country where an Athlete has his nationality is his "own" NF. Proof of nationality is necessary for an Athlete to compete for a country.

1.2 Except as provided in paragraphs 4, 5, 6.2, and 6.3, an Athletemay only compete, at International Events, for his "own NF", as defined in paragraph 1.1.

2. Sport nationality and sport nationality changes: Adult Athletes

2.1 An Athlete who is a national of more than one (1) country must decide as of the age of (eighteen) 18 years which of his countries of nationality will be his own NF for international competition purposes. Thereafter, subject to paragraph 2.2.1, he can only represent that NF in international competition. Further changes to his sport nationality can only be accomplished through a sport national ity change process, subject to the conditions outlined in this paragraph 2.

2.2 Sport nationality changes:

2.2.1 Basic requirement: an Adult A thl ete who becomes the national of more than one (1) country and wishes to compete for his new country of nationality may apply for a sport nationality change to the FEI, provided he has acquired his new nationality by 31st December of the preceding year.

2.2.2.Additional requirements prior to participation in FEI Championships, FEI World Cup ${ }^{\text {TM }}$ Series, FEI Super LeagueSeries, and FEI Nations Cup Series:

(i) Subject to the exceptions set forth in paragraph 2.2 .3 below, the Athlete must have had legal residence in his new country prior to the first competition he wishes to compete in under his new sport nationality, for either: (a) a minimum of two (2) unintermupted years ; or (b) a total of five (5) years of non-consecutive periods.

(ii)The Athlete shall not have taken part in any of the competitions set forth in Article 2.2.2. above for his previous NF in the two (2) years prior to the first competition he wishes to compete in under his new sport nationality.

2.2.3 The residency requirement set out in paragraph 2.2.2 (i) shall be mandatory, except where the Athlete can establish one of thefollowing:

(i) the Athlete's entitlement to his new national ity was established by his birth in that country;

(ii) The Athlete's entitlement to his new nationality was established by one of his biological parents being born in that country;

(iii) the naturalized Athlete was a former national whose loss of nationality was neither voluntary or due to criminal acts; or

(iv) the naturalized Athl ete had to renounce his former national ity as a condition of acquiring a new one

2.2.4 Where the naturalized Athl ete can establish that he is legal ly married to a national of the new country of nationality, the residency requirement set out in paragraph 2.2.2 (i) shall be reduced to one (1) year of uninternupted legal residence or three (3) years of non-consecutive periods of legal residence.

2.2.5 An application for an Athlete's change of sport nationality must be filed with the FEI Secretary General, through his new NF, stating the reason for the change and supported by the Athlete's passport or equivalent document for the new country that he wishes to represent. The FEI must inform the current NF that a request for change of sport nationality has been filed.

2.2.6 An Athlete shall only be entitled to compete for his new NF once theFEI has given its written approval of the change in sport nationality.

2.2.7 In special and exceptional circumstances, the FEI has the discretion to grant exceptions, with the agreement of the NFs concerned.

2.2.8 Participation in the Olympic and Paralympic Games is also subject to Olympic and Paralympic 


\section{APPENDICES}

Regulations (Byelaw to Rule 42, Olympic Charter).

3. Sport nationality and sport nationality changes: $M$ inor Athletes

3.1 A Minor Athlete who is a citizen of more than one country can choose each cal endar year which NF he wants to represent.

3.2 A Minor Athlete may subsequently change his NF (only once per calendar year). Such change of NF is subject to the previous NF's, the new NF's and the FEI's approvals if the Minor Athlete has already participated in an international event for another NF since $1 \mathrm{~J}$ anuary of that calendar year.

3.3 As of the Minor Athlete's 18th birthday, paragraph 2 above applies. At such time, the Athlete will register with the chosen NF who will, in tum, register the Athlete with theFEI.

4. If an associate state, province or overseas department, a country or a colony acquires independence, if a country becomes incorporated within another country by reason of a change of border; or if a new NF is recognized by the FEI, an Athl ete may continue to represent the country to which he belongs or belonged if that country continues to have an NOC. However, he may, if he prefers, choose to represent his new NF. This particular choice must receive the Approval of theFEI and may be made only once

5. An Athlete Living outside his country of nationality who: (i) loses his nationality; (ii) becomes a refugee; or (iii) whose home country does not have an NF which is a member of the FEI, can compete internationally as if he were a national of the host country in all International Events including Championships, until such time as his home country has an NF which is a member of theFEI.

6. Athletes L iving outside their country of nationality:

6.1 An Adult Athlete Living outside his country of nationality can have his entries processed by his "hostNF" for participation in CNs, CIMs as well as Cls if he is given permission of his own NF and the FEI. The Athlete, while keeping his own NF, comes under the jurisdiction of the host NF for the above-mentioned Events and must take part according to the relevant Sport Rules. This administrative facility is not a change of sport nationality. The Athlete will in all circumstances keep his "own NF", and al ways compete under its flag.

6.2 A Minor Athlete may compete for his country of residence in the following Events, and regardless of the country where the Event is organized: Cls for Pony Riders, J unior Riders and Y oung Riders (which excludes $\mathrm{CIOs}$ and Championships), and senior CIMs as defined in Appendix E, GRs. In such circumstances, the Athlete will becompelled to informhis "own NF" as well as theFEl.

6.3 A Minor Athlete who has al ways competed for his country of residence and not his own NF, may apply to the FEI to establish his country of residence as his own NF once he turns 18, even though he is not a national of such country, only if: (i) he has never competed under the flag of his own NF; (ii) the country of residence, in the FEl's opinion, qualifies as a country where obtaining nationality is overly burdensome; (iii) the Minor Athlete has a valid identity card or residence permit for the country of residence, or other equival ent document; and (iii) the Minor Athlete has been a resident of the country of residence for at least the last five (5) consecutive years. The FEI shall have sole discretion to grant or deny an application presented under this provision, weighing the best interests of equestrian sport against the best interests of the Minor Athlete

Article 123 - Olympic and Regional Games under the Patronage of the IOC, and Paralympic Games under the patronage of the IPC

1. Only Athletes who satisfy the conditions laid down in the GRs, the Olympic Regulations, and theOlympic Charter and its Bylaws may be entered for the Olympic and Regional Games under the patronage of the IOC (see Appendix B). Only Athletes who satisfy the conditions laid down in the GRs, the Paralympic Regulations may beentered for the Paralympic Games.

\section{FEI GE NE RAL RE GULATIONS 23rd edition, effective 1 J anuary 2009}

\section{Article 119- Sport Nationality Status of Athletes}

1. TheNF of a country where an Athlete has his national ity/citizenship is his own NF.

2. Except as provided in paragraphs 8 and 12, an Athlete may take part in International Events only under the jurisdiction of his own NF.

3. An Athl ete who is the national/citizen of more than one (1) country must decide from the age of 18 years which is his own NF and must thereafter, subject to paragraph 4, compete under the jurisdiction of that NF.

4. An Athlete who is the national/citizen of more than one (1) country must decide which is his own NF and may take part in competitions for that NF, provided he was citizen/national of that NF by 31st December of the preceding year.

5. Proof of legal citizenship or nationality is necessary to compete for the respective country. In addition, the following conditions apply prior to participation in FEI Championships, FEI World Cup ${ }^{\mathrm{Tm}}$ Series, FEI Super LeagueSeries, and FEI Nations Cup Series:

(i) The Athlete must have had legal residence in his new country for (a) a minimum of two (2) years uninterrupted residence in the new country immediately prior to the competition or (b) a total of five (5) years of non-consecutive periods. 
(ii) In the event of a change of nationality, an Athlete shall not have taken part in competitions mentioned above for his previous NF in the two (2) years prior to the first competition he wishes to compete in under his new nationality/citizenship.

6. In special and exceptional circumstances, the FEI may grant exceptions for justifiable cases, with the agreement of the NFs concerned.

7. Participation to the Olympic and Paralympic Games is subject to Olympic and Paral ympic Regulations.

8. If an associate state, province or overseas department, a country or a colony acquires independence, if a country becomes incorporated within another country by reason of a change of border, or if a new NF is recogni sed by the FEI, an Athlete may continue to represent the country to which he belongs or belonged if that country continues to have an NOC. However, he may, if he prefers, choose to represent his new NF. This particular choice must receive the Approval of theFEI and may be made only once

9. An application for an Athlete's change of nationality must be filed with the FEl Secretary General, through his new NF, stating the reason of the change and supported by the Athlete's passport or equivalent document for the new country that he wishes to represent. TheFEI must inform the current NF that a request for change of nationality has been filed.

10. An Athlete shall only be entitled to compete for his new NF, provided the FEI has given its prior written approval.

11. An Athlete Living A broad can take part regularly in CNs and CIMs and Cls for J uniors, Y oung Riders and Pony Riders of his host country if he is given permission from the NF of his host country or, in very exceptional circumstances, given special approval by theFEI. The Athlete, whilekeeping his own NF, comes under the jurisdiction of the host NF for the above mentioned Events and he must take part according to the relevant Sport Rules.

12. An Athlete Living Abroad who loses his nationality or becomes a refugee or whose home country does not have an NF which is or ever had been a member of the FEI can compete internationally as if he were a national of the host country in all International Events including Championships until his home country has an NF which is a member of theFEI.

Article 123 - Olympic and Regional Games under the Patronage of the IOC, and Paralympic Games under the patronage of the IPC

1. Only Athletes who satisfy the conditions laid down in the GRs, the Olympic Regulations, and the Olympic Charter and its Bylaws may be entered for the Olympic and Regional Games under the patronage of the IOC (see Appendix B). Only Athletes who satisfy the conditions laid down in the GRs, the Paralympic Regulations may beentered for the Paralymic Games.

\section{Changes made to article 123 in the $2008 \mathrm{G}$ eneral Regulations:}

Art. 123.5 was modified as follows:

"Proof of legal citizenship or nationality is necessary to compete for the respective country. In addition, the following conditions apply prior to participation in FEI Championships, FEI World Cup ${ }^{\mathrm{TM}}$ Series, FEI Super LeagueSeries, and FEI Nations Cup Series:

(i) the Competitor must have had legal residence in his new country for (a) a minimum of two uninterrupted years in the new country immediately prior to the competition or (b) a total of five years of non-consecutive periods;

(ii) in the event of a first change of nationality, a competitor shall not havetaken part in competitions for his previous NF in the two years prior to the first compeition hewishes to competein under

his new national ity/citizenship."

\section{FEI GENERAL RE GULATIONS 22 $2^{\text {nd }}$ edition, effective 1] une 2007}

\section{Article 123 -NATIONALITY STATUS OF COM PETITORS}

1. TheNF of a country where a competitor has his national ity/citizenship is his own NF.

2. Except as provided in paragraphs 8 and 12, a competitor may take part in International Events only under thejurisdiction of his own NF.

3. A competitor who is the national/citizen of more than one nation must decide from the age of 18 years which is his own NF and must thereafter, subject to paragraph 4, compete under the jurisdiction of that NF.

4. A competitor who is the national/citizen of more than one country must decide which is his own NF and may take part in competitions for that NF, provided he was citizen/national of that NF by 31st December of the preceding year.

5. Proof of legal citizenship or nationality is necessary to compete for the respective country. In addition, the following conditions apply prior to participation in FEI Championships, FEI World Cup ${ }^{\mathrm{Tm}}$ Series, FEI Super LeagueSeries, and FEI Nations Cup Series:

(i) The Competitor must have had legal residence in his new country for (a) a minimum of two years uninterrupted residence in the new country immediately prior to the competition or (b) a total of five years of non- consecutive periods. 


\section{APPENDICES}

(ii) In the event of a first change of nationality, a competitor shall not have taken part in competitions for his previous NF in the two years prior to the first competition he wishes to compete in under his new nationality/citizenship.

6. In special and exceptional circumstances, the FEI may grant exceptions for justifiable cases, with the agreement of the NFs concemed.

7. Participation to the Olympic and Paralympic Games is subject to Olympic and Paral ympic Regulations.

8. If an associate state, province or overseas department, a country or a colony acquires independence, if a country becomes incorporated within another country by reason of a change of border, or if a new NF is recogni sed by theFEI, a competitor may continue to represent the country to which he bel ongs or bel onged if that country continues to have an NOC. However, he may, if he prefers, choose to represent his new NF. This particular choice must receive the Approval of theFEI and may be made only once

9. All changes of a competitor's NF must be reported by the new NF to the Secretary General of the FEI.

10. Competitors Living Abroad - A competitor is considered to be living abroad if he spends more than six months of a year in one foreign country (the host country).

11. A Competitor Living Abroad can take part regularly in CNs and CIMs and Cls for J uniors, Y oung Riders and Pony Riders of his host country if he is given permission from the NF of his host country or, in very exceptional circumstances, given special Approval by the FEI. The competitor, while keeping his own NF, comes under the jurisdiction of the host NF for the above-mentioned Events and he must take part according to the relevant Sport Rules.

12. A Competitor Living Abroad who loses his nationality or becomes a refugee or whose home country does not havean NF which is or ever has been a member of the FEI can competeinternationally as if he were a national of the host country in all International Events including Championships until his home country has an NF which is a member of theFEl.

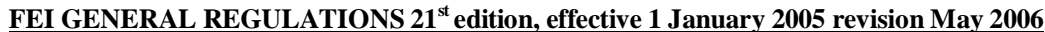
Article 123 -NATIONALITY STATUS OF COM PETITORS

1. TheNF of a country wherea competitor has his nationality/ citizenship is his own NF.

2. Except as provided in paragraphs 4 and 8 , a competitor may take part in international events only under thejurisdiction of his own NF.

3. A competitor who is the national/citizen of more than one nation must decide from the age of 18 years which is his own NF and must thereafter, subject to paragraph 4, compete under the jurisdiction of that NF.

4. If an associate state, province or overseess department, a country or a colony acquires independence, if a country becomes incorporated within another country by reason of a change of border, or if a new NF is recogni sed by the FEI, a competitor may continue to represent the country to which he bel ongs or belonged if that country continues to have an NOC. However, he may, if he prefers, choose to represent his new NF. This particular choice must receive the approval of theFEI and may be made only once

5. All changes of a competitor's NF must bereported by the new NF to the Secretary General of the FEI.

6. The provisions of this Article shall apply to all FEI office holders and candidates for nomination or edection to an office as they apply to competitors.

7. Competitors Living Abroad - A competitor is considered to be living abroad if he spends more than six months of a year in one foreign country (the host country).

8. A Competitor Living Abroad can take part regularly in CNs and $\mathrm{CIMs}$ and $\mathrm{Cl}$ s for J uniors, Y oung Riders and Pony Riders of his host country if he is given permission from the NF of his host country or, in very exceptional circumstances, given special approval by the FEI. The competitor, while keeping his own NF, comes under the jurisdiction of the host NF for the above-mentioned events and he must take part according to the relevant regulations.

9. A Competitor Living Abroad who loses his nationality or becomes a refugee or whose home country does not have an NF which is or ever has been a member of the FEI can compete internationally as if he were a national of the host country in all international events including Championships until his home country has an NF which is a member of theFEl.

FEI GE NE RAL RE GULATIONS $21^{\text {t }}$ edition, effective 1J anuary 2005 Article 123 NATIONALITY STATUS OF COM PETITORS

1. TheNF of a country where a competitor has his nationality/ citizenship is his own NF.

2. Except as provided in paragraphs 4 and 8 , a competitor may take part in international events only under the jurisdiction of his own NF.

3. A competitor who is the national/citizen of more than one nation must decide from the age of 18 years which is his own NF and must thereefter, subject to paragraph 4, compete under thejurisdiction of that NF.

4. If an associate state, province or overseas department, a country or a colony acquires independence, if a country becomes incorporated within another country by reason of a change of border, or if a new NF is recogni sed by the FEI, a competitor may continue to represent the country to which he belongs or belonged if 
that country continues to have an NOC. However, he may, if he prefers, choose to represent his new NF. This particular choice must receive the approval of theFEI and may be made only once

5. All changes of a competitor's NF must bereported by the new NF to the Secretary General of the FEI.

6. The provisions of this Article shall apply to all FEI office holders and candidates for nomination or dection to an office as they apply to competitors.

7. Competitors Living Abroad - A competitor is considered to be living abroad if he spends more than six months of a year in one foreign country (the host country).

8. A Competitor Living Abroad can take part regularly in CNs and CIMs and Cls for J uniors, Y oung Riders and Pony Riders of his host country if he is given permission from the NF of his host country or, in very exceptional circumstances, given special approval by the FEI. The competitor, while keeping his own NF, comes under the jurisdiction of the host NF for the above-mentioned events and he must take part according to the relevant regulations.

9. A Competitor Living Abroad who loses his national ity or becomes a refugee or whose home country does not have an NF which is or ever has been a member of the FEI can compete internationally as if he were a national of the host country in all international events including Championships until his home country has an NF which is a member of theFEl.

\section{Fencing}

\section{FIE Statutes December 2015}

\section{CHAPTER VIII - ELIGIBILITY FOR COM PETITIONS}

8.1.1 Eligibility for competitions

A)To be allowed to participate in the Olympic Games, in all official competitions of the FIE and in all international and national competitions, a fencer must observe and respect the IOC Rules established for admission to the Olympic Games.

\subsection{FE NCERS' NATIONALITY}

9.2.1 At the Olympic Games a competitor's nationality is set by rules of the I.O.C. to which the F.I.E. must conform

9.2.2 For official competitions of the F.I.E., competitors must be strictly of the nationality of the country which they are representing:

a) The fencer who enjoys multiple nationality must choose which country he wishes to represent. The fact that he has fenced for one of the countries implies that he has made a choice If he wishes to represent another country of which he enjoys nationality, he must so advise the Office of the F.I.E. and he may only represent this other country after an interval of three years from when he advised the Central Office of the F.I.E., during which hecan no longer represent the other country.

b) A fencer who has al ready represented a country and acquires a new nationality (from being stateless or through naturalisation) can only represent his new country after an interval of three years from his last participation in a competition for his previous country.

c) The fencer who acquires a new nationality as a result of marriage may fence for that new country immediately, without waiting three years.

d) The Executive Committee of the F.I.E., with the agreement of the member federations concerned, and only for just reasons, may reduce or dispense with the interval of three years.

e)The fencer who has never participated in an official competition of the F.I.E. or in a Regional Championships, is not constrained by these limitations concerning change of nationality and may fence for his new country immediately.

f) Any changein country which a fencer represents is definitive; no further change can be authorised.

g) In cases of dispute the Executive Committee of the F.I.E. will make a ruling, which is not subject to appeal.

9.2.3 For the FIE competitions fencers who are legally stateless may compete as long as they are registered by the member federation of the country in which they live

The practical process for a request of modification of nationality is stated in the FIE Administrative Rules, "Licences and nationality" chapter.

\section{ADMINISTRATIVE RULES OF THE FIE December 2015}

\section{CHAPTER 1}

LICENCES AND NATIONALITY

1.1 The method for awarding FIE licences is determined in Chapter 9 of theFIE Statutes.

1.2 COMMITMENT

The national federations ordering an FIE licence confirm that the athletes who participate in FIE competitions undertaketo:

1) abide by the provisions of theFIE Rules and Statutes; 


\section{APPENDICES}

2) respect the FIE anti-doping Rules, use neither prohibited substances nor prohibited methods and agree to undergo any in competition and out-of competition testing;

3) transfer to the FIE, in FIE competitions, any individual or collective image rights and agree to be filmed (notably by the television), photographed, identified and registered in any way. The FIE undertakes to use these rights only in connection with the promotion and development of fencing on the aids below : publications and reviews, Internet website, audiovisual aids.

\subsection{DE LIVERY}

All application for a licence or a renewal must be made by means of the FIE Internet Website and are only valid if the FIE has al ready been credited with the appropriate licence fe (in Euro/CHF) which is fixed by each Congress for the following season.

A licence is only issued if the following information is provided: family name, first name, nationality, date of birth, gender, personal address, right handed / left handed.

\subsection{CHANGE OF NATIONALITY}

Consult chapter 9.2 of the FIE Statutes.

As delegated by the Executive Committee, all "regular" change of nationality requests are decided by the Legal Commission's Executive Committee representative and by theCEO. The above mentioned persons are also designated to verify that the appropriate grounds for requesting the cancellation or reduction of the 3 year period were indeed presented. The Legal Commission's Executive Committee representative reports periodically on the changes examined.

The "non regular" change of nationality requests (for example a very high level athlete or the multiple transfer of athletes from a federation to another) are decided by the Executive Committee

1.4.1 All athlete change of national ity requests must be made by the particular athlete's new federation.

1.4.2 Any change in country which a fencer represents is definitive; no further change can be authorised.

1.4.3 The federation requesting the change of national ity must forward the foll lowing documents to the FIE: -a letter from the new federation accepting the transfer and requesting the cancellation or reduction of the 3 year period only for just reasons;

-a letter from the athl ete requesting the change of nationality;

-a letter from the former federation accepting the transfer and requesting the cancellation or reduction of the 3 year period only for just reasons;

-a copy of the athlete's valid identity document (passport, ID card, driving licence) indicating his/her new nationality;

-if the athleteis a minor, a letter from his/her parents requesting the change of nationality, and a photocopy of their passports;

-if the new national ity has been obtained by marriage, a copy of the marriage certificate

\section{FIE Statutes, December 2014 (unchanged since 2005)}

\subsection{FE NCERS' NATIONALITY}

9.2.1 At the Olympic Games a competitor's nationality is set by rules of the I.O.C. to which the F.I.E. must conform

9.2.2 For official competitions of the F.I.E., competitors must be strictly of the nationality of the country which they are representing:

a) The fencer who enjoys multiple nationality must choose which country he wishes to represent. The fact that he has fenced for one of the countries implies that he has made a choice If he wishes to represent another country of which he enjoys nationality, he must so advise the Office of the F.I.E. and he may only represent this other country after an interval of three years from when he advised the Central Office of the F.I.E., during which he can no longer represent the other country.

b) A fencer who has al ready represented a country and acquires a new nationality (from being stateless or through naturalisation) can only represent his new country after an interval of three years from his last participation in a competition for his previous country.

c) The fencer who acquires a new nationality as a result of marriage may fence for that new country immediately, without waiting three years.

d) The Executive Committee of the F.I.E., with the agreement of the member federations concerned, and only for just reasons, may reduce or dispense with the interval of three years.

e) The fencer who has never participated in an official competition of the F.I.E. or in a Regional Championships, is not constrained by these limitations concerning change of nationality and may fence for his new country immediately.

f) Any change in country which a fencer represents is definitive, no further change can be authorised.

g) In cases of dispute the Executive Committee of the F.I.E. will make a ruling, which is not subject to appeal.

9.2.3 For the FIE competitions fencers who are legally stateless may compete as long as they are registered by the member federation of the country in which they live 


\section{NATIONALITY REQUIREMENTS IN OLYMPIC SPORTS}

The practical process for a request of modification of nationality is stated in the FIE Administrative Rules, "Licences and nationality" chapter.

\section{Administrative Rules of the FIE, September 2014 \\ 1.4 CHANGE OF NATIONALITY \\ Consult chapter 9.2 of the FIE Statutes.}

As delegated by the Executive Committee, all "regular" change of nationality requests are decided by the Legal Commission's ExecutiveCommittee representative and by theCEO. The above mentioned persons are also designated to verify that the appropriate grounds for requesting the cancellation or reduction of the 3 year period were indeed presented. The Legal Commission's Executive Committee representative reports periodically on the changes examined.

The "non regular" change of nationality requests (for example a very high level athlete or the multiple transfer of athletes froma federation to another) are decided by the Executive Committee

1.4.1 All athlete change of nationality requests must be made by the particular athlete's new federation.

1.4.2 Any change in country which a fencer represents is definitive; no further change can beauthorised.

1.4.3 The federation requesting the change of national ity must forward the foll lowing documents to the FIE:

- a letter from the new federation accepting thetransfer and requesting the cancellation or reduction of the 3 year period only for just reasons;

- a letter from the athlete requesting the change of nationality;

- a letter from the former federation accepting the transfer and requesting the cancellation or reduction of the 3 year period only for just reasons;

- a copy of the athlete's valid identity document (passport, ID card, driving licence) indicating his/her new nationality;

- if the athlete is a minor, a letter from his/her parents requesting the change of nationality, and a photocopy of their passports;

- if thenew nationality has been obtained by marriage, a copy of the marriage certificate

\subsection{OLYM PIC GAMES}

The place and date of the Olympic Games and the Youth Olympic Games are determined by the International Olympic Committee.

Each international Federation recognised by the IOC is responsible for the control and technical organisation of its sport.

Thetechnical liaison with the Organizing Committeeis ensured by the technical delegates of theFIE.

\section{Administrative R ules of the FIE, February 2014}

\section{LICENCES AND NATIONALITY}

1.1 The method for awarding FIE licences is determined in Chapter 9 of the FIE Statutes.

\subsection{COMMITMENT}

The national federations ordering an FIE licence confirm that the athletes who participate in FIE competitions undertaketo:

1) abide by the provisions of theFIE Rules and Statutes;

2) respect the FIE anti-doping Rules, use neither prohibited substances nor prohibited methods and agree to undergo any in competition and out-of competition testing;

3) transfer to the FIE, in FIE competitions, any individual or collective image rights and agree to be filmed (notably by the television), photographed, identified and registered in any way. The FIE undertakes to use these rights only in connection with the promotion and development of fencing on the aids below : publications and reviews, Internet website, audiovisual aids.

\subsection{DELIVERY}

All application for a licence or a renewal must be made by means of the FIE Internet Website and are only valid if the FIE has al ready been credited with the appropriate licence fe (in E uro/CHF) which is fixed by each Congress for the following season. A licence is only issued if the following information is provided: family name, first name, nationality, date of birth, gender, personal address, right handed / left handed.

\subsection{CHANGE OF NATIONALITY}

Consult chapter 9.2 of theFIE Statutes.

As delegated by the Executive Committee, all "regular" change of nationality requests are decided by the Legal Commission's Executive Committee representative and by theCEO. The above mentioned persons are also designated to verify that the appropriate grounds for requesting the cancellation or reduction of the 3 year period were indeed presented. The Legal Commission's Executive Committee representative reports periodically on the changes examined. The "non regular" change of national ity requests (for example a very high level athlete or the multiple transfer of athletes from a federation to another) are decided by the Executive Committee.

1.4.1 All athletechange of national ity requests must be made by the particular athl ete's new federation. 


\section{APPENDICES}

1.4.2 Any change in country which a fencer represents is definitive; no further change can be authorised.

1.4.3 The federation requesting the change of national ity must forward the foll owing documents to the FIE: - a letter from the new federation accepting the transfer and requesting the cancellation or reduction of the 3 year period only for just reasons;

- a letter from the athl ete requesting the change of nationality;

- a letter from the former federation accepting the transfer and requesting the cancellation or reduction of the 3 year period only for just reasons;

- a copy of the athlete's valid identity document (passport, ID card, driving licence) indicating his/her new nationality;

- if the athlete is a minor, a letter from his/her parents requesting the change of nationality, and a photocopy of their passports;

- if the new national ity has been obtained by marriage, a copy of themarriage certificate

\section{Football}

\section{FIFA STATUTE S April 2016 edition}

Regulations Governing the Application of the Statutes Standing Orders of the Congress April 2015 edition

\section{Regulations Governing the Application of the Statutes}

\section{E ligibility to play for representative teams}

\section{Principle}

1. Any person holding a permanent nationality that is not dependent on residence in a certain Country is digible to play for the representative teams of the Association of that Country.

2. With the exception of the conditions specified in article 8 below, any Player who has already partici pated in a match (either in full or in part) in an Official Competition of any category or any type of football for one Association may not play an international match for a representative team of another Association.

\section{Nationality entitling Players to represent more than one Association}

1. A Player who, under the terms of art. 5, is eligible to represent more than one Association on account of his nationality, may play in an international match for one of these Associations only if, in addition to having therel evant nationality, he ful fils at least one of the following conditions:

A) He was born on theterritory of the relevant Association;

B) His bi ol ogical mother or biological father was born on the territory of the relevant Association;

C) His grandmother or grandfather was born on the territory of the relevant Association;

D) He has lived continuously on the territory of the rel evant Association for at least two years.

2. Regardl ess of par. 1 above, Associations sharing a common nationality may make an agreement under which item (d) of par. 1 of this article is deleted completely or amended to specify a longer time limit. Such agreements shall belodged with and approved by the ExecutiveCommittee.

\section{Acquisition of a new nationality}

Any Player who refers to art 5 par.1 to assume a new nationality and who has not played international football in accordance with art. 5 par. 2 shall be eligible to play for the new representative team only if he fulfils one of the following conditions:

A) He was born on theteritory of the relevant Association;

B) His bi ol ogical mother or biological father was born on the territory of the relevant Association;

C) His grandmother or grandfather was born on theterritory of the rel evant Association;

D) He has lived continuously for at least five years after reaching the age of 18 on the teritory of the relevant Association.

\section{Change of Association}

1. If a Player has more than one nationality, or if a Player acquires a new nationality, or if a Player is eligible to play for several representative teams due to nationality, he may, only once, request to change the Association for which he is eligible to play international matches to the Association of another Country of which he holds nationality, subject to the foll owing conditions:

A) He has not played a match (either in full or in part) in an Official Competition at "A" international level for his current Association, and at the time of his first full or partial appearance in an international match in an Official Competition for his current Association, he already had the nationality of the representative team for which he wishes to play.

B) He is not permitted to play for his new Association in any competition in which he has al ready played for his previous Association.

2. If a Player who has been fiel ded by his Association in an international match in accordance with art 5 par. 2 permanently loses the nationality of that Country without his consent or against his will due to a decision by a government authority, he may request permission to play for another Association whose national ity heal ready has or has acquired. 


\section{NATIONALITY REQUIREMENTS IN OLYMPIC SPORTS}

3. Any Player who has the right to change Associations in accordance with par.1 and 2 above shall submit a written, substantiated request to the FIFA general secretariat. The Players' Status Committee shall decide on the request. The procedure will be in accordance with the Rules Governing the Procedures of the Players' Status Committee and the Dispute Resolution Chamber. Once the Player has filed his request, he is not digible to play for any representative team until his request has been processed.

\section{FIFA STATUTE S A pril 2015 edition}

Regulations Governing the Application of the Statutes Standing Orders of the Congress A pril 2015 edition R egulations G overning the Application of the Statutes

III. E ligibility to play for representative teams

5 Principle

1. Any person holding a permanent nationality that is not dependent on residence in a certain Country is eligibleto play for the representative teams of the Association of that Country.

2. With the exception of the conditions specified in article 8 below, any Player who has al ready participated in a match (either in full or in part) in an Official Competition of any category or any type of football for one Association may not play an international match for a representative team of another Association.

\section{Nationality entitling Players to represent more than one Association}

1. A Player who, under the terms of art. 5, is eligible to represent more than one Association on account of his nationality, may play in an international match for one of these Associations only if, in addition to having therelevant nationality, hefulfils at least one of the following conditions:

A) Hewas born on theteritory of the relevant Association;

B) His biological mother or biological father was born on the territory of the relevant Association;

C) His grandmother or grandfather was born on the territory of the relevant Association;

D) Hehas lived continuously on theteritory of the relevant Association for at least two years.

2. Regardless of par. 1 above, Associations sharing a common nationality may make an agreement under which item (d) of par. 1 of this article is deleted completely or amended to specify a longer time limit Such agreements shall belodged with and approved by the Executive Committee

7. Acquisition of a new nationality

Any Player who refers to art. 5 par.1 to assume a new nationality and who has not played international football in accordance with art. 5 par. 2 shall be eligible to play for the new representative team only if he fulfils one of the following conditions:

A) Hewas born on the teritory of the rel evant Association;

B) His biological mother or biological father was born on the territory of the relevant Association;

C) His grandmother or grandfather was born on the teritory of the relevant Association;

D) He has lived continuously for at least five years after reaching the age of 18 on theterritory of the relevant Association.

\section{Change of Association}

1. If a Player has more than one nationality, or if a Player acquires a new nationality, or if a Player is eligible to play for several representative teams due to nationality, he may, only once, request to change the Association for which he is eligible to play international matches to the Association of another Country of which heholds national ity, subject to the foll lowing conditions:

A) He has not played a match (either in full or in part) in an Official Competition at "A" international level for his current Association, and at the time of his first full or partial appearance in an international match in an Official Competition for his current Association, he al ready had the nationality of the representative team for which he wishes to play.

B) He is not permitted to play for his new Association in any competition in which he has al ready played for his previous Association.

2. If a Player who has been fielded by his Association in an international match in accordance with art 5 par. 2 permanently loses the nationality of that Country without his consent or against his will due to a decision by a government authority, he may request permission to play for another Association whose nationality he al ready has or has acquired.

3. Any Player who has the right to change Associations in accordance with par. 1 and 2 above shall submit a written, substantiated request to the FIFA general secretariat. The Players' Status Committee shall decide on the request. The procedure will be in accordance with the Rules Governing the Procedures of the Players' Status Committee and the Dispute Resolution Chamber. Once the Player has filed his request, he is not eligible to play for any representative team until his request has been processed.

São Paulo, 11 J une2014

\section{FIFA ST AT UTE S August 2014 edition}

Regulations Governing the Application of the Statutes of 11 J une 2014

5. Principle 
1. Any person holding a permanent nationality that is not dependent on residence in a certain Country is eligible to play for the representative teams of the Association of that Country.

2. With the exception of the conditions specified in article 8 below, any Player who has al ready participated in a match (either in full or in part) in an Official Competition of any category or any type of football for one Association may not play an international match for a representative team of another Association.

6. Nationality entitling Players to represent more than one Association

1. A Player who, under the terms of art. 5, is eligible to represent more than one Association on account of his nationality, may play in an international match for one of these Associations only if, in addition to having there levant nationality, hefulfils at least one of the foll owing conditions:

A) Hewas born on theteritory of the rel evant Association;

B) His biological mother or biol ogical father was born on the territory of the relevant Association;

C) His grandmother or grandfather was born on the territory of the relevant Association;

D) He has lived continuously on the territory of the relevant Association for at least two years.

2. Regardless of par. 1 above, Associations sharing a common nationality may make an agreement under which item (d) of par. 1 of this article is deleted completely or amended to specify a longer timelimit. Such agreements shall belodged with and approved by the Executive Committee

7. Acquisition of a new nationality

Any Player who refers to art. 5 par.1 to assume a new nationality and who has not played international football in accordance with art. 5 par. 2 shall be eligible to play for the new representative team only if he fulfils one of the following conditions:

A) Hewas born on the teritory of the rel evant Association;

B) His biological mother or biol ogical father was born on the territory of the relevant Association;

C) His grandmother or grandfather was born on the territory of the relevant Association;

D) Hehas lived continuously for at least five years after reaching the age of 18 on the territory of the rel evant Association.

8. Change of Association

1. If a Player has more than one nationality, or if a Player acquires a new nationality, or if a Player is eligible to play for several representative teams due to nationality, he may, only once, request to change the Association for which he is eligible to play international matches to the Association of another Country of which heholds nationality, subject to the following conditions:

A) He has not played a match (either in full or in part) in an Official Competition at "A" international level for his current Association, and at the time of his first full or partial appearance in an international match in an Official Competition for his current Association, he al ready had the nationality of the representative team for which he wishes to play.

B) He is not permitted to play for his new Association in any competition in which he has al ready played for his previous Association.

2. If a Player who has been fiel ded by his Association in an international match in accordance with art. 5 par. 2 permanenty loses the nationality of that Country without his consent or against his will due to a decision by a government authority, he may request permission to play for another Association whose nationality he al ready has or has acquired.

3. Any Player who has the right to change Associations in accordance with par.1 and 2 above shall submit a written, substantiated request to the FIFA general secretariat. The Players' Status Committee shall decide on the request. The procedure will be in accordance with the Rules Governing the Procedures of the Players' Status Committee and the Dispute Resolution Chamber. Once the Player has filed his request, he is not eligibleto play for any representative team until his request has been processed.

\section{FIFA Statutes J uly 2013 edition}

\section{REGULATIONS GOVERNING THE APPLICATION OF THE STATUTES 5 Principle}

1. Any person holding a permanent nationality that is not dependent on residence in a certain Country is eligible to play for the representative teams of the Association of that Country.

2. With the exception of the conditions specified in article 8 below, any Player who has al ready participated in a match (either in full or in part) in an Official Competition of any category or any type of football for one Association may not play an international match for a representative team of another Association.

\section{Nationality entitling Players to represent more than one Association}

1. A Player who, under the terms of art. 5, is eligible to represent more than one Association on account of his nationality, may play in an international match for one of these Associations only if, in addition to having the relevant nationality, he fulfils at least one of the foll owing conditions:

a) Hewas born on the territory of the relevant Association;

b) His biological mother or biological father was born on the territory of the relevant Association;

c) His grandmother or grandfather was born on the territory of the relevant Association; 


\section{NATIONALITY REQUiREMENTS IN Oly mpic SPORTS}

d) Hehas lived continuously on the territory of the relevant Association for at least two years.

2. Regardless of par. 1 above, Associations sharing a common nationality may make an agreement under which item (d) of par. 1 of this article is deleted completely or amended to specify a longer timelimit. Such agreements shall belodged with and approved by the Executive Committee

\section{Acquisition of a new nationality}

Any Player who refers to art. 5 par. 1 to assume a new nationality and who has not played international football in accordance with art 5 par. 2 shall be eligible to play for the new representative team only if he fulfils one of the following conditions:

a) Hewas born on theteritory of the relevant Association;

b) His biological mother or biological father was born on the territory of the relevant Association;

c) His grandmother or grandfather was born on the territory of the relevant Association;

d) Hehas lived continuously for at least fi ve years after reaching the age of 18 on theterritory of the relevant Association.

\section{Change of Association}

1. If a Player has more than one nationality, or if a Player acquires a new nationality, or if a Player is eligible to play for several representative teams due to nationality, he may, only once, request to change the Association for which he is eligible to play international matches to the Association of another Country of which heholds nationality, subject to the foll owing conditions:

a) He has not played a match (either in full or in part) in an Official Competition at " $A$ " international level for his current Association, and at the time of his first full or partial appearance in an international match in an Official Competition for his current Association, he al ready had the nationality of the representative team for which he wishes to play.

b) He is not permitted to play for his new Association in any competition in which he has al ready played for his previous Association.

2. If a Player who has been fiel ded by his Association in an international match in accordance with art. 5 par. 2 permanently loses the nationality of that Country without his consent or against his will due to a decision by a government authority, he may request permission to play for another Association whose nationality he al ready has or has acquired.

3. Any Player who has the right to change Associations in accordance with par. 1 and 2 above shall submit a written, substantiated request to the FIFA general secretariat. The Players' Status Committee shall decide on the request. The procedure will be in accordance with the Rules Governing the Procedures of the Players' Status Committee and the Dispute Resolution Chamber. Once the Player has fi led his request, he is not eligible to play for any representative team until his request has been processed.

FIFA Statutes J uly 2012 edition - REGULATIONS GOVERNING THE APPLICATION OF THE STATUTES

III. Eligibility to play for representative teams

5. Principle

1. Any person holding a permanent nationality that is not dependent on residence in a certain country is eligibleto play for the representative teams of the Association of that country.

2. With the exception of the conditions specified in article 8 below, any Player who has al ready participated in a match (either in full or in part) in an official competition of any category or any type of football for one Association may not play an international match for a representativeteam of another Association.

6 Nationality entitling players to represent more than one Association

1. A Player who, under the terms of art. 5, is eligible to represent more than one Association on account of his nationality, may play in an international match for one of these Associations only if, in addition to having the relevant nationality, he fulfils at least one of the following conditions:

(a)Hewas born on the territory of the relevant Association;

(b)His biological mother or biological father was born on the territory of the relevant Association;

(c) His grandmother or grandfather was born on the territory of the relevant Association;

(d) Hehas lived continuously on the territory of the relevant Association for at least two years.

2. Regardless of par. 1 above, Associations sharing a common nationality may make an agreement under which item (d) of par. 1 of this article is deleted completely or amended to specify a longer timelimit. Such agreements shall belodged with and approved by the Executive Committee

7. Acquisition of a new nationality

Any Player who refers to art. 5 par. 1 to assume a new nationality and who has not played international football in accordance with art. 5 par. 2 shall be eligible to play for the new representative team only if he fulfils one of the following conditions:

(a)Hewas born on the territory of the relevant Association;

(b) His biological mother or biological father was born on the territory of the relevant Association;

(c)His grandmother or grandfather was born on the territory of the rel evantAssociation; 


\section{APPENDICES}

(d) Hehas lived continuously for at least fiveyears after reaching the age of 18 on theteritory of the relevant Association.

\section{Change of Association}

1. If a Player has more than one nationality, or if a Player acquires a new national ity, or if a Player is eligible to play for several representative teams due to nationality, he may, only once, request to change the Association for which he is eligible to play international matches to the Association of another country of which he holds national ity, subject to the foll lowing conditions:

(a) He has not played a match (either in full or in part) in an official competition at " $A$ " international level for his current Association, and at the time of his first full or partial appearance in an international match in an official competition for his current Association, he al ready had the national ity of the representative team for which hewishes to play.

(b)He is not permitted to play for his new Association in any competition in which he has al ready played for his previous Association.

2. If a Player who has been fiel ded by his Association in an international match in accordance with art. 5 par. 2 permanently loses the nationality of that country without his consent or against his will due to a decision by a government authority, he may request permission to play for another Association whose nationality he al ready has or has acquired.

3. Any Player who has the right to change Associations in accordance with par. 1 and 2 above shall submit a written, substantiated request to the FIFA general secretariat. The Players' Status Committee shall decide on the request. The procedure will be in accordance with the Rules Governing the Procedures of the Players' Status Committee and the Dispute Resolution Chamber. Once the Player has filed his request, he is not eligible to play for any representative team until his request has been processed.

\section{FIFA Statutes J uly 2011 edition REGULATIONS GOVERNING THE APPLICATION OF THE}

\section{STATUTES}

III. Eligibility to play for representativeteams

\section{Principle}

1. Any person holding a permanent nationality that is not dependent on residence in a certain country is eligibleto play for the representative teams of the Association of that country.

2. With the exception of the conditions specified in article 8 bel ow, any Player who has al ready participated in a match (either in full or in part) in an official competition of any category or any type of football for one Association may not play an international match for a representative team of another Association.

\section{Nationality entitling players to represent more than one Association}

1. A Player who, under the terms of art. 5, is eligible to represent more than one Association on account of his nationality, may play in an international match for one of these Associations only if, in addition to having the relevant nationality, hefulfils at least one of the foll owing conditions:

(a)Hewas born on the territory of the relevant Association;

(b) His biological mother or biological father was born on the territory of the relevant Association;

(c) His grandmother or grandfather was born on the territory of the rel evant Association;

(d) He has lived continuously on the territory of the relevant Association for at least two years.

2. Regardless of par. 1 above, Associations sharing a common nationality may make an agreement under which item (d) of par. 1 of this article is deleted completely or amended to specify a longer timelimit. Such agrements shall belodged with and approved by the Executive Committee

\section{Acquisition of a new nationality}

Any Player who refers to art. 5 par. 1 to assume a new nationality and who has not played international football in accordance with art. 5 par. 2 shall be eligible to play for the new representative team only if he fulfils one of the following conditions:

(a) Hewas born on the territory of the relevant Association;

(b) His biological mother or biological father was born on the territory of the relevant Association;

(c)His grandmother or grandfather was born on the territory of the rel evant Association;

(d) Hehas lived continuously for at least five years after reaching the age of 18 on theteritory of the relevant Association.

\section{Change of Association}

1. If a Player has more than one nationality, or if a Player acquires a new nationality, or if a Player is eligible to play for several representative teams due to nationality, he may, only once, request to change the Association for which he is eligible to play international matches to the Association of another country of which he holds nationality, subject to the foll owing conditions:

(a) Hehas not played a match (either in full or in part) in an official competition at " $A$ " international level for his current Association, and at the time of his first full or partial appearance in an international match in an official competition for his current Association, he al ready had the national ity of the representative team for which hewishes to play. 


\section{NATIONALITY REQUiREMENTS IN Oly mpic SPORTS}

(b) He is not permitted to play for his new Association in any competition in which he has al ready played for his previous Association.

2. If a Player who has been fielded by his Association in an international match in accordance with art 5 par. 2 permanently loses the national ity of that country without his consent or against his will dueto a decision by a government authority, he may request permission to play for another Association whose nationality he al ready has or has acquired.

3. Any Player who has the right to change Associations in accordance with par. 1 and 2 above shall submit a written, substantiated request to the FIFA general secretariat. The Players' Status Committee shall decide on the request. The procedure will be in accordance with the Rules Governing the Procedures of the Players' Status Committee and the Dispute Resolution Chamber. Once the Player has filed his request, he is not eligible to play for any representative team until his request has been processed.

FIFA Statutes August 2010 edition - RE GULATIONS GOVE R NING THE APPLICATION OF THE STATUTES

\section{ELIGIBILITY TO PLAY FOR REPRESENTATIVE TEAMS}

15. Principle

1. Any person holding a permanent nationality that is not dependent on residence in a certain country is eligible to play for the representative teams of the Association of that country.

2. With the exception of the conditions specified in article 18 below, any Player who has al ready participated in a match (either in full or in part) in an official competition of any category or any type of football for one Association may not play an international match for a representative team of another Association.

16. Nationality entitling players to represent more than one Association

1. A Player who, under the terms of art. 15, is eligible to represent more than one Association on account of his nationality, may play in an international match for one of these Associations only if, in addition to having therelevant nationality, he fulfils at least one of the foll owing conditions:

(a) Hewas born on the territory of the relevant Association;

(b) His biological mother or biological father was born on the territory of the relevant Association;

(c) His grandmother or grandfather was born on the teritory of the relevant Association;

(d) Hehas lived continuously on the territory of the relevant Association for at least two years.

2. Regardless of par. 1 above, Associations sharing a common nationality may make an agreement under which item (d) of par. 1 of this article is deleted completely or amended to specify a longer timelimit. Such agreements shall belodged with and approved by the Executive Committee

17. Acquisition of a new nationality

Any Player who refers to art 15 par. 1 to assume a new nationality and who has not played international football in accordance with art. 15 par. 2 shall be eligible to play for the new representative team only if he fulfils one of the following conditions:

(a) Hewas born on the teritory of the relevant Association;

(b) His biological mother or biological father was born on theterritory of the relevant Association;

(c) His grandmother or grandfather was born on the territory of the rel evant Association;

(d) Hehas lived continuously for at least five years after reaching the age of 18 on theterritory of the relevant Association.

18. Change of Association

1. If a Player has more than one nationality, or if a Player acquires a new nationality, or if a Player is eligible to play for several representative teams due to nationality, he may, only once, request to change the Association for which he is eligible to play international matches to the Association of another country of which he holds nationality, subject to thefollowing conditions:

(a) Hehas not played a match (either in full or in part) in an official competition at " $A$ " international level for his current Association, and at the time of his first full or partial appearance in an intemational match in an official competition for his current Association, he al ready had the national ity of the representative team for which he wishes to play.

(b) Heis not permitted to play for his new Association in any competition in which he has al ready played for his previous Association.

2. If a Player who has been fielded by his Association in an international match in accordance with art 15 par. 2 permanently loses the nationality of that country without his consent or against his will due to a decision by a government authority, he may request permission to play for another Association whose nationality heal ready has or has acquired.

3. Any Player who has the right to change Associations in accordance with par. 1 and 2 above shall submit a written, substantiated request to the FIFA general secretariat. The Players' Status Committee shall decide on the request. The procedure will be in accordance with the Rules Governing the Procedures of the Players' Status Committee and the Dispute Resolution Chamber. Once the Player has filed his request, he is not eligible to play for any representative team until his request has been processed. 
FIFA Statutes August 2009 edition REGULATIONS GOVER NING THE APPLICATION OF THE STATUTES

\section{ELIGIBILITY TO PLAY FOR REPRESENTATIVE TEAMS}

15. Principle

1. Any person holding a permanent nationality that is not dependent on residence in a certain country is eligible to play for the representativeteams of the Association of that country.

2. With the exception of the conditions specified in article 18 below, any Player who has al ready participated in a match (either in full or in part) in an official competition of any category or any type of football for one Association may not play an international match for a representative team of another Association.

16. Nationality entitling players to represent more than one Association

1. A Player who, under the terms of art. 15, is eligible to represent more than one Association on account of his national ity, may play in an international match for one of these Associations only if, in addition to having therelevant nationality, hefulfils at least one of the foll owing conditions:

(a) Hewas born on theteritory of the relevant Association;

(b) His biological mother or biological father was born on the territory of therelevant Association;

(c) His grandmother or grandfather was borm on the teritory of the relevant Association;

(d) Hehas lived continuously on the territory of the relevant Association for at least two years.

2. Regardless of par. 1 above, Associations sharing a common nationality may make an agreement under which item (d) of par. 1 of this article is deleted completely or amended to specify a longer time limit. Such agrements shall belodged with and approved by the Executive Committee

17. Acquisition of a new nationality

Any Player who refers to art 15 par. 1 to assume a new nationality and who has not played international football in accordance with art. 15 par. 2 shall be eligible to play for the new representative team only if he fulfils one of the following conditions:

(a) Hewas born on the territory of the relevant Association;

(b) His biological mother or biological father was born on the territory of the relevant Association;

(c) His grandmother or grandfather was born on the teritory of the relevant Association;

(d) He has lived continuously for at least five years after reaching the age of 18 on theteritory of the relevant Association.

\section{Change of Association}

1. If a Player has more than one nationality, or if a Player acquires a new nationality, or if a Player is eligible to play for several representative teams due to nationality, he may, only once, request to change the Association for which he is eligible to play international matches to the Association of another country of which heholds nationality, subject to thefollowing conditions:

(a) Hehas not played a match (either in full or in part) in an official competition at " $A$ " international level for his current Association, and at the time of his first full or partial appearance in an international match in an official competition for his current Association, he al ready had the national ity of the representative team for which hewishes to play.

(b) Heis not permitted to play for his new Association in any competition in which he has al ready played for his previous Association.

2. If a Player who has been fielded by his Association in an international match in accordance with art 15 par. 2 permanently loses the nationality of that country without his consent or against his will due to a decision by a government authority, he may request permission to play for another Association whose national ity heal ready has or has acquired.

3. Any Player who has the right to change Associations in accordance with par. 1 and 2 above shall submit a written, substantiated request to the FIFA general secretariat. The Players' Status Committee shall decide on the request. The procedure will be in accordance with the Rules Governing the Procedures of the Players' Status Committee and the Dispute Resolution Chamber. Once the Player has filed his request, he is not eligible to play for any representative team until his request has been processed.

\section{FIFA ST AT UTE S R egulations Governing the Application of the Statutes M ay 2008 edition}

Regulations Governing the Application of the Statutes

\section{Article 15 Principle}

1. Any person holding a permanent nationality that is not dependent on residence in a certain country is eligible to play for the representative teams of the Association of that country.

2. With the exception of the conditions specified in article 18 below, any Player who has al ready participated in a match (either in full or in part) in an official competition of any category or any type of football for one Association may not play an international match for a representative team of another Association.

Article 16 Nationality entitling players to represent more than one Association

A Player who, under the terms of art. 15, is eligible to represent more than one Association on account of his nationality, may play in an international match for one of these Associations only if, in addition to having the 


\section{NATIONALITY REQUIREMENTSIN OLYMPIC SPORTS}

relevant nationality, he fulfils at least one of the following conditions:

(a) Hewas borm on theteritory of the relevant Association;

(b) His biological mother or biological father was born on the territory of the relevant Association;

(c) His grandmother or grandfather was born on the territory of the relevant Association;

(d) Hehas lived continuously on the territory of the relevant Association for at least two years.

2. Regardless of par. 1 above, Associations sharing a common nationality may make an agreement under which item (d) of par. 1 of this article is deleted completely or amended to specify a longer timelimit. Such agreements shall belodged with and approved by the Executive Committee

Article 17 Acquisition of a new nationality

Any Player who refers to art 15 par. 1 to assume a new nationality and who has not played international football in accordance with art. 15 par. 2 shall be eligible to play for the new representative team only if he fulfils one of the following conditions:

(a) Hewas born on theteritory of the relevant Association;

(b) His biological mother or biological father was born on the territory of the relevant Association;

(c)His grandmother or grandfather was born on the territory of the rel evant Association;

(d) Hehas lived continuously for at least five years after reaching the age of 18 on theteritory of the relevant Association.

Article $18 \mathrm{C}$ hange of Association

1. If a Player has more than one nationality, or if a Player acquires a new nationality, or if a Player is eligible to play for several representative teams due to nationality, he may, up to his 21st birthday, and only once, request to change the Association for which he is eligible to play international matches to the Association of another country of which he holds nationality, subject to the following conditions:

a) He has not played a match (either in full or in part) in an official competition at " $A$ " international level for his current Association, and at the time of his first full or partial appearance in an international match in an official competition for his current Association, he al ready had the national ity of the representative team for which hewishes to play.

b) He is not permitted to play for his new Association in any competition in which he has al ready played for his previous Association.

2. If a Player who has been fielded by his Association in an intemational match in accordance with art. 15 par. 2 permanently loses the nationality of that country without his consent or against his will due to a decision by a government authority, he may request permission to play for another Association whose nationality heal ready has or has acquired.

3. Any Player who has the right to change Associations in accordance with par. 1 and 2 above shall submit a written, substantiated request to the FIFA general secretariat. The Players' Status Committee shall decide on the request. The procedure will be in accordance with the Rules Governing the Procedures of the Players' Status Committee and the Dispute Resolution Chamber. Once the Player has filed his request, he is not eligible to play for any representativeteam until his request has been processed

Regulations on the Status and Transfer of Players J uly 2005 with amendments in force on 1 J anuary 2008.

ANNEXE 2 ELIGIBILITY TO PLAY FOR ASSOCIATION TEAMS OF PLAYERS WHOSE
NATIONALITY ENTITLES THEM TO REPRESENT MORE THAN ONE ASSOCIATION
Article 1 Conditions

1. A player who, under the terms of article 15 of the Regulations Governing the Application of the FIFA Statutes, is eligible to represent more than one association on account of his nationality, may play in an international match for one of these associations only if, in addition to having the relevant nationality, he fulfils at least one of the following conditions:

a) hewas born on the territory of the relevant association;

b) his biological mother or biological father was born on theteritory of the relevant association;

c) his grandmother or grandfather was born on the territory of the relevant association;

d) he has lived on the territory of the rel evant association for at least two years without interruption.

2. Notwithstanding paragraph 1 of this article, associations sharing a common nationality may make an agreement under which item d) of paragraph 1 of this article is deleted completely or amended to specify a longer timelimit. Such agreements must be lodged with and approved by FIFA.

FIFA ST AT UTES - Regulations G overning the Application of the Statutes 2007 VII. ELIGIBILITY TO PLAY FOR ASSOCIATION TEAMS

Article 15 Principle

1. Any person holding the nationality of a country is eligible to play for the representative teams of the Association of that country. The Executive Committee shall decide on the conditions of eligibility for any Player who has not played international football in accordance with par. 2 below, and either acquires a new 
nationality or is eligible to play for the teams of more than oneAssociation due to his nationality.

2.With the exception of the conditions specified in par. 3 and 4 below, any Player who has already represented one Association in a match (either in full or in part) in an official competition of any category or any type of football may not play an international match for a representative team of another Association.

3. If a Player has more than one nationality, or if a Player acquires a new nationality, or if a Player is eligible to play for several Associations' teams due to nationality, he may, up to his 21st birthday, request to change the Association for which he is eligible to play international matches to the Association of another country of which he holds national ity, subject to the foll lowing conditions:

(a)He has not played a match (either in full or in part) at " $A$ " inter- national level for his current Association, and if at the time of his first full or partial appearance in an international match in an official competition for his current Association, he al ready had the nationality of the Association's team for which he wishes to play. (b) He is not permitted to play for his new Association in any com- petition in which he has al ready played for his previous Association. A player may exercisethis right only once.

4. If a Player who has been fielded by his Association in an international match in accordance with par. 2 above permanently loses the nationality of that country without his consent or against his will due to a decision by a government authority, he may request permission to play for another Association whose nationality heal ready has or has acquired.

5. Any Player who has the right to change Associations in accordance with par. 3 and 4 above shall submit a written, substantiated request to the FIFA general secretariat. The Players' Status Committee shall decide on the request. The procedure will be in accordance with the Rules Governing the Procedures of the Players' Status Committee and the Dispute Resolution Chamber. Once the player has filed his request, he is not eligible to play for any Association team until his request has been processed.

\section{FIFA R egulations for the Status and Transfer of Players 2005}

\section{AnneX II ELIGIBILITY TO PLAY FOR ASSOCIATION TEAMS FOR PLAYERS WHOSE NATIONALITY ENTITLES THEM TO REPRESENT MORE THAN ONE ASSOCIATION Articlel Conditions}

1. A player who, under the terms of Art 15 of the Regulations Governing the Application of the FIFA Statutes, is eligible to represent more than one Association on account of his nationality, may play in an international match for one of these Associations only if, in addition to having the relevant nationality, he fulfils at least one of the following conditions:

a) hewas born on theteritory of the relevant Association;

b) his biological mother or biological father was born on theterritory of the relevant Association;

c) his grandmother or grandfather was born on the territory of the relevant Association;

d) he has lived on the territory of the rel evant Association for at least two years without interruption.

2. Notwithstanding par. 1 of this article, Associations sharing a common national ity may make an agreement under which item d) of par. 1 of this article is deleted completely or amended to specify a longer time limit. Such agreements must belodged with and approved by FIFA.

\section{G olf}

\section{IGF NATIONALITY POLICY J Une 2014}

\section{General}

Any competitor in an International Golf Competition (Section II) must be a National of the country which the competitor is representing or under which the competitor is eligible for the competition.

The IGF publishes this Nationality Policy as it pertains to matters relating to the determination of the country which a competitor may represent in an International Golf Competition listed below, and from timeto-time will advise sanctioning organizations of International Golf Competitions as to guidelines and standards on making determinations on a competitor's Nationality.

Each sanctioning organization has adopted the IGF Nationality Policy and shares decisions based on nationality with the IGF and other sanctioning organizations. All matters relating to the determination of the country which a competitor may represent in an International Golf Competition listed below shall be resol ved by the sanctioning organization for that event, in its sol e discretion.

$$
\text { [...] }
$$

III. Nationality

A competitor will be considered a National of a country if the competitor is a citizen of the country, as defined by the laws of such country.

A competitor who is a National of two or more countries at the same time may represent either one of them, as the competitor may elect. However, after having represented one country in an International Golf Competition, the competitor may not represent another country unless first meeting the conditions set forth below that apply to persons who have changed their national ity or acquired a new national ity.

A competitor who has represented one country in an International Golf Competition, and who has changed 
nationality or acquired a new nationality, may participate in another International Golf Competition representing the new country provided that, as of the start of the qualification period for such event, at least four years have passed since the competitor last represented his/her former country. This period may be extended, reduced or even cancelled, with the agreement of the sanctioning organization, which takes into account the circumstances of each case and any applicable guidelines and standards provided by the IGF.

If an associated State, province or overseas department, a country or colony acquires independence, if a country becomes incorporated within another country by reason of a change of border, or if a country merges with another country, a competitor may continue to represent the country to which the competitor belongs or belonged. However, if the competitor prefers, the competitor may elect to represent the new country. This particular choice may be made only once

Furthermore, in all cases in which a competitor would be eligible to participate in an International Golf Competition, either by representing another country than his/hers or by having the choice as to the country which such competitor intends to represent, the sanctioning organization may take all decisions of a general or individual nature with regard to issues resulting from nationality, citizenship, domicile or residence of any competitor, including the duration of any waiting period, taking into account the circumstances of each case and any applicable guidelines and standards provided by the IGF.

\section{Countries and Continents}

For the purposes of defining a country (or territory, if applicable) of which a competitor is a National, the current list of National Olympic Committees as recognized by the International Olympic Committee will be used. For International Golf Competitions other than the Olympic Games and Y outh Olympic Games, England, Scotland and Wales will beconsidered to be separatecountries.

$$
\text { [...] }
$$

\section{Rankings}

A competitor should ensure that his/her nationality is correctly listed on the appropriate world golf ranking system For women's International Golf Competitions, this shall be the Rolex Women's World Rankings. For men's International Golf Competitions, this shall be the Official World Golf Rankings. For the purposes of applying this policy, the competitor will be presumed to be a National of the country listed on the appropriate world rankings system, subject to verification in accordance with this policy. Any decisions taken related to a compeitor's nationality in accordance with this policy shall be referred by the IGF to the appropriate ranking system, who shall display the correct nationality of each player within the rankings. A competitor eligible to participate in an International Golf Competition by representing another country to the one previously represented (by either changing nationality or acquiring a new nationality) in accordance with this policy will only be eligible for International Golf Competitions for which the qualification period has not yet started, unless otherwise al lowed by the sanctioning organization.

A competitor eligible to participate in an International Golf Competition by having the choice as to the country which such competitor intends to represent in accordance with this policy will only be eligible for International Golf Competitions for which the qualification period has not yet started, unless otherwise all owed by the sanctioning organization.

A competitor who changes his/her nationality for an International Golf Competition prior to the qualifications and eligibility period beginning for such event, yet subsequently fails to qualify for the competition, is subject to the provisions of this policy induding thet ime periods prescribed herein.

\section{Gymnastics}

FÉDÉRATION INTERNATIONALE DE GYMNASTIQUE- QUALIFICATION SYSTEM GAMES OF THE XXXI OLYM PIAD - RIO 2016-Artistic Gymnastics

\section{ATHLETE ELIGIBILITY}

All athletes must comply with the provisions of the Olympic Charter currently in force and only those athletes who have complied with the Olympic Charter may participate in the Olympic Games. This includes Rule41 of the Olympic Charter (Nationality of Competitors).

Age Requirements:

All athletes participating in the Rio 2016 Olympic Games must be born:

on or before 31 December 1998 for the Men's competitions.

on or before 31 December 2000 for theWomen's competitions.

Additional IF Requirements:

To be eligible to participatein the Rio 2016 Olympic Games, all athletes must:

- have reached the minimum technical standard established by FIG. Full information regarding the mini mum technical standards is available on theFIG official website (www.fig- gymastics.com)

- hold a valid FIG License until the end of the 2016 Olympic Games Artistic Gymastics competitions.

In addition, only NOCs which had a team entered at the 2015 World Championships and/or at the 2016 Olympic Games Test Events will be eligible to earn a team quota place 


\section{APPENDICES}

All individual athletes who are not part of a team, including those receiving Host Country and/or Tripartite Commission Invitation places must have participated at the 2015 World Championships and/or at the 2016 Olympic Games Test Events.

FÉDÉRATION INTERNATIONALE DE GYMNASTIQUE - QUALIFICATION SYSTEM GAMES OF THE XXXI OLYM PIAD - RIO 2016- Rhythmic Gymnastics

C. ATHLETE ELIGIBILITY

All athletes must comply with the provisions of the Olympic Charter currently in force and only those athletes who have complied with the Olympic Charter may participate in the Olympic Games. This includes Rule41 of the Olympic Charter (Nationality of Competitors).

Age Requirements:

All athletes participating in the Rio 2016 Olympic Games must be born on or before 31 December 2000.

Additional IF Requirements:

To be eligible to participate in the Rio 2016 Olympic Games, all athletes must:

have reached the mini mum technical standard established by FIG. Full information regarding the mini mum technical standards is available on theFIG official website (www.fig-gymastics.com).

hold a valid FI G License until the end of the 2016 Olympic Games Rhythmic Gymastics competitions.

In addition, only NOCs which had a group entered at the 2015 World Championships and/or at the 2016

Olympic Games Test Events will be eligible to earn a Group quota place. For the Host Country, a Group

must have participated in the 2014 World Championships and, if qualified, in the 2015 World Championships and in the Olympic Games Test Events in order to obtain its quota place

All individual athletes, including those receiving Host Country and Tripartite Commission Invitation places, must have participated at the 2015 World Championships and/or at the 2016 Olympic Games Test Events.

FÉDÉRATION INTERNATIONALE DE GYMNASTIQUE - QUALIFICATION SYSTEM GAME S OF THE XXXI OLYM PIAD - RIO 2016- Trampoline

C. ATHLETE ELIGIBILITY

All athletes must comply with the provisions of the Olympic Charter currently in force, including but not limited to, Rule 41 (Nationality of Competitors). Only those athletes who have complied with the Olympic Charter may participate in the Olympic Games.

Age Requirements:

All athletes participating in the Rio 2016 Olympic Games must be born on or before 31 December 1998.

Additional IF Requirements:

To be eligible to participate in the Rio 2016 Olympic Games, all athletes must:

have reached the mini mum technical standard established by FIG. Full information regarding the mini mum technical standards is available on the FIG official website (www.fig-gymnastics.com)

hold a valid FI G License until the end of the 2016 Olympic Games Trampoline Gymnastics competitions. In addition, NOCs must have participated in the 2015 World Championships and/or the 2016 Olympic Games Test Event for their gymasts to be eligible to competeat the Rio 2016 Olympic Games.

For places obtained through the Continental representation criteria, the Host Country place or the Tripartite Commission Invitation place, the gymmast who obtains the quota place must have participated in the 2015 World Championships and/or the 2016 Olympic Games Test Event to be eligi ble

QUALIFICATION SYSTEM - GAMES OF THE XXX OLYMPIAD FIG ORIGINAL VERSION: ENGLISH APRIL 2011 - PAGE 1/10 FEDERATION INTERNATIONALE DE GYM NASTIQUE Artistic Gymastics APR IL 2011 - PAGE 1/10

C. Athlete Eligibility

ATH LETE ELIG I IL ITY All athletes must comply with the provisions of the Olympic Charter currently in forceand only those athletes who have complied with the Olympic Charter may participatein the Olympic Games.

NOCs which had a team entered at the 2011 World Championships and/or the Olympic Games Test Events will be eligible to earn a team quota place All individual athletes must have participated at the 2011 World Championships and/or the Olympic Games Test Events.

All athletes must have reached the minimum technical standard established by FIG. Full information regarding the minimum technical standards is available on the FIG official website (www.figgymnastics.com).

In order to be eligible to participate, athletes must be born in 1996 or earlier

QUALIFICATION SYSTEM - GAMES OF THE XXX OLYMPIAD FIG ORIGINAL VERSION: ENGLISH APRIL 2011 - PAGE 5/10FEDERATION INTERNATIONALE DE GYM NASTIQUE Rhythmic Gymmastics 


\section{Athlete E ligibility}

\section{ATHLETE ELIGIBILITY}

All athletes must comply with the provisions of the Olympic Charter currently in force and only those athl etes who have complied with the Olympic Charter may participate in theOlympic Games.

Only NOCs which had a group entered at the 2011 World Championships and/or the Olympic Games Test Events will be eligibleto earn a group quota place For the Host Country, the group must have participated in the 2010 World Championships and, if qual ified, in the 2011 World Championships and the Olympic Games Test Events in order to obtain its quota place All individual athletes must have participated at the 2011 World Championships and/or the Olympic Games Test Events.

All athletes must have reached the minimum technical standard established by FIG. Full information regarding the minimum technical standards is available on the FIG official website (mww.figgymastics.com)

In order to be eligible to participate, athletes must be born in 1996 or €arlier.

QUALIFICATION SYSTEM - GAMES OF THE XXX OLYMPIAD FIG ORIGINAL VERSION: ENGLISH APRIL 2011 - PAGE 8/10 FEDERATION INTERNATIONALE DE GYM NASTIQUE

Trampoline

\section{Athlete Eligibility}

\section{ATHLETE ELIGIBILITY}

All athletes must comply with the provisions of the Olympic Charter currently in force and only those athletes who have complied with the Olympic Charter may participate in the Olympic Games.

NOCs must have participated in the 1st and/or 2nd Olympic qualification for their gymasts to be eligible to compete at the Olympic Games

For places obtained through the continental representation criteria, the host country quota or as tripartite invitation, the gymnast who obtains the quota place must have participated in the 1st and/or 2nd Olympic qualification in order to be eligible

All athletes must have reached the minimum technical standard established by FIG. Full information regarding the minimum technical standards is available on the FIG official website (www.figgymnastics.com)

In order to be eligible to participate, athletes must be born in 1994 or earlier.

FIG Licence R ules Final version - last update September 25th 2012/mb 1/5 (unchanged since 2005)

\section{Introduction:}

At the 2008 Council in Cape Town (RSA), Artide 5.1 of the FIG Technical Regulations was extended and the principle of a compul sory Licence or "gymastics passport" was introduced.

\section{Reg. 5.1 GENERAL RIGHTS OF PARTICIPATION IN COMPETITIONSAND LICENCE}

Official FIG competitions are open to gymasts who:

- belong to a federation affiliated to the FIG

- have the nationality of the federation in accordance with the FIG Statutes,

- Technical Regulations and the Olympic provisions

- fulfil the requirements of the Statutes (as well as the admission conditions)

- fulfil specified performance prerequisites (.i.e. limits)

- havea valid licence as long as the prescriptions of the rules elaborated by

$\square$ the FIG Executive Committeeare respected

The following rules have been decided by the FIG Executive Committee based on the above mentioned Article 5.1. of theFIG Technical Regulations.

2. Compulsory Licence or "G ymnastics Passport"

All gymnasts (Age Group, juniors and seniors) must be in possession of a valid FIG Licence in order to be eligible to participate in an international competition. "Gymastics for All" events are exempted from this rule.

The following competitions are defined as INTERNATIONAL COMPETITIONS under these Licence Rules:

World Championships

Continental Championships and Games

Any and all Multisport Games (Olympic Games, World Games, Mediterranean Games,

Commonwealth Games, Central American Games, University Games, etc.)

World Cup events

FIG sanctioned International Events

3. Conditions to obtain an FIG Licence

TheFIG Licence shall only beissued to those gymmasts who: 
$\square$ fulfil the conditions mentioned in Article 5.1 of the FIG Technical Regulations; have personally signed Appendix I of the Licence Rules (FIG Licence - application form). Through their signature, gymasts consent and agree to comply with and be bound by the FIG Statutes and any and all of the FIG Rules and Regulations and their amendments;

- have personally signed Appendix I of the Licence Rules (Acknowledgement and Agreement). Through their signature, gymasts consent and agree to the creation of their profile in WADA Doping Control Clearing House (ADAMS), and/or any other similar system from an authorized National Anti-Doping Organization (NADO) under FIG's agreement for the sharing of information, and to the entry in such systems of data related to their doping controls, Whereabouts and Therapeutic Use Exemptions;

- belong to an FIG affiliated Federation in good standing;

- have obtained the signature of thePresident or the Secretary General of their National

Federation on the application form

5. Validity of the Licence

The Licence shall be valid for two years as of its issue date by FIG.

FÉdÉRATION INTERNATIONALE DE GYMNASTIQUE STATUTES E D I T I 0 N 2015 in effect from J anuary 1st, 2015 (unchanged since 2005)

ARTICLE 36

Nationality of G ymnasts and J udges and membership within a Federation

36.1 Principle

In principle, gymnasts and judges taking part in any international competition must have the nationality (citizenship) of the federations they represent and authority to participate, from their federation.

36.2 Permission to represent another federation

36.2.1 Gymnasts who have represented their countries internationally

When a gymmast who has represented his country, moves to another country and obtains citizenship (official nationality) of the latter country, he may - with the consent of the two federations concerned and the Executive Committee - immediatel y represent the new country. Where such consent is not granted, he may (with the consent of the Executive Committee) represent the new country one year after the date on which he received thenew citizenship.*

36.2.2 Dual Nationality

Where a gymast or a judge has dual nationality he may choose which country he wishes to represent but, having represented that country, hecannot al so - except as provided for in paragraph 36.2.1 above- represent theother country in question.*

36.2.3 G ymnasts who have not represented their countries internationally

Where a gymnast moves to another country, and has not represented his former country, hemay immediately after receiving citizenship (official nationality) represent his new country with the consent of the Executive Committee*

In the case of a gymast -born in a country in which his parents are "bona fide" residents but have not received citizenship (official nationality), the federation of the country in which he was born may include himin its national team subject to the consent of the Executive Committee*

36.2.4 Political Division of C ountries

Where a country ceases to be a political entity and divides into one or more countries a gymast may choose to represent any one of the new countries, or to represent any other country to which he may have moved.*

\subsubsection{C hange of Discipline}

When a gymmast moves from one specific discipline to another discipline, Reg. 36.2.1.will apply with the exception that the gymmast may represent the new country immediately in the new discipline.

36.2.6 Club Competitions

A gymast, temporarily or permanently resident in another country, and who is a bona fide member of a club in that country, may - with the consent of his national federation and that of the country in which he is resident - represent the said club.

36.2.7 0 ther $C$ ases

In other cases (exceptional or unforeseen circumstances) the Executive Committee shall make the determination*.

Rules 36.2.1 to 36.2.4 and 36.2.7 are val id with the exception of Olympic Games. For Olympic Games see the Olympic Charter.

\section{ARTICLE 37}

$37 \mathrm{O}$ bservance of rules of eligibility and $\mathrm{IOC}$ rules

Gymasts, entered into competitions by their federations, must follow the Rules of Eligibility of the FIG (set out in the Technical Regulations) and the relevant Rule of the International Olympic Committee Special 
Rules of the FIG must be followed for advertising and publicity: At the Olympic Games it is necessary to comply with the Rules of the International Olympic Committee

FÉDÉRATION INTERNATIONALE DE GYMNASTIQUE STATUTES E D I T I O N 2013 in effect from J anuary 1st, 2013 (unchanged since 2005)

ARTICLE 36

Nationality of G ymnasts and J udges and membership within a Federation

36.1 Principle

In principle, gymasts and judges taking part in any international competition must have the nationality (citizenship) of the federations they represent and authority to participate, from their federation.

36.2 Permission to represent another federation

36.2.1 G ymnasts who have represented their countries internationally

When a gymnast who has represented his country, moves to another country and obtains citizenship (official nationality) of the latter country, he may - with the consent of the two federations concerned and the Executive Committee - immediately represent the new country. Where such consent is not granted, he may (with the consent of the Executive Committee) represent thenew country one year after the date on which he received thenew citizenship.*

36.2.2 Dual Nationality

Where a gymast or a judge has dual nationality he may choose which country he wishes to represent but, having represented that country, hecannot al so - except as provided for in paragraph 36.2.1 above- represent the other country in question.*

36.2.3 G ymnasts who have not represented their countries internationally

Where a gymnast moves to another country, and has not represented his former country, he may immediately after receiving citizenship (official nationality) represent his new country with the consent of the Executive Committee*

In the case of a gymnast -born in a country in which his parents are "bona fide" residents but have not received citizenship (official nationality), the federation of the country in which he was born may include himin its national teamsubject to the consent of the Executive Committee*

36.2.4 Political Division of C ountries

Where a country ceases to be a political entity and divides into one or more countries a gymast may choose to represent any one of thenew countries, or to represent any other country to which hemay have moved.*

36.2.5 C hange of Discipline

When a gymnast moves from one specific discipline to another discipline, Reg. 36.2.1.will apply with the exception that the gymnast may represent the new country immediately in the new di scipline

36.2.6 Club Competitions

A gymmast, temporarily or permanently resident in another country, and who is a bona fide member of a club in that country, may - with the consent of his national federation and that of the country in which he is resident - represent the said club.

36.2.7 0 ther $C$ ases

In other cases (exceptional or unforeseen circumstances) the Executive Committee shall make the determination*.

* Rules 36.2.1 to 36.2.4 and 36.2.7 are valid with the exception of Olympic Games. For Olympic Games see the Olympic Charter.

ARTICLE 37

$37 \mathrm{O}$ bservance of rules of eligibility and $\mathrm{IOC}$ rules

Gymnasts, entered into competitions by their federations, must follow the Rules of Eligibility of the FIG (set out in the Technical Regulations) and the relevant Rule of the International Olympic Committee Special Rules of the FIG must be followed for advertising and publicity: At the Olympic Games it is necessary to comply with the Rules of the International Olympic Committee

TECHNICAL RE GULATIONS Version 2014 FIG 2014 from J une 2013 (unchanged since 2005) Reg. 5.1 GENERAL RIGHTS OF PARTICIPATION IN COM PETITIONS AND LICENCE Official FIG competitions are open to gymmasts who:

- belong to a NF affiliated to the FIG

- have the nationality of theNF in accordance with theFIG Statutes, the TR and the Olympic provisions

- fulfil the requirements of the Statutes

- fulfil specified performance prerequisites (i.e limits).

- have a valid licence and respect the decisions and rules daborated by theEC

$[\ldots]$

REg. 5.3 CONTROL OF NATIONALITY AND AGE 
Through the accreditation process, before official FIG competitions, personnel of the LOC, in cooperation with the FIG Secretariat, will check the nationality of athletes and judges as well as the age of athletes.

$[\ldots]$

APPENDIX B

RULES OF ELIGIBILITY FOR THE INTERNATIONAL GYMNASTICS FEDERATION

1. Rule of Eligibility

An eligiblegymast is any gymnast who abides by the eligibility rules of the FIG and the gymmast's National Federation.

2. In any competition sanctioned or conducted by the FIG, each National Federation is responsible for certifying the eligibility of gymnasts fromits country.

3. Only gymasts meeting the requirements of Regulation I are authorised to participate in official competitions and particularly those competitions which qualify gymnasts for Olympic Games.

4. Subject to approval by his/her National Federation, a gymmast may receive material and financial support for training and competition as well as prizes from competitions.

5. A gymast may not:

a) have been expelled fromany National or International Sports Federation for the use of drugs

b) take part in any gymastic competition or exhibition which is not sanctioned by the FIG or his/her National Federation

c) bear on his/her sportswear or his/her sports equipment any advertising trademarks during the Olympic Games or any competition sanctioned by the FIG or National Federation, except for the manufacturing trademarks on equipment or sportswear in accordance with the specifications of the IOC, FIG or National Federation.

6. The restrictions detailed in 5 (c) also apply to the Olympic Games, World Cups, Continental and World Championships and the qual ifying toumaments for those Events.

7. The Executive Committee of the FIG interprets these eligibility rules and determines whether they have been violated.

8. Any gymmast infringing these rules, after their enforcement, may not daim to be eligible to participate in the Olympic Games or qualifying tournaments for the Games.

FÉDÉRATION INTERNATIONALE DE GYMNASTIQUESTATUTESE D I T I O N 220009 in effect from J anuary 1st, 2009

ARTICLE 35 NATIONALITY OF GYMNASTS AND JUDGES AND MEMBERSHIP WITHIN A FEDERATION

35.1 Principle

In principle, gymasts and judges taking part in any international competition must have the nationality (citizenship) of the federations they represent and authority to participate, from their federation.

35. 2 Permission to represent another federation

35.2.1 G ymnasts who have represented their countries internationally

When a gymmast who has represented his country, moves to another country and obtains citizenship (official nationality) of the latter country, he may - with the consent of the two federations concerned and the Executive Committee - immediately represent the new country. Where such consent is not granted, he may (with the consent of the ExecutiveCommittee) represent the new country one year after the date on which he received thenew citizenship.*

\subsubsection{Dual Nationality}

Where a gymast or a judge has dual nationality he may choose which country he wishes to represent but, having represented that country, he cannot al so - except as provided for in paragraph 35.2.1 above- represent the other country in question.*

35.2.3 G ymnasts who have not represented their countries internationally

Where a gymnast moves to another country, and has not represented his former country, hemay immediately after receiving citizenship (official nationality) represent his new country with the consent of the Executive Committe**

In the case of a gymnast -born in a country in which his parents are "bona fide" residents but have not received citizenship (official nationality), the federation of the country in which he was born may include himin its national team subject to the consent of the Executive Committee*

35.2.4 Political Division of C ountries

Where a country ceases to be a political entity and divides into one or more countries a gymast may choose to represent any one of the new countries, or to represent any other country to which he may have moved.*

* Rules 35.2.1 to 35.2.4 are valid with the exception of Olympic Games. For Olympic Games see the Olympic Charter.

35.2.5 C hange of Discipline

When a gymast moves fromone specific di sciplineto another discipline, Reg. 


\section{NATIONALITY REQUiREMENTS IN Oly mpic SPORTS}

35.2.1 will apply with the exception that the gymmast may represent the new country immediately in the new discipline

35.2.6 Club Competitions

A gymnast, temporarily or permanently resident in another country, and who is a bona fide member of a club in that country, may - with the consent of his national federation and that of the country in which he is resident - represent the said club.

35.2.70 ther $C$ ases

In other cases (exceptional or unforeseen circumstances) the Executive Committee shall make the determination*.

ARTICLE 36

OBSERVANCE OF RULES OF ELIGIBILITY AND OLYM PIC RULES

Gymasts, entered into competitions by their federations, must follow the Rules of Eligibility of the FIG (set out in the Technical Regulations) and the relevant Rule of the International Olympic Committee Special Rules of the FIG must be followed for advertising and publicity: At the Olympic Games it is necessary to comply with the Rules of the International Olympic Committee

ARTICLE 36

OBSERVANCE OF RULES OF ELIGIBILITY AND OLYM PIC RULES

Gymasts, entered into competitions by their federations, must follow the Rules of Eligibility of the FIG (set out in the Technical Regulations) and the relevant Rule of the International Olympic Committee Special Rules of the FIG must be followed for advertising and publicity: At the Olympic Games it is necessary to comply with the Rules of the International Olympic Committee

FEDERATION INTERNATIONALE DE GYM NASTIQUE STATUTESE D I T I O N 20007 in effect from / anuary 1st, 2007

ARTICLE 35 NATIONALITY OF GYMNASTS AND JUDGES AND MEMBERSHIP WITHIN A FEDERATION

\subsection{Principle}

In principle, gymnasts and judges taking part in any international competition must have the nationality (citizenship) of the federations they represent and authority to participate, from their federation.

35. 2 Permission to represent another federation

35.2.1 G ymnasts who have represented their countries internationally

When a gymnast who has represented his country, moves to another country and obtains citizenship (official nationality) of the latter country, he may - with the consent of the two federations concerned and the Executive Committee - immediately represent the new country. Where such consent is not granted, he may (with the consent of the Executive Committee) represent the new country one year after the date on which he received thenew citizenship.*

35.2.2 Dual Nationality

Where a gymast or a judge has dual nationality he may choose which country he wishes to represent but, having represented that country, hecannot al so - except as provided for in paragraph 35.2.1 above- represent theother country in question.*

35.2.3 G ymnasts who have not represented their countries internationally

Where a gymnast moves to another country, and has not represented his former country, hemay immediately after receiving citizenship (official nationality) represent his new country with the consent of the Executive Committee*

In the case of a gymnast -born in a country in which his parents are "bona fide" residents but have not received citizenship (official nationality), the federation of the country in which he was born may include himin its national teamsubject to the consent of the ExecutiveCommittee*

35.2.4 Political Division of C ountries

Where a country ceases to be a political entity and divides into one or more countries a gymmast may choose to represent any one of the new countries, or to represent any other country to which hemay have moved.*

* Rules 35.2.1 to 35.2.4 are valid with the exception of Olympic Games. For Olympic Games see the Olympic Charter.

35.2.5 C hange of Discipline

When a gymast moves from one specific di scipline to another discipline, Reg.

35.2.1 will apply with the exception that the gymast may represent the new country immediatedy in the new discipline

35.2.6 Club Competitions

A gymast, temporarily or permanently resident in another country, and who is a bona fide member of a club in that country, may - with the consent of his national federation and that of the country in which he is resident - represent the said club.

35.2.70 ther Cases 
In other cases (exceptional or unforeseen circumstances) the Executive Committee shall make the determination*.

\section{ARTICLE 36}

\section{OBSERVANCE OF RULES OF ELIGIBILITY AND OLYMPIC RULES}

Gymasts, entered into competitions by their federations, must follow the Rules of Eligibility of the FIG (set out in the Technical Regulations) and the relevant Rule of the International Olympic Committee Special Rules of the FIG must be followed for advertising and publicity: At the Olympic Games it is necessary to comply with the Rules of the International Olympic Committee

FEDERATION INTERNATIONALE DE GYMNASTIQUE STATUTESE D I T I 0 N 22004 in effect from J anuary 1st, 2005

ARTICLE 35 NATIONALITY OF GYMNASTS AND JUDGES AND MEMBERSHIP WITHIN A FEDERATION

\subsection{Principle}

In principle, gymmasts and judges taking part in any international competition must have the nationality (citizenship) of the federations they represent and authority to participate, from their federation.

35. 2 Permission to represent another federation

35.2.1 G ymnasts who have represented their countries internationally

When a gymnast who has represented his country, moves to another country and obtains citizenship (official nationality) of the latter country, he may - with the consent of the two federations concerned and the Executive Committee - immediately represent the new country. Where such consent is not granted, he may (with the consent of the Executive Committee) represent the new country one year after the date on which he received the new citizenship.*

\subsubsection{Dual Nationality}

Where a gymnast or a judge has dual nationality he may choose which country he wishes to represent but, having represented that country, hecannot also - except as provided for in paragraph 35.2.1 above- represent the other country in question.*

35.2.3 G ymnasts who have not represented their countries internationally

Where a gymnast moves to another country, and has not represented his former country, he may immediately after receiving citizenship (official nationality) represent his new country with the consent of the Executive Committee*

In the case of a gymast -born in a country in which his parents are "bona fide" residents but have not received citizenship (official nationality), the federation of the country in which he was born may indude himin its national teamsubject to the consent of the Executive Committee*

35.2.4 Political Division of C ountries

Where a country ceases to be a political entity and divides into one or more countries a gymast may choose to represent any one of the new countries, or to represent any other country to which he may have moved.*

* Rules 35.2.1 to 35.2.4 are valid with the exception of Olympic Games. For Olympic Games see the Olympic Charter.

\subsubsection{C hange of Discipline}

When a gymnast moves fromone specific disciplineto another discipline, Reg.

35.2.1 will apply with the exception that the gymnast may represent the new country immediately in the new discipline

\subsubsection{Club Competitions}

A gymnast, temporarily or permanently resident in another country, and who is a bona fide member of a club in that country, may - with the consent of his national federation and that of the country in which he is resident - represent the said dub.

\subsubsection{0 ther $C$ ases}

In other cases (exceptional or unforeseen circumstances) the Executive Committee shall make the determination*.

\section{ARTICLE 36}

OBSERVANCE OF RULES OF ELIGIBILITY AND OLYMPIC RULES

Gymasts, entered into competitions by their federations, must follow the Rules of Eligibility of the FIG (set out in the Technical Regulations) and the relevant Rule of the International Olympic Committee Special Rules of the FIG must be followed for advertising and publicity: At the Olympic Games it is necessary to comply with the Rules of the International Olympic Committee

\section{Handball}

IV. R egulations for Transfer Between Federations E dition: 8 J uly 2014

\section{International Transfer C ertificate}

VII. Protection of M inors 


\section{NATIONALITY REQUIREMENTS IN OLy MPIC SPORTS}

§ 1 International transfers of players under the age of 16 shall be permitted only under the following conditions:

a. as a general rule, when the player's family moves to the country in which the new club is located for reasons that are not linked to handball

b. international transfers of amateur players under the age of 16 shall be permitted (eg. students, pupils).

For such transfers ( $§ 1$. a and $b$ of this Article), no fees shall be charged, neither by the releasing federation nor by the Continental Confederation nor the IHF. The same principles apply to the first registration of players under the age of 16 who have a national ity other than that of the country in which they first apply for registration.

\section{IIII. Player E ligibility Code E dition: 1 J uly 2011}

\section{Basic Principles}

All handball players shall be subject to the Player Eligibility Code of the International Handball Federation (IHF). Member federations may issue player eligibility regulations, provided these do not contradict IHF regulations.

\section{ARTICLE 5}

\section{E ligibility to Play}

5.1 Only players eligible to play may take part in games and competitions announced by the National Federation concerned.

5.2 The National Federation must confirmeligibility:

a) if, in the case of a transfer from one federation to another, once the player is in possession of an International Transfer Certificate approved by the IHF and/or the Continental Confederation concemed, releasing him from the previous federation where he was eligible to play.

b) if the player is under 16 at the moment of the request and has not yet played for any other federation.

5.3 The National Federation may confirm the eligibility to play in cases 5.2.a) and 5.2.b) only after receipt of the corresponding written approval from the IHF or the Continental Confederation concerned:

a) if the player has refugee or asylum seeker status and a val id residence permit in the country of the National Federation concerned.

b) if the player has not played in any National Federation for the previous 24 months.

5.4 If 5.3b) applies, the federation for which the player has last been eligible to play shall confirm the date of the last game in writing. This confirmation shall be submitted within 15 days at the latest following the request. In case no confirmation is submitted in compliance with the deadline, the IHF or the Continental Confederation concerned will be able to grant player eligibility following the request by the new federation.

\section{ARTICLE 6}

\section{National Players}

6.1 National team players shall meet the following conditions:

a) Citizenship of the country concerned.

b) They shall not have played in any national team of another country in the three years preceding their first appearance in the national team in an official match. Official matches are considered to be: the qualifying matches for a continental championship, matches in a continental championship, qualifying matches for IHF World Championships and Olympic Games, matches in IHF World Championships and Olympic Games

\subsection{Player eligibility in case of multiple nationalities}

A player who holds more than one nationality and who complies with 6.1., is eligible to officially represent one of those countries if:

a) he was born in the territory of the federation concerned or

b) his biological mother or biological father were born in theterritory of the federation concerned or

c) he has been living in the teritory of the federation concerned for morethan 24 months in any period of his life

\subsection{Change eligibility to play for a National Federation}

It is only permitted to change the National Federation and thus to obtain eligibility to play for a new national team one time In case of dissolution of an existing federation or a constitution of a new one, the IHF shall create a separate body to examine the cases should di sputes over eligibility arise

$[\ldots]$

\section{ARTICLE 8}

\section{Participation in Olympic Games}

Participation in the Olympic Games shall be subject to the IHF's and the Intemational Olympic Committee's eligibility codes.

8.1. Players participating in the Olympic Games

a) shall respect the spirit of fair play and inviolability and act accordingly,

b) shall use no illegal substances or make use of illegal applications as set forth by IOC and International

Handball Federation regulations, 


\section{APPENDICES}

c) shall observethestipulations of the IOC Medical Codeand act accordingly.

8.2. For the duration of the Olympic Games, players taking part in the Olympic Games shall not permit their persons, names, visual representation or performance to be used for advertising purposes.

8.3. There shall be no connection to financial compensation of any kind regarding a player's registration or participation in the Olympic Games.

\section{Regulations for Transfer Between Federations E dition: 1] uly 2011}

\section{International Transfer Certificate}

VII. Protection of M inors

§ 1 International transfers of players under the age of 16 shall be permitted only under the following conditions:

a. as a general rule, when the player's family moves to the country in which the new club is located for reasons that are not linked to handball

b. international transfers of amateur players under the age of 16 shall be permitted (eg. students, pupils).

For such transfers ( $\$ 1$. a and b of this Article), no fees shall be charged, neither by the releasing federation nor by the Continental Confederation nor the IHF. The same principles apply to the first registration of players under the age of 16 who have a national ity other than that of the country in which they first apply for registration.

\section{Hockey}

INTERNATIONAL HOCKEY FEDERATION FIH REGULATIONS Governing the Eligibility of a Player to play International Hockey for a Country/ National Association Approved by Executive Board - 3J uly 2015

\section{General Principles}

1.1 To be eligible to represent a country as a J unior or Senior player in an inter-nations event, a player must be a national of that country. To be eligible to represent a country in a Masters inter-nations event a player must be a national of that country, or have been a resident of that country for a minimum of 12 months immediately prior to the event.

1.2 Nationality is determined by the holding of a valid passport of the country the player is selected to represent.

1.3 The rules for the eligibility of players to compete in Olympic Games are governed by the IOC Olympic Charter.

1.4 The Executive Board is empowered to recognizesuspensions or disqual ifications of dubs declared by the NA to which they belong and, if so, to seeto it that these decisions are applied by all National Associations.

1.5 In the case of J unior and Senior players theFIH Executive Board, and in the case of Masters the Board of IMHA / WGMA, may authorise National Associations to play against non-affiliated associations but only when the non-affiliated association has shown interest in sedking affiliation to the FIH or in the case of Masters then to theIMHA / WGMA.

\section{J unior Players}

2.1 A junior player is any player under twenty-one (21) years of age at the relevant date

2.2 A junior player who is a national of two or more countries at the same time, may elect to represent only one of them but while a junior he may, with the approval of the Executive Board, elect to represent the other of which the player is a national.

2.3 A junior player who, having represented a country while he is a junior, obtains a second or other nationality may, with the approval of the Executive Board, represent that second or other country.

2.4 On a junior player who has represented a country at junior level becoming a senior player, he may makea new choice but, having made that choice and having represented a country at senior level, he cannot then represent another country at senior level for three years from the date he last represented the original country without the prior written approval of the Executive Board and the National Association for whom he has previously represented.

2.5 Any junior player who has represented his country at a senior level ceases to be a junior player for the purposes of this Eligibility Regulation and his eligibility is governed by the provisions of paragraphs 3 and 4 (below) of these Regulations.

\section{Senior Players}

3.1 Senior players are all players selected to represent a country in an FIH sanctioned match or tournament which has no restrictions on age.

3.2 A senior player who is a national of two or more countries at the same time may elect to represent only one of them

3.3 Having represented a country at senior level and / or been on the final entry team list as presented at the pretournament briefing, the player cannot then represent another country (including the other country of 
which he is a national) for three years from the date he last represented the original country and without the prior written approval of the Executive Board.

3.4 A senior player who, having represented a country at senior level, changes nationality or acquires a new nationality, may not represent the new country for three years after the date he last represented the original country without the written approval of the Executive Board and the previous National Association. Unless the player elects to represent the new country in accordance with this paragraph the player may continue to represent the original country assuming he has retained that country's passport.

3.4 If an associated State, a province or overseas department of a country or a colony, acquires its independence, or if a country becomes incorporated within another country by reason of a change of borders, or if a new National Association is recognized by the FIH, a player may continue to represent the country to which he belongs or belonged. However, he may, if he prefers, elect to represent his new country. This choice may only bemade once

3.5 In all cases not expressly addressed in the Statutes or Regulations, in particular in those cases in which a player would be in a position to represent a country other than that of which he is a national or to have a choice as to the country which he intends to represent, the Executive Board may take all decisions of a general or individual nature, and in particular issue specific requirements relating to nationality, citizenship, domicile or residence of players, induding thelength of any waiting period.

\section{M asters Players}

4.1 Masters players are all players selected to represent a country in an FIH sanctioned Masters match or tournament which has restrictions on age The age of a Masters player shall be determined and cal cul ated as at 31st December in the year of the event.

4.2 A Masters player who is a national of two or more countries at the same time may elect to represent only one of them In addition a Masters player may qual ify to represent a country by having been a resident of that country whom he elects to represent for a mini mum of 12 months immediately prior to the event in which he is to play.

4.3 Having represented a country at Masters level and/or been on the final entry team list as presented at the pre-tournament briefing, the player cannot then represent another country for 12 months from the date he last represented the original country without the written approval of the Board of IMHA / WGMA.

4.4 In all cases not expressly addressed in these Regulations the Board of IMHA / WGMA may take all decisions of a general or individual nature, and in particular issue specific requirements relating to nationality, citizenship, domicile or residence of players, including the length of any waiting period.

INTERNATIONAL HOCKEY FEDERATION FIH REGULATIONS Governing the Eligibility of a Player to Play International Hockey for a Country / National Association Approved by EB 29th March 2012

\section{General Principles}

1.1 To be eligible to represent a country in an inter-nations event, a player must bea national of that country. 1.2 Nationality is determined by the holding of a valid passport of the country the player is selected to represent.

1.3 The rules for the eligibility of players to compete in Olympic Games are governed by the IOC Olympic Charter.

1.4 The Executive Board is empowered to recognize suspensions or disqualifications of players declared by the National Association to which they belong and, if so, to see to it that these decisions are applied by all National Associations.

1.5 The Executive Board may authorise National Associations to play against non-affiliated associations but only when the non-affiliated association has shown interest in seeking affiliation to the FIH.

\section{J unior Players}

2.1 A junior player is any player under twenty-one (21) years of age at the relevant date as specified in the regulations or entry application for a tournament.

2.2 A junior player who is a national of two or more countries at the same time may elect to represent only one of them but whilea junior he may, with the approval of the Executive Board, elect to represent the other of which the player is a national.

2.3 A junior player who, having represented a country while he is a junior, obtains a second or other nationality may, with the approval of the Executive Board, represent that second or other country.

2.4 On a junior player who has represented a country at junior level becoming a senior player, hemay makea new choice but, having made that choice and having represented a country at senior leve, he cannot then represent another country at senior level for three years from the date he last represented the original country without the prior written approval of the Executive Board and the National Association for whom he has previously represented. 


\section{APPENDICES}

2.5 Any junior player who has represented his country at a senior level ceases to be a junior player for the purposes of this Eligibility Regulation and his eligibility is governed by the provisions of paragraph 3 (below) of these Regulations.

\section{Senior Players}

3.1 Senior players are all players selected to represent a country in an FIH sanctioned match or tournament which has no restrictions on age

3.2 A senior player who is a national of two or more countries at the same time may elect to represent only one of them

3.3 Having represented a country at senior level and/or been on the final entry team list as presented at the pretournament briefing, the player cannot then represent another country (including the other country of which he is a national) for three years from the date he last represented the original country and without the prior written approval of the Executive Board.

3.4 A senior player who, having represented a country at senior level, changes nationality or acquires a new nationality, may not represent the new country for three years after the date the he last represented the original country without the written approval of the Executive Board and the previous NA. Unless the player elects to represent the new country in accordance with this paragraph the player may continue to represent the original country assuming he has retained that country's passport.

3.5 If an associated State, a province or overseas department of a country or a colony, acquires its independence, or if a country becomes incorporated within another country by reason of a change of borders, or if a new National Association is recognized by the FIH, a player may continue to represent the country to which he belongs or belonged. However, he may, if he prefers, elect to represent his new country. This choice may only be made once.

3.6 In all cases not expressly addressed in the Statutes or Regulations, in particular in those cases in which a player would be in a position to represent a country other than that of which he is a national or to have a choice as to the country which he intends to represent, the Executive Board may take all decisions of a general or individual nature, and in particular issue specific requirements relating to nationality, citizenship, domicile or residence of players, including the length of any waiting period.

INTERNATIONAL HOCKEY FEDERATION STATUTES UPDATED 13 NOVEMBER, 2010 INTERNATIONAL HOCKEY FEDERATION BYE-LAWS UPDATED MARCH, 2011

ARTICLE 5.2 ELIGIBILITY

1. General Principles

1.1 To be eligible to represent a country in an inter-nations event, a player must bea national of that country. 1.2 Nationality is determined by the holding of a valid passport of the country the player is selected to represent.

1.3 The rules for the eligibility of players to compete in Olympic Games are governed by the IOC Olympic Charter.

$[\ldots]$

\section{J unior Players}

2.1 A junior player is any player under twenty-one (21) years of age at the relevant date

2.2 A junior player who is a national of two or more countries at the same time, may elect to represent only one of them but while a junior he may, with the approval of the Executive Board, elect to represent the other of which the player is a national.

2.3 A junior player who, having represented a country while he is a junior, obtains a second or other nationality may, with the approval of the Executive Board, represent that second or other country.

2.4 On a junior player who has represented a country at junior level becoming a senior player, he may makea new choice but, having made that choice and having represented a country at senior level, he cannot then represent another country at senior level for three years from the date he last represented the original country without the prior written approval of the NAs concerned and the Executive Board.

2.5 Any junior player who has represented his country at a senior tournament ceases to be a junior player for the purposes of this Bye-Law and his eligibility is governed by the provisions of paragraphs 3 and 4 of this ByeLaw.

\section{Senior Players}

3.1 Senior players are all players selected to represent a country in an FIH tournament other than a junior tournament.

3.2 A senior player who is a national of two or more countries at the same time may elect to represent only one of them Having represented a country at senior leve, the player cannot then represent another country (including the other country of which he is a national) for three years from the date he last represented the original country without the prior written approval of the NAs concerned and the Executive Board

3.3 A senior player who, having represented a country at senior level, changes nationality or acquires a new nationality, may not represent the new country for three years after the date the he last represented the 
original country without the written approval of the NAs concerned and the Executive Board. Unless the player elects to represent the new country in accordance with this paragraph the player may continue to represent the original country.

3.4 If an associated State, a province or overseas department of a country or a colony, acquires its independence, or if a country becomes incorporated within another country by reason of a change of borders, or if a new NA is recognized by the FIH, a player may continue to represent the country to which he belongs or belonged. However, he may, if he prefers, elect to represent his new country. This choice may only be madeonce

3.5 In all cases not expressly addressed in the Statutes or Bye-Laws, in particular in those cases in which a player would be in a position to represent a country other than that of which he is a national or to have a choice as to the country which he intends to represent, the Executive Board may take all decisions of a general or individual nature, and in particular issue specific requirements relating to nationality, citizenship, domicile or residence of players, including the length of any waiting period.

\section{Players R ecognised by M ore Than One C ountry}

4.1 Where the nationality of a player is recognized by more than one country, that player may only represent the country in which the player is a bona fide resident at the date of initial selection.

4.2 Where countries share common nationality and common residency within one international border a player will bee ligibleto represent one of these countries as determined by where:

$\square$ he was born; or

$\square$ one of his parents was born; or

$\square$ he is a bona fide resident in the country he wishes to represent.

4.3 For the purposes of paragraphs 4.1 and 4.2 of this ByeLaw, bona fide residence means that the player has permanently resided in the country he wishes to represent for a continuous period of 210 days in each of the three(3) years immediately prior to the date of his initial selection.

4.4 Where a player has represented one of the countries that recognizes the nationality of that player, that player may not represent any other of the countries that recognize that player's nationality for three years from the date the player last represented the original country without the prior written approval of the NAs concerned and the Executive Board.

4.5 The provisions of paragraph 3.2 apply to any player who, having represented a country at senior leve, changes nationality or acquires a new nationality, other than a player to which to which paragraph 4.4 would apply.

[...] ]

ARTICLE 5.2 ELIGIBILITY FOR THE OLYMPIC GAMES AND INTERNATIONAL EVENTS

1. General Principles

1.1 All Athletes shall:

(a) Respect the spirit of fair play and non-violence and behave accordingly on the field of play; and

(b) Abstain from using substances prohi bited by therules of the IOC and/or theFIH.

1.2 An Athlete may not:

(a) Have been expelled for life froman International Sports Federation or a National Sports Association.

(b) Allow his person, name, picture or sports performance to be used for advertising purposes during the Olympic Games, unless permitted by the IOC Executive Board.

\section{Ice Hockey}

IIHF ST AT UTE S AND BYLAWS 2014 - 2018 of M ay 2014

\section{COM PETITIONS, ELIGIBILITY, TRANSFERS}

405.0 lympic Competitions

The Olympic ice hockey competitions are operated by the IIHF and are subject to the competition Bylaws, Regulations/Codes and Official Playing Rules of thelIHF.

The eligibility of players must be as permitted by the IIHF and accepted by the IOC.

Participation by the IIHF in the Olympic Winter Games is subject to Congress approval. The IIHF will comply with the IOC Charter with respect to participation.

406.Player E ligibility R ules for Participation in IIH F Championships and Olympic Competitions

It is the objective of the IIHF that national teams competing in IIHF championships shall reflect the status and standard of the sport as currently played by both citizens of and citizens in the country concerned and to protect theintegrity of international competition.

1. Only players meeding the following qualification requirements can participate in the IIHF Championships, the Olympic Competition and in the qual ifications to these Competitions:

1.1 Each player must be under thejurisdiction of a Member National Association of thell HF and bea citizen of the country he represents. The player must properly complete and sign the IIHF Player Entry Form which must al so be completed and countersigned by his Member National Association which shall at all times be responsible for the player's eligibility. 


\section{APPENDICES}

1.2 The player must submit (a) his signed Player Entry Form and (b) his national passport which is valid for the duration of theevent and which must confirm that he is a citizen of the country he represents.

1.3 Once a player has represented a country in any IIHF championship, or in the Olympic competition or in the qualification to these competitions he will not be eligible to represent another country excepting that he may apply to thelIHF to represent another country provided that

A) heis a citizen of that country;

B) he has an international transfer that was approved by thellHF and dated at least four years before the start of thellHF competition in which he wishes to participate;

C) he has participated, on a consistent basis, for at least four consecutive years (1460 days) in the national competitions of his new country during which period he has neither transferred to another country nor played ice hockey for a team registered/located within any other country: and

D)he has not played for his previous country in an IIHF compeition either during this four year period or between completion of this four-year period and the start of thell HF championship he wishes to compete

1.4 A player who has represented a country in any IIHF championship, Olympic competition or in the qualifications to these competitions and has later acquired another citizenship shall still be eligible to represent his old country provided heis still a citizen of that country.

1.5 If a country or part of it becomes independent, or if a country or part of it becomes incorporated into another country, or if two or more countries are united into a new country, or if a country is divided into more countries, a player who has al ready represented a country and whose citizenship was thus changed by decision of the state authorities, may apply to the IIHF to play for any one of the partitioned or united countries without a waiting period subject to his providing proof of his new citizenship. This particular choice may only bemade onceand is final and irrevocable

1.6 When a player has changed his citizenship or has acquired or surrendered another citizenship and wants to participate for the first timein an IIHF championship and/or an Olympic competition or in qual ifications to these competitions, then in order to play for his country of current citizenship hemust:

A) prove that he has participated on a consistent basis, for at least two consecutive hockey seasons and 16 consecutive months (480 days) after his 10th birthday in the national competitions of and having resided in his new country during which period he has neither transferred to another country nor played ice hodkey for a team registered/located within any other country; and

B) if the country of his choice is one to which the player has transferred then he must have had an international transfer that was approved by the IIHF and dated at least 16 months ( 480 days) to his proposed participation.

1.7 When a player has multiple citizenships where the relevant citizenships are for countries of Member National Associations and he has never represented any country in any IIHF championship or an Olympic competition or in qualifications to these competitions, then in order to play for the country of his choice he must:

A) prove that he has participated on a consistent basis, for at least two consecutive hockey seasons and 16 consecutive months ( 480 days) after his $10^{\text {th }}$ birthday in the national competitions of and having resided in the country that he wishes to represent during which period he has neither transferred to another country nor played ice hockey for a team registered/located within any other country; and

B) if the country of his choice is one to which the player has transferred then he must have had an international transfer that was approved by the IIHF and dated at least 16 months (480 days) prior to his proposed participation.

1.8 In the case of Female Hockey, the eligibility requirement described in 1.6 and 1.7 of this By-Law will be met if a player has participated on a consistent basis for at least one (1) hockey season in the competitions of the Member National Association (MNA) of that country, and was a member of that MNA for at least twelve (12) consecutive months during that period.

1.9 When a player wishes to establish his eligibility under subsections 1.3 through 1.7, the Member National Association for which he wishes to play must submit an application to the IIHF together with all relating evidence at the latest four wedks before the competition or game in which the player wishes to play. The General Secretary is responsible for investigating the application and confirming the player's eligibility to play for the country concerned. Notwithstanding the above, the decision of the General Secretary is not conclusive proof of the eligibility of the player to play for the country concerned.

1.10 Cases involving exceptional circumstances can be submitted to Council for a Council exception. All other IIHF eligibility decisions can be appeal ed to the IIHF Disciplinary Board within 14 days of the IIHF eligibility notification in accordance with the Disciplinary Code

$[\ldots]$

Sochi 2014 E ligibility for men

To play in thellHF World Championship, the Olympic ice hockey tournament and the qual ifications to these competitions, players must fulfill the following qualification requirements: 


\section{NATIONALITY REQUIREMENTS IN Oly MPIC SPORTS}

- Each player must be under the jurisdiction of an IIHF member national association

Each player must be a citizen of the country he represents.

Acquiring a new national eligibility (The 'two-year' case)When a player has changed his citizenship or has acquired another citizenship and wants to participate for the first time in an IIHF competition representing his new country he must:

- Prove that he has participated for at least two consecutive years in the national competitions of his new country during which period he has neither transferred to another country nor played ice hockey within any other country.

- Have an international transfer card (ITC) that shows the transfer to the national competition of his new country and which was approved and dated at least two years before the start of the IIHF competition in which he wishes to participate

Change of national eligibility (The 'four-year' case)

A player, who has previously participated in IIHF competition, can switch national eligibility (but only once in a player's life) if:

- Heis a citizen of thenew country of hischoice

Hehas participated for at least four consecutive years in the national competitions of his new country, during which period he has neither transferred to another country nor played ice hockey within any other country and has not played for his previous country in an IIHF competition during this four year period.

- He has an international transfer card (ITC) that shows the transfer to the national competition of his new country and which was approved and dated at least four years before the start of the IIHF competition in which he wishes to participate.

\section{Sochi 2014 E ligibility for women}

To play in the IIHF World Championship, the Olympic ice hockey tournament and the qualifications to these competitions, players must fulfill thefollowing qualification requirements:

- Each player must be under the jurisdiction of an IIHF member national association- Each player must bea citizen of the country he represents.

Acquiring a new national eligibility (The 'two-year' case)

When a player has changed his citizenship or has acquired another citizenship and wants to participatefor the first timein an IIHF competition representing his new country hemust:

- Prove that he has participated for at least two consecutive years in the national competitions of his new country during which period he has neither transferred to another country nor played ice hockey within any other country.

- Have an international transfer card (ITC) that shows the transfer to the national competition of his new country and which was approved and dated at least two years before the start of the IIHF competition in which he wishes to participate

Change of national eligibility (The 'four-year' case)

A player, who has previously participated in IIHF competition, can switch national eligibility (but only once in a player'slife) if:

- Heis a citizen of the new country of hischoice

- He has participated for at least four consecutive years in the national competitions of his new country, during which period he has neither transferred to another country nor played ice hockey within any other country and has not played for his previous country in an IIHF competition during this four year period.

- He has an international transfer card (ITC) that shows the transfer to the national competition of his new country and which was approved and dated at least four years before the start of the IIHF competition in which he wishes to participate.

\section{IIHF STATUTE S AND BYLAWS 2012 - 2014 (September 2012)}

\section{Olympic Competitions}

The Olympic ice hockey competitions are operated by the IIHF and are subject to the competition Bylaws, Regulations and Official Playing Rules of the IIHF. The eligibility of players must be as permitted by the IIHF and accepted by the IOC. Participation by the IIHF in the Olympic Winter Games is subject to Congress approval. ThellHF will comply with the IOC Charter with respect to participation.

406. Player E ligibility R ules for Participation in IIHF Championships and Olympic Competitions

It is the objective of the IIHF that national teams competing in IIHF championships shall reflect the status and standard of the sport as currently played by both citizens of and citizens in the country concerned and to protect the integrity of international competition.

1. Only players meeting the following qualification requirements can participate in the IIHF Championships, the Olympic Competition and in the qualifications to these Competitions:

1.1 Each player must be under thejurisdiction of a Member National Association of thellHF and bea citizen of the country he represents. The player must properly complete and sign the IIHF Player Entry Form which 


\section{APPENDICES}

must al so be completed and countersigned by his Member National Association which shall at all times be responsible for the player's eligibility.

1.2 The player must submit (a) his signed Player Entry Formand (b) his national passport which is valid for the duration of theevent and which must confirm that he is a citizen of the country he represents.

1.3 Once a player has represented a country in any IIHF championship, or in the Olympic competition or in the qualification to these competitions he will not be eligible to represent another country excepting that he may apply to thelIHF to represent another country provided that

a) heis a citizen of that country;

b) he has an international transfer that was approved by the IIHF and dated at least four years before the start of thellHF competition in which he wishes to participate;

c) he has participated, on a consistent basis, for at least four consecutive years (1460 days) in the national competitions of his new country during which period he has neither transferred to another country nor played ice hockey for a team registered/located within any other country: and

d) he has not played for his previous country in an IIHF competition either during this four year period or between completion of this four-year period and the start of thellHF championship he wishes to compete

Such a change will beall owed only oncein a player's life and is final and irrevocable

1.4 A player who has represented a country in any IIHF championship, Olympic competition or in the qualifications to these competitions and has later acquired another citizenship shall still be eligible to represent his old country provided heis still a citizen of that country.

1.5 If a country or part of it becomes independent, or if a country or part of it becomes incorporated into another country, or if two or more countries are united into a new country, or if a country is divided into more countries, a player who has al ready represented a country and whose citizenship was thus changed by decision of the state authorities, may apply to the IIHF to play for any one of the partitioned or united countries without a waiting period subject to his providing proof of his new citizenship. This particular choice may only be made once and is final and irrevocable.

1.6 When a player has changed his citizenship or has acquired or surrendered another citizenship and wants to participate for the first time in an IIHF championship and/or an Olympic competition representing his country of choice hemust:

a) prove that he has participated on a consistent basis, for at least two consecutive years (730 days) after his 12th birthday in the national competitions of and be a legal resident in his new country during which period he has neither transferred to another country nor played ice hockey for a team registered/located within any other country; and

b) havean international transfer that was approved by the IIHF and dated at least two years ( 730 days) before thestart of the championship in which he wishes to participate.

1.7 When a player has multiple citizenships where the relevant citizenships are for countries of Member National Associations and he has never represented any country in any IIHF championship or an Olympic competition or in qualifications to these competitions, then in order to play for the country of his choice he must

a) prove that he has participated on a consistent basis, for at least two consecutive years ( 730 days) after his 12th birthday in the national competitions of and be a legal resident in the country that he wishes to represent during which period he has neither transferred to another country nor played ice hockey for a team registered/located within any other country; and

b) if the country of his choice is one to which the player has transferred then he must have had an international transfer that was approved by the IIHF and dated at least two years (730 days) prior to his proposed participation.

1.8 When a player wishes to establish his eligibility under subsections 1.3 through 1.7 , the Member National Association for which he wishes to play must submit an application to the IIHF together with all relating evidence at the latest four weeks before the competition or game in which the player wishes to play. The General Secretary is responsible for investigating the application and confirming the player's eligibility to play for the country concerned. Notwithstanding the above, the decision of the General Secretary is not cond usive proof of the ligibility of the player to play for the country concerned.

1.9 Exceptional circumstances can be decided by Council.

1.10 Players of non-member organizations who participate in competitions of the IIHF including Olympic competitions and in qualifications to these competitions must, for the period of these events, be under the control and management of the respective Member National Association and be eligible in accordance with the applicable criteria to compete. When competing in the above specified competitions, these players are subject to the same conditions as other players and to the disciplinary procedures of the IIHF.

$[\ldots]$

IIHF STATUTE S AND BYLAWS 2008 - 2012 (with M ay 2011 Amendments) 


\section{NATIONALITY REQUIREMENTS IN OLY MPIC SPORTS}

The current 2008-2012 IIHF Statutes and Bylaws reflect the decisions taken by the General Congress in 2008 in Montreal, Canada and will be applicable from J uly 2008 until J une 2012. It al so includes the amendments approved by the 2011 Extra-Ordinary Congress in Bratislava.

200 COM PETITIONS, ELIGIBILITY, TRANSFERS

203. Olympic Competitions

The Olympic ice hockey competitions are operated by the IIHF and are subject to the competition Bylaws, Regulations and official playing rules of thellHF.

The eligibility of players must be as permitted by the IIHF and accepted by the IOC.

Participation by the IIHF in the Olympic Winter Games is subject to approval of Congress. The IIHF will comply with the IOC Charter.

204. Player Eligibility R ules for Participation in IIHF Championships and Olympic Competitions

It is the objective of the IIHF that national teams competing in IIHF championships shall reflect the status and standard of the sport as currently played by citizens of and in the country concerned and to protect the integrity of international competition.

1. Only players meeting the following qualification requirements can participate in the IIHF championships, the Olympic competition and in the qualifications to these competitions:

1.1. Each player must be under the jurisdiction of a member national ice hockey association of the IIHF and be a citizen of the country he represents. The player must properly complete and sign the IIHF Player Entry Form which must al so be completed and countersigned by his member national association which shall at all times be responsible for a player's eligibility.

1.2 The player must submit (a) his signed Player Entry Formand (b) his valid national passport, which must confirm that heis a citizen of the country herepresents.

1.3 When once a player has represented a country in any IIHF championship, or in the Olympic competition or in the qualification to these competitions he will not be eligible to represent another country excepting that hemay apply to the IIHF to represent another country provided that

A)heis a citizen of that country,

B) he has an international transfer card that was approved and dated by the IIHF at least four years before the start of thellHF competition in which he wishes to participate

he has participated for at least four consecutive years in the national competitions of his new country during which period he has neither transferred to another country nor played ice hockey within any other country, and

D) he has not played for his previous country in an IIHF competition either during this four year period or between completion of this four year period and thestart of thellHF championship he wishes to compete

Such a change will beallowed only oncein a player's life and is final and irrevocable

1.4 A player who has represented a country in any IIHF championship, Olympic competition or in the qualifications to these competitions and has later acquired another citizenship shall still be eligible to represent his old country provided he is still a citizen of that country.

1.5 If a country or part of it becomes independent, or if a country or part of it becomes incorporated into another country, or if two or more countries are united into a new country, or if a country is divided into more countries, a player who has al ready represented a country and whose citizenship was thus changed by decision of the state authorities, may apply to the IIHF to play for any one of the partitioned or united countries without a waiting period subject to his providing proof of his new citizenship. This particular choice may only be made once and is final and irrevocable

1.6 When a player has changed his citizenship or has acquired or has surrendered another citizenship and wants to participate for the first time in an IIHF competition and represent his new country he must

A) have an IIHF international transfer card that was approved and dated by the IIHF at least two years before thestart of the championship in which he wishes to participate, and

B) he must prove that he has participated for at least two consecutive years in the national competitions of and resident in his new country during which period he has neither transferred to another country nor played ice hockey within any other country.

1.7 When a player has multiple citizenships where the relevant citizenships are for countries of member national associations and he has never represented any country in any IIHF championship or an Olympic competition or in qualifications to these competitions, then in order to play for the country of his choice he must

A) prove that he has participated for at least two consecutive years in the national competitions of and resident in the country that he wishes to represent during which period he has neither transferred to another country nor played ice hockey within any other country and

B) if the country of his choice is one to which the player has transferred then he must have had an IIHF international transfer card approved and dated by the IIHF at least two years prior to his proposed participation. 
When a player wishes to establish his eligibility under subsections c) or e) or f) or g) the member national association for which he wishes to play must submit an application to the IIHF together with all relating evidence at the latest four wedks before the competition or game in which the player wishes to play. The General Secretary is responsible for investigating the application and confirming the player's eligibility to play for the country concerned. Notwithstanding the above, the decision of the General Secretary is not condusive proof of the eligibility of the player to play for the country concerned.

1.8 Exceptional circumstances can be decided by Council.

1.9 Players of non-member organizations who participate in competitions of the IIHF induding Olympic competitions and in qualifications to these competitions must, for the period of these events, be under the control and management of the respective member national association and be eligible in accordance with the applicable criteria to compete. When competing in the above specified competitions, these players are subject to the same conditions as other players and to the disciplinary procedures of thellHF.

$[\ldots]$

IIHF STATUTES AND BYLAWS 2003-2008

200 COM PETITIONS, ELIGIBILITY, TRANSFERS

203. Olympic Competitions

The Olympic ice hockey competitions are operated by the IIHF under and are subject to the competition Bylaws, Regulations and official playing rules of the IIHF. The eligibility of players must be as permitted by the IIHF and accepted by the IOC. Participation by the IIHF in the Olympic Winter Games is subject to approval of Congress.

204. Player E ligibility R ules for Participation in IIHF Championships and O lympic Competitions

It is the objective of the IIHF that national teams competing in IIHF championships shall reflect the status and standard of the sport as currently played in the country concemed.

1. Only players meeting the following qualification requirements can participate in the IIHF championships, the Olympic competition and in the qual ifications to these competitions:

a) Each player must be under thejurisdiction of a member national icehockey association of the IIHF and be a citizen of the country he represents. The player must properly complete and sign the IIHF Player Entry Form which must also be completed and countersigned by his member national association which is at all times responsible for the player's eligibility.

b) The player must submit (a) his signed Player Entry Form and (b) his valid national passport, which must confirm that heis a citizen of the country he represents.

c) When once a player has represented a country in any IIHF championship, or in the Olympic competition or in the qualification to these competitions he will not be eligible to represent another country excepting that he may apply to the IIHF to represent another country provided that (a) he is a citizen of that country, (b) he has an international transfer card that was approved and dated by the IIHF at least four years before the start of the II HF competition in which he wishes to participate, (c) he has participated for at least four consecutive years in the national competitions of his new country during which period he has neither transferred to another country nor played ice hockey within any other country, and (d) he has not played for his previous country in an IIHF competition during this four year period. Such a change will be allowed only once in a player's life and is final and irrevocable

d) A player who has represented a country in any IIHF championship, Olympic competition or in the qualifications to these competitions and has later acquired another citizenship shall still be eligible to represent his old country provided heis still a citizen of that country.

e) If a country or part of it becomes independent, or if a country or part of it becomes incorporated into another country, or if two or more countries are united into a new country, or if a country is divided into more countries, a player who has al ready represented a country and whose citizenship was thus changed by decision of the state authorities, may apply to the IIHF to play for any one of the partitioned or united countries without a waiting period subject to his providing proof of his new citizenship. This particular choice may only be made once and is final and irrevocable

f) When a player has changed his citizenship or has acquired another citizenship and wants to participate for the first time in an IIHF competition and represent his new country he must (a) have an IIHF international transfer card that was approved and dated by the IIHF at least two years before the start of the championship in which he wishes to participate, and (b) he must prove that he has participated for at least two consecutive years in the national competitions of his new country during which period he has neither transferred to another country nor played ice hockey within any other country.

g) When a player has multiple citizenship where the relevant citizenships are for countries of member national associations and he has never represented any country in any IIHF championship or an Olympic competition or in qualifications to these competitions, then in order to play for the country of his choice he must (a) prove that he has participated for at least two consecutive years in the national competitions of the country that he wishes to represent during which period he has neither transferred to another country nor 
played ice hockey within any other country and (b) if the country of his choice is one to which the player has transferred then he must have had an II HF international transfer card approved and dated by the IIHF at least two years prior to his proposed participation. When a player wishes to establish his eligibility under subsections $\mathrm{c}$ ) or $\mathrm{e}$ ) or $\mathrm{f}$ ) or $\mathrm{g}$ ) the member national association for which he wishes to play must submit an application to the IIHF together with all relating evidence at the latest four weeks before the compeition or game in which the player wishes to play. The General Secretary is responsible for investigating the application and confirming the player's eligibility to play for the country concerned. Notwithstanding the above, the decision of the General Secretary is not condusive proof of the eligibility of the player to play for the country concerned.

h) Exceptional circumstances can be decided by Council.

i) Players of non-member organizations who participate in competitions of the IIHF including Olympic competitions and in qualifications to these competitions must, for the period of these events, be under the control and management of the respective member national association and be eligible in accordance with the applicable criteria to compete. When competing in the above specified competitions, these players are subject to the same conditions as other players and to the disciplinary procedures of thelIHF.

$[\ldots]$

\section{J udo}

\section{Sports and Organization R ules of the International J udo Federation Edition 2015}

\section{$1.7 \mathrm{M}$ inor Athlete}

The National Federation is responsible for obtaining legal approval and permission for minor athletes to compete in IJ F competitions. This also applies to doping testing. The National Federation must ensure that minor athletes have parental/guardian permission to undergo testing.

\subsection{Nationality}

The athletes must be of the same nationality as the National Federation for which they have been entered. Persons appointed by the Executive Committee of the IJF shall verify the citizenship of the athletes. The evidence of citizenship shall be the production of a passport issued by the represented country.

In the following cases, particular procedures must be applied:

A)Where the competitions are being held in a country in which the residents do not hold passports while in that country.

B)Where there is a possi ble problem of "joint citizenship", eg. Puerto Rico an acceptable substitute for the passport will be a letter or certificate from the athlete's National Olympic Committee or, if there is no such body, from the National Sports Authority confirming the athlete's residence in that country and the citizenship.

If a competitor has multiple citizenships they may compete for only one country. A competitor who has represented one country in the Olympic Games, World Championshi ps, in continental, regional games and/or Championships or International Tournaments organized by IJ F or under its auspices, and who has changed their nationality or acquired a new national ity may participate to represent their new country provided that at least three years have passed since the athletes last represented their former country. If the two National Federations concerned agree, they may request the IJ $F$ to shorten the period of three years or even to cancel the duration (see Olympic Charter, Rule 41 and the Byelaw to Rule 41).

Thus, the IJF can't shorten the three years period without written agrement from both the National Federations concerned.

The aforementioned "three years rule" is only implemented in case of the athl ete having al ready represented a country during Olympic Games, World Championships, in continental, regional games and/or Championships or International Tournaments organized by IJ F or under its auspices.

The request to shorten the "three years period" shall be sent by the host National Federation to the IJF General Secretary.

This request has to be sent with the documents below:

- Letter from the athlete, who has al ready represented their country, giving evidence of their wish to represent their new Federation.

- Letter from the President of the National Federation (the country of origin) certifying the absence of objection to the change of the nationality of the concerned athlete 17

- Letter from the President of the National Federation (the host country) authorizing the athlete to represent this Federation in international competitions.

- A copy of the athlete passport mentioning the nationality of the host country.

On receipt of a complete file the IJF General Secretary will examine it and send it out to the IJF Executive Committee for approval. If the majority of the IJF Executive Committee approves the request, the IJF General Secretary confirms the acceptance of the application to the concerned party, with both origin and host Federations in copy. Any athlete disrespecting this rule may be subject to disciplinary measures. 


\section{APPENDICES}

IF GENERAL SECRETARY 24/01/2014

PROCEDURE OF PARTICIPATION IN IJ F COM PETITIONS FOR THE ATHLETES* WHO WANT TO REPRESENT ANOTHER COUNTRY

The Article 13.3.1 of the IJ F Sport Organization R ules relating to changes of nationality tells that:

"The competitors must be of the same nationality as the National Federation, which has entered them

[...]

If a competitor has multiple citizenships he may compete for only one country. A competitor who has represented one country in the Olympic Games, World Championships, in continental, regional games and/or Championships or International Tournaments organized by IJ F or under its auspices, and who has changed his nationality or acquired a new nationality may participate to represent his new country provided that at least three years have passed since the competitor last represented his former country. If the two National Federations concerned agree they may request the International J udo Federation to shorten the period of three years, even to cancel the duration."

Thus, The IJF can't shorten the three years period requested by the article 13.3.1 of the SOR without written agreement from both federations concerned. The "three years rule" aforementioned is only implemented in case of the athlete have al ready represented a country during Olympic Games, World Championships, in continental, regional games and/or Championships or International Tournaments organized by IJ F or under its auspices.

The request of shorten the " 3 years period" shall be sent by the host national federation to the IJ $F$ General Secretary.

This request has to be sent with the documents below:

- Letter from the athletegiving evidence of his wish to represent his new federation.

- Letter from the President of the National Federation (the country of origin) certifying the absence of objection to the change of the national ity of the concerned athlete

- Letter from the President of the National Federation (the host country) authorizing the athl ete to represent this Federation in theinternational competitions.

- A copy of the athlete passport mentioning the nationality of the host country.

From receipt of a complete filethe General Secretary examines it and sends it out to the IJF EC members for approval.

In the request is approved by the majority of the EC members, the General Secretary confirms the acceptance of the application to the concerned party, with both origin and host Federations in copy.

*Athletes who has al ready represented their country.

\section{Sports and Organization R ules of the International J udo Federation 2013}

\subsection{Gender Control and MINOR athletes}

The gender control is placed under the responsibility of the National Federations neverthel ess the IJF keeps the right to request under certain circumstances the communication of the documentation to the IJ F Medical Director.

\section{M inor athlete}

The National Federation is responsible to obtain all the necessary legal approvals and permissions for the minor athlete to take part in the IJF competition. This also applies for antidoping testing. The national federation is to ensure that the minor athlete has the parent/guardian permission to undergo these tests.

\subsection{Accreditation card}

For each official team member from a national delegation (competitor, coach, team official, doctor,...) an accreditation card is issued from IJ $F$ during official registration. This card contains: Family NAME, Given name, country, IJ F id number, picture and for competitors additionally weight category and World Rarking list number. This accreditation card is valid for duration of the Championships and represents for all controls the personal identity document of the competitor.

\subsubsection{Nationality}

The competitors must be of the same national ity as the National Federation, which has entered them Persons appointed by the Executive Committee of the IJF shall verify the citizenship of the competitors. The evidence of citizenship shall bethe production of a passport issued by the country for which the competitor is entered to compete

In the following cases, particular procedures must be applied:

a) where the competitions are being held in a country in which the residents do not hold passports while in that country;

b) where there is a possible problem of "joint citizenship", eg. Dutch Antilles and the Netherlands an acceptable substitute for the passport will be a letter or certificate from the competitor's National Olympic Committee or, if there is no such body, from the National Sports Authority confirming the competitor's residence in that country and the citizenship. If a competitor has multiple citizenships he may compete for only one country. A competitor who has represented one country in the Olympic Games, World 
Championships, in continental, regional games and/or Championships or International Tournaments organized by IJF or under its auspices, and who bas changed his nationality or acquired a new nationality may participate to represent his new country provided that at least three years have passed since the competitor last represented his former country. If the two National Federations concemed agree they may request the International Judo Federation to shorten the period of three years, even to cancel the duration (see Olympic Charter, Rule 42 and the Byelaw to Rule 42). The competitor himself must come to the control. During the control the name, the age, the sex, the weight category for which the competitor has been entered, and the placing at the previous Olympic Games and World Championships shall beverified [... ]

Annex 1 Regulations for Team Event (M en and Women)

2) CONTROL OF THE RIGHT TO COM PETE

During the control (based on the Sport and Organization Rules of the IJF), identity, gender and weight category in which the competitors have been entered will bechecked:

2.1) Check of the nationality of the competitors

Competitors must be of the same nationality as the country enters them Proof of identity will be established by production of a passport or an official document or its copy from the country for which the competitor has been entered and then the control card will be issued for the competitor. If a competitor has more than one nationality, such competitor can only represent one country and thereafter may not represent any other country, until after a period of three (3) years has elapsed. If the two federations concerned wish so, they can ask the IJ F to reduce or even to suppress this delay in conformity with the Sport and Organization Rules of the IJF and the Olympic Chart, point 42.Only two persons of a National Federation shall be permitted to attend the control and shall producethe competitors' documents.

[... ]

IJF STATUTES (SWISS ASSOCIATION) (Translated from the French original)IJ F CONGRESS AUGUST 23, 2013 RIO DE JANEIRO APPLICABLE IM MEDIATELY AS SOON AS ADOPTED

1.5 Country

A "Country" shall mean an independent State recognized by the international community and which has a flag and a national anthem

$[\ldots]$

5.1 Athletes' right to participate

To be eligible to participate in the Olympic Games, World Championships, Continental Championships, International Competitions and Competitions held under the supervision of or recognized by the IJ F, a judoka must comply with rules of thelJ F and theIOC.

\section{L uge}

\section{Artificial Track}

International Luge Federation IRO INTERNATIONAL LUGE REGULATIONS ARTIFICIALTRACK - 2014 Edition Approved at the 62nd FIL Congress on June 20, 2014 in Innsbruck / Austria

\$ 1 General Regulations

3. Athletes registered by their National Federations (NFs) can participate in all FIL compeitions if they have a valid FIL license

The licenses arefilled out by the respective National Federation on behalf of theFIL and are newly signed by the President of the respectiveNF or by a person authorized by him/her every season.

With the signature of the National Federation's representative, it has to beconfirmed that

A) theathlete is a member of his/her federation or one of its associated dubs,

B) the athleteis insured for practicing the sport of lugeal so in foreign countries,

C) the athlete has a medical certificate that is based on a medical examination conducted during the last 12 month or a subsequent medical examination in the event of a serious injury, and states that from a point of view of sports medicine, he/sheis fit for practicing the sport of luge,

D) the athlete has received such a basic training that one could expect the athlete to be able to master luge tracks used for competitions in a safe way.

The license only becomes valid after the athletes declare in writing that they bindingly acknowledge the statutes and regulations of the FIL, especially the IRO, the Law and Procedure Regulations of the FIL and that they have knowledge of the contents of all regulations.

Thelicense has to be submitted to the race director prior to each competition.

$[\ldots]$

8. Authorization to participate in training

An athleteis authorized to participate in training if 


\section{APPENDICES}

- he/she fulfills the general athletic demands of the sport and has successfully completed a FIL luge school. The confirmation is provided by the responsible FIL coach. If in doubt, an athletics test will be carried out by the responsibleFIL coach, of which the athlete must fulfill the minimum requirements.

- he/she has not started for another nation during the respective sport year,

- a valid licenseis submitted,

- the age class regulations are adhered to,

- he/she has been registered for the competition in correspondence with the regulations for eligibility under $\S 3$ point 3. (Exception: Athletes who do not participate in the competition, but start as forerunners).

IRO INTERNATIONAL LUGE REGULATIONS - ARTIFICIAL TRACK - Approved at the 60th FIL Congress on J une 15, 2012 in Riga / Latvia

3. Athletes registered by their National Federations (NFs) can participate in all FIL competitions if they have a valid FIL license

The licenses are filled out by the respective National Federation on behalf of theFIL and arenewly signed by the President of the respectiveNF or by a person authorized by hi m/her every season.

With the signature of the National Federation's representative, it has to be confirmed that

a) the athleteis a member of his/her federation or one of its associated clubs,

b) the athleteis insured for practicing the sport of lugeal so in foreign countries,

c) the athlete has a medical certificate that is based on a medical examination conducted during the last 12 month or a subsequent medical examination in the event of a serious injury, and states that from a point of view of sports medicine, he/sheis fit for practicing the sport of luge,

d) the athlete has received such a basic training that one could expect the athlete to be able to master luge tracks used for competitions in a safe way.

The license only becomes valid after the athletes declare in writing that they bindingly acknowledge the statutes and regulations of the FIL, especially the IRO, the Law and Procedure Regulations of the FIL and that they have knowledge of the contents of all regulations. The license has to be submitted to the race director prior to each competition.

[...]

8. Authorization to participate in training

An athleteis authorized to participatein training if

$w$ he/she fulfills the general athletic demands of the sport and has successfully completed a FIL luge school. The confirmation is provided by the responsibleFIL coach. If in doubt, an athletics test will be carried out by the responsibleFIL coach, of which the athletemust fulfil theminimum requirements.

w he/she has not started for another nation during the respective sport year,

w a valid license is submitted,

$w$ the age class regulations are adhered to,

w he/she has been registered for the competition in correspondence with the regulations for eligibility under $\S 3$ point 3. (Exception: Athl etes who do not participatein the competition, but start as forerunners).

\section{IRO INTERNATIONAL LUGE REGULATIONS- ARTIFICIAL TRACK -2010 Edition}

Approved at the $58^{\text {th }}$ FIL Congress on J une 18, 2010 in Sochi / Russian Federation

\section{$\S 1$ General Regulations}

3. Athletes registered by their National Federations (NFs) can participate in all FIL competitions if they havea valid FIL license

The licenses are filled out by the respective National Federation on behalf of theFIL and arenewly signed by thePresident of the respectiveNF or by a person authorized by him/her every season.

With the signature of the National Federation's representative, it has to be confirmed that

- the athleteis a member of his/her federation or one of its associated clubs,

- the athleteis insured for practicing the sport of luge al so in foreign countries,

- the athlete has a medical certificate that is based on a medical examination conducted during the last

12 month or a subsequent medical examination in the event of a serious injury, and states that from a point of view of sports medicine, he/sheis fit for practicing the sport of luge, and

- the athlete has received such a basic training that one could expect the athlete to be able to master luge tracks used for competitions in a safe way.

The license only becomes valid after the athletes declare in writing that they bindingly acknowl edge the statutes and regulations of the FIL, especiall ly the IRO, the Law and Procedure Regulations of the FIL and that they have knowledge of the contents of all regulations.

The license has to be submitted to the race director prior to each competition.

The event organizer authorized to stage FIL competitions is obligated to conclude a liability insurance for the entire duration of the competition in which the extent of the coverage is to be regulated through a written agreement. 


\section{NATIONALITY REQUIREMENTS IN OLYMPIC SPORTS}

Any liability of theFIL will be explicitely excluded.

IRO INTERNATIONAL LUGE REGULATIONS- ARTIFICIAL TRACK - 2008 Edition

Approved at the $56^{\text {th }}$ FIL Congress on J une 28, 2008 in Cal gary / Canada

$\S 1$ General Regulations

3. Athletes registered by their National Federations (NFs) can participate in all FIL compeitions if they havea valid FIL license

Thelicenses arefilled out by the respective National Federation on behalf of theFIL and are newly signed by the President of the respectiveNF or by a person authorized by him/her every season.

With the signature of the National Federation's representative, it has to be confirmed that

- the athleteis a member of his/her federation or one of its associated clubs,

- the athleteis insured for practicing the sport of luge al so in foreign countries,

- the athlete has a medical certificate that is based on a medical examination conducted during the last

12 month or a subsequent medical examination in the event of a serious injury, and states that from a point of view of sports medicine, he/sheis fit for practicing the sport of luge, and

- the athlete has received such a basic training that one could expect the athlete to be able to master luge tracks used for competitions in a safe way.

The license only becomes valid after the athletes declare in writing that they bindingly acknowledge the statutes and regulations of the FIL, especially the IRO, the Law and Procedure Regulations of the FIL and that they have knowledge of the contents of all regulations.

The license has to be submitted to the race director prior to each competition.

The event organizer authorized to stage FIL competitions is obligated to cond ude a liability insurance for the entire duration of the competition in which the extent of the coverage is to be regulated through a written agreement.

Any liability of theFIL will be explicitely excluded.

IRO INTERNATIONAL LUGE REGULATIONS- ARTIFICIAL TRACK -2006E dition

Approved at the $54^{\text {th }}$ FIL Congress on J une29, 2006 in Berchtesgaden / Germany

$\S 1$ General Regulations

3. Athletes registered by their National Federations (NFs) can participate in all FIL competitions if they havea valid license

The licenses arefilled out by the respective National Federation on behalf of theFIL and are newly signed by the President of the respectiveNF or by a person authorized by him/her every season.

With the signature of the National Federation's representative, it has to be confirmed that

- theathleteis a member of his/her federation or one of its associated clubs,

- the athleteis insured for practicing the sport of lugeal so in foreign countries,

- the athlete has a medical certificate that is based on a medical examination conducted during the last

12 month or a subsequent medical examination in the event of a serious injury, and states that from a point of view of sports medicine, he/sheis fit for practicing the sport of luge, and

- the athlete has received such a basic training that one could expect the athlete to be able to master luge tracks used for competitions in a safe way.

The license only becomes valid after the athletes declare in writing that they bindingly acknowl edge the statutes and regulations of the FIL, especially the IRO, the Law and Procedure Regulations of the FIL and that they have knowl edge of the contents of all regulations.

The license has to be submitted to the race director prior to each competition.

The event organizer authorized to stage FIL competitions is obligated to concl ude a liability insurance for the entire duration of the competition in which the extent of the coverage is to be regulated through a written agreement.

Any liability of theFIL will be explicitely excluded.

IRO INTER NATIONAL LUGE REGULATIONS - ARTIFICIAL TRACK - 2004 Edition

Approved at the 52 ${ }^{\text {th }}$ FIL Congress on J une 11, 2004 in Rio deJ aneiro / Brazil

$\S 1$ General Regulations

3. Athletes registered by their National Federations (NFs) can participate in all FIL competitions if they have a valid license. The licenses are filled out by the respective NF on behalf of the FIL and are newly signed by the President of the respective NF or by a person authorized by him/her every season. With the signature of the National Federation's representative, it is confirmed that the athleteis a member of his/her federation or one of its associated club, that he/she is sufficiently insured and medically fit for practicing the sport of luge by going through a medical examination with positive result that is not older than 12 months. The license only becomes valid after the athletes declare in writing that they bindingly 
acknowledge the statutes and regulations of the FIL, especially the IRO, the Law and Procedure Regulations of the FIL and that they have knowledge of the contents of all regulations. The license has to be submitted to the race director prior to each competition.

The event organizer authorized to stage FIL competitions is obligated to conclude a liability insurance for the entire duration of the competition in which the extent of the coverage is to be regulated through a written agreement. Any liability of theFIL will be explicitely excluded.

\section{IRO INTERNATIONAL LUGE REGULATIONS- ARTIFICIAL TRACK -2002 Edition}

Approved at the $50^{\text {th }}$ FIL Congress on J une 28, 2002 in St. Wolfgang / AUT

\section{§ 1 General Regulations}

3. Athletes registered by their National Federations (NFs) can participate in all FIL competitions if they have a valid license. The license is issued after the insurance and the medical check-up for the respective sport's year have been entered. The licenses are filled out by the respective NF on behalf of the FIL and arenewly signed by the President of the respectiveNF or by a person authorized by him/her every season. With the signature of the National Federation's representative, it is confirmed that the athlete is a member of his/her federation or one of its associated club, that he/she is sufficiently insured and medically fit for practicing the sport of luge. The license only becomes valid after the athletes declare in writing that they bindingly acknowl edge the statutes and regulations of the FIL, especial ly the IRO, the Law and Procedure Regulations of the FIL and that they have knowledge of the contents of all regulations. The license has to besubmitted to the race director prior to each competition.

\section{IRO INTERNATIONALE RENNRODEL ORDNUNG - KUNSTBAHN -Ausgabe 2000}

Beschl ossen beim 48. FIL-Kongress am 17.6.2000 in Oberhof / GER

\section{$\S 1$ General Regulations}

3. Athletes registered by their National Federations (NFs) can participate in all FIL competitions if they have a val id license. The license is issued after the insurance and the medi cal check-up for the respective sport's year have been entered. The licenses are filled out by the respective NF on behalf of the FIL and are newly signed by the President of the respectiveNF or by a person authorized by him/her every season. With the signature of the National Federation's representative, it is confirmed that the athlete is a member of his/her federation or one of its associated club, that he/she is sufficiently insured and medically fit for practicing the sport of luge. The license only becomes valid after the athletes dedare in writing that they bindingly acknowl edge the statutes and regulations of the FIL, especial ly the IRO, the Law and Procedure Regulations of the FIL and that they have knowledge of the contents of all regulations. The license has to be submitted to the race director prior to each competition.

\section{IRO INTERNATIONAL LUGE REGULATIONS- ARTIFICIAL TRACK -1998 Edition}

\section{Approved at the $46^{\text {th }}$ FIL Congress on J une 7, 1998 in Colorado Springs}

\section{§ 1 General Regulations}

3. Athletes and teams registered by their National Federations (NFs) can participate in all FIL competitions if they have a val id license. The license is issued after the insurance and the medical checkup for the respective sport's year have been entered. The licenses are filled out by the respective NF on behalf of the FIL and signed. The license only becomes valid after the athletes declare in writing that they bindingly acknowl edge the statutes and regulations of theFIL, especially the IRO, the Law and Procedure Regulations of the FIL and that they have knowledge of the contents of all regulations. The license has to besubmitted to the race director prior to each competition.

\section{Natural Track}

IRO INTERNATIONAL LUGE REGULATIONS - NATURAL TRACK - 2014 E dition

Approved at the $62^{\text {th }}$ FIL Congress on J une 20, 2014 in Innsbruck / Austria

International L uge R egulations Natural Track 2014

\section{§ 1 General Regulations}

1.3 Athletes registered by their National Federations (NFs) can participatein all FIL competitions if they have a valid licence The licences are filled out by the respective NF on behalf of the FIL and are newly signed by the President of the respective NF or by a person authorized by him/her every season. With the signature of the National Federation's representative, it has to be confirmed that the athlete

- is a member of his/her federation or one of its associated dub

- that he/sheis insured for practicing the sport of luge al so in foreign countries,

- that he/she possesses a medical certificate that is based on a medical examination conducted 
during the preceeding 12 months and a subsequent medical examination in the event of a serious injury, which states that from a point of view of sports medicine, he/she is fit for participating in the sport of luge, and

- that he/she has received sufficient training so as one could expect the athlete to be able to safely navigatelugetracks during competitions and official training.

The licence only becomes valid after the athlete declares in writing that they bindingly acknowledge the statutes and regulations of the FIL, especially the IRO, the Law and Procedure Regulations of the FIL and that they have knowledge of the contents of all regulations. The licence must be submitted to the chairperson of the jury prior to each competition.

\section{IRO INTERNATIONAL LUGE REGULATIONS - NATURAL TRACK - 2012 Edition}

Approved at the 60th FIL Congress on J une 15, 2012 in Riga/ Latvia

1.3 Athletes registered by their National Federations (NFs) can participate in all FIL competitions if they have a valid licence The licences are filled out by the respective NF on behalf of the FIL and are newly signed by the President of the respective NF or by a person authorized by him/her every season. With the signature of the National Federation's representative, it has to be confirmed that the athlete

- is a member of his/her federation or one of its associated club

- that he/sheis insured for practicing the sport of luge al so in foreign countries,

- that he/she possesses a medical certificate that is based on a medical examination conducted during the preceeding 12 months and a subsequent medical examination in the event of a serious injury, which states that froma point of view of sports medicine, he/sheis fit for participating in the sport of luge, and

- that he/she has received sufficient training so as one could expect the athlete to be able to safely navigate lugetracks during competitions and official training.

The licence only becomes valid after the athlete declares in writing that they bindingly acknowledge the statutes and regulations of the FIL, especially the IRO, the Law and Procedure Regulations of the FIL and that they have knowledge of the contents of all regulations. The licence must be submitted to the chairperson of the jury prior to each competition.

The event organizer authorized to stage FIL competitions is obligated to secure liability insurance for the entire duration of the competition in which the extent of the coverage is to be regulated through a written agreement Any liability of theFIL will be explicitly excluded.

$[\ldots]$

6. Authorization to Participate in Training

An athlete is authorized to participatein training if:

- the athlete has not started for another nation during the respective sport year,

- a valid license is submitted, and

- the age class regulations are adhered to.

During Championships and World Cups one athlete per singles discipline as well as one additional doubles team may start in addition to the athletes named under $\S 3.3 .5$.

All participants in doubles can al so take onetraining run as singles.

\section{IRO INTERNATIONAL LUGE REGULATIONS - NATURAL TRACK - 2010 Edition}

Approved at the 58 $8^{\text {th }}$ FIL Congress on J une 18, 2010 in Sochi / Russian Federation

\section{§ 1 General Regulations}

1.3. Athletes registered by their National Federations (NFs) can participate in all FIL competitions if they have a valid licence The licences are filled out by the respective NF on behalf of the FIL and are newly signed by the President of the respective NF or by a person authorized by him/her every season. With the signature of the National Federation's representative, it has to be confirmed that the athlete

- is a member of his/her federation or one of its associated club

- that he/she is insured for practicing the sport of lugeal so in foreign countries,

- that he/she has a medical certificate that is based on a medical examination conducted during the last 12 month or a subsequent medical examination in the event of a serious injury, and states that from a point of view of sports medicine, he/sheis fit for practicing the sport of luge, and

- that he/she has received such a basic training that one could expect the athl ete to be able to master luge tracks used for competitions and official trainings in a safe way.

The licence only becomes valid after the athletes declare in writing that they bindingly acknowledge the statutes and regulations of the FIL, especially the IRO, the Law and Procedure Regulations of the FIL and that they have knowledge of the contents of all regulations. The licence has to be submitted to the chair rperson of thejury prior to each competition.

The event organizer authorized to stage FIL competitions is obligated to conclude a liability insurance for the entire duration of the competition in which the extent of the coverage is to be regulated through a written 


\section{APPENDICES}

agreement. Any liability of theFIL will be explicitly excluded.

\section{IRO INTERNATIONAL LUGE REGULATIONS - NATURAL TRACK - 2008 Edition}

Approved at the 56 th FIL Congress on J une 28, 2008 in Cal gary / Canada

\section{$\S 1$ General Regulations}

1.3 Athletes registered by their National Federations (NFs) can participate in all FIL competitions if they have a valid licence The licences are filled out by the respective NF on behalf of the FIL and are newly signed by the President of the respective NF or by a person authorized by him/her every season. With the signature of the National Federation's representative, it has to beconfirmed that the athlete

- $\quad$ is a member of his/her federation or one of its associated dub

- that he/sheis insured for practicing the sport of lugeal so in foreign countries,

- that he/she has a medical certificate that is based on a medical examination conducted during the last 12 month or a subsequent medical examination in the event of a serious injury, and states that from a point of view of sports medicine, he/she is fit for practicing the sport of luge, and

- that he/she has received such a basic training that one could expect the athlete to be able to master luge tracks used for competitions and official trainings in a safe way.

The licence only becomes valid after the athletes declare in writing that they bindingly acknowledge the statutes and regulations of the FIL, especially the IRO, the Law and Procedure Regulations of the FIL and that they have knowledge of the contents of all regulations. The licence has to be submitted to the chairperson of the jury prior to each competition.

The event organizer authorized to stage FIL competitions is obligated to concl ude a liability insurance for the entire duration of the competition in which the extent of the coverage is to be regulated through a written agreement Any liability of theFIL will be explicitly excluded.

\section{IR O INTER NATIONAL LUGE REGULATIONS - NATURAL TRACK - 2006 E dition}

Approved at the $54^{\text {th }}$ FIL Congress on J une 29, 2006 in Berchtesgaden / Germany

\section{$\S 1$ General Regulations}

1.3. Athletes registered by their National Federations (NFs) can participate in all FIL competitions if they have a valid licence. The licences are filled out by the respective NF on behalf of the FIL and are newly signed by the President of the respective NF or by a person authorized by him/her every season. With the signature of the National Federation's representative, it has to be confirmed that the athlete

- $\quad$ is a member of his/her federation or one of its associated dub

- that he/sheis insured for practicing the sport of lugeal so in foreign countries,

- that he/she has a medical certificate that is based on a medical examination conducted during the last 12 month or a subsequent medical examination in the event of a serious injury, and states that from a point of view of sports medicine, he/she is fit for practicing the sport of luge, and

- that he/she has received such a basic training that one could expect the athlete to be able to master luge tracks used for competitions and official trainings in a safe way.

The licence only becomes valid after the athletes declare in writing that they bindingly acknowledge the statutes and regulations of the FIL, especially the IRO, the Law and Procedure Regulations of the FIL and that they have knowledge of the contents of all regulations. The licence has to be submitted to the race director prior to each competition.

The event organizer authorized to stage FIL competitions is obligated to concludea liability insurancefor the entire duration of the competition in which the extent of the coverage is to be regulated through a written agreement. Any liability of the FIL will be explicitly excluded.

\section{IR O INTER NATIONAL LUGE REGULATIONS - NATURAL TRACK - 2004 Edition}

Approved at the $52^{\text {nd }}$ FIL Congress on J une 11, 2004 in Rio de J aneiro, Brazil

\section{$\S 1$ General Regulations}

1.3. Athletes registered by their National Federations (NFs) can participate in all FIL competitions if they have a valid licence. The licences are filled out by the respective NF on behalf of the FIL and are newly signed by the President of the respective NF or by a person authorized by him/her every season. With the signature of the National Federation's representative, it is confirmed that the athlete is a member of his/her federation or one of its associated club, that he/she is sufficiently insured and medically fit for practicing the sport of luge by going through a medical examination with positive result that is not older than 12 months. The licence only becomes valid after the athletes declare in writing that they bindingly acknowledge the statutes and regulations of the FIL, especially the IRO, the Law and Procedure Regulations of the FIL and that they have knowledge of the contents of all regulations. The licence has to be submitted to the race director prior to each competition.

The event organizer authorized to stage FIL competitions is obligated to concludea liability insurancefor the 


\section{NATIONALITY REQUIREMENTS IN OLy MPIC SPORTS}

entire duration of the competition in which the extent of the coverage is to be regulated through a written agreement. Any liability of the FIL will be explicitely excluded.

\section{IRO INTERNATIONAL LUGE REGULATIONS - NATURAL TRACK -2002 Edition}

Approved at the $50^{\text {th }}$ FIL Congress on J une 28, 2002 in St. Wolfgang / AUT

\section{\$ 1 General Regulations}

1.3 Athletes registered by their National Federations (NFs) can participate in all FIL competitions if they have a valid license The license is issued after the insurance and the medical check-up for the respective sport's year have been entered. The licenses are filled out by the respective NF on behalf of the FIL and are newly signed by the President of the respective NF or by a person authorized by him/her every season. With the signature of the National Federation's representative, it is confirmed that the athlete is a member of his/her federation or one of its associated clubs, that he/she is sufficiently insured and medically fit for practicing the sport of luge. The license only becomes valid after the athletes dedare in writing that they bindingly acknowledge the statutes and regulations of the FIL, especially the IRO, the Law and Procedure Regulations of the FIL and that they have knowledge of the contents of all regulations. The license has to be submitted to the race director prior to each competition.

\section{IRO INTERNATIONAL LUGE REGULATIONS- NATURAL TRACK -2000E dition}

\section{Approved at the $48^{\text {th }}$ FIL Congress on J une 17, 2000 in Oberhof / GER}

\section{§ 1 General Regulations}

1.3. Athletes registered by their National Federations (NFs) can participate in all FIL competitions if they have a valid license. The license is issued after the insurance and the medical check-up for the respective sport's year have been entered. The licenses are filled out by the respective NF on behalf of the FIL and are newly signed by the President of the respective NF or by a person authorized by him/her every season. With the signature of the National Federation's representative, it is confirmed that the athlete is a member of his/her federation or one of its associated clubs, that he/she is sufficiently insured and medically fit for practicing the sport of luge. The license only becomes valid after the athletes dedare in writing that they bindingly acknowledge the statutes and regulations of the FIL, especially the IRO, the Law and Procedure Regulations of the FIL and that they have knowledge of the contents of all regulations. The license has to be submitted to the race director prior to each competition.

\section{INTERNATIONAL LUGE REGULATIONS- NATURAL TRACK -1998 Edition}

Approved at the $46^{\text {th }}$ FIL Congress on J une 7, 1998 in Colorado Springs

1.3 Athletes and teams registered by their National Federations (NFs) can participate in all FIL competitions, if they have a valid license. The license is issued after the insurance and the medical check-up for the respective sport's year have been entered. The licenses are filled out and signed by the respective NF on behalf of the FIL. The license becomes valid only after the athletes declare in writing that they bindly acknowledge the statutes and regulations of the FIL, especially the IRO, the Law and Procedure Regulations of the FIL and that they have knowledge of the contents of all regulations. The license has to be submitted to the race director prior to each competition.

\section{M odern Pentathlon}

\section{UIPM R ules on Internal Organisation Tapeo November 2015}

\section{Article 1}

1.1 These Rules are established by UIPM General Assembly pursuant to the authority conferred to it by UIPM Statutes (the "Statutes"). In case of conflict or discrepancy between these Rules and the Statues, the English language version of the Statues shall prevail.

\section{Article 2}

2. Official UIPM competitions are: the World Championships, World Cups, World Cup Finals, Champion of Champions and World Ranking Competitions, Qualification World Ranking Compeitions, Masters' Championship, Military Championships. At the Olympic Games and other multi---sport events UIPM represents the interests and movement of Modern Pentathlon (as defined in the Statutes). Each Continental Confederation is responsible for its Continental Championship according to the international calendar, adopted by the UI PM Executive Board.

Article 3

3.1 Only competitors and officials who are eligible according to the UIPM's eligibility rules are allowed to take part in competitions organised by UIPM or any of its Members.

3.2 Specific eligibility rules are included in the Compeition Rules. They are confirmed by the General Assembly and may in no way be contradictory to Rules and By---Laws on eligibility of the International Olympic Committee(IOC). 
3.3 A pentathlete who is a national of two or more countries at the same time may freely choose which to represent. However, after having represented one country in the Olympic Games, in continental or regional games or in world or regional championships recognised by UIPM, the same pentathl ete may not represent another country unless the conditions set forth in paragraph 3.4 below are met.

3.4 A pentathlete who has represented one country in the Olympic Games, in continental or regional games or in world or regional championships recogni sed by UIPM, and who has changed nationality or acquired a new national ity, may participate in the Olympic Games and represent the new country provided that at least 3 years have passed since the compeitor last represented the former country. This period may be reduced or even cancelled, with the agreement of the relevant Members and their respective National Olympic Committees (NOC) and the UIPM Executive Board, by the IOC Executive Board, which takes into account the circumstances of each case

3.5 If an associated State, province or overseas department, a country or colony acquires independence, if a country becomes incorporated within another country by reason of a change of border, if a country merges with another country, or if a new NOC is recogni sed by the IOC, a pentathlete may continue to represent the country to which the pentathlete belongs or belonged. However, a pentathlete may elect to represent the newly formed or recognised country or be entered in the Olympic Games by the relevant new NOC if one exists. This particular choice may be made only once

3.6 Furthermore, in all cases in which a competitor would be eligible to participate in the Olympic Games, either by representing another country or by having the choice as to the country which such competitor intends to represent, the IOC Executive Board may take all decisions of a general or individual nature with regard to issues resulting from nationality, citizenship, domicile or residence of any compeitor, including the duration of any waiting period.

3.7 Decisions made under the rules laid down by paragraphs 3.3 to 3.6 above have legal effect for UIPM competitions foll owing the Olympic Games involving such a change or choice of nationality. Furthermore, a pentathl ete who has represented a country in official UI PM Category A or Category B compeitions and who has changed nationality or acquired a new nationality, may participate in UIPM Category A or B competitions, not including the Olympic Games, and represent the new country starting from the next calendar year.

3.8 UIPM Members and their pentathletes are not all owed to compete in any competition organised by a non--member federation without prior written approval from the UIPM Executive Board. Pentathletes from non--member federations are eligible to participate in UIPM competitions on condition of their prior notification to theUIPM Secretary General by the host Member.

Union Internationale de Pentathlon Moderne(International Union of the Modern Pentathlon) STATUTES - UIPM Rules on Internal Organisation CHAPTER IV. - ELIGIBILITY RULES 2013 (applicable as of J anaury 2013)

CHAPTER IV. - ELIGIBILITY RULES

4.1 Only competitors and officials who are eligible according to the Union's eligibility rules are allowed to take part in competitions organised by theUIPM or its Members.

4.2 Specific eligibility rules are included in the Competition Rules. They are confirmed by the Congress and may in no way be contradictory to Rules and ByeLaws on eligibility of the International Olympic Committee(IOC).

4.3 A pentathlete who has represented a country in a Category " $A$ " competition is not entitled to represent in the Olympic Games his new country where he has established his permanent residence and acquired a new nationality until three years after this change, except upon formal agreement by the UIPM, the concerned NFs and NOCs and subsequent approval by the IOC EB.

4.4 A pentathlete who has represented a country in official UIPM Category " $A$ " or Category " $B$ " competitions is not entitled to represent in UIPM Category " $A$ " or " $B$ " competitions, not including Olympic Games, his new country where he has established his permanent residence and acquired a new nationality in the same cal endar year as this change.

Union Internationale de Pentathlon Moderne (International Union of the Modern Pentathlon) STATUTE S - UIPM Rules on Internal Organisation CHAPTER IV. - ELIGIBILITY RULES 2012

4.1 Only competitors and officials who are eligible according to the Union's eligibility rules are allowed to take part in competitions organised by theUIPM or its Members.

4.2 Specific eligibility rules are included in the Competition Rules. They are confirmed by the Congress and may in no way be contradictory to Rules and ByeLaws on eligibility of the International Olympic Committee (IOC).

Union Internationale de Pentathlon Moderne (International Union of the Modern Pentathlon) STATUTE S - UIPM Rules on Internal Organisation CHAPTER IV. - ELIGIBILITY RULES 2011 


\section{NATIONALITY REQUIREMENTS IN OLYMPIC SPORTS}

4.1 Only competitors and officials who are eligible according to the Union's eligibility rules are allowed to take part in competitions organised by the UIPM or its Members.

4.2 Specific eligibility rules are included in the Competition Rules. They are confirmed by the Congress and may in no way be contradictory to Rules and ByeLaws on eligibility of the International Olympic Committe(IOC).

Union Internationale de Pentathlon Moderne (International Union of the Modern Pentathlon) STATUTE S - UIPM Rules on Internal Organisation CHAPTER IV. - ELIGIBILITY RULES 2010

4.1 Only competitors and officials who are eligible according to the Union's eligibility rules are allowed to take part in competitions organised by the UIPM or its Members.

4.2 Specific eligibility rules are included in the Competition Rules. They are confirmed by the Congress and may in no way be contradictory to Rules and ByeLaws on eligibility of the International Olympic Committe(IOC).

Union Internationale de Pentathlon Moderne (International Union of the Modern Pentathlon) STATUTES - UIPM Rules on Internal Organisation 2009 CHAPTER IV. - ELIGIBILITY RULES 2009

4.1 Only competitors and officials who are eligible according to the Union's eligibility rules are allowed to take part in competitions organised by theUIPM or its Members.

4.2 Specific eligibility rules are included in the Competition Rules. They are confirmed by the Congress and may in no way be contradictory to Rules and ByeLaws on eligibility of the International Olympic Committe(IOC).

Union Internationale de Pentathlon Moderne (International Union of the Modern Pentathlon) STATUTE S - UIPM Rules on Internal Organisation CHAPTER IV. - ELIGIBILITY RULES 2008

4.1 Only competitors and officials who are eligible according to the Union's eligibility rules are allowed to take part in competitions organised by theUIPM or its Members.

4.2 Specific eligibility rules are included in the Competition Rules. They are confirmed by the Congress and may in no way be contradictory to Rules and ByeLaws on eligibility of the Intemational Olympic Committe(IOC).

Union Internationale de Pentathlon Moderne (International Union of the Modern Pentathlon) STATUTE S - UIPM Rules on Internal Organisation CHAPTE R IV. - ELIG IBILITY RULES 2007

4.1 Only competitors and officials who are eligible according to the Union's eligibility rules are allowed to take part in competitions organised by the UIPM or its Members.

4.2 Specific eligibility rules are included in the Competition Rules. They are confimed by the Congress and may in no way be contradictory to Rules and ByeLaws on eligibility of the International Olympic Committæe(IOC).

Union Internationale de Pentathlon Moderne(International Union of the Modern Pentathlon) STATUTE S - UIPM Rules on Internal Organisation CHAPTE R IV. - ELIGIBILITY RULE S 2005

4.1 Only competitors and officials who are eligible according to the Union's eligibility rules are allowed to take part in competitions organised by theUIPM or its Members.

4.2 Specific eligibility rules are included in the Competition Rules. They are confirmed by the Congress and may in no way be contradictory to Rules and ByeLaws on eligibility of the International Olympic Committe(IOC).

\section{Rowing}

\section{FISA R ule Book February 2013}

Rule 18 - Right to Participate

World Rowing Championships for Lightweight, Para-Rowing, Under 23 and Junior rowers as well as lightweight events included in the Olympic Games and events included in the Olympic Games and events in the Paralympic and Y outh Olympic Games are open only to rowers complying with the requirements of the relevant category.

The other events at the World Rowing Championships and Olympic regattas are open to all rowers without restriction of age or weight. Olympic, Paralympic and Y outh Olympic regattas are open only to those rowers whose federations have qual ified in the appropriate boat d asses in accordance with the relevant qual ification system prescribed in the Bye Laws.

Rule 19 - E ligibility and Nationality 


\section{APPENDICES}

World Rowing Championship, World Rowing Cup, Continental Championship and International regattas shall be open to all competitors who are authorised to compete by their member federation and who are eligible under the relevant rules.

To represent a country in a World Rowing Championship regatta, a competitor shall be a national of that country. He must be able to prove this by showing an official document (passport or identity card). In exceptional cases, the Executive Committee may makeexceptions.

To represent a country at a continental or final qualification regatta for the Olympic, Paralympic or Y outh Games, a competitor shall prove that he is eligible under the eligibility rules of the International Olympic Committee or the International Paralympic Committee respectively. In exceptional cases, the Executive Committee may makeexceptions.

A rower who is a national of two or more countries at the sametime may represent either one of them as the rower may elect However, having represented one country in a World Rowing Championship, Olympic or Paral ympic Games regatta, or Continental or Regional Games or Championship regatta, the rower may not represent another country unless the rower meets the conditions set out in the paragraph below that apply to persons who have changed national ity or acquired a new nationality.

A rower who has represented one country in a World Championship or Olympic or Paralympic Games regatta, or Continental or Regional Games or Championship regatta, and who has changed nationality or acquired a new nationality, may participate in a World Championship, Continental or Regional Games or Championship regatta representing the new country provided that at least two years of competition have passed since the year in which the rower last represented the former country. In exceptional cases the Executive Committee may make exceptions, and in doing so may consult the member federations concerned.

\section{FISA R ule Book - eligibility rules applicable 2005 to 2012:}

\section{Rule 43 - Authorisation of the M ember Federation}

a) International Regattas - A crew may compete in an international regatta in another country only if authorised in writing by its member federation. The latter shall be held responsible for the payment of the entry fees. This rule shall not apply to masters.

If an organising committee all lows a crew to enter its regatta without written authorisation from the relevant member federation then that federation cannot be held responsi ble for the crew and for its actions.

b) FISA Championship Regattas - To represent a country in a World Rowing Championship, a competitor shall be a citizen of that country. He must be able to prove this by showing an official document (passport or identity card). In exceptional cases, the Executive Committee may make exceptions.

At World Rowing Championships rowers shall compete under the name of their member federation which shall al one be entitled to represent them At Olympic Regattas rowers shall compete under the name of their National Olympic Committee which shall al one be entitled to represent them

\section{Rugby}

\section{HANDBOOK AS FRAMED BY WORLD RUGBY Last update: 8 M arch, 2016 REGULATION 8} ELIGIBILITY TO PLAY FOR NATIONAL REPRESENTATIVE TEAMS

8.1 Subject to Regulation 8.2, a Player may only play for the senior fifteen-a side National Representative Team the next senior fifteen-a-side National Representative Team and the senior National Representative Sevens Team of the Union of the country in which:

(a) hewas born; or

(b) one parent or grandparent was born; or

(c)hehas completed thirty six consecutive months of Residenceimmediately preceding the time of playing.

8.2 A Player who has played for the senior fifteen-a-side National Representative Team or the next senior fifteen-a-side National Representative Team or the senior National Representative Sevens Team of a Union is not eligible to play for the senior fifteen-a-side National Representative Team or the next senior fifteen-asideNational Representative Team or the senior National Representative Sevens Team of another Union.

8.3 For the purposes of this Regulation, a Player is deemed to have played for the senior fifteen-aside National RepresentativeTeam or the next senior fifteen-a-sideNational Representative Team of a Union if:

(a)He is selected for such team to play in an International Match against the senior fifteen-a-side National Representative Team or the next senior fifteen-a-side National Representative Team of another Union (or in a fifteen-a-side international Match against another Union's senior or next senior Touring Squad during a World Rugby approved International Tour) and is present at the Match played by that team either as a replacement, substitute or a playing member of that team and has, at the time of the Match, reached the age of majority; or

(b) He is selected to represent a Union's senior Touring Squad on an International Tour which includes an International Match or Matches approved by World Rugby and is present at any fifteen-a-side Match played on that International Tour either as a replacement, substitute or a playing member of a team selected from the Union's senior Touring Squad and has, at the time of the Match, reached the age of majority; or 
(c)He is sel ected to represent a Union's next senior Touring Squad on a World Rugby approved International Tour and during that International Tour he is present at a Match against the senior fifteen- a-side National Representative Team or the next senior fifteen-a side National Representative Team of another Union either as a replacement, substitute or playing member of a team selected from the Union's next senior Touring Squad and has, at thetime of the Match reached the age of majority.

(d) He is selected to represent the Under 20s National Representative Team of a Union which has been predesignated as that Union's next senior fifteen-arside National Representative Team and the Player is part of the team which participates in an International Match as part of the World Rugby Junior World Championships, World Rugby J unior World Rugby Trophy or the Six Nations U20 Championship and is present at the Match played by that Teemeither as a replacement, substitute or playing member of that Team and has, at the time of the Match, reached the age of majority.

8.4 For the purposes of this Regulation, a Player is deemed to have played for the senior National Representative Sevens Team of a Union if he is selected to represent a Union's senior National Representative Sevens Team in an International Match against the senior National Representative Sevens Team of another Union and is present at the Match played by that Team either as a replacement, substitute or playing member of that Teem and has, at the time of the Match, reached the age of majority.

8.5 Responsibility, breach and penalties for a breach of Regulation 8

\subsubsection{Unions}

Regulation 8 is a strict liability offence and shall be construed in accordance with the principles of strict liability under English law. It is not, therefore, necessary that fault or intent on the part of a Union be shown in order for a breach of Regulation 8 to be established. Nor is lack of fault or intent on the part of a Union a defence to a breach of Regulation 8. For the avoidance of any doubt (and without limiting a Union's other obligations and responsibilities for the conduct, acts or omissions of its members and Persons under its jurisdiction pursuant to any other Regulation) Unions are responsible and accountable for the conduct of their Players and all Persons under its jurisdiction in relation to compliance with the provisions of Regulation 8 and any breach of Regulation 8 by such Player(s) or Person(s) shall be deemed to be a breach of Regulation 8 by the Union concerned. Each breach of Regulation 8 by a Union, howsoever arising, will result in a minimum fixed fine being imposed on the Union concerned. The minimum fixed fines for each breach of Regulation 8 areas follows:

(a) For a Union that is represented on the Council $£ 100,000$ sterling;

(b) For all other World Rugby Member Unions $£ 25,000$ sterling.

Based on the facts and circumstances of any breach of Regulation 8 the applicable minimum fixed fine as set out above may be increased. In addition, other penalties as set out in Regulation 18.6 may al so be imposed on the Union concerned.

8.5.2 In exceptional circumstances, a Union in breach of Regulation 8 may make submissions to the relevant disciplinary body appointed under Regulation 18 to adjudicate on the case as to why the Uni on should not be subject to the applicable minimum fixed fine. For the avoidance of any doubt, however, the relevant disciplinary body shall only be entitled to reduce the applicable minimum fixed fine set out in this Regulation where the Union is able to provide clear and indisputable evidence that truly exceptional circumstances exist and that the Union concerned had taken all necessary steps to comply with Regulation 8. Players

8.5.3 Notwithstanding Regulations 8.5.1 and 8.5.2 aboveand without prejudice to any sanction imposed on a Union, Players may also be subject to sanction in accordance with Regulation 18 where they breach Regulation 8 in circumstances where they knew or ought reasonably to have known they were not eligible to play for the relevant Union at the time of participation.

8.6 To be eligible to participate in the Olympic Games, Olympic qualification events (together "Olympic Events") or other events governed by the Olympic Charter all members of the senior National Representative Sevens Team(s) of a Union or the selected Olympic Sevens Team(s) of a National Olympic Committee shall comply with Regulation 8.1 and must bea national of the country of the National Olympic Committee which it is representing in such Olympic Events. Regulation 8.2 applies equall ly to all Players.

8.7 A Player who is a national of the country or Union for which he has been captured under Regulation 8.2 and who holds the nationality of another country or Union, may apply to participate in an Olympic Event to represent his new country or Union subject to the foll lowing conditions;

8.7.1 The Regulations Committee shall consider the application of a Player under this Regulation 8.7 which must be submitted with all relevant supporting documentation by the Union for whom the Player wishes to next represent in an Olympic Event (or a Union associated with the Olympic Sevens Team the Player wishes to represent). The application shall be pre-notified to the Player's Union (namely the Union whose National Representative Team the Player represented);

8.7.2 The Player will be required to observe and demonstrate a stand down period of at least 3 years sincethe timethe Player last represented their former Union and thetimethe Player first plays for the second Union or 


\section{APPENDICES}

country, which must be in an Olympic Event. The Player may not represent the second Union in any other form of the Game until after they have participated in such Olympic Event.

(a)Solely in respect of the Rio Olympic Games 2016, a stand down period of at least 18 months will be permitted, between the time the Player last represented their former Uni on and the timethe Player first plays for the second Union or country, which must be in an Olympic Event in the Rio Olympic Games cycle, which the Player must observe and demonstrate.

8.8 Where the Player is not a national of the Union for which he has been captured under Regulation 8.2, and he meets the Olympic eligibility criteria (in Regulation 8.6 to 8.13 ) as determined by the Regulations Committee, he shall be eligible for selection to play for the Union / country of which he is a national, in an Olympic Event, subject to satisfying the applicable stand down period.

8.9 A Player who is eligible or captured for a Union that cannot participate in an Olympic Event because there is no National Olympic Committee sol ely for the territory of such Union, may, subject to the Olympic eligibility criteria (in Regulation 8.6 to 8.13), be eligible to play for the Olympic Sevens Team of a National Olympic Committee of which he is a national, provided that such team is not associated with any one single Union. In such circumstances the following provisions shall apply;

8.9.1 Wherethe Player has been captured under Regulation 8.2 for a Union he shall remain captured for such Union notwithstanding the Player's representation for the Olympic Sevens Team of a National Olympic Committein an Olympic Event;

8.9.2 Wherethe Player has not previously been captured under Regulation 8.2 and he represents the Olympic Sevens Team of a National Olympic Committee in an Olympic Event he will be deemed to be captured for one of the underlying Unions which support the Olympic Sevens Team of the relevant National Olympic Committee, and the Player must elect which of those underlying Unions he shall be captured by for the purposes of Regulation 8.

8.10 A Player who has represented one Union or Olympic Team in an Olympic Event and who has changed his nationality or acquired a new nationality, may apply to participate in an Olympic Event to represent his new Union or country provided that at least three years have passed since the Player last represented his former Union or country and the approval of the International Olympic Committee, the relevant National Olympic Committee(s) and World Rugby is obtained. This period may be reduced or even cancelled with the agreement of the World Rugby and the National Olympic Committees concerned and by the IOC Executive Board, which takes into account the circumstances of each case

8.11 A Player may not represent two different Unions or a Union and an Olympic Sevens Team(s) of a National Olympic Committee in the same Olympic Event(s).

8.12 Once the Player has represented the Union of which he is a national, in an Olympic Event, he shall thereafter betied to that Union for all forms of the Gameand in all events.

8.13 Players who participate in the Olympic Events accept and agree that any disputes relating to eligibility shall first be addressed pursuant to the rules of such Olympic Events and the World Rugby Regulations and that all internal procedures (including applicable National Olympic Committee rules/procedures) and/or World Rugby procedures shall be exhausted first. Thereafter, recourse may be had in respect of Olympic Events only (and not in relation to eligibility matters to which Regulation 8.6 to 8.16 does not apply) to the Court of Arbitration for Sport (CAS) in accordance with the provision applicable before such court and which will resolve definitively the dispute in accordance with the code of sports related arbitration. World Rugby has the right to appear, attend and/or participate as a party in any appeal to CAS involving eligibility considerations for Olympic Events.

8.14 Any Union wishing to obtain clarification around the eligibility of a Player to represent it in the Olympic Games or Olympic Events may do so by referring the matter to the World Rugby Regulations Committee in accordance with Regulation 2 and Regulation 8.7.1 and 8.7.2.

8.15 The list of Olympic Events is set out in Schedule 2 and shall be updated for each Olympic cycle

8.16 The provisions of Regulation 8.5 apply equally to any alleged breach of the Olympic eligibility provisions.

\section{EXPLANATORY GUIDELINES ON THE IM PLEMENTATION OF REGULATION 8} ELIGIBILITY TO PLAY FOR NATIONAL REPRESENTATIVE TEAMS

Following its deliberations on the question of Player eligibility, the Working Party has produced these Explanatory Guidelines on the implementation of Regulation 8. These Explanatory Guidelines must be read in conjunction with the terms of Regulation 8.

1. What is the Rationale/Philosophy of Regulation 8?

The rational e/philosophy of Regulation 8 is to ensure that Players selected to represent either the seni or and next senior fifteen-a-side National Representative Teams of a Union or a Union's senior National Representative Sevens Team havea genuine, close, credible and established national link with the country of the Union for which they have been selected. Such a national link is essential to maintain the unique characteristics and culture of elite international sporting competition between Unions. The integrity of 


\section{NATIONALITY REQUIREMENTS IN OLY MPIC SPORTS}

International Matches between Unions depends upon strict adherence to the eligibility criteria set out in the Regulations.

2. Who establishes the eligibility criteria in Rugby Union?

World Rugby will continue to establish the criteria by reference to which a Player's eligibility to play for the senior or next senior fifteen-a-side National Representative Team of a Union or a Union's senior National Representative Sevens Team will be determined. Citizenship of a country and/or whether a Player holds a passport of a particular country are not, of themselves, determinative in identifying which Union a Player is eligible to represent. This will be determined solely in accordance with World Rugby's eligibility criteria. In relation to Olympic eligibility criteria see the Explanatory Guidelines on the Implementation of Regulation 8 - Olympic Eligibility.

3. What is the eligibility criteria in Rugby Union?

The existing World Rugby eligibility criteria set out in Regulation 8.1 will be maintained. This is based on thefollowing:

(a) The country in which the Player was born; or

(b) The country in which one parent or grandparent of thePlayer was born; or

(c) The country in which the Player has completed thirty-six consecutive months of Residence immediately preceding the time of playing. Residence means the place or location in which a Player has his primary and permanent home and Resident shall be construed accordingly; and

(d) For Olympic Event participation, the nationality of the Union /country the Player wishes to represent is also required.

4. If a Player has dual eligibility, can he play for the senior or next senior fifteen-arside National Representative Team or the senior National RepresentativeSevens Team of more than one Union?

No, save for those Players that, before 1 J anuary 2000, allowed a period of 36 consecutive months to elapse after they had played for another Union and who played for the second Uni on before 1 January 2000. The one Union only rule, introduced by World Rugby from 1st J anuary 2000 (as set out in Regulation 8.2), will be maintained. A Player is only entitled to play Rugby Union for the senior or next senior fifteen-a-side National Representative Team or the senior National Representative Sevens Team of one Union. Accordingly, if a Player is deemed to have played for such a team even if he is ableto satisfy one or more of the eligibility criteria set out in Regulation 8.1, he will not be able to play for any other Union. Consistent with the overall rationale underlying the eligibility Regulations, the one Union only rule is designed to maintain the integrity of the international Game. Once a Player has committed himself to a particular Union, through participation in one of the Matches or Tours identified in Regulations 8.3 or 8.4, he is unable to change his "Rugby Nationality" which becomes fixed.

5. When is a Player deemed to have played for the senior or next senior fifteen-aside National Representative Team of a Union or a Union's senior National Representative Sevens Team?

As a result of the one Union only rule, in particular, it is essential that Players and Unions understand the situations in which Players will be deemed to have played for the senior fifteen-a-side National Representative Team or the next senior fifteen-a-side National Representative Team of a Union or a Union's senior National RepresentativeSevens Team These situations are set out in Regulations

8.3 and 8.4. Players and Unions shall, at all times, have regard to the full terms of Regulations 8.3 and 8.4, however, by way of a summary only, the situations set out bel ow are covered:

\section{Fifteen-a-side}

(a) Players who participate in International Matches for the senior National Representative Team or the next senior National Representative Team of a Union against the senior or next senior National Representative Team of another Union.

(b) Players selected to represent a Union's senior Touring Squad who participate in any Match played by members of that Union's senior Touring Squad during an International Tour provided such International Tour ind udes an International Match(es) approved by World Rugby.

(c) Players who participate in a Match for the senior or next senior National Representative Team of a Union against a team made up of Players from a Union's senior Touring Squad during an International Tour which includes International Match(es) approved by World Rugby.

(d) Players, representing a Uni on's next senior Touring Squad who partici pate in a Match on an International Tour approved by World Rugby against the senior National Representative Team or the next senior National Representative Team or the next senior National Representative Team of another Union.

(e)Players who play for the senior or next senior National Representative Team of a Union against a team selected from a Union's next senior Touring Squad when such Match is played on an International Tour approved by World Rugby.

Seven-a-side

(a) Players who play for a Union's senior National Representative Sevens team in an International Match against the senior National RepresentativeSevens team of another Union.

6. How do I know which teamis a Union's next senior fifteen-a-sideNational Representative Team? 


\section{APPENDICES}

(a) There should be no uncertainty over which team constitutes a Union's next senior National RepresentativeTeam Unions are required to notify World Rugby of the name of their nominated next senior National Representative Team The teamnominated remains the Union's next senior National Representative Team unless the Union notifies World Rugby of a change in this nomination. A Union is entitled to notify World Rugby no more than once per cal endar year of a change to its next senior National Representative Team provided that in doing so it shall takeaccount of any Matches such team may be scheduled to play and shall advise the Union of any senior or next senior National Representative Team it is scheduled to play reasonably in advance of such Match. The identity of a Union's next senior National Representative Team can be verified with the Uni on concerned and/or World Rugby.

(b) Unions must ensure that all persons involved in an International Match (Players and team management induding coaching staff) are made aware of the status of their team as the next senior National Representative Team and that of their opposing team where it is the senior or next senior National Representative Team of another Union and what that means from a capturing perspective under Regulation 8. Notwithstanding the Union's obligation to inform the Player and team management it shall be the sole responsibility of each Player to ensure that heis aware of the status of every Match in which he plays and the implications of playing in an International Match involving the senior or next senior National Representative Teams of two Unions.

(c) In addition to (a) and (b) above, Unions who designate their Under 20s National Representative Team as their next senior National Representative Team have a particular onus to clearly make the Team Players aware of the consequences of being captured for that Union at age grade level. Effective $1 \mathrm{~J}$ uly 2014, the Players on any such Team which participates in the World Rugby J unior World Championships, World Rugby J unior World Trophy or the Six Nations U20 Championship (where they are present at the Match played by that Team either as a replacement, substitute or playing member of that Team and has, at the time of the Match, reached the age of majority) will be captured. In this regard the status of the opposition teams in any Match in these named toumaments is not a factor to be considered.

7. What is the age of majority?

For the purposes of the Regulations (including, but not limited to Regulation 8), the age of majority is deemed to be acquired on a Player's 18th birthday.

8. Does the eligibility criteria apply to all forms of Rugby?

The eligibility criteria applies to the fifteen-a-side Game at senior and next senior National Representative level and in respect of a Union's senior National RepresentativeSevens Team

9. Does the eligibility criteria apply to all Unions in membership of World Rugby?

Yes, all Unions in membership of World Rugby are obliged to comply with the eligibility Regulation

10. How will the eligibility criteria be assessed?

Ordinarily, the task of assessing whether a Player satisfies any of the eligibility criteria set out in Regulation 8.1 is straightforward. However, as a result of professionalism, greater mobility and societal family change this is not al ways the case. Difficult cases have arisen and may continue to emerge The responses to the questions set out below are intended to provide further clarification as to how each eligibility criterion in Regulation 8.1 will beapplied.

The questions and answers should be regarded as guidelines. They have been prepared on the basis of operational experience to date It is not possible to anticipate all scenarios that may arise and a degree of flexibility in the application of the Regulations will be maintained. Moving forward, in the event that there is any uncertainty or the need for clarification in relation to the application of the eligibility criteria in particular circumstances, then the Regulations Committee may be asked by World Rugby to make a ruling on a Player's eligibility. In relation to any

such adjudication, the Regulations Committee will al ways have in mind the rationale behind Regulation 8. The aim of the Regulations Committee in each case where clarification may be required, is to establish whether, in all the circumstances, a Player has, by reference to the eligibility criteria in Regulation 8.1, been able to demonstrate a genuine, close and credible national link with the country that the Player wishes to represent. It is anticipated that over timea body of rulings by the Regulations Committee may develop which may, in turn, assist in providing further guidance to Unions in relation to eligibility matters.

11. When should any uncertainty over a Player's eligibility beclarified?

It is essential that eligibility issues are clarified before a Player represents the senior or next senior fifteen-a side National Representative Team of a Union or a Union's senior National Representative Sevens Team This is particularly important in light of the one Union only rule Accordingly, if a Union has any doubt over a Player's eligibility status it must takeall steps necessary to clarify the position before selecting the Player to play for its senior or next senior fifteen-a-side National Representative Team or its senior National RepresentativeSevens Team

12. What does place of birth mean?

This should be the most straightforward criterion to apply. A Player's place of birth shall be the country within whose geographical borders he was borm. However, difficult scenarios can arise even in relation to 
this criterion. For example, where a Player was born within the geographical borders of one country, but in a part of that country deemed by the law of the country concerned, to be the sovereign teritory of another, or where a Player was born in a military hospital. In such circumstances the matter should be referred to the Regulations Committee for a ruling. The Regulations Committee would need to establish the legal position together with other relevant facts and circumstances. In exceptional circumstances it may be possible for a Player to demonstrate, to the satisfaction of the Regulations Committee, that he is eligible to play for the Union within whose sovereign teritory he was born, even though that sovereign territory may be within the geographical borders of another country.

13. What does Parent mean?

The term "parent" in the Regulations is limited to either a blood parent or a parent that has formally adopted a Player in accordance with the applicable legal requirements of the country concerned. Unless a Player has been adopted in accordance with the formal, legal requirements of the country concerned, the application of this criterion will be based on a Player's blood parent. When a Player has been formally adopted in accordance with the applicable legal requirements of the country concerned, the birth place of the Player's blood parent will no longer be relevant for the purposes of establishing the Player's eligibility pursuant to Regulation 8.1(b). The relevant parent will be the parent that has formally and legally adopted the Player. However in such circumstances, the relevant grandparents for the purposes of establishing a Player's eligibility pursuant to Regulation 8.1(b) will be the Player's blood grandparents. It is not possible under Regulation 8.1(b) to assume eligibility via non-blood grandparents even if a Player has been formally and legally adopted.

For the avoidance of any doubt, stepparents and fostering parents will not be considered to constitute a Player's parent for the purposes of Regulation 8.1(b).

14. How is the Residence criteria satisfied?

Regulation 8.1(c) requires a Player to complete 36 consecutive months of Residence immediately preceding the time of playing. Residence is defined as "the place or location in which the Player has his primary and permanent home" and Resident shall be construed accordingly. In essence, Regulation 8.1(c) constitutes a sporting naturalization procedure, based on a geographical/presence test. As in any naturalisation process, a number of factors will influence the determination of what constitutes a Player's permanent and primary home Such factors include, but are not limited to, the actual time spent in a country and the purpose of any absences during the qualification period. By being Resident in a country for a period of 36 consecutive months immediately preceding the time of playing for a Union, a Player is deemed to acquire a credible, close and established national link with a country/Union that entitles him to participate in sporting competitions for that Union. Based on the overriding rational e of the eligibility Regulations, in cases wherea Player's e igibility is uncertain the Regulations Committee will consider that Player's eligibility by reference to the particular facts and circumstances of his case to establish if the Residency test, in the context of the overall rationale of the eligibility Regulations, has been satisfied. The principles set out in responses to the questions below will act as guidelines to the Regulations Committee when it is asked to consider any cases pursuant to this criterion.

15. Whose burden of proof?

In all cases where a Player is seeking to establish eligibility by reference to the Residency criteria in Regulation 8.1(c) (and, indeed, in relation to Regulation (or 8.1(a) and (b)), the burden of proof is on the Player and the Union that he wishes to represent to prove that Player's eligibility. Under Regulation 8.1(c), the Player and his Union must be able to demonstrate that, during the relevant period, the country in which he claims he has been Resident was, genuinely, the country that the Player treated as his home and is clearly the country in which the Player has his primary and permanent home If a Player has moved from one country to another, and is seeking to establish Residence in that new country, then he must al so be able to demonstrate that he is clearly no longer Resident in the country in which he lived previously and that he no longer treats that country as his home For the avoi dance of any doubt, a Player cannot nominate country as his home without demonstrating that he has satisfied the geographical commitment/presence test enshrined in Regulation 8.1(c). The geographical commitment/presence test will be vigorously upheld and applied to avoid abuse of the Residency criteria. For example, a Player that acquired/leased property in a country and who nominated that property as his permanent and primary home (even though he may only be present at that property and in that Union on a short term/temporary basis) would not satisfy the Residency test. 16. Will short breaks interrupt a period of Residence?

Short breaks in Residence, for example, for holidays, attending family/friends in other countries who may be ill etc, are unlikely to changethe placellocation of a Player's primary and permanent home and are, therefore, unlikely to intermupt a Player's period of Residence By way of a guideline, however, as a minimum requirement, it is likely that, save in exceptional circumstances, at least 10 months actual physical presence of the Player in the country concemed throughout any qualifying year of the Residency period, will be required to demonstrate that the country is the place where the Player has his primary and permanent home 17. Does the 36 month period of Residence have to immediately precede playing for a Union? 


\section{APPENDICES}

Save in exceptional circumstances, the 36 months Residence will be expected to have been completed consecutively and be achieved immediately before the Player represents a Uni on. This is designed to createa contemporary national link with the country of the Union concerned. This factor will be particularly significant if a Player has moved to make a "new" country his Residence having been Resident in another country previously. In essence, in such circumstances, the Player, as well as demonstrating his commitment to a new country, must also be (and seen to be) relinquishing his ties with the country in which he lived previously. For the avoidance of any doubt, sedking to rely on short periods of Residence as a child in a particular country, combined with a short period of Residence in that same country prior to playing for a Union, is likely to create a link that would be too tenuous to satisfy the underlying intentions of establishing a contemporary, permanent, national link with a Union. However, each case will be assessed on its overall merits to establish if a Player is able to demonstrate a genuine, close, credible and established national link by reference to the amount of timethe Player can demonstrate that he has treated the "new" country as his home and other relevant factors.

18. What is the position of students?

As far as students are concerned, particularly those that are not financially independent, being resident, as a full time student, in another country, is likely to be considered as a series of temporary absences from the parental home. It is anticipated that in the majority of cases involving students the parental home is likely to continue to constitute the student's permanent and primary home Accordingly, attendance at college/university in such circumstances is unlikely to break a Player's consecutive period of Residence However, as in all matters of eligibility, the overriding concern of the Regulations Committee in assessing any such case will be to ensure that there remains a close, credi ble and established link with the country in which the Player daims to have retained his primary and permanent home. There could be circumstances in which a student living in another country may be deemed to have interrupted his Residency period.

19. Who is responsible for compliance with the eligibility criteria?

In accordance with Regulation 2.1.2, each Union is responsible for ensuring compliance with all Regulations Relating to the Game This includes, but is obviously not limited to, Regulation 8. Accordingly, it is the responsibility of each Union to ensure that all Players it selects are properly eligible within the provisions of Regulation 8 and, in the event of any uncertainty, to ensure that the position is darified before the Player is selected. Unions must have in place all necessary procedures and internal controls to ensure compliance with the digibility Regulations.

20. What must Unions do to ensure (and demonstrate) compliance with the eligibility Regulations?

Unions must ensure that before a Player is sel ected for the first time for its senior or next senior fifteen-a-side National Representative Team or its senior National Representative Sevens Team the Player completes the standard form dedaration attached to these Explanatory Guidelines at Schedule 1. In addition, before selecting a Player, Unions must ensure that they obtain valid/authentic documentation and such other evidence that may be necessary to prove, definitively, a Player's eligibility to play for that Union. Each Union must notify World Rugby of the names of all Player's selected for its senior and next senior National Representative Team and its senior National Representative Sevens Team on an annual basis. World Rugby shall maintain a database of all such Players. If requested, by the Chaiman, or his designee, Unions must supply copies of the completed declaration forms of a Player(s) together with supporting documentation relied on to demonstrate the Player's eligibility. On 1 December each year, each Uni on must certify to World Rugby that each Player selected to represent the senior or next senior fifteen-a-side National Representative Team of the Union or its National Representative Sevens Team during the past year has completed, in full, the declaration form and that each Player was eligible to represent the Union in accordance with the provisions of Regulation 8.

World Rugby may, through the Chairman, or his designee, of his own motion or on receipt of a complaint undertake an investigation into a Union's compliance with Regulation 8. Unions, Players and officials must provide assistance with any such investigation and disclose such information and documents deemed necessary by the Chairman, or his designee, for the purposes of that investigation.

21. What are the consequences of a breach of the eligi bility Regulations by a Union?

Compliance with Regulation 8 is of fundamental importance in maintaining the integrity of international Rugby Union at senior National Representative level. Any breach of such a fundamental Regulation, howsoever arising, has a detrimental impact on the image and reputation of the sport. Unions must, therefore take all necessary steps to put in place comprehensive review/compliance procedures to ensure that a breach of the eligibility provision does not occur whether negligently or otherwise Alleged breaches of Regulation 8 may be investigated and handled in accordance with Regulation 18 (Disciplinary and Judicial Matters). However, a breach of the eligibility Regulations constitutes a strict liability offence This means that a failure by a Union to fulfill its obligations and to comply with the eligibility Regulations will be regarded as a serious breach of the Regulations, howsoever such breach may have occurred. As a reflection of the seriousness with which any breach of the eligibility Regulations will betreated by World Rugby, it has been agreed by Council to establish a minimum fixed penalty to be imposed on a Union that has breached 


\section{NATIONALITY REQUIREMENTS IN OLY MPIC SPORTS}

Regulation 8. These minimum fixed penalties will appear in Regulation 8 and, for ease of reference, are also set out below.

\subsection{Responsibility, breach and penalties for a breach of Regulation 8}

\subsubsection{Unions}

Regulation 8 is a strict liability offence and shall be construed in accordance with the principles of strict liability under English law. It is not, therefore, necessary that fault or intent on the part of a Union be shown in order for a breach of Regulation 8 to be established. Nor is lack of fault or intent on the part of a Union a defence to a breach of Regulation 8. For the avoidance of any doubt (and without limiting a Union's other obligations and responsibilities for the conduct, acts or omissions of its members and Persons under its jurisdiction pursuant to any other Regulation) Unions are responsible and accountable for the conduct of their Players and all Persons under its jurisdiction in relation to compliance with the provisions of Regulation 8 and any breach of Regulation 8 by such Player(s) or Person(s) shall be deemed to be a breach of Regulation 8 by the Union concerned. Each breach of Regulation 8 by a Union, howsoever arising, will result in a minimum fixed fine being imposed on the Union concerned. The minimum fixed fines for each breach of Regulation 8 by a Union are as follows:

For a Union that is represented on the Council $£ 100,000$ sterling;

For all other World Rugby Merber Unions $£ 25,000$ sterling.

Based on the facts and circumstances of any breach of Regulation 8 the applicable minimumfixed fine as set out above may be increased. In addition, other penalties as set out in Regulation 18.6 may also be imposed on the Union concerned.

22. What must Players do to ensure (and demonstrate) compliance with the eligibility Regulations?

Players are required to act honestly in matters relating to their eligibility to represent a particular Union. This would include, without limitation, fully disclosing to the Union (and World Rugby upon request) any matters relevant to the Player's eligibility and providing all reasonable assistance to the Union (and World Rugby upon request) in order to establish the Player's eligibility at the first available opportunity.

23. What are the consequences of a breach of the eligibility Regulations by a Player?

A Player who knowingly (and/or with reasonable enquiry ought to have known) represents a Union where not eligible to do so commits a breach of Regulation 8. Alleged breaches of Regulation 8 will beinvestigated and handled in accordance with Regulation 18 (Disciplinary and Judicial Matters). Judicial Officers and Judicial Committees may impose sanctions pursuant to their powers taking into consideration, without limitation, the circumstances of the breach including the number of breaches and the level of any deception. This may result in a Player being reprimanded, fined, suspended and/or such other sanction the J udicial Officer or J udicial Committeethinks fit, in accordance with Regulation 18.6.

24. For thePlayer to beliable for a breach must the Union also have been found liable?

$\mathrm{Y} e$, there must also be a finding that the Uni on concerned has played an ineligible Player. However such finding would not be affected in circumstances where there was any reduction or suspension of the ordinarily applicable sanction.

\section{Explanatory G uidelines on the I mplementation of R egulation 8 - 0 lympic E ligibility}

With the reintroduction of Rugby Sevens into the Olympic Games in Rio in 2016 there are certain rules which participants must adhere to for eligibility purposes. The Olympic Eligibility Regulations (8.6 to 8.16) have been introduced to accommodate the Olympic Charter Rules. To assist in the implementation of these Regulations, the following Guidelines have been developed to address the specifics around Olympic Sevens eligibility which differs from that of World Rugby eligibility requirements in that it is based solely upon a nationality consideration al one The two sets of rules have been combined to achieve harmony between the objectives and underlying philosophy of Regulation 8 and the requirements of the Olympic Charter in the context of participation in Olympic Events. These Explanatory Guidelines must be read in conjunction with theterms of Regulation 8 and the Guidelines thereto.

1. Who is eligible to play Olympic Sevens?

Any Player who meets the eligibility criteria in 8.1 and holds the nationality of the Union / country they wish to represent in the Olympic Games or Olympic Qualification process (known as the "Olympic Events"). The eligibility rules in the Olympic Charter together with the World Rugby eligibility rules must be complied with by Players who participatein Olympic Events.

2. Musta Player havethe passport of the Union/ country he represents in Olympic Sevens?

The nationality of the Union / country the Player wishes to represent in Olympic Sevens is a requirement under the Olympic Charter and is therefore necessary for participation in Olympic Events. Nationality is ordinarily demonstrated by the Player holding the passport of the Union / county they wish to represent. All matters relating to the determination of the country which a Player may represent in the Olympic Games shall ultimately be resolved by the IOC ExecutiveBoard.

3. Who will decide on Olympic Sevens eligibility?

Ordinarily, the assessment of whether a Player satisfies the eligibility criteria in Regulation 8.1 and 8.6 will be straightforward. However, in all cases where a Player who has been captured under Regulation 8.2 and 
who holds the nationality of another Union / country and wishes to participate in an Olympic Event(s) for the Union / country of which he is a national, the Player may apply to World Rugby to represent the National Representative Sevens Team of that Union (or the Olympic Sevens Team of an National Olympic Cormittee), and the case shall be determined in the first place by the World Rugby Regulations Committee. In the event there are other cases of uncertainty or there is the need for clarification a referral may be made to the World Rugby Regulations Committee

4. What is required to besubmitted to the Regulations Committee?

Applications should be submitted to World Rugby accompanied by all relevant supporting documents by the Union (or in applicable cases where there is no Union, the National Olympic Committee ("NOC")) of the country the Player wishes to represent in an Olympic Event. The application shall be prenotified to the Player's Union (namely the Union who's National Representative Team the Player has previously represented. The Player's Union may make written submissions to the World Rugby Regulations Committee or may beinvited to do so.

5. Can a Player with dual nationality, or having World Rugby eligibility for one Union but the nationality of another, represent both Unions / countries in the same Olympic qual ification process?

No. A Player may only represent one Union / country in the Olympic Events. For example if a Player played for a Union in the Sevens World Series in the year it was designated as an Olympic Event the Player could not later in the same Sevens World Series play for another Union / country even in circumstances where he was deemed eligibly by the Regulations Committee to play for the second Union / country of which he is a national. The principle of Regulation 8.2 applies equally to Olympic Events, such that if a Player, having represented one Union / country in an Olympic Event they may not represent another Union / country thereafter.

6. Can a Player switch nationality?

Nationality is a matter which is governed by nation states. If a Player does switch nationality the effect of this upon their Olympic eligibility would need to be considered taking into account Regulation 8.6 to 8.16 and the Olympic Charter Rules regarding eligibility which can be found at www.olympic.org. However, a Player who has represented one Union / country in an Olympic Event(s) and who has changed their nationality or acquired a new nationality may participate in Olympic Events to represent their new Union / country provided that at least three (3) years have passed since the Player last represented their former Union / country and the approval of the International Olympic Committee, the relevant National Olympic Committee(s) and World Rugby is obtained.

7. How will the Olympic eligibility criteria be assessed?

In the early days of the Olympic participation the view has been taken by World Rugby that the Regulations Committee should assess all cases where a Player who has al ready been captured for a Union under the one Union only rule (Regulation 8.2) but wishes to subsequently play for another Union / country for which s/he holds nationality in an Olympic Event.

8. Is there any stand-down period?

Yes. The Player will be required to observe and demonstrate a stand down period of three (3) years between the timethe Player last played for

his Union and the time the Player first represents the second Union, which must be in an Olympic Event. Played, shall mean when s/he played for the senior, next senior or senior sevens National Representative Team of that Union for which s/he is captured. The principles of Regulation 8.3 apply in any assessment of this provision.

9. What does 'first represents' mean?

It means the first occasion when the Player represents the second Union in a Match, Tournament or Series of Matches - which must be in an Olympic Event. The Player would not however, be permitted for example to participate in preseason Matches or so-called 'friendly' matches or other Matches which are not Olympic Events representing the second Union. Training with the team of the second Union is permitted but the circumstances should not be such that it presents or implies to third parties that the Player is part of the National Representative Sevens Team or Olympic Sevens Team of the second Union / country.

10. How will the stand-down period be assessed?

The onus will be on the Player to demonstrate to the reasonable satisfaction of the Regulations Committee the last occasion upon which s/he played for their former Union and that they have not represented such Union in the three year period before they represent their new Union/ country in an Olympic Event.

11. Arethese Olympic Guidd ines to be read with the World Rugby Eligibility Guidd ines?

$\mathrm{Yes}$, both sets of Guidelines should be read together.

12. What is the position for Unions who do not have a single NOC to represent them?

Member Unions of World Rugby are not necessarily recognised in their own right with equivalent NOC's, for example the British Olympic Association (Team GB) is the NOC for Great Britain and therefore encapsulates the Unions of England, Scotland, Wales and Northern Ireland (represent by the all-Ireland body of the IRFU). In such case, Players from the underlying Unions would be eligible (where they comply with 


\section{NATIONALITY REQUiREMENTS In Olympic SPORTS}

Regulation 8.1 and 8.6) to represent the Olympic Sevens Team of the NOC (if sel ected) in relevant Olympic Events.

13. If a Player plays for a combined team in an Olympic Event does it affect his eligibility in relation to World Rugby?

If a Player plays for a combined team of a country in an Olympic Event (eg. Team GB) and he was previously not captured for a Union (under Regulation 8.2) then the Player will be deemed to be captured for one of the underlying Unions of the combined team of country he represented. So in the case of Team GB it would mean that the Player would then be free to play for one of England, Scotland, Wales and/or I reland.

If a Player plays for a combined team of a country in an Olympic Event (eg. Team GB) and he was previously was captured for a Union (under Regulation 8.2) then the Player remains captured for such Union and their participation in the combined team in the Olympic Event will not affect their status.

14. Is there a right of appeal from the decision of theWorld Rugby Regulations

Yes. An Olympic Eligibility appeals committee has been established under Regulation 2 to deal with any appeals of decisions by the World Rugby Regulations Committee

15. For the Olympic Games 2016 in Rio, do any special provisions apply?

Rugby Sevens will enter the Olympic Games for the first time in 2016. The qualification process has been established and all persons eligible to participate must have qualified by $11 \mathrm{July} 2016$. In terms of eligibility, the three (3) year stand-down period applies. However, given the timing of the clarification of the qualification process and the constitutional review of the eligibility requirements for Olympic Events a shorter stand-down period in respect only of the Olympic Games 2016 shall apply. In this regard any Player who wishes to represent a Union / country for whom s/he holds the nationality and has previously been captured for another Union may do so provided the Player stands down from their current Union at least 18 months before representing the Second Union in an Olympic Event in the Rio Olympic Games cycle

SCHEDULE 1 REGULATION 8

SCHEDULE 1. EXPLANATORY NOTE

As from 1 J anuary 2000 a player is only entitled to play Rugby Union for the Senior National Representative Team or the next Senior National Representative Team of one Union. This means that if a player is deemed to have played for the Senior National Representative Team or the next Senior National Representative Team of a Union that player will be unable to play for any other Union. This is the position even if that player is able to satisfy one or more of the eligibility criteria set out in Regulation 8.1. It is important that players and Unions understand the situations in which players will be deemed to have played for the Senior National Representative Team or the next Senior National Representative Team of a Union. These situations are set out in Regulation 8.3.

Regulation 8.3 is based on a "selection and participation" test for players who have reached the age of majority [18 or over]. Players and Unions must familiarize themselves with Regulation 8.3. Players should be made aware by Unions of what constitutes that Union's Senior National Representative Team its next Senior National Representative Team its Senior Touring Squad and its next Senior Touring Squad and the Matches that will result in a player being committed to that Unions. The following situations are covered by Regulation 8.3.

1. Players who participate in International Matches for the Senior National Representative Team or the next Senior National Representative Team of a Union against the Senior or next Senior National Representative Team of another Union.

2. Players selected to represent a Union's Senior Touring Squad who participate in any Match played by members of that Union's Senior Touring Squad during an International Tour provided such International Tour includes an International Match(es) approved by World Rugby.

3. Players who participate in a Match for the Senior or next Senior National Representative Team of a Union against a team made up of players from a Union's Senior Touring Squad during an International Tour which indudes International Match(es) approved by World Rugby.

4. Players, representing a Union's next Senior Touring Squad who participate in a Match on an International Tour approved by World Rugby against the Senior National Representative Team or the next Senior National Representative Team of another Union.

5. Players who play for the Senior or next Senior National Representative Team of a Uni on against a team selected from a Union's next Senior Touring Squad when such Match is played on an International Tour approved by World Rugby.

$[\ldots]$

HANDBOOK AS FRAMED BY WORLD RUGBY Last update: 1 J anuary, 2016 REGULATION 8 ELIGIBILITY TO PLAY FOR NATIONAL REPRESENTATIVE TEAMS

8.1 Subject to Regulation 8.2, a Player may only play for the senior fifteen-a side National Representative Team the next senior fifteen-a-side National Representative Team and the senior National Representative Sevens Team of the Union of the country in which: 


\section{APPENDICES}

(a) hewas born; or

(b) one parent or grandparent was born; or

(c)he has completed thirty six consecutive months of Residence immediately preceding the time of playing.

8.2 A Player who has played for the senior fifteen-aside National Representative Team or the next senior fifteen-a-side National Representative Team or the senior National Representative Sevens Team of a Union is not eligible to play for the senior fifteen-a-side National Representative Team or the next senior fifteen-asideNational Representative Team or the senior National Representative Sevens Team of another Union.

8.3 For the purposes of this Regulation, a Player is deemed to have played for the senior fifteen-a-side National RepresentativeTeam or the next senior fifteen-a-sideNational RepresentativeTeam of a Union if: (a)He is selected for such team to play in an International Match against the senior fifteen-aside National Representative Team or the next senior fifteen-a-side National Representative Team of another Union (or in a fifteen-a-side international Match against another Union's senior or next senior Touring Squad during a World Rugby approved International Tour) and is present at the Match played by that team either as a replacement, substitute or a playing member of that team and has, at the time of the Match, reached the age of majority; or

(b)He is selected to represent a Union's senior Touring Squad on an International Tour which includes an International Match or Matches approved by World Rugby and is present at any fifteen-a-side Match played on that International Tour either as a replacement, substitute or a playing member of a team selected from the Union's senior Touring Squad and has, at the time of the Match, reached the age of majority; or

(c)He is sel ected to represent a Union's next senior Touring Squad on a World Rugby approved International Tour and during that International Tour he is present at a Match against the senior fifteen- a-side National Representative Team or the next senior fifteen-a side National RepresentativeTeam of another Union either as a replacement, substitute or playing member of a team selected from the Union's next senior Touring Squad and has, at the time of the Match reached the age of majority.

(d) He is selected to represent the Under 20s National Representative Team of a Union which has been predesignated as that Union's next senior fifteen-a-side National Representative Team and the Player is part of the team which participates in an International Match as part of the World Rugby J unior World Championships, World Rugby J unior World Rugby Trophy or the Six Nations U20 Championship and is present at the Match played by that Teameither as a replacement, substitute or playing member of that Teem and has, at the time of the Match, reached the age of majority.

8.4 For the purposes of this Regulation, a Player is deemed to have played for the senior National Representative Sevens Team of a Union if he is selected to represent a Union's senior National Representative Sevens Team in an International Match against the senior National Representative Sevens Team of another Union and is present at the Match played by that Team either as a replacement, substituteor playing member of that Teamand has, at the time of the Match, reached the age of majority.

8.5 Responsibility, breach and penalties for a breach of Regulation 8

\subsubsection{Unions}

Regulation 8 is a strict liability offence and shall be construed in accordance with the principles of strict liability under English law. It is not, therefore, necessary that fault or intent on the part of a Union be shown in order for a breach of Regulation 8 to be established. Nor is lack of fault or intent on the part of a Union a defence to a breach of Regulation 8. For the avoidance of any doubt (and without limiting a Union's other obligations and responsibilities for the conduct, acts or omissions of its members and Persons under its jurisdiction pursuant to any other Regulation) Unions are responsible and accountable for the conduct of their Players and all Persons under its jurisdiction in relation to compliance with the provisions of Regulation 8 and any breach of Regulation 8 by such Player(s) or Person(s) shall be deemed to be a breach of Regulation 8 by the Union concerned. Each breach of Regulation 8 by a Union, howsoever arising, will result in a minimum fixed fine being imposed on the Union concerned. The minimum fixed fines for each breach of Regulation 8 are as follows:

(a) For a Union that is represented on the Council $f 100,000$ sterling;

(b) For all other World Rugby Member Unions $£ 25,000$ sterling.

Based on the facts and circumstances of any breach of Regulation 8 the applicableminimum fixed fine as set out above may be increased. In addition, other penalties as set out in Regulation 18.6 may al so be imposed on the Union concerned.

8.5.2 In exceptional circumstances, a Union in breach of Regulation 8 may make submissions to the relevant disciplinary body appointed under Regulation 18 to adjudicate on the case as to why the Uni on should not be subject to the applicable minimum fixed fine. For the avoidance of any doubt, however, the relevant disciplinary body shall only be entitled to reduce the applicable minimum fixed fine set out in this Regulation where the Union is able to provide dear and indisputable evidence that truly exceptional circumstances exist and that the Union concerned had taken all necessary steps to comply with Regulation 8. Players 
8.5.3 Notwithstanding Regulations 8.5.1 and 8.5.2 above and without prejudice to any sanction imposed on a Union, Players may also be subject to sanction in accordance with Regulation 18 where they breach Regulation 8 in circumstances where they knew or ought reasonably to have known they were not eligible to play for the relevant Union at the time of participation.

8.6 To be eligible to participate in the Olympic Games, Olympic qualification events (together "Olympic Events") or other events governed by the Olympic Charter all members of the senior National Representative Sevens Team(s) of a Union or the selected Olympic Sevens Team(s) of a National Olympic Committee shall comply with Regulation 8.1 and must bea national of the country of the National Olympic Committee which it is representing in such Olympic Events. Regulation 8.2 applies equally to all Players.

8.7 A Player who is a national of the country or Union for which he has been captured under Regulation 8.2 and who holds the nationality of another country or Union, may apply to participate in an Olympic Event to represent his new country or Union subject to the foll owing conditions;

8.7.1 The Regulations Committee shall consider the application of a Player under this Regulation 8.7 which must be submitted with all relevant supporting documentation by the Union for whom the Player wishes to next represent in an Olympic Event (or a Union associated with the Olympic Sevens Team the Player wishes to represent). The application shall be pre-notified to the Player's Uni on (namely the Union whose National Representative Team the Player represented);

8.7.2 The Player will be required to observeand demonstrate a stand down period of at least 3 years since the timethe Player last represented their former Union and the timethe Player first plays for the second Union or country, which must be in an Olympic Event. The Player may not represent the second Union in any other form of the Game until after they have participated in such Olympic Event.

(a)Solely in respect of the Rio Olympic Games 2016, a stand down period of at least 18 months will be permitted, between the time the Player last represented their former Union and the time the Player first plays for the second Union or country, which must be in an Olympic Event in the Rio Olympic Games cycle, which the Player must observe and demonstrate.

8.8 Where the Player is not a national of the Union for which hehas been captured under Regulation 8.2, and he meets the Olympic eligibility criteria (in Regulation 8.6 to 8.13 ) as determined by the Regulations Committee, he shall be eligible for selection to play for the Union / country of which he is a national, in an Olympic Event, subject to satisfying the applicable stand down period.

8.9 A Player who is eligible or captured for a Union that cannot participate in an Olympic Event because there is no National Olympic Committee sol ely for the teritory of such Union, may, subject to the Olympic eligibility criteria (in Regulation 8.6 to 8.13), be eligible to play for the Olympic Sevens Team of a National Olympic Committee of which he is a national, provided that such team is not associated with any one single Union. In such circumstances the following provisions shall apply;

8.9.1 Wherethe Player has been captured under Regulation 8.2 for a Union he shall remain captured for such Union notwithstanding the Player's representation for the Olympic Sevens Team of a National Olympic Committeein an Olympic Event;

8.9.2 Wherethe Player has not previously been captured under Regulation 8.2 and herepresents the Olympic Sevens Team of a National Olympic Committee in an Olympic Event he will be deemed to be captured for one of the underlying Unions which support the Olympic Sevens Team of the relevant National Olympic Committee, and the Player must elect which of those underlying Unions he shall be captured by for the purposes of Regulation 8.

8.10 A Player who has represented one Union or Olympic Team in an Olympic Event and who has changed his nationality or acquired a new nationality, may apply to participate in an Olympic Event to represent his new Union or country provided that at least three years have passed since the Player last represented his former Union or country and the approval of the International Olympic Committee, the relevant National Olympic Committee(s) and World Rugby is obtai ned. This period may be reduced or even cancelled with the agreement of the World Rugby and the National Olympic Committees concerned and by the IOC Executive Board, which takes into account the circumstances of each case.

8.11 A Player may not represent two different Unions or a Union and an Olympic Sevens Team(s) of a National Olympic Committee in the same Olympic Event(s).

8.12 Once the Player has represented the Union of which he is a national, in an Olympic Event, he shall thereafter betied to that Union for all forms of the Game and in all events.

8.13 Players who participate in the Olympic Events accept and agree that any disputes relating to eligibility shall first be addressed pursuant to the rules of such Olympic Events and the World Rugby Regulations and that all internal procedures (including applicable National Olympic Committee rules/procedures) and/or World Rugby procedures shall be exhausted first. Thereefter, recourse may be had in respect of Olympic Events only (and not in relation to eligibility matters to which Regulation 8.6 to 8.16 does not apply) to the Court of Arbitration for Sport (CAS) in accordance with the provision applicable before such court and which will resolve definitively the dispute in accordance with the code of sports related arbitration. World Rugby has the right to appear, attend and/or partici pate as a party in any appeal to CAS involving eligibility 
considerations for Olympic Events.

8.14 Any Union wishing to obtain clarification around the eligibility of a Player to represent it in the Olympic Games or Olympic Events may do so by refering the matter to the World Rugby Regulations Committee in accordance with Regulation 2 and Regulation 8.7.1 and 8.7.2.

8.15 The list of Olympic Events is set out in Schedule 2 and shall be updated for each Olympic cycle

8.16 The provisions of Regulation 8.5 apply equally to any alleged breach of the Olympic eligibility provisions.

EXPLANATORY GUIDELINES ON THE IM PLEMENTATION OF REGULATION 8

ELIGIBILITY TO PLAY FOR NATIONAL REPRESENTATIVE TEAMS

Following its deliberations on the question of Player eligibility, the Working Party has produced these Explanatory Guidelines on the implementation of Regulation 8. These Explanatory Guidelines must be read in conjunction with the terms of Regulation 8.

1. What is the Rational e/Philosophy of Regulation 8?

The rationale/philosophy of Regulation 8 is to ensure that Players selected to represent either the seni or and next senior fifteen-a-side National Representative Teams of a Union or a Union's senior National RepresentativeSevens Team havea genuine, close, credi ble and established national link with the country of the Union for which they have been selected. Such a national link is essential to maintain the unique characteristics and culture of elite international sporting competition between Unions. The integrity of International Matches between Unions depends upon strict adherence to the eligibility criteria set out in the Regulations.

2. Who establishes the eligibility criteria in Rugby Union?

World Rugby will continue to establish the criteria by reference to which a Player's eligibility to play for the senior or next senior fifteen-a-side National Representative Team of a Union or a Union's senior National Representative Sevens Team will be determined. Citizenship of a country and/or whether a Player holds a passport of a particular country are not, of themselves, determinative in identifying which Union a Player is eligible to represent. This will be determined sole y in accordance with World Rugby's eligibility criteria. In relation to Olympic eligibility criteria see the Explanatory Guidelines on the Implementation of Regulation 8 - Olympic Eligibility.

3. What is the eligibility criteria in Rugby Union?

The existing World Rugby eligibility criteria set out in Regulation 8.1 will be maintained. This is based on thefollowing:

(a) The country in which the Player was born; or

(b) The country in which one parent or grandparent of the Player was born; or

(c) The country in which the Player has completed thirty-six consecutive months of Residence immediately preceding the time of playing. Residence means the place or location in which a Player has his primary and permanent homeand Resident shall be construed accordingly; and

(d) For Olympic Event participation, the nationality of the Union /country the Player wishes to represent is also required.

4. If a Player has dual eligibility, can he play for the senior or next senior fifteen-asside National RepresentativeTeamor the senior National RepresentativeSevens Team of morethan one Union?

No, save for those Players that, before $1 \mathrm{~J}$ anuary 2000 , allowed a period of 36 consecutive months to elapse after they had played for another Union and who played for the second Uni on before 1 January 2000. The one Union only rule, introduced by World Rugby from 1st J anuary 2000 (as set out in Regulation 8.2), will be maintained. A Player is only entitled to play Rugby Union for the senior or next senior fifteen-a-side National Representative Team or the senior National Representative Sevens Team of one Union. Accordingly, if a Player is deemed to have played for such a team, even if he is able to satisfy one or more of the eligibility criteria set out in Regulation 8.1, he will not be able to play for any other Union. Consistent with the overall rationale underlying the eligibility Regulations, the one Union only rule is designed to maintain the integrity of the international Game Once a Player has committed himself to a particular Union, through participation in one of the Matches or Tours identified in Regulations 8.3 or 8.4, he is unable to changehis "Rugby Nationality" which becomes fixed.

5. When is a Player deemed to have played for the senior or next senior fifteen-a-side National Representative Team of a Union or a Union's senior National Representative Sevens Team?

As a result of the one Union only rule, in particular, it is essential that Players and Unions understand the situations in which Players will be deemed to have played for the senior fifteen-a-side National Representative Team or the next senior fifteen-a-side National Representative Team of a Union or a Union's senior National Representative Sevens Team These situations are set out in Regulations

8.3 and 8.4. Players and Unions shall, at all times, have regard to the full terms of Regulations 8.3 and 8.4, however, by way of a summary only, the situations set out below are covered:

Fifteen-a-side 


\section{NATIONAlity ReQuirements in Olympic SPORTS}

(a) Players who participate in International Matches for the senior National Representative Team or the next senior National Representative Team of a Union against the senior or next senior National Representative Team of another Union.

(b) Players selected to represent a Union's senior Touring Squad who participate in any Match played by members of that Union's senior Touring Squad during an International Tour provided such International Tour includes an International Match(es) approved by World Rugby.

(c) Players who participate in a Match for the senior or next senior National Representative Team of a Union against a team made up of Players froma Union's senior Touring Squad during an International Tour which indudes International Match(es) approved by World Rugby.

(d) Players, representing a Uni on's next senior Touring Squad who participate in a Match on an International Tour approved by World Rugby against the senior National Representative Team or the next senior National RepresentativeTeam or the next senior National RepresentativeTeam of another Union.

(e)Players who play for the senior or next senior National Representative Team of a Union against a team selected from a Union's next senior Touring Squad when such Match is played on an International Tour approved by World Rugby.

\section{Seven-a-side}

(a) Players who play for a Union's senior National Representative Sevens team in an International Match against the senior National Representative Sevens team of another Union.

6. How do I know which teamisa Union's next senior fifteen-a-side National Representative Team?

(a) There should be no uncertainty over which team constitutes a Union's next senior National RepresentativeTeam Unions are required to notify World Rugby of the name of their nominated next senior National RepresentativeTeam Theteamnominated remains the Union's next senior National Representative Team unless the Union notifies World Rugby of a change in this nomination. A Union is entitled to notify World Rugby no more than once per calendar year of a change to its next senior National Representative Team provided that in doing so it shall take account of any Matches such team may be scheduled to play and shall advise the Union of any senior or next senior National Representative Team it is scheduled to play reasonably in advance of such Match. The identity of a Union's next seni or National Representative Team can be verified with the Uni on concerned and/or World Rugby.

(b) Unions must ensure that all persons involved in an International Match (Players and team management including coaching staff) are made aware of the status of their team as the next senior National Representative Team and that of their opposing team where it is the senior or next senior National Representative Team of another Union and what that means from a capturing perspective under Regulation 8. Notwithstanding the Union's obligation to inform the Player and team management it shall be the sole responsibility of each Player to ensure that he is aware of the status of every Match in which he plays and the implications of playing in an International Match involving the senior or next senior National Representative Teams of two Unions.

(c) In addition to (a) and (b) above, Unions who designate their Under 20s National Representative Team as their next senior National Representative Team have a particular onus to clearly make the Team Players aware of the consequences of being captured for that Union at age grade level. Effective 1 J uly 2014, the Players on any such Team which participates in the World Rugby J unior World Championships, World Rugby J unior World Trophy or the Six Nations U20 Championship (where they are present at the Match played by that Team either as a replacement, substitute or playing member of that Team and has, at the time of the Match, reached the age of majority) will be captured. In this regard the status of the opposition teams in any Match in these named tournaments is not a factor to be considered.

7. What is the age of majority?

For the purposes of the Regulations (including, but not limited to Regulation 8), the age of majority is deemed to be acquired on a Player's 18th birthday.

8. Does the eligibility criteria apply to all forms of Rugby?

The eligibility criteria applies to the fifteen-a-side Game at senior and next senior National Representative level and in respect of a Union's senior National Representative Sevens Team

9. Does the eligibility criteria apply to all Unions in membership of World Rugby?

Yes, all Unions in membership of World Rugby are obliged to comply with the eligibility Regulation 10. How will the eligibility criteria be assessed?

Ordinarily, the task of assessing whether a Player satisfies any of the eligibility criteria set out in Regulation 8.1 is straightforward. However, as a result of professionalism, greater mobility and societal family change this is not always the case Difficult cases have arisen and may continue to emerge. The responses to the questions set out below are intended to provide further clarification as to how each eligibility criterion in Regulation 8.1 will beapplied.

The questions and answers should be regarded as guidelines. They have been prepared on the basis of operational experience to date It is not possible to anticipate all scenarios that may arise and a degree of flexibility in the application of the Regulations will be maintained. Moving forward, in the event that there is 


\section{APPENDICES}

any uncertainty or the need for clarification in relation to the application of the eligibility criteria in particular circumstances, then the Regulations Committee may be asked by World Rugby to make a ruling on a Player's eligibility. In relation to any

such adjudication, the Regulations Committee will al ways have in mind the rationale behind Regulation 8. The aim of the Regulations Committee in each case where darification may be required, is to establish whether, in all the circumstances, a Player has, by reference to the eligibility criteria in Regulation 8.1, been able to demonstrate a genuine, close and credible national link with the country that the Player wishes to represent. It is anticipated that over time a body of rulings by the Regulations Committee may develop which may, in turn, assist in providing further guidance to Unions in relation to eligibility matters.

11. When should any uncertainty over a Player's eligibility be clarified?

It is essential that eligibility issues are clarified before a Player represents the senior or next senior fifteen-a side National Representative Team of a Union or a Union's senior National Representative Sevens Team. This is particularly important in light of the one Union only rule Accordingly, if a Union has any doubt over a Player's eligibility status it must takeall steps necessary to clarify the position before selecting the Player to play for its senior or next senior fifteen-aside National Representative Team or its senior National RepresentativeSevens Team

12. What does place of birth mean?

This should be the most straightforward criterion to apply. A Player's place of birth shall be the country within whose geographical borders he was born. However, difficult scenarios can arise even in relation to this criterion. For example, wherea Player was born within the geographical borders of one country, but in a part of that country deemed by the law of the country concerned, to be the sovereign teritory of another, or where a Player was born in a military hospital. In such circumstances the matter should be referred to the Regulations Committee for a ruling. The Regulations Committee would need to establish the legal position together with other relevant facts and circumstances. In exceptional circumstances it may be possible for a Player to demonstrate, to the satisfaction of the Regulations Committee, that he is eligible to play for the Union within whose sovereign teritory he was born, even though that sovereign teritory may be within the geographical borders of another country.

13. What does Parent mean?

The term "parent" in the Regulations is limited to either a blood parent or a parent that has formally adopted a Player in accordance with the applicable legal requirements of the country concerned. Unless a Player has been adopted in accordance with the formal, legal requirements of the country concerned, the application of this criterion will be based on a Player's blood parent. When a Player has been formally adopted in accordance with the applicable legal requirements of the country concerned, the birth place of the Player's blood parent will no longer be relevant for the purposes of establishing the Player's eligibility pursuant to Regulation 8.1(b). The relevant parent will be the parent that has formally and legally adopted the Player. However in such circumstances, the relevant grandparents for the purposes of establishing a Player's eligibility pursuant to Regulation 8.1(b) will be the Player's blood grandparents. It is not possible under Regulation 8.1(b) to assume eligibility via non-blood grandparents even if a Player has been formally and legally adopted.

For the avoidance of any doubt, stepparents and fostering parents will not be considered to constitute a Player's parent for the purposes of Regulation 8.1(b).

14. How is the Residence criteria satisfied?

Regulation 8.1(c) requires a Player to complete 36 consecutive months of Residence immediately preceding the time of playing. Residence is defined as "the place or location in which the Player has his primary and permanent home" and Resident shall be construed accordingly. In essence, Regulation 8.1(c) constitutes a sporting naturalization procedure, based on a geographical/presence test. As in any naturalisation process, a number of factors will influence the determination of what constitutes a Player's permanent and primary home Such factors include, but are not limited to, the actual time spent in a country and the purpose of any absences during the qualification period. By being Resident in a country for a period of 36 consecutive months immediately preceding the time of playing for a Union, a Player is deemed to acquire a credible, close and established national link with a country/Union that entitles him to participate in sporting competitions for that Union. Based on the overriding rational e of the eligibility Regulations, in cases wherea Player's eligibility is uncertain the Regulations Committee will consider that Player's eligibility by reference to the particular facts and circumstances of his case to establish if the Residency test, in the context of the overall rationale of the eligibility Regulations, has been satisfied. The principles set out in responses to the questions below will act as guidelines to the Regulations Committee when it is asked to consider any cases pursuant to this criterion.

15. Whoseburden of proof?

In all cases where a Player is seeking to establish eligibility by reference to the Residency criteria in Regulation 8.1(c) (and, indeed, in relation to Regulation (or 8.1(a) and (b)), the burden of proof is on the Player and the Union that he wishes to represent to prove that Player's eligibility. Under Regulation 8.1(c), 


\section{NATIONALITY REQUIREMENTS IN OLY MPIC SPORTS}

the Player and his Union must be able to demonstrate that, during the relevant period, the country in which he claims he has been Resident was, genuinely, the country that the Player treated as his home and is clearly the country in which the Player has his primary and permanent home If a Player has moved from one country to another, and is seeking to establish Residence in that new country, then he must also be able to demonstrate that he is clearly no longer Resident in the country in which he lived previously and that he no longer treats that country as his home For the avoidance of any doubt, a Player cannot nominate a country as his home without demonstrating that he has satisfied the geographical commitment/presence test enshrined in Regulation 8.1(c). The geographical commitment/presence test will be vigorously upheld and applied to avoid abuse of the Residency criteria. For example, a Player that acquired/leased property in a country and who nominated that property as his permanent and primary home (even though he may only be present at that property and in that Union on a short term/temporary basis) would not satisfy the Residency test.

16. Will short breaks interrupt a period of Residence?

Short breaks in Residence, for example, for holidays, attending family/friends in other countries who may be ill etc, are unl ikely to change the place/location of a Player's primary and permanent home and are, therefore, unlikely to interrupt a Player's period of Residence By way of a guideline, however, as a minimum requirement, it is likely that, save in exceptional circumstances, at least 10 months actual physical presence of the Player in the country concerned throughout any qualifying year of the Residency period, will be required to demonstrate that the country is the place where the Player has his primary and permanent home

17. Does the 36 month period of Residence have to immediately precede playing for a Union?

Save in exceptional circumstances, the 36 months Residence will be expected to have been completed consecutively and be achieved immediately before the Player represents a Union. This is designed to createa contemporary national link with the country of the Union concerned. This factor will be particularly significant if a Player has moved to make a "new" country his Residence having been Resident in another country previously. In essence, in such circumstances, the Player, as well as demonstrating his commitment to a new country, must also be (and seen to be) relinquishing his ties with the country in which he lived previously. For the avoidance of any doubt, seeking to rely on short periods of Residence as a child in a particular country, combined with a short period of Residence in that same country prior to playing for a Union, is likely to create a link that would be too tenuous to satisfy the underlying intentions of establishing a contemporary, permanent, national link with a Union. However, each case will be assessed on its overall merits to establish if a Player is ableto demonstrate a genuine, close, credibleand established national link by reference to the amount of timethe Player can demonstrate that he has treated the "new" country as his home and other relevant factors.

18. What is the position of students?

As far as students are concerned, particularly those that are not financially independent, being resident, as a full time student, in another country, is likely to be considered as a series of temporary absences from the parental home It is anticipated that in the majority of cases involving students the parental home is likely to continue to constitute the student's permanent and primary home Accordingly, attendance at college/university in such circumstances is unlikely to break a Player's consecutive period of Residence However, as in all matters of eligibility, the overriding concern of the Regulations Committe in assessing any such case will be to ensure that there remains a close, credible and established link with the country in which the Player claims to have retained his primary and permanent home. There could be circumstances in which a student living in another country may be deemed to have interrupted his Residency period.

19. Who is responsible for compliance with the eligibility criteria?

In accordance with Regulation 2.1.2, each Union is responsible for ensuring compliance with all Regulations Relating to the Game This includes, but is obviously not limited to, Regulation 8. Accordingly, it is the responsibility of each Union to ensure that all Players it selects are properly eligible within the provisions of Regulation 8 and, in the event of any uncertainty, to ensure that the position is darified before the Player is selected. Unions must have in place all necessary procedures and internal controls to ensure compliance with the digibility Regulations.

20. What must Unions do to ensure (and demonstrate) compliance with the eligibility Regulations?

Unions must ensure that before a Player is sel ected for the first time for its senior or next senior fifteen-a-side National Representative Team or its senior National Representative Sevens Team the Player completes the standard form dedaration attached to these Explanatory Guidelines at Schedule 1. In addition, before selecting a Player, Unions must ensure that they obtain valid/authentic documentation and such other evidence that may be necessary to prove, definitively, a Player's eligibility to play for that Union. Each Union must notify World Rugby of the names of all Player's selected for its senior and next senior National Representative Team and its senior National Representative Sevens Team on an annual basis. World Rugby shall maintain a database of all such Players. If requested, by the Chairman, or his designee, Unions must supply copies of the completed declaration forms of a Player(s) together with supporting documentation relied on to demonstrate the Player's eligibility. On 1 December each year, each Union must certify to World Rugby that each Player selected to represent the senior or next senior fifteen-a-side National Representative 


\section{APPENDICES}

Team of the Union or its National Representative Sevens Team during the past year has completed, in full, the dedaration form and that each Player was eligible to represent the Union in accordance with the provisions of Regulation 8.

World Rugby may, through the Chairman, or his designee, of his own motion or on receipt of a complaint undertake an investigation into a Union's compliance with Regulation 8. Unions, Players and officials must provide assistance with any such investigation and disclose such information and documents deemed necessary by the Chairman, or his designee, for the purposes of that investigation.

21. What are the consequences of a breach of the eligibility Regulations by a Union?

Compliance with Regulation 8 is of fundamental importance in maintaining the integrity of international Rugby Union at senior National Representative level. Any breach of such a fundamental Regulation, howsoever arising, has a detrimental impact on the image and reputation of the sport. Unions must, therefore take all necessary steps to put in place comprehensive review/compliance procedures to ensure that a breach of the eligibility provision does not occur whether negligently or otherwise Alleged breaches of Regulation 8 may be investigated and handled in accordance with Regulation 18 (Disciplinary and Judicial Matters). However, a breach of the eligibility Regulations constitutes a strict liability offence This means that a failure by a Union to fulfill its obligations and to comply with the eligibility Regulations will be regarded as a serious breach of the Regulations, howsoever such breach may have occurred. As a reflection of the seriousness with which any breach of the eligibility Regulations will be treated by World Rugby, it has been agreed by Council to establish a minimum fixed penalty to be imposed on a Union that has breached Regulation 8. These minimum fixed penalties will appear in Regulation 8 and, for ease of reference, are also set out below.

\subsection{Responsibility, breach and penalties for a breach of Regulation 8}

\subsubsection{Unions}

Regulation 8 is a strict liability offence and shall be construed in accordance with the principles of strict liability under English law. It is not, therefore, necessary that fault or intent on the part of a Union be shown in order for a breach of Regulation 8 to be established. Nor is lack of fault or intent on the part of a Union a defence to a breach of Regulation 8. For the avoidance of any doubt (and without limiting a Union's other obligations and responsibilities for the conduct, acts or omissions of its members and Persons under its jurisdiction pursuant to any other Regulation) Unions are responsible and accountable for the conduct of their Players and all Persons under its jurisdiction in relation to compliance with the provisions of Regulation 8 and any breach of Regulation 8 by such Player(s) or Person(s) shall be deemed to be a breach of Regulation 8 by the Union concerned. Each breach of Regulation 8 by a Union, howsoever arising, will result in a minimum fixed fine being imposed on the Union concerned. The minimum fixed fines for each breach of Regulation 8 by a Union areas follows:

For a Union that is represented on the Council $£ 100,000$ sterling;

For all other World Rugby Merber Unions $£ 25,000$ sterling.

Based on the facts and circumstances of any breach of Regulation 8 the applicable minimumfixed fine as set out above may be increased. In addition, other penalties as set out in Regulation 18.6 may also be imposed on the Union concerned.

22. What must Players do to ensure (and demonstrate) compliance with the eligibility Regulations?

Players are required to act honestly in matters relating to their eligibility to represent a particular Union. This would include, without limitation, fully disclosing to the Union (and World Rugby upon request) any matters relevant to the Player's eligibility and providing all reasonable assistance to the Union (and World Rugby upon request) in order to establish the Player's eligibility at the first avail able opportunity.

23. What are the consequences of a breach of the eligibility Regulations by a Player?

A Player who knowingly (and/or with reasonable enquiry ought to have known) represents a Union where not eligible to do so commits a breach of Regulation 8. Alleged breaches of Regulation 8 will beinvestigated and handled in accordance with Regulation 18 (Disciplinary and Judicial Matters). Judicial Officers and Judicial Committees may impose sanctions pursuant to their powers taking into consideration, without limitation, the circumstances of the breach induding the number of breaches and the level of any deception. This may result in a Player being reprimanded, fined, suspended and/or such other sanction the J udicial Officer or J udicial Committeethinks fit, in accordance with Regulation 18.6.

24. For the Player to beliable for a breach must the Union al so have been found liable?

$\mathrm{Yes}$, there must also be a finding that the Uni on concerned has played an ineligible Player. However such finding would not be affected in circumstances where there was any reduction or suspension of the ordinarily applicablesanction.

Explanatory G uidelines on the Implementation of R egulation 8 - Olympic Eligibility

With the reintroduction of Rugby Sevens into the Olympic Games in Rio in 2016 there are certain rules which participants must adhere to for eligibility purposes. The Olympic Eligibility Regulations (8.6 to 8.16) have been introduced to accommodate the Olympic Charter Rules. To assist in the implementation of these 
Regulations, the following Guidelines have been developed to address the specifics around Olympic Sevens eligibility which differs from that of World Rugby eligibility requirements in that it is based soley upon a nationality consideration al one. The two sets of rules have been combined to achieve harmony between the objectives and underlying philosophy of Regulation 8 and the requirements of the Olympic Charter in the context of participation in Olympic Events. These Explanatory Guidelines must be read in conjunction with theterms of Regulation 8 and the Guidelines thereto.

1. Who is eligibleto play Olympic Sevens?

Any Player who meets the eligibility criteria in 8.1 and hol ds the nationality of the Union / country they wish to represent in the Olympic Games or Olympic Qual ification process (known as the "Olympic Events"). The eligibility rules in the Olympic Charter together with the World Rugby eligibility rules must be complied with by Players who participate in Olympic Events.

2. Musta Player havethe passport of the Union / country herepresents in Olympic Sevens?

The nationality of the Union / country the Player wishes to represent in Olympic Sevens is a requirement under the Olympic Charter and is therefore necessary for participation in Olympic Events. Nationality is ordinarily demonstrated by the Player holding the passport of the Union / county they wish to represent. All matters relating to the determination of the country which a Player may represent in the Olympic Games shall ultimately be resolved by theIOC Executive Board.

3. Who will decide on Olympic Sevens eligibility?

Ordinarily, the assessment of whether a Player satisfies the eligibility criteria in Regulation 8.1 and 8.6 will be straightforward. However, in all cases where a Player who has been captured under Regulation 8.2 and who holds the nationality of another Union / country and wishes to participatein an Olympic Event(s) for the Union / country of which he is a national, the Player may apply to World Rugby to represent the National Representative Sevens Team of that Union (or the Olympic Sevens Team of an National Olympic Committee), and the case shall be determined in the first place by the World Rugby Regulations Committee In the event there are other cases of uncertainty or there is the need for clarification a referral may bemadeto theWorld Rugby Regulations Committee

\section{What is required to besubmitted to the Regulations Committee?}

Applications should be submitted to World Rugby accompanied by all relevant supporting documents by the Union (or in applicable cases where there is no Union, the National Olympic Committee ("NOC")) of the country the Player wishes to represent in an Olympic Event. The application shall be prenotified to the Player's Union (namely the Union who's National Representative Team the Player has previously represented. The Player's Union may make written submissions to the World Rugby Regulations Committee or may beinvited to do so.

5. Can a Player with dual nationality, or having World Rugby eligibility for one Union but the nationality of another, represent both Unions / countries in the same Olympic qualification process?

No. A Player may only represent one Union / country in the Olympic Events. For example if a Player played for a Union in the Sevens World Series in the year it was designated as an Olympic Event the Player could not later in the same Sevens World Series play for another Union / country even in circumstances where he was deemed eligibly by the Regulations Committee to play for the second Union / country of which he is a national. The principle of Regulation 8.2 applies equally to Olympic Events, such that if a Player, having represented one Union / country in an Olympic Event they may not represent another Union / country thereafter.

6. Can a Player switch nationality?

Nationality is a matter which is governed by nation states. If a Player does switch national ity the effect of this upon their Olympic eligibility would need to be considered taking into account Regulation 8.6 to 8.16 and the Olympic Charter Rules regarding eligibility which can be found at www.olympic.org. However, a Player who has represented one Union / country in an Olympic Event(s) and who has changed their nationality or acquired a new nationality may participate in Olympic Events to represent their new Union / country provided that at least three (3) years have passed since the Player last represented their former Union / country and the approval of the Intemational Olympic Committee, the relevant National Olympic Committee(s) and World Rugby is obtained.

7. How will the Olympic eligibility criteria be assessed?

In the early days of the Olympic participation the view has been taken by World Rugby that the Regulations Committee should assess all cases where a Player who has al ready been captured for a Union under the one Union only rule (Regulation 8.2) but wishes to subsequently play for another Union / country for which s/he holds nationality in an Olympic Event.

8. Is there any stand-down period?

Yes. The Player will be required to observe and demonstrate a stand down period of three (3) years between thetimethe Player last played for

his Union and the time the Player first represents the second Union, which must be in an Olympic Event. Played, shall mean when s/he played for the senior, next senior or senior sevens National Representative 


\section{APPENDICES}

Team of that Union for which s/he is captured. The principles of Regulation 8.3 apply in any assessment of this provision.

9. What does 'first represents' mean?

It means the first occasion when the Player represents the second Union in a Match, Tournament or Series of Matches - which must be in an Olympic Event. The Player would not however, be permitted for example to participate in preseason Matches or so-called 'friendly' matches or other Matches which are not Olympic Events representing the second Union. Training with the team of the second Union is permitted but the circumstances should not be such that it presents or implies to third parties that the Player is part of the National Representative Sevens Team or Olympic Sevens Team of the second Union / country.

10. How will the stand-down period be assessed?

The onus will be on the Player to demonstrate to the reasonable satisfaction of the Regulations Committee the last occasion upon which s/he played for their former Union and that they have not represented such Union in the three year period before they represent their new Union/ country in an Olympic Event.

11. Arethese Olympic Guidel ines to be read with the World Rugby Eligibility Guidelines?

Yes, both sets of Guidelines should be read together.

12. What is the position for Unions who do not have a single NOC to represent them?

Member Unions of World Rugby are not necessarily recognised in their own right with equivalent NOC's, for example the British Olympic Association (Team GB) is the NOC for Great Britain and therefore encapsulates the Unions of England, Scotland, Wales and Northern Ireland (represent by the all-Ireland body of the IRFU). In such case, Players from the underlying Unions would be eligible (where they comply with Regulation 8.1 and 8.6) to represent the Olympic Sevens Team of the NOC (if selected) in relevant Olympic Events.

13. If a Player plays for a combined team in an Olympic Event does it affect his eligibility in relation to World Rugby?

If a Player plays for a combined team of a country in an Olympic Event (eg. Team GB) and he was previously not captured for a Union (under Regulation 8.2) then the Player will be deemed to be captured for one of the underlying Uni ons of the combined team of country he represented. So in the case of Team GB it would mean that the Player would then be free to play for one of England, Scotland, Wales and/or Ireland.

If a Player plays for a combined team of a country in an Olympic Event (eg. Team GB) and he was previously was captured for a Union (under Regulation 8.2) then the Player remains captured for such Union and their participation in the combined team in theOlympic Event will not affect their status.

14. Is there a right of appeal from the decision of the World Rugby Regulations

Yes. An Olympic Eligibility appeals committee has been established under Regulation 2 to deal with any appeal s of decisions by the World Rugby Regulations Committee

15. For the Olympic Games 2016 in Rio, do any special provisions apply?

Rugby Sevens will enter the Olympic Games for the first time in 2016. The qualification process has been established and all persons eligible to participate must have qualified by $11 \mathrm{~J}$ uly 2016. In terms of eligibility, the three (3) year stand-down period applies. However, given the timing of the clarification of the qualification process and the constitutional review of the eligibility requirements for Olympic Events a shorter stand-down period in respect only of the Olympic Games 2016 shall apply. In this regard any Player who wishes to represent a Union / country for whom s/he holds the nationality and has previously been captured for another Union may do so provided the Player stands down from their current Union at least 18 months before representing the Second Union in an Olympic Event in the Rio Olympic Games cycle.

SCHEDULE 1 REGULATION 8

SCHEDULE 1. EXPLANATORY NOTE

As from 1 J anuary 2000 a player is only entitled to play Rugby Union for the Senior National Representative Team or the next Senior National Representative Team of one Union. This means that if a player is deemed to have played for the Senior National Representative Team or the next Senior National Representative Team of a Union that player will be unable to play for any other Union. This is the position even if that player is able to satisfy one or more of the eligibility criteria set out in Regulation 8.1. It is important that players and Unions understand the situations in which players will be deemed to have played for the Senior National Representative Team or the next Senior National Representative Team of a Union. These situations are set out in Regulation 8.3.

Regulation 8.3 is based on a "selection and participation" test for players who have reached the age of majority [18 or over]. Players and Unions must familiarize themselves with Regulation 8.3. Players should be made aware by Unions of what constitutes that Union's Senior National Representative Team, its next Senior National Representative Team its Senior Touring Squad and its next Senior Touring Squad and the Matches that will result in a player being committed to that Unions. The following situations are covered by Regulation 8.3. 


\section{NATIONALITY REQUiREMENTS In Olympic SPORTS}

1. Players who participate in International Matches for the Senior National Representative Team or the next Senior National Representative Team of a Union against the Senior or next Senior National Representative Team of another Union.

2. Players selected to represent a Union's Senior Touring Squad who participate in any Match played by members of that Union's Senior Touring Squad during an International Tour provided such International Tour includes an International Match(es) approved by World Rugby.

3. Players who participate in a Match for the Senior or next Senior National Representative Team of a Union against a team made up of players from a Union's Senior Touring Squad during an International Tour which includes International Match(es) approved by World Rugby.

4. Players, representing a Union's next Senior Touring Squad who participate in a Match on an International Tour approved by World Rugby against the Senior National RepresentativeTeam or the next Senior National RepresentativeTeam of another Union.

5. Players who play for the Senior or next Senior National Representative Team of a Uni on against a team selected from a Union's next Senior Touring Squad when such Match is played on an International Tour approved by World Rugby.

[...]

HANDBOOK AS FRAMED BY WORLD RUGBY Last update: 11 September, 2015

\section{RE GULATION 8. ELIGIBILITY TO PLAY FOR NATIONAL REPRESENTATIVE TEAMS}

8.1 Subject to Regulation 8.2, a Player may only play for the senior fifteen-a- side National Representative Team the next senior fifteen-a-side National Representative Team and the senior National Representative Sevens Team of the Union of the country in which:

(a) he was born; or

(b) one parent or grandparent was born; or

(c) he has completed thirty six consecutive months of Residence immediately preceding the time of playing.

8.2 A Player who has played for the senior fifteen-a-side National Representative Team or the next senior fifteen-a-side National Representative Team or the senior National Representative Sevens Team of a Union is not eligible to play for the senior fifteen-a-side National Representative Team or the next senior fifteen-asideNational RepresentativeTeamor the senior National Representative Sevens Team of another Union.

8.3 For the purposes of this Regulation, a Player is deemed to have played for the senior fifteen-a-side National RepresentativeT eam or the next senior fifteen-a-side National Representative Team of a Union if:

(a) He is selected for such team to play in an International Match against the senior fiften-a-side National Representative Team or the next senior fifteen-aside National Representative Team of another Union (or in a fifteen-a-side international Match against another Union's senior or next senior Touring Squad during a World Rugby approved International Tour) and is present at the Match played by that team either as a replacement, substitute or a playing member of that team and has, at the time of the Match, reached the age of majority; or

(b) He is selected to represent a Union's seni or Touring Squad on an International Tour which includes an International Match or Matches approved by World Rugby and is present at any fifteen-a-side Match played on that International Tour either as a replacement, substitute or a playing member of a team selected from the Union's senior Touring Squad and has, at thetime of the Match, reached the age of majority; or

(c ) He is selected to represent a Union's next senior Touring Squad on a World Rugby approved International Tour and during that International Tour he is present at a Match against the senior fifteen- a side National Representative Teamor the next senior fifteen-a sideNational Representative Team of another Union either as a replacement, substitute or playing member of a team selected from the Union's next senior Touring Squad and has, at the time of the Match reached the age of majority.

(d) He is sel ected to represent the Under 20s National Representative Team of a Union which has been predesignated as that Union's next senior fifteen-a-side National Representative Team and the Player is part of the team which participates in an International Match as part of the World Rugby Junior World Championships, World Rugby J unior World Rugby Trophy or the Six Nations U20 Championship and is present at the Match played by that Teameither as a replacement, substitute or playing member of that Team and has, at thetime of the Match, reached the age of majority.

8.4 For the purposes of this Regulation, a Player is deemed to have played for the senior National Representative Sevens Team of a Union if he is selected to represent a Union's senior National Representative Sevens Team in an International Match against the senior National Representative Sevens Team of another Union and is present at the Match played by that Teameither as a replacement, substitute or playing member of that Team and has, at the time of the Match, reached the age of majority.

Responsibility, breach and penalties for a breach of Regulation 8

8.5 Regulation 8 is a strict liability offence and shall be construed in accordance with the principles of strict liability under English law. It is not, therefore, necessary that fault or intent on the part of a Uni on be shown in order for a breach of Regulation 8 to be established. Nor is lack of fault or intent on the part of a Union a 


\section{APPENDICES}

defence to a breach of Regulation 8. For the avoidance of any doubt (and without limiting a Union's other obligations and responsibilities for the conduct, acts or omissions of its members and Persons under its jurisdiction pursuant to any other Regulation) Unions are responsible and accountable for the conduct of their Players and all Persons under its jurisdiction in relation to compliance with the provisions of Regulation 8 and any breach of Regulation 8 by such Player(s) or Person(s) shall be deemed to bea breach of Regulation 8 by the Union concerned. Each breach of Regulation 8 by a Union, howsoever arising, will result in a minimum fixed fine being imposed on the Union concemed. The minimum fixed fines for each breach of Regulation 8 are as follows:

(a) For a Union that is represented on the Council $£ 100,000$ sterling;

(b) For all other World Rugby Member Unions $£ 25,000$ sterling.

Based on the facts and circumstances of any breach of Regulation 8 the applicable minimum fixed fine as set out above may be increased. In addition, other penalties as set out in Regulation 18.6 may al so be imposed on the Union concerned.

8.5.1 In exceptional circumstances, a Union in breach of Regulation 8 may make submissions to the relevant disciplinary body appointed under Regulation 18 to adjudicate on the case as to why the Union should not be subject to the applicable minimum fixed fine. For the avoidance of any doubt, however, the relevant disciplinary body shall only beentitled to reduce the applicable minimumfixed fine set out in this Regulation where the Union is able to provide clear and indisputable evidence that truly exceptional circumstances exist and that the Union concerned had taken all necessary steps to comply with Regulation 8.

8.6 To be eligible to participate in the Olympic Games, Olympic qualification events (together "Olympic Events") or other events governed by theOlympic Charter all members of the senior National Representative Sevens Team(s) of a Union or the selected Olympic Sevens Team(s) of a National Olympic Committee shall comply with Regulation 8.1 and must bea national of the country of the National Olympic Committee which it is representing in such Olympic Events. Regulation 8.2 applies equally to all Players.

8.7 A Player who is a national of the country or Union for which he has been captured under Regulation 8.2 and who holds the nationality of another country or Union, may apply to participate in an Olympic Event to represent his new country or Union subject to the following conditions;

8.7.1 The Regulations Committee shall consider the application of a Player under this Regulation 8.7 which must be submitted with all relevant supporting documentation by the Union for whom the Player wishes to next represent in an Olympic Event (or a Union associated with the Olympic Sevens Teem the Player wishes to represent). The application shall be prenotified to the Player's Union (namely the Union whose National Representative Team the Player represented);

8.7.2 The Player will be required to observeand demonstratea stand down period of at least 3 years sincethe timethe Player last represented their former Union and the timethe Player first plays for the second Union or country, which must be in an Olympic Event. The Player may not represent the second Union in any other form of the Game until after they have participated in such Olympic Event.

(A) Solely in respect of the Rio Olympic Games 2016, a stand down period of at least 18 months will be permitted, between the time the Player last represented their former Union and the time the Player first plays for the second Union or country, which must be in an Olympic Event in the Rio Olympic Games cycle, which the Player must observeand demonstrate.

8.8 Where the Player is not a national of the Union for which he has been captured under Regulation 8.2, and he meets the Olympic eligibility criteria (in Regulation 8.6 to 8.13 ) as determined by the Regulations Committee, he shall be eligible for selection to play for the Union / country of which he is a national, in an Olympic Event, subject to satisfying the applicable stand down period.

8.9 A Player who is eligible or captured for a Union that cannot participate in an Olympic Event because there is no National Olympic Committee solely for the teritory of such Union, may, subject to the Olympic eligibility criteria (in Regulation 8.6 to 8.13), be eligible to play for the Olympic Sevens Team of a National Olympic Committee of which he is a national, provided that such team is not associated with any one single Union. In such circumstances the following provisions shall apply;

8.9.1 WherethePlayer has been captured under Regulation 8.2 for a Union he shall remain captured for such Union notwithstanding the Player's representation for the Olympic Sevens Team of a National Olympic Committeein an Olympic Event;

8.9.2 Where the Player has not previously been captured under Regulation 8.2 and herepresents the Olympic Sevens Team of a National Olympic Committee in an Olympic Event he will be deemed to be captured for one of the underlying Unions which support the Olympic Sevens Team of the relevant National Olympic Committee, and the Player must elect which of those underlying Unions he shall be captured by for the purposes of Regulation 8.

8.10 A Player who has represented one Union or Olympic Team in an Olympic Event and who has changed his nationality or acquired a new nationality, may apply to participate in an Olympic Event to represent his new Union or country provided that at least three years have passed since the Player last represented his former Union or country and the approval of the International Olympic Committee, the relevant National 
Olympic Committee(s) and World Rugby is obtained. This period may be reduced or even cancelled with the agreement of the World Rugby and the National Olympic Committees concerned and by the IOC Executive Board, which takes into account the circumstances of each case

8.11 A Player may not represent two different Unions or a Union and an Olympic Sevens Team(s) of a National Olympic Committee in the same Olympic Event(s).

8.12 Once the Player has represented the Union of which he is a national, in an Olympic Event, he shall thereafter betied to that Union for all forms of the Gameand in all events.

8.13 Players who participate in the Olympic Events accept and agree that any disputes relating to eligibility shall first be addressed pursuant to the rules of such Olympic Events and the World Rugby Regulations and that all internal procedures (induding applicable National Olympic Committee rules/procedures) and/or World Rugby procedures shall be exhausted first. Thereafter, recourse may be had in respect of Olympic Events only (and not in relation to eligibility matters to which Regulation 8.6 to 8.16 does not apply) to the Court of Arbitration for Sport (CAS) in accordance with the provision applicable before such court and which will resolve definitively the dispute in accordance with the code of sports related arbitration. World Rugby has the right to appear, attend and/or participate as a party in any appeal to CAS involving eligibility considerations for Olympic Events.

8.14 Any Union wishing to obtain clarification around the eligibility of a Player to represent it in the Olympic Games or Olympic Events may do so by referring the matter to the World Rugby Regulations Committee in accordance with Regulation 2 and Regulation 8.7.1 and 8.7.2.

8.15 The list of Olympic Events is set out in Schedule 2 and shall be updated for each Olympic cycle

8.16 The provisions of Regulation 8.5 apply equally to any alleged breach of the Olympic eligibility provisions.

EXPLANATORY GUIDELINES ON THE IM PLEMENTATION OF REGULATION 8

ELIGIBILITY TO PLAY FOR NATIONAL REPRESENTATIVE TEAMS

Following its deliberations on the question of Player eligibility, the Working Party has produced these Explanatory Guidelines on the implementation of Regulation 8. These Explanatory Guidelines must be read in conjunction with the terms of Regulation 8.

1 What is the Rationale/Philosophy of Regulation 8?

The rationale/philosophy of Regulation 8 is to ensure that Players selected to represent either the seni or and next senior fifteen-a-side National Representative Teams of a Union or a Union's senior National RepresentativeSevens Team havea genuine, close, credi ble and established national link with the country of the Union for which they have been selected. Such a national link is essential to maintain the unique characteristics and culture of elite international sporting competition between Unions. The integrity of International Matches between Unions depends upon strict adherence to the eligibility criteria set out in the Regulations.

2 Who establishes the eligibility criteria in Rugby Union?

World Rugby will continue to establish the criteria by reference to which a Player's eligibility to play for the senior or next senior fifteen-a-side National Representative Team of a Union or a Union's senior National Representative Sevens Team will be determined. Citizenship of a country and/or whether a Player holds a passport of a particular country are not, of themselves, determinative in identifying which Union a Player is eligible to represent. This will be determined solely in accordance with World Rugby's eligibility criteria. In relation to Olympic eligibility criteria see the Explanatory Guidelines on the Implementation of Regulation 8 - Olympic Eligibility.

3 What is the eligibility criteria in Rugby Union?

The existing World Rugby eligibility criteria set out in Regulation 8.1 will be maintained. This is based on thefollowing:

(a) The country in which the Player was born; or

(b) The country in which one parent or grandparent of the Player was born; or

(c) The country in which the Player has completed thirty-six consecutive months of Residence immediately preceding the time of playing. Residence means the place or location in which a Player has his primary and permanent homeand Resident shall be construed accordingly; and

(d)For Olympic Event participation, the nationality of the Union / country the Player wishes to represent is also required.

4 If a Player has dual eligibility, can he play for the senior or next senior fifteen-a-side National Representative Teamor the senior National Representative Sevens Team of morethan one Union?

No, save for those Players that, before $1 \mathrm{~J}$ anuary 2000 , al lowed a period of 36 consecutive months to elapse after they had played for another Union and who played for the second Uni on before 1 January 2000. The one Union only rule, introduced by World Rugby from 1st J anuary 2000 (as set out in Regulation 8.2), will be maintained. A Player is only entitled to play Rugby Union for the senior or next senior fifteen-aside National Representative Team or the senior National Representative Sevens Team of one Union. Accordingly, if a Player is deemed to have played for such a team, even if he is ableto satisfy one or more of 
the eligibility criteria set out in Regulation 8.1, he will not be able to play for any other Union. Consistent with the overall rationale underlying the eligibility Regulations, the one Union only rule is designed to maintain the integrity of the international Game. Once a Player has committed himself to a particular Union, through participation in one of the Matches or Tours identified in Regulations 8.3 or 8.4, he is unable to change his "Rugby Nationality" which becomes fixed.

5 When is a Player deemed to have played for the senior or next senior fifteen-a-sideNational Representative Team of a Union or a Union's senior National Representative Sevens Team?

As a result of the one Union only rule, in particular, it is essential that Players and Unions understand the situations in which Players will be deemed to have played for the senior fifteen-a-side National Representative Team or the next senior fifteen-a-side National Representative Teem of a Union or a Union's senior National RepresentativeSevens Team Thesesituations are set out in Regulations

8.3 and 8.4. Players and Unions shall, at all times, have regard to the full terms of Regulations 8.3 and 8.4, however, by way of a summary only, the situations set out below are covered:

Fifteen-a-side

(a) Players who participate in International Matches for the senior National Representative Team or the next senior National Representative Team of a Union against the senior or next senior National Representative Team of another Union.

(b) Players selected to represent a Union's senior Touring Squad who participate in any Match played by members of that Union's senior Touring Squad during an International Tour provided such International Tour includes an International Match(es) approved by World Rugby.

(c ) Players who participate in a Match for the senior or next senior National Representative Team of a Union against a team made up of Players from a Union's senior Touring Squad during an International Tour which includes International Match(es) approved by World Rugby.

(d) Players, representing a Uni on's next senior Touring Squad who participatein a Match on an International Tour approved by World Rugby against the senior National Representative Team or the next senior National Representative Team or the next senior National Representative Team of another Union.

(e) Players who play for the senior or next senior National Representative Team of a Union against a team selected from a Union's next senior Touring Squad when such Match is played on an International Tour approved by World Rugby.

Seven-aside

(a) (a)Players who play for a Union's senior National Representative Sevens team in an International Match agai nst the senior National RepresentativeSevens team of another Union.

6 How do I know which teamisa Union's next senior fifteen-arside National Representative Team?

(a) There should be no uncertainty over which team constitutes a Union's next senior National RepresentativeTeam Unions are required to notify World Rugby of the name of their nominated next senior National Representative Team The teamnominated remains the Union's next senior National Representative Team unless the Union notifies World Rugby of a change in this nomination. A Union is entitled to notify World Rugby no more than once per cal endar year of a change to its next senior National Representative Team provided that in doing so it shall take account of any Matches such team may be schedul ed to play and shall advise the Union of any senior or next senior National Representative Team it is scheduled to play reasonably in advance of such Match. The identity of a Union's next seni or National Representative Team can be verified with the Uni on concerned and/or World Rugby.

(b) Unions must ensure that all persons involved in an International Match (Players and team management including coaching staff) are made aware of the status of their team as the next senior National Representative Team and that of their opposing team where it is the senior or next senior National Representative Team of another Union and what that means from a capturing perspective under Regulation 8. Notwithstanding the Union's obligation to inform the Player and team management it shall be the sole responsibility of each Player to ensure that he is aware of the status of every Match in which he plays and the implications of playing in an International Match involving the senior or next senior National Representative Teams of two Unions.

(c) In addition to (a) and (b) above, Unions who designate their Under 20s National Representative Teamas their next senior National Representative Team have a particular onus to dearly make the Team Players aware of the consequences of being captured for that Union at age grade level. Effective 1 July 2014, the Players on any such Team which participates in the World Rugby J unior World Championships, World Rugby J unior World Trophy or the Six Nations U20 Championship (where they are present at the Match played by that Team either as a replacement, substitute or playing member of that Team and has, at the time of the Match, reached the age of majority) will be captured. In this regard the status of the opposition teams in any Match in these named tournaments is not a factor to be considered.

7 What is the age of majority?

For the purposes of the Regulations (including, but not limited to Regulation 8), the age of majority is deemed to be acquired on a Player's 18th birthday. 


\section{NATIONALITY REQUIREMENTS IN OLYMPIC SPORTS}

8Does the eligibility criteria apply to all forms of Rugby?

The eligibility criteria applies to the fifteen-a-side Game at senior and next senior National Representative level and in respect of a Union's seni or National RepresentativeSevens Team

9 Does the eligibility criteria apply to all Unions in membership of World Rugby?

Yes, all Unions in membership of World Rugby are obliged to comply with the eligibility Regulation

10 How will the eligibility criteria be assessed?

Ordinarily, the task of assessing whether a Player satisfies any of the eligibility criteria set out in Regulation

8.1 is straightforward. However, as a result of professionalism greater mobility and societal family change this is not al ways the case Difficult cases have arisen and may continue to emerge The responses to the questions set out below are intended to provide further clarification as to how each eligibility criterion in Regulation

8.1 will be applied.

The questions and answers should be regarded as guidelines. They have been prepared on the basis of operational experience to date It is not possible to anticipate all scenarios that may arise and a degree of flexibility in the application of the Regulations will be maintained. Moving forward, in the event that there is any uncertainty or the need for clarification in relation to the application of the eligibility criteria in particular circumstances, then the Regulations Committee may be asked by World Rugby to make a ruling on a Playe's s eligibility. In relation to any such adjudication, the Regulations Committee will al ways have in mind the rationale behind Regulation 8 . The aim of the Regulations Committee in each case where clarification may be required, is to establish whether, in all the circumstances, a Player has, by reference to the eligibility criteria in Regulation 8.1, been able to demonstrate a genuine, close and credible national link with the country that the Player wishes to represent. It is anticipated that over time a body of rulings by the Regulations Committee may develop which may, in turn, assist in providing further guidance to Unions in relation to eligibility matters.

11 When should any uncertainty over a Player's eligibility be darified?

It is essential that eligibility issues are darified before a Player represents the senior or next senior fifteen-a side National Representative Team of a Union or a Union's senior National Representative Sevens Team This is particularly important in light of the one Union only rule Accordingly, if a Union has any doubt over a Player's eligibility status it must takeall steps necessary to clarify the position beforeselecting the Player to play for its senior or next senior fifteen-aside National Representative Team or its senior National RepresentativeSevens Team

12 What does place of birth mean?

This should be the most straightforward criterion to apply. A Player's place of birth shall be the country within whose geographical borders he was born. However, difficult scenarios can arise even in relation to this criterion. For example, where a Player was born within the geographical borders of one country, but in a part of that country deemed by the law of the country concerned, to be the sovereign territory of another, or where a Player was born in a military hospital. In such circumstances the matter should be referred to the Regulations Committee for a ruling. The Regulations Committee would need to establish the legal position together with other relevant facts and circumstances. In exceptional circumstances it may be possible for a Player to demonstrate, to the satisfaction of the Regulations Committee, that he is eligible to play for the Union within whose sovereign teritory he was born, even though that sovereign territory may be within the geographical borders of another country.

13 What does Parent mean?

The term "parent" in the Regulations is limited to either a blood parent or a parent that has formally adopted a Player in accordance with the applicable legal requirements of the country concerned. Unless a Player has been adopted in accordance with the formal, legal requirements of the country concerned, the application of this criterion will be based on a Player's blood parent. When a Player has been formally adopted in accordance with the applicable legal requirements of the country concerned, the birth place of the Player's blood parent will no longer be relevant for the purposes of establishing the Player's eligibility pursuant to Regulation 8.1(b). The relevant parent will be the parent that has formally and legally adopted the Player. However in such circumstances, the relevant grandparents for the purposes of establishing a Player's eligibility pursuant to Regulation 8.1(b) will be the Player's blood grandparents. It is not possible under Regulation 8.1(b) to assume eligibility via non-blood grandparents even if a Player has been formally and legally adopted.

For the avoidance of any doubt, stepparents and fostering parents will not be considered to constitute a Player's parent for the purposes of Regulation 8.1(b).

14 How is the Residence criteria satisfied?

Regulation 8.1(c) requires a Player to complete 36 consecutive months of Residence immediately preceding the time of playing. Residence is defined as "the place or location in which the Player has his primary and permanent home" and Resident shall be construed accordingly. In essence, Regulation 8.1(c) constitutes a sporting naturalization procedure, based on a geographical/presence test. As in any naturalisation process, a 


\section{APPENDICES}

number of factors will influence the determination of what constitutes a Player's permanent and primary home. Such factors include, but are not limited to, the actual time spent in a country and the purpose of any absences during the qualification period. By being Resident in a country for a period of 36 consecutive months immediately preceding the time of playing for a Union, a Player is deemed to acquire a credible, close and established national link with a country/Union that entitles him to participate in sporting competitions for that Union. Based on the overriding rational e of the eligibility Regulations, in cases wherea Player's e igibility is uncertain the Regulations Committee will consider that Player's eligibility by reference to the particular facts and circumstances of his case to establish if the Residency test, in the context of the overall rationale of the eligibility Regulations, has been satisfied. The principles set out in responses to the questions below will act as guidelines to the Regulations Committee when it is asked to consider any cases pursuant to this criterion.

\section{Whose burden of proof?}

In all cases where a Player is seeking to establish eligibility by reference to the Residency criteria in Regulation 8.1(c) (and, indeed, in relation to Regulation (or 8.1(a) and (b)), the burden of proof is on the Player and the Union that he wishes to represent to prove that Player's eligibility. Under Regulation 8.1(c), the Player and his Union must be able to demonstrate that, during the relevant period, the country in which he claims he has been Resident was, genuinely, the country that the Player treated as his home and is clearly the country in which the Player has his primary and permanent home If a Player has moved from one country to another, and is seeking to establish Residence in that new country, then he must al so be able to demonstrate that he is clearly no longer Resident in the country in which he lived previously and that he no longer treats that country as his home. For theavoidance of any doubt, a Player cannot nominatea country as his home without demonstrating that he has satisfied the geographical commitment/presence test enshrined in Regulation 8.1(c). The geographical commitment/presence test will be vigorously upheld and applied to avoid abuse of the Residency criteria. For example, a Player that acquired/leased property in a country and who nominated that property as his permanent and primary home (even though he may only be present at that property and in that Union on a short term/temporary basis) would not satisfy the Residency test.

16 Will short breaks interrupt a period of Residence?

Short breaks in Residence, for example, for holidays, attending family/friends in other countries who may be ill etc, are unlikely to change the place/location of a Player's primary and permanent homeand are, therefore, unlikely to interupt a Player's period of Residence By way of a guideline, however, as a minimum requirement, it is likely that, save in exceptional circumstances, at least 10 months actual physical presence of the Player in the country concerned throughout any qualifying year of the Residency period, will be required to demonstrate that the country is the place where the Player has his primary and permanent home

17 Does the 36 month period of Residence have to immediately precede playing for a Union?

Save in exceptional circumstances, the 36 months Residence will be expected to have been completed consecutively and be achieved immediately before the Player represents a Uni on. This is designed to createa contemporary national link with the country of the Union concerned. This factor will be particularly significant if a Player has moved to make a "new" country his Residence having been Resident in another country previously. In essence, in such circumstances, the Player, as well as demonstrating his commitment to a new country, must also be (and seen to be) relinquishing his ties with the country in which he lived previously. For the avoidance of any doubt, sedking to rely on short periods of Residence as a child in a particular country, combined with a short period of Residence in that same country prior to playing for a Union, is likely to createa link that would betoo tenuous to satisfy the underlying intentions of establishing a contemporary, permanent, national link with a Union. However, each case will be assessed on its overall merits to establish if a Player is able to demonstrate a genuine, close, credi bleand established national link by reference to the amount of timethe Player can demonstrate that he has treated the "new" country as his home and other relevant factors.

18 What is the position of students?

As far as students are concerned, particularly those that are not financially independent, being resident, as a full time student, in another country, is likely to be considered as a series of temporary absences from the parental home It is anticipated that in the majority of cases involving students the parental home is likely to continue to constitute the student's permanent and primary home Accordingly, attendance at college/university in such circumstances is unlikely to break a Player's consecutive period of Residence. However, as in all matters of eligibility, the overriding concern of the Regulations Committee in assessing any such case will be to ensure that there remains a close, credi ble and established link with the country in which the Player daims to have retained his primary and permanent home. There could be circumstances in which a student living in another country may be deemed to have interrupted his Residency period. 19 Who is responsible for compliance with the eligibility criteria?

In accordance with Regulation 2.1.2, each Union is responsible for ensuring compliance with all Regulations Relating to the Game This includes, but is obviously not limited to, Regulation 8. Accordingly, it is the responsibility of each Union to ensure that all Players it selects are properly eligible within the provisions of 
Regulation 8 and, in the event of any uncertainty, to ensure that the position is clarified before the Player is selected. Unions must have in place all necessary procedures and internal controls to ensure compliance with the eligibility Regulations.

20 What must Unions do to ensure (and demonstrate) compliance with the eligibility Regulations?

Unions must ensure that before a Player is sel ected for the first time for its senior or next senior fifteen-a-side National Representative Team or its senior National Representative Sevens Team the Player completes the standard form dedaration attached to these Explanatory Guidelines at Schedule 1. In addition, before selecting a Player, Unions must ensure that they obtain valid/authentic documentation and such other evidence that may be necessary to prove, definitively, a Player's eligibility to play for that Union. Each Union must notify World Rugby of the names of all Player's selected for its senior and next senior National Representative Team and its senior National Representative Sevens Team on an annual basis. World Rugby shall maintain a database of all such Players. If requested, by the Chairman, or his designee, Unions must supply copies of the completed declaration forms of a Player(s) together with supporting documentation relied on to demonstrate the Player's eligi bility. On 1 December each year, each Uni on must certify to World Rugby that each Player selected to represent the senior or next senior fifteen-a-side National Representative Team of the Union or its National Representative Sevens Team during the past year has completed, in full, the dedaration form and that each Player was eligible to represent the Union in accordance with the provisions of Regulation 8.

World Rugby may, through the Chairman, or his designee, of his own motion or on receipt of a complaint undertake an investigation into a Union's compliance with Regulation 8. Unions, Players and officials must provide assistance with any such investigation and disclose such information and documents deemed necessary by the Chairman, or his designee, for the purposes of that investigation.

21. What are the consequences of a breach of the eligibility Regulations?

Compliance with Regulation 8 is of fundamental importance in maintaining the integrity of international Rugby Union at senior National Representative level. Any breach of such a fundamental Regulation, howsoever arising, has a detrimental impact on the image and reputation of the sport. Unions must, therefore take all necessary steps to put in place comprehensive review/compliance procedures to ensure that a breach of the eligi bility provision does not occur whether negligently or otherwise. Alleged breaches of Regulation 8 may be investigated and handled in accordance with Regulation 18 (Disciplinary and Judicial Matters). However, a breach of the eligibility Regulations constitutes a strict liability offence This means that a failure by a Union to fulfill its obligations and to comply with the eligibility Regulations will be regarded as a serious breach of the Regulations, howsoever such breach may have occurred. As a reflection of the seriousness with which any breach of the eligibility Regulations will be treated by World Rugby, it has been agreed by Council to establish a minimum fixed penalty to be imposed on a Union that has breached Regulation 8. These minimum fixed penalties will appear in Regulation 8 and, for ease of reference, are also set out below.

8.5 Responsibility, breach and penalties for a breach of Regulation 8

Regulation 8 is a strict liability offence and shall be construed in accordance with the principles of strict liability under English law. It is not, therefore, necessary that fault or intent on the part of a Union be shown in order for a breach of Regulation 8 to be established. Nor is lack of fault or intent on the part of a Union a defence to a breach of Regulation 8. For the avoidance of any doubt (and without limiting a Union's other obligations and responsibilities for the conduct, acts or omissions of its members and Persons under its jurisdiction pursuant to any other Regulation) Unions are responsible and accountable for the conduct of their Players and all Persons under its jurisdiction in relation to compliance with the provisions of Regulation 8 and any breach of Regulation 8 by such Player(s) or Person(s) shall be deemed to bea breach of Regulation 8 by the Union concerned. Each breach of Regulation 8 by a Union, howsoever arising, will result in a minimum fixed fine being imposed on the Union concerned. The minimum fixed fines for each breach of Regulation 8 are as follows:

A) For a Union that is represented on the Council $£ 100,000$ sterling;

B) For all other World Rugby Member Unions $£ 25,000$ sterling.

Based on the facts and circumstances of any breach of Regulation 8 the applicable minimumfixed fine as set out above may be increased. In addition, other penalties as set out in Regulation 17.6 may al so be imposed on the Union concerned.

Explanatory Guidelines on the Implementation of R egulation 8 - Olympic Eligibility

With the reintroduction of Rugby Sevens into the Olympic Games in Rio in 2016 there are certain rules which participants must adhere to for eligibility purposes. The Olympic Eligibility Regulations (8.6 to 8.16) have been introduced to accommodate the Olympic Charter Rules. To assist in the implementation of these Regulations, the following Guiddines have been developed to address the specifics around Olympic Sevens eligibility which differs from that of World Rugby eligibility requirements in that it is based soley upon a nationality consideration al one. The two sets of rules have been combined to achieve harmony between the objectives and underlying philosophy of Regulation 8 and the requirements of the Olympic Charter in the 


\section{APPENDICES}

context of participation in Olympic Events. These Explanatory Guidelines must be read in conjunction with theterms of Regulation 8 and the Guidelines thereto.

1 Who is eligibleto play Olympic Sevens?

Any Player who meets the eligibility criteria in 8.1 and holds the national ity of the Union / country they wish to represent in the Olympic Games or Olympic Qualification process (known as the "Olympic Events"). The eligibility rules in the Olympic Charter together with the World Rugby eligibility rules must be complied with by Players who participate in Olympic Events.

2 Must a Player havethe passport of the Union / country herepresents in Olympic Sevens?

The nationality of the Union / country the Player wishes to represent in Olympic Sevens is a requirement under the Olympic Charter and is therefore necessary for participation in Olympic Events. Nationality is ordinarily demonstrated by the Player holding the passport of the Union / county they wish to represent All matters relating to the determination of the country which a Player may represent in the Olympic Games shall ultimately be resolved by theIOC ExecutiveBoard.

3 Who will decide on Olympic Sevens eligibility?

Ordinarily, the assessment of whether a Player satisfies the eligibility criteria in Regulation 8.1 and 8.6 will be straightforward. However, in all cases where a Player who has been captured under Regulation 8.2 and who holds the nationality of another Union / country and wishes to participate in an Olympic Event(s) for the Union / country of which he is a national, the Player may apply to World Rugby to represent the National Representative Sevens Team of that Union (or the Olympic Sevens Team of an National Olympic Committee), and the case shall be determined in the first place by the World Rugby Regulations Committee In the event there are other cases of uncertainty or there is the need for clarification a referral may bemade to theWorld Rugby Regulations Committee

4 What is required to besubmitted to the Regulations Committee?

Applications should be submitted to World Rugby accompanied by all relevant supporting documents by the Union (or in applicable cases where there is no Union, the National Olympic Committee ("NOC")) of the country the Player wishes to represent in an Olympic Event. The application shall be prenotified to the Player's Union (namely the Union who's National Representative Team the Player has previously represented. The Player's Union may make written submissions to the World Rugby Regulations Committee or may beinvited to do so.

5 Can a Player with dual nationality, or having World Rugby eligibility for one Union but the nationality of another, represent both Unions/ countries in the same Olympic qualification process?

No. A Player may only represent one Union / country in the Olympic Events. For example if a Player played for a Union in the Sevens World Series in the year it was designated as an Olympic Event the Player could not later in the same Sevens World Series play for another Union / country even in circumstances where he was deemed eligibly by the Regulations Committee to play for the second Union / country of which he is a national. The principle of Regulation 8.2 applies equally to Olympic Events, such that if a Player, having represented one Union / country in an Olympic Event they may not represent another Union / country thereafter.

6 Can a Player switch nationality?

Nationality is a matter which is governed by nation states. If a Player does switch nationality the effect of this upon their Olympic eligibility would need to be considered taking into account Regulation 8.6 to 8.16 and the Olympic Charter Rules regarding eligibility which can be found at www. olympic.org. However, a Player who has represented one Union / country in an Olympic Event(s) and who has changed their nationality or acquired a new nationality may participate in Olympic Events to represent their new Union / country provided that at least three (3) years have passed since the Player last represented their former Union / country and the approval of the International Olympic Committee, the relevant National Olympic Committee(s) and World Rugby is obtained.

7 How will the Olympic eligibility criteria be assessed?

In the early days of the Olympic participation the view has been taken by World Rugby that the Regulations Committee should assess all cases where a Player who has al ready been captured for a Union under the one Union only rule (Regulation 8.2) but wishes to subsequently play for another Union / country for which s/he holds national ity in an Olympic Event.

8 Is there any stand-down period?

Yes. The Player will be required to observe and demonstrate a stand down period of three (3) years between the time the Player last played for his Union and the time the Player first represents the second Union, which must be in an Olympic Event. Played, shall mean when s/he played for the senior, next senior or senior sevens National Representative Team of that Union for which s/he is captured. The principles of Regulation 8.3 apply in any assessment of this provision.

9 What does 'first represents' mean?

It means the first occasion when the Player represents the second Union in a Match, Tournament or Series of Matches - which must be in an Olympic Event. The Player would not however, be permitted for example to 
participate in preseason Matches or so-called 'friendly' matches or other Matches which are not Olympic Events representing the second Union. Training with the team of the second Union is permitted but the circumstances should not be such that it presents or implies to third parties that the Player is part of the National Representative Sevens Team or Olympic Sevens Team of the second Union / country.

10 How will the stand-down period be assessed?

The onus will be on the Player to demonstrate to the reasonable satisfaction of the Regulations Committee the last occasion upon which s/he played for their former Union and that they have not represented such Union in the threeyear period beforethey represent their new Union

/ country in an Olympic Event.

11 Are these Olympic Guiddlines to be read with the World Rugby Eligibility Guidelines?

$\mathrm{Y} e s$, both sets of Guidelines should be read together.

12 What is the position for Unions who do not have a single NOC to represent them?

Member Unions of World Rugby are not necessarily recognised in their own right with equivalent NOC's, for example the British Olympic Association (Team GB) is the NOC for Great Britain and therefore encapsulates the Unions of England, Scotland, Wales and Northern Ireland (represent by the all-Ireland body of the IRFU). In such case, Players from the underlying Unions would be eligible (where they comply with Regulation 8.1 and 8.6) to represent the Olympic Sevens Team of the NOC (if selected) in relevant Olympic Events.

13 If a Player plays for a combined team in an Olympic Event does it affect his eligibility in relation to World Rugby?

If a Player plays for a combined team of a country in an Olympic Event (eg. Team GB) and he was previously not captured for a Union (under Regulation 8.2) then the Player will be deemed to be captured for one of the underlying Unions of the combined team of country he represented. So in the case of Team GB it would mean that the Player would then be free to play for one of England, Scotland, Wales and/or Ireland.If a Player plays for a combined team of a country in an Olympic Event (eg. Team GB) and he was previously was captured for a Union (under Regulation 8.2) then the Player remains captured for such Union and their participation in the combined team in the Olympic Event will not affect their status.

14 Is therea right of appeal from the decision of theWorld Rugby Regulations

Yes. An Olympic Eligibility appeals committee has been established under Regulation 2 to deal with any appeal s of decisions by the World Rugby Regulations Committee

15 For the Olympic Games 2016 in Rio, do any special provisions apply?

Rugby Sevens will enter the Olympic Games for the first time in 2016. The qualification process has been established and all persons eligible to participate must have qualified by $11 \mathrm{July} 2016$. In terms of eligibility, the three (3) year stand-down period applies. However, given the timing of the clarification of the qualification process and the constitutional review of the eligibility requirements for Olympic Events a shorter stand-down period in respect only of the Olympic Games 2016 shall apply. In this regard any Player who wishes to represent a Union / country for whom s/he holds the nationality and has previously been captured for another Union may do so provided the Player stands down from their current Union at least 18 months before representing the Second Union in an Olympic Event in the Rio Olympic Games cydle

SCHEDULE 1. EXPLANATORY NOTE

As from 1 J anuary 2000 a player is only entitled to play Rugby Union for the Senior National Representative Team or the next Senior National Representative Team of one Union. This means that if a player is deemed to have played for the Senior National Representative Team or the next Senior National Representative Team of a Union that player will be unable to play for any other Union. This is the position even if that player is able to satisfy one or more of the eligibility criteria set out in Regulation 8.1. It is important that players and Unions understand the situations in which players will be deemed to have played for the Senior National Representative Team or the next Senior National Representative Team of a Union. These situations are set out in Regulation 8.3.

Regulation 8.3 is based on a "selection and participation" test for players who have reached the age of majority [18 or over]. Players and Unions must familiarize themselves with Regulation 8.3. Players should be made aware by Unions of what constitutes that Union's Senior National Representative Team, its next Senior National Representative Team, its Senior Touring Squad and its next Senior Touring Squad and the Matches that will result in a player being committed to that Unions. The following situations are covered by Regulation 8.3.

1. Players who participate in International Matches for the Senior National Representative Team or the next Senior National Representative Team of a Union against the Senior or next Senior National Representative Team of another Union.

2. Players selected to represent a Union's Senior Touring Squad who participate in any Match played by members of that Union's Senior Touring Squad during an International Tour provided such International Tour ind udes an International Match(es) approved by World Rugby. 


\section{APPENDICES}

3. Players who participate in a Match for the Senior or next Senior National Representative Team of a Union against a team made up of players from a Union's Senior Touring Squad during an International Tour which includes International Match(es) approved by World Rugby.

4. Players, representing a Union's next Senior Touring Squad who participate in a Match on an International Tour approved by World Rugby against the Senior National Representative Temmor the next Senior National Representative Team of another Union.

5. Players who play for the Senior or next Senior National Representative Team of a Uni on against a team selected from a Union's next Senior Touring Squad when such Match is played on an International Tour approved by World Rugby.

\section{World R ugby H andbook $1^{\text {st }}$ August 2015}

REGULATION 8. ELIGIBILITY TO PLAY FOR NATIONAL REPRESENTATIVE TEAMS

8.1 Subject to Regulation 8.2, a Player may only play for the senior fifteen-a- side National Representative Team the next senior fifteen-a-side National Representative Team and the senior National Representative Sevens Team of the Union of the country in which:

(A) hewas born; or

(B) one parent or grandparent was born; or

(C) he has completed thirty six consecutive months of Residence immediately preceding the time of playing.

8.2. A Player who has played for the senior fifteen-aside National Representative Team or the next senior fifteen-a-side National Representative Team or the senior National Representative Sevens Team of a Union is not eligible to play for the senior fifteen-a-side National Representative Team or the next senior fifteen-asideNational Representative Team or thesenior National Representative Sevens Team of another Union.

8.3. For the purposes of this Regulation, a Player is deemed to have played for the senior fifteen-a-side National Representative Team or the next senior fifteen-a-side National RepresentativeTeam of a Union if:

(A) He is selected for such team to play in an International Match against the senior fifteen-a-side National Representative Team or the next senior fifteen-a-side National Representative Team of another Union (or in a fifteen-a-side international Match against another Union's senior or next senior Touring Squad during a World Rugby approved International Tour) and is present at the Match played by that team either as a replacement, substitute or a playing member of that team and has, at the time of the Match, reached the age of majority; or

(B) He is selected to represent a Union's senior Touring Squad on an International Tour which includes an International Match or Matches approved by World Rugby and is present at any fifteen-a-side Match played on that International Tour either as a replacement, substitute or a playing member of a team selected from the Union's senior Touring Squad and has, at thetime of the Match, reached the age of majority; or

( C) He is selected to represent a Union's next senior Touring Squad on a World Rugby approved International Tour and during that International Tour he is present at a Match against the senior fifteen- a sideNational Representative Team or the next senior fifteen-a sideNational Representative Team of another Union either as a replacement, substitute or playing member of a team selected from the Union's next senior Touring Squad and has, at the time of the Match reached the age of majority.

(D) He is selected to represent the Under 20s National Representative Team of a Union which has been predesignated as that Union's next senior fifteen-a-side National Representative Team and the Player is part of the team which participates in an International Match as part of the World Rugby Junior World Championships, World Rugby J unior World Rugby Trophy or the Six Nations U20 Championship and is present at the Match played by that Teemeither as a replacement, substitute or playing member of that Teem and has, at thetime of the Match, reached the age of majority.

8.4. For the purposes of this Regulation, a Player is deemed to have played for the senior National Representative Sevens Team of a Union if he is selected to represent a Union's senior National Representative Sevens Team in an International Match against the seni or National Representative Sevens Team of another Union and is present at the Match played by that Teameither as a replacement, substitute or playing member of that Team and has, at the time of the Match, reached the age of majority.

Responsibility, breach and penalties for a breach of Regulation 8

8.5. Regulation 8 is a strict liability offence and shall be construed in accordance with the principles of strict liability under English law. It is not, therefore, necessary that fault or intent on the part of a Uni on be shown in order for a breach of Regulation 8 to be established. Nor is lack of fault or intent on the part of a Union a defence to a breach of Regulation 8. For the avoidance of any doubt (and without limiting a Union's other obligations and responsibilities for the conduct, acts or omissions of its members and Persons under its jurisdiction pursuant to any other Regulation) Unions are responsible and accountable for the conduct of their Players and all Persons under its jurisdiction in relation to compliance with the provisions of Regulation 8 and any breach of Regulation 8 by such Player(s) or Person(s) shall be deemed to bea breach of Regulation 8 by the Union concerned. Each breach of Regulation 8 by a Union, howsoever arising, will result in a 


\section{NATIONALITY REQUiREMENTS In Olympic SPORTS}

minimum fixed fine being imposed on the Union concerned. The minimum fixed fines for each breach of Regulation 8 areas follows:

(A) For a Union that is represented on the Council $f 100,000$ sterling;

(b) For all other World Rugby Member Unions $£ 25,000$ sterling.

Based on the facts and circumstances of any breach of Regulation 8 the applicable minimum fixed fine as set out above may be increased. In addition, other penalties as set out in Regulation 18.6 may al so be imposed on the Union concerned.

8.5.1.In exceptional circumstances, a Union in breach of Regulation 8 may make submissions to the relevant disciplinary body appointed under Regulation 18 to adjudicate on the case as to why the Union should not be subject to the applicable minimum fixed fine For the avoidance of any doubt, however, the relevant disciplinary body shall only beentitled to reduce the applicable mini mumfixed fine set out in this Regulation where the Union is able to provide clear and indisputable evidence that truly exceptional circumstances exist and that the Uni on concerned had taken all necessary steps to comply with Regulation 8.

8.6. To be eligible to participate in the Olympic Games, Olympic qualification events (together "Olympic Events") or other events governed by the Olympic Charter all members of the senior National Representative Sevens Team(s) of a Union or the selected Olympic Sevens Team(s) of a National Olympic Committee shall comply with Regulation 8.1 and must bea national of the country of the National Olympic Committee which it is representing in such Olympic Events. Regulation 8.2 applies equally to all Players.

8.7. A Player who is a national of the country or Union for which he has been captured under Regulation 8.2 and who holds the nationality of another country or Union, may apply to partici pate in an Olympic Event to represent his new country or Union subject to the following conditions;

8.7.1. The Regulations Committee shall consider the application of a Player under this Regulation 8.7 which must be submitted with all relevant supporting documentation by the Union for whom the Player wishes to next represent in an Olympic Event (or a Union associated with the Olympic Sevens Team the Player wishes to represent). The application shall be prenotified to the Player's Union (namely the Union whose National Representative Team the Player represented);

8.7.2. The Player will be required to observe and demonstrate a stand down period of at least 3 years since the time the Player last represented their former Union and the time the Player first plays for the second Union or country, which must be in an Olympic Event. The Player may not represent the second Union in any other form of the Game until after they have participated in such Olympic Event.

(A) Solely in respect of the Rio Olympic Games 2016, a stand down period of at least 18 months will be permitted, between the time the Player last represented their former Union and the time the Player first plays for the second Union or country, which must be in an Olympic Event in the Rio Olympic Games cycle, which the Player must observeand demonstrate

8.8 Where the Player is not a national of the Union for which he has been captured under Regulation 8.2, and he meets the Olympic eligibility criteria (in Regulation 8.6 to 8.13 ) as determined by the Regulations Committee, he shall be eligible for selection to play for the Union / country of which he is a national, in an Olympic Event, subject to satisfying the applicable stand down period.

8.9. A Player who is eligible or captured for a Union that cannot participate in an Olympic Event because there is no National Olympic Committee solely for the territory of such Union, may, subject to the Olympic eligibility criteria (in Regulation 8.6 to 8.13), be eligible to play for the Olympic Sevens Team of a National Olympic Committee of which he is a national, provided that such team is not associated with any one single Union. In such circumstances the following provisions shall apply;

8.9.1. Where the Player has been captured under Regulation 8.2 for a Union he shall remain captured for such Union notwithstanding the Player's representation for the Olympic Sevens Team of a National Olympic Committein an Olympic Event;

8.9.2. Where the Player has not previously been captured under Regulation 8.2 and he represents the Olympic Sevens Team of a National Olympic Committee in an Olympic Event he will be deemed to be captured for one of the underlying Unions which support the Olympic Sevens Team of the relevant National Olympic Committee, and the Player must elect which of those underlying Uni ons he shall be captured by for the purposes of Regulation 8.

8.10. A Player who has represented one Union or Olympic Team in an Olympic Event and who has changed his nationality or acquired a new nationality, may apply to participate in an Olympic Event to represent his new Union or country provided that at least three years have passed since the Player last represented his former Union or country and the approval of the International Olympic Committee, the relevant National Olympic Committee(s) and World Rugby is obtained. This period may be reduced or even cancelled with the agreement of the World Rugby and the National Olympic Committees concerned and by the IOC Executive Board, which takes into account the circumstances of each case

8.11. A Player may not represent two different Unions or a Union and an Olympic Sevens Team(s) of a National Olympic Committein thesameOlympic Event(s). 


\section{APPENDICES}

8.12. Once the Player has represented the Union of which he is a national, in an Olympic Event, he shall thereafter betied to that Union for all forms of the Gameand in all events.

8.13. Players who participate in the Olympic Events accept and agree that any disputes relating to eligi bility shall first be addressed pursuant to the rules of such Olympic Events and the World Rugby Regulations and that all internal procedures (induding applicable National Olympic Committee rules/procedures) and/or World Rugby procedures shall be exhausted first. Thereafter, recourse may be had in respect of Olympic Events only (and not in relation to eligibility matters to which Regulation 8.6 to 8.16 does not apply) to the Court of Arbitration for Sport (CAS) in accordance with the provision applicable before such court and which will resolve definitively the dispute in accordance with the code of sports related arbitration. World Rugby has the right to appear, attend and/or participate as a party in any appeal to CAS involving eligibility considerations for Olympic Events.

8.14. Any Union wishing to obtain clarification around the eligibility of a Player to represent it in the Olympic Games or Olympic Events may do so by refering the matter to the World Rugby Regulations Committee in accordance with Regulation 2 and Regulation 8.7.1 and 8.7.2.

8.15. The list of Olympic Events is set out in Schedule 2 and shall be updated for each Olympic cycle

8.16. The provisions of Regulation 8.5 apply equally to any alleged breach of the Olympic eligibility provisions.

EXPLANATORY GUIDELINES ON THE IM PLEMENTATION OF REGULATION 8

ELIGIBILITY TO PLAY FOR NATIONAL REPRESENTATIVE TEAMS

Following its deliberations on the question of Player eligibility, the Working Party has produced these Explanatory Guidelines on the implementation of Regulation 8. These Explanatory Guidelines must be read in conjunction with the terms of Regulation 8.

1. What is the Rational e/Philosophy of Regulation 8?

The rationale/philosophy of Regulation 8 is to ensure that Players selected to represent either the senior and next senior fifteen-a-side National Representative Teams of a Union or a Union's senior National Representative Sevens Team have a genuine, close, credi ble and established national link with the country of the Union for which they have been selected. Such a national link is essential to maintain the unique characteristics and culture of elite international sporting competition between Unions. The integrity of International Matches between Unions depends upon strict adherence to the eligibility criteria set out in the Regulations.

2. Who establishes the eligibility criteria in Rugby Union?

World Rugby will continue to establish the criteria by reference to which a Player's eligibility to play for the senior or next senior fifteen-a-side National Representative Team of a Union or a Union's senior National Representative Sevens Team will be determined. Citizenship of a country and/or whether a Player holds a passport of a particular country are not, of themselves, determinative in identifying which Union a Player is eligible to represent. This will be determined solely in accordance with World Rugby's eligibility criteria. In relation to Olympic eligibility criteria see the Explanatory Guidelines on the Implementation of Regulation 8 - Olympic Eligibility.

3. What is the eligibility criteria in Rugby Union?

The existing World Rugby eligibility criteria set out in Regulation 8.1 will be maintained. This is based on the following:

(a)The country in which the Player was born; or

(b) The country in which one parent or grandparent of the Player was born; or

(c)The country in which the Player has completed thirty-six consecutive months of Residence immediately preceding the time of playing. Residence means the place or location in which a Player has his primary and permanent home and Resident shall be construed accordingly; and

(D)For Olympic Event participation, the nationality of the Union / country the Player wishes to represent is also required.

4. If a Player has dual eligibility, can he play for the senior or next senior fifteen-a-side National Representative Team or the senior National RepresentativeSevens Team of more than one Union?

No, save for those Players that, before 1 J anuary 2000, allowed a period of 36 consecutive months to elapse after they had played for another Union and who played for the second Union before 1 J anuary 2000. The one Union only rule, introduced by World Rugby from 1st J anuary 2000 (as set out in Regulation 8.2), will be maintained. A Player is only entitled to play Rugby Union for the senior or next senior fifteen-a-side National Representative Team or the senior National Representative Sevens Team of one Union. Accordingly, if a Player is deemed to have played for such a team, even if he is ableto satisfy one or more of the eligibility criteria set out in Regulation 8.1, he will not be able to play for any other Union. Consistent with the overall rationale underlying the eligibility Regulations, the one Union only rule is designed to maintain the integrity of the international Game. Once a Player has committed himself to a particular Union, through participation in one of the Matches or Tours identified in Regulations 8.3 or 8.4, he is unable to changehis "Rugby Nationality" which becomes fixed. 
5. When is a Player deemed to have played for the senior or next senior fifteen-arside National Representative Team of a Union or a Union's senior National Representative Sevens Team?

As a result of the one Union only rule, in particular, it is essential that Players and Unions understand the situations in which Players will be deemed to have played for the senior fifteen-a-side National Representative Team or the next senior fifteen-a-side National Representative Team of a Union or a Union's senior National Representative Sevens Team These situations are set out in Regulations 8.3 and 8.4. Players and Unions shall, at all times, have regard to the full terms of Regulations 8.3 and 8.4, however, by way of a summary only, thesituations set out below are covered:

Fifteen-a-side

(A) Players who participate in International Matches for the senior National Representative Team or the next senior National Representative Team of a Union against the senior or next senior National Representative Team of another Union.

(b) Players selected to represent a Union's senior Touring Squad who participate in any Match played by members of that Union's senior Touring Squad during an International Tour provided such International Tour includes an International Match(es) approved by World Rugby.

(c) Players who participate in a Match for the senior or next senior National Representative Team of a Union against a team made up of Players froma Union's senior Touring Squad during an International Tour which includes International Match(es) approved by World Rugby.

(D)Players, representing a Union's next senior Touring Squad who participate in a Match on an International Tour approved by World Rugby against the senior National Representative Team or the next senior National Representative Team or the next senior National RepresentativeTeam of another Union.

(E) Players who play for the senior or next senior National Representative Team of a Union against a team selected from a Union's next senior Touring Squad when such Match is played on an International Tour approved by World Rugby.

Seven-a-side

(a) Players who play for a Union's senior National Representative Sevens team in an International Match against the senior National Representative Sevens team of another Union.

6. How do I know which teamis a Union's next senior fifteen-a-side National Representative Team?

(a) There should be no uncertainty over which team constitutes a Union's next senior National RepresentativeTeam Unions are required to notify World Rugby of the name of their nominated next senior National RepresentativeTeam Theteamnominated remains the Union's next senior National Representative Team unless the Union notifies World Rugby of a change in this nomination. A Union is entitled to notify World Rugby no more than once per calendar year of a change to its next senior National Representative Team provided that in doing so it shall take account of any Matches such team may be scheduled to play and shall advise the Union of any senior or next senior National Representative Team it is scheduled to play reasonably in advance of such Match. The identity of a Union's next senior National Representative Team can be verified with the Union concerned and/or World Rugby.

(b) Unions must ensure that all persons involved in an International Match (Players and team management induding coaching staff) are made aware of the status of their team as the next senior National Representative Team and that of their opposing team where it is the senior or next senior National Representative Team of another Union and what that means from a capturing perspective under Regulation 8. Notwithstanding the Union's obligation to inform the Player and team management it shall be the sole responsibility of each Player to ensure that he is aware of the status of every Match in which he plays and the implications of playing in an International Match involving the senior or next senior National Representative Teams of two Unions.

(c) In addition to (a) and (b) above, Unions who designate their Under 20s National Representative Team as their next senior National Representative Team have a particular onus to clearly make the Team Players aware of the consequences of being captured for that Union at age grade level. Effective 1 J uly 2014, the Players on any such Team which participates in the World Rugby J unior World Championships, World Rugby J unior World Trophy or the Six Nations U20 Championship (where they are present at the Match played by that Team either as a replacement, substitute or playing member of that Team and has, at the time of the Match, reached the age of majority) will be captured. In this regard the status of the opposition teams in any Match in these named tournaments is not a factor to be considered.

7. What is the age of majority?

For the purposes of the Regulations (including, but not limited to Regulation 8), the age of majority is deemed to be acquired on a Player's 18th birthday.

8. Does the eligibility criteria apply to all forms of Rugby?

The eligibility criteria applies to the fifteen-a-side Game at senior and next senior National Representative level and in respect of a Union's seni or National Representative Sevens Team

9. Does the eligibility criteria apply to all Unions in membership of World Rugby?

Yes, all Unions in membership of World Rugby are obliged to comply with the eligibility Regulation 


\section{APPENDICES}

10. How will the eligibility criteria be assessed?

Ordinarily, the task of assessing whether a Player satisfies any of the eligibility criteria set out in Regulation 8.1 is straightforward. However, as a result of professionalism, greater mobility and societal family change this is not al ways the case Difficult cases have arisen and may continue to emerge The responses to the questions set out below are intended to provide further darification as to how each eligibility criterion in Regulation 8.1 will beapplied.

The questions and answers should be regarded as guidelines. They have been prepared on the basis of operational experience to date It is not possible to anticipate all scenarios that may arise and a degree of flexibility in the application of the Regulations will be maintained. Moving forward, in the event that there is any uncertainty or the need for clarification in relation to the application of the eligibility criteria in particular circumstances, then the Regulations Committee may be asked by World Rugby to make a ruling on a Player's eligibility. In relation to any such adjudication, the Regulations Committee will al ways have in mind the rationale behind Regulation 8 . The aim of the Regulations Committee in each case where clarification may be required, is to establish whether, in all the circumstances, a Player has, by reference to the eligibility criteria in Regulation 8.1, been able to demonstrate a genuine, close and credible national link with the country that the Player wishes to represent. It is anticipated that over time a body of rulings by the Regulations Committee may develop which may, in turn, assist in providing further guidance to Unions in relation to eligibility matters.

11. When should any uncertainty over a Player's eligibility be clarified?

It is essential that eligibility issues are clarified before a Player represents the senior or next senior fifteen-a side National Representative Team of a Union or a Union's senior National Representative Sevens Team This is particularly important in light of the one Union only rule Accordingly, if a Union has any doubt over a Player's eligi bility status it must takeall steps necessary to clarify the position before sel ecting the Player to play for its senior or next senior fifteen-a-side National Representative Team or its senior National RepresentativeSevens Team

12. What does place of birth mean?

This should be the most straightforward criterion to apply. A Player's place of birth shall be the country within whose geographical borders he was borm. However, difficult scenarios can arise even in relation to this criterion. For example, where a Player was born within the geographical borders of one country, but in a part of that country deemed by the law of the country concerned, to be the sovereign territory of another, or where a Player was born in a military hospital. In such circumstances the matter should be referred to the Regulations Committee for a ruling. The Regulations Committee would need to establish the legal position together with other relevant facts and circumstances. In exceptional circumstances it may be possible for a Player to demonstrate, to the satisfaction of the Regulations Committee, that he is eligible to play for the Union within whose sovereign teritory he was born, even though that sovereign territory may be within the geographical borders of another country.

13. What does Parent mean?

The term "parent" in the Regulations is limited to either a blood parent or a parent that has formally adopted a Player in accordance with the applicable legal requirements of the country concerned. Unless a Player has been adopted in accordance with the formal, legal requirements of the country concerned, the application of this criterion will be based on a Player's blood parent. When a Player has been formally adopted in accordance with the applicable legal requirements of the country concerned, the birth place of the Player's blood parent will no longer be relevant for the purposes of establishing the Player's eligibility pursuant to Regulation 8.1(b). The relevant parent will be the parent that has formally and legally adopted the Player. However in such circumstances, the relevant grandparents for the purposes of establishing a Player's eligibility pursuant to Regulation 8.1(b) will be the Player's blood grandparents. It is not possible under Regulation 8.1(b) to assume eligibility via non-blood grandparents even if a Player has been formally and legally adopted.

For the avoidance of any doubt, stepparents and fostering parents will not be considered to constitute a Player's parent for the purposes of Regulation 8.1(b).

14. How is the Residence criteria satisfied?

Regulation 8.1(c) requires a Player to complete 36 consecutive months of Residence immediately preceding the time of playing. Residence is defined as "the place or location in which the Player has his primary and permanent home" and Resident shall be construed accordingly. In essence, Regulation 8.1(c) constitutes a sporting naturalization procedure, based on a geographical/presence test As in any naturalisation process, a number of factors will influence the determination of what constitutes a Player's permanent and primary home Such factors include, but are not limited to, the actual time spent in a country and the purpose of any absences during the qualification period. By being Resident in a country for a period of 36 consecutive months immediately preceding the time of playing for a Union, a Player is deemed to acquire a credible, close and established national link with a country/Union that entitles him to participate in sporting competitions for that Union. Based on the overriding rationale of the eligibility Regulations, in cases wherea 
Player's eligibility is uncertain the Regulations Committee will consider that Player's eligibility by reference to the particular facts and circumstances of his case to establish if the Residency test, in the context of the overall rationale of the eligibility Regulations, has been satisfied. The principles set out in responses to the questions below will act as guiddines to the Regulations Committee when it is asked to consider any cases pursuant to this criterion.

15. Whose burden of proof?

In all cases where a Player is seeking to establish eligibility by reference to the Residency criteria in Regulation 8.1(c) (and, indeed, in relation to Regulation (or 8.1(a) and (b)), the burden of proof is on the Player and the Union that he wishes to represent to prove that Player's eligibility. Under Regulation 8.1(c), the Player and his Union must be able to demonstrate that, during the relevant period, the country in which he claims he has been Resident was, genuinely, the country that the Player treated as his home and is clearly the country in which the Player has his primary and permanent home If a Player has moved from one country to another, and is seeking to establish Residence in that new country, then he must also be able to demonstrate that he is clearly no longer Resident in the country in which he lived previously and that he no longer treats that country as his home. For the avoidance of any doubt, a Player cannot nominate a country as his home without demonstrating that he has satisfied the geographical commitment/presence test enshrined in Regulation 8.1(c). The geographical commitment/presence test will be vigorously upheld and applied to avoid abuse of the Residency criteria. For example, a Player that acquired/leased property in a country and who nominated that property as his permanent and primary home (even though he may only be present at that property and in that Union on a short term/temporary basis) would not satisfy the Residency test.

16. Will short breaks interupt a period of Residence?

Short breaks in Residence, for example, for holidays, attending family/friends in other countries who may be ill etc, are unlikely to change the place/location of a Player's primary and permanent homeand are, therefore, unlikely to intermupt a Player's period of Residence By way of a guideline, however, as a minimum requirement, it is likely that, save in exceptional circumstances, at least 10 months actual physical presence of the Player in the country concerned throughout any qualifying year of the Residency period, will be required to demonstrate that the country is the place where the Player has his primary and permanent home

17. Does the 36 month period of Residence have to immediately precede playing for a Union?

Save in exceptional circumstances, the 36 months Residence will be expected to have been completed consecutively and be achieved immediately before the Player represents a Uni on. This is designed to createa contemporary national link with the country of the Union concerned. This factor will be particularly significant if a Player has moved to make a "new" country his Residence having been Resident in another country previously. In essence, in such circumstances, the Player, as well as demonstrating his commitment to a new country, must also be (and seen to be) relinquishing his ties with the country in which he lived previously. For the avoidance of any doubt, seeking to rely on short periods of Residence as a child in a particular country, combined with a short period of Residence in that same country prior to playing for a Union, is likely to createa link that would betoo tenuous to satisfy the underlying intentions of establishing a contemporary, permanent, national link with a Union. However, each case will be assessed on its overall merits to establish if a Player is able to demonstrate a genuine, close, credibleand established national link by reference to the amount of timethe Player can demonstrate that he has treated the "new" country as his home and other relevant factors.

18. What is the position of students?

As far as students are concerned, particularly those that are not financially independent, being resident, as a full time student, in another country, is likely to be considered as a series of temporary absences from the parental home It is anticipated that in the majority of cases involving students the parental home is likely to continue to constitute the student's permanent and primary home Accordingly, attendance at college/university in such circumstances is unlikely to break a Player's consecutive period of Residence However, as in all matters of eligibility, the overriding concern of the Regulations Committee in assessing any such case will be to ensure that there remains a close, credi ble and established link with the country in which the Player claims to have retai ned his primary and permanent home. There could be circumstances in which a student living in another country may be deemed to have interrupted his Residency period.

19. Who is responsible for compliance with the eligibility criteria?

In accordance with Regulation 2.1.2, each Union is responsible for ensuring compliance with all Regulations Relating to the Game This includes, but is obviously not limited to, Regulation 8. Accordingly, it is the responsibility of each Union to ensure that all Players it selects are properly eligible within the provisions of Regulation 8 and, in the event of any uncertainty, to ensure that the position is clarified before the Player is selected. Unions must have in place all necessary procedures and internal controls to ensure compliance with the eligibility Regulations.

20. What must Unions do to ensure (and demonstrate) compliance with the eligibility Regulations?

Unions must ensure that beforea Player is sel ected for the first timefor its senior or next senior fifteen-a-side National Representative Team or its senior National Representative Sevens Team the Player completes the 


\section{APPENDICES}

standard form dedaration attached to these Explanatory Guidelines at Schedule 1. In addition, before selecting a Player, Unions must ensure that they obtain valid/authentic documentation and such other evidence that may be necessary to prove, definitively, a Player's eligibility to play for that Union. Each Union must notify World Rugby of the names of all Player's selected for its senior and next senior National Representative Team and its senior National Representative Sevens Team on an annual basis. World Rugby shall maintain a database of all such Players. If requested, by the Chairman, or his designee, Unions must supply copies of the completed declaration forms of a Player(s) together with supporting documentation relied on to demonstratethe Player's eligi bility. On 1 December each year, each Uni on must certify to World Rugby that each Player selected to represent the senior or next senior fifteen-a-side National Representative Team of the Union or its National Representative Sevens Team during the past year has completed, in full, the dedaration form and that each Player was eligible to represent the Union in accordance with the provisions of Regulation 8.

World Rugby may, through the Chairman, or his designee, of his own motion or on receipt of a complaint undertake an investigation into a Union's compliance with Regulation 8. Unions, Players and officials must provide assistance with any such investigation and disclose such information and documents deemed necessary by the Chairman, or his designee, for the purposes of that investigation.

21. What are the consequences of a breach of the eligibility Regulations?

Compliance with Regulation 8 is of fundamental importance in maintaining the integrity of international Rugby Union at senior National Representative leve. Any breach of such a fundamental Regulation, howsoever arising, has a detrimental impact on the image and reputation of the sport. Unions must, therefore take all necessary steps to put in place comprehensive review/compliance procedures to ensure that a breach of the eligibility provision does not occur whether negligently or otherwise Alleged breaches of Regulation 8 may be investigated and handled in accordance with Regulation 18 (Disciplinary and Judicial Matters). However, a breach of the eligibility Regulations constitutes a strict liability offence. This means that a failure by a Union to fulfill its obligations and to comply with the eligibility Regulations will be regarded as a serious breach of the Regulations, howsoever such breach may have occurred. As a reflection of the seriousness with which any breach of the eligibility Regulations will be treated by World Rugby, it has been agreed by Council to establish a minimum fixed penalty to be imposed on a Union that has breached Regulation 8. These minimum fixed penalties will appear in Regulation 8 and, for ease of reference, are also set out below.

8.5 Responsibility, breach and penalties for a breach of Regulation 8

Regulation 8 is a strict liability offence and shall be construed in accordance with the principles of strict liability under English law. It is not, therefore, necessary that fault or intent on the part of a Uni on be shown in order for a breach of Regulation 8 to be established. Nor is lack of fault or intent on the part of a Union a defence to a breach of Regulation 8. For the avoidance of any doubt (and without limiting a Union's other obligations and responsibilities for the conduct, acts or omissions of its members and Persons under its jurisdiction pursuant to any other Regulation) Unions are responsible and accountable for the conduct of their Players and all Persons under its jurisdiction in relation to compliance with the provisions of Regulation 8 and any breach of Regulation 8 by such Player(s) or Person(s) shall be deemed to bea breach of Regulation 8 by the Union concerned. Each breach of Regulation 8 by a Union, howsoever arising, will result in a minimum fixed fine being imposed on the Union concerned. The minimum fixed fines for each breach of Regulation 8 areas follows:

(A)For a Union that is represented on the Council $£ 100,000$ sterling;

(B) For all other World Rugby Member Unions $£ 25,000$ sterling.

Based on the facts and circumstances of any breach of Regulation 8 the applicable minimum fixed fine as set out above may be increased. In addition, other penalties as set out in Regulation 17.6 may al so be imposed on the Union concerned.

Explanatory G uidelines on the I mplementation of R egulation 8 - Olympic Eligibility

With the reintroduction of Rugby Sevens into the Olympic Games in Rio in 2016 there are certain rules which participants must adhere to for eligibility purposes. The Olympic Eligibility Regulations (8.6 to 8.16) have been introduced to accommodate the Olympic Charter Rules. To assist in the implementation of these Regulations, the following Guidelines have been devel oped to address the specifics around Olympic Sevens eligibility which differs from that of World Rugby eligibility requirements in that it is based soley upon a nationality consideration al one. The two sets of rules have been combined to achieve harmony between the objectives and underlying philosophy of Regulation 8 and the requirements of the Olympic Charter in the context of participation in Olympic Events. These Explanatory Guidelines must be read in conjunction with theterms of Regulation 8 and the Guidelines thereto.

1. Who is eligibleto play Olympic Sevens?

Any Player who meets the eligibility criteria in 8.1 and holds the national ity of the Union / country they wish to represent in the Olympic Games or Olympic Qualification process (known as the "Olympic Events"). The 
eligibility rules in the Olympic Charter together with the World Rugby eligibility rules must be complied with by Players who participatein Olympic Events.

2. Musta Player havethe passport of the Union / country he represents in Olympic Sevens?

The nationality of the Union / country the Player wishes to represent in Olympic Sevens is a requirement under the Olympic Charter and is therefore necessary for participation in Olympic Events. Nationality is ordinarily demonstrated by the Player hol ding the passport of the Union / county they wish to represent. All matters relating to the determination of the country which a Player may represent in the Olympic Games shall ultimately be resolved by theIOC Executive Board.

3. Who will decide on Olympic Sevens eligibility?

Ordinarily, the assessment of whether a Player satisfies the eligibility criteria in Regulation 8.1 and 8.6 will be straightforward. However, in all cases where a Player who has been captured under Regulation 8.2 and who holds the national ity of another Union / country and wishes to participate in an Olympic Event(s) for the Union / country of which he is a national, the Player may apply to World Rugby to represent the National Representative Sevens Team of that Union (or the Olympic Sevens Team of an National Olympic Committee), and the case shall be determined in the first place by the World Rugby Regulations Committee In the event there are other cases of uncertainty or there is the need for clarification a referral may be made to the World Rugby Regulations Committee

Applications should be submitted to World Rugby accompanied by all relevant supporting documents by the Union (or in applicable cases where there is no Union, the National Olympic Committee ("NOC")) of the country the Player wishes to represent in an Olympic Event. The application shall be prenotified to the Player's Union (namely the Union who's National Representative Team the Player has previously represented. The Player's Union may make written submissions to the World Rugby Regulations Committee or may beinvited to do so.

5. Can a Player with dual nationality, or having World Rugby eligibility for one Union but the nationality of another, represent both Unions/ countries in the same Olympic qualification process?

No. A Player may only represent one Union / country in the Olympic Events. For example if a Player played for a Union in the Sevens World Series in the year it was designated as an Olympic Event the Player could not later in the same Sevens World Series play for another Union / country even in circumstances where he was deemed eligibly by the Regulations Committee to play for the second Union / country of which he is a national. The principle of Regulation 8.2 applies equally to Olympic Events, such that if a Player, having represented one Union / country in an Olympic Event they may not represent another Union / country thereafter.

6. Can a Player switch nationality?

Nationality is a matter which is governed by nation states. If a Player does switch national ity the effect of this upon their Olympic eligibility would need to be considered taking into account Regulation 8.6 to 8.16 and the Olympic Charter Rules regarding eligibility which can be found at www.olympic.org. However, a Player who has represented one Union / country in an Olympic Event(s) and who has changed their nationality or acquired a new nationality may participate in Olympic Events to represent their new Union / country provided that at least three (3) years have passed since the Player last represented their former Union / country and the approval of the Intemational Olympic Committee, the relevant National Olympic Committee(s) and World Rugby is obtained.

7. How will theOlympic eligibility criteria be assessed?

In the early days of the Olympic participation the view has been taken by World Rugby that the Regulations Committee should assess all cases where a Player who has al ready been captured for a Union under the one Union only rule (Regulation 8.2) but wishes to subsequently play for another Union / country for which s/he holds nationality in an Olympic Event.

8. Is there any stand-down period?

Yes. The Player will be required to observe and demonstrate a stand down period of three (3) years between the timethe Player last played for his Union and the time the Player first represents the second Union, which must be in an Olympic Event. Played, shall mean when s/he played for the senior, next senior or senior sevens National Representative Team of that Union for which s/he is captured. The principles of Regulation 8.3 apply in any assessment of this provision.

9. What does 'first represents' mean?

It means the first occasion when the Player represents the second Union in a Match, Tournament or Series of Matches - which must be in an Olympic Event. The Player would not however, be permitted for example to participate in preseason Matches or so-called 'friendly' matches or other Matches which are not Olympic Events representing the second Union. Training with the team of the second Union is permitted but the circumstances should not be such that it presents or implies to third parties that the Player is part of the National RepresentativeSevens Team or Olympic Sevens Team of the second Union / country.

10. How will the stand-down period be assessed? 
The onus will be on the Player to demonstrate to the reasonable satisfaction of the Regulations Committee the last occasion upon which s/he played for their former Union and that they have not represented such Union in the three year period before they represent their new Union/ country in an Olympic Event.

11. Arethese Olympic Guidel ines to be read with the World Rugby Eligibility Guiddlines?

Yes, both sets of Guidelines should be read together.

12. What is the position for Unions who do not have a single NOC to represent them?

Member Unions of World Rugby are not necessarily recognised in their own right with equivalent NOC's, for example the British Olympic Association (Team GB) is the NOC for Great Britain and therefore encapsulates the Unions of England, Scotland, Wales and Northern Ireland (represent by the all-Ireland body of the IRFU). In such case, Players from the underlying Unions would be eligible (where they comply with Regulation 8.1 and 8.6) to represent the Olympic Sevens Team of the NOC (if selected) in relevant Olympic Events.

13. If a Player plays for a combined team in an Olympic Event does it affect his eligibility in relation to World Rugby?

If a Player plays for a combined team of a country in an Olympic Event (eg. Team GB) and he was previously not captured for a Union (under Regulation 8.2) then the Player will be deemed to be captured for one of the underlying Unions of the combined team of country he represented. So in the case of Team GB it would mean that the Player would then be free to play for one of England, Scotland, Wales and/or I reland. If a Player plays for a combined team of a country in an Olympic Event (eg. Team GB) and he was previously was captured for a Union (under Regulation 8.2) then the Player remains captured for such Union and their participation in the combined team in the Olympic Event will not affect their status.

14. Is there a right of appeal from the decision of theWorld Rugby Regulations

Yes. An Olympic Eligibility appeals committee has been established under Regulation 2 to deal with any appeal s of decisions by the World Rugby Regulations Committee

\section{For the Olympic Games 2016 in Rio, do any special provisions apply?}

Rugby Sevens will enter the Olympic Games for the first time in 2016. The qualification process has been established and all persons eligible to participate must have qualified by 11 July 2016 . In terms of eligibility, the three (3) year stand-down period applies. However, given the timing of the clarification of the qualification process and the constitutional review of the eligibility requirements for Olympic Events a shorter stand-down period in respect only of the Olympic Games 2016 shall apply. In this regard any Player who wishes to represent a Union / country for whom s/he holds the nationality and has previously been captured for another Union may do so provided the Player stands down from their current Union at least 18 months before representing the Second Union in an Olympic Event in the Rio Olympic Games cycle

\section{SCHEDULE 1. EXPLANATORY NOTE}

As from 1 J anuary 2000 a player is only entitled to play Rugby Union for the Senior National Representative Team or the next Senior National Representative Team of one Union. This means that if a player is deemed to have played for the Senior National Representative Team or the next Senior National Representative Team of a Union that player will be unable to play for any other Union. This is the position even if that player is able to satisfy one or more of the eligibility criteria set out in Regulation 8.1. It is important that players and Unions understand the situations in which players will be deemed to have played for the Senior National Representative Team or the next Senior National Representative Team of a Union. These situations are set out in Regulation 8.3.

Regulation 8.3 is based on a "selection and participation" test for players who have reached the age of majority [18 or over]. Players and Unions must familiarize themselves with Regulation 8.3. Players should be made aware by Unions of what constitutes that Union's Senior National Representative Team, its next Senior National Representative Team, its Senior Touring Squad and its next Senior Touring Squad and the Matches that will result in a player being committed to that Unions. The following situations are covered by Regulation 8.3.

1. Players who participate in International Matches for the Senior National Representative Team or the next Senior National Representative Team of a Union against the Senior or next Senior National Representative Team of another Union.

2. Players selected to represent a Union's Senior Touring Squad who participate in any Match played by members of that Union's Senior Touring Squad during an International Tour provided such International Tour includes an International Match(es) approved by World Rugby.

3. Players who participate in a Match for the Senior or next Senior National Representative Team of a Union against a team made up of players from a Union's Senior Touring Squad during an International Tour which indudes International Match(es) approved by World Rugby.

4. Players, representing a Union's next Senior Touring Squad who participate in a Match on an International Tour approved by World Rugby against the Senior National RepresentativeTeam or the next Senior National RepresentativeTeam of another Union. 


\section{NATIONAlity ReQuirements in Olympic SPORTS}

5. Players who play for the Senior or next Senior National Representative Team of a Union against a team selected from a Union's next Senior Touring Squad when such Match is played on an International Tour approved by World Rugby.

\section{Rugby HANDBOOK AS FRAMED BY WORLD RUGBY Last update: 15 May, 2015}

RE GULATION 8. ELIGIBILITY TO PLAY FOR NATIONAL REPRESENTATIVE TEAMS

8.1. Subject to Regulation 8.2, a Player may only play for the senior fifteen-a side National Representative Team the next senior fifteen-a-side National Representative Team and the senior National Representative Sevens Team of the Union of the country in which:

(a) hewas born; or

(b) one parent or grandparent was born; or

(c) he has completed thirty six consecutive months of Residence immediately preceding the time of playing.

8.2. A Player who has played for the senior fifteen-aside National Representative Team or the next senior fifteen-a-side National Representative Team or the senior National Representative Sevens Team of a Union is not eligible to play for the senior fifteen-a-side National Representative Team or the next senior fifteen-a side National RepresentativeTeam or the senior National Representative Sevens Team of another Union.

8.3. For the purposes of this Regulation, a Player is deemed to have played for the senior fifteen-a-side National Representative Teamor the next senior fifteen-a-side National Representative Team of a Union if:

(a) He is selected for such team to play in an International Match against the senior fifteen-a-side National Representative Team or the next senior fifteen-a-side National Representative Team of another Union (or in a fifteen-a-side international Match against another Union's senior or next senior Touring Squad during a World Rugby approved International Tour) and is present at the Match played by that team either as a replacement, substitute or a playing member of that team and has, at the time of the Match, reached the age of majority; or

(b) He is selected to represent a Union's seni or Touring Squad on an International Tour which includes an International Match or Matches approved by World Rugby and is present at any fifteen-a-side Match played on that I nternational Tour either as a replacement, substitute or a playing member of a team selected from the Union's senior Touring Squad and has, at the time of the Match, reached the age of majority; or

(c ) He is selected to represent a Union's next senior Touring Squad on a World Rugby approved International Tour and during that International Tour he is present at a Match against the senior fifteen- a side National Representative Teamor the next senior fifteen-a sideNational Representative Team of another Union either as a replacement, substitute or playing member of a teamselected from

the Union's next senior Touring Squad and has, at the time of the Match reached the age of majority.

(d) He is sel ected to represent the Under 20s National Representative Team of a Union which has been pre designated as that Union's next senior fifteen-a-side National Representative Team and the Player is part of the team which participates in an International Match as part of the World Rugby Junior World Championships, World Rugby J unior World Rugby Trophy or the Six Nations U20 Championship and is present at the Match played by that Teameither as a replacement, substitute or playing member of that Team and has, at thetime of the Match, reached the age of majority.

8.4. For the purposes of this Regulation, a Player is deemed to have played for the senior National Representative Sevens Team of a Union if he is selected to represent a Union's senior National Representative Sevens Team in an International Match against the senior National Representative Sevens Team of another Union and is present at the Match played by that Teameither as a replacement, substitute or playing member of that Team and has, at the time of the Match, reached the age of majority.

Responsibility, breach and penalties for a breach of Regulation 8

8.5. Regulation 8 is a strict liability offence and shall be construed in accordance with the principles of strict liability under English law. It is not, therefore, necessary that fault or intent on the part of a Union be shown in order for a breach of Regulation 8 to be established. Nor is lack of fault or intent on the part of a Union a defence to a breach of Regulation 8. For the avoidance of any doubt (and without limiting a Union's other obligations and responsibilities for the conduct, acts or omissions of its members and Persons under its jurisdiction pursuant to any other Regulation) Unions are responsible and accountable for the conduct of their Players and all Persons under its jurisdiction in relation to compliance with the provisions of Regulation 8 and any breach of Regulation 8 by such Player(s) or Person(s) shall be deemed to bea breach of Regulation 8 by the Union concerned. Each breach of Regulation 8 by a Union, howsoever arising, will result in a minimum fixed fine being imposed on the Union concerned. The minimum fixed fines for each breach of Regulation 8 are as follows:

(A)For a Union that is represented on the Council $£ 100,000$ sterling;

(b) For all other World Rugby Member Unions $£ 25,000$ sterling.

Based on the facts and circumstances of any breach of Regulation 8 the applicable minimum fixed fine as set out above may be increased. In addition, other penalties as set out in Regulation 18.6 may al so be imposed on the Union concerned. 


\section{APPENDICES}

8.5.1 In exceptional circumstances, a Union in breach of Regulation 8 may make submissions to the relevant disciplinary body appointed under Regulation 18 to adjudicate on the case as to why the Union should not be subject to the applicable minimum fixed fine For the avoidance of any doubt, however, the relevant disciplinary body shall only be entitled to reduce the applicable minimumfixed fine set out in this Regulation where the Union is able to provide clear and indisputable evidence that truly exceptional circumstances exist and that the Union concerned had taken all necessary steps to comply with Regulation 8.

8.6. To be eligible to participate in the Olympic Games, Olympic qualification events (together "Olympic Events") or other events governed by the Olympic Charter all members of the senior National Representative Sevens Team(s) of a Union or the selected Olympic Sevens Team(s) of a National Olympic Committee shall comply with Regulation 8.1 and must bea national of the country of the National Olympic Committee which it is representing in such Olympic Events. Regulation 8.2 applies equally to all Players.

8.7. A Player who is a national of the country or Union for which he has been captured under Regulation 8.2 and who holds the nationality of another country or Union, may apply to participate in an Olympic Event to represent his new country or Union subject to the following conditions;

8.7.1 The Regulations Committee shall consider the application of a Player under this Regulation 8.7 which must be submitted with all relevant supporting documentation by the Union for whom the Player wishes to next represent in an Olympic Event (or a Union associated with the Olympic Sevens Team the Player wishes to represent). The application shall be prenotified to the Player's Union (namely the Union whose National Representative Team the Player represented);

8.7.2 The Player will be required to observeand demonstrate a stand down period of at least 3 years since the timethe Player last represented their former Union and the time the Player first plays for the second Union or country, which must be in an Olympic Event The Player may not represent the second Union in any other form of the Game until after they have participated in such Olympic Event.

(a Solely in respect of the Rio Olympic Games 2016, a stand down period of at least 18 months will be permitted, between the time the Player last represented their former Union and the time the Player first plays for the second Union or country, which must be in an Olympic Event in the Rio Olympic Games cycle, which the Player must observeand demonstrate

8.8 Where the Player is not a national of the Union for which he has been captured under Regulation 8.2, and he meets the Olympic eligibility criteria (in Regulation 8.6 to 8.13 ) as determined by the Regulations Committee, he shall be eligible for selection to play for the Union / country of which he is a national, in an Olympic Event, subject to satisfying the applicable stand down period.

8.9 A Player who is eligible or captured for a Union that cannot participate in an Olympic Event because there is no National Olympic Committee solely for the territory of such Union, may, subject to the Olympic eligibility criteria (in Regulation 8.6 to 8.13), be eligible to play for the Olympic Sevens Team of a National Olympic Committe of which he is a national, provided that such team is not associated with any one single Union. In such circumstances the following provisions shall apply;

8.9.1 Where the Player has been captured under Regulation 8.2 for a Union he shall remain captured for such Union notwithstanding the Player's representation for the Olympic Sevens Team of a National Olympic Committee in an Olympic Event;

8.9.2 Where the Player has not previously been captured under Regulation 8.2 and he represents the Olympic Sevens Team of a National Olympic Committee in an Olympic Event he will be deemed to be captured for one of the underlying Unions which support the Olympic Sevens Team of the relevant National Olympic Committee, and the Player must elect which of those underlying Unions he shall be captured by for the purposes of Regulation 8.

8.10 A Player who has represented one Union or Olympic Team in an Olympic Event and who has changed his nationality or acquired a new nationality, may apply to participate in an Olympic Event to represent his new Union or country provided that at least three years have passed since the Player last represented his former Union or country and the approval of the International Olympic Committee, the relevant National Olympic Committee(s) and World Rugby is obtained. This period may be reduced or even cancelled with the agreement of the World Rugby and the National Olympic Committees concerned and by the IOC Executive Board, which takes into account the circumstances of each case

8.11 A Player may not represent two different Unions or a Union and an Olympic Sevens Team(s) of a National Olympic Committee in the same Olympic Event(s).

8.12 Once the Player has represented the Union of which he is a national, in an Olympic Event, he shall thereafter betied to that Union for all forms of the Game and in all events.

8.13 Players who participate in the Olympic Events accept and agree that any disputes relating to eligibility shall first be addressed pursuant to the rules of such Olympic Events and the World Rugby Regulations and that all internal procedures (including applicable National Olympic Committee rules/procedures) and/or World Rugby procedures shall be exhausted first. Thereafter, recourse may be had in respect of Olympic Events only (and not in relation to eligibility matters to which Regulation 8.6 to 8.16 does not apply) to the Court of Arbitration for Sport (CAS) in accordance with the provision applicable before such court and 
which will resolve definitively the dispute in accordance with the code of sports related arbitration. World Rugby has the right to appear, attend and/or participate

as a party in any appeal to CAS involving eligibility considerations for Olympic Events.

8.14 Any Union wishing to obtain clarification around the eligibility of a Player to represent it in the Olympic Games or Olympic Events may do so by refering the matter to the World Rugby Regulations Committee in accordance with Regulation 2 and Regulation 8.7.1 and 8.7.2.

8.15 The list of Olympic Events is set out in Schedule 2 and shall be updated for each Olympic cycle

8.16 The provisions of Regulation 8.5 apply equally to any alleged breach of the Olympic eligibility provisions.

EXPLANATORY GUIDELINES ON THE IM PLEMENTATION OF REGULATION 8

ELIGIBILITY TO PLAY FOR NATIONAL REPRESENTATIVE TEAMS

Following its deliberations on the question of Player eligibility, the Working Party has produced these Explanatory Guidelines on the implementation of Regulation 8. These Explanatory Guidelines must be read in conjunction with the terms of Regulation 8.

1. What is the Rationale/Philosophy of Regulation 8?

The rationale/philosophy of Regulation 8 is to ensure that Players selected to represent either the seni or and next senior fifteen-a-side National Representative Teams of a Union or a Union's senior National RepresentativeSevens Team havea genuine, close, credi ble and established national link with the country of the Union for which they have been selected. Such a national link is essential to maintain the unique characteristics and culture of elite international sporting competition between Unions. The integrity of International Matches between Unions depends upon strict adherence to the eligibility criteria set out in the Regulations.

2. Who establishes the digibility criteria in Rugby Union?

World Rugby will continue to establish the criteria by reference to which a Player's eligibility to play for the senior or next senior fifteen-a-side National Representative Team of a Union or a Union's senior National Representative Sevens Team will be determined. Citizenship of a country and/or whether a Player holds a passport of a particular country are not, of themselves, determinative in identifying which Union a Player is eligible to represent. This will be determined solely in accordance with World Rugby's eligibility criteria. In relation to Olympic eligibility criteria see the Explanatory Guidelines on the Implementation of Regulation 8 - Olympic Eligibility.

3. What is the eligibility criteria in Rugby Union?

The existing World Rugby eligibility criteria set out in Regulation 8.1 will be maintained. This is based on thefollowing:

(a)The country in which the Player was born; or

(b) The country in which one parent or grandparent of the Player was born; or

(c) The country in which the Player has completed thirty-six consecutive months of Residence immediately preceding the time of playing. Residence means the place or location in which a Player has his primary and permanent homeand Resident shall be construed accordingly; and

(d)For Olympic Event participation, the nationality of the Union / country the Player wishes to represent is also required.

4. If a Player has dual eligibility, can he play for the senior or next senior fifteen-arside National RepresentativeTeam or the senior National RepresentativeSevens Team of more than oneUnion?

No, save for those Players that, before $1 \mathrm{~J}$ anuary 2000 , al lowed a period of 36 consecutive months to elapse after they had played for another Union and who played for the second Uni on before $1 \mathrm{~J}$ anuary 2000 . The one Union only rule, introduced by World Rugby from 1st J anuary 2000 (as set out in Regulation 8.2), will be maintained. A Player is only entitled to play Rugby Union for the senior or next senior fifteen-a-side National Representative Team or the senior National Representative Sevens Team of one Union. Accordingly, if a Player is deemed to have played for such a team, even if he is able to satisfy one or more of the eligibility criteria set out in Regulation 8.1, he will not be able to play for any other Union. Consistent with the overall rationale underlying the eligibility Regulations, the one Union only rule is designed to maintain the integrity of the international Game Once a Player has committed himself to a particular Union, through participation in one of the Matches or Tours identified in Regulations 8.3 or 8.4, he is unable to change his "Rugby Nationality" which becomes fixed.

5. When is a Player deemed to have played for the senior or next senior fifteen-a-side National Representative Team of a Union or a Union's senior National Representative Sevens Team?

As a result of the one Union only rule, in particular, it is essential that Players and Unions understand the situations in which Players will be deemed to have played for the senior fifteen-a-side National Representative Team or the next senior fifteen-a-side National Representative Team of a Union or a Union's senior National RepresentativeSevens Team These situations are set out in Regulations

8.3 and 8.4. Players and Unions shall, at all times, have regard to the full terms of Regulations 8.3 and 8.4, however, by way of a summary only, the situations set out below are covered: 


\section{APPENDICES}

\section{Fifteen-a-side}

(a) Players who participate in International Matches for the senior National Representative Team or the next senior National Representative Team of a Union against the senior or next senior National Representative Team of another Union.

(b) Players selected to represent a Union's senior Touring Squad who participate in any Match played by members of that Union's senior Touring Squad during an International Tour provided such International Tour ind udes an International Match(es) approved by World Rugby.

(c) Players who participate in a Match for the senior or next senior National Representative Team of a Union against a team made up of Players from a Union's senior Touring Squad during an International Tour which indudes International Match(es) approved by World Rugby.

( d) Players, representing a Union's next senior Touring Squad who participatein a Match on an International Tour approved by World Rugby against the senior National Representative Team or the next senior National RepresentativeTeam or the next senior National RepresentativeTeam of another Union.

( e)Players who play for the senior or next senior National Representative Team of a Union against a team selected from a Union's next senior Touring Squad when such Match is played on an International Tour approved by World Rugby.

Seven-a-side

(a) Players who play for a Union's senior National Representative Sevens team in an International Match against the senior National Representative Sevens team of another Union.

6. How do I know which teamisa Union's next senior fifteen-a-side National Representative Team?

(a) There should be no uncertainty over which team constitutes a Union's next senior National RepresentativeTeam Unions are required to notify World Rugby of the name of their nominated next senior National RepresentativeTeam The teamnominated remains the Union's next senior National Representative Team unless the Union notifies World Rugby of a change in this nomination. A Union is entitled to notify World Rugby no more than once per calendar year of a change to its next senior National Representative Team provided that in doing so it shall take account of any Matches such team may be scheduled to play and shall advise the Union of any senior or next senior National Representative Team it is scheduled to play reasonably in advance of such Match. The identity of a Union's next seni or National Representative Team can be verified with the Union concerned and/or World Rugby.

(b) Unions must ensure that all persons involved in an International Match (Players and team management including coaching staff) are made aware of the status of their team as the next senior National Representative Team and that of their opposing team where it is the senior or next senior National Representative Team of another Union and what that means from a capturing perspective under Regulation 8. Notwithstanding the Union's obligation to inform the Player and team management it shall be the sole responsibility of each Player to ensure that he is aware of the status of every Match in which he plays and the implications of playing in an International

Match involving the seni or or next senior National Representative Teams of two Unions.

( c) In addition to (a) and (b) above, Unions who designate their Under 20s National Representative Team as their next senior National Representative Team have a particular onus to clearly make the Team Players aware of the consequences of being captured for that Union at age grade leve. Effective 1 J uly 2014, the Players on any such Team which participates in the World Rugby Junior World Championships, World Rugby J unior World Trophy or the Six Nations U20 Championship (where they are present at the Match played by that Team either as a replacement, substitute or playing member of that Team and has, at the time of the Match, reached the age of majority) will be captured. In this regard the status of the opposition teams in any Match in these named tournaments is not a factor to be considered.

7. What is the age of majority?

For the purposes of the Regulations (including, but not limited to Regulation 8), the age of majority is deemed to be acquired on a Player's 18th birthday.

8. Does the eligibility criteria apply to all forms of Rugby?

The eligibility criteria applies to the fifteen-a-side Game at senior and next senior National Representative level and in respect of a Union's seni or National Representative Sevens Team

9. Does the eligibility criteria apply to all Unions in membership of World Rugby?

Yes, all Unions in membership of World Rugby are obliged to comply with the eligibility Regulation 10. How will the eligibility criteria be assessed?

Ordinarily, the task of assessing whether a Player satisfies any of the eligibility criteria set out in Regulation 8.1 is straightforward. However, as a result of professionalism, greater mobility and societal family change this is not always the case. Difficult cases have arisen and may continue to emerge. The responses to the questions set out below are intended to provide further clarification as to how each eligibility criterion in Regulation 8.1 will beapplied.

The questions and answers should be regarded as guidelines. They have been prepared on the basis of operational experience to date It is not possible to anticipate all scenarios that may arise and a degree of 


\section{NATIONALITY REQUIREMENTS IN OLYMPIC SPORTS}

flexibility in the application of the Regulations will be maintained. Moving forward, in the event that there is any uncertainty or the need for clarification in relation to the application of the eligibility criteria in particular circumstances, then the Regulations Committee may be asked by World Rugby to make a ruling on a Player's eligibility. In relation to any

such adjudication, the Regulations Committee will al ways have in mind the rationale behind Regulation 8. The aim of the Regulations Committee in each case where darification may be required, is to establish whether, in all the circumstances, a Player has, by reference to the eligibility criteria in Regulation 8.1, been able to demonstrate a genuine, close and credible national link with the country that the Player wishes to represent. It is antici pated that over timea body of rulings by the Regulations Committee may develop which may, in turn, assist in providing further guidance to Unions in relation to eligibility matters.

11. When should any uncertainty over a Player's eligibility be clarified?

It is essential that eligibility issues are clarified before a Player represents the senior or next senior fifteen-a side National Representative Team of a Union or a Union's senior National Representative Sevens Team This is particularly important in light of the one Union only rule Accordingly, if a Union has any doubt over a Player's eligibility status it must takeall steps necessary to clarify the position before selecting the Player to play for its senior or next senior fifteen-a-side National Representative Team or its senior National RepresentativeSevens Team

12. What does place of birth mean?

This should be the most straightforward criterion to apply. A Player's place of birth shall be the country within whose geographical borders he was born. However, difficult scenarios can arise even in relation to this criterion. For example, where a Player was born within the geographical borders of one country, but in a part of that country deemed by the law of the country concerned, to be the sovereign territory of another, or where a Player was born in a military hospital. In such circumstances the matter should be referred to the Regulations Committee for a ruling. The Regulations Committee would need to establish the legal position together with other relevant facts and circumstances. In exceptional circumstances it may be possible for a Player to demonstrate, to the satisfaction of the Regulations Committee, that he is eligible to play for the Union within whose sovereign territory he was born, even though that sovereign territory may be within the geographical borders of another country.

13. What does Parent mean?

The term "parent" in the Regulations is limited to either a blood parent or a parent that has formally adopted a Player in accordance with the applicable legal requirements of the country concerned. Unless a Player has been adopted in accordance with the formal, legal requirements of the country concerned, the application of this criterion will be based on a Player's blood parent. When a Player has been formally adopted in accordance with the applicable legal requirements of the country concerned, the birth place of the Player's blood parent will no longer be relevant for the purposes of establishing the Player's eligibility pursuant to Regulation 8.1(b). The relevant parent will be the parent that has formally and legally adopted the Player. However in such circumstances, the relevant grandparents for the purposes of establishing a Player's eligibility

pursuant to Regulation 8.1(b) will be the Player's blood grandparents. It is not possible under Regulation 8.1(b) to assume eligibility via non-blood grandparents even if a Player has been formally and legally adopted.

For the avoidance of any doubt, stepparents and fostering parents will not be considered to constitute a Player's parent for the purposes of Regulation 8.1(b).

14. How is the Residence criteria satisfied?

Regulation 8.1(c) requires a Player to complete 36 consecutive months of Residence immediately preceding the time of playing. Residence is defined as "the place or location in which the Player has his primary and permanent home" and Resident shall be construed accordingly. In essence, Regulation 8.1(c) constitutes a sporting naturalization procedure, based on a geographical/presence test As in any naturalisation process, a number of factors will influence the determination of what constitutes a Player's permanent and primary home Such factors include, but are not limited to, the actual time spent in a country and the purpose of any absences during the qualification period. By being Resident in a country for a period of 36 consecutive months immediately preceding the time of playing for a Union, a Player is deemed to acquire a credible, close and established national link with a country/Union that entitles him to participate in sporting competitions for that Union. Based on the overriding rational e of the eligibility Regulations, in cases wherea Player's eligibility is uncertain the Regulations Committee will consider that Player's eligibility by reference to the particular facts and circumstances of his case to establish if the Residency test, in the context of the overall rationale of the eligibility Regulations, has been satisfied. The principles set out in responses to the questions below will act as guidelines to the Regulations Committee when it is asked to consider any cases pursuant to this criterion.

15. Whose burden of proof? 
In all cases where a Player is seeking to establish eligibility by reference to the Residency criteria in Regulation 8.1(c) (and, indeed, in relation to Regulation (or 8.1(a) and (b)), the burden of proof is on the Player and the Union that he wishes to represent to prove that Player's eligibility. Under Regulation 8.1(c), the Player and his Union must be able to demonstrate that, during the relevant period, the country in which he claims he has been Resident was, genuinely, the country that the Player treated as his home and is clearly the country in which the Player has his primary and permanent home If a Player has moved from one country to another, and is seeking to establish Residence in that new country, then he must also be able to demonstrate that he is clearly no longer Resident in the country in which he lived previously and that he no longer treats that country as his home. For the avoidance of any doubt, a Player cannot nominate a country as his home without demonstrating that he has satisfied the geographical commitment/presencetest enshrined in Regulation 8.1(c). The geographical commitment/presencetest will be vigorously upheld and applied to avoid abuse of the Residency criteria. For example, a Player that acquired/leased property in a country and who nominated that property as his permanent and primary home (even though he may only be present at that property and in that Union on a short term/temporary basis) would not satisfy the Residency test.

16. Will short breeks interrupt a period of Residence?

Short breaks in Residence, for example, for holidays, attending family/friends in other countries who may be ill etc, are unlikely to change the placellocation of a Player's primary and permanent homeand are, therefore, unlikely to interrupt a Player's period of Residence By way of a guideline, however, as a minimum requirement, it is likely that, save in exceptional circumstances, at least 10 months actual physical presence of the Player in the country concerned throughout any qualifying year of the Residency period, will be required to demonstrate that the country is the place where the Player has his primary and permanent home.

\section{Does the 36 month period of Residence have to immediately precede playing for a Union?}

Save in exceptional circumstances, the 36 months Residence will be expected to have been completed consecutive y and be achieved immediately before the Player represents a Uni on. This is designed to createa contemporary national link with the country of the Union concerned. This factor will be particularly significant if a Player has moved to make a "new" country his Residence having been Resident in another country previously. In essence, in such circumstances, the Player, as well as demonstrating his commitment to a new country, must also be (and seen to be) relinquishing his ties with the country in which he lived previously. For the avoidance of any doubt, seeking to rely on short periods of Residence as a child in a particular country, combined with a short period of Residence in that same country prior to playing for a Union, is likely to createa link that would betoo tenuous to satisfy the underlying intentions of establishing a contemporary, permanent, national link with a Union. However, each case will be assessed on its overall merits to establish if a Player is able to demonstrate a genuine, close, credibleand established national link by reference to the amount of timethe Player can demonstrate that he has treated the "new" country as his home and other relevant factors.

18. What is the position of students?

As far as students are concerned, particularly those that are not financially independent, being resident, as a full time student, in another country, is likely to be considered as a series of temporary absences from the parental home It is anticipated that in the majority of cases involving students the parental home is likely to continue to constitute the student's permanent and primary home Accordingly, attendance at college/university in such circumstances is unlikely to break a Player's consecutive period of Residence However, as in all matters of eligibility, the overriding concern of the Regulations Committee in assessing any

such case will be to ensure that there remains a close, credi ble and established link with the country in which thePlayer claims to have retained his primary and permanent home There could becircumstances in which a student living in another country may be deemed to haveinterrupted his Residency period.

19. Who is responsible for compliance with the eligibility criteria?

In accordance with Regulation 2.1.2, each Union is responsible for ensuring compliance with all Regulations Relating to the Game This includes, but is obviously not limited to, Regulation 8. Accordingly, it is the responsibility of each Union to ensure that all Players it selects are properly eligible within the provisions of Regulation 8 and, in the event of any uncertainty, to ensure that the position is clarified before the Player is selected. Unions must have in place all necessary procedures and internal controls to ensure compliance with the eligibility Regulations.

20. What must Unions do to ensure (and demonstrate) compliance with the eligibility Regulations? Unions must ensure that before a Player is sel ected for the first time for its senior or next senior fifteen-a-side National Representative Team or its senior National Representative Sevens Team the Player completes the standard form dedaration attached to these Explanatory Guidelines at Schedule 1. In addition, before selecting a Player, Unions must ensure that they obtain valid/authentic documentation and such other evidence that may be necessary to prove, definitively, a Player's eligibility to play for that Union. Each Union must notify World Rugby of the names of all Player's selected for its senior and next senior National 
Representative Team and its senior National Representative Sevens Team on an annual basis. World Rugby shall maintain a database of all such Players. If requested, by the Chairman, or his designee, Unions must supply copies of the completed declaration forms of a Player(s) together with supporting documentation relied on to demonstratethePlayer's eligi bility. On 1 December each year, each Uni on must certify to World Rugby that each Player selected to represent the senior or next senior fifteen-a-side National Representative Team of the Union or its National Representative Sevens Team during the past year has completed, in full, the dedaration form and that each Player was eligible to represent the Union in accordance with the provisions of Regulation 8.

World Rugby may, through the Chai rman, or his designee, of his own motion or on receipt of a complaint undertake an investigation into a Union's compliance with Regulation 8. Unions, Players and officials must provide assistance with any such investigation and disclose such information and documents deemed necessary by the Chai rman, or his designee, for the purposes of that investigation.

21. What are the consequences of a breach of the eligibility Regulations?

Compliance with Regulation 8 is of fundamental importance in maintaining the integrity of international Rugby Union at senior National Representative leve. Any breach of such a fundamental Regulation, howsoever arising, has a detrimental impact on the image and reputation of the sport. Unions must, therefore take all necessary steps to put in place comprehensive review/compliance procedures to ensure that a breach of the ligibility provision does not occur whether negligently or otherwise Alleged breaches of Regulation 8 may be investigated and handled in accordance with Regulation 18 (Disciplinary and Judicial Matters). However, a breach of the eligibility Regulations constitutes a strict liability offence. This means that a failure by a Union to fulfill its obligations and to comply with the eligibility Regulations will be regarded as a serious breach of the Regulations, howsoever such breach may have occurred. As a reflection of the seriousness with which any breach of the eligibility Regulations will be treated by World Rugby, it has been agreed by Council to establish a minimum fixed penalty to be imposed on a Union that has breached Regulation 8. These minimum fixed penalties will appear in Regulation 8 and, for ease of reference, are also set out below.

8.5. Responsibility, breach and penalties for a breach of Regulation 8

Regulation 8 is a strict liability offence and shall be construed in accordance with the principles of strict liability under English law. It is not, therefore, necessary that fault or intent on the part of a Uni on be shown in order for a breach of Regulation 8 to be established. Nor is lack of fault or intent on the part of a Union a defence to a breach of Regulation 8. For the avoidance of any doubt (and without limiting a Union's other obligations and responsibilities for the conduct, acts or omissions of its members and Persons under its jurisdiction pursuant to any other Regulation) Unions are responsible and accountabl e for the conduct of their Players and all Persons under its jurisdiction in relation to compliance with the provisions of Regulation 8 and any breach of Regulation 8 by such Player(s) or Person(s) shall be deemed to bea breach of Regulation 8 by the Union concerned. Each breach of Regulation 8 by a Union, howsoever arising, will result in a minimum fixed fine being imposed on the Union concerned. The minimum fixed fines for each breach of Regulation 8 areas follows:

(a) For a Union that is represented on the Council $£ 100,000$ sterling;

(b) For all other World Rugby Member Unions $₫ 25,000$ sterling.

Based on the facts and circumstances of any breach of Regulation 8 the applicable minimum fixed fine as set out above may be increased. In addition, other penalties as set out in Regulation 17.6 may al so be imposed on theUnion concerned.

Explanatory Guidelines on the Implementation of Regulation 8 - Olympic Eligibility

With the reintroduction of Rugby Sevens into the Olympic Games in Rio in 2016 there are certain rules which participants must adhere to for eligibility purposes. The Olympic Eligibility Regulations (8.6 to 8.16) have been introduced to accommodate the Olympic Charter Rules. To assist in the implementation of these Regulations, the following Guidelines have been developed to address the specifics around Olympic Sevens eligibility which differs from that of World Rugby eligibility requirements in that it is based solely upon a nationality consideration al one. The two sets of rules have been combined to achieve harmony between the objectives and underlying philosophy of Regulation 8 and the requirements of the Olympic Charter in the context of participation in Olympic Events. These Explanatory Guidelines must be read in conjunction with theterms of Regulation 8 and the Guidelines thereto.

1 . Who is eligibleto play Olympic Sevens?

Any Player who meets the eligibility criteria in 8.1 and hol ds the national ity of the Union / country they wish to represent in the Olympic Games or Olympic Qualification process (known as the "Olympic Events"). The eligibility rules in the Olympic Charter together with the World Rugby eligibility rules must be complied with by Players who participatein Olympic Events.

2. Must a Player havethe passport of the Union / country herepresents in Olympic Sevens?

The nationality of the Union / country the Player wishes to represent in Olympic Sevens is a requirement under the Olympic Charter and is therefore necessary for participation in Olympic Events. Nationality is 


\section{APPENDICES}

ordinarily demonstrated by the Player holding the passport of the Union / county they wish to represent All matters relating to the determination of the country which a Player may represent in the Olympic Games shall ultimately be resolved by theIOC Executive Board.

3. Who will decide on Olympic Sevens eligibility?

Ordinarily, the assessment of whether a Player satisfies the eligibility criteria in Regulation 8.1 and 8.6 will be straightforward. However, in all cases where a Player who has been captured under Regulation 8.2 and who holds the nationality of another Union / country and wishes to participate in an Olympic Event(s) for the Union / country of which he is a national, the Player may apply to World Rugby to represent the National Representative Sevens Team of that Union (or the Olympic Sevens Team of an National Olympic Committee), and the case shall be determined in the first place by the World Rugby Regulations Committee. In the event there are other cases of uncertainty or there is the need for clarification a referral may be made to the World Rugby Regulations Committee

4. What is required to be submitted to the Regulations Committee?

Applications should be submitted to World Rugby accompanied by all relevant supporting documents by the Union (or in applicable cases where there is no Union, the National Olympic Committee ("NOC")) of the country the Player wishes to represent in an Olympic Event. The application shall be prenotified to the Player's Union (namely the Union who's National Representative Team the Player has previously represented. The Player's Union may make written submissions to the World Rugby Regulations Committee or may beinvited to do so.

5. Can a Player with dual nationality, or having World Rugby eligibility for one Union but the nationality of another, represent both Unions / countries in the same Olympic qualification process?

No. A Player may only represent one Union / country in the Olympic Events. For example if a Player played for a Union in the Sevens World Series in the year it was designated as an Olympic Event the Player could not later in the same Sevens World Series play for another Union / country even in circumstances where he was deemed eligibly by the Regulations Committee to play for the second Union / country of which he is a national. The principle of Regulation 8.2 applies equally to Olympic Events, such that if a Player, having represented one Union / country in an Olympic Event they may not represent another Union / country thereafter.

6. Can a Player switch nationality?

Nationality is a matter which is governed by nation states. If a Player does switch national ity the ffect of this upon their Olympic eligibility would need to be considered taking into account Regulation 8.6 to 8.16 and the Olympic Charter Rules regarding eligibility which can be found at www.olympic.org. However, a Player who has represented one Union / country in an Olympic Event(s) and who has changed their nationality or acquired a new nationality may participate in Olympic Events to represent their new Union / country provided that at least three (3) years have passed since the Player last represented their former Union / country and the approval of the International Olympic Committee, the relevant National Olympic Committee(s) and World Rugby is obtained.

7. How will theOlympic eligibility criteria be assessed?

In the early days of the Olympic participation the view has been taken by World Rugby that the Regulations Committee should assess all cases where a Player who has al ready been captured for a Union under the one Union only rule (Regulation 8.2) but wishes to subsequently play for another Union / country for which s/he holds nationality in an Olympic Event.

8. Is there any stand-down period?

Yes. The Player will be required to observe and demonstrate a stand down period of three (3) years between the time the Player last played for his Union and the time the Player first represents the second Union, which must be in an Olympic Event. Played, shall mean when s/he played for the senior, next senior or senior sevens National Representative Team of that Union for which s/he is captured. The principles of Regulation 8.3 apply in any assessment of this provision.

9. What does 'first represents' mean?

It means the first occasion when the Player represents the second Union in a Match, Tournament or Series of Matches - which must be in an Olympic Event. The Player would not however, be permitted for example to participate in preseason Matches or so-called 'friendly' matches or other Matches which are not Olympic Events representing the second Union. Training with the team of the second Union is permitted but the circumstances should not be such that it presents or implies to third parties that the Player is part of the National RepresentativeSevens Team or Olympic Sevens Team of the second Union / country.

10. How will the stand-down period be assessed?

The onus will be on the Player to demonstrate to the reasonable satisfaction of the Regulations Committee the last occasion upon which s/he played for their former Union and that they have not represented such Union in the threeyear period before they represent their new Union/ country in an Olympic Event. 11. Arethese Olympic Guidel ines to be read with the World Rugby Eligibility Guidelines?

$\mathrm{Yes}$, both sets of Guidelines should be read together. 


\section{NATIONALITY REQUiREMENTS IN Oly mpic SPORTS}

\section{What is the position for Unions who do not have a single NOC to represent them?}

Member Unions of World Rugby are not necessarily recognised in their own right with equivalent NOC's, for example the British Olympic Association (Team GB) is the NOC for Great Britain and therefore encapsulates the Unions of England, Scotland, Wales and Northern Ireland (represent by the all-Ireland body of the IRFU). In such case, Players from the underlying Unions would be eligible (where they comply with Regulation 8.1 and 8.6) to represent the Olympic Sevens Team of the NOC (if selected) in relevant Olympic Events.

13. If a Player plays for a combined team in an Olympic Event does it affect his eligibility in relation to World Rugby?

If a Player plays for a combined team of a country in an Olympic Event (eg. Team GB) and he was previously not captured for a Union (under Regulation 8.2) then the Player will be deemed to be captured for one of the underlying Unions of the combined team of country he represented. So in the case of Team GB it would mean that the Player would then be free to play for one of England, Scotland, Wal es and/or Ireland.

If a Player plays for a combined team of a country in an Olympic Event (eg. Team GB) and he was previously was captured for a Union (under Regulation 8.2) then the Player remains captured for such Union and their participation in the combined team in the Olympic Event will not affect their status.

14. Is therea right of appeal from the decision of the World Rugby Regulations

Yes. An Olympic Eligibility appeals committee has been established under Regulation 2 to deal with any appeal s of decisions by the World Rugby Regulations Committee

15. For the Olympic Games 2016 in Rio, do any special provisions apply?

Rugby Sevens will enter the Olympic Games for the first time in 2016. The qualification process has been established and all persons eligible to partici pate must have qualified by $11 \mathrm{~J}$ uly 2016. In terms of eligibility, the three (3) year stand-down period applies. However, given the timing of the clarification of the qualification process and the constitutional review of the eligibility requirements for Olympic Events a shorter stand-down period in respect only of the Olympic Games 2016 shall apply. In this regard any Player who wishes to represent a Union / country for whom s/he holds the nationality and has previously been captured for another Union may do so provided the Player stands down from their current Union at least 18 months before representing the Second Union in an Olympic Event in the Rio Olympic Games cycle

Regulation 8 SCHEDULE 1. EXPLANATORY NOTE

As from 1 J anuary 2000 a player is only entitled to play Rugby Union for the Senior National Representative Team or the next Senior National Representative Team of one Union. This means that if a player is deemed to have played for the Senior National Representative Team or the next Senior National Representative Team of a Union that player will be unable to play for any other Union. This is the position even if that player is able to satisfy one or more of the eligibility criteria set out in Regulation 8.1. It is important that players and Unions understand the situations in which players will be deemed to have played for the Senior National Representative Team or the next Senior National Representative Team of a Union. These situations are set out in Regulation 8.3.

Regulation 8.3 is based on a "selection and participation" test for players who have reached the age of majority [18 or over]. Players and Unions must familiarize themselves with Regulation 8.3. Players should be made aware by Unions of what constitutes that Union's Senior National Representative Team its next Senior National Representative Team, its Senior Touring Squad and its next Senior Touring Squad and the Matches that will result in a player being committed to that Unions. The following situations are covered by Regulation 8.3.

1. Players who participate in International Matches for the Senior National Representative Team or the next Senior National Representative Team of a Union against the Senior or next Senior National Representative Team of another Union.

2. Players selected to represent a Union's Senior Touring Squad who participate in any Match played by members of that Union's Senior Touring Squad during an International Tour provided such International Tour ind udes an International Match(es) approved by World Rugby.

3. Players who participate in a Match for the Senior or next Senior National Representative Team of a Union against a team made up of players from a Union's Senior Touring Squad during an International Tour which indudes International Match(es) approved by World Rugby.

4. Players, representing a Union's next Senior Touring Squad who participate in a Match on an International Tour approved by World Rugby agai nst the Senior National Representative Team or the next Senior National Representative Team of another Union.

5. Players who play for the Senior or next Senior National Representative Team of a Union against a team selected from a Union's next Senior Touring Squad when such Match is played on an International Tour approved by World Rugby.

[...]

Player availability in circumstances of dual eligibility 
When a Union enters into a written agreement with a Player that contemplates the Player representing that Union at senior or next Senior Fifteen-A-Side National Representative Teamlevel (whether at fifteen- aside or seven-a-side Rugby), the Union may seek the Player's written agreement that the Player shall not be available for selection, attendance and/or appearance in a National Representative Team or National Squad of another Union during the term of that written agreement, including any extension thereof, provided that, prior to the execution of any such written agreement, the foll lowing conditions were satisfied:

(A) The Player had reached the age of majority. For the purposes of the Regulation(s), the age of majority shall be deemed to be acquired by a Player on his 18th birthday.

(B) Pursuant to Regulation 8, the Player was eligible to represent the senior or next senior National Representative Team of the Union with which he has entered into the written agreement and at least one other Union, (i.e, as a minimum requirement the Player had dual Union eligibility status).

(c) The Player had not represented the senior or next senior National Representative Team of any Union in any of the Matches or Tours specified in Regulation 8.3.

(d) As evidenced by completion of the standard form certification set out in Attachment 1, the Player received independent legal advice on the terms of the written agreement In particular, the fact that in signing the written agreement the Player was acknowledging and accepting that during the course of the written agreement, and any extension thereof, he was foregoing his right to represent the senior or next senior National Representative Team of any other Union for which hemay beeligible

If, subject to compliance with the conditions set out in this Regulation 9.38, a Player's written agreement so provides, then that Player shall not be available for selection, attendance and/or appearance in a National Representative Team or National Squad of another Union during the term of the written agreement, or any extension thereof and during such period the Union with whom the Player is contracted shall have no obligation to rel ease the Player to another Union.

\section{RUGBY HANDBOOK AS FRAMED BY WORLD RUGBY Last update: $22 \mathrm{M}$ arch, 2015 REGULATION 8 \\ REGULATION 8. ELIGIBILITY TO PLAY FOR NATIONAL REPRESENTATIVE TEAMS}

8.1. Subject to Regulation 8.2, a Player may only play for the seni or fifteen-a side National Representative Team, the next senior fifteen-a-side National Representative Team and the senior National Representative Sevens Team of the Union of the country in which:

A) hewas born; or

B) one parent or grandparent was born; or

C) he has completed thirty six consecutive months of Residenceimmediately preceding the time of playing.

8.2. A Player who has played for the senior fifteen-a-side National Representative Team or the next senior fifteen-a-side National Representative Team or the senior National Representative Sevens Team of a Union is not eligible to play for the senior fifteen-a-side National Representative Team or the next senior fifteen-a sideNational RepresentativeTeam or the senior National RepresentativeSevens Team of another Union.

8.3. For the purposes of this Regulation, a Player is deemed to have played for the senior fifteen-a-side National RepresentativeTeam or the next senior fifteen-a-side National RepresentativeTeam of a Union if:

A) He is selected for such team to play in an International Match against the senior fifteen-a-side National Representative Team or the next senior fifteen-a-side National Representative Team of another Union (or in a fifteen-a-side international Match against another Union's senior or next senior Touring Squad during a World Rugby approved International Tour) and is present at the Match played by that team either as a replacement, substitute or a playing member of that team and has, at the time of the Match, reached the age of majority; or

B) He is selected to represent a Union's senior Touring Squad on an International Tour which includes an International Match or Matches approved by World Rugby and is present at any fifteen-a-side Match played on that International Tour either as a replacement, substitute or a playing member of a team sel ected from the Union's senior Touring Squad and has, at thetime of the Match, reached the age of majority; or

C) Heis selected to represent a Union's next senior Touring Squad on a World Rugby approved International Tour and during that International Tour he is present at a Match against the senior fifteen- a-side National Representative Team or the next senior fifteen-a side National Representative Team of another Union either as a replacement, substitute or playing member of a team selected from the Union's next senior Touring Squad and has, at the time of the Match reached the age of majority.

D) He is selected to represent the Under 20s National Representative Team of a Union which has been predesignated as that Union's next senior fifteen-a-side National Representative Team and the Player is part of the team which participates in an International Match as part of the World Rugby Junior World Championships, World Rugby J unior World Rugby Trophy or the Six Nations U20 Championship and is present at the Match played by that Teameither as a replacement, substitute or playing member of that Teem and has, at the time of the Match, reached the age of majority. 
8.4. For the purposes of this Regulation, a Player is deemed to have played for the senior National Representative Sevens Team of a Union if he is selected to represent a Union's senior National Representative Sevens Team in an International Match against the senior National Representative Sevens Team of another Union and is present at the Match played by that Teameither as a replacement, substitute or playing member of that Team and has, at the time of the Match, reached the age of majority.

Responsibility, breach and penalties for a breach of Regulation 8

$[\ldots]$

8.6. To be eligible to participate in the Olympic Games, Olympic qualification events (together "Olympic Events") or other events governed by theOlympic Charter all members of the senior National Representative Sevens Team(s) of a Union or the selected Olympic Sevens Team(s) of a National Olympic Committee shall comply with Regulation 8.1 and must bea national of the country of the National Olympic Committee which it is representing in such Olympic Events. Regulation 8.2 applies equally to all Players.

8.7. A Player who is a national of the country or Union for which he has been captured under Regulation 8.2 and who holds the nationality of another country or Union, may apply to participate in an Olympic Event to represent his new country or Union subject to the following conditions;

8.7.1. The Regulations Committee shall consider the application of a Player under this Regulation 8.7 which must be submitted with all relevant supporting documentation by the Union for whom the Player wishes to next represent in an Olympic Event (or a Union associated with the Olympic Sevens Team the Player wishes to represent). The application shall be prenotified to the Player's Union (namely the Union whose National Representative Team the Player represented);

8.7.2. The Player will be required to observe and demonstrate a stand down period of at least 3 years since the time the Player last represented their former Union and the time the Player first plays for the second Union or country, which must be in an Olympic Event. The Player may not represent the second Union in any other form of the Game until after they have participated in such Olympic Event.

A) Soley in respect of the Rio Olympic Games 2016, a stand down period of at least 18 months will be permitted, between the time the Player last represented their former Union and the time the Player first plays for the second Union or country, which must be in an Olympic Event in the Rio Olympic Games cycle, which the Player must observe and demonstrate.

8.8. Where the Player is not a national of the Union for which he has been captured under Regulation 8.2, and he meets the Olympic eligibility criteria (in Regulation 8.6 to 8.13 ) as determined by the Regulations Committee, he shall be eligible for selection to play for the Union / country of which he is a national, in an Olympic Event, subject to satisfying the applicable stand down period.

8.9. A Player who is eligible or captured for a Union that cannot participate in an Olympic Event because there is no National Olympic Committee solely for the territory of such Union, may, subject to the Olympic eligibility criteria (in Regulation 8.6 to 8.13), be eligible to play for the Olympic Sevens Team of a National Olympic Committee of which he is a national, provided that such team is not associated with any one single Union. In such circumstances the following provisions shall apply;

8.9.1. Where the Player has been captured under Regulation 8.2 for a Union he shall remain captured for such Union notwithstanding the Player's representation for the Olympic Sevens Team of a National Olympic Committee in an Olympic Event;

8.9.2. Where the Player has not previously been captured under Regulation 8.2 and he represents the Olympic Sevens Team of a National Olympic Committee in an Olympic Event he will be deemed to be captured for one of the underlying Unions which support the Olympic Sevens Team of the relevant National Olympic Committee, and the Player must elect which of those underlying Uni ons he shall be captured by for the purposes of Regulation 8.

8.10. A Player who has represented one Union or Olympic Team in an Olympic Event and who has changed his nationality or acquired a new nationality, may apply to participate in an Olympic Event to represent his new Union or country provided that at least three years have passed since the Player last represented his former Union or country and the approval of the International Olympic Committee, the relevant National Olympic Committee(s) and World Rugby is obtained. This period may be reduced or even cancelled with the agreement of the World Rugby and the National Olympic Committees concerned and by the IOC Executive Board, which takes into account the circumstances of each case

8.11. A Player may not represent two different Unions or a Union and an Olympic Sevens Team(s) of a National Olympic Committee in the same Olympic Event(s).

8.12. Once the Player has represented the Union of which he is a national, in an Olympic Event, he shall thereafter betied to that Union for all forms of the Gameand in all events.

8.13. Players who participate in the Olympic Events accept and agree that any disputes relating to eligi bility shall first be addressed pursuant to the rules of such Olympic Events and the World Rugby Regulations and that all internal procedures (including applicable National Olympic Committee rules/procedures) and/or World Rugby procedures shall be exhausted first. Thereafter, recourse may be had in respect of Olympic Events only (and not in relation to eligibility matters to which Regulation 8.6 to 8.16 does not apply) to the 


\section{APPENDICES}

Court of Arbitration for Sport (CAS) in accordance with the provision applicable before such court and which will resolve definitively the dispute in accordance with the code of sports related arbitration. World Rugby has the right to appear, attend and/or partici pate as a party in any appeal to CAS involving eligibility considerations for Olympic Events.

$[\ldots$

\section{EXPLANATORY GUIDELINES ON THE IMPLEMENTATION OF REGULATION 8 ELIGIBILITY TO PLAY FOR NATIONAL REPRESENTATIVE TEAMS}

Following its deliberations on the question of Player eligibility, the Working Party has produced these Explanatory Guiddines on the implementation of Regulation 8. These Explanatory Guidelines must be read in conjunction with the terms of Regulation 8.

1. What is the Rationale/Philosophy of Regulation 8?

The rational e/philosophy of Regulation 8 is to ensure that Players selected to represent either the seni or and next senior fifteen-a-side National Representative Teams of a Union or a Union's senior National RepresentativeSevens Team havea genuine, close, credible and established national link with the country of the Union for which they have been selected. Such a national link is essential to maintain the unique characteristics and culture of elite international sporting competition between Unions. The integrity of International Matches between Unions depends upon strict adherence to the eligibility criteria set out in the Regulations.

2. Who establishes the eligibility criteria in Rugby Union?

World Rugby will continue to establish the criteria by reference to which a Player's eligibility to play for the senior or next seni or fifteen-a-side National Representative Team of a Union or a Union's senior National Representative Sevens Team will be determined. Citizenship of a country and/or whether a Player holds a passport of a particular country are not, of themselves, determinative in identifying which Union a Player is eligible to represent. This will be determined sole y in accordance with World Rugby's eligibility criteria. In relation to Olympic eligibility criteria see the Explanatory Guidelines on the Implementation of Regulation 8 - Olympic Eligibility.

3. What is the eligibility criteria in Rugby Union?

The existing World Rugby eligibility criteria set out in Regulation 8.1 will be maintained. This is based on thefollowing:

A) The country in which the Player was born; or

B) The country in which one parent or grandparent of the Player was born; or

C) The country in which the Player has completed thirty-six consecutive months of Residence immediately preceding the time of playing. Residence means the place or location in which a Player has his primary and permanent homeand Resident shall be construed accordingly; and

D) For Olympic Event participation, the nationality of the Union / country the Player wishes to represent is also required.

4. If a Player has dual eligibility, can he play for the senior or next senior fifteen-a-side National RepresentativeTeamor the senior National Representative Sevens Team of more than one Union?

No, save for those Players that, before 1 J anuary 2000, al lowed a period of 36 consecutive months to elapse after they had played for another Union and who played for the second Uni on before 1 January 2000. The one Union only rule, introduced by World Rugby from 1st J anuary 2000 (as set out in Regulation 8.2), will be maintained. A Player is only entitled to play Rugby Union for the senior or next senior fifteen-a-side National Representative Team or the senior National Representative Sevens Team of one Union. Accordingly, if a Player is deemed to have played for such a team, even if he is ableto satisfy one or more of the eligibility criteria set out in Regulation 8.1, he will not be able to play for any other Union. Consistent with the overall rationale underlying the eligibility Regulations, the one Union only rule is designed to maintain the integrity of the international Game Once a Player has committed himself to a particular Union, through participation in one of the Matches or Tours identified in Regulations 8.3 or 8.4, he is unable to change his "Rugby Nationality" which becomes fixed.

5. When is a Player deemed to have played for the senior or next senior fifteen-arside National Representative Team of a Union or a Union's senior National Representative Sevens Team?

As a result of the one Union only rule, in particular, it is essential that Players and Unions understand the situations in which Players will be deemed to have played for the senior fifteen-a-side National Representative Team or the next senior fifteen-a-side National Representative Team of a Union or a Union's senior National Representative Sevens Team These situations are set out in Regulations

8.3 and 8.4. Players and Unions shall, at all times, have regard to the full terms of Regulations 8.3 and 8.4, however, by way of a summary only, the situations set out bel ow are covered:

Fifteen-arside

A) Players who participate in International Matches for the senior National Representative Team or the next senior National Representative Team of a Union against the senior or next senior National Representative Team of another Union. 
B) Players selected to represent a Union's senior Touring Squad who participate in any Match played by members of that Union's senior Touring Squad during an International Tour provided such International Tour ind udes an International Match(es) approved by World Rugby.

C) Players who participate in a Match for the senior or next senior National Representative Team of a Union against a team made up of Players from a Union's senior Touring Squad during an International Tour which indudes International Match(es) approved by World Rugby.

D) Players, representing a Union's next senior Touring Squad who participate in a Match on an International Tour approved by World Rugby against the senior National RepresentativeTeam or the next senior National Representative Team or the next senior National Representative Team of another Union.

E) Players who play for the senior or next senior National Representative Team of a Union against a team selected from a Union's next senior Touring Squad when such Match is played on an International Tour approved by World Rugby.

Seven-a-side

(a) Players who play for a Union's senior National Representative Sevens team in an International Match against the senior National RepresentativeSevens team of another Union.

$\underline{6}$. How do I know which teamis a Union's next senior fifteen-a-side National Representative Team?

A) There should be no uncertainty over which team constitutes a Union's next senior National RepresentativeTeam Unions are required to notify World Rugby of the name of their nominated next senior National RepresentativeTeam The teamnominated remains the Union's next senior National Representative Team unless the Union notifies World Rugby of a change in this nomination. A Union is entitled to notify World Rugby no more than once per calendar year of a change to its next senior National Representative Team provided that in doing so it shall take account of any Matches such team may be schedul ed to play and shall advise the Union of any senior or next senior National Representative Team it is scheduled to play reasonably in advance of such Match. The identity of a Union's next senior National Representative Team can be verified with the Uni on concerned and/or World Rugby.

B) Unions must ensure that all persons involved in an International Match (Players and team management including coaching staff) are made aware of the status of their team as the next senior National Representative Team and that of their opposing team where it is the senior or next senior National Representative Team of another Union and what that means from a capturing perspective under Regulation 8. Notwithstanding the Union's obligation to inform the Player and team management it shall be the sole responsibility of each Player to ensure that he is aware of the status of every Match in which he plays and the implications of playing in an International Match involving the senior or next senior National Representative Teams of two Unions.

C) In addition to (a) and (b) above, Unions who designate their Under 20s National Representative Teamas their next senior National Representative Team have a particular onus to clearly make the Team Players aware of the consequences of being captured for that Union at age grade level. Effective 1 J uly 2014, the Players on any such Team which participates in the World Rugby J unior World Championships, World Rugby J unior World Trophy or the Six Nations U20 Championship (where they are present at the Match played by that Team either as a replacement, substitute or playing member of that Team and has, at the time of the Match, reached the age of majority) will be captured. In this regard the status of the opposition teams in any Match in these named tournaments is not a factor to be considered.

7. What is the age of majority?

For the purposes of the Regulations (including, but not limited to Regulation 8), the age of majority is deemed to be acquired on a Player's 18th birthday.

8. Does the eligibility criteria apply to all forms of Rugby?

The eligibility criteria applies to the fifteen-arside Game at senior and next senior National Representative level and in respect of a Union's seni or National RepresentativeSevens Team

[...]

12. What does place of birth mean?

This should be the most straightforward criterion to apply. A Player's place of birth shall be the country within whose geographical borders he was born. However, difficult scenarios can arise even in relation to this criterion. For example, where a Player was born within the geographical borders of one country, but in a part of that country deemed by the law of the country concerned, to be the sovereign territory of another, or where a Player was born in a military hospital. In such circumstances the matter should be referred to the Regulations Committee for a ruling. The Regulations Committee would need to establish the legal position together with other relevant facts and circumstances. In exceptional circumstances it may be possible for a Player to demonstrate, to the satisfaction of the Regulations Committee, that he is eligible to play for the Union within whose sovereign teritory he was born, even though that sovereign territory may be within the geographical borders of another country.

13. What does Parent mean? 
The term "parent" in the Regulations is limited to either a blood parent or a parent that has formally adopted a Player in accordance with the applicable legal requirements of the country concerned. Unless a Player has been adopted in accordance with the formal, legal requirements of the country concerned, the application of this criterion will be based on a Player's blood parent. When a Player has been formally adopted in accordance with the applicable legal requirements of the country concerned, the birth place of the Player's blood parent will no longer be relevant for the purposes of establishing the Player's eligibility pursuant to Regulation 8.1(b). The relevant parent will be the parent that has formally and legally adopted the Player. However in such circumstances, the relevant grandparents for the purposes of establishing a Player's eligibility pursuant to Regulation 8.1(b) will be the Player's blood grandparents. It is not possible under Regulation 8.1(b) to assume eligibility via non-blood grandparents even if a Player has been formally and legally adopted.

For the avoidance of any doubt, stepparents and fostering parents will not be considered to constitute a Player's parent for the purposes of Regulation 8.1(b).

14. How is the Residencecriteria satisfied?

Regulation 8.1(c) requires a Player to complete 36 consecutive months of Residence immediately preceding the time of playing. Residence is defined as "the place or location in which the Player has his primary and permanent home" and Resident shall be construed accordingly. In essence, Regulation 8.1(c) constitutes a sporting naturalization procedure, based on a geographical/presence test. As in any naturalisation process, a number of factors will influence the determination of what constitutes a Player's permanent and primary home Such factors include, but are not limited to, the actual time spent in a country and the purpose of any absences during the qualification period. By being Resident in a country for a period of 36 consecutive months immediately preceding the time of playing for a Union, a Player is deemed to acquire a credible, close and established national link with a country/Union that entitles him to participate in sporting competitions for that Union. Based on the overriding rational e of the eligibility Regulations, in cases wherea Player's eligibility is uncertain the Regulations Committee will consider that Player's eligibility by reference to the particular facts and circumstances of his case to establish if the Residency test, in the context of the overall rationale of the eligibility Regulations, has been satisfied. The principles set out in responses to the questions below will act as guidelines to the Regulations Committee when it is asked to consider any cases pursuant to this criterion.

15. Whoseburden of proof?

In all cases where a Player is seeking to establish eligibility by reference to the Residency criteria in Regulation 8.1(c) (and, indeed, in relation to Regulation (or 8.1(a) and (b)), the burden of proof is on the Player and the Union that he wishes to represent to prove that Player's eligibility. Under Regulation 8.1(c), the Player and his Union must be able to demonstrate that, during the relevant period, the country in which he claims he has been Resident was, genuinely, the country that the Player treated as his home and is clearly the country in which the Player has his primary and permanent home If a Player has moved from one country to another, and is seeking to establish Residence in that new country, then he must also be able to demonstrate that he is clearly no longer Resident in the country in which he lived previously and that he no longer treats that country as his home For the avoidance of any doubt, a Player cannot nominate country as his home without demonstrating that he has satisfied the geographical commitment/presencetest enshrined in Regulation 8.1(c). The geographical commitment/presence test will be vigorously upheld and applied to avoid abuse of the Residency criteria. For example, a Player that acquired/leased property in a country and who nominated that property as his permanent and primary home (even though he may only be present at that property and in that Union on a short term/temporary basis) would not satisfy the Residency test.

16. Will short breaks internupt a period of Residence?

Short breaks in Residence, for example, for holidays, attending family/friends in other countries who may be ill etc, are unlikely to change the place/location of a Player's primary and permanent homeand are, therefore, unlikely to interrupt a Player's period of Residence By way of a guideline, however, as a minimum requirement, it is likely that, save in exceptional circumstances, at least 10 months actual physical presence of the Player in the country concemed throughout any qualifying year of the Residency period, will be required to demonstrate that the country is the place where the Player has his primary and permanent home

17. Does the 36 month period of Residence have to immediately precede playing for a Union?

Save in exceptional circumstances, the 36 months Residence will be expected to have been completed consecutively and be achieved immediately before the Player represents a Uni on. This is designed to createa contemporary national link with the country of the Union concerned. This factor will be particularly significant if a Player has moved to make a "new" country his Residence having been Resident in another country previously. In essence, in such circumstances, the Player, as well as demonstrating his commitment to a new country, must also be (and seen to be) relinquishing his ties with the country in which he lived previously. For the avoidance of any doubt, sedking to rely on short periods of Residence as a child in a particular country, combined with a short period of Residence in that same country prior to playing for a Union, is likely to createa link that would betoo tenuous to satisfy the underlying intentions of establishing a 
contemporary, permanent, national link with a Union. However, each case will be assessed on its overall merits to establ ish if a Player is ableto demonstrate a genuine, close, credibleand established national link by reference to the amount of time the Player can demonstrate that he has treated the "new" country as his home and other relevant factors.

\section{[... ]}

Explanatory G uidelines on the Implementation of R egulation 8 - Olympic Eligibility

With the re-introduction of Rugby Sevens into the Olympic Games in Rio in 2016 there are certain rules which participants must adhere to for eligibility purposes. The Olympic Eligibility Regulations (8.6 to 8.16) have been introduced to accommodate the Olympic Charter Rules. To assist in the implementation of these Regulations, the following Guidelines have been developed to address the specifics around Olympic Sevens eligibility which differs from that of World Rugby eligibility requirements in that it is based solely upon a nationality consideration alone The two sets of rules have been combined to achieve harmony between the objectives and underlying philosophy of Regulation 8 and the requirements of the Olympic Charter in the context of participation in Olympic Events. These Explanatory Guidelines must be read in conjunction with theterms of Regulation 8 and the Guidelines thereto.

1. Who is eligibleto play Olympic Sevens?

Any Player who meets the eligibility criteria in 8.1 and holds the nationality of the Union / country they wish to represent in the Olympic Games or Olympic Qualification process (known as the "Olympic Events"). The eligibility rules in the Olympic Charter together with the World Rugby eligibility rules must be complied with by Players who participatein Olympic Events.

2. Must a Player havethe passport of the Union/ country he represents in Olympic Sevens?

The nationality of the Union / country the Player wishes to represent in Olympic Sevens is a requirement under the Olympic Charter and is therefore necessary for participation in Olympic Events. Nationality is ordinarily demonstrated by the Player holding the passport of the Union / county they wish to represent. All matters relating to the determination of the country which a Player may represent in the Olympic Games shall ultimately beresolved by the IOC ExecutiveBoard.

3. Who will decide on Olympic Sevens eligibility?

Ordinarily, the assessment of whether a Player satisfies the eligibility criteria in Regulation 8.1 and 8.6 will be straightforward. However, in all cases where a Player who has been captured under Regulation 8.2 and who holds the nationality of another Union / country and wishes to participate in an Olympic Event(s) for the Union / country of which he is a national, the Player may apply to World Rugby to represent the National Representative Sevens Teem of that Union (or the Olympic Sevens Team of an National Olympic Committee), and the case shall be determined in the first place by the World Rugby Regulations Committee. In the event there are other cases of uncertainty or there is the need for clarification a referral may be made to the World Rugby Regulations Committee

4. What is required to be submitted to the Regulations Committe?

Applications should be submitted to World Rugby accompanied by all relevant supporting documents by the Union (or in applicable cases where there is no Union, the National Olympic Committee ("NOC")) of the country the Player wishes to represent in an Olympic Event. The application shall be prenotified to the Player's Union (namely the Union who's National Representative Team the Player has previously represented. The Player's Union may make written submissions to the World Rugby Regulations Committee or may beinvited to do so.

5. Can a Player with dual nationality, or having World Rugby eligibility for one Union but the nationality of another, represent both Unions / countries in the same Olympic qualification process?

No. A Player may only represent one Union / country in the Olympic Events. For example if a Player played for a Union in the Sevens World Series in the year it was designated as an Olympic Event the Player could not later in the same Sevens World Series play for another Union / country even in circumstances where he was deemed eligibly by the Regulations Committee to play for the second Union / country of which he is a national. The principle of Regulation 8.2 applies equally to Olympic Events, such that if a Player, having represented one Union / country in an Olympic Event they may not represent another Union / country thereafter.

6. Can a Player switch nationality?

Nationality is a matter which is governed by nation states. If a Player does switch nationality the effect of this upon their Olympic eligibility would need to be considered taking into account Regulation 8.6 to 8.16 and the Olympic Charter Rules regarding eligibility which can be found at www.olympic.org. However, a Player who has represented one Uni on / country in an Olympic Event(s) and who has changed their nationality or acquired a new nationality may participate in Olympic Events to represent their new Union / country provided that at least three (3) years have passed since the Player last represented their former Union / country and the approval of the International Olympic Committee, the relevant National Olympic Committee(s) and World Rugby is obtained.

7. How will the Olympic eligibility criteria be assessed? 


\section{APPENDICES}

In the early days of the Olympic participation the view has been taken by World Rugby that the Regulations Committee should assess all cases where a Player who has al ready been captured for a Union under the one Union only rule (Regulation 8.2) but wishes to subsequently play for another Union / country for which s/he holds nationality in an Olympic Event.

8. Is there any stand-down period?

Yes. The Player will be required to observe and demonstrate a stand down period of three (3) years between the time the Player last played for

his Union and the time the Player first represents the second Union, which must be in an Olympic Event. Played, shall mean when s/he played for the senior, next senior or senior sevens National Representative Team of that Union for which s/he is captured. The principles of Regulation 8.3 apply in any assessment of this provision.

9. What does 'first represents' mean?

It means the first occasion when the Player represents the second Union in a Match, Tournament or Series of Matches - which must be in an Olympic Event. The Player would not however, be permitted for example to participate in preseason Matches or so-called 'friendly' matches or other Matches which are not Olympic Events representing the second Union. Training with the team of the second Union is permitted but the circumstances should not be such that it presents or implies to third parties that the Player is part of the National Representative Sevens Team or Olympic Sevens Team of the second Union / country.

10. How will the stand-down period be assessed?

The onus will be on the Player to demonstrate to the reasonable satisfaction of the Regulations Committee the last occasion upon which s/he played for their former Union and that they have not represented such Union in the three year period before they represent their new Union/ country in an Olympic Event.

11. Arethese Olympic Guidelines to be read with the World Rugby Eligibility Guiddlines?

Yes, both sets of Guidelines should be read together.

12. What is the position for Unions who do not have a single NOC to represent them?

Member Unions of World Rugby are not necessarily recognised in their own right with equivalent NOC's, for example the British Olympic Association (Team GB) is the NOC for Great Britain and therefore encapsulates the Unions of England, Scotland, Wales and Northern Ireland (represent by the all-Ireland body of the IRFU). In such case, Players from the underlying Unions would be eligible (where they comply with Regulation 8.1 and 8.6) to represent the Olympic Sevens Team of the NOC (if selected) in relevant Olympic Events.

13. If a Player plays for a combined team in an Olympic Event does it affect his eligibility in relation to World Rugby?

If a Player plays for a combined team of a country in an Olympic Event (eg. Team GB) and he was previously not captured for a Union (under Regulation 8.2) then the Player will be deemed to be captured for one of the underlying Uni ons of the combined team of country he represented. So in the case of Team GB it would mean that the Player would then be free to play for one of England, Scotland, Wales and/or

If a Player plays for a combined team of a country in an Olympic Event (eg. Team GB) and he was previously was captured for a Union (under Regulation 8.2) then the Player remains captured for such Union and their participation in the combined team in the Olympic Event will not affect their status.

14. Is therea right of appeal from the decision of the World Rugby Regulations

Yes. An Olympic Eligibility appeals committee has been established under Regulation 2 to deal with any appeal s of decisions by the World Rugby Regulations Committee

15. For the Olympic Games 2016 in Rio, do any special provisions apply?

Rugby Sevens will enter the Olympic Games for the first time in 2016. The qualification process has been established and all persons eligible to participate must have qualified by 11 July 2016 . In terms of eligibility, the three (3) year stand-down period applies. However, given the timing of the clarification of the qualification process and the constitutional review of the eligibility requirements for Olympic Events a shorter stand-down period in respect only of the Olympic Games 2016 shall apply. In this regard any Player who wishes to represent a Union / country for whom s/he holds the nationality and has previously been captured for another Union may do so provided the Player stands down from their current Union at least 18 months before representing the Second Union in an Olympic Event in the Rio Olympic Games cycle.

$[\ldots]$

Player availability in circumstances of dual eligibility

9.38 When a Union enters into a written agreement with a Player that contemplates the Player representing that Union at senior or next Senior Fifteen-A-Side National Representative Team level (whether at fifteenaside or seven-a-side Rugby), the Union may seek the Player's written agreement that the Player shall not be available for selection, attendance and/or appearance in a National Representative Team or National Squad of another Union during the term of that written agreement, including any extension thereof, provided that, prior to the execution of any such written agreement, the following conditions were satisfied: 
A) The Player had reached the age of majority. For the purposes of the Regulation(s), the age of majority shall be deemed to be acquired by a Player on his 18th birthday.

B) Pursuant to Regulation 8, the Player was eligible to represent the senior or next senior National Representative Team of the Union with which he has entered into the written agreement and at least one other Union, (i.e, as a minimum requirement the Player had dual Union eligibility status).

C) The Player had not represented the senior or next senior National Representative Team of any Union in any of the Matches or Tours specified in Regulation 8.3.

D) As evidenced by completion of the standard form certification set out in Attachment 1, the Player received independent legal advice on the terms of the written agreement. In particular, the fact that in signing the written agreement the Player was acknowledging and accepting that during the course of the written agreement, and any extension thereof, he was foregoing his right to represent the senior or next senior National Representative Team of any other Union for which he may be eligible

If, subject to compliance with the conditions set out in this Regulation 9.38, a Player's written agreement so provides, then that Player shall not be available for se ection, attendance and/or appearance in a National Representative Team or National Squad of another Union during the term of the written agreement, or any extension thereof and during such period the Union with whom the Player is contracted shall have no obligation to release the Player to another Union.

INTERNATIONAL RUGBY BOARD HANDBOOK AS FRAMED BY THE INTERNATIONAL RUGBY BOARD Lastupdatad $1^{\text {st }}$ September 2014

\section{RE GULATION 8. ELIGIBILITY TO PLAY FOR NATIONAL REPRESENTATIVE TEAMS}

8.1 Subject to Regulation 8.2, a Player may only play for the senior fifteen-a- side National Representative Team the next senior fifteen-a-side National Representative Team and the senior National Representative Sevens Team of the Union of the country in which:

(a) hewas born; or

(b) one parent or grandparent was born; or

(c) hehas completed thirty six consecutive months of Residenceimmediately preceding the time of playing

8.2 A Player who has played for the senior fifteen-a-side National Representative Teem or the next senior fifteen-a-side National Representative Team or the senior National Representative Sevens Team of a Union is not eligible to play for the senior fifteen-a-side National Representative Team or the next senior fifteen-asideNational Representative Team or the senior National RepresentativeSevens Team of another Union.

8.3 For the purposes of this Regulation, a Player is deemed to have played for the senior fifteen-a-side National RepresentativeTeam or the next senior fifteen-a-sideNational RepresentativeTeam of a Union if:

(a) He is selected for such team to play in an International Match against the senior fifteen-a-side National Representative Team or the next senior fifteen-a-side National Representative Team of another Union (or in a fifteen-a-side international Match against another Union's senior or next senior Touring Squad during an IRB approved International Tour) and is present at the Match played by that team either as a replacement, substitute or a playing member of that team and has, at the time of the Match, reached the age of majority; or (b) He is selected to represent a Union's seni or Touring Squad on an International Tour which includes an International Match or Matches approved by the IRB and is present at any fifteen-a-side Match played on that International Tour either as a replacement, substitute or a playing member of a team selected from the Union's senior Touring Squad and has, at the time of the Match, reached the age of majority; or

(c)He is selected to represent a Union's next senior Touring Squad on an IRB approved International Tour and during that International Tour he is present at a Match against the senior fifteen-a-side National Representative Team or the next seni or fifteen-a-side National Representative Team of another Uni on either as a replacement, substitute or playing member of a team selected from the Union's next senior Touring Squad and has, at the time of the Match reached the age of majority.

(d) He is sel ected to represent the Under 20s National Representative Team of a Union which has been predesignated as that Union's next senior fifteen-a-side National Representative Team and the Player is part of the team which participates in an International Match as part of the IRB J unior World Championships, IRB Junior World Rugby Trophy or the Six Nations U20 Championship and is present at the Match played by that Team either as a replacement, substitute or playing member of that Team and has, at the time of the Match, reached the age of majority.

8.4 For the purposes of this Regulation, a Player is deemed to have played for the senior National Representative Sevens Team of a Union if he is selected to represent a Union's senior National Representative Sevens Team in an International Match against the senior National Representative Sevens Team of another Union and is present at the Match played by that Teameither as a replacement, substitute or playing member of that Team and has, at thetime of the Match, reached the age of majority.

Responsibility, breach and penalties for a breach of Regulation 8

8.5 Regulation 8 is a strict liability offence and shall be construed in accordance with the principles of strict liability under English law. It is not, therefore, necessary that fault or intent on the part of a Uni on be shown 
in order for a breach of Regulation 8 to be established. Nor is lack of fault or intent on the part of a Union a defence to a breach of Regulation 8. For the avoidance of any doubt (and without limiting a Union's other obligations and responsibilities for the conduct, acts or omissions of its members and Persons under its jurisdiction pursuant to any other Regulation) Unions are responsible and accountable for the conduct of their Players and all Persons under its jurisdiction in relation to compliance with the provisions of Regulation 8 and any breach of Regulation 8 by such Player(s) or Person(s) shall be deemed to bea breach of Regulation 8 by the Union concerned. Each breach of Regulation 8 by a Union, howsoever arising, will result in a minimum fixed fine being imposed on the Union concerned. The minimum fixed fines for each breach of Regulation 8 areas follows:

(a) For a Union that is represented on the Council $£ 100,000$ sterling;

(b) For all other IRB Member Unions $f 25,000$ sterling.

Based on the facts and circumstances of any breach of Regulation 8 the applicable minimumfixed fine as set out above may be increased. In addition, other penal ties as set out in Regulation 18.6 may al so be imposed on the Union concerned.

8.5.1 In exceptional circumstances, a Union in breach of Regulation 8 may make submissions to the relevant disciplinary body appointed under Regulation 18 to adjudicate on the case as to why the Union should not be subject to the applicable minimum fixed fine. For the avoidance of any doubt, however, the relevant disciplinary body shall only beentitted to reduce the applicable minimumfixed fine set out in this Regulation where the Union is able to provide clear and indisputable evidence that truly exceptional circumstances exist and that the Uni on concerned had taken all necessary steps to comply with Regulation 8.

8.6 To be eligible to participate in the Olympic Games, Olympic qualification events (together "Olympic Events") or other events governed by the Olympic Charter all members of the senior National Representative Sevens Team(s) of a Union or the selected Olympic Sevens Team(s) of a National Olympic Committee shall comply with Regulation 8.1 and must bea national of the country of the National Olympic Committee which it is representing in such Olympic Events. Regulation 8.2 applies equally to all Players.

8.7 A Player who is a national of the country or Union for which he has been captured under Regulation 8.2 and who holds the nationality of another country or Uni on, may apply to participate in an Olympic Event to represent his new country or Union subject to the following conditions;

8.7.1 The Regulations Committee shall consider the application of a Player under this Regulation 8.7 which must be submitted with all relevant supporting documentation by the Union for whom the Player wishes to next represent in an Olympic Event (or a Union associated with the Olympic Sevens Team the Player wishes to represent). The application shall be prenotified to the Player's Union (namely the Union whose National Representative Team the Player represented);

8.7.2 The Player will be required to observeand demonstratea stand down period of at least 3 years sincethe timethe Player last represented their former Union and the timethe Player first plays for the second Union or country, which must be in an Olympic Event. The Player may not represent the second Union in any other form of the Game until after they have participated in such Olympic Event.

(a)Solely in respect of the Rio Olympic Games 2016, a stand down period of at least 18 months will be permitted, between the time the Player last represented their former Union and the time the Player first plays for the second Union or country, which must be in an Olympic Event in the Rio Olympic Games cycle, which the Player must observeand demonstrate.

8.8 Where the Player is not a national of the Union for which he has been captured under Regulation 8.2, and he meets the Olympic eligibility criteria (in Regulation 8.6 to 8.13 ) as determined by the Regulations Committee, he shall be eligible for selection to play for the Union / country of which he is a national, in an Olympic Event, subject to satisfying the applicable stand down period.

8.9 A Player who is eligible or captured for a Union that cannot participate in an Olympic Event because there is no National Olympic Committee solely for the territory of such Union, may, subject to the Olympic eligibility criteria (in Regulation 8.6 to 8.13), be eligible to play for the Olympic Sevens Team of a National Olympic Committee of which he is a national, provided that such team is not associated with any one single Union. In such circumstances the following provisions shall apply;

8.9.1 Where the Player has been captured under Regulation 8.2 for a Union he shall remain captured for such Union notwithstanding the Player's representation for the Olympic Sevens Team of a National Olympic Committeein an Olympic Event;

8.9.2 Where the Player has not previously been captured under Regulation 8.2 and he represents the Olympic Sevens Teem of a National Olympic Committee in an Olympic Event he will be deemed to be captured for one of the underlying Unions which support the Olympic Sevens Team of the relevant National Olympic Committee, and the Player must dect which of those underlying Unions he shall be captured by for the purposes of Regulation 8.

8.10 A Player who has represented one Union or Olympic Team in an Olympic Event and who has changed his nationality or acquired a new nationality, may apply to participate in an Olympic Event to represent his new Union or country provided that at least three years have passed since the Player last represented his 
former Union or country and the approval of the International Olympic Committee, the relevant National Olympic Committee(s) and the IRB is obtained. This period may be reduced or even cancelled with the agreement of the IRB and the National Olympic Committees concemed and by the IOC Executive Board, which takes into account the circumstances of each case

8.11 A Player may not represent two different Unions or a Union and an Olympic Sevens Team(s) of a National Olympic Committein the same Olympic Event(s).

8.12 Once the Player has represented the Union of which he is a national, in an Olympic Event, he shall thereafter betied to that Union for all forms of the Gameand in all events.

8.13 Players who participate in the Olympic Events accept and agree that any disputes relating to eligibility shall first be addressed pursuant to the rules of such Olympic Events and the IRB Regulations and that all internal procedures (including applicable National Olympic Committee rules/procedures) and/or IRB procedures shall be exhausted first. Thereafter, recourse may be had in respect of Olympic Events only (and not in relation to eligibility matters to which Regulation 8.6 to 8.16 does not apply) to the Court of Arbitration for Sport (CAS) in accordance with the provision applicable before such court and which will resolve definitively the dispute in accordance with the code of sports related arbitration. The IRB has the right to appear, attend and/or participate as a party in any appeal to CAS involving eligibility considerations for Olympic Events.

[...]

\section{EXPLANATORY GUIDELINES ON THE IM PLEMENTATION OF REGULATION 8}

ELIGIBILITY TO PLAY FOR NATIONAL REPRESENTATIVE TEAMS

Following its deliberations on the question of Player eligibility, the Working Party has produced these Explanatory Guidelines on the implementation of Regulation 8. These Explanatory Guidelines must be read in conjunction with the terms of Regulation 8.

1. What is the Rationale/Philosophy of Regulation 8?

The rationale/philosophy of Regulation 8 is to ensure that Players selected to represent either the seni or and next senior fifteen-a-side National Representative Teams of a Union or a Union's senior National RepresentativeSevens Team have a genuine, close, credi ble and established national link with the country of the Union for which they have been selected. Such a national link is essential to maintain the unique characteristics and culture of elite international sporting competition between Unions. The integrity of International Matches between Unions depends upon strict adherence to the eligibility criteria set out in the Regulations.

2. Who establishes the eligibility criteria in Rugby Union?

The IRB will continue to establish the criteria by reference to which a Player's eligibility to play for the senior or next seni or fifteen-a-side National Representative Team of a Union or a Union's senior National Representative Sevens Team will be determined. Citizenship of a country and/or whether a Player holds a passport of a particular country are not, of themselves, determinative in identifying which Union a Player is eligible to represent This will be determined solely in accordance with the IRB's eligibility criteria. In relation to Olympic eligibility criteria see the Explanatory Guidelines on the Implementation of Regulation 8 - Olympic Eligibility.

3. What is the eligibility criteria in Rugby Union?

The existing IRB eligibility criteria set out in Regulation 8.1 will be maintained. This is based on the following:

(a) The country in which the Player was born; or

(b) The country in which one parent or grandparent of the Player was born; or

(c)The country in which the Player has completed thirty-six consecutive months of Residence immediately preceding the time of playing. Residence means the place or location in which a Player has his primary and permanent homeand Resident shall be construed accordingly; and

(d)For Olympic Event participation, the nationality of the Union / country the Player wishes to represent is also required.

4. If a Player has dual eligibility, can he play for the senior or next senior fifteen-a-side National Representative Team or the senior National RepresentativeSevens Team of more than one Union?

No, save for those Players that, before 1 J anuary 2000, allowed a period of 36 consecutive months to elapse after they had played for another Union and who played for the second Uni on before 1 J anuary 2000. The one Union only rule, introduced by the IRB from 1st J anuary 2000 (as set out in Regulation 8.2), will be maintained. A Player is only entitled to play Rugby Union for the senior or next senior fifteen-aside National Representative Team or the senior National Representative Sevens Team of one Union. Accordingly, if a Player is deemed to have played for such a team, even if he is able to satisfy one or more of the eligibility criteria set out in Regulation 8.1, he will not be able to play for any other Union. Consistent with the overall rationale underlying the eligibility Regulations, the one Union only rule is designed to maintain the integrity of the international Game Once a Player has committed himself to a particular Union, 


\section{APPENDICES}

through participation in one of the Matches or Tours identified in Regulations 8.3 or 8.4 , he is unable to change his "Rugby Nationality" which becomes fixed.

5. When is a Player deemed to have played for the senior or next senior fifteen-a-side National Representative Team of a Union or a Union's senior National Representative Sevens Team?

As a result of the one Union only rule, in particular, it is essential that Players and Unions understand the situations in which Players will be deemed to have played for the senior fifteen-a-side National Representative Team or the next senior fifteen-a-side National Representative Team of a Union or a Union's senior National Representative Sevens Team These situations are set out in Regulations 8.3 and 8.4. Players and Unions shall, at all times, have regard to the full terms of Regulations 8.3 and 8.4, however, by way of a summary only, the situations set out bel ow are covered:

Fifteen-a-side

(a)Players who participate in International Matches for the senior National Representative Team or the next senior National Representative Team of a Union against the senior or next senior National Representative Team of another Union.

(b) Players selected to represent a Union's senior Touring Squad who participate in any Match played by members of that Union's senior Touring Squad during an International Tour provided such International Tour includes an International Match(es) approved by theIRB.

(c)Players who participate in a Match for the senior or next senior National Representative Team of a Union agai nst a team made up of Players from a Union's senior Touring Squad during an International Tour which ind ludes International Match(es) approved by the IRB.

(d) Players, representing a Uni on's next senior Touring Squad who participate in a Match on an International Tour approved by the IRB against the senior National Representative Team or the next senior National Representative Team or the next senior National Representative Team of another Union.

(e) Players who play for the senior or next senior National Representative Team of a Union agai nst a team selected from a Union's next senior Touring Squad when such Match is played on an International Tour approved by theIRB.

Seven-a-side

(a)Players who play for a Union's senior National Representative Sevens team in an International Match against the senior National RepresentativeSevens team of another Union.

6. How do I know which teamis a Union's next senior fifteen-a-side National Representative Team?

(a) There should be no uncertainty over which team constitutes a Union's next senior National Representative Team Unions are required to notify the IRB of the name of their nominated next senior National Representative Team The teamnominated remains the Union's next senior National Representative Team unless the Union notifies the IRB of a change in this nomination. A Union is entitled to notify the IRB no more than once per calendar year of a change to its next senior National Representative Team provided that in doing so it shall take account of any Matches such teammay be scheduled to play and shall advise the Union of any senior or next senior National Representative Team it is scheduled to play reasonably in advance of such Match. The identity of a Union's next senior National Representative Team can be verified with the Union concerned and/or the IRB.

(b) Unions must ensure that all persons involved in an International Match (Players and team management including coaching staff) are made aware of the status of their team as the next senior National Representative Team and that of their opposing team where it is the senior or next senior National Representative Team of another Union and what that means from a capturing perspective under Regulation 8. Notwithstanding the Union's obligation to inform the Player and team management it shall be the sole responsibility of each Player to ensure that he is aware of the status of every Match in which he plays and the implications of playing in an International Match involving the senior or next senior National Representative Teams of two Unions.

(c)In addition to (a) and (b) above, Unions who designate their Under 20s National Representative Team as their next senior National Representative Team have a particular onus to clearly make the Team Players aware of the consequences of being captured for that Union at age grade level. Effective $1 \mathrm{~J}$ uly 2014, the Players on any such Team which participates in the IRB J unior World Championships, IRB J unior World Trophy or the Six Nations U20 Championship (where they are present at the Match played by that Team either as a replacement, substitute or playing member of that Team and has, at the time of the Match, reached the age of majority) will be captured. In this regard the status of the opposition teams in any Match in these named tournaments is not a factor to be considered.

7. What is the age of majority?

For the purposes of the Regulations (including, but not limited to Regulation 8), the age of majority is deemed to be acquired on a Player's 18th birthday.

8. Does the eigibility criteria apply to all forms of Rugby?

The eligibility criteria applies to the fifteen-a-side Game at senior and next senior National Representative level and in respect of a Union's seni or National RepresentativeSevens Team 


\section{NATIONALity ReQuirements In Oly mPiC SPORTS}

9. Does the eligibility criteria apply to all Unions in membership of theIRB?

$\mathrm{Yes}$, all Unions in membership of the IRB are obliged to comply with the eligi bility Regulation

10. How will the eligibility criteria be assessed?

Ordinarily, the task of assessing whether a Player satisfies any of the eligibility criteria set out in Regulation 8.1 is straightforward. However, as a result of professionalism greater mobility and societal family change this is not al ways the case Difficult cases have arisen and may continue to emerge The responses to the questions set out below are intended to provide further clarification as to how each eligibility criterion in Regulation 8.1 will be applied.

The questions and answers should be regarded as guidelines. They have been prepared on the basis of operational experience to date It is not possible to anticipate all scenarios that may arise and a degree of flexibility in the application of the Regulations will be maintained. Moving forward, in the event that there is any uncertainty or the need for clarification in relation to the application of the eligibility criteria in particular circumstances, then the Regulations Committee may be asked by the IRB to make a ruling on a Player's eligibility. In relation to any such adjudication, the Regulations Committee will al ways have in mind the rationale behind Regulation 8. The aim of the Regulations Committee in each case where darification may be required, is to establish whether, in all the circumstances, a Player has, by reference to the eligibility criteria in Regulation 8.1, been able to demonstrate a genuine, close and credible national link with the country that the Player wishes to represent. It is anticipated that over time a body of rulings by the Regulations Committee may develop which may, in turn, assist in providing further guidance to Unions in relation to eligibility matters.

11. When should any uncertainty over a Player's eligi bility be clarified?

It is essential that eligibility issues are clarified before a Player represents the senior or next senior fifteen-a side National Representative Team of a Union or a Union's senior National Representative Sevens Team. This is particularly important in light of the one Union only rule Accordingly, if a Union has any doubt over a Player's eligibility status it must takeall steps necessary to clarify the position beforeselecting the Player to play for its senior or next senior fifteen-aside National Representative Team or its senior National Representative Sevens Team

12. What does place of birth mean?

This should be the most straightforward criterion to apply. A Player's place of birth shall be the country within whose geographical borders he was born. However, difficult scenarios can arise even in relation to this criterion. For example, where a Player was born within the geographical borders of one country, but in a part of that country deemed by the law of the country concerned, to be the sovereign teritory of another, or where a Player was born in a military hospital. In such circumstances the matter should be referred to the Regulations Committee for a ruling. The Regulations Committee would need to establish the legal position together with other relevant facts and circumstances. In exceptional circumstances it may be possible for a Player to demonstrate, to the satisfaction of the Regulations Committee, that he is eligible to play for the Union within whose sovereign teritory he was born, even though that sovereign teritory may be within the geographical borders of another country.

13. What does Parent mean?

The term "parent" in the Regulations is limited to either a blood parent or a parent that has formally adopted a Player in accordance with the applicable legal requirements of the country concerned. Unless a Player has been adopted in accordance with the formal, legal requirements of the country concerned, the application of this criterion will be based on a Player's blood parent. When a Player has been formally adopted in accordance with the applicable legal requirements of the country concerned, the birth place of the Player's blood parent will no longer be relevant for the purposes of establishing the Player's eligibility pursuant to Regulation 8.1(b). The relevant parent will be the parent that has formally and legally adopted the Player. However in such circumstances, the relevant grandparents for the purposes of establishing a Player's eligibility pursuant to Regulation 8.1(b) will be the Player's blood grandparents. It is not possible under Regulation 8.1(b) to assume eligibility via non-blood grandparents even if a Player has been formally and legally adopted.

For the avoidance of any doubt, stepparents and fostering parents will not be considered to constitute a Player's parent for the purposes of Regulation 8.1(b).

14. How is the Residence criteria satisfied?

Regulation 8.1(c) requires a Player to complete 36 consecutive months of Residence immediately preceding the time of playing. Residence is defined as "the place or location in which the Player has his primary and permanent home" and Resident shall be construed accordingly. In essence, Regulation 8.1(c) constitutes a sporting naturalization procedure, based on a geographical/presence test. As in any naturalisation process, a number of factors will influence the determination of what constitutes a Player's permanent and primary home Such factors include, but are not limited to, the actual time spent in a country and the purpose of any absences during the qualification period. By being Resident in a country for a period of 36 consecutive months immediately preceding the time of playing for a Union, a Player is deemed to acquire a credible, 


\section{APPENDICES}

close and established national link with a country/Union that entitles him to participate in sporting competitions for that Union. Based on the overriding rationale of the eligibility Regulations, in cases wherea Player's eligibility is uncertain the Regulations Committee will consider that Player's eligibility by reference to the particular facts and circumstances of his case to establish if the Residency test, in the context of the overall rationale of the eligibility Regulations, has been satisfied. The principles set out in responses to the questions below will act as guidelines to the Regulations Committee when it is asked to consider any cases pursuant to this criterion.

15. Whose burden of proof?

In all cases where a Player is seeking to establish eligibility by reference to the Residency criteria in Regulation 8.1(c) (and, indeed, in relation to Regulation (or 8.1(a) and (b)), the burden of proof is on the Player and the Union that he wishes to represent to prove that Player's eligibility. Under Regulation 8.1(c), the Player and his Union must be able to demonstrate that, during the relevant period, the country in which he claims he has been Resident was, genuinely, the country that the Player treated as his home and is clearly the country in which the Player has his primary and permanent home If a Player has moved from one country to another, and is seeking to establish Residence in that new country, then he must also be able to demonstrate that he is clearly no longer Resident in the country in which he lived previously and that he no longer treats that country as his home For the avoi dance of any doubt, a Player cannot nominatea country as his home without demonstrating that he has satisfied the geographical commitment/presence test enshrined in Regulation 8.1(c). The geographical commitment/presence test will be vigorously upheld and applied to avoid abuse of the Residency criteria. For example, a Player that acquired/leased property in a country and who nominated that property as his permanent and primary home (even though he may only be present at that property and in that Union on a short term/temporary basis) would not satisfy the Residency test.

16. Will short breaks interrupt a period of Residence?

Short breaks in Residence, for example, for holidays, attending family/friends in other countries who may be ill etc, are unlike ly to change the placellocation of a Player's primary and permanent home and are, therefore, unlikely to interrupt a Player's period of Residence By way of a guideline, however, as a minimum requirement, it is likely that, save in exceptional circumstances, at least 10 months actual physical presence of the Player in the country concerned throughout any qualifying year of the Residency period, will be required to demonstrate that the country is the place where the Player has his primary and permanent home.

17. Does the 36 month period of Residence have to immediately precede playing for a Union?

Save in exceptional circumstances, the 36 months Residence will be expected to have been completed consecutively and be achieved immediately before the Player represents a Uni on. This is designed to createa contemporary national link with the country of the Union concerned. This factor will be particularly significant if a Player has moved to make a "new" country his Residence having been Resident in another country previously. In essence, in such circumstances, the Player, as well as demonstrating his commitment to a new country, must also be (and seen to be) relinquishing his ties with the country in which he lived previously. For the avoidance of any doubt, sedking to rely on short periods of Residence as a child in a particular country, combined with a short period of Residence in that same country prior to playing for a Union, is likely to createa link that would be too tenuous to satisfy the underlying intentions of establishing a contemporary, permanent, national link with a Union. However, each case will be assessed on its overall merits to establish if a Player is able to demonstrate a genuine, close, credibleand established national link by reference to the amount of time the Player can demonstrate that he has treated the "new" country as his home and other relevant factors.

Explanatory G uidelines on the Implementation of R egulation 8 - Olympic Eligibility

With the reintroduction of Rugby Sevens into the Olympic Games in Rio in 2016 there are certain rules which participants must adhere to for eligibility purposes. The Olympic Eligibility Regulations (8.6 to 8.16) have been introduced to accommodate the Olympic Charter Rules. To assist in the implementation of these Regulations, the following Guiddines have been devel oped to address the specifics around Olympic Sevens eligibility which differs from that of IRB eligibility requirements in that it is based sole y upon a nationality consideration al one The two sets of rules have been combined to achieve harmony between the objectives and underlying philosophy of Regulation 8 and the requirements of the Olympic Charter in the context of participation in Olympic Events. These Explanatory Guidelines must be read in conjunction with theterms of Regulation 8 and the Guidelines thereto.

1. Who is eligibleto play Olympic Sevens?

Any Player who meets the eligibility criteria in 8.1 and hol ds the nationality of the Union / country they wish to represent in the Olympic Games or Olympic Qualification process (known as the "Olympic Events"). The eligibility rules in the Olympic Charter together with the IRB eligibility rules must be complied with by Players who participatein Olympic Events.

2. Must a Player have the passport of the Union / country herepresents in Olympic Sevens?

The nationality of the Union / country the Player wishes to represent in Olympic Sevens is a requirement under the Olympic Charter and is therefore necessary for participation in Olympic Events. Nationality is 


\section{NATIONALITY REQUIREMENTS IN OLY MPIC SPORTS}

ordinarily demonstrated by the Player holding the passport of the Union / county they wish to represent. All matters relating to the determination of the country which a Player may represent in the Olympic Games shall ultimately be resolved by the IOC ExecutiveBoard.

3. Who will decideon Olympic Sevens eligibility?

Ordinarily, the assessment of whether a Player satisfies the eligibility criteria in Regulation 8.1 and 8.6 will be straightforward. However, in all cases where a Player who has been captured under Regulation 8.2 and who holds the nationality of another Union / country and wishes to participate in an Olympic Event(s) for the Union / country of which he is a national, the Player may apply to the IRB to represent the National Representative Sevens Team of that Union (or the Olympic Sevens Team of an National Olympic Committe), and the case shall be determined in the first place by the IRB Regulations Committee In the event there are other cases of uncertainty or there is the need for clarification a referral may be made to the IRB Regulations Committee

4. What is required to be submitted to the Regulations Committee?

Applications should be submitted to the IRB accompanied by all relevant supporting documents by the Union (or in applicable cases where there is no Union, the National Olympic Committee ("NOC")) of the country the Player wishes to represent in an Olympic Event. The application shall be prenotified to the Player's Union (namely the Union who's National Representative Team the Player has previously represented. The Player's Union may make written submissions to the IRB Regulations Committee or may beinvited to do so.

5. Can a Player with dual nationality, or having IRB eligibility for one Union but the nationality of another, represent both Unions / countries in the same Olympic qualification process?

No. A Player may only represent one Union / country in the Olympic Events. For example if a Player played for a Union in the Sevens World Series in the year it was designated as an Olympic Event the Player could not later in the same Sevens World Series play for another Union / country even in circumstances where he was deemed eligibly by the Regulations Committee to play for the second Union / country of which he is a national. The principle of Regulation 8.2 applies equally to Olympic Events, such that if a Player, having represented one Union / country in an Olympic Event they may not represent another Union / country thereafter.

6. Can a Player switch nationality?

Nationality is a matter which is governed by nation states. If a Player does switch nationality the effect of this upon their Olympic eligibility would need to be considered taking into account Regulation 8.6 to 8.16 and the Olympic Charter Rules regarding eligibility which can be found at www.olympic.org. However, a Player who has represented one Uni on / country in an Olympic Event(s) and who has changed their nationality or acquired a new nationality may participate in Olympic Events to represent their new Union / country provided that at least three (3) years have passed since the Player last represented their former Union / country and the approval of the International Olympic Committee, the relevant National Olympic Committee(s) and the IRB is obtained.

7. How will the Olympic eligibility criteria be assessed?

In the early days of the Olympic participation the view has been taken by the IRB that the Regulations Committee should assess all cases where a Player who has al ready been captured for a Union under the one Union only rule (Regulation 8.2) but wishes to subsequently play for another Union / country for which s/he holds nationality in an Olympic Event.

8. Is there any stand-down period?

Yes. The Player will be required to observe and demonstrate a stand down period of three (3) years between the time the Player last played for his Union and the time the Player first represents the second Union, which must be in an Olympic Event. Played, shall mean when s/he played for the senior, next senior or senior sevens National Representative Team of that Union for which s/he is captured. The principles of Regulation 8.3 apply in any assessment of this provision.

\section{What does 'first represents' mean?}

It means the first occasion when the Player represents the second Union in a Match, Tournament or Series of Matches - which must be in an Olympic Event. The Player would not however, be permitted for example to participate in preseason Matches or so-called 'friendly' matches or other Matches which are not Olympic Events representing the second Union. Training with the team of the second Union is permitted but the circumstances should not be such that it presents or implies to third parties that the Player is part of the National Representative Sevens Teamor Olympic Sevens Team of the second Union / country.

10. How will the stand-down period be assessed?

The onus will be on the Player to demonstrate to the reasonable satisfaction of the Regulations Committee the last occasion upon which s/he played for their former Union and that they have not represented such Union in the threeyear period before they represent their new Union/ country in an Olympic Event.

11. Arethese Olympic Guidelines to beread with theIRB Eligibility Guidelines?

Yes, both sets of Guidelines should be read together. 
12. What is the position for Unions who do not have a single NOC to represent them?

Member Unions of the IRB are not necessarily recognised in their own right with equivalent NOC's, for example the British Olympic Association (Team GB) is the NOC for Great Britain and therefore encapsulates the IRB Unions of England, Scotland, Wales and Northern I reland (represent by the all-Ireland body of the IRFU). In such case, Players from the underlying Unions would be eligible (where they comply with Regulation 8.1 and 8.6) to represent the Olympic Sevens Team of the NOC (if selected) in relevant Olympic Events.

13. If a Player plays for a combined team in an Olympic Event does it affect his eligibility in relation to the IRB?

If a Player plays for a combined team of a country in an Olympic Event (eg. Team GB) and he was previously not captured for a Union (under Regulation 8.2) then the Player will be deemed to be captured for one of the underlying Uni ons of the combined team of country he represented. So in the case of Team GB it would mean that the Player would then be free to play for one of England, Scotland, Wales and/or Ireland.

If a Player plays for a combined team of a country in an Olympic Event (eg. Team GB) and he was previously was captured for a Union (under Regulation 8.2) then the Player remains captured for such Union and their participation in the combined team in the Olympic Event will not affect their status.

14. Is therea right of appeal from the decision of the IRB Regulations

Yes. An Olympic Eligibility appeals committee has been established under Regulation 2 to deal with any appeal s of decisions by the IRB Regulations Committee

15. For theOlympic Games 2016 in Rio, do any special provisions apply?

Rugby Sevens will enter the Olympic Games for the first time in 2016. The qualification process has been established and all persons eligible to participate must have qualified by 11 July 2016. In terms of eligibility, the three (3) year stand-down period applies. However, given the timing of the clarification of the qualification process and the constitutional review of the eligibility requirements for Olympic Events a shorter stand-down period in respect only of the Olympic Games 2016 shall apply. In this regard any Player who wishes to represent a Union / country for whom s/he holds the nationality and has previously been captured for another Union may do so provided the Player stands down from their current Union at least 18 months before representing the Second Union in an Olympic Event in the Rio Olympic Games cycle

INTERNATIONAL RUGBY BOARD HANDBOOK AS FRAMED BY THE INTERNATIONAL RUGBY BOARD Lastupdated 1 December, 2013

RE GULATION 8. ELIGIBILITY TO PLAY FOR NATIONAL REPRESENTATIVE TEAMS

8.1 Subject to Regulation 8.2, a Player may only play for the senior fifteen-aside National Representative Team, the next senior fifteen-a-side National Representative Team and the senior National Representative Sevens Team of the Union of the country in which:

(a) hewas born; or

(b) one parent or grandparent was born; or

(c) he has completed thirty six consecutivemonths of Residenceimmediately preceding the time of playing.

8.2 A Player who has played for the senior fifteen-a-side National Representative Team or the next senior fifteen-a-side National Representative Team or the senior National Representative Sevens Team of a Union is not eligible to play for the senior fifteen-a-side National Representative Team or the next senior fifteen-asideNational RepresentativeTeam or the senior National RepresentativeSevens Team of another Union.

8.3 For the purposes of this Regulation, a Player is deemed to have played for the senior fifteen-a-side National RepresentativeTeam or the next senior fifteen-a-sideNational RepresentativeTeam of a Union if:

(a) He is selected for such team to play in an International Match against the senior fifteen-a-side National Representative Team or the next senior fifteen-a-side National Representative Team of another Union (or in a fifteen-a-side international Match against another Union's senior or next senior Touring Squad during an IRB approved International Tour) and is present at the Match played by that team either as a replacement, substitute or a playing member of that team and has, at the time of the Match, reached the age of majority; or (b) He is selected to represent a Union's seni or Touring Squad on an International Tour which indudes an International Match or Matches approved by the IRB and is present at any fifteen-a-side Match played on that International Tour either as a replacement, substitute

or a playing member of a team selected from the Union's senior Touring Squad and has, at the time of the Match, reached the age of majority; or

(c) He is selected to represent a Union's next senior Touring Squad on an IRB approved International Tour and during that International Tour he is present at a Match against the senior fifteen-a-side National Representative Team or the next seni or fifteen-a-side National Representative Team of another Uni on either as a replacement, substitute or playing member of a team selected from the Union's next senior Touring Squad and has, at the time of the Match reached the age of majority.

8.4 For the purposes of this Regulation, a Player is deemed to have played for the senior National Representative Sevens Team of a Union if he is selected to represent a Union's senior National 
Representative Sevens Team in an International Match against the senior National Representative Sevens Team of another Union and is present at the Match played by that Teameither as a replacement, substitute or playing member of that Teamand has, at the time of the Match, reached the age of majority.

Responsibility, breach and penalties for a breach of Regulation 8

8.5 Regulation 8 is a strict liability offence and shall be construed in accordance with the principles of strict liability under English law. It is not, therefore, necessary that fault or intent on the part of a Uni on be shown in order for a breach of Regulation 8 to be established. Nor is lack of fault or intent on the part of a Union a defence to a breach of Regulation 8. For

the avoidance of any doubt (and without limiting a Union's other obligations and responsibilities for the conduct, acts or omissions of its members and Persons under its jurisdiction pursuant to any other Regulation) Unions are responsible and accountable for the conduct of their Players and all Persons under its jurisdiction in relation to compliance with the provisions of Regulation 8 and any breach of Regulation 8 by such Player(s) or Person(s) shall be deemed to be a breach of Regulation 8 by the Union concerned. Each breach of Regulation 8 by a Union, howsoever arising, will result in a minimum fixed fine being imposed on the Union concerned. The minimumfixed fines for each breach of Regulation 8 areas follows:

(a) For a Union that is represented on the Council $£ 100,000$ sterling;

(b) For all other IRB Member Unions $£ 25,000$ sterling.

Based on the facts and circumstances of any breach of Regulation 8 the applicable minimum fixed fine as set out above may be increased. In addition, other penalties as set out in Regulation 18.6 may al so be imposed on the Union concerned.

8.5.1 In exceptional circumstances, a Union in breach of Regulation 8 may make submissions to the relevant disciplinary body appointed under Regulation 18 to adjudicate on the case as to why the Union should not be subject to the applicable minimum fixed fine. For the avoidance of any doubt, however, the relevant disciplinary body shall only beentitled to reduce the applicable mini mumfixed fine set out in this Regulation where the Uni on is able to provide clear and indisputable evidence that truly exceptional circumstances exist and that the Union concerned had taken all necessary steps to comply with Regulation 8.

8.6 To be eligible to participate in the Olympic Games, Olympic qualification events (together "Olympic Events") or other events governed by the Olympic Charter all members of the senior National Representative Sevens Team(s) of a Union or the selected Olympic Sevens Team(s) of a National Olympic Committee shall comply with Regulation 8.1 and must bea national of the country of the National Olympic Committee which it is representing in such Olympic Events. Regulation 8.2 applies equally to all Players.

8.7 A Player who is a national of the country or Union for which he has been captured under Regulation 8.2 and who hol ds the nationality of another country or Union, may apply to participate in an Olympic Event to represent his new country or Union subject to the following conditions;

8.7.1 The Regulations Committee shall consider the application of a Player under this Regulation 8.7 which must be submitted with all relevant supporting documentation by the Union for whom the Player wishes to next represent in an Olympic Event (or a Union associated with the Olympic Sevens Team the Player wishes to represent). The application shall be prenotified to the Player's Union (namely the Union whose National Representative Team the Player represented);

8.7.2 The Player will be required to observeand demonstrate a stand down period of at least 3 years since the timethe Player last represented their former Union and the time the Player first plays for the second Union or country, which must be in an Olympic Event The Player may not represent the second Union in any other form of the Game until after they have participated in such Olympic Event.

(a) Solely in respect of the Rio Olympic Games 2016, a stand down period of at least 18 months will be permitted, between the time the Player last represented their former Union and the time the Player first plays for the second Union or country, which must be in an Olympic Event in the Rio Olympic Games cycle, which the Player must observeand demonstrate.

8.8 Where the Player is not a national of the Union for which he has been captured under Regulation 8.2, and he meets the Olympic eligibility criteria (in Regulation 8.6 to 8.13 ) as determined by the Regulations Committee, he shall be eligible for selection to play for the Union / country of which he is a national, in an Olympic Event, subject to satisfying the applicable stand down period.

8.9 A Player who is eligible or captured for a Union that cannot participate in an Olympic Event because there is no National Olympic Committee solely for the territory of such Union, may, subject to the Olympic eligibility criteria (in Regulation 8.6 to 8.13), be eligible to play for the Olympic Sevens Team of a National Olympic Committee of which he is a national, provided that such team is not associated with any one single Union. In such circumstances the following provisions shall apply;

8.9.1 Where the Player has been captured under Regulation 8.2 for a Union he shall remain captured for such Union notwithstanding the Player's representation for the Olympic Sevens Team of a National Olympic Committeein an Olympic Event;

8.9.2 Wherethe Player has not previously been captured under Regulation 8.2 and herepresents the Olympic Sevens Team of a National Olympic Committee in an Olympic Event he will be deemed to be captured for 


\section{APPENDICES}

one of the underlying Unions which support the Olympic Sevens Team of the relevant National Olympic Committee, and the Player must elect which of those underlying Unions he shall be captured by for the purposes of Regulation 8.

8.10 A Player who has represented one Union or Olympic Team in an Olympic Event and who has changed his nationality or acquired a new nationality, may apply to participate in an Olympic Event to represent his new Union or country provided that at least three years have passed since the Player last represented his former Union or country and the approval of the International Olympic Committee, the relevant National Olympic Committee(s) and the IRB is obtained. This period may be reduced or even cancelled with the agrement of the IRB and the National Olympic Committees concerned and by the IOC Executive Board, which takes into account the circumstances of each case

8.11 A Player may not represent two different Unions or a Union and an Olympic Sevens Team(s) of a National Olympic Committee in the sameOlympic Event(s).

8.12 Once the Player has represented the Union of which he is a national, in an Olympic Event, he shall thereafter betied to that Union for all forms of the Gameand in all events.

8.13 Players who participate in the Olympic Events accept and agree that any disputes relating to eligibility shall first be addressed pursuant to the rules of such Olympic Events and the IRB Regulations and that all internal procedures (including applicable National Olympic Committee rules/procedures) and/or IRB procedures shall be exhausted first. Thereafter, recourse may be had in respect of Olympic Events only (and not in relation to eligibility matters to which Regulation 8.6 to 8.16 does not apply) to the Court of Arbitration for Sport (CAS) in accordance with the provision applicable before such court and which will resolve definitively the dispute in accordance with the code of sports related arbitration. The IRB has the right to appear, attend and/or partici pate as a party in any appeal to CAS involving eligibility considerations for Olympic Events.

[... ]

\section{EXPLANATORY GUIDELINES ON THE IM PLEMENTATION OF REGULATION 8}

ELIGIBILITY TO PLAY FOR NATIONAL REPRESENTATIVE TEAMS

Following its deliberations on the question of Player eligibility, the Working Party has produced these Explanatory Guidelines on the implementation of Regulation 8. These Explanatory Guidelines must be read in conjunction with the terms of Regulation 8.

1. What is the Rationale/Philosophy of Regulation 8?

The rationale/philosophy of Regulation 8 is to ensure that Players selected to represent either the seni or and next senior fifteen-a-side National Representative Teams of a Union or a Union's senior National Representative Sevens Team havea genuine, close, credible and established national link with the country of the Union for which they have been selected. Such a national link is essential to maintain the unique characteristics and culture of elite international sporting competition between Unions. The integrity of International Matches between Unions depends upon strict adherence to the eligibility criteria set out in the Regulations.

2. Who establishes the eligibility criteria in Rugby Union?

The IRB will continue to establish the criteria by reference to which a Player's eligibility to play for the senior or next senior fifteen-a-side National Representative Team of a Union or a Union's senior National Representative Sevens Team will be determined. Citizenship of a country and/or whether a Player holds a passport of a particular country are not, of themselves, determinative in identifying which Union a Player is eligible to represent This will be determined solely in accordance with the IRB's eligibility criteria. In relation to Olympic eligibility criteria see the Explanatory Guidelines on the Implementation of Regulation 8 - Olympic Eligibility.

3. What is the eligibility criteria in Rugby Union?

The existing IRB eligibility criteria set out in Regulation 8.1 will be maintained. This is based on the following:

(a) The country in which the Player was born; or

(b) The country in which one parent or grandparent of the Player was born; or

(c) The country in which thePlayer has completed thirty-six consecutive

months of Residence immediately preceding the time of playing. Residence means the place or location in which a Player has his primary and permanent homeand Resident shall beconstrued accordingly; and

(d) For Olympic Event participation, the nationality of the Union / country the Player wishes to represent is also required.

4. If a Player has dual eligibility, can he play for the senior or next senior fifteen-a-side National RepresentativeTeamor the senior National RepresentativeSevens Team of morethan one Union?

No, save for those Players that, before $1 \mathrm{~J}$ anuary 2000, al lowed a period of 36 consecutive months to elapse after they had played for another Union and who played for the second Uni on before 1 J anuary 2000. The one Union only rule, introduced by the IRB from 1st January 2000 (as set out in Regulation 8.2), will be maintained. A Player is only entitled to play Rugby Union for the senior or next senior fifteen-a-side 
National Representative Team or the senior National Representative Sevens Team of one Union. Accordingly, if a Player is deemed to have played for such a team, even if he is able to satisfy one or more of the eligibility criteria set out in Regulation 8.1, he will not be able to play for any other Union. Consistent with the overall rationale underlying the eligibility Regulations, the one Union only rule is designed to maintain the integrity of the international Game Once a Player has committed himself to a particular Union, through participation in one of the Matches or Tours identified in Regulations 8.3 or 8.4, he is unable to change his "Rugby Nationality" which becomes fixed.

5. When is a Player deemed to have played for the senior or next senior fifteen-a-side National RepresentativeTeam of a Union or a Union's senior National Representative Sevens Team?

As a result of the one Union only rule, in particular, it is essential that Players and Unions understand the situations in which Players will be deemed to have played for the senior fifteen-a-side National Representative Team or the next senior fifteen-a-side National Representative Team of a Union or a Union's senior National Representative Sevens Team These situations are set out in Regulations 8.3 and 8.4. Players and Unions shall, at all times, have regard to the full terms of Regulations 8.3 and 8.4, however, by way of a summary only, the situations set out below are covered:

Fifteen-a-side

(a) Players who participate in International Matches for the senior National Representative Team or the next senior National Representative Team of a Union against the senior or next senior National Representative Team of another Union.

(b) Players selected to represent a Union's senior Touring Squad who participate in any Match played by members of that Union's senior Touring Squad during an International Tour provided such

International Tour includes an International Match(es) approved by the IRB.

(c) Players who participate in a Match for the senior or next senior National Representative Team of a Union agai nst a team made up of Players from a Union's senior Touring Squad during an International Tour which indudes International Match(es) approved by the IRB.

(d) Players, representing a Uni on's next senior Touring Squad who partici pate in a Match on an International Tour approved by the IRB against the senior National Representative Team or the next senior National Representative Team or the next senior National Representative Team of another Union.

(e) Players who play for the senior or next senior National Representative Team of a Union against a team selected from a Union's next senior Touring Squad when such Match is played on an International Tour approved by theIRB.

Seven-a-side

(a) Players who play for a Union's senior National Representative Sevens team in an International Match against the senior National Representative Sevens team of another Union.

6. How do I know which teamis a Union's next senior fifteen-a-side National Representative Team?

(a) There should be no uncertainty over which team constitutes a Union's next senior National Representative Team Unions are required to notify the IRB of the name of their nominated next senior National Representative Team The team nominated remains the Union's next senior National Representative Team unless the Union notifies the IRB of a change in this nomination. A Union is entitled to notify the IRB no more than once per calendar year of a change to its next senior National Representative Team provided that in doing so it shall take account of any Matches such teammay be scheduled to play and shall advise the Union of any senior or next senior National Representative Team it is scheduled to play reasonably in advance of such Match. The identity of a Union's next senior National Representative Team can be verified with the Union concerned and/or the IRB.

(b) Unions must ensure that all persons involved in an International Match (Players and team management including coaching staff) are made aware of the status of their team as the next senior National Representative Team and that of their opposing team where it is the senior or next senior National Representative Team of another Union and what that means from a capturing perspective under Regulation 8. Notwithstanding the Union's obligation to inform the Player and team management it shall be the sole responsibility of each Player to ensure that he is aware of the status of every Match in which he plays and the implications of playing in an International Match involving the senior or next senior National Representative Teams of two Unions.

7. What is the age of majority?

For the purposes of the Regulations (including, but not limited to Regulation 8), the age of majority is deemed to be acquired on a Player's 18th birthday.

8. Does the eligibility criteria apply to all forms of Rugby?

The eligibility criteria applies to the fifteen-a-side Game at senior and next senior National Representative leve and in respect of a Union's seni or National RepresentativeSevens Team

9. Does the eligibility criteria apply to all Unions in membership of the IRB?

Yes, all Unions in membership of the IRB are obliged to comply with the eligi bility Regulation

10. How will the eligibility criteria be assessed? 


\section{APPENDICES}

Ordinarily, the task of assessing whether a Player satisfies any of the eligibility criteria set out in Regulation 8.1 is straightforward. However, as a result of professionalism, greater mobility and societal family change this is not al ways the case Difficult cases have arisen and may continue to emerge The responses to the questions set out below are intended to provide further clarification as to how each eligibility criterion in Regulation 8.1 will be applied. The questions and answers should be regarded as guidelines. They have been prepared on the basis of operational experience to date It is not possible to anticipate all scenarios that may arise and a degree of flexibility in the application of the Regulations will be maintained. Moving forward, in the event that there is any uncertainty or the need for clarification in relation to the application of the eligibility criteria in particular circumstances, then the Regulations Committee may be asked by the IRB to make a ruling on a Player's eligibility. In relation to any such adjudication, the Regulations Committee will al ways have in mind the rationale behind Regulation 8. The aim of the Regulations Committee in each case where clarification may be required, is to establish whether, in all the circumstances, a Player has, by reference to the eligibility criteria in Regulation 8.1, been able to demonstrate a genuine, close and credible national link with the country that the Player wishes to represent. It is anticipated that over time a body of rulings by the Regulations Committee may develop which may, in turn, assist in providing further guidance to Unions in relation to eligibility matters.

11. When should any uncertainty over a Player's eligibility bedarified?

It is essential that eligibility issues are clarified before a Player represents the senior or next senior fifteen-aside National Representative Team of a Union or a Union's seni or National Representative Sevens Teem. This is particularly important in light of the one Union only rule. Accordingly, if a Union has any doubt over a Player's eligi bility status it must takeall steps necessary to clarify the position before selecting the Player to play for its senior or next senior fifteen-a-side National Representative Team or its senior National RepresentativeSevens Team

12. What does place of birth mean?

This should be the most straightforward criterion to apply. A Player's place of birth shall be the country within whose geographical borders he was bom. However, difficult scenarios can arise even in relation to this criterion. For example, where a Player was born within the geographical borders of one country, but in a part of that country deemed by the law of the country concerned, to be the sovereign territory of another, or where a Player was born in a military hospital. In such circumstances the matter should be referred to the Regulations Committee for a ruling. The Regulations Committee would need to establish the legal position together with other relevant facts and circumstances. In exceptional circumstances it may be possible for a Player to demonstrate, to the satisfaction of the Regulations Committee, that he is eligible to play for the Union within whose sovereign territory he was born, even though that sovereign territory may be within the geographical borders of another country.

13. What does Parent mean?

The term "parent" in the Regulations is limited to either a blood parent or a parent that has formally adopted a Player in accordance with the applicable legal requirements of the country concerned. Unless a Player has been adopted in accordance with the formal, legal requirements of the country concerned, the application of this criterion will be based on a Player's blood parent. When a Player has been formally adopted in accordance with the applicable legal requirements of the country concerned, the birth place of the Player's blood parent will no longer be relevant for the purposes of establishing the Player's eligibility pursuant to Regulation 8.1(b). The relevant parent will be the parent that has formally and legally adopted the Player. However in such circumstances, the relevant grandparents for the purposes of establishing a Player's eligibility pursuant to Regulation 8.1(b) will be the Player's blood grandparents. It is not possible under Regulation 8.1(b) to assume eligibility via non-blood grandparents even if a Player has been formally and legally adopted. For the avoidance of any doubt, stepparents and fostering parents will not be considered to constitutea Player's parent for the purposes of Regulation 8.1(b).

14. How is the Residence criteria satisfied?

Regulation 8.1(c) requires a Player to complete 36 consecutive months of Residence immediately preceding the time of playing. Residence is defined as "the place or location in which the Player has his primary and permanent home" and Resident shall be construed accordingly. In essence, Regulation 8.1(c) constitutes a sporting naturalization procedure, based on a geographical/presence test As in any naturalisation process, a number of factors will influence the determination of what constitutes a Player's permanent and primary home. Such factors include, but are not limited to, the actual time spent in a country and the purpose of any absences during the qualification period. By being Resident in a country for a period of 36 consecutive months immediately preceding the time of playing for a Union, a Player is deemed to acquire a credible, close and established national link with a country/Union that entitles him to participate in sporting competitions for that Union. Based on the overriding rationale of the eligibility Regulations, in cases wherea Player's eligibility is uncertain the Regulations Committee will consider that Player's eligibility by reference to the particular facts and circumstances of his case to establish if the Residency test, in the context of the overall rationale of the eligibility Regulations, has been satisfied. The principles set out in responses to the 


\section{NATIONALITY REQUIREMENTS IN OLYMPIC SPORTS}

questions below will act as guidelines to the Regulations Committee when it is asked to consider any cases pursuant to this criterion.

15. Whose burden of proof?

In all cases where a Player is seeking to establish eligibility by reference to the Residency criteria in Regulation 8.1(c) (and, indeed, in relation to Regulation (or 8.1(a) and (b)), the burden of proof is on the Player and the Union that he wishes to represent to prove that Player's eligibility. Under Regulation 8.1(c), the Player and his Union must be able to demonstrate that, during the relevant period, the country in which he claims he has been Resident was, genuinely, the country that the Player treated as his home and is clearly the country in which the Player has his primary and permanent home If a Player has moved from one country to another, and is seeking to establish Residence in that new country, then he must al so be able to demonstrate that he is clearly no longer Resident in the country

in which helived previously and that he no longer treats that country as his home. For the avoidance of any doubt, a Player cannot nominate a country as his home without demonstrating that he has satisfied the geographical commitment/presence test enshrined in Regulation 8.1(c). The geographical commitment/presencetest will be vigorously upheld and applied to avoid abuse of the Residency criteria. For example, a Player that acquired/leased property in a country and who nominated that property as his permanent and primary home (even though he may only be present at that property and in that Union on a short term/temporary basis) would not satisfy the Residency test.

16. Will short breaks interrupt a period of Residence?

Short breaks in Residence, for example, for holidays, attending family/friends in other countries who may be ill etc, are unlikely to changethe place/location of a Player's primary and permanent homeand are, therefore, unlikely to interupt a Player's period of Residence By way of a guideline, however, as a minimum requirement, it is likely that, save in exceptional circumstances, at least 10 months actual physical presence of the Player in the country concerned throughout any qualifying year of the Residency period, will be required to demonstrate that the country is the place where the Player has his primary and permanent home

17. Does the 36 month period of Residence have to immediately precede playing for a Union?

Save in exceptional circumstances, the 36 months Residence will be expected to have been completed consecutively and be achieved immediately before the Player represents a Uni on. This is designed to createa contemporary national link with the country of the Union concerned. This factor will be particularly significant if a Player has moved to make a "new" country his Residence having been Resident in another country previously. In essence, in such circumstances, the Player, as well as demonstrating his commitment to a new country, must also be (and seen to be) relinquishing his ties with the country in which he lived previously. For the avoidance of any doubt, seeking to rely on short periods of Residence as a child in a particular country, combined with a short period of Residence in that same country prior to playing for a Union, is likely to createa link that would betoo tenuous to satisfy the underlying intentions of establishing a contemporary, permanent, national link with a Union. However, each case will be assessed on its overall merits to establish if a Player is able to demonstrate a genuine, close, credi bleand established national link by reference to the amount of timethe Player can demonstrate that he has treated the "new" country as his home and other relevant factors.

[...]

Explanatory Guidelines on the Implementation of Regulation 8 - Olympic Eligibility

With the reintroduction of Rugby Sevens into the Olympic Games in Rio in 2016 there are certain rules which participants must adhere to for eligibility purposes. The Olympic Eligibility Regulations (8.6 to 8.16) have been introduced to accommodate the Olympic Charter Rules. To assist in the impl ementation of these Regulations, the following Guidelines have been devel oped to address the specifics around Olympic Sevens eligibility which differs from that of IRB eligibility requirements in that it is based solely upon a nationality consideration al one. The two sets of rules have been combined to achieve harmony between the objectives and underlying philosophy of Regulation 8 and the requirements of the Olympic Charter in the context of participation in Olympic Events. These Explanatory Guidelines must be read in conjunction with the terms of Regulation 8 and the Guidelines thereto.

1. Who is eligibleto play Olympic Sevens?

Any Player who meets the eligibility criteria in 8.1 and holds the nationality of the Union / country they wish to represent in the Olympic Games or Olympic Qualification process (known as the "Olympic Events"). The eligibility rules in the Olympic Charter together with the IRB eligibility rules must be complied with by Players who participatein Olympic Events.

2. Must a Player havethe passport of the Union / country herepresents in Olympic Sevens?

The nationality of the Union / country the Player wishes to represent in Olympic Sevens is a requirement under the Olympic Charter and is therefore necessary for participation in Olympic Events. Nationality is ordinarily demonstrated by the Player holding the passport of the Union / county they wish to represent. All matters relating to the determination of the country which a Player may represent in the Olympic Games shall ultimately be resolved by the IOC ExecutiveBoard. 


\section{APPENDICES}

3. Who will decide on Olympic Sevens eligibility?

Ordinarily, the assessment of whether a Player satisfies the eligibility criteria in Regulation 8.1 and 8.6 will be straightforward. However, in all cases where a Player who has been captured under Regulation 8.2 and who holds the nationality of another Union / country and wishes to participatein an Olympic Event(s) for the Union / country of which he is a national, the Player may apply to the IRB to represent the National Representative Sevens Team of that Union (or the Olympic Sevens Team of an National Olympic Committee), and the case shall be determined in the first place by the IRB Regulations Committee In the event there are other cases of uncertainty or there is the need for clarification a referral may be made to the IRB Regulations Committee.

4. What is required to be submitted to the Regulations Committee?

Applications should be submitted to the IRB accompanied by all relevant supporting documents by the Union (or in applicable cases where there is no Union, the National Olympic Committee ("NOC")) of the country the Player wishes to represent in an Olympic Event. The application shall be prenotified to the Player's Union (namely the Union who's National Representative Team the Player has previously represented. The Player's Union may make written submissions to the IRB Regulations Committee or may beinvited to do so.

5. Can a Player with dual nationality, or having IRB eligibility for one Union but the nationality of another, represent both Unions/ countries in the sameOlympic qualification process?

No. A Player may only represent one Union / country in the Olympic Events. For example if a Player played for a Union in the Sevens World Series in the year it was designated as an Olympic Event the Player could not later in the same Sevens World Series play for another Union / country even in circumstances where he was deemed eligibly by the Regulations Committee to play for the second Union / country of which he is a national. The principle of Regulation 8.2 applies equally to Olympic Events, such that if a Player, having represented one Union / country in an Olympic Event they may not represent another Union / country thereafter.

6. Can a Player switch nationality?

National ity is a matter which is governed by nation states. If a Player does switch national ity the effect of this upon their Olympic eligibility would need to be considered taking into account Regulation 8.6 to 8.16 and the Olympic Charter Rules regarding eligibility which can be found at www.olympic.org. However, a Player who has represented one Union / country in an Olympic Event(s) and who has changed their nationality or acquired a new nationality may participate in Olympic Events to represent their new Union / country provided that at least three (3) years have passed since the Player last represented their former Union / country and the approval of the International Olympic Committee, the relevant National Olympic Committee(s) and the IRB is obtained.

7. How will the Olympic eligibility criteria be assessed?

In the early days of the Olympic participation the view has been taken by the IRB that the Regulations Committee should assess all cases where a Player who has al ready been captured for a Union under the one Union only rule (Regulation 8.2) but wishes to subsequently play for another Union / country for which s/he holds nationality in an Olympic Event.

8. Is there any stand-down period?

Y es. The Player will be required to observe and demonstrate a stand down period of three (3) years between the time the Player last played for his Union and the time the Player first represents the second Union, which must be in an Olympic Event. Played, shall mean when s/he played for the senior, next senior or senior sevens National Representative Team of that Union for which s/he is captured. The principles of Regulation 8.3 apply in any assessment of this provision.

9. What does 'first represents' mean?

It means the first occasion when the Player represents the second Union in a Match, Tournament or Series of Matches - which must bein an Olympic Event. The Player would not however, be permitted for example to participate in preseason Matches or so-called 'friendly' matches or other Matches which are not Olympic Events representing the second Union. Training with the team of the second Union is permitted but the circumstances should not be such that it presents or implies to third parties that the Player is part of the National RepresentativeSevens Team or Olympic Sevens Team of the second Union / country.

10. How will the stand-down period be assessed?

The onus will be on the Player to demonstrate to the reasonable satisfaction of the Regulations Committee the last occasion upon which s/he played for their former Union and that they have not represented such Union in the three year period beforethey represent their new Union/ country in an Olympic Event.

11. Arethese Olympic Guidd lines to be read with the IRB Eligibility Guidelines?

$\mathrm{Yes}$, both sets of Guidelines should be read together.

12. What is the position for Unions who do not have a single NOC to represent them?

Member Unions of the IRB are not necessarily recognised in their own right with equivalent NOC's, for example the British Olympic Association (Team GB) is the NOC for Great Britain and therefore 
encapsulates the IRB Unions of England, Scotland, Wales and Northern Ireland (represent by the all-Ireland body of the IRFU). In such case, Players from the underlying Unions would be eligible (where they comply with Regulation 8.1 and 8.6) to represent the Olympic Sevens Team of the NOC (if selected) in relevant Olympic Events.

13. If a Player plays for a combined team in an Olympic Event does it affect his eligibility in relation to the IRB?

If a Player plays for a combined team of a country in an Olympic Event (eg. Team GB) and he was previously not captured for a Union (under Regulation 8.2) then the Player will be deemed to be captured for one of the underlying Unions of the combined team of country he represented. So in the case of Team GB it would mean that the Player would then be free to play for one of England, Scotland, Wales and/or Ireland. (eg. Team GB) and he was previously was captured for a Union (under Regulation 8.2) then the Player remains captured for such Union and their participation in the combined team in the Olympic Event will not affect their status.

14. Is therea right of appeal from the decision of the IRB Regulations

Yes. An Olympic Eligibility appeals committee has been established under Regulation 2 to deal with any appeal s of decisions by the IRB Regulations Committee

15 For the Olympic Games 2016 in Rio, do any special provisions apply?

Rugby Sevens will enter the Olympic Games for the first time in 2016. The qualification process has been established and all persons eligible to participate must have qualified by 11 July 2016. In terms of eligibility, the three (3) year stand-down period applies. However, given the timing of the clarification of the qualification process and the constitutional review of the eligibility requirements for Olympic Events a shorter stand-down period in respect only of the Olympic Games 2016 shall apply. In this regard any Player who wishes to represent a Union / country for whom s/he holds the nationality and has previously been captured for another Union may do so provided the Player stands down from their current Union at least 18 months before representing the Second Union in an Olympic Event in the Rio Olympic Games cycle

INTERNATIONAL RUGBY BOARD HANDBOOK 2013 AS FRAMED BY THE INTERNATIONAL RUGBY BOARD L ast updated: 31J uly, 2013

RE GULATION 8. ELIGIBILITY TO PLAY FOR NATIONAL REPRESENTATIVE TEAMS

8.1 Subject to Regulation 8.2, a Player may only play for the senior fifteen-aside National Representative Team, the next senior fifteen-a-side National Representative Team and the senior National Representative Sevens Team of the Union of the country in which:

(a) hewas born; or

(b) one parent or grandparent was born; or

(c) he has completed thirty six consecutive months of Residence immediately preceding the time of playing.

8.2 A Player who has played for the senior fifteen-a-side National Representative Team or the next senior fifteen-a-side National Representative Team or the senior National Representative Sevens Team of a Union is not eligible to play for the senior fifteen-a-side National Representative Team or the next senior fifteen-a sideNational Representative Team or thesenior National RepresentativeSevens Team of another Union.

8.3 For the purposes of this Regulation, a Player is deemed to have played for the senior fifteen-a-side National RepresentativeTeam or the next senior fifteen-a-sideNational RepresentativeTeem of a Union if:

(a) He is selected for such team to play in an International Match against the senior fifteen-a-side National Representative Team or the next senior fifteen-a-side National Representative Team of another Union (or in a fifteen-a-side international Match against another Union's senior or next senior Touring Squad during an IRB approved International Tour) and is present at the Match played by that team either as a replacement, substitute or a playing member of that team and has, at the time of the Match, reached the age of majority; or (b) He is selected to represent a Union's seni or Touring Squad on an International Tour which includes an International Match or Matches approved by the IRB and is present at any fifteen-a-side Match played on that International Tour either as a replacement, substitute or a playing member of a team selected from the Union's senior Touring Squad and has, at the time of the Match, reached the age of majority; or

(c) He is selected to represent a Union's next senior Touring Squad on an IRB approved International Tour and during that International Tour he is present at a Match against the senior fifteen-aside National Representative Team or the next seni or fifteen-a-side National Representative Team of another Uni on either as a replacement, substitute or playing member of a team selected from the Union's next senior Touring Squad and has, at the time of the Match reached the age of majority.

8.4 For the purposes of this Regulation, a Player is deemed to have played for the senior National Representative Sevens Team of a Union if he is selected to represent a Union's senior National Representative Sevens Team in an International Match against the seni or National Representative Sevens Team of another Union and is present at the Match played by that Teameither as a replacement, substituteor playing member of that Team and has, at the time of the Match, reached the age of majority.

Responsibility, breach and penalties for a breach of R egulation 8 
8.5 Regulation 8 is a strict liability offence and shall be construed in accordance with the principles of strict liability under English law. It is not, therefore, necessary that fault or intent on the part of a Uni on be shown in order for a breach of Regulation 8 to be established. Nor is lack of fault or intent on the part of a Union a defence to a breach of Regulation 8. For the avoi dance of any doubt (and without limiting a Union's other obligations and responsibilities for the conduct, acts or omissions of its members and Persons under its jurisdiction pursuant to any other Regulation). Unions are responsible and accountable for the conduct of their Players and all Persons under its jurisdiction in relation to compliance with the provisions of Regulation 8 and any breach of Regulation 8 by such Player(s) or Person(s) shall be deemed to bea breach of Regulation 8 by the Union concerned. Each breach of Regulation 8 by a Union, howsoever arising, will result in a minimum fixed fine being imposed on the Union concerned. The minimum fixed fines for each breach of Regulation 8 are as follows:

(a) For a Union that is represented on the Council $f 100,000$ sterling;

(b) For all other IRB Member Unions $f 25,000$ sterling.

Based on the facts and circumstances of any breach of Regulation 8 the applicable minimum fixed fine as set out above may be increased. In addition, other penalties as set out in Regulation 18.6 may al so be imposed on the Union concerned.

8.6 In exceptional circumstances, a Union in breach of Regulation 8 may make submissions to the relevant disciplinary body appointed under Regulation 18 to adjudicate on the case as to why the Union should not be subject to the applicable minimum fixed fine. For the avoidance of any doubt, however, the relevant disciplinary body shall only beentitted to reduce the applicable minimumfixed fine set out in this Regulation where the Uni on is able to provide clear and indisputable evidence that truly exceptional circumstances exist and that the Uni on concerned had taken all necessary steps to comply with Regulation 8.

EXPLANATORY GUIDELINES ON THE IMPLEMENTATION OF REGULATION 8 ELIGIBILITY TO PLAY FOR NATIONAL REPRESENTATIVE TEAMS

Following its deliberations on the question of Player eligibility, the Working Party has produced these Explanatory Guidelines on the implementation of Regulation 8. These Explanatory Guidelines must be read in conjunction with the terms of Regulation 8.

1. What is the Rational e/Philosophy of Regulation 8?

The rationale/philosophy of Regulation 8 is to ensure that Players selected to represent either the seni or and next senior fifteen-a-side National Representative Teams of a Union or a Union's senior National RepresentativeSevens Team have a genuine, close, credi ble and established national link with the country of the Union for which they have been selected. Such a national link is essential to maintain the unique characteristics and culture of elite international sporting competition between Unions. The integrity of International Matches between Unions depends upon strict adherence to the eligibility criteria set out in the Regulations.

2. Who establishes the eligibility criteria in Rugby Union?

The IRB will continue to establish the criteria by reference to which a Player's eligibility to play for the senior or next senior fifteen-a-side National Representative Team of a Union or a Union's senior National Representative Sevens Team will be determined. Citizenship of a country and/or whether a Player holds a passport of a particular country are not, of themselves, determinative in identifying which Union a Player is eligibleto represent. This will be determined solely in accordance with theIRB's eligibility criteria.

3. What is the eligibility criteria in Rugby Union?

The existing IRB eligibility criteria set out in Regulation 8.1 will be maintained. This is based on the following:

(a) The country in which the Player was born; or

(b) The country in which one parent or grandparent of the Player was born; or

(c) The country in which the Player has completed thirty-six consecutive months of Residence immediately preceding the time of playing. Residence means the place or location in which a Player has his primary and permanent homeand Resident shall beconstrued accordingly.

4. If a Player has dual eligibility, can he play for the senior or next senior fifteen-arside National RepresentativeTeamor the senior National RepresentativeSevens Team of more than one Union?

No, save for those Players that, before 1 J anuary 2000, allowed a period of 36 consecutive months to elapse after they had played for another Union and who played for the second Uni on before 1 J anuary 2000. The one Union only rule, introduced by the IRB from 1st J anuary 2000 (as set out in Regulation 8.2), will be maintained. A Player is only entitled to play Rugby Union for the senior or next senior fifteen-a-side National Representative Team or the senior National Representative Sevens Team of one Union. Accordingly, if a Player is deemed to have played for such a team, even if he is able to satisfy one or more of the eligibility criteria set out in Regulation 8.1, he will not be able to play for any other Union. Consistent with the overall rationale underlying the eligibility Regulations, the one Union only rule is designed to maintain the integrity of the international Game Once a Player has committed himself to a particular Union, 
through participation in one of the Matches or Tours identified in Regulations 8.3 or 8.4, he is unable to change his "Rugby Nationality" which becomes fixed.

5. When is a Player deemed to have played for the senior or next senior fifteen-a-side National Representative Team of a Union or a Union's senior National RepresentativeSevens Team?

As a result of the one Union only rule, in particular, it is essential that Players and Unions understand the situations in which Players will be deemed to have played for the senior fifteen-a-side National Representative Team or the next senior fifteen-a-side National Representative Team of a Union or a Union's senior National Representative Sevens Team These situations are set out in Regulations 8.3 and 8.4. Players and Unions shall, at all times, have regard to the full terms of Regulations 8.3 and 8.4, however, by way of a summary only, the situations set out bel ow are covered:

Fifteen-a-side

(a) Players who participate in International Matches for the senior National Representative Team or the next senior National Representative Team of a Union against the senior or next senior National Representative Team of another Union.

(b) Players selected to represent a Union's senior Touring Squad who participate in any Match played by members of that Union's senior Touring Squad during an International Tour provided such International Tour includes an International Match(es) approved by the IRB.

(c) Players who participate in a Match for the senior or next senior National Representative Team of a Union against a team made up of Players from a Union's senior Touring Squad during an International Tour which includes International Match(es) approved by the IRB.

(d) Players, representing a Uni on's next senior Touring Squad who participate in a Match on an International Tour approved by the IRB against the senior National Representative Team or the next senior National Representative Team or the next senior National Representative Team of another Union.

(e) Players who play for the senior or next senior National Representative Team of a Union against a team selected from a Union's next senior Touring Squad when such Match is played on an International Tour approved by theIRB.

Seven-a-side

(a) Players who play for a Union's senior National Representative Sevens team in an International Match against the senior National Representative Sevens team of another Union. 6. H ow do I know which team is a Union's next senior fifteen-a-side National Representative Team?

(a) There should be no uncertainty over which team constitutes a Union's next senior National Representative Team Unions are required to notify the IRB of the name of their nominated next senior National Representative Team The teamnominated remains the Union's next senior National Representative Team unless the Union notifies the IRB of a change in this nomination. A Union is entitled to notify the IRB no more than once per calendar year of a change to its next senior National Representative Team provided that in doing so it shall take account of any Matches such teammay be schedul ed to play and shall advise the Union of any senior or next senior National Representative Team it is scheduled to play reasonably in advance of such Match. The identity of a Union's next senior National Representative Team can be verified with the Union concerned and/or the IRB.

(b) Unions must ensure that all persons involved in an International Match (Players and team management induding coaching staff) are made aware of the status of their team as the next senior National Representative Team and that of their opposing team where it is the senior or next senior National Representative Team of another Union and what that means from a capturing perspective under Regulation 8. Notwithstanding the Union's obligation to inform the Player and team management it shall be the sole responsibility of each Player to ensure that he is aware of the status of every Match in which he plays and the implications of playing in an International Match involving the senior or next senior National Representative Teams of two Unions.

7. What is the age of majority?

For the purposes of the Regulations (including, but not limited to Regulation 8), the age of majority is deemed to be acquired on a Player's 18th birthday.

\section{Does the eligibility criteria apply to all forms of Rugby?}

The eligibility criteria applies to the fifteen-arside Game at senior and next senior National Representative level and in respect of a Union's seni or National Representative Sevens Team

9. Does the eligibility criteria apply to all Unions in membership of theIRB?

$\mathrm{Yes}$, all Unions in membership of theIRB are obliged to comply with the eligi bility Regulation

10. How will the eligibility criteria be assessed?

Ordinarily, the task of assessing whether a Player satisfies any of the eligibility criteria set out in Regulation 8.1 is straightforward. However, as a result of professionalism, greater mobility and societal family change this is not al ways the case. Difficult cases have arisen and may continue to emerge. The responses to the questions set out below are intended to provide further clarification as to how each eligibility criterion in Regulation 8.1 will be applied. The questions and answers should be regarded as guiddines. They have been 


\section{APPENDICES}

prepared on the basis of operational experience to date It is not possible to anticipate all scenarios that may arise and a degree of flexibility in the application of the Regulations will be maintained. Moving forward, in the event that there is any uncertainty or the need for clarification in relation to the application of the eligibility criteria in particular circumstances, then the Regulations Committee may be asked by the IRB to make a ruling on a Player's eligibility. In relation to any such adjudication, the Regulations Committee will al ways have in mind the rationale behind Regulation 8. The aim of the Regulations Committee in each case where clarification may be required, is to establish whether, in all the circumstances, a Player has, by reference to the eligibility criteria in Regulation 8.1, been able to demonstrate a genuine, close and credible national link with the country that the Player wishes to represent. It is anticipated that over time a body of rulings by the Regulations Committee may develop which may, in turn, assist in providing further guidance to Unions in relation to eligibility matters.

\section{When should any uncertainty over a Player's eligibility beclarified?}

It is essential that eligibility issues are clarified before a Player represents the senior or next senior fifteen-aside National Representative Team of a Union or a Union's senior National Representative Sevens Team This is particularly important in light of the one Union only rule Accordingly, if a Union has any doubt over a Player's eligibility status it must takeall steps necessary to clarify the position before selecting the Player to play for its senior or next senior fifteen-a-side National Representative Team or its senior National Representative Sevens Team

12. What does place of birth mean?

This should be the most straightforward criterion to apply. A Player's place of birth shall be the country within whose geographical borders he was born. However, difficult scenarios can arise even in relation to this criterion. For example, where a Player was born within the geographical borders of one country, but in a part of that country deemed by the law of the country concerned, to be the sovereign territory of another, or where a Player was born in a military hospital. In such circumstances the matter should be referred to the Regulations Committee for a ruling. The Regulations Committee would need to establish the legal position together with other relevant facts and circumstances. In exceptional circumstances it may be possible for a Player to demonstrate, to the satisfaction of the Regulations Committee, that he is eligible to play for the Union within whose sovereign territory he was born, even though that sovereign territory may be within the geographical borders of another country.

13. What does Parent mean?

The term "parent" in the Regulations is limited to either a blood parent or a parent that has formally adopted a Player in accordance with the applicable legal requirements of the country concerned. Unless a Player has been adopted in accordance with the formal, legal requirements of the country concerned, the application of this criterion will be based on a Player's blood parent. When a Player has been formally adopted in accordance with the applicable legal requirements of the country concerned, the birth place of the Player's blood parent will no longer be relevant for the purposes of establishing the Player's eligibility pursuant to Regulation 8.1(b). The relevant parent will be the parent that has formally and legally adopted the Player. However in such circumstances, the relevant grandparents for the purposes of establishing a Player's eligibility pursuant to Regulation 8.1 (b) will be the Player's blood grandparents. It is not possible under Regulation 8.1(b) to assume eligibility via non-blood grandparents even if a Player has been formally and legally adopted. For the avoidance of any doubt, stepparents and fostering parents will not be considered to constitutea Player's parent for the purposes of Regulation 8.1(b).

14. How is the Residence criteria satisfied?

Regulation 8.1(c) requires a Player to complete 36 consecutive months of Residence immediately preceding the time of playing. Residence is defined as "the place or location in which the Player has his primary and permanent home" and Resident shall be construed accordingly. In essence, Regulation 8.1(c) constitutes a sporting naturalization procedure, based on a geographical/presence test. As in any natural isation process, a number of factors will influence the determination include, but are not limited to, the actual time spent in a country and the purpose of any absences during the qualification period. By being Resident in a country for a period of 36 consecutive months immediately preceding the time of playing for a Union, a Player is deemed to acquire a credible, close and established national link with a country/Union that entitles him to participate in sporting competitions for that Union. Based on the overriding rationale of the eligibility Regulations, in cases where a Player's eligibility is uncertain the Regulations Committee will consider that Player's eligibility by reference to the particular facts and circumstances of his case to establish if the Residency test, in the context of the overall rationale of the eligibility Regulations, has been satisfied. The principles set out in responses to the questions below will act as guidelines to the Regulations Committee when it is asked to consi der any cases pursuant to this criterion.

15. Whose burden of proof?

In all cases where a Player is seeking to establish eligibility by reference to the Residency criteria in Regulation 8.1(c) (and, indeed, in relation to Regulation (or 8.1(a) and (b)), the burden of proof is on the Player and the Union that he wishes to represent to prove that Player's eligibility. Under Regulation 8.1(c), 


\section{NATIONALITY REQUIREMENTS IN OLY MPIC SPORTS}

the Player and his Union must be able to demonstrate that, during the relevant period, the country in which he claims he has been Resident was, genuinely, the country that the Player treated as his home and is clearly the country in which the Player has his primary and permanent home If a Player has moved from one country to another, and is seeking to establish Residence in that new country, then he must also be able to demonstrate that he is clearly no longer Resident in the country in which he lived previously and that he no longer treats that country as his home For the avoidance of any doubt, a Player cannot nominate a country as his home without demonstrating that he has satisfied the geographical commitment/presence test enshrined in Regulation 8.1(c). The geographical commitment/presence test will be vigorously upheld and applied to avoid abuse of the Residency criteria. For example, a Player that acquired/leased property in a country and who nominated that property as his permanent and primary home (even though he may only be present at that property and in that Union on a short term/temporary basis) would not satisfy the Residency test.

16. Will short breaks interrupt a period of Residence?

Short breaks in Residence, for example, for holidays, attending family/friends in other countries who may be ill etc, are unlikely to change the placellocation of a Player's primary and permanent home and are, therefore, unlikely to interrupt a Player's period of Residence By way of a guideline, however, as a minimum requirement, it is likely that, save in exceptional circumstances, at least 10 months actual physical presence of the Player in the country concerned throughout any qualifying year of the Residency period, will be required to place where the Player has his primary and permanent home

17. Does the 36 month period of Residence have to immediately precede playing for a Union?

Save in exceptional circumstances, the 36 months Residence will be expected to have been completed consecutively and be achieved immediately before the Player represents a Union. This is designed to createa contemporary national link with the country of the Union concerned. This factor will be particularly significant if a Player has moved to make a "new" country his Residence having been Resident in another country previously. In essence, in such circumstances, the Player, as well as demonstrating his commitment to a new country, must also be (and seen to be) relinquishing his ties with the country in which he lived previously. For the avoidance of any doubt, seeking to rely on short periods of Residence as a child in a particular country, combined with a short period of Residence in that same country prior to playing for a Union, is likely to create a link that would be too tenuous to satisfy the underlying intentions of establishing a contemporany, permanent, national link with a Union. However, each case will be assessed on its overall merits to establish if a Player is able to demonstrate a genuine, close, credibleand established national link by reference to the amount of timethe Player can demonstrate that he has treated the "new" country as his home and other relevant factors.

\section{Sailing \\ 2016 ISAF RE G ULATIONS Updated With Changes Approved By C ouncil November 2015 APPE NDIX 3 - E LIGIBILITY CODE}

Note: From 1J anuary 2017, Regulations 19.8 - 19.13 will be substantially amended. For details, please see Submission 008-15 on the World Sailing website.

\section{ELIGIBILITY CODE}

\subsection{Competition Eligibility}

19.1 An individual shall have Competition Eligibility unless that eligibility has been suspended or revoked. 'Competition Eligibility' means the individual has a general entitlement to take part in competition in the sport of sailing.

19.2 An individual who does not have Competition Eligibility, or who is in breach of any condition imposed on his Competition Eligibility, shall not compete in any competition in the sport of sailing to which the RRS or these Regulations apply in wholeor in part.

19.3 A boat that races with, as part of her crew, a competitor who is in breach of this Code shall be disqual ified fromall such races.

\section{World Sailing Eligibility}

19.4 In addition to Competition Eligibility, a competitor has 'World Sailing Eligibility' if he meets the following conditions:

(a)he is a member of his/her Member National Authority or one of its affiliated organizations. Such membershi p to be established by the competitor either:

(i)by being entered by a national authority of the country of which the competitor is a national or ordinarily a resident; or

(ii)by presenting a valid membership card or certificate, or other satisfactory evidence of identity and membership;

(b)he is registered as an 'World Sailing Sailor' on the World Sailing Website for those events listed under Regulations 19.6(a) to (c), Olympic Qualification Events and World Sailing Graded Match Racing Events; (c)he has agreed to be governed and bound by the Regulations and any other requirements issued by World Sailing; and 


\section{APPENDICES}

(d)he has not had either his Competition Eligibility or World Sailing Eligibility suspended or revoked under Regulation 19.

19.5 In exceptional circumstances the Executive Committee may waive the requirements contained in Regulations 19.4.(a) and (b) for a sai lor who, for good reason, is unable to comply with those requirements.

\section{Events Requiring World Sailing Eligibility}

19.6 World Sail ling Eligibility is required for the following events:

(a)theOlympic Sailing Competition;

(b)the sailing events of Regional Games recognized by the International Olympic Committee;

(c)events including "World Sailing" in their titles;

(d)world and continental championships of World Sailing classes and world championships of the IMS,

Major Events and other events approved by World Sailing as a World Championship;

(e)any event at which the Organizing Authority, Member National Authority or World Sailing has appointed an International Jury, International Umpires,

International Race Officers, International Measurers or World Sailing Technical Delegates to act in that capacity;

(f)any event approved by a Member National Authority of World Sailing as an Olympic qual ifying event;

(h)any event designated by a Member National Authority within its jurisdiction as requiring competitors to satisfy the requirements of Regulation 19.7; and

(i)any event designated by World Sailing.

19.7 Additionally, with the prior approval of the relevant Member National Authority, an Organizing Authority may al so impose the same requirements as in Regulation19.6 above for an event and that fact shall then be stated in the notice of race and the sailing instructions.

\section{Nationality Criteria}

19.8 When participating in an World Sailing Event, a competitor must be a national of the Member National Authority that enters him or that he represents as determined under the guidelines set out in 19.12 below. However, the Notice of Race may specify that Regulation 19.8 does not apply to crew substitutes.

19.9 The following wording shall beincluded in the notice of race and sailing instructions:

"Any competitor in the championship must be a national of the country of the Mernber National Authority which is entering him/her or which herepresents."

19.10 All applications or disputes relating to the determination of the country that a competitor may represent in the championship shall be determined by the Executive Committee

19.11 The requirements of Regulation 19.8 shall not apply to competitors participating in the World Sailing Open Match World Racing Championship, World Sailing Women's Match Racing World Championship or theWorld Sailing Offshore TeamWorld Championship.

19.12 On application, the Executive Committee may grant exemptions to Regulation 19.8 in case of a competitor being a permanent resident of the country he wishes to represent. The following conditions will apply:

(a)a competitor must have been an ordinary resident of the country for more than three (3) consecutive years and must be abl eto establish his residency for this period;

(b) a competitor must have been member of the relevant Member National Authority, or a dub or other organization affiliated to the relevant national authority for at least three (3) consecutive years;

(c)a competitor who has represented one country in the Olympic Games, in continental or regional games or in world or regional championships recognized by the Federation (World Sailing), and who wants to represent another country, may represent this country provided that at least three (3) consecutive years have passed since the competitor last represented a different country in the events referred to above or the Executive Committee has reduced this period.

\section{Nationality Criteria Guiddines}

19.13 Based on the criteria used by the IOC for the Olympic Games and World Sailing policy, the following guidelines shall be used by the Executive Committeein assessing an application or dispute:

(a)A competitor who is a national of two or more countries at the same time may represent either one of them, as he/she may elect. However, after having represented one country in the Olympic Games, in World Sailing events, in continental or regional games or in world or regional champi onships recognized

by World Sailing, he may not represent another country unless he/she meets the conditions set forth in Regulation 19.12 that apply to persons who have changed their nationality or acquired a new nationality.

(b) A competitor who has represented one country in the Olympic Games, in World Sailing events, in continental or regional games or in world or regional championships recognized by World Sailing, and who has changed his national ity or acquired a new nationality, shall not participatein any of the events referred to above in this paragraph to represent his new country until three years after such change or acquisition. The Executive Committee may after taking into account the circumstances of each case, and with the agreement of the Member National Authorities concerned, reduce or cancel this period. 
(c)If a part of an existing country such as an associated state, province or overseas department, a country or colony acquires independence and becomes a new country or is incorporated into or is associated with another country recognized by the IOC, Regulations 19.12(a) and (b) shall not apply and a competitor may: (i)continue to represent the former country if he remains a national of that country; or

(ii) represent the new country of the country into which thenewly independent territory has been incorporated provided that country has a Member National Authority and the compeitor becomes or applies to becomea national of that country; and

(iii)the choice provided for in this paragraph may only be made once in respect of such change in national status.

(d)In all cases not expressly addressed in these Regulations, in particular those cases in which a competitor would be in a position to represent a country other than that of which he/sheis a national, or to have a choice as to the country which he/she intends to represent, the Executive Committee may take all decisions of a general or individual nature, and in particular issue specific requirements relating to nationality, citizenship, domicile or residence of the competitors, including the duration of any waiting period.

(e)In the instance of applications that need to be decided in haste, possibly shortly before the start of a championship, the Executive Committee shall nominate two individuals to determine applications/disputes on its behalf for the specific championships only.

\section{Suspension or revocation of Competitor Eligibility or World Sailing Eligibility}

19.14 Competition Eligibility or World Sailing Eligibility (or both) may besuspended or revoked:

(a)by a National Authority (for events within its own jurisdiction) or by World Sailing:

(i)for a breach of RRS 69.1(a); or

(ii)for competing, within the preceding two years, in an event that the competitor knew or should reasonably haveknown was a Prohibited Event; or

(b)for a breach of RRS 5.

World Sailing's powers in this Regulation are in addition to the provisions of RRS 69.

19.15 A 'Prohibited Event' means an event:

(a) permitting or requiring advertising beyond that permitted by theWorld Sailing Advertising Code;

(a) with prizes or other benefits refered to in Regulation 25.12.2 that is a national event not approved by the National Authority of the venueor an international event not approved by World Sailing;

(b) that is described as a world championship or uses the word "world", either in the title of the event or otherwise, and that is not approved by World Sailing;

(c)that does not conform to the requirements of RRS 89.1 and is not otherwise approved by World Sailing; or (d)for which the Organizing Authority that has not paid the World Sailing event fees, and

(e)has been listed on the World Sail ling website on a list maintained for this purpose

Subsequent review and appeals

19.16 The procedures for reviewing and appeal ing decisions of a National Authority or World Sailing under this Regulation are set out in Regulation 35.

19.17 After a decision to suspend or revoke, or to impose conditions on, Competition Eligibility and/or World Sailing Eligibility has become final, the Chief Executive Officer shall report the decision to all National Authorities, World Sailing Class Associations and other World Sailing affiliated organizations, which may al so suspend eligibility for events held within their own jurisdiction. TheChief Executive Officer may do this by publishing an appropriate notice on the World Sailing website

Reinstatement of Competition and/or World Sailing Eligibility

19.18 A competitor may apply to the World Sailing J udicial Board for his Competition Eligibility and/or World Sailing Eligibility to be reinstated, or haveany conditions imposed upon it removed or amended, if

(a) he establishes substantial, changed circumstances justifying the change; and

(b)a minimum of three years has passed since the original decision.

\section{Class Eligibility}

19.26 19.26 Any competitor whose eligibility has been suspended, denied, or revoked by an World Sailing Class may appeal that decision to the J udicial Board in accordance with Articles 77 to 81 and the procedures set out in theJ udicial Board Rules of Procedure

\section{ISAF RE GULATIONS Updated With Changes Approved By C ouncil November 2014}

APPENDIX 3-ELIGIBILITY CODE

19. ELIGIBILITY CODE

\subsection{Competition Eligibility}

19.1. An individual shall have Competition Eligibility unless that eligibility has been suspended or revoked. 'Compeition Eligibility' means the individual has a general entitlement to take part in competition in the sport of sailing. 


\section{APPENDICES}

19.2 An individual who does not have Competition Eligibility, or who is in breach of any condition imposed on his Competition Eligibility, shall not compete in any competition in the sport of sailing to which the RRS or these Regulations apply in whole or in part.

19.3 A boat that races with, as part of her crew, a competitor who is in breach of this Code shall be disqualified fromall such races.

\section{ISAF Eligibility}

19.4 In addition to Competition Eligibility, a competitor has 'ISAF Eligibility' if he meets the following conditions:

(a) he is a member of his/her Member National Authority or one of its affiliated organizations. Such membership to be established by the competitor either:

(i) by being entered by a national authority of the country of which the competitor is a national or ordinarily a resident; or

(ii) by presenting a valid membership card or certificate, or other satisfactory evidence of identity and membership;

(b) heis registered as an 'ISAF Sailor' on the ISAF Website for those events listed under Regulations 19.6(a) to (c), Olympic Qual ification Events and ISAF Graded Match Racing Events;

(c)he has agreed to be governed and bound by the Regulations and any other requirements issued by ISAF; and

(d) he has not had either his Competition Eligibility or ISAF Eligibility suspended or revoked under Regulation 19.

19.5 In exceptional circumstances the Executive Committee may waive the requirements contained in Regulations 19.4.(a) and (b) for a sailor who, for good reason, is unable to comply with those requirements.

\section{Events Requiring ISAF Eligibility}

19.6 ISAF Eligibility is required for the following events:

(a) the Olympic Sailing Competition;

(b) the sailing events of Regional Games recognized by theInternational Olympic Committee;

(c) events including "ISAF" in their titles;

(d) world and continental championships of ISAF classes and world championships of the IMS, Major Events and other events approved by ISAF as a World Championship;

(e) any event at which the Organizing Authority, Member National Authority or ISAF has appointed an International Jury, International Umpires, International Race Officers, International Measurers or ISAF Technical Delegates to act in that capacity;

(f) any event approved by a Member National Authority of ISAF as an Olympic qualifying event;

(h) any event designated by a Member National Authority within its jurisdiction as requiring competitors to satisfy the requirements of Regulation 19.7; and

(i) any event designated by ISAF.

19.7 Additionally, with the prior approval of the relevant Member National Authority, an Organizing Authority may also impose the same requirements as in 19.6 above for an event and that fact shall then be stated in the notice of race and the sailing instructions.

\section{Nationality Criteria}

19.8 When participating in an ISAF Event, a competitor must be a national of the Member National Authority that enters him or that he represents as determined under the guidelines set out in 19.12 below. However, the Notice of Race may specify that Regulation 19.8 does not apply to crew substitutes.

19.9 The following wording shall beincluded in the notice of race and sail ing instructions:

"Any competitor in the championship must be a national of the country of the Menber National Authority which is entering him/her or which he represents."

19.10 All applications or disputes relating to the determination of the country that a competitor may represent in the championship shall be determined by the Executive Committee

19.11 The requirements of Regulation 19.8 shall not apply to competitors participating in the ISAF Open Match World Racing Championship, ISAF Women's Match Racing World Championship or the ISAF Offshore Team World Championship.

19.12 On application, the Executive Committee may grant exemptions to Regulation 19.8 in case of a competitor being a permanent resident of the country he wishes to represent. The following conditions will apply:

(a) a compeitor must have been an ordinary resident of the country for more than three (3) consecutive years and must be abl eto establish his residency for this period;

(b) a competitor must have been member of the relevant Member National Authority, or a dub or other organization affiliated to the relevant national authority for at least three (3) consecutive years;

(c) a competitor who has represented one country in the Olympic Games, in continental or regional games or in world or regional championships recognized by the Federation (ISAF), and who wants to represent another country, may represent this country provided that at least three (3) consecutive years have passed 


\section{NATIONALITY REQUIREMENTS IN OLYMPIC SPORTS}

since the competitor last represented a different country in the events referred to above or the Executive Committee has reduced this period.

\section{Nationality Criteria Guidelines}

19.13. Based on the criteria used by the IOC for the Olympic Games and ISAF policy, the following guidelines shall be used by the Executive Committeein assessing an application or dispute:

(a ) A competitor who is a national of two or more countries at the same time may represent either one of them, as he/she may elect. However, after having represented one country in the Olympic Games, in ISAF events, in continental or regional games or in world or regional championships recognized by the ISAF, he may not represent another country unless he/she meets the conditions set forth in Regulation 19.12 that apply to persons who have changed their national ity or acquired a new nationality.

(b) A competitor who has represented one country in the Olympic Games, in ISAF events, in continental or regional games or in world or regional championships recognized by the ISAF, and who has changed his nationality or acquired a new nationality, shall not participate in any of the events referred to above in this paragraph to represent his new country until three years after such change or acquisition. The Executive Committee may after taking into account the circumstances of each case, and with the agreement of the Member National Authorities concerned, reduce or cancel this period.

(c) If a part of an existing country such as an associated state, province or overseas department, a country or colony acquires independence and becomes a new country or is incorporated into or is associated with another country recognized by the IOC, Regulations 19.12(a) and (b) shall not apply and a competitor may:

(i) continue to represent the former country if heremains a national of that country; or

(ii) represent the new country of the country into which the newly independent territory has been incorporated provided that country has a Member National Authority and the compeitor becomes or applies to become a national of that country; and

(iii) the choice provided for in this paragraph may only be made once in respect of such change in national status.

(d) In all cases not expressly addressed in these Regulations, in particular those cases in which a competitor would be in a position to represent a country other than that of which he/sheis a national, or to have a choice as to the country which he/she intends to represent, the Executive Committee may take all decisions of a general or individual nature, and in particular issue specific requirements relating to nationality, citizenship, domicile or residence of the competitors, including the duration of any waiting period.

(e) In the instance of applications that need to be decided in haste, possibly shortly before the start of a championship, the Executive Committee shall nominate two individuals to determine applications/disputes on its behalf for the specific championships only.

\section{Suspension or revocation of Competitor Eligibility or ISAF Eligibility}

19.14 Competition Eligibility or ISAF Eligibility (or both) may besuspended or revoked:

(a) by a National Authority (for events within its own jurisdiction) or by ISAF:

(i) for a breach of RRS 69.1(a); or

(ii) for competing, within the preceding two years, in an event that the competitor knew or should reasonably

have known was a Prohibited Event; or

(b) for a breach of RRS 5.

ISAF's powers in this Regulation are in addition to the provisions of RRS 69.

19.15 A 'Prohibited Event' means an event:

(A) permitting or requiring advertising beyond that permitted by the ISAF Advertising Code;

(B) with prizes or other benefits referred to in Regulation 25.12.2 that is a national event not approved by the National Authority of the venue or an international event not approved by ISAF;

(c) that is described as a world championship or uses the word "world", either in the title of the event or otherwise, and that is not approved by ISAF;

(D) that does not conform to the requirements of RRS 89.1 and is not otherwise approved by ISAF; or

(e) for which the Organizing Authority that has not paid theISAF Event Fees, and

(f) has been listed on theISAF website on a list maintained for this purpose

\section{Reviewby ISAF}

19.16 A National Authority must report any decision it makes under RRS 69.3 or Regulation 19.14 to ISAF, induding where it suspends or revokes Competition Eligibility and/or ISAF Eligibility. The decision of the National Authority (together with its reasons) shall be sent promptly in writing to the Chief Executive Officer.

19.17 On receipt of such a report, ISAF may confirm, revise or annul the decision (or remit it to the National Authority for reconsideration in accordance with the ISAF's directions).

19.18 After a decision to suspend or revoke, or to impose conditions on, Competition Eligibility and/or ISAF Eligibility has become final, the Chief Executive Officer shall report the decision to all National Authorities, ISAF Class Associations and other ISAF affiliated organizations, which may also suspend eligibility for 


\section{APPENDICES}

events held within their own jurisdiction. The Chief Executive Officer may do this by publishing an appropriate notice on the ISAF website

\section{Appeals}

19.19 A compeitor may appeal a decision to suspend, revoke, or impose conditions on his Competition or ISAF Eligibility to the Review Board. The competitor shall be advised of the right to appeal and be provided with a copy of the Review Board Rules of Procedure.

19.20 A National Authority or ISAF may ask for a review of its decision by the Review Board. The Review Board Rules of Procedure shall govern all appeals and requests for review.

19.21 Upon an appeal or request for review, the Review Board may confirm, revise or annul the decision, or require a hearing or rehearing.

19.22 Decisions of the Review Board may be appeal ed only in accordance with Article 82.

19.23 The Chief Executive Officer shall promptly notify all National Authorities, ISAF Class Associations and other ISAF affiliated organizations of all Review Board decisions made pursuant to this Regulation. The Chief Executive Officer may do this by publishing an appropriate notice on the ISAF website.

\section{Reinstatement of Competition and/or ISAF Eligibility}

19.24 A competitor may apply to ISAF for his Competition Eligibility and/or ISAF Eligibility to be reinstated, or have any conditions imposed upon it removed or amended, if

A)he establishes substantial, changed circumstances justifying the change; and

B) a minimum of three years has passed since the original decision.

19.25A competitor may appeal a refusal to grant such an application to the Review Board, in which case the procedures set out in Regulations 19.19 to 19.23 shall apply.

\section{Class Eligibility}

19.26 Any competitor whose eligibility has been suspended, denied, or revoked by an ISAF Class may appeal that decision to the Review Board in accordance with Articles 79, 81 and 82 and the procedures set out in the Review Board Rules of Procedure

\section{ISAF RE GULATIONS Updated With Changes Approved By Council November 2013}

\section{APPE NDIX 3 - ELIGIBILITY CODE}

\section{ELIGIBILITY CODE}

\subsection{Competition Eligibility}

19.1 An individual shall have Competition Eligibility unless that digibility has been suspended or revoked. 'Competition Eligibility' means the individual has a general entitlement to take part in competition in the sport of sailing.

19.2 An individual who does not have Competition Eligibility, or who is in breach of any condition imposed on his Competition Eligibility, shall not compete in any competition in the sport of sailing to which the RRS or these Regulations apply in wholeor in part.

19.3 A boat that races with, as part of her crew, a competitor who is in breach of this Code shall be disqual ified fromall such races.

\section{ISAF Eligibility}

19.4 In addition to Competition Eligibility, a competitor has 'ISAF Eligibility' if he meets the following conditions:

(a) he is a member of his/her Member National Authority or one of its affiliated organizations. Such membership to be establ ished by the competitor either:

(i) by being entered by a national authority of the country of which the competitor is a national or ordinarily a resident; or

(ii) by presenting a valid membership card or certificate, or other satisfactory evidence of identity and membership;

(b) heis registered as an 'ISAF Sailor' on the ISAF Website for thoseevents listed under Regulations 19.6(a) to (c), Olympic Qualification Events and ISAF Graded Match Racing Events;

(c) he has agreed to be governed and bound by the Regulations and any other requirements issued by ISAF; and

(d) he has not had either his Competition Eligibility or ISAF Eligibility suspended or revoked under Regulation 19.

19.5 In exceptional circumstances the Executive Committee may waive the requirements contained in Regulations 19.4.(a) and (b) for a sailor who, for good reason, is unable to comply with those requirements.

\section{Events Requiring ISAF Eligibility}

19.6ISAF Eligibility is required for the following events:

(a) the Olympic Sailing Competition;

(b) the sail ing events of Regional Games recognized by the International Olympic Committee;

(c) events induding "ISAF" in their titles; 
(d) world and continental championships of ISAF classes and world championships of the IMS, Major Events and other events approved by ISAF as a World Championship;

(e) any event at which the Organizing Authority, Member National Authority or ISAF has appointed an International Jury, International Umpires, International Race Officers, International Measurers or ISAF Technical Delegates to act in that capacity;

(f) any event approved by a Member National Authority of ISAF as an Olympic qualifying event;

(g) any event designated by a Member National Authority within its jurisdiction as requiring competitors to satisfy the requirements of Regulation 19.7; and

(h) any event designated by ISAF.

[...]

\section{Nationality Criteria}

19.8 When participating in an ISAF Event, a competitor must be a national of the Member National Authority that enters him or that he represents as determined under the guidelines set out in 19.12 below. However, the Notice of Racemay specify that Regulation 19.8 does not apply to crew substitutes. 19.9The following wording shall beincluded in the notice of race and sailing instructions:

"Any competitor in the championship must be a national of the country of the Member National Authority which is entering him/her or which he represents."

19.10 All applications or disputes relating to the determination of the country that a competitor may represent in the championship shall be determined by the Executive Committee

19.11 The requirements of Regulation 19.8 shall not apply to competitors participating in the ISAF Open Match World Racing Championship, ISAF Women's Match Racing World Championship or the ISAF Offshore Team World Championship.

19.12 On application, the Executive Committee may grant exemptions to Regulation 19.8 in case of a competitor being a permanent resident of the country he wishes to represent.

Thefollowing conditions will apply:

(a) a competitor must have been an ordinary resident of the country for more than thre (3) consecutive years and must be able to establish his residency for this period;

(b) a competitor must have been member of the relevant Member National Authority, or a dub or other organization affiliated to the relevant national authority for at least three (3) consecutive years;

(c) a competitor who has represented one country in the Olympic Games, in continental or regional games or in world or regional championships recognized by the Federation (ISAF), and who wants to represent another country, may represent this country provided that at least three (3) consecutive years have passed since the competitor last represented a different country in the events referred to above or the Executive Committee has reduced this period.

\section{Nationality Criteria Guiddines}

19.13 Based on the criteria used by the IOC for the Olympic Games and ISAF policy, the following guidelines shall be used by the Executive Committee in assessing an application:

(a) A compeitor who is a national of two or more countries at the same time may represent either one of them, as helshe may elect. However, after having represented one country in the Olympic Games, in ISAF events, in continental or regional games or in world or regional championships recognized by the ISAF, he may not represent another country unless he/she meets the conditions set forth in Regulation 19.12 that apply to persons who have changed their nationality or acquired a new national ity.

(b) A competitor who has represented one country in the Olympic Games, in ISAF events, in continental or regional games or in world or regional championships recognized by the ISAF, and who has changed his nationality or acquired a new nationality, shall not participate in any of the events refered to above in this paragraph to represent his new country until three years after such change or acquisition. The Executive Committee may after taking into account the circumstances of each case, and with the agreement of the Member National Authorities concerned, reduce or cancel this period.

(c) If a part of an existing country such as an associated state, province or overseas department, a country or colony acquires independence and becomes a new country or is incorporated into or is associated with another country recognized by the IOC, Regulations 19.12(a) and (b) shall not apply and a competitor may:

(i) continue to represent the former country if heremains a national of that country; or

(ii) represent the new country of the country into which the newly independent territory has been incorporated provided that country has a Member National Authority and the competitor becomes or applies to become a national of that country; and

(iii) the choice provided for in this paragraph may only be made once in respect of such change in national status.

(d) In all cases not expressly addressed in these Regulations, in particular those cases in which a competitor would be in a position to represent a country other than that of which he/sheis a national, or to have a choice as to the country which he/she intends to represent, the Executive Committee may take all decisions of a 
general or individual nature, and in particular issue specific requirements relating to nationality, citizenship, domicile or residence of the competitors, including the duration of any waiting period.

(e) In the instance of applications that need to be decided in haste, possibly shortly before the start of a championship, the Executive Committee shall nominate two individuals to determine applications/disputes on its behalf for the specific championships only.

\section{APPE NDIX 3 - ELIGIBILITY CODE Updated With Changes A pproved by C ouncil M ay 2013}

\section{ELIGIBILITY CODE}

\subsection{Competition Eligibility}

19.1 An individual shall have Competition Eligibility unless that eligibility has been suspended or revoked. 'Competition Eligibility' means the individual has a general entitlement to take part in competition in the sport of sailing.

19.2 An individual who does not have Competition Eligibility, or who is in breach of any condition imposed on his Competition Eligibility, shall not compete in any competition in the sport of sailing to which the RRS or these Regulations apply in whole or in part.

19.3 A boat that races with, as part of her crew, a competitor who is in breach of this Code shall be disqual ified fromall such races.

\section{ISAF Eligibility}

19.4 In addition to Competition Eligibility, a competitor has 'ISAF Eligibility' if he mets the following conditions:

(a) he is a member of his/her Member National Authority or one of its affiliated organizations. Such membership to be established by the competitor either:

(i) by being entered by a national authority of the country of which the competitor is a national or ordinarily a resident; or

(ii) by presenting a valid membership card or certificate, or other satisfactory evidence of identity and membership;

(b) he is registered as an 'ISAF Sailor' on the ISAF Website for thoseevents listed under Regulations 19.6(a) to (c), Olympic Qualification Events and ISAF Graded Match Racing Events;

(c) he has agreed to be governed and bound by the Regulations and any other requirements issued by ISAF; and

(d) he has not had either his Competition Eligibility or ISAF Eligibility suspended or revoked under Regulation 19.

19.5 In exceptional circumstances the Executive Committee may waive the requirements contained in Regulations 19.4.(a) and (b) for a sailor who, for good reason, is unable to comply with those requirements.

\section{Events Requiring ISAF Eligibility}

19.6 ISAF Eligibility is required for the following events:

(a) the Olympic Sailing Competition;

(b) the sailing events of Regional Games recognized by theInternational Olympic Committee;

(c) events induding "ISAF" in their titles;

(d) world and continental championships of ISAF classes and world championships of the IMS, Major Events and other events approved by ISAF as a World Championship;

(e) any event at which the Organizing Authority, Member National Authority or ISAF has appointed an International Jury, International Umpires, International Race Officers, International Measurers or ISAF Technical Delegates to act in that capacity;

(f) any event approved by a Member National Authority of ISAF as an Olympic qualifying event;

(g) any event designated by a Member National Authority within its jurisdiction as requiring competitors to satisfy the requirements of Regulation 19.7; and

(h) any event designated by ISAF.

19.7 Additionally, with the prior approval of the relevant Member National Authority, an Organizing Authority may also impose the same requirements as in 19.6 above for an event and that fact shall then be stated in the notice of race and the sailing instructions.

\section{Nationality Criteria}

19.8 When participating in an ISAF Event, a competitor must be a national of the Member National Authority that enters him or that he represents as determined under the guidelines set out in 19.12 below. However, the Notice of Racemay specify that Regulation 19.8 does not apply to crew substitutes.

19.9 The foll owing wording shall beind uded in the notice of race and sail ing instructions:

"Any competitor in the championship must be a national of the country of the Member National Authority which is entering him/her or which he represents."

19.10 All applications or disputes relating to the determination of the country that a competitor may represent in the championship shall be determined by the Executive Committee

19.11 The requirements of Regulation 19.8 shall not apply to competitors participating in the ISAF Open Match World Racing Championship or the ISAF Offshore Team World Championship. 
19.12 On application, the Executive Committee may grant exemptions to Regulation 19.8 in case of a competitor being a permanent resident of the country he wi shes to represent.

Thefollowing conditions will apply:

(a) a competitor must have been an ordinary resident of the country for more than three (3) consecutiveyears and must be able to establish his residency for this period;

(b) a competitor must have been member of the relevant Member National Authority, or a dub or other organization affiliated to the relevant national authority for at least three (3) consecutiveyears;

(c) a competitor who has represented one country in the Olympic Games, in continental or regional games or in world or regional championships recognized by the Federation (ISAF), and who wants to represent another country, may represent this country provided that at least three (3) consecutive years have passed since the competitor last represented a different country in the events referred to above or the Executive Committee has reduced this period.

\section{Nationality Criteria Guidalines}

19.13 Based on the criteria used by the IOC for the Olympic Games and ISAF policy, the following guidelines shall be used by the Executive Committee in assessing an application:

(a) A competitor who is a national of two or more countries at the same time may represent either one of them, as he/she may elect. However, after having represented one country in the Olympic Games, in ISAF events, in continental or regional games or in world or regional championships recognized by the ISAF, he may not represent another country unless he/she meets the conditions set forth in Regulation 19.12 that apply to persons who have changed their national ity or acquired a new nationality.

(b) A competitor who has represented one country in the Olympic Games, in ISAF events, in continental or regional games or in world or regional championships recognized by the ISAF, and who has changed his nationality or acquired a new nationality, shall not participate in any of the events refered to above in this paragraph to represent his new country until three years after such change or acquisition. The Executive Committee may after taking into account the circumstances of each case, and with the agreement of the Member National Authorities concerned, reduce or cancel this period.

(c) If a part of an existing country such as an associated state, province or overseas department, a country or colony acquires independence and becomes a new country or is incorporated into or is associated with another country recognized by the IOC, Regulations 19.12(a) and (b) shall not apply and a competitor may:

(i) continueto represent the former country if heremains a national of that country; or

(ii) represent the new country of the country into which the newly independent teritory has been incorporated provided that country has a Member National Authority and the competitor becomes or applies to become a national of that country; and

(iii) the choice provided for in this paragraph may only be made once in respect of such change in national status.

(d) In all cases not expressly addressed in these Regulations, in particular those cases in which a competitor would be in a position to represent a country other than that of which he/sheis a national, or to have a choice as to the country which he/she intends to represent, the Executive Committee may take all decisions of a general or individual nature, and in particular issue specific requirements relating to nationality, citizenship, domicile or residence of the competitors, including the duration of any waiting period.

(e) In the instance of applications that need to be decided in haste, possibly shortly before the start of a championship, the Executive Committee shall nominate two individuals to determine applications/disputes on its behalf for the specific championships only.

\section{ISAF regulations 2012 APPE NDIX 3 - ELIGIBILITY CODE}

19. ELIGIBILITY CODE

\section{ISAF Eligibility Rules}

19.1 A compeitor whose ISAF eligibility has been suspended or revoked shall not engage in any competition in the sport of sailing.

19.2. To beeligible to competein an event listed in 19.3, a competitor shall:

(a) begoverned by the regulations and rules of ISAF;

(b) be a member of his/her Member National Authority or one of its affiliated organizations. Such membershi p shall be established by the competitor:

(i) being entered by a national authority of the country of which the competitor is a national or ordinarily a resident; or

(ii) presenting a valid membership card or certificate, or other satisfactory evidence of identity and membership.

(c) Be registered as an 'ISAF Sailor' on the ISAF Website for those events listed under 19.3(a), (b) and (c), Olympic Qualification Events and ISAF Graded Match Racing Events.

19.2.1 In exceptional circumstances the Executive Committee may waive the requirements contained in Regulations 19.2.1 (b) and (c) for a sailor who, for good reason, is unable to comply with those requirements. 


\section{Events Requiring ISAF Eligibility}

19.3 ISAF Eligibility is required for the following events:

(a) the Olympic Sailing Competition;

(b) the sailing events of Regional Games recognized by the International Olympic Committee;

(c) events induding "ISAF" in their titles;

(d) world and continental championships of ISAF classes and world championships of the IMS, Major Events and other events approved by ISAF as a World Championship;

(e) any event at which the Organizing Authority, Member National Authority or ISAF has appointed an International Jury or International Umpires, International Race Officers, International Measurers or ISAF Technical Delegates to serve in their capacity for which they hold a Certificate of Appointment issued by ISAF;

(f) any event approved by a Member National Authority of ISAF as an Olympic qualifying event; and

(g) any event desi gnated by a Member National Authority within its jurisdiction as requiring ISAF eligibility. 19.3.1 With the approval of the relevant Member National Authority, an Organizing Authority may also require ISAF eligibility for an event when so stated in the notice of race and sailing instructions.

\section{Shooting}

Official Statutes Rules and Regulations EDITION 2013 (first print, 11/2012; second print, 01/2014; third print, 01/2015; fourth print 03/2016) Effective 1 J ANUARY 2013 Copyright: ISSF (applicable since 2000)

\subsection{ENTRY AND PARTICIPATION}

[...]

3.6.3 Any athlete must bea national of the country they represent

3.6.3.1 All disputes relating to the determination of the country which an athlete may represent shall be resolved by the ISSF Executive Committee

3.6.3.2 An athlete who is a national of two (2) or more countries at the same time may represent either one (1) of them, as hemay select.

However, after having represented one (1) country in the Olympic Games or in any ISSF Championships, he may not represent another country unl ess he meets the conditions set forth in paragraphs bel ow that apply to persons who have changed their nationality or acquired a new nationality.

3.6.3.3 An athl ete who has represented one (1) country in the Olympic Games or in any ISSF Championship, and who has changed his national ity or acquired a new nationality, may participate in ISSF Championships to represent his new country provided that at least three (3) years have passed since the athlete last represented his former country. This period may be reduced or even cancelled, with the agreement of the Federations concerned and by the ISSF Executive Committee, which takes into account the circumstances of each case

3.6.3.4 If an associated State, province or overseeas department, a country or colony acquires independence, if a country becomes incorporated within another country by reason of a change of border, if a country merges with another country, or if a new NOC is recogni sed by the IOC, an athlete may continue to represent the country to which he bel ongs or belonged. However, he may, if he prefers, elect to represent his country or be entered in ISSF Championships by his new Federation when recognized by the ISSF. This particular choice may be made only once.

3.6.3.5 Furthermore, in all cases in which an athlete would be eligible to participate in ISSF Championships, either by representing another country than his or by having the choice as to the country which such athlete intends to represent, the ISSF Executive Committee may take all decisions of a general or individual nature with regard to issues resulting from nationality, citizenship, domicile or residence of any athlete, including the duration of any waiting period.

3.6.4 The period following naturalization may be reduced or even cancelled with the agreement of the two (2) National Federations concerned and the final approval of the ISSF Executive Committee

3.6.5 An official declaration of eligibility for each athlete will be required from the Member Federation. Team officials participating in ISSF Championships must abide by the ISSF Rules and Regulations.

3.6.6 All athletes must sign a "Athl ete's Declaration" and have an ISSF ID Number before participation in any ISSF Championships. Failure to deliver a signed declaration before any start will lead to disqualification and cancellation of the results obtained.

3.6.7 Maximum participation in the Olympic Games is established by the IOC. Qualification standards are established by the ISSF Executive Committee that al so has the authority to take the final decision on the distribution of the quota places and the Wild Cards in cooperation with the IOC TripartiteCommission.

\section{Skating}

INTERNATIONAL SKATING UNION GENERAL REGULATIONS 2014 as accepted by the 55th Ordinary C ongress] une 2014 


\section{NATIONALITY REQUIREMENTS IN OLYMPIC SPORTS}

\section{E ligibility R ule 102}

\section{Eligibility Status}

A) The eligibility Rules of the ISU are based upon the principles that:

I) a person has the privilege to take part in the activities and competitions under the jurisdiction of the ISU only if such person respects the principles and policies of the ISU as expressed in the ISU Statutes and fulfills those obligations on the basis of which the ISU functions and governs all its activities;

ii) the condition of eligibility is made for the adequate protection of the economic and other interests of the ISU, which uses its financial revenues for the administration and development of the ISU sport disciplines and for the support and benefit of the Members and their Skaters.

B) An eligible person is one who elects to take part only in International Competitions which are:

I) sanctioned by the Member and/or theISU;

ii) conducted by ISU recognized and approved Officials, including Referees, Technical Controllers, Technical Specialists, J udges, Starters, Competitors Stewards and others; and

iii) conducted under ISU Regulations.

C) A Skater wishing to take part in ISU activities should not be placed at a disadvantage by reason of the necessity to prepare for and participate in ISU Events, the Olympic Winter Games, the Winter Youth Olympic Games and all International Competitions, exhibitions and tours properly sanctioned by the ISU or a Member. Accordingly, a Skater may receive payments for appearances, endorsements and exhibition performances and still remain eligible, provided:

I) such Skater complies with conditions established by the respective Member of which such Skater is a member concerning such appearances, endorsements and exhibition performances, including all financial arrangements;

ii) payments or other benefits to be received by such Skater for any Skating appearance are made through the respective Member of which such Skater is a member or at least with full information on such payments or benefits given by such Skater to the Member;

iii) such Skater complies with all other provisions of this Rule 102.

D) It is the responsibility of each Member to establish the basis for the receipt of payments by such Skater for appearances, endorsements and exhibition performances.

Members may share such payments in consideration of past and present support of such persons, but with not more than $10 \%$. Members shall monitor their Skaters to ensure that they do not participate in competitions that would render themineligible

\section{Definition of an ineligible person}

A person becomes ineligibleto participate in ISU activities and competitions by:

A) skating or officiating without the prior express authorization of the respective Member, in any capacity in a Skating competition, exhi bition or tour in any of the sport disciplines of theISU;

b) skating or officiating in a competition conducted by Officials (Referees, Technical Controllers, Technical Specialists, J udges, Starters, Competitors Stewards, etc.) not on the approved list of the respective Member or on the ISU approved list;

c) skating or officiating in an event not sanctioned by a Member and/or theISU; or

d) otherwise violating this Rule 102 .

In addition to the consequences and status of ineligibility described in Rule 102, paragraph 7 and Rule 103, paragraph 1, a person specifically declared indigible by the Council, if the Council so states in its decision, may be also declared to be persona non grata within the ISU and such person may not take part in ISU activities, stand for or hold any ISU Office, be a delegate to any Congress, be an ISU Official, be granted credentials to any ISU Event, seminar or meeting in any capacity, or otherwise occupy any position, appointed or otherwise, identified in the ISU Statutes as a position of service or responsibility on behalf of theISU.

\section{Participation of eligible persons}

Only eligible persons, including Skaters, are permitted to take part in ISU Events, ISU Congress, the Olympic Winter Games, the Winter Y outh Olympic Games and other International Competitions unless another Rule explicitly provides otherwise (See paragraph 4 below and Rule 121, paragraph 3.a). Eligible persons may take part in exhibitions and tours which may include ineligibleSkaters, only if such exhibitions and tours are sanctioned by a Member and/or theISU.

Eligible persons may participate in ISU approved Open International Competitions that include invited ineligible Skaters as approved by the Council. Members shall have the obligation to inform the ISU immediately in case that a Skater or Official, who has taken part in international activities as an eligible person, becomes ineligible.

[...]

7. L oss of eligibility

A) The consequence of a breach of the eligibility Rules shall be the loss of eligibility. The status of a person disqualified or suspended under other applicable Rules, does not affect the eligible status of such person, but 


\section{APPENDICES}

it limits, according to the terms of the applicable di sciplinary sanction, the right of such person to participate in the competitions and activities of the ISU.

B) The ISU Council, upon the presentation of such evidence as it considers sufficient at its sole discretion, may rule upon an al leged breach of the eligibility Rules, whether or not any protest has been made against an individual's eligiblestatus in skating.

C) Before a ruling is made by the Council, both the Member and the person concerned shall be notified and the person concerned shall be given the opportunity to furnish an explanation of the alleged breach (which may bein writing).

If the person concerned does not avail himself of such opportunity within fifteen (15) days of receipt of such notice, his right to furnish an explanation shall be waived.

8. Matters concerning eligibility not otherwise foreseen in the ISU Rules shall be considered by the Member concerned in a manner consistent with the spirit and intent of theISU Rules.

[... ]

Rule 109

1. Participation in Competitions

The International Competitions, listed in Rule 107, paragraphs 5, 6, 7, 8, 9, 10, 11 and 12 organized by Members, may be entered only by Competitors who belong to a Member and for whom the entry can be made only through the respective Members. For participation in the Olympic Winter Games, Rule 126 applies.

2a)In principle, a Skater may compete only as a member of the Member of the country of which he is a citizen.

B) A Skater may compete for the Member of the country of which he is not a citizen if he fulfils the following conditions:

I) he has resided for at least one year in that country and has been permitted to compete for that Member by the National Association of the country of which he is a citizen, or he has resi ded for at least one year in that country and he (or his parents if heis not of age) has applied for citizenship in that country;

ii) before J uly 1st immediately prior to his first International Competition as a member of the Member, he has not competed in any International Competition or ISU Championship for another Member during the twelve(12) preceding months;

iii) before J uly 1st immediately prior to his first ISU Championship as a member of the Member, he has not competed in any International Competition or ISU Championship for another Member during the eighteen (18) preceding months;

iv) any denial of a request for permit by the Member submitted in accordance with sub-paragraph (i) above may be the subject of a request to the Council by the involved Skater or any involved Member for exceptional permission as provided in paragraph 5 of this Rule.

C) In the case of a Pair Skating or an Ice Dance couple, one partner at least must be a citizen of the country of the Member for which the Pair Skating or I ce Dance couple competes. The other partner may be a citizen or resident of a country of any other Member. The residence and permit requirements and the waiting periods stated above in paragraph 2.b) i), ii), and iii) and in paragraph 3 do not apply to such partner. However, if such partner has already represented another Member, regardless of the discipline, the permit from the Member the Skater represented is required and the waiting period 12 months from the day of the last competition in which theSkater represented another Member applies.

D) In the case of Synchronized Skating Teams, up to $25 \%$ (four (4) Skaters on a team with sixteen (16) Skaters and three (3) Skaters on a team with twelve (12) Skaters) of a team may be from a foreign Member, if so permitted by the National Association of the country of which the Skater is a citizen, but such Skaters shall only represent one Member in the course of the same season (J uly 1st-J une 30th). Alternates are not included for the cal culation of percentages purposes. Restrictions specified in paragraph 2.b) do not apply.

3. If a Skater, who has al ready represented one Member in an International Competition or ISU Championship, intends to compete in the future for another Member, regardless of the grounds on which the possibility of such change is based, such Skater shall be subject to the waiting periods set forth in subparagraphs 2.b) ii) and iii) above

4. In the course of the same season (J uly 1st-J une 30th) a Skater may skate in competitions and exhibitions for only one and the same Member or affiliated club.

5. Exceptions to paragraphs $2 \& 3$ of this Rule may be granted by the Council, which may also enter a Competitor for an event (see al so Rule 115, paragraph 5 and Rules 130 and 131). A Competitor nominated by the ISU does not count in the quota of the country of his citizenship or residence.

The Council may also reject an application from a Member for a permission that a Skater who has or had foreign citizenship may compete for that Member, although the formalities and requirements stated in this Rule have been met, if in the opinion of the Council granting such application would be contrary to the purpose and spirit of the Rule (eg. in case that a Member tries to "import" several athletes with foreign 


\section{NATIONALITY REQUiREMENTS IN Oly mpic SPORTS}

citizenship, in particular when such athletes should form a new national team of such Member or its substantial part).

6. In exceptional cases, the Council may permit eligible persons to take part in competitions in countries in which there is no Member.

[...]

\section{The Olympic Winter Games R ule 126}

1. Skating Competitions at the Olympic Winter Games

The skating competitions in the Olympic Winter Games are International Competitions and not ISU Championships and are subject to the provisions of the Olympic Charter and ISU Regulations governing such competitions. In accordance with Rule 121, all Referees, Assistant Referees, Technical Controllers, Technical Specialists, Data \& Replay Operators, Judges, Starters and Competitors Stewards acting in the Olympic Winter Games must be designated ISU. A J udge may serve in not more than two (2) events.

2. Entry in the Olympic Winter Games is subject to the requirements of the Olympic Charter, as well as of the applicable ISU Regulations. They are subject to the Regulations of the IOC governing such competitions. [...]

7. Only Competitors from Members may participate in the Skating events of the Olympic Winter Games.

INTERNATIONAL SKATING UNION CONSTITUTION and GENERAL REGULATIONS 2012 as accepted by the 54th Ordinary Congress J une 2012

B. Eligibility R ule 102

1. E ligibility Status a) The ligibility Rules of the ISU are based upon the principles that:

i) a person has the privilege to take part in the activities and competitions under the jurisdiction of the ISU only if such person respects the principles and policies of the ISU as expressed in the ISU Statutes and fulfills those obligations on the basis of which the ISU functions and governs all its activities;

ii) the condition of eligibility is made for the adequate protection of the economic and other interests of the ISU, which uses its financial revenues for the administration and development of the ISU sport disciplines and for the support and benefit of the Members and their Skaters.

b) An digible person is one who elects to take part only in International Competitions which are:

i) sanctioned by the Member and/or theISU;

ii) conducted by ISU recognized and approved Officials, including Referees, Technical Controllers, Technical Specialists, J udges, Starters, Competitors Stewards and others; and

iii) conducted under ISU Regulations.

c) A Skater wishing to take part in ISU activities should not be placed at a disadvantage by reason of the necessity to prepare for and participate in ISU Events, the Olympic Winter Games, the Winter Youth Olympic Games and all International Competitions, exhibitions and tours properly sanctioned by the ISU or a Member. Accordingly, a Skater may receive payments for appearances, endorsements and exhibition performances and still remain eligible, provided:

i) such Skater complies with conditions established by the respective Member of which such Skater is a member concerning such appearances, endorsements and exhibition performances, including all financial arrangements;

ii) payments or other benefits to be received by such Skater for any Skating appearance are made through the respective Member of which such Skater is a member or at least with full information on such payments or benefits given by such Skater to the Member;

iii) such Skater complies with all other provisions of this Rule 102.

d) It is the responsibility of each Member to establish the basis for the receipt of payments by such Skater for appearances, endorsements and exhibition performances. Members may share such payments in consideration of past and present support of such persons, but with not more than $10 \%$. Members shall monitor their Skaters to ensure that they do not participatein competitions that would render themineligible.

\section{Definition of an ineligible person}

A person becomes ineligibleto participate in ISU activities and competitions by:

i) skating or officiating without the prior express authorization of the respective Member, in any capacity in a Skating competition, exhibition or tour in any of the sport disciplines of theISU;

ii) skating or officiating in a competition conducted by Officials (Referees, Technical Controllers, Technical Specialists, J udges, Starters, Competitors Stewards, etc.) not on the approved list of the respective Member or on the ISU approved list;

iii) skating or officiating in an event not sanctioned by a Member and/or theISU; or

iv) otherwise violating this Rule 102. In addition to the consequences and status of ineligibility described in Rule 102, paragraph 7 and Rule 103, paragraph 1, a person specifically dedared ineligible by the Council, if the Council so states in its decision, may be al so declared to be persona non grata within the ISU and such person may not take part in ISU activities, stand for or hold any ISU Office, be a delegate to any Congress, bean ISU Official, begranted credentials to any ISU Event, seminar or meeting in any capacity, or otherwise 


\section{APPENDICES}

occupy any position, appointed or otherwise, identified in the ISU Statutes as a position of service or responsibility on behalf of theISU.

\section{Participation of eligible persons}

Only eligible persons, including Skaters, are permitted to take part in ISU Events, the Olympic Winter Games, the Winter Youth Olympic Games and other International Competitions unless another Rule explicitly provides otherwise (Sœe paragraph 4 below and Rule 121, paragraph 3.a). Eligible persons may take part in exhibitions and tours which may include ineligible Skaters, only if such exhibitions and tours are sanctioned by a Member and/or the ISU. Eligible persons may participate in ISU approved Open International Competitions that ind ude invited ineligibleSkaters as approved by the Council.

Members shall have the obligation to inform the ISU immediately in case that a Skater or Official, who has taken part in international activities as an eligible person, becomes ineligible

$[\ldots]$

\section{L oss of eligibility}

a) The consequence of a breach of the eligibility Rules shall be the loss of eligibility. The status of a person disqualified or suspended under other applicable Rules, does not affect the eligible status of such person, but it limits, according to the terms of the applicable disciplinary sanction, the right of such person to participate in the competitions and activities of the ISU.

b) The ISU Council, upon the presentation of such evidence as it considers sufficient at its sole discretion, may rule upon an al leged breach of the eligibility Rules, whether or not any protest has been made against an individual's eligiblestatus in skating.

c) Before a ruling is made by the Council, both the Member and the person concerned shall be notified and the person concerned shall be given the opportunity to furnish an explanation of the alleged breach (which may be in writing). If the person concerned does not avail himself of such opportunity within fifteen (15) days of receipt of such notice, his right to furnish an explanation shall be waived.

8. Matters concerning eligibility not otherwise foreseen in the ISU Rules shall be considered by the Member concerned in a manner consistent with the spirit and intent of theISU Rules.

\section{Rule 109}

\section{Participation in Competitions}

The International Competitions, listed in Rule 107, paragraphs 5, 6, 7, 8, 9, 10, 11 and 12 organized by Members, may be entered only by Competitors who belong to a Member and for whom the entry can be made only through the respective Members. For participation in the Olympic Winter Games, Rule 126 applies.

2. a) In principle, a Skater may compete only as a member of the Member of the country of which he is a citizen.

b) A Skater may compete for the Member of the country of which he is not a citizen if he fulfils the following conditions:

i) he has resided for at least one year in that country and has been permitted to compete for that Member by the National Association of the country of which he is a citizen, or he has resided for at least one year in that country and he (or his parents if he is not of age) has applied for citizenship in that country;

ii) before J uly 1st immediately prior to his first International Competition as a member of the Member, he has not competed in any International Competition or ISU Championship for another Member during the twelve(12) preceding months;

iii) before J uly 1st immediately prior to his first ISU Championship as a member of the Member, he has not competed in any International Competition or ISU Championship for another Member during the eighteen (18) preceding months;

iv) Any denial of a request for permit by the Member submitted in accordance with sub-paragraph (i) above may be the subject of a request to the Council by the involved Skater or any involved Member for exceptional permission as provided in paragraph 5 of this Rule

c) In the case of a Pair Skating or an Ice Dance couple, one partner at least must bea citizen of the country of the Member for which the Pair Skating or Ice Dance couple competes. The other partner may be a citizen or resident of a country of any other Member. The residence and permit requirements and the waiting periods stated above in paragraph 2.b) i), ii), and iii) and in paragraph 3 do not apply to such partner. However, if such partner has already represented another Member, regardless of the discipline, the permit from the Member the Skater represented is required and the waiting period 12 months from the day of the last competition in which theSkater represented another Member applies.

d) In the case of Synchronized Skating Teams, up to 25\% (four (4) Skaters on a team with sixteen (16) Skaters and three (3) Skaters on a team with twelve (12) Skaters) of a team may be from a foreign Member, if so permitted by the National Association of the country of which the Skater is a citizen, but such Skaters shall only represent one Member in the course of the same season (July 1-J une 30). Alternates are not included for the cal culation of percentages purposes. Restrictions specified in paragraph 2.b) do not apply. 
3. If a Skater, who has already represented one Member in an International Competition or ISU Championship, intends to compete in the future for another Member, regardless of the grounds on which the possibility of such change is based, such Skater shall be subject to the waiting periods set forth in subparagraphs 2.b) ii) and iii) above

4. In the course of the same season (J uly 1st-J une 30th) a Skater may skate in competitions and exhibitions for only one and the same Member or affiliated club.

5. Exceptions to paragraphs $2 \& 3$ of this Rule may be granted by the Council, which may also enter a Competitor for an event (see al so Rule 115, paragraph 5 and Rules 130 and 131). A Competitor nominated by theISU does not count in the quota of the country of his citizenship or residence

The Council may also reject an application from a Member for a permission that a Skater who has or had foreign citizenship may compete for that Member, although the formalities and requirements stated in this Rule have been met, if in the opinion of the Council granting such application would be contrary to the purpose and spirit of the Rule (eg. in case that a Member tries to "import" several athletes with foreign citizenship, in particular when such athletes should form a new national team of such Member or its substantial part).

6. In exceptional cases, the Council may permit eligible persons to take part in competitions in countries in which there is no Member.

[...]

E. The Olympic Winter Games R ule 126

1. Skating Competitions at the Olympic Winter Games

The skating competitions in the Olympic Winter Games are International Competitions and not ISU Championships and are subject to the provisions of the Olympic Charter and ISU Regulations governing such competitions. In accordance with Rule 121, all Referees, Assistant Referees, Technical Controllers, Technical Specialists, Data \& Replay Operators, Judges, Starters and Competitors Stewards acting in the Olympic Winter Games must be designated ISU. A J udgemay servein not more than two (2) events.

2. Entry in the Olympic Winter Games is subject to the requirements of the Olympic Charter, as well as of the applicableISU Regulations. They are subject to the Regulations of the IOC governing such competitions. 3. For the Speed Skating events the provisions of Rules 202, 206, 209, 215 and 241 must be observed. 4. For theFigure Skating events the provisions of Rules 400-403 must be observed.

[... ]

\section{Skiing}

\section{Alpine Skiing}

THE INTERNATIONAL SKI COMPETITION RULES (ICR) BOOK IV JOINT REGULATIONS FOR ALPINE SKIING DOWNHILL SLALOM GIANT SLALOM SUPER-G, COMBINED EVENTS TEAM EVENTS PARALLEL EVENTS KO EVENTSAPPROVED BY THE $49^{\text {th }}$ INTERNATIONAL SKI CONGRESS, BARCELONA (SPA) Web Version July 2015; Oberhofen, J uly 2015

203 Licenceto participate in FIS Races (FIS Licence)

A licence to participate in FIS races is issued by a National Ski Association to competitors who fulfil the criteria for participation through registering the competitor with FIS in the respectivedi scipline(s).

203.1 The FIS licence year begins on J uly $1^{\text {t }}$ and finishes on $J$ une $30^{\text {th }}$ of the foll lowing year.

203.2 To be eligible for participation in FIS events, a competitor must have a licence issued by his National Ski Association. Such a licence shall be valid in the Northern and Southern hemispheres for the licence year only. The validity of a licence can be limited to participation in one specific country or in one or more specific events.

203.2.1 The National Ski Association must guarantee that all competitors registered with a FIS License to participate in FIS races accept the Rules of the International Ski Federation, in particular the provision which foresees the exclusive competence of the Court of Arbitration for Sport as the court of appeal in doping cases.

203.3 A National Ski Association may only issue a FIS licence to participate in FIS races when the competitor has proven his national ity and therefore eligibility by submitting a copy of his passport and signed the Athletes Dedaration in the form approved by the FIS Council and returned it to his National Ski Association. All forms from under-age applicants must be counter signed by their legal guardians. Both the copy of the passport and signed A thl etes Declaration must be made avail able to FIS on request.

203.4 During theFIS licence year, a competitor may only participate in International FIS competitions with a FIS licence to participatein FIS races issued by oneNational Ski Association.

203.5 Application for a change of FIS L icence Registration All applications to change licence registration from one member National Ski Association to another are subject to consideration by theFIS Council at its Meetings in the spring. In principlean application to change 


\section{APPENDICES}

licence registration will not be granted unless the competitor demonstrates his personal association with the new nation.

Prior to submitting an application to change licence regi stration a competitor must possess the citizenship and passport of the country for which he wishes to compete In addition, the competitor must have had his principal legal and effective place of residence in the new country for a minimum of two (2) years immediately prior to the date of the request to change registration to the new country/National Ski Association. An exception to the two year residency rule may be waived if the competitor was born in the territory of the new country, or whose mother or father is a national of the new country. A pplications will not be accepted if a parent has obtained a passport for the new country, but is not resident, and/or there is no family ancestry.

Furthermore the competitor is required to submit a detailed explanation with the application about his personal circumstances and the reason for requesting a change of licence registration.

203.5.1 If a competitor has al ready participated in FIS calendar events for a National Ski Association, he must have the written agreement to be released from the former National Ski Association in addition to the citizenship, passport and residency requirements in art. 203.5 before the new National Ski Association may submit a request to FIS for a change of registration.

If such a written agreement is not given, the competitor may not participate in any FIS calendar events for a period of twelve months from the end of the last season in which he competed for his present National Ski Association, nor may he be issued with a licence to participate in FIS races by the new National Ski Association.

These rules are also valid when a competitor has more than one nationality and would like to change National Ski Association licence registration.

203.5.2 The FIS Council reserves the right in its absolute discretion, to grant or to dedine to grant, a change of licence notwithstanding the fulfilment of the aforementioned conditions where it deems it is contrary to the spirit of the rule and in the best interests of the International Ski Federation to do so (eg. to dedine to grant a change of licence if a member National Ski Association tries to "import" a competitor).

203.5.3 In the event that a competitor does not fulfil all the criteria required to apply for a change of National Ski Association licence registration, the onus shall be on the competitor to demonstrate in writing to the satisfaction of the FIS Council that exceptional circumstances exist and it is in the best interests of the International Ski Federation to grant the change.

203.5.4 A competitor will retain his FIS points if he changes his National Ski Association under the condition that the former National Ski Association granted the release of the competitor.

203.5.5 In the event that any of the documents for an application to change licence registration submitted by the National Ski Association (letter of release from the former National Ski Association, passport, residency papers) are found to be false, the FIS Council will sanction the compeitor and the new National Ski Association.

THE INTERNATIONAL SKI COMPETITION RULES (ICR) BOOK IV JOINT REGULATIONS FOR ALPINE SKIING DOWNHILL SLALOM GIANT SLALOM SUPER-G, COMBINED EVENTS TEAM EVENTS PARALLEL EVENTS KO EVENTS APPROVED BY THE 49INTE R NATIONAL SKI CONGRE SS, BAR CEL ONA (SPA) O berhofen, J uly 2014

203. Licence to participate in FIS R aces (FIS L icence)

A licence to participate in FIS races is issued by a National Ski Association to competitors who fulfil the criteria for participation through registering the competitor with FIS in the respective di scipline(s).

203.1 The FIS licence year begins on J uly 1st and finishes on J une 30th of the foll lowing year.

203.2 To be eligible for participation in FIS events, a competitor must have a licence issued by his National Ski Association. Such a licence shall be valid in the Northem and Southern hemispheres for the licence year only. The validity of a licence can be limited to participation in one specific country or in one or more specific events.

203.2.1 The National Ski Association must guarantee that all competitors registered with a FIS License to participate in FIS races accept the Rules of the International Ski Federation, in particular the provision which foresees the exclusive competence of the Court of Arbitration for Sport as the court of appeal in doping cases.

203.3 A National Ski Association may only issue a FIS licence to participate in FIS races when the competitor has proven his national ity and therefore eligibility by submitting a copy of his passport and signed the Athletes Declaration in the form approved by the FIS Council and returned it to his National Ski Association. All forms from under-age applicants must be counter signed by their legal guardians. Both the copy of the passport and signed Athletes Declaration must be made available to FIS on request.

203.4 During theFIS licence year, a competitor may only participate in International FIS competitions with a FIS licence to participate in FIS races issued by one National Ski Association.

203.5 Application for a change of FIS L icence Registration 
All applications to change licence registration from one member National Ski Association to another are subject to consideration by the FIS Council at its Meetings in the spring. In principlean application to change licence registration will not be granted unless the competitor demonstrates his personal association with the new nation.

Prior to submitting an application to change licence regi stration a competitor must possess the citizenship and passport of the country for which he wishes to compete In addition, the competitor must have had his principal legal and effective place of residence in the new country for a minimum of two (2) years immediately prior to the date of the request to change registration to the new country/National Ski Association. An exception to the two year residency rule may be waived if the competitor was born in the territory of the new country, or whose mother or father is a national of the new country. Applications will not be accepted if a parent has obtained a passport for the new country, but is not resident, and/or there is no family ancestry.

Furthermore the competitor is required to submit a detailed explanation with the application about his personal circumstances and the reason for requesting a change of licence registration.

203.5.1 If a competitor has al ready participated in FIS calendar events for a National Ski Association, he must have the written agreement to be released from the former National Ski Association in addition to the citizenship, passport and residency requirements in art. 203.5 before the new National Ski Association may submit a request to FIS for a change of registration.

If such a written agreement is not given, the competitor may not participate in any FIS cal endar events for a period of twelve months from the end of the last season in which he competed for his present National Ski Association, nor may he be issued with a licence to participate in FIS races by the new National Ski Association.

These rules are also valid when a competitor has more than one nationality and would like to change National Ski Association licence registration.

203.5.2 The FIS Council reserves the right in its absolute discretion, to grant or to dedine to grant, a change of licence notwithstanding the fulfilment of the aforementioned conditions where it deems it is contrary to the spirit of the rule and in the best interests of the International Ski Federation to do so (eg. to dedine to grant a change of licence if a member National Ski Association tries to "import" a competitor).

203.5.3 In the event that a competitor does not fulfil all the criteria required to apply for a change of National Ski Association licence registration, the onus shall be on the competitor to demonstrate in writing to the satisfaction of the FIS Council that exceptional circumstances exist and it is in the best interests of the International Ski Federation to grant the change

203.5.4 A competitor will retain his FIS points if he changes his National Ski Association under the condition that the former National Ski Association granted the rel ease of the competitor.

203.5.5 In the event that any of the documents for an application to change licence regi stration submitted by the National Ski Association (letter of release from the former National Ski Association, passport, residency papers) are found to be false, the FIS Council will sanction the competitor and the new National Ski Association.

THE INTERNATIONAL SKI COMPETITION RULES (ICR) BOOK IV JOINT REGULATIONS FOR ALPINE SKIING DOWNHILL, SLALOM, GIANT SLALOM, SUPER-G, COMBINED EVENTS, TEAM EVENTS, PARALLEL EVENTS, KO EVENTS APPROVED BY THE 48th INTERNATIONAL SKI CONGRESS, KANGWONLAND (KOR) WEB EDITION JULY 2013 203 Licence to participate in FIS R aces (FIS Licence)

A licence to participate in FIS races is issued by a National Ski Association to competitors who fulfil the criteria for participation through registering the compeitor with FIS in the respective di scipline(s).

203.1 The FIS licence year begins on J uly 1st and finishes on J une 30th of the foll lowing year.

203.2 To be eligible for participation in FIS events, a competitor must have a licence issued by his National Ski Association. Such a licence shall be valid in the Northern and Southern hemispheres for the licence year only. The validity of a licence can be limited to participation in one specific country or in one or more specific events.

203.2.1 The National Ski Association must guarantee that all competitors registered with a FIS License to participate in FIS races accept the Rules of the International Ski Federation, in particular the provision which foresees the exclusive competence of the Court of Arbitration for Sport as the court of appeal in doping cases.

203.3 A National Ski Association may only issue a FIS licence to participate in FIS races when the competitor has proven his national ity and therefore eligibility by submitting a copy of his passport and signed the Athletes Declaration in the form approved by the FIS Council and returned it to his National Ski Association. All forms from under-age applicants must be counter signed by their legal guardians. Both the copy of the passport and signed Athletes Declaration must be made available to FIS on request. 
203.4 During the FIS licence year, a compeitor may only participate in International FIS compeitions with a FIS licence to participate in FIS races issued by oneNational Ski Association.

\subsection{Application for a change of FIS L icence Registration}

All applications to change licence registration from one member National Ski Association to another are subject to consideration by theFIS Council at its Meetings in the spring. In principlean application to change licence registration will not be granted unless the competitor demonstrates his personal association with the new nation.

Prior to submitting an application to change licence regi stration a competitor must possess the citizenship and passport of the country for which he wishes to compete In addition, the competitor must have had his principal legal and effective place of residence in the new country for a minimum of two (2) years immediately prior to the date of the request to change registration to the new country/National Ski Association. An exception to the two year residency rule may be waived if the competitor was born in the territory of the new country, or whose mother or father is a national of the new country. Applications will not be accepted if a parent has obtained a passport for the new country, but is not resident, and/or there is no family ancestry. Furthermore the competitor is required to submit a detailed explanation with the application about his personal circumstances and the reason for requesting a change of licence regi stration.

203.5.1 If a competitor has al ready participated in FIS calendar events for a National Ski Association, he must have the written agreement to be released from the former National Ski Association in addition to the citizenship, passport and residency requirements in art. 203.5 before the new National Ski Association may submit a request to FIS for a change of registration.

If such a written agreement is not given, the competitor may not participate in any FIS calendar events for a period of twelve months from the end of the last season in which he competed for his present National Ski Association, nor may he be issued with a licence to participate in FIS races by the new National Ski Association.

These rules are also valid when a competitor has more than one nationality and would like to change National Ski Association licence registration.

203.5.2 The FIS Council reserves the right in its absolute discretion, to grant or to dedine to grant, a change of licence notwithstanding the fulfilment of the aforementioned conditions where it deems it is contrary to the spirit of the rule and in the best interests of the International Ski Federation to do so (eg. to dedine to grant a change of licence if a member National Ski Association tries to "import" a compeitor).

203.5.3 In theevent that a competitor does not fulfil all the criteria required to apply for a change of National Ski Association licence registration, the onus shall be on the competitor to demonstrate in writing to the satisfaction of the FIS Council that exceptional circumstances exist and it is in the best interests of the International Ski Federation to grant the change.

203.5.4 A compeitor will retain his FIS points if he changes his National Ski Association under the condition that the former National Ski Association granted the release of the competitor.

203.5.5 In the event that any of the documents for an application to change licence registration submitted by the National Ski Association (letter of release from the former National Ski Association, passport, residency papers) are found to be false, the FIS Council will sanction the competitor and the new National Ski Association.

\section{Cross-Country}

THE INTERNATIONAL SKI COMPETITION RULES (ICR) BOOK II CROSSCOUNTRYAPPROVED BY THE $49^{\text {th }}$ INTERNATIONAL SKI CONGRESS, BARCELONA (SPA)INCL. CHANGE S AND PRECISIONS 2015 O berhofen, November 2015

203 Licence to participate in FIS R aces (FIS Licence)

A licence to participate in FIS races is issued by a National Ski Association to competitors who fulfil the criteria for participation through registering the competitor with FIS in the respective di scipline(s).

203.1 The FIS licence year begins on J uly $1^{\text {tt }}$ and finishes on J une $30^{\text {th }}$ of the following year.

203.2 To be eligible for participation in FIS events, a competitor must have a licence issued by his National Ski Association. Such a licence shall be valid in the Northern and Southern hemispheres for the licence year only. The validity of a licence can be limited to participation in one specific country or in one or more specific events.

203.2.1 The National Ski Association must guarantee that all competitors registered with a FIS License to participate in FIS races accept the Rules of the International Ski Federation, in particular the provision which foresees the exclusive competence of the Court of Arbitration for Sport as the court of appeal in doping cases.

203.3 A National Ski Association may only issue a FIS licence to participate in FIS races when the competitor has proven his national ity and therefore eligibility by submitting a copy of his passport and signed the Athletes Declaration in the form approved by the FIS Council and returned it to his National Ski 
Association. All forms from under-age applicants must be counter signed by their legal guardians. Both the copy of the passport and signed Athletes Declaration must be made available to FIS on request.

203.4 During theFIS licence year, a competitor may only partici pate in I nternational FIS competitions with a FIS licence to participate in FIS races issued by one National Ski Association.

203.5 Application for a change of FIS L icence Registration

All applications to change licence registration from one member National Ski Association to another are subject to consideration by the FIS Council at its Meetings in the spring. In principlean application to change licence registration will not be granted unless the competitor demonstrates his personal association with the new nation.

Prior to submitting an application to change licence regi stration a competitor must possess the citizenship and passport of the country for which he wishes to compete In addition, the competitor must have had his principal legal and effective place of residence in the new country for a minimum of two (2) years immediately prior to the date of the request to change registration to the new country/National Ski Association. An exception to the two year residency rule may be waived if the competitor was born in the territory of the new country, or whose mother or father is a national of the new country. Applications will not be accepted if a parent has obtained a passport for the new country, but is not resident, and/or there is no family ancestry.

Furthermore the competitor is required to submit a detailed explanation with the application about his personal circumstances and the reason for requesting a change of licence registration.

203.5.1 If a competitor has al ready participated in FIS calendar events for a National Ski Association, he must have the written agreement to be released from the former National Ski Association in addition to the citizenship, passport and residency requirements in art. 203.5 before the new National Ski Association may submit a request to FIS for a change of registration.

If such a written agreement is not given, the competitor may not participate in any FIS calendar events for a period of twelve months from the end of the last season in which he competed for his present National Ski Association, nor may he be issued with a licence to participate in FIS races by the new National Ski Association.

These rules are also valid when a competitor has more than one nationality and would like to change National Ski Association licence registration.

203.5.2 The FIS Council reserves the right in its absolute discretion, to grant or to dedine to grant, a change of licence notwithstanding the fulfilment of the aforementioned conditions where it deems it is contrary to the spirit of the rule and in the best interests of the International Ski Federation to do so (eg. to dedine to grant a change of licence if a member National Ski Association tries to "import" a competitor).

203.5.3 In the event that a competitor does not fulfil all the criteria required to apply for a change of National Ski Association licence registration, the onus shall be on the competitor to demonstrate in writing to the satisfaction of the FIS Council that exceptional circumstances exist and it is in the best interests of the International Ski Federation to grant the change

203.5.4 A competitor will retain his FIS Points if he changes his National Ski Association under the condition that the former National Ski Association granted the release of the competitor.

203.5.5 In the event that any of the documents for an application to change licence regi stration submitted by the National Ski Association (letter of release from the former National Ski Association, passport, residency papers) are found to be false, the FIS Council will sanction the competitor and the new National Ski Association.

\section{THE INTERNATIONAL SKI COMPETITION RULES (ICR) BOOK II CROSS- COUNTRY APPROVED BY THE $49^{\text {th }}$ INTER NATIONAL SKI CONGRESS, BARCELONA (SPA) INCL. CHANGE S AND PRECISIONS 2015 E dition J uly 2015 \\ 203 Licence to participate in FIS R aces (FIS Licence)}

A licence to participate in FIS races is issued by a National Ski Association to competitors who fulfil the criteria for participation through registering the competitor with FIS in the respective discipline(s).

203.1 The FIS licence year begins on J uly $1^{\text {t }}$ and finishes on J une 30 th of the following year.

203.2 To be eligible for participation in FIS events, a competitor must have a licence issued by his National Ski Association. Such a licence shall be val id in the Northem and Southern hemispheres for the licence year only. The validity of a licence can be limited to participation in one specific country or in one or more specific events.

203.2.1 The National Ski Association must guarantee that all compeitors registered with a FIS License to participate in FIS races accept the Rules of the International Ski Federation, in particular the provision which foresees the exclusive competence of the Court of Arbitration for Sport as the court of appeal in doping cases.

203.3 A National Ski Association may only issue a FIS licence to participate in FIS races when the competitor has proven his national ity and therefore eligibility by submitting a copy of his passport and signed 


\section{APPENDICES}

the Athletes Declaration in the form approved by the FIS Council and returned it to his National Ski Association. All forms from under-age applicants must be counter signed by their legal guardians. Both the copy of the passport and signed Athletes Dedaration must be made avail able to FIS on request.

203.4 During theFIS licence year, a competitor may only partici pate in I nternational FIS competitions with a FIS licence to participate in FIS races issued by one National Ski Association.

203.5 Application for a change of FIS Licence Registration

All applications to change licence registration from one member National Ski Association to another are subject to consideration by theFIS Council at its Meetings in the spring. In principlean application to change licence registration will not be granted unless the competitor demonstrates his personal association with the new nation.

Prior to submitting an application to change licence regi stration a competitor must possess the citizenship and passport of the country for which he wishes to compete In addition, the competitor must have had his principal legal and effective place of residence in the new country for a minimum of two (2) years immediately prior to the date of the request to change registration to the new country/National Ski Association. An exception to the two year residency rule may be waived if the competitor was born in the territory of the new country, or whose mother or father is a national of the new country. Applications will not be accepted if a parent has obtained a passport for the new country, but is not resident, and/or there is no family ancestry.

Furthermore the competitor is required to submit a detailed explanation with the application about his personal circumstances and the reason for requesting a change of licence registration.

203.5.1 If a compeitor has al ready participated in FIS calendar events for a National Ski Association, he must have the written agreement to be released from the former National Ski Association in addition to the citizenship, passport and residency requirements in art. 203.5 before the new National Ski Association may submit a request to FIS for a change of registration.

If such a written agreement is not given, the competitor may not participate in any FIS calendar events for a period of twelve months from the end of the last season in which he competed for his present National Ski Association, nor may he be issued with a licence to participate in FIS races by the new National Ski Association.

These rules are also valid when a competitor has more than one nationality and would like to change National Ski Association licence registration.

203.5.2 The FIS Council reserves the right in its absolute discretion, to grant or to dedine to grant, a change of licence notwithstanding the fulfilment of the aforementioned conditions where it deems it is contrary to the spirit of the rule and in the best interests of the International Ski Federation to do so (eg. to dedine to grant a change of licence if a member National Ski Association tries to "import" a competitor).

203.5.3 In theevent that a competitor does not fulfil all the criteria required to apply for a change of National Ski Association licence registration, the onus shall be on the competitor to demonstrate in writing to the satisfaction of the FIS Council that exceptional circumstances exist and it is in the best interests of the International Ski Federation to grant the change

203.5.4 A competitor will retain his FIS Points if he changes his National Ski Association under the condition that the former National Ski Association granted the release of the competitor.

203.5.5 In the event that any of the documents for an application to change licence registration submitted by the National Ski Association (letter of release from the former National Ski Association, passport, residency papers) are found to be false, the FIS Council will sanction the competitor and the new National Ski Association.

\section{THE INTERNATIONAL SKI COMPETITION RULES (ICR) BOOK II CROSS- COUNTRYAPPR OVED BY THE $49^{\text {th }}$ INTER NATIONAL SKI CONGRESS, BARCELONA (SPA) J uly 2014}

203. Licence to participate in FIS R aces (FIS Licence)

A licence to participate in FIS races is issued by a National Ski Association to competitors who fulfil the criteria for participation through registering the competitor with FIS in the respective discipline(s).

203.1 The FIS licence year begins on J uly 1st and finishes on J une $30^{\text {th }}$ of the foll lowing year.

203.2 To be eligible for participation in FIS events, a competitor must have a licence issued by his National Ski Association. Such a licence shall be valid in the Northern and Southern hemispheres for the licence year only. The validity of a licence can be limited to participation in one specific country or in one or more specific events.

203.2.1 The National Ski Association must guarantee that all competitors registered with a FIS License to participate in FIS races accept the Rules of the International Ski Federation, in particular the provision which foresees the exclusive competence of the Court of Arbitration for Sport as the court of appeal in doping cases. 
203.3 A National Ski Association may only issue a FIS licence to participate in FIS races when the competitor has proven his national ity and therefore eligibility by submitting a copy of his passport and signed the Athletes Declaration in the form approved by the FIS Council and returned it to his National Ski Association. All forms from under-age applicants must be counter signed by their legal guardians. Both the copy of the passport and signed Athletes Declaration must be made avail able to FIS on request.

203.4 During theFIS licence year, a competitor may only participate in International FIS competitions with a FIS licence to participate in FIS races issued by oneNational Ski Association.

203.5 Application for a change of FIS L icence Registration

All applications to change licence registration from one member National Ski Association to another are subject to consideration by theFIS Council at its Meetings in the spring. In principlean application to change licence registration will not be granted unless the competitor demonstrates his personal association with the new nation.

Prior to submitting an application to change licence regi stration a competitor must possess the citizenship and passport of the country for which he wishes to compete In addition, the competitor must have had his principal legal and effective place of residence in the new country for a minimum of two (2) years immediately prior to the date of the request to change registration to the new country/National Ski Association. An exception to the two year residency rule may be waived if the competitor was born in the territory of the new country, or whose mother or father is a national of the new country. Applications will not be accepted if a parent has obtained a passport for the new country, but is not resident, and/or there is no family ancestry.

Furthermore the competitor is required to submit a detailed explanation with the application about his personal circumstances and the reason for requesting a change of licence registration.

203.5.1 If a compeitor has al ready participated in FIS calendar events for a National Ski Association, he must have the written agreement to be released from the former National Ski Association in addition to the citizenship, passport and residency requirements in art. 203.5 before the new National Ski Association may submit a request to FIS for a change of registration.

If such a written agreement is not given, the competitor may not participate in any FIS cal endar events for a period of twelve months from the end of the last seeson in which he competed for his present National Ski Association, nor may he be issued with a licence to participate in FIS races by the new National Ski Association.

These rules are also valid when a competitor has more than one nationality and would like to change National Ski Association licence registration.

203.5.2 The FIS Council reserves the right in its absolute discretion, to grant or to dedine to grant, a change of licence notwithstanding the fulfilment of the aforementioned conditions where it deems it is contrary to the spirit of the rule and in the best interests of the International Ski Federation to do so (eg. to dedine to grant a change of licence if a member National Ski Association tries to "import" a competitor).

203.5.3 In the event that a competitor does not fulfil all the criteria required to apply for a change of National Ski Association licence registration, the onus shall be on the competitor to demonstrate in writing to the satisfaction of the FIS Council that exceptional circumstances exist and it is in the best interests of the International Ski Federation to grant the change

203.5.4 A competitor will retain his FIS Points if he changes his National Ski Association under the condition that the former National Ski Association granted the release of the competitor.

203.5.5 In the event that any of the documents for an application to change licence registration submitted by the National Ski Association (letter of release from the former National Ski Association, passport, residency papers) are found to be false, the FIS Council will sanction the competitor and the new National Ski Association.

THE INTERNATIONAL SKI COMPETITION RULES (ICR) BOOK II CROSS-COUNTRY APPROVED BY THE 48TH INTERNATIONAL SKI CONGRESS, KANGWONLAND (KOR) INCL. M ARKED UP CHANGES AND PRECISIONS 2013 WEB EDITION OCTOBER 2013 203 Licence to participate in FIS R aces (FIS Licence)

A licence to participate in FIS races is issued by a National Ski Association to competitors who fulfil the criteria for participation through registering the competitor with FIS in the respective di scipline(s).

203.1 The FIS licence year begins on J uly 1st and finishes on J une 30th of the following year.

203.2 To be eligible for participation in FIS events, a competitor must have a licence issued by his National Ski Association. Such a licence shall be valid in the Northern and Southern hemispheres for the licence year only. The validity of a licence can be limited to participation in one specific country or in one or more specific events.

203.2.1 The National Ski Association must guarantee that all competitors registered with a FIS License to participate in FIS races accept the Rules of the International Ski Federation, in particular the provision which 


\section{APPENDICES}

foresees the exclusive competence of the Court of Arbitration for Sport as the court of appeal in doping cases.

203.3 A National Ski Association may only issue a FIS licence to participate in FIS races when the competitor has proven his national ity and therefore eligibility by submitting a copy of his passport and signed the Athletes Declaration in the form approved by the FIS Council and returned it to his National Ski Association. All forms from under-age applicants must be counter signed by their legal guardians. Both the copy of the passport and signed Athletes Declaration must be made avail ableto FIS on request.

203.4 During theFIS licence year, a competitor may only participate in International FIS competitions with a FIS licence to participate in FIS races issued by oneNational Ski Association.

203.5 Application for a change of FIS L icence Registration

All applications to change licence registration from one member National Ski Association to another are subject to consideration by the FIS Council at its Meetings in the spring. In principlean application to change licence registration will not be granted unless the competitor demonstrates his personal association with the new nation.

Prior to submitting an application to change licence regi stration a competitor must possess the citizenship and passport of the country for which he wishes to compete In addition, the competitor must have had his principal legal and effective place of residence in the new country for a minimum of two (2) years immediately prior to the date of the request to change registration to the new country/National Ski Association. An exception to the two year residency rule may be waived if the competitor was born in the territory of the new country, or whose mother or father is a national of the new country. Applications will not be accepted if a parent has obtained a passport for the new country, but is not resident, and/or there is no family ancestry.

Furthermore the competitor is required to submit a detailed explanation with the application about his personal circumstances and the reason for requetting a change of licence registration.

203.5.1 If a compeitor has al ready participated in FIS calendar events for a National Ski Association, he must have the written agreement to be released from the former National Ski Association in addition to the citizenship, passport and residency requirements in art. 203.5 before the new National Ski Association may submit a request to FIS for a change of registration.

If such a written agreement is not given, the competitor may not participate in any FIS cal endar events for a period of twelve months from the end of the last season in which he competed for his present National Ski Association, nor may he be issued with a licence to participate in FIS races by the new National Ski Association.

These rules are also valid when a competitor has more than one nationality and would like to change National Ski Association licence registration.

203.5.2 The FIS Council reserves the right in its absolute discretion, to grant or to dedine to grant, a change of licence notwithstanding the fulfilment of the aforementioned conditions where it deems it is contrary to the spirit of the rule and in the best interests of the International Ski Federation to do so (eg. to dedine to grant a change of licence if a member National Ski Association tries to "import" a competitor).

203.5.3 In the event that a competitor does not fulfil all the criteria required to apply for a change of National Ski Association licence registration, the onus shall be on the competitor to demonstrate in writing to the satisfaction of the FIS Council that exceptional circumstances exist and it is in the best interests of the International Ski Federation to grant the change

203.5.4 A competitor will retain his FIS Points if he changes his National Ski Association under the condition that the former National Ski Association granted the release of the competitor.

203.5.5 In the event that any of the documents for an application to change licence registration submitted by the National Ski Association (letter of release from the former National Ski Association, passport, residency papers) are found to be false, the FIS Council will sanction the competitor and the new National Ski Association.

\section{Freestyle}

THE INTERNATIONAL FREESTYLE SKIING COMPETITION RULES (ICR) BOOK V JOINT REGULATIONS FOR FREESTYLE SKIING, AERIALS MOGULS, DUAL MOGULS SKI CROSS SKI HALFPIPE SKI SLOPESTYLE APPROVED BY THE $49^{\text {th }}$ INTERNATIONAL SKI CONGRESS, BARCELONA (SPA) INCL. CHANGES AND PRECISIONS 2015 INTERNATIONAL SKI FEDERATION FEDERATION INTERNATIONALE DE SKI INTERNATONALER SKI VE R BAND O berhofen, E dition August 2015

203 Licence to participate in FIS Races (FIS Licence)

A licence to participate in FIS races is issued by a National Ski Association to compeitors who fulfil the criteria for participation through registering the competitor with FIS in the respective di scipline(s).

203.1 TheFIS licence year begins on J uly $1^{\text {tt }}$ and finishes on J une $30^{\text {th }}$ of the following year. 
203.2 To be eligible for participation in FIS events, a competitor must have a licence issued by his National Ski Association. Such a licence shall be valid in the Northem and Southern hemispheres for the licence year only. The validity of a licence can be limited to participation in one specific country or in one or more specific events.

203.2.1 The National Ski Association must guarantee that all competitors registered with a FIS License to participate in FIS races accept the Rules of the International Ski Federation, in particular the provision which foresees the exclusive competence of the Court of Arbitration for Sport as the court of appeal in doping cases.

203.3 A National Ski Association may only issue a FIS licence to participate in FIS races when the competitor has proven his national ity and therefore eligibility by submitting a copy of his passport and signed the Athletes Declaration in the form approved by the FIS Council and returned it to his National Ski Association. All forms from under-age applicants must be counter signed by their legal guardians. Both the copy of the passport and signed Athletes Ded aration must be made avail able to FIS on request.

203.4 During theFIS licence year, a competitor may only participate in International FIS competitions with a FIS licence to participate in FIS races issued by oneNational Ski Association.

203.5 Application for a change of FIS Licence Registration

All applications to change licence registration from one member National Ski Association to another are subject to consideration by the FIS Council at its Meet- ings in the spring. In principle an application to change licence registration will not be granted unless the competitor demonstrates his personal association with thenew nation.

Prior to submitting an application to change licence regi stration a competitor must possess the citizenship and passport of the country for which he wishes to com pete In addition, the competitor must have had his principal legal and effective place of residence in the new country for a minimum of two (2) years immediately prior to the date of the request to change registration to the new country/National Ski Association. An exception to the two year residency rule may be waived if the competitor was born in the territory of the new country, or whose mother or father is a national of the new country. Applications will not be accepted if a parent has obtained a passport for the new country, but is not resident, and/or there is no family ancestry. Furthermore the competitor is required to submit a detailed ex- planation with the application about his personal circumstances and the reason for requesting a change of licence registration.

203.5.1 If a competitor has al ready participated in FIS calendar events for a National Ski Association, he must have the written agreement to be released from the former National Ski Association in addition to the citizenship, passport and residency requirements in art. 203.5 before the new National Ski Association may submit a request to FIS for a change of registration. If such a written agreement is not given, the competitor may not participate in any FIS cal endar events for a period of twelve months from the end of the last season in which he competed for his present National Ski Association, nor may he be is- sued with a licence to participate in FIS races by the new National Ski Association. These rules are also valid when a competitor has morethan one nationality and would liketo change National Ski Association licence registration.

203.5.2. The FIS Council reserves the right in its absolute discretion, to grant or to dedine to grant, a change of licence notwithstanding the fulfilment of the aforementioned conditions where it deems it is contrary to the spirit of the rule and in the best interests of the International Ski Federation to do so (eg. to dedine to grant a change of licence if a member National Ski Association tries to "import" a competitor).

203.5.3 In the event that a competitor does not fulfil all the criteria required to apply for a change of National Ski Association licence registration, the onus shall be on the competitor to demonstrate in writing to the satisfaction of the FIS Council that exceptional circumstances exist and it is in the best interests of the International Ski Federation to grant the change

203.5.4 A competitor will retain his FIS points if he changes his National Ski Association under the condition that the former National Ski Association granted the release of the competitor.

203.5.5 In the event that any of the documents for an application to change licence registration submitted by the National Ski Association (letter of release from the former National Ski Association, passport, residency papers) are found to be false, the FIS Council will sanction the competitor and the new National Ski Association.

FIS THE INTERNATIONAL FREESTYLE SKIING COMPETITION RULES (ICR) BOOK V JOINT REGULATIONS FOR FREESTYLE SKIING, AERIALS MOGULS, DUAL MOGULS SKI, CROSS SKI HALFPIPE, SKI SLOPESTYLEAPPR OVED BY THE 49th INTERNATIONAL SKI CONGRESS, BAR CE L ONA (SPA), Webedition November 2014

Licence to participate in FIS R aces (FIS Licence)

A licence to participate in FIS races is issued by a National Ski Association to competitors who fulfil the criteria for participation through registering the competitor with FIS in the respective discipline(s).

203.1. TheFIS licenceyear begins on J uly 1st and finishes on J une 30th of the following year. 


\section{APPENDICES}

203.2. To be eligible for participation in FIS events, a competitor must have a licence issued by his National Ski Association. Such a licence shall be valid in the Northern and Southern hemispheres for the licence year only. The validity of a licence can be limited to participation in one specific country or in one or more specific events.

203.2.1 The National Ski Association must guarantee that all competitors registered with a FIS License to participate in FIS races accept the Rules of the International Ski Federation, in particular the provision which foresees the exclusive competence of the Court of Arbitration for Sport as the court of appeal in doping cases.

203.3 A National Ski Association may only issue a FIS licence to participate in FIS races when the competitor has proven his national ity and therefore eligibility by submitting a copy of his passport and signed the Athletes Declaration in the form approved by the FIS Council and returned it to his National Ski Association. All forms from under-age applicants must be counter signed by their legal guardians. Both the copy of the passport and signed A thl etes Declaration must be made available to FIS on request.

203.4. During the FIS licence year, a competitor may only participate in International FIS competitions with a FIS licenceto participatein FIS races issued by one National Ski Association.

203.5 Application for a change of FIS L icence Registration

All applications to change licence registration from one member National Ski Association to another are subject to consideration by theFIS Council at its Meetings in the spring. In principlean application to change licence registration will not be granted unless the competitor demonstrates his personal association with the new nation.

Prior to submitting an application to change licence regi stration a competitor must possess the citizenship and passport of the country for which he wishes to compete In addition, the competitor must have had his principal legal and effective place of residence in the new country for a minimum of two (2) years immediately prior to the date of the request to change registration to the new country/National Ski Association. An exception to the two year residency rule may be waived if the competitor was born in the territory of the new country, or whose mother or father is a national of the new country. A pplications will not be accepted if a parent has obtained a passport for the new country, but is not resident, and/or there is no family ancestry. Furthermore the competitor is required to submit a detailed explanation with the application about his personal circumstances and the reason for requesting a change of licence registration.

203.5.1. If a competitor has al ready participated in FIS calendar events for a National Ski Association, he must have the written agreement to be released from the former National Ski Association in addition to the citizenship, passport and residency requirements in art. 203.5 before the new National Ski Association may submit a request to FIS for a change of registration.

If such a written agreement is not given, the competitor may not participate in any FIS cal endar events for a period of twelve months from the end of the last seeson in which he competed for his present National Ski Association, nor may he be issued with a licence to participate in FIS races by the new National Ski Association.

These rules are also valid when a competitor has more than one nationali- ty and would like to change National Ski Association licence registration.

203.5.2. The FIS Council reserves the right in its absolute discretion, to grant or to decline to grant, a change of licence notwithstanding the fulfilment of the aforementioned conditions where it deems it is contrary to the spirit of the rule and in the best interests of the International Ski Federation to do so (eg. to dedine to grant a change of licence if a member National Ski Association tries to "import" a competitor).

203.5.3 In the event that a competitor does not fulfil all the criteria required to apply for a change of National Ski Association licence registration, the onus shall be on the competitor to demonstrate in writing to the satisfaction of the FIS Council that exceptional circumstances exist and it is in the best interests of the International Ski Federation to grant the change

203.5.4 A competitor will retain his FIS points if he changes his National Ski Association under the condition that the former National Ski Association granted the rel ease of the competitor.

203.5.5. In the event that any of the documents for an application to change licence registration submitted by the National Ski Association (letter of release from the former National Ski Association, passport, residency papers) are found to be false, the FIS Council will sanction the competitor and the new National Ski Association.

THE INTERNATIONAL FREESTYLE SKIING COMPETITION RULES (ICR) BOOK V JOINT REGULATIONS FOR FREESTYLE SKIING, AERIALS MOGULS, DUAL MOGULS SKI CROSS SKI HALFPIPE, SKI SLOPESTYLE APPROVED BY THE $48^{\text {th }}$ NTERNATIONAL SKI CONGRESS, KANGWONLAND (K OR) October 2014

203. Licence to participate in FIS R aces (FIS L icence)

A licence to participate in FIS races is issued by a National Ski Association to compeitors who fulfil the criteria for participation through registering the competitor with FIS in the respective discipline(s). 
203.1 The FIS licenceyear begins on J uly 1st and finishes on J une 30th of the following year.

203.2 To be eligible for participation in FIS events, a competitor must have a licence issued by his National Ski Association. Such a licence shall be valid in the Northem and Southern hemispheres for the licence year only. The validity of a licence can be limited to participation in one specific country or in one or more specific events.

203.2.1 The National Ski Association must guarantee that all competitors registered with a FIS License to participatein FIS races accept the Rules of the International Ski Federation, in particular the provision which foresees the exclusive competence of the Court of Arbitration for Sport as the court of appeal in doping cases.

203.3 A National Ski Association may only issue a FIS licence to participate in FIS races when the competitor has proven his national ity and therefore eligibility by submitting a copy of his passport and signed the Athletes Declaration in the form approved by the FIS Council and returned it to his National Ski Association. All forms from under-age applicants must be counter signed by their legal guardians. Both the copy of the passport and signed Athletes Declaration must be made avail lable to FIS on request.

203.4 During theFIS licence year, a competitor may only partici pate in I nternational FIS competitions with a FIS licence to participate in FIS races issued by one National Ski Association.

203.5 Application for a change of FIS L icence Registration

All applications to change licence registration from one member National Ski Association to another are subject to consideration by theFIS Council at its Meetings in the spring. In principlean application to change licence registration will not be granted unless the competitor demonstrates his personal association with the new nation.

Prior to submitting an application to change licence registration a competi- tor must possess the citizenship and passport of the country for which he wishes to compete In addition, the competitor must have had his principal legal and effective place of residence in the new country for a minimum of two (2) years immediately prior to the date of the request to change regis- tration to the new country/National Ski Association. An exception to the two year residency rule may be waived if the competitor was born in the territory of the new country, or whose mother or father is a national of the new country. Applications will not be accepted if a parent has obtained a passport for the new country, but is not resident, and/or there is no family ancestry. Furthermore the competitor is required to submit a detailed explanation with the application about his personal circumstances and the reason for requesting a change of licence regi stration.

203.5.1 If a competitor has already participated in FIS calendar events for a $\mathrm{Na}$ tional Ski Association, he must have the written agreement to be released from the former National Ski Association in addition to the citizenship, passport and residency requirements in art. 203.5 before the new National Ski Association may submit a request to FIS for a change of registration.

If such a written agreement is not given, the competitor may not participate in any FIS calendar events for a period of twelve months from the end of the last season in which he competed for his present National Ski Associa tion, nor may he be issued with a licence to participate in FIS races by the new National Ski Association.

These rules are also valid when a competitor has more than one nationali- ty and would like to change National Ski Association licence registration.

203.5.2 The FIS Council reserves the right in its absolute discretion, to grant or to dedine to grant, a change of licence notwithstanding the fulfilment of the aforementioned conditions where it deems it is contrary to the spirit of the rule and in the best interests of the International Ski Federation to do so (eg. to decline to grant a change of licence if a member National Ski Association tries to "import" a compeitor).

203.5.3 In the event that a competitor does not fulfil all the criteria required to apply for a change of National Ski Association licence registration, the onus shall be on the competitor to demonstrate in writing to the satisfaction of the FIS Council that exceptional circumstances exist and it is in the best interests of the International Ski Federation to grant the change.

203.5.4 A competitor will retain his FIS points if he changes his National Ski Association under the condition that the former National Ski Association granted the release of the competitor.

203.5.5 In the event that any of the documents for an application to change licence registration submitted by the National Ski Association (letter of release from the former National Ski Association, passport, residency papers) are found to be false, the FIS Council will sanction the competitor and the new National Ski Association.

THE INTERNATIONAL FREESTYLE SKIING COMPETITION RULES (ICR) BOOK V JOINT REGULATIONS FOR FREESTYLE SKIINGAERIALS MOGULS, DUAL MOGULS, SKI CROSS, SKI HALFPIPE, SKI SLOPESTYLE APPROVED BY THE 48TH INTERNATIONAL SKI CONGRESS, KANGWONLAND (KOR) WEB EDITION NOVEMBER 2013

$203 \mathrm{~L}$ icence to participate in FIS Races (FIS Licence) 
A licence to participate in FIS races is issued by a National Ski Association to competitors who fulfil the criteria for participation through registering the competitor with FIS in the respective di scipline(s).

203.1 The FIS licence year begins on J uly 1st and finishes on J une 30th of the foll owing year.

203.2 To be eligible for participation in FIS events, a competitor must have a licence issued by his National Ski Association. Such a licence shall be valid in the Northem and Southern hemispheres for the licence year only. The validity of a licence can be limited to participation in one specific country or in one or more specific events.

203.2.1 The National Ski Association must guarantee that all competitors registered with a FIS License to participate in FIS races accept the Rules of the International Ski Federation, in particular the provision which foresees the exclusive competence of the Court of Arbitration for Sport as the court of appeal in doping cases.

203.3 A National Ski Association may only issue a FIS licence to participate in FIS races when the competitor has proven his national ity and therefore eligibility by submitting a copy of his passport and signed the Athletes Declaration in the form approved by the FIS Council and returned it to his National Ski Association. All forms from under-age applicants must be counter signed by their legal guardians. Both the copy of the passport and signed Athletes Declaration must be made available to FIS on request.

203.4 During theFIS licence year, a competitor may only partici pate in International FIS competitions with a FIS licence to participate in FIS races issued by one National Ski Association.

203.5 Application for a change of FIS L icence Registration

All applications to change licence registration from one member National Ski Association to another are subject to consideration by theFIS Council at its Meetings in the spring. In principlean application to change licence registration will not be granted unless the competitor demonstrates his personal association with the new nation. Prior to submitting an application to change licence registration a competitor must possess the citizenship and passport of the country for which he wishes to compete In addition, the competitor must have had his principal legal and effective place of residence in the new country for a minimum of two (2) years immediately prior to the date of the request to change registration to the new country/National Ski Association. An exception to the two year residency rule may be waived if the competitor was born in the territory of the new country, or whose mother or father is a national of the new country. Applications will not be accepted if a parent has obtained a passport for the new country, but is not resident, and/or there is no family ancestry. Furthermore the competitor is required to submit a detailed explanation with the application about his personal circumstances and the reason for requesting a change of licence regi stration.

203.5.1 If a compeitor has al ready participated in FIS calendar events for a National Ski Association, he must have the written agreement to be released from the former National Ski Association in addition to the citizenship, passport and residency requirements in art. 203.5 before the new National Ski Association may submit a request to FIS for a change of registration. If such a written agreement is not given, the competitor may not participate in any FIS calendar events for a period of twelve months from the end of the last season in which he competed for his present National Ski Association, nor may he be issued with a licence to participate in FIS races by the new National Ski Association. These rules are al so valid when a competitor has morethan one nationality and would liketo change National Ski Association licence registration.

203.5.2 The FIS Council reserves the right in its absolute discretion, to grant or to dedine to grant, a change of licence notwithstanding the fulfilment of the aforementioned conditions where it deems it is contrary to the spirit of the rule and in the best interests of the International Ski Federation to do so (eg. to dedine to grant a change of licence if a member National Ski Association tries to "import" a competitor).

203.5.3 In the event that a competitor does not fulfil all the criteria required to apply for a change of National Ski Association licence registration, the onus shall be on the competitor to demonstrate in writing to the satisfaction of the FIS Council that exceptional circumstances exist and it is in the best interests of the International Ski Federation to grant the change

203.5.4 A competitor will retain his FIS points if he changes his National Ski Association under the condition that the former National Ski Association granted the release of the competitor.

203.5.5 In the event that any of the documents for an application to change licence registration submitted by the National Ski Association (letter of release from the former National Ski Association, passport, residency papers) are found to be false, the FIS Council will sanction the competitor and the new National Ski Association.

THE INTERNATIONAL FREESTYLE SKIING COMPETITION RULES (ICR) BOOK V JOINT REGULATIONS FOR FREESTYLE SKIING AERIALS, MOGULS, DUAL MOGULS, SKI CROSS, SK I HALFPIPE, SKI SLOPESTYLE APPROVED BY THE 48TH INTERNATIONAL SK I CONGRESS, KANGWONLAND (K OR), WEB EDITION JULY 2013

203 Licence to participate in FIS R aces (FIS Licence)

A licence to participate in FIS races is issued by a National Ski Association to competitors who fulfil the criteria for participation through registering the compeitor with FIS in the respective di scipline(s). 
203.1 The FIS licenceyear begins on J uly 1st and finishes on J une 30th of the following year.

203.2 To be eligible for participation in FIS events, a competitor must have a licence issued by his National Ski Association. Such a licence shall be valid in the Northem and Southern hemispheres for the licence year only. The validity of a licence can be limited to participation in one specific country or in one or more specific events.

203.2.1 The National Ski Association must guarantee that all competitors registered with a FIS License to participatein FIS races accept the Rules of the International Ski Federation, in particular the provision which foresees the exclusive competence of the Court of Arbitration for Sport as the court of appeal in doping cases.

203.3 A National Ski Association may only issue a FIS licence to participate in FIS races when the competitor has proven his national ity and therefore eligibility by submitting a copy of his passport and signed the Athletes Declaration in the form approved by the FIS Council and returned it to his National Ski Association. All forms from under-age applicants must be counter signed by their legal guardians. Both the copy of the passport and signed Athletes Declaration must be made avail lable to FIS on request.

203.4 During theFIS licence year, a competitor may only partici pate in International FIS competitions with a FIS licence to participatein FIS races issued by one National Ski Association.

203.5 Application for a change of FIS L icence Registration

All applications to change licence registration from one member National Ski Association to another are subject to consideration by theFIS Council at its Meetings in the spring. In principlean application to change licence registration will not be granted unless the competitor demonstrates his personal association with the new nation. Prior to submitting an application to change licence registration a competitor must possess the citizenship and passport of the country for which he wishes to compete In addition, the competitor must have had his principal legal and effective place of residence in the new country for a minimum of two (2) years immediately prior to the date of the request to change registration to the new country/National Ski Association. An exception to the two year residency rule may be waived if the competitor was born in the territory of the new country, or whose mother or father is a national of the new country. Applications will not be accepted if a parent has obtained a passport for the new country, but is not resident, and/or there is no family ancestry. Furthermore the compeitor is required to submit a detail ed ex planation with the application about his personal circumstances and the reason for requesting a change of licence registration.

203.5.1 If a competitor has al ready participated in FIS calendar events for a National Ski Association, he must have the written agreement to be released from the former National Ski Association in addition to the citizenship, passport and residency requirements in art. 203.5 before the new National Ski Association may submit a request to FIS for a change of registration.

If such a written agreement is not given, the competitor may not participate in any FIS calendar events for a period of twelve months from the end of the last seeson in which he competed for his present National Ski Association, nor may he be issued with a licence to participate in FIS races by the new National Ski Association.

These rules are also valid when a competitor has more than one nationality and would like to change National Ski Association licence registration.

203.5.2 The FIS Council reserves the right in its absolute discretion, to grant or to dedine to grant, a change of licence notwithstanding the fulfilment of the aforementioned conditions where it deems it is contrary to the spirit of the rule and in the best interests of the International Ski Federation to do so (eg. to dedine to grant a change of licence if a member National Ski Association tries to "import" a competitor).

203.5.3 In the event that a competitor does not fulfil all the criteria required to apply for a change of National Ski Association licence registration, the onus shall be on the competitor to demonstrate in writing to the satisfaction of the FIS Council that exceptional circumstances exist and it is in the best interests of the International Ski Federation to grant the change

203.5.4 A competitor will retain his FIS points if he changes his National Ski Association under the condition that the former National Ski Association granted the release of the competitor.

203.5.5 In the event that any of the documents for an application to change licence registration submitted by the National Ski Association (letter of release from the former National Ski Association, passport, residency papers) are found to be false, the FIS Council will sanction the competitor and the new National Ski Association.

\section{Nordic Combined}

THE INTERNATIONAL SKI COMPETITION RULES (ICR)BOOK VII NORDIC COMBINED APPROVED BY THE $49^{\text {th }}$ INTERNATIONAL SKI CONGRESS, BARCELONA (SPA) INCL. CHANGE S AND PRE CISIONS 2015, O berhofen, 0 ctober 2015

203 Licence to participate in FIS R aces (FIS Licence)

A licence to participate in FIS races is issued by a National Ski Association to competitors who fulfil the criteria for participation through registering the competitor with FIS in the respective di scipline(s). 


\section{APPENDICES}

203.1 The FIS licence year begins on J uly $1^{\text {t }}$ and finishes on J une $30^{\text {th }}$ of the following year.

203.2 To be ligible for participation in FIS events, a competitor must havea licence issued by his National Ski Association. Such a licence shall be valid in the Northem and Southern hemispheres for the licence year only. The vali idity of a licence can belimited to participation in one specific country or in one or more specific events.

203.2.1 The National Ski Association must guarantee that all compeitors registered with a FIS License to participate in FIS races accept the Rules of the International Ski Federation, in particular the provision which foresees the exclusive competence of the Court of Arbitration for Sport as the court of appeal in doping cases.

203.3 A National Ski Association may only issue a FIS licence to participate in FIS races when the compeitor has proven his nationality and therefore eligibility by submitting a copy of his passport and signed the Athl etes Declaration in the form approved by the FIS Council and returned it to his National Ski Association. All forms from under-age applicants must be counter signed by their legal guardians. Both the copy of the passport and signed Athletes Declaration must be made available to FIS on request.

203.4 During the FIS licence year, a competitor may only participate in International FIS competitions with a FIS licence to participatein FIS races issued by one National Ski Association.

203.5 Application for a change of FIS L icence Registration

All applications to change licence registration from one member National Ski Association to another are subject to consideration by the FIS Council at its Meetings in the spring. In principle an application to change licence registra tion will not be granted unless the competitor demonstrates his personal association with the new nation.

Prior to submitting an application to change licence registration a competitor must possess the citizenship and passport of the country for which he wishes to compete In addition, the competitor must have had his principal legal and effective place of residence in the new country for a minimum of two (2) years immediately prior to the date of the request to change registration to the new country/National Ski Association. An exception to the two year residency rule may be waived if the competitor was born in the territory of the new country, or whose mother or father is a national of the new country. Applications will not be accepted if a parent has obtained a passport for the new country, but is not resident, and/or there is no family ancestry.

Furthermore the competitor is required to submit a detailed explanation with the application about his personal circumstances and the reason for requesting a change of licence registration.

203.5.1 If a competitor has al ready participated in FIS cal endar events for a National Ski Association, he must have the written agreement to be released from the former National Ski Association in addition to the citizenship, passport and residency requirements in art. 203.5 before the new National Ski Association may submit a request to FIS for a change of registration.

If such a written agreement is not given, the competitor may not participate in any FIS cal endar events for a period of twelve months from the end of the last season in which he competed for his present National Ski Association, nor may he be issued with a licence to participate in FIS races by the new National Ski Association.

These rules are also valid when a competitor has more than one nationality and would like to change National Ski Association licence registration.

203.5.2 TheFIS Council reserves theright in its absolute discretion, to grant or to dedineto grant, a change of licence notwithstanding the fulfilment of the aforementioned conditions where it deems it is contrary to the spirit of the rule and in the best interests of the International Ski Federation to do so (eg. to decline to grant a change of licence if a member National Ski Association tries to "import" a competitor).

203.5.3 In the event that a compeitor does not fulfil all the criteria required to apply for a change of National Ski Association licence registration, the onus shall be on the competitor to demonstrate in writing to the satisfaction of the FIS Council that exceptional circumstances exist and it is in the best interests of thel International Ski Federation to grant the change

203.5.4 A competitor will retain his FIS points if he changes his National Ski Association under the condition that the former National Ski Association granted the release of the competitor.

203.5.5 In the event that any of the documents for an application to change licence registration submitted by the National Ski Association (letter of release from the former National Ski Association, passport, residency papers) are found to be false, the FIS Council will sanction the competitor and the new National Ski Association.

THE INTERNATIONAL SKI COM PETITION RULES (ICR) BOOK VII NORDIC COMBINED APPROVED BY THE $49^{\text {th }}$ INTERNATIONAL SKI CONGRESS, BARCELONA (SPA) INCL. CHANGES AND PRE CISIONS 2015] uly 2015

203.1 TheFIS licence year begins on $J$ uly $1^{\text {t }}$ and finishes on $J$ une $30^{\text {th }}$ of the foll lowing year. 
203.2 To be eligible for participation in FIS events, a competitor must have a licence issued by his National Ski Association. Such a licence shall be valid in the Northem and Southern hemispheres for the licence year only. The validity of a licence can be limited to participation in one specific country or in one or more specific events.

203.2.1 The National Ski Association must guarantee that all competitors registered with a FIS License to participate in FIS races accept the Rules of the International Ski Federation, in particular the provision which foresees the exclusive competence of the Court of Arbitration for Sport as the court of appeal in doping cases.

203.3 A National Ski Association may only issue a FIS licence to participate in FIS races when the competitor has proven his national ity and therefore eligibility by submitting a copy of his passport and signed the Athletes Declaration in the form approved by the FIS Council and returned it to his National Ski Association. All forms from under-age applicants must be counter signed by their legal guardians. Both the copy of the passport and signed Athletes Ded aration must be made avail able to FIS on request.

203.4 During theFIS licence year, a competitor may only participate in I nternational FIS competitions with a FIS licence to participate in FIS races issued by oneNational Ski Association.

203.5 Application for a change of FIS Licence Registration

All applications to change licence registration from one member National Ski Association to another are subject to consideration by the FIS Council at its Meetings in the spring. In principlean application to change licence registration will not be granted unless the competitor demonstrates his personal association with the new nation.

Prior to submitting an application to change licence regi stration a competitor must possess the citizenship and passport of the country for which he wishes to compete In addition, the competitor must have had his principal legal and effective place of residence in the new country for a minimum of two (2) years immediately prior to the date of the request to change registration to the new country/National Ski Association. An exception to the two year residency rule may be waived if the competitor was born in the territory of the new country, or whose mother or father is a national of the new country. Applications will not be accepted if a parent has obtained a passport for the new country, but is not resident, and/or there is no family ancestry.

Furthermore the competitor is required to submit a detailed explanation with the application about his personal circumstances and the reason for requesting a change of licence registration.

203.5.1 If a competitor has al ready participated in FIS calendar events for a National Ski Association, he must have the written agreement to be released from the former National Ski Association in addition to the citizenship, passport and residency requirements in art. 203.5 before the new National Ski Association may submit a request to FIS for a change of registration.

If such a written agreement is not given, the competitor may not participate in any FIS calendar events for a period of twelve months from the end of the last season in which he competed for his present National Ski Association, nor may he be issued with a licence to participate in FIS races by the new National Ski Association.

These rules are also valid when a competitor has more than one nationality and would like to change National Ski Association licence registration.

203.5.2 The FIS Council reserves the right in its absolute discretion, to grant or to dedine to grant, a change of licence notwithstanding the fulfilment of the aforementioned conditions where it deems it is contrary to the spirit of the rule and in the best interests of the International Ski Federation to do so (eg. to dedine to grant a change of licence if a member National Ski Association tries to "import" a competitor).

203.5.3 In the event that a competitor does not fulfil all the criteria required to apply for a change of National Ski Association licence registration, the onus shall be on the competitor to demonstrate in writing to the satisfaction of the FIS Council that exceptional circumstances exist and it is in the best interests of the International Ski Federation to grant the change

203.5.4 A competitor will retain his FIS points if he changes his National Ski Association under the condition that the former National Ski Association granted the release of the competitor.

203.5.5 In the event that any of the documents for an application to change licence registration submitted by the National Ski Association (letter of release from the former National Ski Association, passport, residency papers) are found to be false, the FIS Council will sanction the competitor and the new National Ski Association.

THE INTERNATIONAL SKI COMPETITION RULES (ICR) BOOK VII NORDIC COM BINE DAPPROVED BY THE $49^{\text {th }}$ INTER NATIONAL SKI CONGRE SS, BARCE LONA (SPA) August 2014

203. Licence to participate in FIS R aces (FIS L icence)

A licence to participate in FIS races is issued by a National Ski Association to competitors who fulfil the criteria for participation through registering the competitor with FIS in the respectivedi scipline(s). 


\section{APPENDICES}

203.1 The FIS licence year begins on J uly 1st and finishes on J une 30th of the foll lowing year.

203.2 To be eligible for participation in FIS events, a compeitor must have a licence issued by his National Ski Association. Such a licence shall be valid in the Northem and Southern hemispheres for the licence year only. The validity of a licence can be limited to participation in one specific country or in one or more specific events.

203.2.1 The National Ski Association must guarantee that all competitors registered with a FIS License to participate in FIS races accept the Rules of the International Ski Federation, in particular the provision which foresees the exclusive competence of the Court of Arbitration for Sport as the court of appeal in doping cases.

203.3 A National Ski Association may only issue a FIS licence to participate in FIS races when the competitor has proven his national ity and therefore eligibility by submitting a copy of his passport and signed the Athletes Declaration in the form approved by the FIS Council and returned it to his National Ski Association. All forms from under-age applicants must be counter signed by their legal guardians. Both the copy of the passport and signed Athletes Declaration must be made available to FIS on request.

203.4 During theFIS licence year, a competitor may only partici pate in International FIS competitions with a FIS licence to participatein FIS races issued by one National Ski Association.

203.5 Application for a change of FIS L icence Registration

All applications to change licence registration from one member National Ski Association to another are subject to consideration by theFIS Council at its Meetings in the spring. In principlean application to change licence registration will not be granted unless the competitor demonstrates his personal association with the new nation.

Prior to submitting an application to change licence regi stration a competitor must possess the citizenship and passport of the country for which he wishes to compete In addition, the competitor must have had his principal legal and effective place of residence in the new country for a minimum of two (2) years immediately prior to the date of the request to change registration to the new country/National Ski Association. An exception to the two year residency rule may be waived if the competitor was born in the territory of the new country, or whose mother or father is a national of the new country. Applications will not be accepted if a parent has obtained a passport for the new country, but is not resident, and/or there is no family ancestry.

Furthermore the competitor is required to submit a detailed explanation with the application about his personal circumstances and the reason for requesting a change of licence registration.

203.5.1 If a compeitor has al ready participated in FIS calendar events for a National Ski Association, he must have the written agreement to be released from the former National Ski Association in addition to the citizenship, passport and residency requirements in art. 203.5 before the new National Ski Association may submit a request to FIS for a change of registration.

If such a written agreement is not given, the competitor may not participate in any FIS cal endar events for a period of twelve months from the end of the last season in which he competed for his present National Ski Association, nor may he be issued with a licence to participate in FIS races by the new National Ski Association.

These rules are also valid when a competitor has more than one nationality and would like to change National Ski Association licence registration.

203.5.2 The FIS Council reserves the right in its absolute discretion, to grant or to dedine to grant, a change of licence notwithstanding the fulfilment of the aforementioned conditions where it deems it is contrary to the spirit of the rule and in the best interests of the International Ski Federation to do so (eg. to decline to grant a change of licence if a member National Ski Association tries to "import" a competitor).

203.5.3 In the event that a competitor does not fulfil all the criteria required to apply for a change of National Ski Association licence registration, the onus shall be on the competitor to demonstrate in writing to the satisfaction of the FIS Council that exceptional circumstances exist and it is in the best interests of the International Ski Federation to grant the change

203.5.4 A competitor will retain his FIS points if he changes his National Ski Association under the condition that the former National Ski Association granted the release of the competitor.

203.5.5 In the event that any of the documents for an application to change licence registration submitted by the National Ski Association (letter of release from the former National Ski Association, passport, residency papers) are found to be false, the FIS Council will sanction the competitor and the new National Ski Association.

THE INTERNATIONAL SKI COM PETITION RULES (ICR) BOOK VII NORDIC COMBINED APPR OVED BY THE 48th INTERNATIONAL SKI CONGRESS, KANGWONLAND (KOR) WEB EDITION OCTOBER 2013

203 Licence to participate in FIS Races (FIS Licence) 
A licence to participate in FIS races is issued by a National Ski Association to competitors who fulfil the criteria for participation through registering the competitor with FIS in the respective di scipline(s).

203.1 The FIS licence year begins on J uly 1st and finishes on J une 30th of the foll lowing year.

203.2 To be eligible for participation in FIS events, a compeitor must have a licence issued by his National Ski Association. Such a licence shall be valid in the Northem and Southern hemispheres for the licence year only. The validity of a licence can be limited to participation in one specific country or in one or more specific events.

203.2.1 The National Ski Association must guarantee that all competitors registered with a FIS License to participate in FIS races accept the Rules of the International Ski Federation, in particular the provision which foresees the exclusive competence of the Court of Arbitration for Sport as the court of appeal in doping cases.

203.3 A National Ski Association may only issue a FIS licence to participate in FIS races when the competitor has proven his national ity and therefore el igibility by submitting a copy of his passport and signed the Athletes Declaration in the form approved by the FIS Council and retumed it to his National Ski Association. All forms from under-age applicants must be counter signed by their legal guardians. Both the copy of the passport and signed A thl etes Declaration must be made avail able to FIS on request.

203.4 During theFIS licence year, a competitor may only partici pate in International FIS competitions with a FIS licence to participate in FIS races issued by oneNational Ski Association.

203.5 Application for a change of FIS L icence Registration

All applications to change licence registration from one member National Ski Association to another are subject to consideration by theFIS Council at its Meetings in the spring. In principlean application to change licence registration will not be granted unless the competitor demonstrates his personal association with the new nation.

Prior to submitting an application to change licence regi stration a competitor must possess the citizenship and passport of the country for which he wishes to compete In addition, the competitor must have had his principal legal and effective place of residence in the new country for a minimum of two (2) years immediately prior to the date of the request to change registration to the new country/National Ski Association. An exception to the two year residency rule may be waived if the competitor was born in the territory of the new country, or whose mother or father is a national of the new country. Ap-plications will not be accepted if a parent has obtai ned a passport for the new country, but is not resident, and/or there is no family ancestry.

Furthermore the competitor is required to submit a detailed explanation with the application about his personal circumstances and the reason for requesting a change of licence registration.

203.5.1 If a competitor has al ready participated in FIS calendar events for a National Ski Association, he must have the written agreement to be released from the former National Ski Association in addition to the citizenship, passport and residency requirements in art. 203.5 before the new National Ski Association may submit a request to FIS for a change of registration.

If such a written agreement is not given, the competitor may not participate in any FIS calendar events for a period of twelve months from the end of the last season in which he competed for his present National Ski Association, nor may he be issued with a licence to participate in FIS races by the new National Ski Association.

These rules are also valid when a competitor has more than one nationality and would like to change National Ski Association licenceregistration.

203.5.2 The FIS Council reserves the right in its absolute discretion, to grant or to dedine to grant, a change of licence notwithstanding the fulfilment of the aforementioned conditions where it deems it is contrary to the spirit of the rule and in the best interests of the International Ski Federation to do so (eg. to dedine to grant a change of licence if a member National Ski Association tries to "import" a competitor).

203.5.3 In the event that a competitor does not fulfil all the criteria required to apply for a change of National Ski Association licence registration, the onus shall be on the competitor to demonstrate in writing to the satisfaction of the FIS Council that exceptional circumstances exist and it is in the best interests of the International Ski Federation to grant the change.

203.5.4 A competitor will retain his FIS points if he changes his National Ski Association under the condition that the former National Ski Association granted the release of the competitor.

203.5.5 In the event that any of the documents for an application to change licence registration submitted by the National Ski Association (letter of release from the former National Ski Association, passport, residency papers) are found to be false, the FIS Council will sanction the competitor and the new National Ski Association. 


\section{Ski-J umping}

THE INTERNATIONAL SKI COMPETITION RULES (ICR) BOOK III SKI JUMPING APPROVED BY THE $49^{\text {th }}$ INTERNATIONAL SKI CONGRESS, BARCELONA (SPA) INCL. CHANGES AND PRE CISIONS 2015 E dition J uly 2015

203 Licence to participate in FIS Races (FIS Licence)

A licence to participate in FIS races is issued by a National Ski Association to compeitors who fulfil the criteria for participation through registering the competitor with FIS in the respective di scipline(s).

203.1 The FIS licence year begins on J uly $1^{\text {tt }}$ and finishes on $J$ une $30^{\text {th }}$ of the foll lowing year.

203.2 To be eligible for participation in FIS events, a competitor must have a licence issued by his National Ski Association. Such a licence shall be valid in the Northem and Southern hemispheres for the licence year only. The validity of a licence can be limited to participation in one specific country or in one or more specific events.

203.2.1 The National Ski Association must guarantee that all competitors registered with a FIS License to participate in FIS races accept the Rules of the International Ski Federation, in particular the provision which foresees the exclusive competence of the Court of Arbitration for Sport as the court of appeal in doping cases.

203.3 A National Ski Association may only issue a FIS licence to participate in FIS races when the competitor has proven his national ity and therefore eligibility by submitting a copy of his passport and signed the Athletes Declaration in the form approved by the FIS Council and returned it to his National Ski Association. All forms from under-age applicants must be counter signed by their legal guardians. Both the copy of the passport and signed A thl etes Declaration must be made avail lable to FIS on request.

203.4 During theFIS licence year, a competitor may only participate in International FIS competitions with a FIS licence to participate in FIS races issued by one National Ski Association.

203.5 A pplication for a change of FIS L icence Registration

All applications to change licence registration from one member National Ski Association to another are subject to consideration by theFIS Council at its Meetings in the spring. In principlean application to change licence registration will not be granted unless the competitor demonstrates his personal association with the new nation.

Prior to submitting an application to change licence regi stration a competitor must possess the citizenship and passport of the country for which he wishes to compete In addition, the competitor must have had his principal legal and effective place of residence in the new country for a minimum of two (2) years immediately prior to the date of the request to change registration to the new country/National Ski Association. An exception to the two year residency rule may be waived if the competitor was born in the territory of the new country, or whose mother or father is a national of the new country. Ap- plications will not be accepted if a parent has obtai ned a passport for the new country, but is not resident, and/or there is no family ancestry.

Furthermore the competitor is required to submit a detailed explanation with the application about his personal circumstances and the reason for requesting a change of licence registration.

203.5.1 If a compeitor has al ready participated in FIS calendar events for a National Ski Association, he must have the written agreement to be released from the former National Ski Association in addition to the citizenship, passport and residency requirements in art. 203.5 before the new National Ski Association may submit a request to FIS for a change of registration.

If such a written agreement is not given, the competitor may not participate in any FIS calendar events for a period of twelve months from the end of the last seeson in which he competed for his present National Ski Association, nor may he be issued with a licence to participate in FIS races by the new National Ski Association.

These rules are also valid when a competitor has more than one nationality and would like to change National Ski Association licence registration.

203.5.2 The FIS Council reserves the right in its absolute discretion, to grant or to dedine to grant, a change of licence notwithstanding the fulfilment of the aforementioned conditions where it deems it is contrary to the spirit of the rule and in the best interests of the International Ski Federation to do so (eg. to dedine to grant a change of licence if a member National Ski Association tries to "import" a competitor).

203.5.3 In the event that a competitor does not fulfil all the criteria required to apply for a change of National Ski Association licence registration, the onus shall be on the competitor to demonstrate in writing to the satisfaction of the FIS Council that exceptional circumstances exist and it is in the best interests of the International Ski Federation to grant the change

203.5.4 A compeitor will retain his FIS points if he changes his National Ski Association under the condition that the former National Ski Association granted the release of the competitor.

203.5.5 In the event that any of the documents for an application to change licence registration submitted by the National Ski Association (letter of release from the former National Ski Association, passport, residency 
papers) are found to be false, the FIS Council will sanction the competitor and the new National Ski Association.

\section{THE INTERNATIONAL SKI COMPETITION RULES (ICR) BOOK III SKI J UM PINGAPPR OVED BY THE 49th INTERNATIONAL SKI CONGRESS, BARCEL ONA (SPA) J uly 2014 \\ 203. Licence to participate in FIS R aces (FIS L icence)}

A licence to participate in FIS races is issued by a National Ski Association to compeitors who fulfil the criteria for participation through registering the competitor with FIS in the respectivedi scipline(s).

203.1 The FIS licence year begins on J uly $1^{\text {t }}$ and finishes on $J$ une $30^{\text {th }}$ of the foll lowing year.

203.2 To be eligible for participation in FIS events, a competitor must have a licence issued by his National Ski Association. Such a licence shall be valid in the Northern and Southern hemispheres for the licence year only. The validity of a licence can be limited to participation in one specific country or in one or more specific events.

203.2.1 The National Ski Association must guarantee that all competitors registered with a FIS License to participate in FIS races accept the Rules of the International Ski Federation, in particular the provision which foresees the exclusive competence of the Court of Arbitration for Sport as the court of appeal in doping cases.

203.3 A National Ski Association may only issue a FIS licence to participate in FIS races when the competitor has proven his nationality and therefore eligibility by submitting a copy of his passport and signed the Athletes Dedaration in the form approved by the FIS Council and returned it to his National Ski Association. All forms from under-age applicants must be counter signed by their legal guardians. Both the copy of the passport and signed Athletes Declaration must be made available to FIS on request.

203.4 During theFIS licence year, a competitor may only partici pate in International FIS competitions with a FIS licence to participate in FIS races issued by oneNational Ski Association.

203.5 Application for a change of FIS L icence Registration

All applications to change licence registration from one member National Ski Association to another are subject to consideration by theFIS Council at its Meetings in the spring. In principlean application to change licence registration will not be granted unless the competitor demonstrates his personal association with the new nation.

Prior to submitting an application to change licence regi stration a competitor must possess the citizenship and passport of the country for which he wishes to compete In addition, the competitor must have had his principal legal and effective place of residence in the new country for a minimum of two (2) years immediately prior to the date of the request to change registration to the new country/National Ski Association. An exception to the two year residency rule may be waived if the competitor was born in the territory of the new country, or whose mother or father is a national of the new country. Applications will not be accepted if a parent has obtained a passport for the new country, but is not resident, and/or there is no family ancestry.

Furthermore the competitor is required to submit a detailed explanation with the application about his personal circumstances and the reason for requetting a change of licence registration.

203.5.1 If a competitor has al ready participated in FIS calendar events for a National Ski Association, he must have the written agreement to be released from the former National Ski Association in addition to the citizenship, passport and residency requirements in art. 203.5 before the new National Ski Association may submit a request to FIS for a change of registration.

If such a written agreement is not given, the competitor may not participate in any FIS calendar events for a period of twelve months from the end of the last season in which he competed for his present National Ski Association, nor may he be issued with a licence to participate in FIS races by the new National Ski Association.

These rules are also valid when a competitor has more than one nationality and would like to change National Ski Association licence registration.

203.5.2 The FIS Council reserves the right in its absolute discretion, to grant or to dedine to grant, a change of licence notwithstanding the fulfilment of the aforementioned conditions where it deems it is contrary to the spirit of the rule and in the best interests of the International Ski Federation to do so (eg. to dedine to grant a change of licence if a member National Ski Association tries to "import" a competitor).

203.5.3 In the event that a competitor does not fulfil all the criteria required to apply for a change of National Ski Association licence registration, the onus shall be on the competitor to demonstrate in writing to the satisfaction of the FIS Council that exceptional circumstances exist and it is in the best interests of the International Ski Federation to grant the change

203.5.4 A competitor will retain his FIS points if he changes his National Ski Association under the condition that the former National Ski Association granted the release of the competitor. 


\section{APPENDICES}

203.5.5 In the event that any of the documents for an application to change licence registration submitted by the National Ski Association (letter of release from the former National Ski Association, passport, residency papers) are found to be false, the FIS Council will sanction the competitor and the new National Ski Association.

\section{THE INTERNATIONAL SKI COMPETITION RULES (ICR) BOOK III SKI JUMPING APPROVED BY THE 48th INTERNATIONAL SKI CONGRESS, KANGWONLAND (KOR) WEB EDITION OCTOBER 2013 \\ 203 L icence to participate in FIS Races (FIS L icence)}

A licence to participate in FIS races is issued by a National Ski Association to compeitors who fulfil the criteria for participation through registering the competitor with FIS in the respective di scipline(s).

203.1 TheFIS licence year begins on J uly 1st and finishes on J une 30th of the foll lowing year.

203.2 To be eligible for participation in FIS events, a competitor must have a licence issued by his National Ski Association. Such a licence shall be valid in the Northern and Southern hemispheres for the licence year only. The validity of a licence can be limited to participation in one specific country or in one or more specific events.

203.2.1 The National Ski Association must guarantee that all compeitors registered with a FIS License to participate in FIS races accept the Rules of the International Ski Federation, in particular the provision which foresees the exclusive competence of the Court of Arbitration for Sport as the court of appeal in doping cases.

203.3 A National Ski Association may only issue a FIS licence to participate in FIS races when the competitor has proven his nationality and therefore eligibility by submitting a copy of his passport and signed the Athletes Declaration in the form approved by the FIS Council and returned it to his National Ski Association. All forms from under-age applicants must be counter signed by their legal guardians. Both the copy of the passport and signed Athletes Declaration must be made available to FIS on request.

203.4 During the FIS licence year, a competitor may only participate in International FIS competitions with a FIS licence to participate in FIS races issued by one National Ski Association.

\subsection{A pplication for a change of FIS L icence Registration}

All applications to change licence registration from one member National Ski Association to another are subject to consideration by theFIS Council at its Meetings in the spring. In principlean application to change licence registration will not be granted unless the competitor demonstrates his personal association with the new nation.

Prior to submitting an application to change licence registration a competitor must possess the citizenship and passport of the country for which he wishes to compete In addition, the competitor must have had his principal legal and effective place of residence in the new country for a minimum of two (2) years immediately prior to the date of the request to change registration to the new country/National Ski Association. An exception to the two year residency rule may be waived if the competitor was born in the territory of the new country, or whose mother or father is a national of the new country. Applications will not be accepted if a parent has obtained a passport for the new country, but is not resident, and/or there is no family ancestry.

Furthermore the competitor is required to submit a detailed explanation with the application about his personal circumstances and the reason for requesting a change of licence registration.

203.5.1 If a competitor has al ready participated in FIS calendar events for a National Ski Association, he must have the written agreement to be released from the former National Ski Association in addition to the citizenship, passport and residency requirements in art 203.5 before the new National Ski Association may submit a request to FIS for a change of registration.

If such a written agreement is not given, the competitor may not participate in any FIS calendar events for a period of twelve months from the end of the last season in which he competed for his present National Ski Association, nor may he be issued with a licence to participate in FIS races by the new National Ski Association

These rules are also valid when a competitor has more than one nationality and would like to change National Ski Association licence registration.

203.5.2 The FIS Council reserves the right in its absolute discretion, to grant or to decline to grant, a change of licence notwithstanding the fulfilment of the aforementioned conditions where it deems it is contrary to the spirit of the rule and in the best interests of the International Ski Federation to do so (eg. to dedine to grant a change of licence if a member National Ski Association tries to "import" a competitor).

203.5.3 In theevent that a competitor does not fulfil all the criteria required to apply for a change of National Ski Association licence registration, the onus shall be on the competitor to demonstrate in writing to the satisfaction of the FIS Council that exceptional circumstances exist and it is in the best interests of the International Ski Federation to grant the change 
203.5.4 A competitor will retain his FIS points if he changes his National Ski Association under the condition that the former National Ski Association granted the rel ease of the competitor.

203.5.5 In the event that any of the documents for an application to change licence registration submitted by the National Ski Association (letter of release from the former National Ski Association, passport, residency papers) are found to be false, the FIS Council will sanction the competitor and the new National Ski Association.

\section{Snowboard \\ THE INTERNATIONAL SNOWBOARD COMPETITION RULES (ICR)BOOK VI JOINT REGULATIONS FOR SNOWBOARDING SLALOM / GIANT SLALOM TRIPLE-S, PARALLEL EVENTS, SNOWBOARD CROSS, SNOWBOARD HALFPIPE, SNOWBOARD BIG AIR, SNOWBOARD SLOPESTYLE APPROVED BY THE 49TH INTERNATIONAL SK I CONGRESS, BARCELONA (SPA) INCL. CHANGES AND PRECISIONS 2015 Oberhofen, December 2015 Web Edition}

203 Licence to participate in FIS R aces (FIS Licence)

A licence to participate in FIS races is issued by a National Ski Associa tion to competitors who fulfil the criteria for participation through register- ing the competitor with FIS in the respective di scipline(s).

203.1 The FIS licence year begins on J uly $1^{\mathrm{t}}$ and finishes on $J$ une $30^{\text {th }}$ of the foll lowing year.

203.2 To be eligible for participation in FIS events, a competitor must have a licence issued by his National Ski Association. Such a licence shall be valid in the Northem and Southern hemispheres for the licence year only. The validity of a licence can be limited to participation in one specific country or in one or more specific events.

203.2.1 The National Ski Association must guarantee that all competitors registered with a FIS License to participate in FIS races accept the Rules of the International Ski Federation, in particular the provision which foresees the exclusive competence of the Court of Arbitration for Sport as the court of appeal in doping cases.

203.3 A National Ski Association may only issue a FIS licence to participate in FIS races when the competitor has proven his national ity and therefore eligibility by submitting a copy of his passport and signed the Athletes Dedaration in the form approved by the FIS Council and returned it to his National Ski Association. All forms from under-age applicants must be counter signed by their legal guardians. Both the copy of the passport and signed A thl etes Declaration must be made avai lable to FIS on request.

203.4 During theFIS licence year, a competitor may only participate in I nternational FIS competitions with a FIS licence to participate in FIS races issued by oneNational Ski Association.

203.5 Application for a change of FIS L icence Registration

All applications to change licence registration from one member National Ski Association to another are subject to consideration by theFIS Council at its Meetings in the spring. In principle an application to change licence registration will not be granted unless the competitor demonstrates his personal association with the new nation.

Prior to submitting an application to change licence regi stration a competitor must possess the citizenship and passport of the country for which he wishes to compete In addition, the competitor must have had his principal legal and effective place of residence in the new country for a minimum of two (2) years immediately prior to the date of the request to change registration to the new country/National Ski Association. An exception to the two year residency rule may be waived if the competitor was born in the territory of the new country, or whose mother or father is a national of the new country. Applications will not be accepted if a parent has obtained a passport for the new country, but is not resident, and/or there is no family ancestry. Furthermore the competitor is required to submit a detailed ex- planation with the application about his personal circumstances and the reason for requesting a change of licence registration.

203.5.1 If a competitor has already participated in FIS calendar events for a Na tional Ski Association, he must have the written agreement to be released from the former National Ski Association in addition to the citizenship, passport and residency requirements in art. 203.5 before the new National Ski Association may submit a request to FIS for a change of registration.

If such a written agreement is not given, the competitor may not participate in any FIS calendar events for a period of twelve months from the end of the last season in which he competed for his present National Ski Association, nor may he be issued with a licence to participate in FIS races by the new National Ski Association.

These rules are also valid when a competitor has more than one nationality and would like to change National Ski Association licence registration.

203.5.2 The FIS Council reserves the right in its absolute discretion, to grant or to dedine to grant, a change of licence notwithstanding the fulfilment of the aforementioned conditions where it deems it is contrary to the spirit of the rule and in the best interests of the International Ski Federation to do so (eg. to dedine to grant a change of licence if a member National Ski Association tries to "import" a competitor). 


\section{APPENDICES}

203.5.3 In the event that a competitor does not fulfil all the criteria required to apply for a change of National Ski Association licence registration, the onus shall be on the competitor to demonstrate in writing to the satisfaction of the FIS Council that exceptional circumstances exist and it is in the best interests of the International Ski Federation to grant the change.

203.5.4 A competitor will retain his FIS points if he changes his National Ski Association under the condition that the former National Ski Association granted the rel ease of the competitor.

203.5.5 In the event that any of the documents for an application to change licence registration submitted by the National Ski Association (letter of release from the former National Ski Association, passport, residency papers) are found to be false, the FIS Council will sanction the competitor and the new National Ski Association.

THE INTERNATIONAL SNOWBOARD COMPETITION RULES (ICR) BOOK VI JOINT REGULATIONS FOR SNOWBOARDING SLALOM / GIANT SLALOM TRIPLE-S, PARALLEL EVENTS, SNOWBOARD CROSS SNOWBOARD HALFPIPE SNOWBOARD, BIG AIR SNOWBOARD SLOPESTYLE APPROVED BY THE 49TH INTERNATIONAL SKI CONGRESS, BARCELONA (SPA) INCL. CHANGES AND PRECISIONS 2015 WEB EDITION SEPTEMBER 20150 berhofen, September 2015

203 Licence to participate in FIS R aces (FIS L icence)

A licence to participate in FIS races is issued by a National Ski Associa tion to competitors who fulfil the criteria for partici pation through registering the competitor with FIS in the respectivedi scipline(s).

203.1 The FIS licence year begins on J uly $1^{\text {t }}$ and finishes on $J$ une $30^{\text {th }}$ of the following year.

203.2 To be eligible for participation in FIS events, a competitor must have a licence issued by his National Ski Association. Such a licence shall be valid in the Northem and Southern hemispheres for the licence year only. The validity of a licence can be limited to participation in one specific country or in one or more specific events.

203.2.1 The National Ski Association must guarantee that all competitors registered with a FIS License to participate in FIS races accept the Rules of the International Ski Federation, in particular the provision which foresees the exclusive competence of the Court of Arbitration for Sport as the court of appeal in doping cases.

203.3. A National Ski Association may only issue a FIS licence to participate in FIS races when the competitor has proven his nationality and therefore eligibility by submitting a copy of his passport and signed the Athletes Dedaration in the form approved by the FIS Council and returned it to his National Ski Association. All forms from under-age applicants must be counter signed by their legal guardians. Both the copy of the passport and signed Athletes Dedaration must be made available to FIS on request.

203.4 During theFIS licence year, a competitor may only participate in International FIS competitions with a FIS licence to participate in FIS races issued by oneNational Ski Association.

203.5 Application for a change of FIS L icence Registration

All applications to change licence registration from one member National Ski Association to another are subject to consideration by theFIS Council at its Meetings in the spring. In principlean application to change licence registration will not be granted unless the competitor demonstrates his personal association with the new nation.

Prior to submitting an application to change licence regi stration a competitor must possess the citizenship and passport of the country for which he wishes to compete In addition, the competitor must have had his principal legal and effective place of residence in the new country for a minimum of two (2) years immediately prior to the date of the request to change registration to the new country/National Ski Association. An exception to the two year residency rule may be waived if the competitor was born in the territory of the new country, or whose mother or father is a national of the new country. Applications will not be accepted if a parent has obtained a passport for the new country, but is not resident, and/or there is no family ancestry. Furthermore the competitor is required to submit a detailed ex- planation with the application about his personal circumstances and the reason for requesting a change of licence registration.

203.5.1 If a compeitor has al ready participated in FIS calendar events for a National Ski Association, he must have the written agreement to be released from the former National Ski Association in addition to the citizenship, passport and residency requirements in art. 203.5 before the new National Ski Association may submit a request to FIS for a change of registration.

If such a written agreement is not given, the competitor may not participate in any FIS calendar events for a period of twelve months from the end of the last season in which he competed for his present National Ski Association, nor may he be issued with a licence to participate in FIS races by the new National Ski Association. These rules are also valid when a competitor has more than one nationality and would like to change National Ski Association licence registration.

203.5.2 The FIS Council reserves the right in its absolute discretion, to grant or to dedine to grant, a change of licence notwithstanding the fulfilment of the aforementioned conditions where it deems it is contrary to 
the spirit of the rule and in the best interests of the International Ski Federation to do so (eg. to dedine to grant a change of licence if a member National Ski Association tries to "import" a competitor).

203.5.3 In the event that a competitor does not fulfil all the criteria required to apply for a change of National Ski Association licence registration, the onus shall be on the competitor to demonstrate in writing to the satisfaction of the FIS Council that exceptional circumstances exist and it is in the best interests of the International Ski Federation to grant the change

203.5.4 A competitor will retain his FIS points if he changes his National Ski Association under the condition that the former National Ski Association granted the release of the competitor.

203.5.5 In the event that any of the documents for an application to change licence registration submitted by the National Ski Association (letter of release from the former National Ski Association, passport, residency papers) are found to be false, the FIS Council will sanction the competitor and the new National Ski Association.

FIS THE INTERNATIONAL SNOWBOARD COMPETITION RULES (ICR) BOOK VI JOINT REGULATIONS FOR SNOWBOARDING SLALOM / GIANT SLALOM TRIPLE-S, PARALLEL EVENTS SNOWBOARD CROSS SNOWBOARD HALFPIPE, SNOWBOARD BIG AIR SNOWBOARD SLOPESTYLE, APPROVED BY THE 49TH INTERNATIONAL SKI CONGRESS, BARCE L ONA (SPA) Web edition Oberhofen, October 2014

203 Licence to participate in FIS R aces (FIS Licence)

A licence to participate in FIS races is issued by a National Ski Association to competitors who fulfil the criteria for participation through registering the competitor with FIS in the respectivedi scipline(s).

203.1. The FIS licenceyear begins on J uly $1^{\text {t }}$ and finishes on J une $30^{\text {th }}$ of the following year.

203.2 To be eligible for participation in FIS events, a compeitor must have a licence issued by his National Ski Association. Such a licence shall be valid in the Northern and Southern hemispheres for the licence year only. The validity of a licence can be limited to participation in one specific country or in one or more specific events.

203.2.1 The National Ski Association must guarantee that all competitors registered with a FIS License to participate in FIS races accept the Rules of the International Ski Federation, in particular the provision which foresees the exclusive competence of the Court of Arbitration for Sport as the court of appeal in doping cases.

203.3. A National Ski Association may only issue a FIS licence to participate in FIS races when the competitor has proven his national ity and therefore eligibility by submitting a copy of his passport and signed the Athletes Declaration in the form approved by the FIS Council and returned it to his National Ski Association. All forms from under-age applicants must be counter signed by their legal guardians. Both the copy of the passport and signed A thl etes Dedaration must be made avai lable to FIS on request.

203.4. During the FIS licence year, a competitor may only participate in International FIS competitions with a FIS licenceto participatein FIS races issued by oneNational Ski Association.

203. 5 A pplication for a change of FIS L icence Registration

All applications to change licence registration from one member National Ski Association to another are subject to consideration by theFIS Council at its Meetings in the spring. In principle an application to change licence registration will not be granted unless the compeitor demonstrates his personal association with the new nation.

Prior to submitting an application to change licence regi stration a competitor must possess the citizenship and passport of the country for which he wishes to compete In addition, the competitor must have had his principal legal and effective place of residence in the new country for a minimum of two (2) years immediately prior to the date of the request to change registration to the new country/National Ski Association. An exception to the two year residency rule may be waived if the competitor was born in the territory of the new country, or whose mother or father is a national of the new country. Applications will not be accepted if a parent has obtained a passport for the new country, but is not resident, and/or there is no family ancestry. Furthermore the competitor is required to submit a detailed ex- planation with the application about his personal circumstances and the reason for requesting a change of licence registration.

203.5.1 If a compeitor has al ready participated in FIS calendar events for a National Ski Association, he must have the written agreement to be released from the former National Ski Association in addition to the citizenship, passport and residency requirements in art. 203.5 before the new National Ski Association may submit a request to FIS for a change of registration.

If such a written agreement is not given, the competitor may not participate in any FIS calendar events for a period of twelve months from the end of the last season in which he competed for his present National Ski Association, nor may he be issued with a licence to participate in FIS races by the new National Ski Association. These rules are also valid when a competitor has more than one nationality and would like to change National Ski Association licence registration. 


\section{APPENDICES}

203.5.2. The FIS Council reserves the right in its absolute discretion, to grant or to decline to grant, a change of licence notwithstanding the fulfilment of the aforementioned conditions where it deems it is contrary to the spirit of the rule and in the best interests of the International Ski Federation to do so (eg. to dedine to grant a change of licence if a member National Ski Association tries to "import" a competitor).

203.5.3. In the event that a competitor does not fulfil all the criteria required to apply for a change of National Ski Association licence registration, the onus shall be on the competitor to demonstrate in writing to the satisfaction of the FIS Council that exceptional circumstances exist and it is in the best interests of the International Ski Federation to grant the change

203.5.4. A competitor will retain his FIS points if he changes his National Ski Association under the condition that the former National Ski Association granted the release of the competitor.

203.5.5. In the event that any of the documents for an application to change licence registration submitted by the National Ski Association (letter of release from the former National Ski Association, passport, residency papers) are found to be false, the FIS Council will sanction the competitor and the new National Ski Association.

THE INTERNATIONAL SNOWBOARD COMPETITION RULES (ICR) BOOK VI JOINT REGULATIONS FOR SNOWBOARDING SLALOM / GIANT SLALOM TRIPLE-S, PARALLEL \begin{tabular}{llllllll}
\hline EVENTS & SNOWBOARD & CROSS & SNOWBOARD & HALFPIPE & SNOWBOARD & BIG AIR \\
\hline
\end{tabular} SNOWBOARD SLOPESTYLE APPROVED BY THE 49TH INTERNATIONAL SK I CONGRESS, BAR CE L ONA (SPA) October 2014

203. L icence to participate in FIS R aces (FIS L icence)

A licence to participate in FIS races is issued by a National Ski Association to competitors who fulfil the criteria for participation through registering the competitor with FIS in the respective di scipline(s).

203.1 The FIS licence year begins on J uly $1^{\text {st }}$ and finishes on J une $30^{\text {th }}$ of the following year.

203.2 To be eligible for participation in FIS events, a competitor must have a licence issued by his National Ski Association. Such a licence shall be valid in the Northern and Southern hemispheres for the licence year only. The validity of a licence can be limited to participation in one specific country or in one or more specific events.

203.2.1 The National Ski Association must guarantee that all competitors registered with a FIS License to participate in FIS races accept the Rules of the International Ski Federation, in particular the provision which foresees the exclusive competence of the Court of Arbitration for Sport as the court of appeal in doping cases.

203.3 A National Ski Association may only issue a FIS licence to participate in FIS races when the competitor has proven his nationality and therefore eligibility by submitting a copy of his passport and signed the Athletes Declaration in the form approved by the FIS Council and returned it to his National Ski Association. All forms from under-age applicants must be counter signed by their legal guardians. Both the copy of the passport and signed Athletes Declaration must be made available to FIS on request.

203.4 During the FIS licence year, a competitor may only participate in International FIS competitions with a FIS licence to participate in FIS races issued by one National Ski Association.

203.5 Application for a change of FIS L icence Registration

All applications to change licence registration from one member National Ski Association to another are subject to consideration by theFIS Council at its Meetings in the spring. In principlean application to change licence registration will not be granted unless the competitor demonstrates his personal association with the new nation.

Prior to submitting an application to changelicence registration a competitor must possess the citizenship and passport of the country for which he wishes to compete In addition, the competitor must have had his principal legal and effective place of residence in the new country for a minimum of two (2) years immediately prior to the date of the request to change registration to the new country/National Ski Association. An exception to the two year residency rule may be waived if the competitor was born in the territory of the new country, or whose mother or father is a national of the new country. Applications will not be accepted if a parent has obtained a passport for the new country, but is not resident, and/or there is no family ancestry. Furthermore the competitor is required to submit a detailed ex- planation with the application about his personal circumstances and the reason for requesting a change of licence registration.

203.5.1 If a competitor has al ready participated in FIS calendar events for a National Ski Association, he must have the written agreement to be released from the former National Ski Association in addition to the citizenship, passport and residency requirements in art. 203.5 before the new National Ski Association may submit a request to FIS for a change of registration.

If such a written agreement is not given, the competitor may not participate in any FIS calendar events for a period of twelve months from the end of the last season in which he competed for his present National Ski Association, nor may he be issued with a licence to participate in FIS races by the new National Ski Association. 
These rules are also valid when a competitor has more than one nationality and would like to change National Ski Association licence registration.

203.5.2 The FIS Council reserves the right in its absolute discretion, to grant or to dedine to grant, a change of licence notwithstanding the fulfilment of the aforementioned conditions where it deems it is contrary to the spirit of the rule and in the best interests of the International Ski Federation to do so (eg. to dedine to grant a change of licence if a member National Ski Association tries to "import" a competitor).

203.5.3 In the event that a competitor does not fulfil all the criteria required to apply for a change of National Ski Association licence registration, the onus shall be on the competitor to demonstrate in writing to the satisfaction of the FIS Council that exceptional circumstances exist and it is in the best interests of the International Ski Federation to grant the change

203.5.4 A competitor will retain his FIS points if he changes his National Ski Association under the condition that the former National Ski Association granted the rel ease of the competitor.

203.5.5 In the event that any of the documents for an application to change licence registration submitted by the National Ski Association (letter of release from the former National Ski Association, passport, residency papers) are found to be false, the FIS Council will sanction the competitor and the new National Ski Association.

THE INTERNATIONAL SNOWBOARD COMPETITION RULES (ICR) BOOK VI JOINT REGULATIONS FOR SNOWBOARDING SLALOM / GIANT SLALOM, TRIPLE-S, PARALLEL EVENTS, SNOWBOARD CROSS, SNOWBOARD HALFPIPE, SNOWBOARD BIG AIR, SNOWBOARD SLOPESTYLE APPROVED BY THE 48TH INTERNATIONAL SKI CONGRESS, KANG WONLAND (KOR) WE B EDITION AUGUST 2013

$203 \mathrm{~L}$ icence to participate in FIS R aces (FIS Licence)

A licence to participate in FIS races is issued by a National Ski Association to competitors who fulfil the criteria for participation through registering the competitor with FIS in the respective di scipline(s).

203.1 The FIS licence year begins on J uly 1st and finishes on J une 30th of the foll lowing year.

203.2 To be eligible for participation in FIS events, a compeitor must have a licence issued by his National Ski Association. Such a licence shall be valid in the Northem and Southern hemispheres for the licence year only. The validity of a licence can be limited to participation in one specific country or in one or more specific events.

203.2.1 The National Ski Association must guarantee that all competitors registered with a FIS License to participate in FIS races accept the Rules of the International Ski Federation, in particular the provision which foresees the exclusive competence of the Court of Arbitration for Sport as the court of appeal in doping cases.

203.3 A National Ski Association may only issue a FIS licence to participate in FIS races when the competitor has proven his national ity and therefore eligibility by submitting a copy of his passport and signed the Athletes Declaration in the form approved by the FIS Council and returned it to his National Ski Association. All forms from under-age applicants must be counter signed by their legal guardians. Both the copy of the passport and signed Athletes Dedaration must be made available to FIS on request.

203.4 During theFIS licence year, a compeitor may only participate in International FIS competitions with a FIS licence to participatein FIS races issued by one National Ski Association.

203.5 Application for a change of FIS L icence Registration

All applications to change licence registration from one member National Ski Association to another are subject to consideration by theFIS Council at its Meetings in the spring. In principlean application to change licence registration will not be granted unless the competitor demonstrates his personal association with the new nation.

Prior to submitting an application to change licence registration a competitor must possess the citizenship and passport of the country for which he wishes to compete In addition, the compeitor must have had his principal legal and effective place of residence in the new country for a minimum of two (2) years immediately prior to the date of the request to change registration to the new country/National Ski Association. An exception to the two year residency rule may be waived if the competitor was born in the territory of the new country, or whose mother or father is a national of the new country. Applications will not be accepted if a parent has obtained a passport for the new country, but is not resident, and/or there is no family ancestry. Furthermore the competitor is required to submit a detailed explanation with the application about his personal circumstances and the reason for requesting a change of licence registration.

203.5.1 If a competitor has al ready participated in FIS calendar events for a National Ski Association, he must have the written agreement to be released from the former National Ski Association in addition to the citizenship, passport and residency requirements in art. 203.5 before the new National Ski Association may submit a request to FIS for a change of registration. If such a written agreement is not given, the competitor may not participate in any FIS cal endar events for a period of twelve months from the end of the last season 


\section{APPENDICES}

in which he competed for his present National Ski Association, nor may he be issued with a licence to participate in FIS races by thenew National Ski Association.

These rules are also valid when a competitor has more than one nationality and would like to change National Ski Association licence registration.

203.5.2 The FIS Council reserves the right in its absolute discretion, to grant or to decline to grant, a change of licence notwithstanding the fulfilment of the aforementioned conditions where it deems it is contrary to the spirit of the rule and in the best interests of the International Ski Federation to do so (eg. to decline to grant a change of licence if a member National Ski Association tries to "import" a competitor).

203.5.3 In the event that a competitor does not fulfil all the criteria required to apply for a change of National Ski Association licence registration, the onus shall be on the competitor to demonstrate in writing to the satisfaction of the FIS Council that exceptional circumstances exist and it is in the best interests of the International Ski Federation to grant the change.

203.5.4 A competitor will retain his FIS points if he changes his National Ski Association under the condition that the former National Ski Association granted the release of the competitor.

203.5.5 In the event that any of the documents for an application to change licence registration submitted by the National Ski Association (letter of release from the former National Ski Association, passport, residency papers) are found to be false, the FIS Council will sanction the competitor and the new National Ski Association.

\section{T able Tennis}

\section{ITTF H andbook $1^{\text {st } J \text { anuary } 2016}$}

\subsection{INTERNATIONAL ELIGIBILITY}

3.8.1 Eligibility in Olympic title competitions is regulated separately by 4.5.1 and eligibility in Paralympic title competitions is regulated separately by the IPC and 4.6.1; additional eligibility regulations apply to World title events $(4.1 .3,4.2 .3,4.3 .6,4.4 .3)$.

3.8.2 A player shall be regarded as representing an Association if he or she accepted to be nominated by this Association and subsequently participates in a competition listed in 3.1.2.3 or in regional championships other than individual events at Open I nternational Championships.

3.8.3 A player is eligible to represent an Association only if he or she is a national of the country in which that Association has jurisdiction, except that a player who has al ready represented an Association of which heor she was not a national in accordance with previous rules may retain that eligibility.

3.8.3.1 Where the players of more than one Association have the same national ity, a player may represent one of these Associations only, if he or she is born in or has his or her main residence in the teritory controlled by that Association.

3.8.3.2 A player who is eligible to represent more than 1 Association shall have the right to choose which of the relevant Associations he or shewill represent.

3.8.4 A player is eligible to represent a Continental Federation (1.18.1) in an event of continental teams only if he or she is eligible to represent a member Association of this Continental Federation according to 3.8.3.

3.8.5 A player shall not represent different Associations within a period of 3 years.

3.8.6 An Association may nominate a player under its jurisdiction (1.21) to enter any individual events of Open International Championships; such nomination may be indicated in results lists and ITTF publications but does not affect the eligibility of this player according to 3.8.2.

3.8.7 A player or his or her Association shall, if so requested by the referee, provide documentary evidence of his or her eligibility and his or her passport.

3.8.8. Any appeal on a question of eligibility shall be referred to an Eligibility Commission, consisting of the Executive Committee, the chair of the Rules Committee and the chair of the Athletes' Commission, whose decision shall be final.

\subsection{WORLD CHAMPIONSHIPS}

\subsubsection{Eligibility}

4.1.3.1 Only an Association which is not in arrears (1.16.3.3) and has taken part with at least one player or team (an entry) in its preceding Continental Championships, induding qualification tournaments, or Continental Games, shall be eligibleto enter teams or individual players in the Championships.

4.1.3.2 In addition to provisions of 3.8, players who have acquired a new nationality and wish to represent the association corresponding to the new national ity shall register with ITTF through this new Association.

4.1.3.3 Such player shall not represent thenew Association before:

4.1.3.3.1 3 years after the date of registration, if the player is under the age of 15 when registered, but only 1 year after the date of registration if the player has never represented another association;

4.1.3.3.2 5 years after the date of registration, if the player is under the age of 18 but at least 15 years of age when registered; 


\section{NATIONALITY REQUiREMENTS In Olympic SPORTS}

4.1.3.3.3 7 years after the date of registration, if the player is under the age of 21 but at least 18 years of age when registered.

4.1.3.4 Players being 21 years of age or older will not be registered with the ITTF and will not be eligible to represent a new association at World Championships.

4.2 WORLD JUNIOR CHAM PIONSHIPS

4.2.3 Eligibility

4.2.3.1 Only an Association which is not in arrears (1.16.3.3) shall be eligible to enter teams or individual players in the Championships.

4.2.3.2 The system of qualification for team and individual events shall be determined by the Board not later than 18 months before the start of the Championships.

4.2.3.3 All players shall bejuniors according to 3.7.4.2.

4.2.3.4 In addition to provisions of 3.8, players who have acquired a new nationality and wish to represent the association corresponding to the new national ity shall register with ITTF through this new Association. 4.2.3.5 Such player shall not represent the new Association before 3 years after the date of registration, if the player is under the age of 15 when registered, but only 1 year after the date of registration if the player has never represented another association.

\subsection{WORLD CUP}

4.3.6 Eligibility

4.3.6.1 In addition to provisions of 3.8, players who have acquired a new nationality and wish to represent theassociation corresponding to the new national ity shall register with ITTF through this new Association.

4.3.6.2 Such player shall not represent thenew Association before:

4.3.6.2.1 3 years after the date of registration, if the player is under the age of 15 when registered, but only 1 year after the date of registration if the player has never represented another association;

4.3.6.2.2 5 years after the date of registration, if the player is under the age of 18 but at least 15 years of age when registered;

4.3.6.2.3 7 years after the date of registration, if the player is under the age of 21 but at least 18 years of age when registered.

4.3.6.3 Players being 21 years of age or older will not be registered with the ITTF and will not be eligible to represent a new association at the World Cup.

\subsection{WORLD TEAM CUP}

4.4.6 Eligibility

4.4.6.1 In addition to provisions of 3.8, players who have acquired a new nationality and wish to represent the association corresponding to the new national ity shall register with ITTF through this new Association.

4.4.6.2 Such player shall not represent thenew Association before

4.4.6.2.1 3 years after the date of registration, if the player is under the age of 15 when registered, but only 1 year after the date of registration if the player has never represented another association;

4.4.6.2.2 5 years after the date of registration, if the player is under the age of 18 but at least 15 years of age when registered;

4.4.6.2.3 7 years after the date of registration, if the player is under the age of 21 but at least 18 years of age when registered.

4.4.6.3 Players being 21 years of age or older will not be registered with the ITTF and will not beeligible to represent a new association at the World Team Cup.

\subsection{OLYM PIC COM PETITIONS}

4.5.1 Eligibility

4.5.1.1. To be eligible for participation in the Olympic Games a player, coach or official shall comply with the Olympic Charter as well as with the ITTF rules. In particular the above mentioned persons shall

4.5.1.1.1 beentered by their National Olympic Committee(NOC);

4.5.1.1.2 respect the spirit of fair play and non violence, and behave accordingly on the field of play;

4.5.1.1.3 respect and comply in all aspects with the World Anti-Doping Code;

4.5.1.1.4 not allow their person, name, picture or sports performances to be used for advertising purposes during the Olympic Games, except as permitted by the IOC Executive Board.

4.5.1.2 The entry or participation of a player in the Olympic Games shall not be conditional on any financial consideration.

4.5.1.3 Any player shall bea national of the country of the NOC which is entering himor her.

4.5.1.3.1 A player who is a national of 2 or more countries at the same time may represent either one of them, as heor she may elect.

4.5.1.3.2 After having represented one country in the Olympic Games, in continental or regional games or in world or regional championships recognised by the ITTF, a player may not represent another country unless he or she meets the conditions set forth in 4.5.1.3.3.

4.5.1.3.3 A player who has represented one country in the Olympic Games, in continental or regional games or in world or regional championships recognised by the ITTF and who has changed his or her 


\section{APPENDICES}

national ity or acquired a new nationality, may participate in the Olympic Games to represent his or her new country provided that at least 3 years have passed since the player last represented his or her former country.

4.5.1.3.4 The 3-years-period mentioned in 4.5.1.3.3 may be reduced or even cancelled, with the agreement of the NOCs concerned and the ITTF Executive Committee, by the IOC Executive Board, which takes into account the circumstances of each case

4.5.1.3.5 If an associated state, province or overseas department, a country or colony acquires independence, if a country becomes incorporated within another country by reason of a change of border, or if a new NOC is recognised by the IOC, a player may continue to represent the country to which he or she belongs or belonged. However, he or she may, if he or she prefers, choose to represent his or her country or be entered in the Olympic Games by his or her new NOC if one exists. This particular choice may be made only once.

4.5.1.4 All disputes relating to the determination of the country which a player may represent in the Olympic Games and in particular issue specific requirements relating to nationality, citizenship, domicile or residence of the player, including the duration of any waiting period, shall be resolved by the IOC Executive Board.

\section{ITTF Handbook 2014-2015}

\subsection{INTERNATIONAL ELIGIBILITY}

3.8.1 Eligibility in Olympic title competitions is regulated separately by 4.5 .1 and eligibility in Paralympic title competitions is regulated separately by the IPC and 4.6.1; additional eligibility regulations apply to World titleevents $(4.1 .3,4.2 .3,4.3 .6,4.4 .3)$.

3.8.2 A player shall be regarded as representing an Association if he or she accepted to be nominated by this Association and subsequently participates in a competition listed in 3.1.2.3 or in regional championships other than individual events at Open International Championships.

3.8.3 A player is eligible to represent an Association only if he or she is a national of the country in which that Association has jurisdiction, except that a player who has al ready represented an Association of which heor she was not a national in accordance with previous rules may retain that eligibility.

3.8.3.1 Where the players of more than one Association have the same nationality, a player may represent one of these Associations only, if he or she is born in or has his or her main residence in the teritory controlled by that Association.

3.8.3.2 A player who is eligible to represent more than 1 Association shall have the right to choose which of therelevant Associations heor she will represent.

3.8.4 A player is eligible to represent a Continental Federation (1.18.1) in an event of continental teams only if heor she is eligibleto represent a member Association of this Continental Federation according to 3.8.3.

3.8.5 A player shall not represent different Associations within a period of 3 years.

3.8.6 An Association may nominate a player under its jurisdiction (1.21) to enter any individual events of Open International Championships; such nomination may be indicated in results lists and ITTF publications but does not affect the eligibility of this player according to 3.8.2.

3.8.7 A player or his or her Association shall, if so requested by the referee, provide documentary evidence of his or her eligibility and his or her passport.

3.8.8 Any appeal on a question of eligibility shall be referred to an Eligibility Commission, consisting of the Executive Committee, the chair of the Rules Committee and the chair of the Athletes' Commission, whose decision shall be final.

4.1.3 E ligibility

4.1.3.1 Only an Association which is not in arrears (1.16.3.3) and has taken part with at least one player or team (an entry) in its preceding Continental Championships, including qualification tournaments, or Continental Games, shall be eligibleto enter teams or individual players in the Championships.

4.1.3.2 In addition to provisions of 3.8, players who have acquired a new nationality and wish to represent the association corresponding to the new national ity shall register with ITTF through this new Association.

4.1.3.3 Such player shall not represent thenew Association before:

4.1.3.3.1 3 years after the date of registration, if the player is under the age of 15 when registered;

4.1.3.3 25 years after the date of registration, if the player is under the age of 18 but at least 15 years of age when registered;

4.1.3.3.3 7 years after the date of registration, if the player is under the age of 21 but at least 18 years of age when registered.

4.1.3.4 Players being 21 years of age or older will not be registered with the ITTF and will not be eligible to represent a new association at World Championships.

[...]

4.2 WORLD JUNIOR CHAM PIONSHIPS

4.2.3 E ligibility 


\section{NATIONALITY REQUIREMENTS IN OLYMPIC SPORTS}

4.2.3.1 Only an Association which is not in arrears (1.16.3.3) shall be eligible to enter teams or individual players in the Championships.

4.2.3.2 The system of qual ification for team and individual events shall be determined by the Board not later than 18 months before the start of the Championships.

4.2.3.3 All players shall bejuniors according to 3.7.4.2.

4.2.3.4 In addition to provisions of 3.8, players who have acquired a new nationality and wish to represent the association corresponding to the new national ity shall register with ITTF through this new Association.

4.2.3.5 Such player shall not represent the new Association before 3 years after the date of registration, if the player is under the age of 15 when registered.

[...]

4.3 WORLD CUP

4.3.6 Eligibility

4.3.6.1 In addition to provisions of 3.8, players who have acquired a new nationality and wish to represent the association corresponding to the new national ity shall register with ITTF through this new Association.

4.3.6.2 Such player shall not represent the new Association before:

4.3.6.2.1 3 years after the date of registration, if the player is under the age of 15 when registered;

4.3.6.2.2 5 years after the date of registration, if the player is under the age of 18 but at least 15 years of age when registered;

4.3.6.2.3 7 years after the date of registration, if the player is under the age of 21 but at least 18 years of age when registered.

4.3.6.3 Players being 21 years of age or older will not be registered with the ITTF and will not be eligible to represent a new association at the World Cup.

[...]

\subsection{WORLD TEAM CUP}

4.4.6 E ligibility

4.4.6.1 In addition to provisions of 3.8, players who have acquired a new nationality and wish to represent the association corresponding to the new national ity shall register with ITTF trough this new Association.

4.4.6.2 Such player shall not represent thenew Association before

4.4.6.2.1 3 years after the date of regi stration, if the player is under the age of 15 when registered;

4.4.6.2.2 5 years after the date of registration, if the player is under the age of 18 but at least 15 years of age when registered;

4.4.6.2.3 7 years after the date of registration, if the player is under the age of 21 but at least 18 years of age when registered.

4.4.6.3 Players being 21 years of age or older will not be registered with the ITTF and will not be eligible to represent a new association at the World Team Cup.

$[\ldots]$

4.5 OLYM PIC COMPETITIONS

4.5.1 Eligibility

4.5.1.1 To be eligible for participation in the Olympic Games a player, coach or official shall comply with the Olympic Charter as well as with the ITTF rules. In particular the abovementioned persons shall

4.5.1.1.1 beentered by their National Olympic Committee(NOC);

4.5.1.1.2 respect the spirit of fair play and non violence, and behave accordingly on the field of play;

4.5.1.1.3 respect and comply in all aspects with the World Anti-Doping Code;

4.5.1.1.4 not allow their person, name, picture or sports performances to be used for advertising purposes during the Olympic Games, except as permitted by the IOC Executive Board.

4.5.1.2 The entry or participation of a player in the Olympic Games shall not be conditional on any financial consideration.

4.5.1.3 Any player shall bea national of the country of the NOC which is entering himor her.

4.5.1.3.1 A player who is a national of 2 or more countries at the sametimemay represent either one of them, as he or she may elect.

4.5.1.3.2 After having represented one country in the Olympic Games, in continental or regional games or in world or regional championships recognised by the ITTF, a player may not represent another country unless heor she meets the conditions set forth in 4.5.1.3.3.

4.5.1.3.3 A player who has represented one country in the Olympic Games, in continental or regional games or in world or regional championships recognised by the ITTF and who has changed his or her nationality or acquired a new nationality, may participate in the Olympic Games to represent his or her new country provided that at least 3 years have passed since the player last represented his or her former country.

4.5.1.3.4 The 3-years-period mentioned in 4.5.1.3.3 may be reduced or even cancelled, with the agreement of the NOCs concerned and the ITTF Executive Committee, by the IOC Executive Board, which takes into account the circumstances of each case 


\section{APPENDICES}

4.5.1.3.5 If an associated state, province or overseas department, a country or col ony acquires independence, if a country becomes incorporated within another country by reason of a change of border, or if a new NOC is recognised by the IOC, a player may continue to represent the country to which he or she belongs or belonged. However, he or she may, if he or she prefers, choose to represent his or her country or be entered in the Olympic Games by his or her new NOC if one exists. This particular choice may be made only once 4.5.1.4 All disputes relating to the determination of the country which a player may represent in the Olympic Games and in particular issue specific requirements relating to nationality, citizenship, domicile or residence of the player, including the duration of any waiting period, shall be resolved by theIOC ExecutiveBoard.

\section{ITTF H andbook $2013-2014$}

\subsection{INTERNATIONAL ELIGIBILITY}

3.8.1 Eligibility in Olympic title competitions is regulated separately by 4.5 .1 and eligibility in Paralympic title competitions is regulated separately by the IPC and 4.6.1; additional eligibility regulations apply to World titleevents $(4.1 .3,4.2 .3,4.3 .6,4.4 .3)$.

3.8.2 A player shall be regarded as representing an Association if he or she accepted to be nominated by this Association and subsequently participates in a competition listed in 3.1.2.3 or in regional championships other than individual events at Open International Championships.

3.8.3 A player is eligible to represent an Association only if he or she is a national of the country in which that Association has jurisdiction, except that a player who has al ready represented an Association of which heor shewas not a national in accordance with previous rules may retain that eligibility.

3.8.3.1 Where the players of more than one Association have the same nationality, a player may represent one of these Associations only, if he or she is born in or has his or her main residence in the teritory controlled by that Association.

3.8.3.2 A player who is eligible to represent more than 1 Association shall have the right to choose which of the relevant Associations he or she will represent.

3.8.4 A player is eligible to represent a Continental Federation (1.18.1) in an event of continental teams only if heor she is eligibleto represent a member Association of this Continental Federation according to 3.8.3.

3.8.5 A player shall not represent different Associations within a period of 3 years.

3.8.6 An Association may nominate a player under its jurisdiction (1.21) to enter any individual events of Open International Championships; such nomination may be indicated in results lists and ITTF publications but does not affect the eligibility of this player according to 3.8.2.

3.8.7 A player or his or her Association shall, if so requested by the referee, provide documentary evidence of his or her eligibility and his or her passport.

3.8.8 Any appeal on a question of eligibility shall be referred to an Eligibility Commission, consisting of the Executive Committee, the chair of the Rules Committee and the chair of the Athletes' Commission, whose decision shall be final.

\section{WORLD CHAM PIONSHIPS}

\subsubsection{Eligibility}

4.1.3.1 Only an Association which is not in arrears (1.16.3.3) shall be eligible to enter teams or individual players in the Championships.

4.1.3.2 In addition to provisions of 3.8, players who have acquired a new nationality and wish to represent the association corresponding to the new national ity shall register with ITTF through this new Association.

4.1.3.3 Such player shall not represent thenew Association before:

4.1.3.3.1 3 years after the date of regi stration, if the player is under the age of 15 when registered;

4.1.3.3.2 5 years after the date of registration, if the player is under the age of 18 but at least 15 years of age when registered;

4.1.3.3.3 7 years after the date of registration, if the player is under the age of 21 but at least 18 years of age when registered.

4.1.3.4 Players being 21 years of age or older will not be registered with the ITTF and will not be eligible to represent a new association at World Championships.

[...]

4.2 WORLD JUNIOR CHAM PIONSHIPS

4.2.3 Eligibility

4.2.3.1 Only an Association which is not in arrears (1.16.3.3) shall be eligible to enter teams or individual players in the Championships.

4.2.3.2 The system of qualification for team and individual events shall be determined by the Board not later than 18 months before the start of the Championships.

4.2.3.3 All players shall bejuniors according to 3.7.4.2.

4.2.3.4 In addition to provisions of 3.8, players who have acquired a new nationality and wish to represent the association corresponding to the new national ity shall register with ITTF trrough this new Association. 


\section{NATIONALITY REQUiREMENTS IN Oly mpic SPORTS}

4.2.3.5 Such player shall not represent the new Association before 3 years after the date of registration, if the player is under the age of 15 when registered.

[...]

4.3 WORLD CUP

\subsubsection{E ligibility}

4.3.6.1 In addition to provisions of 3.8, players who have acquired a new nationality and wish to represent the association corresponding to the new national ity shall register with ITTF through this new Association.

4.3.6.2 Such player shall not represent thenew Association before:

4.3.6.2.1 3 years after the date of regi stration, if the player is under the age of 15 when registered;

4.3.6.2.2 5 years after the date of registration, if the player is under the age of 18 but at least 15 years of age when registered;

4.3.6.2.3 7 years after the date of registration, if the player is under the age of 21 but at least 18 years of age when registered.

4.3.6.3 Players being 21 years of age or older will not be registered with the ITTF and will not be eligible to represent a new association at the World Cup.

$[\ldots]$

\subsection{WORLD TEAM CUP}

\subsubsection{E ligibility}

4.4.6.1 In addition to provisions of 3.8, players who have acquired a new nationality and wish to represent the association corresponding to the new national ity shall register with ITTF through this new Association.

4.4.6.2 Such player shall not represent thenew Association before

4.4.6.2.1 3 years after the date of registration, if the player is under the age of 15 when registered;

4.4.6.2.2 5 years after the date of registration, if the player is under the age of 18 but at least 15 years of age when registered;

4.4.6.2.3 7 years after the date of registration, if the player is under the age of 21 but at least 18 years of age when registered.

4.4.6.3 Players being 21 years of age or older will not be registered with the ITTF and will not be eligible to represent a new association at the World Team Cup.

$[\ldots]$

\subsection{OLYM PIC COM PETITIONS}

\subsubsection{E ligibility}

4.5.1.1 To be eligible for participation in the Olympic Games a player, coach or official shall comply with the Olympic Charter as well as with the ITTF rules. In particular the abovementioned persons shall

4.5.1.1.1 beentered by their National Olympic Committee(NOC);

4.5.1.1.2 respect the spirit of fair play and non violence, and behave accordingly on the field of play;

4.5.1.1.3 respect and comply in all aspects with the World Anti-Doping Code;

4.5.1.1.4 not allow their person, name, picture or sports performances to be used for advertising purposes during the Olympic Games, except as permitted by theIOC Executive Board.

4.5.1.2 The entry or participation of a player in the Olympic Games shall not be conditional on any financial consideration.

4.5.1.3 Any player shall bea national of the country of the NOC which is entering himor her.

4.5.1.3.1 A player who is a national of 2 or more countries at the sametime may represent either one of them, as he or she may dect.

4.5.1.3.2 After having represented one country in the Olympic Games, in continental or regional games or in world or regional championships recognised by the ITTF, a player may not represent another country unless heor she mets the conditions set forth in 4.5.1.3.3.

4.5.1.3.3 A player who has represented one country in the Olympic Games, in continental or regional games or in world or regional championships recognised by the ITTF and who has changed his or her nationality or acquired a new nationality, may participate in the Olympic Games to represent his or her new country provided that at least 3 years have passed since the player last represented his or her former country.

4.5.1.3.4 The 3-years-period mentioned in 4.5.1.3.3 may be reduced or even cancelled, with the agreement of the NOCs concerned and the ITTF Executive Committee, by the IOC Executive Board, which takes into account the circumstances of each case

4.5.1.3.5 If an associated state, province or overseas department, a country or col ony acquires independence, if a country becomes incorporated within another country by reason of a change of border, or if a new NOC is recognised by the IOC, a player may continue to represent the country to which he or she belongs or belonged. However, he or she may, if he or she prefers, choose to represent his or her country or be entered in theOlympic Games by his or her new NOC if one exists. This particular choicemay be made only once 4.5.1.4 All disputes relating to the determination of the country which a player may represent in the Olympic Games and in particular issue specific requirements relating to nationality, citizenship, domicile or residence of the player, including the duration of any waiting period, shall be resolved by theIOC ExecutiveBoard. 


\section{APPENDICES}

ITTF Handbook 2012 - 2013

\subsection{INTERNATIONAL ELIGIBILITY}

3.8.1 Eligibility in Olympic title competitions is regulated separately by 4.5 .1 and eligibility in Paralympic title competitions is regulated separately by the IPC and 4.6.1; additional eligibility regulations apply to World title events $(4.1 .3,4.2 .3,4.3 .6,4.4 .3)$.

3.8.2 A player shall be regarded as representing an Association if he or she accepted to be nominated by this Association and subsequently participates in a competition listed in 3.1.2.3 or in regional championships other than individual events at Open International Championships (effective 1 J uly 2012).

3.8.3 A player is eligible to represent an Association only if he or she is a national of the country in which that Association has jurisdiction, except that a player who has al ready represented an Association of which heor she was not a national in accordance with previous rules may retain that eligibility.

3.8.3.1 Where the players of more than one Association have the same nationality, a player may represent one of these Associations only, if he or she is born in or has his or her main residence in the teritory controlled by that Association.

3.8.3.2 A player who is eligible to represent more than 1 Association shall have the right to choose which of the relevant Associations he or she will represent.

3.8.4 A player is eligible to represent a Continental Federation (1.18.1) in an event of continental teams only if he or sheis eligibleto represent a member Association of this Continental Federation according to 3.8.3.

3.8.5 A player shall not represent different Associations within a period of 3 years.

3.8.6 An Association may nominate a player under its jurisdiction (1.21) to enter any individual events of Open International Championships; such nomination may be indicated in results lists and ITTF publications but does not affect the eligibility of this player according to 3.8.2.

3.8.7 A player or his or her Association shall, if so requested by the referee, provide documentary evidence of his or her eligibility and his or her passport.

3.8.8 Any appeal on a question of eligibility shall be referred to an Eligibility Commission, consisting of the Executive Committee, the chair of the Rules Committee and the chair of the Athletes' Commission, whose decision shall be final.

\subsection{WORLD CHAM PIONSHIPS}

\subsubsection{E ligibility}

4.1.3.1 Only an Association which is not in arrears (1.16.3.3) shall be eligible to enter teams or individual players in the Championships.

4.1.3.2 In addition to provisions of 3.8, players being eligible to represent an association other than the one they intend to represent, shall register with the ITTF, through this new Association.

4.1.3.3 Such player shall not represent thenew Association before:

4.1.3.3.1 3 years after the date of regi stration, if the player is under the age of 15 when registered;

4.1.3.3.2 5 years after the date of registration, if the player is under the age of 18 but at least 15 years of age when registered;

4.1.3.3.3 7 years after the date of registration, if the player is under the age of 21 but at least 18 years of age when registered.

4.1.3.4 Players being 21 years of age or older will not be registered with the ITTF and will not be eligible to represent a new association at World Championships.

[...]

\subsection{WORLD JUNIOR CHAM PIONSHIPS}

\subsubsection{Eligibility}

4.2.3.1 Only an Association which is not in arrears (1.16.3.3) shall be eligible to enter teams or individual players in the Championships.

4.2.3.2 The system of qualification for team and individual events shall be determined by the Board not later than 18 months before the start of the Championships.

4.2.3.3 All players shall bejuniors according to 3.7.4.2.

4.2.3.4 In addition to provisions of 3.8, players being eligible to represent an association other than the one they intend to represent, shall register with the ITTF, through this new Association.

4.2.3.5 Such player shall not represent the new Association before 3 years after the date of registration, if the player is under the age of 15 when registered.

$[\ldots]$

4.3 WORLD CUP

4.3.6 Eligibility

4.3.6.1 In addition to provisions of 3.8, players being eligible to represent an association other than the one they intend to represent, shall register with the ITTF, through this new Association.

4.3.6.2 Such player shall not represent thenew Association before: 


\section{NATIONALITY REQUiREMENTS In Olympic SPORTS}

4.3.6.2.1 3 years after the date of registration, if the player is under the age of 15 when registered;

4.3.6.2.2 5 years after the date of registration, if the player is under the age of 18 but at least 15 years of age when registered;

4.3.6.2.3 7 years after the date of registration, if the player is under the age of 21 but at least 18 years of age when registered.

4.3.6.3 Players being 21 years of age or older will not be registered with the ITTF and will not be eligible to represent a new association at the World Cup.

[...]

\subsection{WORLD TEAM CUP}

4.4.6 Eligibility

4.4.6.1 In addition to provisions of 3.8, players being eligible to represent an association other than the one they intend to represent, shall register with the ITTF, through this new Association.

4.4.6.2 Such player shall not represent thenew Association before

4.4.6.2.1 3 years after the date of regi stration, if the player is under the age of 15 when registered;

4.4.6.2.2 5 years after the date of registration, if the player is under the age of 18 but at least 15 years of age when registered;

4.4.6.2.3 7 years after the date of registration, if the player is under the age of 21 but at least 18 years of age when registered.

4.4.6.3 Players being 21 years of age or older will not be registered with the ITTF and will not be eligible to represent a new association at the World Team Cup.

\subsection{OLYM PIC COM PETITIONS}

\subsubsection{E ligibility}

4.5.1.1 To be eligible for participation in the Olympic Games a player, coach or official shall comply with the Olympic Charter as well as with the ITTF rules. In particular the abovementioned persons shall

4.5.1.1.1 beentered by their National Olympic Committee(NOC);

4.5.1.1.2 respect the spirit of fair play and non violence, and behave accordingly on the field of play;

4.5.1.1.3 respect and comply in all aspects with the World Anti-Doping Code;

4.5.1.1.4 not allow their person, name, picture or sports performances to be used for advertising purposes during the Olympic Games, except as permitted by the IOC Executive Board.

4.5.1.2 The entry or participation of a player in the Olympic Games shall not be conditional on any financial consideration.

4.5.1.3 Any player shall bea national of the country of the NOC which is entering himor her.

4.5.1.3.1 A player who is a national of 2 or more countries at the sametimemay represent either one of them, as he or she may elect.

4.5.1.3.2 After having represented one country in the Olympic Games, in continental or regional games or in world or regional championships recognised by the ITTF, a player may not represent another country unless heor she meets the conditions set forth in 4.5.1.3.3.

4.5.1.3.3 A player who has represented one country in the Olympic Games, in continental or regional games or in world or regional championships recogni sed by the ITTF and who has changed his or her nationality or acquired a new nationality, may participate in the Olympic Games to represent his or her new country provided that at least 3 years have passed since the player last represented his or her former country.

4.5.1.3.4 The 3-years-period mentioned in 4.5.1.3.3 may be reduced or even cancelled, with the agreement of the NOCs concerned and the ITTF Executive Committee, by the IOC Executive Board, which takes into account the circumstances of each case

4.5.1.3.5 If an associated state, province or overseas department, a country or col ony acquires independence, if a country becomes incorporated within another country by reason of a change of border, or if a new NOC is recognised by the IOC, a player may continue to represent the country to which he or she belongs or belonged. However, he or she may, if he or she prefers, choose to represent his or her country or be entered in the Olympic Games by his or her new NOC if one exists. This particular choicemay be made only once 4.5.1.4 All disputes relating to the determination of the country which a player may represent in the Olympic Games and in particular issue specific requirements relating to nationality, citizenship, domicile or residence of the player, including the duration of any waiting period, shall be resolved by the IOC Executive Board.

\section{ITTF Version 1 Sep 2010 - 31 Aug 2012}

\subsection{INTERNATIONAL ELIGIBILITY}

3.8.1 Eligibility in Olympic title competitions is regulated separately by 4.3 .1 and additional eligibility regulations apply to World titleevents (4.1.3, 4.2.6, 4.4.3).

3.8.2 A player shall be regarded as representing an Association if he accepted to be nominated by this Association and subsequently participates in a competition listed in 3.1.2.3 other than individual events at Open International Championships. 


\section{APPENDICES}

3.8.3 A player is eligible to represent an Association only if he is a national of the country in which that Association has jurisdiction, except that a player who has represented an Association of which he was not a national before ist September 2004 in accordance with previous rules may retain that eligibility.

3.8.3.1 Where the players of more than one Association have the same nationality, a player may represent one of these Associations only, if he is born in or has his main residence in the territory controlled by that Association.

3.8.3.2 A player who is eligible to represent more than 1 Association shall have the right to choose which of therelevant Associations he will represent.

3.8.4 A player is eligible to represent a Continental Federation (1.17.1) in an event of continental teams only if heis eligibleto represent a member Association of this Continental Federation according to 3.8.3.

3.8.5 A player shall not represent different Associations within a period of 3 years.

3.8.6 An Association may nominatea player under its jurisdiction (1.20) to enter any individual events of Open International Championships which may be indi cated in ITTF publications such as the World Ranking list but does not result in eligibility of this player to represent the nominating Association according to 3.8.2.

3.8.7 A player or his Association shall, if so requested by the referee, provide documentary evidence of his eligibility.

3.8.8 Any appeal on a question of eligibility shall be referred to an Eligibility Commission, consisting of the Executive Committee, the chairmen of the Rules and Ranking Committee and the chairman of the Athletes' Commission, whose decision shall befinal.

\section{ITTF Version - 1 Sep 2009 - 31 Aug 2010}

\subsection{INTERNATIONAL ELIGIBILITY}

3.8.1 Eligibility in Olympic title competitions is regulated separately by 4.5 .1 and additional eligibility regulations apply to World title events (4.1.3, 4.2.3, 4.3.6, 4.4.6).

3.8.2 A player shall be regarded as representing an Association if he accepted to be nominated by this Association and subsequently participates in a competition listed in 3.1.2.3 other than individual events at Open International Championships.

3.8.3 A player is eligible to represent an Association only if he is a national of the country in which that Association has jurisdiction, except that a player who has al ready represented an Association of which he was not a national in accordance with previous rules may retain that eligibility.

3.8.3.1 Where the players of more than one Association have the same nationality, a player may represent one of these Associations only, if he is born in or has his main residence in the territory controlled by that Association.

3.8.3.2 A player who is eligible to represent more than 1 Association shall have the right to choose which of therelevant Associations he will represent.

3.8.4 A player is eligible to represent a Continental Federation (1.17.1) in an event of continental teams only if heis eligibleto represent a member Association of this Continental Federation according to 3.8.3.

3.8.5 A player shall not represent different Associations within a period of 3 years.

3.8.6 An Association may nominate a player under its jurisdiction (1.20) to enter any individual events of Open International Championships; such nomination may be indicated in result lists and ITTF publications but does not affect the eligibility of this player according to 3.8.2.

3.8.7 A player or his Association shall, if so requested by the referee, provide documentary evidence of his eligibility and his passport.

3.8.8 Any appeal on a question of eligibility shall be refered to an Eligibility Commission, consisting of the Executive Committee, the chairman of the Rules Committee, the chairman of the Ranking Committee and the chairman of the Athletes' Commission, whose decision shall befinal.

\section{ITTF Version - 1 Sep 2008 - 31 Aug 2009}

\subsection{INTERNATIONAL ELIGIBILITY}

3.8.1 Eligibility in Olympic tite competitions is regulated separately by 4.3 .1 and additional eligibility regulations apply to World title events $(4.1 .3,4.2 .6,4.4 .3)$.

3.8.2 A player shall be regarded as representing an Association if he accepted to be nominated by this Association and subsequently participates in a competition listed in 3.1.2.3 other than individual events at Open International Championships.

3.8.3 A player is eligible to represent an Association only if he is a national of the country in which that Association has jurisdiction, except that a player who has already represented an Association of which he was not a national before 1st September 2004 in accordance with previous rules may retain that eligi bility.

3.8.3.1 Where the players of more than one Association have the same nationality, a player may represent one of these Associations only, if he is born in or has his main residence in the territory controlled by that Association if indicated in the player's passport. 
3.8.3.2 A player who is eligible to represent more than 1 Association shall have the right to choose which of there levant Associations he will represent.

3.8.4 A player is eligible to represent a Continental Federation (1.17.1) in an event of continental teams only if he is eligibleto represent a member Association of this Continental Federation according to 3.8.3.

3.8.5 A player shall not represent different Associations within a period of 3 years.

3.8.6 An Association may nominate a player under its jurisdiction (1.20) to enter any individual events of Open International Championships; such nomination may be indicated in result lists and ITTF publications but does not affect the eligibility of this player which may be indicated in ITTF publications such as the World Ranking list but does not result in eligibility of this player to represent the nominating Association according to 3.8.2.

3.8.7 A player or his Association shall, if so requested by the referee, provide documentary evidence of his eligibility and his passport.

3.8.8 Any appeal on a question of eligibility shall be referred to an Eligibility Commission, consisting of the Executive Committee, the chairmen chairman of the Rules Committee, the chairman of the and Ranking Committee and the chairman of the Athletes' Commission, whosedecision shall befinal.

\section{ITTF Version - 1 Sep 2005 - 31 Aug 2008}

\subsection{INTERNATIONAL ELIGIBILITY}

3.8.1 Eligibility in Olympic title competitions is regulated separately by 4.3.1.

3.8.2 A player shall be regarded as representing an Association if he accepted to be nominated by this Association and subsequently participates in a competition listed in 3.1.2.3 other than individual events at Open International Championships.

3.8.3 A player is eligible to represent an Association only if he is a national of the country in which that Association has jurisdiction, except that a player who has represented an Association of which he was not a national before ist September 2004 in accordance with previous rules may retain that eligibility.

3.8.3.1 Where the players of more than one Association have the same nationality, a player may represent one of these Associations only, if he is born in or has his main residence in the territory controlled by that Association.

3.8.3.2 A player who is eligible to represent more than 1 Association shall have the right to choose which of therelevant Associations he will represent.

3.8.4 A player is eligible to represent a Continental Federation (1.17.1) in an event of continental teams only if heis eligibleto represent a member Association of this Continental Federation according to 3.8.3.

3.8.5 A player shall not represent different Associations within a period of 3 years.

3.8.6 An Association may nominate a player under its jurisdiction (1.20) to enter any individual events of Open International Championships which may be indi cated in ITTF publications such as the World Ranking list but does not result in eligibility of this player to represent thenominating Association according to 3.8.2.

3.8.7 A player or his Association shall, if so requested by the referee, provide documentary evidence of his eligibility.

3.8.8 Any appeal on a question of eligibility shall be refered to an Eligibility Commission, consisting of the Executive Committee, the chairmen of the Rules and Ranking Committee and the chairman of the Athletes' Commission, whose decision shall befinal.

\section{Taekwando}

WORLD TAEK WONDO FEDERATION COM PETITION RULES \& INTERPRETATION In force as of $M$ ay 11, 2015

Article 4 Contestant

1. Qualification of Contestant

1.1 Holder of the nationality of the participating team

1.2. One recommended by theWTF National Tadkwondo Association

1.3. Holder of Tadkwondo Dan/Poom certificate issued by the Kukkiwon or WTF

1.4. Holder of theWTF Global AthleteLicense(GAL)

1.5. Contestants at the age of at least 17 years old in the year the pertinent tournament is held (15-17 years old for J unior Tadkwondo Championships and 12-14 years old for Cadet Championships). Ages for $Y$ outh Olympic Games might be different depending on the decision of the IOC.

(Interpretation)

The age limit is based on the year, not on the date. For instance, if the J unior Tadkwondo Championships are held on June 11, 2013, those contestants born on between J anuary 1, 1996 and December 31, 1998 are eligibleto participate

(Explantion \#1)

Holder of the nationality of the participating team: 
When a contestant is a representative of a national team, his/her nationality is decided by citizenship of the country he/she is representing before submission of the application to participate. Verification of citizenship is done by inspection of the passport.

A competitor who is a national of two or more countries at the same time may represent either one of them, as he may elect. However, after having represented one country in the Olympic Games, in Qualification Toumaments for Olympic Games, in continental or regional games or in world or regional championships Promoted or recognized by the WTF, he may not represent another country unless at least three (3) years have passed since the competitor last represented his former country. This period may be reduced or even cancelled, with the agreement of the NOCs and the WTF. The WTF may takedisciplinary actions at any time against the athlete and his member national association that violates this article including but not limited to deprival of the achievements. In case of an athlete aged 16 or less, this article shall not be applied unless there is an appeal fromany of thetwo countries. In case of dispute, theWTF shall makeevaluation and make a final decision. After the decision, no further appeal shall be acceptable.

(Explanation \#2)

One recommended by the WTF National Taekwondo Association: Each National Federation is responsible for control of non-pregnancy and gender and shall ensure that all team members have been given medical exams that show them to be of adequate health and fitness to participate. Also each National Federation assumes full responsibilities for accident and health insurance as well as the civil liabilities for their contestants and officials during theWTF-promoted championships.

WORLD TAEK WONDO FEDERATION COM PETITION RULES \& INTERPRETATION In force as of J anuary 1,2015

Article 4 Contestant

1. Qualification of Contestant

1.1. Holder of the nationality of the participating team

1.2. One recommended by the WTF National Taekwondo Association

1.3. Holder of Taekwondo Dan/Poom certificate issued by the Kukkiwon or WTF

1.4. Holder of theWTF Global AthleteLicense(GAL)

1.5. Contestants at the age of at least 17 years old in the year the pertinent tournament is held (15-17 years old for J unior Tadkwondo Championships and 12-14 years old for Cadet Championships). Ages for Y outh Olympic Games might be different depending on the decision of theIOC.

(Interpretation)

The age limit is based on theyear, not on the date. For instance, if the J unior Taekwondo Championships are held on June 11, 2013, those contestants born on between J anuary 1, 1996 and December 31, 1998 are eligibleto participate

(Explanation \#1)

Holder of the nationality of the participating team:

When a contestant is a representative of a national team, his/her nationality is decided by citizenship of the country he/she is representing before submission of the application to participate Verification of citizenship is done by inspection of the passport.

A competitor who is a national of two or more countries at the same time may represent either one of them, as he may elect. However, after having represented one country in the Olympic Games, in Qualification Tournaments for Olympic Games, in continental or regional games or in world or regional championships Promoted or recognized by the WTF, he may not represent another country unless at least three (3) years have passed since the competitor last represented his former country. This period may be reduced or even cancelled, with the agreement of the NOCs and theWTF. The WTF may takedisciplinary actions at any time against the athlete and his member national association that violates this article including but not limited to deprival of the achievements. In case of an athlete aged 16 or less, this article shall not be applied unless there is an appeal fromany of the two countries. In case of dispute, theWTF shall makeevaluation and make a final decision. After the decision, no further appeal shall be acceptable.

WORLD TAEK WONDO FEDERATION COM PETITION RULES \& INTERPRETATION In force as of J uly 1,2014

Article 4 Contestant

1. Qualification of Contestant

1.1 Holder of the nationality of the participating team

1.2 One recommended by theWTF National Taekwondo Association

1.3 Holder of Tadkwondo Dan/Poom certificate issued by the Kukkiwon or WTF

1.4 Holder of theWTF Global Athlete License(GAL) 
1.5 Contestants at the age of at least 17 years old in the year the pertinent tournament is held (15-17 years old for Junior Takwondo Championships and 12-14 years old for Cadet Championships). Ages for Youth Olympic Games might be different depending on the decision of theIOC.

(Explanation \#1)

Holder of the nationality of the participating team:

When a contestant is a representative of a national team, his/her nationality is decided by citizenship of the country he/she is representing before submission of the application to participate Verification of citizenship is done by inspection of the passport.

A competitor who is a national of two or more countries at the same time may represent either one of them, as he may elect. However, after having represented one country in the Olympic Games, in Qualification Tournaments for Olympic Games, in continental or regional games or in world or regional championships Promoted or recognized by the WTF, he may not represent another country unless at least three (3) years have passed since the competitor last represented his former country. This period may be reduced or even cancelled, with the agreement of the NOCs and the WTF. The WTF may takedisciplinary actions at any time against the athlete and his member national association that violates this article including but not limited to deprival of the achievements. In case of an athlete aged 16 or less, this article shall not be applied unless there is an appeal fromany of the two countries. In case of dispute, theWTF shall makeevaluation and make a final decision. After the decision, no further appeal shall beacceptable.

\section{WOR LD TAEK WONDO FEDERATION RULES \& INTER PRETATION Amended 14 J uly, 2013}

\section{Article 4 Contestant}

1 Qualification of Contestant 1.1

1.1 Holder of the nationality of the participating team

1.2 One recommended by theWTF National Taekwondo Association

1.3 Holder of Taekwondo Dan/Poom certificate issued by the Kukkiwon or WTF

1.4 Holder of theWTF Global Athlete License(GAL)

1.5 Contestants at the age of at least 17 years old in the year the pertinent tournament is held (15-17 years old for Junior Tadkwondo Championships and 12-14 years old for Cadet Championships). Ages for Youth Olympic Games might be different depending on the decision of theIOC.

(Interpretation: The age limit is based on the year, not on the date. For instance, if the J unior Tadkwondo Championships are held on J une 11, 2013, those contestants born on between J anuary 1, 1996 and December 31, 1998 are eligible to participate)

\section{Explanation :1}

Holder of the nationality of the participating team:

When a contestant is a representative of a national team, his/her nationality is decided by citizenship of the country he/she is representing before submission of the application to participate Verification of citizenship is done by inspection of the passport.

A compeitor who is a national of two or more countries at the same time may represent either one of them, as he may elect. However, after having represented one country in the Olympic Games, in Qualification Tournaments for Olympic Games, in continental or regional games or in world or regional championships Promoted or recognized by the WTF, he may not represent another country unless at least three (3) years have passed since the competitor last represented his former country. This period may be reduced or even cancelled, with the agreement of the NOCs and theWTF. The WTF may takedisciplinary actions at any time against the athlete and his member national association that violates this article including but not limited to deprival of the achievements. In case of an athlete aged 16 or less, this article shall not be applied unless there is an appeal fromany of the two countries. In case of dispute, theWTF shall makeevaluation and make a final decision. After the decision, no further appeal shall be acceptable.

\footnotetext{
WORLD TAEK WONDO FEDERATION COMPETITION RULES \& INTERPRETATION In force as of December 26, 2012

Article 4 Contestant

1. Qualification of Contestant

1.1 Holder of the nationality of the participating team

1.2 One recommended by theWTF National Taekwondo Association

1.3 Holder of Taekwondo Dan/Poom certificate issued by the Kukkiwon or WTF

1.4 Holder of the WTF Global Athlete License (GAL)

1.5 Contestants at the age of at least 17 years old in the year the pertinent tournament is held (15-17 years old for Junior Takwondo Championships and 12-14 years old for Cadet Championships). Ages for Youth Olympic Games might be different depending on the decision of theIOC.

$[\ldots]$
} 
(Explanation \#1)

Holder of the nationality of the participating team

When a contestant is a representative of a national team, his/her nationality is decided by citizenship of the country he/she is representing before submission of the application to participate Verification of citizenship is done by inspection of the passport.

A competitor who is a national of two or more countries at the same time may represent either one of them, as he may elect. However, after having represented one country in the Olympic Games, in Qualification Tournaments for Olympic Games, in continental or regional games or in world or regional championships recognized by the WTF, he may not represent another country unless at least three (3) years have passed since the competitor last represented his former country. This period may be reduced or even cancelled, with the agreement of the NOCs and the WTF. The WTF may take disciplinary actions at any time against the athlete and his member national association that violates this article including but not limited to deprival of the achievements.

WORLD TAEK WONDO FEDERATION COMPETITION RULES \& INTER PRETATION In force as of October 4,2011

Article 4 Contestant

1. Qualification of Contestant

1.1 Holder of the nationality of the participating team

1.2 One recommended by theWTF National Taekwondo Association

1.3 Holder of Taekwondo Dan certificate issued by the Kukkiwon or WTF

1.4 Contestants at the age of at least 15 years old in the year the pertinent tournament is held ( $14-17$ years old for J unior Tadkwondo Championships)

(Interpretation)

The age limit is based on theyear, not on the date For instance, if the J unior Taekwondo Championships are held on February 22, 2010, those contestants born on between J anuary 1, 1993 and December 31, 1996 are eligibleto participate

[...]

(Explanation \#1)

Holder of the nationality of the participating team:

When a contestant is a representative of a national team, his/her nationality is decided by citizenship of the country he/she is representing before submission of the application to participate Verification of citizenship is done by inspection of the passport

A competitor who is a national of two or more countries at the same time may represent either one of them, as he may elect. However, after having represented one country in the Olympic Games, in Qualification Tournaments for Olympic Games, in continental or regional games or in world or regional championships recognized by the WTF, he may not represent another country unless at least three (3) years have passed since the competitor last represented his former country. This period may be reduced or even cancelled, with the agreement of the NOCS and the WTF. The WTF may take disciplinary actions at any time against the athlete and his member national association that violates this article including but not limited to deprival of the achievements.

WORLD TAEKWONDO FEDERATION COMPETITION RULES \& INTERPRETATION Amended: October 7, 2010

Article 4 Contestant

(1) Qualification of Contestant

1.1 Holder of the nationality of the participating team

1.2 One recommended by the WTF National Taekwondo Association

1.3 Holder of Taekwondo Dan certificate issued by the Kukkiwon or WTF

1.4 Contestants at the age of at least 15 years old in the year the pertinent tournament is held (14-17 years old for J unior Taekwondo Championships)

(Interpretation)

The age limit is based on the year, not on the date. For instance, if the J unior Taekwondo Championships are held on February 22, 2010, those contestants born on between J anuary 1, 1993 and December 31, 1996 are eligibleto participate

[...]

(Explanation \#1)

Holder of the nationality of the participating team

When a contestant is a representative of a national team, his/her nationality is decided by citizenship of the country he/she is representing before submission of the application to participate Verification of citizenship is done by inspection of the passport. In the event nationality of a contestant holding more than one 


\section{NATIONALITY REQUIREMENTS IN OLY MPIC SPORTS}

citizenship causes conflict, the contestant shall decide which team he/she will compete for. As per the Olympic Games and matters pertaining to the Olympic qualification places, the Olympic Charter shall prevail.

\section{Tennis}

Memorandum, Articles of Association and Bye-laws of ITF LIMITED Trading as the International Tennis Feder ation 2016

Chapter 5 - The Olympic Games

\section{Participation in the Olympic Games R ule 40 Eligibility Code}

To participate in the Olympic Games, a competitor, team official or other team personnel must respect and comply with the Olympic Charter and World Anti-Doping Code, including the conditions of participation established by the IOC, as well as with the rules of the relevant IF as approved by the IOC, and the competitor, team official or other team personnel must be entered by his NOC.

\section{Bye-law to R ule 40}

1. Each IF establishes its sport's rules for participation in the Olympic Games, including qual ification criteria, in accordance with the Olymic Charter. Such criteria must be submitted to the IOC Executive Board for approval.

2. The application of the eligibility criteria lies with the IFs, their affiliated national federations and the NOCs in the fields of their respective responsibilities.

3. Except as permitted by the IOC Executive Board, no competitor, team official or other team personnel who participates in the Olympic Games may allow his person, name, picture or sports performances to be used for advertising purposes during the Olympic Games.

4. The entry or participation of a competitor in the Olympic Games shall not be conditional on any financial consideration.

\section{R ule 41 Nationality of Competitors}

1. Any competitor in the Olympic Games must be a national of the country of the NOC which is entering such competitor.

2. All matters relating to the determination of the country which a competitor may represent in the Olympic Games shall beresolved by the IOC Executive Board.

\section{Bye-law to $R$ ule 41}

1. A competitor who is a national of two or more countries at the same time may represent either one of them, as he may elect. However, after having represented one country in the Olympic Games, in continental or regional games or in world or regional championships recognised by the relevant IF, he may not represent another country unless he meets the conditions set forth in paragraph 2 below that apply to persons who have changed their nationality or acquired a new nationality.

2. A competitor who has represented one country in the Olympic Games, in continental or regional games or in world or regional champi onships recognised by the relevant IF, and who has changed his national ity or acquired a new nationality, may participate in the Olympic Games to represent his new country provi ded that at least three years have passed si nce the competitor last represented his former country. This period may be reduced or even cancelled, with the agreement of the NOCs and IF concerned, by the IOC Executive Board, which takes into account the circumstances of each case.

3. If an associated State, province or overseas department, a country or colony acquires independence, if a country becomes incorporated within another country by reason of a change of border, if a country merges with another country, or if a new NOC is recognised by the IOC, a competitor may continue to represent the country to which he belongs or belonged. However, he may, if he prefers, elect to represent his country or be entered in the Olympic Games by his new NOC if one exists. This particular choice may be made only once.

4. Furthermore, in all cases in which a competitor would be eligible to participate in the Olympic Games, either by representing another country than his or by having the choice as to the country which such competitor intends to represent, the IOC Executive Board may take all decisions of a general or individual nature with regard to issues resulting from nationality, citizenship, domicile or residence of any competitor, including the duration of any waiting period.

\section{FC Extract 2016}

VII. ELIGIBILITY

31. ELIGIBILITY OF PLAYERS AND CAPTAINS

(a) AgeEligibility 


\section{APPENDICES}

Only Players who have reached their fourteenth birthday by the first day of the tie (for the World Group and World Group II) and the Monday of the week of a Zone Group Event may participate in the Fed Cup Competition.

(b) Eligibility to Represent a Nation

A player or captain is entitled to represent one Nation only at senior professional international level.

Any tennis player who is in good standing with her National Association in accordance with Appendix D shall be qual ified to represent that Nation as a player or Captain if she:

Is a citizen of that Nation and has held a current valid passport of that Nation for a minimum of 2 years (24 months) or;

Is a citizen of that Nation, but in circumstances where that Nation does not issue its own passport has held a qualifying passport issued by or on behalf of that Nation for a period of two years (24 months) which confirms the player's place of birth as that Nation or;

If after a consecutive period of five years ( 60 months) residence in that Nation can provide a genuine reason for being unable to hold or make application to hold a current val id passport where:

Shewas born, or has a parent or grandparent born in that Nation; or,

She has obtained or procured the right to remain permanently or has been granted humanitarian protection in that Nation.

If a player is qualified under this sub-section to represent more than one Nation and the National Association of one of those Nations wishes to nominate her to represent it, that Association must submit an application to the ITF Executive, who will forward a copy to any other National Association concerned, which shall be entitled to comment within 15 days of receipt. The initial application must be received by the ITF Executive at least thre months prior to the event for which the player wishes to be nominated.

The ITF Executive will give a ruling having taken into account all relevant matters.

i) A player who has represented, or has been eligible to represent a Nation and such Nation is divided into two or more Nations, shall immediately be eligible to represent any one of those Nations.

ii) A player who has represented, or has been eligible to represent a Nation and such Nation is absorbed in whole or in part by another Nation, shall immediately be eligible to represent such other Nation.

(d) A player shall be deemed to have represented a Nation if she shall have been nominated at the time of the draw and shall have accepted the nomination to play in the Olympic Tennis Event or in any International Team Competition recognized by the ITF and listed in Byelaw 2.1(a).

(e) A National Association may appeal to the Fed Cup Committee to nominate a player who is not eligible under the above Rules and the Fed Cup Committee may agree the application if the full circumstances warrant an exception being made. Such application must be received by the ITF Executive not later than one month after the decision of the Executive has been received by theNational Association.

(f) The Fed Cup Committee has the right to ask a National Association to produce evidence to show how a player is qualified to represent that Nation.

Note: A player, who represented a Nation under the Regulations in force in 1994 or prior thereto, shall continue to be eligible to represent that Nation even if she is no longer qualified to do so under the amended terms of this Regulation.

\section{DC extract 2016}

VI. ELIGIBILITY OF PLAYERS AND CAPTAINS

35. ELIGIBILITY TO REPRESENT A NATION

A player or captain is entitled to represent one nation only at senior professional international leved.

Any tennis player who is in good standing with his National Association in accordance with Appendix D shall be qual ified to represent that nation as a player or captain if he:

(a) (i) Is a citizen of that nation and has held a current valid passport of that nation for a minimum of two years (24 months) or;

(ii) Is a citizen of that nation, but in circumstances where that nation does not issue its own passport has held a qualifying passport issued by or on behalf of that nation for a period of two years ( 24 months) which confirms the player's place of birth as that nation or;

(iii) If after a consecutive period of five years (60 months) residence in that nation can provide a genuine reason for being unable to hold or make application to hold a current val id passport where:

(a) hewas born, or has a parent or grandparent born in that nation; or,

(b) he has obtained or procured the right to remain permanently or has been granted humanitarian protection in that nation.

If a player is qualified under this sub section to represent more than one nation and the National Association of one of those nations wishes to nominate him to represent it, that Association must submit an application to the ITF Executive, who will forward a copy to any other National Association concerned, which shall be entitled to comment within 15 days of receipt. The initial application must be received by the ITF Executive at least three months prior to the event for which the player wishes to be nominated. 
The ITF Executive will givea ruling having taken into account all relevant matters.

(b) (i) A player who has represented, or has been eligible to represent a nation and such a nation is divided into two or more nations, shall immediately be eligible to represent any one of those nations.

(ii) A player who has represented, or has been eligible to represent a nation and such nation is absorbed in whole or in part by another nation, shall immediately be eligible to represent such other nation.

(c) A player shall be deemed to have represented a nation if he shall have been nominated at the time of the draw, and shall have accepted, the nomination to play in the Olympic Games Tennis Event or in any International Team Competition recognised by the ITF and listed in Bye Law 2.1(a).

(d) A National Association may appeal to the Davis Cup Committee to nominate a player who is not eligible under the above Rules and the Davis Cup committee may agree the application if the full circumstances warrant an exception being made Such application must be received by the ITF Executivenot later than one month after the decision of the Executive has been received by the National Association.

(e) The Davis Cup Committee has the right to ask a National Association to produce evidence to show how a player is qualified to represent that nation.

Note: A player who represented a nation under the Rules in force in 1994 or prior thereto, shall continue to be eligible to represent that nation even if he is no longer qualified to do so under the amended terms of this Regulation.

\section{The Constitution of ITF L imited 2015 trading as international tennis federation}

Memorandum, Articles of Association and Byelaws of ITF LIMITED trading as the International Tennis Federation 2015

APPENDIX E INTERNATIONAL OLYMPIC COMMITTEE

(Any amendments made to these Rules by the IOC will be accepted by the Company) Extracts from the Olympic Charter

\section{Chapter 5 - The Olympic Games}

II Participation in the Olympic Games R ule 40 E ligibility Code

To be eligible for participation in the Olympic Games, a competitor, coach, trainer or other team official must comply with the Olympic Charter, induding the conditions of eligibility established by the IOC, as well as with the rules of the IF concerned as approved by the IOC, and the competitor, coach, trainer or other team official must be entered by his NOC. The abovenoted persons must: respect the spirit of fair play and nonviolence, and behave accordingly; and respect and comply in all aspects with the World Anti-Doping Code Byelaw to Rule 40

1. Each IF establishes its sport's own eligi bility criteria in accordance with the Olympic Charter. Such criteria must besubmitted to theIOC Executive Board for approval.

2. The application of the eligi bility criteria lies with theIFs, their affiliated national federations and the NOCs in the fied ds of their respective responsibilities.

3. Except as permitted by the IOC Executive Board, no compeitor, coach, trainer or official who participates in the Olympic Games may allow his person, name, picture or sports performances to be used for advertising purposes during the Olympic Games.

4. The entry or participation of a competitor in the Olympic Games shall not be conditional on any financial consideration.

Rule 41 Nationality of C ompetitors

1. Any competitor in the Olympic Games must be a national of the country of the NOC which is entering such competitor.

2. All matters relating to the determination of the country which a competitor may represent in the Olympic Games shall be resolved by the IOC Executive Board.

\section{Bye-law to R ule 41}

1. A competitor who is a national of two or more countries at the same time may represent either one of them, as he may elect. However, after having represented one country in the Olympic Games, in continental or regional games or in world or regional championships recognised by the rel evant IF, he may not represent another country unless he meets the conditions set forth in paragraph 2 below that apply to persons who have changed their national ity or acquired a new national ity.

2. A competitor who has represented one country in the Olympic Games, in continental or regional games or in world or regional championships recognised by the relevant IF, and who has changed his nationality or acquired a new national ity, may participate in the Olympic Games to represent his new country provi ded that at least three years have passed since the competitor last represented his former country. This period may be reduced or even cancelled, with the agreement of the NOCs and IF concerned, by the IOC Executive Board, which takes into account the circumstances of each case

3. If an associated State, province or overseas department, a country or colony acquires independence, if a country becomes incorporated within another country by reason of a change of border, if a country merges with another country, or if a new NOC is recogni sed by the IOC, a competitor may continue to represent the 


\section{APPENDICES}

country to which he bel ongs or belonged. However, he may, if he prefers, elect to represent his country or be entered in the Olympic Games by his new NOC if one exists. This particular choice may bemade only once 4. Furthermore, in all cases in which a competitor would be eligible to participate in the Olympic Games, either by representing another country than his or by having the choice as to the country which such competitor intends to represent, the IOC Executive Board may toke all decisions of a general or individual nature with regard to issues resulting from nationality, citizenship, domicile or residence of any competitor, including the duration of any waiting period.

[... ]

The Constitution of ITF L imited 2014 trading as international tennis federation

Memorandum, Articles of Association and Bye-laws of ITF LIMITED Trading as the International Tennis Federation

II Participation in the Olympic Games

Rule 40 E ligibility Code

To be eligible for participation in the Olympic Games, a competitor, coach, trainer or other team official must comply with the Olympic Charter, including the conditions of eligibility established by the IOC, as well as with the rules of theIF concerned as approved by the IOC, and the competitor, coach, trainer or other team official must beentered by his NOC.

The abovenoted persons must:

- respect the spirit of fair play and non-viol ence, and behaveaccordingly; and

- respect and comply in all aspects with the World Anti-Doping Code.

Bye-law to Rule 40

1 Each IF establishes its sport's own eligibility criteria in accordance with the Olympic Charter. Such criteria must be submitted to the IOC Executive Board for approval.

2 The application of the eligibility criteria lies with the IFs, their affiliated national federations and the NOCs in the fields of their respective responsibilities.

3 Except as permitted by the IOC Executive Board, no compeitor, coach, trainer or official who participates in theOlympic Games may allow his person, name, pictureor sports performances to be used for advertising purposes during the Olympic Games.

4 The entry or participation of a competitor in the Olympic Games shall not be conditional on any financial consideration.

Rule 41 Nationality of C ompetitors

1 Any competitor in the Olympic Games must be a national of the country of the NOC which is entering such competitor.

2 All matters relating to the determination of the country which a compeitor may represent in the Olympic Games shall beresolved by the IOC Executive Board.

Bye-law to Rule 41

1 A competitor who is a national of two or more countries at the sametime may represent either one of them, as he may elect. However, after having represented one country in the Olympic Games, in continental or regional games or in world or regional championships recogni sed by the relevant IF, he may not represent another country unl ess he meets the conditions set forth in paragraph 2 below that apply to persons who have changed their national ity or acquired a new nationality.

2 A competitor who has represented one country in the Olympic Games, in continental or regional games or in world or regional championships recognised by the relevant IF, and who has changed his nationality or acquired a new national ity, may partici pate in the Olympic Games to represent his new country provided that at least three years have passed since the competitor last represented his former country. This period may be reduced or even cancelled, with the agreement of the NOCs and IF concerned, by the IOC Executive Board, which takes into account the circumstances of each case

3 If an associated State, province or overseas department, a country or colony acquires independence, if a country becomes incorporated within another country by reason of a change of border, if a country merges with another country, or if a new NOC is recogni sed by the IOC, a competitor may continue to represent the country to which he bel ongs or bel onged. However, he may, if he prefers, elect to represent his country or be entered in the Olympic Games by his new NOC if oneexists. This particular choice may be made onl y once 4 Furthermore, in all cases in which a competitor would be eligible to participate in the Olympic Games, either by representing another country than his or by having the choice as to the country which such competitor intends to represent, the IOC Executive Board may take all decisions of a general or individual nature with regard to issues resulting from nationality, citizenship, domicile or residence of any competitor, induding the duration of any waiting period.

The Constitution of ITF L imited 2013 trading as international Tennis Federation 


\section{NATIONALITY REQUiREMENTS IN Oly MPIC SPORTS}

Memorandum Articles of Association and Byelaws of ITF LIMITED Trading as the International Tennis Federation (unchanged since 2005)

Rule 40 E ligibility Code

To be eligible for participation in the Olympic Games, a competitor, coach, trainer or other team official must comply with the Olympic Charter, including the conditions of eligibility established by the IOC, as well as with the rules of theIF concerned as approved by the IOC, and the compeitor, coach, trainer or other team official must beentered by his NOC.

The abovenoted persons must:

- respect the spirit of fair play and non-violence, and behave accordingly; and

- respect and comply in all aspects with the World Anti-Doping Code.

Bye-law to Rule 40

1 Each IF establishes its sport's own eligibility criteria in accordance with the Olympic Charter. Such criteria must be submitted to the IOC Executive Board for approval.

2 The application of the eligibility criteria lies with the IFs, their affiliated national federations and the NOCs in the fields of their respective responsibilities.

3 Except as permitted by the IOC Executive Board, no compeitor, coach, trainer or official who participates in theOlympic Games may allow his person, name, pictureor sports performances to be used for advertising purposes during the Olympic Games.

4 The entry or participation of a competitor in the Olympic Games shall not be conditional on any financial consideration.

Rule 41 Nationality of C ompetitors

1 Any competitor in the Olympic Games must be a national of the country of the NOC which is entering such competitor.

2 All matters relating to the determination of the country which a competitor may represent in the Olympic Games shall be resolved by theIOC Executive Board.

Bye-law to Rule 41

1 A competitor who is a national of two or more countries at the sametimemay represent either one of them, as he may dect. However, after having represented one country in the Olympic Games, in continental or regional games or in world or regional championships recognised by the relevant IF, he may not represent another country unless he meets the conditions set forth in paragraph 2 below that apply to persons who have changed their national ity or acquired a new nationality.

2 A competitor who has represented one country in the Olympic Games, in continental or regional games or in world or regional championships recognised by the relevant IF, and who has changed his nationality or acquired a new national ity, may partici patein theOlympic Games to represent his new country provided that at least three years have passed since the competitor last represented his former country. This period may be reduced or even cancelled, with the agreement of the NOCs and IF concerned, by the IOC Executive Board, which takes into account the circumstances of each case

3 If an associated State, province or overseas department, a country or colony acquires independence, if a country becomes incorporated within another country by reason of a change of border, if a country merges with another country, or if a new NOC is recogni sed by the IOC, a competitor may continue to represent the country to which he bel ongs or belonged. However, he may, if he prefers, elect to represent his country or be entered in the Olympic Games by his new NOC if one exists. This particular choice may be made only once. 4 Furthermore, in all cases in which a competitor would be eligible to participate in the Olympic Games, either by representing another country than his or by having the choice as to the country which such competitor intends to represent, the IOC Executive Board may take all decisions of a general or individual nature with regard to issues resulting from nationality, citizenship, domicile or residence of any competitor, including the duration of any waiting period.

\section{Triathlon}

INTERNATIONAL TRIATHLON UNION CONSTITUTION Text as approved by ITU Congress Approved: ITU C ongress C hicago, September 2015

CHAPTER 6: ELIGIBILITY

Article 28: Only those competitors, who are eligible according to the ITU eligibility rules, are allowed to take part in competitions organised by ITU, CCs or their member NFs. Other than as provided in this article, the eligibility rules areincluded in the Competition Rules.

28.1 Wherean athlete:

a)Wishes to represent a NF other than the NF to which they originally belonged, they must reside in the country of the subsequent NF for at least three years after the date they last represented the original NF in any sanctioned event. This period of residence can be reduced to one year if the two NFs concerned agree, and the Executive Board of ITU consents.

b) Holds or is legally entitled to hold citizenship of two or more countries, provided that it is at least three 
years since the athlete last represented the first NF in any competition, the period of residence may be reduced to one year, if the two NFs concerned agre and if the Executive Board approves.

28.2 If a State, province or overseas department, a country acquires independence, if a country becomes incorporated within another country by reason of a change of border or if a new NF is recognised by the ITU, an athl etemay choose with which existing NF is he/she willing to compete This particular choice may be made only once, and the Executive Board has to approve it.

ITU Competition Rules Approved by the ITU Executive Board, in December 2014 (unchanged since 1989)

\subsection{Eligibility:}

a.) All athletes must be in good standing with their National Federations. To ensure this, all the entries must be done by theNFs, not by the athletes themselves;

b.) Athletes under suspension are not al lowed to compete in any ITU event, in any competition sanctioned by

ITU members, or in any competition held under theITU Rules;

c.) An athlete's age is determined by their age on December $31^{t}$ in the year of compeition;

d.) Athletes aged 15 to 17 years old are eligible to competein the Y outh category;

e) Athl etes aged 16 to 19 years old are eligible to compete in the J unior category;

f.) Athl etes aged 18 to 23 years old are eligible to compete in the U23 category;

g.) The different qualification criteria are published in Appendix E;

h) Specific Olympic qualification criteria are published in Appendix E;

i)Athletes may not compete within 48 hours (as determined by the start times of the first wave) in more than one related multi-sport event (see A ppendix I) when one event is of standard distance or longer. Exceptions will befor the PT5 guides and team relay events at the defined super-sprint distances (see 15.1.a);

j)Age limits: athletes must be a minimum age to compete in any ITU Event, as outdined in Appendix A. Continental Confederations may add other age limits for Continental Championships, for youth categories with super-sprint events. The age limits as outtined in Appendix A cannot be modi fied;

k) An athlete who competes in a category different from his/her age, in a distance in which is not all lowed, or before the 48-hour period, will be disqualified from the events he/she took part in. Any awards, prizes and points will beremoved.

ITU Competition Rules Approved by the ITU Executive Board, February 2013 (unchanged since 1989)

2.5. E ligibility:

a.) All athletes must be in good standing with their National Federations. To ensure this, all the entries must be done by theNFs, not by the athletes themselves.

b.) Athletes under suspension are not al lowed to competein any ITU event, in any competition sanctioned by

ITU members, or in any competition held under thelTU Rules.

c.) An athlete's age is determined by their age on December 31st in the year of compeition.

d.) Athl etes aged 15 to 17 years old are eligible to compete in the Y outh category.

e) Athletes aged 16 to 19 years old are eligible to compete in the J unior category.

f.) Athletes aged 18 to 23 years old are eligible to compete in the U23 category.

g.) The different qualification criteria are published in Appendix E.

h.) Specific Olympic qualification criteria are published in Appendix E.

i.) Athletes may not compete within 48 hours (as determined by the start times of the first wave) in more than one related multi-sport event (see Appendix J) when one event is of standard distance or longer. An exception will be for team relay events at the defined super-sprint distances (see 15.1.a.).

j.) Age limits: athletes must be a minimum age to compete in any ITU Event, as outlined in Appendix A. Continental Confederations may add other age limits for Continental Championships, for youth categories with super-sprint events. The age limits as out lined in A ppendi $x$ A cannot be modi fied.

k.) An athl ete who competes in a category different from his/her age, in a distance in which is not allowed, or before the 48-hour period, will be disqualified from the events he/she took part in. Any awards, prizes and points will beremoved.

INTERNATIONAL TRIATHLON UNION CONSTITUTION Text as approved by ITU CongresS, September 2013

\section{CHAPTER 6: ELIGIBILITY}

Article 28. Only those competitors, who are eligible according to the ITU eigibility rules, are allowed to take part in competitions organised by ITU, CCs or their member NFs. Other than as provided in this article, the eligibility rules are included in the Competition Rules.

28.1 Whereanathlete:

a) Wishes to represent a NF other than the NF to which they originally belonged, they must reside in the 
country of the subsequent NF for at least three years after the date they last represented the original NF in any sanctioned event. This period of residence can be reduced to one year if the two NFs concerned agree, and the Executive Board of ITU consents.

b) Holds or is legally entitled to hold citizenship of two or more countries, provided that it is at least three years since the athlete last represented the first NF in any compeition, the period of residence may be reduced to one year, if the two NFs concerned agree and if the Executive Board approves.

28.2 If a State, province or overseas department, a country acquires independence, if a country becomes incorporated within another country by reason of a change of border or if a new NF is recogni sed by the ITU, an athlete may choose with which existing NF is he/she willing to compete This particular choice may be made only once, and the Executive Board has to approve it.

\section{Volleyball}

SPORTS RE GULATIONS Volleyball FIVB Sports regulations Version: 15 M ay 2015

CHAPTER 2: Participation Conditions and Structurefor FIVB Competitions

\section{ELIGIBILITY OF PLAYERS}

5.1ELIGIBLE PLAYERS

Only players who meet the eligibility conditions laid down by the FIVB in Chapter 9 of the Sports

Regulations may participatein FIVB and World Competitions.

\subsection{CITIZE NSHIP}

Only players holding the citizenship of the country they represent may be registered to participate in FIVB and World competitions, except for the FIVB Club World Championships. They must produce a valid passport as proof.

\subsection{EXCEPTIONS TO CITIZENSHIP}

For official competitions, governing bodies may submit to the Board of Administration exceptional ruling concerning citizenship.

\subsection{NATURALISED PLAYERS}

Naturalized players may participate whenever the FIVB Sports Regulations allow them to do so (see Articles 41 and 45.3).

\subsection{AGE}

Whenever an age limit is imposed, players must present their individual passports.

\section{SE CTION II: Status of Players, Teams and R eferees}

CHAPTER 9: Status of Players

\section{ELIGIBILITY}

40.1 SUPREME AUTHORITY

The FIVB is the supreme authority in volleyball to decide all questions and disputes relating to the eligibility of players for national and international competitions.

\subsection{RIGHT TO DETERMINE PLAYERS' ELIGIBILITY}

Each National Federation has the right to determine the eligibility of its players subject to the provisions of theFIVB Constitution and Regulations.

\subsection{CRITERIA FOR THE ELIGIBILITY OF PLAYERS}

The eligibility of a player may be determined after taking into consideration the following criteria:
A) citizenship
B)age
C) sex
D) height (if applicable)
E) other eligibility criteria

40.4 PLAYER PARTICIPATION IN A MATCH

A player is considered to bein the match when

40.4.1 his nameis registered in theO-2bis form, and

40.4.2 there is visual confirmation from the passport/ ID (identification document) that the player is actually present.

\section{SECTION II CHAPTER 9}

41 CITIZENSHIP

41.1 NATIVE PLAYERS

Any person holding the citizenship of a country, whether acquired at birth or later (by application or any other means), is eligible to play for the national team of the National Federation of the same country, provided that said National Federation is his Federation of Origin and that the conditions set out in these Regulations arefulfilled.

\subsection{NATURALIZED PLAYERS}

41.2.1 Only one player having previously played for another national team of the same age category can be 


\section{APPENDICES}

part of a team, for a given event

41.2.2 The O-2bis form and the player's International Transfer Certificate shall include the additional information of the player's former national team, whereapplicable

\subsection{ELIGIBILITY TO PLAY FOR A THIRD NATIONAL TEAM}

A player is not eligible to play for a third national team, nor may he return to the initial national team of his Federation of Origin after having changed his Federation of Origin (see al so Article 44.1).

\subsection{FIRST REGISTRATION IN OWN OR FOREIGN COUNTRY}

41.4.1 The Federation which is the first to:

A) register the player in its national teamfor an FIVB, World or Official Competition through the final FIVB

O-2bis Form, with the player's s presence being certified by the Control Cormitter; or

B) issuea national licensefor the player or otherwise register the player within its Federation;

is considered to bethe player's Federation of Origin regardless of the player's citizenship.

41.4.2 If at the time of registration the player holds the citizenship of another country only, he becomes eligible to play in the national team of his Federation of Origin immediately after obtaining the same citizenship as his Federation of Origin.

\subsection{PASSPORT}

All players wishing to participate in FIVB, world or official competitions, must present an individual passport issued by the competent authorities of the country they represent The FIVB Board of Administration may establish different or additional requirements.

\section{AGE AND GENDER}

\subsection{AGE AND GENDER CATEGORIES}

TheFIVB has determined the following age categories: Girls' Under 18,

Boys' Under 19,

Women's Under 20,

Men's Under 21,

Men's and Women's Under 23

\subsection{GENDER VERIFICATION CERTIFICATE}

42.2.1 The gender must be attested by the National Federations through the birth certificate of the player.

42.2.2 Women competitors in FIVB, world and official competitions, may be required to present the official Gender verification certificate issued by the FIVB Medical Commission or by the International Olympic Committee (IOC).

\section{OTHER ELIGIBILITY RULES}

\subsection{GENERAL RULE}

Any player who fulfils the requirements of the rules on citizenship, age, gender and other criteria established by FIVB (and/or IOC, where applicable), is eligible for participation in FIVB competitions, including the Olympic Games and qualifying tournaments, on the condition that he complies with the principles of affiliation established by the respective National Federation and fulfils the conditions set out in these Regulations.

\subsection{ELIGIBLE PLAYERS}

43.2.1 An eligible player may receive, during the period of his preparation and his sports activity, material and financial assistance, either from sports organizations (NF, NOC, League, Committees or Clubs belonging to vol untary organizations recognized by his Federation), or from privateor public institutions.

43.2.2. An eligible player may receive his country's support for preserving and raising the level reached in his studies and in his work within his community at the moment of his incorporation in a sports program

43.2.3. Material assistanceincludes:

A) board and lodging expenses;

B) sportswear and equipment;

C) travel expenses; and

D) expenses for medical and dental treatment, physiotherapy, induding therapeutic and psychological services and necessary medicine.

\subsubsection{Financial help may be granted without limitation as foll ows:}

A) compensation to replace a justified loss of sal ary or a scholarship to continue his studies or to continue his professional carer;

B) pocket money;

C) subscription to an insurance or pension plan whether governmental or private under the terms of the national law; and

D) engagement by or endorsement for a sports, government, privateorganization, or sports club.

43.2.5. No National Federation, club or player may demand any financial guarantee or special economic conditions to participate in FIVB competitions. Infringement of this rule is a basis for sanctions according to FIVB Regulations.

43.3 DECISIONS ON THE ELIGIBILITY OF PLAYERS 


\section{NATIONAlity ReQuirements in Olympic SPORTS}

TheFIVB Board of Administration, or in urgent cases the Executive Committee/the President, decides on the application of the rules for the eligibility of players. It may ask the Legal Commission to study the case and submit recommendations.

\section{CHANGE OF FEDERATION OF ORIGIN}

44.1 GENERAL

A player's Federation of Origin may be changed only once Changes of Federation of Origin may be approved only by theFIVB Executive Committee upon proposal of theFIVB President.

\subsection{CONDITIONS}

A change of Federation of Origin (hereinafter "the Change") may be approved only if the following conditions are cumulatively met:

44.2.1 The player has established residence in the country of his new Federation of Origin (hereinafter "the new Federation") for a minimum of two (2) continuous years.

44.2.2 The player has obtained the citizenship of the country of the new Federation.

44.2.3 The player's Federation of Origin agrees to the Change

44.2.4 The new Federation agrees to the Change

44.2.5 The applicable administration fee for the Change has been paid to the FIVB (see Artide 44.3.2 below).

\subsection{PR OCE DURE}

44.3.1 The following documents shall besubmitted to theFIVB:

A) 6 original copies of the respectiveFIVB form (seewww.fivb.org), duly signed and stamped by the player, his Federation of Origin and the new Federation; and

B) Proof of two (2) years continuous residence in the country of the new Federation; and

C) Copy of the player's International Passport of the country of the new Federation.

44.3.2. The administrative fee for a Change is CHF 15,000. If the player has played for a senior national team, the applicable administrativefeeis CHF 25,000.

44.4. SPE CIAL CASE S

44.4.1 In case the player has never played for any national teamand had al ready at birth the citizenship of the country of the new Federation, the FIVB may approvethe Change as follows:

A) The conditions of Article 44.2 shall be met, except for the condition of 2-year continuous residence.

B) The documents mentioned under Article 44.3.1.a and 44.3.1.c above shall be submitted to FIVB, along with proof of when the player acquired the citizenship of the country of the new Federation.

C)The applicableadministration feeis CHF 2,000.

D)The National Federations involved (NFs) and the FIVB may agree that the Player's transfers between the two NFs will be exempted from the payment of administration and transfer fees.

44.4.2. In case

A) the player has established residence in the country of the new Federation for a minimum of eight (8) continuous years; and

B) the application for a Change is filed with the FIVB on or after the 1st of January of the calendar year during which the player turns 38 (for men) or 35 (for women); and

C) the conditions of Article 44.2.2 (citizenship) as well as 44.2.3 and 44.2.4 (agreement of two NFs) are met, the condition of Article 44.2.5 (administration fee) shall be waived.

\subsection{ONSE QUE NCES}

44.5.1. Unless decided otherwise, the decision of the FIVB Executive Committee to approve a Change is effective from the day of its notification to the new Federation.

44.5.2. As of that date, the player shall have the same rights and obligations with players of the new Federation (eg. he can directly compete in club competitions of the new Federation without a need for ITC). However, if the player has previously played for another national team of the same age category, he will be eligible to play for the national team of the new Federation only after two (2) years have elapsed. This twoyear period starts from the day that the complete application file, containing all required documents, is received by the FIVB.

\subsection{CHANGE OF RESIDENCE}

45.6.1 The change of a player's residence to another country, whether voluntary or not, still requires the player, the Receiving Federation and the Receiving Club to follow the established transfer procedures as set out in these Regulations.

45.6.2 Players who have citizenship problems or have completed two (2) years' proven inactivity may be allowed to play in national and/or international competitions under the FIVB umbrella with club teams of their new country of residence before they obtain the citizenship of their new country and/or satisfy other legal requirements. In such cases, the FIVB shall act as the player's Federation of Origin for the purposes of thetransfer.

CHAPTER 10: Status of Teams

46. TEAMS AND INTERNATIONAL COMPETITIONS 


\section{APPENDICES}

46.1 NATIONAL TEAM

46.1.1 The team selected by its NF and authorized to bear its country's name is considered the national team 46.1.2. The national teammust not include foreign players, in accordance with Section I, Chapter II Article5 and Section II, Chapter 9 of these Regulations

46.1.3. A national teammay only play against another national team When a club team is involved, theteam will be named "All-Star Team of (the country or region)" during the whole competition.

46.1.4. A national team that has participated as such in any international competition may not be given the status of a club team for international competitions.

\section{FIVB Sports Regulations(2014)SPOR TS RE G ULATIO NS Volleyball Version: 15 M ay 2014}

\section{ELIGIBILITY OF PLAYERS}

\subsection{ELIGIBLE PLAYERS}

Only players who meet the eligibility conditions laid down by the FIVB in Chapter 9 of the Sports Regulations may participatein FIVB and World Competitions.

\subsection{CITIZENSHIP}

Only players holding the citizenship of the country they represent may be registered to participate in FIVB and World competitions, except for the FIVB Club World Championships. They must produce a valid passport as proof.

\subsection{EXCEPTIONS TO CITIZENSHIP}

For official competitions, governing bodies may submit to the Board of Administration exceptional ruling concerning citizenship.

\subsection{NATURALISED PLAYERS}

Naturalized players may participate whenever the FIVB Sports Regulations all low them to do so (see Articles 41 and 45.3).

[... ]

SECTION II

Status of Players, Teams and Referees

These regulations apply equally to both genders. A reference to one gender (eg. he) includes a reference to theother gender (eg. she).

CHAPTER 9 Status of Players

40 ELIGIBILITY

40.1 SUPREME AUTHORITY

The FIVB is the supreme authority in volleyball to decide all questions and disputes relating to the eligibility of players for national and international competitions.

\subsection{RIGHT TO DETERMINE PLAYERS' ELIGIBILITY}

Each National Federation has the right to determine the eligibility of its players subject to the provisions of the FIVB Constitution and Regulations.

\subsection{CRITERIA FOR THE ELIGIBILITY OF PLAYERS}

The eligibility of a player may be determined after taking into consideration the following criteria:
A) citizenship
B) age
C) sex
D) height (if applicable)
E) other eligibility criteria

\subsection{PLAYER PARTICIPATION IN A MATCH}

A player is considered to be in the match when

40.4.1 his nameis registered in the O-2bis form, and

40.4.2 there is visual confirmation from the passport / ID (identification document) that the player is actually present.

\section{CITIZENSHIP}

\subsection{NATIVE PLAYERS}

Any person holding the citizenship of a country, whether acquired at birth or later (by application or any other means), is eligible to play for the national team of the National Federation of the same country, provided that said National Federation is his Federation of Origin and that the conditions set out in these Regulations are fulfilled.

\subsection{NATURALIZED PLAYERS}

41.2.1 Only one player having previously played for another national team of the same age category can be part of a team for a given event.

41.2.2 The O-2bis form and the player's International Transfer Certificate shall include the additional information of the player's former national team, where applicable

41.3 ELIGIBILITY TO PLAY FOR A THIRD NATIONAL TEAM 
A player is not eligible to play for a third national team, nor may he return to the initial national team of his Federation of Origin after having changed his Federation of Origin (see al so Article 44.1).

41.4 FIRST REGISTRATION IN OWN OR FOREIGN COUNTRY

41.4.1 The Federation which is the first to:

A) register the player in its national teamfor an FIVB, World or Official Competition through the final FIVB

O-2bis Form, with the player's presence being certified by the Control Committer; or

B) issuea national license for the player;

is considered to bethe player's Federation of Origin regardless of the player's citizenship.

41.4.2 If at the time of registration the player holds the citizenship of another country only, he becomes eligible to play in the national team of his Federation of Origin immediately after obtaining the same citizenship as his Federation of Origin.

\subsection{PASSPORT}

All players wishing to participate in FIVB, world or official competitions, must present an individual passport issued by the competent authorities of the country they represent The FIVB Board of Administration may establish different or additional requirements.

[...]

\section{OTHER ELIGIBILITY RULES}

\subsection{GE NERAL RULE}

Any player who fulfils the requirements of the rules on citizenship, age, gender and other criteria established by FIVB (and/or IOC, where applicable), is eligible for participation in FIVB competitions, induding the Olympic Games and qualifying tournaments, on the condition that he complies with the principles of affiliation established by the respective National Federation and fulfils the conditions set out in these Regulations.

[...]

\subsection{DECISIONS ON THE ELIGIBILITY OF PLAYERS}

The FIVB Board of Administration, or in urgent cases the ExecutiveCommittee/the President, decides on the application of the rules for the eligibility of players. It may ask the Legal Commission to study the case and submit recommendations.

\section{CHANGE OF FEDERATION OF ORIGIN}

\subsection{GE NERAL}

A player's Federation of Origin may be changed only once Changes of Federation of Origin may be approved only by theFIVB ExecutiveCommittee upon proposal of theFIVB President.

44.2 CONDITIONS

A change of Federation of Origin (hereinafter "the Change") may be approved only if the following conditions are cumulatively met:

44.2.1 The player has established residence in the country of his new Federation of Origin (hereinafter "the new Federation") for a minimum of two (2) continuous years.

44.2.2 The player has obtained the citizenship of the country of the new Federation.

44.2.3 The player's Federation of Origin agrees to the Change

44.2.4 The new Federation agrees to the Change.

44.2.5 The applicable administration fee for the Change has been paid to the FIVB (see Artide 44.3.2 below).

\subsection{PR OCE DURE}

44.3.1 The following documents shall besubmitted to theFIVB:

A) 6 original copies of the respectiveFIVB form(seewww.fivb.org), duly signed and stamped by the player, his Federation of Origin and the new Federation; and

B) Proof of two (2) years continuous residence in the country of the new Federation; and

C) Copy of the player's International Passport of the country of the new Federation.

44.3.2 The administrative fee for a Change is CHF 15,000. If the player has played for a senior national team, the applicableadministrative feeis CHF 25,000.

44.4 SPE CIAL CASE S

44.4.1 In case the player has never played for any national team and had al ready at birth the citizenship of the country of the new Federation, the FIVB may approvethe Change as follows:

A) The conditions of Article 44.2 shall be met, except for the condition of 2-year continuous residence.

B) The documents mentioned under Article 44.3.1.a and 44.3.1.c above shall be submitted to FIVB, along with proof of when the player acquired thecitizenship of the country of the new Federation.

C) The applicable administration feis CHF 2,000.

D) The National Federations involved (NFs) and the FIVB may agree that the Player's transfers between the two NFs will beexempted from the payment of administration and transfer fees.

44.4.2 In case 


\section{APPENDICES}

A) the player has established residence in the country of the new Federation for a minimum of eight (8) continuous years; and

B) the application for a Change is filed with the FIVB on or after the 1st of J anuary of the cal endar year during which the player turns 38 (for men) or 35 (for women); and

C) the conditions of Artide 44.2.2 (citizenship) as well as 44.2.3 and 44.2.4 (agreement of two NFs) aremet, the condition of Article44.2.5 (administration fee) shall bewaived.

\section{SPORTS RE GULATIONS Volleyball Version: 15 M ay 2013}

\section{ELIGIBILITY OF PLAYERS}

5.1 ELIGIBLE PLAYERS

Only players who meet the eligibility conditions laid down by the FIVB in Chapter 9 of the Sports Regulations may participatein FIVB and World Competitions.

\subsection{CITIZENSHIP}

Only players holding the citizenship of the country they represent may be registered to participate in FIVB and World competitions, except for the FIVB Club World Championships. They must produce a valid passport as proof.

\subsection{EXCEPTIONS TO CITIZENSHIP}

For official competitions, governing bodies may submit to the Board of Administration exceptional ruling concerning citizenship.

\subsection{NATURALISED PLAYERS}

Naturalized players may participate whenever the FIVB Sports Regulations allow them to do so (see Articles 41 and 45.3).

\subsection{AGE}

Whenever an age limit is imposed, players must present their individual passports.

[...]

CHAPTE R 9 Status of Players

40 ELIGIBILITY

\subsection{SUPREME AUTHORITY}

The FIVB is the supreme authority in volleyball to decide all questions relating to the eligibility of players for national and international competitions.

40.2 RIGHT TO DETERMINE PLAYERS' ELIGIBILITY

Each National Federation has the right to determine the eligibility of its players within the provisions of the FIVB Constitution and these Regulations.

\subsection{CRITERIA FOR THE ELIGIBILITY OF PLAYERS}

The eligibility of a player may be determined after taking into consideration the following criteria:

a) citizenship

b) age

c) sex

d) height (if applicable)

e) other eligibility criteria

\subsection{PLAYER PARTICIPATION IN A MATCH}

A player is considered to bein the match when

40.4.1 his nameis registered in the O-2bis form, and

40.4.2 there is visual confirmation from the passport / ID (identification document) that the player is actually present.

41 CITIZENSHIP

\subsection{NATIVE PLAYERS}

Any person holding the citizenship of a country is eligible to play for the national team of the National Federation of the same country, subject to the conditions set out in these Regulations.

\subsection{NATURALIZED PLAYERS}

41.2.1 In principle, players who have acquired a new citizenship (naturalized players) can play in national teams of their new country.

41.2.2 Only one player having previously played for another national team of the same age category can bea part of a team for a given event.

41.2.3 The O-2bis form and the player's International Transfer Certificate shall include the additional information of the player's former national team, where applicable

41.3 ELIGIBILITY TO PLAY FOR A THIRD NATIONAL TEAM

A player is not eligible to play for a third national team, nor may he return to the initial national team of his Federation of Origin after having changed his Federation of Origin (see al so Article44.1).

41.4 FIRST REGISTRATION IN OWN OR FOREIGN COUNTRY 
41.4.1 The Federation which is the first to issue a license or register the player with one of its club teams is consi dered to be the Federation of Origin regardl ess of the player's citizenship.

41.4.2 If at the time of registration the player holds the citizenship of another country only, he becomes eligible to play in the national team of his Federation of Origin immediately after obtaining the same citizenship as his Federation of Origin.

41.4 PASSPORT

In order to be eligibleto participate in FIVB, world and official competitions, all competitors must present an individual passport issued by the competent authorities. The FIVB Board of Administration may establish different or additional requirements.

[...]

43 OTHER ELIGIBILITY RULES

43.1 GENERAL RULE

Any player who fulfils the requirements of the rules on citizenship, age, gender and other criteria established by FIVB (and/or IOC, where applicable), is eligible for participation in FIVB competitions, including the Olympic Games and qualifying tournaments, on the condition that he complies with the principles of affiliation established by the respective National Federation and fulfils the conditions set out in these Regulations.

[...]

43.3 DECISIONS ON THE ELIGIBILITY OF PLAYERS

TheFIVB Board of Administration, or in urgent cases the Executive Committee/thePresident, decides on the application of the rules for the eligibility of players. It may ask the Legal Commission to study the case and submit recommendations.

\section{CHANGE OF FEDERATION OF ORIGIN}

44.1 GE NERAL

A player's Federation of Origin may be changed only once Changes of Federation of Origin may be approved only by theFIVB Board of Administration.

44.2 CONDITIONS

A change of Federation of Origin (hereinafter "the Change") may be approved only if the following conditions are cumulatively met:

44.2.1 The player has established residence in the country of his new Federation of Origin (hereinafter "the new Federation") for a minimum of two (2) continuous years.

44.2.2 The player has obtained the citizenship of the country of the new Federation.

44.2.3 The player's Federation of Origin agrees to the Change

44.2.4 The new Federation agrees to the Change.

44.2.5 The applicable administrative fee for the Change has been paid to the FIVB (see Article 44.3.2 below).

44.3 PROCEDURE

44.3.1 The foll lowing documents shall besubmitted to theFIVB:

a) 6 original copies of the respective FIVB form (see www.fivb.org), duly signed and stamped by the player, his Federation of Origin and thenew Federation; and

b) Proof of two (2) years continuous residencein the country of the new Federation; and

c) Copy of the player's International Passport of the country of the new Federation.

44.3.2 The administrativefeefor a Change is CHF 15,000. If the player has played for a senior national teem, theapplicableadministrativefeis CHF 25,000.

\subsection{SPE CIAL CASES}

If the player has never played for any national team and had al ready at birth the citizenship of the country of thenew Federation, theFIVB Board of Administration may approvethe Change as follows:

44.4.1 The conditions of Article 44.2 shall be met, except for the condition of 2-year continuous residence 44.4.2 The documents mentioned under Article 44.3.1.a and 44.3.1.c above shall be submitted to FIVB, al ong with proof of when the player acquired the citizenship of the country of thenew Federation.

44.4.3 The applicableadministrativefeis CHF 2,000.

[...]

45.6 CHANGE OF RESIDENCE

45.6.1 A change of legal residence by a player, whether voluntary or not, involving a move to another country, still requires the player and the Receiving Federation to follow the established transfer procedures as set out in these Regulations.

45.6.2 Players who have citizenship problems or have completed two (2) years' proven inactivity may be allowed to play under the FIVB umbrella with club teams of their new country of residence (including international events) before they obtain the citizenship of their new country and/or satisfy other legal requirements. In such cases, the FIVB shall act as theFederation of Origin for the purposes of thetransfer.

46 TE AM S AND INTERNATIONAL COMPETITIONS 


\section{APPENDICES}

\subsection{NATIONAL TEAM}

46.1.1 The team selected by its NF and authorized to bear its country's name is considered the national team 46.1.2 The national team must not ind ude foreign players, in accordance with Section I, Chapter II Article5 and Section II, Chapter 9 of these Regulations

46.1.3 A national team may only play against another national team When a club team is involved, the team will be named "All-Star Team of (the country or region)" during the whole competition.

46.1.4 A national team that has participated as such in any international compeition may not be given the status of a club team for international competitions.

\section{Weightlifting}

IWF Technical \& competiton rules Approved by the IWF Congress - Baku - 2012 Updated by IWF Congress - K azan - 2014 U pdated in Almaty - 2014 in effect with 01.01.2015

\subsubsection{Athlete's CAR D}

3.4.6.1 The Athlete's Card is issued for each athlete and is the official document to record the athletes' declarations, attempts and Team Officials / athletes' initials or signature as all lowed by theTCRR.

Each Athlete's Card contains the following athleteinformation:

- Name

- date of birth

- IWF / IOC code

- Bodyweight

- bodyweight category

- group, if applicable

- Entry Total

- start number, assigned at the completion of weigh-in

\subsection{OLYMPIC GAMES}

5.3.1 As soon as available but no later than twenty-four (24) months before the opening of the Olympic Games and in consultation with the IWF Executive Board, the IOC, the IWF Technical Delegates (TDS) and the Organising Committee of the Olympic Games (OCOG), the IWF shall communicater levant information to all Member Federations.

5.3.2 All sport and TCRR related documents must be approved by the IWF before publication.

5.3.3 A National Olympic Committee (NOC) may enter athletes to the Olympic Games and Y outh Olympic Games in accordance with the relevant "Olympic Games Qualification Regulation".

5.3.4 Olympic gold, silver and bronze medals are awarded respectively to the first three (3) places for the Total in each of the bodyweight categories.

5.3.5 The IWF Executive Board appoints two (2) Technical Delegates (TDs) for the Olympic Games whose task is to coordinate and assist with the technical organisation of the weightlifting competition.

\subsection{VERIFICATION OF FINAL ENTRIES}

6.2.1 Prior to the Technical Congress / Conference, a Verification of Final Entries (VFE) Meeting shall be held chaired by theCD/TD.

6.2.2 A copy of each participating athlete's passport must be presented at the VFE Meeting by the relevant Team Official (s).

6.2.3 The VFE Meeting consists of each participating team receiving a Verification Form on which they are requested/ eligibleto do the following:

correct the spelling of the athletes' name

correct the athletes' date of birth

modify the athletes' bodyweight category

modify the athletes' Entry Total

6.2.4 Substitution of athletes will not be accepted.

6.2.5 Maximum seven (7) women and eight (8) men shall remain on the Verification Form with a maximum of two (2) athletes per bodyweight category, unless Y outh and J unior competitions are held together. All additional athlete(s) must be deleted.

6.2.6 OncetheVerification Form is verified, signed and returned the Entries are considered final.

6.2.7 Teams with no representation at the VFE Meeting must accept the information according to their submitted Final Entry Formas final and binding.

IWF Consitution and Bylaws Approved by the IWF Congress - Baku Modified by IWF Congress Almaty 2014 in effect with 1.1.2015

\section{ELIGIBILITY}

13.1 Eligibility of athletes to participate in competition is determined by the rules of the IWF. The IWF exercises jurisdiction over the eligibility of athletes to participate in IWF World Championships and other IWF Events. 


\section{NATIONALITY REQUIREMENTS IN OLYMPIC SPORTS}

13.2 For the Olympic Games, the IOC Eligibility Rule prevails.

\section{BY-LAW TO 13 ELIGIBILITY}

1. A condition of participation for a given country is that an athlete must hold the citizenship of that country, proven by an official document issued by such country (such as passport). In the case of double or multiple citizen- ship, proven by an official document issued by such country (such as passport), any athlete may participate in IWF Calendar Events and may represent not more than one (1) country within a period of twelve (12) months. In case a country does not issue its own passport or any similar document, for the determination of nationality the IWF accepts the applicable rules of the UN and/or IOC.

2. An athlete residing in a foreign country may only participate in competitions organised in that country if he or she has an authorisation from his or her Member Federation

3. An athlete may represent a new country in international competitions provided that: (i) the athlete obtains thecitizenship of that new country, and

(ii) the athlete gets the approval of the Member Federation he/she is currently representing, the approval of the Member Federation he/she wish- es to represent and the approval of the IWF. If theathlete cannot get the approval of the Member Federation he/she is currently representing, then the athlete has to wait for a period of one (1) year (to be counted from the date of the request for approval) before being automatically authorised to represent the new Member Federation. In the case of a second or further change of citizenship, the condition of participation in international events is four (4) years' of new citizenship, including one Olympic Games.

\section{IWF GUIDE LINES FOR NATIONALITY CHANGE September 2014}

\section{What shall I do if I want to change my nationality and represent another country?}

Please note that in all cases a condition of participation for a given country is that you must hold the citizenship of that country, proven by an official document issued by such country (such as passport). In case a country does not issue its own passport or any similar document, for the determination of nationality the IWF accepts the applicable rules of the UN and/or IOC and/or IWF.

\section{CASE 1.}

In case you never represented your former country at any international competition, after you got the citizenship of your new country and registered in ADAMS you are free to compete on behalf of your new country.

\section{CASE 2.}

In case you have al ready represented your former country at international events and you have no double or multiplecitizenship then you have to

1. obtain the citizenship of the new country

2. get a written approval from your former Federation

3. get a written approval from your new Federation

4. and lastly get an approval from the IWF.

After you got all the above documents you have to be registered in ADAMS and so you are eligible to compete on behalf of your new Federation.

\section{CASE 3.}

In case you have al ready represented your former country at international events and you have no double or multiplecitizenship but you cannot get the written approval from your former Federation, then you have to

1. submit a written request to the IWF that you wish to represent a new country and then you have to wait one year from the date of the request submission to be automatically eligible to compete on behalf of your new Federation.

2. obtain the citizenship of thenew country

3. submit a written approval fromyour new Federation

4. and lastly obtain an approval from the IWF.

\section{CASE 4.}

In the case you have double or multiple citizenship, proven by an official document issued by such country (such as passport), you may participate at IWF Calendar Events but may represent not more than one (1) country within a period of twe ve (12) months.

\section{CASE 5.}

In the case of a second or further change of citizenship, the condition of participation at international events is four (4) years of new citizenship, including one Olympic Games.

Please note that for those who wish to compete at the Olympic Games the Olympic Charter's special Rules shall apply: http://www.olympic.org/documents/olympic_charter_en.pdf

Should you have any questions regarding the nationality change do not hesitate to contact the IWF through Dr. MagdolnaTrombitás at magdol na.trombitas@iwfnet.net 


\section{APPENDICES}

Approved by the IWF Congress - Baku in effect with 01.01.2013

3.4.6 Athlete'sC ard

3.4.6.1 The Athlete's Card is issued for each athlete and is the official document to record the athletes' declarations, attempts and Team Officials / athletes' initials or signature as all lowed by theTCRR.

Each Athl ete's Card contains the following athlete information:

name

date of birth

IWF / IOC code

bodyweight

bodyweight category

group, if applicable

Entry Total

start number, assigned at the completion of weigh-in

\subsection{OLYM PIC GAMES}

5.3.1 As soon as available but no later than twenty-four (24) months before the opening of the Olympic Games and in consultation with the IWF Executive Board, the IOC, the IWF Technical Delegates (TDS) and the Organising Committee of the Olympic Games (OCOG), the IWF shall communicater levant information to all Member Federations.

5.3.2 All sport and TCRR related documents must be approved by the IWF before publication.

5.3.3 A National Olympic Committee (NOC) may enter athletes to the Olympic Games and Y outh Olympic Games in accordance with the relevant "Olympic Games Qual ification Regulation".

5.3.4 Olympic gold, silver and bronze medals are awarded respectively to the first three (3) places for the Total in each of the bodyweight categories.

5.3.5 The IWF Executive Board appoints two (2) Technical Delegates (TDs) for the Olympic Games whose task is to coordinate and assist with the technical organisation of the weightifting competition.

6.2 VERIFICATION OF FINAL ENTRIES

6.2.1 Prior to the Technical Congress / Conference, a Verification of Final Entries (VFE) Meeting shall be held chaired by the CD/TD.

6.2.2 A copy of each participating athlete's passport must be presented at the VFE Meeting by the relevant Team Official (s).

6.2.3 The VFE Meeing consists of each participating team receiving a Verification Form on which they are requested / eligibleto do the following:

correct the spelling of the athletes' name

correct theathletes' date of birth

modify the athletes' bodyweight category

modify theathletes' Entry Total

6.2.4 Substitution of athletes will not be accepted.

6.2.5 Maximum seven (7) women and eight (8) men shall remain on the Verification Form with a maximum of two (2) athletes per bodyweight category, unless Y outh and J unior competitions are held together. All additional athlete(s) must be deleted.

6.2.6 OncetheVerification Form is verified, signed and returned the Entries are considered final.

6.2.7 Teams with no representation at the VFE Meeting must accept the information according to their submitted Final Entry Formas final and binding.

IWF Constitution and By-L aws 2013-2016

Approved by IWF Congress - Baku in effect with 01.01.2013

13 ELIGIBILITY

13.1 Eligibility of athletes to participate in competition is determined by the rules of the IWF. The IWF exercises jurisdiction over the eligibility of athletes to participate in IWF World Championships and other IWF Events.

13.2 For the Olympic Games, the IOC Eligibility Rule prevails.

(By-Lawto 13)

BY-LAW TO 13 ELIGIBILITY

1 A condition of participation for a given country is that an athlete must hold the citizenship of that country, proven by an official document issued by such country (such as passport). In the case of double or multiple citizenship, proven by an official document issued by such country (such as passport), any athlete may participate in IWF Calendar Events and may represent not more than one (1) country within a period of twelve (12) months. In case a country does not issue its own passport or any similar document, for the determination of nationality the IWF accepts the applicable rules of the UN and/or IOC.

2 An athleteresiding in a foreign country may only partici patein competitions organised in that country if he or she has an authorisation from his or her Member Federation. 


\section{NATIONALITY REQUIREMENTS IN OLYMPIC SPORTS}

3 An athlete may represent a new country in international competitions provided that:

(i) the athlete obtains the citizenship of that new country, and

(ii) the athlete gets the approval of the Member Federation he/she is currently representing, the approval of the Member Federation he/she wishes to represent and the approval of the IWF. If the athlete cannot get the approval of the Member Federation he/she is currently representing, then the athlete has to wait for a period of one (1) year (to be counted from the date of the request for approval) before being automatically authorised to represent the new Member Federation. In the case of a second or further change of citizenship, the condition of participation in international events is four (4) years' of new citizenship, including one Olympic Games.

\section{Wrestling}

International $\mathrm{R}$ ules for the $\mathrm{C}$ hange of Nationality approved by the Executive C ommittee on 13

December 2015.

Introduction

In principle any wrestler who participates in official competitions in the United World Wrestling calendar represents the country of which he/sheholds the nationality.

For various reasons - professional, sports, family or political - athleteemigratein other countries and obtain their national ity only after a few years and under strict conditions. This should not prevent wrestlers from carrying on an international sports career on the highest level in their country of adoption.

Accordingly, United World Wrestling admits, under certain conditions laid down in the present rules, that wrestlers obtain the sports national ity of the country of adoption without hol ding the nationality certified by a passport.

The sports national ity is defined as theright granted to a wrestler by United World Wrestling to represent a country of which he/she does not necessarily hold the nationality.

\section{Article 1 - General principles}

In order to participatein a competition in the United World Wrestling calendar, a wrestler must hold the international athlete's license issued by United World Wrestling and valid for the current year.

This license determines the wrestler's sports national ity and thus the country he/she represents in international competitions.

A wrestler has the possibility to change his/her sports nationality once during his/her carer whatever the age and the wrestling style In such case, thenew sports national ity is granted definitively and the wrestler who has changed his/her sports national ity may not return to his/her previous sports nationality.

\section{Article 2 - Scope of application}

The rules laid down in the present rules apply to wrestlers in the cadet, junior, senior and veteran age categories and to all types of competitions under the authority of United World Wrestling (international tournaments, Golden Grand Prix, continental championships and cups, world championships and cups). For Olympic Games and Olympic games qualifying tournaments, the rules of the Olympic Charter apply. For competitions under the authority of major events organizations (Continental Games, Multisport Games or other and qualifying tournaments for these competitions), the rules of the organizer apply.

The present rules apply to all wrestling styles administered under the authority of United World Wresting. The principles described in theserules do not apply to international transfers of wrestlers between clubs for interclub competition for which an authorization is granted temporarily by United World Wrestling or a continental council, without change of sports nationality.

\section{Article 3 - Limitation of the number of sports nationality changes}

In order to prevent any abuse, a country may receive only one foreign wrestler who applies for a change of sports nationality by wrestling style per year in each age category (cadet, junior, senior, veteran).

In cases where a wrestler practices more than one wrestling style, the host federation shall indicate to United World Wrestling under which stylethe change of nationality must be recorded.

The age category under which the change of nationality will be recorded shall bethe wrestler's age category theyear after the application for a change of nationality.

\section{Article 4 - Procedure for the grant of the new sports nationality}

A wrestler who wishes to changehis/her sports nationality shall send a request in writing, through his/her national federation, to United World Wrestling in the period between 1 and 31 December.

No change of sports nationality will begranted by United World Wrestling outsidethis period.

Notwithstanding the conditions listed hereunder, the authorization for the change of sports nationality will be effective from 1 J anuary of the following year.

The applicant's Federation shall provide the foll lowing documents (together with an official translation in French or English):

A)Official attestation by the left federation (signed by its president, on a letter with official header and seal) agreeing with the applicant's change of sports nationality; 
B)Official attestation by the host federation (signed by its president, on a letter with official header and seal) agreeing with the applicant's change of sports nationality;

C)Copy of the wrestler's original passport (corresponding to the sports national ity waived by the wrestler)

D)Copy of wrestler's new passport or his/her country's official residence permit where the applicant lives

and for which he/she applies for the sports nationality;

E)Copy of the country's official work permit where the applicant lives and for which he/she applies for the sports nationality;

F)Proof of payment to United World Wrestling of the feefor the change of sports nationality set to 5.000

Swiss Francs.

G)A parental authorization for minors (under 18 years old)

Wherea licence is granted by United World Wrestling for the first timeto a wrestler on the basis of a

residence and work permit (letter d and e here above), it will be considered as a change of nationality and the present rules and requirements apply except letter a) of the present article.

United World Wrestling's authorization for the change of sports national ity shall be sent to the host

federation with copy to the left federation.

\section{Article 5 - Training compensation}

When an application for a change of sports national ity is submitted by an Olympic Games medal list, a world or continental medal list, the left federation may ask for a training compensation to the host federation

according to the scal e hereunder. It must obligatorily inform United World Wrestling when such a compensation is requested.

This compensation may only be requested for wrestlers in thejunior and senior age category at the time of theapplication.

To determine the compensation, only the results obtained in the age category the year of the application to United World Wrestling will betaken into account.

Whether a training compensation has been requested or not according to paragraph 1 of the present article, $10 \%$ of the compensation amount cal cul ated according the scal e here bel ow will be automatically invoiced by United World Wrestling to the host federation.

A medal obtained in a continental championship has not the same val ue froma continent to another if one consi ders the number of participants in each category. Accordingly, the above scale shall be adjusted in function to the participation ratein a category and taking into account as a referencethe continental championship with the highest number of participants in theyear and category consi dered ${ }^{1}$.

Article 6 - Dual nationality

Any wrestler with dual national ity may obtain theinternational license for only one sports nationality. If he/she wishes to change for the other nationality or for another, the rules and conditions laid down in these rules shall apply in the same way as for any sports nationality change.

\section{Article 7 - Expiry of the contract with the former federation}

Any binding contract between a wrestler and his/her federation of origin is deemed terminated by the signing by its presi dent of the federation's official attestation as provided by article 4, letter a here above In case the federation of origin is opposed for any reason to a wrestler's change of sports nationality, he/she will obtain the new sports nationality only after a period of twenty-four (24) months. Passed this period the authorization of the federation of origin will not be required anymore During this period the wrestler may only take part in international tournaments with the federation of origin.

Article 8 - Disputes

In case of a disputebetween the applicant wrestler and a national federation regarding a change of sports national ity or between two federations regarding a change of sports nationality or the payment of the compensation provided in article 5 here above, United World Wrestling's Secretary General shall settle the dispute

Any proceedings of disputesettlement regarding a change of sports national ity may be accompanied by the suspensive effect against the applicant wrestler.

Article 9 - Information duties between federations before a change of sports nationality A national federation which want to hirea wrestler shall inform in writing his/her current federation of its interest before starting the negotiations with this wrestler.

Any direct or indirect contact with the wrestler, orally or in writing, in violation of the above mentioned obligation will lead to disciplinary consequences.

TheUnited World Wrestling di sciplinary committee shall decide on the necessary sanctions based on these rules, the United World Wrestling Disciplinary Procedureand Dispute Resolution rules as well as the nature of the case considered.

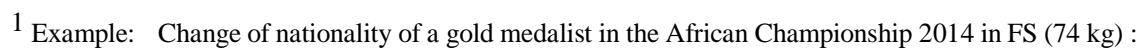
Number of $74 \mathrm{~kg} F S$ wrestlers in the European championship: 40

Number of $74 \mathrm{~kg}$ FS wrestlers in the African championship: 10 Compensation $=100.000 / 4=25.000$ 


\section{NATIONALITY REQUIREMENTS IN OLy MPIC SPORTS}

\section{Article 10 - Appeals}

TheSecretary General's decision (article 8) may be subject to a complaint in accordance with the complaint procedure described in the Disciplinary Procedure and Dispute Resolution Regulations.

Article 11 - Persons entitled to appeal

The national federations and the wrestlers directly concemed by the General Secretary's decision may

appeal. The appeal ed decision may be upheld, quashed or modi fied.

Article 12 - Deadline to appeal

The deadl ine to appeal is 21 days. It starts from the day the appeal ed decisi on has been notified to the parties by United World Wrestling's secretariat.

\section{Article 13 - R evocation and annulment of a change of sports nationality}

Once the authorization for a change of sports national ity is given by United World Wrestling, no revocation for any reason (doping case, illness, injury, change of style or age category, etc.) may begranted by United World Wrestling.

However, an annul ment may be pronounced for cases of deception in the conditions for granting the sports nationality.

\section{Article 14 - 0ther disputes}

All situations not provided in the present rules may be settled definitively by United World Wrestling's ExecutiveCommittee

\section{INTER NATIONAL RULES FOR THE CHANGE OF NATIONALITY J anuary 2015}

International Rules for the Change of Nationality approved by the Bureau on 15J anuary 2015.

\section{Introduction}

In principle any wrestler who participates in official competitions in the United World Wrestling calendar represents the country of which he/she holds the nationality.

For various reasons - professional, sports, family or political - athlete emigrate in other countries and obtain their nationality only after a few years and under strict conditions. This should not prevent wrestlers from carrying on an international sports career on the highest level in their country of adoption.

Accordingly United World Wrestling admits, under certain conditions laid down in the present rules, that wrestlers obtain the sports national ity of the country of adoption without hol ding the nationality certified by a passport.

The sports nationality is defined as the right granted to a wrestler by United World Wrestling to represent a country of which he/she does not necessarily hold the nationality.

Article 1- General principles

In order to participate in a competition in the United World Wresting calendar, a wrestler must hold the international athlete's license issued by United World Wrestling and valid for the current year.

This license determines the wrestler's sports nationality and thus the country he/she represents in international competitions.

A wrestler has the possibility to change his/her sports nationality once during his/her career whatever the age and the wrestling style In such case, the new sports nationality is granted definitively and the wrestler who has changed his/her sports nationality may not return to his/her previous sports nationality.

\section{Article 2 - Scope of application}

The rules laid down in the present rules apply to wrestlers in the cadet, junior, senior and veteran age categories and to all types of competitions under the authority of United World Wrestling (international tournaments, Golden Grand Prix, continental championships and cups, world championships and cups).

For Olympic Games and Olympic games qualifying tournaments, the rules of the Olympic Charter apply.

For competitions under the authority of major events organizations (Continental Games, Multisport Games or other and qualifying tournaments for these competitions), the rules of the organizer apply.

The present rules apply to all wresting styles administered under the authority of United World Wrestling.

The principles described in these rules do not apply to international transfers of wrestlers between clubs for interclub competition for which an authorization is granted temporarily by United World Wrestling or a continental council, without change of sports nationality.

Article 3- Limitation of the number of sports nationality changes

In order to prevent any abuse, a country may receive only one foreign wrestler who applies for a change of sports nationality by wrestling style per year in each age category (cadet, junior, senior, veteran).

In cases where a wrestler practices more than one wrestling style, the host federation shall indicate to United World Wrestling under which stylethe change of nationality must be recorded.

The age category under which the change of national ity will be recorded shall be the wrestler's age category the year after the application for a change of nationality.

\section{Article 4 - Procedure for the grant of the new sports nationality}

A wrestler who wishes to change his/her sports nationality shall send a request in writing to United World Wrestling in the period between 1 and 31 December. 


\section{APPENDICES}

No change of sports nationality will be granted by United World Wrestling outsidethis period.

Notwithstanding the conditions listed hereunder, the authorization for the change of sports nationality will be effective from 1 J anuary of the following year.

The applicant shall provide the following documents (together with an official translation in French or English):

A) Official attestation by the left federation (signed by its president, on a letter with official header and seal) agreeing with the applicant's change of sports nationality;

B) Official attestation by the host federation (signed by its president, on a letter with official header and seal) agreeing with the applicant's change of sports nationality;

C) Copy of the country's official residence permit where the applicant lives and for which he/she applies for the sports nationality;

D) Copy of the country's official work permit where the applicant lives and for which he/she applies for the sports nationality;

E) Proof of payment to United World Wrestling of the fe for the change of sports nationality set to 5.000 Swiss Francs.

F) A parental authorization for minors (under 18 years old)

Where a licence is granted by United World Wresting for the first time to a wrestler on the basis of a residence and work permit (letter $c$ and d here above), it will be considered as a change of national ity and the present rules and requirements apply except letter a) of the present article

United World Wrestling's authorization for the change of sports nationality shall be sent to the host federation with copy to the left federation.

Article5- Training compensation

When an application for a change of sports national ity is submitted by an Olympic Games medal list, a world or continental medallist, the left federation may ask for a training compensation to the host federation according to the scale hereunder. It must obligatorily inform United World Wrestling when such a compensation is requested.

This compensation may only be requested for wrestlers in the junior and senior age category at the time of the application.

To determine the compensation, only the results obtained in the age category the year of the application to United World Wrestling will betaken into account.

$10 \%$ of this amount will be automatically paid to United World Wrestling within 30 days from the date of the authorization for the change of nationality.

Scale:

- Olympic \& World gold medallist Swiss Francs 300'000.-

- Olympic \& World silver or bronze medall list Swiss Francs 200'000.-

- Continental championship gold medall list Swiss Francs 100'000.-

- Continental championship silver or bronze medal list Swiss Francs50'000.-

A medal obtained in a continental championship has not the same value from a continent to another if one consider the number of participants in each category. Accordingly the above scale shall be adjusted in function to the participation rate in a category and taking into account as a reference the continental championship with the highest number of participants in theyear and category consideredl.

Article6- Dual nationality

Any wrestler with dual national ity may obtain theinternational license for only one sports nationality.

If he/she wishes to change for the other national ity or for another, the rules and conditions laid down in these rules shall apply in the same way as for any sports national ity change

Article 7- Expiry of the contract with the former federation

Any binding contract between a wrestler and his/her federation of origin is deemed terminated by thesigning by its presi dent of the federation's official attestation as provided by article4, letter a hereabove

In case the federation of origin is opposed for any reason to a wrestler's change of sports nationality, he/she will obtain the new sports nationality only after a period of twenty-four (24) months. Passed this period the authorization of the federation of origin will not be required anymore. During this period the wrestler may only take part in international tournaments with the federation of origin.

Article8-Disputes

In case of a dispute between the applicant wrestler and a national federation regarding a change of sports nationality or between two federations regarding a change of sports nationality or the payment of the compensation provided in article 5 here above, United World Wrestling's Secretary General shall settle the dispute

Any proceedings of dispute settlement regarding a change of sports nationality may be accompanied by the suspensive effect against the applicant wrestler.

Article 9- Information duties between federations before a change of sports nationality 


\section{NATIONALITY REQUiREMENTS In Oly mpic SPORTS}

A national federation which want to hire a wrestler shall inform in writing his/her current federation of its interest before starting the negotiations with this wrestler.

Any direct or indirect contact with the wrestler, orally or in writing, in violation of the above mentioned obligation will lead to disciplinary consequences.

The United World Wrestling disciplinary committee shall decide on the necessary sanctions based on these rules, the United World Wrestling Disciplinary Procedure and Dispute Resolution rules as well as the nature of the case considered.

1 Example: Change of nationality of a gold medalist in the African Championship 2014 in FS (74 kg) : Number of $74 \mathrm{~kg}$ FS wrestlers in the European championship: 40

Number of 74 kg FS wrestlers in the African championship: 10 Compensation $=100.000 / 4=25.000$

Article 10 - Appeals

The Secretary General's decision (article 8) may be subject to a complaint in accordance with the complaint procedure described in the Disciplinary Procedure and Dispute Resolution Regulations.

Artide 11 - Persons entitled to appeal

The national federations and the wrestlers directly concerned by the General Secretary's decision may appeal. The appeal ed decision may be upheld, quashed or modified.

Article 12 - Deadlineto appeal

The deadl ine to appeal is 21 days. It starts from the day the appeal ed decision has been notified to the parties by United World Wrestling's secretariat.

Article 13-Revocation and annulment of a change of sports nationality

Once the authorization for a change of sports nationality is given by United World Wrestling, no revocation for any reason (doping case, illness, injury, change of style or age category, etc.) may be granted by United World Wrestling.

However an annulment may be pronounced for cases of deception in the conditions for granting the sports nationality.

Article 14- Other disputes

All situations not provided in the present rules may be settled definitively by United World Wrestling's Executive Committee.

\section{INTER NATIONAL REGULATIONS FOR THE CHANGE OF NATIONALITY 2012}

\section{Effective3rd August 2012}

General conditions

Pursuant to article 34 of theFILA Constitution:

a. No one taking part in a competition can represent a country, be included in its National team if he/she does not have the nationality of the country concerned.

b. In case of dual nationality, the participation in international competitions is only possible under one nationality, which will bechosen by the wrestler(s) concerned and retai ned definitely.

c. The National Federation is competent for the participation of a foreign wrestler residing in the country in the national championship of this country.

d. In case of a change of nationality, for all wrestlers holding a FILA licence, whether cadets, juniors or seniors, thefollowing provisions are applicable:

A wrestler who has obtained a new nationality by naturalization may participate, for his/her new country, in all competitions entered in the FILA calendar (tournaments, championships, cups, games, etc.) only after having obtained his/her new nationality which shall be proved by a new passport and upon agreement by FILA within the period between 1 and 31 December. He/she shall be only eligible to participate in the above mentioned competition the year following the request for the change of nationality. For Olympic Games qualifying tournaments and for the Olympic Games, the provisions of the Olympic Charter are applied. A change of nationality is accepted only once by FILA and the wrestler cannot return to his/her previous nationality.

e Compul sory procedure for the change of nationality: Refer to Appendix.

Article 1

A wrestler who changes his/her nationality cannot be admitted by the National Federation of his/her new country

a. If the contract binding him/her to his/her previous Federation is not falling due and expiring within the next six months; or

b. If the contract binding him/her to the Federation that has been left has been terminated by one or the other party for a right ground; or

c. If the contract binding him/her to the Federation that has been left has been terminated by both parties by mutual agreement.

The transfer of a wrestler who changed nationality is only possible from 1st December to $31^{\text {st }}$ December of each year provided the procedure described in the appendix has been fully complied with. 


\section{APPENDICES}

\section{Article 2}

A National Federation wanting to hire a wrestler must inform in writing his/her Federation of its interest beforestarting the negotiations with this wrestler. Any direct or indirect contact with the wrestler, orally or in writing, in violation of the above mentioned obligation will lead to disciplinary consequences. The FILA Executive Committee decides on the necessary sanctions based on the FILA Disciplinary Regulations.

\section{Article 3}

When a wrestler concludes a contract with his/her new Federation after having changed his/her nationality, his/her former Federation is entitled to an education or promotion all owance as fixed in the appendix of the present regulations. For every change of nationality, FILA will receive CHF 5'000.- administrative charges from the new Federation of the concerned wrestler.

\section{[... ]}

Article 5

If, within a period of 30 days at the latest, both National Federations did not manage to agree on the payment of the education or promotion allowance, the dispute must be submitted to FILA which will decide The decision is not subject to an appeal. In case of a disagreement, the wrestler who has changed his/her nationality shall wrestle for his/her new country only after the dispute regarding the payment of allowance has been settled.

Article 6

When two National Federations disagreeing with the allowance have addressed the FILA, the dispute is transmitted to a special commission.

[...]

\section{Article 8 Appeal proceedings to the Executive Committee}

The decisions made by the special Commission may be appeal ed before the Executive Committee In order to ensure that the appeals are treated quickly, the competence of the final decision is delegated to an ad hoc Commission formed of the Executive Committee members appointed by the FILA President other than the members of the special Commission.

\section{Article 10}

The National Federations and the wrestlers directly concerned by the decision contested can lodge an appeal. The contested decisions can be confirmed, nullified or modified. The modification of a decision even if it is detrimental to the party lodging an appeal is possi ble

\section{Article 11}

The deadline to lodge an appeal to the Executive Committee is 20 days. The deadl ine starts from the day the disputed decision is notified to the parties by the FILA Secretariat. FILA will only takeinto consideration the appeals received through a National Federation. The appeal file must be validly signed by the party(ies) lodging an appeal against the decision. An appeal fee of CHF 2'000.- must be paid to the FILA Secretariat, within 20 days. In casethe appeal is accepted the appeal feeis reimbursed. If the appeal is rejected, this feeis kept by FILA. In the event of an obviously abusive appeal, the appeal authority can, in addition, conderm the party at fault to a fine of order. The appeal authority can take any decision it deems useful concerning the obligation to bear the expenses caused by the appeal audition.

\section{Article 12 Special provisions}

The validity of the transfer contract for a change of nationality cannot be subordinate to the positive result of a medical control or to the obtaining of a work authorization. In consequence the concerned National Federation must, at the risk of being condemned, pay the whole allowances for education and promotion fixed in the present regulations and carry out any desired studies or other necessary steps before the contract is conduded.

\section{Article 13}

All cases not considered in the present regulations shall be settled, without possibility of appeal, by the Executive Committee

\section{Article 14}

The present Regulations have been adopted by the FILA Congress and are effective 3rd August 2012.

\section{APPE NDIX - Compulsory procedure for the change of nationality}

A wrestler who wishes to change his/her nationality to wrestle in another country shall request permission in written to FILA. His/her request shall contain the following documents:

1. A certificate from his/her former Federation granting the departure of the wrestler

2. A certificate from his/her new Federation

3. A copy of the contract with his/her new Federation

4. A copy of his/her new and former passport

5. The payment to FILA of a CHF 5.000.- fee for the change of nationality.

6. For J unior and Senior (but not for Cadet), the payment to the former Federation of the following training compensations, $10 \%$ them being paid to FILA :

- Olympic Gold Medallist or World Champion CHF 300'000.- 


\section{NATIONALITY REQUIREMENTS IN OLYMPIC SPORTS}

- Olympic or World Silver \& Bronze Medallist CHF 200'000.-

- Continental Gold Medallist CHF 100'000.-

- Continental Silver or Bronze Medallist and others CHF 50' 000.-

In compliance with the regulations in force it is understood that the wrestler who changes his/her nationality shall not compete for his/her new country only after the settlement of all regulatory requirements.

A country may induct a foreign wrestler requesting his/her new nationality at the rate of one (1) wrestler per style and per year. The request file for the change of nationality shall betransmitted to FILA between 1 and 31 December of each year. No change of nationality will be granted outside this period. A wrestler who has not received FILA's agreement for the change of national ity may not compete for his/her new country even if he/she has obtained the new nationality. Any incomplete file will not betaken into consideration.

\section{FILA International Regulations For The C hange Of Nationality 2011}

\section{General conditions}

Pursuant to article 34 of theFILA Constitution:

A) No one taking part in a competition can represent a country, be included in its National team if he/she does not have the nationality of the country concerned.

B) In case of dual nationality, the participation in international competitions is only possible under one national ity, which will bechosen by the wrestler(s) concerned and retained definitely.

C) The National Federation is competent for the participation of a foreign wrestler residing in the country in thenational championship of this country.

D) In case of a change of nationality, for all wrestlers holding a FILA licence, whether cadets, juniors or seniors, the following provisions are applicable:

A wrestler who has obtained a new nationality by naturalization may participate, for his/her new country, in Olympic Qualification Tournaments or Olympic Games, World Championships and World Cups, University Championships and Games, Military Championships and Games, Continental Championships and Games only after having obtained his/her new nationality which shall be proved by a new passport and after a two years period of non-participation in the aforementioned competition under the former nationality.

During this two years period the wrestler may participate in international toumaments for his new nationality provided that he/she possesses the new passport, but not in competitions mentioned in the preceding chapter.

A change of nationality is accepted only once by FILA and the wrestler cannot return to his/her previous nationality.

E) Compul sory procedurefor the change of nationality: Refer to Appendix I

\section{Article 1}

A wrestler who changes his/her nationality cannot be admitted by the National Federation of his/her new country

A) If the contract binding him/her to his/her previous Federation is not falling due and expiring within the next six months; or

B) If the contract binding him/her to the Federation that has been left has been terminated by one or the other party for a right ground; or

C) If the contract binding him/her to the Federation that has been left has been terminated by both parties by mutual agreement.

However, in any of the eventualities described here above, a wrestler can sign a contract with another Federation only if the National Federation regulations allow it.

The transfer of a wrestler who changed nationality is only possible from 1st December to 31st December of each year, providing the transferred wrestler complies with a two-year period of non- participation, starting from the date of his/her last international Championship for the national team of the country he/she left and as the date he/she obtained his/her new nationality.

Article 2

A National Federation wanting to hire a wrestler must inform in writing his/her Federation of its interest before starting the negotiations with this wrestler. Any direct or indirect contact with the wrestler, orally or in writing, in violation of the above mentioned obligation will lead to disciplinary consequences. The FILA Executive Committee decides on the necessary sanctions based on the FILA Disciplinary Regulations.

\section{Article 3}

When a wrestler concludes a contract with his/her new Federation after having changed his/her nationality, his/her former Federation is entitled to an education or promotion all owance

For every change of nationality, FILA will receive CHF 5'000.- administrative charges from the new Federation of the concerned wrestler.

Article 4

The amount of allowances mentioned in article 3 must be agreed between both Federations. Agreements between wrestlers or other parties with dubs regarding these allowances are prohibited. The agreement between both clubs must be communicated to the concerned Federations and particularly the former 


\section{APPENDICES}

Federation which is entitled to an education or promotion all lowance

\section{Article 5}

If, within a period of 30 days at the latest, both National Federations did not manage to agree on the amount of the education or promotion allowance, the dispute must be submitted to FILA which will decide The decision is not subject to an appeal .

In case of a disagreament, the wrestler who has changed his/her nationality shall wrestle for his/her new country only after the dispute regarding the all owance has been seltled, even if the two years wait provided by the regulations is spent.

\section{Article 6}

When two National Federations di sagreeing with the amount of the all owance have addressed the FILA, the disputeis transmitted to a special commission.

[...]

\section{Article 16}

The present Regulations were approved by the FILA Executive Committee and come into force in March 2009.

\section{APPE NDIX I - C ompulsory procedure to follow for the change of nationality:}

A wrestler who wishes to change his/her nationality to wrestle in another country shall request permission in written to FILA.

His/her request shall contain the following documents:

1) A certificatefrom his/her former Federation granting the departure of the wrestler

2) A certificatefrom his/her new Federation

3) A copy of the contract with his/her new Federation

4) A copy of his/her new and former passport

5) The payment to FILA of the CHF 5'000.- feefor the change of nationality.

In compliance with the regulations in force it is understood that the wrestler who changes his/her nationality shall not compete for his/her new country before the completion of a two years period starting from the date of his/her last participation to an Olympic Qualification Tournament or to the Olympic Games, World Championships, World Cups, University Championships and Games, Military Championship and Games, Continental Championships and Games.

During this period the wrestler is authorized to compete in international tournaments with his/her new country on the condition he/she has received the new passport, but not in competitions mentioned in the preceding chapter.

A country may induct a foreign wrestler requesting his/her new nationality at the rate of one (1) wrestler per style and per year.

The request file for the change of nationality shall be transmitted to FILA between 1 and 31 December of each year. No change of nationality will begranted outsidethis period.

A wrestler who has not received FILA's agreement for the change of national ity may not compete for his/her new country even if he/shehas obtained the new nationality.

Any incomplete filewill not betaken into consideration. 



\section{Summary}

This dissertation sets out to explore the terra incognita of nationality requirements in Olympic sports. Themain aim was to answer thethree research questions:

1) What arethe eligi bility criteria currently employed by theOlympic Sports?

2) To what extent is it problematic to align these currently applicable eligibility criteria with international standards of nationality law?

3) How can tensions that may exist between the criteria applied by the sporting federations and theinternational standards of national ity law be solved?

In order to achieve this, the dissertation relied on the means of legal comparison with the standards of intemational nationality law acting as the tertium valutationis. The terti umcomparationis was established by creating a standard set of citeria, which was in force on one specific date For this date the $15^{\text {th }}$ October 2013, the start of the research was chosen.

Throughout this dissertation, the exact terminology used by the different federations is important, as inconsistencies in the terms used in an eligibility code create confusion. The term used in this dissertation to describe the link between a person and a state will be 'nationality' as opposed to 'citizenship'. This choice was made as the focus for eligibility criteria is purely the link between a person and the state he or she represents and without the added notion of (civil) rights as implied by 'citizenship'.

\subsection{Nationality L aw and Sports L aw (Chapters $3 \& 4$ )}

Prior to turning to the eligibility criteria themselves, it was necessary to institute the tertium valutationis, meaning the relevant essence of nationality law. With the focal point being the relationship between a person and a state, the concept of a 'genuine link', which was first brought up in the 1955 Nottebohm case, was essential. Such a link is usually established at birth when nationality or citizenship is transferred upon children. Here factors like the place of birth (ius soli) or blood relations (ius sanguinis) determine which nationality or citizenship a child acquires. The situation of found ings is more problematic, though it is generally agreed that they, as well as children who would otherwise be stateless, should acquire the national ity of the country where they were bom or respectively found in.

Establishing a genuine link and thus acquiring a (new) nationality at a point after birth through a process called naturalisation is usual ly significantly more difficult For this an individual needs to have created a significant link with a country which is not the country of origin, eg. through permanent residence This process mainly aims at induding those into the political community that have spent a significant part of their lives there, such as children who migrated to the country at an early age and spend 
their formative years there or second generation migrants in a ius sanguinis country and to whom option rights or facilitated naturalisation procedures are avail able Improved travel possibilities and cross-border marriages haveled to people devel oping ties to more than one country: some people acquire a second nationality through naturalisation, and children bom to nationals from different ius sanguinis countries may acquire two nationalities at birth. While multiple nationality has become more accepted in recent years, there are still reasons why it can be seen as problematic, with issues such as double taxation, military obligations and general divided loyal ty being cited.

The genuine link and thus a person's national ity may be subject to changes due to extemal circumstances, eg. when the state's teritory changes through either state succession, cession or decol onization. In such a situation, the states invol ved will often draft treaties with rules tail ored to the circumstances.

Furthermore, while the genuine link between a person and a state is usually deemed to be permanent or at least stable and long lasting, actions by either thestateor theperson may sever the bond. However, it is important to stress that no person should be arbitrarily deprived of his or her nationality, especially if this might result in statelessness.

Having seen the underlying prindiples of nationality law, it was necessary to distil the touchstone principles of nationality law (see Chapter 3.8) that were to be used when analysing and eval uating the sport's eligi bility criteria. These principles are

- No violation of fundamental human rights, in particul ar theright to nationality;

- Statelessnessis to beavoided;

- Right to change one's nationality

- Renunciation of nationality should beal lowed, if it does not causestatelessness

- Attribution of nationality has to be based on a genuine link between person and state,

- Birth right citizenship can be based on ius sanguinis or ius soli or a combination thereof;

- Family unity should be upheld;

- Gender equality shoul d berespected;

- No arbitrary deprivation of nationality;

- No discrimination.

Additionally, the position of children and minors is of paramount importance as they arein an especial ly vulnerable position and need additional protection.

\subsection{What are the eligibility criteria currently employed by the Olympic Sports? (C hapter 5 - 15)}

To answer the first research question the eligibility codes of all Olympic sports were examined in the following chapters. The focus was on the possibility to change the country of representation under different circumstances, as well as on the position of 
minors and stateless athletes. In addition, close attention was paid to the wording of the respective statutes and digibility laws, eg. whether 'nationality' and 'citizenshi p' are used, which meaning is attributed to the terms, and whether an actual distinction between these is made For better comparability, this was not done al phabetically, but according to the sporting category, namely:

- Chapter 5: Classic Sports IAAF (Athletics), IBU (Biathlon), UIPM (Modern Pentathl on), ITU (Triathl on), IWF (Weightlifting).

- Chapter 6: Sports focussing on body control: FINA (Aquatics), FIG (Gymastics).

- Chapter 7: Martial Arts without bodily contact between contestants: WA (Archery), FIE (Fencing), ISSF (Shooting).

- Chapter 8 Martial Arts with direct bodily contact between contestants: AIBA (Boxing), IJ F (Judo), WTF (Taekwondo), UWW (Wrestling).

- Chapter: 9 Team sports involving a ball: FIBA (Basketball), FIFA (Football), IHF (Handball), FIH (Hockey), IIHF (Ice Hockey), World Rugby (Rugby), FIVB (Volleyball).

- Chapter 10: Ball sports with radkets: BWF (Badminton), ITTF (Table Tennis), ITF (Tennis).

- Chapter 11: Aiming with an object for a goal: WCF (Curling), IGF (Golf).

- Chapter 12: Movement over ground: UCI (Cycling), FEI (Equestrian).

- Chapter 13: Movement over water: ICF (Canœe Kayak), FISA (Rowing), ISAF (Sailing).

- Chapter 14: Movement over ice and snow: IBSF (Bobsleigh), FIL (Luge), ISU (Skating), FIS (Skiing).

It became dear that the 35 Olympic sports present a very diverse picture regarding their eligibility criteria. Generally, there are three different approaches taken by the sports. Some have extremely detailed rules, others only briefly mentioned problematic points and even others remai ned rather unspecific in their rules.

In Chapter 15 the rules previously examined were brought together for the comparison. Here the tertium comparationis was difficult to establish, for different reasons. Firstly, rules applicable prior to 2013 were not al ways forthcoming from the federations. Secondly, not all topics, which are of interest for the purpose of this dissertation, were treated in equal detail amongst the federations' current eligibility codes. Thirdly, not all sports experienced a substantial change in their eligibility criteria within the examined period.

Consequenty, thereis a certain bias in theresults not onl y because several aspects were dealt with by less than a third of the sports, but al so as devel opments could only be monitored in a limited number of cases. However, the most striking observation is that while the sports differ hugel y regarding the details, most sports have rules in force that require athletes to have a genuine link with the country they represent, either through residence or by being a national of the country.

While few trends could be determined, eg. with regard to stateless athletes and competing for the country of residence, this is bound to change as for the upcoming 
Olympics, when the IOC will for the first time allow refugee athletes to compete Similarly, since 2013, trends regarding teritorial transfers have been limited to the introduction of a rule dealing with the aftermath of state succession by golf in 2014 and modem pentathlon in 2015. Likewise, the important topic of minor athletes also has not been brought up by many sports and while on the one hand since 2008 FIFA does no longer focus on an athlete's $21^{\text {st }}$ birthday, on the other hand ice hockey now places importance on the $10^{\text {th }}$ birthday and the country in which an athlete has lived in since

There was, however, a discernible trend towards allowing changes of country of representation, even after an athlete competed internationally. In 2012 athletics introduced such a rule for athletes who wish to change their country of representation and since 2013 their approach is even more detailed. Similarly, boxing has added the possibility to change the country of representation in 2015, as did golf in 2014. Furthermore, athl etes with mul tiple nationality have become more important and most federations have chosen to treat them like those having changed their nationality and face the same waiting periods, eg. four years for golf since 2014 or two years for boxing since 2015 .

The opposite held true regarding the federations' take on modes of acquisition of nationality, which do not feature prominenty in most eligibility codes. Similarly, while residence periods are still used by many federations, recently three federations changed this aspect of their eligi bility criteria, eg. in 2007 equestrian first introduced a residence requirement, but is allowing exceptions to the rule since 2010. Noncompetition periods have become more important and new ones were recently introduced, eg. two years for boxing in 2015 or rowing since 2013 . However, on the other side of the spectrum wrestling only imposes a two year period since 2012 if the federations do not agree, and since 2013 athletics offers the possibility to reduce the three year non-competition period by proving three continuous years of residence in therelevant country. $Y$ et, the overall trend goes towards limiting changes of country of representation by means of non-competition periods.

\subsection{To what extent are these currently applicable eligibility criteria in accordance with the international standards of nationality law? (C hapter 16)}

Having compared the different eligibility codes, the focus tumed to the compatibility of the eligibility codes with the touchstone principles of nationality. It was most important that the definitions the sporting federations gave for a genuine link should not be at odds with the principles of international nationality law. In order to better examine other potential clashes between the two systems, the previously established principles were used to formulate several desiderata, i.e desirable aspects of eligi bility criteria:

a) Sporting federations should recognise the athlete's nationality and should have provisions for stateless athletes and refugees that allow them to continue to competeinternationally; 
b) Changes of country of representation have to be all owed and should not be limited by a maximum number of changes;

c) The genuine link between athleteand country should be recognised by the sporting federations if established via i) ius soli, ius sanguinis or a combination thereof; ii) option rights; iii) facilitated natural isation after marriage or iv) naturalisation;

d) Gender equality should berespected;

e) Sporting federations should provide rules for those who lost their nationality and al low them to continuetheir career;

f) There should beno discriminatory rules;

g) Rules concerning minor athletes shoul d offer additional protection.

Upon comparing the current status quo with the desiderata, several problems became clear.

- Firstly, the terminology used and the definitions of the various terms are inconsistent and contradictory;

- Secondly, the issue of stateless athletes and asylum seckers is being inadequately addressed by most federations, better rules are needed that provide fast solutions and allow athletes to continuether carer;

- Thirdly, al lowing only a set number of changes of the country of representation, or noneat all, is contrary to theright of changing one's nationality;

- Fourthly, additional requirements may have discriminatory elements, such as focussing on the biological parents and thus placing adopted children and foundlings at a di sadvantage

- Fifthly, waiving or reducing residence and waiting periods leads to similar cases not being treated equally. Consequently, there is no legal certainty and, what is even more problematic, discriminatory practices cannot be counter-acted;

- Finally, minors who do not have the legal capacity to make binding decisions are expected to make binding decisions concerning their nationality and country of representation.

22.4. How can tensions that may exist between the criteria applied by the sporting federations and the international standards of nationality law be solved? (C hapters $17 \&$ 18)

After establishing, that the current eligi bility criteria clash with the principles of international national ity law, the question arose how these problems might be solved.

\subsubsection{Option one: a free market approach}

The first suggestion was to further reduce the federations' artides on eligibility and adopt a freemarket approach. Without the often contradictory and sometimes even discriminatory rules, supply and demand would be the determining factors in international sports. The countries wanting the best athletes would need to invest in the best facilities and other benefits to the athletes. Sport development would see new investments and the sport as a whole could benefit In tum, athletes could fredy 
choose for which country they want to compete Due to fast-track naturalisation procedures they might quickly acquire the nationality of a country and changes between countries could be immediately effective. For practical reasons dhanges within a tournament would not be allowed, but for the rest athlete transfers between countries could be handl ed akin to the ones between the top sporting dubs.

Herein lies one of the main problems of this approach, as fast-track naturalisation schemes have recently fuel led heated debates on citizenship as a whole Examples of this were the investor citizenship programmes currently operating in some European Union member states such as Malta, Cyprus and Portugal. As almost no residence requirements are in place for rich investors, who are thus able to buy a European passport from one of these countries and consequently gain free access to the Schengen area, an EU-wide discussion on these practices has arisen. Furthermore, while the genuine link between athlete and country should be recognised by the sporting federations if established by naturalisation, these fast-track options are often circumventing the standard national ity law. Altematively also the principle of taking nationality as a basis for selecting national teams might be reconsidered. However, in that case the whol e matter of representativenational teams becomes a moot point.

Another problem might arise as creating a market akin to the market for athletes for national leagues could lead to an alignment between the national leagues and the national teams, as richer dubs are situated in the countries in which more money is allocated to sporting issues. Such an alignment would render the distinction between international dub and intermational compeitions obsolete Totally abol ishing the rules is therefore not an option.

\subsubsection{Option two: a separate sporting nationality}

The second suggestion was to follow the lead of some authors who proposed the introduction of a separate sporting nationality. As they did not go into detail of how this was to be achieved, some problems arose in this context Firstly, the precise definition of 'sporting national ity' was und ear and secondly, to what extent a sporting nationality should be dependent on an athlete's state nationality was debatable. As authors suggested a concept in which the sporting nationality would be entirely disconnected from the athlete's nationality, this led to the question how such a notion of national belonging can be established without referring to nationality itself or without relying on the same criteria on which the attribution of nationality usually relies. Examining all possibilities to establish a genuine link between athlete and country of representation and seeing that this proposal would only shift the focus of the problem one has to conclude that introducing a separate sporting nationality does not have major benefits. Moreover, the term sporting nationality should al so not be chosen because any workable definition of this concept is at odds with the generally accepted use of theterm 'nationality'.

Having examined nationality law not only in general, but also more specifically the concept of sporting nationality, one finds that while greater simplicity for athlete 
eligibility in international competitions is certainly desirable, the introduction of a sporting national ity is not.

\subsubsection{Option three: A sporting licence in accordance with international standards of nationality law}

The solution favoured in this dissertation is to introduce a separate sporting licence issued by the national federations, as presented in a 'Draft artide' (see Chapter 17.4.2).This sporting licence would notably not be a sporting nationality as advocated by some scholars. The criteria for granting a sporting licence need to be very detailed and have to guarantee that there is indeed a genuine link between athletes and the country of representation in order to prevent fast track naturalisations prior to major sporting events. The underlying principles determining these criteria have to be in line with the general standards of intemational nationality law, and such a sporting licence cannot be given to athletes who do not have a genuine link with the state In general, one can presume that an athlete who holds the nationality of a state does have such a link. If, however, as in the case of dual nationals, additional requirements are introduced to ensure or select the link created by the nationality, these requirements have to be selected very carefully. Caution is needed because countries set down different rules regarding the acquisition and loss of nationality. Consequently, there is al ready an inherent imbalance between states based on their domestic national ity rules. If states with more restrictive domestic laws aim to counterbalance this through providing option rights or facilitated naturalisation procedures, there should not be additional requirements reimposing theimbal ance

The problems encountered by stateless and refugee athletes need to be explicitly addressed and a solution like the one currently favoured by the IOC for the Rio 2016 Games needs to be provided. Furthermore, the position of minors needs special attention and they should be able to decide fredy for which country they wish to compete before they reach the age of majority. After their eighteenth birthday they need to have a chance to re ded de within the next three years without fading a noncompetition period.

For this sporting license, the rules need to refer explicitly to all modes of acquisition of nationality, ensuring that option rights and facilitated naturalisation procedures are recognised and treated akin to acquisition of nationality at birth. In addition, changes of nationality are to be allowed without any limits and the proposed waiting period of two years is not too strict Moreover, as the waiting period cannot be wai ved, legal certainty is ensured. Since terms and terminol ogy have been a largeissue with current codes, the definitions and explanations should be spelled out before the artideto clarify all issues. 



\section{Samenvatting}

Het doel van dit proefschrift was het ontdekken van de terra incognita van de nationaliteitsregels in deolympischesporten. De vraagstelling was:

1) Welke nationaliteitsregeds bestaan er op dit moment binnen de olympische sporten?

2) In hoeverre zijn deze regels problematisch en mogelijk in het licht van de international estandaarden van nationaliteitsrecht?

3) Hoekan men de spanning tussen dezeregels en de beginselen van de internationale standaarden van nationaliteitsrecht opl ossen?

Hievvoor heeft dit proefschrift gebruik gemaakt van rechtsvergelijking met de beginselen van intemationaal nationaliteitsrecht als tertium valutationis. Het tertium comparationis werd gecreëerd door het vastleggen van en standaard nationaliteitsregel die op en bepaal de datum gel dig was. Deze datum was 15 oktober 2013, de dag waarop dit onderzoek begon.

Voor dit proefschrift zijn de precieze woorden en definities die door de sportorganisaties gebruikt worden van belang geweest, omdat verschillen hierin tot verwaring kunnen leiden. In dit proefschrift zelf zal van het begrip 'nationality' gebruik worden gemaakt en niet van 'citizenship', omdat het tweede begrip meer in verband met de rechten van een burger wordt gebruikt

\subsection{Nationaliteitsrecht en sportrecht (H oofdstukken $3 \& 4$ )}

Voor het onderzoek naar de nationaliteitsregels van de olympische sporten was het belangrijk om het tertium valutationis, namelijk de beginselen van internationaal national iteitsrecht, vast te stellen. Een national iteitsrechtelijke band tussen een persoon en een land bestaat als er en ' genuine link' band vastgesteld kan worden. Dit concept is bij de Nottebohm bestissing van 1955 gëntroduceerd. Meestal ontstaat deze band tussen en persoon en een land bij de geboorte van en kind. Factoren zoals de plek waar een kind wordt geboren (ius soli) of de bloedrelaties (ius sanguinis) bepalen welkenational iteit een kind heeft. Vondelingen of kinderen di e anders staat oos zullen zijn verkrijgen in beginsed denationaliteit van het land waarin ze gevonden of geboren worden.

Het crëren van een genuine link later in het leven en dus het verkrijgen van een nieume nationaliteit is moeilijker. Hievoor moet een genuinelink met een nieuw land ontstaan, bijvoorbeeld door het hebben van een vaste woonplaats in het land. Landen gebruiken naturalisatie om mensen die al lang in het land leven, meer in de gemeenschap telaten integreren en hen meer inspraak, bijvoorbeeld ook in de politiek, te geven. Voorbeelden hiervan zijn ten eerste mensen die als kinderen in het land kwamen en er dus hun vormende jaren hebben doorgebradht, of ten tweede kinderen van tweede generaties al lochtonen in een ius sanguinis land, voor wie optierechten of versnel de naturalisatie procedures mogelijk zijn. 
Verbeterdereismogelijkheden en grensoverschrijdendehuwelijken hebben etoege leid dat mensen banden met meer dan één land ontwikkelen. Sommige mensen verkrijgen een tweede nationaliteit door middl van naturalisatie en kinderen van ouders uit verschillende ius sanguinis landen kunnen twee nationaliteiten bij de geboorte verkrijgen. Terwijl in de afgel open jaren meervoudige national iteit meer geaccepteerd is geworden, wordt het voor redenen zoals dubbel e bel astingheffing, dubbele militaire verplichtingen en al gemene conflicterendel oyal iteiten soms als problematisch gezien.

De genuine link en dus denational iteit van een persoon kan als gevolg van exteme omstandi gheden veranderen, bijvoorbeeld als het grondgebied van de staat verandert, zowel via staatsopvolging, cessie of dekolonisatie In deze situaties maken de betrokken landen vaak gebruik van onderling verdragen om de vraag van nationaliteit op telossen.

Terwijl de genuine link tussen een persoon en een staat meestal wordt geacht permanent of op zijn minst stabie en langdurig te zijn, is het voor de staat en de persoon zelf mogelijk deze verbinding te doorbreken. Het is edhter belangrijk te benadrukken dat niemand willekeurig zijn of haar nationaliteit mag verliezen, vooral al s het verlieszal leiden tot staat oosheid.

$\mathrm{Na}$ het vaststel len van de beginselen van internationaal nationaliteitsrecht was het nodig de grondbeginselen vast te leggen (Hoofdstuk 3.8) met wel ke de nationaliteitsregels van de verschillende sporten vergeleken zullen worden. Deze grondbeginselen zijn:

- Geen schending van de fundamentele rechten van de mens, in het bijzonder het recht op en national iteit;

- Staatl oosheid moet worden vermeden;

- Iedereen heeft het recht om van national iteit te veranderen;

- Afstand doen van de nationaliteit moet worden toegestaan, zolang het niet tot staatloosheid leidt;

- Nationaliteit wordt verkregen op basis van en genuine link tussen persoon en staat;

- Verkrijging van nationaliteit bij geboorte kan worden gebaseerd op ius sanguinis of ius soli of en combinatie daarvan;

- De enheid van het gezin moet worden ondersteund;

- Gendergelijkheid moet worden gerespecteerd;

- Geen willekeurig verlies van denationaliteit;

- Geen discriminatie

Daarnaast is de positie van kinderen en mindejarigen van groot belang, aangezien zij zich in €en bijzonder kwetsbare positie bevinden en extra bescherming nodig hebben.

\subsection{Welke nationaliteitsregels bestaan er op dit moment binnen de olympische sporten? (H oofdstukken 5 - 15)}

Voor de errste onderzokssuraag worden alle nationaliteitsregels van de olympische sporten in de vol gendehoofdstukken onderzocht Defocus lag op de mogelijkheid om 
tussen landen van representatie te wisselen, alsmede op de positie van minderjarigen en staatloze atleten. Daamaast werd aandacht besteed aan de formulering van de respectieve regelboeken, bijvoorbedld of de termen 'nationality' of 'citizenship' worden gebruikt, welke betekenis deze termen wordt toegeschreven en of er een werkelijk onderscheid tussen deze begrippen wordt gemaakt Voor een betere vergelijkbaarheid werd dit niet al fabetisch gedaan, maar per sportcategorie

- Hoofdstuk 5: Klassieke Sporten: IAAF (Atletiek), IBU (Biatlon), UIPM (Moderne vijfkamp), ITU (Triatlon), IWF (Gewichtheffen).

- Hoofdstuk 6: Sporten gericht op lichaamscontrole: FINA (Zwemsport), FIG (Gymastiek).

- Hoofdstuk 7: Gevechtssporten zonder direct lichamelijk contact tussen atleten: WA (Boogschieten), FIE (Schermen), ISSF (Schiesport).

- Hoofdstuk 8 Gevechtssporten met direct lichamelijk contact tussen atteten: AIBA (Boksen), IJF (J udo), WTF (Taekwondo), UWW (Worstelen).

- Hoofdstuk 9 Teamsporten met en bal: FIBA (Basketbal), FIFA (Voetbal), IHF (Handbal), FIH (Hockey), IIHF (ljshockey), World Rugby (Rugby), FIVB (Volleybal).

- Hoofdstuk 10: Bal sporten met rackes: BWF (Badminton), ITTF (Tafeltennis), ITF (Tennis).

- Hoofdstuk 11: Een object naar een doel toe brengen: WCF (Curling), IGF (Golf).

- Hoofdstuk 12: Beweging over de grond: UCI (Wielersport), FEI (Paardensport).

- Hoofdstuk 13: Beweging over water: ICF (Kanovaren), FISA (Roeien), ISAF (Zeilen).

- Hoofdstuk 14: Beweging over ijs en sneeuw: IBSF (Sleesporten), FIL (Rodelen), ISU (Schaatsen), FIS (Skiën).

Hier werd duidelijk dat de 35 Olympische sporten ved verschillende nationaliteitsregels en verdere voorwaarden of vereisten gebruiken. Over het al gemeen zijn er drie manieren waarop de sporten met nationaliteitsregels omgaan. Sommige hebben extreem gedetailleerde regels, andere benoemen slechts kort welke punten problematisch zijn en andere hebben zelfs hel emaal geen spedifiekeregeds.

In Hoofdstuk 15 werden de eerder onderzochte regels met elkaar vergeleken. Het hievvoor benodi gdetertium comparationis was om verschillende redenen moeilijk vast te stellen. Ten erstehadden niet al le sporten hun regels, di e voor 2013 van toepassing waren, doorgegeven. Ten tweede werden in de huidige regels niet alle onderwerpen die van belang zijn voor het doel van dit proefschrift in gelijk detail behandeld. Ten derde hebben niet alle sporten substantiële veranderingen in hun criteria ondergaan binnen de onderzochteperiode Hierdoor is een bepaal de bias in de resul taten ontstaan, niet alleen omdat een aantal aspecten door minder dan een derde van de sporten ter sprake werden gebracht, maar ook omdat ontwikkelingen maar in een beperkt aantal gevallen hebben plaatsgevonden. Echter, de meest opval lende observatie is dat de meeste sporten wel eisen dat een atleet een genuine link met een land heeft om het in 
een internationaal toemooi te mogen representeren, terwijl de sporten met betrekking tot de details hierin enorm verschillen.

Desondanks was het mogelijk enkeletrends te ontdekken. Hoewel er tot nu toenog weinig ontwikkelingen met betrekking tot destaatl oze atleten zijn geweest zal dit door de komende Olympische Spelen veranderen omdat het IOC voor de erste ker vluchteling atleten toestaat ook ded te nemen. Evenzo zijn de trends met betrekking tot teritoriale transfers sinds 2013 gering geweest tot de invoering van zulke regels over de gevolgen staatsopvolging, cessie of dekolonisatie bij golf in 2014 en voor moderne vijfkamp in 2015. Ook het belangrijkethema van minderjarige sporters wordt tot nu toeniet vaak ter sprake gebracht. FIFA maakt sinds 2008 geen gebruik meer van en regel met betrekking tot de $21^{\text {te }}$ verjaardag van een atleet, maar aan de andere kant is nu de $10^{\text {de }}$ verjaardag en het land waarin een atteet hierna zijn vaste woonplaats had hed belangrijk voor ijshockey geworden.

Toch zijn er sommige duidelijk ontwikkelingen in de laatste jaren geweest, bijvoorbedd dat atleten hun land van representatie mogen wisselen zelfs als ze al eerder bij intemationale toernooien mee hadden gedaan. In 2012 introduceerde Atletiek een dergelijke regel en sinds 2013 zijn hun voorschriften nog gedetailleerder. In 2015 heeft ook boksen deze mogelijkheid aan hun regelboek toegevoegd, net als golf in 2014. Bovendien zijn atteten met meer dan één national iteit steeds belangrijker geworden en de meeste federaties hebben ervoor gekozen om hen gelijk te stel len met atteten die en nieuwe nationaliteit hebben verkregen. Zij moeten nu dezelfde wachtperiodes in acht nemen, bijvoorbedd vier jaar voor golf sinds 2014 of twee jaar voor boksen sinds 2015.

Het tegenovergestelde gold ten aanzien van de wijze waarop de national iteit wordt verkregen, die in de meeste regelboeken geen of weinig attentie krijgt Regels met berrekking tot de (vaste) woonplats van atteten zijn in de laatste jaren voor sommige sporten veranderd. In 2007 wordt een woonplaatsvereiste voor het eerst gëntroduceerd voor paardensport maar al in 2010 worden er uitzonderingen op toegelaten. Een wachttijd of geen-competitie periode wordt voor de meeste sporten steeds belangrijker en nieuwe vereisten werden onlangs gëntroduceerd, zoals en twe jaar geencompeitie periode voor boksen in 2015 of voor roeien sinds 2013. Maar er zijn ook tegenovergestel de ontwikkelingen geweest: worstelen eist sinds 2012 enke een geencompeitie periode van twee jaar als de federaties niet akkoord zijn met het wisselen van land. Verder biedt attetiek sinds 2013 de mogelijkheid om de drie jaar geencompeitie periode te verminderen als de atteet kan bewijzen dat zijn of haar vaste woonplaats voor minstens drie jaar in het betreffende land was. Toch wordt de algemene ontwikkeling gezien in de richting dat veranderingen van het land van representatie beperkt worden door middel van geen-competitieperiodes.

\subsection{In hoeverre is het problematisch om deze regels met de internationale standaarden van nationaliteitsrecht overeen te brengen? (H oofdstuk 16)}

$\mathrm{Na}$ de vergelijking tussen de verschillende regelboeken was het belangrijk om te anal yseren in hoeverre de national iteitsvereisten van de sporten met de beginselen van 
internationaal national iteitsrecht overeen stemmen. Hiervoor was het essentied dat de definities van de 'genuine link' zoal s gebruikt door de sporten niet in tegenstrijd waren met de definities van international nationaliteitsrecht Om beter te kunnen onderzoeken waar potentiële conflicten tussen de twee systemen ontstaan, zijn de eerder vastgestelde beginselen gebruikt om verschillende desiderata, dat wil zeggen wenselijke aspecten, van dezenational iteitsrege s te formul eren:

a) Sportfederaties moeten de national iteit van de atleet erkennen en moeten regels voor staatl ozen atleten en vluchtel ingen hebben waardoor deze hun ded name aan international etoernooien kunnen continueren;

b) Wisselen tussen landen van representatie moet worden toegestaan en mag niet worden beperkt door een maximum aantal wissels;

c) Sportfederaties moeten erkennen dat en genuine link tussen de atl eet en het land bestaat als deze is ontstaan door i) ius soli, ius sanguinis of en combinatie daarvan; ii) optierechten; iii) vergemakkelijkte natural isatie na en huwelijk of iv) naturalisatie

d) Gendergelijkheid moet worden gerespecteerd;

e) Sportfederaties moeten regel s voor atteten die hun national iteit verliezen hebben en hen in staat stellen om hun carrière voort tezetten;

f) Er mogen geen discriminerenderegels zijn;

g) De regels voor minderjarige att leten moeten extra bescheming bieden.

Bij het vergelijken van de huidige status quo met de desiderata, werd en aantal problemen duidelijk.

- Ten eerste zijn de terminologie en de definities van de verschillende termen vaak inconsistent en tegenstrijdig;

- Ten tweede wordt de kwestie van de staatloze att eten en asiedzoekers onvol doende aangepakt door de meeste federaties; betere regels zijn nodig om sne een opl ossing te vinden zodat deze atd eten hun carrière voort kunnen zetten;

- Ten derde zijn regels waardoor en atleet nie, of slechts €en bepaald aantal ker, het land van representatie mag wisselen in strijd met het recht om van national iteit te veranderen;

- Ten vierde kurnen aanvul lende eisen, zoals special e aandacht voor de bi d ogische ouders waardoor geadopteerde kinderen en vondelingen een naded hebben, discriminerende gevolgen hebben;

- Ten vijfde worden door de mogelijkheid om vereisten van woonplaats of geencompeitie periodes te verminderen of te verwerpen niet all levergelijkbare gevallen gelijk behandeld. Bijgevolg is er geen rechtszekerheid en, wat nog problematischer is, is het niet mogelijk om discriminerende praktijken tegen tegaan;

- Ten slotte wordt van minderjarigen, dienormaal geacht worden onbekwaam te zijn om bindende beslissingen te nemen, verwacht dat ze bindende beslissingen over hun nationaliteit en het land van representatie nemen. 


\subsection{Hoe kan men de spanning tussen deze regels en de beginselen van de internationale standaarden van nationaliteitsrecht oplossen? (H oofdstukken $17 \& 18)$}

$\mathrm{Na}$ vastgesteld te hebben dat de huidige regels vaak in strijd zijn met de beginselen van internationaal national iteitsrecht was de vraag hoe deze probl emen kunnen worden opge lost

\subsubsection{Optie één: een vrije markt}

De erste suggestie was omalle regels met berekking tot nationaliteit en het land van representatie uit de regelboeken te verwijderen waardoor er een vije markt zal ontstaan. Zonder de vaak tegenstrijdige en soms zelfs discriminerende regels zouden vraag en aanbod de bepal ende factoren in de internationale sport zijn. Landen die de beste atdeten willen, zouden dan moeten investeren in de beste faciliteiten en andere voordelen voor de sporters. Van de nieuwe ontwikkelingen en investeringen zou de sport als gehed kunnen profiteren. Atteen zullen vij kunnen kiezen voor welk land ze willen deelnemen bij internationale wedstrijden. Dankzij versnelde naturalisatie procedures kunnen atleten ook snel enn nieuwe national iteit verknijgen en hierdoor zal de wisseling tussen landen direct effect hebben. Om praktische redenen zullen deze veranderingen nie tijdens een toemooi worden toegestaan, maar op andere momenten kunnen transfers van atleten tussen landen op dezelfde manier plaatsvinden als de transfers tussen detop sportdubs.

Hierin ligt een van de belangrijkste problemen van deze optie, ook omdat de versnelde naturalisatie procedures onlangs debatten over burgerschap als gehed hebben uitgelokt Voorbeelden hievvan waren de 'investor citizenship' programma's die momented gebruikt worden in een aantal lidstaten van de Europese Unie, zoals Malta, Cyprus en Portugal. Aangezien er voor rijke investeerders bijna geen vereisten qua woonplaats bestaan, kunnen deze hierdoor hed makkelijk een Europees paspoort kopen waardoor zemakkelijk toegang tot he Schengen-gebied verkrijgen.

Bovendien, terwijl sportfederaties het ontstaan van een genuine link tussen de sporter en een land door natural isatie moeten herkennen, worden deze fast-tradk opties vazk gebruikt om aan de vereisten van het standaard nationaliteitsrecht te ontkomen. Altematief zal ook het beginsel dat de nationaliteit belangrijk is voor de selectie van een nationaal team kunnen worden heroverwogen. Maar deze suggestie is in tegenstrijd met het heleidee van het representeren van een land.

Een ander probleem zou kunnen ontstaan als het creëren van een vije markt, die gelijk is aan de markt voor atteten voor de nationale competities, leidt tot en samensmel ting van denational e competities en denational eteams, omdat rijkere clubs meestal gesitueerd zijn in landen zijn diemeer geld voor sport uitgeven. Een dergel ijke samensmelting zou het onderscheid tussen internationale club en internationale wedstrijden overbodig maken. Het helemad afschaffen van de regels s is dus geen optie. 


\subsubsection{Optie twee: een separate sporting nationality}

De tweede optie was om de suggestie van een aantal auteurs te vol gen en en aparte sporting nationality of sportnationaliteit in te voeren. Omdat de definities en de uitleg van dezeauteurs nie hed gedetaill lerd waren, zijn hier een aantal probl emen ontstaan. Ten erstewas de precieze definitievan sporting national ity ondui delijk en ten tweede blijft het di sautabel in hoeverreeen sporting nationality afhankelijk is van de 'gewone' nationaliteit van een atleet. Sommige auteurs wilden een sporting nationality die volledig losgekoppeld zou worden van de nationaliteit van de atleet. Dit leidde tot de vraag hoe 'national iteit' kan worden erkend zonder ook aan de vereisten die voor een normal enational iteit gebrui kelijk zijn te vol doen. Als men al le verdere mogelijkheden hoe een genuine link tussen een atteet en het land kan ontstaan heeft geanal yseerd, wordt duidelijk dat door dit voorstel de focus van het problemal leen zal verschuiven. De invoering van een aparte sporting nationaltiy zal dus geen grote voordelen hebben. Bovendien is de term 'sporting nationality' zelf een probleem, omdat elke werkbare definitievan dezeoptiein tegenstrijd is met het concept en determ 'nationaliteit' zoals dezeal gemeen gebruikelijk is.

Terwijl en envoudigere manier van nationaliteitsregels wenselijk is om de hui dige problemen op te lossen is de invoering van een sportnational iteit niet dejuiste manier hiervoor.

\subsubsection{Optie drie: Een sporting licence in overeenstemming met de beginselen van internationaal nationaliteitsrecht}

Volgens dit proefschrift zou de best mogelijke opl ossing voor de probl emen een aparte 'sporting licence' zijn, zoals in he 'Draft Article' wordt beschreven (zie Hoofdstuk 17.4.2). Deze sporting licence zou met name niet en sporting nationality zijn, maar gebruik maken van de desiderata om voldoende gedetailleerde vereisten voor de toetsing van de genuine link tussen atleet en land te kunnen toepassen. Hierdoor zal deze regeling in overeenstemming met de beginselen van international nationaliteitsrecht zijn, bijvoorbeeld omdat een licenceniet door atd eten verkregen kan worden die geen genuine link met het land hebben. In het algemeen kan men veronderstellen dat een atl eet die denationaliteit van een staat bezit wel en dergelijke genuine link met het land heeft Indien echter, zoals in het geval van dubbele nationaliteit, aanvul lende eisen worden gebruikt om dit verband te toetsen, moeten de eisen zer zorgvul dig worden geselecteerd. Voorzichtigheid is geboden omdat landen verschillende regels met betrekking tot verkrijging en velies van de nationaliteit hebben. Door het verschil tussen de national ewetten over national iteit bestaat er al een disbal ans tussen landen. Als landen met strengere wetten proberen dit door middel van optierechten of vergemakkelijkte natural isatie mogelijkheden te compenseren, zullen strikte aanvul lende isen van de sportfederaties opnieuw en di sbalans veroorzaken.

De problemen van staatloze atteten en vluchtelingen moeten expliciet aan de orde komen en een opl ossing, bijvoorbedd de opl ossing di e momented door het IOC voor de Rio 2016 Spelen gebruikt wordt, moet gëntroduceerd worden. Bovendien is de positie van minderjarigen bijzonder belangrijk omdat deze de mogelijkheid moeten 
krijgen om vij te beslissen welk land ze willen representeren. Na hun achttiende verjaardag moeten ze de kans krijgen om binnen drie jaar opnieuw te beslissen zonder door een geen-competitie periodetegengehouden te worden.

Voor deze sporting licence moeten de regels ook expliciet naar alle vormen van verkrijging van de nationaliteit verwijzen en evvoor zorgen dat de optierechten en vergemakkelijkte naturalisatie als gelijkwaardige mogelijkheden erkend worden. Bovendien moet het verkrijgen van een nieuwenationaliteit worden toegestaan zonder en maximum aantal keer hiervoor te bepalen. Als en atlet niet van optierechten, vergemakkelijkte naturalisatie mogelijkheden of een gewone naturalisatie gebruik heeft gemaakt is een geen-competitie periode van twee jaren vereist Aangezien termen en definitie een groot probleem zijn geweest bij de huidige codes, moeten de definities en toelichtingen bij het artike in de regel boeken staan om duidelijk te maken wat er precies bedoeld wordt 


\section{Zusammenfassung}

DieStaatsangehörigkeitsvorschriften in den Olympischen Sportarten waren bis jęt eine Terra incognita, welche nur jeweils für einzelne Sportarten halbwegs efforscht war. Daher war das Ziel dieser Dissertation, das gesamte Gebiet nicht zur zu erkunden, sondern auch die Ergebni sse besser und übersichtlicher wiederzugeben. Hierbei wurde auf drè Forschungsfragen zurückgegriffen:

1) Welche Staatsangehörigkeitsvorschriften getten derzeit für die Olympischen Sportarten?

2) In wie weit sind die derzeit geltenden Staatsangehörigkeitsvorschriften der Olympischen Sportarten mit den Intemationalen Grundsätzen des Staats angehörigkeitsrechts in Einklang zu bringen?

3) Wie können die Spannungen, die zwischen den derzeit geltenden Staats angehörigkeitsvorschriften der Olympischen Sportarten und den Intemationalen Grundsätzen des Staatsangehörigkeitsrechts existieren, aufgel öst werden?

Diehieffür verwendete Methode war die des Rechtsvergleichs, wodurch es geboten war sowohl ein tertiumcomparationis, d.h. einen werteneutral en Standard der benuttt murde um die verschiedenen Regeln miteinander zu vergleichen, als auch ein tertium valutationis, d.h. ein Standard der benutt wird um de verschiedenen Regeln zu bewerten, festzulegen. Das tertium comparationis wurde durch das Festlegen eines Basisstandards, unter Berüdksichtigung der zu einemfesten Zeitpunkt geltenden Regeln, gebildet Der Stichtag hiefür war der 15. Oktober 2013, da an diesem Tag die die vorliegendeA Arbeit begonnen wurde

Im Gegensatz hierzu wurden die Intemationalen Grundsäze des Staats angehörigkeitsrechts als tertiumvalutationis genutzt.

Darüber hinaus waren nicht nur die verschiedenen Regeln, sondern auch deren Wortlaut und Formulierungen wichtig bei der Analyse, da Ungenauigkeiten in den verschiedenen Regelwerken zu Verwirrung und Missverständhissen führen können. Daher war es geboten für die Dissertation sel bst festzul egen, welche Begriffe benuttt werden sollten um die Beziehung zwischen einer natürlichen Person und einem Staat zu beschrieben. Dies wurde zumeist durch den Begriff ,nationality' (Nationalität) getan und nicht durch ,citizenship' (Staatsangehörigkeit). Grund hiefür war, dass der Fokus der Regelwerke nur auf der Verbindung zwischen der natülichen Person und des zu repräsentierenden Staates liegt und nicht auch die implizierten (bürgerlichen) Rechte und Pflichten, die durch ,citizenship' im Englischen zum Ausdrudk gebradht werden, berücksichtigt werden. Da ,Nationalität' im Deutschen jedoch weniger oft gebraudht wird, wird diese Zusammenfassung den Begriff ,Staatsangehörigkeit' verwenden. 


\subsection{Staatsangehörigkeitsrecht und Sportrecht (Kapitel $3 \& 4$ )}

Wie bereits enwähnt musste zunächst das tertium valutationis festgel egt werden, bevor man sich den Regelwerken der Sportverbände selbst zuwenden konnte, musste ein Hierür war es zunächst notwendig, die relevanten Grundsätze des Intemationalen Staatsangehörigkeitsrechts zu ergründen. Der wichtigste Aspekt iln diesem Zusammenhang ist der ,genuine link', d.h. ein besonderes NäheVehältnis zwischen Staat und der betreffenden natülichen Person, wie er zuerst im Fall Nottebohm von 1955 angeführt wird. Solch ein NäheVerhältnis entsteht normalerweise schon bei der Geburt eines Kindes, wenn es aus Gründen der Blutsverwandischaft (ius sangui nis) oder durch Geburt auf dem Teritorium eines Staates (ius soli) eine Staatsangehörigkeit bzw. National ität ehält Findelkinder, sowie Kinder dieandemfalls staatenlos wären, ehalten zumeist dieStaatsangehörigkeit des Landes in dem sie geboren bzw. gefunden wurden.

Es ist durchaus möglich einen genuinelink nach der Geburt aufzubauen und durch ein Einbürgenungsverfahren eine neue Staatsangehörigkeit zu erwerben, al lerdings ist dies deutlich schwieriger, da in diesen Fällen die Verbindung zwischen Staat und der natürlichen Person sehr genau geprürt wird. Die betreffende natürliche Person muss eine besondere Beziehung zu dem Land, dessen Staatsangehörigkeit er oder sie erlangen will, aufbauen, zum Beispiel durch einen festen Wohnsitz und somit der Entscheidung, den Lebensmittel punkt in dem Land zu haben. Einbürgerungsverfahren bieten Ländem die Möglichkeit, Menschen in die politische Gemeinschaft aufzunehmen, di ezwar einen großen Teil ihres Lebens in dem Land verbracht haben, jedoch nicht die Staatsangehörigkeit des Landes besitzen. Beispiele hiefür sind zum einen die Kinder, die in sehr jungen J ahren mit in das Land gekommen sind und ihre Kindheit und Jugend dort verbracht haben, oder zum anderen Kinder von Einwanderem der zweiten Generation in einem Land, dessen Staats angehörigkeitsrecht primär ius sanguinis vorsieht. Für diese beiden Gruppen gibt es zumeist Optionsrechte oder vereinfachte oder beschle unigteEinbürgerungsverfahren.

Fragen der Staatsangehörigkeit treten darüber hinaus auch auf, wenn eine natürliche Person, z.B. durch verbesserte Reisemöglichkeiten oder den hieraus resultierenden grenzübergreifenden Ehen, einen genuine link mit mehr als nur einem Land haben. Während einige von innen durch Einbürgerungsverfahren eine weitere Staatsangehörigkeit erlangen, haben Kinder von Eltern aus ius sanguinis Ländern oftmals eine doppelte Staatsangehörigkeit von Geburt an. Obwohl die mehrfache Staatsangehörigkeit in den lezzten Jahren flächendeckender akzeptiert wird, bleiben einige Probleme wie die Doppel besteverung oder die doppelte Verpflichtung zum Militärdienst bestehen.

Zudem kann sich der genuine link und di e daraus resultierende Staatsangehörigkeit im Laufe eines Lebens durch exteme Einflüsse verändem, so z.B. wenn sich die Grenzen eines Staatsgebiete ändern, entweder durch Staatennachfolge, Dekol oni sation oder das Abtreten eines Gebiets an einen anderen Staat In diesen Fällen der Gebietsübertragung lösen die betroffenen Staaten die hieraus resultierenden Staatsangehörigkeitsfragen zumeist durch bilateral eV erträge 
Obwohl der genuine link normal erweise als permanent oder zumindest sehr beständig angesehen wird, gibt es sowohl für die betreffende natürlichePerson, als auch für den Staat die Möglichkeit, dieses Verhältnis aufzukündigen. Dies darf jedoch nicht durch staatli iche Willkür geschehen und sol ltenie dazu führen, dass jemand staatenl os wird.

Aus diesen Regeln kristallisieren sich die Intemationalen Grundsätze des Staatsangehörigkeitsrechts heraus, welche für die Analyse und Evaluierung der Regel werke der Sportsverbändeals Prüfstein dienen sollten. Diese Grundsätze können fol gendermaßen zusammengefasst werden:

- Gegen die Menschenrechte und besonders gegen das Recht auf eine Staatsangehörigkeit darf nicht verstoßen werden;

- Staatenl osigkeit sol lte vermieden werden;

- J eder hat das Recht, seineStaatsangehörigkeit zu ändern;

- Die Widerufung einer Staatsangehörigkeit ist nur dann zulässig, wenn diese nicht zu Staatenl osigkeit führt,

- Staatsangehörigkeit kann nur durch einen genuine link zwischen einer natürlichen Person und einem Staat erworben werden;

- Der Erwerb der Staatsangehörigkeit bei der Geburt effol gt basiert auf ius sanguinis oder ius soli oder einer Mischform der beiden vorgenannten;

- Familienmitglieder sollten diesel beStaatsangehörigkeit haben;

- DieGleichberechtigung sollterespektiert werden;

- Staatsangehörigkeit kann nicht willkürlich entzogen werden;

- Diskriminierung ist nicht erlaubt

Zusätzlich ist dieSituation von Kindem und Minderjährigen sehr wichtig, da diese sich in einer besonders schützenswerten Position befinden, der Rechenschaft getragen werden sollte

\subsection{Welche Staatsangehörigkeitsregeln gelten derzeit in den Olympischen Sportarten (K apitel 5 - 15)}

In den fol genden Kapiteln wurden die derzeitig geltenden Regel werke der Sportverbände analysiert, wobei sich das Augenmerk besonders auf die Möglichkeiten der Athleten, zwischen den Repräsentationsländem zu wedhseln, sowie auf die Position von mindejährigen oder staatenl osen Sportlem, ridhtete Zudem murde besonders auf die Formulierungen der jeweiligen Regeltexte geadhte, so z.B. darauf ob der Sportverband ,nationality' oder ,citizenship' verwendete, welche Definitionen gegeben wurden und ob es einen realen Unterschied zwischen den Begriffen gab. Um die verschiedenen Sportverbände und deren Regel n besser miteinander vergl eichen zu können, wurden die Sportarten in folgende Kategorien eingeteilt:

- Kapite 5: Klassische Sportarten: IAAF (Leichtathleik), IBU (Biathlon), UIPM (Modemer Fünfkampf), ITU (Triathlon), IWF (Gewidhtheben).

- Kapite 6: Sportarten mit Hauptzid Körperbeherrschung: FINA (Schwimmsport), FIG (Gymnastik). 
- Kapite 7: Kampfsport ohne Körperkontakt zwischen Sportlem: WA (Bogenschießen), FIE (Fechten), ISSF (Schießen).

- Kapite 8: Kampfsport mit direktem Körperkontakt zwischen Sportlem: AIBA (Boxen), IJ F (Judo), WTF (Tadkwondo), UWW (Ringen).

- Kapite 9: Teamsportarten mit Ball: FIBA (Basketball), FIFA (Fußsball), IHF (Handball), FIH (Hockey), IIHF (Eishockey), World Rugby (Rugby), FIVB (Volleyball).

- Kapite 10: Ballsportarten mit Schlägem: BWF (Badminton), ITTF (Tischtennis), ITF (Tennis).

- Kapite 11: Sportarten bei denen ein Objekt zu einem Ziel gebracht werden muss: WCF (Curling), IGF (Golf).

- Kapite 12: Bewegung über festen Grund: UCl (Radsport), FEl (Reitsport).

- Kapite 13: Bewegung über Wasser: ICF (Kanusport), FISA (Rudem), ISAF (Segen).

- Kapite 14: Bewegung über Eis oder Schnee IBSF (Bobsport), FIL (Rennrodeln), ISU (Eislauf), FIS (Skisport).

Im Laufe der Analyse murde schnell deutidh, dass die 35 Olymischen Sportarten sedr unterschiedliche Staatsangehörigkeitsvorschriften haben, welche sich in drè generelle Strömungen einteilen lassen. Dieerstedieser Strömungen geht sehr genau ins Detail und gibt verschiedene Beispiele für die Anwendungen der Regeln, während die zweite Strömung nur bei den problematischen Aspekten genauere Regen vorsieht Im Gegensatz hierzu haben dieanderen Sportverbändewenige oder nur sehr vage Regedn.

Im 15. Kapite sollten die vorher analysierten Regeln nun miteinander und mit einem tertium comparationis verglichen werden, dessen Erstelen sich aus vielerle Gründen jedoch als problematisch erwies. Erstens war es in mehreren Fällen unmöglich gewesen, die Regelwerke, welche vor 2013 in Kraft waren, zu erhalten. Zweitens wurden nicht alle Aspekte, welche für diese Dissertation von Belang waren, von allen Sportverbänden in deren Regelwerken erwähnt und selbst wenn Sportverbände sich mit diesen Themen auseinander setzten, so geschah dies auf sehr unterschiedlich detaillierter Weise Und drittens war es nicht möglich bei allen Sportarten eine Entwidklung in ihrer Position zu Staatsangehörigkeitswechseln aufzuzeigen, da sich die Regelwerke im Bezug hierauf oftmals nidht inhaltich geändert hatten. Hieraus resultiet ene gewisse Verzerrung der Ergebnisse, da einige Themen nur von eine Drittel der 35 Sportarten behandelt werden und von diesem Drittel oftmals nur ein Bruchteil die Regeln zu diesen Themen in den letzten J ahren verändert hat Nichtsdestotrơz lässt sich feststellen, dass alle Sportarten, unabhängig davon wie stark sie sich ansonsten unterscheiden, im Prinzip darauf Wert legen, dass Sportler nur dann ein Land bei einem intemationalen Wettkampf repräsentieren können, wenn sie einen genuine link mit diesem Land haben. Zumeist wird solch ein 
genuine link anerkannt, wenn der betreffende Sportler ein Staatsangehöriger des Landes ist oder dort seinen festen Wohnsitz hat.

Bislang gab es nur wenige neue Entwidklungen mit Auswirkungen für Sportler in extremen Situationen, so wie staatenl ose Sportler, Flüdhtlinge oder Sportlern, die aus anderen Gründen für das Land ihres festen Wohnsitzes anzutreten wollen. Dies wird sich mit Sicherheit in Folge der nächsten Olympischen Spiele in Rio ändem, da das IOC dort zum ersten Mal Flüchtlinge bewusst unter der Flagge des IOC antreten lässt Es bleibt al so zu erwarten, dass mehrere Sportverbändenachziehen und eigene Regeln für ihre internationalen Wettbewerbe entwickeln werden, die es Flüdhtingen ermöglichen, ihre Sportkarriere fortzusetzen. Auch andere widhtige Themen mit hohem Konfliktpotential, wie die Fragestellung, für welches Land ein Sportler nach einer Gebietsübertragung, d.h. wenn sich die Grenzen eines Staates verändert haben, antreten kann, waren in den lezten Jahren wenig Wande unterworfen. So haben nur Golf und Modemer Fünfkampf ihre Regeln hierzu in den Jahren 2014 bzw. 2015 geändert Regeln mit Bezug auf minderjährige Sportler, welche sich von Anfang an nur in wenigen Regelwerken finden ließen, haben sich in zwè Richtungen hin entwickelt Während die FIFA seit 2008 nicht mehr besonders darauf achtet, dass Sportler ab ihrem 21. Geburtstag als erwachsene Athleten gelten, prüft Eishockey im Gegensatz hierzu nun. in welchem Land ein Sportler nach seinem zehnten Geburtstag gelebt hat, wenn es darum geht, einen genuine link zwischen Sportler und Land herzustellen.

Andererseits gab es einige Entwicklungen, die sich deutlich ablesen lassen. So erlauben nun die meisten Sportverbände, dass Sportler im Laufe ihrer Karriere für mehr als ein Land antreten können. Solche Regeln wurden zum Beispie von Boxen 2015 eingeführt, während Golf dies 2014 tat. Für Leichtathleik gelten solche Regeln seit 2012, die seitdem detaillierter ausgearbeitet wurden. Auch die Möglichkeit für Sportler mit doppelter oder mehrfacher Staatsangehörigkeit, ebenfalls zwischen Repräsentationsländern zu wechseln, haben zugenommen. Zumeist werden diese Sportler behandelt wie solche, die eine neue Staatsangehörigkeit erworben haben und danach ihr Repräsentationsland ändern wollen. In beiden Fällen müssen Sportler einen gewissen Nichtwettbewerbszeitraum beachten, bevor sie wieder an intemationalen Tumieren teilnehmen dürfen, so z.B. seit 2014 vier J ahre bei Golf oder zwè J ahre seit 2015 be Boxen.

Im Gegensatz hierzu haben Sportverbände wenige Regeln, die sich genau mit dem Erwerb einer Staatsangehörigkeit beschäftigen. Auch hat der Fokus auf den festen Wohnsitz in den lełten Jahren nadhgelassen. Während Reitsport noch 2007 Regeln mit Berücksidhtigung der Dauer und Existenz eines festen Wohnsitzes in dem relevanten Land einführte, wurden bereits 2010 Ausnahmeregelungen zugelassen. Dem gegenüber steht, dass im se ben Zeitraum viele Sportarten fixierten, dass Sportler bei Repräsentationsl and-Wechseln einen Nichtwettbewerbszeitraum beachten müssen, wiez.B. zwei Jahre Boxen seit 2015 (wie schon oben erwähnt) oder Rudern seit 2013. Andererseits hat sich Ringen 2012 dafür entschieden, solch einen Nichtwettbewerbszeitraum nur noch zu verlangen, wenn sich die Sportverbände bei einem 
Wechsel nicht einig werden können. Leichtathletik erlaubt nun eine Verringerung des Nichtwettbewerbszeitraums, wenn der betreffende Sportler dre Jahre seinen festen Wohnsitz in dem relevanten Land hatte Generel bleiben die vorgeschriebenen Nichtwettbewerbszeiträume jedoch das meisteingesetzte Mitte, um Repräsentationsland-Wechsel zu unterbinden.

24.3. In wie weit existieren Spannungen zwischen den derzeit geltenden Staatsangehörigkeitsvorschriften der Olympischen Sportarten und den Internationalen G rundsätzen des Staatsangehörigkeitsrechts? (K apitel 16) Nach diesem Vergleich der verschiedenen Regel werkeging es nun darum festzustellen, ob Regeln der Sportverbände mit den Internationalen Grundsätzen des Staatsangehörigkeitsrechts kongruent seien. Dreh- und Angelpunkt hierbei war der genuine link, welchen die Sportverbände nicht konträr zu den Internationalen Grundsätzen des Staatsangehörigkeitsrechts definierten sollten. Um dieses Verhältnis besser zu ergründen, wurden verschiedene Desiderata, d.h. wünschenswerte Aspekte von Staatsangehörigkeitsvorschriften, festgelegt:

a) Sportverbände sollten die Staatsangehörigkeit eines Sportlers anerkennen und sollen dafür Sorge tragen, dass staatenlose Sportler, sowie Flüchtlinge, itre internationale Sportkarierefortsezen können;

b) Repräsentationsland-Wechsel sollten erlaubt werden, ohne dass eine Höchstzahl an Wechsel $n$ festgel egt ist;

c) Ein genuinelink zwischen Sportler und Land soll von den Sportverbänden anerkannt werden, wenn dieser durch i) ius soli, ius sanguinis oder eine Mischform von beiden ii) Optionsrechteiii) eleichterteEinbürgerung in Folgeeiner Eheschließung oder iv) Einbürgerung, zu Standegekommen ist;

d) Gleichberechtigung sollterespektiert werden;

e) Sportverbände sollten Regeln haben, die es Sportlem erlauben, ihre Karriere fortzusetzen, nachdem dieseihre Staatsangehörigkeit verloren haben;

f) Es sol ltekeine Regeln geben, diein irgendeiner Weisediskriminierend wirken;

g) Minderjährige Sportler sollten besonders geschüttt werden.

Vergleidht man dieser Desiderata mit den derzeitigen Regel werken, so werden schnell mehrereProblemeund Spannungsfälle deutlich.

- Erstens, sind die Begrifflichkeiten, welche benutzt werden, oftmals inkonsistent und widersprüchlich;

- Zweitens, gilt es derzeit zu wenige und zudem inadäquate Regeln für staatenlose Sportler und Flüchtlinge; hier ist besonderer Handlungsbedarf gegeben, da diese Sportler sich in Extremsituationen befinden und möglichst schnell wieder ihre Kariere aufnehmen können sollten;

- Drittens, verstoßen Regen, welche eine Höchstzahl von RepräsentationslandWechseln vorschreiben oder solche Wechsel nicht zulassen, gegen das Recht, die Staatsangehörigkeit zu wechseln; 
- Viertens, können zusätlliche Anforderungen diskriminierend wirken, so z.B. wenn nur die biologischen Eltem in Beradht gezogen werden und hierdurch Findelkinder sowieAdoptivkinder einen Nachteil haben;

- Fünftens, führt das Erlassen oder Reduzieren von vorgeschriebenen Aufenthaltsdauem oder Nichtwettbewerbszeiträumen dazu, dass gleiche Fälle nicht gleich behandelt werden. Daher gibt es in soldhen Fällen oftmals keine Rechts sicherheit und darüber hinaus können diskniminierende Praktiken nicht erkannt und behoben werden;

- Letztens, wird von Minderjährigen, die normalerwiese als nichts geschäftsfähig betrachtet werden, erwarte, dass sie bindende Entscheidungen bezüglich ihrer Staatsangehörigkeit und des Repräsentationslandes treffen.

24.4. Wie können die Spannungen, die zwischen den derzeit geltenden Staatsangehörigkeitsvorschriften der Olympischen Sportarten und den Internationalen Grundsätzen des Staatsangehörigkeitsrechts existieren, aufgel öst werden? (Kapitel $17 \&$ 18)

Da nur ein Aufzeigen der deutliche Spannungen zwischen den derzeitigen Regel werken der Sportverbände und den Internationalen Grundsätzen des Staatsangehörigkeitsrechts nur den Status quo beschreiben würde, war die folgerichtige Frage, wie die erkannten Problemegelöst werden könnten.

\subsubsection{Option eins: ein freier $M$ arkt}

DieersteMöglichkeit wäre, in den Regel werken der SportverbändealleBeschränkungen zu beseitigen und einen freien Markt zu schaffen. Ohne die oft widersprüchlichen Regeln könnten so dieK Käfte von Angebot und Nadhfrage den intemational en Sport bestimmen. Sportlich ambitionierte Länder müssten mehr in ihre Sportler und ihre Sporteinrichtungen investieren, was dem Sport generell zu Gutekommen würde, da hier durch neve und bessere Werkstoffe, Techniken und Trainingspläne gefördert würden. Sportler wären nicht nur vollkommen frè sich für ein Repräsentationsland zu entscheiden, sondern könnten auch dank schnel lerer Einbürgenungsverfahren leicht eine neve Staatsangehörigkeit erwerben und direkt für das neve Land antreten. Aus technischen Gründen gäbe es nur die Einschränkung, dass dies nicht im Laufe eines internationalen Wettbewerbs geschehen dürfte Darüber hinaus würde sich aber schnel ein Transfersystem wiezwischen den großen Sportclubs etablieren.

Dies führt jedoch auch zu den Hauptkritikpunkten dieser Option, da solche schnellen Einbürgerungsverfahren, wie es derzeit auf Malta, Zypern oder in Portugal gilt, bereits eine hitzige Debatte über Staatsangehörigkeit in der Europäischen Union ausgelöst haben. Da in solchen Fällen zumeist der Antragsteller keinen festen Wohnsitz in dem jeweiligen Land haben muss, sind diese Verfahren sehr beliebt bei reichen Investoren, diesich somit einen europäi schen Pass und hierdurch freien Zutritt zum Schengen-Raum erkaufen. Während Sportverbände Einbürgerungsverfahren und den daraus resultierenden genuine link zwischen Sportler und Land anerkennen sollten, umgehen diese schnellen Einbürgenungsverfahren jedoch das normal geltende 
Staatsangehörigkeitsredht der einzelnen Länder. Alternativ könnte man sich von dem Prinzip der Staatsangehörigkeit als Ausgangspunkt für die Auswahl eines Repräsentationslandes lösen. Dies würde jedoch dazu führen, dass eine ,Nationalmannschaft' nur noch wenig mit dem Repräsentationsland zu tun hätte

Ein weiteres Problem in diesem Zusammenhang ist, dass durch solch einen freien Markt der Unterschied zwischen den Nationalmannschaften und den nationalen Ligawettbewerben verschwimmen würde Die réchen Klubs befinden sich zumeist in Ländern, welche grundsätzlich mehr Geld für Sport ausgeben und daher auch für die Nationalmannschaften mehr Ressourcen hätten. Solch eine Vermischung von Klubund Nationalmannschaftswettbewerben würde das Fortbestehen der Nationalmannschaften ad absurdum führen. Daher kann die Aufhebung sämtlicher Regeln nicht dierichtige Lösung sein.

\subsubsection{Option zwei E ine separate sporting nationality(Sportstaatsangehörigkeit)}

EinezweiteMöglichkeit, wiesieeinige Autoren anraten, wärees, eine separatesporting nationality, d.h. eine Sportstaatsangehörigkeit, einzuführen. Da diese Autoren nicht genau beschreiben, wiesiehier vorgehen würden, ergeben sich einige Probleme Erstens, gibt es derzeit keine präzise Definition von 'sporting nationality' und zweitens bleilt es unklar, in wie weit eine sporting nationality noch von der Staatsangehörigkeit des Sportlers abhängt Da einige Autoren vorschlugen, dass die sporting nationality komplett unabhängig von der Staatsangehörigkeit des Sportlers sein soll te, stel tesich die Frage, wie man eine Sportstaatsangehörigkeit feststellen wollte, ohne dabe in irgendeiner Weise auf Staatsangehörigkeit und deren normalen Erwerb zu verweisen. Nach Prüfung sämtlicher Möglichkeiten wie ein altemativer genuine link zwischen Sportler und Land entstehen könnte, murde deuttich, dass hier das Problem nur verschoben und nicht behoben würde Daher hätte die Einführung einer separaten sporting nationality keine Vorzüge Darüber hinaus ist der Begriff der Sportstaats angehörigkeit oder sporting nationality an sich schon problematisch, da man bei jeglicher 'Staatsangehörigkeit' erwartet, dass es umeine voll wertige Staatsangehörigkeit handelt und nicht, wiehier vorgeschlagen, davon komplett gelöst ist.

Wenn man Staatsangehörigkeitsrecht im Ganzen und das Konzept der sporting nationality im Besonderen betrachtet, wird deutlich, dass diese sporting nationality nicht zu der erhofften Vereinfachung der Situation beitragen, sondern, im Gegenteil, die bestehenden Probleme vergrößern würde

\subsubsection{Option drei: E ine sparting licence(Sportlizenz), welch im Einklang mit den internationalen G rundätzen des Staatsangehörigkeitsrechts ist}

Die Lösung, welche von dieser Dissertation bevorzugt wird, wäre die Einführung einer separaten Sportizenz oder sporting licence wie im 'Draft article' (Kapitel 17.4.2) beschrieben. Diese sporting licence wäre keine Variante der sporting national ity, wie einige Autoren sie vorschlagen, da ihr Kriterien sehr detailliet wären und somit garantieren, dass ein genuine link zwischen Sportler und Repräsentationsland besteht, auch um schnellen Einbürgenungsverfahren vor intemationalen Wettbewerben 
vorzubeugen. Diese Kriterien müssen mit den internationalen Grundsätzen des Staatsangehörigkeitsrechts übereinstimmen, und es ist daher nicht möglich, dass sein Sportler die Sportizenz eines Landes erwirbt, mit dem er oder sie keinen genuine link hat Generell karn men solch einen genuinelink als existent ansehen, wenn der Sportler die Staatsangehörigkeit des Landes hat; aber in anderen Fällen, so z.B. bei doppelter Staatsangehörigkeit, müssten zusätzliche Kriterien betradhtet werden um sicherzustellen, dass wirklich ein NäheVerhältnis besteht Da Länder in ihren nationalen Gesetzten verschieden mit dem Erwerb oder dem Verlust der Staatsangehörigkeit umgehen, existiert ein generelles Ungleichgewicht zwischen den Ländern. Wenn Länder mit restriktiverem Staatsangehörigkeitsrecht versuchen, des durch Möglichkeiten wie Optionsrechte oder vereinfachte Einbürgenungsverfahren nach einer Eheschließung auszugleichen, sollten die Sportverbände durch strikte Regen dieses Ungleichgevicht nicht wieder herstellen.

Für die Probleme, denen sich Flüchtlinge und staatenlose Sportler gegenüber sehen, sollte es Klare Lösungen in den Regelwerken geben. Hierbei sollten sich die Verbändean dem Lösungsansatz, wieer vomIOC für dieOlympischen Spiele 2016 in Rio vorgesehen ist, orientieren. Des Weiteren sollte besonderes Augenmerk auf die Situation von minderjährigen Sportlem gerichtet werden, die nicht dazu gezwungen werden sollten, vor Erreichen ihrer Volljährigkeit bereits bindend festzulegen, für welches Land sie bei internationalen Wettbewerben antreten wollen. Nach Erreichen des 18. Lebensjahres sollten sie die Möglichkeit haben, innerhalb der nächsten drè J ahre sich nochmals um zu entscheiden, ohne von einem Nichtwettbewerbszeitraum betroffen zu sein.

Die Kriterien für diese Sportlizenz müssen genau auf die Weisen, durch welche eine Staatsangehörigkeit erworben werden kann, Bezug nehmen, sodass auch Optionsrechte und erleichterte Einbürgerungsverfahren anerkannt und als gleichwertig mit dem Erwerb einer Staatsangehörigkeit bei der Geburt behandelt werden. Zudem müssen Staatsangehörigkeitswechsel ellaubt werden, ohne dass hiefür eine Höchstanzahl festgeselzt ist Für Sportler, die nicht beweisen können, dass sie bereits einen genuine link zu dem jeweiligen Land durch ius soli, ius sanguinis oder eine Mischform der beiden, durch Optionsrechte, durch erleichterte Einbürgerung in Folge einer Eheschließung oder durch die normal gebräuchliche Einbürgenungsverfahren, aufgebaut haben, gilt ein nicht reduzierbarer Nichtwettbewerbszeitraum von zwe Jahren. Da die gewählten Begriffe und deren Definitionen in den derzeitigen Regelwerken sehr widersprüchlich und verworren sind, sollten Begriffe und deren Beziehung zueinander vorab erklärt werden, um Verwirnung vorzubeugen. 



\section{Valorisation addendum for: Nationality requirements in Olympic sports}

\subsection{Olympic sports and nationality requirements in the societal and economic context}

Sports are an important aspect of everyday life for many people around the globe, regardl ess whether they practice a sport themselves, are involved in the organisation of a dub or just enjoy watching it. In addition, sports are amongst the topics almost everyone has an opinion on, whether it concems coaching, the composition of a team or a decision made by a referee, umpire or judge Sports do not only have an integrating aspect, bringing together people from different countries or societies, but al so have become a universal language

Sports and sporting activities are organised on different levels with the local sports clubs forming val uable parts of their respective communities. The dubs help to bring people together and provide possibilities for young people to form val uable parts of their local communities and society as a whole. Especially troubled youths have been taught the values of faimess, respect and teamwork by their sport's continuous emphasis on fair play both on and off thefield.

Besides amateur sports and ther contribution to society, there are the professional sports, which are multi-million businesses. $Y \in$, unlike some other multi-national corporations, the professional dubs are businesses about which people are extrem $1 y$ passionate Competitive leagues and other sporting compeitions generate a lot of money for all stakeholders, ranging from the sponsoring companies, whose logos are printed on the athletes' jerseys, to TV rights and specialised TV channels and to the sporting clubs and athletes themselves. World Championships for each sport and the Olympic Games at which bring together the best athletes of all sports, are highly profitable for all businesses involved. This profitability has however has a negative impact on some sports and the organisers of the tournaments. After all, this flourishing industry is unfortunately not, as recent al legations of both doping and comuption have shown, immune to controversies and scandal s and may thus sometimes be detrimental to theaforementioned value of fairness.

Nationality has always been an essential topic and has been brought to the forefront of political debates in recent times in the context of the refugee crisis. Recent developments have been occurring on two sides of the spectrum on the one hand, some countries are now selling their passports and the travel rights that come with them, while on the other hand asylum seekers from war torn countries are desperately trying to reach safety abroad. In both cases, the issue of which passport one holds and which country one might be all owed to enter, as well as where one might be allowed to stay or settle, is of paramount importance

This dissetation focussed on the overlap between nationality laws and sports. For representative sporting teams, especial ly the legal issue for which country an athlete may compete for arises. Whereas this question seems to be straightforward at first 
glance, there are several aspects, which have resulted in a more complicated picture such as dual nationality and the tendency of weal thier countries to offer their passports to promising athletes. While on the one hand flexibility is needed to adapt to new circumstances, on the other hand there has been a 'muscle drain' with tal ented athl etes leaving their countries of origin, causing problems for their national teams and the development of the sport in these countries.

With the current refugee crisis, the issue of refugee and stateless athletes has further gained importance The IOC has started to tackle the problem for the 2016 Games in Rio by all owing refugees to compete under the IOC flag, which will be the first time such a measure was taken. In view of modem conflicts, these problems are likely going to increase in frequency and hence a solution that goes beyond one international competition shoul $d$ be reached.

\subsection{The importance of Olympic sports and their nationality requirements for different audiences}

Many people care a lot about sports and espedal ly the Olympic Games and as such this dissertation will be of interest to many people and may be used for many purposes, which may be broadl y characterized as practical, academic and general.

As sports are interesting to many people, the general public - or at least all those with a liking for sports - might find the book at hand interesting to read and especially fans of one particular sport might enjoy the indi vidual sports chapters.

With regard to academic impact, this dissertation was written mainly two aims; firstly to provide other researchers and students with a first insight into the current position of athletes and the nationality requirements they may be faced with at the Olympics and other international competitions; and secondly to lay a foundation for further research. Such further research and the monitoring of developments will be needed as the chapters 5 to 15 can only providea picture of today's situation and give a brief analysis of the past 10 or 15 years. With the contemporary rules acting as a basis, future trends and devel opments can beanal ysed and eval uated in the context

As this dissertation al so has practical impact on thein the relatively narrow field of sports law and nationality law, the sporting federations and athletes themselves or athlete representatives are certainly a core part of the target audience. For sporting federations the comparison between their own eligibility criteria and those used by similar sports may help to identify best practices. Especially Chapter 15 can serve as basis for discussions, as common grounds and similarities are underlined therein and critical reflections of the aspects missing from the various federations are provided. Moreover, the relation between eligibility criteria and standards of international nationality laws is of paramount importance for the federations when deciding on new rules or when amending the old ones to better deal with newly arisen circumstances.

In addition, athleterepresentatives as well as athletes may find the overview of the current situation hel pful to assess the rules they may be faced with when deciding to compete for another country. This might be especially the case for young or junior athletes wishing to decide for which country to embark on an international carer. 
They might also find the underlying legal principles, which are frequently addressed when critically assessing thenationality requirements, helpful when bui lding their case in problematic situations.

\subsection{The innovative character of this dissertation's approach}

As not much had been written so far about the topic of eligibility criteria in Olympic sports this dissertation is innovative in several ways.

Firstly, this is the first time the comparative method has been used on this scale on all Olympic sports. Prior to this dissertation, neither federations nor scholars could see the similarities, differences as well as overall trends in such a comprehensive manner. Until now, most research was either focussed on one particular sport, which was then thoroughly examined, or took a more general approach without going into extensive detail. However, it was only in the context of all Olympic sports that certain problems became apparent, such as the general lack of rules for refugee or stateless athletes at thelevel of theindividual federations. Furthermore, with the help of thenew overview best practices can beidentified.

Secondly, eligibility codes had not been systematically scrutinized with regard to standards of international nationality law. Based on nationality law, this dissertation has first formulated several touchstone principles that should be respected by all entities dealing with nationality law. Furthermore, several desiderata for eligibility rules based on nationality for the sporting context were established, which had not been done before Hence, the resulting anal ysis of all the problems and the consequent proposal s for solutions areentirely new.

Thirdly, the solutions advocated in the dissetation at hand largely relied on the principles of nationality law. It was possible to bring forward the first real alternative to both the current status quo and the advocated 'sporting nationality' forward while taking legal concepts such as the genuine link into consideration.

\subsection{The practical applicability of the research results}

The practical implications and applicability of this research are threefold. Most importantly, the draft article, which is brought forward in Chapter 17 and which is in accordance with nationality law, marks the first artide encompassing all issues brought forward by the individual sports. This article, or a slight variation thereof, should not only be incorporated by the sporting federations in their rulebooks, but could also find its way into the more overarching IOC eligibility code. That way several problems, such as the inadequate way in which stateless athletes or refugee athletes are addressed or the problems of waiving or reducing residence and waiting, could be solved.

Furthermore, through corresponding with several sporting federations, a discussion of the eligibility criteria has al ready been sparked. In some instances, pointing out the differences between the rules currently applicable and the principles of nationally law, has al ready given rise to the federations critically reflecting on their eligibility codes. 
With the help of the comparative aspects of this dissertation, sporting federations might find it easier to work together and to agree on common grounds in the future

Finally, besides furthering the research in the field of sports law, this dissertation has provided the fiedd of nationality law with some examples how nationality laws are employed by non-state entities and which problems might arise in these cases. While athletes wishing to change their country of representation area relatively small part of the world's population, the issues they are faced with, eg. refugee status or passports offered to them, mirror problems that affect many. Moreover, the established touchstone principles and desiderata may prove important in other contexts, since they are applicable to all issues of nationality law and to all cases in which a person's nationality may us used as an eligibility criterion.

\subsection{Implementing the research results}

In order to further theimplementation of the findings, this dissertation will be send not only to the relevant sporting federations, some of which are al ready eagerly awaiting the research results, but also to the IOC. This way the organisations most concerned with eligi bility criteria in Olympic sports will beableto review and adapt their current eligi bility criteria accordingly. The costs for such an implementation largely depend on the extend that current rules differ from the suggested solution and on the process necessary to changethe federation's rule book.

Furthemore, copies will be distributed to international legal scholars and law schools offering sports law programmes as well as to sport universities or colleges. This dissertation shall also be published by Wolf Legal Publishers and thus reach a wider distribution. As the publisher will promote the book at relevant conferences and to research institutes, a great number of interested scholars will have access to the research results. Thus, there is a high number of scholars potentially using this dissertation as a stepping-stone for their own research. The costs for the initial distribution is comparative ly low, as only the posting will requireadditional funds. 


\section{Biography}

Born in Bonn, Germany, in J uly 1988, Anna Sabrina Wollmann attended the Nicolaus Cusanus Gymasium in Bonn from 1999 to 2008. Following her bilingual German English Abitur, Sabrina started studying Europeen Studies at Maastricht University Faculty of Arts and Social Sciences in September 2008. FromJ une2010 till December 2011 Sabrina worked at TIER (TOP Institute for Evidence based education research) in Maastricht as a research assistant In addition, she started her second bachelor at Maastricht University Faculty of Law in September 2010, choosing the English language track of the European Law School with a minor in Dutch law. After graduating from the European Studies Programme in J une 2011, Sabrina enrolled in the Master Programme of the European Law School in February 2012 and special ised in European Union Law. In addition to following two fulltime studies for three years, Sabrina has also participated in PREMIUM, the Honours Programme for excellent Master students at Maastricht University in 2013.

From February 2012 until June 2013 Sabrina worked as student assistant to prof. dr. Hildegard Schneider. In addition, she was a national reporter for a project on shareholding requirements and legal form requirements in Germany for Maastricht University and the European Commission, DG Internal Market Sabrina graduated with an LL.B. and LL.M. European Law School with civil effect due to her minor in Dutch law in July 2013 and started working as an external PhD candidate in October 2013. Besides writing her dissertation Sabrina has worked as Admissions Assistant at Maastricht University Faculty of Psychology and Neuroscience in 2014 as well as Marketing and PR Agent at VinAuthority since 2015.

In her free time Sabrina is an enthusiastic athlete herself, having joined Maastricht University Fencing Club MAS Incontro in autumn 2008. Sabrina has had a passion for acting since secondary school, attended several summer school sat the Royal A cademy of Dramatic Art in London and has been an active member of the Bonn University Shakespeare Company since 2014. 


\section{Who may compete for a country at the Olympics?}

While the qualification rounds for the Rio Olympics have received huge media attention, the underlying question regarding which country an athlete may compete for only makes headlines when prominent athletes change the country for whom they are competing. Nationality requirements are an issue that has yet to be brought to the forefront of public discussion, as most recent works have only focussed on a small number of Olympic sports.

This book explores the terra incognita of nationality requirements in Olympic sports, providing not only a comprehensive overview of the different sports, but also placing them in the wider context of the international standards of nationality law. The following questions are examined:

What are the eligibility criteria currently employed by the Olympic Sports? To what extent is it problematic to align these currently applicable eligibility criteria with international standards of nationality law? How can tensions that may exist between the criteria applied by the sporting federations and the international standards of nationality law be solved?

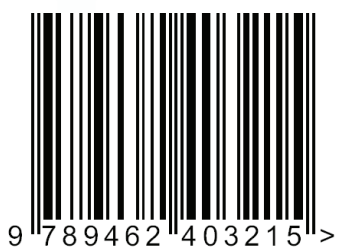

